Performanz und Imagination in der Oralkultur Südosteuropas

Walter Puchner 


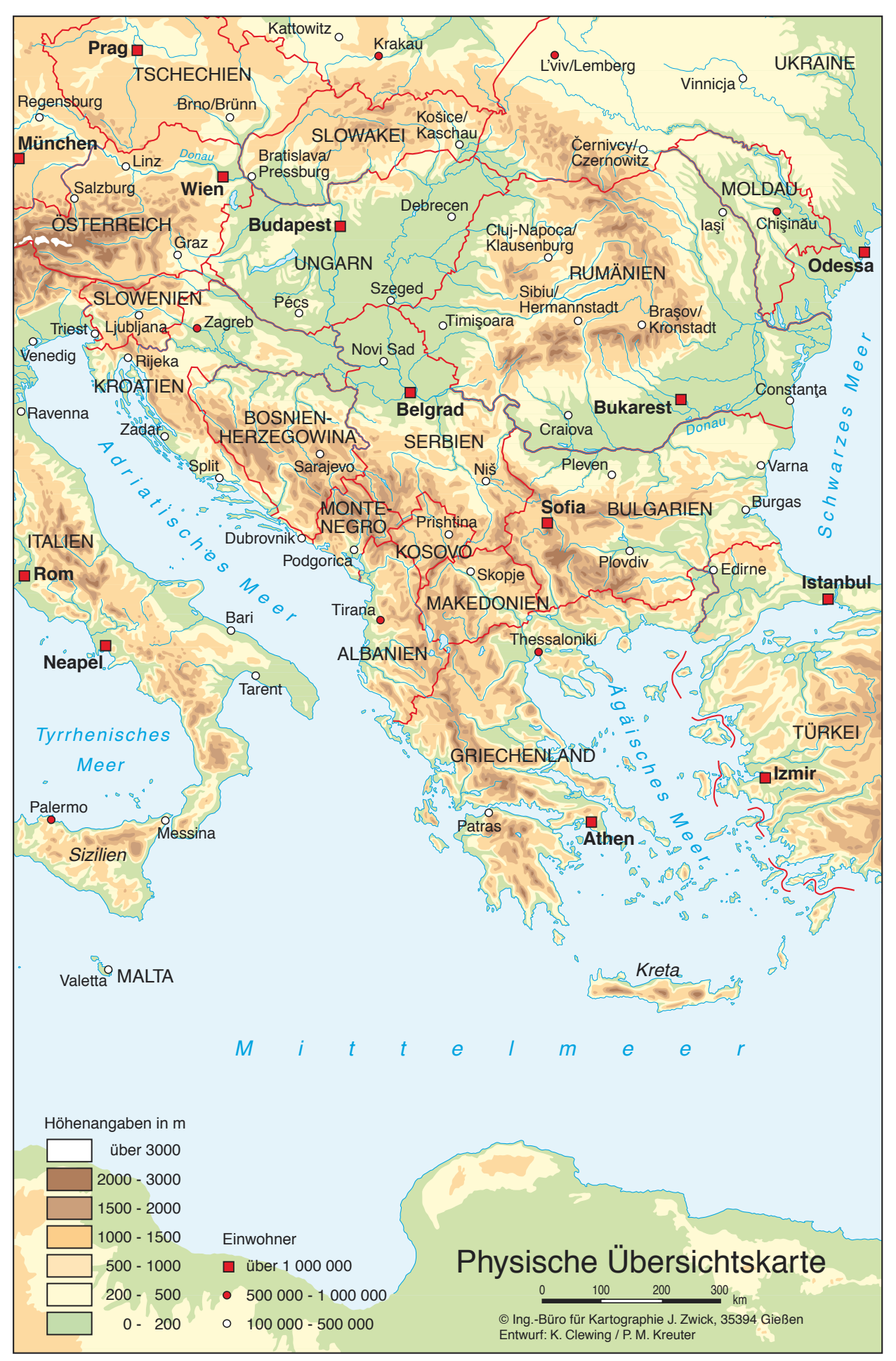


böhlau 
Walter Puchner

\section{Performanz und Imagination in der Oralkultur Südosteuropas}

2

BÖHLAU VERLAG WIEN KÖLN WEIMAR 


\section{FWF $\boldsymbol{F}_{\text {Derwssenschatstonons }}$}

\section{Veröffentlicht mit der Unterstützung des Austrian Science Fund (FWF): PUB 370-G23}

Open Access: Wo nicht anders festgehalten, ist diese Publikation lizenziert unter der Creative-

Commons-Lizenz Namensnennung 4.0; siehe http://creativecommons.org/licenses/by/4.0/

Bibliografische Information der Deutschen Nationalbibliothek:

Die Deutsche Nationalbibliothek verzeichnet diese Publikation in der

Deutschen Nationalbibliografie; detaillierte bibliografische Daten sind im Internet über http://dnb.d-nb.de abrufbar.

(C) 2017 by Böhlau Verlag Ges.m.b.H \& Co. KG, Wien Köln Weimar

Wiesingerstraße 1, A-1010 Wien, www.boehlau-verlag.com

Alle Rechte vorbehalten. Dieses Werk ist urheberrechtlich geschützt.

Jede Verwertung außerhalb der engen Grenzen des Urheberrechtsgesetzes ist unzulässig.

Korrektorat: Ernst Grabovszki, Wien

Umschlaggestaltung: Michael Haderer, Wien

Satz: Michael Rauscher, Wien

Druck und Bindung: Prime Rate, Budapest

Gedruckt auf chlor- und säurefrei gebleichtem Papier

Printed in the EU

ISBN 978-3-205-20327-8 
Für Klaus Roth und Thede Kabl 


\section{Inhaltsverzeichnis}

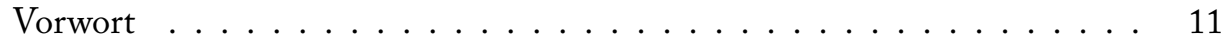

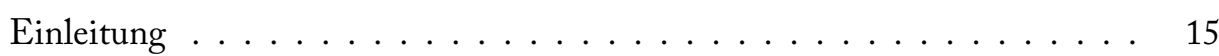

\section{Erster Teil: Performanz}

Einleitung: Der performative turn in der vergleichenden Balkanologie . . . . 27

1. Formen nonverbaler Kommunikation: Gesten und Gebärden . . . . . . . . 32

2. Performative Riten und professionelle Schaustellerei _ . . . . . . . 38

2.1 Performative Riten . . . . . . . . . . . . . . . . . . 38

2.1.1 Der heortologische und okkasionelle Konnex . . . . . . . . . . . . 40

Exkurs 1: Mittwinterriten: Zwölften und Karneval . . . . . . . . . . . . . 42

Exkurs 2: Frühjahrsriten: Ostern und Pfingsten $\ldots \ldots \ldots \ldots \ldots$

2.1.2 Umzug und Prozessionen . . . . . . . . . . . . . . . . 53

2.1.3 Maske und Verkleidung . . . . . . . . . . . . . . . . . . . 65

2.1.3.1 Maskentheorie und Verkleidungssemiotik . . . . . . . . . . . 65

2.1.3.2 Phytomorphe Verkleidung . . . . . . . . . . . . . . 70

2.1.3.3 Zoomorphe Verkleidung . . . . . . . . . . . . 79

2.1.3.4 Theriomorphe Verkleidung _. . . . . . . . . . . . . 88

2.1.3.5 Anthropomorphe Verkleidung . . . . . . . . . . . . 92

2.1.3.6 Anthropomorphe Ersatzobjekte . . . . . . . . . . . . . . . 114

Exkurs: Regionalzonen und Maskentermine . . . . . . . . . . . . . . . . . 120

2.1.4 Rollenspiel und Dialog . . . . . . . . . . . . . . . . . . . . . 146

2.1.5 Populares Amateurtheater . . . . . . . . . . . . . . . . . . 186

2.1.6 Zeremonien und Festivitäten . . . . . . . . . . . . . . . . 200

2.2 Professionelle Schaustellerei ． . . . . . . . . . . . . . . . . . 210

2.2 .1 Fahrende Komödianten . . . . . . . . . . . . . . . . . . . 211

2.2 .2 Panoramen . . . . . . . . . . . . . . . . . . . . . . 213

2.2 .3 Puppentheater . . . . . . . . . . . . . . . . 215 
2.2.4 Schattentheater . . . . . . . . . . . . . . . . . . . . . . . 228

Sonderformen der Performativität A: Spiel und Sport . . . . . . . . . . 251

Sonderformen der Performativität B: Magische Praktiken und empirische

Therapeutik . . . . . . . . . . . . . . . . . . . . . 269

Bildtafeln . . . . . . . . . . . . . . . . . . . . . . . . . 287

Zweiter Teil: Imagination

Einleitung: Sakralität und Superstition _ . . . . . . . . . . . . . . 299

3. Sakralität und Profanisierung . . . . . . . . . . . . . . . . . 303

3.1 Numinosum und do ut des . . . . . . . . . . . . . . . . . . . . . 304

3.2 Auferstehung und Wiedergeburt . . . . . . . . . . . . . . . . . 308

3.3 Das Zwischenreich der Magie ．. . . . . . . . . . . . . . . . . 313

3.4 Ekstase und Prophezeiung . . . . . . . . . . . . . . . . . 325

3.5 Mantik und Orakel . . . . . . . . . . . . . . . . . . . . . . . 328

3.6 Im Netzwerk der Superstitionen $\ldots \ldots \ldots$

4. Populare Devotionsformen und Superstition _. . . . . . . . . . . 347

4.1 Theologische Dogmatik und gelebte Pastoralpraxis . . . . . . . . . . 348

4.2 Bilderverehrung und Wallfahrtswesen ． . . . . . . . . . . . 350

4.3 Heiligenfeste und Handelsmärkte ． . . . . . . . . . . . . . . . . . . 359

4.4 Ikonenkuß und Blumenschmuck . . . . . . . . . . . . . . . . . . . 370

4.5. Votivgaben und Tieropfer $\ldots \ldots \ldots \ldots 75$

5. Sonderformen der Pastoralpraxis ．. . . . . . . . . . . . . . . 384

5.1 Wahlbruderschaft mit ekklesialer Benediktion . . . . . . . . . . . 384

5.2 Bittprozessionen . . . . . . . . . . . . . . . . . . . . . 401

6. Die Kehrseite des Heiligen: Komik und Terror . . . . . . . . . . . . . . . . . 406

6.1 Parodie und Sakralität . . . . . . . . . . . . . . . . . 407

6.2 Dämonologie und Prophylaktik . . . . . . . . . . . . . . . . 409

6.2.1 Totenseelen und Jenseitsglaube oder die Implikationen der invisiblen

Präsenz . . . . . . . . . . . . . . . . . . . . 427

6.3 Zauber und Gegenzauber oder die Modalitäten des Animismus _ . . . . . 432

6.4 Der böse Blick oder die Dominanz der Durchschnittlichkeit . . . . . . . . . 434 
7. Typologische Übertragung und assoziative Vernetzung oder Denkfiguren zwischen Schrift-Theologie und Oral-Kultur . . . . . . . . . . . . . . . . 447

Schlußwort ........................... . 453

Bibliographischer Teil . . . . . . . . . . . . . . . . 457

A. Kommentierte Bibliographie . . . . . . . . . . . . . . . . . . . . 457

Kommentierte Bibliographie zum ersten Teil . . . . . . . . . . . . . . . . 458

Kommentierte Bibliographie zum zweiten Teil . . . . . . . . . . . . . . . . 465

B. Auswahlbibliographie zum vorliegenden Band . . . . . . . . . . . . . 468

Abbildungsverzeichnis ...................... 525

Kartenverzeichnis ...................... 527

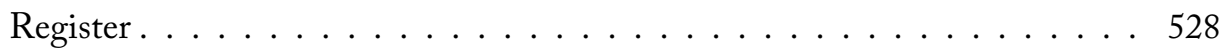


Vorliegender Band bildet den dritten Teil der Trilogie, die einer vergleichenden Übersicht der traditionellen schriftlichen und mündlichen Kultur Südosteuropas gewidmet war. Der erste Band untersuchte die Belletristik bis ins frühe 20. Jh. (Die Literaturen Südosteuropas. 15. bis frühes 20. Jh. Ein Vergleich), der zweite Band behandelte die sprachlichen Manifestationen der traditionellen Oralkultur (Die Folklore Südosteuropas. Eine komparative Übersicht), der dritte Band ist den performativen und imaginären Aspekten der Oralkultur gewidmet, jenen übergreifenden Kontexten, in die die sprachlichen Manifestationen eingebettet sind und die sie inhaltlich bestimmen. Auch dieser Band ist aus den Vorarbeiten zum Teilband 3 des Handbuchs zur Geschichte Südosteuropas entstanden, zu dem ich als Mitherausgeber einige Kernkapitel beizusteuern hatte, das vom Institut für Ost- und Südosteuropaforschung in Regensburg und einem eigenen Editorenteam herausgegeben wird und in sechs Bänden voraussichtlich 2016-2018 erscheinen soll; die Teilbände 3 und 4 behandeln »Sprache und Kultur«, der Halbband 3 ist der "Vormoderne gewidmet. Auch hier, wie schon im ersten Band der Trilogie, ist schon in den Anfangsphasen der Vorarbeiten klargeworden, daß ein einigermaßen systematischer komparativer Überblick der Kommunikationssituationen und Kontextstrukturen der vorwiegend traditionellen Folklore Südosteuropas den zur Verfügung stehenden Raum eines Handbuchartikels um ein Vielfaches überschreiten wird, allein schon aus der Materialfülle heraus; die Oralkultur des Balkanraums, ihre Performanz und imaginären Inhalte, zählen zu den starken Seiten dieses Kommunikationsraums, doch auch hier verläuft die Forschung vielfach immer noch in nationalen Grenzen. Sprachübergreifende und transnationale Vergleiche sind vorwiegend dann anzutreffen, wenn spezifische internationale Rahmenbedingungen gegeben sind bzw. die Phänomene selbst in ihrer stupenden Komparabilität eine Ausweitung des Blickwinkels geradezu provozieren; auch hier bilden die Fülle des aufgezeichneten Materials, wie sie sich in der ausufernden Spezialbibliographie niederschlägt, und die ausschließliche Existenzweise der Phänomene in Paletten und Fächern der Variabilität ein unüberwindliches Hindernis für jegliches Vollständigkeitsstreben, was mutatis mutandis auch für die Sekundärliteratur gilt, die nicht nur thematisch überaus zersplittert ist, sondern auch aufgeteilt auf alle Kleinsprachen Südosteuropas und die Hauptsprachen Europas und ediert in einer Vielfalt von ethnographischen und volkskundlichen Zeitschriften nationaler oder auch regionaler Reichweite, Kongreßakten, Akademieberichten, Fakultätsjahrbüchern usw.

Schon im Vorwort sei darauf hingewiesen, daß dieser komparative Überblick nicht auf alle Formen der Performanz und Spielarten des Imaginativen ausreichend eingehen 
kann. Bei den performativen Aspekten sind z.B. nicht Musik und Tanz berücksichtigt, die gerade im Balkanraum eigenständige Forschungsgebiete darstellen, die auch institutionell im akademischen Wissenschaftsbetrieb eine separate Verankerung erfahren haben, was von der spezifischen Methodologie dieser Fachbereiche her durchaus seine Berechtigung hat. Formen der Imagination wie die Glaubensvorstellungen um die Effektivität magischer Aktionen, wie etwa bei der Krankenheilung, sind sowohl im ersten wie auch im zweiten Teil anzutreffen, da sie fast durchwegs auch performative Qualitäten besitzen. Performanz und Imagination bilden insofern die sprachübergreifenden Kontextstrukturen der Oralkultur, als sich Sprachmanifestationen in bestimmten Kommunikationssituationen artikulieren und jede Verbaläußerung aus sich heraus darstellende Aspekte besitzt, welche allerdings auch in nonverbalen Zusammenhängen auftreten können, das Gesagte, vor allem in ritualisierten Handlungsfeldern, auf gewissen Glaubensvorstellungen fußt, die als Konstruktionen der Imagination die kulturelle Lebenswirklichkeit einer Region bestimmen, wenn sie auch in der unmittelbar wahrnehmbaren Sozialrealität unsichtbar bleiben mögen.

Insofern folgt die Trilogie einer sachinhärenten Präsentationslogik von Sprache zum Sprechen und vom Gesprochenen zu seinen Voraussetzungen, vom Lesen zur Kommunikation und von dort zum Sprechakt als Handlung und als Ausdruck einer nicht ausgesprochenen Weltordnung und eines latenten Seinsverständnisses, vom Begriff zum Bild und zur Denkfigur, von Kausallogik zur assoziativen Vernetzung usw. Dabei ist den Sprachkunstwerken des ersten Bandes vielfach schon die Ästhetik der Denkmodalitäten der Volkskultur, ihre Poetik und Magie, eingeschrieben.

Auch diese Darstellung richtet sich sowohl an Balkan-Spezialisten, komparative Folkloristen als auch ein breiteres interessiertes Lesepublikum, das seine Aufmerksamkeit dem Zauber des Andersseins der Oralkultur in Südosteuropa zugewendet hat, welches vielfach in seinen Denkweisen und Mentalitäten der mittel- und westeuropäischen Voraufklärung adäquat ist. Die zahlreichen Fußnoten wenden sich an die Fachleute: Daher sind Studientitel, wie auch in den voraufgegangenen Bänden, aus Respekt vor der Eigenständigkeit der Kleinsprachen nicht übersetzt. Zum Überblick über die einschlägige Literatur ist dem Band eine kommentierte Bibliographie beigegeben, gegliedert nach performativen Aspekten und Kontexten des Imaginativen sowie den Einzelländern und Einzelsprachen. Trotz aller Bemühungen um eine vertretbare bibliographische Dokumentation der Literaturfülle in den Fußnoten und in der bibliographie raisonnée ist es, wie schon in den vorherigen beiden Bänden, schon allein vom Umfang her praktisch unmöglich, eine erschöpfende Zusammenstellung zu bieten.

Für das Zustandekommen dieser Monographie bin ich auch diesmal vielen Personen und Institutionen zu bleibendem Dank verpflichtet: vor allem dem Bibliothekspersonal des Instituts für Ost- und Südosteuropaforschung in Regensburg (und Dr. Konrad 
Clewing für die gewährte Gastfreundschaft), das heute die umfangreichste Spezialbibliothek für den Balkanraum besitzt, der Österreichischen Nationalbibliothek in Wien und der Bayerischen Staatsbibliothek in München, dem Österreichischen Museum für Volkskunde mit seinen reichhaltigen südosteuropäischen Beständen, Herrn Dr. Edvin Pezo, der mich, soweit möglich, elektronisch mit digitaler Spezialliteratur versorgt hat, sowie einer Reihe von wissenschaftlichen Persönlichkeiten, von denen die meisten nicht mehr am Leben sind: Leopold Kretzenbacher, Felix Karlinger, Dragoslav Antonijević, Petăr Dinekov, Zmaga Kumer, Dimitrios Lukatos, Michael G. Meraklis und viele andere. Zu danken habe ich ebenfalls dem Fonds zur Förderung der wissenschaftlichen Forschung in Wien, ohne dessen Unterstützung die Drucklegung der Monographie nicht möglich gewesen wäre, sowie dem Böhlau Verlag für die gastfreundliche Aufnahme der Arbeit in sein Verlagsangebot und die bewährte Zusammenarbeit.

Hagios Georgios im thessalischen Pelion-Gebirge

Sommer 2016

Walter Puchner 


\section{Einleitung}

Der dritte Band zu den Literaturen und mündlichen Kulturen Südosteuropas, nach der in Druckform publizierten Belletristik und der kommunikativen Oralkultur in ihren aufgezeichneten Varianten, reicht über die Sprache hinaus und verfolgt als Methodenachsen der Darstellung zwei verschiedene Sektoren, die den Sprachmanifestationen jenseits der Schriftlichkeit erst einen rezipierbaren Seinsstatus zuweisen: r. die Performanz und Performativität des Gesagten in der jeweils spezifischen Kommunikationssituation einer konventionellen oder rituellen Handlungssequenz, die im Falle quasi-sprachlicher Bedeutungsübermittlung auch ohne verbale Artikulierung auskommen kann (z.B. Gesten und Gebärden, Verkleidung und Maske), und 2. die Inhalte des Gesprochenen, die auf nichtartikulierten Voraussetzungen und Kontexten von Weltbilderfassung und Wirklichkeitskonstruktion, magisch-religiösem Seinsverständnis und assoziativen Denkfiguren und Vernetzungen rekurrieren, ohne deren Kenntnis und Verständnis die Verbaläußerung in ihrer Semantik nicht immer entschlüsselt werden kann und vielfach rätselhaft bleibt. Insofern stellt der dritte Band eine notwendige Ergänzung des zweiten dar, aber auch des ersten, wenn man die Praktiken des Vorlesens vor einem größeren Publikum und die unmittelbare Abhängigkeit großer Teile der Balkanliteraturen von der oralen Tradition und ihrem Weltverständnis in Rechnung stellen will; das (prae-) animistische Weltbild der Volkskulturen korrespondiert dabei mit der Wirklichkeitsüberschreitung in der Literaturästhetik, Poetik und Poesie der Totalvernetzung aller Dinge in der Weltordnung der Magie entsprechen dem Überwiegen der semantischen Konnotationen in der Funktionsweise und Korrelierung ästhetischer Zeichen, wo der Vorgang, wie die Zeichen zu ihren Bedeutungen kommen, die Semiosis, in ähnlicher Weise ambivalent und variabel bleibt wie in den vorwiegend oralen Volkskulturen ${ }^{1}$. Diese Neigung zur Bereitschaft intensiver Sinnzuweisung durch universelle Symbolhaftigkeit entspricht darüberhinaus auch der Kinderpsychologie; die Welt der Kinderkultur spielt in den performativen Riten der Balkanhalbinsel eine herausragende Rolle als konservierender Faktor von Brauchhandungen, die aufgrund der Mechanisierung der Landwirtschaft aus der Übung gekommen sind bzw. durch den Verlust des Glaubens an die magische Effektivität der Aktionen einen Theatralisierungsprozeß durchgemacht haben ${ }^{2}$, der durch den rezenten Funktionswandel als lokales Folkloreprogramm zu blo-

I Erika Fischer-Lichte, Bedeutung - Probleme einer semiotischen Hermeutik und Ästhetik, München I979, dies., "Zum Problem der Bedeutung ästhetischer Zeichen«, Kodikas/Code 3 (I980) 279-283.

2 Walter Puchner, Brauchtumserscheinungen im griechischen Jahreslauf und ibre Beziehungen zum Volks- 
ßer Unterhaltung, Befriedigung der Schaulust und Touristenattraktion oder auch zur Festigung regionaler Kulturidentität beiträgt ${ }^{3}$. In der elektronischen Adresse fast jedes Dorfes sind solche events und Attraktionen abzulesen.

Die drei Bände verbindet insofern eine Präsentationstaktik sukzessiver Erweiterung des Blickwinkels und eine Intensivierung des Tiefengangs im Erfassen vorrationaler Kulturschichten als ein Gang vom geschriebenen Wort der ästhetischen Fiktion bzw. seiner Rezeption durch den Vorgang des Lesen oder Vorlesens ( balinhalten der Sprech- bzw. Singprozesse der Oralkultur in ihren Kommunikationssituationen und Verbalakten (2. Band) und von dort zu den Handlungen der Performanz, die die Verbaläußerungen begleiten bzw. eine eigene symbolische Metasprache bilden, welche auch "sprachlos« ohne verbale Artikulationen auskommen kann bzw. zu dem Nicht-Gesagten im Ausgesprochenen, das in Vorstellungen der Weltkonstruktion (Imagination) fußt, die nur symbolisch in Mythen, Riten und Glaubensvorstellungen zum Ausdruck kommt (3. Band). Hier ist der Bereich der Sprache bereits zum Teil verlassen; die magisch-religiöse Vernetzung aller Dinge in einem dynamistischen (prae-)animistischen Weltbild bedarf des Wortes als Sinnträger und Kommunikationsinstrument (noch) nicht in jenem ausschließlichen Sinne wie die Alltagsrealität der gelebten Kulturformen.

Insofern trägt der 3. Band dem performative turn Rechnung ${ }^{4}$, in dessen Folge die Phänomene der Lebenswelt nicht mehr als (lesbarer) Text aufgefaßt werden wie zur Zeit des Strukturalismus und der Semiotik, sondern als performance (Darstellung), wobei der schillernden Polysemie des kaum noch definierbaren Terminus sowohl rituelle Zwanghaftigkeit und Wiederholung wie auch Spiel- und Theaterhaftigkeit eingeschrieben sind ${ }^{5}$. Kulturelle Performativität in diesem Sinne, statt der Vertextung des Seins in einem Schreibe- und Leseprozess, umfaßt nun auch neben der programmierten In-

theater. Theaterwissenschaftlich-volkskundliche Querschnittstudien zur südbalkan-mediterranen Volkskultur, Wien 1977 , pass.

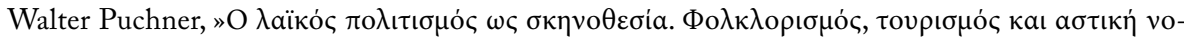

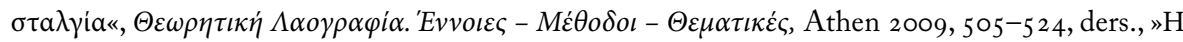

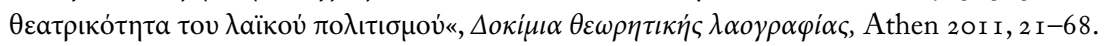

4 Erika Fischer-Lichte, »Vom `Text zur `Performance senschaften«, Kunstforum ${ }_{1}{ }_{2}$ (Okt.-Dez. 2000) 6 I-63, dies., Ästhetische Erfahrung. Das Semiotische und das Performative, Tübingen $200 \mathrm{I}$, dies./Christoph Wulf (eds.), Theorien des Performativen, Widmungsheft der Paragrana. Internationale Zeitschrift für Historische Anthropologie 10/I (2001), dies. (eds.), Praktiken des Performativen, ibid. I3/I (2004).

5 Zur Unmöglichkeit einer konzisen Definition des Terminus aufgrund seines ausufernden Gebrauchs vgl. Marvin Carlson, Performance: a critical introduction, London/New York I 997, 6 f. Siehe auch Sandra Umathum, »Performance«, Erika Fischer-Lichte/Doris Kolesch/Matthias Warstat (eds.), Metzlers Lexikon Theatertheorie, Stuttgart/Weimar 2005, 23 I-234. 
szenierung die Emergenz von Unvorhergesehenem, wo, ähnlich wie in einem Dialog die Kommunikationspartner ihre vorgefaßten Meinungen überschreiten können und zu neuen Einsichten kommen, die Handlungs- und Erlebnisakte von Produktion und Rezeption die Ebene der anfänglichen Intentionen zu transgredieren in der Lage sind und zu qualitativ neuen ko-produzierten Synthesen führen, die nicht vorhergesehen und vorhersehbar waren ${ }^{6}$. Insofern fußt das Performativitätskonzept nur zum Teil in der Welttheatervorstellung, da die Rollenvergabe und -annahme nicht einseitig einem universellen Inszenierungskonzept und seiner individuellen Ausführungsstrategie durch die »Schau-Spieler« folgt ${ }^{7}$, sondern die Vor-Stellung eine Eigendynamik entwickeln kann, die etwas wesentlich Neues hervorbringt. In der Aufhebung der Funktionsspaltung der Aufführung in aktive und passive Teilnehmer (selbst der passive Zuschauer ist vom Theaterverständnis niemals entfernt worden), gleicht sich das Theaterereignis des Lebensvollzugs zum Teil wieder dem Ritus an, an dem alle in gleicher Weise teilhaben $^{8}$. Das rituell-magische Lebensverständnis kennt die grenzscharfe Trennung von Realität und Imagination im heutigen konventionellen Sinne nicht, die fundamentalen Antithesen der neuzeitlichen Weltbildkonzeptionen wie Subjekt-Objekt, Innen-Außen, Diesseits-Jenseits, lineare und zyklische Zeit, faktische Wirklichkeit und fiktive Vorstellung usw. sind aus der universellen Vernetzung des Bestehenden und des Gedachten nicht herauszudifferenzieren ${ }^{9}$.

Inosfern ist die Aufeinanderfolge der drei Bände der Trilogie auch ein rekursiver (Gedanken-) Gang vom Text zum Akt der Darstellung, von Verbalem in Schrift und Wort zu Non-Verbalem, von Sprechbarem (Text) und Gesprochenem zu sprachlosen Kommunikationssystemen und symbolisch-zeichenhafter Sinnvermittlung (Gebärden, Gesten, Körpersprache; Verkleidung und Verwandlung, Symbole und Zeichen mit unterschiedlicher Bedeutungsklarheit); in der retrospektiven Reihenfolge des Triptychons ist ein Übergang von Sprache zu Vorsprachlichem eingelagert, von Begrifflich-

6 Erika Fischer-Lichte, Ästhetik des Performativen, Frankfurt/M. 2004, dies., Performativität. Eine Einfübrung, Bielefeld 2012.

7 Walter Puchner, "Zum Schicksal der antiken Theaterterminologie in der griechischen Schrifttradition«, Beiträge zur Theaterwissenschaft Südosteuropas und des mediterranen Raums, 2 Bde., Wien/Köln/ Weimar 2006-07, II I 69-200, bes. I 83-193.

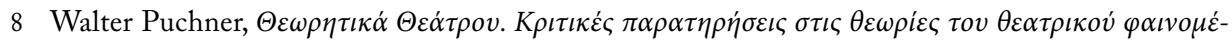

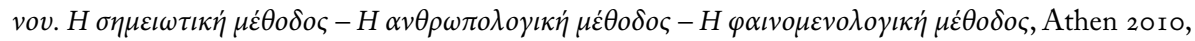
$23 \mathrm{I}-255$.

9 Vgl. das Spinnennetzmodell in Walter Puchner, Studien zum Kulturkontext der liturgischen Szene. Lazarus und Judas als religiöse Volksfiguren in Bild und Brauch, Lied und Legende Südosteuropas, 2 Bde., Wien I 99 ( Österr. Akademie der Wissenschaften, phil.-hist. Klasse, Denkschriften 2 I 6), I 20 Abb. 3 . 
keit zur Bildhaftigkeit, von Denkfiguren der Logik zu Assoziation und Analogie, von der Faktizität zur Imagination, von Ausgesprochenem zu Unausgesprochenem bzw. Unaussprechlichem (Imagination/ Numinosum), von Bewußtem zu Unterbewußtem; der thematische Dreisprung führt von der Belletristik als Monolog mit zeitverschobener Rezeption zur Kommunikation als alternativer Reihe von Sprechakten, zu Dialog oder intendiertem Dialog, und von dort zur Denkfigur, der Vorstellung und kollektiv normierten Phantasie, die sich in Riten und Mythen institutionalisiert. War der Akt des Lesens zeit- und ortsunabhängig (Schrift), so ist der Akt des Sprechens/Zuhörens/ Antwortens bedingt durch die Anwesenheit der Kommunikationspartner (raumzeitlich abhängig), während Glaubensvorstellungen wiederum teilweise zeitneutral sein können (»überzeitlich« und großräumig wie kosmogonische Mythen), doch zeit- und ortsabhängig wie die Repetition der Riten zu bestimmten Zeitpunkten und an bestimmten Orten, die Herausgehobenheit der Festzeit folgt jedoch einem anderen Zeitverständnis.

Insofern bildet der dritte Band wieder einen Übergang zum ersten: Ritual und Spiel, Religion und Traum sind in einer ähnlichen Weise aus dem Zeitverlauf der Alltagsrealität herausgehoben wie Kunst und Literatur ${ }^{10}$. Sakralität, Säkularisierung und Profanisierung bieten sich in Mischformen der Ritualisierung des Kulturfeldes an ${ }^{11}$ ähnlich wie Belletristik, Satire und Parodie in der graduellen Verwendung von Fiktionalität und (verzerrter) Faktizität ${ }^{12}$. Die prae-realistischen Vorstellungen des magisch-religiösen Weltbildes führen über den neuzeitlichen Realitätsbegriff zur Überwindung der Wirklichkeit in der Ästhetik. Dabei ist das Verb »führen« irreführend: Die Gleichzeitigkeit des Ungleichzeitigen, das Nebeneinander und Durcheinander von Zeit- und Kulturschichten zeugen vom Versagen des Evolutionsmodells; es gibt auch im südosteuropäischen Kommunikationsraum keine unilinearen und irreversiblen Entwicklungen ${ }^{13}$.

Performanz beinhaltet demnach als dynamischer Begriff den Gang vom Ritual zum Theater und wieder zurück (Reritualisierung), Imagination als Aktivität der menschlichen Phantasie die Interpretation und den Manipulationsversuch der (Überlebens-) Wirklichkeit; mit dem Aussetzen des Glaubens an die magische Effektivität der Ritualhandlungen aufgrund der Mechanisierung der landwirtschaftlichen Produktion und des Vorherrschens des wissenschaftlichen Weltbildes kann dieses darstellende Aktionsmaterial in seiner Theaterhaftigkeit als spielhafte Außerkraft-Setzung des Wirklichen (konsequenzvermindertes Probehandeln) fungieren, was der Fiktionalität der Künste

\footnotetext{
Io Peter L. Berger/Thomas Luckmann, The Social Construction of Reality, New York 1966.

I I Paul Weidkuhn, Agressivität Ritus Säkularisierung, Basel I 965 .

I 2 Walter Puchner, Die Literaturen Südosteuropas: 15. bis frühes 20. Jahrbundert. Ein Vergleich, Wien/

Köln/Weimar 2015, 209-2 I 8.

I 3 Puchner, Studien zum Kulturkontext der liturgischen Szene, op. cit., 9- I I.
} 
entsprechen würde ${ }^{14}$. Damit aber wird die Konstruiertheit und gesellschaftliche Setzung und Satzung des Realitätsbegriffes im europäischen Denken greifbar, seine Dialektik und seine nur lückenhafte Gültigkeit; soziale Weltbildordnungen weisen eine inhärente Tendenz zur Transgression auf, wie die unwiderstehliche Magie der Tabuüberschreitung in Märchen und Mythen zeigt; in die Alltagswirklichkeit sind Inseln der Imagination eingelagert, wie Traum, Tagtraum, religiöse Erlebnisse, Kunsterlebnisse, Reflexion und Selbstreflexion, Selbstvergessenheit als Voraussetzung des Schaffensprozesses usw. ${ }^{15}$; hier zeigt sich auch die Dialektik jeglicher gesatzten Ordnung: Durch Imagination überschritten, fußt sie als Setzung selbst auf unbewußten Vorstellungen, die sich nur indirekt äußern; jegliche Grenzziehung lockt bereits zur Überschreitung; allgemeiner formuliert: Jede Norm trägt in sich bereits die Normübertretung als Denkmöglichkeit (die Gottheiten der Mythologien vollbringen das, was die Menschen nicht dürfen). Somit ergibt sich gleichzeitig eine Immanenz und Transzendenz von Realität (und Rationalität), die als gleitender Normbegriff immer schon die eigene Relativierung in sich trägt. Ein solches archaisches Substrat der Kulturleistungen ist nicht nur in den Volkskulturen gegenwärtig, sondern auch in dem bis heute gültigen aufklärerischen Weltbild der sogenannten Hoch-, Hegemonial- oder Elite-Kulturen, nur in anderer Form ${ }^{16}$. Der Sammelbegriff der Gegen-Aufklärung (oder auch der Vormoderne) ${ }^{17}$ ist jedoch für eine Demonstration und Bewußtmachung des enormen Ausmaßes der Gleichzeitigkeit des Ungleichzeitigen wenig geeignet. In Südosteuropa mit seiner historischen Armut an Eliten und Institutionen ${ }^{18}$ ist manches von diesen nichtrationalen Glaubens- und Weltvorstellungen deutlicher zu beobachten ${ }^{19}$.

Doch sind die eurozentrischen und westorientierten szientifischen Begriffsbildungen der Sozialanthropologie und Geschichtsphilosophie oft wenig geeignet, die differenzierte Wirklichkeit realitätsadäquat zu erfassen. Als Beispiel dafür mag die Diskussion um das Balkanpatriarchat stehen, das als unreflektierte wissenschaftliche Konstruk-

I4 Puchner, Brauchtumserscheinungen, op. cit., 335-353.

I5 Berger/Luckmann, op. cit.

I6 Vom Horoskop bis zum Medium, vom Hufeisen bis zum Sparschwein; in Südosteuropa auch besonders der irrationale Glaube an den Bösen Blick und anderen Schadenszauber.

I7 Zur Kritik an dem Begriff der Vormoderne Puchner, Die Literaturen Südosteuropas, op. cit., I6- I 8, zum problematischen Sammelbegriff der Gegen-Aufklärung Zeev Sternhell, Les anti-Lumières. Du XVIIIe siècle à la guerre froide, Paris 2006.

I $8 \mathrm{Karl}$ Kaser/Siegfried Gruber/Robert Pichler (eds.), Historische Anthropologie im südöstlichen Europa. Eine Einführung, Wien etc. 2003.

I9 Zur Parallelisierung der Volkskulturen des orthodoxen Südosteuropas mit dem lateinischen Mittelalter vgl. Puchner, Studien zum Kulturkontext der liturgischen Szene, op. cit., I4-I6. 
tion noch bis in den Jugoslawienkrieg hinein weitertradiert wird ${ }^{20}$ und die differenziertere gesellschaftliche Realität (regional, konfessionell; Normen und Leitbilder entsprechen nicht immer der gelebten Wirklichkeit) die verdeckte Komplementarität der Geschlechterrollen nivelliert ${ }^{21}$, wobei die Macht und das Ansehen der Matrone, die entscheidende Rolle der Frau in den vier Wänden des Hauses und ihre Krisen-Funktion bei Krankheit und Tod, Geburt und Hochzeit, Heilwissen und Kommunikation mit metaphysischen Instanzen usw., übergangen wird ${ }^{22}$. Oder die sensationsträchtige Diskussion der gender studies um die eingeschworene Mannfrau und ihre Institution in Liedfiktion und Realität, die als »drittes « gender oder Zwischen-Geschlecht pseudoszientifisches Aufsehen erregt hat und Bachofens geschichtsphilosophische Matriarchats-Frage wieder hat aufleben lassen ${ }^{23}$. Die naiven Balkan-Bilder des Westens, die manchmal an die deskriptiven Stereotypen von Karl May erinnern, sind in ihrer Entwicklung an der Reiseliteratur abzulesen, wo das geistige Gepäck und die Bildungsbrille des jeweiligen Periegeten bestimmt, was er sieht und erfaß $\mathrm{t}^{24}$. Begriffe wie balkanizacija und die journalistische Literatur zum Jugoslawienkrieg haben solche Vorurteile wieder aufleben lassen und bestimmen manchmal den intellektuellen Hintergrund von großflä-

20 Zur Entmythisierung dieses Konstrukts vgl. etwa Jochen Raecke, »Kollektivität und Individualität als literarische Leitbilder oder Wenn kollektives Heldentum (der Männer) nur individuelles Leid (der Frauen) bedeutet«, Kulturelle Orientierungen und gesellschaftliche Ordnungsstrukturen in SüdostEuropa, Wiesbaden 2010, 4I-80.

2 I Vgl. z.B. Ernestine Friedl, terly 40/3 (1967) 97-108, Jill Dubisch, »The domestic power of women in a Greek island village«, Studies in European Society I (1974) 23-33, dies., »Greek woman: Sacred or profane«, Journal of Modern Greek Studies I (1983) I 28 - 85 usw. Zum gegenteiligen Bild René Hirschon, „Property, power and gender relations", Women and property, Women as property, London I 984, I-22.

22 Walter Puchner, »Frauenbrauch. Alterssoziologische Betrachtungen zu den exklusiv femininen Riten Südosteuropas«, Studien zur Volkskunde Südosteuropas und des mediterranen Raums, Wien/Köln/

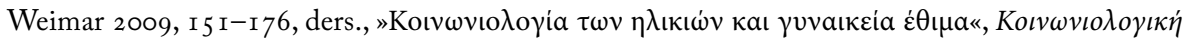

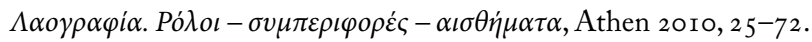

23 Walter Puchner, Die Folklore Südosteuropas. Eine komparative Übersicht, Wien/Köln/Weimar 2016, 37-39. Vgl. vor allem Karl Kaser, „Die Mannfrau in den patriarchalen Gesellschaften des Balkans und der Mythos vom Matriarchat", L'Homme. Zeitschrift für feministische Geschichtswissenschaft 5 (1994) 59-77.

24 Zur Reiseliteratur über Südosteuropa siehe South Slavic Folk Culture: a Bibliography of Literature in English, German, and French, on Bosnian-Hercegovian, Bulgarian, Macedonian, Montenegrin and Serbian Folk Culture, compiled and edited by Klaus Roth and Gabriele Wolf with the collaboration of Tomislav Helebrant, Columbus, Ohio I 993, 465-507, Nr. 7004-7654 und Greek Folk Culture. A Bibliography of Literature in English, French, German, and Italian on Greek Folk Culture in Greece, Cyprus, Asia Minor (before 1922) and the Diaspora (up to 2000). Compiled and edited by Walter Puchner with the collaboration of Manolis Varvounis, Athens 20 I I (Laografia, Suppl. I 5) 598-678 Nr. 6855-7820. 
chigeren Darstellungen, während regionale Deskriptionen vielfach von nationalen Heterostereotypen bestimmt sind oder als case studies von wissenschaftlichen Schulbildungen an den westlichen Universitäten und dem funktional-strukturellen Begriffsapparat, der in der Dritten Welt zur Zeit des Imperialismus entstanden ist ${ }^{25}$.

Für eine Fixierung von Zeitgrenzen wie im Fall von Band I und z. T. auch Band 2 besteht kaum Notwendigkeit und auch wenig Möglichkeit: Im Falle von Umzügen von Haus zu Haus mit performativen Riten, Verkleidung und Maskierung, Symbolhandlungen, Fertilitätssprüchen usw. und Prozessionen auf Feldern bzw. zu Heiligtümern in Wallfahrten mit Litaneien und religiösen Symbolen reicht die Dokumentierbarkeit sowohl ins hellenische wie ins römische und frühchristliche Altertum zurück; ein gleiches gilt für magische Praktiken und Heilmethoden, die sich auf das Analogie-Denken und Similität bzw. die transplantatio morborum (Übertragbarkeit von Krankheiten durch Kontakt oder das zauberkräftige Wort) stützen, welche schon in den ägyptischen Zauberpapyri festgehalten sind und in Magiebüchern und iatrosophia (praktische Anleitungen der empirischen Heilkunde) durch die Jahrhunderte abgeschrieben und bis fast in die unmittelbare Gegenwart weitertradiert werden, ebenso wie für Prophezeiungen, Orakel, Traumdeutungen, Wetterprognosen, astrologische Schriften, Horoskope usw. Hier sichert die schriftliche Kontinuität eine erstaunliche Vergleichbarkeit, die sich in den Oralkulturen Südosteuropas noch ohne weiteres ablesen läßt.

Ähnliches gilt auch für die räumliche Begrenzung: Die griechischen Zauberpapyri und das Medizinwesen des Altertums sind über arabische Vermittlung sowohl nach Mittel-, West- und Südwesteuropa gelangt wie über byzantinische und slavische Vermittlung nach Ost- und Südosteuropa, durch die Islamisierung der Araber auch in den Mittleren Osten. Lateinisches und orthodoxes Prozessionswesen und die entsprechenden heortologischen Festkalender sind auch über Südosteuropa hinaus nachzuweisen und vergleichbar. Wallfahrten und Votivopfer sind im islamischen Bereich ebenso verbreitet wie im christlichen. Magische Vorstellungen wie der Böse Blick und anderer Schadenszauber sowie prophylaktische und apotropäische Handlungen und Amulette sind als baskania sowohl in der Antike wie in einem viel weiteren geographischen Bereich nachzuweisen, der auch den Mittleren Osten und Gebiete Zentralasiens bzw. in polygenetischer Diffusionslage eine fast globale Verbreitung in vielen Kulturen umfaßt, die zueinander kaum in Kontakt gestanden haben. Sobald die Sprache als Differenzialkriterium wegfällt, bewegt man sich in den weit größeren raumzeitlichen Dimensionen eines fast universalistischen magisch-religiösen Weltbildes, wo Analogie und Proxemik,

25 Walter Puchner, »Vergleichende Volkskunde - Ethnologia Europaea - Home-Anthropology, oder: Sind Namen Schall und Rauch?«, Studien zur Volkskunde Südosteuropas und des mediterranen Raums, Wien/Köln/Weimar 2009, I 9-46. 
Similität als Identität, Berührung und Übertragung, Gestalt- und Handlungssymbolik sowie die magische Wirkmächtigkeit des unverständlichen Wortes die grundlegenden Denkfiguren in der Vernetzung aller Dinge zwischen Imagination und Realität bilden und Welt- und Lebensverständnis regulieren.

Es sind dieselben Denkfiguren, die schon bei den oralen Sprachmanifestationen in der Fiktion der mündlichen Literatur anzutreffen waren; auch für Riten und Verkleidungen, Heilsprüche und magische Therapiemethoden, Traumdeutungen und Dämonologie gilt, ähnlich wie bei Märchentypen und Liedformen, das grundlegende Prinzip der Vielfalt des Wenigen, das die Volkskulturen im Gegensatz zu den Elite-Kulturen charakterisiert ${ }^{26}$, der Variabilität von Basiselementen und Strukturmustern, die jedoch auch eine fast durchgehende Ambilavenz und Ambiguität aufweisen. Die Phänomene der Volkskultur existieren fast ausschließlich in Variationen; die Bedeutungszuweisung von Symbolen und Zeichen ist in ihrer Semantik kontextabhängig und zielorientiert: Die Dinge können auch ihr Gegenteil bedeuten, was vom jeweiligen Zusammenhang abhängt und der Teleologie der rituellen oder therapeutischen Handlungsakte. Man kann von einer ars combinatoria und multiplikativen Vervielfältigung und Ausfaltung in Variationen einiger weniger Grundprinzipien sprechen: Analogie und Similität, Proxemik

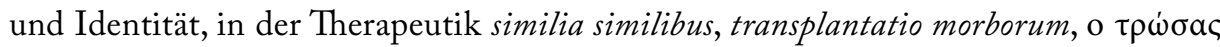

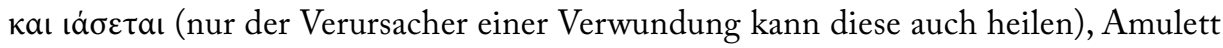
und Apotropäum, etymologische und linguistische Prophylaxe (Euphemismus) usw. Die Varianz und Variierung der Grundprinzipien erfolgt nach lokalen und regionalen Gegebenheiten, wie dies das gemeinbalkanische Sprichwort »Jeder Ort seine Sitte, jedes Viertel seinen Brauch « prägnant ausdrückt ${ }^{27}$.

Die ausschließliche Existenzweise der Phänomene von Oralkulturen in der Varianz macht nicht beim Sprachmedium halt, sondern erstreckt sich jenseits von Mythologie, Märchen und Liedern auch auf Masken, Riten und die Ornamentierung von Gebrauchsgegenständen oder Stickmustern, deren funktionale Symbolik (z.B. Hahn auf den balkanischen Frauenschürzen) in immer neuen, z.T. auch individuellen Variationen nachgebildet wird ${ }^{28}$. Erst die schriftliche Fixierung diktiert die Einmaligkeit, die

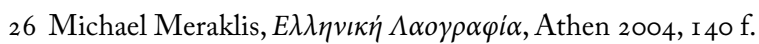

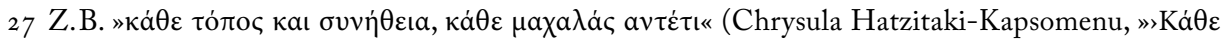

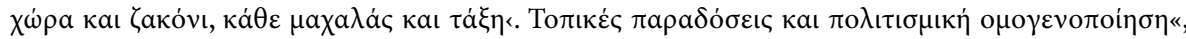

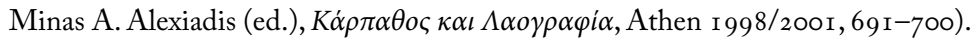

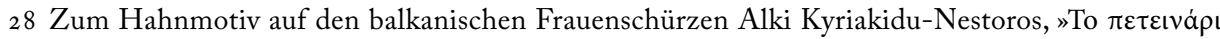

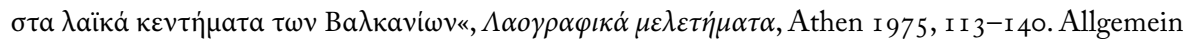

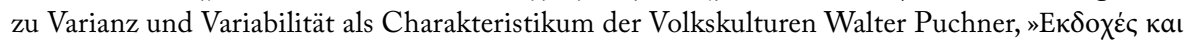

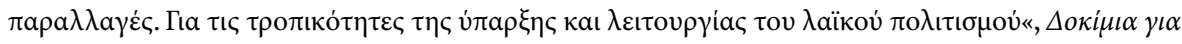

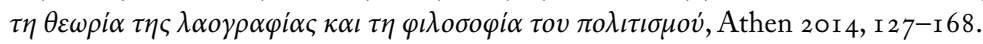


Originalität und das Verlassen der Anonymität. Dasselbe Kriterium unterscheidet die »Hochreligionen« von den popularen Devotionsformen der »Volksfrömmigkeit « ${ }^{29}$ : »es steht geschrieben« erlaubt keine Varianz, Verschiebung oder Innovation, das sakrale Dogma besteht in seiner außerzeitlichen Unveränderlichkeit über der Geschichte und außerhalb des kollektiven und individuellen Bewußtseins und seinen Gleitlagen und Bedürfnissen. Jede Änderung des kirchlichen Hochrituals bedarf daher einer institutionellen Sanktion und einer spezifischen und begründeten Entscheidung.

Noch stärker als bei der mündlichen Literatur spielt hier der Begriff von Tradition und Traditionalität herein, denn Brauchhandlungen und Maskenwesen sind heute vielfach Attraktionspunkte des Binnentourismus geworden und in den Katalogen der Jahres-events jedes Dorfes im Internet abzulesen; die Therapiemethoden der empirischen Volksmedizin sind zwar dem wissenschaftlich organisierten Gesundheitswesen erlegen, doch magische Praktiken und Vorstellungen wie Zukunftsprognose, Horoskope und Entzauberung vom Bösen Blick sind weiterhin in massiver Weise im Alltagsleben der Urbanzentren anzutreffen. Tradition als Ideologie wird von Politikern und regionalen Kulturprogrammen beschworen und wurde, vor allem in den ehem. sozialistischen Staaten, in Folklore-Festivals organisiert und propagiert. Dabei bedeutet der Begriff traditio eigentlich keinen Inhalt des Tradierten, sondern nur den Vorgang; da auch die Volkskultur Südosteuropas im ehem. osmanischen Bereich sich nicht in einer nostalgisch imaginierten Zeitlosigkeit (am Gegenpol der immer stärker werdenden Akzeleration der Innovationen auf allen Gebieten) bewegt, sondern in Schüben und Sprüngen zwischen Phasen der Konstanz, ist das Tradierte der Tradition selbst bereits eine Synthese von übernommener und adaptierter Innovation und älterer Tradition, die wiederum eine solche Synthese darstellt. Kultur ist nur als Prozeß denkbar; allerdings hat Volkskultur oft eine andere Zeitdynamik als die Elitekultur. Aus der gleichen Denkkonstellation als projezierter Gegensatz zum bürgerlichen Zeitverständnis ist die fehlgeleitete Diskussion um den »Fortschritt« entstanden, der ebenfalls keine Inhalte bezeichnet, sondern den Prozess der Zukunftsorientierung ${ }^{30}$. Doch steht dieser Begriff hier weniger in Frage.

29 Vgl. z.B. Fiona Bowie, The Anthropology of Religion: an Introduction, Oxford 2000.

30 Pascal Boyer, Tradition as Truth and Communication: a cognitive description of traditional discourse,

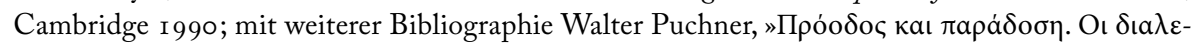

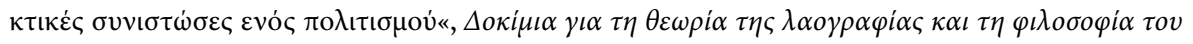
$\pi \circ \lambda \iota \tau \iota \sigma \mu o v ́ . ~ o p . c i t ., 87-126$. 


\section{ERSTER TEIL: PERFORMANZ}




\section{Einleitung: Der performative turn in der vergleichenden Balkanologie}

Der performative turn, zusammen mit dem spatial turn und anderen "Wenden« um I $990^{1}$, stellt eine Re-Orientierung methodologischer Sichtweisen in den Kulturwissenschaften dar, die die Phase holistischer und a-historischer Konzepte wie Strukturalismus und Semiotik mit ihrer Interpretationsstrategie der Erfassung der Wirklichkeit als (lesbarem) Text ablöst, und dem postmodernen Partikularismus insofern Rechnung trägt, als nun auch das Unvorhersehbare des Kommunikationsverlaufs einbezogen wird ${ }^{2}$. Ausgehend von der Sprechakt-Theorie von Austin und Searle wird das Gesagte nicht bloß als transmitted message zur Dechiffrierung verstanden, sondern das Sagen selbst als Handlungsakt einer Interaktion ${ }^{3}$, der sprachbegleitend aber auch nonverbal vor sich gehen kann. Die Folkloristik erfaßt das Erzählen und Singen als eine darstellende Tätigkeit, die ein Auditorium voraussetzt und sich nicht nur auf die Sprache bzw. die paralinguistischen Zeichen beschränkt ${ }^{4}$. Der definitorisch kaum noch eingrenzbare Begriff Performanz $z^{5}$ läßt sich semantisch nach zwei Grundrichtungen hin ausfalten: als aus-

I Jörg Döring/Tristan Thielmann (eds.), Spatial Turn. Das Raumparadigma in den Kultur- und Sozialwissenschaften, Bielefeld 2008, Nigel J. Thrift, Spatial Formations, London 1996. Zum performative turn vgl. auch Peter Dirksmeier/Ilse Helbrecht, »Time, Non-representational Theory and the >Performative Turn $<$ Towards a New Methodology in Qualitative Social Research«, Forum: Qualitative Social Research 9 (2008) I-24.

2 Erika Fischer-Lichte, »Einleitende Thesen zum Aufführungsbegriff «, dies./Clemens Risi/Jens Roselt (eds.): Kunst der Auffübrung - Auffübrung der Kunst, Berlin 2004, I I-26. Als charakteristische Eigenschaften der Performativität der tatsächlichen Aufführung, im Unterschied zur Inszenierung als Programmierung des intendierten Bühnenereignisses, werden Unvorhersehbarkeit, Ambivalenz (destruktiv oder produktiv), Wahrnehmung (Rezeption, die Ökonomie der Aufmerksamkeit im Zusammenspiel von Imagination, Erinnerung und Reflexion) und transformative Kraft bezeichnet (dies., Performativität, op. cit.). Vgl. auch Sebastian Nestler, Performative Kritik. Eine philosophische Intervention in den Begriffsapparat der Cultural Studies, Bielefeld $20 \mathrm{I}$.

3 John L. Austin, How to do things with words, Oxford I 962, John R. Searle, »Collective Intentions and Actions", Ph. R. Cohen/J. Morgan/M. E. Pollack (eds.), Intentions in Communication, Cambridge/Mass. I 990, 40I-4I 5 .

4 Donald Braid, »Performanz«, Enzyklopädie des Märchens ıо (200I) 730-743 mit umfangreicher Bibliographie.

5 Carlson, op. cit., 6 f. Weiters in Auswahl: Dell Hymes, »Breakthrough into performance«, D. BenAmos/K. S. Goldstein (eds.), Folklore: Performance and Communication, The Hague 1975, I I-74, Richard Schechner, Performance Studies. An Introduction, New York 2006, ders., »Ritual and perfor- 
fübren und auffübren. Beiden Aspekten wird hier Rechnung getragen, denn Ritualakte als selbstreferenzielle Handlungen können in der Symbolvermittlung auch als Teile von Interaktionsformen verstanden werden (mit oder ohne Publikum) bzw. bei Opferhandlungen etwa gehören die adressierten Instanzen der Imagination an. In der Ausdifferenzierung der Kommunikationssituation (mit oder ohne Zuschauer) konstituiert sich der Grad der Theaterhaftigkeit einer Handlung ${ }^{6}$, die Rezeptionsorientiertheit wird durch die Festlegung der Modalitäten und des Handlungsrahmens nach raumzeitlichen und okkasionellen Kriterien unterstrichen. Das Begriffsbündel Ritus/Brauch/dromenonwobei jeder Ausdruck aus verschiedenen Wissenschaftstraditionen herrührt - bezeichnet formverfestigte und repetierte Handlungsakte vor einem bestimmten Sinnhintergrund mit einem gewissen Variationsspielraum, die in ihrer Herausgehobenheit aus der Alltagswirklichkeit die Beziehung zwischen Realität und Imagination strukturieren ${ }^{7}$; im Falle eines (partiellen) Glaubensverlustes an die magisch-religiöse Wirkmächtigkeit dieser Aktionen kann die spielhafte Komponente eines konsequenzverminderten Probehandelns zunehmen, wobei ästhetische und kommunikative, zuschauerorientierte und theaterhafte Darstellungsstrategien dominant werden ${ }^{8}$. Damit ist der Übergang zum popularen Folklore-Theater schon kurz beschrieben'.

Diese performativen Dimensionen sind jedoch bereits dem Sakralritus inhärent und es ist wirklichkeitsinadäquat, sich diesen Übergang als eine kontinuierliche Entwicklung vorzustellen ${ }^{10}$. Was Ritus ist, darüber gehen die Meinungen von Dutzenden von

mance «, Tim Ingold (ed.), Companion Encyclopedia of Anthropology, London/New York 1995, 6 I 3 6 1 5 , E. Schieffelin, »Problematising Performance«, F. Hughes-Freeland (ed.), Ritual, Performance, Media, London 1998, I 94-207, Tracy C. Davis, The Cambridge Companion to Performance Studies, Illinois 2008, Uwe Wirth (ed.), Performanz. Zwischen Sprachphilosophie und Kulturwissenschaften, Frankfurt/M. 2002, Richard Bauman, Verbal Art as Performance, Illinois ${ }^{2}$ I 984, ders., "Differential Identity and the Social Base of Folklore«, Americo Paredes/Richard Bauman (eds.), Toward New Perspectives in Folklore, Austin/London 1972, 3 I-4I I ders., Story, Performance, and Event, New York I 986, ders./Donald Braid, »The Ethnography of Performance in the Study of Oral Traditions«, John M. Foley (ed.), Teaching Oral Traditions, New York 1 998, I06-1 2 2, Linda Dégh, Narratives in Society. A Performer-Centered Study of Narration, Helsinki 1995 (FFC 255), etc.

6 Andreas Kotte, Theaterwissenschaft. Eine Einführung, Wien/Köln/Weimar 2005, 62-66.

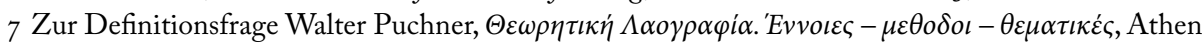
2009, 1 80-206.

8 Zum Begriff des konsequenzverminderten Probehandelns Puchner, Brauchtumserscheinungen, op. cit., 335-353. und von dort übernommen bei Kotte, op. cit., I 5 f., 3 I $\mathrm{f}$.

9 Richard Bauman (ed.), Folklore, cultural performances and popular entertainments, Oxford/New York I 992.

Io Zur Kritik des Entwicklungsbegriffes im Sakraltheater zwischen Ritus und performance Walter Puchner, Studien zum Kulturkontext der liturgischen Szene, 2 Bde., Wien I 99 I (Österr. Akad. d. Wiss., phil.-hist. K1., Denkschriften 2 I6) I 9-I 2. 
Definitionsversuchen weit auseinander, und es ist hier nicht der Ort, diese Divergenzen in ihrer Hinsichtlichkeit auszudiskutieren: In der Folge von Victor Turner und seinen einflußreichen Ansichten ${ }^{11}$ ist es zu immer lockereren und unverbindlicheren Beschreibungen gekommen, wo sich der Begriff bereits aufzulösen beginnt und sich auf die Wiederholung reduziert ${ }^{12}$, die vielleicht auch der tieferliegende Ursprung alles Ritualen gewesen sein mag ${ }^{13}$, das jegliche Formen von Übergangsphasen zu meistern hat ${ }^{14}$. In einem gewissen Sinne ist jede Kulturmanifestation kommunikativ ausgerichtet; dies gilt vor allem für die popularen Oralkulturen, wobei jedoch die Sprache keine Voraussetzung sine qua non ist $^{15}$. Der nonverbale Ritualakt stellt eine Art Meta-Sprache dar, die jedoch ebenso auf kommunikatives Verstehen ausgerichtet ist, auch wenn dieses auf Schwundstufen nicht mehr einlösbar ist. Die Mythos-Ritus-Kontroverse ist eindeutig zugunsten der Vorgängigkeit des Ritualaspekts gelöst worden, ohne daß die Mythologie nur auf ätiologische Sagen hätte reduziert werden müssen.

Performanz und Ritualität stehen demnach in einer dynamischen Wechselbeziehung: Sakralhandlungen oder auch therapeutische Rituale sind von einer gewissen teleologischen Zweckhaftigkeit bestimmt, die imaginäre bzw. reale Ziele verfolgt; Performanz in Reinform, wie etwa bei der professionellen Schaustellerei, ist aus dem magisch-religiösen bzw. magisch-therapeutischen Vorstellungsgeflecht herausgetreten und dient der

I I Victor Turner, The anthropology of performance, New York I 986 bzw. seine früheren Arbeiten wie From Ritual to Theater. The Human Seriousness of Play, New York 1982.

I 2 Z.B. »ritual is pure activity, without meaning or goal (Catherine M. Bell, Ritual Theory, Ritual Practice, New York/Oxford I 992, I). Vgl. auch Axel Michaelis, »Le rituel pour le rituel oder wie sinnlos sind Rituale«, C. Caduff/J. Pfaff-Czernecka (eds.), Rituale heute. Theorien - Kontroversen - Entwürfe, Berlin I 999, 23-47, Jack Goody, »Against >Ritualı: Loosely Structured Thoughts on a Loosely Defined Topic«, S. F. Moore/B. G. Myerhoff (eds.), Secular Ritual, Assen/Amsterdam 1977, 25-35. Weiters: Tomas Gerholm, »On ritual: a post-modernist view«, Ethnos 3-4 (r 988) I 90-203, Jan Snoek, "Defining >Rituals«", J. Kreinath/J. Snoek/M. Strausberg (eds.), Theorizing Rituals: Classical Topics, Theoretical Approaches, Analytical Concepts, Annotated Bibliography, Leiden 2006, 3-1 5, Stanley J. Tambiah, »A Performative Approach to Ritual«, Proceedings of the British Academy 65 ( 1 979) I I $3-169$ usw.

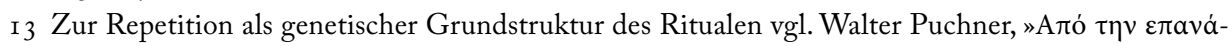

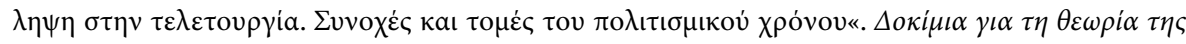

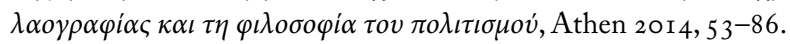

I 4 Terence S. Turner, "Transformation, hierarchy, and transcendence: a reformulation of Van Gennep's model of the structure of rites de passage«, S. F. Moore/B. G. Myerhoff (eds.), Secular ritual, Assen/ Amsterdam i 977, 65-70.

I5 Ruth Finnegan, Oral traditions and the verbal arts: a guide to research practice, London/New York 1 992. Zum Begriff der Popularkultur Ray B. Browne, »Popular Culture: Notes toward a Definition«, R. B. Browne/R. J. Ambrosetti (eds.), Popular Culture and Curricula, Bowling Green, OH I 972, 4-7, J. Storey, An Introduction to Cultural Theory and Popular Culture, London 1993, 7-10. 
Belustigung und Unterhaltung. Erkennungszeichen dieser funktionalen Autonomie ist das Fehlen einer datumsmäßigen oder okkasionellen Bindung bzw. der größere Variationsspielraum bei den Repetitionen der an sich immer noch stereotypen Aktionsform. Performativität und Ritualität treten in den Oralkulturen selten in Reinform auf: Ein gewisser darstellender Aspekt ist auch fast allen Sakralhandlungen eigen, und Reste von Ritualelementen lassen sich noch in popularen Folklore- oder Volkstheatern nachweisen.

Nicht auf alle Aspekte des Performativen in den Oralkulturen Südosteuropas kann hier eingegangen werden. Die Macht und Allgegenwart der Öffentlichkeit in den dörflichen Kleingruppen der traditionellen Kommunitäten des Balkanraums, das kontrollierende Auge und Ohr der Nachbarn sowie die Bühne der Selbstpräsentation in Kaffeehaus und am Brunnen lassen kaum Raum für privacy, abgesehen von der Überwachung durch metaphysische und imaginäre Instanzen, so daß sich ein großer Teil des Gesamtlebens der Einzelperson in einer Zone permanenter Performativität und Selbstdarstellung abspielt, welche die Einhaltung der verhaltensregulierenden Normen der Sozietät demonstriert und den Ruf von Person und Familie sowie das soziale Ansehen zu verteidigen hat. Zahlreiche kultur- und sozialanthropologische Studien haben diese Aspekte des "Lebenstheaters « untersuch $t^{16}$. Die vorliegende Darstellung beschränkt sich daher, nach einem einleitenden Kapitel zu Formen nonverbaler Kommunikation, exklusiv auf performative Riten wie Umzüge und Prozessionen, Maske und Verkleidung, Zeremonien und Festivitäten, und im Übergang auch zu ersten Theaterformen wie Rollenspiel und Dialog, populares Amateurtheater sowie auf professionelle Schaustellerei, Puppenund Schattentheater bzw. auf Sonderformen der Performativität wie Spiel und Sport, magische Praktiken und empirische Therapeutik. Letzteres steht bereits im Übergang zum zweiten Teil, doch verfügen magische Praktiken und empirische Therapeutik oft über deutlich performative Elemente.

Eine solche Ausweitung stellt freilich die Frage, warum dann nicht auch Musik und Tanz, die in Südosteuropa universell präsent sind und deutlich darstellende Züge tragen. Vor allem letzterer ist vorwiegend ein Schauerlebnis. Doch ist es gerade diese Universalität, die sich einer komprimierten Darstellung entzieht, denn mit den Reigen- und Rundtänzen, den Paar- und Solotänzen (mit und ohne Gesang) und ihren choreographischen Schrittkombinationen, Körperbewegungen und pantomimischen Elementen wäre auch das wechselnde Tanzrepertoire zu erfassen, die Tanzgelegenheiten, die Trachten und Kostüme, die Kommunikation der Einzeltänzer mit den Musikern (Blickkontakt, Gebärdensprache), Rezeptions- und Reaktionsformen der Zuschauer, Volkstanzgruppen, Folklorefestivals usw. Die Ethnochoreologie Südosteuropas ist ein

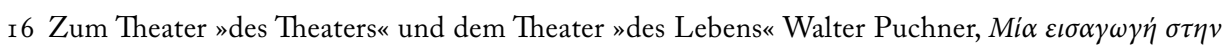

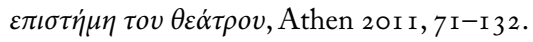


eigener Wissenschaftszweig ${ }^{17}$. Ähnliches gilt für die Musik: Neben Stilen, Polyphonie, Singweisen, Stimm-Modulationen, Spielgelegenheiten und Repertoire wäre die gesamte Instrumentenkunde ${ }^{18}$ bis hin zu den abgestimmten Viehglocken der Herde

I7 Vgl. in Auswahl: Olivera Vasić, Etnokoreologija, Beograd 2004, Richard Wolfram, »Der Volkstanz als kulturelle Ausdrucksform der südosteuropäischen Völker«, Die Volkskultur der südosteuropäischen Volker, München 1962, 63-85, Felix Hoerburger, "Gestalt und Gestaltung im Volkstanz«, Studia Musicologica Academiae Scientiarum Hungaricae 6 (1964) 3 I I-3 I6, Antony Shay/Dick Crum, Balkan Dance: Essays on characteristics, performance and teaching, Farland \& Co. 2008, Ljubica S. Janković/ Danica S. Janković, "Masked Dancers in Serbia«, Journal of the International Folk Music Council I/4 ( 1968 223-227, Robert H. Leibman, Dancing Bears and Purple Transformations: The Structure of Dance in the Balkans (Macedonia, Serbia, Bulgaria), $\mathrm{PhD}$ diss., University of Pennsylvania I992, György Martin, »East-European Relations of Hungarian Dance Types«, Europa et Hungaria. Congressus ethnographicus in Hungaria I963 $_{3}$, Budapest 1965, 469-5 I 5, ders., »Die balkanischen Beziehungen im ungarischen Mädchenreigen«, Makedonski Folklor 7/1 3 ( I 974) 71-75, Olivera Mladenović, „Forms and Types of Serbian Folk Dances«, Dance Studies 4 (1980) 53-85, dies. »La danse (ronde) féminine des peuples balkaniques", Actes du IIe congrès international des études du Sud-est européen, Athènes I 98 I, Bd. 6, 509-5 I 5, Ernö Pesovár, "Die geschichtlichen Probleme der Paartänze im Spiegel der südosteuropäischen Tanzüberlieferung", Studia musicologica Academiae Scientiarum Hungaricae I5 (1973) I4I-163, Janet S. Reineck, Wedding Dances from Kossovo, Yugoslavia: a Structural and Contextual Analysis, M. A. thesis, University of California, Los Angeles I 986, Olga Skovran/Olivera Mladenović, "Problèmes et méthodes de l'adaption scéniques des dances populaires«, Journal of the International Folk Music Council 8 (1956) 41-45, Lisbet Torp, Chain and Round Dance Patterns - a Method for Structural Analysis and its Application to European Material, 3 Bde., Copenhagen I990, Frank Hall/Irene Loutzaki (eds.), Traditional dance and its historical sources. Creative process in dance: improvisation and composition, Istanbul 2000, Jaffé Allenby, Hungarian Dance, Folk Dance Enterprise I990, George Buday, Dances of Hungary, New York I950, Béla Bartók, Roumanian Folk Dances, London 2004, Ivan Donkov, Folk Dances from the Region of Veliko Turnovo, Bulgaria, Sofia 1997, Anca Giurchescu/Sunni Bloland, Romanian Traditional Dance. A Contextual and Structured Approach, Mill Vally, Calif. 1995, Ricke Holden/Mary Vouras, Greek Folk Dances, Newark/N. J. I 965, Raina Katsarova, Dances of Bulgaria, London 195 I, dies./Kiril Djenev, Bulgarian Folk Dances, Cambridge/Mass. 1 976, György Martin, Hungarian Folk Dances, Budapest I 974, Theodore Petrides, Greek Dances,

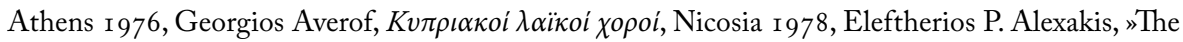
dance in Greece«, Ethnografia 8 (1992) 7 I-86, I 9 I-20I, Jane K. Cowan, Dance and body politics in Northern Greece, Princeton NJ I 990, Rena Loutzaki, The traditional dance in Greece, Thessaloniki

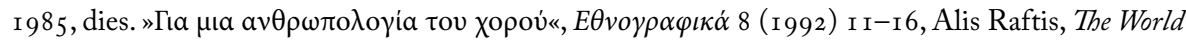
of Greek Dance, Athens I 987 , etc. Weitere Bibliographie in Dick Oakes, Folk Dance Bibliography 20 I I (http://www.phantomranch.net/folkdanc/teaching/bibliofd.htm), Puchner, Greek Folk Culture, op. cit., I 68-I 73 (Nr. I 774-1838), Roth, South Slavic Folk Culture, op. cit., 2 I 3-2 20 (Nr. 301 3-3 I 56). I 8 Leopold Kretzenbacher, »Südosteuropäische Primitivinstrumente vom >Rummelpott<-Typ in vergleichend-musikvolkskundlicher Forschung", Volksmusik Südosteuropas, München 1 966, 50-97, Jerko Belzić/Walter W. Kolar, A Survey of Folk Musical Instruments in Yugoslavia. Membranophones, Pittsburgh/Penns. 1978, Fivos Anoyanakis, Greek Popular Musical Instruments, Athens 1979, Chr. Ahrens, Aulos-touloum-fischietti. Antike Traditionen in der Musik der Pontos-Griechen und der Graeko- 
darzustellen, Taktformen und Tonleitern, Klein- und Großformen der Improvisation usw. Die Ethnomusikologie Südosteuropas verwaltet hier ein bedeutendes Wissensfeld $^{19}$. Aus diesen Gründen müssen, ähnlich wie im zweiten Band zur Folklore Südosteuropas, Musik und Tanz hier ausgeklammert bleiben, da sie von sich aus einer ganz eigenen Darstellung bedürfen.

\section{FORMEN NONVERBALER KOMMUNIKATION : GESTEN UND GE B ÄRDEN}

Körperlichkeit und Körperverständnis sind in den traditionellen Oralkulturen Südosteuropas in anderer Form eine Selbstverständlichkeit als in den Elitekulturen des Westens $^{20}$, die erst mit dem Beginn des 20. Jh.s eine Wende von der ratio-orientierten

Kalabrier, Aachen I 987, M. Askari/R. M. Brand1/H.-J. Mauksch, „Das volkstümliche Klarinettenensemble zwischen Orient und Balkan«, Studia instrumentorum musicae popularis 8 (Stockholm I 985 ) 67-85, Laurence Picken, Folk Musical Instruments of Turkey, London 1975, Nikos Malliaras,

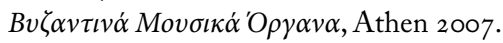

I 9 Felix Hoerburger, Volksmusikforschung. Aufsätze und Vorträge 1953-1984 über Volkstanz und instrumentale Volksmusik, Laaber I 986, Susanne Ziegler, „Der Einfluß der Türken auf die Musik der Balkanvölker«, P. Ausländer/J. Fritsch (eds.), Weltmusik 3, Köln I 986, 88-ı02, Ghizela Suliteanu, "Antique South-East-European Elements in the Rumanian and Greek Contemporary Musical Folklore«, A. Mauerhofer (ed.), Historische Volksmusikforschung, Graz 1985, I 83-208, Kurt Reinhard, »Musik am Schwarzen Meer«, Jahrbuch für Musikalische Volks- und Völkerkunde 2 (1966) 9-58, Christian Ahrens, Instrumentale Musikstile an der osttürkischen Schwarzmeerküste, München I 970, Biljana Milavonić, "The Balkans as a Cultural Symbol in the Serbian Music of the First Half of

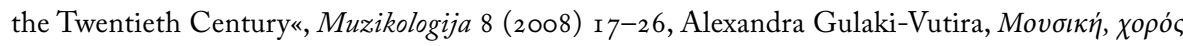

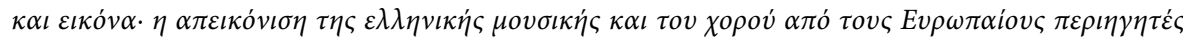

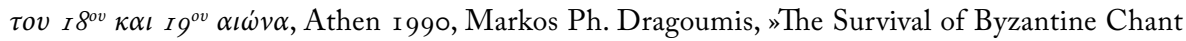
in the Monophonic Music of the Modern Greek Church", Studies in Eastern Chant I ( 1966) 9-36, Tiberiu Alexandru, Romanian Folk Music, Bucharest r 980, Doris \& Erich Stockmann, »Die vokale Bordun-Mehrstimmigkeit in Südalbanien«, Les Colloques de Wégimont 4 (Liège I 964) 85-135, Boris A. Kremenliev, Bulgarian-Macedonian Folk Music, Berkeley I952, Rudolf Maria Brandl, »Regionalstile traditioneller Musik in Griechenland«, R. Lauer/P. Schreiner (eds.), Die Kultur Griechenlands in Mittelalter und Neuzeit, Göttingen I 996, 308-440, ders., "Die Tektonik der griechischen Volksmusik (das skopos-Prinzip)«, H. Braun (ed.), Probleme der Volksmusikforschung, Bern etc. I 990, I 35-1 57, Egon Wellesz, A History of Byzantine Music and Hymnography, Oxford I 96 I, Mirjana Laušević, Balkan Fascination, Oxford 2007, usw. Weiter Bibliographie in Puchner, Greek Folk Culture, op. cit., 349-36r (Nr. 3993-4I 33) und Roth, South Slavic Folk Culture, op. cit., 346-364 (Nr. 5 I I 3-5452).

20 Vgl. den Kongreßband Dagmar Burkhart (ed.), Körper, Essen und Trinken im Kulturverständnis der Balkanvölker (Beiträge zur Tagung vom 19.-24. Nov. 1989 in Hamburg), Berlin I 99 I. 
Kultur des bürgerlichen Zeitalters zur Gesamtsinnlichkeit vollziehen ${ }^{21}$. Erscheinung (Kleidung), Verhalten und Bewegung bilden die nonverbale Körpersprache, die in oral dominierten Kulturschichten im allgemeinen stärker ausgeprägt ist als in vorwiegend schriftlichen Elitekulturen ${ }^{22}$ und mit ihrem kultur- und regionsspezifischen Zeichenrepertoire der raschen Verständigung dient ${ }^{23}$. Dies betrifft besonders spezielle Körperzonen, die in verschiedenen Kommunikationssituationen unterschiedlich eingesetzt werden: das Auge (Blickkontakt, Flirt), das Gesicht (Mimik), die Hände (Gestik), der Gesamtkörper und seine Haltung im Sitzen, Stehen, Gehen und seine Plazierung im Raum (Proxemik, Abstandsverhältnisse zum Kommunikationspartner). Die Dichte selbst der rein zweckorientierten Blickkontakte ist im mediterranen und balkanischen Bereich im allgemeinen hoch zu veranschlagen: im Straßenverkehr, beim Bestellungswunsch im Kaffeehaus, zwischen Instrumentenspielern und Tänzern. Zu diesen Formen der Kontaktaufnahme gibt es kaum Untersuchungen, doch auf der Dynamik und Dichte der Blickkontakte beruhen Vorstellungen wie evil eye und böser Blick, die als baskania bis ins Altertum zurückreichen, ähnlich wie die traditionellen Klagegebärden bei der Totenlamentation ${ }^{24}$. Die Kodifizierungsversuche beschränken sich eher auf typisierte Gesten und Gebärden ${ }^{25}$, doch ist eine nationale Zuordnung kaum möglich, da

2 I Dazu ausführlich in Walter Puchner, „Gesten, Gebärden, Körpersprache. Am Beispiel Griechenlands", Studien zur Volkskunde Südosteuropas und des mediterranen Raums, Wien/Köln/Weimar 2009,

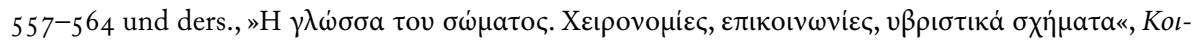

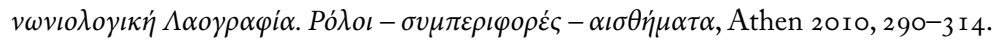

22 Vgl. dazu die bekannten Ansichten von Norbert Elias über den Zivilisationsprozeß (Über den Prozeß der Zivilisation, 2 Bde., Bern/München I969).

23 Dazu schon Wilhelm Wundt, Die Gebärdensprache. Völkerpsychologie, Bd. I, Stuttgart I 90o, Marcel Mauss, »Les techniques de corps«, Journal de pyschologie et pathologique 32/3-4 (I 935 ) 279-293, David Efron, Gesture, Race and Culture, The Hague/Paris 1972 (I94I); zur Verständigungskapazität Paul Ekman/Wallace V. Friesen, »The repertoire of nonverbal behavior: Categories, origins, usage and coding", Semiotica I ( 1 969) 49-98, McDonald Critchley, Silent Language, London I 975, Raymond Firth, Symbols, Public and Private, London 1973, R. L. Saitz/E. C. Cervenka, Handbook of Gestures: Columbia and the United States, Den Haag 1972 usw.

24 Margaret Alexiou, The ritual lament in Greek tradition, Cambridge 1974 (erw. Aufl. von Dimitrios Yatromanolakis und Panagiotis Roilos, Lanham/Boulder/New York/Oxford 2002). Vgl. auch die erschütternden Photographien eines jungen maniatischen Klageweibs bei Dikaios V. Vagiakakos,

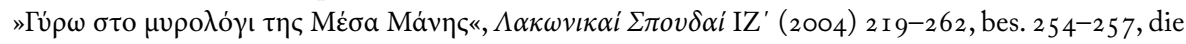
an eine Tragödienaufführung erinnern.

25 Für den Tourismus in Griechenland etwa W. Papas, Instant Greek, Athens 1972, als sprachbeglei-

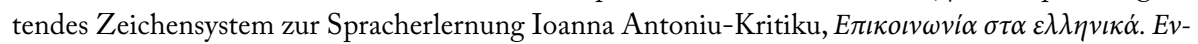

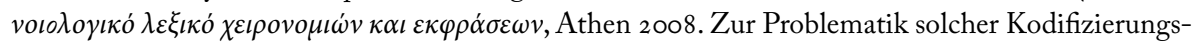
versuche vgl. auch Lenz Kriss-Rettenbeck, »Probleme der volkskundlichen Gebärdenforschung", Bayerisches Jahrbuch für Volkskunde I 964-65, 20-22. Zu weiteren Studien in Auswahl: Rainer Wehse, 
der Verbreitungsradius sich meist auf größere geographische Kommunikationsräume erstreckt. In der Folge seien einige Beispiele aus dem mimischen, gestischen und proxemischen Bereich exemplarisch dargestellt.

Ein typisches Beispiel ist das "griechische« Nein als Zeichen der Ablehnung: nicht das Kopfschütteln ${ }^{26}$, sondern das Zurückwerfen des Kopfes mit (oder ohne) dem Hochziehen der Augenbrauen, manchmal verbunden auch mit einem Schnalzlaut der Zunge. Dieses nonverbale mimisch-gestische Zeichen der Verneinung einer Frage ist jedoch in einem viel größeren Raum gebräuchlich oder zumindest verständlich ${ }^{27}$ : in Kleinasien, Dalmatien, auf Malta, Sizilien, in Süditalien, Bulgarien und in den arabischen Ländern; in Süditalien kann das Zurückwerfen des Kopfes noch durch einen Kinnklaps verstärkt werden. Exakte Grenzziehungen lassen sich selten verifizieren; etwa im vorliegenden Fall die erste Gebirgskette nördlich von Neapel. Doch solche Kodifizierungen aus den Kompendien der empirischen Kulturpsychologie bleiben in gezielter Feldforschung erst zu verifizieren und in ihren Variationsmöglichkeiten zu modifizieren ${ }^{28}$. Vor allem gehen hier die empirisch faßbaren individuellen Ausführungs- und Anwendungsformen verloren, die einen breiten Variationsspielraum aufweisen oder (wie im Sprichwort) auch die Möglichkeiten ironischen und unkonventionellen Gebrauchs ${ }^{29}$.

»Gebärde«, Enzyklopädie des Märchens 5 ( 1987 ) 782-792, W. D. Brewer, »Patterns of Gesture among the Levantine Arabs«, American Antbropologist 53 (I95 I) 232-237, David Efron, Gesture, Race and Culture, Den Haag 1972, G. Müller, »Über die geographische Verbreitung einiger Gesten im östlichen Mittelmeergebiet und dem nahen Orient«, Zeitschrift für Ethnologie 7I (1939) 99-102, K. Haiding, Von der Gestensprache des Märchenerzäblers, Helsinki 1959 (FFC I 55), István Sándor, »Dramaturgy of Tale-telling", Acta Ethnographica Academiae Scientiarum Hungaricae I6 (I 967 ) 305-338, Maja Bošković-Stulli, »Darstellerische Aspekte des Erzählen«, Fabula 26 (I985) 58-7 I.

26 Roman Jakobson, »Motor signs for >Yes« and `No«", Language Sociology I ( 1972) 9I-96.

27 Nur bei äthiopischen Stämmen, auf Borneo und den Philippinen hat das Zeichen die gegenteilige Bedeutung der Bejahung.

28 Desmond Morris, Der Mensch mit dem wir leben, München r982, $69 \mathrm{f}$.

$29 »$ Ersatzgesten durch bloßes Hochziehen der Augenbrauen, wobei der Kopf nicht bewegt wird, aber intensiver Blickkontakt mit dem Fragenden besteht; auch ist das Kopfschütteln nicht gänzlich unbekannt (ähnlich wie in Süditalien), vor allem als Ausdruck des Nichtwissens ist es in AuskunftsSituationen anzutreffen. Dazu kommen noch bedeutungsmäßige Nuancierungen: Das Zurückwerfen des Kopfes hat starke emotionelle Färbung und Betonung bis hin zur Verbotsanzeige. Das Zungenschnalzen, oft verbunden mit einem Zuspitzen der Lippen, kann auch ganz allein (also bloß akustisch) die Bedeutung der Ablehnung hervorbingen. Oder das Hochziehen der Augenbrauen wird mit einem Hochheben der Hand verbunden usw. Das sogenannte >Griechische Nein besteht aus einem Set von Zeichenmöglichkeiten, die miteinander kombiniert werden können. Dies scheint sowohl semantisch relevant (Verstärkung, Abschwächung) als auch situationsgebunden zu sein (der gerade Rauchende etwa kann nicht mit der Zunge schnalzen), ist aber auch vom verschiedenen Gestenrepertoire des einzelnen Individuums, seiner emotionellen Gestimmtheit und Laune, abhängig. 
Universellere Verbreitung in Zeit und Raum, trotzdem unverstanden in Mittelund Westeuropa, weist das zweite Beispiel auf: das Entgegenhalten der Handflächen mit gespreizten Fingern als Ausdruck des Schimpfes und der Verachtung, eine Schimpfgebärde von fast ritueller Intensität, deren Grundlage eigentlich das Apotropäum und die Prophylaxe vor dem Bösen Blick darstellt ${ }^{30}$. Die abwehrende Hand, allerdings mit geschlossenen Fingern und in der Handfläche ein abgebildetes blaues oder grünes Auge, ist als »Hamsa«-Amulett oder »Hand der Fatima« im gesamten Mittelmeerraum und im Mittleren Osten bis tief nach Zentralasien, im arabischen Raum und in Mittel- und Nordafrika verbreitet, durch die Kolonialisierung auch in Hispano-Amerika, während der Glaube an das evil eye in Mittel- und Westeuropa zurückgegangen ist ${ }^{31}$. Die abwehrende Hand mit den gespreizten Fingern ist als apotropäische Geste sowohl dem Altertum ${ }^{32}$ bekannt als dem byzantinischen Jahrtausend $^{33}$ : Die schlammspritzende Hand (muza oder muntza) ist bei Schandumzügen und Prangerprozessionen der diapompeusis im byzantinischen Hippodrom zu beobachten $^{34}$, und steht etymologisch in Zusammenhang mit anderen entehrenden Praktiken, wie Schwärzen, Rußen, Pechen und Teeren ${ }^{35}$; Rußschwärzen und Haupthaarund Bartscheren gehören noch bis ins I9. Jh. zu den Prangerhandlungen im Dorfleben

Systematische Untersuchungen, sowohl im Labor mit Video-Kamera und elaboriertem Fragebogen wie auch durch Beobachtung im Feld würden hier vermutlich ein ganzes Spektrum von Möglichkeiten sichbar machen. Es wäre zu zeigen, daß der abstrahierte Stereotyp auch hier Wissensersatz ist und vielfältige Kombinationsmöglichkeiten und Bedeutungsschattierungen verdeckt« (Puchner, »Gesten, Gebärden, Körpersprache«, op. cit., 56 I f.).

30 Bernhard Schmidt, »Der böse Blick und ähnlicher Zauber im neugriechischen Volksglauben«, Neue Jahrbücher für das klassische Altertum 3 I (I 9I 3) 574-6 13, John C. Lawson, Modern Greek Folklore and Ancient Greek Religion, Cambridge I 9 Iо, I4, Albin Lesky, »Abwehr und Verachtung in der Gebärdensprache«, Anzeiger der phil.-hist. Klasse der Österreichischen Akademie der Wissenschaften 106 (1969) I 49-I 57. Politis unterstreicht in seiner materialreichen Studie vor allem die hybride Funk-

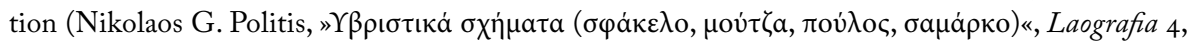
I9I 2-I3, 60 I-669).

3I Dazu noch ausführlich im zweiten Teil.

32 Sphakelos bedeutet eigentlich den Mittelfinger, und der ausgestreckte Mittelfinger hatte als infamus digitus phallische Bedeutung sowohl in Griechenland wie auch in Rom und heute noch im mediterranen Raum. Zum Vorweisen der Geschlechtsteile als apotropäische Geste im Alterum vgl. Lesky, op. cit., Politis, op. cit., 609 f., zur heutigen Verwendung Morris, op. cit., I $98 \mathrm{f}$.

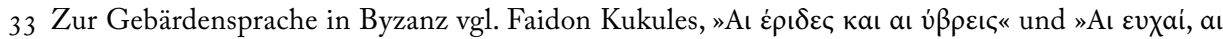

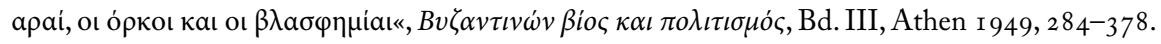

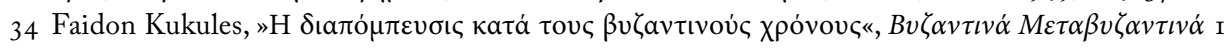
(i949) 75-гог.

35 Puchner, Brauchtumserscheinungen, op. cit., 259 f. und pass. 
für Diebe und "gefallene« Mädchen ${ }^{36}$; Schwärzen, Aschewerfen und verkehrt auf dem Esel Reiten (mit dem Schwanz in der Hand) gehören umgekehrt auch zum parodistischen »Vokabular« der Verkehrten Welt des Karnevals. Sprachgeschichtlich verweist sfakela (faskela) auf das Alterum ${ }^{37}$, die schmutzwerfende, rußende, schwärzende, entehrende offene Hand der $m u(n t) z a$ verweist auf byzantinische Praktik ${ }^{38}$. Vokabular und Praktik durchziehen die gesamte nachbyzantinische Periode ${ }^{39}$ und die aggressive Schimpfgebärde gehört im Verein mit anderen z.T. obszönen (wie Hodenweisen, Feige, der ausgestreckte Mittelfinger, intendierte Blendung durch ausgestreckten Zeige- und kleinen Finger [corna]) Gesten und keineswegs zimperlichen Verbalflüchen (skatologischer und sexueller Art, Schändung von Verwandten des Beschimpften, ja selbst von Sakralpersonen) zur Alltagsempirie im südbalkanisch-mediterranen Raum, entweder humorvoll nachsichtig abgeschwächt durch die Verwendung von nur zwei gespreizten Fingern oder verstärkt durch das Kreuzen beider ausgestreckten Hände mit den zehn gespreizten Fingern ${ }^{40}$. Auch hier ergeben sich in der Praxis viele Variationsmöglichkeiten, die sich einer katalogartigen Kodifizierung der Symbolgesten entziehen. Ähnlich wie Volkslieder und Oralerzählungen nur in Varianten existieren, ist auch dieses Gestenrepertoire in Ausführung und Bedeutungsnuancierungen nur in seinen Spielarten empirisch dokumentierbar.

Die Beziehung entehrender Schimpfgebärden zu apotropäischen Abwehrgesten, als Umkehrung der dämonischen Aggressivität bzw. gedankenloser Anwendung in einer säkularisierten Alltagswelt (»Brauch ohne Glaube«) ${ }^{41}$ als emotionsabführende Ventilhandlung in einer Stress-Situation, ist unmittelbar; der semantische Zugang durch die Etymologie und die symbolische Kinetik (z.B. magische Wirkmächtigkeit der Geschlechtsteile) führt über verschiedene Zeit- und Bedeutungsschichten, regional-, sprach- und religionsübergreifend in das animistische Weltverständnis der Totalvernetzung aller Dinge in einer prae-rationalen Lebensorganisation »vormoderner« Ge-

36 Politis, op. cit., 62 I f., 639 f., 645 f.

37 Ältere Arbeiten haben andere Etymologien vorgeschlagen (Carl Sittl, Die Gebärden der Griechen und Römer, Leipzig I 890, 102, Gustav Meyer, Neugriechische Studien, Wien I 894/95, III 69). Doch die heute anerkannte Bedeutung findet sich schon bei Adamantios Koraïs um I 800 ('A $\tau \alpha \kappa \tau \alpha$ IV 58 I).

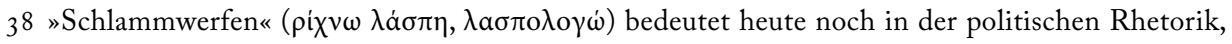
ähnlich wie das deutsche »Anschwärzen«, die falsche Anschuldigung des Sykophanten.

39 D. G. Moutsos, »The Origin of an opprobrious gesture in middle and modern Greek«, Modern Greek Studies Yearbook 7, I 99 , 353-363 ( $\mu$ ovv $\tau \zeta \omega \nu \omega$ bereits im I 2. Jh. nachzuweisen). Weitere Beispiele

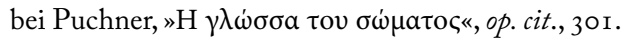

40 Weitere Details bei Puchner, Gesten, Gebärden, Körpersprache«, op. cit., 56 I .

4I Leopold Schmidt, »Brauch ohne Glaube. Die öffentlichen Bildgebärden im Wandel der Interpretationen«, Volksglaube und Volksbrauch, Berlin I 966, 289-3 2 (Nachdruck Brauch ohne Glaube, Würzburg 1977 [Ethnologia Bavarica 5]). 
sellschaftsformen. Dies gilt grundsätzlich auch für säkularisierte Sakralgebärden, auch wenn sich das hier zu exemplifizierende Beispiel des aspasmos (Umarmung durch Schulterfassen mit angedeutetem Wangenkuß) im orthodoxen Bereich Südosteuropas bewegt (dreimalig bei den Südslaven, zweimalig bei den Hellenophonen). Dieses rituell und gesellschaftlich sanktionierte Eindringen in die engste Vertrautheitsszone rund um den menschlichen Körper (proxemische Intimzone) mit Berührung und imitiertem oder ausgeführtem Wangenkuß, im Altertum, in AT und NT mehrfach nachzuweisen, auf den orthodoxen Judaskuß-Darstellungen der Sakralmalerei tausendfach dargestellt, hat nichts Erotisches an $\operatorname{sich}^{42}$, sondern ist Ehrerbietung und Darbringung positiver Gefühle, Anbetung und Proskynese zugleich wie beim Küssen von Sakralobjekten (Ikonen, Evangelien, Reliquien, Kreuzen, Epitaphen usw. $)^{43}$. Diese vergeistigte Kußgeste bedeutet in der verbalen Anwendung im Alltagsleben Umarmung, Kuß, Begrüßung und Verabschiedung zugleich ${ }^{44}$, in der Praxis ist sie, ohne das theologische Bedeutungsambiente, bloß Grußzeremoniell wie der Handschlag. Und doch haftet der Geste etwas Feierliches, Würdiges, Außerordentliches und dem Alltag Enthobenes an, das erst bei Routinebegegnungen wie beim Kaffeekränzchen oder beim Einkaufsbummel verflacht. In der Ausführungsweise ist ein großer Variationsspielraum gegeben, der hier auch nicht andeutungsweise wiedergegeben werden kann.

Und dies führt wiederum zu dem schon erwähnten Forschungsdefizit um die Varianz von Gebärden und Gesten sowohl in Ausführung, Situationskontext und Bedeutungsnuancen, die im mikro- und makroregionalen Bereich kaum noch Gegenstand von eigenen Untersuchungen geworden sind und in wörterbuchartigen Kodifizierungen mit Skizzen und Erläuterungen nur sehr ungefähr dargestellt werden können ${ }^{45}$. Es ist so, als ob die Erzählforschung sich mit der Wiedergabe eines groben Inhaltsskeletts eines Märchentypus begnügen würde, statt Varianten zu sammeln und zu vergleichen, um Variationsradius und Kontaminationsformen mit anderen Typen zu bestimmen. Denn auch die Gebärdensprache verfügt über die Möglichkeit des kreativen Umgangs mit der Konvention und besitzt eine ähnliche Ästhetik und Poesie wie die oralen Verbalmanifestationen, nur ist diese in das philologisch-verbalgeprägte Bewußtsein der Folkloristen noch nicht in dem Maße eingedrungen wie in die Sichtweise einer etwa theaterwissen-

42 Obwohl auch diese Bedeutungsnuance in der byzantinischen und nachbyzantinischen Volksliteratur

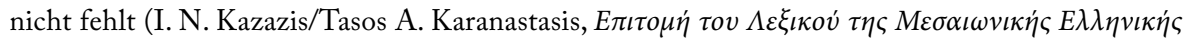

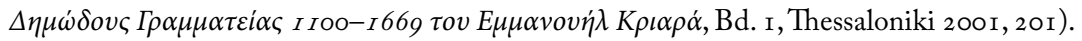

43 Michael Penn, »Performing family: ritual kissing and the construction of early Christian kinship«, Journal of Early Christian Studies 10/3 (2002) I 5 I-I 74.

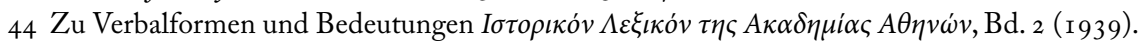

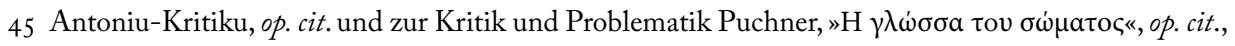
307-3I4. 
schaftlich orientierten Untersuchung, der das Gestenrepertoire, sprachbegleitend oder autonom, einer Kulturzone und eines Kommunikationsraums als untersuchenswertes Phänomen sofort ins Auge springt. Dies wird bei der Analyse von Videoaufzeichnungen von Erzählerpersönlichkeiten der Oralkultur sofort evident.

\section{PERFORMATIVE RITEN UND PROFESSIONELLE SCHAUSTELLERE I}

Dieses Kapitel bildet den Hauptteil des ersten Teils zur Performativität der Oralkulturen Südosteuropas und bewegt sich im Übergangsbereich von sakralkultischen Manifestationen und der popularen Religiosität (Volksfrömmigkeit) und magischen Praxis bis zu Vorformen und Hauptformen des ambulanten und ortsfesten improvisierten Volkstheaters, das noch ohne schriftlich fixierte Texte auskommen kann. Nach Maßgabe des Umfangs und der Reichweite des Begriffes des Performativen umfaßt dieser Übergangsbereich signifikante Teile des traditionellen öffentlichen Lebens der südosteuropäischen Kommunitäten und zeichnet die zumindest hypostasierbare Strukturentwicklung vom Ritus zum Theater in einem spezifischen teilhomogenen Kulturraum nach. Auf die theoretischen Implikationen einer solchen hypothetischen "Evolution« soll hier jedoch nicht eingegangen werden ${ }^{46}$.

\section{I PERFORMATIVE RITEN}

Aufgrund der Formenvielfalt der explizit performativen Riten in den südosteuropäischen Ländern ist es sinnvoll, zwischen einem engeren und einem weiteren Begriff des Volksschauspiels ${ }^{47}$ einen Unterschied zu machen: Die engere Begriffsfassung

46 Dazu ausführlich Walter Puchner, Brauchtumserscheinungen im griechischen Jahreslauf und ibre Beziebungen zum Volkstheater. Theaterwissenschaftlich-volkskundliche Querschnittstudien zur südbalkan-mediterranen Volkskultur, Wien 1977 (Veröffentlichungen des Österr. Museum für Volkskunde XVIII), auch Nora A. Tahy, Das theatralische Brauchtum des ungarischen Sprachbereichs, Frankfurt/M. etc. I 989.

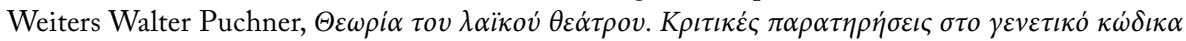

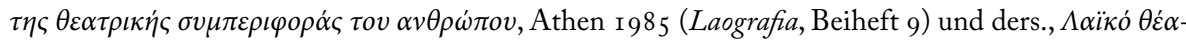

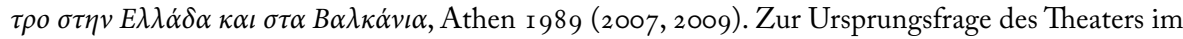
rituellen Brauchtum vgl. auch die südosteuropäische Bibliographie in Walter Puchner, »Performative Riten, Volksschauspiel und Volkstheater in Südosteuropa. Vom Dromenon zum Drama«, Studien zur Volkskunde Südosteuropas und des mediterranen Raums, Wien/Köln/Weimar 2009, 253-298, bes. 254-257 sowie den Artikel dess., "Volksschauspiel« in der Enzyklopädie des Märchens I 4 (20 I I) $350-360$.

47 Der etwas unscharfe Dachbegriff für die Übergangszone zwischen Ritus und Theater ist nach wie 
umfaßt dabei termin- und anlaßgebundene Brauchspiele mit gewöhnlich noch erkennbarem magisch-religiösem Fundament und der tragenden Umzugsstruktur, an die sich symbolische Aktionen, Maskierung und Verkleidung sowie szenische Elemente anlagern können; der erweiterte Definitionsrahmen inkludiert auch komplexere Formen (manchmal auch mit schriftlich fixiertem Text): In katholisch-protestantischen Bereichen Südosteuropas entstammen solche in der Regel organisierten Theaterformen religiöser oder weltlicher Provenienz aus den mittelalterlichen und frühneuzeitlichen Jahrhunderten, die den Restriktionen und Verboten der mitteleuropäischen Aufklärung entgangen sind und in Ungarn, Slovenien, Kroatien und im Karpatenraum noch bis zum Zweiten Weltkrieg weiterleben. Diese regelrechten Vorstellungen stehen bereits im Übergang zum popularen Amateurtheater. Beide Kategorien sind jedoch jenseits ihrer morphologischen Formenvielfalt durch die konstanten Funktionen des magisch-religiösen Ritualrahmens miteinander verbunden: Fruchbarkeitsförderung und Abwehr jeglichen Übels bzw. darstellerische Verlebendigung von (christlichen) Glaubensinhalten im ekklesialen Heortologion. Diese Funktionen können bei komplexeren Schauspielformen auch verblassen und der Unterhaltung und Schaulust, Satire und Parodie, der Verkehrten Welt des Karnevals bzw. ästhetischem Genuß eine größere Bedeutung einräumen. Die Lust am Schönen ist jedoch auch schon der einfachen Festkleidung (als erster Form der Verkleidung in

vor heuristisch unersetzlich, da der englische Begriff »drama« noch problematischer ist. Vgl. eine der rezenten Definitionen und Deskriptionen: »Der gegen Ende des I 8. Jh.s beiläufig entstandene, mit definitorischen Schwierigkeiten behaftete Brücken- und Sammelbegriff V. deckt einen breiten Spielraum ab. Sein Spektrum reicht von performativen Riten, Spiel- und Umzugsbräuchen mit magisch-religiösen Handlungen (bei denen der zugehörige Glaubenshintergrund auch verblaßt sein kann) bis zu regelrechten theateralischen Aufführungen mit oder ohne schriftl. Vorlage, die von professionellen Schauspielern oder Laien dargeboten werden können. Dabei ist die Spaltung in aktive und passive Teilnehmer, Schauspieler und Zuschauer, deutlich ausgeprägt und bleibt während der gesamten Aktion irreversibel. Eines der grundsätzlichen Merkmale, die das V. vom Volkstheater unterscheiden, ist die rituelle Grundlage kalendermäßiger Terminbindung; von anderen Brauchformen unterscheidet es der darstellende Spielcharakter mit der Tendenz zur Rollenausformung. Allerdings ist es nicht möglich, scharfe Trennlinien zu ziehen; man könnte auch von Vorformen des Theaters sprechen ... Grundlegend für die Ausformung theaterkonstitutiver Züge wie der Gestaltung der Rollen durch Maskierung, Aktion und Dialog bleibt für lange Strecken einer hypothetischen Entwicklung der Sammelumzug (Heischegang) von Haus zu Haus zu den Festterminen des Jahreslaufs; allg. weisen erst komplexere Spielformen die Tendenz zur Konstituierung eines temporär stabilen Bühnenraums (Kirchhof, Dorfplatz etc.) auf. Die kollektive Teilnahme (Ritus, Feier, Messe) macht dabei einer sukzessiven Ausdifferenzierung in 'Schauspieler (Verkleidete, rudimentäre Rollentypen) und Zuschauer Platz, wobei die direkte Kommunikation und Interaktion, im Gegensatz zum bürgerlichen Theater, ein charakteristisches Merkmal bleibt« (Puchner, »Volksschauspiel«, op. cit., 35 of.). 
die Rolle einer idealen Selbstdarstellung) inhärent, und Fruchtbarkeitsmagie schimmert noch bei jedem nuptialen Happy-End in der Popularkomödie durch ${ }^{48}$.

\section{I.I Der heortologische und okkasionelle Konnex}

Dieser einführende Exkurs dient der Strukturierung nachfolgender Ausführungen durch die Vermittlung zusätzlicher Informationen und der Offenlegung methodologischer Vorentscheidungen, da eine erschöpfende Darstellung in dieser Übersicht jenseits des Realisierbaren liegt, die Frage der Repräsentativität jedoch nicht einfach wortlos übergangen werden kann. Die Terminbindung im kirchlichen Festkreis des Jahreslaufes wird sich vorwiegend mit dem orthodoxen bzw. christlichen Bereich beschäftigen, der die größten Teile der Balkanhalbinsel umfaßt, die Anlaßbindung umfaßt sowohl die Epochenabfolge im Jahreszyklus als auch die Hauptstationen des Lebenslaufes.

Die kalendermäßige Kodifizierung von Brauchvorkommen in Jahreslaufkompendien (meist in nationalem Rahmen von Staatsgebieten) ist an sich schon problematisch, weil sie I. die lokalen Variationen nicht oder nur ungenügend berücksichtigen kann, 2. die Vernetzung der Phänomene durch Übertragung und Proxemik im Assoziationsgeflecht similer Formen und Funktionen verlorengeht und 3. der sukzessive und graduelle Glaubensverlust magischer Effektivität (stufenweise Entritualisierung, Theaterhaftigkeit) nicht darstellbar ist (oft wird durch Rekurs auf die Vergangenheit eine folkloristische »Urform« konstruiert, die in sich in einem quasi-logischen Sinne einleuchtend ist, aber so kaum vorkommt oder abfragbar ist). Auf der anderen Seite aber bilden sie heuristische Arbeitsinstrumente und Einstiegshilfen der Gliederung ${ }^{49}$, denn sonst ist der Interessierte einem kaum überschaubaren Chaos von Informationsmaterial ausgeliefert, mit dem er nicht viel anfangen kann. Ohne solche Konstruktionen sind großräumige Untersuchungen gar nicht möglich (dies ist der Vorteil der case study, die solche Kodifi-

48 Puchner, »Volksschauspiel«, op. cit., 355.

$49 \mathrm{Zu}$ solchen Jahreslaufkompendien vgl. in Auswahl: Eugen Fehrle, Feste und Volksbräuche im Jah-

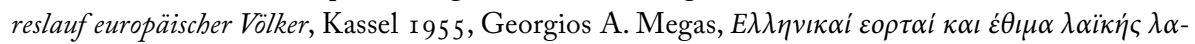

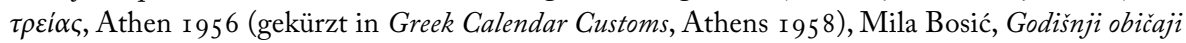
Srba u Vojvodini, Novi Sad 1996, Emil Schneeweis, Grundriß des Volksglaubens und Volksbrauchs der Serbokroaten, Celje I 935, Johann Georg von Hahn, Albanesische Studien I-III, Jena I 854, Mihail Arnaudov, Die bulgarischen Festbräuche, Leipzig I 9 I 7 , Niko Kuret, Maske slovenskih pokrajin, Ljubljana 1984, ders., Slovenska koledniška dramatika, Ljubljana 1986, Christo Vakarelski, Bulgarische Volkskunde, Berlin I 969, 3 I 2-336, Octavian Buhociu, Die rumänische Volkskultur und ibre Mythologie, Wiesbaden 1 974, ders., Le folklore roumain de printemps, Thèse, Paris I 957, ders., »Die Feiertage des Sommers und Herbstes in Rumänien", Zeitschrift für Balkanologie 6 (1968) 3-39, Ivan Balassa/ Gyula Ortutay, Die ungarische Volkskunde, Budapest/München 1982, 644-71 0 usw. 
zierungen nicht braucht, aber im allgemeinen weiterführende Vergleiche scheut). Ähnliches gilt für die Kodifizierung der Lebenslaufriten, die meist Geburt und Säuglingsalter, Verlobung und Hochzeit, Krankheit und Krise, Tod und Begräbnis umfassen ${ }^{50}$.

Ein ganzes Bündel von Mittwinterriten konzentriert sich auf den Zeitabschnitt der Zwölften (Weihnachten, Neujahr [H1. Basileios], Theophanie [H1. Drei Könige], ev. noch H1. Domnike 8. Jänner mit dem Hebammenfest), oft verschmolzen mit der dreiwöchigen Karnevalsperiode (mit Höhepunkten dem Donnerstag der Fleischwoche [Schweineschlachten], dem Sonntag der Fleischwoche, dem Montag der Käsewoche [Butterwoche, masljanica], dem Sonntag derselben, dem »Reinen Montag « [Aschermittwoch]) und dem Beginn der Quadragesima (mit dem Seelensamstag der H1. Theodore $)^{51}$. Die Karnevalsperiode mit ihrer Verkehrten Welt ${ }^{52}$ hängt von der jeweiligen Festsetzung des verschiebbaren Osterfestes ab, während der Schwalbenumzug als Frühlingsbeginn Anfang März durchgeführt wird und der H1. Georg als Beginn der Sommerarbeiten regelmäßig auf den 23. April fällt. Der Osterfestkreis beginnt mit dem "Lazarussamstag" und dem Palmsonntag, sodann der Karwoche (mit Höhepunkten der rituellen Aktivität am Gründonnerstag, Karfreitag mit dem Epitaph-Umzug, Karsamstag mit Auferstehungsnacht und Ostersonntag mit dem Agape-Fest) und endet mit der Nachosterwoche (Sonntag des Ungläubigen Thomas) ${ }^{53}$. Die 50 Tage bis zum Pfingstfest gelten als Zeit der Anwesenheit der Seelen auf der Oberwelt und kulminieren in der

50 An dieser Stelle sei nur die enorme Materialsammlung aus den mündlichen Quellen des Zyprioti-

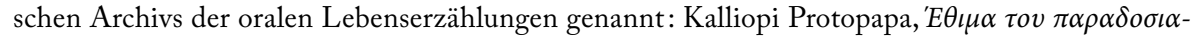

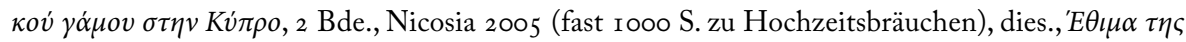

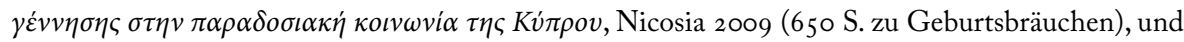

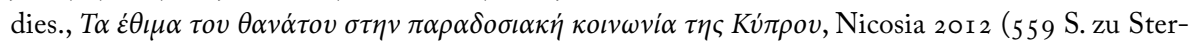
bebräuchen), sowie die luzide materialreiche Arbeit von Manolis G. Sergis, $\Delta \iota \alpha \beta \alpha \tau \eta \dot{\rho} \rho \varepsilon \varsigma \tau \varepsilon \lambda \varepsilon \tau o v \rho-$

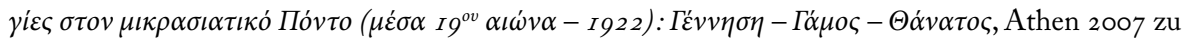
den Lebenslaufbräuchen an der kleinasiatischen Schwarzmeerküste vor 1922. Vgl. auch Vakarelski, Bulgarische Volkskunde, op. cit., 28 I-3 I I.

5 I Zum System der Seelensamstage (psychosabbata) vgl. Walter Puchner, »Im Namen der Rose. Zum Nachleben des Rosalienfestes auf der Balkanhalbinsel«, Studien zur Volkskunde Südosteuropas, op. cit., 47-106, bes. 78-90.

52 Vgl. Dieter Richter, »Verkehrte Welt«, Enzyklopädie des Märchens I 4 (20 I I) 53-59 mit ausführlicher Bibliographie.

53 Dazu Bernard Vonderlage, Das griechische Osterfest, Hamburg I952, Margaret Louise Arnott, Folk Customs surrounding the great days of Easter in Greece, M. A. thesis, Hartford Seminary Foundation I 953, Anne Anthony, Greek Holiday, Athens 1957, Aranca,»Christos anesti«. Osterbräuche im heutigen Griechenland, Zürich I968, Rachel Dalven, »The Yearly Cycle of the Ioannina Jews«, Conservative Judaism 2 (1974) 47-53, Kostas P. Kyrris, »Das Fest des Kataklysmos auf Zypern. Herkunft, Überlieferung und Weiterleben«, J. Herrman/H. Köpstein/R. Müller (eds.), Griechenland - Byzanz-Europa, Berlin $1985, \mathrm{I} 7 \mathrm{I}-\mathrm{I} 85$. 
Rosalien-Woche bis zum Pfingstsamstag. Als feststehender Festtermin ist inzwischen der r. Mai zu nennen sowie die Sommersonnenwende mit den Feuern des H1. Johannes am 24. Juni und den Orakelbräuchen um den klidonas. In den Sommerabschnitt fallen eine Reihe von Heiligenfesten, wobei das panegyri des Propheten Elias auf den Berggipfel-Kapellen dominiert, sowie der I $_{5}$. August, das Fest der Entschlafung Marias mit der vorhergehenden Fastenperiode. Der Herbst setzt ein mit dem Fest der Kreuzerhöhung am I 4. September, gefolgt vom Festtag des H1. Demetrios am 22. Oktober (Ende der Sommerarbeiten), und geht in den Winter über mit dem Fest des H1. Nikolaos am 6. Dezember und dem Einsetzen der Weihnachtsfasten bzw. dem Advent-Abschnitt.

$\mathrm{Zu}$ den okkasionellen Performanzriten zählen etwa der Flurumgang mit der Bittlitanei um Regen in Dürreperioden (»Kreuztragen«) und das grünverkleidete Regenmädchen im Spätfrühling und Frühsommer, die ekklesialen Versteigerungen des temporären Besitzrechts von Sakralgegenständen bzw. das Trageprivileg der hl. Ikone in der Prozession, die Lebenslaufbräuche um Geburt, Heirat und Sterberitual. Neben dem ekklesialen Heortologion existiert auch ein säkularer Festkalender mit Nationalfeiertagen, Gedenktagen des kollektiven Erinnerns aus der Geschichte und dem Mythos der Nation, Revolutions- und Unabhängigkeitsjubiläen, auch personenkultische Anlässe wie Geburtstage des Königs oder Staatspräsidenten, Schulfeiern, Paraden, Staatsbesuche mit Folklore-Darbietungen usw. Vor allem in den ehem. sozialistischen Staaten Südosteuropas hat dieser Festkalender signifikante Ausmaße angenommen und wurde mit bedeutendem Aufwand gefeiert; das »Theater der Macht« als imperialer Selbstdarstellung und Demonstration militärischer oder kultureller Überlegenheit wurde jedoch in den venezianischen Inselbesitzungen des Mittelmeers mit dem gleichen Pomp und ähnlicher finanzieller Aufwendigkeit schon in der Frühneuzeit bis zum Ende des r 8 . Jh.s in Szene gesetzt ${ }^{54}$.

EXKURS I : MITTWINTERRITEN : ZWÖLFTEN UND KARNEVAL

Die Zwölften (Les douze jours, I dodici giorni, The twelve days), die zwölf Tage und Nächte zwischen Weihnachten und Theophanie (Epiphanie, H1. Drei Könige), bilden in manchen Gebieten Südosteuropas (Ungarn, kleinasiatische Schwarzmeerküsten) zusammen mit dem Karneval eine durchgehende Fest- und Maskenzeit und weisen vielfach strukturelle Ähnlichkeiten auf, wenn auch die Zwölften durch die Wintersonnenwende und das Neujahr, christlich überformt durch die Christgeburt und die Taufe

54 Walter Puchner, Giostra und barriera. Ostmediterrane Turnierspiele von Venedig bis Zypern in ihrer geschichtlichen Entwicklung und machtpolitischen Funktion«, Studien zur Volkskunde Südosteuropas, op. cit., $2 \mathrm{I} 3^{-2} 5^{2}$. 
im Jordan, einen anderen Sinnakzent besitzen als der Fasching mit seiner Verkehrten Welt (mundus reversus) der Narreteien und der Freiheit, die die Umkehrung der Alltagswerte (Aufhebung der sozialen Hierarchie, Geschlechtswechselverkleidung, Obszönitäten statt Schamhaftigkeit, entehrende Handlungen wie Rußen, Schwärzen, Eselsumzug usw.) mit sich bringt. Kaum noch bewußte Grundvorstellung ist die Anwesenheit der Totenseelen auf der Oberwelt, die in der kollektiven Imagination die Gestalt von schädlichen Zwölftendämonen annehmen, welche wiederum den mimetischen Prototyp der Verkleideten bei den Umzügen der kalanda (colida, colinde) bilden, die Glückwünsche übermitteln, symbolische Prosperitätsakte ausführen (Feueraufschüren, mit dem rechten Fuß Eintreten), religiöse und Loblieder auf die Familienmitglieder singen und für das Glück-Bringen mit Sachspenden oder Geldgaben belohnt werden ${ }^{55}$. Beim Überblick über das enorme Fallmaterial und die einschlägige umfangreiche Bibliographie (mit ihren häufigen Rekursen auf dakische, thrakische, altslavische Gottheiten und Mythologien bzw. den Dionysoskult) ist prima vista augenfällig, daß sich hier verschiedene historische Schichten von prähistorischer, antiker, römisch-hellenistischer bzw. christlicher und neuerdings neo-säkularer und utilitaristischer Natur überlagern und mit assoziationslogischen (»irrationalen « und paretymologischen) Verknüpfungsweisen vernetzt sind, so daß die Zwölften als Paradebeispiel für die Gleichzeitigkeit des Ungleichzeitigen $(\text { Ernst Bloch })^{56}$ gelten können.

Als rite de passage stellen die Zwölften eine Schwellenphase mit Grenzüberschreitungen zum Jenseits dar (Seelenzeit, Gedenkmessen, Mantik und Glücksorakel, Opfer, Dämonen und Prophylaktik), eine Krise der Identität (Maskierung, Ekstatisches) bzw. eine Erneuerung der Zeit (Jahreswechsel, calendae des r. März - Karneval, mundus reversus, Zerstörung des Alten als kosmogonische Katharsis $)^{57}$, so daß es nicht verwundern kann,

${ }_{55} \mathrm{Zu}$ dieser konventionellen Gleichung Totenseelen = Zwölftendämonen = Verkleidete, die sich manchmal auch in der Namensgebung äußert aber keineswegs mehr dem abfragbaren Bewußtsein der Brauchausführenden entspricht, nach der klassischen Studie von Karl Meuli, »Bettelumzüge im Totenkultus, Opferritual und Volksbrauch", Schweizer. Archiv für Volkskunde 28 (I 928) I-38 und ders., »Maske, Maskereien «, Handwörterbuch des deutschen Aberglaubens 5 (1932/33) I 744-I 852, sind auch neuere Theorien getreten, die die Besucher aus dem Jenseits als Glücksbringer interpretieren und die Maskenumzüge als Inszenierung ihres Empfangs zur Teilhabe am gemeinsamen Fest (Liudmila N. Vinogradova, Zimnjaja kalendarnaja poezia zapadnyh i vostočnyh slavjan. Genezis i tipologija koljadovanija, Moskva I982).

56 Hermann Bausinger, »Ungleichzeitigkeiten. Von der Volkskunde zur empirischen Kulturwissenschaft«, Helmut Berking/Richard Faber (Hrsg.): Kultursoziologie - Symptom des Zeitgeistes?,Würzburg $1989,267-285$.

57 Vgl. die weit verbreitete Überlieferung, daß die Zwölftendämonen (kalikantzaroi, vgl. in der Folge), die das ganze Jahr über am Weltenbaum gesägt haben, in diesen Tagen auf die Oberwelt kommen, am Theophanietag in einem eigenen Kinderumzug verjagt werden, in die Unterwelt zurückkehren 
daß Einflüsse von anderen transitorischen Riten wie Geburt, Hochzeit und Tod nachzuweisen sind ${ }^{58}$. In der Phase der Wiedergeburt der Zeit in den poganoto, mrăsni(ci), bugani, nekrăsteni, karakon(d)žovi dni ${ }^{59}$ sind die Neugeborenen (Christus) besonders gefährdet, denn wenn sie ungetauft sterben, werden sie zu karakondžula ${ }^{60}$. Der soziale Marginalstatus von Wochenbett-Müttern und neonati äußert sich in der 4otägigen Phase der »Unreinheit ${ }^{61}$ mit einem ganzen Bündel von prophylaktischen Handlungen: Das ungetaufte Kind ist potentiell dämonisch ${ }^{62}$.

Die Grenzen zur Anderen Welt und ihre Transgression durch die Besucher aus dem Jenseits liegen meist in der Vertikalachse Herd/Feuerstelle - Kamin - Rauchfang, be-

und dort den Weltenbaum unversehrt antreffen, worauf sie aufs Neue ihr Zerstörungswerk als Holzfäller des Weltenbaums beginnen. Vgl. die komparative Studie von Vitalii Zaikovskyi, $\Sigma v \mu \beta o \lambda \dot{\eta} \sigma \tau \eta$

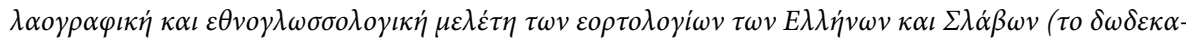
$\dot{\eta} \mu \varepsilon \rho o$ $\omega \varsigma \pi \varepsilon \rho i o \delta o \varsigma ~ \delta i \dot{\alpha} \beta \alpha \sigma \eta \varsigma)$, Diss. Athen 1998. Weiters: Monett Ribeyrol, »La cycle des douze jours dans la Macedoine«, Makedonski folklor I 5-I6 (I 975) 55-6I, Slobodan Zečević,, »Les Douze Jours«, ibid. 5 I-54, in Übersicht auch Puchner, Brauchtumserscheinungen, op. cit., I IO-I I 5 (mit weiterer Literatur).

58 Dies gilt für Arbeitsverbote wie Stricken und Verknotungen, prophylaktische Handlungen wie Bindezauber gegen Wölfe und Füchse (Bosnien), die von den Dämonen gefürchteten Stachelpflanzen, Abfälle bleiben im Haus usw., sowie eine ganze Reihe von anderen Verboten, die bei Sterbefällen, Hochzeit oder Geburt eingehalten werden (Slobodan Zečević, Kult mrtvih kod Srba, Beograd 1982).

59 "Schlechte«, »unreine«, »ungetaufte« usw. Tage (Dimitar Marinov, Narodni vjara i religiozni narodni običai, Sofija I 9I 4, Sbornik za Narodna Umotvorenija XXVIII, 2 2of., Hristo Vakarelski, Etnografija na Bălgarija, Sofija 1977, 506), im Serbischen nekršteni dani (Savatije Grbić, Sprski narodni običaji iz sreza Boljevačkog, Beograd I 909, 7, Petar Petrović, Život i običaji narodni u Gruži, Beograd I 948, ${ }_{23} 3$ f., Milenko S. Filipović, Život i običaji narodni i Visočkoj nabiji, Beograd I949, I 28 usw.).

6o Oder karakandžula (Bălgarski etimologičen rečnik, 4 Bde., Sofija I97I-96, II 234), im Griechischen

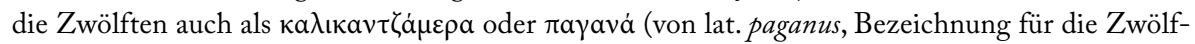
tengeister der kalikantzaroi), in assoziativer Übertragung im Raum Gevgelija auch samovilski denovi genannt (Vera Kličkova, »Rusalski običai na Gevgelisko«, Makedonski Folklor 3-4, I 969, 377-385,

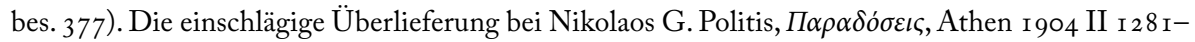
I 290. Diese Gefährdung erstreckt sich auch auf das Jesuskind: Das ungesäuerte Weihnachtsbrot gilt als die Windeln des Herrn und beim Essen der božja liturdijica herrscht Sprechverbot (Sreten Petrović, Mitologija, magija i običaji, Niš I 992, 2 I 2). Die assoziative Verchristlichung hat auch andere ätiologische Mythen hervorgebracht: Das rituelle Schweineschlachten etwa wird mit der Verwüstung des Pfades bei der Flucht der H1. Familie nach Ägypten in Zusammenhang gebracht

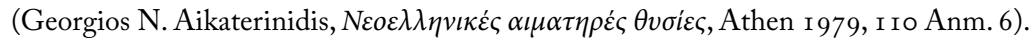

6I Tihomir Đorđević, Deca u verovanjima i običajima našega naroda, Beograd/Niš I 990, I 5 I-I 58.

62 Richard \& Eva Blum, The Dangerous Hour. The Lore of Crisis and Mystery in Rural Greece, London I 970, I 4. Dies äußert sich in einer Reihe von Bezeichnungen: pagano, drakos, mokos (Blum, op. cit., 4I), serb. turče, cigančica (Savatije Grbić, Srpski narodni običaji iz Sreza Boljevačkoj, Beograd I9o9, I I2), bulg. kušle (Hündchen, M. Račeva, Linguistique balkanique 36/3, I993, 275-280). 
liebter Eindringensweg auch für andere Dämonen wie dem zmej ${ }^{63}$, wo der Christblock brennt, ein Holzklotz oder Baumstrunk der I 2 Tage und Nächte lang nicht erlöschen darf $^{64}$; dieses wird vom Anführer/Glückspilz der Besuchergruppe der Sänger nach dem Eintreten mit dem rechten Fuß (podariko, polaznik), als symbolischer Prosperitätsakt mit den entsprechenden Wünschen begleitet, aufgeschürt ${ }^{65}$ bzw. verschiedene Akte der Pyromantie (mit Salzkörnern, Olivenblättern usw.) durchgeführt ${ }^{66}$. Die Ambivalenz des Feuers (Lebenspender/ Verbrennen) kennzeichnet den Weg der Jenseitsreise mit Verbindungsbrücke dem Kamin; die gleiche Ambivalenz hat auch die zurückbleibende Asche: Als Fruchbarkeitsbringer wird sie in Haus und Hof verstreut ${ }^{67}$, als Apotropäum verwendet man sie gegen Ungeziefer ${ }^{68}$. Neben Schweinsknochen, Amuletten, Kreuzen,

63 Slobodan Zečević, „Zmaj u narodnom verovanju severoistočne Srbije - sa slovenskim i balkanskim paralelama«, Makedonski Folklor 2 ( I 969) 36 I-368.

64 Christblock von Mannhardt benannt (Wilhelm Mannhardt, Wald- und Feldkulte, 2 Bde., Berlin I 905 (Darmstadt I 962) I 226 f.), „Weihnachtsklotz« bei den Südslaven (Schneeweis, op. cit., I 55 f.): badnjak oder blaženo drvo (gesegnetes Holz, Crnagora), bădnik im Bulgarischen, auch babka und dednik (Vakarelski, Bălgarski Folklor, op. cit., 5 or f.); ein aufrechtes und ein liegendes Holz bekommen manchmal auch die Bedeutung der "Feuerhochzeit" (Angeliki Hatzimichali, $\Sigma \alpha \rho \alpha \kappa \alpha \tau \sigma \alpha ́ v o l$, Athen I 957, vc' f.). Vgl. auch Hahn, Albanesische Studien, op. cit., I I 54, zur fast paneuropäischen

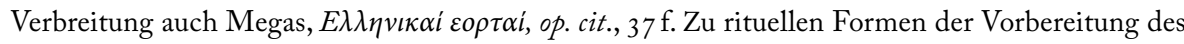
Feuers und des Entfachens Zaikovskyi, op. cit., rog f.

65 Dazu umfangreiches Fallmaterial bei Puchner, Brauchtumserscheinungen, op. cit., 99-108. Es geht eigentlich um einen Hochzeitsbrauch, den der strojnik (Vermittler) oder die Braut im neuen Hause vornimmt. Zu den unabdingbaren Voraussetzungen des »Glückspilzes« zählt, daß beide Elternteile

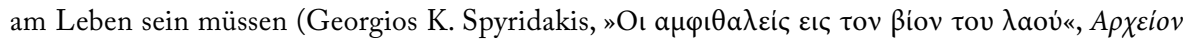

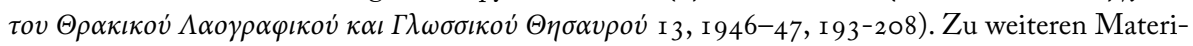
alien vgl. Petru Caraman, »Descolindatuk dans le Sud-est européen«, Comptes-rendus du IVe Congrès des géographes et ethnographes slaves à Sofia 1936, Sofia I 939, 32 I-327, Mária Kiss, »Contribution à létude des coutumes de Noël des Serbes de Pomáz", Acta Ethnographica Academiae Scientiarum Hungaricae I6/I-2 (1967) I6 I-I80, Brigitte Krug-Mann, Weibnachten auf dem Balkan. Sitten - Bräuche naive Maler, Würzburg I 980, A. Petrović, »The Celebration of Christmas, New Year, and Easter Among the Serbian Gypsies«, Journal of the Gypsy Lore Society 1 938, 67-74, Edmund Schneeweis, Die Weihnachtsbräuche der Serbokroaten, Wien 1925.

66 Vgl. dazu noch im zweiten Teil.

67 Bzw. die Verkleideten schlagen die Zuschauer mit Aschenbeutel. Bei den Jahresfeuern trägt man Glut und Asche nach dem Niederbrennen des Feuers ins eigene Haus. $\mathrm{Zu}$ den Jahresfeuern in

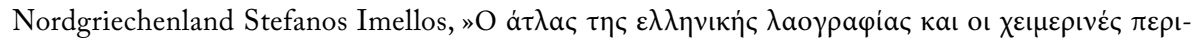

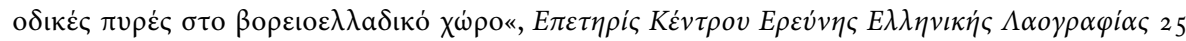
(1977-80) 3-12.

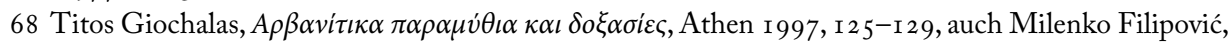
Tragovi Perunova kulta kod Južnih Slovena, Sarajevo I948, I3 I. Zu weiteren apotropäischen Akten wie dem Verbrennen von Dornengestrüpp und Stachelpflanzen und fertilitätspromovierenden 
Zwiebel- und Knoblauchgebinden hängt man als Abwehrmittel gegen die unerwünschten Besucher auch ein Sieb hinter die Tür nahe beim Schlüsselloch oder in den Kamin: In ihrer sprichwörtlichen Dummheit zählen die Dämonen die Löcher bis ins Morgengrauen $^{69}$; charakteristisch für die Bedeutungsambivalenz der bedeutenden Dinge ist, daß das Sieb als kreisrunder magischer Gegenstand zugleich Gabenbehälter für die Besucher ist $^{70}$. Ein weiteres Apotropäum ist das Verbrennen alter Schuhe, was nicht nur einen üblen Geruch verbreitet, der die Dämonen vertreibt, sondern Schuhe brauchen sie, um den Gang aus dem Jenseits ins Diesseits anzutreten; die Symbolik ist evident, wenn

Handlungen wie dem Zerschlagen des Granatapfels Puchner, Brauchtumserscheinungen, op. cit., I IoI 2 (mit weiterer Literatur).

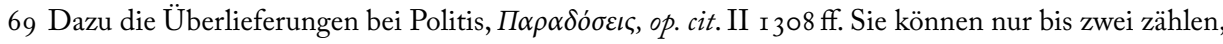
denn Drei ist die H1. Dreifaltigkeit (Bernhard Schmidt, Der Volksglaube der Neugriechen und das hellenische Alterthum, Leipzig I 875, I46). Das Zählen der Unzähligen bzw. des Unzählbaren ist auch bei den Bannsprüchen bekannt, wo das Motiv des Sterne-Zählens vorkommt. Vgl. auch A. Marmorstein, »Das Sieb im Volksglauben«, Archiv für Religionswiss. 2 I (I 922 ) 235-238, Eugen Fehrle, »Das Sieb im Volksglauben«, ibid. I9 (I916-I9) 547-55 I.

70 Mit Weizen, Mais, Äpfeln usw. für die lazarkite, kukeri, prperudata usw. (Zaikovskyi, op. cit., I 34 f.). Das Sieb ist auch der Behälter für die Weihnachts-Gebildbrote (vgl. Walter Puchner, »Anthropomorphe Brotgebilde in Südosteuropa und ihre Beziehungen zur byzantinischen Ikonographie«, Thede Kahl/Peter Mario Kreuter/Christina Vogel (eds.), Culinaria balcanica, Berlin $20{ }_{5}$, 29-37), manchmal auch als baba bezeichnet, z.B. beim slava-Fest der Ostserben (Sreten Petrović, »Magijsko-mitološki smisao slavskog obrednog hleba `baba i ustočnoj Srbiji«, Hljabăt v slavjanskata kultura, Sofija I 997, 7-2 I). Zur vielfachen Bedeutung des Brotes vgl. auch Leopold Kretzenbacher, »Heiliges Brot und Heilbrot. Gedanken zu einer neugriechischen Brotmonographie«, Münchener

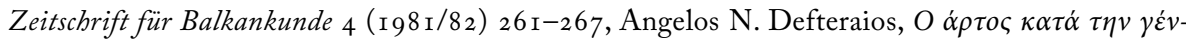

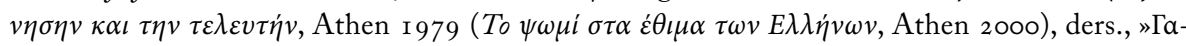

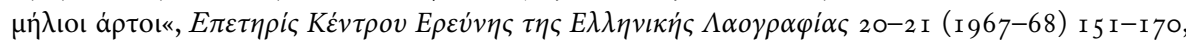

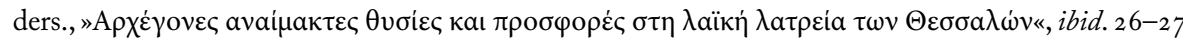
( 198 I-86) bes. 258-260, V. J. Pankova, »Terminologija i ritual'nyje funkcii hleba v južnoslavjanskih rodinnyh obrjadah«, Simvoličeskij jazyk tradicionnoj kul'tury. Balkanskite čtenija II, Moskva I 993, 6374, Anna A. Plotnikova, »Roždjestvjenskaja simvolika v terminologii obrjadovogo hljeba u sjerbov«, ibid. 37-62, B. K. Sokolova, Hleb (zlaki, soloma) v zimnej obrjadnosti vostočnyh i južnih slavjan«, Makedonski Folklor I 5-i6 (1 975) 43-49, N. F. Sumcov, Hleb v obrjadah i pesnjah, Har'kov I 885, Dagmar Burkhart, »On the Semiotics of Zoomorphous and Anthropomorphous Elements in South Eastern Ritual Bread«, Makedonski Folklor I9/38 (I 986) 2 I I-220 (deutsch in Acta Ethnographica Academiae Scientiarum Hungaricae 34, 1986/88, I I 7-1 95, engl. auch in International Folkore Review 5, I 987, 43-47), Stanka Janeva, Ritual Loaves. Bulgarian Folk Customs and Rituals, Sofia I 983 , dies., "L'opposition masculin/féminin dans les formes du pain rituel«, Dagmar Burkhart (ed.), Körper, Essen und Trinken im Kulturverständnis der Balkanvölker, Beiträge zur Tagung vom 19.-24. November I989 in Hamburg, Wiesbaden I 99 I, 25-35, Gustav A. Küppers-Sonnenberg, »Balkanisches Festtagsbackwerk (Gebildbrot). Ornamentik, Symbolik, Stellung im Festbrauch«, Zeitschrift für Ethnologie 87 (1962) 93-I I 4 etc. 
man daran denkt, daß die Schuhe des Verstorbenen umgedreht werden, Schuhe als Geburtshelfer gelten (das Neugeborene als Wanderer aus dem Jenseits) usw. ${ }^{71}$

Spezielle Wegmarken auf dem Gang zum Jenseits sind die Speisen und das Essen: Grundgedanke der mnemosyna-Gedenkmessen ist die Bewirtung der leiblichen Toten mit Essenspflicht der speziellen Wegzehrung zur anderen Welt durch die Lebendigen ${ }^{72}$, die sie vertreten (Übergang vom Alltag zum Fest und umgekehrt am Ende): die Neunzahl (neun Speisen, eine Speise von neun Materialien) erstreckt sich schon auf die Fastenspeisen, dann auf die Festspeisen, gerahmt von speziellen Broten ${ }^{73}$. Die aus dem Totenbrauchtum bekannten leiblichen Bedürfnisse der Verstorbenen sind auch hier zu beobachten: Festspeisen werden am Vorabend von Weihnachten für die Dämonen (Toten, verchristlicht Christus und Maria, Kind und Mutter) stehengelassen ${ }^{74}$ oder der erste Wein und die erste Speise den imaginären Besuchern angeboten ${ }^{75}$. Unter allen Spei-

7I Das Märchenmotiv der Eisenschuhe ist auch auf die Zwölftendämonen und ihre Überlieferungen übertragen. In diesen Vorstellungskreis um die Jenseits- und Diesseitswanderung als Fußmarsch gehört auch die Symbolik der Fußwaschung, das Huf (Ritt) als Glückssymbol und Apotropäum, Schuhe und Strümpfe als Geschenke der (Vor)Weihnachtsperiode, Spuren-Hinterlassen in der Asche als Apotropäum usw. (Zaikovskyi, op. cit., I 39 f.).

$72 \mathrm{Zu}$ Details mit unveröffentlichten Materialien Walter Puchner, »Im Namen der Rose«, op. cit., $73^{-78}$ (»Nekrolatria«: Gedenkmesse, Grabbesuch und Speiseopfer«) und 78-90 (»Allerseelen « - das heortologische System der spsychosabbata : liturgische Brotweihe, kollyba-Gabe und Hochzeitsorakel«).

73 Bohnen, Erbsen, Kohl, Nüsse, Kürbis, Fisch, Honig (Veselin Čajkanović, Sabrana dela iz srpske religije i mitologije u pet knjiga, Beograd 1994 (reprint), I I 22-I33, Alki Kyriakidu-Nestoros, »Ta $\varepsilon \lambda$ -

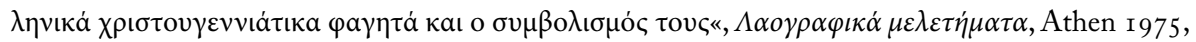
I42-I 56). Bohnen und Erbsen sowie andere Hülsenfrüchte gelten als Totenspeise und Förderer der Fruchtbarkeit; der Nußbaum gilt als dämonisch, die Zwölftendämonen kommen auf Nußschalen

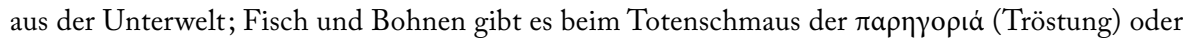

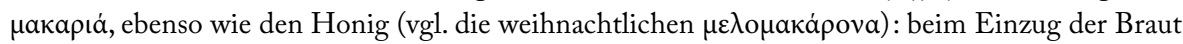
ins neue Haus bestreicht sie den Türrahmen mit Honig (Zaikovskyi, op. cit. I 5 I f.). Zum Kohl vgl. Max Höfler, »Der Kohl«, Hessische Blätter für Volkskunde 9 ( I 9 Iо) I6 I-I 99.

74 Als eine Art Einladung für die Besucher (Kyriakidu-Nestoros, op. cit., I 49). In Bosnien wird die vuku večera den Wölfen an Wegkreuzungen serviert (Ljubomir Pećo, »Običaji i verovanja iz Bosne«, Srpski etnografski zbornik 37, 1925, 363-386, bes. 377), im Raum Florina auf der Hausschwelle für die Bären (damit sie sich zur Fertilitätspromotion auf den Feldern wälzen, Pavlos Kufis, $\Lambda \alpha o \gamma \rho \alpha \varphi \iota \kappa \alpha ́$

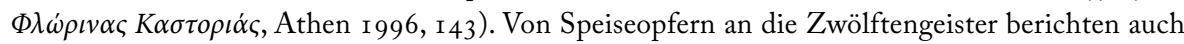

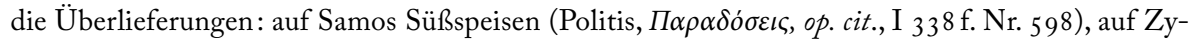
pern Würste (ibid., 342, Nr. 6o3).

75 Meist im Rauchfang oder an der Feuerstelle (dort sind auch die Kieferknochen vom Schwein als Apotropäum u.a. auch für Unwetter angebracht), Opfer, Abwehr und Bewirtung zugleich; die stummen Verkleideten fordern auch den Schweine-Teil für ded i baba (Vinogradova, Zimnjaja kalendarnaja poezia, op. cit., I4I I dies., „Devič'i gadanija o zamužeste v cikle slavjanskog kalendarnoj obrjadnosti«, Slavjanskij i balkanskij fol'klor: Objad. Tekst, Moskva I 98 I , I 4-22). 
sen dominiert allerdings das Schweinerne, in vielen Varianten: vom Spanferkel bis zur Schweinssülze ${ }^{76}$, das Schweineschlachten gilt als rituelles »Schweinefest ( vielfach mit eigener Onomatologie und datumsmäßiger Fixierung ${ }^{77}$; Schweinekiefer oder -knochen gelten als Apotropäum ${ }^{78}$, die Sau selbst in charakteristischer Ambivalenz des Sakralen und Dämonischen gilt als dämonisches Tier der Vegetation und Fertilität $\left(\right.$ Glückssymbol) ${ }^{79}$; vielfach mit Füllung wird das geschlachtete Schwein in öffentlichem

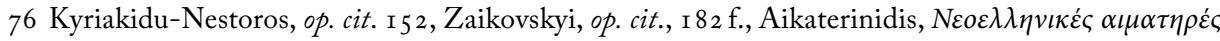
$\theta v \sigma i \varepsilon \varsigma$, op. cit., Iо9-1 I 2, Kostas Karapatakis, To $\delta \omega \delta \varepsilon \kappa \alpha \dot{\alpha} \mu \varepsilon \rho o$, Athen ${ }^{3}$ I 98 I , 80 etc.

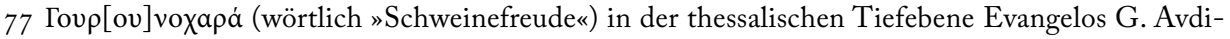

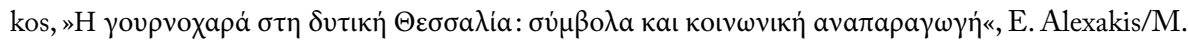

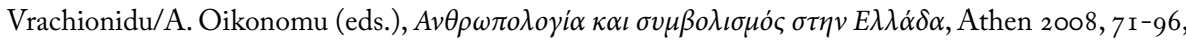

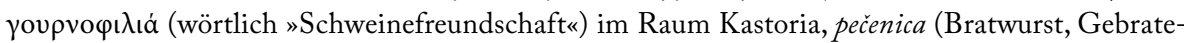
nes) oder božićar bei den Serben usw.; geschlachtet wird am Vorband des H1. Ignatius (20. I 2., Ignatul porcilor im Rumänischen, vgl. Katja Atanasova, »Obreda rolja i značenieto na trapezata v kolednite praznici na bălgarii i rumănci«, Etnografski problemi na narodnata duhovna kultura, Bd. 3, Sofija I 994, 48-79, bes. 54 f.), am Stefanitag (Aikaterinidis, op. cit., 57-64, I09-I I4), oder auch ab Sankt Nikolaus (6. I 2.). Bei den Bulgaren wird am Vortag der surovaki des Neujahrstags geschlachtet (»Tag des Schweins«, Mihail Arnaudov, Očerki po bălgarski folklor, Sofija I 934, 27, Vakarelski, Etnografija na Bălgarija, op. cit., 505), während in Slovenien der H1. Anton als Schutzheiliger der Schweine gilt und an seinem Festtag 17./30. Jänner werden seiner Statue Würste geopfert (Niko Kuret, Praznično leto Slovencev. Starosvetne šege in navade od pomlade do zime, Celje I 970, 330 f.). In Südserbien und Kosovo wird das unschädliche harmlose Tier auch als Glücksbringer am Neujahrstag morgen als erster Eintretender über die Türschwelle des Hauses gebracht (Grbić, op. cit., 78). Auswahl, Eigenschaften und Aufzucht des Schlachttieres sind nicht zufällig; während der Schlachtung wird das dämonische Tier beweihräuchert. In Doliani wird der Schweinsfuß abgeschnitten und der toten Sau

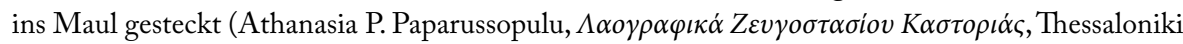

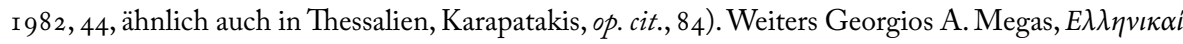

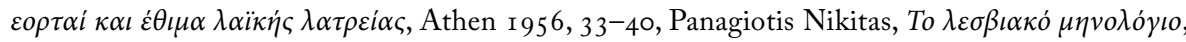
Mytilene I 953, I 5 I, Mar. Paraskevopoulou, Recherches sur les fêtes religieuses populaires de Chypre, Ni-

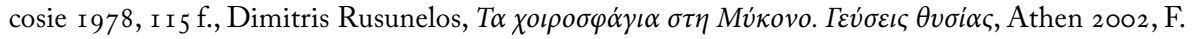

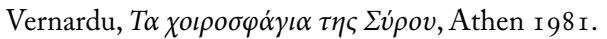

78 Gegen die Zwölftendämonen (Aikaterinidis, op. cit., I I I), auf Kos auch als Blitzabwehr und gegen

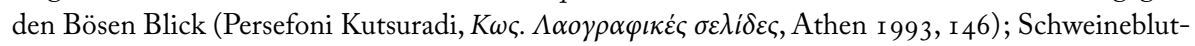
kreuze werden auf die Tür gemalt (magisches Befruchtungsmittel), Schweinegrunzen gilt im gesamten südslavischen Raum als Apotropäum gegen Hagel (Sima Trojanović, »Glavni srpski žretveni običaji «, Srpski etnografski zbornik I 7, I 9 I I , I-239, bes. I 40 f., Verscheuchung von Toten und Dämonen, die den Hagel leiten). Zur gefährlichen Ambivalenz von Sakralem und Dämonischem Michael

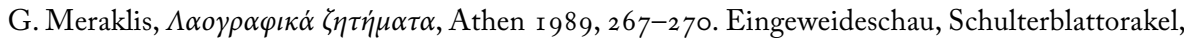
Milz- und Leberschau spielen in Mantik und Wettervorhersage eine Rolle usw.

79 Neben den Glücksspielen am Silversterabend und den mantischen Bräuchen für das Neue Jahr könnte man auch das Einbacken einer Münze in die vasilopitta rechnen, den Festkuchen des H1. Basileios, des Kirchenvaters aus Kappadokien, der am r. Jänner gefeiert wird (Margaret M. Hasluck, 
Schmaus verzehrt, Teile des Fleisches an Nachbarn, die Kirche und an Arme verteilt ${ }^{80}$. Es ist kein Zufall, daß die rituelle Schweineschlachtung und der öffentliche Verzehr auch am Donnerstag der »Fleischwoche « im Karneval (tsiknopefti) vorgenommen wird ${ }^{81}$. Eine christliche Umdeutung hat auch der Frauenbrauch (»Weiberfastnacht«) des $b a-$

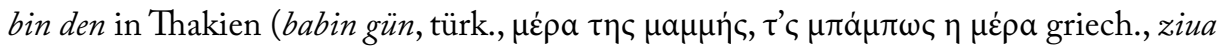
babelor rumän.) und nach der Aussiedlung der hellenophonen Bevölkerung aus Bulgarien auch in Griechisch-Makedonien (mit dem Zentrum Monokklisia bei Serres), ein Fest zu Ehren der Hebamme am 8. Jänner (H1. Domnike) ${ }^{82}$, erfahren, da Maria durch die Christgeburt zur Mutter geworden ist; dazu kommt noch das Motiv der gynäkologischen Jungfernschaftsprüfung der Theotokos in Bethlehem durch die ungläubige Hebamme Salome, ein Motiv aus dem apokryphen Protevangelium des Jacobus ( $§$ I 8 ), das sich über die Legenda aurea und die frühe Kirchenmalerei in der gesamten mittelalterlichen Welt, auch im byzantinischen Osten, verbreitet hat ${ }^{83}$ und auch in den kalanda-

"The Basil-cake of the Greek New Year«, Folk-Lore 38/2, I 927, I43-I 77); zur ätiologischen Sage um die Entstehung des kreisrunden Kuchens, der in gleiche Teile zerschnitten wird, und wer die Münze bekommt, gilt als Glückspilz für das kommende Jahr vgl. auch Walter Puchner, »Die >Rogatsiengesellschaften'. Theoriomorphe Maskierung und adoleszenter Umzugsbrauch in den Kontinentalzonen des Südbalkanraum«, Studien zur Volkskunde Südosteuropas, op. cit., Iо7-1 50, bes. I I 4 f. Anm. 8o.

80 Für die Füllung des Schweinebratens gibt es weitere Symboliken: Vögel (Sperlinge) oder Hasen (Seele des Schlachttiers), gefüllte Gedärme, in Weinbergblätter gewickelt (yaprak) usw. Überlieferungen wissen von der Abstammung des Menschen vom Schwein zu berichten, diese imaginäre Verwandtschaft hat noch in der Ethnolinguistik Spuren hinterlassen (Zaikovskyi, op. cit., 208 f.); das Motiv ist auch im Märchen bekannt (ATU I 540 und Oikotypen).

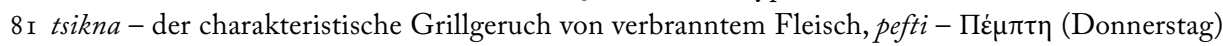
(Puchner, Brauchtumserscheinungen, op. cit., 258).

82 Vakarelski, Bulgarische Volkskunde, op. cit., 3 I9, Mihail Arnaudov, „Babinden văv Velingradsko«, Văprosi na etnografijata i folkloristikata, Sofija I980, 92-ıоo, G. Kraev, "Za smešnosto v babindens-

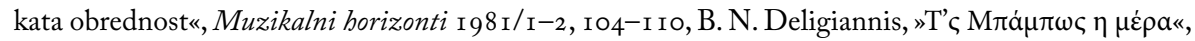

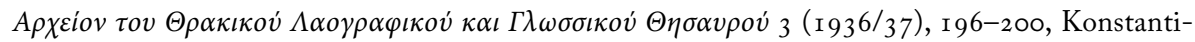

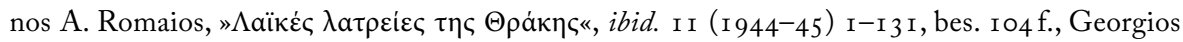

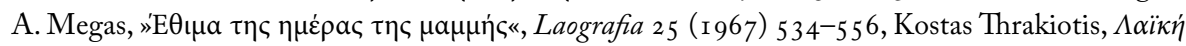

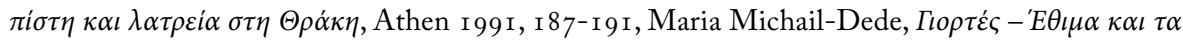

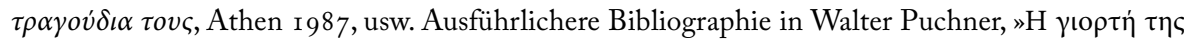

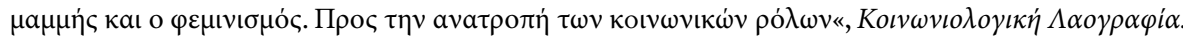

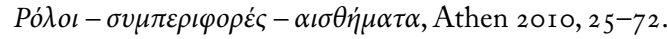

83 J. C. Thilo, Codex apocryphus Novi Testamenti I, Lipsiae r 882, 250-253 (dort auch die Wunderheilung der verdorrten Hände der wegen ihrer Ungläubigkeit bestraften Hebamme). Vgl. Leopold Kretzenbacher, »Malbild-Erzählen aus dem Apokryphenwissen des Mittelalters«, Fabula 20 ( ( 979)

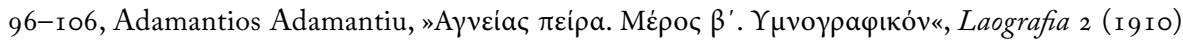

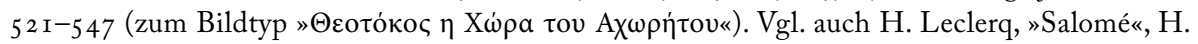


Ansingelieder zu Weihnachten besungen wird ${ }^{84}$. In seiner einfachen Form (Männer verrichten Hausarbeit, Frauen feiern, Mütter besuchen die Hebamme und schenken Seife, fahren sie mit einer Kutsche zur Quelle oder dem Fluß, wo sie mit Wasser bespritzt wird) hat die Ehrung der Hebamme weitere Verbreitung ${ }^{85}$ und wird auch an anderen Tagen gefeiert ${ }^{86}$. Auf die komplexeren Formen und den heutigen Feministenklub »Lysistrata« wird noch zurückzukommen $\operatorname{sein}^{87}$.

Marrou (ed.), Dictionnaire d'archéologie chrétienne et le liturgie I 5, Paris I950, Sp. 587 ff., Lexikon

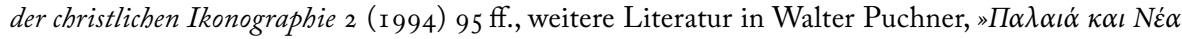

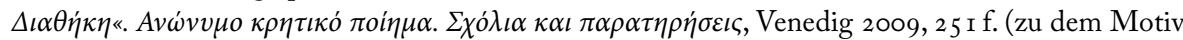
in einer versifizierten kretischen Historienbibel des I7. Jh.s). Das byzantinische Lexikon von Suda gibt noch an, daß als Beweis dafür, daß Christus keinen Vater in dieser Welt habe, die Gottesmutter noch in fortgeschrittenem Alter von den Hohepriestern mit Hilfe von Hebammen einer

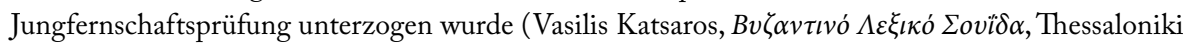
2002, 567 f.).

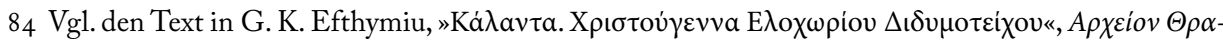

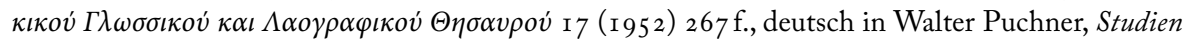
zum griechischen Volkslied, Wien I 996, 202. Vgl. auch ders., Die Folklore Südosteuropas, op. cit., 57-63.

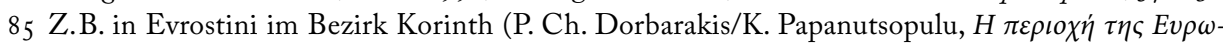

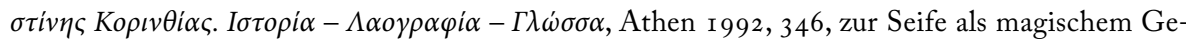
genstand ibid. 39 I, 397), zu weiteren bulgarischen Gebieten Vakarelski, Etnografija na Bălgarija, op. cit., 506, Dimitar Marinov, Narodna vjara i religiozni narodni običai, Sofija I 914 ( ${ }^{2}$ I 994) 353 ff., in der Dobrudscha (M. Vasileva, „Kalendarni praznici i običai«, Dobrudža: Etnografski, folklor i ezikovi proučavanija, Sofija I 974, 30I-342, bes. 314 f.).

86 Bei den Serben werden die "Tücher der Hebamme« (babine rubi) bereits am Vorabend von Weihnachten gefeiert, in Ostserbien jedoch am 8./2 I. Jänner (Mile Nedeljković, Godišnji običaji u Srba, Beograd I990, 8), Verbot von Frauenarbeiten gibt es jedoch bereits am 7. Jänner, dem Festtag des H1. Johannes des Täufers; bei den Aromunen in Nordostserbien werden die babice gebacken, kleine Brote für die Kinder, die gegen Kindbettkrankheiten helfen sollen (Vladimir Nikolić, Etnološka grada i rasprave iz Lužice i Nišave, Beograd ı 910, I 27); die Hebamme (moša) hebt sie dreimal hoch und wünscht Glück (Petar Kostić, »Godišnji, običaji u okolini Bora«, Glasnik Etnografskog muzeju u Beogradu 38, I975, I7 I-1 94, bes. I78). Dieselben Brote finden sich auch in Rumänien am ziua babelor (Tag der Alten) (Anna A. Plotnikova, »Roždjestvjenskaja simvolika v terminologii obrjadovogo hljeba u sjerbov«, Simvoličeskij jazyk tradicionnoj kul'tury. Balkanskite čtenija II, Moskva 1993, 37-62), in Rußland wird babin den am 26./27. Dezember gefeiert (ibid.45), babski velikden oder babska Paska am Donnerstag der Nachosterwoche. Eine solche Datumsverschiebung findet sich auch in Serbien (letzte Märztage) oder in Kali Vrysi (Gornica) im Raum Drama (Georgios N. Aikaterinidis, $\Delta \rho \omega \dot{-}$

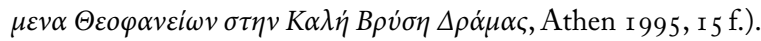

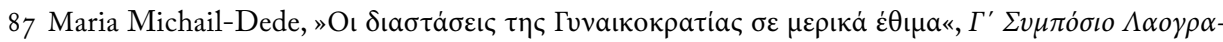

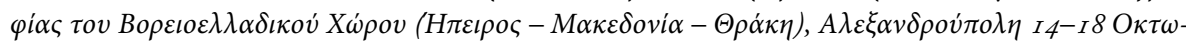

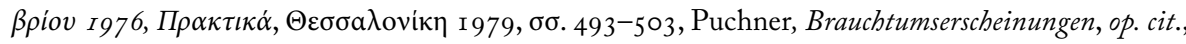
I 5 2-I 54, ders., Studien zur Volkskunde Südosteuropas, op. cit., I69-I 7 I. 
Die Umkehrung der gender roles leitet jedoch unmittelbar zum Karneval über, wenn auch die Geschlechtswechselverkleidung von Frau zu Mann im traditionellen Südosteuropa nicht so häufig ist ${ }^{88}$, allerdings heute nicht mehr so selten ${ }^{89}$. Auf die Kontroversen von ev. Abhängigkeiten vom römisch-hellenistischen Festkalender oder noch älteren Kultursubstrat-Schichten sei hier nicht eingegangen ${ }^{90}$, auch nicht auf die teilweise mißglückten Integrationstaktiken von paganen Elementen in den christlichen Festkalender durch die Strategien der frühchristlichen und hochmittelalterlichen accommodatio $^{91}$ sowie die umstrittene Ursprungsfrage des neuzeitlichen Karnevals ${ }^{92} . \mathrm{Im}$ Zentrum des Interesses stehen nicht die traditionellen urbanen Umzugs- und Verkleidungsformen, wohl aber die offeneren nord- und westbalkanischen Formen von poklade und farsang, sondern der agrarische Karneval, der sich in Symbolik und Ästhetik von den Zwölftenriten nicht grundlegend unterscheidet: Auch hier wird der nicht ungefährlichen Anwesenheit der Totenseelen (Dämonen) durch erhöhte soziale Mobilität (Verwandtenbesuche, öffentliche events, Tänze, Umzüge, Musikunterhaltungen, Gräberbesuch usw.), Imitation und Prophylaxe (Verkleidungen), Arbeitsverbote und andere Superstitionen, erhöhte Konsumption (Schmausen, Durchzechen), Vitalmanifestationen aller Art, Lachen und Satire (und was die Bachtin'sche Karnevalstheorie sonst noch vorsieht), erlaubte Normübertretungen in Bezug auf Verhalten und Sprechen (Phallisches, Sexuelles, verbale Freizügigkeit) usw. begegnet ${ }^{93}$. In den nordbalkanischen Spinnstubenunterhaltungen bilden Zwölften und Karneval eigentlich eine einheitliche Periode. Der mundus reversus der Karnevalsperiode mit der Umkehrung der sozialen Ordnung und der Alltagsnormen bzw. der Inversion von Oben und Unten, Innen und Außen, Hoch und Tief, Geistigem und Körperlichem, Erlaubtem und Unerlaubtem bildet das Paradebeispiel der verschiedenen Fest-Theorien, die sich auf die Herausgehobenheit der Festzeit aus dem Alltag stützen, die spezifische Rahmung, die Geltung einer anderen (Un)Ordnung (von der wahllosen Orgie bis zum ausgetüftelten Zeremoniell),

88 Niko Kuret, »Frauenbünde und maskierte Frau«, Schweizer. Archiv für Volkskunde 68/69 (1972/73) 334-347, Richard Wolfram, »Weiberbünde«, Zeitschrift für Volkskunde N. F. 4 ( I 933 ) I 37-I 46.

89 Vgl. z.B. Ivan Lozica, Hrvatski karnevali, Zagreb I 997.

90 Puchner, Brauchtumserscheinungen, op. cit., 280-284 (mit Bibliographie).

9I Walter Puchner, Akkommodationsfragen. Einzelbeipiele zum paganen Hintergrund von Elementen der frühkirchlichen und mittelalterlichen Sakraltradition und Volksfrömmigkeit, München 1997.

92 Dietz-Rüdiger Moser, Fastnacht - Fasching - Karneval. Das Fest der "verkehrten Welt«, Graz/Köln/ Wien 1986 (mit der umfangreichen älteren Literatur). Vgl. Dieter Richter, »Verkehrte Welt«Enzyklopädie des Märchens I 4 (20 I I) 53-59, Hedwig Kenner, Das Phänomen der verkehrten Welt in der griechisch-römischen Antike, Klagenfurt/Bonn 1970.

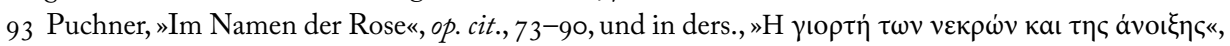

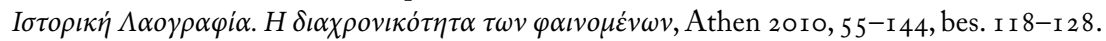


die Transgression der Identitäten bzw. die kollektive Darstellung eines idealen Selbst bzw. der Dunkelseite der conditio humana; der hieros chronos dieser »anderen « Wirklichkeit bildet den strukturellen Rahmen der Ausformung von Theater aus dem Ritual ${ }^{94}$.

\section{EXKURS 2:FRÜHJAHRSRITEN : OSTERN UND PFINGSTEN}

Nach der Exemplifizierung der Verschachtelung von kulturellen Substrat- und Adstratschichten verschiedenen Alters und unterschiedlicher Herkunft in Festkonglomeraten wie den Zwölften kann einer etwas pauschaleren Darstellung Raum gegeben werden. Der Frühlingsabschnitt setzt ein mit Umzügen und Idolvernichtungen, die früher der Kategorie »Winteraustreiben« zugeschrieben wurden, bzw. mit den Schwalbenumzügen mit der beweglichen Holzschwalbe Anfang März, die seit der Antike den Einzug des Lenzes symbolisiert ${ }^{95}$. Meist in die Fastenzeit der Quadragesima fallen die Kinderumzüge der Schlangen- und Ungeziefervertreibung zu Mariä Verkündigung (Evangelismos, 25. März/7. April $)^{96}$. Die Festgruppe des Osterzyklus setzt mit den Lazarusumzügen im gesamten orthodoxen Balkanraum ein ${ }^{97}$, gefolgt von den Palmsonntagsumgängen und dem Rutenschlag der Kinder, der Marienklage am Karfreitag, der Epitaphprozession, dem Brauchbündel der Auferstehungsnacht und des Ostermorgens, während spielhafte Riten noch am Ostermontag oder -dienstag folgen ${ }^{98}$. Am H1. Georgstag erfolgen die sportlichen Agone und während der ganzen Zeitspanne auch das

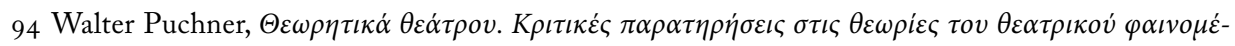

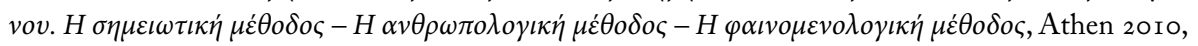
395-398 (mit der einschlägigen Literatur).

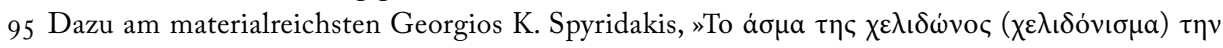

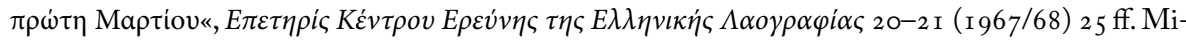
chael Herzfeld, »Ritual and Textual Structures: The advent of spring in rural Greece«, R. K. Hain (ed.), Text and Context: The Social Anthropology of Tradition, Philadelphia 1977, 29-50. Vgl. auch Puchner, Die Folklore Südosteuropas, op. cit., 57-59.

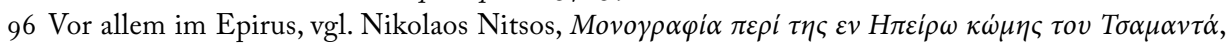

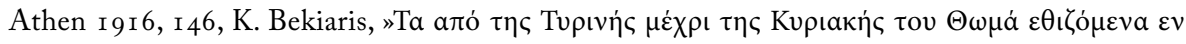

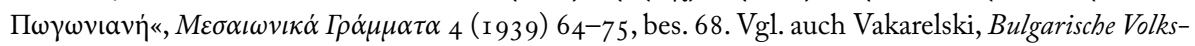
kunde, op. cit., $322 \mathrm{f}$.

97 Walter Puchner, »Lazarusbrauch in Südosteuropa«, Österr. Zeitschrift für Volkskunde 32/8 I (1 978) I 7-40, ders., "Südosteuropäische Versionen des Liedes von `Lazarus redivivus«", Zeitschrift für Volksliedforschung 24 ( I 979) 8 1 - I 26. Vgl. ders., Die Folklore Südosteuropas, op. cit., 65-68. Vgl. auch Margarita Vasileva, Lazarouvane: Bulgarian Feasts and Customs, Sofia 1982.

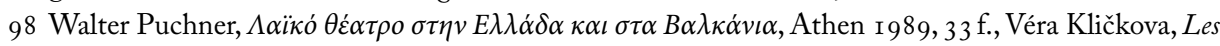
coutumes de pâques dans la région de Poretch, Macédonie, Skopje 1957. 
rituelle Schaukeln der Mädchen ${ }^{99}$. Die 50 Tage von Ostern bis Pfingsten bilden einen weiteren Seelen-Termin: In der Rusalien-Woche vor Pfingsten (rusalksa sedmica, rusalna nadelja) kommt es zu Riten rund um die Feen der rusalki und rosaliile und die Heilung der Übertreter der Arbeitsverbote von den als Strafe verhängten Krankheiten (die ekstatischen Heiltänze der căluşarii ${ }^{100}$. Im nördlichen Balkan findet der Pfingstköniginnen-Umzug der kraljice statt. Als Fixtermin ritueller Tätigkeit steht der I. Mai fest, während der Regenmädchen-Umzug und liturgische Flurbegehungen wetterabhängig sind (Dürre und Trockenheit) ${ }^{101}$. Am Vorabend des Festtages des H1. Johannes werden die Sonnwend-Feuer übersprungen und der klidonas-Orakelbrauch wird ausgeführt.

Waren bei den Winterumzügen vorwiegend männliche Jugendliche beteiligt, mit z.T. martialischem Aussehen und Gehabe bzw. paramilitärischer Ordnung und Organisation, so sind es im Frühlingsabschnitt vorwiegend die Mädchen, manchmal getrennt in eine vorpubertäre Altersschicht und heiratsreife Mädchen, die die Umzugsriten ausführen ${ }^{102}$. Die Sammelumzüge ${ }^{103}$ der Kinder finden ohne geschlechtsspezifische Selektion oft parallel zu den anderen Prozessionsformen statt bzw. stellen z.T. dysfunktionale Schwundstufen der Brauchübung dar, die in eine Art privater Spendenaktion ausmünden; der Glaube an das tatsächliche Glückbringen der Besucher bzw. der kollektive Normzwang, sie zu empfangen und zu beschenken, ist zum Großteil verlorengegangen.

\section{I.2 Umzug und Prozessionen}

Der kollektive geordnete Gang in Raum und Zeit von einem Symbolort zu einem anderen gehört zu den grundlegendsten Formen ritueller Aktion; unabhängig von Funktion und Morphologie ist sie Bestandteil fast aller Religionen, aber auch säkularer öffentlicher Rituale wie Paraden, oder auf kommunaler Ebene wie der Reihenbesuch aller (vieler) Häuser von Maskierten und Sängern zu den Festtagen des Jahreskreises bzw.

99 Gabriella Schubert, »Der H1. Georg und der Georgstag auf dem Balkan«, Zeitschrift für Balkanologie 2 I/I (I985) 80-I05.

Ioo Gail Kligman, Căluș. Symbolic Transformation in Roumanian Ritual, Chicago/London I 98 I.

Iо I Walter Puchner, »Zur Typologie des balkanischen Regenmädchens«, Schweizer. Archiv für Volkskunde 78 (1982) 98-I 25, ders., "Liedtextstudien zur balkanischen Regenlitanei mit spezieller Berücksichtigung der bulgarischen und griechischen Varianten«, Jahrbuch für Volksliedforschung 29 ( 1 984) Iоo- I I r. Vgl. auch ders., Die Folklore Südosteuropas, op. cit., $63-65$.

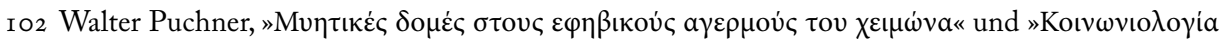

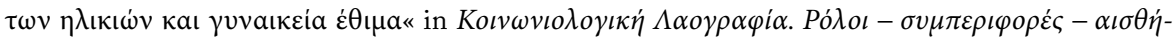
$\mu \alpha \tau \alpha$, Athen 2010, $98-189$ und $26-72$ respektive.

I03 Der neutrale Terminus ersetzt die älteren Bezeichnungen von »Heischegang« und »Bettelumzug« mit ihren einseitigen semantischen Ausrichtungen (Puchner, Brauchtumserscheinungen, op. cit., pass.). 
die Karnevalsprozessionen in den größeren Städten. In einer Typologie der Umzugsformen in den traditionellen Oralkulturen Südosteuropas sind vorab ekklesial-religiöse Prozessionen der Pastoralpraxis von profanen Schau-Umzügen wie den Faschingsumgängen zu unterscheiden, und von beiden magisch-rituelle Gänge von Haus zu Haus in Gruppen mit Symbolgegenständen, Symbolhandlungen, Wünschen, Liedabsingen, Verkleidungen und Darstellung von Kurz-Szenen zu gewissen Festtagen, Interaktionen die als verbindlich gelten und eine Gegenleistung im Sinne von do-ut-des hervorrufen, bei Verweigerung des Besuchs oder mangelnder Entlohnung für die »Dienstleistung" jedoch überaus aggressive Reaktionen zur Folge haben ${ }^{104}$. Diese scheinbar dysanaloge Reaktion auf Verweigerung des Kontakts oder des Austausches der "Dienstleistung« kann als Indikator dafür gelten, daß bei diesem glückbringenden Besuch als Glaubenshintergrund ursprünglich mehr auf dem Spiel gestanden hat als eine soziale Konvention. Das Von-Haus-zu-Haus-Gehen in der gesamten Kommunität (mit Ausnahme von Familien, die sich in der Trauerperiode der 40 Tage nach einem Todesfall befinden) kann auch als zyklische Prozession und magische Kreisziehung um das Dorf gesehen werden, ähnlich wie die Errichtung von Kapellen, Wegkreuzen, H1. Quellen und geheiligten Bäumen (hypsomata), die das Siedlungsgebiet der Dorfgemeinschaft umgeben als magischer Schutzwall gegen Übel aller Art (Viehepidemien, Dämonen, Krankheiten, Feinde, Unwetter usw. ${ }^{105}$; dieselbe Funktion haben die Riten an Wegkreuzungen vor dem Dorf, wo sich entscheidet, ob das Übel haltmacht oder weiterzieht.

Unter räumlichen Kriterien kann man Prozessionen innerhalb oder außerhalb der Kommunität unterscheiden: Karnevalsumzüge mit Verkleideten oder Wagenprozession im Siedlungsbereich, Flurumgänge um Erntesegen, Kapellenbesuch mit Bittlitaneien

I04 Eine dynamistische Interpretation kann sich noch auf andere Indizien stützen. »Gewisse Dysanalogien in der Begegnung von Aktion und Reaktion (Geschenkverweigerung/ Anathematisierung), das Sich-Kreuzen von Aktionssträngen (Gruppenbegegnung und Kampf), Sekundärätiologien aus dem Munde der Agierenden (knotiger Stock als Schutz vor Hunden) sowie gewisse Manipulationen mit den Geschenken (Verzehr noch während des Festtermins) legen die Vermutung nahe, daß an der Tauschaktion nicht nur Realwerte, sondern auch - in ungewissem Grade -Symbolwerte beteiligt sind «(Puchner, Brauchtumserscheinungen, op. cit., I 38 f.). Das Konzept einer Umverteilung der glückbringenden und segenspendenden "Kraft« in der Kommunität wird heute eher vermieden (Hinrich Siuts, Die Ansingelieder zu den Kalenderfesten, Göttingen I968, I33), ist jedoch an der „Überreaktion« der Sänger (symbolisches Hauseinreißen, Wüstungsfluch in den Spottliedern) im Balkanraum und in Kleinasien noch spurenhaft abzulesen (vgl. Puchner, Die Folklore Südosteuropas, op. cit., 57-59).

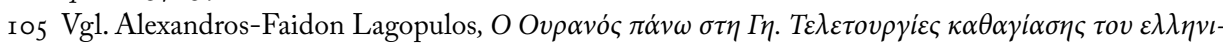

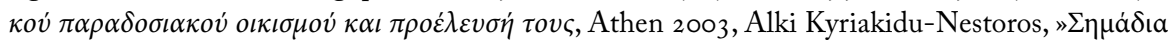

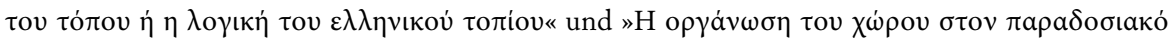

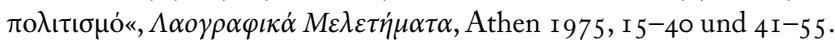


um Regen und gegen Hagel, Dürre und Trockenheit, oder (oft mehrtägige) Wallfahrten konventioneller oder persönlich begründeter Art (Gelübde, Krankheit, Votivspende usw.). Fernwallfahrten wie Pilgerreisen ins H1. Land oder nach Mekka sind nicht mehr ohne technische Verkehrsmittel zu bewältigen (wie etwa noch die Jakobspilger nach Santiago di Compostella) und dauern in ihrem risikoreichen Ablauf (Räuber, Piraten, Unglückfälle, Krankheiten) mehrere Monate oder auch Jahre. Unter morphologischen Aspekten sind Sakralprozessionen innerhalb und außerhalb der Kirche, wie die Epitaph-Prozession, Ikonen-Umgänge und Reliquienprozessionen mit oder ohne Krankenheilung, Fronleichnams-Umgänge mit performativem Charakter, Festprozessionen zu Heiligenkapellen bei panegyria, religiöse Bruderschaften an Festtagen usw. von säkularen Umgängen und demonstrativen Schauprozessionen wie die Lanzenreiter der giostra, Maskenprozessionen u. a. zu unterscheiden, aber auch Schulparaden an Nationalfeiertagen, Blasmusikkapellen, Aufmärsche von Schützenvereinen und Feuerwehr, Reiterprozessionen, wesentliche Teile des sozialistischen Festkalenders im 20. Jh., aber auch private Hochzeitszüge, Begräbnisprozessionen usw. gehören dazu.

Eine Morphologie des Prozessionswesens in Südosteuropa zu geben, überschreitet die Möglichkeiten dieser Übersicht; außerdem kommt das Thema bei den popularen Devotionalformen im zweiten Teil nochmals ausführlich zur Sprache. Hier geht es mehr um die Fixierung von Umzug und Prozession als tragender Grundstruktur und signifikantem Manifestationsrahmen öffentlicher Darbietungen, wofür exemplarisch einige Selektivbeispiele genannt seien, die als Bausteine einer möglichen Typologie aufgefaßt werden können, in Antithese zu jenen public events performativer Art, die nicht ambulant und mobil sind, sondern ortsfest und mehr oder weniger raumbedingt. Grundlegend kann man zwei Haupttypen unterscheiden: r. die Sakralprozession mit der Beteiligung geistlicher Würdenträger und dem Mitführen von sakralen Symbolgegenständen, dem Absingen von Litaneien und Hymnen sowie der Ausführung ekklesialer Symbolakte (Beweihräuchern, Gebete, »Baumerhöhung ${ }^{106}$, Feldmessen oder Kapellenbesuch an Festtagen des Heiligen mit Symposia, Musik und Tanz, sportlichem Kräftemessen usw.), und 2. den Sammelumzug der kalanda-Sänger von Haus zu Haus, mit oder ohne Symbolhandlungen, Maskierungen und dromena, der im Falle von komplexen Formen auch das Vorspiel für eine Darbietung ortsfester Art bilden kann, wobei dann das Publikum zum Schauspiel kommt und nicht mehr das Schauspiel zum Publikum. Zwischen diesen Haupttypen sakraler und (semi)profaner Art gibt es eine ganze Reihe von Zwischenformen, wie den privaten Gang zu einem Heiligtum bzw. einem Wegkreuz oder Kapellenimitation in Kleinformat, um Blumen zu erneuern oder das Öllicht zu kontrollieren

Io6 Zum hypsoma-Brauch vgl. noch in der Folge. 
und Petroleum nachzufüllen ${ }^{107}$, lärmende Kinderumzüge, um die Zwölftengeister bzw. das Ungeziefer (Schlangen, Eidechsen usw.) zu vertreiben, manchmal in Begleitung des Popen mit dem Weihwedel, der den hagiasmos (Wasserweihung) durchführt ${ }^{108}$, Hochzeitszüge mit Fahnen und Reitern mit oder ohne »Wegsperrung« und »Lösegeld« zum Brauthaus, zur Kirche, zum Haus des Bäutigams (im Falle der virilokalen Heirat) ${ }^{109}$ usw.

Prozessionen und Symbolgänge sind im proxemischen Sinne raumkonstituierend, in ganz ähnlichem Sinne wie die Kinetik des Schauspielerkörpers einen Bühnenraum schafft, indem seine Bewegungen spatiale Bedeutungen hervorbringen (z.B. in Reinform bei der Pantomime) $)^{110}$. Dies ist etwa bei Gängen im Kirchenraum, einem Symbolraum katexochen, evident ${ }^{111}$ : etwa beim Kleinen und Großen Einzug ( $\mu \varepsilon \gamma \alpha \dot{\alpha} \lambda \eta$

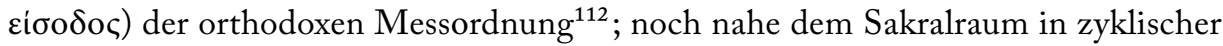
Form, Teile des Siedlungsraums der Kommunität umfassend, bewegt sich der Epi-

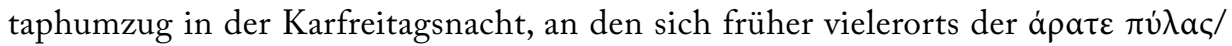
tollite portas-Ritus angeschlossen hat, der Christi Abstieg in die Hadeshölle und die Befreiung der Toten aus der Unterwelt (und der Menschheit vom Tod) symbolisch darstellt ${ }^{113}$. An die Grenzen des sakral beschützten Siedlungsraums der Kommunität können die hypsomata-Prozessionen führen ${ }^{114}$, $\mathrm{zu}$ "geheiligten « Bäumen an den Siedlungsrändern, Kapellen, Wegkreuzen, H1. Quellen (bagiasmata) usw., die den Sakralbezirk menschlichen Wohnens gegenüber der dämonischen Natur ausgrenzen ${ }^{115}$.

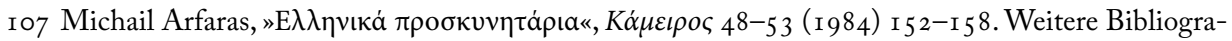
phie noch in der Folge.

ro8 Z.B. am Festtag des H1. Johannes des Täufers (7. Jänner). Vgl. Walter Puchner, Studien zum griechischen Volkslied, Wien I996, 2 Iо.

Io9 Dieter Dünninger, Wegsperre und Lösung. Formen und Motive eines dörflichen Hochzeitsbrauchs, Berlin 1967 .

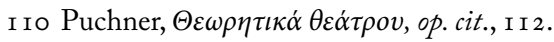

I I I Thomas Kirchner, Raumerfabrung im kirchlichen Theater des Mittelalters, Diss. Wien 1982.

I 2 Robert F. Taft, The Great Entrance. A History of the Transfer of Gifts and other Pre-anaphoral Rites of the Liturgy of St. John Chrysostom, Rome I 975.

I I 3 Walter Puchner, »Abgestiegen zur Hölle«. Der descensus ad inferos als Keimzelle eines inexistenten orthodoxen Auferstehungs-Spiels«, Beiträge zur Theaterwissenschaft Südosteuropas, op. cit., I I 8 I 226.

I 4 Nach der Festliturgie und feierlicher Prozession (gewöhnlich in der Nachosterwoche) zu einem der Bäume am Rand der Siedlung schneidet der Priester ein Stück Rinde ab und legt ein »hypsoma« hinein (Weihbrot der Meßlesung); der Rindenschnitt wird mit Wachs verklebt; solche H1. Bäume stehen an der Dorfgrenze als Abwehr von Epidemien und jeglichem Übel. Als symbolische Kreisziehung um die Kommunität stehen solche Bäume in jeder Himmelsrichtung (Georgios A. Megas,

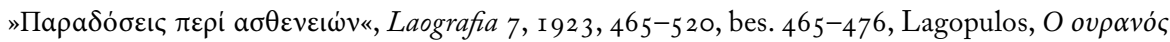
$\pi \alpha \dot{v} \omega \omega \sigma \tau \eta \gamma \eta$, op. cit. I 5 f.). Weitere Bibliographie noch im zweiten Teil.

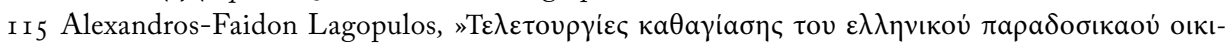

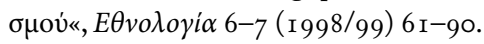


Und noch größere Kreise können die stunden- oder tagelangen Flurumgänge und Bittlitaneien des »Kreuztragens « zur Abwendung von Unwetter und Seuchen, Beendigung der Trockenzeit durch Regenfall usw. ziehen ${ }^{116}$, welche Kapellen, H1. Quellen, Klöster usw. im weiteren Umraum des Dorfes unter Abhaltung von Gebetspausen, Sakralhandlungen, Niederknien, Psalmodieren usw. unter Mitführung von Kruzifixen, Hexapterygen usw. miteinbeziehen ${ }^{117}$. Diese erweiterte Form bildet bereits einen Übergang zur organisierten Wallfahrt zu Fuß, die allerdings keinen Symbolkreis mehr um die Kommunität zieht, sondern linear ein einziges Sakralziel anstrebt, von dem man auf gleichem oder anderem Weg wieder zurückkehrt ${ }^{118}$. Die Symbolobjekte und Symbolaktionen von linearen oder zyklischen Prozessionen können auch einen exklusiv performativen Charakter erhalten, wie z.B. bei den Fronleichnamsprozessionen, mit deklamatorischem Charakter und allegorischen Darstellungen wie bei den jesuitischen Corpus Christi-Prozessionen der Katholiken auf Chios und Naxos im I 7. Jh. ${ }^{119}$ oder mit gespieltem Theatertext wie bei den Kapuziner-Passionsprozessionen in Ljubljana und Škofja Loka in Slovenien ${ }^{120}$.

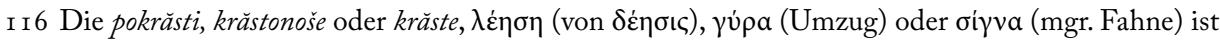
von Serbien und Bulgarien bis nach Kreta bekannt (Vakarelski, Bulgarische Volkskunde, op. cit., 33 I, Mihail Arnaudov, »Pokrăsti i peperuda«, Bălgarsko narodno tvorčestvo 5, I 962, 47 I-475, Marko Kitevski, »Letni običai od Debarca (Ochridsko)«, Makedonski Folklor I9/20 (1977) I63-I67, Tiho-

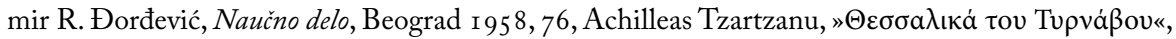

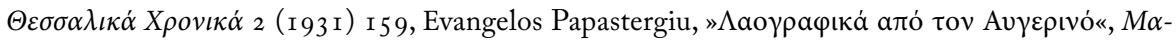

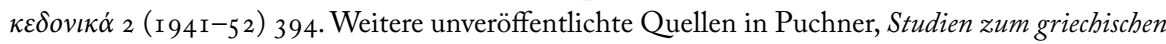
Volkslied, op. cit., $\mathrm{I} 2 \mathrm{2}$.

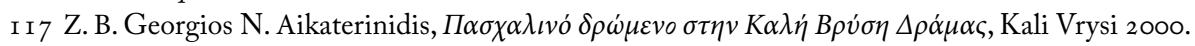

I 8 Wolfgang Brückner, "Wallfahrten«, Enzyklopädie des Märchens I 4 (20 I I) 458-466, Hans Dünninger/Wolfgang Brückner (eds.), Wallfahrt und Bilderkult, Würzburg I 995. Weitere Bibliographie noch im zweiten Teil.

I $9 \mathrm{Zu}$ den Prozessionsbeschreibungen auf den Ägäisinseln in den Archiven der Propaganda fide in Rom und in den Archiven der französischen Ostmittelmeermission in St. Benoit in Galata (Istanbul) vgl. Walter Puchner, Griechisches Schuldrama und religiöses Barocktheater im ägäischen Raum zur Zeit der Türkenherrschaft (1580-I750), Wien 1999 (Österr. Akad. d. Wiss., phil.-hist. Klasse, Denkschriften 277).

I 20 Der über ıoo० Verse umfassende slovenische Passionstext von Pater Romuald (Lovrenz Marušić), "Instruction pro Processione Locopolitana in die Parasceves«, wurde im Zeitraum von I 72 I-34 jährlich in Škofja Loka aufgeführt, vgl. F. Koblar, Stareša slovenska drama, Ljubljana I 95 I, I 50 ff. $\mathrm{Zu}$ den großangelegten Prozessionsspielen der Kapuziner in Ljubljana I 598-I6 77 vgl. Johann W. Valsavor, Die Ehre des Herzogthums Crain, Nürnberg r 689, III 695. Weitere Beispiele bei Walter Puchner, Ordensspiele und Jesuitentheater zwischen Doppeladler und Halbmond«, Beiträge zur Theaterwissenschaft Südosteuropas und des mediterranen Raums, 2 Bde., Wien/Köln/Weimar 2006/7, II $4 \mathrm{I}-68$. 
Ausgangspunkt und Zielort der zyklischen Umzüge ist der Sakralort der Kommunität oder Nachbarschaft in den Städten, die Kirche; bei den linearen Prozessionen wie der Wallfahrt dominiert die Sakralität des Zielortes. Weniger zentrumsorientiert sind die (semi)profanen Sammelumzüge, bei denen allerdings im Falle komplexerer Umgangsformen das temporäre Versammlungshaus (»Burschenhaus« bzw. eines der Familienhäuser der Mädchen, das als Versammlungsort dient) der Adoleszenten (bzw. das Tanzhaus im nördlichen Südosteuropa), wo der Erlös des Sammelumzugs in einer Feier verzehrt wird, ev. auch die Schule oder die Kirche, wo dann die Einnahmen meist für einen wohltätigen Zweck abgeliefert werden, eine solche Funktion einnehmen kann; dies gilt vor allem für jene Formen des Sammelumzugs, wo noch Spuren einer initiativen Funktion (Absonderung von der Kommunität, Prüfung, Aufgabe, Dienstleistung für die Gemeinschaft) ausgemacht werden können ${ }^{121}$. Die nordbalkanischen Spinnstuben-Unterhaltungen bilden eine Übergangsform ${ }^{122}$ einer »Entwicklung «, die vom Von-Haus-zu-Haus-Gehen des zykloiden Gangs zu allen Familien des Dorfes (mit oder ohne Hierarchie) zu einer öffentlichen Darbietung ortsfester Art (Kirchhof, Dorfplatz, Wegkreuzung) führen: Die performative Schaustellung ist dann so komplex geworden, daß sie nicht mehr in oder vor jedem Haus (bzw. im Hof) dargestellt werden kann, sondern einmalig vor der gesamten Kommunität aufgeführt wird, wobei sich die Mobilität des zyklischen Umgangs auf einen zielgerichteten Gang der Zuschauer, die das Schauspiel verfolgen wollen, zum Handlungsort überträgt ${ }^{123}$. Diese »Entwicklung« ist nur typologisch zu verstehen, denn es gibt zahlreiche Zwischenformen, wo sowohl Sammelumzüge durchgeführt werden wie auch das einmalige komplexere »Schauspiel« am Dorfplatz aufgeführt wird ${ }^{124}$.

Bei einer systematischen Auswertung von über I 500 Fallbeispielen aus dem hellenophonen Raum in Südosteuropa läßt sich dabei nachweisen, daß etwa $55 \%$ aller performativen Primärformen des Theatralischen noch die tragende Grundstruktur des Sam-

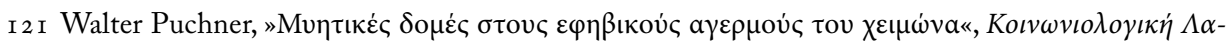

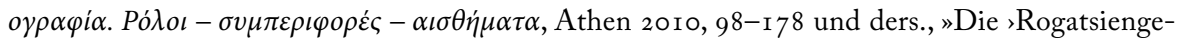
sellschaften . Theriomorphe Maskierung und adoleszenter Umzugsbrauch in den Kontinentalzonen des Balkanraums«, Studien zur Volkskunde Südosteuropas, op. cit., , ı7-1 50. Zu den größeren Lazarusmädchen und ihrer temporären Absonderung von der Kommunität zur Vorbereitung des Umzugs und der Lieder Walter Puchner, Studien zum Kulturkontext der liturgischen Szene. Lazarus und Judas als religiöse Volksfguren in Bild und Brauch, Lied und Legende Südosteuropas, 2 Bde., Wien I 99 I (Österr. Akad. d. Wiss., phil.-hist. Klasse, Denkschriften 2 I6) 48-54, I94-209.

I 22 Nora A. Tahy, Das theatralische Brauchtum des ungarischen Sprachbereichs, Frankfurt/M. I 989, pass.

I 23 Puchner, Brauchtumserscheinungen, op. cit., 257-259.

I 24 Vgl. dazu die statistischen Angaben zu Verkleidungen und Masken, Rollentypen und Szenentypen in Puchner, Brauchtumserscheinungen, op. cit., $262-272$. 
melumzugs von Haus zu Haus beibehalten haben ${ }^{125}$; d. h., genetisch gesehen, stellt die Prozessionsform des reihenweisen Hausbesuchs die strukturelle Nabelschnur der Performativität von der embryonalen Theaterhaftigkeit bis hin zur explizit szenischen Gestaltung dar. Diese »Materialisierung« des Performativen aus der Symbolhaftigkeit von Bedeutungen führt über den Festanlaß, den Besuch, den nonverbalen und aktionslosen Sammelumzug, über undefinierte und definierte Gabe bzw. Bewirtung, dem Sammeln von Holz für ein Festfeuer, zu ersten Formen mit Verbalisierung der Gabenforderung; dies kann geschehen durch Exklamationen bzw. einen ausformulierten Prosperitätswunsch oder dem Absingen der Fest- und Ansingelieder ${ }^{126}$, wobei heortologisch fixierte von kalendarisch nicht fixierten Liedern zu unterscheiden sind bzw. von Spezialliedern zum Lobe von Familienmitgliedern ${ }^{127}$. Die Exekutionsweise dieser Umzüge kann, je

I 25 Puchner, Brauchtumserscheinungen, op. cit., 292-294. "Die motorische Zyklokinese der Agierenden und die dynamistische Zirkulation der `Kraft` (mit den Aspekten des `Glücks`, der `Eueterie`, der Fertilität usw.) geben die grundlegende Strukturvoraussetzung ab für die Anlagerung vorstruktureller Bauelemente wie Agon, Opfer, Dialog, Maskierung und Dromenon. Vorstrukturell sind diese Elemente nur unter dem Aspekt der Priorität der Sammelumzugsstruktur; wie weit sie selbst entwicklungsfähig sind im Sinne einer genetischen Evolution zum Theater hin, ist zu überprüfen. Die absolute Priorität des >Bauelements` Sammelumzug für eine solche Entwicklung läßt sich am vorliegenden Fallmaterial jedoch empirisch verifizieren und schafft die Voraussetzungen dazu, die Zyklokinese als Grundstruktur des realitätshältigen Rollengeflechts anzusprechen. Von allen topologischen Expressionsformen läßt sich die Maske (Verkleidung) am leichtesten in die Grundstruktur integrieren und besitzt die höchste Kapazität in bezug auf die potentielle Theatrogenese. Der Durchgängigkeit der formalen Strukturen, die in Modifikation und Elementkombinationen den wechselnden Erscheinungsformen zugrundeliegt, entspricht eine Durchgängigkeit der inhaltlichen Topoi. Gleichbleibende Skelettelemente wie der Ehrenschutz der Dorfhonoratioren, die temporär begrenzte Funktion der Agierenden sim Dienste der Gemeinde`, Pflügung/Kopulation, Parodie, Normübertretung, Gelächter, die Rolle der Frau usw. stehen in ursächlicher Beziehung zu verschiedenen Aspekten der Finalität: Fertilität, Fekundität, Karpophorie, Teknogonie, Prosperität usw. Diese Aspekte könnte man unter dem Begriff der Reaktivierung der Vitalität zusammenfassen« (op. cit., 293).

I $26 \mathrm{Zu}$ Alter und Geschlecht der Ausführenden, der Gruppengröße und -zusammensetzung und der Art der Gaben vgl. die statistischen Angaben von über 6oo Fallbeispielen in Puchner, Brauchtumserscheinungen, op. cit., I 28-I33. Zu Exklamationen und ausformuliertem Prosperitätswunsch vgl. ibid. 6 of.

I $27 \mathrm{Zu}$ den Liedern Puchner, Die Folklore Südosteuropas, op. cit., 57-59. Die Nomenklatur bezieht sich dabei sowohl auf die Lieder wie auch auf den Umzug: kalanta, kalanda (von lat. calendae), koleda (Emil Schneeweis, Grundriß des Volksglaubens und Volksbrauchs der Serbokroaten, Celje 1935, I64), kolendra (Johann Georg von Hahn, Albanesische Studien, Heft I-III, Jena I 854, I I 54), culinda oder

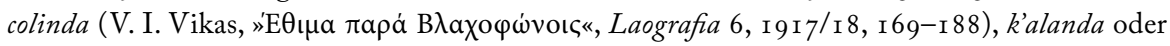
k'alandoba (Robert Bleichsteiner, "Masken und Fastnachtsbräuche bei den Völkern des Kaukasus«, Österr. Zeitschrift für Volkskunde 55/VI, I 95 2, 3-76, bes. I 6 f.), auch basilti (vom H1. Basileios-Tag, 
nach Altersstufe, auch strenge Organisationsformen mit einer Reihe von Verboten und paramilitärischen Strukturen annehmen ${ }^{128}$.

Das Absingen des Ansingeliedes ist an sich bereits ein performativer $\mathrm{Akt}^{129}$. Er kann allerdings verstärkt werden durch das Mitführen eines Symbolgegenstands: einem speziellen Stock mit verdicktem Ende (Lärminstrument, Türklopfen, Hundeabwehr, fertilitätsspendende Bedeutung) ${ }^{130}$, Papierschiffen, Pappklöstern, Kartonlaternen, Krippen usw. ${ }^{131}$, dem blumengeschmückten Korb (Lazarusumzug) ${ }^{132}$, dem

der zu Neujahr gefeiert wird), vasilizari (Michael Arnaudoff, Die bulgarischen Festbräuche, Leipzig I 917,23 f.) usw.

I 28 Bei den Burschenumzügen kommt es auch zu (bewaffneten) Zusammenstößen zwischen den Gruppen. Restelemente einer initiatorischen Funktion dürften bei folgenden Tatsachen vorliegen: Entfernung von der Familie und der Kommunität (manchmal mit spezieller Vereidigung durch den Priester), Unterwerfung des Eigenwillens unter einen Anführer, Widmung an eine gemeinnützige Aufgabe. Spezielle Verbote bestehen z.B. im Sprechverbot, bei den Gängen den Fußstapfen des Vordermannes zu folgen usw. Vgl. auch Puchner, Studien zur Volkskunde Südosteuropas, op. cit., ro7-I I 3.

I 29 Dies vor allem wenn die Lazaruskalanda von Mädchen in zwei Halbchören fast kanonartig ab-

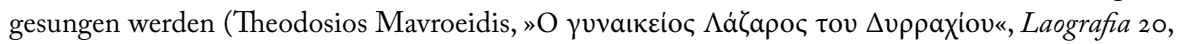
r 962, 576-578) oder wenn sie sich halbkreisförmig rund um die Herdstelle in symmetrischer Form

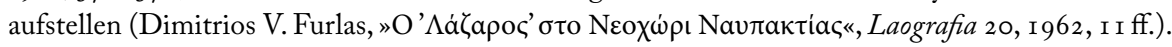

I 30 Brauchtumserscheinungen, op. cit., 86-88. Da der Stock mit dem aufblühenden Wander-Wunderstock des H1. Basileios, des Kirchenvaters aus Kappadokien des Ansingeliedes zu Neujahr in $\mathrm{Zu}-$ sammenhang gebracht wird, ergeben sich weitere Bedeutungsfelder wie: Baum, Stock; und Symbolfelder wie: Paradiesbaum - Lebensbaum - blühender Wunderstock - Phallus. Dieser Stock bekommt verschiedene Namen wie matsuki, klutsa, tzobanika, tziomaka usw.; ebenso die Verkno-

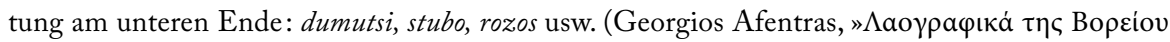

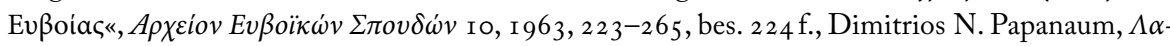

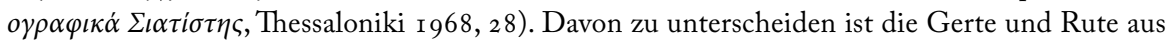
Kornelkirschholz, deren Schlag durch die survaknici, surovari usw. Gesundheit und Robustheit bringen soll (Assen Nicoloff, Bulgarian Folklore, Ohio I975, 20 f., Christo Vakarelski, Bulgarische

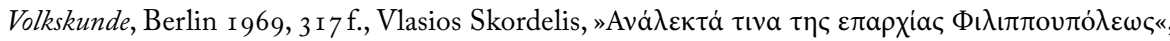

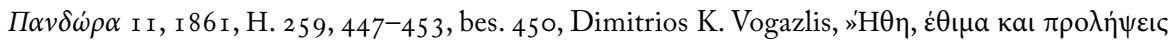

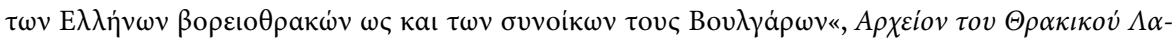

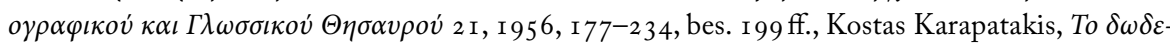

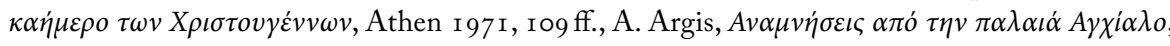
Athen 1930, 32 usw.).

I 3 Vor allem im Inselbereich. Zur Entwicklung des Brauchs zur Darstellung richtiger Kriegsschiffe mit Matrosen, Kanonen usw. in jüngster Zeit auch Chios vgl. Stella Tsiropina, $H \theta \varepsilon \alpha \tau \rho \iota k o ́ \tau \eta \tau \alpha ~ \tau \omega v$

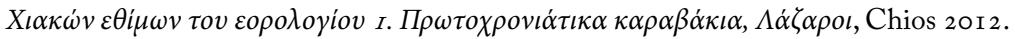

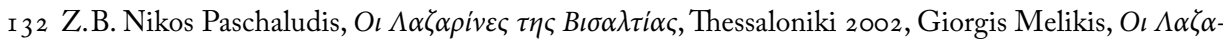

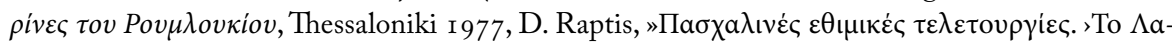

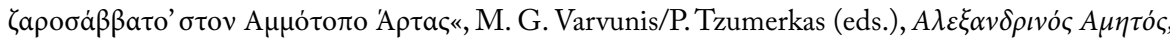
FS I. M. Hatzifotiu, Alexandria 2008, 485-499. 
geschmückten Kreuz (Karfreitag), dem beweglichen Schwalbenidol im zentralbalkanischen Schwalbenumzug ${ }^{133}$, Zweigen (Maizweig, Palmzweig, Granatapfelzweig), primitiven Lazaruspuppen ${ }^{134}$. $\mathrm{Zu}$ den eueterischen und apotropäischen Handlungen zählt das Aufschüren des Herdfeuers ${ }^{135}$, der »Schlag mit der Lebensrute ${ }^{136}$, das Nachahmen von Geflügel und Vieh, das sich vermehren soll, in Bewegung und Laut ${ }^{137}$,

I 33 Zum Lied vgl. Puchner, Die Folklore Südosteuropas, op. cit., 57-59, zur Herstellungstechnik des beweglichen Schwalbenidols (durch Schnurzug nickend, um eine Achse sich drehend) ders., Brauchtumserscheinungen, op. cit., 94-96, I42 f. (und die Photographien 4-7 ebd.). Vgl. in Auswahl: Va-

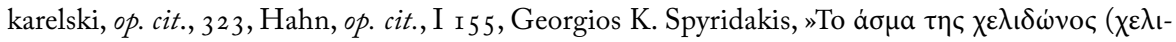

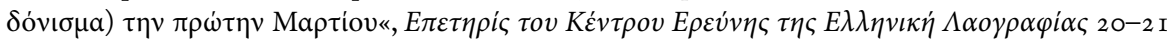
( 1 967/68) 25 ff., Skordelis, op. cit., 45 of., Vogazlis, op. cit., I 90 f., Georgios N. Aikaterinidis, »Eapıvá

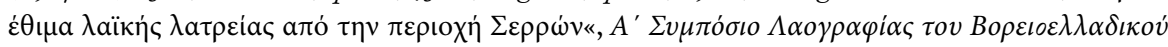

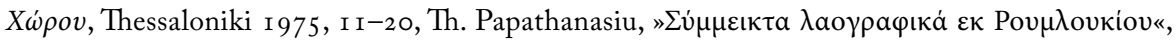

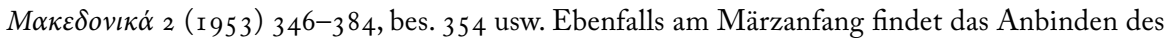
rot-weißen März-Fadens (martinički, martenica, martis, manak) am Handgelenk statt; der angeblich gegen die Sonne schützende und schon in Byzanz nachweisbare Faden wird manchmal der Schwalbe umgehängt, beim Erscheinen der ersten Schwalbe abgenommen und im Auferstehungsfeuer zu Ostern verbrannt. Dazu in Auswahl: Spyridakis, op. cit., Skordelis, op. cit., 45of., Vogazlis, op. cit., I 90 f., Ljubomir Mikov, Părvomartenska obrednost (Bălgarski praznici i običai), Sofija I 985 , Philip V. R. Tilney, »The Martenitsa: An Old World Custom with New World Significance«, $\mathrm{Ca}-$

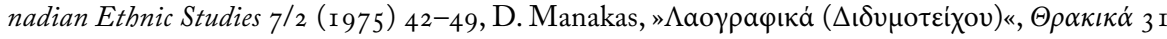

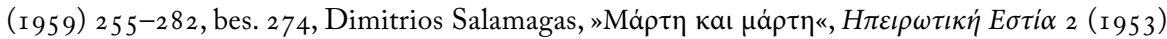
263-265, weitere Literatur in Puchner, Brauchtumserscheinungen, op. cit., 94-96. Zum roten Bändchen am Arm gegen bösen Blick in Ungarn Balassa/Ortutay, op. cit., 7 I $5 \mathrm{f}$. Zur magischen Fadengürtung von Ikonen, Kirchen und Dörfer bzw. dem Faden-Binden in Praktiken des Bindezaubers vgl. noch im Zweiten Teil.

I34 Aus zwei gekreuzten Stäben geformt (der längere auch als Bratschaufel, Kochlöffel oder Spindel), häufig in Leinen gewickelt; der Kopf wird mit mehr oder weniger deutlichen Gesichtszügen ausgestattet.

I35 Puchner, Brauchtumserscheinungen, op. cit., roo-I03. Dieses symbolische »Auflebenlassen« der Vitalität ist auch in den Hochzeitsbräuchen nachgewiesen.

I36 Als surva, subra, suvra zu Neujahr, mit den Palmzweigen am Palmsonntag. Vgl. in Auswahl: Vo-

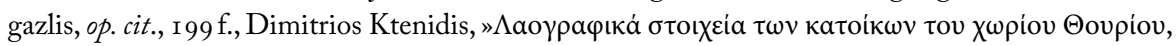

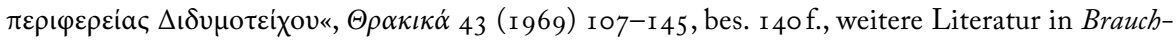
tumserscheinungen, op. cit., 102 $\mathrm{f}$.

I 37 Z. B. in Lykudi im Raum Larisa schüren die Kinder das Feuer auf und werfen Salz hinein, so daß es prasselt, wünschen »Schafe, Ziegen« und kriechen auf den Knien, blöken und schlagen mit den Stöcken auf den Boden sowie Bräute und kinderlose Frauen; in Galanovrysi im selben Raum sagen sie: „Wir bringen Bräute, bringen Bräutigame, Lämmer, Ziegen, Rinder und Hennen mit Kücken« (die Fruchtbarkeit von Feld, Vieh und Mensch ist einheitlich). In Vlachogianni werden Kücken, Lämmer, Zicklein und Kälber akustisch nachgeahmt. In Chiliodendri im Raum Kastoria lesen die Kinder vor dem Haus Gerste, Kastanien, Nüsse und Äpfel vom Boden auf, gebückt oder kniend 
Lärmerzeugung ${ }^{138}$, Hämmern an die Türen ${ }^{139}$, vielfach spielt auch das Nicht-ErkanntWerden eine signifikante Rolle ${ }^{140}$. Agonales Agieren hat auch performative Züge, ebenso wie das ekstatische Agieren ${ }^{141}$, in jedem Fall aber das mimetische Agieren, wie »Maikugeln« in Thrakien ${ }^{142}$, "phallisches« Agieren ${ }^{143}$ oder liturgische Verkörperung ${ }^{144}$.

wie pickende Hühner. In Grintades im Raum Kozani müssen sich die Kinder auf den Boden setzen, damit die Hennen Eier legen (weiter Beispiele in Puchner, Brauchtumserscheinungen, op. cit., IOO-IO3).

I38 Dies geschieht mit schweren Viehglocken, Triangel, Eisen- und Blechzeug, durch das An-die-TürHämmern mit dem Stock, durch Singen, Rufen und Schreien; diese tumultuösen Sammelumzüge dienen auch zur Vertreibung der Zwölftendämonen, im Frühjahr zur Abwehr von Schlangen, Ungeziefer und Übel jeglicher Art (Puchner, Brauchtumserscheinungen, op. cit., I03-106).

I 39 In Damaskinia im Raum Kozani wird bei Geschenkverweigerung sogar die Tür eingeschlagen, auch in Nymfaio an der kleinasiatischen Ägäisküste (op. cit., ro6f.); das Hämmern an die Tür auch

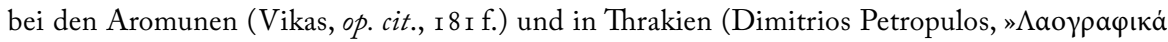

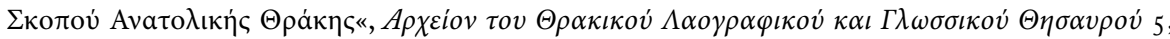
I $939 / 40$, I $45-229$, bes. I 56 f.)

I 4 O Z.B. bei den griechischen Minderheiten in Kappadokien (Dimitrios Lukopulos/Dimitrios Petro-

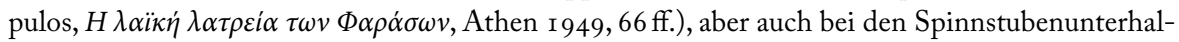
tungen in Ungarn (Tahy, op. cit.).

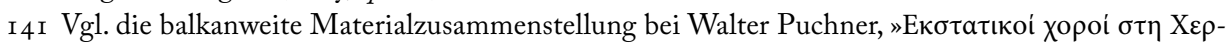

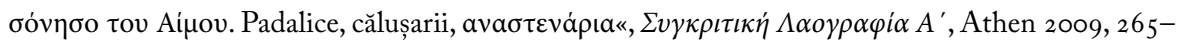
323.

I 42 Im historischen Thrakien (Bulgarien, Europäische Türkei, NO-Griechenland, Brauchtumserscheinungen, op. cit., I49).

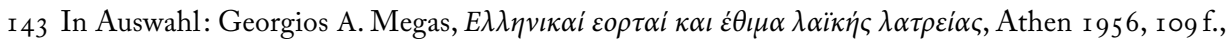

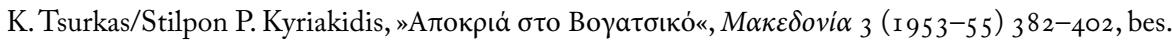

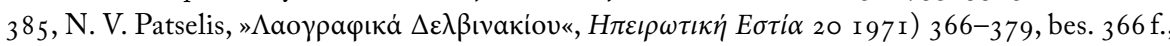

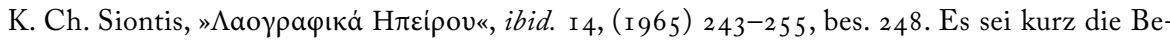
schreibung einer einschlägigen Karnevalsunterhaltung in Chalki auf Chios beschrieben: "Then all the revellers would enter, one of them in the middle performing various antics which all the rest imitated«. Es geht um den mimetischen Pfeffertanz, der zeigt, wie die Teufel den Pfeffer reiben. "In particular, there was one performance so unlike the sedulously decent behaviour of the average Chian as to suggest that it descended from ancient phallic ritual; each man would thrust the

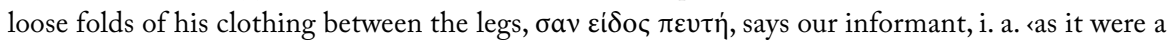

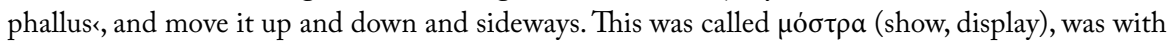
the women looking on and considered very funny" (Philip P. Argenti/A. J. Rose, The Folk-Lore of Chios, Cambridge I 949, 358). Vgl. die Abb. I 3-14 vom »Burani«-Fest in Tyrnavos, Thessalien $200 \mathrm{I}$ in Walter Puchner, Studien zur Volkskunde Südosteuropas und des mediterranen Raums, Wien/Köln/ Weimar 2009).

I 44 Z.B. nichtliturgische Primitiv-Darstellung der Auferweckung des Lazarus am Palmsamstag durch

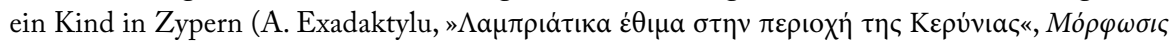
26, I 97 I, H. 3 I 2, I6 f.), oder die mimetische Darstellung des Opfers Isaaks in Farasa in Kappadokien (Lukopulos/Petropulos, op. cit., I 22 f.). 
Die performative Funktion der imitativen Handlungen wird intensiviert, wenn die Aktion einen symbolischen Gegenstand miteinbezieht, wie etwa bei der »Hundeschaukel« am Reinen Montag ${ }^{145}$, dem phallischen »Maiholz« und den Geschlechtsidolen beim Hebammentag ${ }^{146}$, den Scheinpflügungen ${ }^{147}$, und ganz besonders dann, wenn dieser Gegenstand anthropomorph ist: Judasverbrennung ${ }^{148}$, karnevaleskes Scheinbegräbnis ${ }^{149}$,

I45 Zur balkanischen Verbreitung dieser traditionellen Tierquälerei am »Reinen Montag« (čisti po-

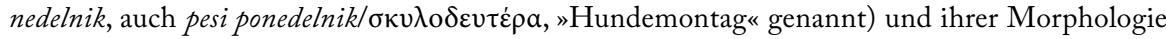

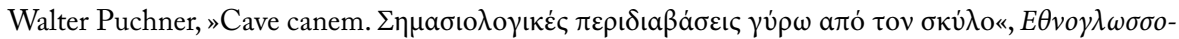

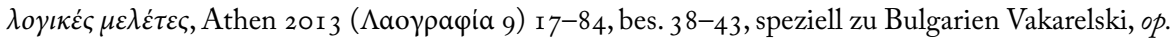
cit., 282.

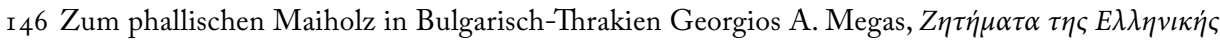

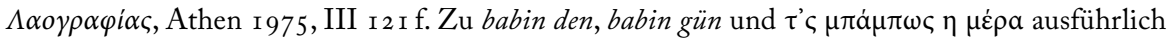

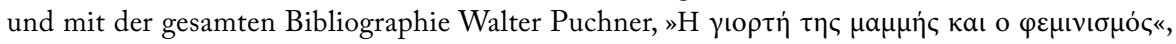

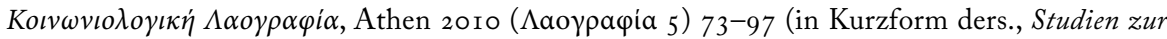

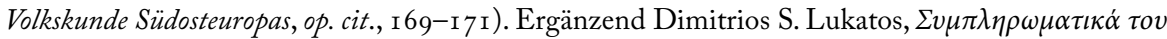

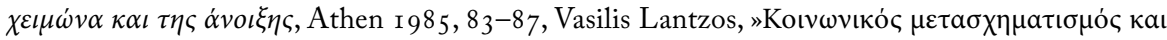

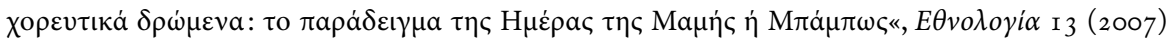
I 97-2 I I, Manolis G. Varvounis, »Balkan resultants and folkloristic influences in the Thracian dro-

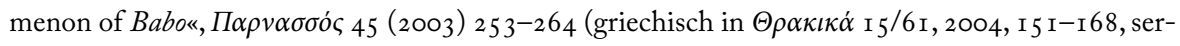

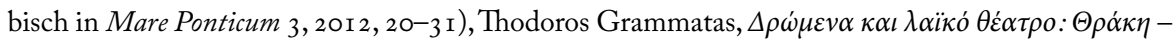

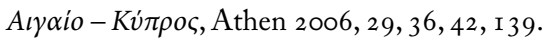

I 47 Die Scheinpflügungen sind Bestandteil vieler Brauchhandlungen und oft mit phallischen dromena

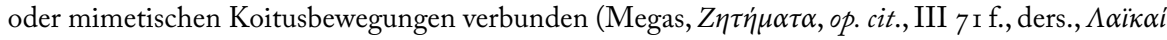

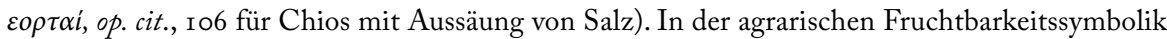
wird das Pflügen der Erde in sexueller Symbolik interpretiert, weshalb auch ein verbreiteter Hochzeitsbrauch besteht, daß die Braut beim Eintritt in das neue Haus auf einen Pflug treten muß

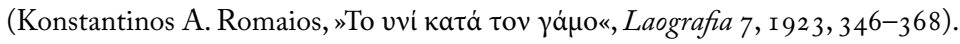

I $48 \mathrm{Zu}$ Formen und Funktionen der Judasverbrennung, Puppenherstellung, Exekution durch InBrand-Schießen oder Scheiterhaufen, antisemitisches Bedeutungs-Ambiente, Verbrennung von unbeliebten Ersatzfiguren der (politischen) Aktualität usw. vgl. Walter Puchner, Studien zum Kulturkontext der liturgischen Szene. Lazarus und Judas als religiöse Volksfiguren in Bild und Brauch, Lied und Legende Südosteuropas, 2 Bde., Wien I 99 I (Österr. Akad. d. Wiss., phil.-hist. K1., Denkschrif-

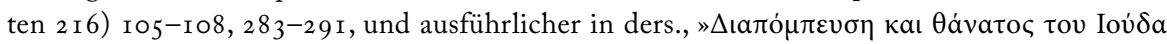

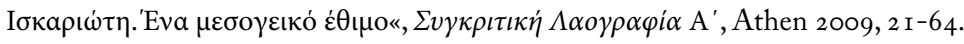

I 49 Puchner, Brauchtumserscheinungen, op. cit., I64-167. Das Scheinbegräbnis ist meist eine obszöne Parodie der Bestattungszeremonie mit deutlich phallischen Zügen (vgl. Abb. 28 in Puchner, Studien zur Volkskunde Südosteuropas, op. cit.). Einen Sonderfall bildet die Beweinung der Christus-

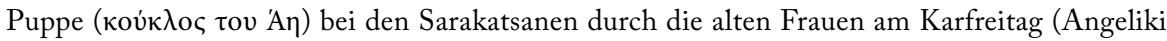
Hatzimichali, $\Sigma \alpha \rho \alpha \kappa \alpha \tau \sigma \alpha \dot{v} o l$, Athen I957, I64), ernsthaft ist auch die Lamentation der lebensgroßen Puppe leidinos auf Ägina (Brauchtumserscheinungen, op. cit., I6 6 f.), eher spielhaft jedoch das Idolbegräbnis des kannavuri in Ano Amisos (Kleinasien), der Sandfigur krantonellos auf Mykonos, ebenso wie das Blumengrab der Totenpuppe (auch von einem Mädchen gespielt) des $z a-$ 
Lazaruswiegen $^{150}$ usw. Der Bereich des explizit Performativen wird jedoch erst mit der Metamorphose durch Maske und Verkleidung betreten: nonmimetisch (Festkleidung, Karneval ${ }^{151}$, mimetisch: phytomorph, zoomorph, theriomorph, anthropomorph ${ }^{152}$; erste Formen des Theatralischen werden dann erreicht, wenn ein interaktives Rollengeflecht zustandekommt: undialogisch bzw. dialogisch ${ }^{153}$.

Diese Formenreihe einer Kategorienbildung des Performativen läßt sich nun sprachunabhängig in vielen Bereichen Südosteuropas exemplifizieren. Dies soll in der Folge geschehen, notwendigerweise stichprobenartig, allerdings weitgehend unabhängig von einer solchen »entwicklungs«-theoretischen Reihung, die aus dem Interesse an der Fragestellung entsprungen ist, wie man sich den Ursprung des Theatralischen aus dem Rituellen vorzustellen hat, eine theaterwissenschaftlich aktuelle Frage, da derartigen Formen eines solchen Rekurses auf die »Anfänge« ein großer Teil der theatralischen Avantgarde des 20. Jh.s, von seinem Beginn in der klassischen Moderne bis zu seinem Ende und Neuanfang im nächsten Jahrtausend in der postmodernen Neo-Avantgarde, verpflichtet zu sein scheint ${ }^{154}$.

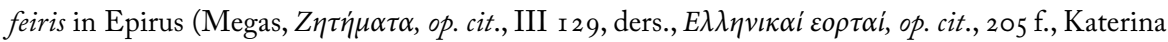

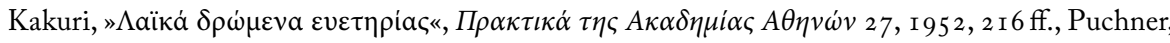
Brauchtumserscheinungen, op. cit., I 65 f.). Zu solchen Idolbestattungen gehören auch der german und scalojan in zentralbalkanischen Bereichen südlich und nördlich der Donau (Walter Puchner, »Primitividole und Idolbestattung auf der Balkanhalbinsel. (Zur rituellen Frühgeschichte des Puppentheaters)«, Acta Ethnographica Academiae Scientiarum Hungaricae 34, I 986-88, 229-244 mit der gesamten Spezialliteratur). Vgl. auch Račko Popov, Butterfly and Gherman, transl. M. Alexieva, Sofia 1989 .

I 50 Die Lazaruspuppe kann dabei ein blumengeschmückter durchlöcherter Schöpflöffel auf zwei gekreuzten Holzstäbe gebunden sein, ein verkleideter Besen oder eine Puppe in Taufkleidern, die von den Lazarusmädchen während des Singens des Lazarusliedes gewiegt wird. Bei den Sarakatsanen gehen die Knaben mit einem solchen Blumenidol des toten Viertägigen herum, wobei einer der Sänger die Puppe hält, ein anderer den blumengeschmückten Eierkorb (Lazarusgrab und Kleinkindwiege zugleich), ein dritter das »epirotische Glockenbrett«, ein Querholz mit aufgehängten Viehglocken an einen Haltestab genagelt, der rhythmisch hin- und herbewegt wird (Puchner, Brauchtumserscheinungen, op. cit., I67).

I 5 I In einer Abstufung der identitätsalterierenden (Ver)Kleidung kann die Festkleidung als eine erste Form der Metamorphose bezeichnet werden, die eine Selbstdarstellung des idealen Selbst der Mitglieder der Kommunität bildet. Der urbane Karneval hingegen verwendet fertige Kostüme bzw. nichtnormierte Formen des spielhaften Identitätswechsels als bloßes temporäres Anders-Scheinen in der Freiheit des karnevalesken mundus reversus (mit vielen Abbildungen Ivan Lozica, Hrvatski karnevali, Zagreb 1997).

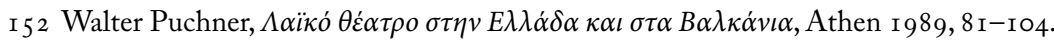

I 53 Puchner, Brauchtumserscheinungen, op. cit., 224-257.

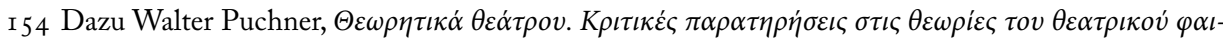
vopḱvov, Athen 2010, 307-328 (zu den Reritualisierungsstrategien). 


\section{I.3 Maske und Verkleidung}

Die Maskierung betrifft nicht nur die Gesichtsmaske, sondern auch die Metamorphose des Gesamtkörpers, ebenso wie die Verkleidung nicht nur die einzelnen Kleidungsstücke mit ihrer semantischen identitätsstiftenden Funktion umfaßt, sondern auch somatische Veränderungen und Eingriffe wie Perücke, Haartracht, Bart und Schnurrbart, Korsette, künstliche Höcker und auch andere Gegenstände und Requisiten, die Gebrechen signalisieren (Stock, Krücke, Hörrohr, Brille usw.). Maskentragen und Kleidungsänderung sind an sich öffentliche Symbolakte ${ }^{155}$, auf Kommunikation und Interaktion hin angelegt, die eine intendierte Verändung der Identität des Maskenträgers anzeigen und signalisieren, die von den Interaktionspartnern akzeptiert oder abgelehnt werden kann, temporär toleriert oder auch übernommen, wie das Phänomen der Mode zeigt ${ }^{156} \mathrm{bzw}$. das ständige Maskentragen der Damen in Venedig und seinen mediterranen Besitzungen in Südosteuropa im I6. und I 7. Jh.

\section{I.3.I Maskentheorie und Verkleidungssemiotik ${ }^{157}$}

Bestimmte Kleidungstheoretiker sind der Ansicht, daß jedes Kleidungsstück nicht nur praktische Funktionen (Bedeckung der Nacktheit, Kälteschutz) hat, sondern auch symbolische Bedeutungssignale aussendet, als Einkleidung der naturgegebenen Somatik

I 55 G. Lienhardt, »The control of experience: symbolic action«, Michael Lambek (ed.), A Reader in Anthropology of Religion, Malden etc. ${ }^{2} 2005,330 \mathrm{ff}$., Don Handleman, Models and Mirrors: Towards an Anthropology of Public Events, Cambridge 1990.

I 56 Georg Simmel, „Die Mode«, Philosophische Kultur, Leipzig I919, 25-57, René König, Kleider und Leute. Zur Soziologie der Mode, Frankfurt/M. 1967.

I 57 Südosteuropäische Forscher haben Wesentliches zur Maskenforschung und -semiotik beigetragen. Vgl. in Auswahl: Vesna Marjanović, Maske, maskiranje i rituali u Srbiju, Beograd 2008, 30 I f., Oto Bihalji-Merin, Maske sveta, Beograd/Ljubljana 1970, Dragoslav Antonijević, Dromena, Beograd I 997, 84 f., Ivan Kovačević, Semiologija rituala, Beograd I 985, ders., Semiologija mita i rituala I-III, Beograd 200I, Radoslav Đokić, Znak i simbol, Beograd 2003, M. Prosić, »Teorijsko-hipotetički okvir, za proučavanje poklada kao obreda prelaza«, Etnološke sveske I (Beograd I 978) 33-49, D. Rnjak, »Od kulta do pozorišta«, Antički teatar na tlu Jugoslavije, Novi Sad I979, I3-4I, Anastasia Sami-

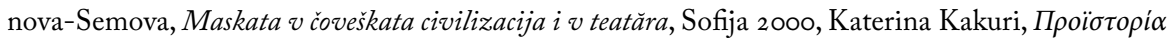
$\theta \varepsilon \alpha \dot{\tau} \rho \rho v$, Athen 1974. Vgl. auch die Übersichten zur südosteuropäischen Maskenforschung: Zoltán Ujváry, Játék és maszk, 3 Bde., Debrecen I 983, Romulus Vulcănescu, Măștile populare, București I 970, Niko Kuret, Maske slovenskih pokrajin, Ljuljana I984, Ivan Lozica, Izvan teatra, Zagreb I990, ders., Hrvatski karnevali, Zagreb 1 997, ders., Poganska baština, Zagreb 2002, Georg Kraev, Bălgarski maskaradni igri, Sofija I996, ders., Maska i bulo, Sofija 2003, ders., »Obredno i dramatično dejstvo«, Maska i ritual, Sofija I999, Iо I-I I 3, Robert Wildhaber (ed.), Masken und Maskenbrauchtum in Ost-und Südosteuropa, Basel 1968. 
bereits Verkleidung im Sinne sozialer Zeichenhaftigkeit darstellt: Jedes Kleidungsstück ist aus dieser Optik bereits eine Art Theaterkostüm ${ }^{158}$. Diese Sichtweise mag etwas extrem anmuten, offenbart aber das Faktum, daß Kleidung in traditionellen Gesellschaften, prima vista und von erster Güte, ein Informationsträger der sozialen Identität ist: An der traditionellen Tracht kann man die soziale, religiöse, familiäre und altersmäßige Position einer Person auf den ersten Blick erkennen ${ }^{159}$. Die Ver-Kleidung bildet einen Eingriff in diese Spiegelfunktion und täuscht etwas vor, was nicht der »Realität« (der sozialen Rollenzuweisung) entspricht ${ }^{160}$. Dies mag etwa bei der Theaterkonvention des Bühnenkostüms oder bei sakralen Ritualhandlungen gesellschaftlich sanktioniert sein, oder, in offenen Gesellschaften der Moderne, dem Bestreben des Individuums nach einem gewissen zur Schau getragenen body-image anheimgestellt sein, um dem gesellschaftlichen Beurteilungs- und Taxonomie-Streben zuvorzukommen oder dieses zu beeinflussen ${ }^{161}$. Die traditionellen Verkleidungsformen in Südosteuropa oszillieren im allgemeinen zwischen idealisierender Festtracht und dämonischer Lumpenkleidung, zwischen ritueller Metamorphose mit Identitätsverschiebungen plus ihrer Akzeptanz in der Rezeption und der libertinistischen Narrenfreiheit des Karnevals, wo das Unerlaubte erlaubt ist, unterhaltsame Normübertretung, Störung und Deftiges erwartet werden, wurzeln sie doch in der nicht mehr bewußten Fruchtbarkeitsmagie einer Krisenphase im Jahreskreis der Kommunität oder im Lebenslauf des Einzelnen. Die Erklärungsstrategien für das Überkommene folgen rationalisierenden und ideologisierenden Tendenzen auf lokaler, regionaler und staatlicher Ebene ${ }^{162}$; die Morphologie der Verkleidungen tendiert nach den Gesetzen des Folklorismus zu ästhetisierenden Lösungen oder auch zu Neo-Obszönität ${ }^{163}$ und integriert sich in die event-Kataloge der Internet-Adressen, wo sich jedes Dorf mit seinen Attraktionen in seiner Eigenart profiliert, um Tourismus anzuziehen oder lokales Selbstbewußtsein zur Schau zu tragen.

I 58 James Laver, Costume in the Theatre, London I964, I5.

I 59 Dazu gibt es eine umfangreiche Bibliographie. Vgl. die klassische Studie von Petr Bogatyrev, The Functions of Folk Costume in Moravian Slovakia, The Hague/Paris $197 \mathrm{I}$.

I60 Insofern ist Kleidung und Verkleidung unmittelbar mit der soziologischen Rollentheorie verknüpft.

Vgl. B. J. Biddle/E. J. Thomas, Role Theory: Concepts and Research, New York I 966, Rolf Dahrendorf, Homo sociologicus, Köln I 959, Hans Joas, Die gegenwärtige Lage der soziologischen Rollentheorie, Wiesbaden 1978 und zunehmend kritischer Bruce Wilshire, Roleplaying and Identity: The Limits of Theatre as Metaphor, Bloomington 1982 .

i6r R. Broby-Johansen, Body and Clothes, London i 968.

I62 Zu diesen sekundären Explikationsstrategien Tekla Dömötör, "Zur Frage der sogenannten Kausalfiktionen ", IV. Intern. Congress for Folknarrative Research in Athens, Laografia 27 ( 1968) 88-93.

I63 Dazu etwa die analytische Bibliographie zur Obszönität in der rezenten griechischen Volkskultur

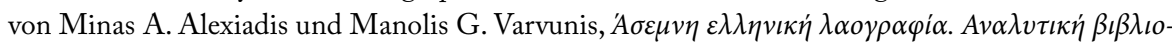

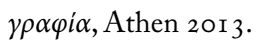


Die Körper-Maske, aber vor allem die Gesichtsmaske - nach Maßgabe der Tatsache, daß das Gesicht mit seiner Mimik und dem Blick der wichtigste Zeichen- und Bedeutungsproduzent der Gesamtsomatik ist - stellt an sich das materialisierte Artefakt der Metamorphose dar; in seinem Gegenstand ist die Schauspieler-Verwandlung der Theatervorstellung in ihrer Dialektik bereits eingeschrieben: Sie propagiert die Änderung der Identität des Maskenträgers, aber auf sichtbare Weise, als abhebbare Verfremdung der Physiognomie, die diesen Eingriff keineswegs verbirgt, sondern in nicht-illusionistischer Weise zur Schau stellt. Was heute als sozial akzeptierter, spielhaft ausgeführter »Schwindel« des Masken- und Kostümballs der Unterhaltung dient (von der Frühkirche noch in bis in die Neuzeit hinein bitterlich verdammt) ${ }^{164}$, war einst fester Bestandteil von Ritualpraktiken von Hoch- und Volksreligionen, wo das Maskentragen noch die tatsächliche Metamorphose des Maskenträgers indizierte; von diesen Vorstellungen ist auch im Balkanraum wenig geblieben, nur in älteren Quellen (z.T. mit Vorsicht zu benutzen) schimmert bei den martialischen Mittwinterverkleidungen noch die frühere Bedeutung der imaginären Anwesenheit von Unterweltsdämonen und den Totenseelen auf der Oberwelt durch ${ }^{165}$.

In diesem Sinne hat das südosteuropäische Maskenrepertoire an zwei Realitätsebenen gleichzeitig teil: einer fiktiven (Teufel, Dämonen, Totenseelen, H1. Georg, Lazarus usw.) und einer faktischen (Mimesis von Pflanzen, Tieren, aber auch Menschen in typisierten sozialen Rollen: Brautpaar, Priester, Schwiegerleute, Arzt, Richter usw.). Jeder Maskentyp enthält zugleich in nuce eine (ausgeführte oder nichtausgeführte) Aktion: das Brautpaar die Hochzeit, der Arzt die Untersuchung, der Richter das Gericht usw. ${ }^{166}$ Grundlage der meist parodistischen Handlungen sind im allgemeinen exzeptionelle Ereignisse der Kommunität (Hochzeit, Tod, Geburt, Gericht usw.) ${ }^{167}$. Die ganzkörperliche Maskierung besteht in ihrer traditionellen Form aus Materialien, die in der Agrarregion vorhanden sind: Hörner, Schwänze, Felle, Pelze, Kürbisse, Viehglokken usw.; fertige und eigens verfertigte Masken sind nur in lokalen Urbanzentren in neuerer Zeit nachzuweisen, ganz abgesehen vom Karneval westlichen Typs mit seinen Kostümen, Wagenprozessionen und Preisverleihungen, der allerdings schon im späten I 9. Jh. anzusiedeln ist ${ }^{168}$. Die primitivste Form der Gesichtsmaske ist das Schwärzen mit Ruß, Asche, Kohle usw. An die illusionistische Wirkung der Maskierung werden

I64 Walter Puchner, »Acting in Byzantine theatre: evidence and problems«, Pat Easterling/Edith Hall (eds.), Greek and Roman Actors. Aspects of an Ancient Profession, Cambridge 2002, 304-324.

I65 Vgl. Walter Puchner, »Im Namen der Rose. Zum Nachleben des Rosalienfestes auf der Balkanhalbinsel«, Studien zur Volkskunde Südosteuropas, op. cit., 47-106, bes. 73-90.

I66 Puchner, Brauchtumserscheinungen, op. cit., 209-2 I 4.

I67 Dies entspricht dem Begriff des »Volksschauspiels« in seiner engeren Fassung (vgl. Walter Puchner,

Enzyklopädie des Märchens I4, 201 I , 350-360).

I68 Diese urbanen Formen werden hier nur punktweise tangiert. 
ursprünglich minimale Anforderungen gestellt, was sich jedoch im Laufe des 20. Jh.s in Richtung immer realistischerer Ausgestaltung zu ändern beginnt.

Im allgemeinen vermitteln die südosteuropäischen Maskenformen zwei konträre, jedoch synchron existierende Handlungsatmosphären: auf der einen Seite Würde und Gravität, Pathos und naiver Ernst, was sich in der Festkleidung und manchen komplexen Brauchaktionen manifestiert, deren rituelles Glaubensfundament (Fertilitätspromotion, Apotropäum von Übel jeglicher Art) noch einigermaßen intakt ist, auf der anderen Seite Ausgelassenheit und Überschwang, Deftigkeit und Laszivität, was die »dionysische« Seite der Brauchmanifestationen, entweder in ihrer Unterhaltungsfunktion oder der rituellen Obszönität (ebenfalls zur Fertilitätspromotion), betrifft. Maskierungen und Verkleidungen, Aktionen und Interaktionen, Ritus und Spektakel in ihrer imaginären Dimension sind zentrale Bestandteile der Überlebensstrategie jeder Kommunität, die Realität und Überwirklichkeit gleichermaßen umfassen. Vor allem in den Folklore-Festivals während der sozialistischen Herrschaft wurde die fertilitätskultische und »dionysische« Dimension der Brauchhandlungen entschärft und der ideologisierte und inszenierte Schaustell-Effekt der didaktischen Kultivation des nationalen Kulturerbes in den Vordergrund gestellt ${ }^{169}$.

An der Materialerfassung der südosteuropäischen Maskenformen und ihrer theoretischen Verarbeitung in den Antwortstrategien auf die Ursprungsfrage des Theatralischen waren wesentlich ungarische, rumänische, südslavische und griechische, aber auch andere Forscher beteiligt ${ }^{170}$. Die innerösterreichischen Länder im Süden und

I69 Z.B. M. Benovska, »Praznik na kukerite i survakarite«, Bălgarski Folklor 3 (I 977) H. 3, 63-66. Zu den theatralischen Aspekten des Folklorismus und den Begriff der Inszenierung in den Kultur-

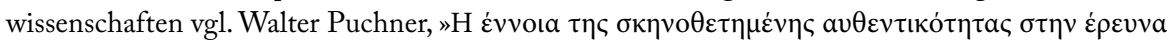

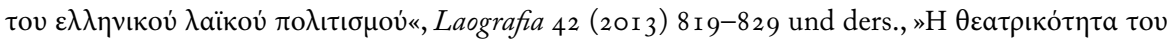

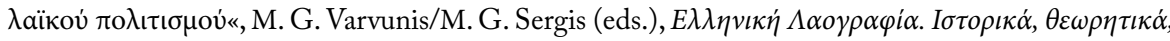

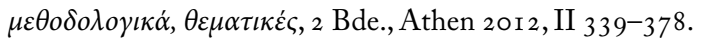

I 70 F. Hont, „Folklore und Theaterwissenschaft«, Acta Ethnografica Academiae Scientiarum Hungaricae I 9 (1 970) I 83-190, Linda Dégh, A magyar népi szinjátszás, Budapest 1947, Tekla Dömötör, »Literatur and folklore. Problems of reseach in old Hungarian dramatic art«, Annual Universitatis Scientiarum Budapestensis, Sectiones Philologiae I (1 957) 53-65, dies., A zujkori szinjátszás kialakulása kelet-Európában, Budapest I964, dies., A népi szinjátsás Európában, Budapest I 966, dies., „Folk Drama as Defined in Folklore and Theatrical Research«, Narodna Umjetnost, special issue, Zagreb I 98 I, 79-82, G. Angelova, »Teatăr v života«, Teatăr I 968/4, 59-64, Rosica Angelova, »Les masques populaires bulgares«, Schweizer. Archiv für Volkskunde 63 (1976) 226-239, Christo Vakarelski, »Jeux et coutumes théâtrales chez les Bulgares«, Ethnologia Slavica I (I969) I 2 I-I 42, ders., Bulgarische Volkskunde, Berlin $1969,380-389$, T. I. Živkov, »Obrednost i obredno izkustvo«, Obredi i obreden folklor, Sofija I 98 I, 7-28, Dimitrie C. Ollanescu, Teatrul la români, Bd. I, București r 898, 45 ff., Teodor T. Burada, Istoria teatrului in Moldova, Bd. I, Iași I 91 5, I-88, Simion Alterescu, »Unele probleme de orientare în Isto- 
Osten Österreichs, im Bereich der Oralkultur nur schwer von Südosteuropa zu trennen ${ }^{171}$, ebenso wie die Sprachinseldeutschen im Norden Südosteuropas können hier nur punktweise zur Sprache kommen.

riografia teatrală contemporeană«, Studii și cercetări de istoria artei 5/I (1958) I 85-198, Olga Flegont, "Contribuții la cercetărea formelor vechi de artă teatrală populară«, ibid. 9/2 (1962) 347-359, dies., Istoria Teatrului in România, București 1965, 23-40, 4I-78, Vasile Adăscăliței, Teatrul folkloric, Iași I 969, Niko Kuret, »Masken aus Slovenien«, Schweizer. Archiv für Volkskunde 63 ( I 967) 203-225, ders., "Frauenbünde und maskierte Frauen«, ibid. 68/69 (1972/73) 334-347, M. Slivka, »Scénsky priesto v l'udovom divadle«, Slovénske divadla 22 (1974) 383-425, Milovan Gavazzi, „Das Maskenwesen Jugoslawiens«, Schweizer. Archiv für Volkskunde 63 (1976) I 85-202, Dragoslav Antonijević (ed.), Folklorni teatar u balkanski i podunavskim zemljama, Beograd I 984, Ivan Lozica, "Folklorno kazalište i scenska svojstva običaja «, Mogućnosti 32 ( I 985) I 5-24, Nikola Bonifačić-Rožin, »Čovjek kao scenski rekvizit«, Rad VIII kongresa saveza udruženja folklorista Jugoslavije o Titovom Užicu, Beograd I 96 I, 4I 9-425, Tvrtko Cubelić, Narodno dramsko stvaralaštvo, Zagreb i 964, ders., Usmena narodna retorika i teatrologija, Zagreb I 970, ders., Na stazama usmenog narodnog stvaralaštva, Osijek I 982, Ivan Lozica, $O$ određenju folklornog kazališta«, Narodna Umjetnost I 3 (I976) I4I-I 53, Maja BoškovićStulli, »Predstavljački aspekti usmenog pripovejedanja«, Mogućnosti 32 (I985) 45-56, Ivan Lozica, "Prolemi klasifikacije folkornih kazališnih oblika«, Croatica I4 ( I 983) 64 ff., Josip Kekez, »Smjerovi istraživanja usmenoknjiževni drame«, Mogućnosti 32 ( 1985 ) 45-56, ders., »Usmenoknijževni prilog oblikovanju poslijerate hrvartske drame«, ibid. 3 I ( I 984) 76-97, Ivan Lozica, »Teatralnost, teatrabilnost, i folklorni teatar", Gradina 3 (Niš I 980) 79-9I, Olga Supek-Zupan, »Ritualni aspekti sajmova", Mogucnosti 32 ( 1985 ) 250-257, Olga Supek, »Gender Inversion in the Contemporary Carnival: Saturnalia or an Echo of a Changing Reality?«, Z. Rajković et al. (eds.), Contributions to the Study of Contemporary Folklore in Croatia, Zagreb I 988, 23-34, N. Frudić, "Metafore i dvosmislice u narodnoj drami«, ibid. 32 ( 1985 ) 340-348, Dragoslav Antonijević, »Vizantijske brumalije i savremene maskirane prvorke balkanskich naroda«, Balcanica Io ( I 979) 93-I 29, Ž. Ilić, „Etnoteatrološka građa iz Bosne u novosadskom Javaru« «, Scena 4 (Novi Sad I 977) 3 I-33, Ivan Lozica, »Inscenacija običaja kao kazališna predstava«, Narodna Umjetnost 22 ( I985) 26 I-27 I, F. A. Dubinskas, »Ritual on Stage: Folkloric Performance as Symbolic Action «, ibid., special issue, Zagreb I98 I, 92-ı o6, Oto Bihalji-Merin, Maske sveta, Beograd/Ljubljana I970, Ivan Lozica, »Theatrical Conventions and Oral Communication «, ibid., 83-92, ders., Izvan Teatra, Zagreb i 99o, ders., Folklorno kazalište (Zapisi i tekstovi), Zagreb 1996, Slobodan Zečević, Elementi naše mitologije u narodnim obredima uz igru, Zenica I973, I25-I43, D. Nikolić, Gornje Dragačevo, etnološko proučavanje kulturnih promena, Beograd

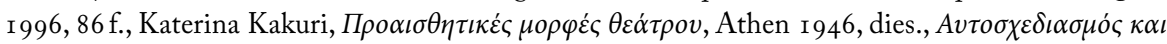

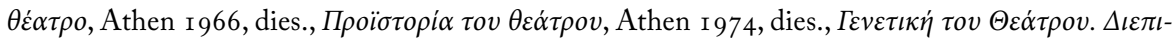

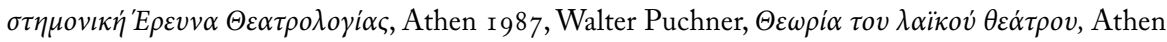

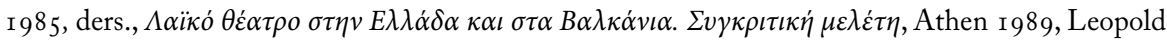
Schmidt (ed.), Le théâtre populaire Européen, Paris 1965, ders. (ed.), Masken in Mitteleuropa, Wien I 955, Robert Wildhaber (ed.), Masken und Maskenbrauchtum aus Ost- und Südosteuropa, Basel I 968, A. D. Avdeev, Proizchoždenie teatr, Moskva I969, M. Balašov, »Drama i obrjadovoe dejstvo (K probleme dramaturgičeskogo roga v folklore)«, Narodnyj teatr. Sbornik statej, Leningrad 1974, 7-I 9 usw.

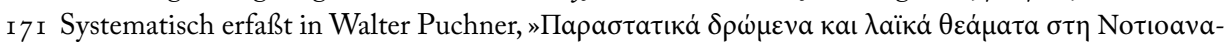

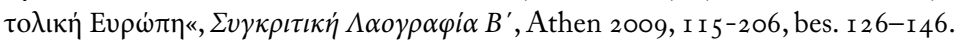




\section{I.3.2 Phytomorphe Verkleidung}

Unter den Formen der fertilitätsmagischen Vegetativmetamorphosen dominiert die Blüten- und Blätterverkleidung (Anthomorphie, Phyllomorphie) des Frühlingsabschnittes mit ausschließlicher Beteiligung der Mädchen. Eine Ausnahme bildet der unerkenntlich in einem bis zum Schopf reichenden Blätterwald versteckte slovenische Zelenj Juraj, der grünverkleidete H1. Georg, der während seines Hausumganges von einem Burschen dargestellt wird, während ein zweiter Bursch den Geschenkkorb hält ${ }^{172}$. Der gesamte Osterzyklus mit der Resurrektion von Lazarus und Christus, dem Epitaph-Blüten-Baldachin der Gründonnerstags/Karfreitags-Riten und den geschmückten Blumenkörben der Lazarus-Mädchen kann unter dem Aspekt der vegetativen Anagenese als rekapitulierende Wiedervergegenwärtigung des Epochendramas in zwei aufeinanderfolgenden Akten eines Thanatos/Palingenesie-Dramas gesehen werden ${ }^{173}$.

I72 Vgl. die Abb. 22 in Puchner, Studien zur Volkskunde Südosteuropas, op. cit., und vor allem Višnjia Huziak, Zeleni Juraj, Zageb I957; im Vergleich Roy Judge, The Jack-in-the-Green. A May Day Custom, London 2000. Zu anderen Verkleidungsformen am Festtag des H1. Georg, dem 23. April, vgl. Gabriella Schubert, "Der H1. Georg und der Georgstag auf der Balkan«, Zeitschrift für Balkanologie 2I/I (1985) 80-I05, Tatiana A. Koleva, »Sur l'origine d'une groupe de coutumes et rites dans la région Balkano-Carpathique. La fête de Saint Georges«, Thracia 2 (I 974) 2 I 9-226, dies., »Sur l'origine de la fête de Saint-Georges chez les Slaves du Sud«, Ethnologia Slavica 6 (1974) I 47-1 73 , dies., „Typologie de la fête de la Saint-Georg chez les Slaves du Sud«, Études balkaniques I 977/I, I I6-I 2 I , dies., "Vestiges de rites d'initiation dans les coutumes de printemps des jeunes filles bulgares«, Études balkaniques Io/I (1974) 65-85, D. Antonijević, »Đurđevdanski folklor kao obeležje specifičnosti i zajednice etnički grupa prizrena«, Rad XIV kongresa saveza udruženja folklorista Jugoslavije u Prizrenu I0.-13. IX. 1967, Beograd I974, I93-202, D. Nedeljković, »Đurđensko jagnje i ’kravaj< kao participacioni relikt primitivnog mentaliteta«, Vjesnik Etnografskog Muzeja, Zagreb I938, I-Io, G. Palikruševa, "Jedan đurđevdanski običaj kod Juruka u okolini Radovita«, Rad IX-og kongresa saveza folklorista Jugoslavije u Mostaru i Trebinju 1962, Mostar-Trebinje 1962, 363-370,

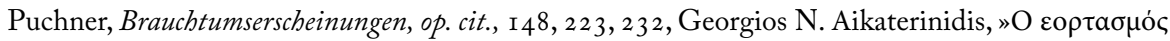

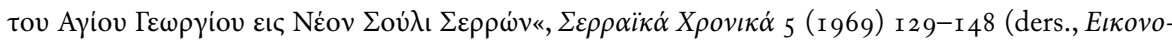

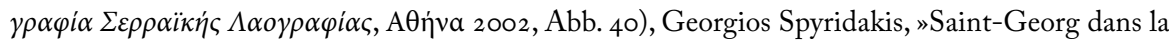
vie populaire«, L' Hellénisme Contemporaine 6 (I952) I 26-I 45, St. Novaković, »Zu den Gebräuchen um das Georgi-Fest«, Archiv für slavische Philologie I 2 ( I 890) 303-306, Barrie Machin, »St. George and the Virgin: Cultural Codes, Religion and Attitudes to the Body in a Cretan Mountain Village«, Social Analysis 14 ( 1983 ) ro7-I 26, usw.

I73 Walter Puchner, »Lazarus redivivus und österlicher Blumenheld«, Akkommodationsfragen. Einzelbeispiele zum paganen Hintergrund von Elementen der frübkirchlichen und mittelalterlichen Sakraltradition und Volksfrömmigkeit, München 1997, 60-63. Den Zusammenhang zwischen der Erweckung des amicus Christi und der erwachenden Natur hat der H1. Chrysostomos schon in seiner Homilie "Auf den viertägigen Lazarus« festgestellt (Patr. Graec. 50: 64I-644, Gesamtausgabe Athen I96769, IV 32 I ff., deutsch bei Puchner, Studien zum Kulturkontext, op. cit., I 2 I). 
In dem auf Zypern dargestellten suscitatio-dromenon durch den in gelbe Totenblüten gekleideten Lazarusknaben, der sich in der Lazarus-Kirche in Larnaka ${ }^{174}$ bei der Evangelienlesung der Perikope Joh. I I, 43 nach der Messe am sabbato ante palmas zur Freude der gesamten Gemeinde aus seinem Blumengrab erhebt, bekommt das Blumenfest des »Viertägigen« (tetrahemeros, tetartaios) performativen Charakter.

Durch Christus vom Tode auferweckt, kamen Lazarus und Maria Magdalena nach Kition [heute Larnaka], wo beide starben und deren Gebeine 890 n. Chr., durch Kaiser Leo, den Pbilosophen, nach Byzanz gebracht wurden. Am leeren Grabe des hl. Lazarus, einem schlichten römischen Sarkophage in der Gruft unter der Ikonostasis, der goldfunkelnden Bilderwand der altbyzantinischen Lazaruskirche, beginnt die vom jeweiligen Bischof von Kition zelebrierte Lazarusfeier und wird am Altartische vor der Bilderwand beendet.Die ganze Kirche ist mit Lazaruszweigen zu einer Riesenlaube austapeziert. In der Fest Liturgbia näselt der Protopappâs (d. h. der erste Priester) seine Gesänge, dem die ganze Gemeinde in gleichem Nasentone gegensingt, wäbrend der Bischof im vergoldeten Chorstüble steht, umgeben vom Archimandriten, Exarchos und zwei Diakonen mit dreiarmigen Leuchtern. Die Luft wird dick vom vielen Weibrauchschwenken und von Tausenden brennender Kerzen./Zum Schlusse drängt sich die ganze Volksmasse zum Lazarusbilde, einer gemalten Holztafel am Hauptplatze in der Bilderwand, um dieses zu küssen. Selbst jeder Säugling wird emporgehoben und mit den Lippen gegen die Hand des Heiligenbildes gepreßt. Noch größeres Gedränge aber umgibt die heilige Säule am Lazarusgrabe, die jeder küssen, an der jeder, auch der ärmste Bettler, die ibm geschenkte brennende Wachskerze ankleben muß.Nun zieht der Metropolit mit den Priestern und der Gemeinde nach dem großen Empfangsraume, der Sala des anstoßenden Lazarusklosters. Inzwischen haben die Epitropoi, d. h. die Kirchenvorsteher und Diakonen [sic] den schönsten und intelligentesten Knaben des Ortes, das Paedi tù Lazáru, den Lazarusknaben, in das eigens für das Fest von den besseren Frauen der Stadt aus gelben Lazarusblumen, den "lulúdia tù Lazáru« (der präcbtigen Pflanze Chrysanthemum coroniarum L.) geflochtene Lazaruskleid gebüllt./Unter Anstimmung von Trauerliedern und Trauermusik wirft sich der mitten im Gemach auf ein buntes Blumen-, Blätter- und Teppichlager. Das duftet von Rosen und Orangen, glüht von purpurnen Granatenblüten, ist umragt von Palmen, Lorbeer und Myrten, umstanden von grünem in Töpfen gezogenen Getreide und umflackert von riesigen Wachskerzen in silbernen mehrarmigen Leuchtern./Der Protopapas [sic] verliest das Lazarus-Evangelium im I I. Kapitel St. Johanni und wenn er zum 43. Verse kommt, erhebt er seine Stimme, genau wie Christus tat: "Da er das gesagt hatte, rief er mit lauter Stimme: Lazarus, komm heraus«. Wäbrend des "Lazare éxelthe«-Rufes (d. h. Steh auf, komm heraus aus der Grabkammer) des Protopapas sind drei gleichzeitig zelebrierende Priester oder

I 74 Vgl. den »Exkurs: Des Lazarus zweites Leben in Ost und West« in Puchner, Die Folklore Südosteuropas, op. cit., I $26-\mathrm{I} 29$. 
Diakonen [sic] beschäftigt. Der eine legt das Kruzifix auf den Kopf des Lazarus-Knaben, der zweite beschwenkt ihn mit Weibrauch und der dritte besprengt ihn mit einem in das Weibwasserbecken getauchten Myrtenbüschel./Nun erst erwacht der Totgesagte. Der Lazarusknabe springt auf, die Frauen begießen ihn mit Rosenwasser, bewerfen ihn mit Rosenblüten und stecken ihm Rosenglykò und andere Süßigkeiten in den Mund und ein Epitropos (ein Kirchenvorsteher) reicht ibm einen Schluck Wein und einen Bissen Lazarusbrot./Die Pfeifen, Flöten und Tamburine, die Geigen und Lauten mitsamt dem Kirchenchor intonieren im Walzertakt einen Freudenhymnus, in den die Gemeinde einstimmig einfällt. "Der Lazarus ist auferstanden«, ruft jeder neu Herantretende dazwischen./Die den Kirchenvorstand und Festausschuß bildenden Larnakioten reichen nun mit ibren Frauen und Töchtern bei den Bevorzugten allerlei Speisen und Getränke herum, so besonders die reich mit Früchten und Konfekt dekorierte Toten-Gedächtnisspeise, das bereits beschriebene Kollyva des Lazarus, dazu phantastisch geformte Kuchen und Brote, wie wir sie beim Ostergebäck wiederfinden, ferner in silbernen Prunkgefäßen das Glyko, d. h. die Süßigkeit, nach Landesart eingemachte Früchte der verschiedensten Art. Auch kredenzen sie Landesliköre und Mastika, den cyprischen Weinschnaps und Commanderia, den cyprischen Süßwein ... Dabei gießen sie eilig auch noch Rosen- und Orangenblütenwasser aus silbernen Prunkflaschen den Festteilnehmern auf die Hände und gehen zum Schluß noch eiliger mit schön modellierten silbernen Rauchgefäßen, den Kapnisterien bei den Honoratioren herum, damit diese sich den Weibrauch gegen den bösen Blick zuwehen. So endet die erste feierliche Zeremonie der Lazaruserweckung im Hofe der Lazaruskirche./Denn nun stürmt der Festausschuß und der ganze Lazarusfestzug, so schnell die angezündeten Wachskerzen das Gehen der Prozession, gestatten, bis tief in die Nacht durch die Straßen und Häuser der Stadt nach den prächtig geschmückten improvisierten Totenkammern und Totenlagern des Lazarus in den Privathäusern. Jede Hausfrau sucht es der anderen vorzutun im Teppichlager, im Blumen-, Pfanzen- und Lichterschmuck, in künstlich für den Tag erzeugten Getreidekulturen, in Back-und Zuckerwerk, in eingemachten Früchten, guten Schnäpsen und Weinen und, was für die Priester und Kirchenvorsteher nicht Nebensache, in Geschenken an Geld, Wachs, Honig, Festbrot und Festkuchen, in Zigaretten und Tabak./Überall wird dieselbe Zeremonie wiederholt, je nach dem Ansehen und Reichtum länger oder kürzer. Nur die ganz Armen und wer kein Lazaruslager bereitete, werden ausgelassen, auch wird nur eine bestimmte Prozessionsstraße innegehalten ${ }^{175}$.

I75 Magda Ohnefalsch-Richter, Griechische Sitten und Gebräuche auf Cypern, Berlin I913, 86-88. Das in gelbe Totenblüten gekleidete Lazaruskind wurde früher auch in anderen Städten und Dörfern Zyperns mit und ohne Priesterbegleitung von Männern herumgeführt, legte sich während des Absingens des langen Lazarusliedes auf den Boden und erhob sich beim biblischen Erweckungsruf

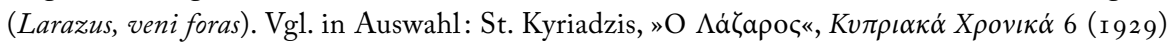

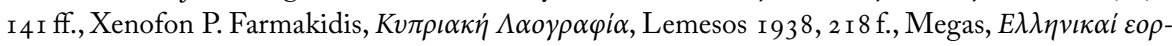
$\tau \alpha i$, op. cit., I 42. Zu den gelben Totenblüten (similludkia, achillea santolina, chrysanthemum segetum), „Lazarus« genannt, die vielfach auch das Gesicht des »Toten« bedecken, vgl. Chr. Hatziiosif, 
Ein ähnliches Blumengrab wird auch dem zafeiris-Mädchen auf den Weidegründen des gebirgigen Epirus errichtet in einem spielhaften Frühlingsbrauch zur Erlernung der Lamentations-Attitüden durch die Jungfrauen; der Ritus der sich Totstellenden und ihrer Verlebendigung nach dem threnos-Absingen kann auch durch ein Idol dargestellt werden ${ }^{176}$, ähnlich wie german und scalojan in Bulgarien und Rumänien und andere Regenbitt-Riten des Frühjahrs- und Frühsommer-Abschnittes ${ }^{177}$. Ein Blütenkleid bedeckt auch das kleine Maikind, das von Mädchen herumgeführt wird ${ }^{178}$, im Gegensatz zu der Strohbekleidung der Puppeneffigien, die beim sogenannten Winteraustreiben verbrannt und fern der Kommunität zerrissen und zerstört werden (totes Stroh - lebendige Blüten). Doch ist dies eher auf die Nordzonen der Balkanhalbinsel beschränkt ${ }^{179}$;

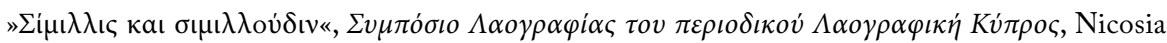
I 972, 7 I-75, zum Phänomen der Metonymie, der Übertragung des Festnamens auf Requisten

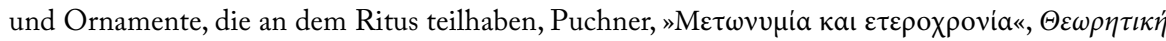
$\Lambda \alpha о \gamma \rho \alpha \varphi i \alpha$, op. cit., 282-30 I mit weiteren Beispielen.

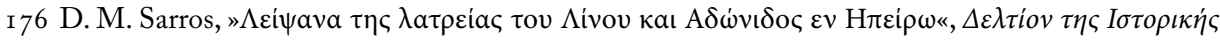

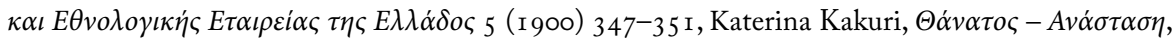

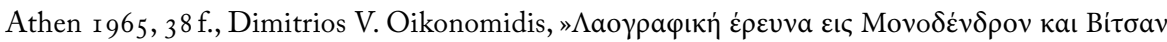

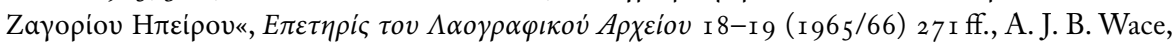
"North Greek Festvals and the Worship of Dionysos", The Annual of the British School in Athens 16

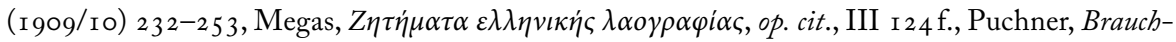
tumserscheinungen, op. cit., I98-200.

I77 Vgl. dazu noch in der Folge. Zum Pflanzengrab des fuskodentri (Schwellbaum) in Kastania im

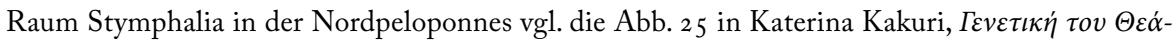
$\tau \rho o v$, Athen 1987, 78 und Abb. 26 in Puchner, Studien zur Volkskunde Südosteuropas, op. cit.

I7 8 Diese »Verkleidung« des maiopulo reicht von einem einfachen Blumenkranz im Haar bis zum kör-

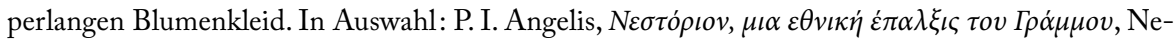

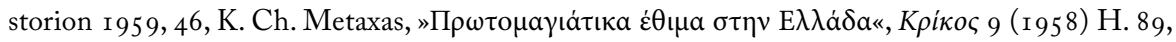

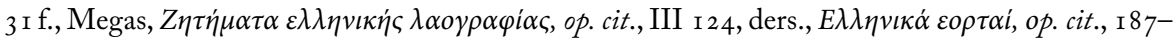
I 89. Weitere Bibliographie bei Puchner, Brauchtumserscheinungen, op. cit., 202 f. Grünverkleidungen sind jedoch balkanweit im Frühjahrsabschnitt nachzuweisen. Bei Vlachophonen in Gudovasda im Raum Trikala in Thessalien dominiert die »dionysische« Atmosphäre eines fruchtbarkeitsmagischen Kontexts: Hier tanzt eine dermaßen verkleidete alte Frau mit Netzschleier über dem Gesicht, einen leeren Wasserkürbis um den Hals und ein Holzstück (Phallusidol?) in Händen die ganze Nacht des Pfingstsonntags mit allen Männern des Dorfes, begleitet von obszönen Redensarten und

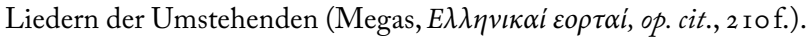

I79 Z.B. beim Faschingsbegräbnis in Ungarn (Tekla Dömötör, „Népi színjatéktípusok«, Mưveltség és Hagyomány 10, 1 968, I6I-1 74), beim Winterhinaustragen in Szeged (János Kovács, Szeged és népe, Szeged r 90 I, 3 I 7 f.), bei der »Ermordung« der »Brigita« im Spinnhaus von den Burschen und der parodistischen Funeralprozession ihrer "Leiche« in Ipolydamazsd (János Manga, Tájékosztato szinjátékszerü népszokások gyüjtéséhez, Budapest 1953, 27), bei den Szeklern schon I 7 I 4 verboten (Balázs Orbán, $A$ székelyföld leirása, Budapest I 873, IV 29 I f.); die Strohpuppe wird auch verbrannt 
im Gegensatz dazu hat das grünverkleidete Regenmädchen Verbreitung von der Pannonischen Tiefebene bis nach Kreta ${ }^{180}$.

Trotz der enormen geographischen Verbreitung bietet die Brauchmorphologie des dodola/perperuna-Ritus, ähnlich wie das dazugehörige Regenbittlied ${ }^{181}$ ein ziemlich einheitliches Bild ohne allzu großen Variationsspielraum, was nicht nur in dem intakten Glaubensgefüge an die magische Effektivität des Ritus in einer Krisensituation (Trokkenperiode, Erntegefährdung) und der strengen Funktionsbindung und Erfolgsabhängigkeit der Analogiehandlung zur Herbeiführung von Regenfällen zu suchen ist, sondern auch mit ihrer Existenz als paganer Parallelaktion zu den Regenbitt-Litaneien des »Kreuztragens«, welche als Flurumzug von den kirchlichen Autoritäten und der Kommunität selbst durchgeführt werden, und den speziellen Regenbitt-Messen, die in den orthodoxen Kirchenbüchern festgehalten sind, zusammenhängt ${ }^{182}$. Die Brauchträger sind häufig Kinder (mit noch ambivalenter Sexusrolle) ${ }^{183}$, meist junge Mädchen (selten Frauen) ${ }^{184}$, wobei in einigen Fällen die Unberührtheitsverpflichtung noch manifest ist $^{185}$. Häufig stellt ein Waisenkind oder Waisenmädchen ${ }^{186}$ (oder die Letztgeborene) das Regenmädchen dar (um Gott zu rühren, wie es die orale Sekundärätiologie will) Armut als unbedingte Voraussetzung ${ }^{187}$-, in rezenten Jahren meist Zigeunerkinder oder

oder in den Fluß geworfen (I. Molnar, »Osterspiel im Morgengrauen«, Néprajzi Közlemények 7, 1 962, 3-17) usw. Vgl. noch in der Folge. Vgl. auch die verschiedenen Formen des Todaustragens bei den Westslaven (Friedrich Sieber, Deutsch-slawische Beziebungen in Früblingsbräuchen, Berlin 1968).

I 80 Walter Puchner, "Zur Typologie des balkanischen Regenmädchens«, Schweizer. Archiv für Volkskunde $78 / \mathrm{I}-2$ (I982) 98-1 25.

I 8 I Vgl. Puchner, Die Folklore Südosteuropas, op. cit., 63-65.

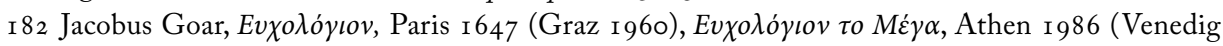
I862) 5 I9-530.

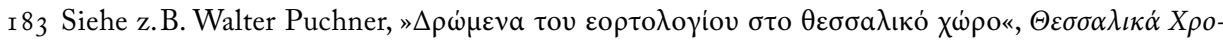

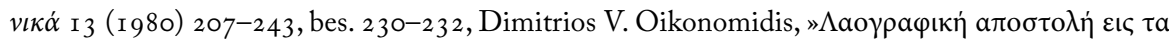

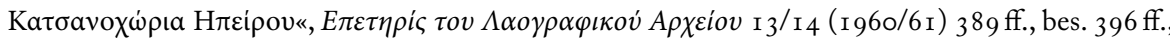

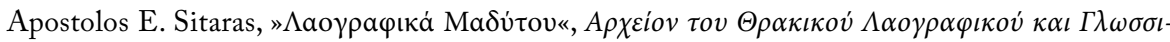

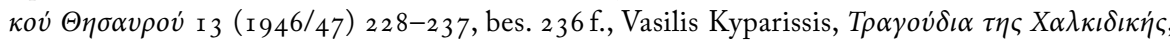
Thessaloniki I 940, 2 usw.

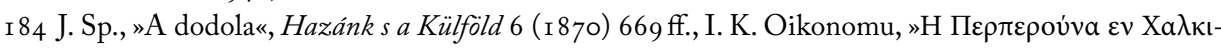

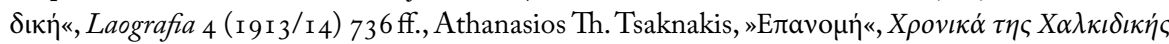
I7-I 8 ( I 969) 5-209, bes. I 24 .

I 85 Á. Pavel, "Nagy száraszág idején«, Vasi Szemle 5 (Szombathely 1938) 359, Pop/Eretescu, op. cit. [Anm. 39] I70, Schneeweis, Grundriß, op. cit. [Anm. 39] 2 I gf.

I 86 G. Eckert/P. E. Formozis, Makedonischer Volksglaube, Thessaloniki I 943, 49 f., dies., Regenzauber in

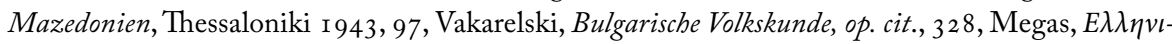

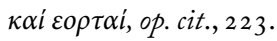

I 87 A. Hegyesi, »A >dodolak«, Magyarország és a Nagyvilág 7 (Budapest I 87 I) 538, K. Vakarcs, »Dodo- 
-mädchen ${ }^{188}$, seltener unverheiratete Burschen ${ }^{189}$ oder Männer ${ }^{190}$. Gewöhnlich hat die Prozessionsgruppe rein femininen Charakter, wobei nur ein Mitglied verkleidet ist und tanzt, während die anderen Mädchen die parakletische Litanei absingen ${ }^{191}$. Die begleitende Gruppe ist von unterschiedlicher Größe und Zusammensetzung ${ }^{192}$ : von zwei Begleiterinnen bis zu 20 Personen. Manchmal gehen auch mehrere Regenmädchen in einer Kommunität um; in rückgebildeten Formen geht das grünverkleidete Mädchen allein von Haus zu Haus, oder es wird durch eine Puppe ersetzt ${ }^{193}$. Der Umgang mit der

lajárás a délmagyarországi szerbeknél«, Néprajzi Értesető I 4 (Budapest I9I3), 307, Wace/Thompson, op. cit. [Anm. 39] I 32 .

I 88 T. R. Gjorgjevic, "Die Zigeuner in Serbien«, Ethnologische Mitteilungen aus Ungarn (Budapest I 903) 80, B. Bellosics, »Dodola«, Ethnographia 6 (Budapest I 895) 4I 8, ders., "Regenzauberlieder aus Ungarn«, Ethnologische Mitteilungen aus Ungarn 5 (Budapest I 896) 283.

I 89 M. I. Kollárov, »Arad város és Arad megye szerb népe«, B. Jancsó/G. Somogyi, Arad megye és Arad

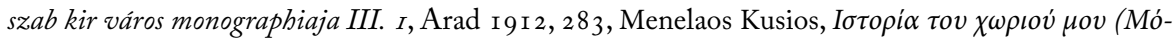

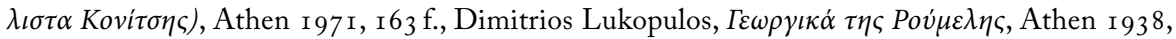
$205 \mathrm{f}$.

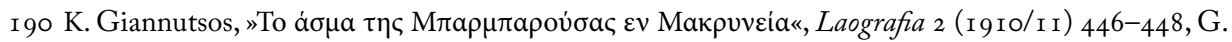

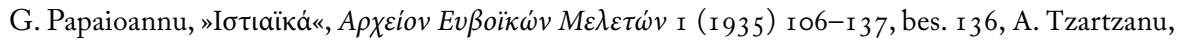

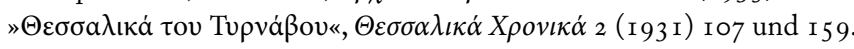

I9I Die besonderen Beziehung der Frau zu Erde und Wetter im balkanischen Volkglauben bedarf keiner spezifischen Erläuterung (Demetrios A. Petropoulos, „Le rôle des femmes et de la Terre dans quelques pratiques magiques«, Mélanges offerts à Octave et Melpo Merlier, Bd. 2, Athènes I 956 , 275-285, Milenko S. Filipović, »Volksglauben auf dem Balkan«, Südost-Forschungen I9 (1960) 239-

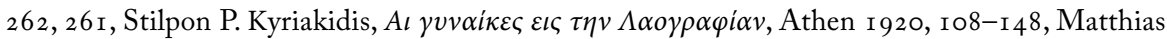
Zender, »Die Frauen machen im Februar das Wetter«, Dona Ethnologica. Festschrift L. Kretzenbacher, München 1973, 340-347); die Unberührtheit erhöht die Effektivität magischer Praktiken (Eugen Fehrle, Die kultische Keuschbeit im Altertum, Gießen I 9 ro (1 966), bes. 54 f.).

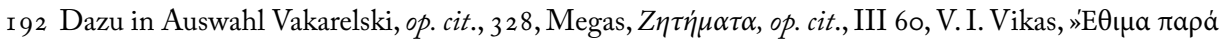

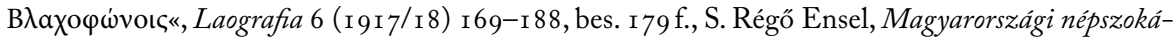

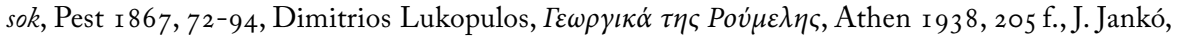
"Adatok a Bács-bodrog megyei sokacznog néprajzához«, Ethnographia 7 (Budapest I869) I6I.

I93 Vgl. die wichtigste Literatur: I. Karavelov, Pamjatniki narodnogo bjita bolgar, Moskva I 86 I, $226 \mathrm{ff.}$,

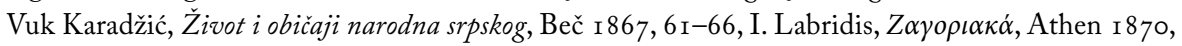

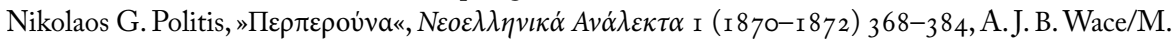
S. Thompson, The Nomads of the Balkans, London I 914, 32 ff., Emil Schneeweis, Grundriß des Volksglaubens und Volksbrauches der Serbokroaten, Celje 1935, 222, ders., Serbokroatische Volkskunde. I. Volksglaube und Volksbrauch, Berlin i 961, I6I-I64, Zoltán Ujváry, »Une coutume des Slavs du Sud: la >Dodola«", Publicationes Instituti Pbilologiae Slavicae Debreceniensis 38 (1963) I 3 I-I40, Tekla Dömötör/E. Eperjessy, »Dodola and other slavonic folk-customs in county Baranya (Hungary)«, Acta Ethnographica Academiae Scientiarum Hungaricae I6 (1967) 399-408, Tekla Dömötör, »Masken in Ungarn«, Schweizer. Archiv für Volkskunde 63 (I967) I 4 I-I6I, bes. I 5 2-I 54 (Robert Wildhaber [ed.], Masken und Maskenbrauchtum aus Ost- und Südosteuropa, Basel I 968, I6-35, bes. 26 f.), Milovan Ga- 
Puppe ist auch als Folklore-Attraktion inszeniert worden ${ }^{194}$.

vazzi, "Das Maskenwesen Jugoslawiens«, Schweizer. Archiv für Volkskunde 63 (1967) I85-202, bes. I 98 f. (Wildhaber, Masken, op. cit., 59-76, bes. 72 f.), Christo Vakarelski, Bulgarische Volkskunde, Berlin I 969, 328 f. (ders., Bălgarski Folklor, Sofija I 974, 609, 61 2-6 1 5, 692, 697), Niko Kuret, »Frauenbünde und maskierte Frau«, Schweizer. Archiv für Volkskunde 68/69 (1972/73) 334-347, bes. 338, Blaze Ristovski, »Makedonskite dodolski i drugi običai i pesni za dožd«, Makedonski Folklor 1 9-20 ( 1977 ) 37-63, Branko Ćupurdija, Agrarna magija u tradicionalnoj kulturi Srba, Beograd 1982, 30-35, I. Kovačević, »Dodole - integrativni pristup proučavanju običaja«, Glasnik Etnografskog instituta SANU I 5 (1976) 67-88, ders., Semiologija mita i rituala, I, Beograd 200 I, 86-I04, Dragutin Đorđević, Život i običaji narodni u leskovačkom kraju, Leskovac $1985,76-78$, A. Muraj, "Iz Istraživanja Žumberka (preperuše, preslice, tara)«, Narodna Umjetnost 24 (I 987 ) I 57-1 76, bes. I 5 8-166, Vesna ČulinovićKonstantinović, »Dodole i prporuše«, Narodna Umjetnost 5 ( 1963) 73-96, Mihai Pop/Constantin Eretescu, »Die Masken im rumänischen Brauchtum«, Schweizer. Achiv für Volkskunde 63 ( 1967 ) I62-I 76, bes. I 70 (Wildhaber, Masken, op. cit., 36-5o, bes. 44), Mihai Pop/Pavel Ruxandoiu, Folklore literar rominesc, București I976, I64, Lia Stoica-Vasilescu, »Paparuda«, Revista de Etnografie și Folclor I 5 ( I 970) 375-394, M. Tirtja, »Les cultes de l'agriculture et de l'élevage chez le peuple albanais«, Ethnographie albanaise 9 (1979) 20 I ff., bes. 202 f., Metin And, Dances of Anatolian Turkey, New York

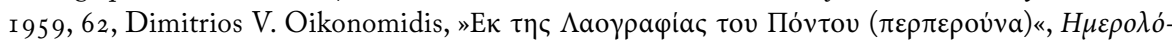

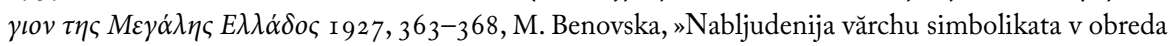
za dăžd speperuda««, Folklor, ezik i narodna sŭdba, Sofija I979, I42-1 53, Račko Popov, Peperuda i German, Sofija I 989 , St. Genčev, »Perperuda. Tradicionen naroden običaj ot Jugoiztočna Bălgarija«, Izvestija na muzeite ot jugoiztočna Bălgarija 7 (Plovdiv I984) I 47-I 55, R. Kolev, „Varianti na obredite Peperuda i German«, Bălgarski Folklor I 2/3 (I 986) 47-58, M. Samokovlieva, »Teritorialno razprostranie na njakoi tipove kalendarno obredi pesni v Severna Bălgarija«, ibid. 4/4 (I978) I 5-33, Chr. Tsvetkova, »Njakoi specifični čerti na obredite za vukane na dăžd sred bălgarskite preselnici v Besara-

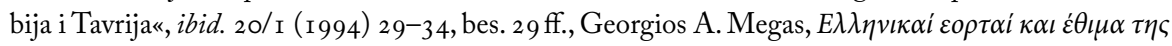

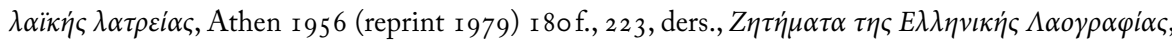
Athen I975, I 107, II 23 ff., V. 60, 65, Puchner, Brauchtumserscheinungen, op. cit., 4 I, I 97 f., 202, 26 I,

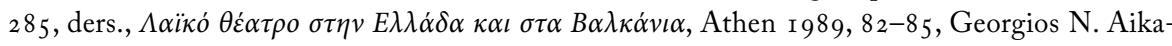

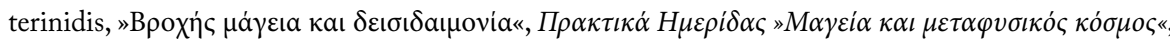

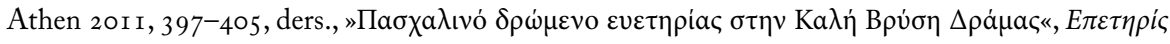

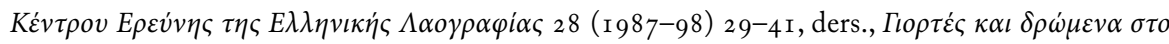

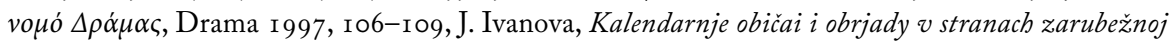
Evropy, Moskva I 978, 224 f., N. Veleckaja, »Rudimenty indoevropejskich i drebne balkanskich ritualov v slavjano balkanskoj obrjadnosti mediacii sil privadu (dodola - peperuda - german)«, $M a-$ kedonski Folklor 23 ( I 979) 87-ıо, bes. 97 f. Unveröffentlichte Quellen auch in Walter Puchner, »To

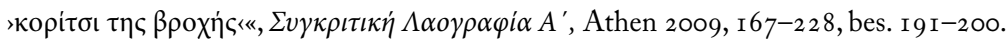

I94 Im jugoslawischen Vincovici wurden die filipovciče-Regenmädchen und ihr Umgang I 979 als Theatervorstellung aufgeführt (F. A. Dubinskas, »Ritual on Stage: Folklore Performance as Symbolic Action«, Narodna Umjetnost, Special issue: Folklore and Oral Communication, Zagreb I 98 I, 93-ro6, bes. 95 f.). Zur Puppenform Lj. Mikov, »Ženska antropomorfna plastika v dva obreda za dăžd ot Jambolski okrăg", Bălgarski Folklor I I/4 (1 985) I 9-27 und Iva Stoaneva, »Tjaloto - golo u obleceno«, ibid. 20/2 (1994) 74-82, Abb. 77. 
Das Verkleidungsmaterial besteht in allen Fällen aus Blättern, Zweigen, Reisig, Grün, Gras, Blumen, das den nackten oder halbnackten Körper des Mädchens in verschieden dicken Schichten bedeckt ${ }^{195}$. In anderen Fällen trägt das Mädchen auch ein weißes oder weites Kleid bzw. Lumpen, an die das Pflanzenkleid angeheftet wird (manchmal auch mit Viehglocke); auch Brautkleid oder bloßer Blumenschmuck ist nachgewiesen ${ }^{196}$. Diese Verkleidung kann den Gesamtkörper bedecken, so daß nur das Gesicht freibleibt, oder auch nur den halben (manchmal beschränkt sich die Verkleidung auf einen Stirnkranz bzw. ein Büschel, das in Hand gehalten wird, bzw. eine Pflanzengürtung um die Mitte ${ }^{197}$. Bei dieser phytomorphen Verkleidung spielen diverse Pflanzenarten eine symbolische Rolle: Holundersträucher, Platanenblätter, Mohnblumen, Weidenzweige, Oliven- und Nußbaumzweige, wilder Wein, Akazienzweige, Nesseln, Sauerampfer und diverse andere Pflanzenarten, die in ihrer lokalen dialektalen Namensbezeichnung nicht immer identifizierbar sind und deren magisch-semantischer Wirkungskontext nicht immer gleich erschlossen werden kann; es liegt jedoch nahe, anzunehmen, daß sie in irgendeiner Form mit dem erwünschten Regen in Zusammenhang stehen. Nach den Gesetzen der Metonymie überträgt sich die Brauchbezeichnung manchmal auch auf die Pflanze selbst ${ }^{198}$. Besonderer Quellenwert kommt den Bildquellen $\mathrm{zu}^{199}$, die ganz verschiedene Techniken und Bedeutungsstrategien der Grünmaskierung zeigen: von der völligen Unkenntlichkeit der Verkleideten als wandelnden buschartigen Gebilden bis zu einem kurzen, fast nur mehr symbolischen Blätterschurz, wobei von magischer Nacktheit keine Rede mehr sein kann ${ }^{200}$.

Stereotyp und invariabel ist das Umzugselement der Brauchhandung: Das dermaßen verkleidete Mädchen geht von Haus zu Haus, singt (entweder es selbst oder die Mädchengruppe) und tanzt vor der Haustüre oder im Innenhof (bei den bulgarischen

I95 Körperliche Blöße gehört ebenso zu den Strategien der Erhöhung der Effizienz magischer Praktiken wie die Jungfräulichkeit (Handwörterbuch des Deutschen Aberglaubens Bd. 6, Sp. 895 ff.).

I96 Detaillierte Nachweise finden sich in Puchner, Studien zum griechischen Volkslied, op. cit., I02-1o9

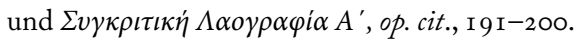

I97 Vgl. die Abb. 23-25 und 27 in Puchner, Studien zur Volkskunde Südosteuropas, op. cit.

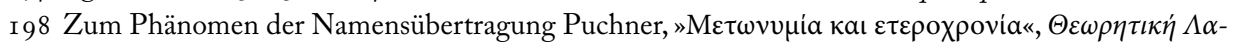

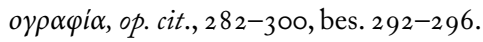

I 99 Nicht nur Photographien, sondern auch älteren Malereien. Z.B. ein Aquarell von E. Tittelbach aus dem I9. Jh. zeigt tanzende Männer, wobei einer von der Hausfrau mit Wasser angeschüttet wird (O. Vasić, Etnokoreologija. Tragovi, Beograd 2004, I I-I 2, Čulinović-Konstantinović, op. cit., 78), ein anderes Aquarell aus dem 19. Jh. zeigt tanzende Mädchen in Festkleidung im Kreis Nišs, wobei eines Wasser verschüttet (Marjanović, op. cit., I 90).

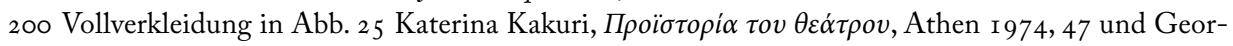

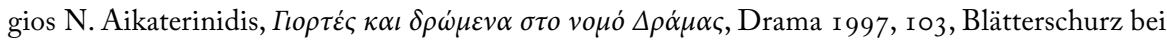
Wildhaber, op. cit., Abb. 5 und 26. 
Umzügen gibt es auch neben der eigentlichen Regenlitanei ein »Straßenlied« beim Umgang) ${ }^{201}$, wird von den Hausfrauen (seltener Hausherren) mit Wasser besprengt, in Kannen begossen (ev. auch vom Fenster oder Balkon aus) oder mit vollen Kübeln angeschüttet, bis es patschnaß ist, worauf die Gruppe (oder das Mädchen) die Gabe (Münzen, Eier, Lebensmittel, Süßigkeiten, Trockenfrüchte, Feldfrüchte, Milchprodukte, Mehl, Wachs, Weihrauch, Salz, Fleisch, Brot, Öl, gebrauchte Kleider usw.) in Empfang nimmt (in Bulgarien in einem »Sieb« überreicht) ${ }^{202}$, die oft bei einem gemeinsamen Mahl verzehrt oder verbraucht wird. Dazu kommen noch im Sinne der magischen Analogiehandlungen zum Regenfall oder im Sinne der »Rührung Gottes« verschiedene Praktiken, die einen größeren Variationsspielraum zu haben scheinen ${ }^{203}$. Diese magischen Akte werden häufig, um ihre Effizienz zu steigern, von Sprüchen begleitet oder auch von eigenen Liedern. Nach der dazugehörigen Glaubensvorstellung ist nun der Regenfall nach einer gewissen Zeitspanne gesichert; sollte er trotzdem ausbleiben, wird der Umzug wiederholt.

Nach Maßgabe des Ausbreitungsgebietes ${ }^{204}$, das im wesentlichen den Grenzen der Orthodoxie folgt, dürfte die magisch-pagane Variante der kirchlichen Regenbittlitanei

20 I Benovska, op. cit., I 48 .

202 Sito wird paretymologisch mit sit (satt) in Zusammenhang gebracht: Die Geschenke im Sieb werden mit den Prosperitätsspruch für ein »sattes« Jahr da e sita godinata überreicht (Vakarelski, op. cit., 329).

${ }_{20}$ Z.B. in eine Pfanne auf dem Kopf des Mädchens wird Wasser gegossen (Regengeräusch), die Mädchen baden vor dem Umzug mit den Kleidern im Fluß, das Regenmädchen wird nach dem Umzug ins Wasser geworfen, ein Kreuz wird ins Wasser geworfen, der perperuna wird ein Totenkreuz an den rechten Fuß gebunden, ihr werden getrocknete oder lebendige Frösche angehängt, eine Schwalbe wird verkehrt an einer Planate über dem Fluß aufgehängt, ein Weidenkranz wird ans Ufer gelegt oder ins Wasser geworfen, ein Lappen mit Kirchenkehricht wird eine Spanne über dem Wasser aufgehängt, mit einer Schaufel werden beim Absingen des Liedes kleine Wassergräben in die Erde gezogen, das Regenmädchen wird aus einem Sieb begossen, es schüttet selbst Wasser aus einer Kanne, es geht zum Dorfbrunnen und singt dort das Regenbittlied. Die Aromunen Nordgriechenlands kennen auch ein tanzendes »Greisenpaar«, das die Funktion des Regenmädchens übernimmt (Vikas, op. cit., I 79 f.).

204 Das Ausbreitungsgebiet ist natürlich an die Landwirtschaft und ihre regionalspezifischen Produkte gebunden, die im Lied aufgezählt werden. Kartographische Darstellungen gibt es für Griechenland und den thrakischen Raum (Bulgarien, Europäische Türkei) in Puchner, Brauchtumserscheinungen, op. cit., 276 sowie für das heutige Serbien in Vesna Marjanović, Maske, maskiranje i rituali u Srbiju, Beograd 2008, I86-194 dodola und Verbreitungskarte 187: Der Umgang ist praktisch überall und dicht belegt, nicht allerdings im südwestlichen Bergland gegen Crna Gora zu. In der Vojvodina überschneiden sich auch Ethnien in der Brauchübung: Serben, Ungarn und Rumänen (M. Bosić, Godišnji običaji Srba u Vojvodini, Novi Sad I996, 339-345, M. Maluckov, Rumuni u Banatu, Novi Sad I985, 295). 
auf das byzantinische Kulturfundament rekurrieren (wofür auch gewissen Charakteristika des Liedes und der Liedmelodie plädieren), aber neuerdings sind auch Spekulationen bezüglich Vergleichen mit altgriechischen Regenriten angestellt worden ${ }^{205}$.

\section{I.3.3 Zoomorphe Verkleidung}

Beschränkte sich die mimetische Komponente bei den phytomorphen Verkleidungen auf die festliche Ornamentik der Blüten und des Blumenschmuckes in symbolischer Relation zur erwachenden Vegetation des Frühlingsabschnittes bzw. auf den ungefähren morphologischen Eindruck eines wandelnden Buschwerks oder kleinwüchsigen Baumes mit dichtem Blätterwerk, so ist bei den zoomorphen Maskierungen der Grad der Similität in der Imitation eines konkreten Tieres nach Aussehen und Bewegungsart doch wesentlich höher, wenn auch von realistischer Nachahmung meist nicht die Rede sein kann und die theriomorphe Schreck-Komponente vieler dieser Maskierungen einem konkreteren Mimesisbestreben eher zuwiderläuft. Phantastik und Groteske bestimmen die Ästhetik dieser Verkleidungsformen, der animale Prototyp ist hinter der Ausgestaltung oft nur dunkel zu erahnen; ähnliches ist bei den Dämonenvorstellungen zu beobachten, die als Imaginationen nur eine sehr lose definierbare Typologie kennen. Diese Verkleidungen verbinden sich neben ihrer Unterhaltungsfunktion oft auch mit magischen Vorstellungen und Praktiken und sind vielfach eingebunden in rituelle Umzugsformen oder auch größere Gruppenbildungen von Kalanda-Sängern, die auch andere Maskentypen umfassen. Vorwiegende Maskentermine der zoomorphen Verkleidungen sind der Mittwinterabschnitt und der Karneval ${ }^{206}$.

Equidenmaske. Die morphologische Bandbreite und Varianz der Maskenformen wird deutlich bei der am weitesten verbreiteten Verkleidungsform, der Equidenmaske. Der Begriff umfaßt sowohl zwei- wie auch vierbeinige Phantasietiere (manchmal auch vielbeinige), die als Krauthinkl oder Habergeiß, turcă und capră, Steckenpferd u.a. auftreten, oder von zwei Burschen gespielt, als Kamel, Esel oder Pferd, manchmal mit »Reiter«. Gemeinsam ist die gebückte Haltung des Spielers mit dem mit einer Decke bedeckten Rücken und den »Kopf « des Tieres auf einer Stange nach vorne gehalten, der manchmal durch Schnurzug sein Maul auf- und zumachen kann. Vielfach wird die Maskenfigur

205 Evy Johanne Håland, »Rituals of Magic Rain-Making in Modern and Ancient Greece. A Comparative Research", Cosmos. The Journal of the Traditional Cosmology Society I 7/2 (2005) I 97-25 I.

206 Vlasta Domaćinović, „Zoomorfne maske«, Narodna umjetnost 23 ( (1985) I 26-I 28, Tekla Dömötör, "Állatalakoskodás a magyar népszokásokban«, Ethnographia 1940, Zoltán Ujváry, »Probleme der zoomorphen Dämonen in den ungarischen Agrarriten«, Müveltség és Hagyomány I 5-I6 (1 972-74) I 29-I 50 usw. 
begleitet von einem Kameltreiber, der das Tier auch verkaufen will, um Arzneien für seine Krankheit bittet, bis es entweder verendet oder mit Geschenken geheilt wird. In der rudimentären tanzartigen Kinetik des Zwei- und Vierbeiners ist in parodierender Weise die jeweilige Bewegungsart des imitierten Tieres nachgestaltet.

Habergeißformen. Der Übergang von Zweibeinern zu Vierbeinern ist gleitend: als rusa bei den Slovenen, turcă, capră und brezaiă in Ungarn, Rumänien und Nordbul-

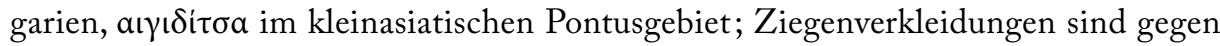
Osten zu bis nach Armenien hinein geläufig ${ }^{207}$. Die turica ist schon im I 8. Jh. in Ragusa (Dubrovnik) auf einem Kupferstich zu sehen ${ }^{208}$. In Mitteleuropa stehen diese gehörnten Ziegenmasken (Steiermark, košuta in Slovenien) ${ }^{209}$ als Schreckmasken im Übergang zu Teufelsfiguren im religösen Volksschauspiel ${ }^{210}$ oder mit geschnitzten Holzmasken wie

207 S. Lisician, Stariunje pliaski i teatrolnje predstavlenija armjanskogo narodna, Bd. I. Jerewan I958, Abb. CXXVII.

208 Die in ganzkörperliches Fell gehüllte und mit Tierkopf versehene »Turizza, ovvero Marte« in F. M. Appendini, Notizie istorico-critiche sulle antichità, istoria e letteratura de' Ragusei, 2 Bde., Dubrovnik I 802/3 (vgl. Nikola Batušić, Povijest Hrvatskoga Kazalista, Zagreb 1978, 32, Puchner, Studien zur Volkskunde Südosteuropas, op. cit., Abb. 6). Ein Erlaß des Stadtsenats beschäftigt sich bereits I 4 I 2 mit »ioculatoribus Turce« (Milovan Rešetar, »Dubrovačka Turica«, Zbornik za narodni život i običaje 29/2, Zagreb 1934). Die Abbildung dürfte dabei als stilisierte Chalkographie möglicherweise nicht ganz der Wirklichkeit entsprechen, denn Dimitrie Cantemir spricht in seiner »Descriptio Moldaviae« von turca als einem alten Weihnachtsbrauch, wo ein Maskierter einen Hirschkopf mit Geweih trägt, an den ein schillernder Stoff gebunden werde, der bis auf den Boden reicht, während ihn ein anderer Maskierter als buckliger Greis begleite, und beide gingen unter großem Gefolge mit Tänzen und Spielen von Haus zu Haus durch die Straßen (Dimitrie Cantemir, Beschreibung der Moldau. Faksimiledruck der Originalausgabe von I77 I, Bukarest I973, 3 I 6 f.). Ein Reisender des frühen I 8. Jh.s gibt auch den Namen dieses »Alten«, an: uncbiass, allerdings für die Walachei (A. del Chiaro Fiorentino, Istoria delle moderne rivoluzioni della Valachia. III. Riti de' Valachi, Venezia I 7 I 8 , 6o). Cantemir schreibt den Namen der Verkleidung dem Haß gegen die Türken zu, doch handelt es sich um die slavische Bezeichnung für den Auerochsen, der in den colinda-Liedern der Rumänien eine so große Rolle spielt (Puchner, Die Folklore Südosteuropas, op. cit., 6o f.): tur (Vitomir Belaj, "Einige Tiermasken des Westbalkans", A. Mauerhofer (ed.), Musikethnologisches Kolloquium. Die Südosteuropäische Volkskultur in der Gegenwart, Referate der 4. Internationalen Balkanologentagung, Graz I983, 4I-52, bes. 43 f.). Damit ist die gleitenden Morphologie dieser Tiermaskierungen gut umschrieben. Hirschmaskierungen und Hirschtanz sind im I7. Jh. auch für Adrianopel/Edirne quellenkundig (Alessandro Bombaci, »Rappresentazioni drammatiche di Anatolia«, Oriens I6, 1963, I85-197, bes. I 89 f.).

209 A. Schlossar, Cultur- und Sittenbilder aus der Steiermark, Graz I 885, 20 ff., Kuret, »Masken aus Slowenien«, op. cit., 2 I $7 \mathrm{f}$.

2 ro Leopold Kretzenbacher, „Schlangenteufel und Satan im Paradeisspiel. Zur Kulturgeschichte der Teufelsmasken im Volksschauspiel«, Leopold Schmidt (ed.) Masken in Mitteleuropa, Wien 1955, $72 \mathrm{ff}$. 
die alpinen Perchten und die slovenischen koranti im Übergang zu rein theriomorphen Verkleidungen $^{211}$; charakteristischerweise kann die slovenische rusa sowohl zwei wie vier Füße haben ${ }^{212}$ ebenso wie die mittelkärntnerische Pferdeverkleidung oder das zweibeinige »Pferd « in Südserbien, während die burgenländischen »Pferde« und »Esel« (mit Reiter) eher zwei Darsteller beanspruchen ${ }^{213}$.

Im nördlichen Balkanraum von der Pannonischen Tiefebene bis an die Meeresküsten des Euxinischen Pontus bilden der »Alte» und die "Ziege« ein unzertrennliches satirisches Erscheinungpaar, das bei verschiedenen Gelegenheiten auftritt, sowohl im Jahreslauf (Winterabschnitt) wie auch bei Lebenslaufriten (Hochzeit, Totenwache) ${ }^{214}$.

2 I I Robert Wildhaber, „Zur Problematik eines slowenischen Maskenattributs«, Schweizer. Arcbiv für Volkskunde 56 (1960) $40 \mathrm{ff}$.

2 I 2 Leopold Kretzenbacher, »Rusa< und `Gambela< als Equiden-Masken der Slowenen«, Lares I 965, 49-74. Vgl. die vierbeinige rusa mit einer Puppe (faček) als Reiter in Niko Kuret, Maske slovenskib pokrajin, Ljubljana I984, Abb. 57 (Puchner, Studien zur Volkskunde Südosteuropas, op. cit., Anm. 7).

2 I 3 Georg Graber, "Alte Gebräuche bei der Flachsernte in Kärnten und ihr religionsgeschichtlicher Hintergrund«, Zeitschrift für Österr. Volkskunde I 7 ( I 9 I 2) I 48 ff., I 85 ff., D. Đorđević, »Narodna gluma na svadbi u leskovačkom kraju«, Rad X. Kongresa SFJ, Cetinje I 964,336 ff., vgl. Abb. 274 bei L. S. Janković/D. S. Janković, Narodne Igre VII, Beograd I952, 4I, Leopold Schmidt, »Der Eselsreiter von Moschendorf. Seine Stellung im mitteleuropäischen Umzugsspiel und Maskenbrauch«, Österr. Zeitschrift für Volkskunde 3/52 (I 949) 77-98, R. Fuchs, »Landegger Volksbräuche«, ibid. 4/53 (1960) I $68 \mathrm{ff}$.

$2{ }_{4}$ Z.B. bei der Totenwache, wo das »Pferd« von zwei Burschen gespielt wird, während der "Alte« (moş) auf ihm reitet oder es herumführt, um es zu verkaufen, doch der Preis fällt ständig, so daß es der Alte letztlich tötet (Olga Flegont, »The Moș in the Romanian popular theatrical art", Revue roumain d'bistoire del'art 3, I 966, I I 9-I 3 I). Solche satirischen Szenen neben dem Leichnam werden in der Moldau seit dem I7. Jh. von den unchiașii aufgeführt (Henri H. Stahl, Nerej, un village d'une region archaique, monographie sociologique. Vol. II, Les manifestations spirituelles, Bucharest I 939, 29I-296), sind in der Ukraine schon seit dem I6. Jh. nachweisbar (Vsevolod N. VsevolodskijGherngross, Russkaja ustnaja narodnaja drama, Moskva 1959, 29). In Ungarn ist die turkasok beliebte Spinnstubenunterhaltung: Das entweder mit einem holzgeschnitzten Ziegenkopf gespielte oder von einem knienden Spieler in einem Bauernmantel, einen Ärmel mit Axt als Kopf mit der Hand hochgehalten, dargestellte Tier grast bei seinem störenden Besuch in der Stube, schlägt mit der Axt auf den Boden, springt wild herum, neckt die Mädchen, sticht mit seinen Hörnern unter die Röcke usw.; soll sie »gemelkt« werden, verschüttet sie die »Milch« (frischen Schnee), sie soll auch verkauft werden, macht Prophezeiungen bezüglich der Heirat der Mädchen (wie viele Jahre noch) usw. Vgl. Zoltán Ujváry, Kecskemaszkos szokás Hajdudorogon, Debrecen i 966, ders., „Turkajárász az erdélyi és a magyarországi romanok körében«, Népi kulturo - Népi társadolom 7 (1973), 38 I-4 I 3 Zsigmond Vita, »Nagyenyedvidéki turkások«, Ethnographia 1939, Nora A. Tahy, Das theatralische Brauchtum des ungarischen Sprachbereichs, Frankfurt/M. etc. 1989, I 20-1 22. Zur turica im westbalkanischen Raum vgl. auch Ivan Lozica, »Turicinim tragom«, Poganska baština, Zagreb 2002, I I I-I 42 und Niko Kuret, Maske slovenskih pokrajin, Ljubljana I 984, 44-48. 
Die Ziegenmaske, die ihr Maul öffnen kann, belästigt die Zuschauer und »verstirbt « während des Umzugs ${ }^{215}$. Der phallische und satirische »Alte« (rumän. mos, bulg. măš) dürfte ursprünglich den Ahn dargestellt haben, erscheint bei den mocanii auch im erotischen Techtel-Mechtel mit der Alten ${ }^{216}$. Im allgemeinen bildet der satirische Alte eine weitverbreitete Maskenform im Balkanraum ${ }^{217}$, manchmal auch in Begleitung einer »Hirschkuh« (bulg. rogač) ${ }^{218}$; bezeichnenderweise sind die Begleittiere meist in ihrer femininen Spielart vorgestellt. In ihrer rudimentären Form wird die Tiermaske allein gespielt: z.B. an der Nordküste Kleinasiens ging vor I 922 die aiditsa am Vortag von Neujahr oder auch Weihnachten in einem Riesenkleid von Kopf bis Fuß und mit einem Ziegenschädel, der die Kiefer klappernd auf- und zumachen kann, beim Einbruch der Dunkelheit mit zwei Unmaskierten (Lyraspieler, Gabensackträger) um und tanzte in jedem Haus; das türkisch-griechische Lied hat ungefähr folgenden Inhalt: »Meine Geiß, meine Geiß weiß nicht den Weg/hinkt und kann nicht weiden/weidet Geld « ${ }^{219}$.

Eine der am weitesten in Südosteuropa verbreiteten Tiermasken ist das sogenannte »Kamel« (gambela, kamela, kamelce, $\gamma \kappa \alpha \mu \eta \dot{\lambda} \alpha$ ), ein vierbeiniges giraffenhalsiges Fabeltier (Kamelopard) von erschreckendem Aussehen und störendem Verhalten, das zumindest in der Nomenklatur dem Dromedar oder Kamel (mit ein oder zwei Höckern)

2 15 Teodor T. Burada, "Priveliști și datini strămoșești«, Arbiva (Iași r 909) 289-306, Gheorghe Vrabie, »Teatrul popular romînesc«, Studii și cercetări de istorie literară și folclor 6/3-4 (1957) 485562, bes. 526 f., Simion Alterescu, Istoria teatrului in România, vol. I, București r 965, 42, 67 f., V. Adăscăliței/I. H. Ciubotaru, »Date privind variedatea și raspîndirea teatrului folcloric în județele Iași și Vaiu«, Anarul de Lingvistică și Istorie literară I 9 (I 968) I 5 I-I 57 . Dasselbe auch in Bulgarien, vgl. Mariela Hristova, »Maskaradnata igra Brăzaja i instrumentalnite melodii, svarzani s neja«, Bălgarski Folklor 2 ( 1993) 74-77, und in Armenien vgl. Abb. I 27 in Lisician, op. cit.

2 I6 T. Gălușcă, »Mocanii - un Joc dramatic al românilor din Dobrogea«, Anarul Arbivei de Folclor 7 (1 945) I 2-34, V. Adăscăliței/L. Çireș, »Mocănașii«. Datina - spectacol«, Revista di Etnografia și Folclor 15 (1970) 323-333.

2 I 7 Als didi oder didici in den ehem. jugoslawischen Ländern (Nikola Bonifačić-Rožin, »Pokladne maškare u Konovlina«, Narodna Umjetnost 4, I 966, I 53-I 73), als babušar und kuker in Bulgarien (Mihail Arnaudov, »Kukeri i rusalii«, Sbornik za narodni umotvorenija i narodopis 34, Sofija I 920 ,

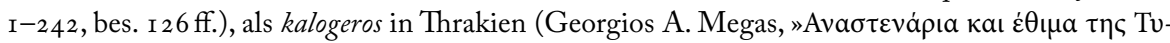

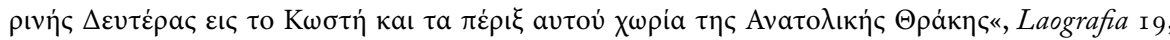
I 960/6 I, 472-534 und ibid. 20, I 962, 552-557), als momogeros im kleinasiatischen Pontus-Gebiet

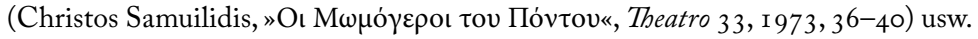

2 I 8 Vasile Adăscăliței, »Jocul Cerbului în Moldova«, Revista di Etnografia și Folclor I 968, 42 I-433, D. Tacit, »Daținile Românilor de Crăiun«, Actele Soc. Transilvania 4I ( I 9 ro) I35-I46, Octavian Buhociu, Die rumänische Volkskultur und ibre Mythologie, Wiesbaden 1974, 54-56.

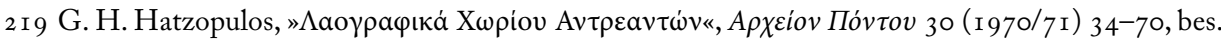
4of., Puchner, Brauchtumserscheinungen, op. cit., 209. 
entspricht $^{220}$. Die Übergänge zu anderen Tierformen in der Gruppe der Equidenmasken sind fließend ${ }^{221}$. Das Kamel ist fast immer weiblich gedacht und hat manchmal auch einen »Reiter«, der ihr Kind vorstellt ${ }^{222}$. In solchen Fällen wird auch eine frucht-

220 Die fließenden Grenzen zur Giraffe hin sind schon bei Heliodor X,27 evident (Pauly-Wissowa, Realenzyklopädie X/2, I 824 ff.). Im byzantinischen Konstantinopel wurden exotische Tiere als Spektakel herumgeführt, Elephanten, Kamele und Giraffen (Talbot T. Rice, Everyday life in By-

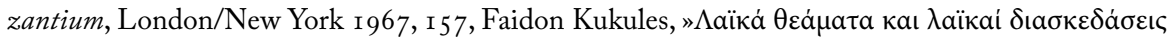

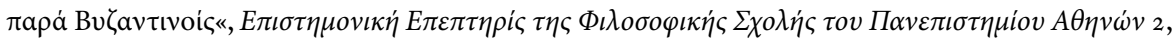
I 938, 5-29, bes. 9). Diese Maskenform geht in Südosteuropa zweifellos auf historische Erfahrung mit dem Haus-, Nutz- und Lasttier der Osmanen zurück. Eine der ältesten Beschreibungen findet sich in der Knaff-Handschrift I 8 I 3 aus dem steirischen Bezirk Fohnsdorf: „... Am Schluß des Zuges befindet sich ein Kameel, dieses wird durch 2 Menschen auf folgende Art dargestellt. Der Vordermann hat auf einer Stange einen von Holz ausgeschnitzten Thierkopf. Es ist nicht heiglich; ob solcher einem Bären oder Adler gleiche, erforderlich aber ist es, daß der Kopf und die Ohren rauch überzohen, die Augen hervorstehend seyen und die herabhängende Zunge von rothen Tuch, ein schreckendes, Menschen gefährliches Thier anzeigt. Diese Stange nihmt der Vordermann zwischen die Füsse, beugt sich so hökericht zusammen und schreitet so mit Lämmerfellen oder Kotzen bis an die Fersen embalirt, vorwärts. Inzwischen schließt sich rückwärts an ihn der Hintermann an, welcher der hintere oder respective $2^{\text {te }}$ Theil des Kameels seyn sollenden Thieres ausmacht. Seine Hände ruhen an den Schultern, Sein Kopf an den Rücken des Vordermannes und formt den Höcker des Kameels. Da nun auch der Hintermann bis zur Ferse mit Kotzen oder Thierfellen bedeckt und dann erst der Raum zwischen beyden auch mit Kotzen oder Fellen überhängt ist, so giebt so ein Kameel imer eine auffallende Täuschung ...« (Victor von Geramb, Die Knaff-Handschrift, Berlin/Leipzig I 928, 50 f., Leopold Kretzenbacher, »Rusa und Gambela«, op. cit., 6 I ff.). Ganz ähnlich sieht die Kamelverkleidung im Raum Didymoteicho in Griechisch-Thrakien aus

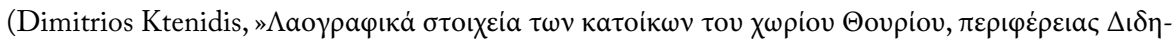

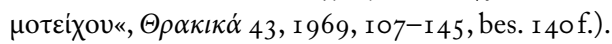

22 I "In der Maskenforschung ist der Begriff der Equidenmaske so breit gehalten, daß damit nicht nur pferdeähnliche, sondern auch Auerochs-, Hirsch-, Ziegen-, Kamel-, ja sogar Vogelmasken u. ä. m. bezeichnet werden « (Niko Kuret in H. Gerndt/G. R. Schroubek (eds.), Dona Ethnologica. Beiträge zur vergleichenden Volkskunde, München I 973, 56).

222 Niko Kuret beschreibt die gambela für Slovenien folgendermaßen: »Die rgambela ... wird ... von zwei Personen dargestellt. Diese nehmen ein längliches hölzernes Gerüst auf die Achseln, welches mit einem großen Leintuch bedeckt wird. Bei der primitiven Form hält der Vordermann einen großen irdenen Topf auf einem Stock aus dem Gestell und stellt damit den Kopf des Tieres vor. Der Hintermann hält einen alten Besen hinten heraus, der den Schwanz markieren soll. Gewöhnlich hat aber das Tier einen hölzernen Kopf mit beweglichem Unterkiefer. Der Hals ist mit Hasenfell überzogen und an seinem Halsriemen sind Schellen befestigt. Auf dem Rücken des Tieres reitet eine Puppe (`faček`), die gewöhnlich einen Türken vorstellt ... Das Tier wird von einem Treiber begleitet. Es ist ein recht unruhiges Biest, schnappt nach jedem, den es trifft, und der Treiber hat seine Mühe, es zu bändigen. Darum möchte er es los sein. Bei jedem Hof hält er es feil, doch kommt es zum Kaufe nicht. Wohl aber bekommt er die üblichen Gaben (Eier, Würste, Käse)« (Schmidt, Masken in Mitteleuropa, op. cit., I 8, Abb. auch in Puchner, Studien zur Volkskunde Südosteuropas, op. cit., Abb. 7). 
barkeitsmagische Komponente manifest, wie etwa bei der džamala im historischen Thrakien $^{223}$. Davon gibt es auch vielbeinige Varianten ${ }^{224}$, oder das Verkleidungstier gilt

223 So z.B. im thrakischen Epivates, heute Europäische Türkei, am Vorabend des Festtages des H1. Demetrios (26. Io., Ende der Sommerarbeiten, Saattermin), wo nach dem Kinderumzug am Abend das überdimensionale glockenbehangene Kamel im Bauernviertel (nach dem Umzug džamalacka genannt) von einem Kameltreiber herumgeführt wird: Ein Holzskelett von drei Männern getragen und mit einem gewebten Teppich behangen, der Vordermann hält auf einer Stange einen Pferdeschädel hoch, der bis in den zweiten Stock der Häuser reicht; auf dem Rücken des Tiers sitzt ein aus Lumpen geformtes Kind. Dahinter folgt ein rußgeschwärztes Gefolge von "Arabern«, darunter ein Buckliger mit ausgestopftem Höcker, der, sobald die tzamala aus Schwäche in Ohnmacht fällt, mit einer Peitsche geschlagen wird, worauf sich diese wieder erhebt. In türkisch-griechischem Kauderwelsch wird ein Umzugslied folgenden Inhalts gesungen: Ich geb ibr Stroh, sie frißt nicht/ ich zieh sie, sie kommt nicht/ tzamala, tzamala, vorwärts./Di-dili, mantili, di-dili/das Kind der tzamala/tut was Schlechtes am fti [offenbar Genitalien]/und will eine Frau./Ich gehe zu Bett/sie geht

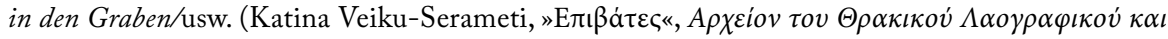

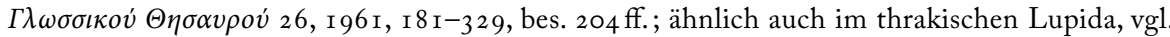

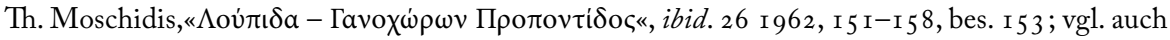
Puchner, Brauchtumserscheinungen, op. cit., 207f.;). Als Phänomen der Metonymie wird der Maskenname tzamala (arab. Kamel) auch für Karnevalsfeuer gebraucht (ibid. 206) bzw. in Ioannina für den Sammelumzug um Holz für die Faschingsfeuer (Konstantinos Krystallis, »Aı Ато́к $\rho \varepsilon \omega \varepsilon v$

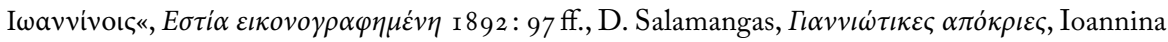
1957, 34); in Abdera im Raum Xanthi wird ein Maskenumzug im Oktober vor der Aussaat so genannt, mit der Vorstellung der »türkischen Hochzeit«, der Schwangeren und anderen Nummern

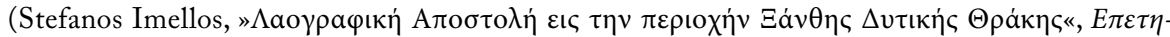

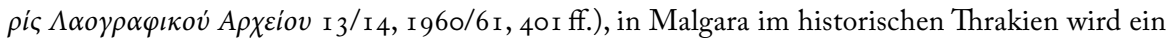
dromenon mit Tod und Auferstehung des Bräutigams so genannt, gespielt Ende Oktober/Anfang

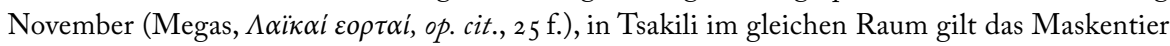
als Aussteuer der hanumissa, ein Arzt untersucht das kranke Tier, das schließlich mit Arzneien aus der Nachbarschaft, Wein, Brot, Geldspenden usw., wieder gesund wird (Kallisthenis Churmuziadis,

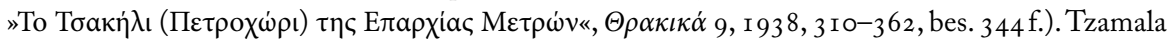
wird endlich auch eine Klapper mit Schnurzug als Lärminstrument genannt, die den klappernden Kinnladen der Kamelmaske nachgebildet ist (bei den Zwölftenumzügen im thrakischen Kastanies,

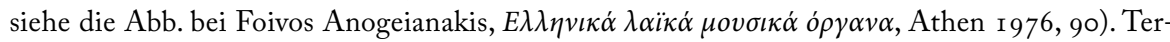
minverschiebungen sind an der Tagesordnung: im Raum Drama in Nordgriechenland schon wäh-

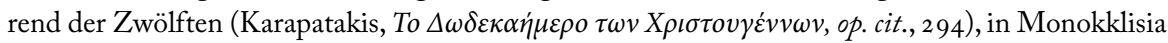

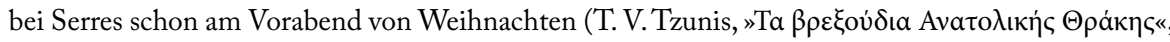

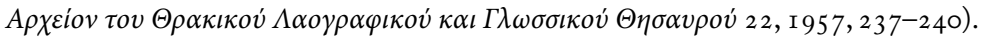

224 Z.B. in Aspropyrgos bei Athen, wo das Recht der Schwärzens (mit einem in Tinte getauchten Zitronenstempel auf die Stirn) schon in der ersten Karnevalswoche versteigert wird. Ein Schädelknochen von Pferd oder Esel mit zwei Zitronen als Augäpfel und Kinnladen mit Schnurzug, ein Holzgestell mit Säcken bedeckt, bildet die mammi (Hebamme), von vier Männern getragen, die der Kameltreiber tanzen läßt. Dieser schlägt sich und weint, wenn sein »Kamel« krank wird (Träger gehen in die Knie und lassen den Kopf hängen) (Puchner, Brauchtumserscheinungen, op. cit., 206 f.). 
auch als Esel ${ }^{225}$. Dieses fabulöse Maskentier ist auch an der Nordküste Kleinasiens verbreitet $^{226}$, in Westbulgarien (džamalari, kamila) ${ }^{227}$, im altthrakischen Raum (auch bei Muslimen $)^{228}$, in Rumänien (cămilă, girafă $)^{229}$ und bis nach Slovenien und in die Untersteiermark ${ }^{230}$. Panbalkanische Verbreitung hat aber auch das »Pferd « in der Form des Steckenpferdes ${ }^{231}$ oder als Vierbeiner ${ }^{232}$, eine beliebte nordbalkanische Spinnstubenunterhaltung in mehreren Versionen: r. mit hölzernem Pferd (Einheit von Reiter und Pferd): ein umgedrehter Trog in Hüfthöhe mit einem Kopf aus Holz oder Lumpen (Husarenkleidung) oder einem Tontopf, der bei dem »Tod« des Pferdes zerschlagen wird, wenn die Verkaufsverhandlungen scheitern ${ }^{233}$; 2. das dreibeinige Steckenpferd mit

225 Z.B. auf der Insel Symi der Dodekanes während des Karnevals wird als Kinderschreck die »kokkala« (die Knochige) dargestellt: ein halbzerfallener Eselsschädel auf einer Stange, die untere Kinnlade an eine Schnur gebunden und von zwei Männern unter einer großen braunen Decke herumge-

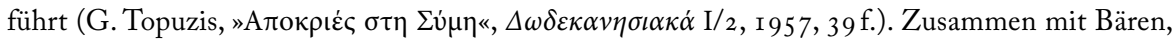
Schiffen, Ochsen im Joch usw., Pantomimen wie der Alte mit der Alten schläft usw., eine beliebte Karnevalsunterhaltung auf den Inseln (»Masken«, $\mu^{\prime} \sigma o v \dot{v}$ ol, $\mu^{\prime} \tau \zeta$ ov́v' genannt, z.B. in Telonia auf Mytilene: Puchner, Brauchtumerscheinungen, op. cit., 206). Davon zu unterscheiden ist der Schandritt verkehrt auf dem Esel mit dem Schwanz in der Hand, der auf den Prangerumzug im byzantinischen

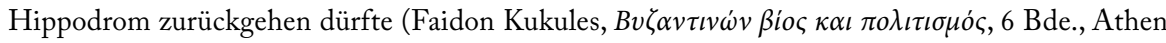
I $948-55$, III 73-75, I 84-I 86, V 6 f.), und im südbalkanischen Karneval anzutreffen ist, ebenso wie das Schwärzen, Asche-Werfen, die Lumpenkleidung, der Glockenbehang, die Geschlechtswechselverkleidung und die obszönen Lieder (Näheres in Puchner, Brauchtumserscheinungen, op. cit., 265 f.).

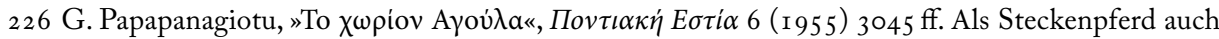
bei der Maskenvorstellung der momoeria. Vgl. dazu in der Folge.

227 Vakarelski, Bulgarische Volkskunde, op. cit., 384 f., M. Videnov, »Godečkaja džamala«, Bălgarska Etnografija 3-4 (I994) 4I-53.

228 Manolis Varvounis, "Balkan dimensions and Moslem variations at the custom of Tzamala in Thrace«, Journal of Oriental and African Studies $\mathrm{I} 2$ (2003) 53-6 I.

229 Romulus Vulcănescu, Măștile populare, București i 970, 55-57, Horia Barbu Oprișan, Teatru fără scena. Evocări ale unor spectacole, personaje și interpreti ai teatrului popular românesc, București $\mathrm{I} 98 \mathrm{I}$, $60-62$.

230 Vgl. wie oben.

23 I Zoltán Ujváry, »Probleme der zoomorphen Dämonen in den ungarischen Agrarriten«, Múvveltség és Hagyomány 6 (I964) I 29 ff., ders., »A ló az alföldi falvak dramatikus néps zokásaiban«, ibid. I 5-I6 ( $972-74$ 299-340. In derselben Form werden die »Pferdemenschen« der căluşarii in Siebenbürgen dargestellt (vgl. dazu in der Folge).

232 Schmidt, »Der Eselreiter von Moschendorf «, op. cit. (mit balkanischem Vergleichsradius), Michael Arnaudoff, Die bulgarischen Festbräuche, Leipzig I9 17, 8, John C. Lawson, Modern Greek Folklore and Ancient Greek Religion, Cambridge 1 910, 192, 203, Waldemar Liungman, Traditionswanderungen Euphrat - Rhein, 2 Bde., Helsinki 1937 (FFC I I 8, I I 9), 6 I 5 ff. Zu den Techniken der Pferdeverkleidung Jean Baumel, Le»Masque-Cheval«, Paris I 954.

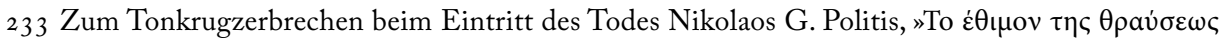

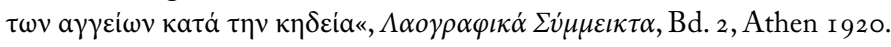


dem Pferdekopf auf einer langen Stange, der Spieler steht gebückt und ist mit einer Decke behangen, jedoch am häufigsten 3. die vierbeinige Version mit zwei Spielern und den Tontopf als Pferdekopf (auch bei Hochzeiten gespielt). Ebenso gibt es mehrere Episoden: Nach den Einlaß- und Eintrittsversen des Bittstellers ${ }^{234}$ wird das Tier in wortreichen Dialogen angepriesen, es sei mit dem letzten Geld gekauft worden usw., und man bittet um Almosen; tumultartig ist die Szene mit dem versuchten Beschlagen des Pferdes, das unruhig ist, bockt, Pferdemist in der sauberen Spinnstube verstreut usw.; detaillierte Improvisationsdialoge weist der Verkauf des Tieres mit endlosem Feilschen, ohne eine Einigung zu erzielen, auf, so daß der Besitzer es lieber tötet (Tonkrug als Kopf zerschlagen); das allgemeine Bedauern führt zur Wiederauferstehung des Tiers ${ }^{235}$. Das Tod-Auferstehungs-Motiv zeigt den fruchtbarkeitsmagischen Hintergrund der elaborierten Sammelumzug-Szene mit den Heischesprüchen, den deutlich sexuellen Anspielungen vor den Mädchen, dem Schreck-Effekt, der Clownerie in Performanz und Verbalität, der spielhaften Kommunikation der Jugend untereinander ${ }^{236}$.

Die ebenfalls häufige arktomorphe Bärenmaskierung kennt im wesentlichen zwei Spielarten: den Stroh- oder Erbsenbär ${ }^{237}$ und den von einem geschwärzten Zigeuner an einer Kette geführten Tanzbären, der früher bei allen öffentlichen Festveranstaltungen und Jahr-

${ }_{234}$ Zoltán Ujváry, »A népi szinjáték bekéretö-beköszöntö formuláirol«, Emlékkönyv a Turkevei $M u$ seum fennállásának 20. évfordulojához, Turkeve 1970.

235 Nora A. Tahy, Das theatralische Brauchtum des ungarischen Sprachbereichs, Frankfurt/M. etc. 1989, 98-гоo.

${ }_{23} 6$ Neben der latenten Obszönität der Darstellung (das Pferd manchmal auch phallisch) und dem bedeutenden Störfaktor bzw. Schreck-Effekt bietet das Szenenkonglomerat mit den endlosen Verkaufsverhandlungen jedoch auch interaktive Kommunikation mit Witz und Schlagfertigkeit an, Gelegenheit zum Schäkern mit den Mädchen, doch bedürfen die z.T. ausführlichen Dialoge auch der intensiven Vorbereitung, der Erlernung von Texten bzw. der Organisation der Vorstellung. $\mathrm{Zu}$ dem fertilitätsmagischen Hintergrund der zoomorphen Verkleidungen vgl. auch Manolis G. Varvounis, "Fertility and Zoomorphic Masking in the folk culture of the Balkan people«, Church Studies. Annual Journal of the Centre of Church Studies of the University of Niš 4 (2007) 287-295.

237 Zur europaweiten Verbreitung Handwörterbuch des Deutschen Aberglaubens Bd. 8, 945 ff., Wilhelm Mannhardt, Wald- und Feldkulte, 2 Bde., Berlin I 905, II I 86 ff., Mircea Eliade, Die Religionen und das Heilige, Salzburg 1954, 37 ff. Zum hypostasierten Zusammenhang mit dem antiken ArtemisKult in Brauron Schmidt, Masken in Mitteleuropa, op. cit., 23, Karl Kerényi, Die Religionen der

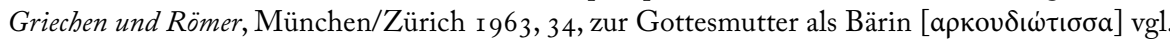

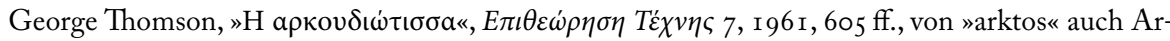
kadien). Strohverkleidungen tauchen auch ohne die Bedeutung der arktomorphen Maskierung auf, wie z.B. der Pflugführer bei der Scheinpflügung in der Steiermark (E. Keiter, „Die Faschingszeit in den österreichischen Alpen«, Österreichisch-Ungarische Revue 8, Wien I 894, 40I) oder beim Zeremonienleiter des Blochziehens in Kärnten (Karl M. Klier, Das Blochziehen. Ein Faschingsbrauch von der Südostgrenze Österreichs, Eisenstadt I953, 38). Dazu noch in der Folge. 
märkten auf der Balkanhalbinsel aufgetreten ist ${ }^{238}$. Die Strohverkleidung ist wesentlich komplizierter, langwieriger in ihrer Herstellung (und überdies feuergefährdet) als die Fellverkleidung. Komplexere Gerichtsspiele wie das Bärenjagen in den Südostalpen, wo der Wilderer das gefährliche Tier gesetzeswidrig erlegt ${ }^{239}$, sind weiter südlich und östlich eher selten: Hier dominiert der immer weiblich gedachte Tanzbär (medvjed) mit seinem plumpen Tanz (mečeško horo) mit oder ohne Führer ${ }^{240}$, der schon als Unterhaltungsnummer im byzantinischen Hippodrom aufgetreten ist ${ }^{241}$. Kultisch-magische Vorstellungen scheinen sich an die Amulett-Funktion der Haare des Bärenfells zu knüpfen, ähnlich wie der Tritt der Bärin als therapeutisches Gesundheitsmittel gilt ${ }^{242}$. Bei den Spinnstubenunterhaltungen gibt es neben dem Bärentanz auch gespielte Verkaufsverhandlungen ${ }^{243}$.

${ }_{23} 8$ T. P. Vukanović, »Gypsy Bear Leaders in the Balkan Peninsula«,Journal of the Gypsy Lore Society ser. 2,38 (I 959 ) IO6-I 27.

239 Karl Stöffelmayer, »Das Obermurtaler Faschingsrennen «, Österreichische Zeitschrift für Volkskunde 7/45 ( I 953) 37 ff., Richard Wolfram, »Bärenjagen und Faschingslaufen im oberen Murtal«, Wiener Zeitscbrift für Volkskunde 37 (1932) 59 ff., Oskar Moser, »Faschingsbrauch in Kärnten - Pflugumfahrt und Bärenjagen«, Deutsche Volkskunde 4 (München I 942) $390 \mathrm{ff}$.

240 In Bulgarien schon im I 9. Jh. als Solotanz eines Verkleideten beschrieben (Albert Dumont, Le Balkan et l'Adriatique, Paris I 873, I 38 f.). In Rumänien und im Zentralbalkan handelt es sich um die häufigste Tiermaskierung überhaupt (Vulcănescu, Măstile populare, op. cit., 55 ff., Vakarelski,

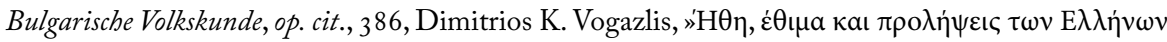

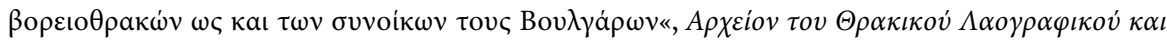

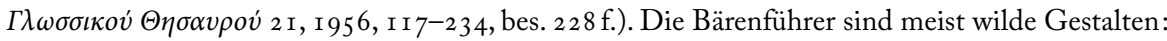
ein alter Zigeuner (in Ungarn ein Rumäne) mit Ruß im Gesicht, in Lumpen oder umgedrehte Fetzenkleider gehüllt, mit fettigen Hüten und krummen Stöcken, manchmal auch als altes Weib, mit einer Trommel oder Imitation dieses Instruments (alter Topf usw.). Die Bärin in ein umgedrehtes Fell gekleidet (oder Trikot, Federn, haarige Mäntel usw.), an einem Strick geführt, »tanzt« zur Trommel. In einer Feldforschungsaufnahme aus dem Bezirk Elasson in Nordthessalien (I 977) hat der »Bär« sogar eine Doppelfunktion: Er bläst auch eine Trompete, um den Maskenzug, den der Kirchenvorsteher mit der Spendenbüchse anführt, anzukündigen; aufgrund eines gleichzeitig stattfindenden Fußballmatches waren die beiden an diesem Neujahrstag die einzige Maskennummer (Puchner, Studien zur Volkskunde Südosteuropas, op. cit., Abb. I-4, genauere Feldforschungsangaben

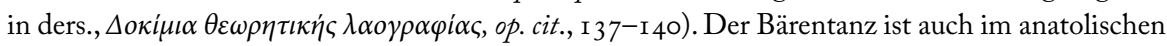
Kleinasien nachgewiesen (Metin And, Dances of Anatolian Turkey, New York 1959, 33-35, 40-42).

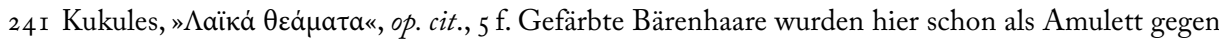
Krankheiten verkauft.

${ }_{242}$ Zur fertilitätsmagischen Bedeutung der Bärin vgl. Eliade, op. cit. I92. Vgl. auch das Motiv des Bärensohns als Drachentöter in den Märchen vom Typ ATU 300 und 30 r. Zum therapeutischen Bärentritt auch Puchner, Brauchtumserscheinungen, op. cit., 208 f.; zur gesundheitsmagischen Bedeutung der Kornelkirschrute (surva) und ihrer Früchte, die zu den Lieblingsspeisen des Waldbären zählen, vgl. ibid. I $24 \mathrm{f}$.

243 Tahy, op. cit., 92-94. Der Verkauf des Tiers zieht sich in interaktiven und improvisierten Dialogen 
Andere zoomorphe Verkleidungsformen. Neben anderen Verkleidungen von Vierbeinern (Schwein, Ochse, Stier, Hirsch, Kuh, Hund, Wolf, Widder, Hase usw. ${ }^{244}$ finden sich auch z.T. phantastische Vogelmaskierungen wie der vielbeinige »Truthahn« in Varoš in Slavonien ${ }^{245}$, die brezaja und klocalica in Rumänien, Bulgarien und ehem. Jugoslawien ${ }^{246}$, der »Krauthinkl in Westungarn ${ }^{247}$ und die skandalösen Storchimitationen im nordbalkanischen Raum ${ }^{248}$ usw.

\section{I.3.4 Theriomorphe Verkleidung}

Gespensterartige Verkleidungen, Dämonenmasken, Fratzen, Larven und Schreckgesichter, Teufelsfiguren, geschwärzte, glockenbehangene und fellverkleidete »Araber»

mit den Zuschauern durch Versteigerungen und Feilschen in die Länge, das Tier macht sich los, hebt den Mädchen die Röcke, beschmiert sie usw.; vorgetäuschtes Verhalten gibt es auch auf der anderen Seite mit gespielter Abwehr, scheinbarem Erschrecken usw. Die Leiterin der Spinnstube kann dem Tumult ein jähes Ende bereiten, indem sie die verkleideten Burschen hinauswirft, wie dies etwa bei mimetischen Kopulationsimitationen (einer der beiden Bären phallisch) geschieht.

${ }_{244}$ Zur Hasenverkleidung bei den theriomorphen "Derwischen« im Raum Pasardžik vgl. Rayna Katzarova, »Derwisch-Karnevalsspiele im Dorf Lessitschevo - Kreis Pasardschik«, A. Mauerhofer (ed.) Musikethnologisches Kolloquium. Die Südosteuropäische Volkskultur in der Gegenwart. Referate der 4. Internationalen Balkanologentagung, Graz I 983, 97-I I 4. Zur Wolfsverkleidung Vitomir Belaj, »Običaji vučara u Južnih Slavena i pokušaji njegova interpretiranja«, Zbornik za narodni život $i$ običaji južnih slavena 49 (Zagreb I983) 73-94, N. I. Tolstoj, »Južnoslavjanskije vučari. Obrjad, jego struktura geografija«, Obraz mira v slove i rituale. Balkanskije čtenija I, Moskva I 992, 46-57.

245 J. Čolić, „Godišnij običai (Varoš u Slavoniji)«, Zbornik za narodni život i običaje 2 I (Zagreb I97I).

246 V. Belaj, „Einige Tiermasken des Westbalkans«, Mauerhofer, Musikethnologisches Kolloquium, op. cit., 4I-52, M. Maluckov, »Klocalica kod Srba i Rumuna u Banatu«, Posebni otisak, Radovi Simposijuma o juslovensku-rumunskim uzajamnostima u oblasti narodne književnosti, Pančevo I 972, 34I356, M. Ilić, »Klocalica, šerbulj ili curka - jedna maska u običajima Srba i Rumuna u Banatu«, Rad vojvočanskih muzeja I 2-I3 (Novi Sad i 964) 45-68.

247 J. Weidlein, »Jahrzeitbräuche in der mittleren Tolnau«, Deutsch-ungarische Heimatblätter 7 (I 935) $56 \mathrm{ff}$.

248 Wobei dem Schnabel phallische Bedeutung zukommt. Vgl. Zoltán Ujváry/Imre Ferenczi, „Farsangi dramatikus«, Mû̃veltseg és Hagyomány 4 (1962) 3-I 5 . Die Verkleidung besteht aus einem weißen Laken, dem geschnitzten Schnabel mit beweglichem Unterkiefer (oder einfacher: einem ausgestreckten Finger, einer Paprikaschote usw.), die auch ein Puppenkleinkind tragen kann. Neben dem Frühlingsbringer Storch ist auch der Kinderbringer angesprochen: Der Storch sticht die Mädchen, legt ihnen das Baby in den Schoß (oder ihren Schnabel), diese kreischen, fliehen, wehren sich, werfen die Puppe weg. Wenn sie zu zweit erscheinen, gibt es auch eine Paarungsszene (reiben die »Schnäbel«); Altjungfern werden verspottet. Ein Bittsteller holt die Erlaubnis des Eintretens ein, bittet am Ende um Verzeihung für die Aufdringlichkeit; wenn die etwa 5 Minuten dauernde Darstellung zu obszön wird, werden die Burschen des Hauses verwiesen. 
(Schwarze, Mohren, Sarazenen) bilden das Panoptikum der theriomorphen Mittwinterund Karnevalsverkleidungen im südosteuropäischen Raum. Diese Maskierungen sind insofern nur teilweise mimetisch, als die Dämonenvorstellungen der kollektiven Imagination angehören und eine regional überaus variable Morphologie besitzen ${ }^{249}$. Die maskenhaften Objektivationen dieser Vorstellungen lassen sich grob in weibliche und männliche Maskengestalten teilen: Erstere sind typisch für den Nord- und Nordwestbalkanraum (Perchten, šemen, Sv. Lucija, Lutzelfrau, Budelmutter, Verkörperung der Quadragesima, $b a b a$ u.a. Hexenmaskierungen $)^{250}$, zweitere universell vom Ostalpenvorland bis ins Mit-

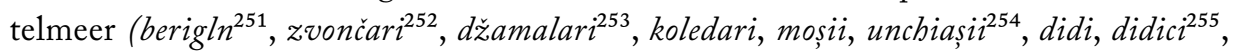

249 Dies betrifft z.T. auch die Eigenschaften und Funktionen, die durchaus ambivalente Aspekte aufzeigen: vgl. z.B. zu den Übergängen von den Feen- zu den Hexenvorstellungen im Nord- und Zentralbalkanraum É. Pócs, Fairies and Witches at the Boundary of South-Eastern and Central Europe, Helsinki 1989 (FFC 243).

250 V.Waschnitius, »Percht, Holda und verwandte Getalten«, Sitz. ber. d. kaiserl. Akad. d. Wiss. in Wien, phil.-hist. Kl., Abh. I 74, Wien I 91 3, Niko Kuret, „Die Mittwintersfrau der Slowenen (Prehta baba und Torka)«, Alpes Orientales 5 (Ljubljana I 969) 209-239, Oswin Moro, »Maskenbräuche in gemischtsprachigen Dörfer Oberkärntens«, Carinthia I/ 25 (Klagenfurt I 935) 2 I I ff., H. L. Estocq, »Unterkärntner Brauchtum«, ibid. I/I 20 (I 930) I 50-I75, Leopold Schmidt, »Berchtengestalten im Burgenland«, Burgenländische Heimatblätter I 3 (I 95 I) I 29 ff. und ibid. I4, I 952 , I 22 ff., I 70 ff. Zum Lucienkult Leopold Kretzenbacher, Santa Lucia und die Lutzelfrau. Volksglaube und Hochreligion im Spannungsfeld Mittel- und Osteuropas, München 1959, ders., "Lutzelfrau und Pudelmutter«, Burgenländische Heimatblätter I 3 (I 95 I) I 62 ff., Niko Kuret, Maske slovenskib pokrajin, Ljubljana I 984 , I 37-I 45. Zum blutigen Abstechen der Quadragesima (Osterfasten) vgl. Georg Graber, Kärntner Volksleben, Graz ${ }^{3}$ I953, 239, was dem "Zersägen der Alten« bei den Slovenen (baba žagajo) entspricht (Niko Kuret, »Baba žagajor. Slovenske oblike pozabljenega obredja in njegove evropske paralele (Scier le vieille. Formes slovenes et parallèls européennes d'une cérémonie oubliée)«, Slovenski Etnograf I 8, I 960, I I 5 ff., ders., »Ljudsko gledališče pri Slovenich«, ibid. I I, I 958, 35 ff.

25 I F. Freiherr von Andrian, Die Altausseer. Ein Beitrag zur Volkskunde des Salzkammergutes, Wien 1905 , 207.

252 Die theriomorphen Glockenmänner werden so bezeichnet vom dalmatinischen Küstenstreifen bis in den Raum um Florina, vgl. Nikola Bonifačić-Rožin et al., Narodne drame, poslovice i zagonetke, Zagreb I 963, 67 ff., I. Jardas, »Kostovski zvončari«, Riječka revija 3 (I 954) I6-г 8, Karapatakis, To

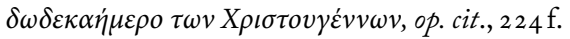

253 Vakarelski, Bulgarische Volkskunde, op. cit., $384 \mathrm{f}$.

254 T. Gălușcă, »Mocanii - un joc dramatic al românilor din Dobrogea«, Annarul Arbivei de Folklor 5 (1945) I 2-34, Vulcănescu, Măștile populare, op. cit., I6 I f.

255 Nikola Bonifačić-Rožin, »Pokladne maskare u Konavlina«, Narodna Umjetnost 4 (I 966) I 53-I 73, Niko Kuret, »Die >Alten in den Maskenumzügen Südosteuropas«, Etnografski folkloristični izsledvanija, FS Christo Vakarelski, Sofija I 979, 2 I 5-225. 
rogatsia, rugatsiaria ${ }^{256}$, babušaria, babogeri, kukeri ${ }^{257}$, arapides usw. $)^{258}$. Vielfach steht die Dämonenmaskierung im Übergang sowohl zu den zoomorphen Verkleidungen (z.B. die medved-Bärenmaske in Serbien) ${ }^{259}$ als auch zu den anthropomorphen. Für die Gesichtsmasken werden verschiedene Materialien benutzt: von der kunstvoll geschnitzten und bemalten Holzmaske bis zum einfachen Rußschwärzen des Gesichts. In manchen Fällen haben auch Vogelscheuchenfiguren oder strohgestopfte Effigien die Schreckfunktion der theriomorphen Verkleidung ${ }^{260}$.

Neben den grotesken und obszönen phallischen »Alten« ist es vor allem die Maskenfigur des schwarzen »Arabers" (arapul, harapis, arapis, arapin usw.), der als Protoyp des kohlpechrabenschwarzen Mohren den historischen Sarazenen bzw. eine schwer bestimmbare Dämonengestalt als Kinderschreck verkörpert, ausgestattet mit Attributen der zoomorphen Verkleidung (Felle, Hörner, Schwänze), und als apotropäischer Lärmmacher mit den umgehängten Viehglocken (die Klöppel auch in phallischer Bedeutung), seinem teuflischen Herumspringen und Schreien ein Garant der Prosperität und Eueterie (gutes Erntejahr) ist ${ }^{261}$. In manchen Fällen bilden die Verkleideten eine streng

${ }_{25} 6$ Walter Puchner, »Die >Rogatsiengesellschaften . Theriomophe Maskierung und adoleszenter Umzugsbrauch in den Kontinentalzonen des Balkanraum«, Studien zur Volkskunde Südosteuropas, op. cit., I07-I 50 .

257 Mihail Arnaudov, "Kukeri i Rusalii«, Sbornik za Narodni Umotvorenija i Narodopis 34 (Sofija 1924) I-242, bes. I 38 ff., Christo Vakarelski, "Jeux et coutumes théâtrales chez les Bulgares«, Ethnologia

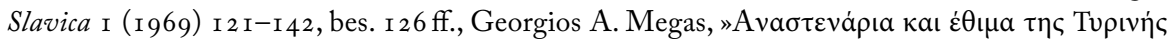

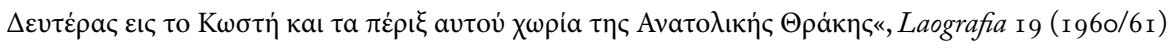
$472-534$.

258 Niko Kuret, »Die Zwölften und das wilde Heer in den Ost-Alpen«, Alpes Orientales 5 ( ( 975 ) 80-91, ders., »Sredozimske maske: Poglavje iz primerjalnega narodopisja«, Etnolog 5 (LVI) (I 995) I 3-49, Florica Lorinț/Constantin Eretescu, »Moșii în obiceiurile vieții familiale«, Revista de Etnografie și Folclor I 2 ( I 967) 299-308.

259 Vgl. Vesna Marjanović, Maske, maskiranje i rituali u Srbiju, Beograd 2008, 209, 3 I I. Vgl. die Abb. ibid. $247^{-2} 29$.

260 Z.B. die sackförmige ungarische duszas-Figur in ausgestopften Kleidern mit großen Glocken an Hüften und Beinen (Zoltan Szilády, »Suhancok játékai«, Ethnographia I 930, 208 ff.).

26r Der Mohrenkopf ist ein beliebtes Apotropäum in der Volksarchitektur (z. B. über dem Ofenloch der Tonbrenner bei Roland Hampe/Adam Winder, Bei Töpfern und Töpferinnen in Kreta, Messenien und Zypern, Mainz 1962), il moro dient beim corse alla quintana auf Zante als Ziel des berittenen Lanzenstechens der giostra (Puchner, »Giostra und barriera. Ostmediterrane Turnierspiele von Venedig bis Zypern in ihrer geschichtlichen Entwicklung und machtpolitischen Funktion«, Studien zur Volkskunde Südosteuropas, op. cit., 21 3-252). Zur Araber-Figur in den Volkserzählungen und der Dämonologie vgl. auch Emmanuella Moser-Karagiannis, »Les êtres fantastiques et la parole dans les légendes populaires grecques. B. Les Arapides«, Littérature orale de la Grèce moderne. Recueil d'études, Athènes 2005, 45 I-462. 
hierarchisch gegliederte Gruppe und es kommt zu bewaffneten Zusammenstößen beim Aufeinandertreffen zweier Gruppen. Zu den Standardattributen der »Araber«Figur gehört der umgestülpte Fellüberwurf mit dem Pelz nach außen, die umgehängten Viehglocken, die Gesichtsmaske aus einem Fellstück mit den ausgeschnittenen Löchern für Augen und Mund oder einfach eine Ofenrußschminke, Knüppel, Holzschwert und andere Waffen ${ }^{262}$, oft auch ein Aschensack, aus dem die Leute beworfen werden. Die Araber schlagen mit ihren Glocken und Stöcken einen wahren »Heidenlärm«, indem sie herumlaufen und -springen und die Leute erschrecken ${ }^{263}$. In den Pausen dieses Pandämoniums werden die Festlieder gesungen. Man trägt auch martialische Scheinkämpfe mit Holzschwertern aus, schlägt auf Trommeln und bläst in Dudelsäcke, nimmt Leute fest und läßt sie gegen Lösegeld frei, stiehlt den Hühnern die Eier, Würste aus der Selchkammer usw. ${ }^{264}$ und bewirft die Leute mit Asche. Handtrommel (dübelek) und Sackpfeife (gajda) werden dabei gleichermaßen als Lärm- und Musikinstrumente verwendet, wie auch die Glocken zur Liedbegleitung dienen können ${ }^{265}$. Nach Maßgabe der Maskenattribute (Schaf- und Ziegenfelle) scheint die theriomorphe Verkleidung heute eher an Zonen extensiver Viehwirtschaft mit ausgedehntem Weideland gebunden, da Raubtierfelle nur in älteren Quellen angeführt sind ${ }^{266}$. Die Maskenfigur des Arabers ist nicht nur in allen Balkanzonen anzutreffen ${ }^{267}$, sondern als arap oyun $u^{268}$ auch in den Wintersonnwendspielen der islamischen Volkskultur Kleinasiens ${ }^{269}$ sowie in den Hochzeitsspielen Anatoliens.

262 Eine ältere Deskripition aus den Dörfern um das Pangaion-Gebirge in Thrakien führt für den Umzug der babogeroi am 7. Jänner Folgendes an: „Eine Gruppe von Menschen kleidet sich in Lumpen, hängt sich Glocken um und alles, was den übrigen Menschen Schrecken einjagen kann, und geht

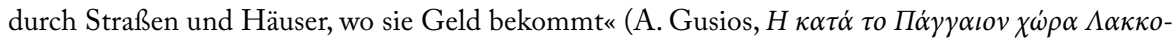
$\beta \eta \kappa i \omega v$, Leipzig I 894, 40 f., Ü. d. A.).

263 Vgl. Abb. 8-1o in Puchner, Studien zur Volkskunde Südosteuropas, op. cit.

${ }_{26} \mathrm{Zu}$ verschiedenen Formen des Stehlrechts bei Vlachen und Griechen in der Provinz Elasson in Thessalien vgl. A. J. B. Wace/M. S. Thompson, The Nomads of the Balkans, London I 9 I 4, I 37 ff.

${ }_{26} \mathrm{Zu}$ den Viehglockenformen Angeliki Hatzimichali, Oı $\Sigma \alpha \rho \alpha \kappa \alpha \tau \sigma \alpha \dot{v o l}$, Athen I957, I 20 ff. Die konische »Doppelkypros« wird manchmal auch in phallischer Bedeutung gehandhabt. Zu weiteren Quellen und Details, Beispielen und Bibliographie siehe Puchner, Brauchtumserscheinungen, op. cit., 203-206 und ders., Studien zur Volkskunde Südosteuropas, op. cit., I 24-I 27. Dort auch genauere Angaben zu den Fellformen, Gesichtsmasken usw.

266 Z.B. Arnaudoff, Die bulgarischen Festbräuche, op. cit., I 3.

267 A. A. Plotnikova, „Demoničeskie čerty v južnoslavjanskom rjaženii«, Mif $i$ kul'tura: čelovek - nečelovek, Moskva I 994, 27-30, dies., »Erotičeskije elementy v južnoslavjanskom rjaženii«, A. L. Toporkov (ed.), Seks i erotika v russkoj tradicionoj kul'ture, Moskva I 996, 305-3 I 2.

268 Metin And, $A$ history of theatre and popular entertainment in Turkey, Ankara I 963/64, $53 \mathrm{ff}$.

${ }_{269}$ Pertev N. Boratav, »The Negro in Turkish Folklore«, Journal of American Folklore 64 (I 95 I) 83-88. 
Im Dorf Sığırcı im Raum Belikesir besteht die Bevölkerung aus bäuerlichen Rückwanderern aus Bulgarien im Zuge der Populationsverschiebungen nach dem Ersten Weltkrieg. In der Nacht vor dem Hochzeitstag kommt es vor der Moschee zu folgender Szene: Nach langem Warten schoß zunächst der arap (Neger) in Unterhosen ..., weißem Hemd und hoher, spitzer Mütze aus Pappe durch die Menge und brachte diese mit seinen Bocksprüngen schon erheblich zum Joblen. Darauffolgte ein ganzer Haufen schreiender Bübchen in gleicher Tracht, die hinter dem dede (Großvater) her schrieen. Sie stießen nach den vielen kaputten Sieben auf seinem Rücken (Anlehnung an Zigeuern, die oft das Dorf besuchen?); der dede wehrte sich mit einer großen Keule, das ganze löste sich in Tumult auf. Dazwischen schoß der arap, die Spitze seiner hohen Mütze brannte. Einer der Knaben blieb scheintot liegen; laut klagend und schreiend stürzte der dede davon, die Bübchen hinter ihm her. Der arap unterbielt auch weiterbin die Zuschauer in den Pausen mit seinen Sprüngen und einer neuen, brennenden Mütze ... In der Folge kommt es zu einer Hochzeitsparodie mit Brautpaar und Standesbeamten, auch das bekannte Umzugskamel mit einem festlich gekleideten deve bași (Kamelführer) in Yürükenart tritt auf ${ }^{20}$.

\section{I.3.5 Anthropomorphe Verkleidung}

Sowohl die Festtracht als auch die dämonische Lumpen(ver)kleidung bezieht sich auf das Exzeptionelle des Umzugstermins ${ }^{271}$; dort wo sie sich über diese bloß datumsmäßige Funktion erhebt und typensignalisierende Funktion übernimmt, konstituiert sie ein Figurenrepertoire, das auf zwei verschiedene Realitätsebenen hinweist: Zum einen steht der anthropomorphe Maskentyp in einem Konnex mit einem Dromenon, das ausgespart oder ausgeführt wird, angedeutet oder verloren ist, aus dem Sinnkontext der Brauchhandlung oder durch Komparation erschlossen werden kann oder an den ritualisierten Verkürzungen abzulesen ist; zum andern weist er in seiner konkreten Mimetik bereits auf den Kanon sozialer Positionen und Rollen, nach Alter, Status, Geschlecht und Beruf gegliedert, die die spezifische Kommunität in Historie und Gegenwart aufzuweisen hat ${ }^{272}$. Damit reflektiert die Typologie der Vermummungen Elemente des fiktiven und realen Lebenshorizontes. Zugleich enthält jede Figur in nuce eine ausagierte, verkürzte oder unausgeführte Aktion: das Brautpaar die Hochzeitsparodie, der Richter

270 Leonore Kosswig, »Hochzeitsgebräuche in Anatolien«, Oriens I3/14 (I 960/6r) 240-250, bes. $246 \mathrm{f}$.

27I Die Festkleidung der traditionellen Tracht als Zur-Schau-Stellung des idealen Selbst der kollektiven Gruppenidentität und der idealisierten sozialen Rollenposition des individuellen Trägers; die Lumpenkleidung als sozial irrelevante Verkleidung, die einfach komisch wirkt und in ihrer Bettelhaftigkeit die Umkehr der Werte im mundus reversus des Karnevals signalisiert.

272 Darüberhinaus gibt es auch Rollen eines fiktiven und imaginären Kulturkontextes, wie Teufel, Dämonen, der Hl. Georg, Lazarus usw. 
das Gerichtsspiel usw. Meist jedoch sind die Maskentypen multifunktional und imstande, in den Ritualhandlungen ganz verschiedene Rollenfunktionen zu übernehmen, so daß sie z.T. auch auswechselbar erscheinen: der »Araber«, der Bräutigam, der König usw.

Die wichtigste Figur einer Maskengruppe scheint dabei die »Braut« zu sein, oder das die potenzielle Fekundität verkörpernde Brautpaar, die oder das beschützt wird: Symbol der virtuellen Fertilität und dynamistisches Bedeutungszentrum des Maskenzugs. Auf diesem Grund ist das Brautstehlen, jenseits der Bedeutungsmöglichkeit eines spielhaft ausagierten Brautraubs als Stereotypmotiv der Heldenlieder ${ }^{273}$, bzw. das »Küssen« oder Belästigen der Braut ein absichtlich herbeigeführtes oder mit allen Mitteln verhindertes, in jedem Falle aber bedeutungsvolles Ereignis. Die einfachste Form der Metamorphose ist die Geschlechtswechselverkleidung: nicht ein bloßer simpler Kleidertausch, wenn man an die Codes der traditionellen Verhaltensvorschriften denkt. Auch die »Braut« wird fast immer von einem jungen Burschen gespielt. Beim Brautpaar kommt es noch zu keiner richtigen Rollenbeziehung, es handelt sich eher um einen komplementären Bedeutungskomplex fruchtbarkeitsmagischer Performanz.

Die Braut(ver)kleidung tritt oft bei den frühlinghaften Mädchenumzügen ohne gender-Wechsel zusammen mit Festtracht, Blumenkränzung, Reigentänzen usw. auf: Dazu zählen die Pfingstköniginnen-Umzüge der kraljice ${ }^{274}$, in Slavonien und der Batschka von einem oder mehreren fahnentragenden barjaktar(uše) begleitet ${ }^{275}$, die ćaraice in

273 Vgl. Puchner, Die Folklore Südosteuropas, op. cit., I 9-29.

274 Im südslavischen Raum, in der Vojvodina auch bei Ungarn und Rumänen. Vgl. Vesna Marjanović, Maske u tradicionalnoj kulturi Vojvodine, Novi Sad I992, Thekla Dömötör, "Whitsun mummers in Hungary«, FS R. Wildhaber, Basel/Bonn I 973, I 97 ff., beschrieben schon bei Vuk Karadžić (V. St. Karadžić, Život i običaji naroda srpskog, Beč i 867, 35-49). Vgl. auch die Marienmädchen in Ungarn (Balassa/Ortutay, Ungarische Volkskunde, op. cit., i 77 Abb. Nr. 38 ).

275 J. Lovretić, »Kraličari ili Kraljice«, Zbornik za narodni život i običaji 2 (Zagreb I 897), B. Gušić, Ljelje - Kraljice kao bistorijski spomenik, Zagreb i 967 . In der Batschka wird der Königinnenzug begleitet von zwei Spielern barjaktaruše (Fahnenträgern), vier pevačice, und jede kraljica hat einen schwerttragenden (sablje, jatagana), martialisch-magischen diver (Hochzeitsführer). Vgl. J. Erdeljanović, O poreklu Bunjecava, Beograd I930, 269-273, Lj. \& D. Janković, Narodne igre, V, Beograd I949, 85. In der Vojvodina gingen um I 9 Io neben den fünf Mädchen im Alter von IO-I 5 Jahren folgende Spieler um: die kraljica, der kralj, ein barjaktar, die dvorkinja (Aufwartefrau) und die sluškinja (Dienerin) (B. Petrović, "Kraljice«, Rad, Sprski narodni veliki kalendar sa savremenim slikama za godinu I9 I I, Novi Sad I 9 Io, 5 I-53). Weitere Materialien in M. Škarić, „Život i običaji >Planinacar pod Fruškom gorom«, Srpski etnografski zbornik 24 (1939) I-275, bes. 99-1or, Mila Bosić, Godišnji običaji Srba u Vojvodini, Novi Sad I 996, 324-339, Slobodan Zečević, Elementi naše mitologije u narodnim obredima uz igru, Zenica I 973, Iо8-1 10, Mile Nedeljković, Godišni običaji kod Srba, Beograd I990, I 2 I-I 25. Vgl. Marjanović, Maske, op. cit., I 76-I 86, Verbreitungskarte I 77 und mehrere Abb. (ein rezentes Photo S. I 85 aus Miloševac zeigt eine ganz in weiß gekleidete kralijca 
Serbien $^{276}$, die kreuztragenden krićari zu Christi Himmelfahrt in Slovenien ${ }^{277}$, der cărăbița-Tanz ${ }^{278}$, die Pfingst-Rituale der rusalije bei den Aromunen im ostserbischen Bergland ${ }^{279}$, der sirnica-Umgang in Bulgarien ${ }^{280}$ usw., auch als Königspaar kralj und kraljice, lazar und lazarica, Vasyl und Malanka usw. ${ }^{281}$ Besonders signifikant sind jedoch die Umzüge der lazarice, lazarki, lazarines usw. am lazarovden, dem Palmsamstag, im gesamten orthodoxen Bereich Südosteuropas, wo kleine und große Mädchen (Lazarus hatte nur Schwestern) in Festtracht, oft in Vierergruppen (weil er als tetrahemeros oder tetartaios vier Tage in der Unterwelt verbracht hat), auf ihrem Gang von Haus zu Haus begleitet von einem »Hundeburschen«, der den Eierkorb trägt und die Mädchen beschützt ${ }^{282}$, umgehen, wobei das Lazaruslied (im Zentral- und Nordbalkanraum auch Frühlings-, Liebes- und Hochzeitslieder) sowie die Loblieder auf Familienmitglieder

mit Brautschleier und Blumenkränzung sowie farbiger Schürze; vgl. O. Mladenović, »Narodne igre ćerdapskog stanovništva«, Zbornik radova Etnografskog instituta 7, 1974, 91-108, bes. 97). Siehe auch Svetlana M. Tolstoj/Ljubinko Radenković, Slovenska mitologija, Enciklopedijski rečnik, Beograd 200 , Lemma kraljice. Der Pfingstköniginnen-Umzug war eine beliebte Nummer bei den FolkloreFestivals.

276 Jelica Belovic, Die Sitten der Südslaven, Dresden r 927, r 20 f.

277 Niko Kuret, »Frauenbünde und maskierte Frauen«, Schweizer. Archiv für Volkskunde 68/69 (1972/73) 334-347, bes. 34r.

278 Octavian Buhociu, Folklore roumain de Printemps, Diss. Paris I 957, 259-265.

279 Friedrich Salomo Krauss, »Rusalije«, Am Urquell I (I 890) I 45, G. A. Küppers, »Rosalienfest und Trancetänze in Duboka. Pfingstbräuche im ostserbischen Bergland «, Zeitschrift für Ethnologie 76 (1954) 2 I 2-224, V. Jakovljević, »Preživeli obliči orgiastičkog vidu archaičnich Rusalskich obreda Homoljske - Rusalje, Padalice«, Etnološki pregled 2 (Beograd I960), L. Jaković, »Rusalije«, Glasnik etnografskog muzeja I4 (Beograd I934), M. Majzner, »Dubočke Rusalije«, Godišnjica N. Čupica 34 (Beograd I 97 I) 226-257, Slobodan Zečević, »Predanja o rusalijski grobljima u Istočnoj Srbiji«, Narodno stvaralaštvo folklor I (Beograd I 962) 235-243, Gail Kligman, Căluș. Symbolic Transformation in Romanian Ritual, Chicago/London I98 I, 63 f., C. Călin, „Condica limbii românești«, Revista de Etnografia și Folclor 2 I ( 1976) 89-107, bes. 98, Mircea Eliade, "'Schamanismus bei den Rumänen?«, Von Zalmoxis zu Dschingis-Khan. Religion und Volkskultur in Südosteuropa, Köln 1982 , 20I-2 I 4, bes. 209-2 I I T. Georgevici, »Printre Români nostri. Note de călătorie«, ed. C. Constante, Români din Timoc, Bd. 3, București I 843, 25-I 47, bes. 97 ff., Octavian Buhociu, Folklore roumain de Printemps, Diss. Paris 1957, 262-264.

280 V. Kuzmanova, »Za sistemnija charakter na proletnite obredi«, Obred i obreden folklor, Sofija I 98 I, II 5-I 45 .

28 I Petru Caraman, Obręzed kolędowania u Stowien i u Rumunów, Kraków i 933, 576 f.

282 Zur Umzugsmorphologie Walter Puchner, Studien zum Kulturkontext der liturgischen Szene. Lazarus und Judas als religiöse Volksfiguren in Bild und Brauch, Lied und Legende Südosteuropas, 2 Bde., Wien I99 (Österr. Akad. d. Wiss., phil.-hist. Kl., Denkschriften 2 I6) 48-54, I 94-209. Zur realen

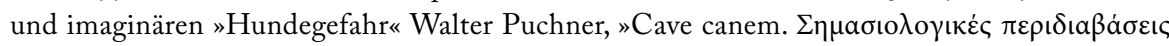

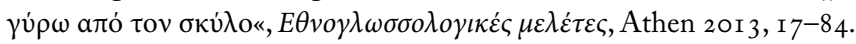


abgesungen werden ${ }^{283}$. Die komplexeren Umgänge werden oft nach Altersstufen getrennt durchgeführt, wie die der momice (kleinen Mädchen), der mome (Mädchen) und godenice (»Bräute«, heiratsreife Mädchen) ${ }^{284}$, und enden mit einem zyklischen Reigentanz auf dem Dorfplatz ${ }^{285}$, manchmal angeführt von der im roten Brautschleier verhüllten buenec $^{286}$. Bei den serbischen Lazarusumzügen wird die Anführerin cara Lazara genannt ${ }^{287}$, es gibt manchmal auch einen Lazarusknaben ${ }^{288}$ bzw. auch eigene männliche Lazarusprozessionen $^{289}$.

Die »Braut« ist bis zur Gegenwart eine der beliebtesten Geschlechtswechselverkleidungen, wobei der Effekt der transmutierten gender-Rolle jedoch zunehmend ab-

283 Vgl. Puchner, Die Folklore Südosteuropas, op. cit., 65-68.

284 L. Jordanova, "Za običaja lazaruvane v Bălgarija«, Izvestija na Etnografskija institut i muzej 9 ( 1966 ) ı 7-1 62, bes. I I (Abb. 2), J. Zachariev, "Lazaruvane v Kamenitsa (Kjustendilstvo)«, Izvestija na narodnija etnografski muzej $v$ Sofja I0-I I (1932) I 87-202, bes. I 88, Vakarelski, Bulgarische Volks-

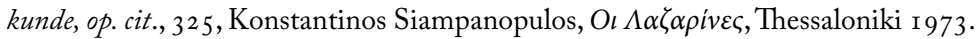

285 Zum Tanz vgl. Olivera Vasić, Etnokoreologija, Beograd 2004, 9 f. und Mila Bosić, Godišnji običaji Srba u Vojvodini, Novi Sad 1996, 232-244. Beim boeniško horo in Ostbulgarien kommt es auch zu

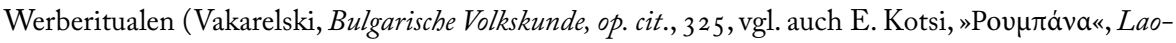
grafia I 9, I 960/6 I , 566-568) und ein Bursch, der die buenec zu heiraten gedenkt, führt den Tanz an. Als Vegetationsheros ist »Lazarus« im Abschlußtanz in Polyfyto in Griechisch-Makedonien

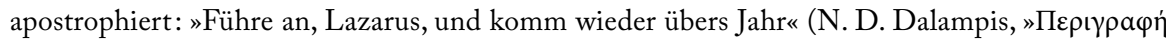

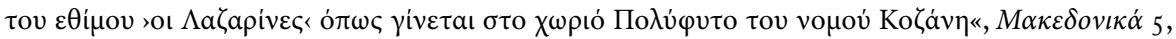
I 96 I $-63,244^{-252}$ ).

286 Anna Ilieva, »Istoričeski plastove v tancovija folklor na Slivenski okrăg«, Bălgarski Folklor 7/3 (I98I) 57-63, bes. 6I-63, dies./I. Račeva, »Istoričeski aspekti na problema za ritmoobrazuvaneto v bălgarskija tancov folklor «, ibid. 8/3 ( I 982) 28-37, Jordanova, op. cit., I 42-144, Anni Ilieva, »Traits antiques des coutumes printanières de certains peuples balkaniques«, Makedonski Folklor 6/I 2 ( 1 973) 75-80. Zur Symbol des roten Brautschleiers Dagmar Burkhart, "Der rote Schleier. Zur traditionellen Brautausstattung bei den Türken und Bulgaren«, G. Völger/K. v. Welck, Die Braut. Geliebt, verkauft, getauscht, geraubt, Bd. 2, Köln 1985, 450-455 und dies., "Der rote Schleier als Brautverhüllung«, Kulturraum Balkan, Hamburg/Berlin I 989, 54-64.

287 J. H. Veselinović, »Lazarice«, Bratstvo 4 (Beograd I 89o) 66-94, bes. $67 \mathrm{f}$.

288 So im Raum Prizren Marjanović, Maske, op. cit., I66 Abb. Vgl. M. S. Riznić, »Lazarice«, Bratstvo 4 (Beograd I 890) 43-52.

${ }_{289}$ So z.B. in Gornja Pšinja (M. Filipović/P. Tomić, Gornja Pšinja, Beograd r 955, 95). Zu dem Material in Kosovo vgl. D. Debeljković, Običaji sprskog naroda na Kosovu polju, Beograd 1907, 302, V. Nikolić-Stojančević, Vranjsko Pomoravlje, Beograd i 974, 536 f., D. M. Đorđević, »Lazarice u Leskovačkoj Moravi«, Rad kongresa folklorista Jugoslavije, I, na Bjelašnici 1955. i u Puli 1952., Bjelašnica I955, I I 7-I 24; und allgemein: Slobodan Zečević, Elementi naše mitologije u narodnim obredima uz igru, Zenica 1973, 65-90, auch in P. Kostić, »Lazarice u Surlici«, Glasnik Etnografskog muzeja 46 (I982) 9-39, Dragoslav Antonijević, Dromena, Beograd I997, I09-I I6, Marjanović, Maske, op. cit., I64-I74. 
nimmt ${ }^{290}$. Die seltenere Version ist die Verkleidung der Frau in ihr maskulines Ebenbild, was bei traditionellen Formen der »Weiberfastnacht« wie dem thrakisch-makedonischen Hebammentag vorkommen kann ${ }^{291}$, beim dalmatischen Karneval (z.B. in Lastovo ${ }^{292}$, in Slovenien ${ }^{293}$, in Serbien nördlich der Donau ${ }^{294}$, die Frauenfeste der todorice in Batschka und Banat ${ }^{295}$, das Frauenfest der slava mit Musik, Hausversammlungen, Festtracht und Verkleidungen ${ }^{296}$ usw. ${ }^{297}$ Besonders prägnant ist der Wechsel der Sexusrollen am thrakischen babin den (babin gün, $\tau^{\prime} \varsigma \mu \pi \alpha \dot{\alpha} \mu \pi \omega \varsigma \eta \mu \dot{\varepsilon} \rho \alpha$ ), dem 8. (oder 2 г.) Januar, wo neben der Ehrung der Hebamme ein Festgelage der verheirateten Mütter stattfindet, die Männer sich ins Haus sperren und Hausarbeiten verrichten, während die Frauen angeheitert durch die Straßen schwärmen und am Dorfplatz tanzen, in den Kaffeehäusern werden Symposien mit exzessivem Weingenuß, obszönen Liedern und Tänzen und lockeren Reden und Spielen abgehalten ${ }^{298}$. Die feministische Bewe-

290 Die Attraktivität des Brautkleids auch als Frauenverkleidung ist bei modernen Maskeraden in Südosteuropa des öfteren zu beobachten. Vgl. z.B. die phantastischen Brautkleider bei Vesna Marjanović, Maske, maskiranje i rituali u Srbiju, Beograd 2008, 277, aufgenommen in Novi Sad 2007.

29I Manolis Varvounis, "Balkan resultants and folkloristic influences in the Thracian dromenon of

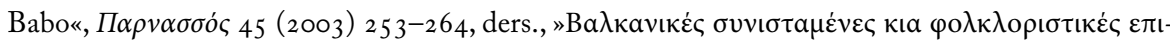

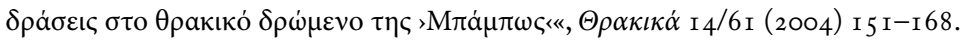

292 Sanja Puljar d'Alessio, »Realities of the Carnival Expressed by Ethnographic Film«, Narodna Umjetnost 38/I (2001) 67-76, Iva Niemčić, ibid. 39/2 (2002) 77 ff., Nevena Skrbić Alempijević, ibid. $43 / 2(2006) 4 \mathrm{I}$ ff.

293 Niko Kuret, »Frauenbünde und maskierte Frauen«, Schweizer. Archiv für Volkskunde 68/69 (1972/73) 334-347.

294 Vesna Marjanović, »Pokladni običaji u Banatu i istočnoj Srbiji«, Etno-kulturološki zbornik I I (Svrljig I996) 95-Io I, vgl. die Verbreitungskarte in dies., Maske, op. cit., I I I.

295 Marjanović, Maske, op. cit., I 59-163.

296 M. Milosavljević, »Revena - običajno pravno udruživanje ljudi u jelu i piću«, Rad vojvoćanskib muzeja 20 (I 97I) 335-338, Lj. Reljić, »Žensko slavje«, Zbornik Etnografsko muzeja u Beogradu, I9o I200 I, Beograd 200I, 56-86.

297 Vgl. auch den »Sonntag der Mädchen« (Fleischsonntag) im ungarischen Karancs (Andorné Szabo, "Lányok vasárnapja a Karancs környékén«, Néprajzi Közlemények 3-4, I957) usw.

298 Ältere Quellen berichten, daß, sollte ein Mann auf der Straße angetroffen werden, er entkleidet wurde und sich nur durch Weinspenden freikaufen konnte. Vom Ausschluß der Männer war bloß der Instrumentenspieler nicht betroffen; auf seinen Augenzeugenberichten beruhen die älteren

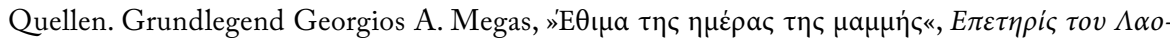

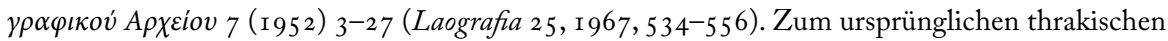

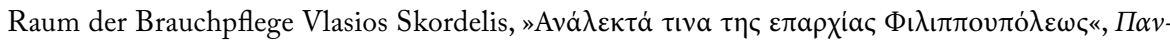

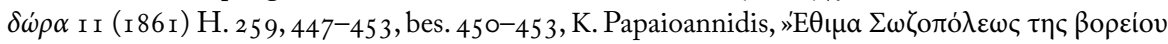

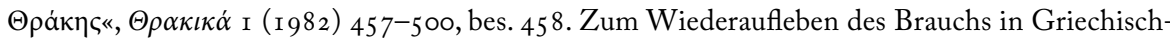

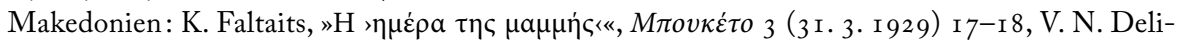


gung hat diese Gynaikokratie bereits seit I 963 auf ihre Fahnen geschrieben und den Frauenklub »Lysistrata« in Monokklisia im Raum Serres (ehem. Flüchtlinge aus heute Bulgarisch-Thrakien) gegründet, wo das »dionysische« Fest im »Haus der Frauen« stattfindet, während die Berichterstattung vor allem die phallischen und neo-obszönen Elemente herausstreich ${ }^{299}$; vom ehemaligen Hebammenfest ist neben der Umkehrung der Sexusrollen, den Spekulationen um Reste ehemals matriarchalischer Strukturen und der Sensation der "pornographischen « Manifestationen wenig geblieben ${ }^{300}$. Und wer dem bulgarischen babin den im Internet nachgeht, wird feststellen, daß das Fest bei Vereinen in den USA und Australien sittsam gepflegt wird als Reminiszenz an die Heimat, ein Gesellschaftstreffen, an dem selbstverständlich auch die Männer teilnehmen ${ }^{301}$.

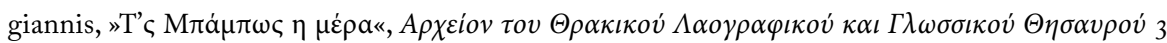

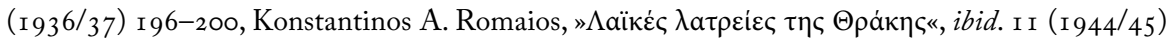

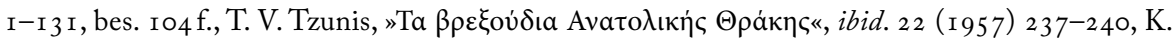

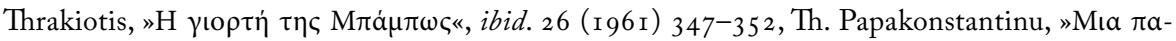

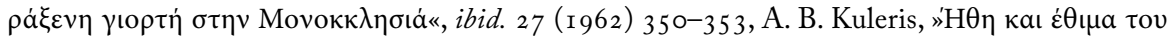

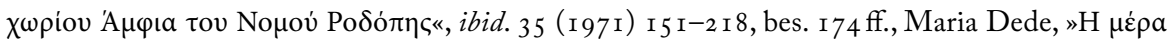

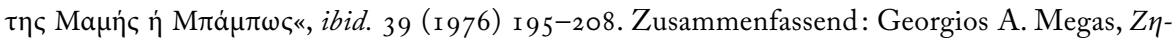

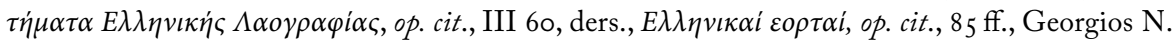

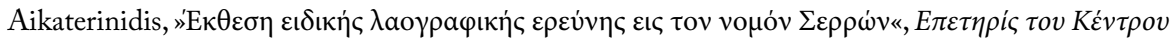

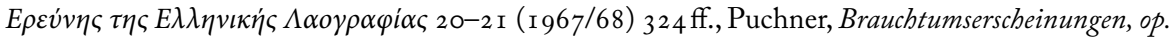

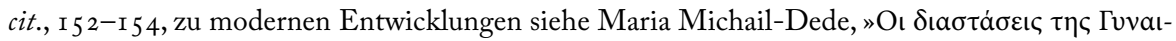

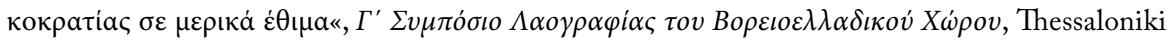

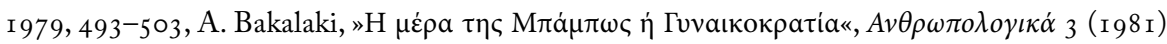

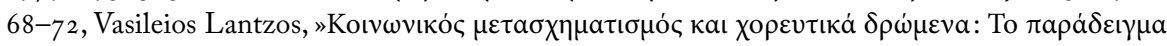

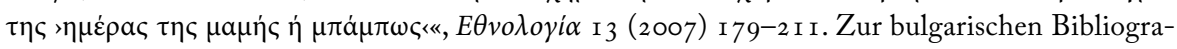
phie: G. K. Rakovski, Gorski Pătnik, Sofija I 857 (Odessa I 859) 2 (A. Tomov, »Gorski Pătnik i tradiciite na bălgarski folklor «, Bălgarski Folklor 2 ( I 976) Nr. 3-4, 42-5 I), N. I. Dancov, Bălgarskija Enciklopedija, Sofija 1936, 94, Christo Vakarelski, Bulgarische Volkskunde, Berlin I969, 3 I 9 , Mihai Arnaudov, "Babinden văv Velingradsko«, Văprosi na etnografijata i folkloristikata, Sofija I 980, 92-Ioo, Ifigeneia I. Anastasiadou, »Deux cérémonies de travestissement en Thrace: le jour de Babo et les Caloyeri«, L'Homme i6 (I 976) 89-ıог, Georg Kraev, "Za smešnosto v babindenskata obrednost «, Muzikalni horizonti I 981/I-2, I04-1 Io usw.

299 Zur Bibliographie über diese zahlenmäßig anwachsenden Manifestationen, die auch als Attraktion des lokalen Binnentourismus organisiert werden, vgl. Minas A. Alexiadis/Manolis Varvunis, A $\sigma \varepsilon-$ $\mu v \eta \varepsilon \lambda \lambda \eta v \iota \kappa \eta \dot{\lambda} \alpha \alpha o \gamma \rho \alpha \varphi i \alpha . A v \alpha \lambda v \tau \iota \kappa \eta \dot{~} \beta \iota \beta \lambda \iota 0 \gamma \rho \alpha \varphi i \alpha$, Athen 2013.

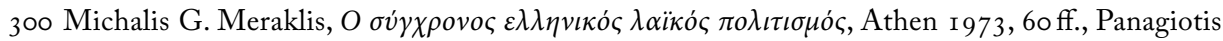

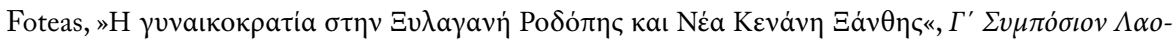

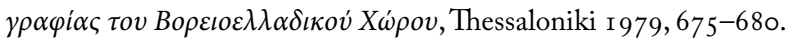

3ог $\mathrm{Zu}$ den modernen Entwicklungen in Griechisch-Makedonien und der bulgarischen Diaspora vgl.

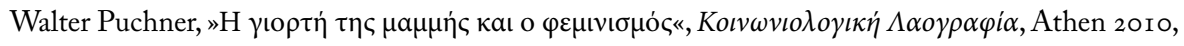
73-97, bes. $89-97$. 
Rudimentäre Maskengruppen. In der Folge der Entdeckung der komplexen thrakischen Karnevalsszene des kalogeros durch den englischen Archäologen Richard M. Dawkins $1906^{302}$ ging sein Kollege und Landsmann Alan J. B. Wace den rudimentäreren Formen der zentral- und südbalkanischen Mittwinterriten nach ${ }^{303}$ und konnte als Grundstruktur dieser Verkleidungstypen das Hochzeitspaar von Braut und Bräutigam, mit oder ohne Begleitung durch den theriomorphen »Araber«, der auch mit der Figur des Bräutigams zusammenfallen kann ${ }^{304}$, feststellen. Diese Dreieckskonstellation kann sich auch in undifferenziert Vermummte auflösen oder im Verband mit noch mehr Verkleidungstypen auftreten ${ }^{305}$. Seine Angaben betreffen die Südslaven, Aromunen, Arvaniten und Griechen, sowohl transhumante Hirtengruppen wie auch seßhafte Kommunitäten, und sind von spezifischer Signifikanz, als sie Maskierungsformen noch während der Türkenzeit in diesen Regionen festhalten. Nachfolgende Forschungen konnten für die zentral- und südbalkanischen Landschaften Thrakien, Makedonien und Thessalien die Grundstruktur der triadischen Verkleidungsgruppe Braut/Bräuti-

302 Richard M. Dawkins, »The modern Carnival in Thrace and the Cult of Dionysos «, Journal of Hellenic Studies 26 ( 1906) I 9 I-206. Zur bibliographischen Karriere dieser Brauchbeschreibung vg1. Walter Puchner, »Die thrakische Karnevalsszene und die Ursprungstheorie zum altgriechischen Drama. Ein Beitrag zur wissenschaftsgeschichtlichen Rezeptionsforschung«, Balkan Studies 24/I (Thessaloniki 1983) I07-I 22.

303 A. J. B. Wace, "North Greek Festivals and the Worship of Dionysos", The Annual of the British School in Athens 16 (1 909/10) 232-253, ders., "Mumming Plays in Southern Balkan«, The Annual of the British School in Athens 19 (1912/13) 248-250, A. J. B. Wace/M. S. Thompson, The Nomads of the Balkans, London I 9I 4. An Namensformen sind angeführt rugatsiari, arugutshari, ligutshari, ishk'nari, dzhamalari (Wace, "Mumming Plays«, op. cit., 250, 258 f., 26o-262).

304 Mit Araber bei den dzhamalari in L'umnitsa/Makedonien (Wace, »Mumming Plays«, op. cit., 262), ohne in Serfije/Makedonien, wo eine Spielgruppe aus sechs Bräutigamen und sechs Bräuten (verkleidete Burschen) den Bänder-Tanz des gaitani tanzten (ibid. 250 ). In Platanos/Thessalien gingen bei den Theophaniekalanda 5-6 Personen um, wovon zwei als Paar maskiert waren: die Braut (oft nur ein Kopftuch vor dem Gesicht und eine Frucht in Händen als Einladungszeichen zur Hochzeit), der Bräutigam in Fellen und mit Hörnern (wird als »Gehörnter« verspottet), oder in fustanella, mit rotem Fez, geschwärztem Gesicht, eine Glocke am Gürtel, ein altes Schwert in Händen, mit dem er Passanten bedroht und festnimmt, so daß sie sich freikaufen müssen (Wace, »North Greek Festivals«, op. cit., 236 f.).

305 Der erste Fall bei Burschen im Bezirk Veroia/Makedonien, die in Fellverkleidung, Gesichtsmasken aus Stoff mit Bart und Schnurrbart aus Ziegenhaar, an die Türen schlagend, Gaben fordernd und Passanten festnehmend zu Neujahr herumzogen (Wace, »Mumming Plays«, op. cit., 26of.), der zweite etwa bei den Aromunen im zentralen Pindus-Gebiet, wo sich Gruppen von I 5-20 Verkleideten bilden, die unter dem Instrumentenspiel eigens angestellter türkischer Zigeuner am Neujahrstag durchs Dorf ziehen; die Masken bestehen hier aus Hochzeitspaaren, türkischen Soldaten und zwei zdrugamani, Fellverkleideten mit umgehängten Glocken, die Passanten festnehmen und sie Lösegeld zahlen lassen, womit die Musikanten bezahlt werden (ibid., 258 f.). 
gam/Araber bestätigen ${ }^{306}$, allerdings läßt sich nun eine Kerngruppe und eine erweiterte Maskengruppe unterscheiden ${ }^{307}$ : Bei ersterer kann die Mannesrolle von Bräutigam und "Araber« in Aussehen und Funktion kontaminieren ${ }^{308}$ bzw. sich zu einer festlich gekleideten Gruppe multiplikativ vervielfältigen ${ }^{309}$, während die vor Zudringlichkeiten beschützte Braut unabdingbar ist ${ }^{310}$; bei zweiterer kommt der »europäisch « gekleidete

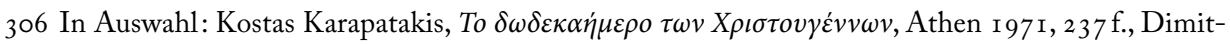

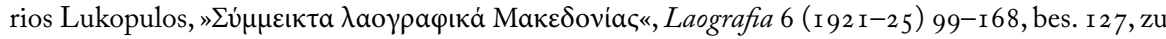

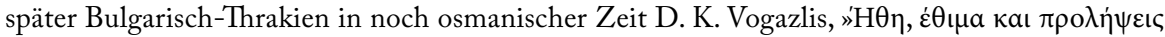

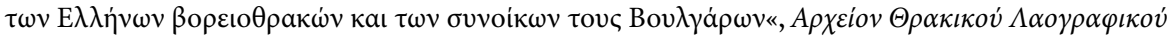

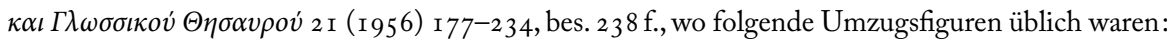
Braut-Bräutigam, der Teufel (Hörner, Schwanz, kleine Glocken, Stock oder Dreizack in Händen), der Arzt (hoher Hut, Mörser in der Hand), die moma (Dorfmädchen), der Aga, Ritter, Fustanellenträger u.a.

307 In Kornofolia etwa in Griechisch-Thrakien gingen am Weihnachtstag bis etwa 935 eine Braut und ein rußgeschwärzter Bräutigam (rugatsiarus) in die Häuser und am folgenden Tag Engel, Ma-

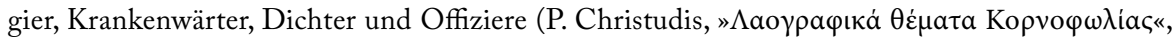

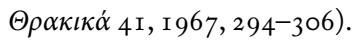

308 In Xirokampos/Thessalien hat der Araber die Glocken auf den Rücken gebunden, hält Messer und Stöcke in Händen; der Bräutigam unterscheidet sich in seiner Lumpenverkleidung nicht viel von ihm: Er trägt bloß noch eine Phallusandeutung. Die »Braut« in langem Kleid und mit Schürze küßt die Hände der jeweiligen Hausbewohner (Handschrift des Laografischen Seminars der Univ. Athen I375, 20I f.). In Pisoderi/Makedonien übernimmt der kapetanios (Anführer der rugatsaria) die Rolle des Bräutigams. Er rammt in jedem Haus seinen Dolch in die Zimmerdecke und fordert den Hausherrn auf, ihn zu reinigen. Dieser tut es mit einem Geldschein. Der Araber sammelt inzwischen Würste (Karapatakis, op. cit., 224 f.). In Paliokastro/Thessalien besteht eine Maskengruppe (4.-6. Jänner) aus dem Brautpaar und einem Araber, der über und über mit Glocken und Waffen behangen ist. Bei der Begegnung zweier Gruppen muß eine unter den gekreuzten Schwertern von Bräutigam und Araber durchmarschieren, sonst kommt es zum Kampf. Der Maskenumzug dient auch zur Kontaktaufnahme von Burschen und Mädchen (Laografia 4, I9 I3/I4, 3 I I f.). Zur Kontamination der Maskierung: z.B. in Anakasia/Thessalien: Der Araber trägt die fustanella, einen Fez mit Gesichtsmaske, in der rechten Hand ein Messer und große Glocken um die Taille gebunden (Laografisches Seminar, Hs I 253, 98). Die Maskierung dient hier auch dem NichtErkannt-Werden. Aufgabe des Bräutigams ist die Beschützung der Braut vor Anzüglichkeiten, was manchmal auch der Araber übernimmt: In Kalochi/Makedonien achtet ein Fellverkleideter (Ara-

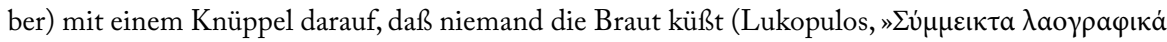

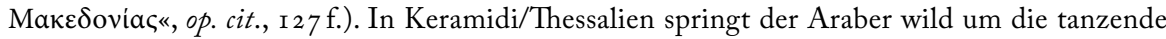

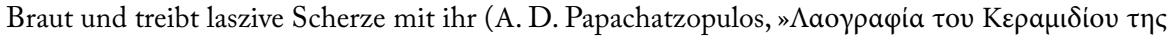

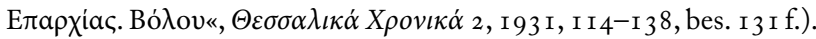

309 Auch die Bräute können sich vervielfältigen. In Domeniko/Nordthessalien verkleidet sich die Hälfte der Umzugsgruppe als Bräutigame (tsoliades), die andere als Bräute (dames) (Hs des Laografischen Archivs der Akademie Athen 1972, r6).

3 Io Sie fehlt eher selten. Einige Beispiele dazu: Im Gebiet südlich von Glykomilea/Thessalien ge- 
Arzt ${ }^{311}$ hinzu (erweckt die ohnmächtig gewordene Braut, mit der man auch laszive Späße treibt ${ }^{312}$, zum Leben) $)^{313}$, der Alte und die Alte ${ }^{314}$ und andere Figuren des Alltagslebens ${ }^{315}$; die Bräutigame erscheinen auch phallisch ${ }^{316}$, die Araber »bestrafen« im Falle

hen nur dämonisch Verkleidete von Haus zu Haus: in weiten Mänteln, mit umgehängten Glokken, Masken aus Tierköpfen, mit Schwertern und Pfluggeräten. Jeder Passant wird umringt und muß sich freikaufen (Karapatakis, op. cit., 233 ff.). Ähnlich treten auch die arapki im Bezirk Kavala/ Makedonien auf: in großen weiten Kleidern mit überlangen Ärmeln, in Schuhen bis zum Knie geschnürt, mit ausgestopftem Höcker, an dem eine Glocke hängt, drei an Brustriemen befestigte schwere Viehglocken, einer Kopfmaske aus Ziegenfell mit Augen- und Mundlöchern, über deren kapuzenförmiges Ende ein besticktes Tuch geschlagen wird, die Hände in dicken Wollhandschuhen, mit einem großen Holzschwert (Karapatakis, op. cit., 224f.). Dem Zug voran gehen zwei Fustanellenträger. In Nikisiani sind diese kapetane (in Ordnungsfunktion) in den letzten Jahren

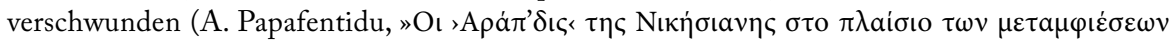

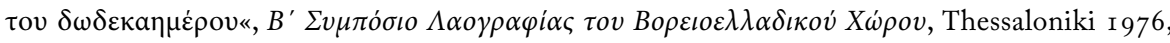
383-392).

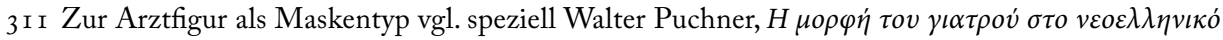
$\theta \varepsilon \dot{\alpha} \alpha \rho o$, Athen 2004, 49-67. Die Arztfigur des Heilmagiers, der selbst "Tote« zum Leben erweckt, ist als Verkleidungsfigur nicht nur im balkanischen Raum bekannt (V. Adăscăliței/L. Çireș, "'Mocănașii<, Datine-Spectacol«, Revista di Etnografia și Folclor I 5, 1970, 323-333), sondern auch im Schwarzmeergebiet bis in den Kaukasus (Robert Bleichsteiner, »Masken und Fastnachtsbräuche bei den Völkern des Kaukasus«, Österr. Zeitschrift für Volkskunde 55 /VI, I 952 , Kongreßheft, 3-76, bes. I 6 ff.).

3 2 Meist der Bräutigam oder der Araber. In Agiopigi begleiten die Kalandagruppe 4-5 Araber, ein Brautpaar, ein greises Paar, ein Arzt, ein Flöten- und ein Dudelsackspieler. Die Maskierten laufen voraus und schrecken die Kinder. Braut und Bräutigam ergehen sich in Anzüglichkeiten, die Braut küßt die Hände und sammelt Geld (Karapatakis, op. cit., 237 f.).

3 3 So begleitet in Almyros/Thessalien das Brautpaar eine bucklige Schwiegermutter, ein Araber mit

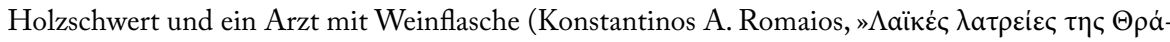

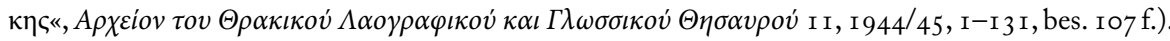

3 I 4 Niko Kuret, "Die Alten in den Maskenumzügen Südosteuropas«, Etnografski i folkloristični izsledovanija, FS Chr. Vakarelski, Sofija I 979, 2 I 5-225. Vgl. auch weiter oben.

31 5 Zur erweiterten Maskengruppe der liukantzaria in Agioi Theodoroi in Thessalien zählen etwa der Priester, der Gendarm, der Weinbergwächter, der Lehrer, die »Aschenfrau«, die mit einem Aschenbeutel zudringliche Kinder abwehrt u.a. In Lygaria/Thessalien kommt ein Tanzbär mit Bärenführer hinzu (Hs des Laografischen Seminars der Univ. Athen I 565, 96). In den Bergdörfern von Pieria/ Südmakedonien ein Hauptmann und ein Unterführer sowie handlesende Zigeunerinnen (Karapatakis, op. cit., $224 \mathrm{f}$.).

3 I6 So bei den Neujahrsumzügen im Raum Kalambaka/Thessalien. Hier trägt der Araber einen hölzernen Mörserstössel zwischen den Beinen, den er unter dem Gelächter der Zuschauer herumzeigt und sich damit auch der Braut nähert. Ein Arzt mit Heilkräutern und eine bucklige Alte (baba) sowie viele festlich Gekleidete bilden den Zug. Alle achten darauf, daß sich niemand dem Brautpaar nähert (Karapatakis, op. cit., 224 f.). 
des Brautraubs die Entführer aus dem Publikum ${ }^{317}$; oft entspinnt sich auch ein Zweikampf zwischen »Araber« und Bräutigam um die Braut, wobei einer der beiden »getötet« wird $^{318}$, die Braut beweint ihn und der Arzt erweckt ihn wieder zum Leben mit einer komischen Untersuchung und Therapie ${ }^{319}$; ein Priester nimmt eine Hochzeitsparodie vor ${ }^{320}$, ein Zigeuner mit Tanzbär und andere Masken komplettieren das Bild. Die Interaktionen zwischen den einzelnen Maskentypen bleiben jedoch rudimentär, und die Maskengruppe ist meist eingebettet in einen Umzug von festlich gekleideten Burschen und Männern, die in der Zwölftenperiode vor den Häusern Ansingelieder vortragen und tanzen. Die Ausschließlichkeit des Maskenprivilegs führt beim Aufeinandertreffen von zwei Gruppen manchmal zu bewaffneten Auseinandersetzungen ${ }^{321}$.

Ein Augenzeugenbericht aus dem Raum Siatista in Griechisch-Makedonien aus der Türkenzeit berichtet folgendes: »Bei uns am Hl. Basileios-Tag [Neujahr] gehen die $r u-$ gatsiaria in den Dörfern um. Mich machten sie zur Braut, daran erinnere ich mich, als ob es heute wäre. Ich war I 5 Jahre alt und sie zogen mich als Frau an. Es gab auch einen Bräutigam mit einem Schaffell im Gesicht und zwei Löchern für seine Augen. Und

3I7 Solche Entführungsspiele und Scheinhochzeiten scheinen der Karnevalsszene »entnommen« zu sein. Eine scharfe Grenze zwischen Brauchinhalten und Begehungsterminen wird sich hier nicht ziehen lassen. So gehen bei den Neujahrsumzügen in Iliolusto in Makedonien ein greises Paar mit Kleinkind, ein Arzt mit Arzneien, zwei »Mädchen« und einige Beschützer (tospagades) mit leinenumwundenen Knüppeln um. Die »Mädchen« lassen sich von männlichen Zuschauern entführen. Die Beschützer machen den Wüstling ausfindig und erlegen ihm eine Geldstrafe auf. Will dieser

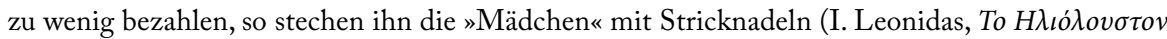

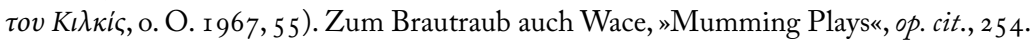

3 I 8 »The play is begun by the Arab, who approaches the bride and attempts some familiarity, such as stealing a kiss. This is naturally resented by the bridegroom, and a lively quarrel ensues, which ends in the Arab killing the bridegroom. The bride in despair flings herself on the body and gives way to violent weeping. Then, remembering the doctor, she hurries off and fetches him to cure her husband. The doctor assumes a professional air, feels the pulse, etc., of the bridegroom, thumps him, and drusts some drug such as a piece of soap into his mouth, or indulges in other horseplay at his expense. This has a miraculous effect, the bridegroom comes to life again, jumps up, and dances with the other actors. The play usually ends with an obscene pantomime between the bride and the bridegroom " (Wace, North Greek Festivals, op. cit., 233 f. für Kokkotoi in Thessalien). In Keramidi im gleichen Raum wurde (um I 900) bei diesen Scheinkämpfen regelmäßig versehentlich die Braut "getötet«. Der Arzt nahm sich der am Boden ausgestreckt Liegenden in sehr ernsthafter Weise an: Er steckte ihr ein Kraut in den Mund, wodurch sie sich wiederbelebte und den nachfolgenden Maskentanz anführte (Papachatzopulos, op. cit., I 3 I f.).

3 I 9 Wace, »Mumming Plays«, op. cit., $255 \mathrm{f}$.

320 Vgl. in der Folge.

2 I Vgl. das Fallmaterial in Puchner, Brauchtumserscheinungen, op. cit., 2 IO-2 I 4 (mit Detailbibliographie). 
oben hing ein Fuchsschwanz als Quaste. In der rechten Hand hielt er die tziumanika. Die tziumanika war ein kurzes Holz, eine Elle lang, ganz schön, und vorne hatte es so etwas wie einen Kopf mit runden Häutchen, rot, grün, schwarz, mit Nägeln befestigt. Der rugatsiaris hatte, Entschuldigung, zwischen seinen Schenkeln zwei Zwiebeln und ein Holzstück in Lumpen, wie ein echter (-Penis-), und mit der tziumanika erregte er ihn. Er war auch voll kleiner und großer Glocken, so daß der Ort nur so dröhnte. Ich, als Braut, hielt den Apfel und warf dem Hausherrn das Tuch zu, wenn wir tanzten, denn außer der Braut und dem Bräutigam waren da noch viele andere. Wenn wir in ein Haus gingen, begann der rugatsiaris das Feuer aufzuschüren und sagte: ich bringe Lämmer, ich bringe Zicklein, ich bringe Einkünfte. Gingen wir zu einer unfruchtbaren Frau, dann, erinnere ich mich, gab der rugatsiaris der Frau seine tziumanika zu küssen « ${ }^{322}$.

Als Bräutigam der Maskengruppe, deren Teilnehmer manchmal direkt den Namen der Zwölftendämonen, kalikantzaroi, tragen ${ }^{323}$, wird im allgemeinen der Stärkste der Gruppe ausgewählt, als Braut der Hübscheste ${ }^{324}$. Manchmal ist die Aufstellung der dämonischen Masken und der Festverkleideten fast choreographisch kunstvoll plaziert, so daß sich der Umzug einem rudimentären Stationendrama in prozessionaler Aufführung nähert, das bei seinen Aufenthalten vor und in den Häusern immer wieder die gleiche Szene repetiert ${ }^{325}$. Die Interaktionen der einzelnen Maskentypen bleiben jedoch insta-

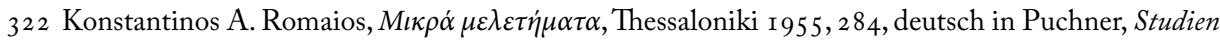
zur Volkskunde Südosteuropas, op. cit., I $32 \mathrm{f}$.

323 Andere Bezeichnungen sind karakantzalia, kal'katzar, rogatsia, rugatsiaria, rukantzaria, baboerides, babaiurdes, survari, lagatsiaraioi, futadis, kapetanareoi, džamalari, ligučari, koledari, vasiličari, eškari, zvongari, arapkoi, kalindrades, karnavalia usw. (Puchner, Brauchtumserscheinungen, op. cit., 2 I0-2 I 4).

324 Hs des Laografischen Archivs der Akademie Athen 2 I 54 A, I 93 f. In der Stadt Karditsa (Thessalien) bildeten sich etwa um I960 Umzugsgruppen, bestehend aus einem Bräutigam in fustanella oder schwarzem Wollstoff, einer Braut im Hochzeitskleid, Schwiegerleuten, einem Priester mit Kutte, einem Arzt mit Zylinderhut, schwarzem Anzug, Brillen und Arzneitasche in der Hand, der auf einem Esel verkehrt ritt, und einem Hodscha mit Fez. Alle trugen Masken aus Schaffell und Pelzüberwürfe. Allgemein besteht der Glaube, mit diesen Maskierungen die kalikantzaroi zu erschrecken; man schreckt aber vor allem die kleinen Kinder. An jeder Wegkreuzung tanzt das Brautpaar; es folgen improvisierte »Szenen«: Die Braut fällt in Ohnmacht; der Arzt hilft ihr. Zu diesem Zweck müssen die Maskierten in ein Haus eintreten, wo sie große Unordnung anrichten; hier werden den Bewohnern auch die panegyrischen Loblieder gesungen. Es tanzt auch die Bärin (ein Mann in Felle gekleidet mit einer großen Glocke um den Hals) an einer Kette; sie wiegt sich im Rhythmus, während der Bärenführer auf einen Blechkübel schlägt und dazu singt. Zur Vermeidung von Zusammenstößen der Gruppen wird die Stadt in Umzugsdistrikte unterteilt (Hs des Laografischen Seminars der Univ. Athen I4I4, o. S.).

325 Im Raum Almyros in Thessalien bilden um I 900 Burschen im Alter von 20-25 Jahren zwei Gruppen: die Vermummten und die Tänzer. Die Verkleideten bestanden aus Braut (ein unverheirateter Bursch in der reichsten Kleidung des Dorfes), Bräutigam (ein unverheirateter Bursch in wechseln- 
bil und gehen über kurzfristige andeutungsweise Kontaktaufnahmen nicht hinaus, und von einer Rollenbeziehung bzw. verbalem Dialog oder »Handlung« kann nur in übertragenem Sinne gesprochen werden.

Ein anderes Beispiel aus dem nördlichen Balkanraum, wo öfter auch holzgeschnitzte Masken zur Anwendung kommen, ist der Busó-Maskenzug im ungarischen Mohács mit seinen eindrucksvollen und ausdrucksstarken Holzmasken, eine Ausnahmeerscheinung im sonst eher holzmaskenarmen magyarischen Kommunikationsraum ${ }^{326}$. Der Faschingsumzug, bei dem die jankele mit Aschen(Mehl-)säcken auf lästige Zuschauer einschlagen, war usprünglich ein Sammelumzug von Haus zu Haus: Man schlug mit Streitkolben an die Tür, machte Krach über den ganzen Hof (mit Bao-Bao-Rufen), bei Einlaßverweigerung wurde der Hof umgepflügt, im Stall Asche gestreut usw.; die Maskierten wurden im Haus bewirtet, gingen gruppenweise auf den Hauptplatz und tanzten den kolo. In der Zwischenkriegszeit wurde der Maskenzug vom Regime folklorisiert, die Obszönitäten bereinigt und eine Preiskrönung der besten Maske eingeführt ${ }^{327}$. Eine historische Quelle von I 783 spricht bloß von Kleidertausch ${ }^{328}$, erst I 845 sind die grell bemalten Holzmasken mit der furchterregenden Visage (larva), den herausstehenden Zähnen und der angenagelten Lammfellkapuze (kapa) zum erstenmal erwähnt, als Riesenmasken hergestellt von eigenen Holzschnitzern; die Aktionen beschränken sich auf den mit verschiedenen Geräten, Kuhglocken, Keulen, Hörnern usw. verursachten Höllenlärm, Herumspringen und Wälzen im Schlamm, die Interaktion der Verkleideten

der Kleidung, ein Holzmesser zur Verteidigung der Braut tragend), Schwiegermutter (ein verheirateter Mann; alt, komisch; fehlt manchmal), Araber (in weißem Kleid, Fez, Ledergürtel mit Glokken behangen, als Beschützer des Brautpaars) und Arzt (europäisch gekleidet, eine Weinflasche als Arznei). Die Tänzer bildeten zwei Halbchöre zu je Io-I 5 Mann, die einander in zwei Riegen gegenüberstanden. Dazwischen tanzten die Verkleideten in anzüglicher Weise. Die Braut wurde ohnmächtig, der Arzt sprang herzu und nahm eine groteske Untersuchung vor. Er gab der Braut Arznei aus der Weinflasche und sie kam langsam zu sich. Es folgte ein neuer obszöner Tanz mit

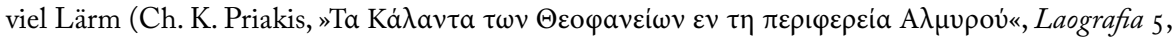
I9I 5/I6, 225-232).

326 Jozsef Csalog, Busójárás, a mohácsi sokácok ünnepe, Pécs I 949, Jószef Ernyey, »A busójárás és más farsangi játétok«, Néprajzi Értesitö I 907, Lászlo Földes, »A néprajzi museum Busomaszkjai«, Néprajzi Értesitö 1 958, Lászlo Mándoki, »Busómaszkok«, A Janus Pannonius Muzeum Évkönyvem, Pécs I 96 I, ders., Busójárás Monácson, Pécs I 963, Nora A. Tahy, Das theatralische Brauchtum des ungarischen Sprachbereichs, Frankfurt/M. etc. 1989, 28 I-300.

327 Die Umzugsstruktur ist heute noch in einem parallel durchgeführten Heischegang der Kindern (Schwundstufe) greifbar; der Maskenzug ist mehrfach verfilmt worden, hat die Maskenmoden der urbanen Karnevalszüge beeinflußt und wird in rezenten Jahren von Schülern als touristische Attraktion durchgeführt.

328 Frauen in Männerkleidung sind auch am Rande der Darbietungen nachgewiesen. Die Verkleideten waren Männer in zeugungsfähigem Alter. 
mit dem Publikum auf das Kneifen und Belästigen von Frauen und Mädchen ${ }^{329}$, das Schlagen mit dem aschengefüllten Sack und die Interaktion zwischen den Verkleideten in Ringkämpfen. Derartige lärmende, störende und obszöne Maskenumzüge ${ }^{330}$ sind im gesamten Balkanraum verbreitet ${ }^{331}$.

329 In manchen Quellen ist davon die Rede, daß die Frauen von den Verkleideten auf der Straße abgetastet wurden, ihr Geschlecht sei festgestellt worden und man habe an den Schamhaaren gezupft, damit der Mais wachse (Tahy, op. cit., 287). Solchen Angaben aus älteren Quellen ist im allgemeinen mit einer gewissen Vorsicht zu begegnen, ebenso wie den Feuertänzern nestinari/anastenaria

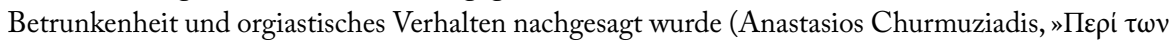

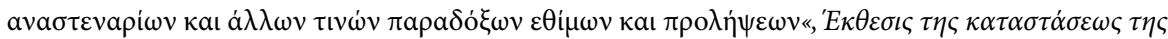

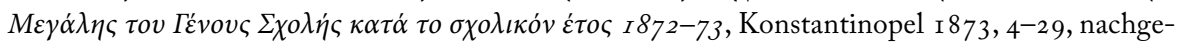

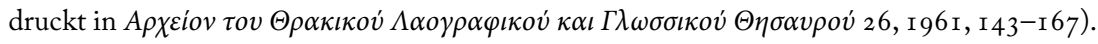

330 Als ätiologischer Sekundärmythos wird angeführt, daß mit diesen Schreckmasken die Türken vertrieben worden seien. Neben den Masken haben die Verkleideten auch phallische Puppen mit überdimensionalem beweglichem Penis auf den Rücken gebunden. Die Einmaligkeit des Maskenzugs von Mohács an der Südgrenze Ungarns dürfte auf die slavophonen Schokatzen (Šokci, Sokácok) zurückgehen, die den Großteil der Bevölkerung dieses Raums ausmachen. Deshalb ist der Maskenumzug von Mohács auch in einschlägigen kroatischen Darstellungen zu finden (Ivan Lozica, Hrvatski karnevali, Zagreb I 997, 66-7 I , Zdenka Lechner, »Buše - pokladni običaj baranjskih Hrvata", Etnološki prilozi I, I978, I 59-174, Katica Benc Bošković, Pokladne maske iz zbirki Etnografskog muzeja u Zagrebu i muzeja u Mohaču, Mohács/Zagreb 1973; vgl. auch S. Velin, »Obnovljeni pokladnii običaji Šokaca u Santovu«, Etnografija Južnih Slovena u Mađarskoj, Budimpešta 1 982, 2 1 5-237). Eindrucksvolle Abbildungen dieser Masken in Péter Korniss, Bräutigam des Himmels. Bilder ungarischer Volksbräuche, Budapest 1975 (o. S., Abschnitt »Buscho<-Aufzüge«).

33 I Zu Mittwinterverkleidungen vgl. in Auswahl: Ivan Milčetić, Koleda u južnih slavena, Zagreb I 917, S. Trojanović, »Maske kod našega naroda«, Bulićev Zbornik, Zagreb/Split I 924, 695-699, Mile Nedeljković, Godišnji običaji kod Srba, Beograd I 99o, Mila Bosić, Godišnji običaji kod Srba i Vojvodini, Novi Sad I 995, Georg Kraev, »Obredno i dramatično dejstvo«, Maska i ritual, Sofija I 999, Io I-I I3, Valentin Angelov, »Obrednata maska«, Bălgarskija etnografija 3-4 ( 1 994) 28-34, Katia Atanasova, „Obreda rolja i značenieto na trapezata v kolednite praznici na bălgarii i rumănci«, Etnografski problemi na narodnata duhovna kultura, Bd. 3, Sofija I 994, 48-79, Mila Bosić, Božićni običaji srba u Vojvodini, Beograd I985, Vladimir Bocev, »Maskiranjeto i običaite pod maski vo Makedonija«, Etnolog 3 (Skopje I 993) I I4-I 24, Marin Mladenov, »Koleda< i ’koledari< u dimitrovgradskom (caribrodskom) kraju«, Etno-kulturološki zbornik 2 (Svrljig I996) 86-88, P. Kostić, »Godišnji običaji, Cjeničko-pešterska visoravan «, Glasnik etnografkog muzeja 52-53 (1988-89) 73-I 23, Romulus Vulcănescu, "Ritual Masks in European Cultures«, Mircea Eliade (ed.), The Encyclopedia of Religion, vol. 7-8, New York/London 1993, 270-276, Wace, »North Greek Festivals«, op. cit., ders., "Mumming Plays«, op. cit., 250, 258 f., 260-262, Michael Arnaudoff, Die bulgarischen Festbräuche, Leipzig I $917,7-9,23^{-25}$, Vakarelski, Bulgarische Volkskunde, op. cit., 380-382, Kostas Karapatakis,

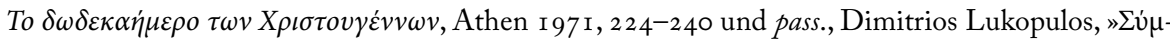

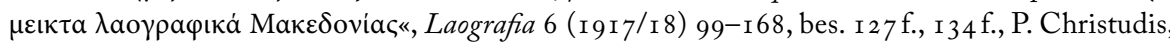

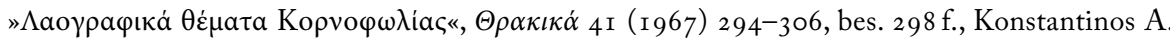

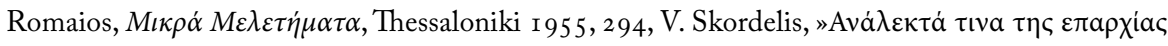


Komplexere Gruppen. War die rudimentäre Maskengruppe in die koleda/kalanda-Umzüge der Zwölftenperiode integriert, so bringen die Maskenzüge der Karnevalsperiode Differenzierungen der Maskentypen, ohne jedoch in der Prozessionsform zwangsläufig Formen dichterer Interaktion zu entwickeln ${ }^{332}$. Typologisch ist auch der urbane, westlich beeinflußte Karneval mit seiner Nummernstruktur, den Wagenumzügen, der individuellen Ausgestaltung und den Preisverleihungen zu unterscheiden von den agraren Faschingsmanifestationen im Dorfmilieu mit den eher feststehenden Maskentypen, deren rituell fruchtbarkeitsmagischer Glaubenshintergrund noch nicht zur Gänze verschwunden ist. Aber auch hier läßt das Nebeneinander der einzelnen Maskengestalten noch kein explizit interaktives Rollengeflecht erkennen, auch wenn dies z.T. der Detailliertheit bzw. Pauschalität der Quellenangaben anzulasten sein mag.

Zum südosteuropäischen Karneval existiert eine Fülle von Fallmaterial, Einzelbeschreibungen, regionalen und nationalen Übersichten sowie reichhaltige Sekundärliteratur unterschiedlicher Güte, von der hier nur ein kleiner Teil angeführt werden kann ${ }^{333}$.

$\Phi \iota \lambda \iota \pi \pi$ เ

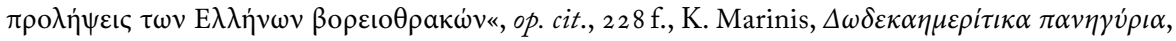

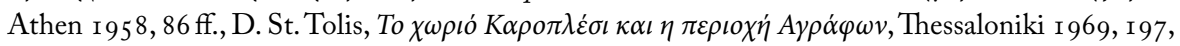
Puchner, Brauchtumserscheinungen, op. cit., 2 IO-2 I 4 usw.

$332 \mathrm{Zu}$ Typologie und Morphologie allgemein Dieter Richter, Verkehrte Welt«, Enzyklopädie des Märchens I 4 (20 I I) 53-59, Susanne Friede, »Verkleidung«, ibid. 59-66 mit ausführlicher Bibliographie.

Vgl. auch Richard Weihe, Die Paradoxie der Maske. Die Geschichte einer Form, München 2004.

333 Slobodan Zečević, »Fašanke u Banatu«, Rad XX Saveza folklorista Jugoslavije, Novi Sad 1977, Beograd I 978, 443-446, ders., Sprske narodne igre, Beograd I983, Tatomir Vukanović, Srbi na Kosovu, Vranje 1986, Dragoslav Antonijević, „Vizantijske brumalije i savremene maskirane, povorke balkanskih stočara«, Balcanica 8 (I 979) 93-I29, Georg Kraev, Bălgarski maskaradni igri, Sofija 1996, Marjanović, Maske, op. cit., I Io-I63, dies., »Pokladni običaji u Banatu i istočnoj Srbiji«, Etnokulturološki zbornik I I (Svrljig I996) 95-ıо , S. Dimitrijević, »Običaji o praznicima preko godine, Banatske Here«, Posebna izlanja, Vojvoćanski myzej, Novi Sad I 958, 296-3 I 3, bes. 303, M. Škarić, "Život i običaji >Planinaca pod Fruškom gorom«, Srpski etnografski zbornik 24 (1939) I-275, bes. 92, Oto Bihalji-Merin, Maska, ritual i pozorište, Beograd ı 970, H. G. Bogdani, »Valle në festat kalendarike të ripërtëritjes së natyrës«, Kultura Popullore I-2 (Tirana I994) I 59-I67, Aleš Gaćnik, Moć tradicije, Kurentovanje in karneval na Ptuju, Ptuj 2000, M. Prošić-Dvornić, »Pokladni ritual na trimeru šumadijske variante pogladnih igara", Folklorni teatar u balkanskim h podunavskim zemljama, Beograd I 984, I 43-I 58 , L. Stojanović, "Dramski elementi u pokladnim običajima Slavonije i Baranje«, Osiječki zbornik I 8-I 9 ( I 987) 245-258, S. Tansung, "Jeux populaires masqués de villages Turcs«, Le Masque dans la Tradition Européenne, Catalogue, Binche 1975, 30 I-3 Io, Ede Solymos,

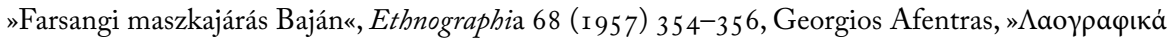

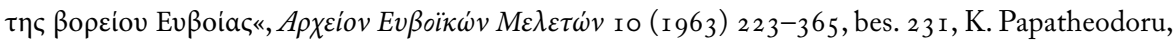

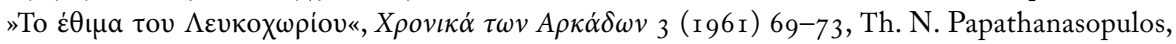

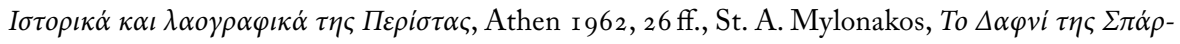

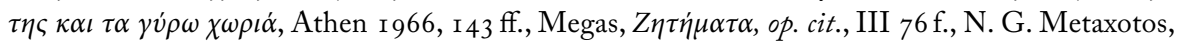


Methodologische Überlegungen sind eher selten ${ }^{334}$, ebenso wie vergleichende Ansätze ${ }^{335}$. Neben Stadt und Land ist auch der traditionelle Karneval von modernen, typisierten oder individuellen Verkleidungsformen zu unterscheiden, wie der Kinderkarneval, maškarada, mačkare, masken-bal, der Kostümball ${ }^{336}$, von Verkleidungen bei Massendemonstrationen und Studentenprotesten, die durchaus karnevaleske Züge haben können ${ }^{337}$, von Folklori-

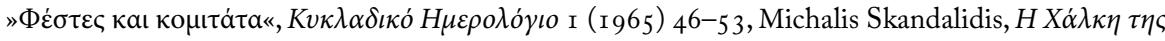

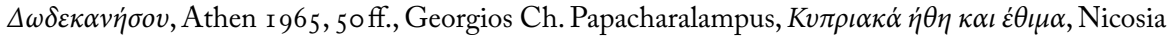
I 965, I 79 f., Puchner, Brauchtumserscheinungen, op. cit., 2 I 4-224, usw.

334 Vgl. wie oben. Z. B. Jane Cowan, »Folk Truth: When a Scholar comes to carnival in straditional community«,Journal of Modern Greek Studies 6 (I 988) 245-260, Fred Gearing, »Preliminary Notes on Ritual in Village Greece«, John G. Peristiany (ed.), Contributions to Mediterranean Sociology (Mediterranean Rural Communities and Social Change). Proceedings of the Mediterranean and Sociological Conference, Athens, July 1963, Paris/The Hague/Athens I 968, 65-72, Marjanović, Maske, op. cit., I I ff., 33-49, zur Semiotik 30 I ff. (vgl. auch Senka Kovač, Maska kao znak, Beograd I 996).

335 Dragoslav Antonijević, »Igre pod maskami u svetlu komparacije i kontinuiteta«, Glasnik Etnografskog muzeju u Beogradu 54-55 (1991) I65-I78, ders., "Some theatrical elements in carnival rites of the Balkan people«, Balcanica I6-I7 (1985-86) I 59-166, ders., Dromena, Beograd I997, Rossitsa Anguélova-Georguéva, "La culture théâtrale folklorique chez les Slaves du sud à travers leurs coutumes et leurs jeux d'hiver en travestis et avec masques«, Makedonski Folklor I 5-I6 (I975) 353-36I, Milena Benovska-Săbkova, „Bălgarskata maskaradna obrednost v konteksta na evropejskata tradicija«, Bălgarskija etnografija 3-4 (1994) 3-I5. Komparationen mit dem antiken Festkalender sind eher seltener geworden. Vgl. neuerdings Evy Johanne Håland, „From Modern Greek Carnivals to the Masks of Dionysos and Other Divinities in Ancient Greece «, Narodna Umjetnost 49/I (201 2) I I 3-I30, dies., Greske Fester, Moderne of Antikke. En Sammenlignende Undersøkelse av Kvinnelige og Mannlige Verdier, Kristiansand 2007 (Greek Festivals, Modern and Ancient. A Comparison of Femals and Male Values), dies., "Greek Women, Power and the Body. From Fieldwork on Cults Connected with the Femals Sphere Towards a Deconstruction of Male Ideologies, Modern and Ancient«, $M e-$ diterranean Review 3/I (2010) 3 I-57, dies., Konkurrerende ideologier i gresk religion for of nå, Bodø 2012 (Competing Ideologies in Greek Religion, Ancient and Modern). Vgl. auch Studien zu thrakischen Maskierungeformen, die auf den Dionysoskult rekurrieren sollen, z.B. Stojan Rajčevski, "Proučavanija vărhu kulta na Dionis v tradicionnite običai maskirani izpălniteli ot Trakija«, Bălgarski Folklor 2 (1 993) 68-73.

336 M. Ilijin/O. Mladenović, "Narodne igre okolini Beograda«, Zbornik radova Etnografskog instituta SANU 4 (I 962) I 72-I 78, M. Ivanović, »Poklade u okolinu Beograda", Etno-kulturološki zbornik I I (Svrljig I 996) Iо2-г Iо, Lozica, Hrvatski karnevali, I 92 f., Marjanović, Maske, op. cit., I 5 of., dies., "Pokladni ritual u Sremu na trimeru sela: Golubinci u Novi Slankamen«, Rad vojvoćanskih muzeja 30 (Novi Sad I 986/87) I73-I8 I. Zu einschlägigen Kinderveranstaltungen auch Maja BoškovićStulli, »O folklorizmu«, Zbornik za narodni život i običaje Južnih Slavena 45 (I 986) 3 I-57.

337 Marjanović, Maske, op. cit., 2 I 3-244, 245-297 mit rezentem Abbildungsmaterial. Vgl. auch L. David, »Teatralizacija studentskog protesta ili o odumiranju pozorišta «, Zbornik radova studenata etnologije i antropologije Filozofskog fakulteta u Beogradu 1997, 75-85. Besonders interessant auch N. Pavković/S. Haumović, »Fașancu la Grebenaț: Folklorizam simboličke strategije i etnički identitet 
sierungen bei den regionalen Folklore-Festival ${ }^{338}$. Nicht alle Publikationen berücksichtigen auch diese modernen Formen der Verkleidung ${ }^{339}$. Als Beispiel eines traditionellen urbanen Karnevals mit trionfiartigen Wagenumzügen mit allegorischen und satirischen tableaux vivants, freien Kostümierungen oft mit sozialkritischer und aktuell-politischer Note, sei ein Ausschnitt aus der literarischen Beschreibung des Athener Karnevals um

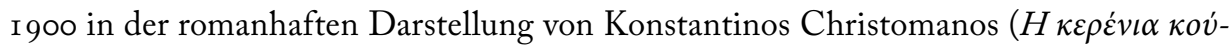
$\kappa \lambda \alpha$, I 909) wiedergegeben:

»Das war ein Leben und Treiben da unten! In dichte Staubwolken gehüllt, fuhren langsam die Landauer vorüber, einer hinter dem anderen, besetzt mit roten, gelben und schwarzen Dominos mit blauen Spitzen, weißen Handschuhen und grünen Bändern, die ihnen vom Rücken herabhingen. Ein ohrenbetäubender Lärm. Ein Regen von Papierschlangen, Konfetti und Blumen, dazwischen das Geschrei der Straßenverkäufer und das Rasseln der Knarren [...]. In endloser Reihe fuhren die geschmückten Wagen vorbei: olympische Götter, Ritter, clowneske Gestalten, die das politische Leben persiflieren sollten, Clowns, Zwerge und Riesen. Ein allgemeines Aaa! durchbrauste die Luft, als der Wagen des Eros erschien. Der kleine beflügelte Liebesgott mit dem Köcher hatte als Zügel bunte Bänder in der Hand, an denen Tauben festgebunden waren [...]. Dann kamen wieder andere Wagen mit halbnackten, in Laken gehüllte Menschen, ein Monstrum mit drei langen Nasen und einem Bein auf dem Rücken « ${ }^{340}$.

Maskentragen war in allen venezianischen Besitzungen, vom dalmatinischen Küstenstreifen bis nach Kreta, üblich; auf Zante im i 8. Jh. konnten die maskierten Frauen (bauta) sogar auf der Straße ungestraft die Männer belästigen, Kreta (bis r 669) war bekannt für seine Orangenschlachten ${ }^{341}$. Öffentliches Maskentragen war zur Faschings-

rumunske nacionalne manjine u Banatu«, Popožaj manjina Saveznoj Republici Jugoslaviji, Beograd 1 996, 697-708, bes. 699-70 I, wo der Umzug zum Nationalsymbol der rumänischen Minderheit geworden ist, an dem auch Frauen teilnehmen; ähnlich auch in Ungarn mit dem cigánybál: E. Király, »Pokladno veseljke kod Mađara u Vojlovici«, Rad IX kongresa Saveza folklorista Jugoslavije, Sarajevo I963, 383-391.

338 Z.B. I. Bokova, »Festivalăm - tradicija i săvremenost«, Maska i ritual, Sofija I 999, I I 7-I 3 I, Vesna Marjanović, »Folklor i folklorizam u pokladnim običajima na primeru Hrvata u Sremu i Rumuna u Banatu«, Folklor u Vojvodini 4 (Novi Sad I990) 8 I-89, Joan Sheffler, »Mask Rituals of Bulgaria: The Pernik Festival, r 980 «, K. K. Shangriladze/E. W. Townsend (eds.), Papers for the V. Congress of Southeast European Studies, Belgrade, September 1984, Columbus, Ohio I 984, 338-36 I.

339 Vorbildlich z.B. Ivan Lozica, Hrvatski karnevali, Zagreb I997, auch Marjanović, Maske, op. cit.

340 Konstantinos Christomanos, Die Wachspuppe. Deutsch von Fr. Steinmetz, Hamburg 1 929, 24-26.

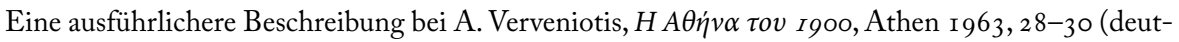
sche Übersetzung bei Puchner, Brauchtumserscheinungen, op. cit., I 90 f.)

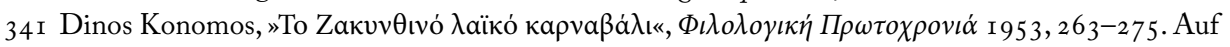
Kefalonia begann das Maskentragen gleich nach dem Theophanie-Tag und währte bis zum »Rei- 
zeit sogar im türkenzeitlichen Ioannina üblich ${ }^{342}$. Beim größten und bekanntesten Karneval in den Mediterranzonen der Balkanhalbinsel, in Patras, hatte der vor ca. I 50.000 Zusschauern paradierende Wagenzug schon i 96 I zwei Kilometer Länge ${ }^{343}$.

Die Namensformen der Maskierten und des Umzugs sind z.T. sprachübergreifend: skylareoi, kiopek-bey ${ }^{344}$, bules, barbutes, m'tsunes, mutsunarides, kamu(d)zelles ${ }^{345}$, prosopades $^{346}$, karnavalia, kukeri, kukuti, chuchuti ${ }^{347}$, džamalari ${ }^{348}$, bey, rogatsiaria ${ }^{349}$, kalindrades, kudunates, zvongari, eškari, arapi usw. ${ }^{350}$ und eine ganze Namensreihe, die von geroi (starci, didi, Alte) und babo ihren Ausgang nimmt: kalogeroi, momogeroi, kukugeroi, babugeroi, babušari, babajurdes, bubucheria usw. ${ }^{351}$; vgl. weiters cigani, komendijaši, komendije (Raum Kragujevac), maskirani, mačkare (in Rilji, in der Batschka), bele babe,

nen Montag«(Faschingsende); I 840 wurde von den britischen Behörden eine Verordnung erlassen,

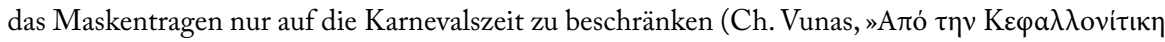

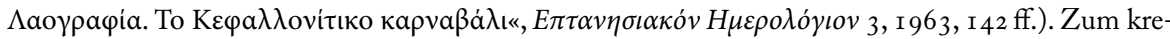
tischen Karneval in der ersten Hälfte des I7. Jh.s vgl. die im venezianischen Dialekt geschriebenen Memoiren von Zuanne Papadopoli (Memoirs of seventeenth-century Crete: L'occio (Time of Leisure) by Zuanne Papadopoli, edited with an English Translation, Introduction, Commentary and Glossary by Alfred Vincent, Venice 2007).

342 Die Maskenparade fand im Stadtzentrum statt, mehrere Männer in anatolischen Trachten tanzten,

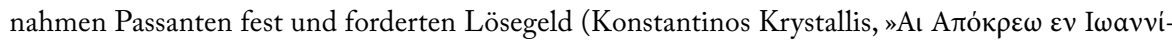

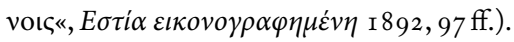

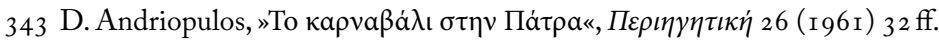

344 Zum Zusammenhang mit den »Hündischen«, dem Hunde-Bey (köpek-bey) und dem Masken- und

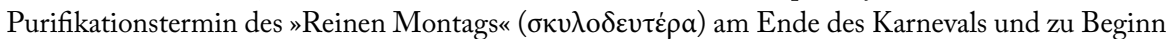

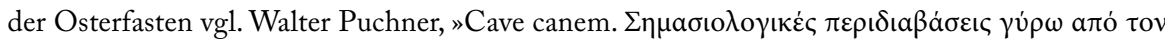

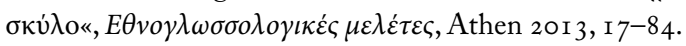

345 Dies vor allem im Inselraum. Zur Etymologie Puchner, Brauchtumserscheinungen, op. cit., $259 \mathrm{f}$.

346 Bei den Sarakatsanen (Hatzimichali, $\Sigma \alpha \rho \kappa \alpha \tau \sigma \alpha \dot{v} v o$, op. cit., $\rho v \varsigma^{\prime}$ f.).

347 G. Kazarow, "Karnevalsbräuche in Bulgarien«, Archiv für Religionswissenschaft I I (I g08) 407-409,

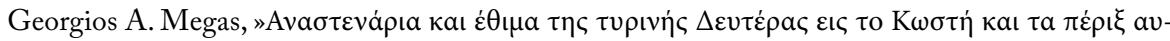

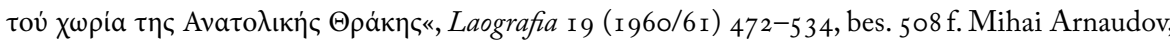
Folklore bulgare (La Bulgarie devant le IVe Congrès des Géographes et Ethnographes Slaves), Sofia 1936, I6I-I65 (»Les >Koukeri< de Thrace. Les jeux >nestenari«), Arnaudoff, Die bulgarischen Festbräuche,

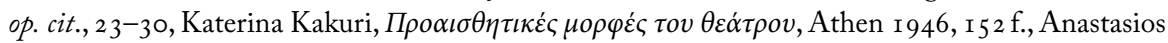

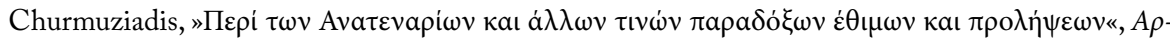

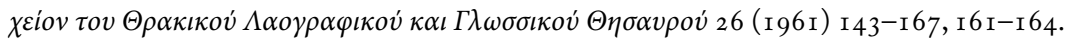

348 Vgl. wie oben.

349 Vgl. Puchner, »Die Rogatsiengesellschaften<, Studien zur Volkskunde Südosteuropas, op. cit., I 39-I 45 zu Namensmorphologie und Etymologievorschlägen.

350 Vakarelski, Bulgarische Volkskunde, op. cit., $380 \mathrm{of}$.

35 I Waldemar Liungman, »Das Kukeri-Spiel in Hagios Georgios und zwei damit zusammenhängende Namensreihen«, Byzantinisch-neugriechische Jahrbücher 15 (I 939) 2 I-29. 
debele babe (Smederevo), graćenici, maskirci (Šumadija), svadbari, mečkari, strašila (Smilovo), preličnici (Südost-Serbien), kamile, starci, fašange, farsang (Fasching), lorfe, buše, prerušenci (Banat), svatovi $i^{352}$, maškara, larfa, obraz, oblicje, pustovi, šeme, koranti $i^{353}$ usw. Zur Population der processionaliter umziehenden Maskentypen zählen in der erweiterten Verkleidungsgruppe funktionale und dysfunktionale Figuren: funktional, wenn sie Teil (oder Reste) einer (ev. nicht mehr ausgeführten) Handlungsnummer sind, dysfunktional, wenn sie bloß die ornamentale Rolle eines spektakulären Elements besitzen. Der fertilitätsmagische Sinnuntergrund der Darstellungen und Verkleidungsformen ist im südosteuropäischen Ruralkarneval weiterhin manifest, protektiert durch die Umkehrung der Verhaltensnormen in der Narrenfreiheit der Faschingsperiode ${ }^{354}$. Neben dem seine Potenz kaum verbergenden oder in offener Phallophorie auftretende Bräutigam mit seinem beeindruckenden Zeugungsorgan ${ }^{355}$ (machmal auch einfach in Festkleidung) und der ihre Weiblichkeit überbetonenden Braut, die Gegenstand sexueller Belästigungen wird (bis hin zu mimetischen Koitusparodie, die oft dem Paar der Alten vorbehalten bleibt) ${ }^{356}$ und dem Gegenspieler (»Araber«) oder Beistand (dever, Hochzeitsführer) des

352 Vesna Marjanović, »Pokladne maske i povorke«, Glasnik etnografkog muzeja 67-68 (2004) I 55-1 76.

353 Niko Kuret, Maske slovenskih pokrajin, Ljubljana I 984.

354 Der Jesuitenorden und katholische Geistliche haben sich im I7. Jh. auf Chios und Santorini bemüht, die einheimische Bevölkerung durch das Aufführen erbaulicher Komödien von den obszönen Maskenzügen gegen Karnevalsende fernzuhalten (vgl. dazu die Quellen in Walter Puchner, Griechisches Schuldrama und religiöses Barocktheater im ägäischen Raum zur Zeit der Türkenherrschaft (I580-1750), Wien 1999 (Österr. Akad. d. Wiss., phil.-hist. Kl., Denkschriften 277) 79 f., 88 f.)

355 Z.B. Mirjana Prošić-Dvornić, »Pokladni ritual na primeru šumadijske variante pogladnih igara«, Folklorni teatar u balkanskim u podunavskim zemljama, Beograd I 984 , I43-1 57, bes. I 50-1 56, Vakarelski, Bulgarische Volkskunde, op. cit., 388.

356 Zur Kopulationsparodie des didi mit der baba in Kaštel Starom in Kroatien (1987) siehe Abb. 2 I in Puchner, Studien zur Volkskunde Südosteuropas, op. cit. Die phallischen Elemente und die aristophanischen Späße sind fast überall präsent, sowohl in älteren Spielarten der Verkleidungsformen, aber auch bei Puppen und Idolen mit betonten Zeugungsorganen (german, kalojan, leidinos auf Ägina usw.), in Altthrakien als Phallusidole bei den Maibräuchen und beim babin den, wo früher mit Effigien von Geschlechtsorganen Zeugungsakte mimetisch simuliert wurden (im Haus der Hebamme,

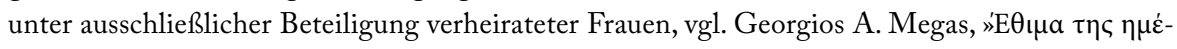

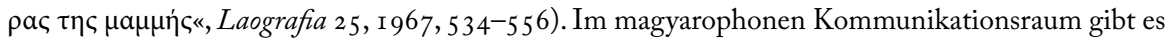
auch nicht-obszöne Erossatiren mit tändelnden tanzenden Liebespaaren (zwei Burschen), Küssen und Zärtlichkeiten, oder die pantomimische Imitation des Spaziergangs, während die drastischen Auftritte dem Altenpaar mit betonten Geschlechtsmerkmalen vorbehalten bleiben; auch die Herbergsuche des Ehemanns mit der hochschwangeren Frau wird dargestellt (Tahy, Das theatralische Braucbtum des ungarischen Sprachbereichs, op. cit., I 87-202). Anders ist die entsprechende "Nummer« in zentral- und südbalkanischen Karneval, wo die Sitzengebliebene knapp vor der Niederkunft im Zuschauerpublikum nach dem »Schuldigen« sucht. Zu einem reinen Phallus-Fest hat sich der burani-Ritus am »Reinen Montag« im thessalischen Tyrnavos entwickelt (vgl. die Photos von $200 \mathrm{I}$ 
Brautpaars ${ }^{357}$ gibt es gewöhnlich folgende Maskentypen: den europäisch gekleideten Arzt mit seinen lustigen Untersuchungen und Heilmethoden; den Pseudopopen, der die Hochzeitstravestie vornimmt, Mist statt Weihrauch verbrennt und eine deftige Ansprache hält; dem Richter, der Gericht hält und Strafen verteilt und dessen Schergen die Passanten verhaften, die sich freikaufen müssen; aber auch, neben den Tierverkleidungen, eine Fülle von anderen Figuren wie die Schwiegerleute der Heiratsparodie, Zigeuner, Leibwächter, den König (car), Jäger, Derwische, čauši, arnăutii (Arvaniten), den haidukenartigen kapetan (căpitanul), in den nordbalkanischen Spinnstubenunterhaltungen auch landwirtschaftsfremde Wanderberufe wie Handwerker, Hausierer, Rauchfangkehrer, Bettler, Zigeunerschmiede, Topf- und Geschirrhändler, Blutegelverkäufer usw. ${ }^{358}$ Im Banat z.B. gehen das Brautpaar um, die obszönen starci, der Arzt (charakteristischerweise »tot« genannt), Offiziere, der Photograph, Musiker, Astronauten, manchmal auch Heldenfiguren wie Marko Kraljević, Alexander der Große usw. ${ }^{359}$

Als Beispiel eines umfangreichen Maskenzugs sei der ehem. traditionelle Karneval von Sammakovi (Demirköy), nördlich der ehem. thrakischen Hauptstadt Vizye (Vize) in der heutigen Europäischen Türkei nahe der bulgarischen Grenze angeführt, die $p i-$ terades (mit Kleie bestrichene Gesichter, auch mit dem Bodensatz des Weinfasses, heute mit Ruß oder Mehlstaub). Dem morgendlichen Hochzeitszug in der Käsewoche (letzte Karnevalswoche) gehen voraus: ein Tanzbär mit Bärenführer, ein Friseur mit Rasierklingen, Gepäckträger, eine Brautpaarpersiflage, die seimenides, die "Schwarze Haube«,

in Puchner, Studien zur Volkskunde Südosteuropas, op. cit., Abb. I3-14). Neben der am Hauptplatz in großen Kesseln gekochten Suppe (burani) und den lasziven Liedern und obszönen Tänzen bzw. den Phallen verschiedener Größe und Materials gab es früher auch die Wahl eines Königs, der Gericht hielt und Geldstrafen verteilte, aber verkehrt auf einem Esel saß und dessen Schwanz in

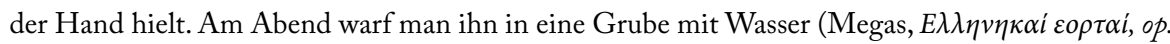
cit., I I 6 f.). Zu mimetischen Begattungsakten der džamalari im Kreis Küstendil auch Vakarelski, Bulgarische Volkskunde, op. cit., 385 .

357 Zum Hochzeitszug (pokladi svatovi) der komendijaci in Gruža mit mlad, mladožena und dever, aber auch dedice, starci, Tierverkleidungen usw. vgl. P. Ž. Petrović, »Život i običaji narodni u Gruži«, Srpski etnografski zbornik 26 (1948) $236 \mathrm{f}$.

358 Meist rußgeschwärzt, in Lumpen oder umgedrehte alte Kleider gesteckt bleiben sie unerkannt, beschmieren auch die Leute, bieten ihre Dienste an und feilschen in improvisierten Dialogen um den Preis, verursachen Störungen (die Zigeuner bringen Pferdemist in die saubere Stube, die Bettler verstreuen Asche, die Topfhändler breiten alten Krempel aus usw.) und nähern sich den Mädchen und verwickeln sie in Verkaufsdialoge voll der Anspielungen (Tahy, Das theatralische Brauchtum des ungarischen Sprachbereichs, op. cit., I $\left.52-16_{5}\right)$.

359 Slobodan Zečević, „Fašange u Banatu«, Rad XX kongresa Saveza udruženja folklorista Jugoslavije u Novom Sadu 1973. godine, Novi Sad 1978, ro7-1 10; man hat hier auch Einflüsse von den rumänischen căluşarii konstatiert (Dragoslav Antonijevic et al., Ritualni trans, Beograd I990, I 89-267). 
eine groteske erosbesessene Alte, die schockierende Lieder singt, komische Lazzi und Zierereien macht; es folgt der eigentliche Hochzeitszug: voraus der provodos (eine Art Herold $)^{360}$, der Glockenmann mit seinen Bockshörnern, der mit seinen Sprüngen die um die Hüften gebundenen Viehglocken in verschiedenen Tonlagen zum Klingen bringt, der Dudelsackspieler, drei Knirpse mit den Brautgeschenken in Körben am Kopf (reine Fetzen), der Bräutigam in Lumpen mit einem gigantischen Schnurrbart und einer Spielkette (komboloi) aus Zwirnsspulen in der Hand (Zeichen seiner Virilität), die bescheidene Braut mit gesenktem Blick, riesigen Brüsten und einem rundgewölbten Hinterteil, die vor lauter Scham alle Augenblicke in Ohnmacht fällt, der Beistand, der sie an der Hand führt und sie mit einer Zitronenhälfte, unter die Nase gehalten, wieder zu sich bringt; es folgen noch der Esel mit der Mitgift (Schnapsflaschen und alte Kisten), daneben ein Buckliger, der die Aussteuer anpreist (Stickereien, die der Braut das Augenlicht gekostet haben) und mit einem Staubwedel gewissenhaft rein hält, ein Arzt mit hundeartigem Gesicht, ein Satyr, ein Tänzer mit Hirschgeweih ${ }^{361}$. Ähnlich reichhaltig an Maskentypen ist der Lazarusumzug in der Woche vor der Karwoche (Terminverschiebung) ${ }^{362}$ im albanischen Lunxhëri im Raum Gjirokastër: Anführer $(k a-$ petan) mit Fustanella und Krummsäbel, sein »Stiefsohn« (Unterführer), der Arzt im Gehrock mit Arzneitasche und zwei weißblusigen Krankenschwestern, das Brautpaar, ein bajazzo mit einem bunten Papierminarett, umringt von Palikaren, die ihn beschützen; es folgt der $b a b a-s e h$, eine Art Weihnachtsmann mit weißem Bart, der Alte und die Alte mit Spindel, der lärmende Satan mit riesigen Schwanzauswüchsen, als letzter der Araber $^{363}$.

360 Er ist mit einem langen Kleid mit breitem Gürtel, in dem ein Holzmesser steckt, gekleidet, in der rechten Hand hält er einen Stab mit einem in Schmutzwasser getauchten Lappen, mit dem er die Passanten beschmutzt, in der linken ein Rinderhorn, in das er hineinschreit und alle Zuschauer zum Hochzeitsschmaus einlädt.

36r Die Maskierten werden oft angehalten, trinken viel, fallen auf den Erdboden und ergehen sich in losen Reden. Die eigentliche »Vorstellung « findet dann am Hauptplatz mit sarkastischen und obszönen Liedern statt. Prosperitätswünsche bezüglich der Ernte, gegen Tierseuchen, zur Vertreibung der kalikantzaroi usw. werden gesprochen, sodann die Hochzeitsparodie vollzogen. Die

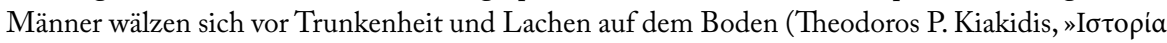

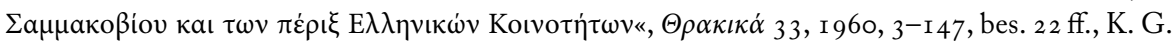

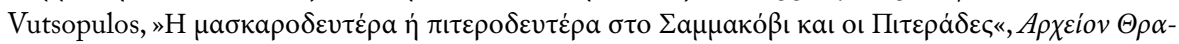

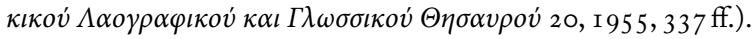

$362 \mathrm{Zu}$ solchen Terminverlagerungen (Heterochronie) und ihren Ursachen vgl. das Matieral bei Walter

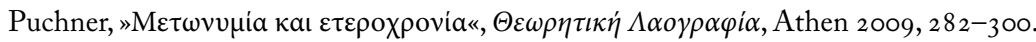

363 Alle außer dem Brautpaar tragen Glocken und Klappern, die Araber sogar mehrere Reihen um die Mitte gebunden. Jedes Dorf der Region bildet in Konkurrenz mit den anderen Kommunitäten seine eigene Maskenprozession und besucht auch die umliegenden Dörfer. Beim Zusammentreffen 
Neben diesen z.T. martialischen Maskenprozessionen mit deutlich fruchtbarkeitsmagischem Hintergrund gibt es auch semiurbane Formen, die die Maskenfiguren des Agrarkarnevals noch beibehalten, aber ihrer fertilitätspromovierenden Obszönität berauben, an der Wende zum Folklorismus und dem »Brauch ohne Glauben«. Ein solcher Fall ist die Maskenparade an den Karnevalssonntagen im ehem. Kotyora (heute Ordu) vor der Aussiedlung der Pontusgriechen 1922 an der Nordküste Kleinasiens am Schwarzmeer ${ }^{364}$.

Dort wird die einheimische Tracht getragen. Die Mädchen verkleiden sich als Haremsdamen; Greise und Greisinnen, Teufel mit Schwanz, Hörnern und schwarzem Trikot, Dorfmädchen, Zigeuner; klassische Figuren sind der Arzt und seine Frau: er im alten Gehrock, mit weißer Weste, einer riesigen Zwiebel in der Westentasche, mit einer Schnur angebunden, als Taschenubr, einen Stock, der meist das Skelett eines Regenschirms ist, Brillenrahmen obne Gläser, oft auch aus Besenhaaren, einen riesigen Hut oder einen Legekorb für Hühner am Kopf; sie mit riesigen ausgestopften Brüsten, mit einem alten zerrupften Besen in der Luft herumfuchtelnd. Außer Teufel und Zigeuner, die das Gesicht geschwärzt haben, sind sonst alle Verkleideten maskiert. Es gibt auch europäisch Gekleidete, Fustanellaträger, Vlachen mit Drabtmasken und obne, Geschlechtswechselverkleidungen usw. So zieht man in verwandte und bekannte Häuser. Der Arzt wird dauernd nach der Zeit gefragt, die Ärztin fächelt sich mit dem Besen Luft zu, ein anderer kehrt ununterbrochen Spinnen aus allen Ecken, die Alten belästigen einander, die Europäer bleiben ernst mit geöffneten Regenschirmen stehen. Man singt und tanzt ${ }^{365}$.

Hier ist ein anderer, subtilerer Humor am Werk, dem das landwirtschaftliche Bangen um die Fertilität (von Feld, Vieh und Mensch) bereits fremd ist. Um diesen Gegensatz noch schnittklarer herauszuarbeiten, seien noch zwei Bespiele einer festeren rituellen Bindung angeführt, beide aus dem epirotischen Bergland: die eine Beschreibung beidseitig der albanisch-griechischen Grenze, wo die Verkleideten (mutsunes) noch über das Faschingsfeuer springen müssen und die Leute mit verkohlten Holzstücken beworfen werden $^{366}$, die andere in den Zagori-Dörfern nördlich von Ioannina (Monodendri), wo

zweier Gruppen kommt es zum Kampf: Sieger ist, wer das Minarett am Kopf des Bajazzo mit dem Schwert abschlägt (Fahnenfunktion). Man singt das religiöse Lazaruslied und die Loblieder auf die

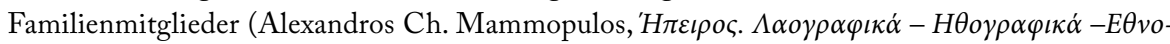

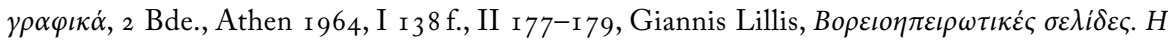

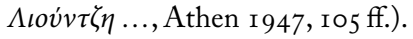

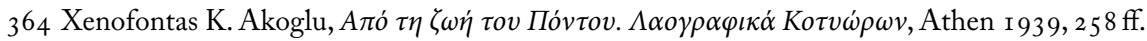

365 Zitat auch Puchner, Brauchtumerscheinungen, op. cit., 22 I.

366 In Pogoniani auf der griechischen Seite sind die Maskierten Bräutigame, Bräute, Alte, Frauen, Vetteln u.a. Am Dorfplatz wird getanzt (der lasziv-mimetische piperi-Tanz, wie die Teufel den Pfeffer reiben) und dann das Feuer entzündet. Man wirft mit Asche um sich und erschreckt die 
die glockenbehangenen Maskierten (Alter, Alte, Arzt, Zigeuner) schwarze Tücher vor den Gesichtern tragen, um nicht erkannt zu werden, wenn sie hinkend und stolpernd von Haus zu Haus humpeln, wo sie wilde und plumpe Tänze aufführen, ohne dabei zu sprechen $^{367}$. Erkennungsverbot und Sprechverbot sind archaische Elemente, die sich bei manchen Maskenumzügen und Vorstellungen vom Zentralbalkan bis nach Ungarn hinein z.T. noch erhalten haben.

Doch gibt es noch eindrucksvollere Formen, die früh die Aufmerksamkeit der Wissenschaft auf sich gezogen haben ${ }^{368}$ : die fellmaskierten buckligen geroi (Alten) auf Skyros, die mit mehr als 5o Viehglocken an einem Holzgestell um die Hüften einen Höllenlärm erzeugen ${ }^{369}$, mit ihren Krummstäben Passanten fangen und mit Asche bewerfen, untereinander regelrechte Wettkämpfe im Glockenschlagen austragen, begleitet von den lappenbedeckten und lumpentragenden maskierten korelles mit Strohbesen ohne Stiel (entsprechen dem Maskentyp der Alten), beschützen die »Bräute«, angeführt von einem Janitscharen; dazu kommen noch ein europäisch gekleideter »Frankos« (Lateiner), Berufsmasken (Fischer mit Angel, Siebmacher, Apotheker, Ärzte mit ihren Roßkuren), »Bären«, »Kamele«, bemalte Kinder, die als Sklaven verkauft werden usw. ${ }^{370}$

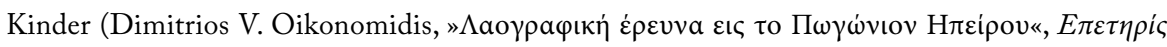

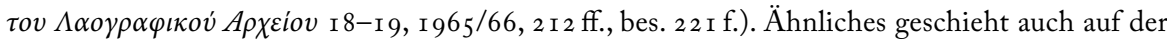

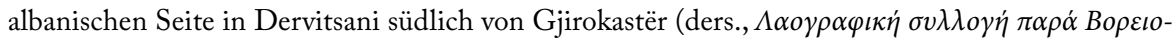
$\eta \pi \varepsilon \iota \rho \omega \tau \dot{\omega} v \pi \rho o \sigma \varphi \dot{v} \gamma \omega v$, Ioannina $195 \mathrm{I}$ ).

367 Man bewirtet die Maskierten mit Wein und Süßigkeiten und versucht, sie zu demaskieren; diese jedoch werfen mit Asche um sich, die sie in den Hosentaschen tragen, und schrecken die Leute

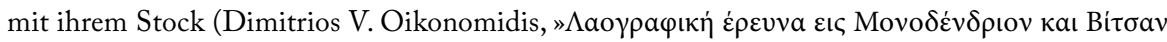

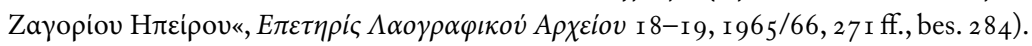

368 Karl Gustav Fiedler, Reise durch alle Theile des Königreichs Griechenland, 2 Bde. Leipzig I 840, II 80, John C. Lawson, »A beast dance in Scyros«, The Annual of the British School in Athens 6 (1 899/1 900) I 25-I 27, Richard M. Dawkins, »A visit to Scyros«, ibid. I I (1904/05) 72-80, C. Fredrich, Mittheilungen des Kaiserlich Deutschen Archäologischen Instituts 3 I ( 1906 ) 99 ff. Manche Mißverständnisse sind von der griechischen Forschung berichtigt worden.

369 Zur Rolle und Morphologie der Viehglocken bei den Verkleidungen Georgios N. Aikaterinidis,

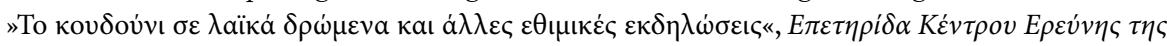

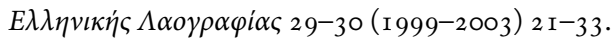

370 Die einzelnen Brauchbeschreibungen weichen in Details durchaus voneinander ab, was auch auf die lange Zeitdistanz zurückzuführen ist, in der der Ritus beobachtet wird (seit I 840). Vgl. M.

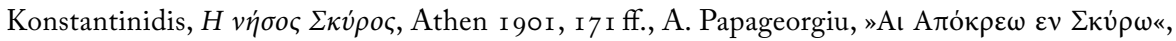

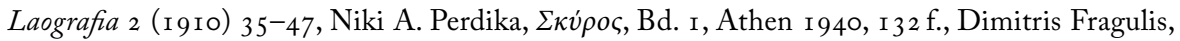

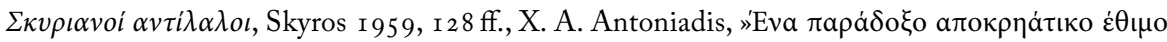

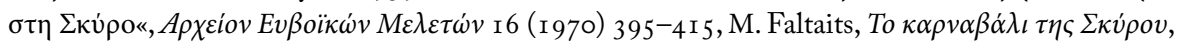
Athen 1972; Angaben zu Forschungsgeschichte und Detailvarianz in Puchner, Brauchtumserscheinungen, op. cit., 2 I $7-2 \mathrm{I} 9$. 
Allein das Gewicht dieser Glockenreihen und das Wettläuten erfordert enorme Köperkraft und zeugt von der Virilität der ${ }^{2}$ Alten ${ }^{371}$.

\section{I.3.6 Anthropomorphe Ersatzobjekte}

Eine Sonderform der rituellen Metamorphose-Strategien des Menschen ist der Ersatz der lebendigen Körperlichkeit durch einen »verkleideten« leblosen Gegenstand. Die Morphologie und Technik dieser Substitution der Somatik reicht vom »eingekleideten« Holzstück bis zum Vogelscheuchenskelett der gekreuzten Hölzer ${ }^{372}$ bzw. dem mit Stroh ausgestopften Körper einer provisorisch angekleideten menschengroßen Effigie. Dies ist bei den Judaspuppen der österlichen Judasverbrennungen im mediterranen Raum ${ }^{373}$ der Fall wie auch bei den Faschingsbegräbnissen und dem Winteraustragen vom ostmitteleuropäischen Raum bis in die Ägäis und nach Kreta ${ }^{374}$. Die Realitätsstufen der Effigienausgestaltung reicht dabei von Primitividolen bis zu kunstvollen Kostümpuppen. Erstere ist vor allem bei der rituellen Idolbestattung, die vom Karpatenbogen bis in die Ägäis und nach Kleinasien nachzuweisen ist, mit wechselndem Funktionskontext, gegeben $^{375}$, zweitere etwa bei folkloristischen Ausformungen der Lazaruspuppe.

Dazu einige Beispiele: In Südrumänien und Bulgarien wird am 9. Mai oder in Trokkenperioden des Frühlings- und Frühsommerabschnittes von Frauen und Mädchen

37 I Vgl. Abb. 8 in Puchner, Studien zur Volkskunde Südosteuropas, op. cit., und die zahlreichen Abb. in Joy Coulentianou, The goat-dance of Skyros, Athens 1977.

372 Die Grundform dieser Menschendarstellung ist schon im »epirotischen Glockenbrett« (für den Lazarus) gegeben, wobei an dem angenagelten Querholz schwere Viehglocken hängen, die während des Absingens der Lazaruslieder von den Sängern geschlagen werden (Puchner, Braucbtumserscheinungen, op. cit., 4I, I03, I35, I67, 275, 277, Verbreitungskarte 275).

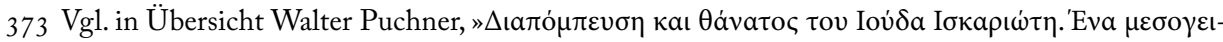

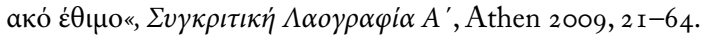

$374 \mathrm{Zu}$ solchen Strohpuppen des parodistischen Faschingsbegräbnisses János Manga, Tájékosztato szinjátékszerü népszokások gyüjtéséhez, Budapest I 953, 27, Tahy, op. cit., 22 2, Jenö Bruckner, »A nagy böjt eltemetése a Pestmegeyei Boldogon«, Ethnographia I 933, Tekla Dömötör, »Népi színjatéktípusok«, Múveltség és Hagyomány Io ( I 968) I6 I-I 74, dies., "Zur Frage der sogenannten Kausalfiktionen«, IV. Intern. Congress for Folknarrative Research in Athens, Laografia 27, 1968, 88-93; in Szeged auch ein Schneemann in einem Lumpengestell, das in die Theiß gestoßen wird (János Kovács, Szeged és népe, Szeged I 90 I, 3 I 7 f.). Diese Idolvernichtung entspricht auch dem westslavischen Todaustragen (Friedrich Sieber, Deutsch-slawische Beziehungen in Frühlingsbräuchen, Berlin I 968). Zum

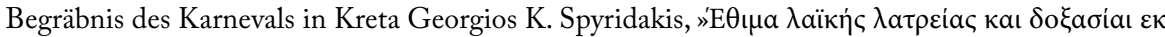

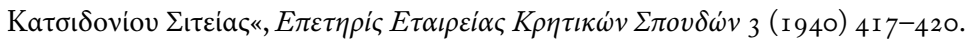

375 W. Puchner, »Primitividole und Idolbestattung auf der Balkanhalbinsel (zur rituellen Frühgeschichte des Puppentheaters)«, Acta Ethnogaphica Academiae Scientiarum Hungaricae 34 (1986-88) 229-244. 
eine Lehmpuppe mit ausgeprägten Geschlechtsteilen geformt, german, germančo, caloianul, kalojan oder skalojan genannt, von ihnen beweint, beklagt und begraben oder in den Fluß geworfen ${ }^{376}$. Die Morphologie der rituellen Handlungen mit dieser Puppe ist breit gestreut: Die Figur wird auf ein Brett gelegt und mit Blumen geschmückt, erhält eine Totenwache oder ein regelrechtes Begräbnis (manchmal sogar mit Priester); in anderen Fällen wird sie im Sand neben dem Fluß bestattet oder auch in einem Brunnen oder Dorfteich, ein Rutenkreuz wird auf das Grab gelegt, und regelrechte Totengedächtnisfeiern werden abgehalten, sollte es weiterhin nicht regnen. Manchmal wird die Figur auch einfach zerrissen ${ }^{377}$. Derselbe Brauch findet sich auch in Serbien und Makedonien ${ }^{378}$ sowie in Bessarabien ${ }^{379}$. Diese Idole sind meist aus getrocknetem Lehm ohne erkennbare ästhetische Bemühung hergestellt ${ }^{380}$, manchmal auch von einem strohoder lumpenverkleideten Besen gebildet ${ }^{381}$. Die Figur hat vielfach die Arme gekreuzt und hält eine brennende Kerze. Die ausgeprägten Geschlechtsteile sind ein häufiges

376 Vakarelski, Bulgarische Volkskunde, op. cit., 329-33 I.

377 In Auswahl: E. Fischer, »Paparuda und Scalojan«, Globus XCIII (rgo8) I 4 ff., Teodor T. Burada, O călătorie în Dobrogea, Iași I 880, 28, I. A. Candrea, „Caloianul«, Nouvă Revista Română 2 ( 1900 ) 94-96, Maran Beza, Paganism in Roumanian folklor, London 1926, 32-36; G. Ivănescu, »O influență bizantînă sau slavă în folclorul românesc și în limba românească. Caloianul«, Folklor Literar I (I 967) I 3-23, V. S. Zelenčuk/J. V. Popović, "Antropomorfnye obrazy v obrjadach plodorodija u vostočnoromanskich narodov (XIX - načalo XX veka)«, Balkanskie issledovanija. Problemi istorii $i$ kultury, Moskva 1976, I 95-201, St. L. Kostov, »Kultăt na Germane u bălgarite«, Izvestija na Bălgarskoto archeologičesko družestvo v Sofija 3 (I 9 I 3) I08-I 24, Dimităr Marinov, »Narodna vjara i religiozni narodni običai«, Sbornik za Narodni Umotvorenija i Narodopis 28 (I9I4) 553 ff., Hristo Vakarelski, Etnografija na Bălgarija, Sofija I 97 I , 6 13 f., Mihai Arnaudov, Studii vărchu bălgarskite obredi i legendi, tom. I, Sofija I97 I, K. Kaufman, »Oplakvaneto na >German< u kapancite. Ot plač kăm pesen«, Izvestija na Instituta za Muzika I 3 ( I 969) I 55-1 75, St. Genčev, »Običajat German v Dobrudža«, Vekove I 973, H. 2, 3 I-38, K. Masinski, „Călzi i dăžd«, Sbornik v čest na prof. L. Miletić, Sofija I933, 475-478, St. Genčev, »Običai i obredi za dăžd«, Dobrudža, Sofija 1974, 349, L. V. Markov, Bolgary Kalendarnye obyčai i obrjady v stranach zarubežnoj Evropy, Moskva 1978, 226, Natalija N. Veleckaja, Jazyčeskaja simbolika slavjanskich archaičeskich ritualov, Moskva I978, I6 I f.; M. Benovska, »Săštnost i estetičeski izmerenija na obreda German«, Obredi i obreden folklor, Sofija I 98 I, $235^{-2} 5^{6}$ usw.

378 Slobodan Zečević, „Germain (coutume printanière pour invoquer la pluie)«, Makedonski Folklor VI/I 2 (1973) 255-257, ders., "German«, Glasnik Etnografskog muzeja u Beograd I 976, 39-40, ders., „Vanbračno dete u narodnom verovanju istočne Srbije«, Glasnik Etnografskog Instituta I 4-I 5 ( 1969) I $33-\mathrm{I} 35$.

379 C. Ginčev, »Narodni običai ot Besarabija«, Sbornik za Narodni Umotvorenija i Narodopis VIII (I982) 276 .

380 Vakarelski, Bulgar. Volkskunde, op. cit., 404.

38 I Op. cit., 33 o. 
Charakteristikum dieser Idole und haben mit fertilitätsmagischer Bedeutung zu tun ${ }^{382}$. Charakteristisch ist die ausschließliche Beteiligung der Frauen an dem Idolbegräbnis (Kinder erst sekundär) ${ }^{383}$. Neben der regenmagischen Funktion scheint auch das Einlernen des Klageverhaltens eine Rolle zu spielen; in Bulgarien z.B. werden die Kinder in manchen Gebieten zum Mitweinen gezwungen ${ }^{384}$.

Im Raum Epirus wird im Mai oder im ganzen Frühlingsabschnitt ein in der Kirche geweihtes, mit Blumen geschmücktes Puppenidol bestattet, begraben und in einem elaborierten Klagelied von den Mädchen beweint. Diese Puppe, zafeiris ${ }^{385}$, wird ab I 930 etwa und früher schon von einem Mädchen oder Kind ersetzt, wobei der Brauch spielhaften Charakter angenommen hat ${ }^{386}$. In dieser Form herrscht die Funktion der Threnoserlernung vor ${ }^{387}$. Das Bedecken mit Blumen oder Aufbahren auf Blumen ist dem Totenbrauchtum entnommen, wo Blüten, Grün und Früchte dem Toten auf die Hades-

382 Selbst für den epirotischen zafeiris gibt es Anzeichen, daß das eingekleidete Holz phallische Be-

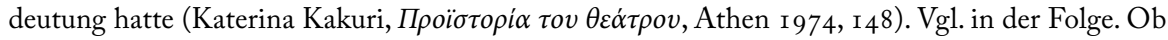
der Name german mit dem H1. Germanos (Patriarch 638-733) in Zusammenhang zu bringen ist, wie es das heortologische Datum nahelegt (Vakarelski, Bulgar. Volkskunde, op. cit., 33 r), oder mit vorchristlichen Mythologemen (P. Z. Petrović, »German«, Z. Kuližić/P. Z. Petrović/I. Pantelić, Srpski mitoloski rečnik, Beograd I970, 87 f.), ist ein Problem, das hier nicht gelöst werden muß. Die Volksetymologie läuft auf gărmež, Donner, und wird mit der regenmagischen Finalität des Brauches in Zusammenhang gebracht. Ähnlich ungewiß ist, auf welchen Wegen caloianul auf den bul-

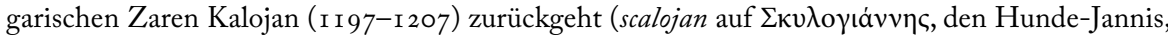
eine Bezeichnung, die ihm seine Grausamkeit eingetragen hat), den Belagerer von Thessaloniki I 207 (Karl Krumbacher, Geschichte der Byzantinischen Litteratur, München I 897, I035 f., I04 I f.), der nach der Demetrius-Legende vom Stadt-Heiligen selbst mit der Lanze getötet worden sein soll, was auf manchen Demetrius-Ikonen mit unmißverständlicher Beischrift zu sehen ist (Leopold Kretzenbacher, Griechische Reiterheilige als Gefangenenretter, Wien 1983, 44-46, 56 und Walter

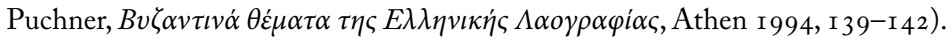

383 Die regenmagische Symbolik läßt die Effigie meist an der Dürre zugrundegegangen sein, die Analogiehandlungen sollen das Mitleid Gottes erregen und den Regenguß »erzwingen«. Dieser Logik gemäß stirbt german an Trockenheit und wird am oder im Wasser beigesetzt; die Symbolik verläuft von der Dürre (dem getrockneten Lehm) zur Feuchtigkeit (Schlamm- und Wassergrab). Ähnliche Strategien der Sympathieerweckung metaphysischer Instanzen sind auch beim perperuna/dodolaRitus am Werk (vgl. wie oben).

384 Die entsprechenden Lamentationen sind relativ primitiv (z.B. »German ist tot, German ist tot, der Arme, er starb wegen der Trockenheit, er starb dürstend nach Regen«, Vakarelski, Bulgar. Volkskunde, op. cit., 329) und gehen in unartikuliertes Weinen über (Kaufman, op. cit.).

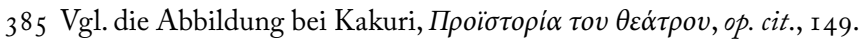

386 Katerina Kakuri, $\Theta \alpha \dot{v} \alpha \tau o \varsigma-A v \alpha \dot{\sigma} \sigma \alpha \sigma \eta$, Athen $\mathrm{r}_{965}, 38 \mathrm{ff}$.

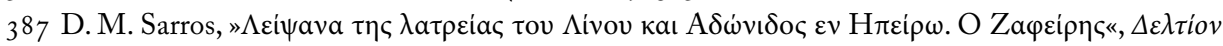

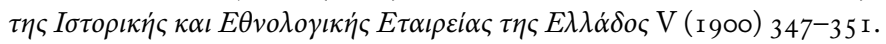


reise mitgegeben werden ${ }^{388}$ (ähnlich fuskodentri in der Peloponnes) ${ }^{389}$. Die Namensform bedeutet den dunkelblauen »Zaphir«, im übertragenen Sinne dann etwas Teures, Wertvolles ${ }^{390}$. Hier herrscht das Einlernen des ergreifenden Threnos-Gesangs und des rituellen Lamentationsverhaltens vor, denn der Brauch wird in seiner Spiel-Version mehrfach wiederholt ${ }^{391}$. Neben diesen Ritualformen gibt es balkanweit auch parodistische Formen, wie die Bestattung und Beweinung des Eies in Thrakien ${ }^{392}$, das Maulwurfsbegräbnis in der Ukraine ${ }^{393}$ oder des Makaroni-Manns auf Chios, womit wir wieder bei den parodistischen Faschingsbegräbnissen angelangt wären ${ }^{394}$.

388 Margaret Alexiou, The ritual lament in Greek tradition, Cambridge 1974, 38, und allgemein: Loring Danforth, Until the Crow Becomes a Dove: The Death Rituals of Rural Greece, Princeton 1983, Bernhard Schmidt, "Totengebräuche und Gräberkultus im heutigen Griechenland «, Archiv für Religionswissenschaft I 4 (1926) 28 I-3 18 und I 5 (1927) 62-82.

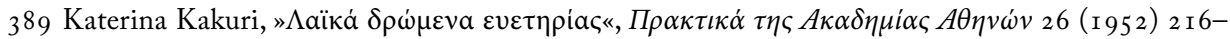
228, bes. 225 f. Vgl. Abb. 26 in Puchner, Studien zur Volkskunde Südosteuropas, op. cit.

390 Eine hypothetische Verbindung mit dem Adonis-Kult (Sarros, op. cit.), ähnlich wie im Falle des

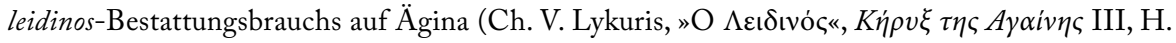

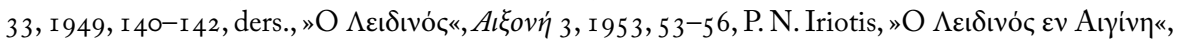
Laografia 8, I 92 I-25, 289-296) braucht heute nicht mehr diskutiert zu werden (Puchner, Brauchtumserscheinungen, op. cit., 165 f.).

39г Zum Lied vgl. Puchner, Die Folklore Südosteuropas, op. cit., 73-75. Ein ähnliches EinlernungsSpiel ist auch auf der Insel Mykonos vor I 9 Io nachgewiesen, wo Kinder in den Sand gezeichnete Umrisse eines Menschen mit Meergras und Blumen ausgefüllt und die Totendarstellung beweint haben; zum Schluß wurde der krantonellos in den Sand gestampft (St. I. Makrymicha-

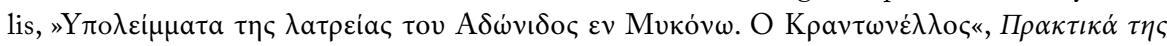

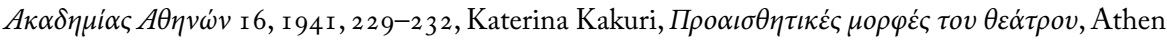
I 946, I66). Ein vergleichbares Bestattungsritual mit einer tönernen Menschenfigur (kannavos, kannavuri) wurde an der Südküste des Schwarzmeers zwischen Ostern und Pfingsten begraben, beweint und die Totenspeise (kollyba) verteilt; die Zeremonie schlägt in der Folge in ein heiteres

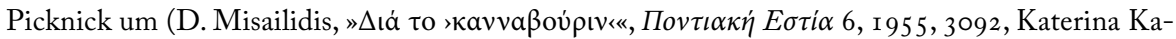

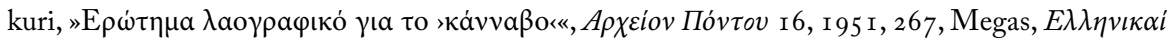

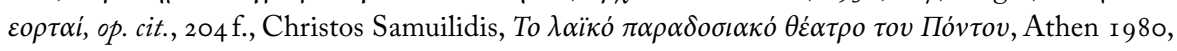
238). Idolbestattungen finden als kuç kuçura oder kuchkutera in Kleinasien auch als Regenmagie

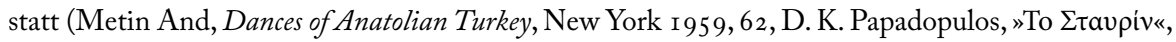

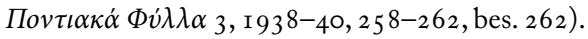

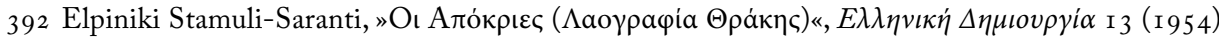
$282 \mathrm{f}$.

393 Misailidis, op. cit., 3092.

394 Zoltán Ujváry, »Das Begräbnis parodierende Spiele in der ungarischen Volksüberlieferung«, Österreichische Zeitschrift für Volkskunde 69/XX (1966) 267-276, Gyula Ortutay, Kleine ungarische Volkskunde, Budapest $1963,93 \mathrm{ff}$. 
The guisers prepare a dummy of wood and old clothes known as the Macaroni man... His head is decorated with tsarkatou, a kind of water-vessel, and he is adorned with a phallos, or what our informant interprets as such. It is held that he eats up all the macaroni that is left over. On Clean Monday this interesting person falls ill and dies, whereupon his funeral ceremonies are conducted. It is noteworthy these are not a parody of a real ritual of the dead. Before finally despairing of this life they consult a doctor, who is grieved to discover that his patient is past curing; too much macaroni has been the death of him. In the afternoon the remains are escorted out of the village by everyone, guiser or not, to the accompaniment of ribald songs, and the final disposal is prosaic; he is simply taken to piece, by the way, getting after a fashion the sdissolution which is whished to all the dead. With this act Carneval comes definitely to an end ${ }^{395}$.

Nichtsdestotrotz können solche Idole, wie schon eingangs mit einigen Beispielen erhärtet, auch Gegenstand ernsthafter Ritualhandlungen sein, und zwar auch innerhalb des christlichen Heortologions. Bei den transhumanten Sarakatsanen wird die Grablegung Christi am Karfreitag mit einem Idol spielhaft dargestellt, wobei eine Frau den Marienthrenos absingt ${ }^{396}$. Das Primitividol besteht aus einem Stück Holz oder aus zwei gekreuzten Holzstäben, die im allgemeinen die Grundlage der Menschendarstellung

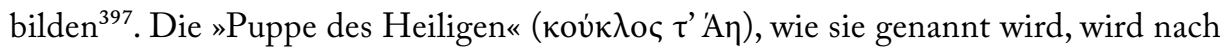
dem Karfreitag in eine unzugängliche Schlucht geworfen (rituelle Vernichtung). Das Zerreißen der Puppe dürfte im Falle der lebensgroßen Effigie des leidinos auf Ägina das einstige rituelle Begräbnis ersetzt haben ${ }^{398}$. In jedem Fall ist das Zerstören des Idols als symbolischer Vernichtungsakt obligatorisch, was bei der Verbrennung der Judaspuppen im Osterfeuer im gesamten Mittelmeerraum (von der Vogelscheuchenfigur bis zum kunstvollen Feuerwerk) ${ }^{399}$ den Höhepunkt bildet, wobei der proditor/predatel des Herrn

395 Philip P. Argenti/H.J. Rose, The Folklore of Chios, Cambridge r 949, $380 \mathrm{f}$.

396 Angeliki Hatzimichali, $\Sigma \alpha \rho \alpha \kappa \alpha \tau \sigma \alpha \dot{v o l}$, Athen $1957, \rho \xi \delta^{\prime}$.

397 Dies ist z. B. bei griechischen Lazarusumzügen evident, wo das blumen- und tüchergeschmückte Holzkreuz den "Lazarus« vorstellt (Puchner, Brauchtumserscheinungen, op. cit., 9r). Zur Morphologie der Lazaruspuppe auch Walter Puchner, „Lazarusbrauch in Südosteuropa. Proben und Überblick«, Österreichische Zeitschrift für Volkskunde XXXII/8 I ( I 978) I 7-40.

398 Die lebensgroße anthropomorphe Puppe hat auch in diesem Fall betonte Geschlechtsteile (vgl. Abb. 32 in Puchner, Studien zur Volkskunde Südosteuropas, op. cit.). Bei dem einstigen Frauenfest, das einen Infantilisierungsprozess durchgemacht hat, wurde die Effigie mit Blumen beworfen, von den Kindern in einem Sarg durch die Stadt getragen und begraben. Leidinos dürfte etymologisch von deilino kommen und eine Verkörperung des Vesperbrots, d. h. der Sommerarbeiten darstellen (der Kreuzerhöhungs-Tag als Brauchtermin fällt auf den I4. September; beim Hineinwerfen der Erde ins Grab spricht man: »Hör auf, armer Mann, mit dem Vesperbrot« und der alte leidinos vom Vorjahr wird ausgegraben). Zu dem elaborierten Threnos Puchner, Die Folklore Südosteuropas, op. cit., 73-75.

399 Das gesamte Material in Walter Puchner, Studien zum Kulturkontext der liturgischen Szene. Lazarus 
von so manchem unliebsamen Politiker ersetzt werden kann. Der Feuertod des Iskariotischen Bösewichts kann spektakuläre Formen annehmen ${ }^{400}$, seine Figur auch realistisch gestaltet sein wie etwa in Larnaka auf Zypern um i 900.

Ein Cypriot kennt zwar nur einen Osterfeiertag. Dafür findet am zweiten Feiertage die originelle Judasverbrennung statt und in den Orten mit mehreren Kirchen und Parochien wird Tag für Tag ein Judas mehr verbrannt, bis man durch alle Kirchensprengel hindurch ist./Da wird denn erst in der Kirche der Gemeinden aus dem Evangelium die Sünde des Judas Ischariot, des verräterischen Jüngers Jesu, klargemacht und dann nach dem feierlichen Gottesdienste in den Hof der Kirche gezogen, um den Judas zu verbrennen. Auch dieses Fest hat sich trotz der Unterdrückungsversuche der gebildeten Griechen bis heute erhalten und wurde wiederum am eindringlichsten in Larnaka gefeiert, von der Bischofskirche ausgehend die ganze Woche bei allen orthodoxen Kirchen der Stadt. Eine lebensgrosse Judas-Puppe, die mit brennbaren Stoffen, oft auch mit Feuerwerkskörpern gefüllt ist, wird erst unter frenetischem Jubel der Menge auf die verschiedenste Weise umgebracht und dann auf dem Scheiterhaufen verbrannt. In einem Falle wurde der Judas erst an einem Galgen erhängt, dann von den Palikaris, einzelne in der griechischen weiberrockartigen Männertracht, durch zabllose Pistolenschüsse durchbohrt, dabei die in der Puppe angebrachten Feuerwerkskörper zur Explosion gebracht, schliesslich die angebrannten und zerrissenen Reste der Puppe gesammelt und auf dem Holzstoss verbrannt. Jede Kirchengemeinde sucht es in der Judasfeier der anderen in seltsamer und effektvoller Verkleidung der Puppe und Erfindung neuer Todesarten vorzutun ${ }^{401}$.

Die Realistik der Effigie spielt eigentlich keine wesentliche Rolle: Sie reicht von der Lazaruspuppe bei den Lazarusumzügen ${ }^{402}$, in der einfachsten Form als »epirotisches

und Judas als religiöse Volksfiguren in Bild und Brauch, Lied und Legende Südosteuropas, 2 Bde., Wien I 99I (Österr. Akad. d. Wiss., phil.-hist. K1., Denkschriften 2 I6) I I05-I08, II 283-29I und erweitert

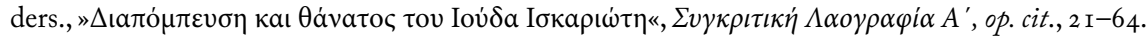

400 Wie z.B. in Gomati auf Chalkidike (Walter Puchner, »Forschungsnotiz zum Judasbrennen«, Österreichische Zeitschrift für Volkskunde XXXI/80, 1977, 229-23I).

40 I Magda Ohnefalsch-Richter, Griechische Sitten und Gebräuche auf Cypern, Berlin I 9 1 3, 92-94. Zum Judasprozeß als improvisierter theatralischer Vorstellung in Dörfern des Zentralgebirges des Eilands der Aphrodite Walter Puchner, »Das Judasgericht auf Zypern«, Österreichische Zeitschrift für Volkskunde XXXVI/85 (1982) 402-405.

402 Zur Morphologie vgl. Puchner, »Lazarusbrauch in Südosteuropa«, op. cit., 27 ff., ders., Studien zum Kulturkontext der liturgischen Szene, op. cit., 48-54 (und erweitert ders., „Lazarus redivivus. $\Theta \rho \eta-$

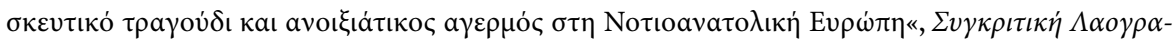

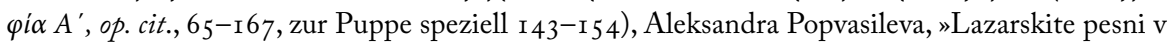
Kosturskoto Popolje (egejska makedonija)«, Makedonski Folklor I (I968) i 55-ı66, L. Jordanova, "Za običaja lazaruvane v Bălgarija ", Izvestija na Etnografskija institut i muzej 9 ( 1966) 107-162. 
Glockenbrett ${ }^{403}$ bis hin zu Kinderspielpuppen beim selben Brauch ${ }^{404}$ oder lazarkaund buenec-Puppen, die deutlich eine Entwicklung zur Kostümpuppe durchgemacht haben $^{405}$. Hierher gehören auch die Lazarus-Gebildbrote in Bulgarien (kukla) und auf der Dodekanes (lazari), die den Mumientypus der byzantinischen Seelen- und Totendarstellung nachahmen ${ }^{406}$. Doch das Einzelidol dieser Art ist nicht in der Lage, in eine Rollenbeziehung bzw. Interaktion mit anderen Effigien zu treten; dies geschieht schon eher im Kinderspiel. Im rumänischen Puppentheater etwa spielt das archaische Tod/ Auferstehung-Motiv noch mehrfach eine Rolle ${ }^{407}$. Doch verlaufen die möglichen Entwicklungen zum interaktiven Rollenspiel und dem Verbaldialog eher über die Maske und Verkleidung lebendiger Spieler ${ }^{408}$.

\section{EXKURS : REGIONALZONEN UND MASKENTERMINE}

Doch bevor wir zu den elaborierten und komplexeren Spielformen, welche ein realitätshältiges Rollengeflecht als Fundament einer von der sozialen Wirklichkeit abhebbaren Fiktivzone organisierten Bühnenspiels konstituieren, übergehen, sei ein Exkurs zu den Maskenterminen im Jahreskreis nach Maßgabe einer Ausfaltung in Großregionen eingeschoben, denn die bisher angesprochenen datumsmäßigen Anlässe sind keineswegs die einzigen im Heortologion des festlichen Jahreskreises. Obwohl die konventionellen Jahreslaufkaleidoskope der Einzelnationen und konkreten Sprachzonen ein verzerrtes weil systematisiertes Einheitsbild konstruieren, in dem die regionale Varianz

403 Zwei gekreuzte Holzstangen, an der waagrechten hängen Glocken, die während des Absingens der Lazarus-Kalanda geläutet werden - Primitivdarstellung des »Auferstandenen« (Walter Puchner,

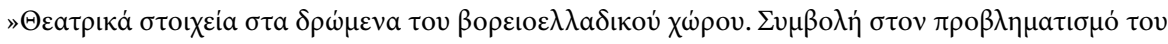

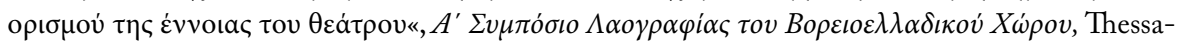
loniki $1983,225^{-2} 73$, bes. 243 f.).

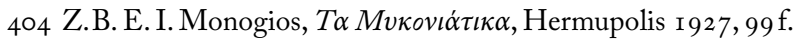

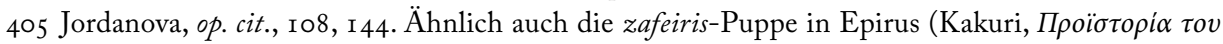
$\theta \varepsilon \dot{\tau} \tau \rho o v$, op. cit., I49 Abb. I 23).

406 Vgl. Walter Puchner, „Die Mumienseelen«, in: Akkommodationsfragen. Einzelbeispiele zum paganen Hintergrund von Elementen der frühkirchlichen und mittelalterlichen Sakraltraditon und Volksfrömmigkeit, München 1997, 28-33. Speziell zu dem Thema auch ders., »Anthropomorphe Brotgebilde in Südosteuropa und ihre Beziehungen zur byzantinischen Ikonographie«, Thede Kahl/Peter M. Kreuter/Christina Vogel (eds.), Culinaria balcanica, Berlin 201 5, 29-37.

407 Horia Barbu Oprișan, »Das rumänische Volks-Puppenspiel«, Österreichische Zeitschrift für Volkskunde XXX/84 (I98I) 84-го6.

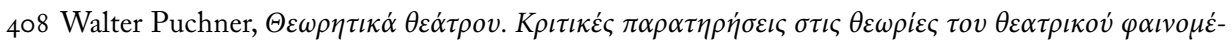

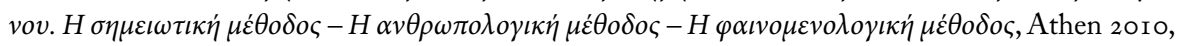
$363-369$. 
bis zu einem gewissen Grad notwendigerweise übergangen wird, ist eine solche regionenweise Übersicht dennoch angebracht, um die Orientierung im Festkalender zu erleichtern, aber auch aus Gründen jenes feed-back-Effekts, den die ethnographische Erfassung und Klassifizierung auf die Brauchträger selbst hat: Ein Blick ins Internet genügt, um sich vom Vorherrschen der datumsmäßigen Kodifizierung der events, mit denen sich jedes Dorf in seinem elektrischen site vorstellt, zu überzeugen ${ }^{409}$, so daß sich performativen Riten zum Großteil wirklich nach den nationalen Handbüchern und Kompendien der Volkskunde und Ethnologia Europea richten ${ }^{410}$. Im größten Teil der Balkanhalbinsel, den ehem. sozialistischen Staaten, ist dieser Vereinheitlichungsprozeß seit vielen Jahrzehnten bereits durch die regimegetreuen zentralgesteuerten FolkloreFestivals in eine ideologisch überhöhte nationale und gesellschaftliche Selbstdarstellung übergeführt, ein Vorgang, der auch nach der Wende und unter geänderten politischen Vorzeichen irreversibel erscheint, da sich Folklorismus nicht rückgängig machen läßt und neue Wirklichkeiten konstituiert. Der Exkurs ist darüberhinaus auch eine willkommene Gelegenheit, zusätzliche regionalspezifische Spezialbibliographie anzuführen, die für weiterführende Studien nützlich sein $\mathrm{mag}^{411}$. Nach Maßgabe der Populationsmischung in den Einzelbereichen in dem quellenmäßig dokumentierbaren Zeitraum

409 Eine solche Zusammenstellung öffentlicher Folklore-events im Jahreskreis, unabhängig von Fragen der Traditionalität oder Innovativität, aus den Internet-Adressen von Dörfern und Regionen hat kürzlich Terina Armenaki für den hellenophonen Raum zusammengestellt (Terina Armenaki, Greek Folklore, Athens 20I7), wodurch sich eine gänzlich neue Sichtweise (und ein neues Forschungsfeld) für die Folkloristik auftut, die auch als interpretative Meta-Ebene interessant ist, weil die Internet-Angaben und Bürgermeister-Interviews zu den einzelnen Brauch- und Festmanifestationen gleich auch die Interpretationskonstrukte der Brauchträger, die meist auf hohes Alter und Traditionalität abzielen bzw. Sekundärätiologien (Türkenzeit) propagieren, mitgeliefert werden, die als invented traditions ihren autonomen Wissenswert haben (vgl. dazu die Einleitung von Walter Puchner, »Foreword«, Armenaki, op. cit.).

410 Zoltán Ujváry, Játék és maszk, 3 Bde., Debrecen I 983, Romulus Vulcănescu, Măstile populare, București I 970, Niko Kuret, Maske slovenskih pokrajin, Ljuljana i 984, Ivan Lozica, Izvan teatra, Zagreb I990, ders., Hrvatski karnevali, Zagreb I 997, ders., Poganska baština, Zagreb 2002, Georg Kraev, Maska i bulo, Sofija 2003, Christo Vakarelski, Bulgarische Volkskunde, Berlin I969, ders., Et-

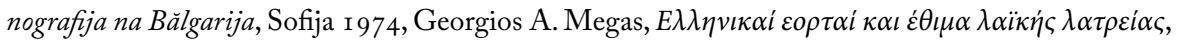
Athen 1956, ders., Greek Calendar Customs, Athens 1958 usw. Vgl. auch Eugen Fehrle, Feste und Volksbräuche im Jahresablauf europäischer Völker, Kassel 1955.

4I I Besonders hilfreich sind auch die Bibliographien von Klaus Roth/Gabriele Wolf (eds.), South Slavic Folk Culture. A Bibliography of Literature in English, German, and French on Bosnian-Hercegovinian, Bulgarian, Macedonian, Montenegrin and Serbian Folk Culture, Columbus, Ohio 1994 und Walter Puchner, Greek Folk Culture. A Bibliography of Literature in English, French, German, and Italian on Greek Folk Culture in Greece, Cyprus, Asia Minor (before 1922) and the Diaspora (up to 2000), Athens $201 \mathrm{I}$, bes. I55-165. 
von der zweiten Hälfte des I 9. Jh.s ist die Darstellung sprachübergreifend, auch wenn die Quellenlage Dominanzen von Einzelsprachen aufweisen mag. Dies ist auch eine Frage der Forschungstraditionen und der Hierarchisierung ihrer Fragestellungen, aber auch eine Konsequenz der zwangsweisen Populationsverschiebungen, da die Flüchtlingsvolkskunde häufig zur Kumulation von Informationen aus den verlassenen Herkunftsgebieten führt.

Historisches Thrakien und Scharzmeerküsten. Weit ausschlaggebender als die Sprachzugehörigkeit ist in Südosteuropa im allgemeinen die religiöse oder konfessionelle $\mathrm{Zu}$ gehörigkeit einer Population, oft mit hybriden Mischzonen oder auch punktweisem graduellem Synkretismus, wie dies z.T. im historischen Thrakien ${ }^{412}$ und der kleinasiatischen Schwarzmeerküste und ihrem Hinterland ${ }^{413}$ zwischen orthodoxen Christen und Muslimen bis in die ersten Jahrzehnte des 20. Jh.s der Fall war ${ }^{414}$ : Vor allem die Ausbreitung des Bektași-Ordens seit dem I 4. Jh. ${ }^{415}$ hat hier zu bemerkenwerten christlich-

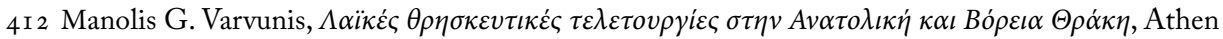

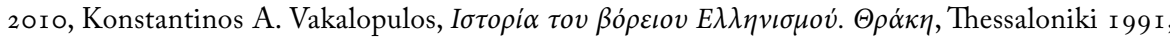

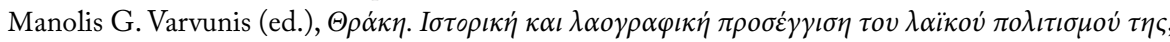

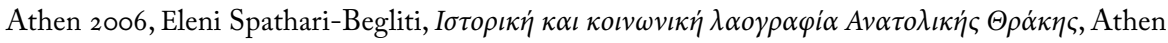
I 997, H. Carnoy/J. Nicolaïdes, Folklore de Constantinople, Paris I 894, dies., Traditions populaires de Constantinople et de ses environs. Contributions au Folklore des Turcs, Chrétiens, Arméniens, etc., Paris I 892 .

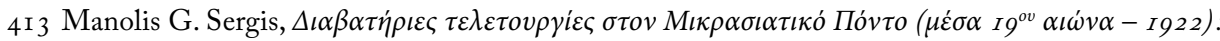

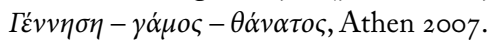

4I 4 Gabriella Schubert, „Verbindendes und Trennendes in den Alltagskulturen von Christen und Muslimen in Südosteuropa«, Th. Kahl/C. Lienau (eds.), Christen und Muslime. Interethnische Koexistenz in südosteuropäischen Peripheriegebieten, Wien/Berlin 2009, I 73-1 90, Stephen Ladas, The exchange of minorities; Bulgaria, Greece and Turkey, New York I932, A. M. Mansel, Trakya'nin Kültür Taribi, Istanbul I938, Stavro Skendi, „Crypto-christianity in the Balkan area under the Ottomans«, Slavic Review 26 ( I 967) 227-246, Christo Vakarelski, »Altertümliche Elemente in Lebensweise und Kultur der bulgarischen Mohammedaner«, Zeitschrift für Balkanologie 4 (I 966) I 49-I 72, Abdurrahim Dede, Bati Trakya Türk Folkloru, Istanbul I 975, Cornelius Fligier, Ethnologische Entdeckungen im Rhodope-Gebirge, Wien I 879, Nikolaj A. Hajtov, Asenovgrad, Sofija I 963 (Thessaloniki I 964), Yusuf Halaçoğlu et al., »Turkish settlements in Rumelia (Bulgaria) in the $15^{\text {th }}$ and $16^{\text {th }}$ centuries: Town and Village population «, International Journal of Turkish Studies 4/2 (I989) 23-42 usw.

4I 5 Hans Joachim Kissling, Dissertationes Orientales et Balcaniae collectae (ed. Brigitte Moser-Weithmann), I. Das Derwischtum (Vorwort Leopold Kretzenbacher), München I 986, ders., „Derwisch«, Enzyklopädie des Märchens 3 ( (1981) 428-432, ders., Beiträge zur Kenntnis Thrakiens im I7. Jahrbundert, Wiesbaden I 956, ders., „Das islamische Heiligenwesen auf dem Balkan, vorab in Thrakien«, Zeitschrift für Balkanologie I ( 1962 ) 46-59, John Kingsley Birge, The Bektashi order of dervishes, Lon-

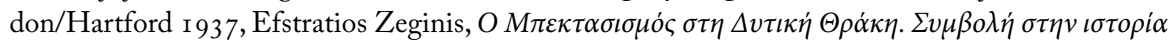

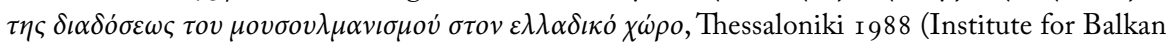
Studies 220). 
muslimischen Symbiosen geführt, wie die gemeinsame Verehrung des H1. Georg, des H1. Demetrius, des Propheten Elias, die Wallfahrten und Feste bei Quellenheiligtümern mit rituellen Ringkämpfen und dem Aufhängen von Lumpen und Unterwäsche auf Bäume nahe der Quelle usw. ${ }^{416}$ Beim çem-Fest der Bektași-Derwische und ihrer Anhänger waren nicht nur Frauen zugelassen, sondern rituelles Weintrinken und Tanz angesagt ${ }^{417}$. $\mathrm{Zu}$ der religiösen Symbiose treten noch ethnisch-sprachliche Hybride (griechisch, bulgarisch, türkisch), die sich auch im Festkalender äußern ${ }^{418}$ : im Winterabschnitt ${ }^{419}$ die surva-Umzüge ${ }^{420}$, die džamala-Kamelverkleidung ${ }^{421}$, die Araber $^{422}$, die dyligaroi ${ }^{423}$, das Hebammen-Fest (babin den, banin gün, $\mu \pi \dot{\alpha} \mu \pi \omega)^{424}$, im Frühjahr der Schwalbenum-

4I6 Frederick W. Hasluck, Christianity and Islam under the Sultans, New York I 973, 576-586, Mehmet Eroz, Turkiye 'de Alevilık Bektașilık, Istanbul I 977, 225 f., Manolis G. Varvounis, Historical and Ethnological influences on the traditional civilization of Pomaks of the Greek Thrace«, Balcanica 34

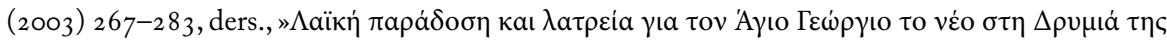

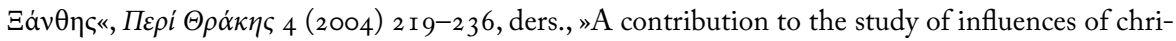
stian upon moslem customs in popular worship«, Journal of Oriental and African Studies 5 (I 993) 75-89, ders., »Christian orthodox and moslem popular religions customs: a study of influences and

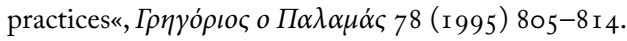

4I7 Spathari-Begliti, op. cit., 68-70.

4 8 Dazu auch Walter Puchner, »Altthrakische Karnevalsspiele und ihre wissenschaftliche Verwertung. `Dionysos im Länderdreieck Bulgarien - Griechenland - Türkei«, Studien zur Volkskunde Südosteuropas, op. cit., $\mathrm{I} 77^{-1} 92$.

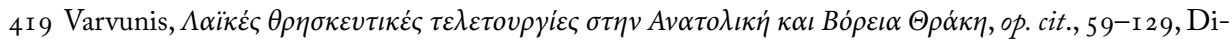

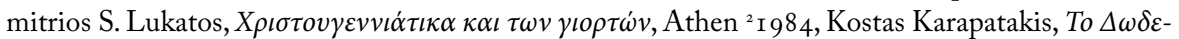

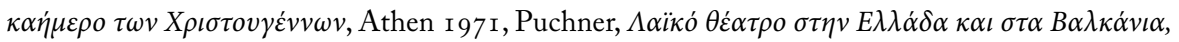
op. cit., $27-36$ usw.

420 Vakarelski, Bulgarische Volkskunde, op. cit., 3 I 7-3 I 9, Petăr Dinekov, Bălgarski folklor, Sofija I 972 ,

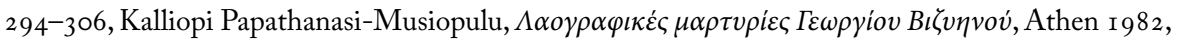
50, George F. Abbott, Macedonian Folklore, Cambridge i 893, 8 I f.

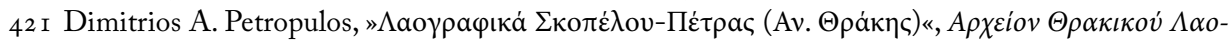

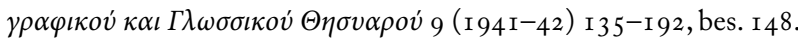

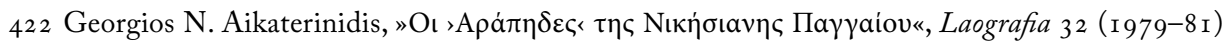
$215^{-2} 26$.

423 Mit dem kokkinos als Anführer (roter Gürtel), aber auch Frau und Neugeborenem (Elpiniki Stamuli-

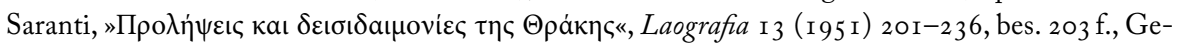

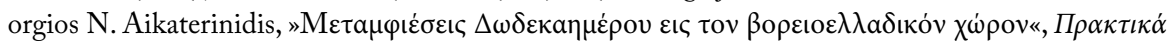

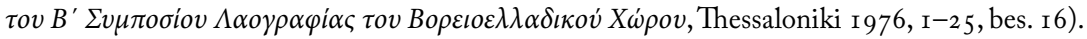

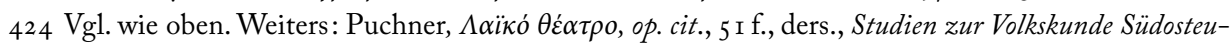
ropas, op. cit., I 30, I 40, I 8 I f., Manolis G. Varvounis, "Balkan resultants and folkloristic influences

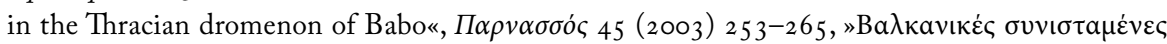

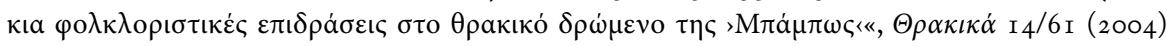
I 5 I-I68, Vakarelski, Bulgarische Volkskunde, op. cit., 3 I9, Mihail Arnaudov, »Babinden văv Velin-

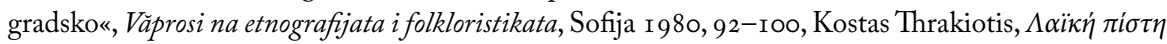


zug $^{425}$, die Karnevalsverkleidung mit dem kalogeros/kuker/köpek-bey ${ }^{426}$, die Judasverbrennungen ${ }^{427}$, das Maikugeln der Frauen und Mädchen ${ }^{428}$, die Feuertänzer der anastenarial nestinari ${ }^{429}$, im Sommer die klidonas-Mantik am Festtag des H1. Johannes (24. 6.), die kallinitsa ${ }^{430}$, die Heiligenfeste (panegyria) und Wallfahrten zu den hagiasmata (H1. Quellen), und im Herbst zum Saattermin am Vortrag des H1. Demetrios (25. Io.) neuerlich die Kamelverkleidung der džamala ${ }^{431}$. Zu den okkasionellen Ritualakten zählen die perperuda und der funktionsäquivalente lapatas ${ }^{432}$.

$\kappa \alpha \iota \lambda \alpha \tau \rho \varepsilon i \alpha \sigma \tau \eta \Theta \rho \alpha \dot{\kappa} \eta$, Athen I99I, I 87-I9I, zu ev. Verbindungen mit dem antiken baubo-Kult der

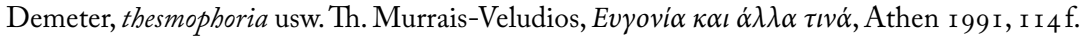

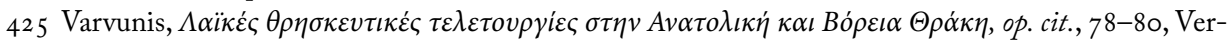
breitungskarte $8 \mathrm{r}$.

426 Vgl. noch in der Folge. Die letzte bibliographische Zusammenstellung bei Walter Puchner,

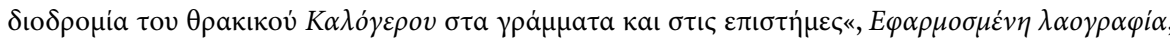
Athen 2014, 57-ror.

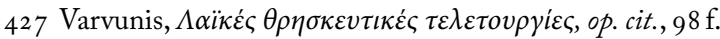

428 Varvunis, op. cit., ro I f., Puchner, Brauchtumserscheinungen, op. cit., I 49.

429 Vgl. die erschöpfende analytische Bibliographie in Walter Puchner, »Beiträge zum thrakischen Feuerlauf (Anastenaria/Nestinari) und zur thrakischen Karnevalsszene (Kalogeros/Kuker/Köpek Bey). Anmerkungen zur Forschungsgeschichte und analytische Bibliographie«, Zeitschrift für Balkanologie I 7 (198I) 47-75. Und ergänzend: M. Lesk et al., "Auf's Feuer Gehen. Feuerlauf in Griechenland und Selbstversuche«, Curare 4 (198I) I69-192, Rena Loutzaki, Dance as a cultural message. $A$ study of style among the Greek from northern Thrace in Micro Monastiri, Neo Monastiri and Aeginion, Belfast 1989, B. Marakis, Fire Dance in Greece, Greece 1982, Stavroula Christodoulou, Continuity and Change among the Anastenaria, Ph. D. diss., State Univ. of New York at Stony Brook 1978 , Alex. Kanellon-Thanasoulas, The Anastenari. A popular thracian religious custom, Diss., Univ. of Leeds 1976, George G. Mitrevski, Description of Adaptations of Religious and Folklore Texts: with Examples from Yugoslav Theater and Drama, Ph.D. diss. Ohio State University I 984, Gustav A. KüppersSonnenberg, »Bei den Feuertänzern (Nestinari) im bulgarischen Strandschagebirge«, Zeitschrift für Ethnologie 8 I (1956) I I 8-I 23, Olive C. Lodge, »Fire-Dances in Bulgaria - I 939«, The Slavonic and East European Review 26 (1 947/48) 467-483, Grete Sykora, "Ruinenstädte und Feuertänzer am bulgarischen Pontus«, Slavische Rundschau 5 (1933) 389-397 usw.

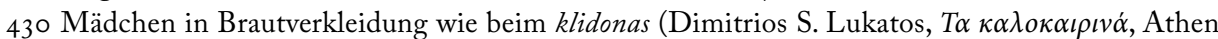
I 98 I, 56-59).

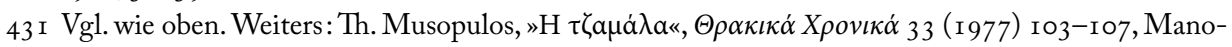

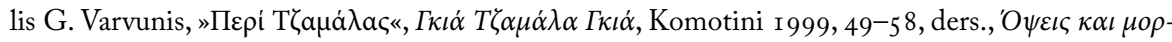

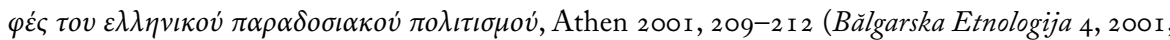
54-62), ders., "Balkan dimensions and moslem variations at the custom of >Tzamala in Thrace«, Journal of Oriental and African Studies I 2 (2003) 53-6 I ; zur Kamelverkleidung und dem Tanz der

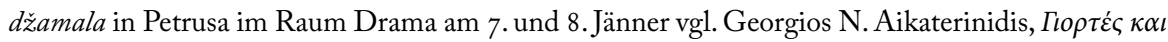

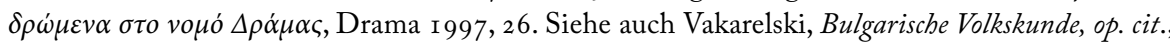
384 f., Romulus Vulcănescu, Măstile Populare, București I 970, 55 f.

432 Zum Regenmädchen vgl. wie oben, zu lapatas Papathanasi-Musiopulu, op. cit., II $24 \mathrm{I}$. 
Die griechische Flüchtlingsvolkskunde aus Altthrakien hat enormes Informationsmaterial zur einstigen Volkskultur dieses Kommunikationsraums zusammengetragen ${ }^{433}$.

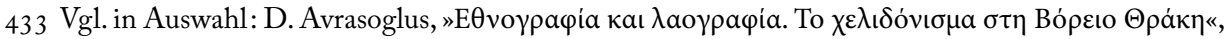

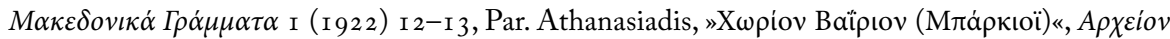

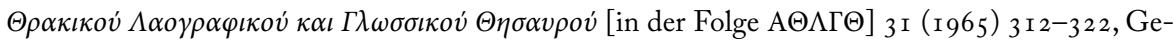

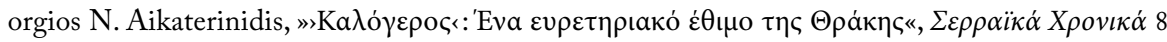

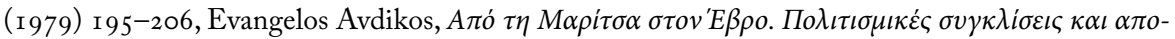

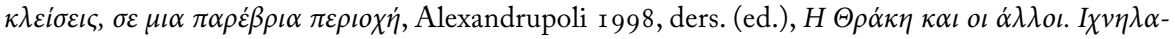

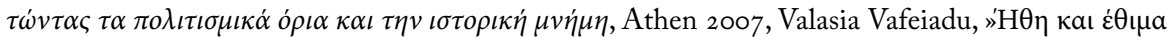

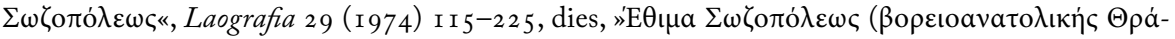

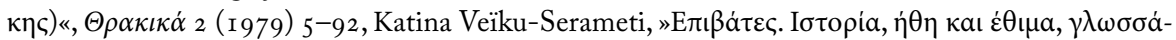

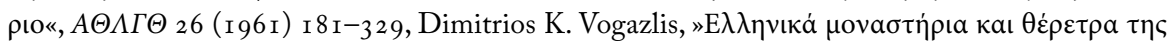

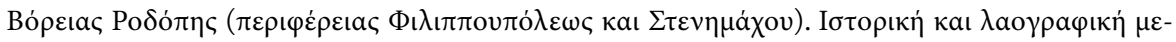

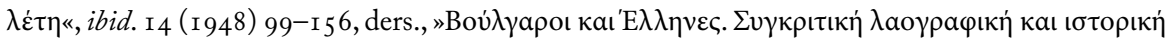

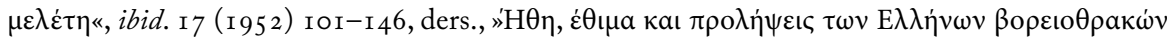

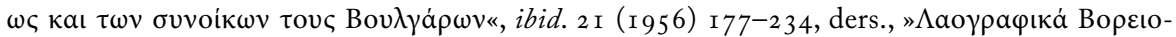

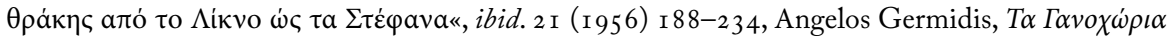

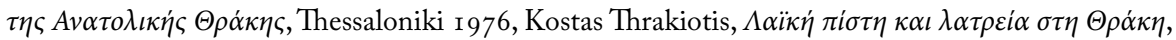

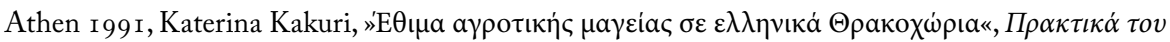

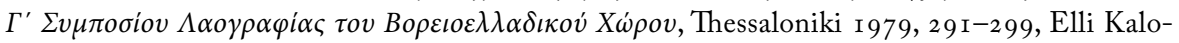

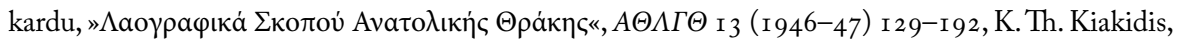

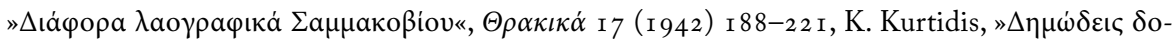

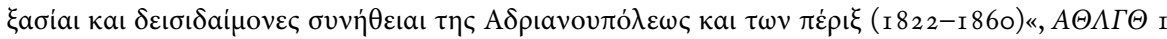

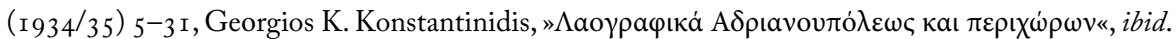

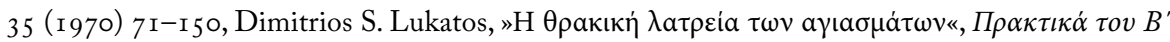

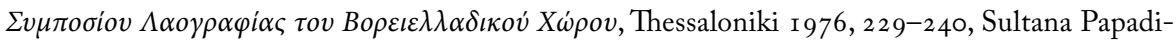

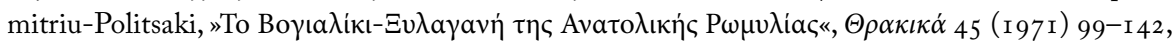

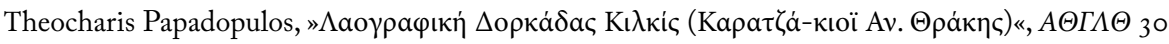

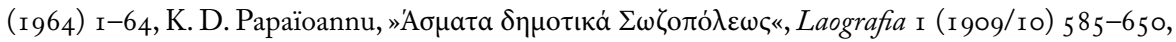

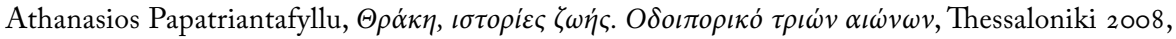

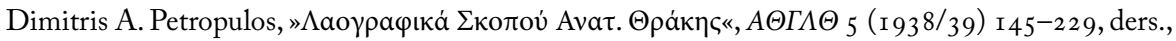

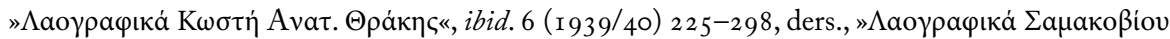

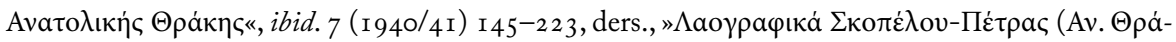

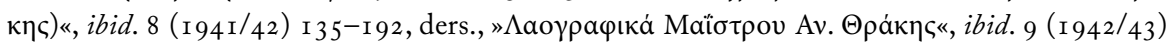

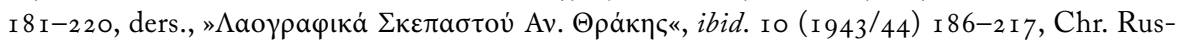

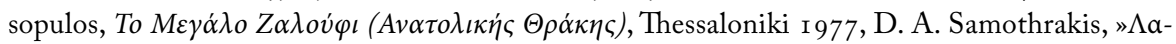

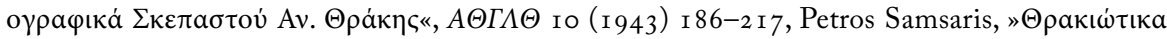

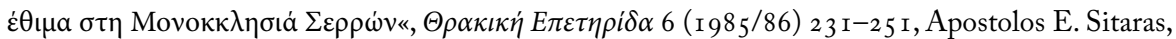

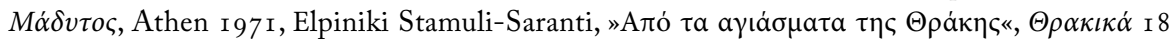

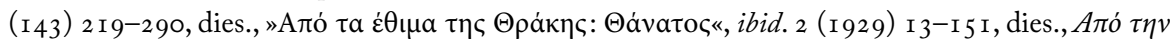

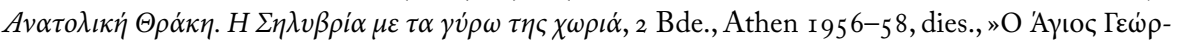

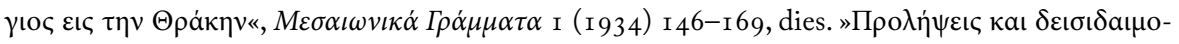

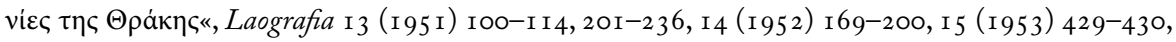


Ähnlich wie auch in anderen Maskenzonen des Balkanraums ist die Verkleidungstätigkeit eingebettet in ein Geflecht von superstitionellen und magisch-religiösen Symbolakten und Glaubensvorstellungen ${ }^{434}$ wie dem Feueraufschüren durch die KalandaSänger während der Zwölften ${ }^{435}$, dem Beweihräuchern der Ikonen, des Pflugs und des Hauses, den Neujahrs-koleda $a^{436}$, der vasilopitta (Basil-Kuchen) mit der eingebackenen Glücksmünze ${ }^{437}$, dem ersten Brunnengang mit dem »ungesprochenen« Wasser (rituelles Schweigen) im Neuen Jahr, fertilitätspromovierenden Akten wie dem Zerschlagen des Granatapfels, dem Werfen von kollyba (koljiva) $)^{438}$ an die Eingangstür, dem

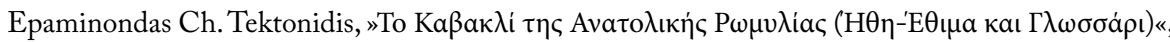

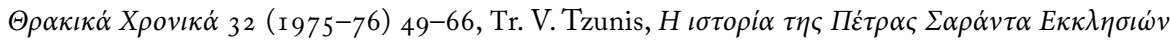

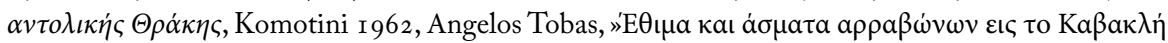

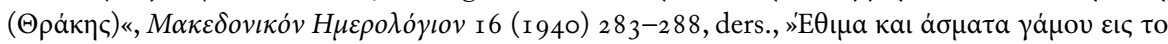

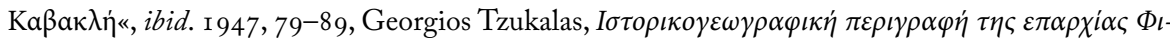

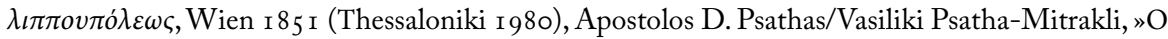

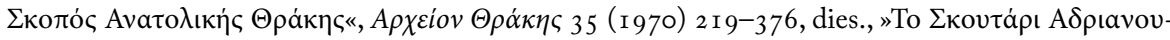

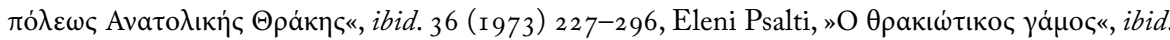

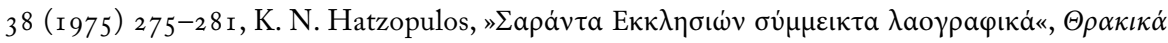

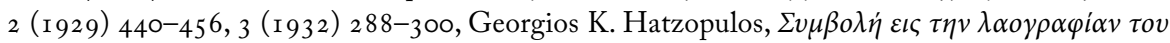

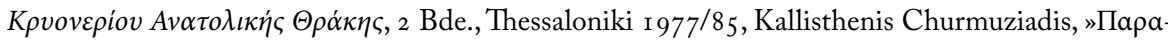

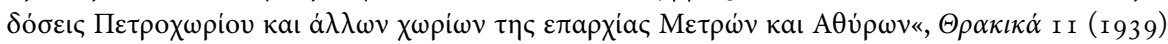

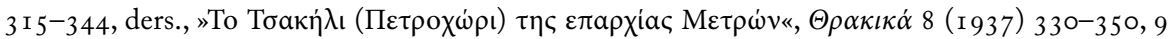

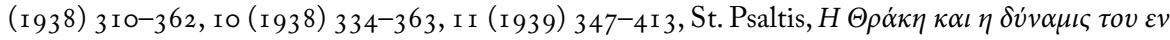

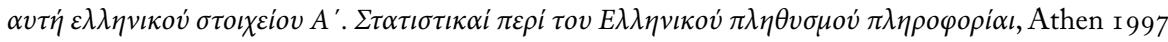
usw.

434 G. Lienhardt, »The control of experience: symbolic action«, Michael Lambek (ed.), A Reader in Anthropology of Religion, Malden etc. ${ }^{2} 2005,330 \mathrm{ff}$.

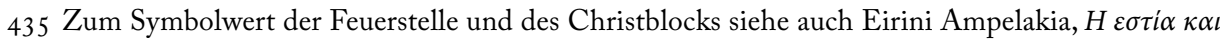

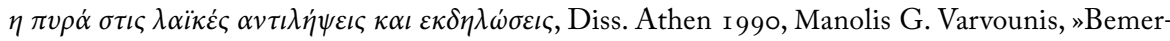
kungen zur byzantinischen Tradition des Wachstums des Feuerbrands oder des Trockenen Stocks (AaTh 756)«, Byzantion 76 (2006) 32 I-329.

$436 \mathrm{Zu}$ den Umzügen in Plovdiv/Philippopel siehe Kalliopi Papathanasi-Musiopulu, $\Lambda \alpha o \gamma \alpha \varphi \iota \kappa \dot{\alpha} \Theta \rho \alpha \dot{-}$ $\kappa \eta \varsigma, 2$ Bde., Athen $1979 / 80, I_{33} \mathrm{f}$.

437 M. M. Hasluck, »The Basil-cake of the Greek New Year«, Folklore 38 (1927) I43-I77, Dimitrios S.

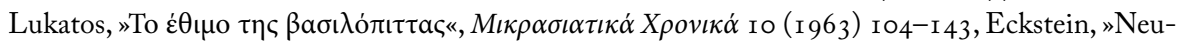
jahrs- und Dreikönigsgebäck", Handwörterbuch des Deutschen Aberglaubens 6 (1 934) I045-56.

438 Die Totenspeise hat hier fruchbarkeitsfördernde Funktion; vgl. die Ambivalenz von Tod/Fruchtbarkeit, Saat/Ernte (Erde als Reich der Toten und gleichzeitig Lebenspender) sowie vieler Dämonenvorstellungen, die schädlich aber auch helfend sein können. Das Zerschlagen des Granatapfels mit seinen vielen Kernen findet sich auch im Hochzeitsbrauch. Vgl. Sergis, $\Delta \iota \alpha \beta \alpha \tau \dot{\eta} \rho \iota \varepsilon \varsigma \tau \varepsilon \lambda \varepsilon \tau$ cov $\rho-$

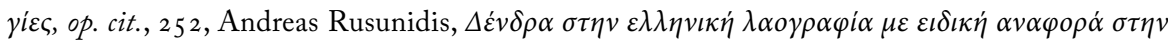
Kút $\rho$ o, Nicosia I 988, I 3 I. 
surva-Umzug mit dem Gesundheits-Schlag ${ }^{439}$, Süßspeisen, Glückwünschen, bei der Taufsymbolik des Theopanie-Festes der Ikonenwaschung, dem Anspritzen des Popen, Feldgerätewaschung, vrexudia (Besprengen oder Anschütten bzw. Ins-Wasser-Werfen als Analogiehandlung zur Christustaufe im Jordan $)^{440}$, verschiedenen apotropäischen Akten bezüglich der Zwölftendämonen, die als Totengeister charakteristisch ambivalent sein können ${ }^{441}$ : Schädlich und helfend, dämonisch und heilig, die bezüglichen Riten sind blasphemisch und sakral zugleich; durch die Ambiguität der Erde in den Ackerbaukulturen sind die Toten der Unterwelt zugleich Herren über die Fruchtbarkeit und das Leben ${ }^{442}$.

Die Zwölftenperiode wird von einer ganzen Reihe von Heiligenfesten vor und nach der Spanne von Weihnachten bis Theophanie flankiert ${ }^{443}$, bis hin zu den beweglichen

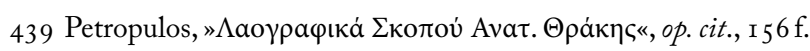

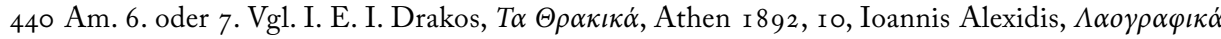

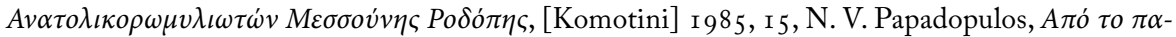

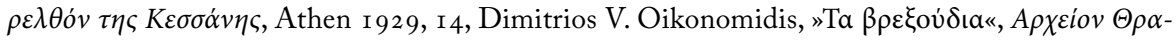

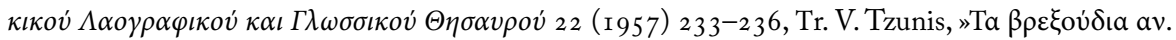

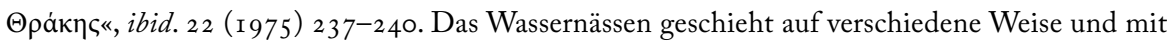
differenten Akteuren, wobei sich die religiöse Symbolik mit der lebenspendenden Kraftmagie des um diese Zeit kühlen Nasses verquickt. Z.B. benetzt der kumbaros (Hochzeitsbeistand) den Kopf

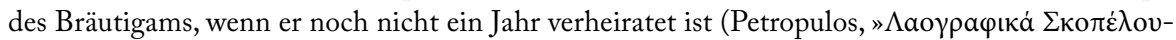

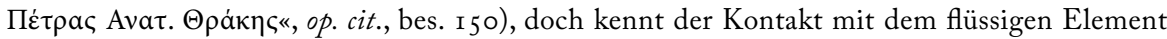
viele Varianten: besprengen, anspritzen, anschütten, in Pfütze stoßen, beginnend mit Jungen und Ortsfremden, die Wein spendieren müssen, um die Prozedur zu einem Ende zu bringen; am 7.Jänner kommt die Reihe an die Alten (nur verheiratete Männer mit Frauen), in den Küstengebieten werden an diesem Tag auch Neuverheiratete ins Meer geworfen, Frauen mit einem Krug Wasser am Kopf begossen (Dimitrios S. Lukatos, X

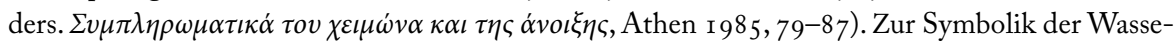

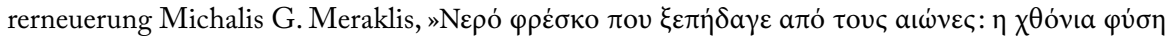

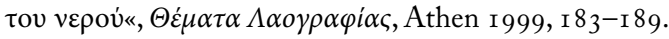

44I Neben ihrer miasmatischen Tätigkeit (Urinieren in Wein und Öl) haben sie auch die Fähigkeit, Zwiebelschalen in Gold zu verwandeln; entprechend ambivalent ist der ihnen bereitete Empfang: Neben den apotropäischen Akten werden für sie auch Süßigkeiten und Trockenfrüchte vor die Haustür gelegt.

442 Zur Dialektik von Sakralität und Satire in der Volkskultur vgl. Walter Puchner, »Tragik und Komik in der griechischen Volkskultur. Zu Dramaturgie und Inszenierung des Gefühlslebens«, Studien zur Volkskunde Südosteuropas, op. cit., 53 I-540.

443 Der Festkalender der Heiligen unterliegt zu einem geringeren Maße lokalen Variationen. Der Dezember setzt mit der H1. Barbara als Krankenhelferin (4. I 2.) ein (Lukatos, $\Sigma v \mu \pi \lambda \eta \rho \omega \mu \alpha \tau \iota \kappa \dot{\alpha}, ~ o p$. cit., I 8-27), für die eine panspermia aus Feldfrüchten an Wegkreuzungen vor dem Dorf verstreut wird; am Feiertag des H1. Nikolaos (6. I 2.) wird bei Seesturm seine Ikone oder kollyba seines Festes ins Meer geworfen; am H1. Spyridon-Tag (I 2. I 2.) wird kein Mais gegessen, damit man keine 
Festen des Osterkreises ${ }^{444}$, die mit dem Karneval einsetzen ${ }^{445}$, durch die Quadragesima

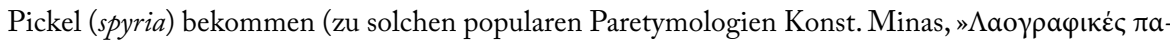

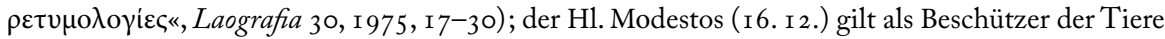
(George F. Abbott, Macedonian Folklore, Cambridge I 903, 24I, Stefanos Imellos, "O áyıఁ Mó-

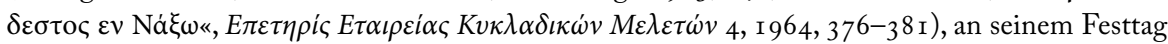
besteht Arbeitsverbot, seine Fest-kollyba werden gesegnet und mit Weihbroten den Tieren zum Fraß gegeben. Nach den Zwölften: Der H1. Tryphon (I. 2.) gilt als Heiliger der Bauern, besonders

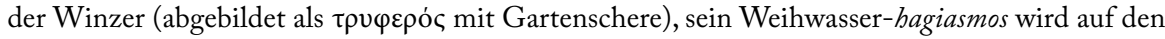
Feldern versprengt (gegen Insekten, auch in Bannsprüchen gegen Schädlinge wird sein Name genannt), in seiner Legende straft er einen Winzer, der an seinem Festtag am Weinberg arbeitet und

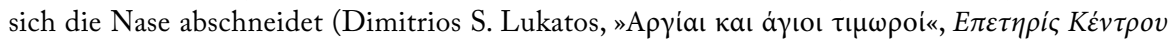

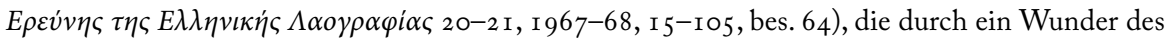
Heiligen wieder angeheilt wird (der Heilige schneidet Nasen auch bei anderen blasphemischen

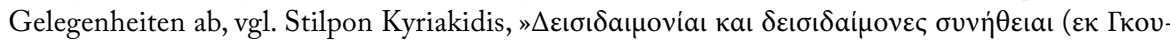

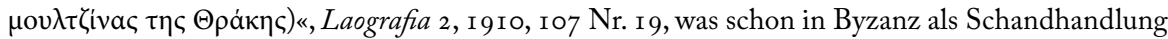

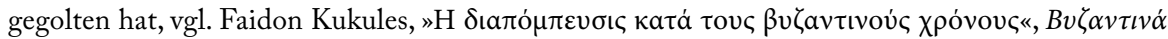

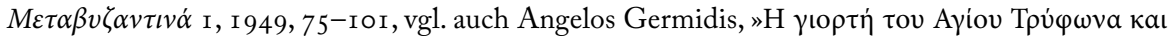

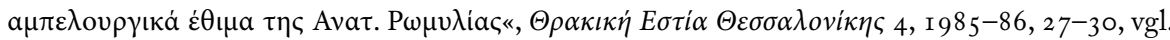
auch Assia Popova, »Ni chair, ni poisson: Tryphon le coupé«, Cahiers de littérature orale 3 ( 1977 ) I 5-69, Lucienne A. Roubin, »Les vignerons danseurs de la Saint Tryphon«, Objets et mondes. La Revue du Musée de l'homme I I/2 (1971) I 83-196); dieselbe Geschichte wird auch vom H1. Symeon (3. 2.) erzählt (Übertragung aufgrund der Proxemik der Festtermine), an dessen Festtag ein Gelage in

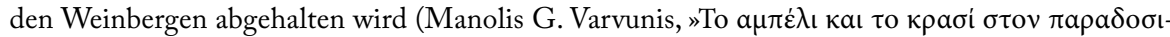

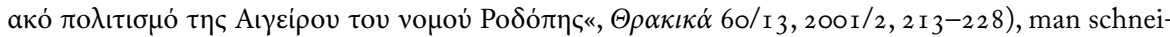
det auch Weinstöcke ab und legt sie an die vier Ecken des Weinbergs (zur magischen Kreisziehung

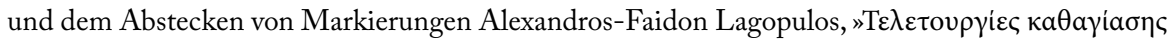

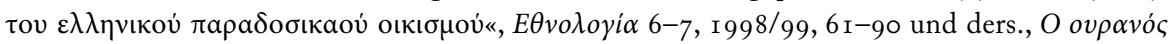

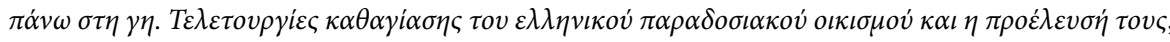
Athen 2003); es folgt der Pestheilige und Beschützer des Viehs H1. Charalampos (ıо. 2.) (Vasilis

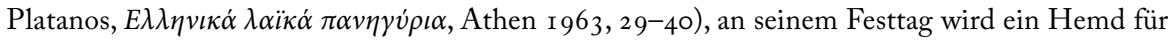

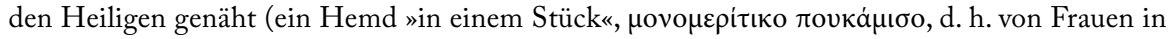

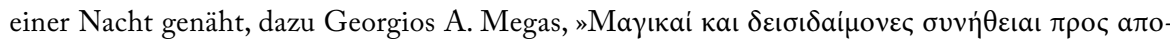

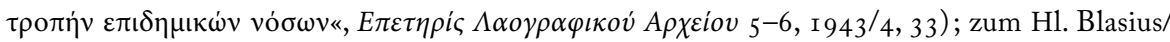
Vlasios-Tag (I r. 2.) gibt es eine Wallfahrt in Ainos (Papathanasi-Musiopulu, op. cit., I 7 I).

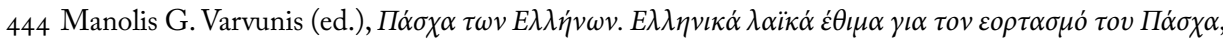

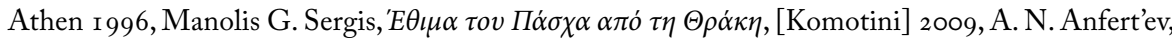
"Zur Geschichte der März-Zeremonien in Griechenland«, Sovietski Etnografie I (I 979) I 33-I39.

445 Z.B. finden am Käsesonntag Pferdewettrennen am Strand des Schwarzmeers statt (Varvunis, $\Lambda \alpha-$

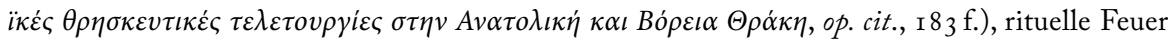
(bubunes) werden entzündet (Elpeniki Stamuli-Saranti, A $\mu \varepsilon \tau \alpha \gamma \dot{v} \rho \omega \tau \eta \varsigma \chi \omega \rho \iota \dot{\alpha}, 2$ Bde., Athen 1 956, I I 48), es wird geschossen und Lärm gemacht (Chri-

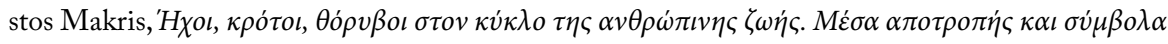

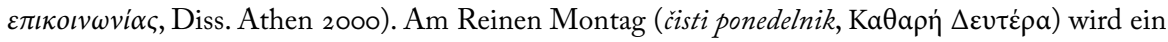


mit dem Lazarussamstag/Palmsonntag verbunden ${ }^{446}$, sodann dem Karwochengeschehen ${ }^{447}$, dem frühlingshaften rituellen Schaukeln der Mädchen ${ }^{448}$, bis hin zu Christi

Ei bei einem hypsoma (geheiligten Baum) vergraben, Reinigung der Küchengeräte vorgenommen, der Fastenbeginn setzt mit einem dreitägigen absoluten Fasten ein; am »Hunde-Montag«, wie der Reine Montag auch genannt wird, wird den unverheirateten Männern in Sozopol ein ungewaschener bänder- und blumengeschmückter Käsetopf auf den Kopf gesetzt und ein Spottlied abgesun-

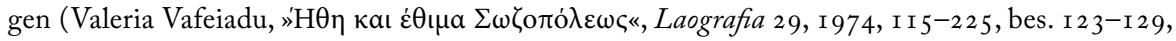
Papathanasi-Musiopulu, op. cit., I I 38-140, solche Spotthandlungen auch beim Blochziehen in

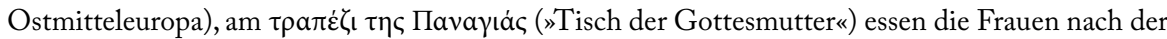
Messe zusammen 20 Fastenspeisen, das satirische Faschingsbegräbnis findet statt, auch mantische

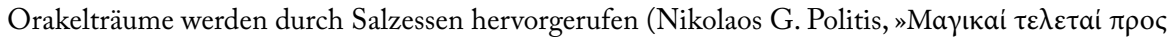

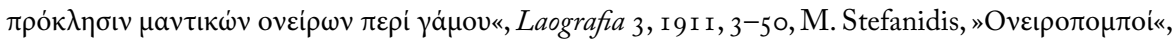
ibid. 7, 1923, 259-265) bzw. werden Salzkringel oder Fastengebäck unter den Kopfpolster gelegt

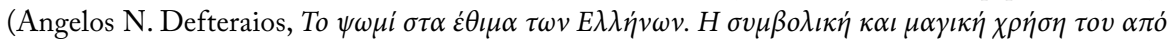

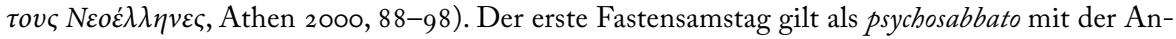
wesenheit der Totenseelen auf der Oberwelt: Totenklagen und trishagia an den Gräbern, Kuchen-

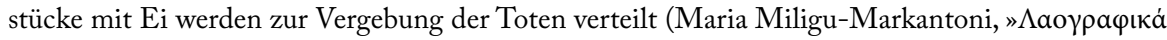

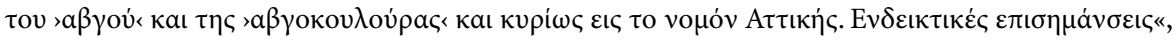

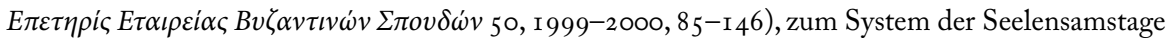
Puchner, Studien zur Volkskunde Südosteuropas, op. cit., 79-83 und Lukatos, $\Sigma v \mu \pi \lambda \eta \rho \omega \mu \alpha \tau \iota \kappa \dot{\alpha}$, op. cit., I $52-155$.

446 Zum Lazarusumzug vgl. wie oben (vgl. auch F. Gearing, „Preliminary Notes on Ritual in Village Greece«, John G. Peristiany (ed.), Contributions to Mediterranean Sociology (Mediterranean Rural Communities and Social Change). Proceedings of the Mediterranean and Sociological Conference, Athens, July 1963 , Paris/The Hague/Athens 1968, 65-72). In Thrakien ist der Umzug nicht »christlich" (paganes Lied wie in anderen Regionen des Zentralbalkans, vgl. Puchner, Die Folklore Südosteuropas, op. cit., 65-68), neben den Mädchen gehen auch Burschen in Mittwinterverkleidungen um (wie die Lazarusumzüge in Südalbanien), in Silivria gibt es auch einen Lazarusknaben in Grün gekleidet

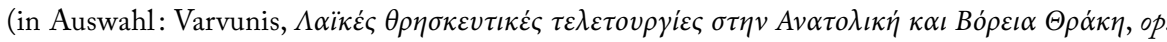

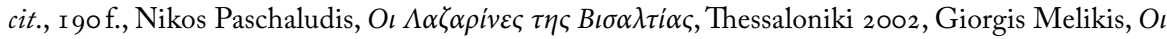

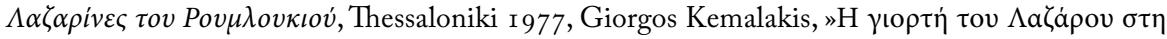

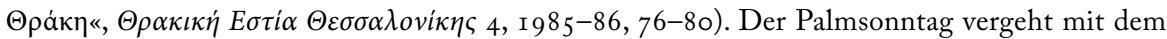
Palmzweig-Schlagen für Gesundheit und Robustheit, der Ungeziefervertreibung usw.

447 In der Karwoche wird die nipter-Szene (Fußwaschung, lavipedium, mandatum) in Madytos (heute Eceabat) gespielt (dazu Puchner, Brauchtumserscheinungen, op. cit., 3 I 9-33 I und neuerdings auch

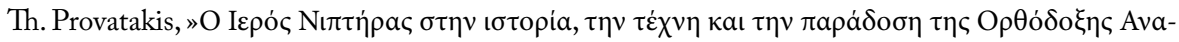

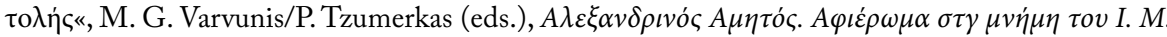
$X \alpha \tau \zeta \eta \varphi \omega \tau i o v$, Alexandria 2008, 47 I-483), die Kranken übernachten und schlafen in der Kirche, die Marienklage wird gesungen, die Eier werden rot gefärbt (Christi Blut, vgl. Vasiliki Papagiotopulu,

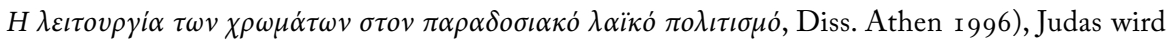
verbrannt, die Blumen vom Epitaph dienen verschiedenen magischen Zwecken usw.

$448 \mathrm{Zu}$ Ostern und in der Nachosterwoche findet das balkanweit geübte fertilitätpromovierende rituelle Schaukeln der Mädchen statt (Martin Nilsson, »Die Anthesterien und die Aiora«, Eranos I5, 
Himmelfahrt und Pfingsten ${ }^{449}$. Unter den stabilen Festen des Lenzes ist vor allem der Schwalbenumzug am r. März zu erwähnen ${ }^{450}$, die zahlreichen Ritualhandlungen am Festtag des H1. Georg (23. 4. $)^{451}$, die spezifischen thrakischen Maibräuche am I. Mai,

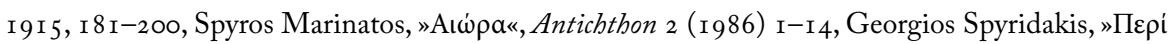

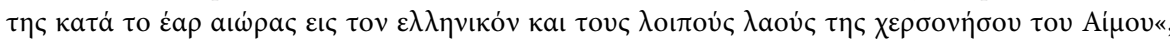

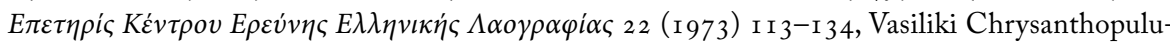

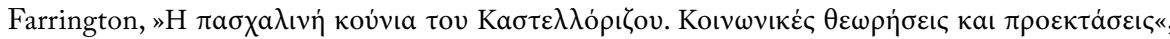

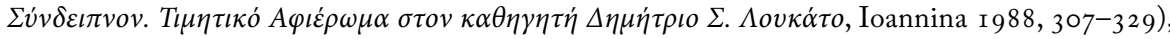
Liebeslieder werden gesungen und Geschenke und Wünsche ausgetauscht.

$449 \mathrm{Zu}$ Christi Himmelfahrt sammelt man Wasser von 40 Wellen und bringt den »behaarten Stein« (Algen) vom Meer ins Haus für Gesundheit und Glück. Am Seelensamstag vor Pfingsten ( $\sigma \alpha \lambda$ เov́) tafelt man an den Gräbern; die Totenseelen müssen nun nach dem 5 otägigen Aufenthalt seit Ostern zurück in die Unterwelt (dazu Puchner, Studien zur Volkskunde Südosteuropas, op. cit., 84-88).

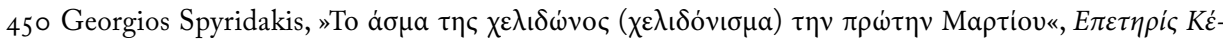

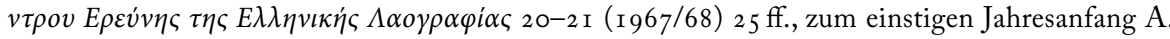
Müller, »Die Neujahrsfeier im römischen Kaiserreiche«, Philologus 68 (r g09) 404 ff, F. Scheider, "Über Kalendae Januariae und Martiae im Mittelalter «, Archiv für Religionswissenschaft 20 (1920/2 I)

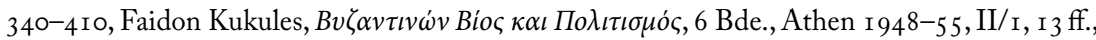

45 I Gabriella Schubert, "Der Heilige Georg und der Georgstag auf dem Balkan«, Zeitschrift für Bal-

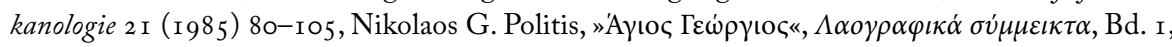

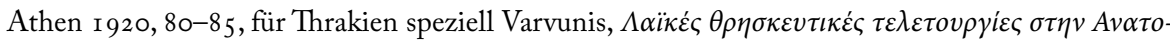

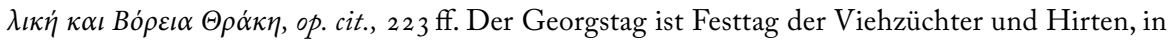
Adrianopel/Edirne nimmt man Wasser vom Fluß in den Mund und bringt es nach Hause ( $\alpha \mu$ í $\lambda \eta \tau$ тo vepó, nach der Lokallegende soll der Heilige diesen Fluß durchritten haben), ähnliches geschieht in Kosti, dem Hauptort der anastenaria/nestinari als Apotropäum und fertilitätspromovierende

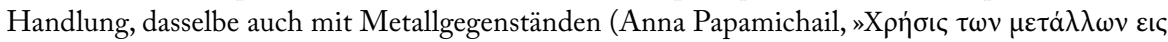

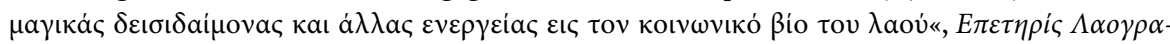

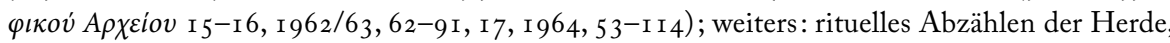
Abwägen der Frauen, Burschen ziehen mit einem großen Zweig mit Blättern an der Spitze als "Fahne" (baïraki) und unter Musikbegleitung von Haus zu Haus, schlagen damit an die Türen und Fenster der Häuser, die Mädchen hängen Tücher an die »Fahne«, alte Frauen rote Tücher, dann werden zwei Schafe in der Kirche geschlachtet (Priestersegnung), ein Symposium findet statt, sodann geht man zur Tenne, dort kommt es zum Ringkampf: Der Sieger bekommt ein Schaf und das schönste Tuch (um Hals gebunden), die übrigen Tücher gehören der Kirche, von ihrem Verkauf geht der Erlös an die Schulen; am nächsten Tag wird bei der hl. Quelle weitergefeiert, mit Wagen fährt man auch in die umliegenden Dörfer (Papathanasi-Musiopulu, op. cit., I 75 f., zur

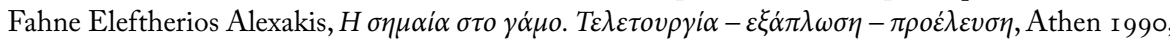

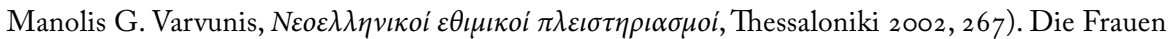

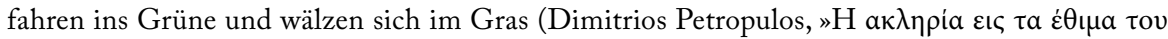

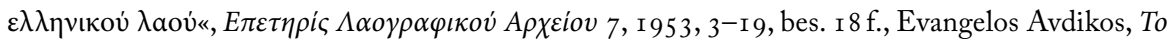

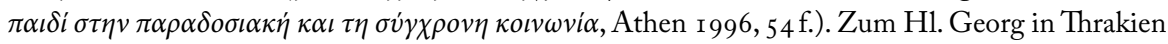

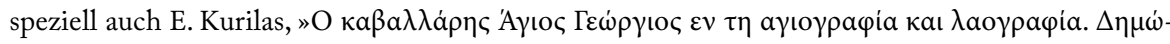

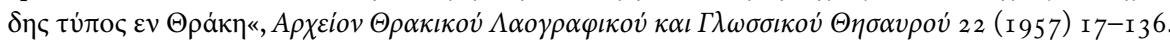


der H1. Christophoros (9.5.), der ein Arbeitsverbot auch für die Muslime bringt und mit Bittlitaneien und Flurumzügen gegen Hagel gefeiert wird ${ }^{452}$. Der Sommerabschnitt mit seinem Bangen um den Ernteertrag setzt mit den Feuer- und Orakelbräuchen am Festtag des H1. Johannes (24. 6.) ein ${ }^{453}$, gefolgt von der H1. Marina (I 7. 7. ${ }^{454}$ und mit besonderer Festaktivität dem Propheten Elias (20. 7.) (55 $^{45}$, der H1. Paraskevi (26. 7.), der

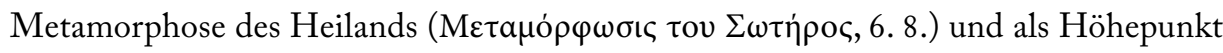

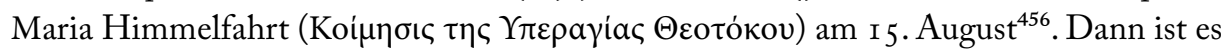
schon Herbst: Taxiarches (8. I r.), H1. Minas ( I I. I r.), Darbringung Marias im Tempel

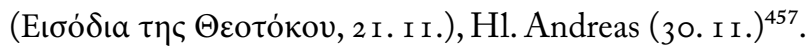

452 Zu Maikugeln, Blumenschmuck, Umzug und Mailied Papathanasi-Musiopulu, op. cit., II 242. Zu der deesis (Bittlitanei) auf den Feldern gegen Hagelschlag in Thrakien Aikaterini Polymeru, "O

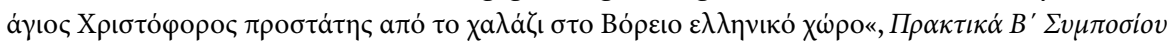

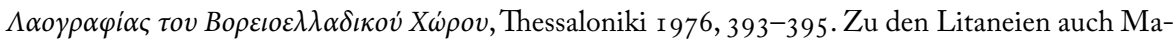

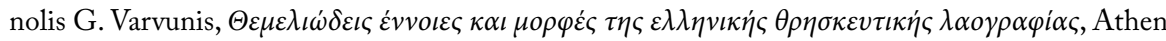
2013, 299-302.

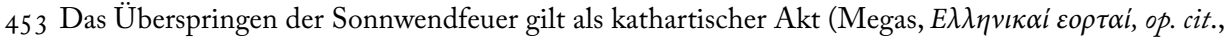
2 I 3 f.). Die Mädchen holen das »ungesprochene« Wasser vom Brunnen und üben den mantischen

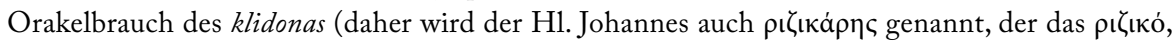
das Schicksal [künftiger Gatte] verteilt); es wird der Toten/Ahnen gedacht, die die Fertilität und

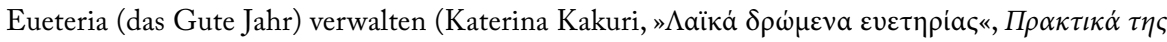

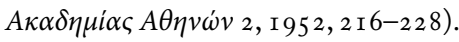

454 Zur Helferin gegen Ernteschädlinge, ihrem Festtag (auch in den Städten) und dem einschlägigen

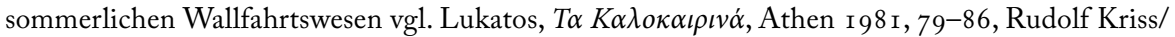
Hubert Kriss-Henrich, »Beiträge zum religiösen Volksleben auf der Insel Cypern mit besonderer Berücksichtigung des Wallfahrtswesens«, Rheinisches Jahrbuch für Volkskunde I 2 (I 96 I) I 35-2 10,

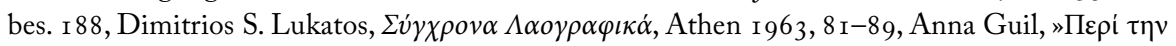

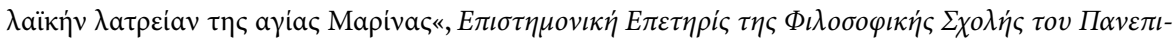

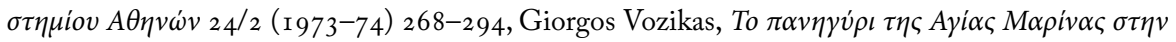
H入ıиं $\pi 0 \lambda \eta$, Athen 2006.

$455 \mathrm{Zu}$ dem auf hochgelegenen Bergkapellen mit Tieropfer usw. gefeierten Donner- und Wetter-Hei-

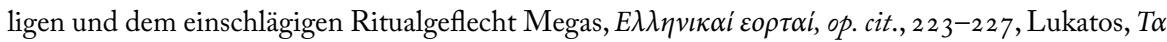

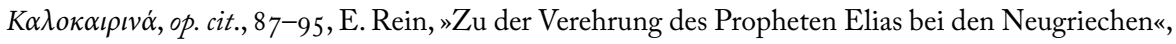

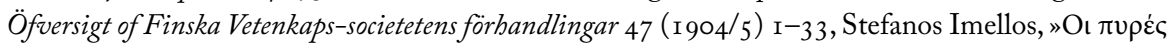

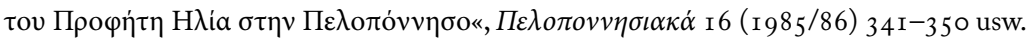

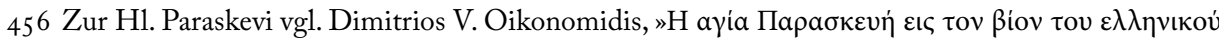

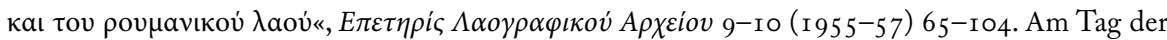
Metamorphose des Heilands kommt es in Thrakien neuerlich zum rituellen Schaukeln, vor allem

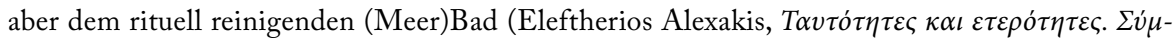
$\beta o \lambda \alpha, \sigma v \gamma \gamma \varepsilon \dot{v \varepsilon l \alpha, \kappa o l v o ́ \tau \eta \tau \varepsilon \varsigma \sigma \tau \eta v} E \lambda \lambda \dot{\alpha} \delta \alpha-B \alpha \lambda \kappa \alpha \dot{\alpha} l \alpha$, Athen 200I, 274 f.), zu Tanz, Liedern und Festgelage. Die Entschlafung der Gottesmutter ist ein Totenfest der nekrolatria, das mit Grabbesuch, Tieropfern, Kehr- und Waschverbot für die Kleider usw. begangen wird.

457 Die taxiarches (Erzengel Michael und Gabriel) gelten als psychopompoi, Seelenbegleiter ins Jen- 
Die komplexeren performativen Riten dieses Kulturraums, der zusammen mit der nördlichen Ägäis, Kleinasien und Zypern einen teilhomogenen Bereich der traditionellen Oralkultur darstellt, werden uns in der Folge noch zu beschäftigen haben.

Donauraum und Karpatenbogen. In dieser Zone, die von dem transdanubischen Fürstentum der Moldau über Siebenbürgen, Ungarn, bis nach Kroatien und Slovenien reicht, ist einerseits der mitteleuropäische und westslavische Einfluß spürbar, andererseits der orientalische und ostslavische Einfluß, in der Oberschichtenkultur der östlichen Zonen auch der griechische aus der Phanariotenzeit (I7 I I/I 5-I 82 I). In den Waldgebirgen der Karpaten sind im 19. Jh. noch relativ archaische Gesellschaftsstrukturen und Institutionen anzutreffen, die in anderen Balkanbereichen nur mehr in Reliktformen existieren. Doch beginnen wir mit dem magyarischen Kommunikationsraum, mit seiner konfessionellen Zersplitterung und den bedeutenden Minderheiten und Untergruppen, die die vielfältige Volkskultur zum Teil geprägt haben. Zentrale Bedeutung für Fest- und Performanzwesen hatte hier die Institution der Spinnstuben, die seit dem I 4./ I 5. Jh. existieren, alle religiöse Nachstellungen und aufklärerische Verbote des i 8. Jh.s überlebt haben und noch im 20. Jh. nachzuweisen $\operatorname{sind}^{458}$. Daneben gibt es natürlich

seits, daher werden die Schuhe im Haus versteckt (Symbole der Seelenwanderung ins Jenseits), damit der Erzengel Michael sie nicht sieht (Papathanasi-Musiopulu, op. cit., I 84). Am Festtag des H1. Minas, dem Beschützer der Herdentiere, müssen die Scheren geschlossen bleiben, damit die Mäuler der Wölfe und die Münder mit den bösen Zungen geschlossen bleiben (Maria Miligu-

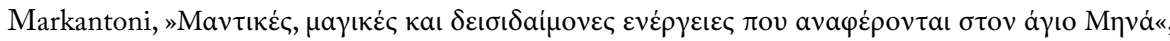
Laografia 33, 1 982-84, 257-267). Am Festtag der Darbringung Marias im Tempel wird für die

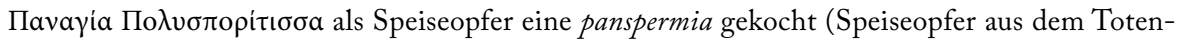
brauch, kollyba/koljivo, vgl. Puchner, Studien zur Volkskunde Südosteuropas, op. cit., 50, 59, 75-78, 284

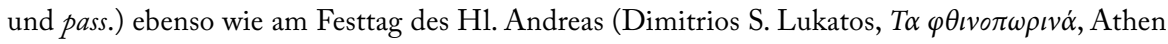
I 982, I 82-1 87, Maria Paraskevopoulou, Researches into the traditions of the popular religious feasts

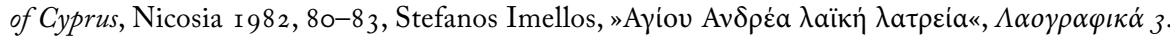

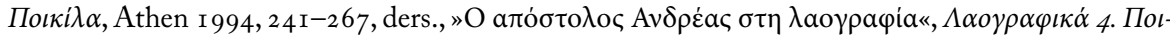
$\kappa i \lambda \alpha$, Athen 2003, 21 5-224).

458 Árpad Lájos, Este a fonoban, Budapest I 974. Im religiösen Schrifttum der Neuzeit wurde diese temporäre Institution der Gemeinschaftsarbeit von Mädchen und Frauen im Winterabschnitt als frivole und unkeusche Versammlung mit obszöne Maskierungen, Geschlechtswechselverkleidungen und unzüchtigen Liedern verunglimpft, obwohl die Leiterin der Spinnstube unerwünschte Besucher des Hauses verweisen kann. Dieses Hausrecht ist auch bei den Einlaßritualen der Sänger und Maskenträger evident (bei komplexeren Spielen holt diese Erlaubnis ein eigener Bittsteller mit Frageversen ein), z.B. beim farsangkönszöntes, dem Ansingelied des Karnevals, der sofort nach dem Theophanie-Fest (H1. Drei Könige) einsetzt und bis zum Aschermittwoch dauert (Tekla Dömötör, »Regelö‘-Monday (The First Monday after Epiphany)«, Acta Ethnographica Academiae Scientiarum Hungaricae 8, 1959, I-25); die Maskierten oder Rußverschmierten halten lange Spieße für die Speckstücke in Händen. Die Einlaßbitte wird im allgemeinen auch unter dem Fenster 
auch das Umzugs- und Prozessionswesen, das sich aufgrund der konfessionellen Vielfalt auf nationaler Ebene nur schwer auf einen Nenner bringen läßt $\mathrm{t}^{459}$. In den katholischen Gebieten ist neben den universellen Lärmumzügen der Kinder und Burschen als regös-Sänger im Mittwinterabschnitt auch der Luzientag (I3. I2.), die vorweihnachtliche Herbergsuche, das Sternsingen und das Krippenspiel mit oder ohne Puppen anzutreffen $^{460}$, die Kinderumzüge zum Blasiustag (3. 2.) und Gregoriustag (I 2. 3. . $^{461}$, das Ausrufen der unverheirateten Mädchen und das Blochziehen am Faschingsende, das Begießen der Mädchen zu Ostern, Maibaum, Wahl und Umzug der Pfingstkönigin, Johannesfeuer usw. ${ }^{462} \mathrm{Zu}$ mobilen Fest- und Ritualterminen gehören Flurbegehungen mit Aufwerfen der Grenzhügel, das Radanschlagen zángózás (ein charivari-Ritus) bei Normübertretungen ${ }^{463}$, Dachgleiche-Riten beim Hausbau, bei Musterung und Ab-

ausgesprochen, nach der Einlaßgewährung sprechen die Besucher ihre Glückwünsche aus, singen und tanzen und bekommen Speck und Wein, die Mädchen Eier; im Falle der Einlaßverweigerung wird ein Bannspruch ausgesprochen. Faschingslieder und Neujahrslieder gehen manchmal eine charakteristische Kontamination ein (z.B. János Berze Nagy, Baranyai magyar népszokások, Pécs I940, I00), nach Maßgabe der Tatsache, daß die Zwölften- und Karnevalsperiode epochenmäßig, klimatisch und mythologisch (Anwesenheit der Totenseelen) auf denselben Grundlagen fußen (vgl. auch Ivan Lozica, »Dva karnevala«, Narodna umjetnost 25, I 988, 87-1 I 3 ).

459 Sándor Bálint, Ünnepi kalendárium, 2 Bde., Budapest I977, Ivan Balassa/Gyula Ortutay, Ungarische Volkskunde, München/Budapest I $982,644 \mathrm{ff}$.

460 Bei den Szeklern (Székelys) wird im Winterabschnitt auch eine Strohpuppe begraben bzw. andere Formen des »Winteraustreibens« geübt. Zu Sternsingen und Krippenspiel mit der Pappkirche vgl. die Photos in Péter Korniss, Bräutigam des Himmels. Bilder ungarischer Volksbräuche, Budapest 1975 , o. S. Weiters András Benedek/Lajos Vargyas, Az istenesi székelyek betlehemes játéka, Kolozsvár 1943. Dazu noch in der Folge.

46 I Der H1. Blasius gilt als Schutzheiliger der Kinder, vor allem gegen die Diphtherie. Die Verkleidungsumzüge der Kinder verwenden gewöhnlich allgemeine und funktionelle für den Sammelumzug Maskentypen, wie Soldat, General, Bischof, Korporal, Fahnenträger, Feldwebel, Speckmeister, Spießer, Korbwächter usw. Der Gregoriustag ist ein Schülerfest, bei dem eine Spendensammlung für die Schule vorgenommen wird.

462 Zum »Anschwärzen« im farsang vgl. die Abb. 298 in Balassi/Ortutay, op. cit. und bei Korniss, op. cit. (im Abschnitt »Kinderspiele - spielerische Bräuche«). Zum Ausrufen der Altjungfern und dem Blochziehen vgl. noch in der Folge. Bei den Palotzen (palóc) wird die kisze-Puppe verbrannt oder ins Wasser geworfen (Balassa/Ortutay, op. cit. Abb. 30I). Das fertilitätspromovierende Begießen der Mädchen zu Ostern (»Keine Blume darf vertrocknen«) geht unter schallendem Gelächter vor sich (vgl. die Abb. »Ostern« in Korniss, op. cit., o. S.). Wahl und Umzug der Pfingstkönigin ist heute zum Kinderbrauch geworden (kleines Kind als Pfingstkönigin, siehe die Abb. in Korniss, op. cit.); zu den älteren Formen des Pfingstkönigpaars Gyula Sebestyén, »A pünkösdi király és királyné«, Ethnographia I 906.

463 Z.B. die Streitsucht von Ehepaaren wird mit Kuhglockengeläut und Geschrei der Leute vor ihrem Haus geahndet, wobei ihre Vergehen aufgezählt werden (ähnlich korrektive Funktion hat das 
schied von der Familie, bei der Firmung, die Umzüge der Marien-Mädchen, der RosenMädchen mit Königinnenwahl usw., aber auch Flurprozessionen bei Trockenheit und Hagelgefähr, Zunftbräuche, Ernte- und Weinlesefeste usw. ${ }^{464}$

Ähnlich wie Spinnstube und das gemietete Tanzhaus die institutionalisierten Versammlungsorte der Kommunität in Ungarn waren, der einzige Ort des sanktionierten Zusammentreffens der Jugend ${ }^{465}$, so ist es auch bei den orthodoxen Rumänen die judia, das Burschenhaus, jedoch mit dem Unterschied, daß hier die männliche Jugend in Form von z.T. paramilitärischen Burschenschaften strengere organisatorische Formen aufweist, die als latente gesellschaftliche Dauerstruktur in der Vorweihnachtszeit, den Zwölften bis zum Karnevalsende, zu Ostern und in der »Rusalienwoche« vor Pfingsten einen Großteil der gesamten rituellen Manifestationen übernimmt ${ }^{466}$. Daneben

parodierenden Blochziehen und das Ausrufen der unverheirateten Mädchen, vgl. dazu noch in der Folge), oder eine Hochzeitsparodie aufgeführt: Ein »Geistlicher« zählt in obszöner Weise die Vergehungen auf (Komitat Bihar).

464 Balassa/Ortutay, op. cit., 706 ff., Tekla Dömötör, A népszokások költészete, Budapest I 974. Vgl. z.B. die Weizeneinsegnungsprozession in Ungarn Balassa/Ortutay, op. cit., I 77 Abb. Nr. 30, den Umgang mit dem Holzpuppen-Husaren (Bak-Husar) auf einem Faß beim nordungarischen Winzerfest in der Tokajer-Gegend des Bezirks Tolnar Abb. im Abschnitt »Weinlese« bei Korniss, op. cit., o. S.

465 Vgl. die stimmungsvollen Abb. bei Korniss, op. cit. (Abschnitt »Tanzhaus«, aus dem protestantischen Dorf Szék bei den Ungarn in Siebenbügen, Jud. Cluj). Das »Tanzhaus« ist im Winter ein gemietetes geräumiges Zimmer mit eingerichteten Sitzen, einem Podium für die Musikanten und dem »Tanzboden«, im Sommer eine große Scheune. Für die Ausgaben (Miete, Musikanten) kommen die Burschen auf, die Mädchen für das Essen. Die seit dem I9.Jh. feststehenden Tanzordnung umfaßt langsame Paartänze mit Gesang, den schnelleren csárdás, die Rundtänze und die virtuosen Solotänze der Männer.

466 Die hierarchische Struktur dieser adoleszenten Gruppierung besteht aus dem Anführer (jude, vătaf), den Funktionären und den Mitgliedern: Zwei sorgen für Ordnung, vier für die Nahrung, es gibt auch einen Ausrufer, Fahnenträger usw. Das Burschenhaus (judia) ist auch ein Ort der Rechtsprechung für die Mitglieder der Organisation, das Festessen, das Gemeinschaftsleben, Empfangsort der Mädchen, die für die Ausgaben der gemeinsamen Veranstaltungen aufkommen; die Burschen beschäftigen sich mit Waffenübungen, Exerzieren, Erlernen von Tänzen und den colindeTexten für den Umzug des colindat mit Prozession, Maskenspiel, Tänzen, paganen Weihnachtsliedern, dem Repertoire der Loblieder auf die Familienmitglieder, veranstalten Pferderennen, treten in paramilitärischen Verbänden parallel zu den Männerbünden auch beim Begräbnis für Unverheiratete auf, bei Hochzeiten, Agrarriten wie dem Feuerrad (roata de foc) und dem ÄhrenkranzRitus (cununa grîului). Sie bilden in ihrer Initiations-Funktion auch die brauchhafte Grundlage für andere paramilitärische Vereinigungen wie die Bogenschützen in der Bukowina (Arcaşii), die Karpatenfalken (S, Soimii Carpaților), die transylvanische Jungmänner (Junii), aber auch die Organisationsstruktur für die berühmten Pferdemenschen călusarii in der Vorpfingstwoche mit ihren akrobatischen Ekstase-Tänzen (dazu noch in der Folge); diese lokalen Burschenschaften befinden 
gibt es freilich auch die Kinder-, Mädchen- und anderen Umzüge, die der orthodoxe Festkalender des heortologions vorsieht ${ }^{467}$. Doch charakteristisch ist der martialische und paradeartige Grundzug dieser Prozessionen, die noch bis zu Beginn des 20. Jh.s geübt ${ }^{468}$ und später von den Kinderumzügen nachgeahmt wurden. Bei der Organisation der z.T. parallelen Kinderumzüge im Mittwinterabschnitt bis zur Quadragesima spielen die Burschenschaften eine wesentliche Rolle ${ }^{469}$; hier taucht auch der colindeț-

sich auch im Austausch (lătureni) mit analogen Gruppierungen in anderen Dörfern (Octavian Buhociu, Die rumänische Volkskultur und ibre Mythologie, Wiesbaden 1974, 44-72).

467 Vgl. wie oben. Zur Übersicht Buhociu, Die rumänische Volkskultur, op. cit., ders., "Die Feiertage des Sommers und Herbstes in Rumänien«, Zeitschrift für Balkanologie 6 ( 1968 ) 3-39, ders., Le folklore roumain de printemps, Paris $1957 . \mathrm{Zu}$ den Lazarusumzügen und verwandten Prozessionen vgl. Puchner, Studien zum Kulturkontext der liturgischen Szene, op. cit., 48-54, zu calojanul vgl. wie oben.

468 Um I 885 marschierten in der Moldau etwa 50 Burschen, unter Anführung des vătaf oder primicer

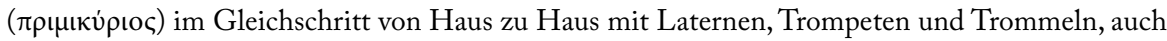
in Nationaltrachten mit Fahnen und Kriegsliedern (Vasile Adăscăliței, »Teatru folcloric cu subiecte de război în Moldova«, Lîmbă și Literatură ıo, I 965, 328); in Siebenbürgen, im Banat und in der subkarpatischen Region war diese Parade bis I 9 I 4 lebendig, aber auch als Kinderumzug, der den Burschenaufmarsch in den Zwölften imitiert. Bei den Aromunen in Makedonien werden diese durch Blutsbrüderschaft verbundenen Mitglieder der Burschenschaft caracandzali genannt (der Name der Zwölftendämonen auch im Märchen Pericle Papahagi, Basme Aromâne, și glosar, București 1 905, 558); in der Moldau führten sie die Scheinpflügung (pluguşor) durch, in Transylvanien das Feuerrad (roata de foc). Zwölften und Karneval bilden eine einzige Maskenperiode mit ähnlichen Riten (Richard Wolfram, »Altersklassen und Männerbünde in Rumänien«, Mitteilungen der Anthropologischen Gesellschaft in Wien 44, I 934, I I 2-I 28). Zur Blutsbrüderschaft Octavian Buhociu, Le folklore roumain de printemps, Paris I957, I 83 u. pass., Leopold Kretzenbacher, Rituelle Wablverbrüderung in Südosteuropa, München I 97 I, ders., "Serbisch-orthodoxe $>$ Wahlverbrüderung zwischen Gäubigenwunsch und Kirchenverbot von heute«, Südost-Forschungen 38 (I979) I63-I 83 (Geheiligtes Recht, Wien/Graz/Köln I988, 233-252), ders. "Kirchlich eingesegnete Wahlverbrüderung in Südosteuropa «, Ethnologia Europea, München 1986, I 27-I34, Walter Puchner, »Adoptio in fratrem. Kirchliche Segnung der Wahlbruderschaft zwischen theologischem Verdikt und gelebter Pastoralpraxis«, Studien zur Volkskunde Südosteuropas, op. cit, 353-383 und ders., "Griechisches zur radoptio in fratrem«", Südost-Forschungen 64 (1994) I 87-224.

469 Kinderbeteiligung ist auch bei der Idolbestattung des calojanul üblich (Marcu Beza, Paganism in roumanian folklore, London 1 928, 32-36) ebenso wie bei der Totenwache (Simion Florea Marian, Inmormântarea la Români, București i 892, I 96 f.). Diese Kinderumzug zu Weihnachten oder am Lazarussamstag umfassen gewöhnlich 10-50 Mitglieder, manchmal auch über roo (Simion Mangiuca, Călindariu Julian, Gregorian, Brașov I 882, 9-13). Alle halten den bedeutungsvollen Stock in der Hand (colinda, im Westen auch pițarei genannt), als colindători (Elisabeta Moldoveanu-Nestor, "Date inedite privind practicile folclorice tradiționale de Anul Nou în zona Buzău«, Revista de Etnografie și Folclor 1971, 307-325) bilden sie etwa in Siebenbürgen mehrere Gruppen von 5-1o Mitgliedern, wobei die größeren Burschen im Morgengrauen beim Feuer die Ränge und Funktionen unter den Kindern verteilen: Es wird der vătaf bestimmt (mit kohlegeschwärztem Gesicht), der 
Stock auf, der im Hochzeitsbrauchtum als Steckenpferd benützt wird, aber auch bei den călușarii ${ }^{470}$.

Die Feingliederung der Hierarchien und Funktionen und die Zeremonialisierung der Versammlungen und Umzüge unterliegt manchmal einer erstaunlichen Systematisierung $^{471}$; Prozessions-Formierung mit Aufstellung und Fahne, Maskierung, Musik, Tanz

rîndaș (»Knecht«, als Zeremonienmeister sorgt er für die Aufstellung), der cîneru (Hundebursch), zwei scobicei zum Aufschüren des Feuers in den Häusern, ein focari (Feuerwächter), mehrere motcoși (die Unordnung in den Zimmern verursachen), die norocoși (die in Ställe gehen und Glück und Gesundheit für Vieh bringen); alle zusammen singen den »Moș Ajunul« (Onkel Vortag), tragen Taschen für die Gaben (colindeți), Stöcke haben hier nur die Ranginhaber (meist aus Haselnuß, z.T. auch kunstvoll geschnitzt, mit Wollfäden und Bändern verziert). Dieser Brauch wird auch bei den Rumänen in Serbien geübt. Diese bedeutungsvollen und polyfunktionalen Stöcke sind, wie oben erwähnt, bei den Mittwinterumzügen auf der ganzen Balkanhalbinsel verbreitet und übliches Requisit der theriomorphen Verkleidung.

470 In Oltenien und Argeș bilden sich drei parallele Kinderumzüge: etwa 5o Kinder bis 9 Jahre, roo von 5-10 Jahren und I 50 von Io-20 Jahren: Sie werden im Burschenhaus in ihrer Aufstellung für den Häuserumgang organisiert, die ganz Kleinen singen nicht die colinde, sondern sagen gleich den Heischespruch, sie schüren das Feuer auf und bekommen Kringel (Mariana Kahane, OObiceiul colindatului în satele Lupșa de sus (Strehaia, Oltenia) și Bărbătești (Horezu, Argeș)«, Revista de Etnografie și Folclor 1 965, 425 ff.). Der von allen mitgeführte colindeț-Stock wird bei Hochzeitsbräuchen zum Steckenpferd: Der Anführer des Bräutigamzuges muß als Reiter sein »Pferd« tanzen lassen, der Brautführer versucht, ihm den Stock zu entreißen, gelingt ihm dies, so gilt es als Ruhm für das »Brautheer (Elena Sevastos, Nunta la Români, București I 889, I 57). In der Moldau werden auch Pferdewettrennen beim Hochzeitshaus veranstaltet (Simion Florea Marian, Nunta la români, București r 890, 6 rof., Elena Niculiță-Voronca, Studii in folclor, Bd. I, București r 908, 94), der Sieger bekommt einen Stock mit Fahne (= Pferd); derselbe Stock wird als buzdugan bei paramilitärischen Burschenschaften in Brașov als Waffe gebraucht (Ion Mușlea, Obiceiul junilor brașoveni, Cluj I930, ders., "Noi contribuții la studiul Obiceiul junilor brașoveni«, Anuarul Muzeului Etnografic al Transilvaniei 1 962-64, 225-248, Wolfram, »Altersklassen und Männerbünde in Rumänien «, op. cit. I I 4), als Pferdeattrappe bei den Trancetänzern der călușarii (Romulus Vuia, »Originea jocului de călușari«, Dacoromania 2, I 92 I-22, 2 I 5-254, bes. 2 I6-2 I 8.), in Oltenien und Banat gilt ganz derselbe, schon bei Dimitrie Cantemir erwähnte (Dimitrie Cantemir, Descrierea Moldoviei, București I 94I, I 68) Stock als Schwertersatz (Tudor Pamfile, Sărbătorile la români. Crăciunul, București I 9 I 4 , I62-r96). Dieses polyfunktionale Hauptrequisit der Winterumzüge und Maskierungen in ganz Südosteuropa bildet einen interessanten Exempelfall der Polysemie und Bedeutungsambivalenz, die zwischen praktischem Gebrauch, morphologischer Symbolik und dem Situationskontext oszilliert: Requisit zum An-die-Türen-Hämmern, Auf-den-Boden-Stampfen, Lärminstrument, rhythmische Begleitung der kalanda/colinde-Lieder, phallische Bedeutung als Fruchtbarkeitsspender (Berührungsmagie), Schwertersatz und Schlagwaffe, Fahnenstock, Steckenpferd.

47 I Dazu einige Fallbeispiele: Bei den Burschenschaften in Țara Oltului wird bei der jährlichen Versammlung in der Vorweihnachtszeit (toană) der Anführer gewählt (birău, auch primicer, meist jedoch jude oder vătaf), dem das Strafrecht obliegt, zwei Stockhalter (vornici), die auch für Essen 
und colinde-Gesang bilden ein multimediales Schauspiel mit bemerkenswertem ästhetisierenden Formwillen. Doch dieses Umzugs-System erfährt in Siebenbürgen auch eine mikroregionale Vernetzung durch die »Seitengenossen« (lătureni) und die »Gastspiele« in den umliegenden Dörfer, die auf einem geregelten gegenseitigen Austauschabkom-

und Trinken sorgen, zwei Richter (juzi), verantwortlich auch für das Geldkassieren, zwei Herolde (pristavi), die auch Kontrollfunktion ausüben, und vier Schulzen (pirgari), die die Anweisungen ausführen. I 2 Tage lebt man zusammen im Versammlungshaus, in großen Dörfern in zwei Gruppen: unverheiratete Burschen unter und über 2 I Jahre; Mädchen werden zu Tanz und Festschmaus eingeladen, man zieht mit der turca-Maske herum (Vasile Adăscăliței, »Jocul Cerbului în Moldova«, Revista de Etnografie și Folclor 1968, 42 I-438), zwei Burschen singen dialogisch die colinda, der turcar oder cerbutul mit der Holzmaske mit beweglicher Zunge und dem Hirschgeweih tanzt dazu (Einzelheiten bei Teodor T. Burada, »Priveliști și datini strămoșești«, Arbiva 20, Iași I 909, 289-306, Gheorghe Vrabie, Folclorul. Obiect, principii, metodă, categorii, București I 970, 426-5 10); die Tänzer werden vor den Umzügen vom Priester gesegnet, beichten und kommunizieren aber erst am ersten Tag der Quadragesima (Einheitlichkeit der Maskenzeit von Zwölften und Karneval). In Siebenbürgen konstituiert sich die Burschenschaft in der judia durch die Versammlung (strînsul feciorilor) und die Wahl des jude oder vătaf wird vorgenommen: Weiters werden gewählt ein »Bürger« (pîrgarul mare), der Geld von den Mädchen einsammelt, ein pîrgarul mic, zuständig für den Schnaps, der goagă (Neuankömmling) trägt den Beutel mit den Gaben (Victor Tulbure, »Strînsul feciorilor la Crăciun«, Transilvania 36, I 905, 9 ff., I. G. Pitiș, »Turca la Perșani«, Revista Nouă 6/8-9, I 894, 344-346). Das Erlernen der colinda-Lieder wird von den Alten kontrolliert, mit Trommel, Fiedeln und Dudelsack geht man in Festkleidung nach dem Segen der Honoratioren auf den Sammelumzug; in den Häusern singen zwei Gruppen im Wechselgesang die colinda, man tanzt mit den Mädchen des Hauses und wird bewirtet; um Mitternacht kehrt man in die judia zurück und rechnet ab; die cerbut,-Maske wird hier nicht verwendet (Sabin V. Drăgoi, »2o de colinde din com. Zam-Hunedoara«, Revista de Etnografie și Folclor I 957, II, 5). Am nächsten Sonntag werden colinda im Morgengrauen am Fenster gesungen, nach der Messe kommt es zu einem öffentlichen Reigen$\operatorname{tanz}$ im Dorf, bis zum 7. I. wird in den Häusern der befreundeten Mädchen der Rangträger getanzt, am 8. r. zum letzten Mal in der judia, das Geld wird von den Mädchen einkassiert. In Hunedoara gibt es auch Maskentänze (Tibolt Schmidt, »Turca în comitatul Hunedoarei«, Transilvania 4I, I 9 IO, I 35-I 46, bes. I 40 f.): Der »Hirsch« fängt die Münzen mit dem Maul auf, neun von den insgesamt ca. 40 Themen der Speziallieder werden gesungen, die Tochter des Hauses wird zum Fest am dritten Tag nach Weihnachten eingeladen. Dort wird die Maske abgenommen; der "Hirsch" stirbt zu Neujahr, der letzter Tanz des turcaş findet an der Wegkreuzung vor dem Dorf statt: Einer »erschießt« den »Hirschen«, der »Pope« begräbt die Maske und die »Popenfrau« beweint sie, in der judia wird die Maske auf eine Leiter gehängt, beim Festessen bleibt der Ehrenplatz frei für den Hirsch. Noch ein Bespiel: In Drăguș in T, ara Oltului fand die Wahl 1932 am Nikolaustag (6. I 2.) statt (Wolfram, op. cit., I I 2): Gewählt wurden der große Anführer (vătaful cel mare), ein Bursch über 2 I Jahre, der kleine Anführer (vătaf cel mic), der Kassier usw. Bei den zweiwöchigen Mittwinterumzügen wird die Fahne vom kleinen Anführer getragen, die aus Tüchern der Mädchen besteht (Octavian Buhociu, Le Folklore roumain de printemps, Paris 1957, 65-76 u.pass., Beschreibung der Hochzeitsfahne auch in G. Cernea, »Nunta la Paloș«, Folclor din Transilvania 2, I962, I49). Am Neujahrstag tanzt man auch mit den kleinen Mädchen. 
men beruhen (ganz im Gegensatz zu den zentralbalkanischen Zusammenstößen der Maskengruppen $)^{472}$. Die oft durch Blutsbruderschaft verbundenen und auch berittenen Burschenschaften, manchmal auch mit Statuten und Reglementen für ihre Organisation und ihr Funktionieren, übernehmen auch anderen kommunale Aufgaben, wie das Ausrufen der nichtverheirateten Mädchen (strigarea pesta sate), die scheinobrigkeitlichen Gerichte am Ostertag für Vergehen gegen die Kommunität und ihre sozialen Normen usw. ${ }^{473}$

472 In Zentraltransylvanien gehen die Burschenschaften nach dem Einüben der Lieder als Gäste in die Nachbardörfer, wo sie bewirtet werden und mit den Mädchen tanzen; der Austausch wird durch Versammlungsbeschluß festgelegt und kann auch weitere Dörfer umfassen, so daß in den Zwölften ein ganzes interaktives Netzwerk von solchen Besuchen und Gegenbesuchen entsteht (Alexiu Viciu, Colinde din Ardeal. Datini de Crăciun și credințe poporane, București I 9 I4, Io ff.). Die Versammlung wird durch den Brummton des bucium, einer alphornähnlichen langen Flöte, am Vorabend von Weihnachten einberufen: Es werden zwei vătafi gewählt, zwei wachhabende Hochzeitsredner (colăceri), zwei Korporale (căprari), die sich um das Weihnachtsgebäck kümmern; der Umzug geht in zwei Gruppen vor sich, am Folgetag geht man ins Nachbardorf mit Haken für die Kringel, wird von den lătureni mit Musik und Umtrunk willkommen geheißen, spendiert Geldsummen als eine Art Kaution; den Höhepunkt des Besuchs bildet das Gastmahl und die Tänze mit den Dorfmädchen; am dritten Tag erfolgt die Rückkehr. Damit wird das Austauschprogramm in Bewegung gesetzt: Die Begastung der Nachbardörfler erfolgt ebenfalls drei Tage lang. Der Wahltermin variiert von 40 Tage vor Weihnachten bzw. dem Nikolaustag bis zum letzten Sonntag vor Weihnachten bzw. dem Vortag vor dem Christtag. Der Wahlvorgang sieht folgendes vor: Nominalvotum oder Losziehen, oder die Wahl wird der Muskelkraft der Wähler anheimgestellt: körperliches Emporheben der Einzelkandidaten für das Amt des vătaf, bis sein Kopf an das Hausgebälk stößt (Wahlerfolg), während die, die dagegen sind, nach unten ziehen (Ion Chelcea, „Organizarea tradițională a tineretului în viața satelor noastre«, Revista Fundației Regale 1942, 356-359). In der Region Cluj/ Klausenburg werden auch vier chizeși gewählt, die für die Unterhaltung verantwortlich sind. Vielfach sind diese Burschenschaften auch am Thomassonntag aktiv, zu Fastnachtsende, am Palmsonntag, zu Christi Himmelfahrt und am Pfingstsonntag. Die Institution besteht mehr oder weniger das ganze Jahr über und hat deutliche Initiationsfunktion für beide Geschlechter (Kennenlernen der Jugend in einer Mikroregion); in Moldau und Muntenien besteht kein Gemeinschaftshaus mehr, wohl aber die Ränge und Funktionen sowie die Vorführungen mit Maskierung und Tanz. Ein Komitee (vălăret) organisiert hier die Aufführung der horă-Tänze. Ähnliche paramilitärische Burschenschaften sind die Arcași-Bogenschützen in Bukovina, die Șoimii Carpaților in Siebenbürgen (Karpaten-Falken) (Vasile Ion Farca, The falcons of Rumania, Cleveland/Ohio I 966), die Junii (Jungmänner) in der Region von Brașov (Ion Mușlea, Obiceiul Junilor brașoveni, Cluj I 93o, ders., "Neue Beiträge zum Brauch der Juni brașoveni<, Anuarul Muzeului Etnografic al Transilvaniei I 96 I-64, 22 5-248, G. I. Pitis, »Sărbătoarea junilor la Paști«, Revista Nouă I 899, 278-280, 299-303, ders., »Junii la Crăciun«, Convorbiri Literare 24, I890, 1056-63) und die căluşarii in Südrumänien von Maramureș bis zur Donau (Buhociu, Le folklore roumain de printemps, op. cit., 235-266, Horia Barbu Oprișan, Călușarii, București I 969 , Gheorghe Focșa, »Les village roumain pendant les fêtes religieuses d'hiver«, Zalmoxis 3, 1940-42, 6 1 -102). Doch dazu noch in der Folge.

473 Das am Theophanietag ins Wasser geworfene Kreuz (hagiasmos) wird von den Burschen mit der 
Es darf angenommen werden, daß diese polyfunktionale Institution der Burschenschaften, wie sie vor allem aus den älteren rumänischen Quellen hervortritt, die manifeste Form einer latent vorhandenen Sozialstruktur und spezifischen Jugendkultur mit initiativer und gruppenstabilisierender Funktion und Hilfestellung für das öffentliche Wohl der Kommunität in den traditionellen Lokalgesellschaften des weiteren Balkanraums bildet, deren spezifische Morphologie, Organisationsweise und Effizienz nach Maßgabe der lokalen und regionalen historischen und politischen Gegebenheiten sehr unterschiedlich sein kann. Zugleich bildet diese »Jugend« und ihre Umzüge auch ein repräsentatives Idealbild der Kommunität selbst, eine öffentliche Schaustellung der Verwirklung der imaginären sozialen Rollenvorbilder, eine performative Präsentierungsfunktion, die späterhin Kirche, Schule und Staat übernehmen werden.

Gegen Westen zu in den katholisch/protestantischen südslavischen Regionen ist dieser Prozeß des Eingriffs obrigkeitlicher Instanzen in die autochthone und teilautonome Selbstorganisation der Kommunitäten durch den italienischen und habsburgischen Kultureinfluß und die venezianische und ungarische Administrationszugehörigkeit schon viel früher vor sich gegangen, so daß das Kronland Slovenien und das magyarisch verwaltete Binnenkroatien nicht mehr ohne mitteleuropäische Vergleichsbasis zu untersuchen sind, ebenso wie der dalmatinische Küstenstreifen und die Adria-Inseln mit den anderen Insel-Besitzungen der Serenissima in den Meeren rund um die Balkanhalbinsel in Komparation zu stellen sind. Unter dem Einfluß der Ordenstheater und der elaborierten innerösterreichischen religiösen Volksschauspielkultur ist der Zug zu Dialoghaftigkeit, Dramatik und Theatralität der Masken- und Umzugsspiele höher zu veranschlagen als für den eigentlichen Balkanraum ${ }^{474}$, dem als Teil des Osmanischen

Fahne reitend aus dem Fluß geholt; diese besprengen die Leute auch mit dem geweihten Wasser. An diesem Tag findet auch eine kollektive Kindertaufe der Neugeborenen während der Zwölften (Dämonengefahr) statt, die Burschen organisieren Pferderennen, ähnlich wie am Samstag der Hl. Theodore (Tudorica, San Toader), dem wichtigsten psychosabbaton der Karnevalszeit, das schon in die Fastenzeit fällt; der Hl. Theodor, »das große Pferd« (mit den santoaderi, dem zentaurenhaften Gefolge), ist auch der Schutzheilige der Bluts- und Wahlbrüder (zu den Brauchhandungen am ersten Fasten-Samstag der kollyba-Segnung, im Zentralbalkan auch »Pferde-Ostern« genannt, konski velikden, wegen der rituellen Hippodromien, vgl. Puchner, Studien zur Volkskunde Südosteuropas, op. cit., 78-84). Zum Ausrufen der nichtverheirateten Mädchen auch Victor Păcală, Monografia satului Răşinari, jud. Sibiu, Sibiu I 91 5, I 89; die Anklagen beim Ostergericht, wo der vătaf das Urteil spricht und die Strafen verhängt, betreffen üblicherweise mangelhaften Ackerbau, Trunkenheit, Diebstahl usw.

474 Ein gutes Beispiel dafür sind der Sammel- und Textbände von Niko Kuret, Slovenska koledniška dramatika, Ljubjana 1986 und Ivan Lozica, Folklorno kazalište, Zagreb i 996. Daneben gibt es jedoch auch Maskierungs- und Verkleidungsformen, die mit mittel- und südosteuropäischen Gegebenheiten konform gehen. Niko Kuret etwa dokumentiert in seinem Buch Maske slovenskih 
Reiches diese Theatertraditionen, die bis in das Spätmittelalter und den Humanismus zurückreichen, abgeht ${ }^{475}$.

Zentraler Balkanraum. Darunter sei in dieser exkursiven Zusammenstellung Hercegbosna, Montenegro, Nordalbanien, Kosovo, das heutige Serbien, Bulgarien, sowie die grenzübergreifenden Kulturlandschaften Makedonien, Epirus und Thessalien verstanden, die sprachlich südslavische Bevölkerung, aromunische, albanophone und hellenophone umfassen, Orthodoxe, Muslime sowie Katholiken ${ }^{476}$. Auch hier dominiert in

pokrajin, Ljubljana 1984 folgende Maskentypen (jeweils mit Photographien und Verbreitungskarten): die schon genannten šeme ( 107 ff.), die mittwinterlichen theoriomorphen otepovci in Bohinj ( I 5 ff.), die alte Schreckhexe pehtra baba (I 23 ff.), die lucija am I 3. I 2. (I 37 ff.), die NikolausMaskierung des miklavž (I $45 \mathrm{ff}$.), die zoo- und anthropomorphen Faschingsmasken (fašanek) in 46 verschiedenen Lokalzonen ( $162 \mathrm{ff}$.), wobei moderne Entwicklungen nicht ausgeschlossen bleiben, den zeleni jurij und die St. Georg-Bräuche (423 ff.), Hochzeitsmasken (437 ff.), Sternsingen und Dreikönigsspiel (kraljitarji, 46 I ff.) usw. Vgl. dazu auch B. Zlabadnik, Volksbrauchtum der Kärntner Slowenen, Klagenfurt I 992, ders., Od zibelke do groba, Čelovec I 982 . Ähnlich, aber auf den Karneval beschränkt, ist das materialreiche Buch von Ivan Lozica, Hrvatski karnevali, Zagreb I 997, das als rezente Bestandsaufnahme (viele Photos) konzipiert ist: r. Teil (7-54) Sinn- und Gestaltaspekte, 2. Teil (55-190) Kroatien nach Orten, 3. Teil (r9I-244) Anatomie des Karnevals, wobei der städtische vom ruralen Typ unterschieden wird. Spezifische Regionen und Maskentypen kommen zur Sprache, wie Baranya (Ungarn), das Zwischenmurgebiet, Scheinhochzeit in Lobor (79 ff.), der urbane Karneval in Zagreb (86 ff.), Samobor, die dialogische buzeštini in Istrien, das Robinja-Spiel auf der Insel Pag (I 33 ff.), die Glockenmänner der zvončari in Kasavštin (I I I ff., vgl. auch Lidija Nikočević, "Zvončari u zapadnom dijelu Kastavštine«, Narodno stvaralaštvo Folklor 24/I-4, I 985, 22-35, Nikola Bonifačić-Rožin, Narodne drame, poslovice i zagonetke, Zagreb 1963, 67-70), die Fastenfrau und das Faschingsbegräbnis in Novo Vinodolski ( 20 ff.), die Inseln Krk und Olib, die čarojice in Bucovica (vgl. auch Vladimir Ardalic, »Bucovica (nastavak), Godišnji običaji: domaći (kućni) običaji kod svetkovanja«, Zbornik za narodni život i običaje južnih Slavena 7/2, I 902, 237-294), Radošić bei Split, Split, Imotsk ( 58 ff, die Sprechdialoge in Ivan Lozica (ed.), Folklorno kazalište (Zapisi i tekstovi), Zagreb I996, I 55-1 58), das moreška-Spiel mit dem Waffentanz der kumpanija auf der Insel Korčula (г6I-I67 zusammen mit dem Spieltext, siehe auch Vid Vuletić-Vukasović, Narodni običaji na otoku Korčuli, Zagreb I 89 I, Vinko Foretić, »Prilozi o moreški u dalmatinskim gradovima«, Zbornik za narodni život i običaje južnih Slavena 42, 1964 , I 55-1 82 und eine ausgedehnte neuere Bibliographie), der Frauenkarneval in Lastovo ( 7 I ff., Folklorno kazaliste, op. cit., I 20-I26, Ivan Lozica, "From Ritual to Theater and Back: The Lastovo Island Carnival«, Narodna Umjetnost 32/. I I 995, I 55-179), die turca-Maskierung in Dubrovnik ( 182 ff.). Vgl. des weiteren in Auswahl: Nikola Bonifačić-Rožin, »Pokladne maškare u Konavlima«, Narodna umjetnost 4 (1966) I 53-I 74, ders., "Narodna drama i igre u Sinjkog krajini«, ibid. 5-6 (I 968) 5 I 7-578, ders., „Maškare i njihove dramski igre na otoku Braču«, ibid. I I-I 2 (I 975) 365-396 usw.

475 Vgl. Walter Puchner, Die Literaturen Südosteuropas (15. bis frühes 20. Jahrbundert). Ein Vergleich, Wien/Köln/Weimar 2014, $193 \mathrm{f}$.

476 In dieser sprachlichen Zuordnung sind Roma, Romanioten, Sefarden, Armenier u.a. Sprachmin- 
Bezug auf die Maskentermine deutlich der orthodoxe Festkalender. Nur im Donaubekken im Nordwesten von Serbien lassen sich auch Maskentermine ausmachen, die eher typisch für das westkirchliche Ostmitteleuropa sind, wie Nikolausumzüge, St. Lucia, Krippenspiel, Sternsingen und Dreikönigsspiel, Paradeisspiel usw. ${ }^{477}$, während die koledari universelle Verbreitung besitzen ${ }^{478}$, die sirovari allerdings nur im Südosten gegen Bulgarien $\mathrm{zu}^{479}$. Speziell in der populationsmäßig hybriden Vojvodina (Serben, Ungarn, Rumänen) überschneiden sich die Kultureinflüsse unentwirrbar ${ }^{480}$. Eine gewissen Maskengrenze zwischen NW und SO läßt sich bei den Pfingstwochenumzügen feststellen:

derheiten nicht berücksichtigt, da sie für das Maskierungswesen keine ausschlaggebende Rolle spielen.

477 Vesna Marjanović, Maske, maskiranje i rituali u Srbiju, Beograd 2008, 69-244, Verbreitungskarte 72. 4. I 2. Sv. Varvare, I 2. I 2. Sv. Lucije, 5./ I 8. I 2. Sv. Nikole, 24. I 2/6. I. badnjeg dan (Christblock), zu Weihnachten vertep (Krippenspiel), Sternsingen und Dreikönigsspiel, Paradeisspiel.

478 Die koledari bingen neben den Lobliedern auch Weihbrot mit (koledarski kolač), sind von martialischem Gehabe und Aussehen, oft phallisch, mit Glocken um die Mitte gebunden und einer Tiermaske auf dem Kopf, manchmal auch Pferdeverkleidung; übliche Maskentypen sind das altes Paar (majka/dada, stašca/staric, deda/dedica) und das Brautpaar (Tihomir R. Đorđević, Srpske narodne igre, Beograd I 907, 42 f., Slobodan Zečević, Srpske narodne igre, Beograd I 983, 69, Dragutin T. Đorđević, Život i običaji narodni u leskovačkom kraju, Leskovac 1985 , 50-53, Petar Kostić, »Godišnji običaji u okolini Zaječara", Glasnik etnografskog muzeja 42, I 978, 399-44I, bes. 403 f., 4I 5 f.); dedica bei den Serben in Kosovo (D. Janković, »Igrame pod maskama u Sbriji«, Narodno stvaralaštvo 6, I 963, 40 I407, bes. 40 I, Tatomi Vukanović, Srbi na Kosovu II, Vranje 1986, 377-379), dort auch kalinarke (D. Debeljković, »Običaji srpskog naroda na Kosovu polju«, Srpski etnografski zbornik 7, I 907, 3 I 6-3 I 8 , V. Kozarac/K. Halimi, »Kalinarke«, Glasnik Kosova i Metohije I, Priština I95 2, 3 I I-3 I 4).

$479 \mathrm{Zu}$ den sirovari Marjanović, op. cit., 85 f., zu den survački/survaknici Vakarelski, Bulgarische Volkskunde, op. cit., 3 I 7 f.; anders die Wolfsverkleidung der vučari, die sich auf das Berggebiet westlich von Kragujevac beschränkt (Marjanović, op. cit., 87 f.).

480 Marjanović, op. cit., 89-95, weiters Mila Bosić, Božićni običaji Srba u Vojvodini, Novi Sad/Beograd I 985, ders., Godišnji običaji Srba u Vojvodini, Novi Sad I 996, zur Scheinpflügung (plugușorul) bei den Rumanophonen Mirjana Maluckov, Rumuni u Banatu, Novi Sad I985, 274, zur St. Lucia, Sveti Lucija Vesna Marjanović, Maske u tradicionalnoj kulturi Vojvodine, Novi Sad i 992, 6, dies., Maske i rituali u Srbiji, Beograd 2005, 49 f., Kretzenbacher, Santa Lucia und die Lutzelfrau, op. cit., Waldemar Lingman, Traditionswanderungen Euphrat-Rhein, 2 Bde., Helsinki I938, II 828, Niko Kuret, Maske slovenskih pokrajin, Ljubljana I 984, I 37-I 45, zu Sv. Barbare und Sveti Nikola auch Kuret, Maske, op. cit., I 45-I 52, Marjanovic, Maske i rituali u Srbiji, op. cit., 49. Zu den seit dem I8. Jh. nachweisbaren Krippenspielen vertepi, betlehemari, viflejem usw. auch Bosić, Godišnji obicaji, op. cit., I I 6-I 25, Lozica, Izvan teatra, op. cit., I I 7, J. Olejar, »Godišnji običaji u Ruskom Krsturu«, Rad Kongresa Saveza folklorista Jugoslavije u Novom Sadu 1973. godine, Beograd 1978, 325-346, bes. 328-33 I, I. Volly, Népi Játétok, Betlehemes, Bölcsöskem, Háromkirály, Budapest I 94 I ; zu den religiösen Spielen pastir, tri kralja, Adam i Eva usw. Marjanović, Maske, op. cit., Iо4f., zu Deda Mraz dies. Io8f. 
Während die Umzüge der lazarica praktisch universell sind ${ }^{481}$, sind die Pfingstköniginnen-Prozessionen hier dem NW vorbehalten, die z.T. ekstatischen rusalija-Bräuche, so typisch für Rumänien, dem $\mathrm{O}$ und $\mathrm{SO}^{482}$.

Dazu gibt es reichhaltige ältere und neuere Literatur, von großräumigen Übersichten bis hin zu Fallstudien ${ }^{483}$, ebenso wie für Bulgarien, wo die kukeri-Spiele die Aufmerksamkeit der Forschung auf sich gezogen haben. In Wirklichkeit handelt es sich eher um einen Sammelbegriff, der z.T. sehr unterschiedliche Masken- und Umzugsformen bezeichnet ${ }^{484}$, wie überhaupt die gleitende Terminologie zu den schwer lösbaren metho-

48 I Vgl. die Verbreitungskarte in Marjanovic, Maske, op. cit., I65. Im Frühlingsabschnitt findet auch der Umzug am Festtag des Sv. Jeremija r./r 4. Mai (I 74f.) statt, ein Maiumzug mit Anrufung des Heiligen gegen den Gewitterdrachen zmej (Biljana Sikimih, Sveci creva motaju, Kult svetih na Balkanu, Kragujevac 200I, 39-87, bes. 45 f., Petar Ž. Petrović, Život i običaji narodni u Gruži, Beograd I 948, 244-246, Ivan Kovačević, Semiologija mita i rituala I, Beograd 2001, 35-46).

482 Marjanovic, Maske, op. cit., I76-I86. Zu den kraljice S. Trojanović, "Maske kod našeg naroda", Bulicev Zbornik, Zagreb/Split 1924, 695-699, bes. 698, Lozica, Izvan teatra, op. cit., I 49, Zečević, Elementi naše mitologije, op. cit., 99 f. usw. Zu den äquivalenten čaraice Adik Effende Uglien, »Ethnographische Varia. I. Der Umzug der Čaraice in Jaice. 2.: Aehnliche Festgebräuche der Muhammedaner im Bezirke Prozor. 3.: Die Heilung der Strava«, Wissenschaftliche Mittheilungen aus Bosnien und der Hercegovina 3 ( ( 895 ) 55 2-557. Zu den Rusalien Walter Puchner, »Zum Nachleben des Rosalienfestes auf der Balkanhalbinsel«, Südost-Forschungen 46 ( I987) 197-278, Lj. Janković, "Rusalije«, Glasnik Etnografkog muzeja I 4 ( 1 939) 20-30, Natko Nodilo, Stara vjera Srba i Hrvata, Split I98 I, I 79, die umfangreiche Monographie von V. Skurativs'kyj, Rusalii, Kyjiv I 996, zu den ekstatischen padalice der Aromunen in den ostserbischen Berggebieten Zečević, Elementi naše mitologije, op. cit., 93-I 2 I, Dragoslav Antonijević, Ritualni trans, Beograd I 990, I47-I 79, D. Bandić, „Šamanistička komponenta rusalijskog rituala«, Carstvo zemaljsko i carstvo nebesko, Beograd I 997 , 203-224 usw. Vgl. noch in der Folge.

483 Hier sei nur stichprobenartig erwähnt Vuk Vrčević, Srpske narodne igre, Beograd I868, Milan Milićević, Život Srba seljanka, Beograd I 894, Dena Debeljković, Običaji sprskog naroda na Kosovu polju, Beograd I907, Ante Sekulić, Narodni život i običaji bačkih Bunjevaca, Zagreb I986, Mila Bosić, Godišnji običaji Srba i Vojvodinu, Novi Sad r 996, J. Cvetanovska, Igre po smrti, Skopje 1999. vgl. auch Maria Constantin, »Les coutumes dans les cortèges à masques chez les roumains et chez les peuples balkaniques«, Makedonski Folklor 8/I 5-i6 (I 975) 335-345, Boris Kuhar, »Ceremonial Masks in Yugoslavia«, Walter W. Kolar (ed.), The Folk Arts of Yugoslavia, Pittsburgh, Penn. I 976, 89-I02, Ioan Popa, "Les cortèges aux masques chez les Roumains et chez les Bulgares de Banat", Makedonski Folklor 4/7-8 (I97I) I 59-I64.

484 Charakteristisch dafür ist z. B. die rezente Erhebung der einschlägigen Brauchmanifestationen in den 7oer und 80 Jahren von Stojan Rajčevski/Valerija Fol, Kukerăt bez maskata, Sofija I 993, wobei sich das »ohne Maske« auf das Fehlen von Holzmasken bezieht; die Rückführung der Maskenformen auf altthrakisches Kultursubstrat braucht hier nicht zur Debatte stehen (vgl. auch meine Rezension in Südost-Forschungen 53, 1994, 534-536). Das Buch bringt nach der Erhellung der bulgarischen Forschungsgeschichte (7-40) Theoretisches zur Abstammung usw. (68-94), sodann die kodifizierte »Handlung« der Vorstellung (95-I07), das Maskenpersonal (I08-I35) und 
dischen Schwierigkeiten der Maskenforschung gehört: Identische Benennungsweisen sagen noch nichts über den Inhalt aus, gleiche Inhalte können durchaus unterschiedlichen Namen tragen ${ }^{485}$. Davon sind auch die kukerski igri nicht ausgenommen, die unter verschiedenen Bezeichnungen laufen ${ }^{486}$; Vakarelski unterscheidet zwei verschiedenen Umzugstypen: den simpleren mit der majka oder baba im Zentrum und den kukove, die sie beschützen ${ }^{487}$, sowie den vielpersonigen Typ aus dem Osten und Südosten des Lan$\operatorname{des}^{488}$. Doch dazu noch ausführlicher in der Folge. Der Maskenraum und die Umzüge

dann die rezente Datenerfassung von Rollen und Spielern aus r 8 Dörfern (г $36-184)$ : Belevren, Blaca, Bliznak und Erekler, Brodilovo und Madžura, Bulgari, Bjala Voda, Gramatikovo, Zabernovo, Indže Vojvoda, Kondolovo, Kosti, Kulata, Malăk Samokov, Sinemorec, Slivarovo, Stoilovo u.a.

485 Namen und Sachen können durchaus unterschiedliche Traditionswege gehen; dies ist besonders augenfällig bei all jenen Manifestationen, die den Namen des ehem. römischen Rosalienfestes tragen (Walter Puchner, »Im Namen der Rose. Zum Nachleben des Rosalienfestes auf der Balkanhalbinsel«, Studien zum Volkskultur Südosteuropas, op. cit., 47-1o6, und ausführlicher »H P $\omega \mu \alpha-$

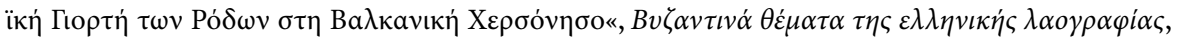
Athen 1994, I-95).

486 Kukeri, kukuvci, babugeri, džamalari, starci, derviši, arapi, kjopek bej, karuala, kalugeri, drakusi, eškari, babušari, brezaja usw. (Vakarelski, op. cit., 380). Die Tierbezeichnungen sind dabei manchmal irreführend.

${ }_{487}$ Z. B. in der Dobrudscha. Eine spinnende "Alte« wird von den in Lumpen gekleideten, glokkentragenden, mit Kürbismaske versehenen und mit einem Stock (kljunk) bzw. Holzsäbeln und Keulen bewaffneten kukove begleitet, die den choro tanzen, während die Zuschauer sie zu entführen versuchen. Mit ihr als Pflüger findet auch die Scheinpflügung statt. In Westbulgarien finden diese Maskenzüge nicht zur Karnevalszeit, sondern schon während der Zwölften statt, z. B. die džamalari (zum Namen vgl. wie oben) oder dedici bzw. koledžane, die im Gebiet von Kamenica aus zwei dedici und einer baba (oder nevesta, "Braut«) bestehen, einem dever (Brautführer), einem konjar (Pferdeknecht) und einem gajdar (Dudelsackspieler). Die lumpenverkleideten Alten haben Glocken um die Mitte gebunden und einen Höcker aus Stroh, eine spitze Fellmütze, tragen ascheverstreuende Keulen und Holzsäbeln, schreien und treiben Unsinn bzw. in einer phallischen Variante vollziehen sie eine Scheinhochzeit mit Kopulationsparodie. Diese Spielgruppen sind oft auch von den schon erwähnten Tiermaskierungen begleitet (Vakarelski, op. cit., 384-386).

488 In einer Übersichtskodifizierung gibt Vakarelski folgende Maskentypen an: den kuker, die baba, die jungen momci und devojki, den Car mit den telochraniteli (Leibwächtern), den ververin (Barbier) und sădija (Richter), den pop (Popen), mečkar und mečka (Tanzbär), Zigeuner, Affenhalter usw. Der in haariges Fell mit Gesichtsmaske (oder rußgeschwärzt) gekleidete, glockentragende mit oder ohne Phallus, mit einem Kaminbesen oder Stock bewaffnete kuker gilt als Bräutigam der $b a b a$, bucklig oder auch schwanger (oder mit einem Holzstück-Kind). Der König (car, bej) erscheint schöngekleidet auf einem Wagen, von den Leibwächtern gezogen, der Richter (auch kadija) mit seinen charačari (Schergen, auch arapi), hebt Steuern ein und verteilt Strafen usw. Die Zuschauer versuchen die $b a b a$ oder die momi (Mädchen der momci) zu stehlen, was die kukeri 
des heortologions sind in Nordgriechenland bis in die thessalische Tiefebene durchaus vergleichbar. In Südalbanien stechen dabei die martialischen Lazarusumzüge der Burschen hervor ${ }^{489}$, die im wesentlichen dem Maskenrepertoire der Mittwintermaskierungen entstammen; Ähnliches gilt für die r.-Mai-Umzüge am Peliongebirge in Ostthessalien $^{490}$.

Südlicher Balkanraum und Mediterranzonen. Die unterschiedlichen geographischen, historischen und verkehrstechnischen Gegebenheiten führen vor allem im Inselbereich und Küstenraum, aber auch im Hinterland und in peninsularen Formationen wie der Peloponnes dazu, daß im Verein mit der Lateinerherrschaft in Spätbyzanz und der venezianischen Herrschaft z.T. bis ins I 8. Jh. Westeinflüsse eine dominierende Rolle spielen in einer Form, wie dies in kontinentalen und zentralbalkanischen Zonen niemals der Fall war ${ }^{491}$. Die Überschichtung der Volkskultur durch Elitekulturen hat für den Maskensektor zwei wesentlich Auswirkungen: I. der christlich-religiöse Charakter der meisten Manifestationen des Festkalenders ist wesentlich ausgeprägter (nachweisbar z.B. an den Inhalten des Lazarusliedes) ${ }^{492}$, und 2. der Einfluß einer bestehenden Theatertradition seit dem I6./I7. Jh. hat unmittelbare Auswirkungen auf die Formen des Volksschauspiels und vor allem das morphologische Profil der Karnevalsunterhaltungen $^{493}$ : Nicht nur ist die Tendenz zu elaboriertem Verbaldialog höher zu veranschlagen,

und momci verhindern. Umgekehrt stellen die kukeri den Frauen und Mädchen im Publikum nach, von ihren Holzphallen deutlichen Gebrauch machend oder mit der Alten eine Kopulationsparodie vorführend. Der car ist oft Teil der Schlußzeremonie, wo er bewirtet wird, die kukeri werfen ihn auf dem Boden und er pflügt unter Segenswünschen den Hauptplatz um. Diese Scheinpflügung wird an anderen Orten auch von den kukeri selbst vorgenommen (Vakarelski, op. cit., $38 \mathrm{I}-383$ ). Diese komplexeren Zeremonien werden im nächsten Kapitel noch ausführlich zur Darstellung kommen.

$489 \mathrm{Vgl}$. wie oben.

490 Eine Maskengruppe von ca. I 5 Personen geht um: Sechs zeybek tanzen zur Musik, der mais (Mai) in weißen blumengeschmückten Kleidern mit einer Art Phallus in der Hand, »Bursch« und »Mädchen« tanzen erotische Tänze, ein Zigeunerpaar laszive; weitere Maskenfiguren sind der Araber, Bärin und Bärenführer, zwei bis drei »europäisch« Gekleidete (frangulia), ein Arzt. Der Araber tötet den »Burschen«, der Arzt gibt ihm Blumen zu riechen und er steht wieder auf (Puchner,

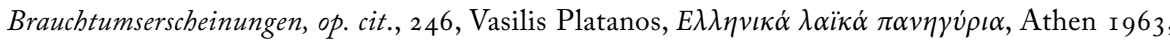

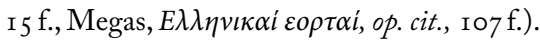

49 I Zur Gesellschaftsstruktur und Administrationsform der verschiedenen Mittelmeerbesitzungen der

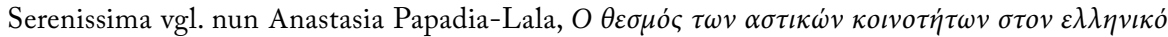

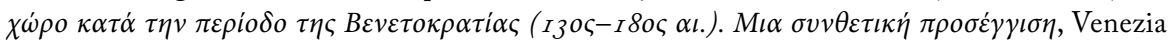
2004 .

492 Vgl. Puchner, Die Folklore Südosteuropas, op. cit., 65-68.

$493 \mathrm{Zu}$ den Theatertraditionen im südbalkan-ostmediterranen Raum vgl. Puchner, Die Literaturen Südosteuropas, op. cit., 94-1 35 . 
das Maskenrepertoire variationsfähiger und typenreicher, sondern auch die Übergänge zu Formen des Volkstheaters mit regelrechtem Rollenspiel und Bühnenhandlung vollzieht sich leichter und häufiger als in den zentalbalkanischen Zonen ${ }^{494}$. Der städtische Karneval mit seiner Nummernstruktur ist z.T. auch in Dörfern zu finden, wie z.B. in Agiasos auf Lesbos (Mytilene) ${ }^{495}$, und improvisierte Karnevalsszenen erreichen häufig einen Komplexitätsgrad, der für die szenische Struktur von Volkstheateraufführungen charakteristisch ist ${ }^{496}$. Volksbearbeitungen der kretischen Renaissancetragödie Erofile werden im gesamten Westgriechenland während der Faschingszeit gespielt ${ }^{497}$. Der religiöse Festkalender der panegyria ist angereichert mit Lokalheiligen und Festtagen, die wieder mit regionalen Wallfahrten vernetzt sind ${ }^{498}$, bzw. Wallfahrtszentren mit einem umfangreichen Einzugsgebiet, wie z.B. die Insel Tinos ${ }^{499}$. In diesem Bereich umfaßt die Lust am Performativen auch religiöse Thematiken, wie z.B. das Judas-Gerichtsspiel im zyprischen Bergland ${ }^{500}$, die dialogische Fußwaschungsszene im Johannes-Kloster auf Patmos $^{501}$ oder die in manchen Kirchen heute noch geübte Darstellung der katabasis Christi in die Unterwelt im arate pylas/tollite portas-Ritus nach dem Epitaphumzug

494 An dieser Stelle sei nur an das »Homilien«-Theater auf Zante und Kefalonia erinnert (vgl. dazu in

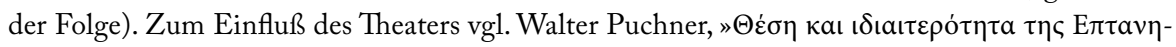

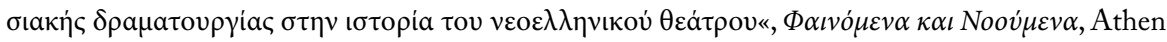
I 999, 22 I-240.

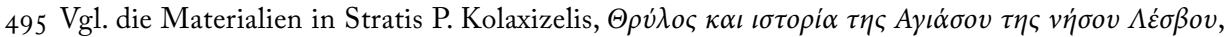

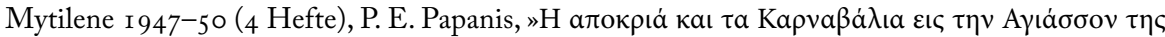

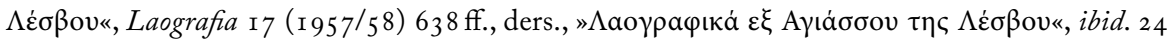
( 966 ) $373-405$, bes. $390 \mathrm{ff}$. Beschreibung einiger satirischer Darstellungsnummern bei Puchner, Brauchtumserscheinungen, op. cit., $242 \mathrm{f}$.

496 Vgl. dazu in der Folge.

497 Walter Puchner, Kretische Renaissance- und Barockdramatik in Volksaufführungen auf den Sieben Inseln", Österr. Zeitschrift für Volkskunde XXX/79 (1976) 232-242. Zu den Texten Aikaterini

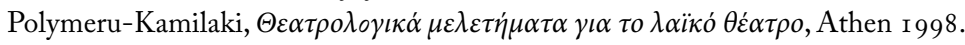

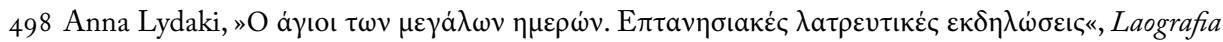

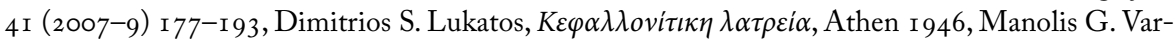

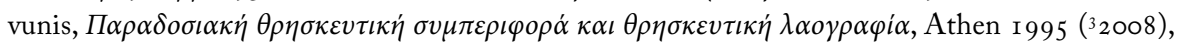

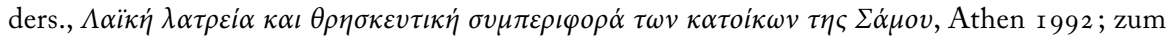

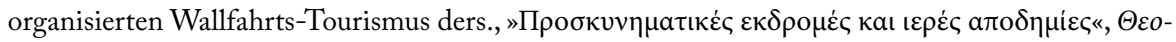

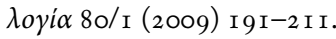

499 Margaret Kenna, In a different place. Pilgrimage, Gender, and Politics at a Greek Island Shrine, Princeton 1995 .

500 Walter Puchner, „Das Judasgericht auf Zypern«, Österr. Zeitschrift für Volkskunde 36/85 (1982) 402-405.

50I Der Dialogtext und die Beschreibung des nipter-Ritus in deutscher Übersetzung in Puchner, Brauchtumserscheinungen, op. cit., 3 I9-33 I (dort auch weitere Bibliographie). 
am Karfreitag oder in der Auferstehungsnacht ${ }^{502}$, das Kreuzigungsspiel in Marpissa auf $\operatorname{Paros}^{503}$ usw.

\section{I. 4 Rollenspiel und Dialog}

Die progressive Konkretisierung der imitativen Metamorphosebestrebungen findet in der Konstitution einer Rollenfigur ihren Abschluß. Treten nun die anthropomorphen Verkleidungstypen in einen interdependenten Aktionszusammenhang, so ist ein »Drama« entstanden, ein interaktives und realitätshältiges Rollengeflecht. Mit »Geflecht « ist die (sinnhältige oder nicht) Zueinandergeordnetheit und Aufeinanderbezogenheit gemeint, mit »realitätshältig«, daß die derart durchgestalteten Rollenfiguren in ihrer Korrelation eine von der Alltagswirklichkeit abgehobene Realität augenscheinlich verkörpern. Vor diesem Bedeutungshintergrund verwandelt sich die Verkleidung potentiell zum Kostüm, der Symbolgegenstand zum Spielrequisit, der Platanenbaum zum Praktikabel, die dynamistischen Bedeutungszentren der Kommunität (Tenne, Kirchplatz, Haushof, Wegkreuzung) zur Bühne, der kalendermäßig fixierte Brauchtermin zum Aufführungsdatum. Die Konstituierung dieser Gegen-Wirklichkeit wird durch eine meist rudimentäre Handlung geleistet; der soziokulturelle Kontext bestimmt den (archetypischen) Inhalt der Szene, eine Improvisation rund um ein stereotypes Aktionsfundament. Die dramatis personae sind grob schematisierte Typen der Alltagswirklichkeit; Individualität und ästhetische Bemessungskriterien können noch nicht in ihre Rechte treten.

Die verbale Kommunikation als spezielle Form der Interaktion ist für die Herstellung einer Rollenbeziehung nicht unbedingte Voraussetzung; Aktion und Reaktion können auch auf anderen Zeichensystemen beruhen (Maske, Gestik, Somatik, Verhaltensweisen), rituell festgelegten Ablauf haben oder sich spontan ergeben. Temporäre Verbaläußerungen müssen noch keine Kommunikation ergeben. Diese Vorformen der Verbalkommunikation sind vom eigentlichen Dialog jedoch kaum schnittklar abzugrenzen. Die Konstituierung eines ausdefinierten neuen Wirklichkeitsraums hängt nicht so sehr von der Anzahl der Rollenfiguren, sondern von der Überkreuzung ihrer Rollenhinsichten und der Dialektik der Perspektiven ab. In Analogie zur Geometrie scheinen

502 Walter Puchner, »Abgestiegen zur Hölle«. Der descensus ad inferos als Keimzelle eines inexistenten orthodoxen Auferstehungs-Spiels«, Beiträge zur Theaterwissenschaft Südosteuropas und des mediter-

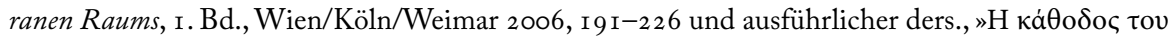

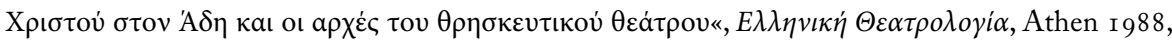
$7 \mathrm{I}-\mathrm{I} 26$.

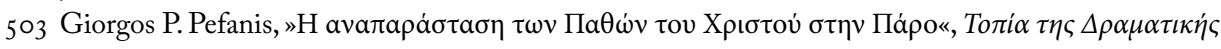
$\Gamma \rho \alpha \varphi \dot{\eta} \varsigma$, Athen $2003,525-536$. 
drei Rollenfiguren und die Kreuzung ihrer Blickwinkel zur Definiton eines abhebbaren Realitätsraumes zu genügen. Die typisierten Rollenfiguren sind der Erklärungslast ihres Wirklichkeitshintergrundes meist enthoben, da ihre Perzeptionsperspektive dem Publikum bekannt ist und schon ihr Auftreten den Bedeutungskontext signalisiert. Insofern ist die sprachliche Seite der Interaktion von ihrer Definitionsfunktion großteils entlastet und Spielball der Improvisations- und Variationslust der Ausführenden und Zuschauer sowie Spielboden für Fäkal- und Sexualwitz, absichtliche Mißverständnisse, Satire und Parodie, Bildung von Assoziationsketten usw.

Viele der zentalbalkanischen maskierten Mittwinterumzüge verharren in Formen der nonverbalen Interaktion mit latenten und instabilen Kommunikationsmomenten. Dazu ein Beispiel aus Eptachori im Raum Kastoria: Noch während der Neujahrsmesse gehen die bubaroi, »Araber", »Damen« und Kavaliere auf Sammelumzug; bei den Darbietungen am Dorfplatz dominiert der wiederholte (im voraus von den Zuschauern bezahlte) Brautraub, daneben gibt es europäisch Gekleidete, den Tanzbären, das obszöne Paar der Alten, Zigeuner mit Lärm und Geschrei, ihr Hab und Gut von Eseln abladend, Zelte errichtend, Feuer entzündend, die Frauen lesen aus der Hand, die Männer trinken und lachen, die kleinen Kinder treiben Unfug, weiters ein Akrobat, andere klettern auf Balkone, um eine »Dame« zu befreien usw. ${ }^{504}$ Hier sind die einzelnen Spielnummern nur durch das simultane Durcheinander eines unüberschaubare Pandämoniums verbun$\operatorname{den}^{505}$.

504 Mehr Details in Puchner, Brauchtumserscheinungen, op. cit., 244 f. (Nr. I 596). Weiteres Material bei Wace, »North Greek Festivals«, op. cit., 233-235, 24I f., ders., »Mumming Plays in the Southern

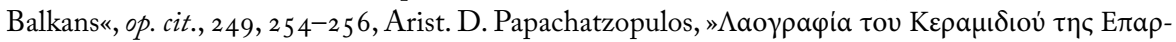

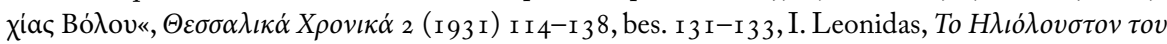

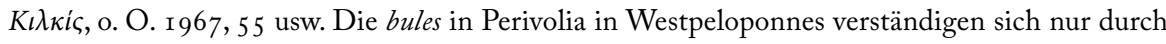
Zeichen (Handschrift des Laografischen Archivs der Akademie Athen 24I 8, I I 2).

505 Ein anderes Beispiel der Unverbundenheit der Maskierungstypen und Rollenhandlungen untereinander: Im nordthessalischen Lykudi gehen die rogatsiaria oder babajurdes am Neujahrstag um: drei kapetane mit ihren Frauen, ein pappus mit seiner mako, ein dämonischer sultaris (ganz in weiß mit einer konischen Kopfbedeckung), der Zigeuner mit Weib und vielen Kindern, der Arzt, der Feldhüter. Während des Sammelumzugs belästigt der Alte seine mako, die sich mit der Spindel wehrt, der sultaris belästigt die Kapetansfrauen, wird gejagt, steigt auf Rauchfänge usw. Man singt das Basileios-Lied und geht auch in Nachbardörfer. Beim Zusammentreffen zweier Maskengruppen muß sich eine unterwerfen und unter den gekreuzten Messern der anderen durchmarschieren, sonst kommt es zum Kampf. Bei Zweikämpfen werden später hölzerne Messer verwendet; um Tote zu vermeiden, legt man auch von vornherein Routen und Umgangszeiten fest. Viele toponymica zeugen von solchen Scharmützeln in der Vergangenheit (Puchner, Brauchtumserscheinungen, op. cit., 243 f. mit unveröffentlichter Quelle). In Kokkotoi im Raum Magnesien (Ostthessalien) gehen bei den kalindrades am Vorabend der Theophanie um I 860 folgende Maskentypen um: das Brautpaar mit Schwiegermutter, der Araber, ein Arzt. Die kalanda werden in zwei Halbchören ge- 
Krippenspiel und Figurentheater. Einen Sonderfall bildet das nordbalkanische weihnachtliche Krippenspiel mit dem Figurentheater des »Herodeskasten«, oft auch mit Sternsingen und Drei-Königsspielen kontaminiert, wobei Puppen und Verkleidete simultan agieren und mitteleuropäische, polnische, tschechische und ukrainische Kulturzonen mit ungarischen und rumänischen zusammentreffen: Die Morphologie der ungarischen Krippenspiele und des tragbaren »Herodeskasten « ist überaus groß ${ }^{506}$, dem entsprechen in Rumänien die vicleim-Spiele, die sich, stets mit den rituellen Weihnachtsumzügen verbunden ${ }^{507}$, in verschiedenen Varianten als vertep, vertepaši, szopka,

sungen, während die Masken obszöne Tänze vorführen. Der Araber beschützt mit seinem hölzernen Krummschwert das Brautpaar, die Braut fällt in Ohnmacht, der Arzt untersucht sie und gibt ihr einen Löffel Wein, worauf sie zu sich kommt und sich neuerlich in lasziven Tanzbewegungen

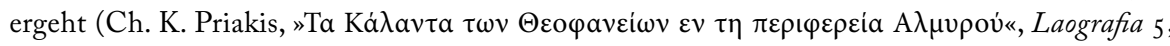
I9I 5/I6, 225-232).

506 F. Schram, »Három történelmi bethlehemes jaték«, Irodalomtörténeti Közlemények 1 964, 497-520, der Fragebogen zur Sammlung von Krippenspielen Gyula Ortutay, »Kérdőiv bethlehemes játekok gyüjtéséhez«, Ethnograpia 68 (1956) 91-98 (auch als Separatum Budapest I 956), J. Faragó, Betlehemezők és kántálok Pusztakamaráson, Kolozsvár I 947, Lajos Vargyas, „Mimos elemek a magyar bethlehemes játékban«, Antiquitas Hungarie, Budapest I 955, I I 7 ff., L. Földes, »A Budajenöre telepitett székelyek bethlehemezése«, Ethnographia 69 (1958) 209-259, Robert Gragger, »Deutsche Puppenspiele aus Ungarn", Archiv für das Studium der neueren Sprachen und Literaturen I 48 ( 1925 ) I6 I-I80, Hedwig Belitska-Scholz, »Gaukler und Wanderpuppenspieler aus Ungarn«, Maske und Kothurn 2 I (1975) Io6-I 22, Ivan Balassa/Gyula Ortutay, Ungarische Volkskunde, München I 982 , 699-702, L. Köldu, »Krippenspiel«, Ethnographia 69 ( ( 958 8) 209-259, F. Debreczeni (ed.), A Bábjátszás Magyarországon, Budapest 1 955, 5-49, Dezso Szilágyi, Contemporary Hungarian Puppet Theatre, Budapest 1 978, K. Vamossy, A hazai Bábjáték, Budapest I 94 I, Nora A. Tahy, Das theatralische Brauchtum des ungarischen Sprachbereichs, Frankfurt/M. etc. I 989, 26, É. Szacsvay, »A magyarországi bábtáncoltató betlehemézes«, Néprajzi Értesitő 60 (1978/82) 57-102, dies., Bábtáncoltató betleheméz Magyarorszagon és Közép-Klet-Europában, Budapest I 987 ; E. v. Hlavats, Német Bábjátékosaink, Diss. Budapest I 940 etc.

507 Im Sammelwerk Die österreichisch-ungarische Monarchie in Wort und Bild findet sich im Band zu Rumänien eine Beschreibung polnischer Weihnachtssänger und Puppenspieler: „Die Begleitworte zu den Aufführungen in den kleinen Puppentheatern (wertepa), welche die Weihnachtssänger mit sich tragen, sind immer polnisch. Um dieses Puppentheater herzustellen, wird die auch anderwärts übliche Krippe mit dem Jesuskindchen, mit Maria und Josef, dem Esel und Ochsen und so weiter mit einem Doppelboden versehen. Die beiden Böden stehen soweit voneinander ab, daß derjenige, welcher das Spiel leitet, von rückwärts die Arme in diesen Raum stecken kann und die Figuren, indem er sie durch eine hiezu bestimmte Öffnung des oberen Bodens emporhält, in Bewegung setzt. Dazu singt oder spricht er die den einzelnen Figuren in den Mund gelegten Worte. Der Text ist witzig gehalten und entbehrt nicht der derben Spässe; insbesondere der Teufel und der Jude müssen herhalten. Als Jude ist übrigens auch der Weihnachtssänger verkleidet; er ist zugleich Spaßmacher und Prügelknabe. Zwischen ihm und einem der anderen Weihnachtssänger entspinnt sich stets ein lebhafter Dialog. Auch kommt ein Weihnachtsfest vor, in welchem die als König, Ritter 
vicleim, betlejka, betlemaši, kriskindle usw. von der Ukraine und Weißrußland, Polen und der Slowakei über Rumänien und Ungarn bis nach Slavonien und Serbien, ja sogar bis nach Skoplje und Bitola im Süden hinziehen ${ }^{508}$; am dalmatinischen Küstenstreifen und in Slovenien bestehen hier noch Zusammenhänge mit spätmittelalterlichen geistlichen Schauspielen (z.B. I6I 5 wird in Šibenik ein Dreikönigsspiel mit Herodes gegeben, dal libretto scritto in schiavo $)^{509}$. Unter morphologischen Gesichtspunkten stellt der derart weitverbreitete ambulante »Herodeskasten« aber einen Sonderfall dar, auch dadurch, daß er an den Zwölftentermin gebunden bleibt, was für das professionelle Puppenspiel nicht mehr üblich ist ${ }^{510}$. Insofern ist er eher in den Rahmen der Hirtenspiele, des Sternsingens und der Drei-Königs-Spiele zu plazieren ${ }^{511}$, welche jedoch vielfach von Jesuiten redigierte feststehende Texte benutzen.

Tod/Auferstehung/Begräbnisparodie. Wie bereits erwähnt, bildet der Tod/Auferstehungs-Zyklus mit seinen Maskentypen Braut, Bräutigam, Araber, und der Symbolik des begrabenen Saatsamens und seine Wiederaufstehung im vegetativen Zyklus des

usw. vermummten Weihnachtssänger lebhafte Unterredungen führen und sich mit ihren Waffen bedrohen« (Bd.XI, $306 \mathrm{f}$.).

$508 \mathrm{~V}$. Antić, "Trojcata mudreci od istok i račanjeto na Isus Christos vo makedonskite narodni običai i pesni«, Makedonski Folklor I 5-I6 (1975) I 83-195 (die vertep-Krippe wird von drei Buben am Drei-Königs-Tag herumgetragen). Vgl. die Verbreitungskarte in Marjanović, Maske, op. cit. 72, $99 \mathrm{f}$. Abb. der verkleideten Spieler und der herumgetragenen Pappkirche. Vgl. auch Balassa/Ortutay, op. cit. Abb. LIV und LV.

509 F. Fančev, »Liturgijsko obredne igre u zagrebačkoj stolnoj crkvi«, Narodna starin Io (Zagreb 1925), Niko Kuret, »Trikraljevske igre in Kolede na Slovenskom«, Slovenski Etnograf 3-4 (I95 I). Zum geistlichen Schauspiel am dalmatinischen Küstenstreifen und im Hinterland Francesco Saverio Perillo, Le sacre rappresentazioni Croate, Bari 1975 und Nikola Batušić, Povijest Hrvatskoga Kazališta, Zagreb I 978 , I-25.

5 I 0 Katholische Orden haben Umzüge mit Krippendarstellungen auch im Osmanischen Reich organisiert, z.B. im Advent I 6 I 2 in Konstantinopel. Der Erfolg dieser Darstellung verleitete den französische Abt von St. Benoît in Galata gegen Ende seines Jahresberichtes zu Ausrufen des Entzückens: Nous avons cette année fait une autre representation avec moins d'appareil, mais avec plus de fruict. Ca esté d'une petite grotte avec la chresche de ce grand Dieu, fait petit pour nous. Les latins et les grecs, hommes et femmes, ont, avec grand ressentiment, honoré cut humble et simple spectacle et representation du saint mystere de la Nativité, que nous celebrions pour lors. Bon Dieu! mes RR. PP. et tres chers freres, combien d'ames se perdent à faute de secours! Prions ce bon Dieu qu'il nous donne la force et l'adresse de cooperer à l'application des merites de son fils, nostre Sauveur Jesus-Christ. C'est le but de nostre vocation (Auguste Carayon, Relations inédites des missions de la Compagnie de Jésus à Constantinople et dans le Levant, Paris I 864, 84, zitiert in der originalen Orthographie auch bei Walter Puchner, Griechisches Schuldrama und religiöses Barocktheater im ägäischen Raum zur Zeit der Türkenherrschaft (1580-1750), Wien 1999 [Österr. Akad d. Wiss., phil.-hist. Klasse, Denkschriften 277] 60).

5 I I Dazu vor allem Niko Kuret, Slovenska koledniška dramatika, Ljubljana 986. 
Frühlingsabschnittes das rudimentäre Fundament der agraren Maskierungsformen des Winterabschnitts von der Peloponnes bis zur Pannonischen Tiefebene und dem transdanubischen Karpatenbogen. Bei den katholischen Csángómagyaren im Kreis Brașov wird in den Boritzen-Waffentanz das sogenannte $k u k a-$ Spiel integriert (ähnlich auch bei den Csángómagyaren in der Moldau, dort matahala genannt $)^{512}$ : Um I 862 fallen drei der schrecklichen cuca-Masken über den Schwächsten her, schlitzen ihn mit ihren Holzschwertern auf und ziehen ihm pantomimisch die Haut ab. In der Folge beklagen und beweinen sie ihn, legen ihre Peitschengriffe auf ihn und pusten ihn an, bis er zum Leben erwacht und wegläuft ${ }^{513}$. Der lebenspendende Hauch ist eine archaische Vorstellung, die bei den momogeria im Pontus-Gebiet auch durch das Entlüften des Darmwindes der Braut auf dem Kopf des toten Bräutigams parodisiert wird ${ }^{514}$. Auch das Enthäuten des Leichnams des Unterlegenen ist ein archaisches Motiv, das sich ebenso in Thrakien wie auch auf Zypern wiederfindet ${ }^{515}$. Will man nach balkanischen Quer-

5 I 2 Pál Pétér Domonkos, "A moresca Europában és a magyar hagyományban «, Filologiai Közlönyi ( 1958$) 202$ ff., ders., „Der Moriskentanz in Europa und in der ungarischen Tradition«, Studia Musicologiae Io (I 968) 229-3 I I, Julius Treutsch, »Der Boritzentanz der Csangomagyaren in den Sieben Dörfern bei Kronstadt«,Jahrbuch des Siebenbürgischen Karpathenvereins 1943, Separatum, Antal Horger, »Hétfalusi Csángok boricatánca«, Ethnographia I 899 usw.

513 Géza Roheim, Magyar néphit és népszokások, Budapest I 927, I 48 f., Tahy, op. cit., 225-233. Spätere Quellen dokumentieren eine Rückbildung des Spiels: I 899 gibt es nur noch die Maskenfiguren, I 943 haben sie keine Holzschwerter mehr, I 948 ist der Resurrektionsvorgang rudimentär und rein pantomimisch, allerdings noch ohne die Arztfigur; die cuca nehmen am Tanz nicht teil und haben die Rolle von Spaßmachern. Sie sind in schwarze Jacken gekleidet, haben vier Glocken umgebunden, tragen eine Peitsche und ein Holzschwert, die Holzmaske zeigt eine Visage mit verzerrter Physiognomie, hat einen Schnurrbart aus Pferdeschweif, auf dem Kopf lange Adlerfedern, ein richtiger Kinderschreck; später wird der Kukakopf mit der schrecklichen Gesichtsmaske aus angemaltem Filz gemacht, der Schnurrbart aus Schweinsborsten usw. Bei den matahala wird der Tod und die Auferstehung des szimki (z.B. in Vágfarcasd, slowak. Vlčany) ebenfalls durch Pusten bewerkstelligt. Auch hier sind die Masken gräßlich und verjagen die Kinder mit ihren Peitschen: Der szimki ist als alter Jude in abgewetzter Kleidung und mit riesiger Nase dargestellt; er schlägt die Kinder mit seinem Bündel.

5 I 4 Vgl. dazu noch in der Folge.

5 I 5 In der Beschreibung des kalogeros-dromenons in Hagios Georgios in Thrakien durch Richard M. Dawkins 1906 (»The modern Carnival in Thrace and the Cult of Dionysos«, Journal of Hellenic

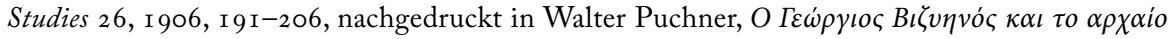

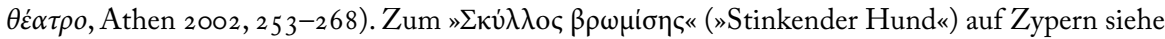

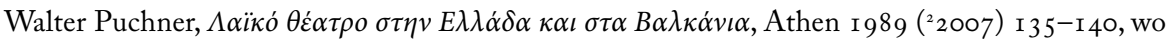
das Fleisch des "Getöteten« auch an die Zuschauer versteigert wird. Vgl. dazu noch in der Folge. $\mathrm{Zu}$ den Maskenanalogien des östlichen Hellenentums siehe auch Thodoros Grammatas, $\Delta \rho \omega \dot{\mu} \mu v \alpha$

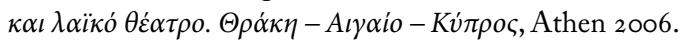


verbindungen suchen ${ }^{516}$, so bieten sich die südslavischen kukeri in ihrer Variantenfülle ${ }^{517}$ und die rumänischen »Pferdemenschen« und Trancetänzer căluşarii mit ihren therapeutischen Heiltänzen $a^{518}$, mit denen sie die Verbotsübertreter der von den Pfingstfeen

5 I $6 \mathrm{Zu}$ den angeblichen Trancezuständen der Tänzer vgl. die Beschreibung der incantatores beim Missionar Bandinus (Mitte i 7. Jh.), siehe V. A. Ureche, »Codex Bandinus«, Analele Academiei Române, Memorii, Seç̦ia istorică, seria 2 Bd. XVI, I 893/94 (Bucureşti I 897) I-335, bes. 328, I. Györffy, »A bubájolás a moldvaia knál«, Ethnographia 36 ( 1925 ) I69f., Geza Róheim, »Hungarian Shamanism«, Psychoanalysis and Social Sciences 3 ( 195 I) I 3 I-I69, bes. I 47. Bei den Ungarn werden schamanische Reste in manchen Tänzen stark diskutiert (vgl. z.B. Vilmos Dioszégi, „Die Überreste des Schamanismus in der ungarischen Volkskultur ", Acta Ethnographica Academiae Scientiarum Hungaricae 7, I 955, 97-1 35), doch geht es eher um paraekstatische Zustände (M. Eliade, Von Zalmoxis zu Dschingis-Khan, Köln/Lövenich I 982, 20I-203).

5 I 7 Vgl. in Auswahl R. Angelova, "Kukerski igri-običai za plodorodie i zdrave i naroden teatăr«, Teatăr 2 ( I 956) 95-106, M. Benovska, »Praznik na Kukerite i survakarite« Bălgarski Folklor 3/3 ( 977 ) 63-66, M. Bočev, »Kukerski igri. Kukeri. Kukeri maski«, Problemi na izkustvoto 3 ( I 976) 27-34, M. M. Čerkezova, »Kukerskite običaji i maski v obrednata tradicija na bălgarina«, Chudožestvena samodejnost 3 (I977) 2 I-23, dies., "Kukerskite običaji i maski«, Vekove 2/3 (I 974) 42-45, Georg Kraev, »Tipologija na Kategoriajata parodija v Kukerskija obred«, Folklor, ezik i narodna sădba, Sofija I 979, I 54-165, Stanka Janeva, »Za kukerskite maski«, Etno-kulturološki zbornik 2 (I996) 79-85, Dimitrina Mitova-Džonova, »Naj-rannijat komponent na kukerskite igri«, Annali. Spisanie za istorija, klasičeska kultura i izkustvoznanie 2 (1995) 39-63 und noch in der Folge.

5 I 8 Schon von Cantemir beschrieben (Opere principului Demetriu Cantemir, T. I, Descriptio Moldaviae, București I 872, I 29), auch bei Sulzer (Franz Josef Sulzer, Geschichte des Transalpinischen Daziens, 3 Bde., Wien I782, II 407). Zu den akrobatischen Trance-Heiltänzen der călușarii existiert eine umfangreiche Literatur. Vgl. in Auswahl: Romulus Vuia, »Originea jocului de căluşarii«, Dacoromanica 2 (1 92 I/22) 21 15-254 (Wiederabdruck in Studi de Etnografie şi Folclor 1975, I IoI 40 und englische Übersetzung I 4 I-I 54), Perikle Papahagi, „Căluşerii sau aruguciarii«, Graiul Brun I (1906) 32-36, Traian Gherman, »Tovărăşiile de Crăciun de feciorilor români din Ardeal«, Anarul Arhivi de Folklor 5 ( 1 939) 57 ff., Gheorghe Focşa, "Le village roumain pendant les fêtes religieuses d'hiver«, Zalmoxis 3 (1940-42) 61-IO2, Tudor Pamfile, Sărbătorile de văra la Români, Bucureşti I 9 Iо, 54-75, Teodor T. Burada, Istoria teatrului în Moldova, Iaşi I 905, 62-70, Andrei Bucşan, »Contribuții la studiul jocurilor căluşareşti«, Revista de Etnografie şi Folclor 2 I (I 976), Mircea Eliade, »The Fairies and the Căluşarii«, International Journal fo Rumanian Studies 2 (1980) H. 3/4, 5-I 2, Horia Barbu Oprişan, Căluşarii, Bucureşti i 969, Gail Kligman, Căluş. Symbolic Transformation in Romanian Ritual, Chicago I98 I, der Sammelband Studii, referati şi communicari de la festivalul Căluşului, Slatina 1969 ediert von Mihai Pop, E. Bernea, A. Giurescu, G. Sulițeanu und G. Stoica; I. Aurel, »Călucienul sau Căluceriul«, I. Pop (ed.), Legende, povestiri şi obiceiuri româneşti, Bucureşti I 973, E. Elefterescu, »Originea şi istoricul jocului Căluşarilor «, Revista Šezatoarea I 8 ( I 922) 296-303, Anca Giurchescu, "The Căluş«, Balkan Arts and Traditions I (I 974) 25-29, Gail Kligman, „From the village to the stage: ritual dance and dancers«, ibid. 2 ( 977 ) 32-36, E. Petruțiu, »O ceată de Căluşeri din cîmpia Transilvaniei«, Anuarul museului etnografie al Transilvaniei, Cluj 1979, 409-4I 7, ders., „Forme tradiționale de organizare a tineretului: Căluşarii (din materiale Arhivei de folclor, Cluj-Napoca)«, ibid. (Cluj I 976) 263-273, Mihai 
der rosaliile/rusalii auferlegten Restriktionen während der Rusalienwoche heilen ${ }^{519}$; dort kann die Wiederbelebung des »Toten« auch durch einen phallusartigen Stock des lustigen mut (der Stumme) erreicht werden ${ }^{520}$.

Das Auferweckungswunder, das den Verblichenen wieder ins Dasein zurückführt, wird jedoch meist von einem Arzt in »europäischer« Kleidung und nach einer grotesken Untersuchung des »Todkranken« und einer noch groteskeren Therapie vollzogen ${ }^{521}$. Da-

Pop, »Consideraţii etnografice şi medicale asupră Căluşului oltenesc«, Despre medicină populară românească, Bucureşti I 970, 2 I 3-223, ders., "Căluşul: Lectura unui text «, Revista de Etnografie şi Folclor 20 (1975) I 5-32, T. Speranția, Miorița şi Căluşarii, urme de la Daci, Bucureşti r 9 I 4 usw.

5 I 9 Zu den Straf-Krankheiten zählen psychomentale Affektionen, Rheumatismus, hemiplegia, Epilepsie, Cholera, Pest usw.; davon können auch die căluşarii selbst befallen werden, z.B. wenn sie den Ritualkreis, den der mut zu Beginn der Tänze zieht, übertreten. Die geheilten Frauen werden craițe (Pfingstmädchen) genannt und sind den heilenden căluşarii durch Blutsbrüderschaft verbunden; sie ziehen mit der Gruppe mit und leisten bei neuen Therapietänzen der durch Hypnose und Autosuggestion in Ekstase verfallenden Tänzer Hilfestellung. Die Therapie geschieht durch das Prinzip der transplantatio morborum, indem der Tänzer das Übel auf sich nimmt.

520 Die strenge Organisationsform der Tänzer ist gruppiert um den vătaf (Anführer) und seinen komischen Gegenspieler mutul (den Stummen) sowie um die Gruppenfahne (steag), verfügt über komplizierte Konstituierungs- und Aufösungsriten (legarea steagului, deslegarea), einen paramilitärischen und von vielen Verboten regulierten Verhaltenscode während der Rusalienzeit, die akrobatischen Tänze und Tanzrituale, mit dem manchmal phallische Bedeutung annehmenden Symbolstock (cioc), werden von bewaffneten Männer in Haushöfen, Cafés und auf Plätzen, heute auch auf Folklorebühnen vorgeführt, zwischen dem gefährlichen Ernst der Tranceheilung (vindecare) der Rusalien-Befallenen (luat din rusalii), wobei der Tänzer Leben und Gesundheit riskiert, und den komischen Einlagen des mutul oder des vătaf selbst (da wo der halb weiblich halb männlich gedachte Clown fehlt). In diese Tanzformen sind fertilitätsmagische Dialogspiele eingelagert, wie z.B. das Pferdespiel, das Strafspiel (für die Bestrafung der Übertretung des sexuellen Enthaltsamkeitsverbotes), eine Hochzeitsparodie, die Todes-/Auferstehungsszene, Kampfspiele (mit einem Kosaken, Türken, Frau, Priester und Arzt) usw.

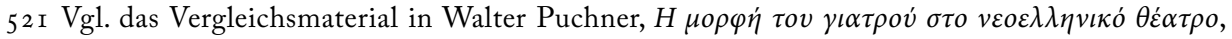
Athen 2004, 49-67. Dem Tötungs- und Erweckungsritual liegt die Vorstellung des Vegetationszyklus im Jahreskreis zugrunde unter Anlagerung zweier parodistischer Elemente: der Begräbnispersiflage mit dem Pseudothrenos und der Therapieparodie des "Wiedererweckers«, des Wunderdoktors. Das Sich-Tot-Stellen hat nicht nur fertile Finalität im Sinne des biblischen Samenkorngleichnisses, sondern ist auch Apotropäum für das tatsächliche Ableben vor der Zeit. Erkrankung und Tod sind in manchen dromena funktionsgleich und austauschbar. Die Arztfigur ist historisch identifizierbar: Es geht nicht um den fahrenden Heilpraktiker oder das heilkundige Kräuterweiblein, sondern um den studierten Arzt in westlicher Kleidung mit Brille, Zylinder, Frack, Arzneitasche und aufgeblasenem Gehabe. Die Roßkuren der effizienten Therapiemethoden bilden eine variationsreiche Zielscheibe des Spottes, doch die »Auferstehung« kann auch ohne den Medicus erfolgen: durch Berührung mit Wasser, In-den-Mund-Stecken von Früchten, Wein, Seife, Blasen und Entlüften, durch Körpergeruch der Braut usw. 
bei ist es durchaus variabel, welcher Maskentyp der zu Tod Gekommene ist: Im thessalischen Bergland ist es ein »Araber ${ }^{522}$, im Bezirk Argolis in der Nordpeloponnes eine Schwangere ${ }^{523}$, im isolierten Bergdorf Olympos auf Karpathos ist es der Alte ${ }^{524}$, auf den Ionischen Inseln die Alte ${ }^{525}$, auf Syra bei den zeybek wird der Araber zum Feuertod verurteilt, weil er die Braut geküßt hat ${ }^{526}$ usw. ${ }^{527}$ Ähnliche Variationen des The-

522 Im Karneval gehen etwa ıo Personen verkleidet um: das Brautpaar, ein Arzt mit gebügelter Hose, Arzneitasche, Thermometer und Klistier, ein Alter mit Glocken, eine Frau, ein Aschenwerfer mit Aschenstrumpf sowie mehrere »Araber«. Während des Sammelumzugs wird ein Araber krank und fällt zu Boden. Der Arzt mißt das Fieber (Rohrstab als Thermometer) und macht ihm einen Einlauf; ein Flötenspieler begießt ihn und er kommt zum Leben und ergeht sich in Obszönitäten (Zeichen der Vitalität). Die Araber vollführen eine Steinschlacht (Handschrift der Laografischen Archivs der Akademie Athen 230r: 84 f.).

523 Hier ist die Auferweckungsszene in eine Geburtsparodie eingelagert. Am Reinen Montag spielen die Männer die schwangeren Frauen: Sie legen sich in ein Bett und schreien. Die »Männer« (verkleideten Frauen) laufen um den Arzt und die Hebamme. Die Schwangere stirbt jedoch und wird beweint. Auch eine Scheinhochzeit findet statt: Wenn sich herausstellt, daß die Braut keine Jungfrau mehr war, versucht sie der »Vater« (verkleidete Frau) zu töten (Handschrift des Laografischen Seminars der Univ. Athen 603/1 969: 237 f.).

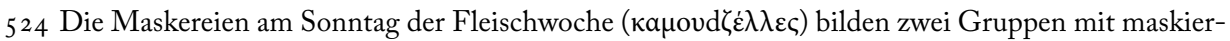
ten Fustanellaträgern und verschleierten Bräuten, dem Alten und der Alten in Lumpenkleidung, dem unmaskierten Arzt mit Pillen und Spritzen und dem geschwärzten Araber. Neben verschiedenen Spielnummern (Kamel usw.) versetzt ein Fustanellaträger dem Alten einen Stoß, so daß dieser hinfällt und sich tot stellt. Der Arzt gibt ihm Pillen und er kommt wieder zum Leben. Diese Szene wird in jedem Haus gespielt (Hs des Laografischen Seminars der Univ. Athen 780/1 969, I 80 f.).

525 Hier fehlt der Arzt und die Erweckungstherapie. Ein Mann spielt die Tote, die anderen versammeln sich rundherum und halten als Verwandte die Totenwache. Sie beklagen sie, zählen ihre Schrullen und Sauertöpfischkeiten auf. Sie wiederholen diese so oft und lachen so viel und laut,

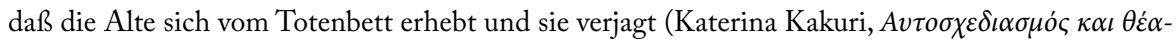
$\tau \rho o$, separatum, Athen I966, 7).

526 20-30 zeybek in schmucken Trachten begleiten vier Bräute, zwei »Lords« beobachten den Vorgang, drücken mit lebhaften Handgebärden ihre Verwunderung aus und machen sich Notizen; ihr Diener ist der Araber mit Ohrringen, Eisenring um den Hals und ein großes blankes Schwert in Händen. Während der Solotänze im Kreis der Burschen werden die »Lords« vom Araber entführt und beraubt; man vergibt ihm jedoch, und die Reisenden werden gegen Lösegeld freigelassen. Zum Schluß befiehlt der kapetan dem Araber, mit der kapetanissa zu tanzen, dieser küßt sie jedoch. Er

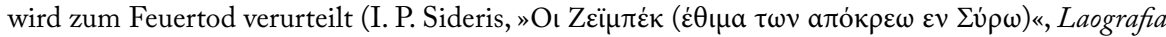
4, I9I3/I4, 559-57I). Es handelt sich um eine »kultiviertere "Variante, wo für die Tötung eine Motivation als Strafakt für ein Vergehen eingeführt wird und die sexuelle Komponente der Fruchtbarkeitsmagie bereits in den Hintergrund tritt.

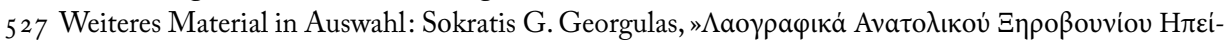

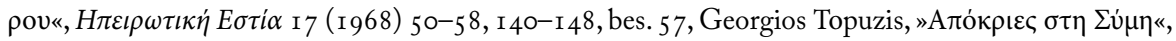

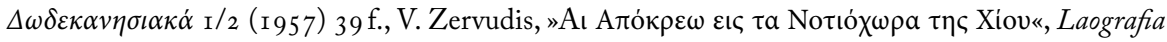


mas sind auch in Kleinasien nachgewiesen ${ }^{528}$. Doch sind dies bereits Variationen eines fertilitätsmagischen Grundschemas, wo die Arztfigur und die Untersuchungssatire die ursprüngliche Dreieckskonstellation überlagert hat, wobei der dämonische Araber den Bräutigam im Zweikampf um die Braut tötet, diese den Toten beweint, welcher als Vegetationsheros wieder zum Leben kommt. Als Spielnummer ist diese komische Resurrektion mit oder ohne Arztfigur auch in komplexere Szenenagglomerate integriert.

Unabhängig von dem Tod/Auferstehungs-Zyklus wird die Begräbnisparodie auch als Separatnummer im Ruralkarneval gespielt: Im Zentrum des Interesses steht nun nicht mehr die fertilitätsmagische vegetationssymbolische Resurrektion bzw. die satirischen Arztuntersuchungen des Toten, sondern das Begräbnisritual selbst mit den Lamentationen, den parodistischen Lobpreisungen und den deutlichen sexuellen »Lebenszeichen « des angeblich Toten. Morphologisch ist das allegorische Begräbnis des Karnevals ${ }^{529}$ von den eigentlichen Begräbnisparodien ${ }^{530}$ zu unterscheiden, und bei diesen elaborierte Formen von rudimentären. Obzöne Bestattungszeremonien mit z. T. umfangreichen Textteilen sind in Ungarn nachgewiesen, die zur Karnevalszeit, aber auch bei Hochzeiten gespielt werden ${ }^{531}$. Bei der »Resurrektion des Phallus« als Stubenspiel nehmen

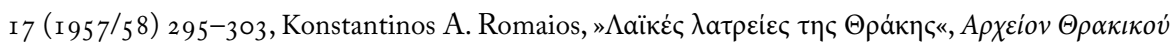

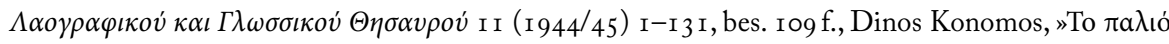

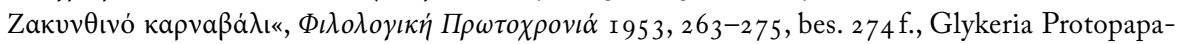

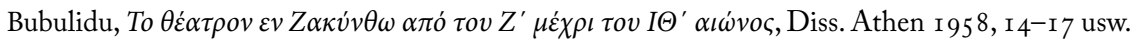

$528 \mathrm{Als}$ arap oyunu, Efe ve Kadi oyunu, köse oyunu, geyik oyunu, kalkagan oyunu usw. (Metin And, A bistory of theatre and popular entertainment in Turkey, Ankara I963/64, 53-58 und pass.).

529 Im Bergdorf Lefkogia des Kreises Rethymno auf Kreta wird am Reinen Montag der Karneval begraben. Die maskierten Dorfbewohner versammeln sich um den »Toten« auf einem Brett, während ihn die Frau Sarakosti (Quadragesima, die Großen Fasten), hager, groß und ganz in Schwarz gekleidet, begräbt. In anderen Dörfern ist sie auch ohne Mund (damit sie nicht essen kann), hat sieben Beine ( 7 Wochen) usw. Die Kirchenglocken läuten, die Kinder tragen Grabkränze aus Zwiebeln und Knoblauch, der ganze Trauerzug beklagt den Verstorbenen in satirischen Distichen

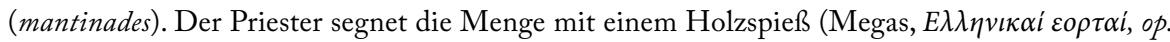

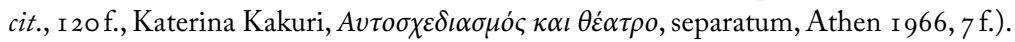

530 Hiezu liegen vor allem ungarische Spezialstudien vor. Vgl. in Auswahl Zoltán Ujváry, »A temetést parodizáló szinjátékszerü szokások kérdéséhez«, Szolnokmegyei Muzeumi Évkönyve I 973, 22 I-230, ders., A temetés paródiája, Debrecen I 978, ders., „Das Begräbnis parodierende Spiele in der ungarischen Volksüberlieferung“, Österreichische Zeitschrift für Volkskunde 2o/69 (I 966) 267-278, Péter Morvay, »A templokertben, temetöben és halotti toron tácolás és halottas játék népszokásához«, Ethnographia I934.

53 I Zu den Volksschauspielen im ungarischen farsang vgl. Tekla Dömötör, „Adatok a magyar farsangi játétok történetéhez«, Szinháztörténeti értesitö 2, I953, Imre Ferenczi/Zoltán Ujváry, »Farsangi dramatikus játétok Szatmárban«, Müveltség és Hagyomány 4 ( 1962 ) 3-15, dies., »Népi dramatikus játétok alkalmai és tipusai az Alföldön«, Müveltség és Hagyomány 8 (г 966) I 8 I-1 96. 
an der Zeremonie neben dem Toten ein Pfarrer, ein Kantor, ein Glöckner, zwei Klageweiber und die Ehefrau (mit ausgestopftem Busen), ein Totengräber, der »Doktor « und der Bittsteller, der die Eintrittsverse spricht, teil; Höhepunkt der Darstellung bildet die obszöne Rede des Geistlichen über die Potenz und das Sexualleben des Verblichenen (ein Art Meßparodie), der Arzt konstatiert die Leblosigkeit seines Penis, seine Frau beweint das leblose Ding (Maiskolben), das sich unter dem Laken doch noch hie und da zu einer Erektion aufschwingt; unter den Zuschauern befinden sich auch Mädchen und Kinder, der Text bringt gehäufte Koitushinweise, doch gibt es keine imitierenden Aktionen. Der pornographische Humor (einstige Fertilitätsmagie) bedient sich bereits folklorisierter Texte (Kleindrucke von Texten der vergleichbaren Zigeunerhochzeit sind aus dem i 8. Jh. erhalten und stimmen mit den späteren oralen Aufzeichnungen überein), die intensive Probenarbeit erfordern, einen Spielleiter usw. ${ }^{532}$

Rudimentäre Improvisationen finden sich vor allem im ägäischen Inselraum: Auf Chios wird am Reinen Montag der Geizhals begraben: Auf einem Brett wird der Tote durch das Dorf getragen und an jeder Kreuzung sein Testament verlesen, das ausschließlich sexuell ist (dieser und jener Witwe sei das und das zu vermachen); der Zug endet bei der Wassermühle, wo der "Tote « in den Wasserspeicher geworfen wird ${ }^{533}$.

Scheinhochzeit, Brautraub und Hochzeitstravestie. Eine besondere Form der Rügebräuche der sozialen Kontrolle stellen jene Strafriten dar, die sich gegen die Normübertretungen der sozialen Rolle richten (z.B. zankhaftes Ehepaar) oder die sitzengebliebenen Altjungfern, die in der Überlebensstrategie der Kommunität ihre Rolle, im sanktionier-

532 Tahy, op. cit., 203-224, 248-269. Daneben tauchen auch Teufel und Tod (als Sensenmann) als Schreckfiguren bei den Spinnstubenunterhaltungen auf: Der Tod ist in ein Bettlaken gekleidet, als Totenkopf gilt das mehlbeschmierte Gesicht mit Karottengebiß, in der Hand eine Holzsense, ein großes Messer oder auch ein Sieb (Sieb als magisches Apotropäum); der Teufel steckt in einem Sack mit Strohstrumpfschwanz, Hörner aus Maiskolben, einen schwarzen Strumpf über dem Gesicht, Hände und Füße geschwärzt, mit einer großen Gabel für seine Opfer (Einfluß kirchlicher Darstellungen). Handlung: Ein Bursch spielt ein Mädchen der Spinnstube, das der Tod bei gelöschtem Licht mit sexuellen Verbalanspielungen und Handgreiflichkeiten unter den Mädchen sucht (ibid. 243-247).

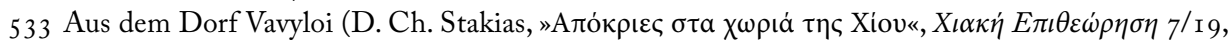

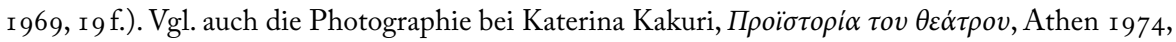
229, Abb. 2 Io (Puchner, Studien zur Volkskunde Südosteuropas, op. cit. Abb. 28), wo eine ithyphallische Menschenfigur, von einem Laken bedeckt, auf einer Leiter herumgetragen wird, von den lachenden Männer verspottet, von der verschleierten »Witwe« beweint, während den größten Anteil der Zuschauer Kinder bilden. Kleinasiatische Flüchtlinge aus Adramyttio (Edremit im Kreis Balıkesir) spielen auf der benachbarten Insel Mytilene (Lesbos) auch ein satirisches Judenbegräbnis mit lasziver Leichenrede (Handschrift des Laografischen Archivs der Akademie Athen 1466B, I 57). 
ten Rahmen einer Ehe für Nachkommenschaft aufzukommen, verfehlt haben und nun dem strafenden Spott der Gemeinde ausgesetzt sind; solche Riten werden gewöhnlich als charivari bezeichnet ${ }^{534}$ oder auch als »Schreien über die Dörfer« (strigarea peste sate $)^{535}$. Eine besondere Form einer solchen öffentlichen performativen Schandhandlung ist das in Mitteleuropa verbreitete Blochziehen ${ }^{536}$, das in Ungarn auch eine Hochzeitsparodie mitbeinhaltet ${ }^{537}$. Das öffentliche Baumstammziehen für sitzengebliebene Mädchen (und Burschen) ist seit dem I 8. Jh. als Holzstrunktragen nachgewiesen und endet, nach dem Ende der Prozession und dem Schleifen des geschmückten »Blochs« bis zum Ziel, mit der Wahl des Brautpaars und der Hochzeitsparodie (mit Priester, Notar, Brautraub, Verstecken usw.), während der »Bloch« zum Schluß versteigert oder billig verkauft wird; die institutionalisierte Organisation der satirischen Vorstellung mit fixiertem Text, mit Gästen, Ankündigung und intensiven Vorarbeiten bewegt sich bereits am Rande des Amateurtheaters ${ }^{538}$. Dasselbe gilt für die elaborierten Hochzeitsparodien, die die Burschen am Faschingsdienstag in den Spinnstuben zum besten geben, wobei bereits individuelle Karikaturen und rudimentäre Schauspielkunst zu beobachten sind, ebenso wie z.T. schriftlich fixierte Texte in Versform verwendet werden ${ }^{539}$.

534 Tekla Dömötör, »Erscheinungsformen des Charivari im ungarischen Sprachgebiet«, Acta Ethnographica Academiae Scientiarum Hungaricae 6 (1957) $72-89$.

535 Octavian Buhociu, Die rumänische Volkskultur und ihre Mythologie, Wiesbaden 1974, 69.

536 K. M. Klier, Das Blochziehen. Ein Faschingsbrauch von der Südostgrenze Österreichs, Eisenstadt I953, A. Schlossar, Cultur- und Sittenbilder aus Steiermark, Graz I 885, 20 ff., O. Bertram, „Das Radschleifen«, Bayerisch-Südostdeutsche Hefte für Volkskunde I 855, I 76 ff. usw.

537 Zum Blochziehen bei den westungarischen germanophonen Hienzen vgl. Alice Csávásy, »Tuskohuzás a Hienzeknél«, Ethnographia 33 (1922) 9r ff., zum Grenzbezirk St. Gotthard Kálmán Vakarc, "Tuskohuzás a Szentgotthárdi járásban«, Ethnographia 1923 und dem Dorf Rábatótfalu/Windischdorf Tekla Dömötör, »Das Blochziehen in Rábatótfalu I 968 - eine ungarische Variante eines interethnisch verbreiteten Faschingsbrauches«, Kontakte und Grenzen. Probleme der Volkskultur-und Sozialforschung, Göttingen I 969, 385-392.

538 Die Verspottung der Altjungfern findet am Faschingsdienstag (entspricht dem Reinen Montag bei den Orthodoxen) auch ohne Bloch statt. Ob dem Baumstamm phallische Bedeutung zukommt oder nicht, hat Diskussionen erweckt; sicher ist nur, ähnlich wie bei der Scheinpflügung durch die nichtverheirateten Dorfmädchen, daß sie performativ zum Arbeitsvieh degradiert werden. Unter morphologischen Gesichtspunkten ist das eigentliche Blochziehen von der charivari-Katzenmusik und der Spottprozession mit Kuhglocken, Krach und Tumult zum Haus der Altjungfer mit gegenseitiger Verspottung zu unterscheiden, ebenso wie von dem Schleppen eines Baumstumpfes vor das Haus der Sitzengebliebenen, wobei man mit verschiedenen Tricks bemüht ist, das Mädchen zum Bewegen des (offenbar phallischen) Stumpfs (Axt, Stock usw.) zu überlisten (er wird z.B. an die Haustür gebunden, wenn das Mädchen die Tür öffent, zieht sie den Strunk an sich). Auch hier kommt es zu Spottdialogen, die eine große Varianz aufweisen können (Tahy, op. cit., r66-186).

539 Neben dem Brautpaar, dem katholischen Priester und/oder Notar, zwei Brautführern (zugleich 
Es ist nicht uninteressant festzustellen, daß im südslavischen Bereich neben den Karnevalsunterhaltungen ${ }^{540}$ Hochzeitsparodien auch bei Hochzeitsfeierlichkeiten zur Aufführung kommen ${ }^{541}$, die verschleierte Braut (nevesta, mlada) als Verkleidungsfigur beim Hochzeitsball ${ }^{542}$, aber auch verschiedene Maskenfiguren (zabavljač, čauš, čavud, lažlja, glumac, vojvoda, buklijaš, žarač, komendijaš, circusant, muškarac) ${ }^{543}$, die den Hochzeitszug begleiten, wobei auch die falsche Braut ihr Unwesen treibt ${ }^{544}$. Doch die Hochzeit selbst als performatives Ereignis, als Inszenierung und Maskerade wird uns noch an anderer Stelle beschäftigen ${ }^{545}$.

Bittstellern), zwei Brautjungfern, zwei Trauzeugen (Beistände), alle in realistischer Bekleidung oder vereinfacht, ohne Bestreben nicht erkannt zu werden, spielen nach dem Umzug mit Musik und der Formierung vor dem Eintritt, den Eintrittsversen des Bittsteller, der um Erlaubnis anfrägt, dem feierlichen Einzug in die Spinnstube unter Musikbegleitung usw. eine Hochzeitsgesellschaft bei Tisch mit Begrüßung durch den Brautführer, dem Vertragsverlesen des Notars, dem Segen und der »andächtigen« Rede des Geistlichen, einem ausgelassenen Gelage mit Trinksprüchen, Musik und Tanz (auch der Zuschauer), der abschließenden Geldsammlung und dem Auszug; die theaterhafte Vorstellung setzt eine Probenarbeit und durchdachte Rollenbesetzung voraus, kalkulierte Komik in der Vorführungstechnik usw. Von der fruchtbarkeitsmagischen Dimension dieser Hochzeitssatiren ist nur die Obszönität der Verbaläußerungen geblieben (Tahy, op. cit., I 87-199).

540 Z.B. Nikola Pantelić, »Ženidbeni običaji na teritoriji opštine Zaječar«, Glasnik Etnografskog muzeja 42 (1978) 355-382, bes. 379.

54I Vesna Marjanović, Maske, maskiranje i rituali u Srbiju, Beograd 2008, I 95-2 I 2 (Verbreitungskarte für Serbien ibid. 200), D. Krstić, »Svadbeni običaji u selu Ošljane«, Pirotski zbornik 25-26 (Pirot 2000) 6i-78, bes. 70, Lj. Reljić, »Običaji i verovanja vezani za životni ciklus - poćenje, brak i smrt«, Glasnik Etnografskog muzeja 62 (1998) 50-86, bes. 73, Sanja Zlatanović, „Značenjski sklop tradicijske svadbe«, Etnologija 4 (Sofija 200I) 7-50, bes. 34, D. Đorđević, Život i običaji narodni u leskovačkom kraju, Leskovac I985, Ior f. usw.

542 R. Popov, „O jednoj varianti karnevalske svadbe kod Bugara«, Svadba 3 (Beograd I 998) Io3-г Io, Bojan Jovanović, Magija sprskib obreda, Niš 200 I, I 28, Vidosava Nikolić-Stojančević, Vranjsko Pomoravlje, Beograd I 974, 30I-303, Nikola Pantelić, »Ženidbeni običaji na teritoriji opštine Zaječar«, Glasnik Etnografskog muzeja 42 (1978) 355-382, bes. 372.

543 Jovanović, Magija sprskih obreda, op. cit., I 26, V. Vlahović, »Narodno glumovanje u svadbenim običajima Rusina u Vojvodinu«, Folklorni teatar u balkanskim i podunavskim zemljama, Beograd I 984 , I 7 I-I 80, bes. I 75 (ibid. D. Nikolić, »Čauš kao glumac i reditelj«, I 8 I-I 90), Sunčica Mihailović, "Svadbeni običaji u Nišavu«, Glasnik Etnografskog muzeja 34 (197I) 85-103, bes. 94 f., D. Zlatković, "Mesto i uloga neveste u svadbenom obredu staroplaninskih cela u Srbiji«, Etnologija 4 (Sofija 200 I) 5 I-85, bes. 6I (im selben Band auch S. Zlatanović, "Značenjski sklop tradicijske svadbe«, 7-50), Mila Bosić, »Glavni elementi svadbenih običaja Srba u Vojvodini«, Glasnik Etnografskog muzeja 54-55 (I99I) I 85-20I, bes. I9 If.

544 Mila Bosić, Ženidbeni običaji Šokaca - Hrvata u Bačkoj, Novi Sad I 992, 59.

545 Vgl. an dieser Stelle bloß Radost Ivanova, »Svadbata kato maskarad«, Bălgarska Etnografija 3-4 (1994) 35-40. 
Ähnlich wie der Rollentyp Brautpaar und Araber zum Tod/Auferstehungs-Zyklus und in der Folge zur Arztparodie und zum Scheinbegräbnis geführt haben, wobei der Maskentyp Arzt durch die komische Untersuchung mit der archetypischen Szene der agrarvegetativen Fertilitätsmagie vernetzt wird ${ }^{546}$, birgt das Brautpaar allein schon die Dynamik der Hochzeitstravestie in sich ${ }^{547}$, die dann durch Figuren wie den Popen, die Schwiegerleute verkehrt auf Eseln reitend, aber auch Geburtsparodien der vorzeitigen Niederkunft der schwangeren Braut ${ }^{548}$, Verlesen von Aussteuerverträgen usw. erweitert wird, und dies neben den Kopulationsparodien, dem fingierten Brautraub und anderen Kernszenen, die noch auf die Glaubensvorstellung der magischen Effektivität der Ritualhandlungen verweisen ${ }^{549}$. In ähnlicher Weise kann sich die Figur des Richters mit

546 Vgl. die Statistik zum griechischen Material Fig. Io: Entstehung von Dromena-Typen aus Rollentypen in zahlenmäßiger Darstellung (Puchner, Brauchtumserscheinungen, op. cit., 272): Von I69 Beispielen des Rollentyps Brautpaar und Araber entwickeln sich 63 Fälle zur Arztparodie und dem Scheinbegräbnis (37, I7\%), vom Rollentyp Arzt mit 68 Beispielen führen 27 Fälle zur Arztparodie der Untersuchung $(43,50 \%)$.

547 Von 90 Fällen des Rollentyps Brautpaar entwickeln sich 36 zur Hochzeitsparodie (40\%) (Puchner, Brauchtumserscheinungen, op. cit., 272).

548 Das Dialogspiel von der Schwangeren kann auch völlig unabhängig von der Hochzeitstravestie stattfinden, z.B. in Kyparisia in der westlichen Peloponnes. Nach dem pantomimischen Pfeffertanz, der zeigt wie die Teufel den Pfeffer reiben, spielt ein Mann eine ledige Schwangere, ein anderer ihren Vater. Die Zuschauer sitzen mit gekreuzten Beinen rundherum. Der Vater führt die gefallene Tochter, die er weidlich mit Kopfstücken versieht, jedem einzelnen Zuschauer vor und fragt, $\mathrm{ob}$ er sie geschwängert habe. Alle verneinen dies. Bei irgendeinem Zuschauer bleibt er letztlich stehen, behauptet, dieser sei der Schuldige und beschmiert ihm das Gesicht mit Ruß. Über den verwerflichen Wüstling wird Gericht gehalten: Er muß auf die Anklagebank, die aus einem Gefäß mit Wasser besteht, über das ein Teppich gespannt ist. Nach dem unvermeidlichen Unglück geht der Betroffene nach Hause und wechselt die Kleider (Handschrift des Laografischen Seminars der Univ. Athen I645/r $972,228 \mathrm{ff}$.).

549 »Das Brautpaar stellt meist keine eigene Rollenbeziehung dar; über sexuelle Neckereien, Tanz oder Beschützerfunktion des Bräutigams geht die Interaktion selten hinaus. Potenzieller Konfliktpartner des Bräutigams ist der Araber; es geht um die Braut; der eventuelle Streit kann in einen Kampf münden, worauf sich die Tod-Threnos-Auferstehungsszene mit der Arztparodie anschließt. Die Hochzeitszeremonie ist besonders geeignet für sozialsatirische Anreicherungen. Hierher gehört die Karikierung von Außenseitergruppen, die einen Heterostereotyp verzerrt wiedergibt: die venezianische Hochzeit, die Zigeunerhochzeit, die Bauernhochzeit usw.; oder die Anprangerung von nicht normgerechtem Verhalten während des Zeremoniells: die Braut, die übermäßig ißt, der Bräutigam, der es eilig hat, mit der Braut ins Bett zu kommen. Oft ist auch die Braut schwanger, und es wird eine Hebamme gebraucht ( 3 Fälle), woran sich eine Geburtssatire anschließt (4 Fälle). Der Figurentyp der Schwangeren erscheint auch unabhängig davon (I 4 Fälle) und bezieht seine Komik aus dem entstellten körperlichen Aussehen, lauten Schmerzensschreien und saftigen Idiosynkrasien. Unentbehrlich für das Mysterium ist in jedem Fall der Priester (28 Fälle). Beim 
seinen Schergen in ein Gerichtsspiel verwandeln. In der primitivsten Form besteht die Hochzeitssatire aus einer pantomimischen Begattungsparodie, wie etwa bei der "Zigeunerhochzeit« oder dem Paar der Alten mit »verspielt gerontaler Sexualität mit garantierter Folgenlosigkeit $\aleph^{500}$.

Bei den Sarakatsanen wird in der Nacht vom Käsesonntag auf den Reinen Montag folgende Szene gespielt: Ein großes Feuer wird entzündet und eine Scheinhochzeit findet statt: Männer verkleiden sich als Bräutigam, Braut, Priester, Schwiegermutter und Gefolge des Bräutigams ( $\beta \lambda \dot{\alpha} \mu \eta \delta \varepsilon \varsigma)$. Nach der Parodie einer christlichen Hochzeit folgt der Tanz des Brautpaares. Die Braut trägt einen grellroten Schleier, der Bräutigam eine Schafhautmaske, lange Haare und einen Riesenschnurrbart. In Wort und Gebärde kommt es zu Obszönitäten. Nach dem Tanz begibt man sich in einen leeren Konak, wo folgende Szenen folgen: Die Braut wirft den Bräutigam hinaus; andere folgen; keiner ist ibr gut genug. Die Abgewiesenen gehen zum Feuer und ergehen sich dort in obszönen Pantomimen. Die Braut trifft endlich ihre Wabl; im Konak erfolgt eine Parodie der Geschlechtsvereinigung. Vor dem Zelt tanzt man inzwischen den Piperi-Tanz (er wird hier auch am zweiten Tag der Hochzeit getanzt $)^{551}$.

Mysterium selbst kann eine Stimmungsumschlag zum Seriösen eintreten. Rein parodistisch ist der Zug der Schwiegerleute ( 19 Fälle), die - manchmal im Gegensatz zum Brautpaar - immer in Lumpenkleidung kommen, mit Buckeln, Höckern, betonten Genitalien, und einen Höllenlärm verursachen, die Zuschauer beschimpfen usw. [...] Die Schwiegerleute reiten oft verkehrt auf Eseln (Schandzug), - auf Eseln kommt auch die Aussteuer der Braut an, bestehend aus den verschiedensten völlig wertlosen Dingen; manchmal verliest der Notar auch den Aussteuervertrag. Eine solche erweiterte Hochzeitszeremonie ist $36 \mathrm{mal}$ nachgewiesen« (Puchner, Brauchtumserscheinungen, op. cit., 267 f.).

550 Sexualität per se ohne das Ziel der Teknogonie wird immer pejorativ beurteilt und als grotesklächerlich verspottet (vgl. die vielen Sprichwörter um die "Alten« in Puchner, Die Folklore Südosteuropas, op. cit., I39-I4I). Die mit der Spindel sich gegen die Zudringlichkeit des Greises wehrende Alte tritt auch allein auf ( 34 Fälle): Sie ist dann meist Mutter eines Kleinkindes (oft das SiebenMonate-Kind), dargestellt durch eine Puppe oder ein Holzstück, das sie in Windeln legt, verzärtelt usw. (Puchner, Brauchtumserscheinungen, op. cit., 268).

55 I Puchner, Brauchtumserscheinungen, op. cit., 238 f., nach Hatzimichali, $\Sigma \alpha \rho \alpha \kappa \alpha \tau \sigma \alpha \dot{v} o l$, op. cit., $\rho v \eta$ ' ff. Es folgt noch die Parodie einer Kindstaufe und gegen Morgen ein Totenbegräbnis mit Auferstehung. "Eine Grube wird ausgehoben, rundherum Steine ausgelegt. Alle binden sich schwarze Tücher um den Kopf und ziehen sie als Schleier bis zum Mund herab. In die Grube legt man einen Hirten mit dem Gesicht gegen Sonnenaufgang. Man bekreuzigt sich, bindet ihm die Hände kreuzweise mit einem Stück Leinentuch (Leichentuch) zusammen. Er wird geschmückt, dann mit Steinchen und Holz oder Zweigen bis zum Hals bedeckt, niemals mit Blumen oder Gras. Man zündet Kerzen an, setzt sich rundherum und beginnt den Threnos ( $\kappa \lambda \dot{\alpha} \psi \mu \nu$ ). Im Morgengrauen (niemals in der Nacht) singt man die üblichen Moirologien, rauft sich die Haare, zerkratzt sich die Wangen, schlägt sich die Brust und weint. Männer tun das sonst nie, doch hier treten sie an die Stelle der Frauen. Nach einer halben Stunde steht man auf, um den Toten einzuschaufeln. Man hebt ihn an Kopf und Beinen auf - da erwacht er zum Leben. Es folgt ein großer zyklischer Tanz 
In die Hochzeitszeremonie ist oft auch der Brautraub eingelagert, der zur Tod/Auferstehungs-Szene (des Bräutigams, der Braut, des Arabers) mit Arztsatire führen kann oder zu einem Gerichtsspiel mit Aburteilung des Entführers ${ }^{552}$.

Die elaborierten Hochzeitstravestien versammeln in loser Verbindung zur eigentlichen Zeremonie oft eine große Anzahl von Verkleidungstypen ${ }^{553}$.

Eine der stark folklorisierten Hochzeitstravestien ist die "vlachische« Hochzeit in Theben, die alljährlich vor Tausenden von Zuschauern aufgeführt wird. Am Vorabend des Reinen Montags wird die Verlobung arrangiert. Braut, Bräutigam und Schwiegerleute tragen vlachische Trachten oder alte Kleidung. In größerem Abstand werden zwei Hütten errichtet (Lastwagen dekoriert mit Priemelzweigen), das Haus der Braut und das des Bräutigams. Wegen des großen Abstands werden Mikrophone verwendet, früher vermittelten Boten. Zwei Gefolgszüge berwegen sich auf die beiden "Häuser « zu. Der Stadtälteste ist als Brautjungfer gekleidet. Am Mittag des Festtages wird auf zwei auf der Straße aufgestellten Tischen der Hochzeitsschmaus abgehalten. Dann beginnt das Feilschen um die Aussteuer und die Heimfübrung der Braut. Die Maultiere werden mit der Mitgift beladen, die Braut sitzt im Wagen, dahinter

von Männern und Frauen, den der >Tote` anführt. Der Brauch wird geübt, >damit keine Dürre ausbricht« (ibid., vgl. auch Patrick L. Fermore, Roumeli. Travels in Northern Greece, London 1966 , 42 f.).

552 Dazu noch in der Folge. »Der Brautraub findet auch unabhängig von einer Hochzeitsparodie statt: Voraussetzung ist ja nur die Figur der Braut. Als Beschützer tritt häufig der kapetan in Erscheinung (24 Fälle), mit Waffengepränge und Festkleidung, die Verkörperung des Mannesideals. Die Entführung der Braut wird mit jedem Mittel verhindert, oder sie ist eingeplant und wird stillschweigend toleriert. In jedem Falle setzt sie eine Reihe von Aktionen in Gang: die turbulente Suche nach der Braut, ihre Auffindung, die Abrechnung mit dem Entführer. Dieser Zusammenstoß, gewöhnlich mit Tod oder Verwundung einer der beiden Streitparteien endend, kann auch schon durch die Belästigung der Braut (Brautküssen) herbeigeführt werden. Es folgt der komische Threnos der Braut. Die Arztfigur und ihre therapeutischen Bemühungen um den >Patienten sind Höhepunkte der Komik und Ansatzfläche oft ausgedehnter Erweiterungen [...]. Nun kann die Arzsatire auch gänzlich ohne die agonale Auseinandersetzung um die Braut stattfinden: Der Arzt suntersucht ‘ die Passanten, gibt gute Ratschläge und kassiert sein Honorar. Ähnliches gilt für den Threnos der Braut: Die Begräbnisparodie kann auch ohne gewaltsamen Tod und ohne Braut stattfinden ( 36 Fälle): Ein Mann stellt sich tot, wird beweint und zu Grabe getragen. Kurz vor dem Einschaufeln belebt er sich meist wieder" (Puchner, Brauchtumserscheinungen, op. cit., 269).

553 Interessant ist auch die statistische Auswertung des griechischen Materials (Puchner, Brauchtumserscheinungen, op. cit., 27I): Zahlenmäßig am häufigsten ist das Brautpaar (90 Fälle), gefolgt vom Araber/kuker/kalogeros (79), der Arztfigur (68), der Braut allein (5 I), sodann die Geschlechtswechselverkleidung (42), die Tanzbärin (42), das Kamel (37), die alte babo (34), der Alte und die Alte (29), der König/Bey (29), der Priester (28), theriomorphe Verkleidung (27), die Zigeuner (24), der Teufel (24), der kapetan (24), die Schergen/Häscher/Gerichtsvollzieher (23), der Eselsumzug/ Schandritt (I 8), der kadi (I 5), die Schwangere (I4), die Schwiegerleute (10), der Hodscha (9), der Bräutigam allein (7), die Hebamme (3). 
die »Brautjungfer«. Der Bräutigam wird öffentlich rasiert. Es stellt sich heraus, daß die Braut keine Jungfrau mehr ist. Dann beginnt ein Schachern mit dem Brautvater um böhere Mitgift. Doch ist nur mehr ein lahmer Esel und ein Lamm herauszuschlagen. 1959 erfolgte nach der Hochzeit plötzlich der Tod eines der Schwiegerleute. Man beklagt den Leichnam und er erwacht wieder zum Leben ${ }^{554}$.

Auch der berühmte Schattentheaterheld Karagiozis hat seinen Namen für eine sol-

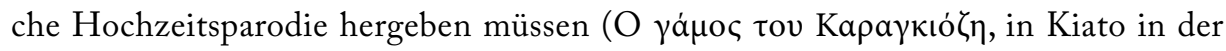
Nordpeloponnes $)^{555}$, die sich jedoch nach dem Zeitgeschmack entwickeln kann, wie hier z.B. durch die Anreicherung der Szene mit dem Photographen ${ }^{556}$.

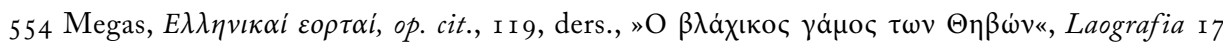
( 1957/58) 632-638, Aranca, Christos anesti, Zürich 1968, I 9 f. Daneben gibt es auch die »aristokratische« Hochzeit auf Kefalonia, wo der Notar einem Schreiber den Aussteuervertrag diktiert, der Bräutigam Frack und Zylinder trägt, jedoch die Geladenen auf Eseln kommen und lustige

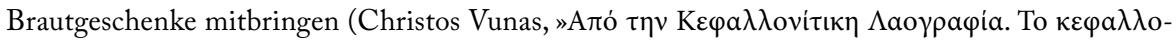

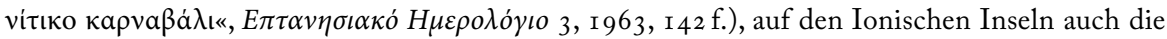

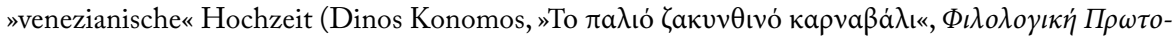

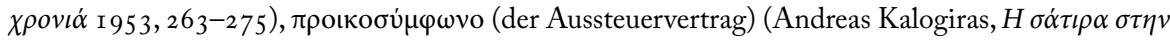

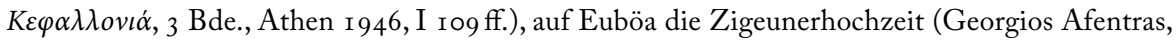

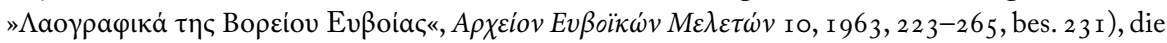

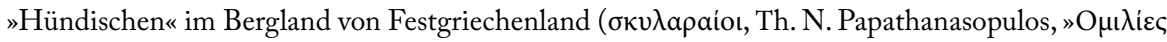

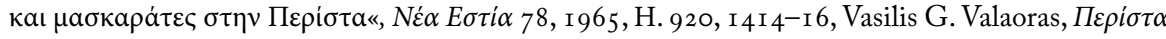

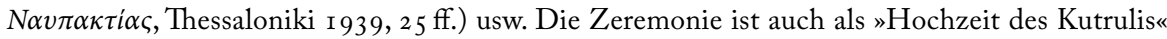

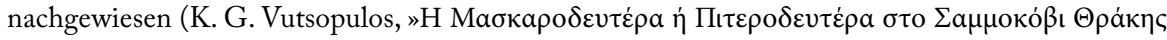

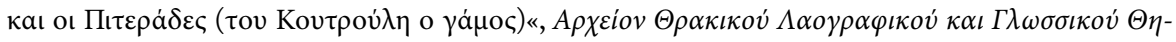

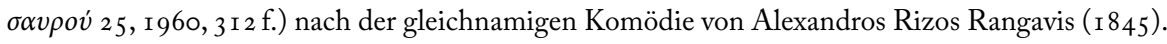

555 Die teilnehmenden Personen sind die Braut, der Bräutigam, der Priester und die Schwiegerleute. Braut und Bräutigam werden aus jeweils verschiedenen Nachbardörfern ausgewählt und für beide werden verschiedene Zelte an verschiedenen Plätzen aufgestellt. Die reich geschmückte Braut trägt neue Brautkleider, eine große Kopfmaske, die auf den Schultern aufruht, bei der das Gesicht freibleibt, aber mit einem Schleier verdeckt ist. Sie wird von Männern gespielt. Der Bräutigam trägt eine Gesichtsmaske wie auch der mit einem Aschenstrumpf bewaffnete Pope. Die weiblichen Schwiegerleute haben uralte Sachen an, ihre Zöpfe sind in Tücher gehüllt und überall hängen Knoblauch- und Zwiebelgebinde; oft haben sie übergroße Brüste, Höcker, Bäuche usw. Unter der Kleidung werden Glocken getragen, in den Händen halten sie Regenschirme, Stöcke, Aschensäcke usw. Die männlichen Schwiegerleute tragen eine Phantasiekleidung aus Lumpen, eine Gesichtsmaske aus Schaf- oder Ziegenleder, auch Kartontierköpfe oder Tierohren mit Menschenmasken. Vor den Geschlechtsteilen hängen viele Glocken, Zwiebeln und Knoblauch, die Hosen sind zur Betonung der Zeugungsorgane ausgestopft. Meist reitet man auf Eseln mit blumenbekränzten

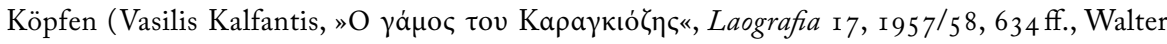
Puchner, Das neugriechische Schattentheater Karagiozis, München I975, I 58 ).

556 Ein Esel mit Maske dient als Photoapparat. Der Photograph hat seine Hände mit einem schwarzen Tuch bedeckt. Auch er trägt eine Hose, die nichts verbirgt. Er will Braut, Bräutigam und Bei- 
Die Begehung beginnt mit einem Festzug zum Haus der Braut. Voran die "Instrumente" (Blechbebälter, Klappern usw.), dann der Schwager, dahinter der Bräutigam, der Beistand mit den Hochzeitskronen, der Pope, die Schwiegerleute auf Eseln oder zu Fuß. Unter Singen, Witzen, Schreien und Nachabmung von Tierlauten erreicht man das Haus der Braut. Die Schwiegermutter erwartet sie und bietet ihnen nach altem Brauch eine "Süßspeise an, die hier frisch vom Esel stammt. Mit einem Strick werden Bräutigam und Schwager von ibr ins Haus gezogen und sie übergibt sie der Braut. Die Brautleute erscheinen in der Tür, und alles läuft schnell zur Tenne oder zum Kaffeehaus, wo die Trauung stattfinden soll. Frauen und Mädchen werden gejagt, sie stecken sich kleine Kinder in die Unterröcke. Die Dorfbewohner belästigen die als Frauen Verkleideten, und diese wehren sich mit Aschenbeuteln und Stöcken. Auf beiden Seiten bäufen sich die Indiskretionen. Der Ort der Zeremonie wird erreicht, die Schwiegerleute jagen noch wilder die Frauen, ibre prallen Geschlechtsteile überdeutlich bewegend und satirische Wortgefechte abhaltend. Mitten in diesem Höllenlärm wird die Krönung des Brautpaares vorgenommen. Der Pope beweibräuchert die Leute, auf einem Tisch liegen die Kronen. Dann tritt Rube ein und das Mysterium beginnt. Kerzen werden angezündet, die Menge murmelt andächtig, Hymnen werden abgesungen. Die Kronen bestehen aus Knoblauch und Zwiebeln. Das Brautpaar hat es eilig, aber der Pope läßt sich Zeit. Er krönt in Ruhe die beiden, liest das Evangelium, und die Feier ist zu Ende. Die "Instrumente "beginnnen zu spielen, man tanzt. Zuerst der Beistand mit der Braut, dann der Bräutigam, dann der Pope und dann das ganze Dorf. Braut, Bräutigam und Beistand begeben sich am Ende ins Haus des Bräutigams ${ }^{57}$.

Hier wird eine relativ »zivilierte« Parodieform bevorzugt, bei der der fruchtbarkeitsmagische Hintergrund vor der gesellschaftlichen Satire bereits verblaßt ist.

Kalogeros/kuker/köpek bey. Eines der umfangreichsten performativen Ritualagglomerate im thrakisch-makedonischen Balkanraum ist eine Karnevalsszene, die in verschiedenen Variationen unter dem Titel kalogeros ${ }^{558}$, kuker ${ }^{59}$ oder köpek bey

stand photographieren, aber immer kommt etwas dazwischen: Einmal sitzen die drei nicht beisammen, dann geht der Apparat wieder nicht, dann kommen andere Leute ins Bild, weil natürlich alle photographiert werden wollen usw.

557 Kalfantis, op. cit., Puchner, Das neugriechische Schattentheater Karagiozis, op. cit. I 59 f. Weiteres Beispielmaterial und Bibliographie in Puchner, Brauchtumserscheinungen, op. cit., 237-239.

558 Der Ausdruck bedeutet nicht »Mönch«, wie manchmal irrigerweise übersetzt wird (z. B. in der deutschen Brauchbeschreibung von Stilpon P. Kyriakides, Neugriechische Volkskunde, Thessalonike I 936, 24 f.), sondern ist einfach eine Adjektivkombination des Wortes "geros« (der Alte).

559 Nach Vakarelski bezeichnet der Stamm kuk den maskierten Menschen (Christo Vakarelski, Bulgarische Volkskunde, Berlin 1969, 380 f.). Konstantinos A. Romaios leitet die kukeri von lat. cuculla ab

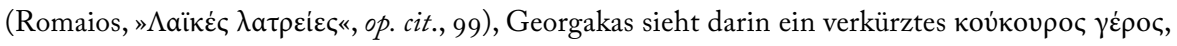


$(\text { Hunde-Bey })^{560}$, die etwa ab der Mitte des I 9. Jh.s in der bulgarischen und griechischen Bibliographie beschrieben wird ${ }^{561}$, bis Richard Dawkins 1906 seine Autopsie in Hagios Georgios (heute in der Europäischen Türkei) im Journal of Hellenic Studies veröffentlicht und mit dem Weiterleben des Dionysoskults im historischen Thrakien in Beziehung setz ${ }^{562}$, eine Meldung, die in der klassischen Philologie und Religionswissenschaft die Runde um die Welt gemacht hat ${ }^{563}$. Trotz des frühen Einsetzens der bulgarischen Forschung zu den kukeri ${ }^{564}$ liegt die erste ausführliche Beschreibung im

wobei der erste Ausdruck eventuell dem lat. cucurum entnommen sein könnte (Dimitris I. Ge-

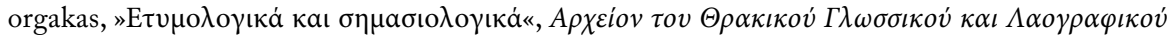
$\Theta \eta \sigma \alpha v \rho o v ́$ I 2, I 946, 40-56).

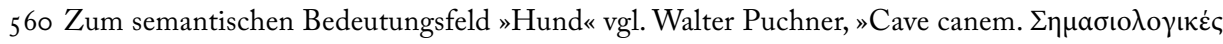

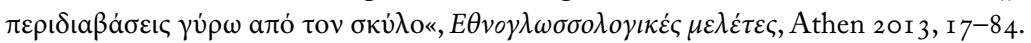

56 I Zur Zusammenstellung der einschlägigen und verstreuten Bibliographie vgl. Walter Puchner, »Beiträge zum thrakischen Feuerlauf (Anastenaria/Nestinari) und zur thrakischen Karnevalsszene (Kalogeros/Kuker/Köpek-Bey). Anmerkungen zur Forschungsgeschichte und analytische Bibliographie«, Zeitscbrift für Balkanologie I 7/I (I982) 47-75.

562 Richard Dawkins, »The modern Carnival in Thrace and the Cult of Dionysos«, Journal of Hellenic

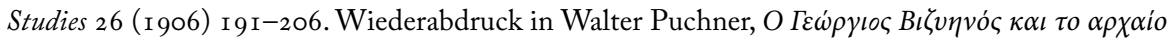

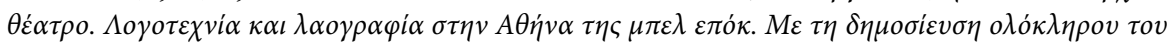

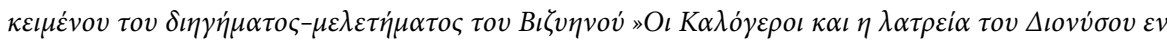
$\Theta \rho \alpha ́ \kappa \eta$ «, Athen 2002, 253-268.

563 Vgl. Walter Puchner, »Die thrakische Karnevalsszene und die Ursprungstheorie zum altgriechischen Drama. Ein Beitrag zur wissenschaftsgeschichtlichen Rezeptionsforschung", Balkan Studies 24/I (1983) I07-I 22.

${ }_{5} 64$ Zuerst in der noch literarischen Reisebeschreibung von Rakovski I 857/58 (Georgi S. Rakovski, Gorski Pătnik, Sofija I 857 [Neuauflage Petăr Dinekov, Sofija I958], ders., »Programa za folklorni zapisi [Odessa I 858] «, Izbrani sučinenija, Sofija I952, 66 f.), als »Alte« (starci) bei Šivačov (S. K. Šivačov, "Starci«, Sbornik na narodna umotvorenija, nauka i knižnina III, I 890, 264 f. Kuker-Beschreibung aus Rupčosko), in der Studie von D. Makedonski r 89 r zu den kukeri (D. Makedonski, „Kukeri«, Periodičesko spisanije na bălgarskoto knižovno družestvo 8 (Sredez) H. 37/38), zum kukerTag bei Šivačev (Stefan Šivačev, »Kukerov den v Malko Tărnovsko, Odrinski vilaet«, Sbornik za narodna umotvorenija, nauka i knižnina IV, I891, 273, auch bei Dobruški, »Materiali po archeologija na Bălgarija«, ibid. I6-I 7, I 900, 78-82), die »Alten« beschreibt Kovačev I 900 (Chr. P. Kovačev, "Običaj >Starci< ot s. Arapova (Karlovsko)«, ibid. I6-ı 7, I900, ı f.), während der klassische Philologe Kacarov in der Einleitung seiner Ausgabe der Euripideischen »Bacchae« I 903 auch auf die kukeri zu sprechen kommt (G. Kacarov, Uvod kăm "Bakchanki« ot Evripid, Sofija 1903, 3-10) und I 907 eine vergleichende Studie zu den kukeri vorlegt (G. Kacarov, »Kukerite«, Periodičesko spisanije na bălgarskoto knižovno družestvo v Sofja 68, I 907, 454-458), Fallstudien aus dem Rhodopengebirge steuert 1907 Marinov bei (D. Marinov, »Kukovi ili kukeri«, Izvestija na Etnografičskija muzej I, I 907, 2 I-28 mit Fallmaterial und Beschreibungen aus Vetren, Aitoško, Srebren, M. Tărnovo, Arapovo, Lozengrad, Burgas u.a.), I 9 Io dann Kostov zu kukovi, kukeri und babugeri (St. L. Kostov, »Kukovi, kukeri, babugeri i pr. (Kak se maskirat po bălgarskite sela)«, Arcbiv na Ministerstvoto na 
Griechischen vor, vom thrakischen Heimatdichter Georgios Vizyinos (Viza I 849 Athen I 896 ${ }^{565}$, der das Zeremoniell aus seiner Heimatstadt Viza (Vizye) um i 860 beschreibt.

Verkleidung und szenisches Rollenspiel sind eingelagert in den Sammelumzug (den Umzug von Haus zu Haus), die komplexe Szene, die man eine "rückgebildete dramatische Vorstellung" genannt hat ${ }^{566}$, findet am Käsemontag ${ }^{567}$ nachmittag auf dem Hauptplatz statt. Dramatis Personae sind zwei fellverkleidete und glockengegürtete Burschen, kalogeroi genannt, von denen einer einen phallusförmigen Stock, der andere einen Bogen hält, mit dem er Asche verschießt, eine Alte (babo) mit Höcker und einem Kind aus Holz im Korb, drei bis vier geschwärzte Zigeuner und ihre Frauen. Die Handlung setzt gestaffelt an verschiedenen Orten und zu verschiedenen Zeitpunkten ein: I. Die babo sitzt mit gekreuzten Beinen im Gras und wickelt ihr Kind in die gestohlenen Unterkleider. Auf eine Frage hin sagt sie, sie sei eine zu beklagende Mutter, denn ibr Kind sei ein Sieben-Monate-Kind; sie kenne seinen Vater nicht und habe es aus Angst zu früh geboren. Mit ulkigen Worten und Gebärden nimmt sie es aus dem Korb, streichelt, wickelt es, legt es an die Brust, zankt es aus und schlägt es. - 2. Zu gleicher Zeit wollen die Zigeuner eine Pflugschar schmieden, aus verrostetem Blech. Man zündet ein Feuer an, die Zigeunerin bläst es an und fächelt mit der Schürze. Der Zigeuner geht vorüber und rempelt sie scheinbar unabsichtlich an. Sie fällt auf den Rücken und schreit und schimpft. Der Mann bittet um Entschuldiung, wiederholt die Attacke aber sogleich wieder. - Die babo beschwert

narodnoto prosveštenie II, H. I, Sofija I 910, 35 I-357), aber erst der materialreiche deutsche Artikel von G. Kazarow, »Karnevalsbräuche in Bulgarien« (I 908) in dem angesehenen Archiv für Religionswissenschaft XI (I g08) 407-409 erfährt eine internationale Rezeption (von James G. Frazer in The golden bough zitiert, Bd. 8, 33 I ff.) und dann vor allem Mihail Arnaudovs Buch zu den bulgarischen Festbräuchen I9I7 (Mihail Arnaudoff, Die bulgarischen Festbräuche, Leipzig 191 7, 25-27). $\mathrm{Zu}$ diesem Zeitpunkt fehlen auch die griechischen Brauchbeschreibungen nicht, die allerdings

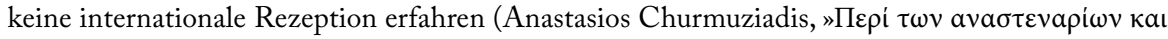

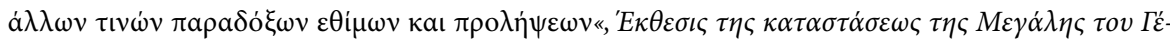

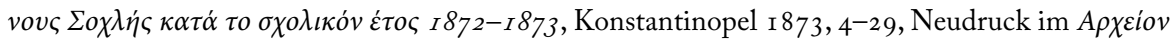

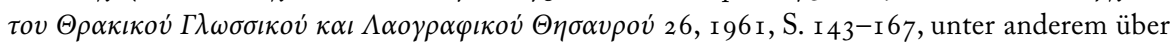

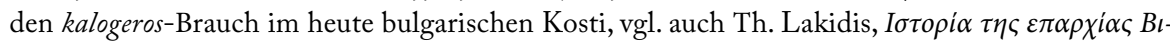

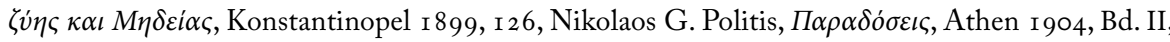
I 264 , Anm. I).

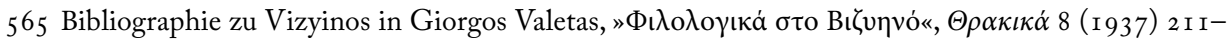

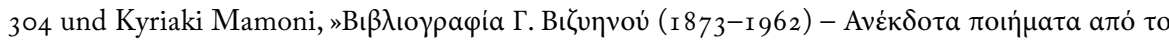

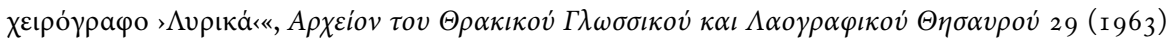

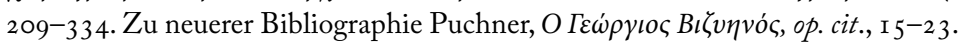

566 Nikolaos Politis in Laografia 2 ( I 9 Io) 47 Anm. I.

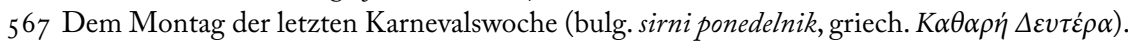


sich inzwischen, ibr Kind sei plötzlich so groß geworden, daß es nicht mehr in den Korb passe. Es habe furchtbaren Appetit, habe schon sieben Brotlaibe gegessen und ganze Kelter voll Wein ausgetrunken, mache sie ganz schwindlig mit seinem Geschrei, und jetzt fordere es auch noch eine Frau von ibr. - Hier setzt 3. die kalogeros-Handlung ein: ein kalogeros, offenbar das großgewordene Kind, beginnt eines der "Mädchen "(sämtliche Verkleidete sind Burschen) zu belästigen und holt es sich aus der Schar. Es schlägt ihn auf den Rücken, aber er hebt es auf seine breiten Schultern und kehrt im Triumph zurück. Es scheint jetzt völlig willig bei soviel Männlichkeit und folgt ihm verschämt. Sie gehen zur Hochzeit mit Musik, der Priester und der Beistand (der andere kalogeros) führen die Hochzeitsparodie mit vielen lasziven Scherzen und handfesten Obszönitäten aus. Sie heben den Beistand hoch, bis er Brotlaibe und ganze Kelter voll Wein verspricht. Dann geht er hinter dem Brautpaar her und parodiert ibren geheimen Wortwechsel und ibr verliebtes Getue. Es kommt zum Streit: der Beistand wird zornig und zielt mit seinem Bogen auf den Bräutigam, schießt ihm Asche auf den Kopf, und dieser fällt breitbeinig rücklings ausgestreckt zu Boden. Die Braut wirft sich weinend auf den scheinbar Toten, doch am lautesten weint der zweite kalogeros selbst. Er beginnt Grabgesänge zu psalmodieren (lauter Zoten), steckt dem Toten ein Holzstück zwischen die Beine und beweihräuchert ihn mit Kubmist. Vier Männer heben ihn auf und tragen ibn weg, um ihn zu begraben, doch schon nach zwei Schritten springt der"Tote "herunter und beginnt zu tanzen. - Die letzte Phase des dromenons findet in ernster Atmosphäre statt: Der öffentliche Diener hat einen echten Pflug auf den Platz vor der Kirche gebracht. Hier findet nun die Zigeunerhandlung ihre Fortsetzung. Sie bringen eine echte Pflugschar herbei und richten ein neues, blumengeschmücktes Joch ein. Die kalogeroi schreiten ernst voran und ziehen den Pflug. Ihr Anführer hat einen Saatsack auf der Schulter, fübrt den Pfug mit der rechten und sät mit der linken Hand. Die kalogeroi ziehen eine zyklische Furche rund um den Dorfplatz ${ }^{568}$. Der Anführer ruft mit verhaltener Stimme: Möge der Scheffel Weizen ro grosi kosten! - Die Menge: Amen, mein Gott, daß die Armen zu essen haben! - Fünf grosia der Scheffel Roggen! - Ja, mein Gott, damit das arme Volk satt wird! - Drei grosia der Scheffel Gerste! - usw. ${ }^{569}$

568 Eine rezente Photographie aus Meliki, Griechisch-Makedonien 1998, bei Puchner, Studien zur Volkskunde Südosteuropas, op. cit., Abb. I 2.

${ }_{569}$ Zitiert nach Walter Puchner, »Altthrakische Karnevalsspiele und ihre wissenschaftliche Verwertung. >Dionysos im Länderdreieck Bulgarien - Griechenland - Türkei«, Studien zur Volkskunde Südosteuropas, op. cit., I 77-1 92, bes. I 80 f. Ausführlicher bei Puchner, Brauchtumserscheinungen, op.

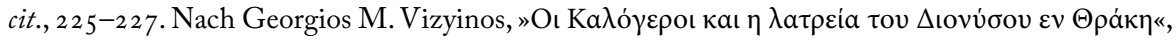

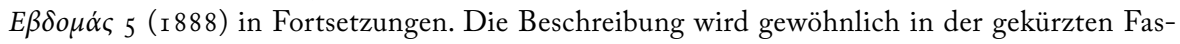

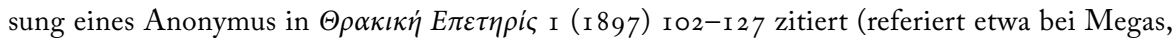

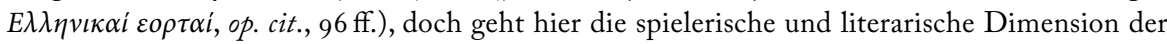
Beschreibung verloren (der Gesamttext in kritischer und kommentierter Edition nun bei Puchner,

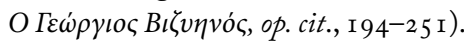


Diese Version aus der Jugendzeit des bekannten Novellenschriftstellers Vizyinos stellt allerdings nur eine Variante eines ganze Bündels von kumulierenden Brauchhandlungen dar ${ }^{570}$. Bei Dawkins 1906 fehlt bereits die Szene mit der babo und die Hochzeitsszene ${ }^{571}$.

570 Vgl. einen Augenzeugenbericht aus dem ehemalig griechischen anastenaria-Dorf Kosti (im heutigen Bulgarien): Hier war die Szene eingelagert in Sammelumzüge, wobei jeder Passant oder $\mathrm{Zu}$ schauer in den Schlamm geworfen wurde oder man machte ihm bloß ein Schlammkreuz auf die Stirn, wenn er den obolus für die »Schauspieler« bzw. öffentliche Zwecke bezahlt hatte. In einem anderen Umzug versucht das Publikum, das »Mädchen « zu küssen, es wird jedoch von einer Burschengruppe bewacht. »Auf einem Platz im Dorf hatten wir einen Pflugführer und einen Wagen mit zwei Rädern. Auf dem saßen die Honoratioren. Es sammelten sich die Alten und zogen den Wagen an den Radspeichen nach hinten. Die Burschen nach vorne und die Alten nach hinten. Die Burschen konnten den Wagen nicht in ihre Gewalt bringen. Sie gingen und baten die Alten, den Wagen loszulassen. Der Pflugführer sprach zu den Alten: - Die Kerle können den Wagen nicht weiter ziehen, nur ihr die Alten, es genügt, daß ihr den Wagen nicht nach hinten zieht, denn es wird Nacht und wir wollen säen. - Da ließen die Alten den Wagen. Die Burschen traten ins Joch, fünf links und fünf rechts, um jenen Platz umzupflügen. Wir hatten auch einen König. Der König hatte das Kommando und säte vor dem Wagen. Säend sprach er flegelhafte Sachen: - >Der Mais soll so dick werden wie die Brüste der Kalogeros-Frau ..., > >Ameeen . >Die Zuckermelone soll aufplatzen wie ... der Kalogeros-Frau ... , , Ameeen ‘. >Die Gurken sollen werden wie das Glied des Kalogeros 'Ameeen. Und andere solche flegelhafte Sachen sagten wir an diesem Tag, denn da galt es nicht als Schande. Die Burschen, die im Joch standen, zogen den Wagen, gingen und gingen, und wenn sie Frauen sahen, warfen sie sich bäuchlings auf die Erde. Da ging der König hin mit seiner Pfeife voll Rauch, schlug sie mit dem Pfeifenkopf und sagte: - Zieht, Kerle, das soll Euch genug sein. - Dann säte der Pflugführer. Die Burschen zogen den Wagen und warfen sich wieder bäuchlings auf die Erde. Der Pflugführer schlug sie mit der Peitsche. Er nahm Erde von dort, wo Frauen gesessen hatten und schmierte es ihnen ins Gesicht. Die Burschen standen auf und zogen wieder und wieder fielen sie hin. Der Pflugführer säte und sprach ähnliche Worte wie der König: `Der Mais soll werden wie die Brüste der Kalogeros-Frau, die Gurken sollen werden wie das Glied des Kalogeros, die Zuckermelonen sollen platzen wie die Hoden des Pflugführers ... und andere solche Sachen« (Di-

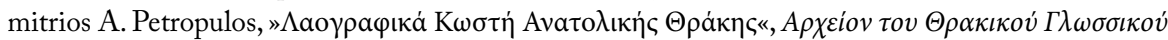

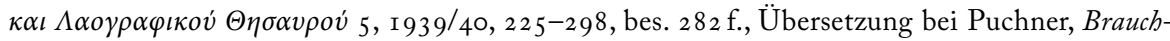
tumserscheinungen, op. cit., 228 f.). Die deftige Bildsprache agrarer Fruchtbarkeitssymbolik gibt hier eine völlig andere Atmosphäre, so daß der Verdacht nicht ganz abzuweisen ist, daß der thrakische Heimatdichter Vizyinos für das Athener Lesepublikum eine »entschärfte« Variante erstellt hat.

57 I » saw none of this, but I was understood that the koritsia were the wives of the kalogheroi, and I was understood that in the adjacent village of Dzakli such a mock marriage is performed with old baskets instead of crowns and the burning of dirt for incense ..." (Dawkins, op. cit., I 9 I f.). Zur Illustration der Variabilität der Brauchhandlung sei noch eine Feldstudie aus Agia Eleni in Griechisch-Makedonien zitiert, wo die griechischen Flüchtlinge aus dem Bulgarien zugefallenen Kosti nach dem Ersten Weltkrieg zur Ansiedlung kamen. Hier sind die Ausführenden des Brauches zugleich anastenaria-Feuertänzer. Die Personen der Szene sind: der (Karnevals)König, der Königssohn, der Zaumzeughalter (kapistras), die babo mit dem Sieben-Monate-Kind, die vier »Jungstiere« vor dem Pflug, ihr Besitzer, der sie zähmt, die Zigeuner mit dem Tanzbär (immer 
Der »tote « kalogeros wird hier allerdings gehäutet ${ }^{572}$ (ein archaisches Element ähnlich wie bei dem Spiel vom »stinkenden Hund« im zypriotischen Bergland, wo auch das Fleisch des »Toten« versteigert wird) ${ }^{573}$. Die Struktur des Sammelumzugs, der pompe, der theriomorphen Maskierung, der Hochzeitstravestie, des Tod/Auferstehungs-Motives, der Begräbnisparodie und letztlich der rituellen Scheinpflügung wurden nun in Beziehung zu analogen Elementen des Dionysoskults gesetzt ${ }^{574}$ und als Überlebensreste

weiblich), die »Gendarmen« als Ordnungshüter usw. Requisiten: ein zweirädriger Zugwagen für den König, die Seile für das Tauziehen, die phallomorphe Lyra, die auf die geackerte Erde gelegt wird. Die Verkleidungskostüme sind im Detail festgelegt. Am Dorfplatz nimmt der kalogeros einen langen rußigen Ofen-Stock (zur Reinigung der Backöfen) entgegen, dann beginnen die Sammelumzüge der Masken von Haus zu Haus. Die Leute werden mit dem Ofenstock beschmutzt, die vorderen Glocken am Gurt der Verkleideten bekommen phallische Bedeutung. Auf dem (schlammigen) Dorfplatz erfolgt dann das Tauziehen der verheirateten und unverheirateten Männer um den Königswagen; siegen die Burschen, so wird es ein gutes Jahr. Unter der Platane findet dann die Imitation der Pflügung und Aussaat statt. Vier Burschen ziehen den Pflug gegen die Sonnenrichtung. Beim Anblick von Frauen werfen sie sich auf die Erde und beschmieren sich mit Schlamm. Der kalogeros führt den Pflug. Der König-Sämann wird mit dem Wagen umgestürzt; sein Fall hat mantische Bedeutung für die kommende Ernte. Drei zyklische Pflugfurchen werden gezogen, dann folgt die simulierte Aussaat mit obszönen Anrufungen, Wünschen und Epoden. Dann wird von den Zigeunern der Phallus in Form einer Lyra unter obszönen Pantomimen auf den umgeakkerten Boden gelegt. Der kalogeros setzt sich in die Mitte des konzentrischen Kreises und genießt Brot, Käse und Oliven. Dann wird er zu Boden geworfen und "getötet«. Rücklings schleift man den "Leichnam« über die gepflügte Erde. Sodann wird der "Tote« in einen Trog getaucht, was ihn gleich wiederbelebt. Er führt den folgenden Tanz an (Katerina Kakuri, $\Delta \iota$ ovvoı $\alpha \kappa \dot{\alpha}$, Athen I 963 , 3 I ff., deutsch bei Puchner, Brauchtumserscheinungen, op. cit., 229-23 I).

$572 » \ldots$ He then pretended to flay $(\gamma \delta \dot{\varepsilon} \rho v \omega)$ the dead body, using for the purpose a kind of pick ... and also making a show of sharpening a stick, as if it had been a knife. A wooden knife is sometimes used. Of this flaying Vizyenos says nothing ...« (Dawkins, op. cit., I 9 I f.).

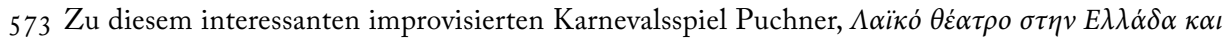
$\sigma \tau \alpha$ B $\alpha \lambda \kappa \dot{\alpha} v i \alpha$, op. cit., I $35^{-1} 40$ und noch in der Folge.

574 Diese Diskussion wird vor allem von Dawkins (op. cit., I 9 I f.), Liungman (Waldemar Liungman, Traditionswanderungen Euphrat-Rhein, Helsinki I 937, FFC I I 8-I I 9, II 768 ff., 780 ff., 839 ff. und ders., »Das Kukerispiel in Hagios Georgios und zwei damit zusammenhängende Namensreihen«, Byzantinisch-neugriechische Jahrbücher I 5, 1939, 2 I-29), Romaios (Konstantinos A. Romaios, » $\Lambda \alpha-$

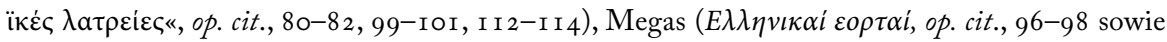

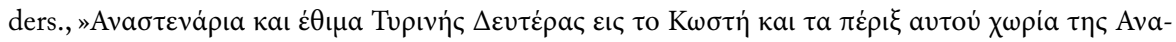

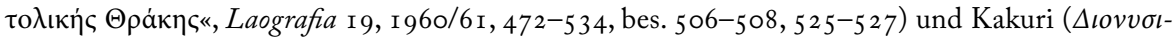

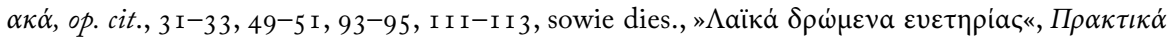
$\tau \eta \varsigma A \kappa \alpha \delta \eta \mu i \alpha \varsigma$ A $\theta \eta v \omega \dot{v}$ 27, I952, 2 I 6 ff.) geführt. Zur Ausdiskutierung der Argumente Puchner, Brauchtumserscheinungen, op. cit., 284-292. Es ist bezeichnend, daß kaum ein Argument unwidersprochen blieb und daß, wenn sich tatsächlich Übereinstimmungen einwandfrei erweisen lassen, diese überaus allgemeiner Natur sind. 
desselben in Thrakien gedeutet ${ }^{575}$, ohne auch nur die zu byzantinischer und osmanischer Zeit überaus bewegte Siedlungsgeschichte der potentiellen Brauchträgerschichten im weiteren Hinterland von Konstantinopel/Istanbul in Rechnung zu stellen ${ }^{576}$. Darüberhinaus erweist sich die Beschreibung von Dawkins für das gesamte Phänomenspektrum der kuker/kalogeros-Szene sowie der hierhergehörigen Szene des thrakischen bey oder »Hunde-Bey«(köpek-bey) ${ }^{577}$ als zu eng.

Zur Illustration dieses Variationsnetzes der thrakischen Karnevalsszenen zwei Beschreibungen des »Hunde-Bey«: I . aus der Stadt Didymoteicho im Länderdreieck Bulgarien, Griechenland und Europäische Türkei im 20. Jh. und 2) aus dem heute bulgarischen Dorf Ortakioi (Ortaköy) im i 9. Jh. Der zwar von Bauern organisierte, aber von der bürgerlichen Kultur beeinflußte »Hunde-Bey« am Käsemontag in der thrakischen Grenzstadt Didymoteicho besteht im wesentlichen aus einem Maskenumzug: der Bey als komischer Richter - Schaffell, Stierhörner, Bart aus Schafwolle, Halskette aus Zwirnsspulen, Pfeife aus Kürbis mit brennendem Stroh, Holzstück als Schreibfeder, der After des Esels, auf dem er verkehrt sitzt (Schandritt im byzantinischen Hippodrom), als Tintenfaß verhaftet Leute, die sich freikaufen müssen usw., die schwangere Zigeunerin, die unter den Zuschauern nach dem untreuen Vater ihres Kindes sucht, die Bäuerin in ähnlichen Umständen, zwei »Töchter« (Männer), die »Zigeuner«, Dudelsackspieler, Gespenster, der "Arzt« mit seinen komischen Untersuchungen und Therapien, ein jüdischer Kurzwarenverkäufer, die »Vögel des Glücks« (Horoskopverkäufer), die »Bärin« und der Bärenführer usw. Von den rituellen Elementen ist nur die Scheinpflügung am Hauptplatz geblieben ${ }^{578}$.

Komplexer waren die Zeremonielle im bulgarischen Dorf Ortaköy (Ortakioi) bei Edirne/Adrianopel am Käsemontag: Hier sind Bey und Richter verschiedene Perso-

575 Das survival-Konzept ist schon aus vielen der angeführten Titel zu erkennen.

576 Vgl. etwa Ömer L. Barkan, »Les déportations comme méthode de peuplement et de colonisation dans l'Empire Ottoman«, Revue de la Faculté des Sciences Économiques de l'Université d' Istanbul I I (I953) No I-4.

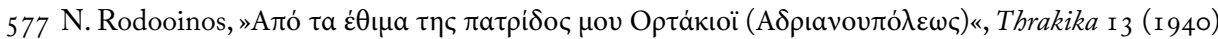
3 I I-320, deutsch bei Puchner, Brauchtumserscheinungen, op. cit., 234-236). Weitere Quellen und Beschreibungen: D. Petropulos/S. Karakasis, unveröffentlichte Handschrift des Volkskundearchivs der Akademie Athen Nr. 2343, Raum Orestiada 1960, 448 f., L. Svinu, ibid. Nr. 2374, Valtos im

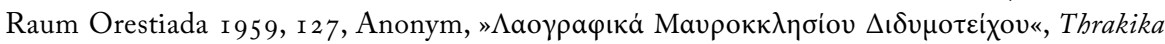

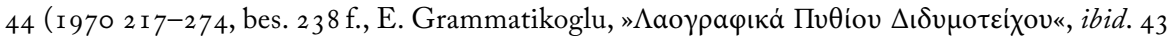

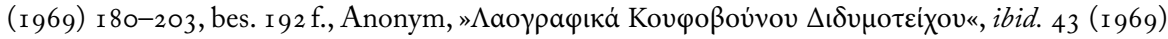

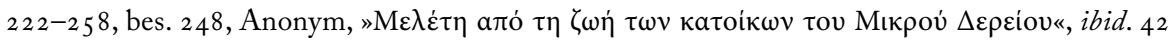
(1968) 105-1 Iо, bes. 108 usw.

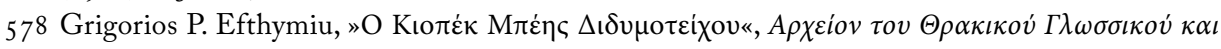

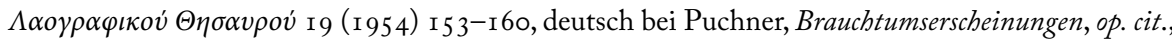
$233 \mathrm{f}$. 
nen. Der Bey ist der Festorganisator und Mäzen, ein Bauer ausgewählt aus den ersten Familien des Ortes. In Festtracht mit Gefolge sitzt er auf einem Wagen, einen großen (Feld)Früchteteller zu Füßen. Beim Hausumzug sät er und wünscht Prosperität. Zu gleicher Zeit unternimmt der berittene Richter in türkischer kadi-Tracht seinen eigenen Sammelumzug; alles ist bei ihm riesig: Bart aus Schafshaaren, Spielkette aus Zwirnsspulen, riesige Pfeife usw. Er verhaftet Leute, die sich freikaufen müssen, und prüft in allen Geschäften Maße und Gewichte und verteilt Strafen. Der Karneval garantiert ihm Scheinobrigkeitsrecht, er besucht auch den Metropoliten, Bürgermeister, zivile und militärische Behörden (bis I 9 г 2 keinerlei Behinderungen von seiten der osmanischen Behörden). Bei Zahlungsweigerung muß man Stockhiebe hinnehmen, auch von Anschuldigungen kann man sich freikaufen und in einer Versteigerungsaktion den Ankläger selbst beschuldigen. Ein weiterer Umzug besteht aus den »Arabern«, die die kadina in rotem Hochzeitskleid begleiten und vor dem zudringlichen Publikum beschützen. Am Nachmittag trifft man sich bei der Tenne außerhalb des Dorfes. Der Richter wird vom Pferd gerissen und sein Fall hat mantische Bedeutung. Dort erfolgt auch das Scheinpflügungs-Zeremoniell und die Wettkämpfe. Zwei »Araber« treten ins Joch, die kadina führt die Pflugschar, der Bey sät. Die Leute wollen ihm den Saatkrug entreißen, die Araber schlagen mit ihren Holzschwertern zu. Endlich gelingt es, den Bey umzuwerfen: Lage und Richtung des umgefallen Saatkrugs hat ebenfalls mantische Bedeutung für die Ernte des kommenden Jahrs (rücklings - gutes Jahr). Dann folgen fünfkampfartige Agone mit Jury: Weit- und Dreisprung, Steinwurf, Lauf, Ringkampf. Am Lauf nehmen nur die kadina und ein Araber teil; sie gewinnt immer durch List (früher Pferderennen). Im Ringkampf messen sich viele Paare. Zuletzt tritt der Araber und die kadina an: Nach hartem Kampf wirft er sie auf den Rücken und »schwängert« sie vor aller Augen (vgl. die Maximo-Episode im Epos von »Digenes Akrites). Die Siegespreise werden verteilt, der neue Bey für das nächste Jahr gewählt ${ }^{579}$.

$\mathrm{Daß}$ die Brauchbeschreibung bei Dawkins mit ihrer enormen bibliographischen Karriere nicht als repräsentativ für den gesamten Ritenkomplex im thrakisch-makedonischen Raum stehen kann, das dokumentieren sowohl bulgarische Quellen ${ }^{580}$ als

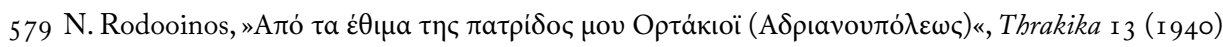
3 I I-320, deutsch bei Puchner, Brauchtumserscheinungen, op. cit., 234-236). Weitere Quellen und Beschreibungen: D. Petrpoulos/S. Karakasis, Handschrift des Laografischen Archivs der Akademie Athen 2343, I 960, 448 f. (Raum Orestiada), L. Svinu, ibid. 2374, I 959, I 27 (Valtos im Raum Ore-

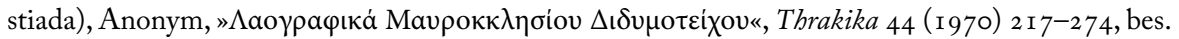

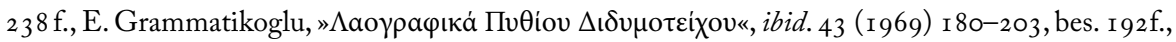

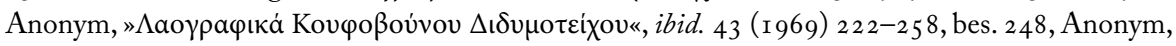

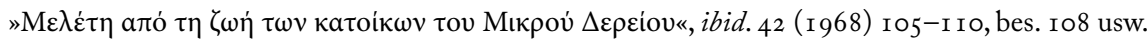
580 Mihail Arnaudov, »Kukeri i rusalii«, Sbornik za narodni umotvorenija i narodopis 34 (I920) I-244 
(grundlegende Studie mit umfassender Bibliographie, die die Zusammenhänge mit der dionysischen Religion betont; Brauchbeschreibungen aus den Kreisen Silistra, Tutraka, Burgas, M. Tărnovo, Lozengrad, Bunahisar, Viden, aus der Dobrudscha und Bessarabien), Anton P. Stoilov, "Folklor văv v. ।Maritza< (I $878-$ I 885)《, Izvestija na narodnija etnografski muzej v Sofja 4 (I926) H. I-4, R. Slavejkov, Bălgarski narodni običai i vjarvanija, Sofija 1924, 26-28, N. Konstantinov, »Igrata na starci< v Trakija (v s. Kavaklija, Lozengradsko)«, Trakija 4 (I927) H. 23 I, Hristo Vakarelski, »Bit na trakijskite i maloaziatski bălgari«, Trakijski sbornik I 935, 427-433 (u.a. kukeri-Spiele bei thrakischen und kleinasiatischen Bulgaren), ders., „Starinnite elementi v bălgarskite narodni običai", Prez vekovete, Sofija I 938, 270 f., ders., "Karnaval „kukeri«, Bălgarskite praznični običai, Sofija I 943 , 37-4I, G. Danev, »Kukeri i kukerov den v s. Bojanovo, Elchovska okolija«, Bălgarski narod I I (Sofija I 947) H. I, 26-29, Rajna Kacarova-Kukudova, Bălgarski tancov folklore, Sofija I 955, 63 f., R. Angelova, "Teatăr v života«, Teatăr (Sofija I 956) H. 4, 59-64 (Lebenslaufriten unter theatralischem Aspekt, u.a. auch die kukeri, vgl. auch dies., "Les masques populaires bulgares«, Schweizer. Archiv für Volkskunde 63, I 967, 226-239, auch in Robert Wildhaber [ed.], Masken und Maskenbrauchtum aus Ost-und Südosteuropa, Basel I 968, ıоo-I I3), Vassilka Tăpkova-Zaimova, »Svedenija za srednovekovi kukerski igri v Silistrensko«, Ezikovedsko-etnografski izsledvanija v pamet na St. Romanski, Sofija I 960, 705-708 (über türkenzeitliche kuker-Spiele im Raum Silistra), P. A. Petrov, »Kukeri v s. Pădarevo, Burgasko«, Sbornik za narodni umotvorenija i narodopis 50 (1963) 345-368, T. D. Zlatkovskaja, "O proizchoždenii nekotorich elementov kukerskogo v bolgar ( $\mathrm{k}$ voprosu o frakijskich tradicijach u narodno jugo-vostočnoj Evropi)«, Sorjetskaja Etnografija 1967, H. 4, 3 I-46 (zu den Wurzeln des kuker-Brauchs im Dionysoskult mit reicher Bibliographie), Rajna Kacarova, »Kukeri v s. Vresovo, Ajtosko, i v s. Asparuchovo, Provadijsko«, Izsledvanija v čest na akad. M. Arnaudov, Sofija I 970, 433-454, dies., „Derviši«, Bălgarsko muzikoznenija 4 (1978) 73-96 (zu einer kukerVariante aus Lesičevo im Gebiet von Pasardžik), M. Vasileva, »Kalendarni praznici i običai - kukovden (Kukerovden)«, Dobrudža, Sofija I 974, 320-322, B. Tichova, »Običai i obredi v Karlăk«, Rodopi I 975, H. 2, I 2 f. (Fallstudie zum kuker-Brauch), T. Koleva, »Bolgari«. Kalendarnie običai i obrjadi v stranach zarubežnoj Evropi. Verenni prazdniki, Moskva I977, 69- I I I (zu Kalenderbräuchen bei den Bulgaren) usw. Spätere Studien gehen bereits gezielt auf Details ein: z.B. L. Mikov, »Kăm problema za tipologijata na materialnata kultura v obreda«, Folklor, ezik i narodna sădba, Sofija I 979, I 26-I34, bes. I 3 I zu den kuker-Spielen in Südostbulgarien im Rahmen der Typologisierung der Materialkultur in Bulgarien, oder G. Michailova, »Kăm problema za semantikata na vestite v patriarchalnija svjat na Bălgarina «, ibid., I I 7-I 25 , bes. I 23 zu den kuker-Spielen als burschenbündische Organisationsform. Ähnliche Studien erscheinen auch bei Gelegenheit der Folkore-Festivals, z.B. M. Benovska, »Praznik na kukerite i survakarite«, Bălgarski Folklor 3 (I 977) H. 3, 63-66 berichtet über das VI. Kuker-Festival am r6. I. I 977 mit 46 Gruppen aus ganz Bulgarien. Zugleich findet eine Konferenz mit Thema »Traditionalität und Modernität der Kuker-Spiele« statt, mit Beiträgen wie von M. Čerkezova über Kukerbräuche und -masken in der Volkstradition, St. Džudžev über die kukeri als Träger von Spuren altthrakischer Musikkultur, D. Săbotinova zu den kukeri in Silistra, Georg Kraev zu den kukeri zwischen Tradition und Modernität usw. Zu den Folklore-Festivals allgemein Richard Bauman (ed.), Folklore, Cultural Performance, and Popular Entertainment, Oxford I 992. 
auch rumänische ${ }^{581}$ und griechische ${ }^{582}$. Aus diesem umfangreichen Vergleichsmaterial geht eindeutig hervor, daß zur thrakischen Karnevalsszene auch die Institution des Faschingskönigs mit Scheinobrigkeitsrechten (als Richter ${ }^{583}$ usw.) gehört, sowie seine symbolische Tötung (Wagen-Umstürzen, Verbrennung seiner Kopfbedeckung, In-

58 I Romulus Vulcănescu, »Măştile cucilor «, Studii şi Cercării Istituta Artei 7 ( I 960) I 59-I67 (rumänische Fallstudie zum cuci-Brauch, der auf die kukeri zurückgeht, aber zeremonielle Rückbildungen aufweist), Olga Flegont, Storia Teatrului în România, vol. I, Bucureşti r 965, 63 f. (die rumänische Theatergeschichte berücksichtigt gezielt auch die theatralischen Vorformen in der Volkskultur), Mihai Pop/C. Eretescu, „Die Masken im rumänischen Brauchtum«, Schweizer. Archiv für Volkskunde 63 (1976) I62-I76 (I 7 I über die cuci und die kukeri-Spiele südlich der Donau, vgl. Robert Wildhaber [ed.], Masken und Maskenbrauchtum aus Ost-und Südosteuropa, Basel I 968, 36-50), E. Popescu-Judetz, »Pageant of scuci< at Shrovetide in Romania«, Viltis 28 ( I 970 ) no 6, 4-7.

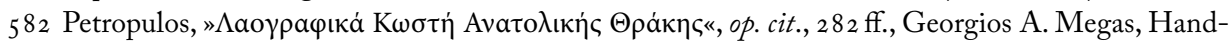
schrift aus dem Laografischen Archiv der Akademie Athen r I04 D, I937, I-36 (mit volkskundlichen Augenzeugenberichten aus dem heute bulgarischen Dorf Kosti und Interviews mit Flüchtlingen, u.a. über den kalogeros-Brauch im I 9. Jh.), Petropulos/Karakasis, Hs Laografisches Archiv

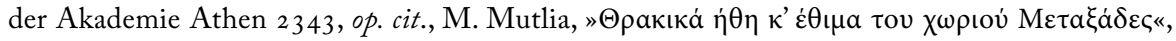

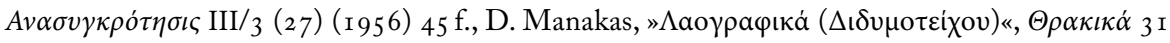

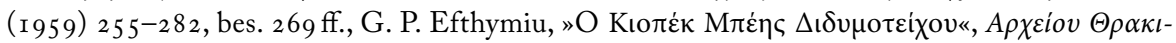

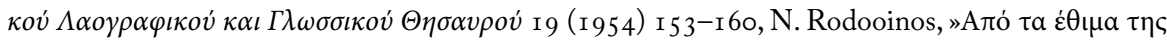

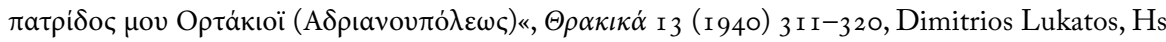
des Laografischen Archivs der Akademie Athen I I 52, I 938, 2 I, L. Svinu, ibid., 2374, I I I ff., Poly-

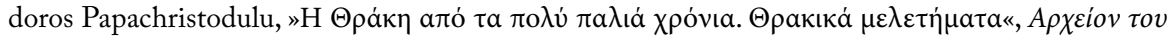

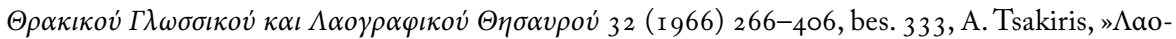

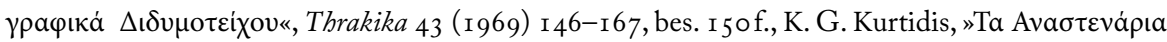

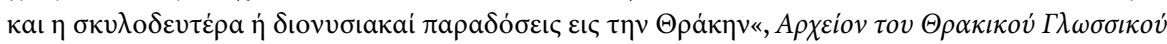

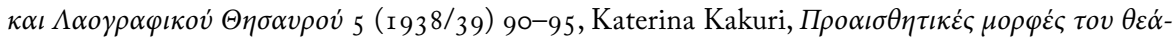

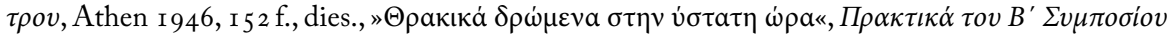

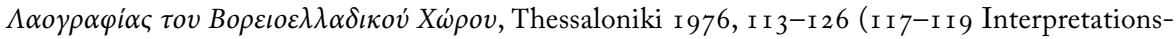
fragen zu älteren Brauchberichten, I 20 kuker in Brodivo und Lankadas, I 2 I kalogeros in Meliki Griechisch-Westmakedonien, I 2 I f., Köpek-Bey im Evros-Gebiet: bis zum Ersten Weltkrieg eine

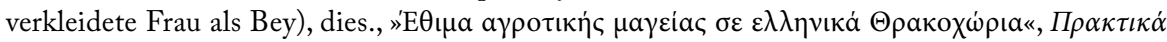

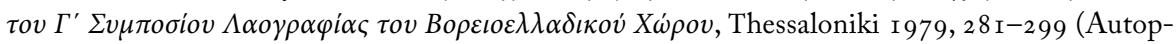
sie-Berichte und Studien zur Scheinpflügung mit besonderer Berücksichtigung des kalogeros und

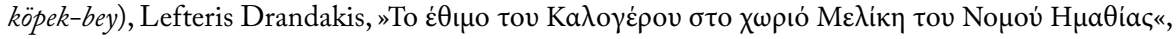
ibid., 233-253 (Autopsiebericht aus dem Dorf Meliki 1976-77) usw.

583 Gerichtsspiele sind vor allem auf der Dodekanes und den der kleinasiatischen Küste vorgelagerten Inseln anzutreffen (Puchner, Brauchtumserscheinungen, op. cit., 25 2-254), aber auch im Zentralbalkan, auf Zypern, in der Peloponnes und auf den Ionischen Inseln (vgl. jetzt Walter Puchner, »Improvisierte Gerichtsspiele und karnevaleske Schauprozesse in der Volkskultur des Zentralbalkans und des hellenophonen Mittelmeerraums«, Südost-Forschungen 63/64, 2004/05, 2 I I-23 I). Vgl. dazu noch in der Folge. 
den-Fluß-Werfen usw.), Tier-Verkleidungen (Kamel, Tanzbär) ${ }^{584}$, inszenierter Brautraub, Ringkämpfe ${ }^{585}$, die Arztfigur mit lustiger Untersuchungs- und Therapie-Szene und anderes mehr. Bei den nach Nordgriechenland ausgesiedelten Populationsteilen hat das Zeremoniell noch neue Anreicherungen und Erweiterungen erfahren ${ }^{586}$. An diesen komplexen performativen Riten und dem Radius ihrer Varianz wird auch deutlich, bis zu welchem Grad konstruiert die Kodifizierungsversuche einer südosteuropäischen Maskentypologie sind.

Momogeria und andere Gerichtsspiele. Ansatzpunkt für die Ausformung der Gerichtsspiele vor allem im Mediterranraum Südosteuropas ist die Maskenfigur des osmanischen kad $\imath$ mit den Scheinobrigkeitsrechten der Karnevalszeit ${ }^{587}$ bzw. die improvisierten Prozeßspiele in den ehem. venezianischen Inselbesitzungen. Unter den termingebundenen (Zwölften, Karneval) rituellen Formen nehmen die hellenophonen momogeroi oder momogeria ${ }^{58}$ im östlichen Teil der Nordküste Kleinasiens zum Schwarzmeer hin, bis tief in das Hinterland und weiter östlich nach Georgien ${ }^{59}$, eine herausragende Stellung ein, die nach der gewaltsamen Aussiedlung 1922 durch die pontischen Vereine in Griechenland an verschiedenen Stellen wieder zum Leben erwacht $\operatorname{sind}^{590}$. Die theatralischen

584 Vgl. wie oben.

585 Puchner, Brauchtumserscheinungen, op. cit., 102, I 47 f., 224, 232 f., 236 und pass.

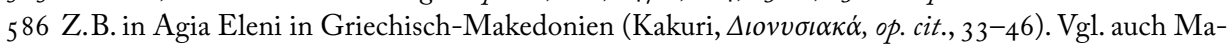

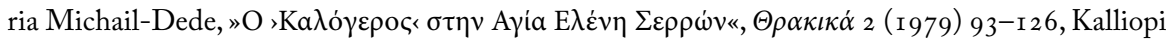

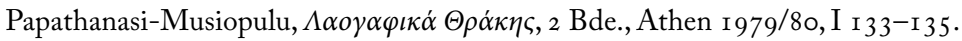

587 »... die Gerichtsszene, die durch eine handlungskausale Klammer an den Brautraub gebunden sein kann, gewöhnlich aber große Eigenständigkeit aufweist. Sie macht die Gestalt des Kadi erforderlich ( 5 Fälle), der satirische Scheinprozesse abwickelt oder auch durchaus ernsthafte Fälle. Unumstritten jedenfalls ist seine temporäre Rechtsgewalt. Ihm zur Seite stehen die Häscher und Gendarmen (23 Fälle), die die Gefangennahme der Angeklagten vornehmen und allgemein für Ordnung sorgen" (Puchner, Brauchtumserscheinungen, op. cit., 270).

588 Der zweite Wortteil verweist auf die »Alten«, der erste, $\mu \dot{\omega} \mu$ oc, ist eigentlich der Sarkast, der Ironiker, $\mu \omega \mu$ ó $\varepsilon \rho о \varsigma$ in sprichwörtlichen Redensarten der Pontus-Griechen hat dann die Bedeutung der

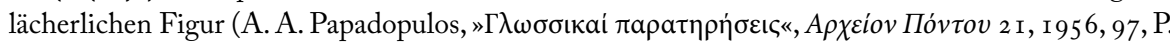

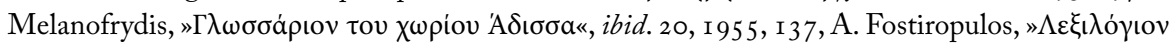

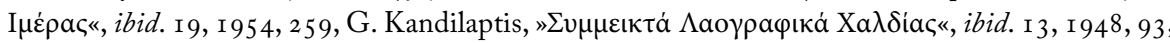

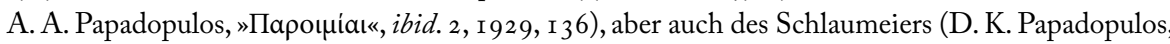

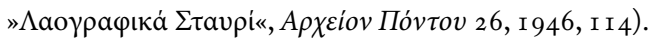

589 Tatjana Zajkovskaja, »Momoery-novogodnije rjaženyje u grekov Adžarii«, Polevyje issledovanija, n. s. I (Moskva r 993) 94-Io5 (Umraum von Batumi).

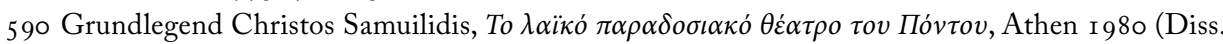

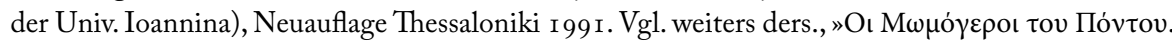

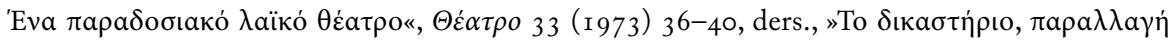

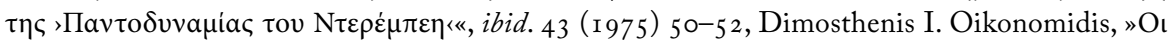


Improvisationsdialoge könnten einerseits von der griechischen Laienspieltradition in Trapezunt (ab 1 880), Kars und Batumi profitiert haben ${ }^{591}$, andererseits mit Brauchspielen, die von der türkischen Forschung beschrieben werden ${ }^{592}$, in Zusammenhang stehen; doch lassen sich hier ethnische Grenzziehungen aufgrund der systematischen Aus- und Umsiedlungen bzw. der okkasionellen Populationsverschiebungen seit byzantinischen Zeiten kaum ziehen, überdies ist die Terminologie (oyun, köy tiyatrosu) z.T. irreführend ${ }^{593}$. Und das relativ gut erforschte orta oyunu, das bereits dem Amateurthea-

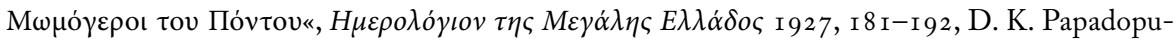

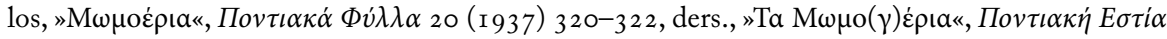

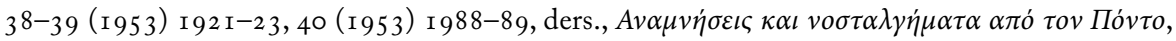

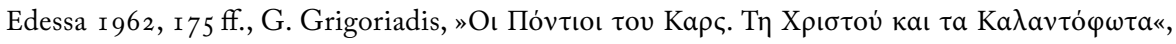

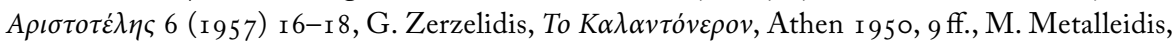

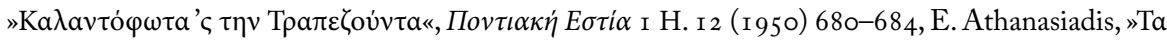

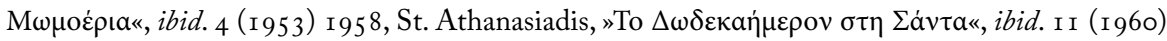

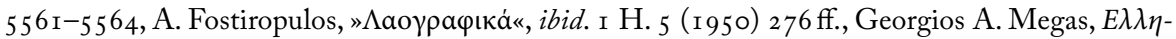

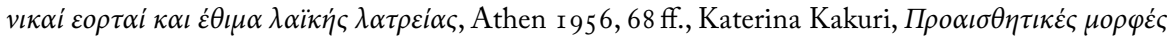

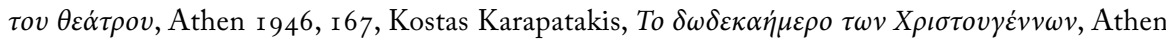
I 97 I , 22 I-225 usw.

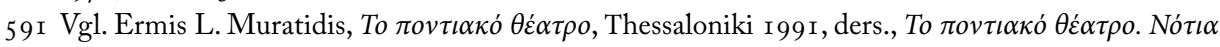

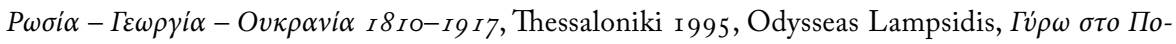

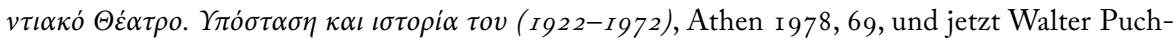
ner, Hellenophones Theater im Osmanischen Reich (1600-1923). Zur Geschichte und Geographie einer geduldeten Tätigkeit, Wien/Berlin 201 2, I30-135 (zur Laienspielbewegung und professionellen Truppen-Gastspielen vor 1922 in Trapezunt, Kerasus/Giresun, Amisos/Samsun, Matsuka/Maçka, Santa/Dumanl, Kotyora/Ordu, Rizus/Rize usw.) I 46-I 5 I (zu Batumi, Tiflis/Tbilisi usw.). Dazu auch die Korrespondentenberichte in russischen und griechischen Zeitungen von Odessa in Irena

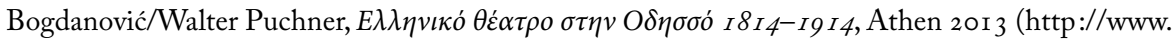
theatre.uoa.gr/ereyna/ekdoseis/parabasis.html).

592 Metin And, A bistory of theatre and popular entertainment in Turkey, Ankara 1963/64, 53 ff., ders., Dances of Anatolian Turkey, New York 1959, ders., Dionisos ve Anadolu Köylüsü, Istanbul 1 962, ders., Oyun ve Bügü, Istanbul s.a., ders., Kirk Gür Kirk Gece, Istanbul I959, Sükrü Elçin, »Parayi ver Oyunu«, Türk Folklor Arastirmalari Dergisi I 42 ( I96 I) 73-76, ders., »Karakancilo oyunu«, ibid. I 47 ( 1 96 I ) 79-80, ders., Anadolu köy osta oyunlari, Ankara 1964, Alessandro Bombaci, »Rappresentazioni drammatiche di Anatolia«, Oriens r6 (1 963) I 7 I-193, A. K. Tecer, Köylü Temsilleri, Ankara I940, Pertev N. Boratav, »The Negro in Turkish Folklore«, Journal of American Folklore 64 (I 95 I) $83-88$, ders., "Les Noirs dans le folklore turc et le folklore des Noirs de Turquie (Notes)«, Journal de la Société des Africanistes 28 ( 1958) 7-23, H. B. Yönetken, »Anadoluda Türk Halk temașasi«, Varlik n. 272 (1944), H. Z. Koșay, Türkiye Türk Düğünleri üzerine Mukayeseli Malzeme, Ankara I 944 usw.

593 Dazu auch Puchner, „Maskenraum Kleinasien. Von der Relativität ethnischer Grenzen«, Studien zur Volkskunde Südosteuropas, op. cit., 327-339. Mit den gleichen Termini werden dromena, spielhafte und darstellende Brauchhandlungen, pantomimische Tänze und theatralische Aufführungen bezeichnet. 
ter zuzurechnen ist, läßt sich erst ab Mitte des I 9. Jh.s dokumentieren ${ }^{594}$. Man kann aber vielleicht davon ausgehen, daß das fruchtbarkeitsmagische Ritualfundament nicht grundsätzlich unterschiedlich vom Balkanraum gewesen sein kann.

In seiner elaboriertesten Form ist das pontische Gerichtsspiel ein mehrszeniges Konglomerat mit rudimentärer Handlung, das jedoch noch deutlich magisch-rituelle Reste aufweist und die Richter-Satire mit einer Tod/Auferstehungs-Szene verbindet. Es besteht noch die datumsmäßige Bindung an die Periode der Zwölften bzw. des Karnevals und an die Umzugsstruktur der kalanda-Sänger bzw. den Gang von Haus zu Haus. Die dramatis personae sind der türkische Lehensherr (Alogas, Reiter) mit Steckenpferd oder als echter Reiter, der Amtsdiener (kizir), der Satan, der kleine Teufel, der Kadi, dikolon (der "Zweiärschige«, Bruder des Kizir, den Toten als lebensgroße Effigie auf den Rükken gebunden), der Arzt, die Braut des Kizir, ein Gendarm, der Kassier, Instrumentenspieler, ev. noch Tierverkleidungen und Tänzer. Gespielt wird am Neujahrstag früh in Häusern, auf Höfen, in Tennen in verschiedenen Dörfern bei Tageslicht, nachdem sich die Truppe schon am Tag nach Weihnachten formiert hat ${ }^{595}$.

Die Aufstellung ist folgende: Allen voran steht der Alogas, dann sitzt der Kadi auf einem hohen Stubl, rechts von ihm stehen der Gendarm, die Braut, der Arzt, links Dikolon. Die Teufel springen um den Alogas herum, der zu tanzen beginnt. Dann reitet er eine Runde ums Dorf, kommt und ruft: Das ist der Beginn der Vorstellung. - Der Alogas mit Anhang kommt in ein Dorf seiner Lehensherrschaft. Er ruft den Amtsdiener des Dorfes (Kizir); dieser fürchtet

594 Vgl. dazu noch in der Folge.

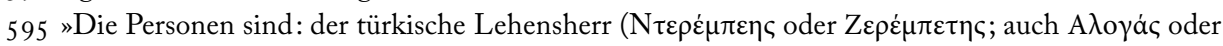

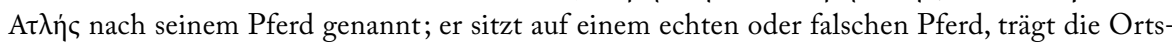
kleidung [کi $\pi \kappa \alpha]$, einen Seiden-Chiton, einen Seidengürtel, ein goldbesticktes Seidentuch um den Kopf, Pfeil und Bogen sowie andere Waffen umgehängt, Sporen; rechts hält er die Peitsche, links die Zügel), der Kı \i $(=$ türkischer Amtsdiener, der Proto-Momoeros, auch Karneval genannt: Er trägt ein Bocksfell mit einem am Rücken eingenähten Polster, um die Peitschenhiebe nicht zu spüren, eine Lederkopfbedeckung mit kleiner Glocke, rund um den Hals Knoblauchgebinde, Gräser

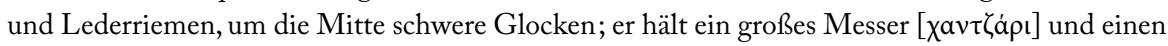
dicken Stock), der Ko $\rho$ Eeïtáv (der Satan, ganz in Schwarz mit Maske, Hörner und Schwanz; in Händen hält er zwei schlanke Gerten), der kleine Teufel (o Mıкрóv o $\Delta \varepsilon \dot{\beta} о \lambda o v$, kann auch fehlen),

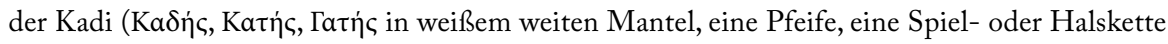

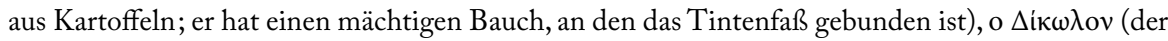
Bruder des Kizir, ärmlich gekleidet; bei seinem Auftritt hat er die Leiche seines Bruders auf den Rücken gebunden), der Arzt (o Гıатрóv mit hohem Hut, Brille, Arzneikiste, reuropäisch gekleidet), die Braut des Kizir (ein Mann ohne Schnurrbart, in weißem Brautkleid, mit Schmuck), der Gen-

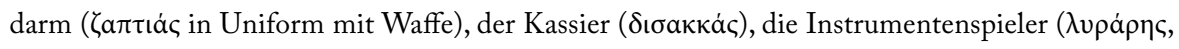
$\lambda v \rho \iota \tau \zeta \dot{\eta} \varsigma, \kappa \varepsilon \mu \varepsilon v \tau \zeta \varepsilon \tau \zeta \dot{\eta} \varsigma$ u.a.)«(Puchner, Brauchtumserscheinungen, op. cit., 249). 
sich und kommt nicht; man holt ihn mit Gewalt, und der Herr peitscht ihn und erteilt ihm Befehle: >Bring Stroh für mein Pferd,, >Bring Gerste`, ’Bring frisches Wasser, , Bring Hufeisen<, >Bring Nägek, ,Such einen Stall für mein Pferd،. Kizir fübrt eines nach dem anderen aus. Zuletzt soll er das Pferd am Zügel führen; dieses schlägt aus, und er fällt tot (in Varianten halbtot) zu Boden. (In einer Variante ist es auch der Alogas, der ihn zu Tode peitscht). Der Arzt kümmert sich um den Toten. - Kurze Pause. Die zweite Szene spielt vor dem Kadi. Dikolon erscheint vor dem Richter mit dem Leichnam seines Bruders auf dem Rücken und erhebt Anklage gegen den Lehensherrn wegen Mordes. Der Kadi denkt lange nach, verlangt nach Tinte und schreibt das Urteil: langjährige Haft für den Alogas. Er fordert unverschämt viele Geschenke von Dikolon, die dieser bringen will. Dann schickt er den Gendarmen aus und lädt den Angeklagten vor. Dieser erscheint beritten und grüßt den Richter herablassend. Der Prozeß beginnt: Auf die Frage, warum er Kizir getötet habe, antwortet der Lehensherr, daß er seinem Pferd nicht genug Gerste und Stroh gegeben habe und ibm selbst nicht seine schöne Frau (Variante: eine seiner zwei schönen Frauen). Der Richter fragt die umstehenden Zuschauer, ob die Frau des Kizir wirklich so schön sein. Man versichert ibm dies. Da spricht der Richter den Alogas frei und fällt das Urteil: >Ich an deiner Stelle hätte dasselbe getan<. - Die dritte Szene spielt im Haus des Toten: Kizir liegt am Boden, neben ihm steht seine Frau (die Braut) und über ibm der Satan, der auf seine Seele wartet. Der Alogas kommt angeritten, die Braut macht ihm schöne Augen und auch handfestere Gesten. Da niest der Kizir und erhebt sich, nimmt seine Frau in die Arme. Masken und Zuschauer rufen und sind begeistert, die Instrumente spielen, die Vorstellung ist beendet. Die Maskengruppe zieht, die Neujahrskalanda singend, weiter ${ }^{596}$.

Neben ausgeformten Gerichtsspielen gibt es »verbürgerlichte« Varianten als Stubenspiel der Neujahrssänger ohne die fertilitätsmagischen Szenen (z.B. in Trapezunt vor I 922$)^{597}$ oder rückgebildete Restformen mit rudimentärer Gerichtsszene um den Braut-

596 Für die Auferstehung sind auch andere deftigere Varianten bekannt: Der Kizir kommt zum Leben, weil sich seine Frau auf sein Gesicht setzt und entlüftet. In den abschließenden Tanz kann auch ein Brautraub eingelagert sein: Der Richter kann sich nicht mehr beherrschen und will auf die Braut zustürmen, doch man hält ihn zurück. Im Tumult wird die Braut gestohlen. Bis sie wiedergefunden wird, kann es zu harten Zwischenfällen kommen. Dann befiehlt der Lehensherr dem Kizir, er solle ihm den (Weiter)Weg zeigen. Dieser führt ihn absichtlich auf Steil- und Abwege, bis er gepeitscht wird und ihm den »Königlichen Weg« zeigt. Die Türken nehmen an den Vorstellungen nicht teil, befinden sich aber unter den Zuschauern. Vgl. Hs des Laografischen Archivs der Akademie Athen I I 5 2, I 7 ff. und die oben angeführte Literatur (deutsch bei Puchner, Brauchtumserscheinungen, op. cit., 249 f.).

597 Ausführliche Beschreibung in Puchner, Brauchtumserscheinungen, op. cit., 25 of. 
raub $^{598}$ oder die Verwendung der Maskentypen ohne die Richterfigur in mittel- und nordgriechischen Orten, wo die Pontusflüchtlinge angesiedelt worden sind ${ }^{599}$.

Solche karnevalesken Gerichtsspiele sind in elaborierter Form vor allem im Norden und im Süden der Balkanhalbinsel verbreitet und können die Funktion der Scheinobrigkeit erlangen, wobei tatsächliche Verfehlungen des Vorjahrs abgehandelt und bestraft werden und Reste einer pharmakos-Funktion (Sündenbock, in manchen Versionen auch mit Strohfiguren als Opfer) auszumachen sind, etwa beim Gerichtsspiel des "Räuberschlachtens« (rabvagas) in Ungarn: Bänkelsangartig wird das Sündenregister des Vorjahrs in Gedichtform vorgetragen, und am Rosenmontag werden die Rollen des Gerichtsspiels festgelegt: Der Richter ist meist auch der Textverfasser, zwei Henker halten die beiden »Räuber« im Tanzhaus fest, doch diesen gelingt die Flucht ins Wirtshaus, wo der Henker eine Runde spendieren muß, um ihrer wieder habhaft zu werden; am Faschingsdienstag werden die Übeltäter unter Musikbegleitung dem Richter mit Brille und Papierrolle vorgeführt, Anklage und Urteil werden verlesen, die Henker zerschla-

598 Z.B. im Raum Kilkis von Flüchtlingen aus Metalliko im kleinasiatischen Pontus (Neujahr 1940).

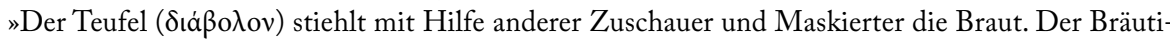
gam gerät außer sich und rast in der Zuschauermenge herum, läuft Leute nieder und schlägt mit dem Stock um sich. Aber er findet sie nicht; sie ist in der Zuschauermenge versteckt. Er kommt verzweifelt zum König ( $\beta a \sigma ı \lambda \varepsilon ́ \varsigma$ in offizieller Generalsuniform mit Orden, Goldborten, Szepter, Krone und roten Streifen an der Stiefelhose) und zeigt den Raub an. Dieser schickt den кaßáไnৎ (Amtsdiener auf Pferd) auf die Suche. Der findet die Braut und verhaftet den Teufel. Dieser wird vor den König gebracht, und der Prozeß beginnt sofort. Der Kadi (in Richtertracht, sehr dick) setzt sich neben den König, doch zieht ihm jemand den Stuhl weg, so daß er hinfällt. Das Aufstehen ist für ihn wegen seines Körperumfanges sehr schwierig, und er fällt wieder hin. Endlich sitzt er auf dem Richterstuhl, hat aber nun seine Kaltblütigkeit verloren und verurteilt alle zum Tod durch Erhängen. Die Braut hört das Urteil und fällt besinnungslos zu Boden. Der Arzt (in üblicher Kleidung) kommt und untersucht sie. Als Folge seiner komischen Therapiebemühungen stirbt sie. Da weint der Bräutigam, beugt sich über sie und küßt sie. Das erweckt sie wieder zum Leben. Der König ist von diesem Wunder bewegt und begnadigt alle (Puchner, Brauchtumserscheinungen, op. cit., 248).

599 Z.B. in Babalio in Ätoloakarnanien bei Flüchtlingen aus Keppekklisia im Pontus am Vortrag vor Weihnachten. Hier ziehen der weißhaarige Chuspos (mit Holzschwert und Sack), der Araber, der Alogas (hier nur mehr funktionsloser Pferdezüchter), die Braut und ein Lyraspieler von Haus zu Haus. Zuerst tritt der Chuspos ein, grüßt den Hausherrn mit dünner Stimme und legt sich, müde geworden, am Boden hin. Auf die Fragen des Hausherrn, woher er komme usw., antwortete er einsilbig. Sobald dieser jedoch die Erlaubnis zum Bleiben erteilt, ruft er die anderen Masken herein. Man tanzt zur Lyra, doch die Braut ist lustlos. Der Araber beschuldigt den Chuspos, er habe ihm die Frau gestohlen und die beiden geraten aneinander. Nach der Auseinandersetzung wird die Braut gefragt, wen sie lieber habe; sie bevorzugt den jüngeren Araber und hat nun auch Lust zum Tanzen. Die Masken werden bewirtet und verlassen mit einem Glückwunsch das Haus (Handschrift des Laografischen Seminars der Univ. Athen I622, 1972, 72 f.). Die Szene ähnelt dem Umzugsspiel der westpontischen karakotzadoi (vgl. in der Folge). 
gen die Tontöpfe auf ihrem Kopf (Enthauptung), die Toten springen auf und rennen ins Wirtshaus ${ }^{600}$.

Das Karnevalsrecht der Jurisdiktion ist auch im südosteuropäischen Inselbereich anzutreffen, z. B. beim traditionellen Aga-Spiel in Olympoi auf Chios, wo tatsächliche Geldstrafen für Vergehen ausgeteilt werden ${ }^{601}$, ähnlich wie bei der Kadi-Vorstellung auf $\mathrm{Samos}^{602}$, wo der Richter in einer älteren Version »erhängt« wurde ${ }^{603}$, ein Schauspiel, das sich in folkloristischer Version mit neo-obszönen Liedern und Tänzen als Touristenattraktion bis in die Gegenwart hineinzieht ${ }^{604}$. Humorvoller gestaltet sich die Gerichtsszene in Pylias an der Südspitze der Peloponnes, wo ein Schuldiger zum Tode verurteilt wird, weil er am Donnerstag der Fleischwoche ( $\tau$ $\sigma \kappa о л \varepsilon \dot{\varepsilon} \varphi \tau \eta$, traditioneller Termin des Schweineschlachtens) ${ }^{605}$ seine Sau mitleidlos ermordet habe.

600 Nora A. Tahy, Das theatralische Brauchtum des ungarischen Sprachbereichs, Frankfurt/M. etc. I 989 , $238-242$.

6or Eine burschenschaftartige Vereinigung der Jugend organisiert im Zeitraum von der Theophanie bis zum Karneval Tanzfeste mit den Mädchen am Hauptplatz, welche die Burschen bewirten. Am Käsemontag wird der Aga und der Wesir gewählt, im Festzug mit Musik begeben sie sich zum Dorfplatz, wo die öffentlichen und persönlichen Angelegenheiten des Dorfes geprüft werden. Bei begangenem Unrecht werden die einzelnen Personen vorgeladen. Als einziger darf der Wesir seine Meinung sagen, der Schreiber protokolliert. Geldstrafen werden verhängt für Holzstehlen usw., aber hauptsächlich für Ehezwistigkeiten, bei denen meist die Frauen das Anklagerecht haben

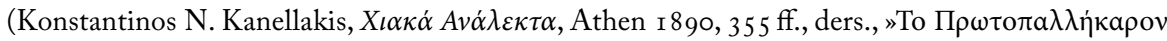

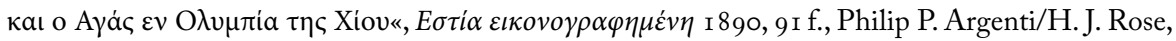
The Folk-Lore of Chios, 2 Bde., Cambridge 1949, 357 f.).

602 Der Richter des Karnevalsgerichts muß dicklich sein, schlagfertig und humorvoll. In Prozession zieht der Gerichthof begleitet von Kindergeschrei durchs Dorf. Am Hauptplatz werden Zeugen vernommen und Angeklagte verhört. Alle Vorfälle des vergangenen Jahrs werden behandelt. Die Verurteilten müssen Geldstrafe zahlen oder sie bekommen Stockschläge auf die Fußsohlen (D. Faraklas, $H$

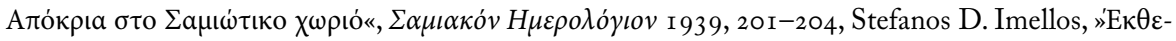

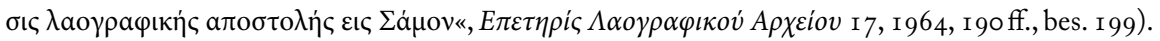

603 Der osmanische Kadi wird von einigen Lateinern (»Franken«) festgenommen und zum Galgentod verurteilt, doch der Strick reißt und unter dem Gelächter der Menge wird ihm das Bestechungsgeld seiner Richtertätigkeit abgenommen (Epaminondas Stamatiadis, $\Sigma \alpha \mu \iota \alpha \kappa \alpha$, Bd. 5, Samos I 887 , 369 ff.). In neueren Varianten fehlen die »Franken« und die Soldaten sind es, die ihn erhängen

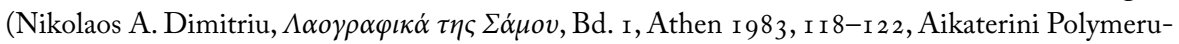

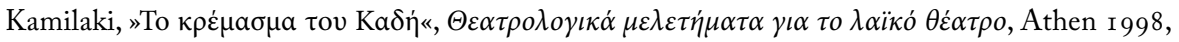

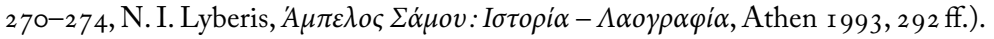

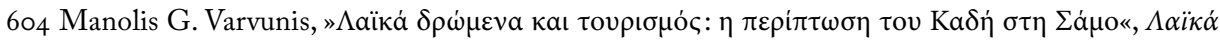

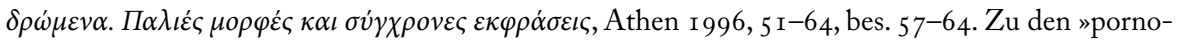

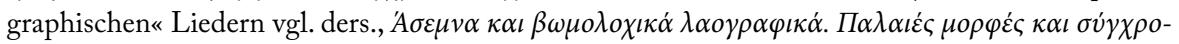

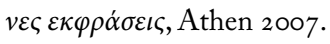

605 Vgl. wie oben. 
Viele Personen spielen mit: der Schuldige, der Kommandochef, der Vorsitzende des Gerichts, Staatsanwalt, Rechtsanwalt, Amtsdiener, Henker, Nachrichtenbote, eine Abteilung Gendarmen. Die Zuschauer sind zugleich Zuschauer beim Prozeß. In der ersten Szene fahnden Gendarmen und der Kommandochef nach dem "Mörder". Sie schießen mit Pistolen in die Luft, fangen ibn endlich und bringen ihn zum Gerichtsplatz. Zu Beginn der zweiten Szene nehmen Staatsanwalt, Vorsitzender, Richter und Amtsdiener in einer Ecke des Dorfplatzes (= Gerichtssaal) Platz. Die Zuschauer verteilen sich auf dem Dorfplatz. Der Verhaftete wird vorgeführt. - Kommandochef: Herr Vorsitzender, wir bringen dir den Angeklagten, der vorgestern seine Sau getötet hat. - Vorsitzender: Was sagst du, mein Lieber. (Zum Schuldigen) Du hast deine Sau getötet? - Staatsanwalt: Schlagen wird ibm den Kopf ab. - Rechtsanwalt (geht in die Mitte und improvisiert eine Verteidigungsrede). Schuldiger (weint, die Hände vor dem Gesicht): Herr Vorsitzender, hast du kein Mitleid mit mir? Wenn ich den Mord auch beging, so war es, um meine Kinder zu ernähren. Hast du kein Mitleid mit mir, wo ich Familienvater bin? - Staatsanwalt: Schlagen wir ibm den Kopf ab. - Chor der Zuschauer: Schlagen wir ihm den Kopf ab... - Vorsitzender (fragt die versammelten Leute): Schlagen wir ihm den Kopf ab oder lassen wir ihn? - Chor der Zuschauer: Schlagen wir ihm den Kopf ab... Schlagen wir ihm den Kopf ab.../Hier endet die zweite Szene. Für die dritte übersiedelt das Ensemble und die Zuschauer in das Geschäft des Dorfmetzgers. Dort stellt der Metzger den Henker dar, gegürtet mit einem alten Säbel. Henker (während der Schuldige sich nähert): Geh zum Teufel. - Schuldiger (weint und wird geschlagen). Henker: Gebt ibn mir, damit ich ihm den Kopf abhaue wie eine Zwiebel. (Die Gendarmen plazieren den Kopf des Schuldigen auf dem Holzstrunk, wo das Fleisch gehackt wird, und der Henker zieht den Säbel, um ihm den Kopf abzuschlagen). Nachrichtenbote (kommt von weit, laufend, schreiend): Haltet ein, meine Lieben. Schlagt ibm nicht den Kopf ab, der König gab Begnadigung. - Schuldiger (wird freigelassen, aber durch seine Furcht erlitt er die Pannen eines Kleinkindes und kann nicht zum großen Fest des Publikums mitgehen) ${ }^{606}$.

Es gibt eine Reihe von Belegen, daß diese Gerichtsspiele in den venezianischen Inselbesitzungen des Mittelmeers besonders beliebt waren ${ }^{607}$. Im Februar I 666 verfolgt ein deutscher Palästina-Reisender, Franz Ferdinand von Troili, der eine detaillierte Beschreibung seiner abenteuerlichen Reise veröffentlicht hat ${ }^{608}$, die ihn auch nach Kon-

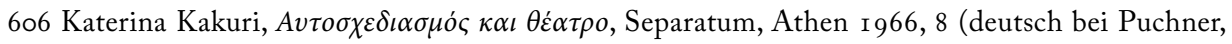
Brauchtumserscheinungen, op. cit., 252 f.).

607 Vgl. das spielhafte Judasgericht in den Bergdörfern von Zypern (Walter Puchner, „Das Judasgericht auf Zypern«, Österr. Zeitschrift für Volkskunde 36/85, I 982, 402-405), aber auch die Dialog-

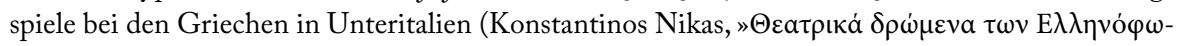

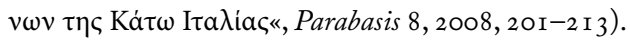

608 Orientalische Reise-Beschreibung, Dresden 1676 (der langatmige barocke Titel sei hier ausgespart). 
stantinopel und Ägypten, und auf der Rückreise von Piraten als Sklave verkauft, nach Algier geführt hat, durch eine Seesturm auf seiner Reise von Venedig nach Kreta zu einem einwöchigen Aufenthalt auf Zante gezwungen, auf dem for di Levante ein Karnevalsspiel, das er selbst folgendermaßen betitelt: »Die Griechen spielen Comoedi von dem Sabatai Sevi als von den Juden neugebohrenem Meßia ${ }^{609}$. Höhepunkt dieser Parodie, an der die ganze Stadtbevölkerung in jüdischer Verkleidung teilnahm und die die Ankunft per Schiff und den triumphalen Einzug in die Stadt umfaßte, war der Theaterprozeß des Großwesirs gegen den Pseudomessias auf einem Podium auf dem Hauptplatz, der zur Verurteilung zur Todesstrafe für den Volksaufwiegler führte, welcher nach einem Schandumzug, in eine Ochsenhaut gebunden und durch die Stadt geschleift, an einem Pfahl seinen Geist aufgegeben hat; die Hebräer von Zante haben versucht, den venezianischen provedittore durch bedeutende Geldzuwendungen von dieser antisemitischen Karnevalskundgebung abzuhalten, doch erwies sich dies als unmöglich ${ }^{610}$.

$609 \mathrm{Zu}$ dem historischen Hintergrund dieser antisemitischen Manifestation und den Gerüchten, daß der Gründer der Sekte der Sabbatianer Sabatai Zwi (I626-I676) vom Sultan in Konstantinopel, wo er sich befand, um als König der Juden anerkannt zu werden, im apokalytischen Jahre r 666 das Martyrium erfahren habe vgl. Walter Puchner, »Karnevalsprozess und Theatertod des Sabbai Zwi im apokalyptischen Jahr r 666 auf der Insel Zante«, Österr. Zeitschrift für Volkskunde 60/ıo9 (2006)

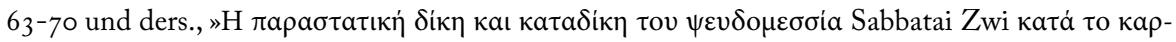

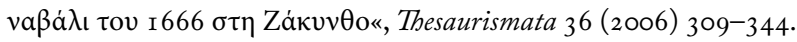

6 Io »Es war da zumahlen gleich hier die Fastnacht Zeit/da hab ich unterschiedliche Gauckelspiele Comoedien und Kurtzweilen gesehen/welche die Grichen [sic] trieben und verübten: Unter andero repraesentierten Sie auff öffentlichem Platze/des Sabathai Sevi der Jüden neu ankommenden Messiae Geburth und Ankunfft/welcher von einer grossen Anzahl Volcks/so alle wie die Jüden beklei$\mathrm{det} / \mathrm{hinnaus}$ an des Meersgestade gingen/eingeholet/mit großen Triumph und Frolocken/auß dem Schiffe/darinnen er von einer großen Suite begleitet/in den Hafen ankame [sic]/auffgenommen/ und mit Paucken und Trompete in die Stad/vor den GrosTürcken/so auff den Platze seiner wartete/gebracht wurde/da er nach fürhergegangener Verhörung auff sein eigenes Bekäntnnes/als ein Auffwiegler des Volcks/so wohl von dem Groß-Türcken/als deßen gantzen herumsitzenden Rathe sein Urtheil empfangen: Daß er auff eine Ochsenhaut gebunden/lebendig durch die Stad auff allen Gassen geschleiffet/und endlich an einem Pfale seinen Geist auffgeben solte. Es war eine große Menge Volcks auff dem Platze vorsamlet/wo diese Comaedi [sic] auff einem aufgerichteten Theatro agiret und gespielet wurde: So alles denen da selbst wohnenden Juden/deren sich dann viel zu Zante befinden/zur confusion/Schand und Spott von den Christen geschehen. Diese hatten aber all ihre Häuser und Fenster feste versperret/und ließ sich in zweyen Tagen keiner auff den Gaßen sehen; Haben auch vorhin viel Geld dem Gouverneur schon spendiret/und noch ein mehrers zu geben erboten/im fall er diese Comoedi verhindern/und ihren Meßiam so schimpflich zu tractiren nicht gestatten wolte; Es kunte aber nicht seyn/denn der Tumult unterm Volck war zu groß/und dem Gouverneur zu stillen unmöglich« (Troili, op. cit., I 5 f.). Zur Wahrscheinlichkeit, daß diese Schleifung mit einer der üblichen Judas-Puppen vorgenommen wurde, vgl. auch Walter Puchner,

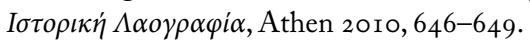


Für die Beliebtheit dieser Prozeßspiele lassen sich noch andere Indizien aufbringen: In den kretischen Varianten des griechischen Märchentyps der »Vergessenen Braut» (AaTh 3 I 3c, ATU 3 I 3) haben sich in Versform zwei Dialogszenen einer unbekannten kretischen Komödie aus dem I 7. Jh. erhalten (möglicher Titel: »Fiorentinos und Dolcetta«), die eine Gerichtsszene umfassen, wo die von ihrem Bräutigam in spe verlassene (weil durch magische Mittel vergessene) Königstochter, angeklagt von den geprellten Liebhabern einer versprochenen Liebesnacht, die sie durch Festzaubern zu verhindern wußte, vor dem Königsgericht den vergeßlichen Königssohn des gebrochenen Versprechens wegen beschuldigt und dieser ebenfalls durch magische Mittel seine verlassene Braut wiedererkennt ${ }^{611}$. Die unbekannte kretische Märchenkomödie kommt aus der Novellentradition der italienischen Renaissance, und diese Szene dürfte sich in der mündlichen Inseltradition erhalten haben, weil sie die improvisierten Dialogtexte dieser karnevalesken Gerichtsspiele ersetzt zu haben scheint und dermaßen in die mündliche Tradition der Zaubermärchen Einlaß gefunden hat, die sonst kaum Fragmente von Theaterstücken überliefert ${ }^{612}$.

Damit ist ein indirekter Nachweis für die Popularität dieser Gerichtsszenen gegeben. Doch dafür gibt es noch andere Beispiele, von den ebenfalls unter venezianischer Herrschaft stehenden Ionischen Inseln: Im »Homilien-Theater« des Karnevals auf Zante, das bereits geschriebene Texte verwendet, gibt es Stücke wie »Chrysavgi« und »Krinos«, die die Handlung der Tragödie "Erofile« von Georgios Chortatsis (um I6oo) und des Versromans »Erotokritos« von Vincenzo Cornaro (erste Jahrzehnte des I 7. Jh.s) kontaminieren ${ }^{613}$ : Doch das geflüchtete Liebespaar wird aufgegriffen und zum Gericht des Königs gebracht, nach einem komischen Prozeß aber freigesprochen ${ }^{614}$. Eine ähnlich abgewandelte Handlungsführung ist auch bei den westgriechischen Volksversionen der »Erofile«-Tragödie nachgewiesen ${ }^{615}$. Doch gehören diese Formen bereits dem AmateurTheater an.

6i I Textrekonstruktion in Manusos I. Manusakas/Walter Puchner, Die vergessene Braut. Bruchstücke einer unbekannten kretischen Komödie des I7. Jahrbunderts in den griechischen Märchenvarianten vom Typ AaTh 3 I3c, Wien 1984 (Österr. Akademie der Wissenschaften, phil.-hist. Klasse, Sitz. ber. 436),

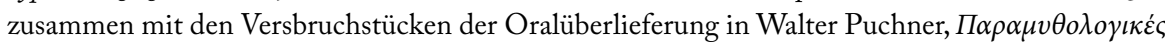

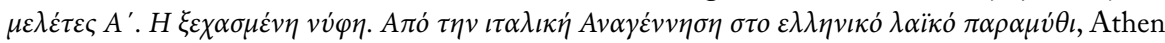

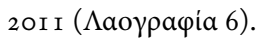

6 г 2 Zu diesem seltenen Fall auch Walter Puchner, »The Forgotten Fiancée. From the Italian Renaissance Novella to Modern Greek Fairy Tales«, Fabula 5 I (2010) H. 3/4, 20 I-2 I 6.

6 1 3 Zu diesen Literaturwerken siehe Puchner, Die Literaturen Südosteuropas, op. cit., Register 291.

6r 4 Walter Puchner, »Kretische Renaissance- und Barockdramatik in Volksaufführungen auf den Sie-

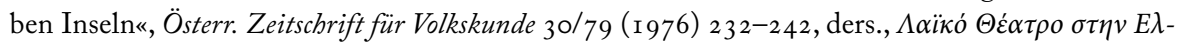
$\lambda \dot{\alpha} \delta \alpha \kappa \alpha \iota \sigma \tau \alpha B \alpha \lambda \kappa \alpha \dot{v} \iota \alpha$, Athen 1989, I 83-186.

6I 5 Dazu noch im nächsten Kapitel. 
Andere Dialogspiele. Neben dem Gerichtsspiel gibt es jedoch auch eine ganze Reihe von Dialogspielen, die entweder in einen Umzug von Haus zu Haus eingebettet sind oder nicht. Zur ersten Kategorie kann man die karakotzadoi im westlichen Pontusgebiet zählen, die während der Zwölften von Griechen in türkischen Dörfern gespielt werden und noch deutlich ein fruchtbarkeitsmagisches Fundament aufweisen: Der Dialog zwischen dem alten akbaba, der Maruska, dem Hausherrn und letztlich dem jungen karababa basiert auf dem Konflikt zwischen Bräutigam und Araber um die Braut, der Tötung des Bräutigams, seiner Auferstehung, aber in der Folge auf seiner Verstoßung ${ }^{616}$. Solche Dialogspiele können sich aber auch an den Osterzyklus anlagern, wie z.B. das

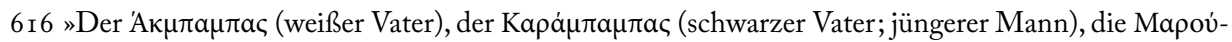
$\sigma \kappa a$ (in weißen Fellen), alle die Köpfe in Fellen, die Männer mit Glocken sowie der Hausherr oder eine Hausfrau bilden eine Spielgruppe. Die Maruska flieht in ein Haus, gejagt, und bittet um den Beistand des Hausherrn.- M (küßt ihm die Hand): Herr, wo soll ich mich verstecken? Man jagt mich.- H (Hausherr): Wer jagt dich, meine Tochter?- M: Der Akbabas, mein Gatte-- H: Geh und versteck dich drinnen. (Zeigt ihr ein anderes Zimmer des Hauses. M flieht dorthin. Akbabas tritt ein). A: Guten Abend, Herr.- H: Guten Abend. Sei willkommen. Was willst du?- A.: Herr, ich habe meine Gattin verloren, die Maruska. Hast du sie nirgendwo gesehen?- H: Nein. Ich habe sie nicht gesehen.- A: Ich jedenfalls suche sie und werde sie finden. Nur gib mir zwei Meter Raum, damit ich suchen kann.- H: Mach schon, such und find sie. (A. mißt mit seinem Stock sechs, statt zwei Meter im Viereck aus und beginnt zu suchen). A: Herr- - H.: Was ist?- A: Ihr Geruch steigt mir in die Nase. Ich werde sie finden.- H: Find sie! Mach schon! (Nach einiger Zeit der Durchsuchung hört man einen Schuß und im selben Augenblick fällt A tot zu Boden. M kommt heraus und nähert sich ihm. Sie überzeugt sich, daß er tot ist. Dann hebt sie ihren Rock und entlüftet sich. A wird wieder lebendig, steht erfreut auf). A: Herr, das war ein großartiges Heilmittel. Ich bin wieder lebendig geworden! (Noch bevor er ausgesprochen hat, hört man von neuem Lärm, Glockengebimmel, und gleich danach tritt K(arababas) ein, ein junger Mann mit schwarzem Haar und scharzem Bart, eine Waffe in Händen). A (sieht ihn und stürzt auf ihn los, rufend): Du hast meine Frau gestohlen. Du hast geschossen. Ich werde dich töten! (Sie kommen ins Handgemenge und schlagen sich wild). H (ruft): Halt! Halt! Auseinander! (Die beiden Gegner hören auf und treten auseinander). H: Sagt mir, was ist los? Was ist zwischen euch?- A: Hör zu, Herr. Ich hatte eine Frau, die Maruska, und die hat der da gestohlen, der Karababas.- K: Nein! Er lügt ... Diese Frau gehört mir.- A: Nein! Mir!- K: Nein! Mir!- H: Frau, komm her. (M kommt näher). A (mißt mit seinem Stock und verkündet): Das ist sie! Meine Maruska!- H: Sag mir, Maruska, wen von beiden magst du? Wen willst du?- M: Den Karababas!- A (regt sich auf, schlägt seine Glocken, dreht sich verzweifelt im Kreis, weint und sagt): Eine Glocke voll Lires hab ich für sie ausgegeben. Eine Glocke Lires ...- K (stößt A und bringt ihn hinaus): Geh, Alter!- Stimme des A: Eine

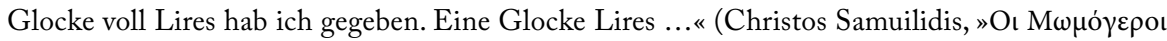

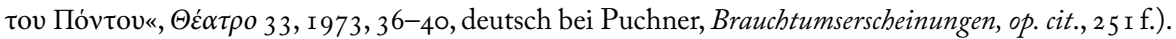
In dieser Schiedsgericht-Szene ist der improvisierte Dialog im altertümlichen pontischen Dialekt vom Dramatiker Samuilidis in eine lebhafte Theaterszene umgeschrieben worden; aus theatertheoretischem Gesichtswinkel handelt es sich um interaktives Theaterspiel, bei dem der Zuschauer (Hausherr) an der Handlung aktiv teilnimmt. 
zypriotisch-griechische Dialektspiel vom »Stinkenden Hund« ( $\sigma \kappa u ่ \lambda \lambda \propto \varsigma \beta \rho \omega \mu$ i $\sigma \eta \varsigma)$ im zypriotischen Bergland (Hagios Georgios im Bezirk Lemessos), wo am Osterdienstag abend auf dem Kirchplatz ein großes Feuer entzündet wird und die Zuschauer dem prahlerischen Streitgespräch der beiden Stinkenden Hunde (Heldenparodie) und dem muchtar (Dorfvorsteher) lauschen, der mit der Tötung des einen endet, wobei ihn der zweite beklagt, dann den Leichnam häutet und sein Fleisch an die Menge versteigert ${ }^{617}$.

6I7 Der zweite Stinkende Hund kommt beritten (als Steckenpferd eine Abflußröhre) und fortwährend wiehernd in eigenartigem Aufzug (weißes Hemd, weiße Pluderhose, schwarzer Gürtel, schwarze Kopfbedeckung) die Straße heruntergaloppierend zum Kirchplatz und fragt die Umstehenden und speziell den Bürgermeister: - Der stinkende Hund, wo ist er? Man soll ihn mir herschaffen! - Ein Gemurmel geht durch die Reihen, das »Pferd« wiehert ununterbrochen, allgemeine Unruhe entsteht. Der Reiter »sprengt« auf den Kirchplatz, dreht einige Runden, das Wiehern des »Hengstes« will nicht aufhören. Er fragt erneut: - Wo ist der stinkende Hund? Wo ist der Kerl? Wenn ich ibn kriege, mache ich Kleingeld aus ihm [Die Artikelverwechslung für bakira = grosi, türkische Münzeinheit, die seiner Rede etwas Fremdartiges verleiht, kann hier nicht wiedergegeben werden]. Hör zu, Bürgermeister, wo ist dein Amtsdiener? - Hier ist er. - Ich brauche ihn. Er übergibt die "Zügel« seines Pferdes dem Bürgermeister. Ist keiner hier vorbeigekommen? - Ja, einer ist gekommen und dann weitergegangen. Er hat mir was gesagt und das da hinterlassen. Das da hinter dir, den Stein [ditzimin - der Lüpfstein, schwerer Stein zur Kraftprobe], den hat er aufgehoben, hat sich hingesetzt und dann ist er gegangen [Sprechfehler und Verballhornungen werden hier nicht wiedergegeben]. - Ha, wird gemacht, schau meine Schenkel an, und du sagst, den hat er aufgehoben? - Der hatte solche Schenkel, wie das Kamel. Und Arme, solche! - Was für Arme, ha, der hat Arme wie das Ding vom Pferd ...-Ohren, was für Ohren hat er? - Ohren wie die vom Esel, noch größer. - Augen wie Backofenlöcher? - Freilich, was sind deine Augen dagegen! - Einen Kopf wie der vom Esel? - Größer als der vom Esel. - Ein Gesicht wie das Kamel? - Ich hab dir doch gesagt, größer als das Kamel! - Hat er nichts dagelassen? - Das Ding da hat er dagelassen. Er hat es angefaßt, aufgehoben, wieder hingeworfen und dann ist er gegangen. - Wie ist das möglich, mein Lieber? - Da, hier. Noch ist der Abdruck zu sehen. Wenn du den Stein aufhebst und ibn wirfst, dann will ich glauben, daß du ein Mordskerl bist. - Ist das möglich? Diesen Brocken, Herr Bürgermeister? - Ja, den da. - Soll ich ibn umdrehen? - Ja wenn du ibn umdrehst, dann bist du ein Mann. Der Stinkende Hund versucht den Stein zu bewegen, der Bürgermeister aber rät ihm davon ab, er könne sich nicht mit dem anderen Stinkenden Hund messen, der soeben weggegangen sei. - Gib's auf, gib's auf, das hat keinen Sinn ... Der »Stinkende Hund« bemüht sich weiterhin, den Stein zu bewegen. Er nimmt all seine Kraft zusammen und gibt sich optimistisch. - Warum denn, Herr Bürgermeister? Warum? Gib ibm! - Du tust gut daran, dein Pferd zu nehmen und zu verschwinden, denn wenn der andere kommt und dich sieht, ich weiß nicht, was er mit dir macht. - Hast du was gesagt? - Ja, das was ich gesagt habe, worauf wartest du noch? -

Da macht sich der zweite Stinkende Hund davon. Es entsteht Unruhe in der Menge, Rufe sind zu hören, der erste Stinkende Hund kommt herangesprengt und fragt: Wer ist der Bürgermeister und Amtsdiener? - Ich bin der Bürgermeister. Die Szene mit der Übergabe der Pferdezügel wiederholt sich. - Hat jemand diesen Stein geworfen? - Ja, einer hat ibn geworfen, aber jetzt ist er weggegangen. - Wer war das? - Ein stinkender Hund. - Ha, gerade den such ich, den such ich. - So? Der hat auch gesagt, er sucht dich. - Wie groß war er? - Wie groß? Du bist so groß wie sein Schenkel. - Einen 
Derartige totemistische Häutungs-Pantomimen sind in Zypern auch beim sogenannten »Messer«-Tanz in der Auferstehungsnacht, bei Hochzeiten und Jahrmärkten nachgewiesen $^{618}$, oder im »Vasilis«-Spiel oder »Hirtenspiel«, das in der Auferstehungsnacht oder am Osterdienstag gespielt wird ${ }^{619}$.

solchen Brustkorb? - Wo ist dein Brustkorb? - Solche Schenkel? - Wo sind deine Schenkel? - Hat er kein Zeichen hinterlassen? - Nur immer langsam! Da ist das Zeichen, der Stein, den bat er genommen und aufgehoben. - Den da? - Jetzt wird sich zeigen, ob du ein Mann bist. Nicht mit Gerede über Schenkel und Brustkorb, das zäblt nicht. Der hat ibn genommen und hochgehoben und ist gerade damit gegangen.Er versucht den Stein hochzuheben, fällt aber tot hin, weil ihn der zweite »Stinkende Hund«, der wiehernd heransprengt, erschießt. Er sagt zum Bürgermeister: Aber, Herr Bürgermeister, ist das der, den ich gesucht habe? - Das ist er. - Das ist der Hund, den ich gesucht habe. Das ist der, den ich gesucht habe. Er betrachtet den Toten, den ersten Stinkenden Hund, nähert sich ihm, betrachtet ihn wieder, fragt sich, wo er ihn schon einmal gesehen habe, und letztlich steigt in ihm der Verdacht auf, daß es sich um seinen Bruder handeln könne. Ha, sag, bist du mein Bruder? Ach, Mutter, Mutter! Er weint und klagt: Freunde, das ist mein Bruder! Der Bürgermeister: Schau ihn gut an, vielleicht ist er es auch nicht. Und laß das Geheule und Geschrei! - Laß mal sehen. Jetzt scheint mir, als ob er es nicht ist. - Er ist es nicht. Der da ist der Stinkende Hund. - Der ist um einen Kopf zu groß. - Zu groß, er ist es nicht. Der Stinkende Hund geht näher an ihn heran, schnüffelt und bemerkt: Aber der stinkt ja. Wer ist der? Was wollte er mir sagen? Jetzt hab ich ibn erschossen. Ich glaubte, er wäre weg. - Schau ihn gut an, ob es nicht doch der ist. - Das ist nicht der.- Er schneidet Stücke vom toten Körper des ersten Stinkenden Hundes.- Kommt, Freunde, wir haben Fleisch.- Er bietet den Dorfbewohnern der Reihe nach Fleischstücke an und ruft weiterhin: Der näcbste. - Holt euch alle, sagt einer der Zuschauer, und der Stinkende Hund fordert auch die anderen auf: Holt euch alle ein Stück Fleisch. Er wiederholt diese Aufforderung an alle Zuschauer und bietet das Fleisch an. Holt euch alle ein Stück. Jetzt verkaufen auch wir, da wir schon hier sind... Der nächste... Zebn Schilling... Zebn Schilling fünfzig ... Es ist teurer geworden ....... Das hochinteressante Volksschauspiel wurde zuerst von Petros Stylianu und

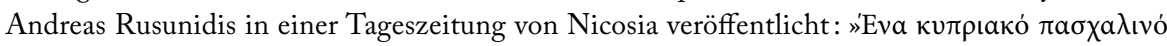

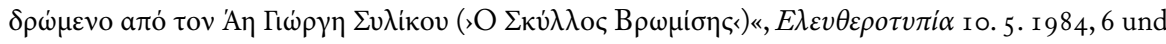
I I. 5. I 984, 6. Ausführlich mit dem gesamten Dialog wurde das Spiel wiedergegeben von Walter

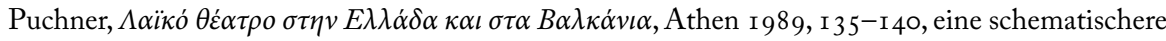

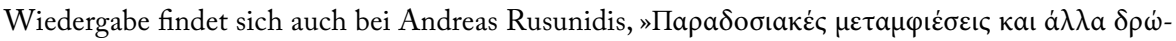

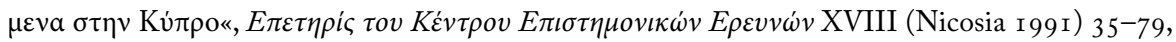
bes. 6 of.

6r 8 Beim »Messer-Tanz« stellt einer den Jäger und ein anderer das Tieropfer vor: Dieses wird pantomimisch verwundet, getötet, schließlich gehäutet und ersteht durch Wasserausspucken wieder

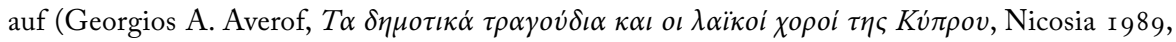
I 23 f.). Es geht eigentlich um Faschings-Verkleidungen, die eine Terminverschiebung zur Osterzeit durchgemacht haben (Rusunidis, op. cit. $5 \circ$ f.). Dies betrifft neben den genannten Spielen auch Gerichtsspiele, die »Alten« der Auferstehungsnacht (vgl. die geroi auf Skyros), reine Frauenspiele, und besonders das komplexe Kamel-Spiel (64 f.) mit Kameltreiber und Tochter, Brautraub, Pseudopriester, Scheinhochzeit, Meßparodie mit Zoten usw.

6I 9 Das "Vasilis-Spiel« existiert in mehreren Varianten. Nach den ältesten Aufzeichnungen steckt der Hirten-Gehilfe Vasilis betrunken in einem Sack (seinen Kopf bezeichnet ein irdener Topf) und 
Solche Osterspiele sind auch in einem ganz anderen Kommunikationsraum, in Epirus, nachzuweisen, wo z.B. im Dorf Mazia östlich des Sees von Ioannina am Osterdienstag ein agonales Dialogspiel ohne Verkleidung von Frauen dargestellt wird, um die "Hinkende« (кочтбокá $\lambda \omega$ ), wobei die Frauen einen geschlossenen Kreis bilden: Innen stehen der Müller (eine verheiratete Frau) und das Mädchen, außen die Mutter des

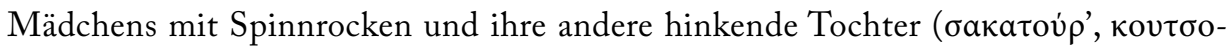
$\kappa a ́ \lambda \omega$, ebenfalls eine verheiratete Frau):

Die Mutter spinnt die Mitgift ihrer Töchter. Sie will in den Kreis sehen und nähert sich, doch die Frauen verhindern das. Mutter: Was riecht hier drinnen? Irgendwas riecht. - Eine oder viele Frauen antworten: Was soll riechen? Äpfel und Wildbirnen riechen. - Die hinkende Tochter folgt ihrer Mutter mit einem Stock. Die Mutter sieht in den Kreis hinein und sieht den Müller nahe ihrer Tochter. Sie wird wild und gestikuliert mit Händen und Füßen. Mutter: Was für Äpfel und Wildbirnen, sagt ihr. Das ist der Müller mit meiner Tochter. - Zur Tochter innen: Du bist es, du Schlampe... bist mit dem Müller gegangen, bringst Schande über mein Haus und läßt mich mit diesem Krüppel. - Sie zeigt auf die hinkende Tochter und zeigt vor, wie diese hinkt. Beide sagen zusammen: Jetzt werden wir dir's zeigen, Schlampe, und versuchen mit Stock und Spindel in den Kreis einzudringen und die gefallene Tochter zu schlagen. Die Frauen halten sie jedoch ab. Beide ermüden und beruhigen sich. Ein neuer Dialog beginnt. Mutter: Ach, du Schlampe, was hast du mir angetan. Ach, ich Unglückliche, was hast du mir angetan? Was soll aus mir werden? Ich hab dich in die Mühle geschickt und du bist nicht zurückgekommen, hast du dort geschlafen? - Tochter: Ich hab geschlafen, womit. Mit der Unterhose des Müllers. - Beide werden wieder zornig, knirschen mit den Zähnen und versuchen mit Gewalt in den Kreis einzudringen, um die Sünderin zu

gibt auf die Rufe seines Herrn, der krank ist und die Tiere nicht beisammenhalten kann, keine Antwort. Der Reihe nach kommen Gärtner, Olivenbaumbesitzer, Salatpflanzer, Bauern usw. und beschweren sich über den Schaden, den die Tiere anrichten. Dann erscheint der betrunkene Vasilis selbst und singt und lacht und kümmert sich keinen Deut um seinen Herrn. Der zerschlägt ihm den Kopf (den irdenen Topf) und beginnt, ihn mit dem Messer zu häuten, wobei ihm das ganze Dorf hilft (seine Haut soll sie für den entstandenen Schaden entschädigen). Dabei wird ihm der Sack langsam über den Kopf gezogen. Als sie seine Augen offen finden, erschrecken sie, halten ihn

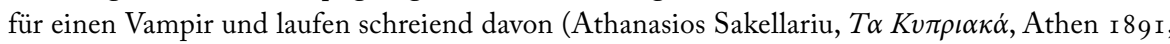
267-269). In Varianten davon erwacht der hier namenlose Hirtengehilfe zum Leben während der Häutung, indem er Wasser auf die Umstehenden spuckt (L. Antoniadis, „E Laografia I 9, I 960-6 I , 542 f.). Manchmal ist der Gehilfe auch schwerhörig und spielt Flöte, oder die Tiere des Hirten sind läufig, oder die Schuster kommen und interessieren sich für die abgezogene Haut des Gehilfen (Rusunidis, op. cit., 55 f.). Von dem Spiel gibt es auch eine nur von Frauen gespielte Variante, wo eine den »Hund« vorstellt, der das Zicklein fressen will (ibid. 57). Vgl. dazu das in der Folge behandelte Osterspiel der Frauen in Epirus. 
schlagen. Im Falle daß sie hineinkommen, schlüpfen Müller und Tochter aus dem Kreis und Mutter und Tochter müssen drinnen bleiben. Meist gelingt ihnen das aber nicht. Mutter zum Müller: Warum, du Hund, hast du mir die Tochter genommen und bringst Schande über mich? - Müller: Hättest du sie nicht zur Mühle geschickt. - Mutter: Du hast sie mir genommen und läßt mich hinkend, ha? Was soll ich jetzt mit diesem Krüppel anfangen? Wie soll ich sie verheiraten? - Müller: Was interessiert mich das? Deine Tochter ist schuld. - Die Mutter läuft wieder wütend um den Kreis, beruhigt sich abermals. Eine Frau aus dem Kreis: Was willst du mit der Spindel, was spinnst du? - Mutter: Was soll ich tun, ich Unglückliche, was soll ich tun? Ich mache die Mitgift für diesen Krüppel da, für diese Hinkende (zeigt auf die hinkende Tochter). Ein Bräutigam hat sich gefunden, aber womit soll ich ihn auszahlen, ich Unglückliche? Was soll aus mir werden, ich Unglückliche? - Müller: Gut, meine Liebe, gut. Sei nicht so wild. Schön, zahle ich die Mitgift für die Hinkende. - Mutter: Gut, wenn du mir das Geld gibst. Aber du hättest das nicht tun sollen, die Tochter behalten, und den Esel mit schleifenden Zügeln allein kommen zu lassen. Du hast mir Schande gebracht $t^{620}$.

Hier ist der Übergang zu agonalen Wettkampfspielen durchaus gegeben. Diese improvisierten Spott-Dialoge sind im gleichen Raum auch in der letzten Karnevalswoche zu verorten (z.B. das Spiel vom untreuen »Pferdeknecht«, B $\alpha \lambda \mu \alpha \dot{c} \varsigma)^{621}$, oder auch andere Osterspiele der Frauen, z.B.»Rumana«, wiederum mit dem geschlossenen Kreis, in den die

620 Das Spiel endet mit einer Art Kompromiß. Der Dialog ist improvisiert. Auch ein unversöhnliches Ende ist möglich. Mit diesem Spiel enden die Osterfeiertage. Es wird vor der Kirche aufgeführt (Hs des Laografischen Seminars der Univ. Athen I676, I972, 39 ff., Puchner, Brauchtumserscheinungen, op. cit., 255 f., die epirotischen Dialekttexte wurden hier ausgelassen).

62 I Auch in der Nordpeloponnes gespielt. Die Verkleideten, hier bules, genannt, versammeln sich unter der Platane am Dorfplatz, der eine in Schweinshaut, der andere in Lumpen, wieder andere in verschiedenen Fellen. Man spielt den »Pferdeknecht «.»Vorne stand der Herr und dahinter $30-40$ Menschen, die die Pferde vorstellten. Ganz hinten war der Pferdeknecht, der die Pferde hütete. Der Herr fragt vorne: - Pferdeknecht, Pferdeknecht. - Bitte sehr, mein Herr. - Was ist aus der schwarzen Stute geworden, die nicht da ist? - Ein Wolf kam vorbei und hat sie uns gefressen. - Was hast du mit dem Schwanz gemacht? - Den hab ich dem alten Sakellariu gegeben zum Fliegenerschlagen (er hatte einen Krämerladen). - Was hast du mit den Zähnen gemacht? - Die hab ich dem alten Tragotsulas gegeben, und er macht sich ein Gebiß daraus. - Was hast mit dem Fell gemacht? - Das gaben wir der alten Markina, die macht sich einen Pelz daraus. - Die Füße? - Die Füße gaben wird dem alten Sakellariu, daß er sich einen Tisch macht. - (Jetzt wurde der Herr böse und sagte zum Pferdeknecht): Warum hast du mir das solange Zeit nicht gesagt? - Du hast mich schwindlig gemacht die ganze Zeit, Herr. (Da schlug der Herr den Pferdeknecht mit der Peitsche aus Lumpen, während die anderen Pferde spielten und ausschlugen. Wir hatten auch einen Wolf mit Fell, der kam und mitten unter die Pferde sprang. Da schrie der Pferdeknecht): Ein Wolf, ein Wolf, auf ihn!« und die Szene endete in Tumult (Hss des Laografischen Seminars der Univ. Athen I 277, I 97 I, 5 ff., 992, I970, 4 o f. und I676, I 972, 37 ff., Puchner, Brauchtumserscheinungen, op. cit., 255). 
Protagonistin einzudringen versucht, um zu ihrem Freund innerhalb des Kreises zu kommen, aber von den Frauen abgewehrt wird ${ }^{622}$, oder ein anderes ( $\left.\tau \sigma \gamma \kappa \lambda \dot{\omega}\right)$, wo die »Henne« und ihre »Kücken« eine Reihe bilden, vor ihnen der »Falke«, der das letzte Kücken ganz am Ende der Reihe fangen muß: Nach einem Eingangsdialog stürmt der »Falke« los und die Schlange (jede Frau hält sich an den Röcken der vorderen) windet sich dermaßen, daß das letzte Kücken in der Schlange beschützt wird; beim Mißlingen des Versuches muß der »Falke« gewechselt werden, im gegenteiligen Fall gilt die letzte als Gefangene des Falken, die Reihe wird immer kürzer und die Jagd auf das Schwanzende immer leichter ${ }^{623}$. Doch hier ist der Übergang vom performativen Ritual zum agonalen Spiel fast schon vollzogen; nur der Eingangsdialog verweist noch auf szenisches Verständnis.

\section{I.5 Populares Amateurtheater}

Der Übergang von komplexen performativen Riten mit kommunikativer Interaktion und Dialogführung zu regelrechten Theateraufführungen von Dilettanten mit Probearbeit und Bühnenverständnis, vielfach fixierten Texten und Kalkulation der Publikumswirkung ist schnittklar und grenzscharf gar nicht zu ziehen; die Datumsabhängigkeit ist bei religiösen Spielen fast immer gegeben, wie auch die Karnevalsperiode den traditionellen Rahmen abgibt für weltliche Aufführungen zur Unterhaltung und Unterweisung. Das große Kapitel des von der Schule und Konservatorien, Bildungsinstitutionen und Kulturvereinen, Festivals und Tourismusorganisationen organisierten ruralen und urbanen Laientheaters muß hier zum Großteil ausgeklammert bleiben, da es sich vielfach um Innovationen handelt, die mit der traditionellen Volkskultur nur noch lose verbunden sind ${ }^{624}$. Eine konfessionelle und administrative Differenzierung ist jedoch zonengeographisch anzubringen: In den regionalen Einflußräumen des Markuslöwen und des Doppeladlers sind elaborierte und komplexe Volksschauspiele im engeren Sinn ${ }^{625}$

622 Ebenfalls in Mazia. Die Rumana nähert sich dem Kreis. Die Frauen: Rumana, Rumana, wo willst du hin? - Ich will verreisen. - Wo willst du hin? In die Fremde? - Ich will zu meinem Freund. - Der sieht sie von innen im Kreis: Da ist sie, da ist sie, mit Schafen tanzend und mit Ziegen spielend. Die Rumana sieht ihn und will in den Kreis eindringen, doch die Frauen, die sich an den Händen halten, wehren sie ab. Sie läuft rundherum, um eine schwache Stelle zu finden. Diejenige Frau, bei der sie eindringt, muß die nächste Rumana spielen. Frauen und Männer beobachten das Spiel und

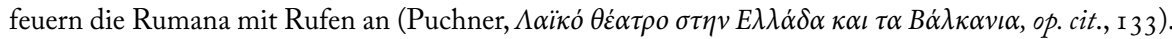

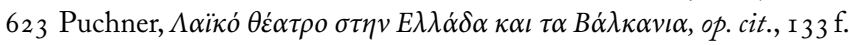

624 Zur theoretischen Ausdifferenzierung von traditionellem und modernem »Volkstheater« vgl. Wal-

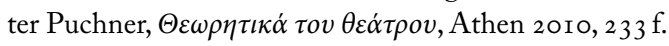

625 Vgl. die Unterscheidung zwischen Volksschauspiel im engeren und weiteren Sinne bei Walter Puchner, »Volksschauspiel«, Enzyklopädie des Märchens I 4 (Berlin/Boston 20 I I) 350-360. 
eher anzutreffen als in Regionen des Halbmonds, und was das religiöse Volksschausspiel betrifft: in katholisch/protestantischen Gebieten eher als in orthodoxen. Eine Grenzziehung gegen Mitteleuropa zu ist hier kaum möglich, denn die ehem. innerösterreichischen Landschaften stehen in engem Konnex zum südslavischen Katholizismus ebenso wie das Burgenland zu Ungarn und den Sprachinseldeutschen in Ostmitteleuropa ${ }^{626}$.

Dies ist beim geistlichen Volksschauspiel Innerösterreichs unmittelbar augenfällig, ob es sich nun um Ausläufer mittelalterlicher Passionsspiele handelt, Reste humanistischer Spiele der Reformationszeit oder Volksversionen von religiösen Ordensspielen aus der Zeit der Gegenreformation ${ }^{627}$; hier sind anzutreffen: die Passion ${ }^{628}$, der Einzug

626 Z.B. Richard Wolfram, Brauchtum und Volksglaube in der Gottschee, Wien I980.

627 In Auswahl: Leopold Kretzenbacher, Lebendiges Volksschauspiel in der Steiermark, Wien I 95 I, Viktor v. Geramb, Volkskunde der Steiermark, Wien 1925, Georg Graber, Kärntner Volksleben, Graz ${ }^{3}$ I 953 , Niko Kuret, "Ljudsko gledališče pri Slovenich", Slovenski Etnograf 3 (I 965) I 26-I 42, Leopold Schmidt, Das deutsche Volksschauspiel in zeitgenössischen Zeugnissen vom Humanismus bis zur Gegenwart, Berlin 1954, F. Sartori, Neueste Reise durch Österreich ob und unter der Enns. Salzburg, Berchtesgaden, Kärnten und Steiermark, Wien I 8 I I , A. Schlossar, Deutsche Volksschauspiele. In Steiermark gesammelt, 2 Bde., Halle I 89 I, F. Moro (ed.), Aus Kärntens Volksüberlieferung. Georg Graber zum 75. Geburtstag, Klagenfurt 1957 (Kärntner Museumsschriften Bd. XVII), K. Polheim, »Bericht über die mit Unterstützung der kaiserlichen Akademie der Wissenschaften unternommenen Vorarbeiten zur Herausgabe steirischer Volksschauspiele«, Anzeiger der phil.-bist. Klasse der Kaiserlichen Akademie der Wissenschaften in Wien XVI, I 906, 3 ff., H. Stanek, Das steirische Schäferspiel, Diss. Graz I935, Leopold Schmidt, »Gesellschaftliche Grundlagen des alpenländischen Volksschauspielwesens«, Theater der Welt I (Wien I 937) 382 ff., ders., "Zur Innengeschichte der deutschen Passionsspiele. Volksschauspiel und Volksfrömmigkeit«,Jahrbuch für Volkskunde 3 (München I 938) 2 I I ff., J. Wackernell, „Ein Tiroler Passionsspiel in Steiermark«, Forschungen zur neuesten Literaturgeschichte. Festgabe R. Heinzel, Weimar I 908, 2 I I ff., R. Bünker, Volksschauspiele der Obersteiermark, Wien I9 I 5, K. Weinhold, »Die Bauernspiele in Innerösterreich «, Deutsche Wochenschrift, Hannover I 854 , I 47 ff., H. L. Estocq, »Geistliche Bürgerspiele in Völkermarkt im I 8. Jahrhundert«, Carinthia I/ I I 6 (Klagenfurt 1926), Leopold Kretzenbacher, „Die Steiermark als Volksschauspiellandschaft Innerösterreichs«, Österreichische Zeitschrift für Volkskunde 2/5 I ( I 948) I 48-I 94, ders., "Jesuitendrama im Volksmund «, Volk und Heimat. Festschrift V. v. Geramb, Graz I 949, I 33 ff.

628 Leopold Kretzenbacher, Passionsbrauch und Christi-Leiden-Spiel in den Südost-Alpenländern, Salzburg 1952, H. Costa, »Ein Passions-Schauspiel in Krain«, Mitteilungen der Historischen Vereins für Krain I 857, S. 68 ff., Georg Graber, Das Kärntner Spiel vom Leiden und Sterben Christi, Wien I 923 , Niko Kuret, Igra o Kristusovem trplenju, Ljubljana 1937 (Ljudske igre, Nr. I7), Georg Graber, Passionsspiel aus Köstenberg. Das Leiden Christi, ein Trauerspiel in drei Aufzügen samt dem Kreuzzug und der Kreuzigung, Graz 1937, R. Ottitsch, Die Kärntner Christi-Leiden-Spiele, Diss. Graz 1937, Leopold Kretzenbacher, »Barocke Spielprozessionen in Steiermark. Zur Kulturgeschichte der theatralischen Festfeiern in der Gegenreformation", Aus Archiv und Chronik II (Graz I 949) I 3 ff., 43 ff., 83 ff., ders., "Ein Jesuitenpassionsspiel des frühen I 8. Jahrhunderts in Steiermark«, Österreichische Zeitscbrift für Volkskunde 2/5 I ( 1 948) 76 ff., H. Lange, »Passionsspiele in Fürstenfeld«, Mitteilungen des Historischen Vereins für Steiermark 35 (Graz I 887) I 3 I ff., Leopold Kretzenbacher, »Altsteiri- 
Christi in Jerusalem ${ }^{629}$, Hirtenspiel ${ }^{630}$, Dreikönigsspiel ${ }^{631}$, $^{\text {Paradeisspiel }}{ }^{632}$ usw. $^{633}$, ganz

sches Passionsspiel«, Blätter für Heimatkunde XX (Graz I 946) I 8 ff., O. Wonisch, Das St. Lambrechter Passionsspiel von I606, Passio Domini und Dialogus in Epiphania Domini des Johannes Geiger, Wien 1957 (Veröffentlichungen des Österreichischen Museums für Volkskunde XI), Georg Graber, Kärntner Volksschauspiele III. Passionsspiele, Wien 1923, A. Hauffen, »Passionsspiele in Krain«, Zeitschrift des Vereins für Volkskunde 4 (Berlin I 894) 443 ff., Leopold Schmidt, »Neuere Passionsspielforschung in Österreich «,Jahrbuch des Österreichischen Volksliedwerkes 2 (I953) I 42 ff. usw.

629 Leopold Kretzenbacher, "Palmesel-Umfahrten in Steiermark«, Blätter für Heimatkunde 27 (Graz I953) 83 ff., O. Wonisch, »St. Lambrechter Osterfeiern und dramatische Zeremonien der Palmweihe«, St. Lambrechter Quellen und Abhandlungen I (Graz I 928) H. I, 7 ff.

630 Georg Graber, Das Gmünder Hirtenspiel aus dem I7. Jahrhundert, Spittal/Drau I 930, Oskar Moser, »Theatergeschichtliches zum Gmünder Hirtenspiel«, Carinthia I/I 48 (Klagenfurt I958) 4I 7 ff., Leopold Kretzenbacher, »Frühbarockes Weihnachtsspiel in Kärnten und Steiermark«, Archiv für vaterländische Geschichte und Topographie 39 (Klagenfurt 1952), Leopold Schmidt, Formprobleme der deutschen Weihnachtsspiele, Emsdetten 1937 (Die Schaubühne 20).

63 I Oskar Moser, „Die Kärntner Sternsingbräuche. Beiträge zur Erforschung ihrer Vergangenheit und Gegenwart«, in: Lied und Brauch. Aus der Kärntner Volksliedarbeit und Brauchforschung, Klagenfurt I 956 (Kärntner Museumschriften VIII), I 3 I ff., F. Koschier, »Das Heiligenbluter Sternsingen«, ibid., I I 3 ff., Oskar Moser, »Das Gailtaler Dreikönigssingen«, Jahrbuch des Österreichischen Volksliedwerkes 6 (I 957) i 7 ff.

632 Leopold Schmidt, "Das Triebener Paradeisspiel«, Wiener Zeitschrift für Volkskunde XLVII (I 942) 53 ff., K. Mautner, »Aufführung eines Paradeisspieles«, ibid., 27 (I 92 I) I 2 ff., Leopold Kretzenbacher, »Frühformen des Paradeisspieles in Inneröstereich«, Zeitschrift des Historischen Vereins für Steiermark 39 (Graz I 948) I 37 ff., ders., "Schlangenteufel und Satan im Paradeisspiel«, Schmidt, Masken in Mitteleuropa, op. cit., 72 ff., Georg Graber, Kärntner Volksschauspiele II. Das Kärntner Paradeisspiel, Kärntner Jedermann, Wien I 923, Niko Kuret, »Ljubljanska igra o paradizu in ujen evropsky okvir«, Razprave SAZU 4 (1958) 204-252.

633 K. Bünker, »Das Spiel vom reichen Prasser und dem armen Lazarus (Steirisch-Lassnitz)«, Zeitschrift für Österreichische Volkskunde I 9, I60 ff., H. Koren, Die Steirischen Josephsspiele, Diss. Graz I 93 I, F. Franziszi, „Lieder aus dem Josefispiel«, Carinthia I (I839) I 9 ff., K. Wurdack, »Das Mitterndorfer Nikolausspiel«, Das deutsche Volkslied 35 (1933) 83 ff., Leopold Schmidt, "Zum Mitterndorfer Nikolausspiel«, ibid. 36 (I 934) I6, ders., Die burgenländischen Sebastianispiele im Rabmen der barocken Sebastianiverehrung und der Volksschauspiele vom Hl. Sebastian, Eisenstadt I 95 I, ders., „Vom österreichischen गJedermann«", Austria 3 (Graz I 948) 6r ff., Leopold Kretzenbacher, »Die steirischkärntnerischen Prasser- und Hauptsündenspiele«, Österr. Zeitschrift für Volkskunde I/5o (I 947) 56 ff., Georg Graber, Der Kärntner Totentanz, Komödie vom grimmigen Tod, Wien I 924, Leopold Kretzenbacher, "Adams Testament und Tod. Apokalypse und Totentanz im lebendigen Volksschauspiel der Steiermark «, Schweizer. Archiv für Volkskunde 54 (I 958) I 29 ff., ders., »Totentänze im Südosten", Ostdeutsche Wissenschaft. Jahrbuch des ostdeutschen Kulturrates 6 (München I959) I 25 ff., ders., „Magdalenenlegende und Volksschauspiel«, Beiträge zur Volkskunde Tirols, Festschrift H. Wopfner, Innsbruck 1948 (Schlern-Schriften 53), Teil II, 2 I 9 ff., Georg Graber, »Ein Kärntner Puppenspiel von Dr. Faust«, Carinthia I (I 94I) 462 ff., ders., Ein Kärntner Spiel vom Doktor Faust. Nach einer Handschrift des Klosters St. Georgen am Längsee, Graz 1943 (Kärntner Forschungen I/2) usw. 
wie bei Slovenen und Kroaten ${ }^{634}$, oder im Burgenland ${ }^{635}$ und in Westungarn ${ }^{636}(\mathrm{~Pa}-$ radeisspiel ${ }^{637}$, Christgeburtsspiele, besonders von Oberufer ${ }^{638}$ usw. $\left.^{639}\right)$ und bei anderen germanophonen Enklaven in Südosteuropa bis etwa zum Zweiten Weltkrieg, vor allem an den Donauufern, in der Batschka, im Banat, dem Karpatenbogen, in Dobrudscha und Bessarabien, vorwiegend protestantischer Konfession ${ }^{640}$.

634 K. Kumbatovič, »Die Barockkultur Mitteleuropas und die Ursprünge des slowenischen Theaters«, Maske und Kothurn 7 (196I) 248-273, P. v. Radics, "Älteste Geschichte des Laibacher Theaters«, Blätter aus Krain VIII (I 863) Nr. I 8, A. Trstenjak, Slovensko gledališče, Ljubljana I 892, Io ff., Niko Kuret, »Ljudsko gledališče pri Slovenich", Slovenski Etnograf XI (I958) i I ff.

635 Leopold Schmidt, Das alte Volksschauspiel des Burgenlandes, Wien I 980.

636 K. J. Schröer, Deutsche Weihnachtsspiele aus Ungern. Geschildert und mitgeteilt, Wien 2 I 862, R. Weinhold, Weihnachts-Spiele und Lieder aus Süddeutschland und Schlesien, Graz I 855, M. Heinzel, Deutsche Weihnachtsspiele aus Ungarn, Raab I 865, G. Kurzweil, »Remigius Sztachovics und die Anfänge der deutschungarischen Volkskundeforschung", Deutsch-Ungarische Heimatblätter 3 (Budapest I 93 I) 3 I 9 ff., K. J. Schröer, Das Weihnachtsspiel von Oberufer. Faust, Leipzig r 86o, W. Köppen, Beiträge zur Geschichte der deutschen Weihnachtsspiele, Diss. Marburg I 893, J. Ernyey/G. KarzaiKurzweil/L. Schmidt, Deutsche Volksschauspiele aus den oberungarischen Bergstädten, Bd. 2, Budapest 1938, A. Dörrer, Tiroler Volksgut auf dem Heideboden. Unterinntaler Weihnachtsspiele in der Dreiländerecke des Neusiedlersees, Eisenstadt $195 \mathrm{I}$.

637 Leopold Schmidt, "Zur Paradeisspielverbreitung im Osten«, Deutsch-Ungarische Heimatblätter 5 (Budapest I 934) I 50 ff., R. Hartmann, »Das Töttöser Adam- und Eva-Spiel«, ibid. 2 (r 930) 3 I 4 ff., 638 K. J. Schröer, Christgeburtsspiel aus Oberufer bei Pressburg, Leipzig 1923, ders., Die Oberuferer Weihnachtsspiele im Urtext, K. J. Schröers Fassungen von 1858 , in Verbindung mit der Andauer Handschrift und dem anonymen Druck von I693, ed. v. H. Sembdner, Stuttgart I977, K. Schröer, Über die Oberuferer Weihnachtsspiele, ed. v. H. Sembdner, Stuttgart I 963, K. J. Schröer/K. E. Fürst, Das Oberuferer Paradeisspiel, Originalaufzeichnung einer Inszenierung aus dem Jahr 1926, München I978, V. Stegemann, »Der Stern von Bethlehem im Oberuferer Weihnachtsspiel«, Germanisch-romanische Monatsschrift 30 (1 942) 73 ff., H. Klein, Das Oberuferer Paradeisspiel in ursprünglicher Gestalt, Kassel I 928, ders., "Die Weisen des Oberuferer Christgeburtsspiels«, Jahrbuch des Österreichischen Volksliedwerkes 9 ( 1960 ) 40 ff., Leopold Schmidt, „Der Oberuferer Spielkreis«, Sudetendeutsche Zeitschrift für Volkskunde 7 (1934) I45-I 57, ders., "Oberufer und die Volksschauspiellandschaft Burgenland«, Güssinger Begegnung 1975, Eisenstadt 1976, 67-80, Ch. Jenssen, Die Spiele von Oberufer. Rückblick und Aufgabe, Hamburg (1964), H. Brandt, Das Oberuferer Christgeburtsspiel, München 1950, H. Beranek-Wolf, Das Verdienst von Dr. Hans Klein um die Oberuferer Weibnachtsspiele, Pressburg 1934, H. Amanshauser, Das Paradeisspiel von Oberufer, Berlin 1935, Hans Klein, »Die Oberuferer-Spiele«, Karpathen-Jahrbuch 9 ( I 958) I 57-I63, R. Netolitzky, »Die Weihnachtsspiele von Oberufer. Rückblick und Aufgabe«, Südostdeutsche Vierteljabresblätter 8 (I959) I 24-I 30, Hans Klein, „Die Oberuferer Volksschauspiele und ihre Auswirkung", Karpathen-Jahrbuch I 3 (1962) 50-57 usw.

639 Das Jüngste Gericht, das Spiel vom armen Lazarus, St. Sebastian usw.

640 Hans Moser, »Volksschauspiele im Auslandsdeutschtum«, Dichtung und Volkstum 36 (Stuttgart 1934) 84 ff., J. Ernyey/G. Karsai-Kurzweil/L. Schmidt, Deutsche Volksschauspiele in oberungarischen Bergstädten, Bd. I-2, Budapest I932-38, A. Hartmann, »Die Christkindlspiele der `Schwäbischen 
In der Tradition moraldidaktischer Fastnachtsspiele steht hier etwa der burgenländische "Steffl von Neuhausen ${ }^{641}$ oder das satirische Spiel vom Schuster und vom Schneider im Gefolge der Oberuferer Weihnachtsspiele ${ }^{642}$, doch ist die oberschichtliche Überarbeitung nicht zu verleugnen. Näher an der Unterschichtenideologie stehen die ungarischen Betyaren-Spiele, die wandertruppenartig zum Karneval, bei Hochzeiten, in den Spinnstuben und im Gefolge der Bethlehemspiele zum Besten gegeben werden; die Betyaren stehen einerseits in der westlichen Tradition der romantisierten Räuber-, Wilderer- und edlen outlaws-Geschichten (vgl. die Betyarenlieder des I9. Jh.s, Marktdrucke und Volksstücke), andererseits in der östlichen Hajduken-Tradition des Osmanischen Reiches. Kernszene der Aufführung ist die Beraubung der Kaufleute im Wirtshaus durch die Betyaren, die damit bei dem unsympathischen und geldgierigen Wirt ihre Zeche zahlen; die Tochter und Frau des Wirtes liebäugeln offen mit den Räubern; manchmal verkündet der Nachtwächter die Sperrstunde, doch die Betyaren zechen weiter, bis sie von den Gendarmen verhaftet werden ${ }^{643}$.

Türkei«, Zeitschrift für Volkskunde N. S. I (Berlin I929) I6 5 ff., Alfred Karasek-Langer, »Die Erforschung des deutschen Volksschauspiels in Galizien«, Schaffen und Schauen 8 (Kattowitz 1932) I ff., G. Fischer-Wellenborn, Das deutsche Volksschauspiel in den Volksgruppen des Innerkarpathischen Raumes, Wien 1942, B. Schier, Hirtenspiele im Karpathenraum, Berlin-Dahlem 1943, L. Wohlstand, "Das Volksschauspiel im Hauerland«, Karpathen-Jahrbuch 7 (1956) Iо I-ıo6, Alfred KarasekLanger, »Die oberschwäbische Volksschauspiellandschaft. Entdeckung und Untergang «, Jahrbuch für Volkskunde der Heimatvertriebenen I (Salzburg 1954) 93 ff., ders., "Deutsche Herodes- und Schwertfechter-Spiele am Nordrand der Karpathen«, ibid. 5 (1959/60) I 90 ff., ders., Volksschauspiel und Volkstheater der Sudetendeutschen, München I 96o, Alfred Karasek, Das deutsche Volksschauspiel in Galizien, Salzburg 1960, Alfred Karasek/J. Lanz, Das deutsche Volksschauspiel in der Bukowina, Marburg 197 I, Alfred Karasek/K. Horak, Das deutsche Volksschauspiel in der Batschka, in Syrmien und Slawonien, Marburg 1972, Alfred Karasek, Das deutsche Volksschauspiel in der Schwäbischen Türkei, Marburg 1974, A. E. Emeritzy, „Das Volksschauspiel Südosteuropas«, Karpathen-Jahrbuch 30 (I979) I 23-I 46.

64I Johannes Bolte, „Kleine Beiträge zur Geschichte des Dramas«, Zeitschrift für deutsches Altertum 32 (Berlin I 888) 20 ff., Leopold Schmidt, Steff von Neuhausen. Ein burgenländisches Fastnachtsspiel des I7. Jahrhundert, Horn I 949, ders., »Zum >Steffl von Neuhausen«", Burgenländische Heimatblätter I 2 (I950) $89 \mathrm{ff}$.

642 K. Benyovsky, Die Oberuferer Weihnachtsspiele, Pressburg I 934, I 39 ff., Leopold Schmidt, »Nachkomödie und Streitgespräch", Bayerische Hefte für Volkskunde I I (1939) 25 ff.

643 Manchmal wird auch der Wirt, der bereit ist für Geld auch die Ehre von Frau und Tochter zu opfern, arretiert, weil er keine Konzession besitzt. Das Stück wird auch auf Bühnen aufgeführt, ohne Masken aber mit rollengemäßer Ausstattung. Die Aufführung setzt intensive Proben voraus, das Erlernen der Texte, aber auch die Bereitschaft, auf Einwürfe der Zuschauer in Form von Improvisationen einzugehen, besonders die Rolle des Wirtes zeigt bereits Ansätze zur individuellen Charakterisierung; oft werden auch Betyarenlieder gesungen. Das Vorspiel bringt die Wirtsfamilie im Wirtshaus, den Eintritt der Kaufleute (oder Edelleute), das schleimige und unterwürfige Verhalten 
Besonderen Formenreichtum in der Übergangszone der Entwicklung vom performativen Ritual zum Amateurtheater weist der rumänische Kommunikationsraum auf, für welchen sich die rumänische Theatergeschichtsschreibung schon früh interessiert hat ${ }^{644}$ und für den eine Reihe von monographischen Darstellungen vorliegen ${ }^{645}$. Der gleitende Übergang läßt sich gut dokumentieren, wenn man analysiert, was Horia Barbu Oprișan in seinem Buch »Theater ohne Bühne« ( 198 I) von den Weihnachtsvermummungen bis zu regelrechten Theateraufführungen aufgenommen hat ${ }^{646}$. Manche davon sind noch

des Wirts, beim Eintritt der Betyaren versteckt er die Kaufleute, doch ein am Tisch liegengebliebenes Notizbuch verrät sie; zuerst leugnet er, Wein zu haben, doch Frau und Tochter nehmen dann an dem Gelage teil, während er sich den Verlust ausrechnet; da ihm die Betyaren versichern zu zahlen, beruhigt er sich; nach der Ausraubung der Kaufleute bekommt er sein Geld und das happy end sieht vor, daß sie seine Tochter letztlich doch nicht rauben (Nora A. Tahy, Das theatralische Brauchtum des ungarischen Sprachbereichs, Frankfurt/M. etc. 1989, 270-280).

644 D. C. Ollanescu, Teatrul la români, vol. I. București I 898, 45 ff., Teodor T. Burada, Istoria teatrului in Moldova, vol. I, Iași I 91 5, I-88, Simion Alterescu, »Unele probleme de orientare în Istoriografia teatrală contemporană«, Studii și cercetări de istoria artei 5/I (1958) I 85-198, Olga Flegont, "Contribuții la cercetărea formelor vechi de artă teatrală populară«, ibid. $9 / 2$ (1962) 347-359, dies., Istoria Teatrului în România, București I 965, 23-40, 4 I-78.

645 Vasile Adăscăliței, Teatrul folkloric, Iași I 969, Horia Barbu Oprișan, Jienii. Teatru popular haiducesc, București 1 974, Vasile Adăscăliței/Ion Ciubotaru, Teatru folcloric din județul Iași, Iași I 969, V. Adăscăliței, Teatru folcloric din județele Bacău Neamt, Bacău I968, Gheorghe Vrabie, »Teatrul popular romîneșc«, Studii și cercetări de istorie literară și folclor 6 (1957) no 3-4, 485-562, Mihai Vulpescu, Irozii, papușile, teatrul țărănesc al vicleimului, caloianului și paparudele, București I94I.

646 Horia Barbu Oprișan, Teatru fără scena. Evocări ale unor spectacole, personaje și interpreti ai teatrului popular românesc, București $198 \mathrm{I}$. Er bringt in lockerer Folge und mit Textbruchstücken völlig inhomogenes Material: den Neujahrsumzug mit dem Maskentyp Moș Ajun (24-27), Kiralesa (28 f.), „Irod» (29-37) mit Masken oder Puppen oder als Theaterstück gespielt, das Trajans-Spiel »Bădica Traian« (38-49), die Ziegenmaske Brezaia (50-52), den surva-Schlag der sorcova (55), das Bethlemenspiel vicleiul (56-59), die Kamelverkleidung Girafa (6of.), das Stück um »Mircea și Baiazid« (63 f.), die Araber-Verkleidung Harapu (67 f.), das Stück »Štefan cel Mare« (69-72), die Pferdemaske Calus (73-75), das Neujahrsspiel »Anul Nou și Anul Vechi« (76-78), die Tierverkleidung Capra (79f.), das Haidukenspiel »Jianu« (80-Ior), das Königsspiel mit der »Capra cu Împerăti« ( I 2-I I ), Mutul-Szenen aus den călusarii ( I I I-I I 4), die Zigeunerhochzeit Nunta țigănească

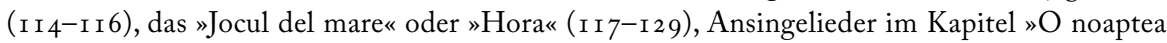

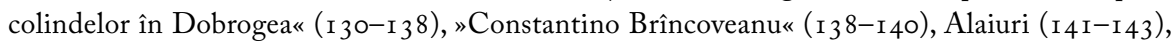
das Puppenspiel von »Vasilache și Marioara« ( $150-152)$, Hochzeitsspiele in »Nunta țărănească« (I53-I 56), das Spiel »Kaiserul« (I 57-I6r), die Tiermaske der Turca (I64-I68), den Einigkeitstanz »Hora Unirii« ( $169-\mathrm{I} 7 \mathrm{I})$, das Legendenspiel »Genoveva de Brabant« nach dem bekannten Volksbuch (I 72-I 75), Puppentheater (I 78-I 80), Neujahrsverkleidungen silivestri (I 8 I-I 84), Maskierungen ( $185-187$ ), die burschenschaftlichen »Steaua cu orații im Banat (I 89-192), den Maskentyp der Arnăuţii in Uniformen (195-198), Scaraoschi (199-2 I 2), das »Bujor«-Spiel (2 I 3-222), »Satelitul I 962« mit Astronauten (226-23 I), das elaborierte Spiel von »Gruia lui Novac« (232-234), 
datumsmäßig an die Zwölften gebunden ${ }^{647}$, stammen jedoch aus dem rumänischen Theater des Provinzrealismus des I 9. Jh. $s^{648}$. Die Volkstheateraufführung des »Jianu“ stammt aus einem Theaterstück von I 885 mit einem Türkenkampfthema aus den Freiheitskriegen des I9. Jh. $\mathrm{s}^{649}$. Die handelnden Personen sind Jianu, zwei bis drei haiduci, die Geliebte des Freiheitshelden, ein Hirte, ein Hauptmann, ein Jäger, ein Soldat. Die Handlung umfaßt die Gefangennahme des Helden und seine Befreiung. Die Vorstellung existiert in vielen Versionen, ebenso wie das Haidukenspiel von »Bujor ${ }^{650}$. Andere historische Thematiken dieser Spielkategorie sind dem Freiheitskrieg $1877 / 78$ entnommen, der der Moldauwalachei die Loslösung vom Osmanischen Reich brachte, oder beziehen sich auf den Ersten Weltkrieg (»Der grüne Tisch«), wo auch Personifikationen von Krieg und Frieden, Englands, Frankreichs, Serbiens, Österreichs usw. auftreten; in neueren Versionen auch Stalin, Hitler, Roosevelt usw. Ein ähnlich patriotisches Thema findet sich auch beim Volkstheater der Mädchen, die den "Tanz der Einheit« aufführen $^{651}$, eine Reihe von Liedern und Tänzen (auch ritueller Herkunft) um die zentralen Szenen der Vereinigung von Siebenbürgen (Transylvanien), Moldau und Walachei, die als Töchter der Mutter Rumänien auftreten, vom Ersten Weltkrieg entführt werden, um in der Folge wieder zu ihrer Mutter zurückzukehren. Andere solche Stücke sind »Adela und der König« oder das »Spiel«, wo sich Mädchen in Burschen verkleiden und die

den Maskentyp des Doctor in verschiedenen Konnexen (236-240), die Capra-Maske in verschiedenen Spielen (24I-253), die Bärenmaske Ursu (255 f.) u.a., die Hirschmaske Cerbarul (269-27I), der Boul (272 f.), die Lazarusumzüge lazărul (276f.), paparudele (278-28o), die theriomorphen Vogelmasken der Cucii (28 I-284), Călușarul in Mihai Bravu (285-289).

647 Mihai Pop, »Bräuche, Gesang und Spiel zu Neujahr in der heutigen rumänischen Folklore«, Beiträge zur Sprachwissenschaft, Volkskunde und Literaturforschung. Festschrift W. Steinitz, Berlin I 965, 3I 4 - 32 I.

648 Horia Barbu Oprișan, „Das volkstümliche rumänische Theater«, Österr. Zeitschrift für Volkskunde 8I (1978) I78-20r. Eine Ausnahme bildet das weihnachtliche Herodesspiel (»Irod«), das um die Mitte des 19. Jh. über Siebenbürgen in die Moldauwalachei kam und bis heute in Form von Puppentheatern von Kindern bei den Umzügen gespielt wird (Walter Puchner, Vergleichende Beiträge zum traditionellen Volkspuppenspiel auf der Balkanhalbinsel«, Beiträge zur Theaterwissenschaft Südosteuropas und des mediterranen Raums, r. Bd., Wien/Köln/Weimar 2006, 73-96, bes. 82-92). Vgl. dazu noch in der Folge. »Irod« wird allerdings auch mit Masken oder Theaterkostüm gespielt (Oprișan, Teatru fără scena, op. cit., 29-38).

649 G. Nadoeanu, »O ipoteză ascapra originii teatrului haiducesc Jianii«, Revista de Etnografia și Folclor 1o (1965) 31 7-325, Horia Barbu Oprișan, Jienii. Teatru popular haiducesc, București i 974, C. A. Adăscăliței, »Teatrul haiducesc `Gruia dui Novac«", Revista de Etnografia și Folclor I7 (1972) $48 \mathrm{I}-490$.

650 Oprișan, Teatru fără scena, op. cit., 2 I 3-222. Ähnlich auch »Jocul del Mare«, das I 935 in Piatra Neamț als Theaterstück gegeben wurde.

65 I »Hora unii«, I 943 aufgenommen (Oprișan, Teatru fără scena, op. cit., I69-17I). 
traditionellen Weihnachtskalanda mit den Lobliedern und Dialogen über den Heroismus der Freiheitskämpfer singen. Solche schöpferische Synthesen von Brauch- und Ritualthemen ${ }^{652}$ jenseits der Tradition - die allerdings selbst zu traditionsstiftenden Elementen werden können - sind ziemlich einzigartig im Balkanraum, wo dieses Spielgut im allgemeinen verkümmert und verschwindet, sobald sich der Rahmen der volkskulturellen Tradition lockert und nicht neue Spielmotivationen, wie etwa der Folklorismus, auf den Plan treten.

Am dalmatinischen Küstenstreifen unter einstiger venezianischer Herrschaft sind noch Reste von mittelalterlichem geistlichem Schauspiel erhalten, zusammen mit Spuren jesuitischer Theatertätigkeit zur Zeit der Gegenreformation, wie z.B. das Dreikönigsspiel, Krippenspiel und Sternsingen ${ }^{653}$. Dialogszenen beim Hochzeitsfest können noch auf das dalmatinisch/ragusäische Renaissance- und Barocktheater rekurrieren ${ }^{654}$, ebenso wie kurze Karnevalsszenen ${ }^{65}$. Der Konnex ist mehr als plausibel, wie etwa bei dem »Robinja«-Spiel auf der Insel Pag, das mit dem ersten Stück des dalmatinischen

652 Oprișan, »Das volkstümliche rumänische Theater«, op. cit., I 78 ff. Z.B. ist der Moșul aus dem »Jianu«-Spiel noch theriomorph gekleidet, der Doktor aus dem »Caprei«-Spiel I 962 trägt noch eine Holzmaske wie der Moș Begu aus dem vicleim-Krippenspiel.

653 Nikola Batušić, Povijest Hrvatskoga Kazalista, Zagreb I 978, I 44 f., I69 f., J. Glaser, »Verske igre v Ruseh", Slawistische Revue 4 (1950) I66-I 72, Niko Kuret, »Trikraljevske igre in Koleda na Slovenskom«, Slovenski Etnograf 3/4 (I95 I) 240-275, Nikola Batušić, Pučki igrokazi I9. stoljeca, Zagreb I 973, Nikola Bonifačić-Rožin, »Igre >trikralja i >vertepi« kod jednog dijela stanovništa Hrvatske«, Rad XIV kongresa saveza udruženja folklorista Jugoslavije u Prizrenu 10.-13. LX. 1967, Beograd I974, 433-440, ders., Folklorna građa Petrinje i okolice, Zagreb i 96o, ders., Narodne igre (Voćin i Čačinci), Zagreb 1960. Die Krippendarstellung mit Puppen wird auch bei den Serben vertep genannt, betlemaši bei den Kroaten und kriskindle in Slavonien, in der Ukraine betlejka (J. M. Solokov, Ruskii folklor, Moskva I94I, 375). Zum kroatischen Sternsingen und dem Dreikönigsspiel vgl. außerdem I. Milčetić, »Koleda u Južnih Slavena«, Zbornik za naroden život i običaji Južnih Slavena XXI/I, 27 ff., Nikola Bonifačić-Rožin, Hvratske narodi običaji iz kotara Pazin, Zagreb I 959, 36. Dasselbe geschieht in Istrien (ders., Hrvatski narodni običaji, priče i pjesme iz kotara Rijeka, Zagreb 1952) sowie am Dalmatinischen Küstenstreifen, früher sogar in weit elaborierterer Form, z.B. in Šibenik I6 I 5 (»da libretto scritto in schiavo«). Zu ähnlichen Fällen in Trogir N. Bezić-Božanić, »Od trogirskog >Biranja Kralja««, Slobodna Dalmacija XI, No I 2 I 53, Split I 9. 5. I 984 , S. 4 und Zagreb F. Fančev, "Liturgijsko obredne igre u zagrebačkoj stolnoj crkvi«, Narodna starina 1o (Zagreb 1925).

${ }_{54}$ Puchner, Die Literaturen Südosteuropas, op. cit., 96-1 16.

655 Milovan Rešetar, „Der Hochzeitsschwank im ragusanischen Liederbuch vom Jahr I 507«, Archiv für slavische Philologie 22 ( 1900 ) 61 3 ff., N. R. Rožin, »Svadbena dramatika u Dubrovačkom primorju «, Narodna Umjetnost 3 (1964-65) 38-74, M. Patković, "Poklade starih Dubrovčana«, Mladost 6 (1950) 752-756, Nikola Bonifačić-Rožin, »Folkloruv kazalište in južnom dijelu Hrvatskog zagorja«, Narodna umjetnost Io (I 973) 2 I 7-25 8, N. R. Rožin, »Pokladne maškare konavlima«, ibid., 5 ( I 966) I 53-I 74, Nikola Bonifačić-Rožin et al., Narodne drame, poslovice i zagonetke, Zagreb I963, I $33 \mathrm{ff}$. 
Renaissancetheaters, der »Robinja« von Hanibal Lucić, aufgeführt auf der Insel Hvar I530, in Zusammenhang stehen mag, eine Kontroverse, die auf zahlreiche Stellungnahmen zurückblicken kann ${ }^{656}$, ohne daß sich eine eindeutige Lösung abgezeichnet hätte ${ }^{657}$.

Solche Abhängigkeiten la longue durée lassen sich auch weiter südlich nachweisen, sowohl im heptanesischen Homilien-Theater der Ionischen Inseln wie auch bei den westgriechischen Volksaufführungen verkürzter Versionen der Tragödie »Erofile« von Georgios Chortatsis aus Rethymno (um r6oo). Das karnevalske Homilien-Theater auf Zante und Kefalonia ${ }^{658}$, das möglicherweise bis ins $17 . J h$. zurückreicht, wird auf einem

656 Die Streitfrage war dabei nicht so sehr die Frage nach dem möglichen Zusammenhang, sondern um die Vorgängigkeit, ob das Folklorestück aus dem Renaissancedrama hervorgegangen sei oder umgekehrt (Slobodan Prosperov Novak/Josip Lisac, Hrvatska drama do narodnog preporoda, 2 Bde., Split 1984, 64, Slobodan Prosperov Novak, Teatar u Dubrovniku prije Marina Držića, Split 1977 , Maja Bošković-Stulli, Usmena knjizevnost (Povijest hrvatske knjizevnosti I, 7-353), Zagreb I978, I73-I76). Dazu auch Nikola Bonifačić-Rožin, »Folklorno kazalište u južnom dijelu Hrvatskog zagorja«, Narodna umjetnost Io (I 973) 2 I 7-258.

657 Ivan Lozica läßt alle Möglichkeiten offen, nicht nur der Vorgängigkeit, sondern auch des unabhängigen Entstehens (Ivan Lozica, Hrvatski karnevali, Zagreb I 997, I 33, ders., Izvan teatra, Zageb I 990, I 93-196, ders., Folklorno kazaliste, Zagreb r 996, 35 f., 375 f., Text I 34-I 46, vgl. auch ders., »Customs Staged as Theatrical Performance«, Narodna umjetnost 25, I 988 , I 8 I-I 90 ).

658 Das »Homilien«-Volkstheater auf Heptanesos scheint aus drei verschiedenen Wurzeln herzurühren: I) aus darstellenden improvisierten Karnevalsszenen (Michalis G. Meraklis, »To $\pi \rho o ́ \beta \lambda \eta \mu \alpha$

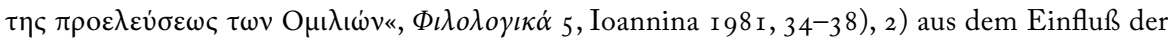
Commedia dell'arte, der in der heptanesischen Dramatik ab dem Beginn des I 8. Jh.s greifbar wird (Walter Puchner, "Spuren der commedia dell'arte im griechischen Theater des I 8. und I 9. Jh.s«, Beiträge zur Theaterwissenschaft Südosteuropas und des mediterranen Raums, Bd. 2, Wien/Köln/Weimar 2007, 31 7-322 und ders., "Traces of the commedia dell'arte in Modern Greek Theatre in the I $8^{\text {th }} \& \mathrm{I} 9^{\text {th }}$ century " La commedia dell'arte nella sua dimensione europea. Giornata di studio Venerdi I4 novembre 2003, Venezia, Istituto Ellenico di Studi Bizantini e Postbizantini di Venezia 2004, I03-107 mit der älteren Bibliographie), und 3) aus dem heimischen Volkstheater (Walter Puchner,

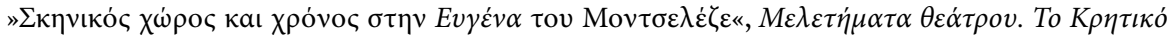

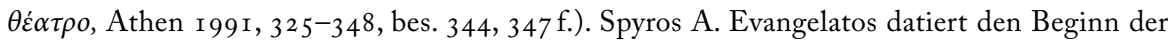

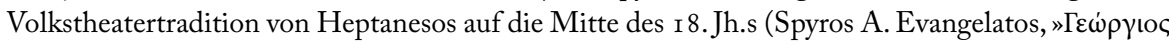

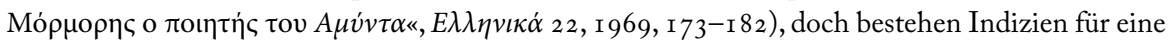

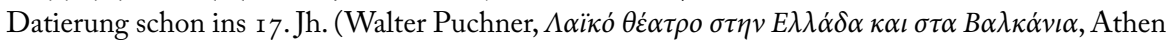

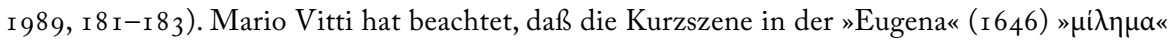

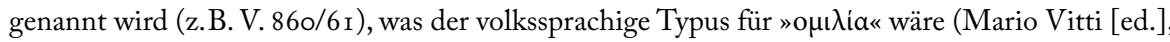

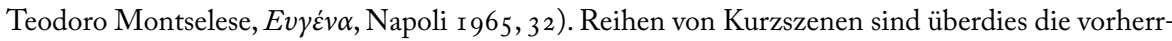
schende dramatische Struktur der heptanesischen Theaterstücke von der "Eugena» (I646) bis zum »Chasis« (ca. I 795). Die Szenenbezeichnung als »Rede« (o $\mu \lambda$ ia, Homilie) könnte einen Kontrast zu stummen Darstellungen z.B. beim älteren Karneval auf Zante bilden, wo als Pantomimen und tableaux vivants die Chinesische Hochzeit dargestellt wurde, die Drachen, die Eselshochzeit, die Monate, das Fest des H1. Lypios, die Breierzeugung, die Kefalonier, die Großen Fasten, die Ver- 
Podium in der Stadt Zante und auf den jeweiligen Dorfplätzen nur von Männern mit einer Halbmaske, wie bei der commedia dell'arte, in charakteristischer sing-sang-artigen Deklamation gespielt. Das Repertoire besteht aus gekürzten, aber schriftlich festgehaltenen Volksfassungen der kretischen Renaissance- und Barockdramatik (»Das Opfer Abrahams«, »Erofile«) $)^{659}$ bzw. dem barocken Versroman »Erotokritos ${ }^{660}$, romantischen Idyllen aus dem I 9. Jh. ${ }^{661}$ sowie Volksbearbeitungen rezenter Trivialliteratur ${ }^{662}$. Besonderes Interesse dürfen jedoch die Volksbearbeitungen der Renaissancetragödie »Erofile» von Georgios Chortatsis aus Rethymno (um I6oo) beanspruchen, die vermutlich über

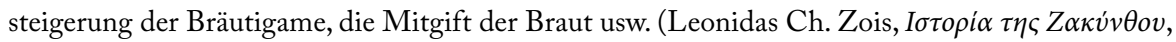
Athen 1955, 395).

659 Walter Puchner, »Kretische Renaissance- und Barockdramatik in Volksaufführungen auf den Sieben Inseln«, Österreichische Zeitschrift für Volkskunde XXX/79 (1976) 232-242. Aus Westgriechenland sind bis heute sechs Volksfassungen der "Erofile« aufgezeichnet (Aikaterini Polymeru-Kami-

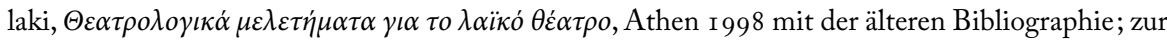

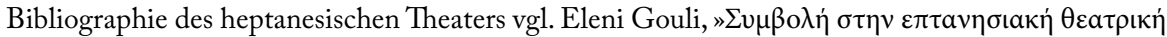

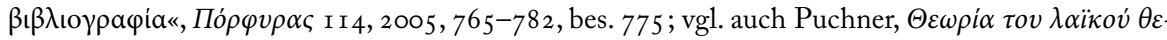
$\alpha$ á $\rho o v$, Athen $1985,64-67$ ). Das kretische Versdrama vom »Opfer Abrahams« wurde im Zeitraum von I91 3-25 in einer kürzenden Bearbeitung von Spyros Mylonopulos in der Hauptstadt der Insel aufgeführt, und zwar 4-5 mal am Tag, insgesamt während der Faschingsperiode 70-80 mal mit üblicherweise über roo Zuschauern, bei der letzten Vorstellung jedoch 2000-3000. Die Proben begannen schon vier Monate vorher; die Vorstellung dauerte ungefähr eine Stunde (Konidis Porfyris,

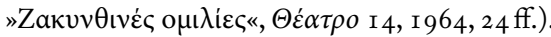

660 Vgl. dazu noch in der Folge.

66r Z.B. »Krinos und Anthia«, »Myrtilos und Daphne«, "Chrysavgi« usw. Letztere wurde I 865 auch

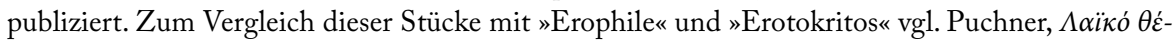

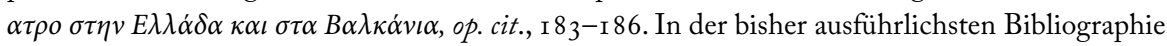

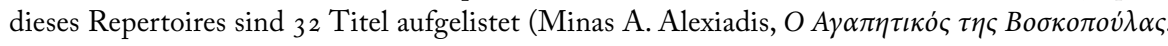

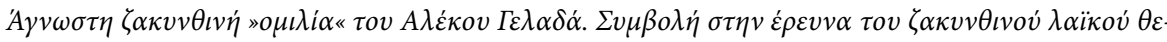

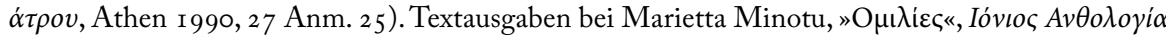
8 (I 934) I 4 I ff., I 52 ff., I 62 ff. Die Handlungen weisen z.T. noch rituelle Spuren auf (Brautraub, Gerichtsspiel), aber auch motivmäßige und sprachliche Einflüsse aus dem Kretischen Theater. In „Chrysavgi« entführt der verliebte Alexis die Chrysavgi aus ihrem Haus. Man ergreift sie und bringt sie vor Gericht. Der Hautptteil des Spiels besteht aus den komischen Prozeßverhandlungen, die für das Paar positiv enden.- Die Handlung von »Krinos« ist von der »Erofile« beeinflußt, doch anders als in der kretischen Tragödie beschließen die heimlich verheirateten Königskinder zu fliehen, werden ergriffen und vor das königliche Gericht gestellt, das sie jedoch freispricht. Das Stück endet im Gegensatz zu Chortatsis'Werk von r6oo mit einer Heirat.

662 Vor I 900 die komischen Idyllen »Golfo«, »Esme« und »Despo«, die Bearbeitung des bekannten dramatischen Idylls von Dimitris Koromilas »Der Liebhaber der Schäferin« mit dem Zusatz einer komischen Figur, die im Zante-Dialekt die rührseligen Ereignisse satirisch kommentiert (Alexiadis, op. cit.); im 20. Jh. dann populare Lesestoffe wie »H $\gamma \varepsilon \dot{\varepsilon} \varphi \rho \rho \alpha \omega v \sigma \tau \varepsilon v \alpha \gamma \mu \omega \dot{v} \ll$ (Die Seufzerbrücke), »Roland und Hildegunde«, Octavius und Valeria«, »Die unglückliche Liebe« usw. 
das Homilien-Theater der Ionischen Inseln ${ }^{663}$ in den westgriechischen Raum, von Epirus bis hinunter in den Korinthischen Golf und nach Osten zu bis in die thessalische Tiefebene, gelangt sind ${ }^{664}$, zwischen 16 und über 300 Versen umfassen, mit dem Titel »Panaratos« handschriftlich fixiert sind und in Volksaufführungen während des Karnevals mit Symbolrequisiten und Theaterkostümen zur Aufführung kommen ${ }^{665}$. Die stark

663 Dazu gibt es zwei Indizien: Im handschriftlichen Katalog der nach der osmanischen Invasion r645/69 verlorenen Bibliothek des kretischen Gelehrten Francesco Zeno ( $\left.\dagger_{1} 680\right)$ sind zwei nichterhaltene Handschriften angeführt, die den Titel »Panaratos opera greca« und »Erofigli opera Greca« tragen. Nachdem Panaretos der Name des zu Tode gefolterten Liebhabers der Königstochter Erofile ist, ist man zur Annahme gekommen, daß es sich höchstwahrscheinlich um eine Version

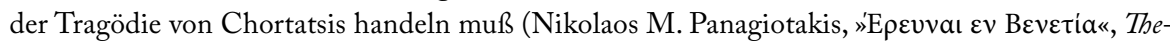
saurismata 5, I 968, 45-I I 8, bes. I02 f.). Alle erhaltenen Fassungen der Volksaufführungen in Westgriechenland tragen den Titel »Panaratos«. Im venezianischen Katasteramt von Lefkada (Leucas, Santa Maura) wurde für das Jahr I 77 I eine Eintragung entdeckt, wo von »einem alten Flugblatt-

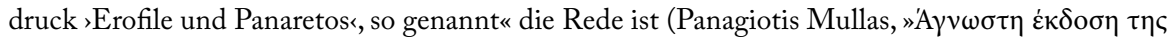

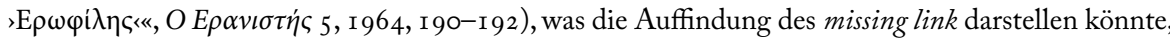
denn unter den bekannten Homilientexten aus Zante befindet sich kein »Panaratos«, andererseits ist es quellenkundig, daß Erntearbeiter aus Epirus das Spiel auf der Insel gesehen und auf das Festland gebracht haben (I 886 wurde das Spiel als Innovation nach Suli gebracht, vgl. N. Ch. Pa-

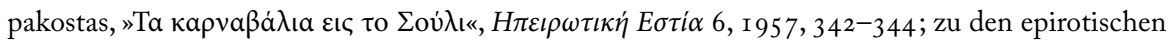

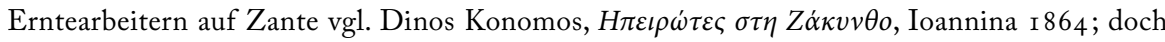
auch andere Berufe, wie die epirotischen Maurergilden, dürften das Spiel bis in die thessalische

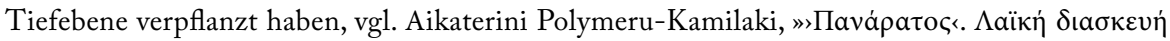

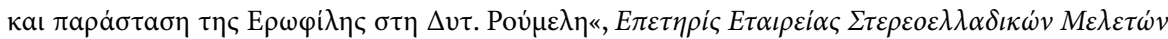
6,1976/77, 225-249, bes. 236-249). Daß die berühmte Tragödie von Chortatsis auf Zante gespielt

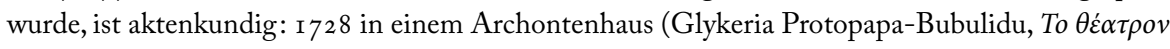

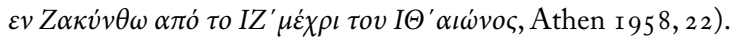

664 Die textlich erfaßten Bearbeitungen stammen aus Ioannina, Arta, Amfilochia, Karpenisi, Fanari im Raum Karditsa und im Bezirk Makryneia bei Mesolongi. Vgl. Polymeru-Kamilaki, »Пavápato૬«, op.

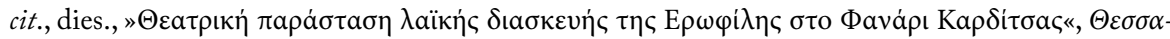

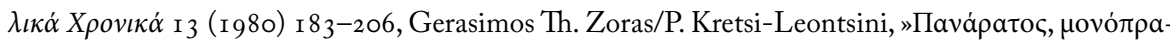

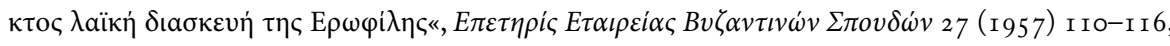

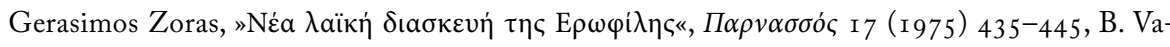
staruchas, »A

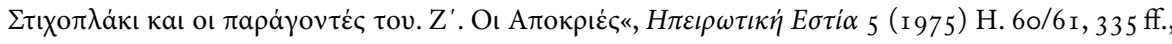

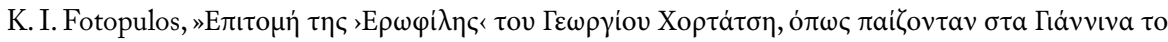

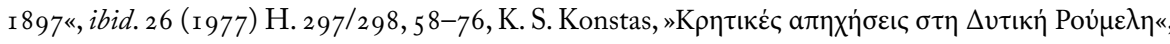

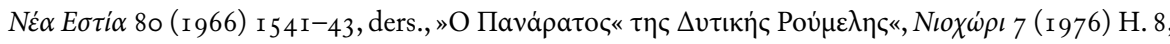
I 2-I 4, vgl. auch Leopold Schmidt (ed.), Le théâtre populaire Européen, Paris I 965, $396 \mathrm{ff}$.

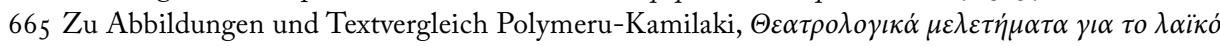
$\theta \varepsilon \dot{\alpha} \tau \rho o$, op. cit. Zu den Eingriffen in die Tragödienhandlung und Aufführungseinzelheiten vgl. auch

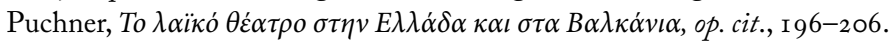


reduzierte Handlung beschränkt sich auch hier auf die Flucht der Königskinder (Brautraub), die jedoch hingerichtet werden. Die Spieler sind durchwegs Männer, die Proben beginnen bereits zur Weihnachtszeit. Manche Versionen sind derartig stark gekürzt, so daß die Kenntnis des Inhalts der Tragödie, die als popularer Lesestoff über weite Teile der Balkanhalbinsel zirkulierte, zum Verständnis des Dargestellten unabdingbar ist $^{666}$. Aus den Zagori-Bergdörfern nördlich von Ioannina ist auch der seltene Fall einer Reritualisierung überliefert, wobei die Ausführenden der karnevalesken Maskennummer (Tötung des Bräutigams durch den Araber) keine Ahnung davon hatten, daß sie die Szene einer Tragödie der Weltliteratur darstellen: Der König tötet den heimlichen Bräutigam seiner Tochter, worauf ihn die Umstehenden ums Leben bringen. Die Szene wurde am Käsesonntag in jedem Haus während des Umzugs der Verkleideten gespielt ${ }^{667}$.

Im Gegensatz dazu ist das türkische orta oyunu (»Spiel der Mitte«, weil die Zuschauer rund um die palanka, den Spielort, stehen oder sitzen), der witzige und derbe Dialog zwischen Kavuklu und Pișekâr sowie die von einem Mann gespielten zenne, etwa seit der Mitte des I 9. Jh. nachgewiesen, in republikanischer Zeit dann ausgestorben, Improvisationstheater geblieben ${ }^{668}$. Die ersten schriftlichen Aufzeichnungen haben dann

666 So umfaßt die Version von 1920 zwar 20 Personen, aber der Text bloß I 6 Verse. Der kretische Dialekt und der komplizierte Versbau werden von den Volksbearbeitern vereinfacht.

667 Polymeru-Kamilaki, »Пavápato૬«, op. cit., 230 mit der unveröffentlichten Quelle. Zu den theatertheoretischen Implikationen einer solchen Reritualisierung der Bühnenszene vgl. Walter Puchner,

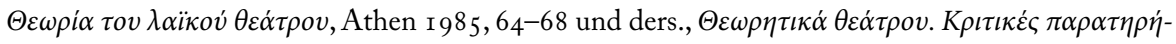

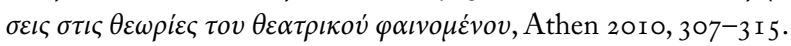

668 Vgl. dazu in Auswahl: Cevdet Kudret, Orta Oyunu, Ankara I973, Herbert W. Duda, „Das türkische Volkstheater«, Bustan 2 (Wien I 961), Alessandro Bombaci, »Ortaoyunu«, Wiener Zeitschrift für die Kunde des Morgenlandes 56 ( I960) 285-297, Nicholas N. Martinovitch, The Turkish Theatre, New York 1933, Ignác Kúnos, »Türkisches Volksschauspiel Orta Ojun«, Keleti Szemle 8 (1 907) I-93, 262-263, ders., Das türkische Volksschauspiel - Orta Ojun, Leipzig I 908, Selim N. Gerçek, Türk Temașasi (Meddah - Karagöz - Orta oyunu), Istanbul I 942, Edmond Saussey, Littérature populaire turque, Paris I 936, 74-82, Refik A. Sevengil, Türk Tiyatrosu Taribi, I., Istanbul I 959, 66-73, Metin And, $A$ History of theatre and popular entertainment in Turkey, Ankara 1963/64, 39 ff., ders., "Orta oyunu nasil çikti?«, Türk Dili No I 98 (Ankara 1968) 685-693, ders., »Wie entstand das türkische Orta Oyunu (Spiel der Mitte)?«, Maske und Kothurn I6 (r970) 201-2 I6, Max Meinecke, »Die türkische Theaterliteratur. Ein Reservoir des Komödiantischen«, Maske und Kothurn I I ( 1965) I 20-I 33, Otto Spies, »Die türkische Volksliteratur«, Handbuch der Orientalistik I/5/I, Altaistik, Leiden/Köln I 952 ff., 383-4I 7, Helga Uplegger, »Das Volksschauspiel«, J. Deny et al. (eds.), Philologiae Turcicae Fundamenta, 2 Bde., Wiesbaden I959-64, Bd. 2, I 47-168, Theodor Menzel, Meddah, Schattentheater und Orta Oyunu, Prag 194I, Özdemir Nutku, "Die Verfremdung im Orta Oyunu«, Maske und Kothurn I6 (1970) 2 I 7-228 usw. 
gezeigt, daß eine unmittelbare Verwandtschaft zum Schattentheater Karagöz besteht ${ }^{669}$. Gespielt wird gewöhnlich im ramadan oder bei anderen Gelegenheiten, auch im Sultanspalast und am phanariotischen Hof in Bukarest. Von dort liegt eine kritische Beschreibung aus der Feder von Franz Joseph Sulzer (in seiner Geschichte von Dacien, Wien I 78 I) vor, der einer solchen Vorstellung beiwohnen durfte.

Einer von den fürstlichen Tschauschen oder Hoftrabanten, welcher gemeiniglich den Hofnarren und den Principalen von ibnen machet, empfänget von dem Fürsten den Befehl, ein Schauspiel aufzuführen. Dies geschieht nicht öfters, als wenn der Fürst nach dem Mittagessen in guter Laune ist, und lange Weile hat, oder etwa einem Ausländer, der bei ihm speiset, einen Vorgeschmack vom Glanze seines Hofstaates geben will. Sogleich legen sechs solcher Kerle in weissen oder rothen aufgestülpten langen türkischen Unterkleidern, mit Silber beschlagenen Stäben in der Hand, und hohen runden Pelzmützen auf dem Kopfe, ibre Hände mit einer kleinen Verbeugung auf die Brust, zum Zeichen, dass Effendi augenblicklich bedient werden soll; tretten aus dem Speisesaal ab, und eröffnen nach einer kleinen Weile die Bübne mit einer Vorrede, die insgemein der Geschickteste unter ibnen hält. Der Boden des Saales selbst, wo man gespeiset hat, ist die Bühne, und die Kleidung der Schauspieler etwa eine zerrissene Montour eines österreichischen Ueberläufers, oder sonst einige alte Fetzen von irgendeiner fremden oder einheimischen Tracht, die weibliche nicht ausgenommen, wenn etwa ein Frauenzimmer aufzutretten hätte, dessen Rolle ebenfalls ein vermummter schnurrbärtiger Tschausche spielet. Das Stück wird in walachisch, griechisch, und türkischer Sprache aus dem Stegreif aufgeführet. Der Innhalt, und die Entwicklung muss, nach dem, was ich aus den eingemischten walachischen bon mots abnehmen konnte, Burlesk, und sehr erbaulich seyn, alles im Geschmack des berühmten Marionetten-Theaters. Bald hätte ich mich beredet, dass der witzige Verfasser dieses beissenden Lustspiels, den ich persönlich kenne, und hochschätze, dieser hospodaralischen Komödie mit mir beygewohnet haben musste, so geschickt hat er die Scene nach türkisch-walachischem Zuschnitte von Salzburg nach Berlin, und von Berlin in die Türkey zu transferiren, und vollkommen die Sprache dieser lehrreichen Tschauschen nachzuabmen gewusst. Wenigstens fehlte es ibnen an Zoten nicht; an Zoten, die auch einem gewissen teutschen Parterre noch

669 Viele der 46 aufgezeichneten Stücke sind mit Schattentheaterstücken, zumindest dem Titel nach, identisch. Auch weisen Dialoge und Sujets ganz ähnliche Charakteristika auf: Wortwitz und Wortspielereien, Mißverständnisse, Obszönitäten; Kavuklu tritt wie Karagöz in verschiedenen Berufen auf, stellt sich dumm, ist aber auch schlau, prahlerisch und schlagfertig, ahmt auch verschiedene Dialekte nichttürkischer Minderheiten nach. Er ist in Rot gekleidet mit dem kavuk (türkische Kopfbedeckung), aber nicht ithyphallisch wie der Karagöz. Mehrere Darsteller dieser Figur sind namentlich bekannt. Der Gegensatz der Hauptfigur zu dem halbgebildeten Opportunisten Pișekâr entspricht der Oppositionsachse Karagöz-Haçivat im Schattentheater. Vgl. dazu noch in der Folge. 
vor kurzer Zeit zur Ergötzung, und einem B-, dem Vater der teutschen komischen Dichtkunst von der Faust, zum Muster hätte dienen können. Zu gutem Glück und zur Ehre der walachischen Nation kommen diese sinnreichen Schauspiele selten vor, dauern nicht lange, erregen kein grosses Gelächter, und werden wenigstens nicht mit Schriften verfochten ${ }^{670}$.

Trotz der reichhaltigen Bibliographie an Studien und Texteditionen ist die Herkunftsfrage der Spielgattung keineswegs geklärt ${ }^{671}$. Der Name ist erst im I9. Jh. nachzuwei$\operatorname{sen}^{672}$, viele Forscher halten dafür, daß die Volksschauspielgattung schon Jahrhunderte früher in eventuell unterschiedlicher Form bestanden habe ${ }^{673}$, wenn auch im Vergleich mit den heute bekannten Spielformen und ihren Sujets ${ }^{674}$ gravierende Unterschiede festzustellen sind ${ }^{675}$. Metin And hat die Theorie aufgestellt, daß die sefardim bei ihrer Ostwanderung ins Osmanische Reich Ende des 15 . Jh.s das blühende spanische Volkstheater in die Küstenstädte des Ostmittelmeers mitgebracht hätten ${ }^{676}$. Es ist bekannt, daß das Schaustellerwesen Istanbuls in den Händen von Andersgläubigen gelegen hat, Hebräern, Armeniern, Griechen und Zigeunern ${ }^{677}$. Rein jüdisches Theater gibt es späterhin in Izmir ${ }^{678}$, auch in Thessaloniki, Volos u.a. Städten. And nimmt an, daß das »orta oyunu« aus dem jüdischen Schaustellerwesen in Istanbul hervorgegangen sei ${ }^{679}$.

Amateur- und Laientheater, in semitraditioneller Form folklorisiert oder innovativmodern, von schulischen, vereinsmäßigen oder staatlichen Instanzen organisiert und subventioniert, oder auch aus der privaten Initiative von lokalen Persönlichkeiten und

67o Franz Joseph Sulzer, Geschichte des transalpinischen Daciens, das ist: der Walachey, Moldau und Bessarabiens, im Zusammenhange mit der Geschichte des übrigen Daciens als ein Versuch einer allgemeinen Geschichte mit kritischer Freyheit entworfen von ..., Zweeter Band, Wien I 78 I, 40 I f. Die Anspielungen in aufklärerischer Ironie und Überlegenheit beziehen sich auf den Hans-Wurst-Streit.

67 I Kúnos etwa glaubte noch an die Herkunft vom byzantinischen Mimus (dessen Existenz nach Wilhelm Reich, Der Mimus, Berlin I903), andere ältere Forscher glaubten an einen Zusammenhang mit der commedia dell' arte. Diese Thesen brauchen heute nicht mehr diskutiert zu werden.

672 And, »Wie entstand das türkische Orta Oyunu«, op. cit.

673 Atsiz, op. cit., Bombaci, »Orta oyunu«, op. cit.

674 Kudret, op. cit., Nutku, op. cit., Kúnos, op. cit.

675 Quellen in Metin And, Kirk Gün Kirk Gece, Istanbul I959, pass. Ferner J. T. Bent, Dr. John Covel's Diary (I670-1679), Early Voyages and Travels in the Levant, London I 893, 2 I 5 ff., G. Cornelius von der Driesch, Historia Magnae Legationis Caesareae ..., Vienna I 72 I, 454 ff., Sulzer, op. cit., 40 I f.

676 And, Wie entstand das türkische Orta oyunu«, op. cit.

677 Das gilt für das Osmanische Reich im allgemeinen und trifft auch auf andere Formen des Volkstheaters zu, wie etwa das Schattentheater (vgl. dazu noch in der Folge).

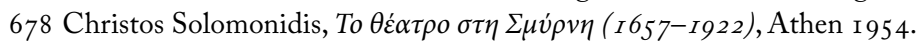

679 Sein Vergleich mit dem spanischen Volkstheater führt verschiedene Argumente an, die allerdings nicht immer überzeugen können. 
engagierten Lehrern heraus, ist jedoch ein Bereich, der hier wegen der enormen Fülle des Materials gar nicht tangiert werden kann, in einer Zeit, wo jede Region ihre eigenen Festivals veranstaltet und deren Traditionswurzeln in möglichst weit zurückreichende zeitliche Tiefen gleich dazuerfindet ${ }^{680}$. Viel diesbezügliches Material ist auch in lokalen Theatergeschichten zu finden, wie z.B. der rumänischen.

\section{I.6 Zeremonien und Festivitäten}

Waren die Anlässe für performative Riten, MXaskierung und Verkleidung vor allem bei fixen und mobilen Anlässen im Jahreskreis mit seinem Festkalender (heortologion) zu suchen, so fehlen sie nicht gänzlich auch bei den Festen des Lebenslaufs, angefangen von der individuellen Geburtstagsparty ${ }^{681}$ über das slava-Fest bis zu Gemeinschaftsereignissen wie Geburt, Hochzeit und Tod. Für das traditionelle Hochzeitsfest hat vor allem die ungarische Forschung eine Reihe von »dramatischen « Aktionen ausgemacht ${ }^{682}$, wie Brautwerbedialoge, das Verstecken der Braut usw. Forscher aus allen südosteuropäischen Ländern haben die traditionelle Hochzeit mit theatralischen Termini zu beschreiben versucht ${ }^{683}$. Szenische Arrangements bzw. Formen zeremonieller Regieführung $^{684}$ sind auch bei den Prozessionen zu beobachten, bei der Abholung der Braut, der Überführung ins Haus des Bräutigams usw. Der Performativitätsfaktor ist oft so hoch

$680 \mathrm{Zu}$ Morphologie, Typologie und Bibliographie z. B. für Griechenland vgl. Walter Puchner, „To $\theta \dot{\varepsilon}-$

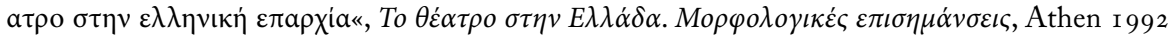
$33 \mathrm{I}-37 \mathrm{I}$.

68 I Zur wesentlich höheren Einschätzung des Namensfestes als des Geburtstages im orthodoxen Festkalender vgl. N. Gabrielides, »Name Days and Feasting: Social and Ecological Implications of Visiting Patterns in a Greek Village of the Argolid«, Anthropological Quarterly 47/I (I 974) 48-70.

682 Ákos Szendrey, "Die Vorbereitung der Hochzeit und der Abschluss des Ehevertrags bei den Ungarn«, Acta Ethnographica Academiae Scientiarum Hungaricae 6 ( I957) 37 I-434, J. Mango, "Die Hochzeitsbräuche der Paloczen und ihre slowakischen Analogien«, ibid. I 9 (1970) 247-279, R. Žatko, »Svadba u Slovákov v Mad'arsku«, Národopisny Sbornik 9 (Bratislava 1950) I 72-197.

683 Vgl. in Auswahl: M. V. Knežević, »Svadbeni običaji kao obred i inscenacija«, Zbornik kongresa saveza udruženja folklorista Jugoslavije v Celju 1965, Ljubljana I968, I 9 I-I 94, Zorica Rajković, "Dramski momenti u svadbenim običajima«, Mogućnosti 32 (1985) I 32-1 46 (Dani hrvatskog kazališta, Split 1985, I 77-1 96), Ioan Meițoiu, Spectacol nunților, București 1969, Nikolaos A. Di-

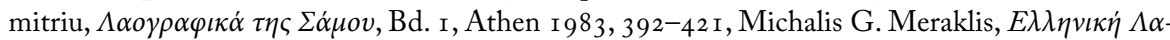

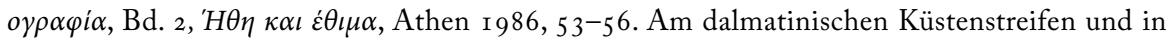
Slovenien gehen diese Hochzeitsspiele z.T. auf regelrechte Theateraufführungen in älterer Zeit zurück (vgl. Nikola Bonifačić-Rožin, »Svadbena igra >Traženje ptice« kod Valsavora i danas«, Narodno stvaralaštvo folkor I [Beograd I 962 ], 27-3 I, ders., "Svadbena dramatika u Dubrovačkom primorju«, Narodna umjetnost 3, 1964/65, 38-74).

684 Gyula Ortutay, Kleine ungarische Volkskunde, Budapest I963, 86 . 
zu veranschlagen, daß im Zuge der Folklorisierung älterer Zeremonielle die traditionelle Hochzeit auch als Theatervorstellung bei Folklore-Festivals aufgeführt wird ${ }^{655}$. Vor allem bei der Brautwerbung sind regelrechte Dialog-Spiele als Teil einer vorgetäuschten retardierenden Hinhalte-Taktik zu beobachten ${ }^{686}$.

Doch beschränken sich performative Riten und theaterhaft täuschende Praktiken keineswegs auf die Hochzeitszeremonie und haben nicht immer spielhaften Charakter, sondern bei den prophylaktischen und apotropäischen bzw. therapeutischen Riten rund um Geburt, Wochenbett und die Kleinkinderkrankheiten sind magische Aktionen aufgrund der hohen Mortalitätsrate von Neugeborenen blutiger Ernst und zeugen von der Verzweiflung und Angst um die Nachkommenschaft, von der das Überleben der Kommunität abhängt. Im vorwissenschaftlichen Weltbild wird die Bedrohung von Mutter und Kind durch Infektionen im Wochenbett zur auf dämonische Wesen projezierten Angst vor dem Ungewissen. Diese Krisensituation liegt in den Händen der älteren Frauen, der Hebammen und der Magierinnen, die das nötige Wissen um die Prophylaktik gegen Dämonen und Schadenszauber besitzen ${ }^{687}$. Unter den magischen Praktiken zum Schutz des Neugeborenen (wie z.B. das Verstecken von Mutter und Kind) ${ }^{688}$ bzw. bei Kinderkrank-

685 Thekla Dömötör, Ungarische Volksbräuche, Budapest r 972, 86 ff.

686 Z.B. im Komitat Szabolcs. Dramatis personae der Szene sind der Brautwerber, der Gevatter, der Schwager, der Bruder des Bräutigams, wenn er verheiratet ist; Ort der improvisierten »Aufführung« im Haus der Braut: Der Brautwerber und die anderen treten ein und bitten als müde Reisende um Unterkunft; sie seien einem guten Stern gefolgt. Man bittet sie, sich zu setzen, doch die Unterkunftsfrage bleibt vorerst noch offen. Die Besucher sagen, sie hätten eine Blume gebracht und suchten dazu ein Gegenstück; der Hausherr bringt Blumen, doch nein, diese sei größer - man bringt einen Ast. Das Spiel geht weiter mit genaueren Definitionen: Es handle sich um lebendige Blume - was gespielte Ratlosigkeit hervorruft; die gehen kann - man bringt eine Katze mit Blumen; sie habe zwei Füße - man bringt ein Huhn mit Blumen; sie könne sprechen - man bringt ein kleines Kind verkleidet; das sei zu klein - man zeigt ihnen ein Mädchen; das sei nicht genug aufgeblüht - da läßt eine junge Frau ihre Röcke rauschen; diese habe bereits eine Blume - man bringt eine Witwe; dies sei eine verwelkte Blume usw., bis die Braut mit Anstand vorgestellt wird und man sich zum Festessen setzt (Ivan Balassa/Gyula Ortutay, Ungarische Volkskunde, Budapest/ München I 982, 645 f.). Zur ungarischen Hochzeit vgl. vor allem Lajos Kiss, Lakodalom, Budapest I 955/56, Sándor Göney, »Tréfás lakodalmi játékok Csurgónagymártonban «, Ethnographia I934, Károly Török, Magyar lakodalmi szokások az Alföldön, Pest I 864, Franz (Ferenc) Simon, Hochzeitsbräuche, Diss. Göttingen 1964 .

$687 \mathrm{Zu}$ diesem dem Balkanpatriachalismus und seiner Vitrinenhaftigkeit zugrundeliegenden inoffiziellen Wertesystem der älteren Frauen und Mütter, das nur in Krisensituationen aktiviert wird, vgl. vor allem R. \& E. Blum, Health and Healing in Rural Greece. A Study of Three Communities, Stanford 1965, dies., The Dangerous Hour. The Lore of Crisis and Mystery in Rural Greece, London 1970, sowie die obigen Ausführungen zum Hebammen-Tag.

688 Eine Zusammenstellung der einschlägigen Aktionen für die traditionelle Gesellschaft Zyperns 
heiten und ihrer Therapie ${ }^{689}$ befinden sich auch Handlungen, die jenseits der Theatralität

vor der Zweiteilung der Insel der Aphrodite, aus dem Archiv für mündliche Kultur und orale $\mathrm{Au}$ -

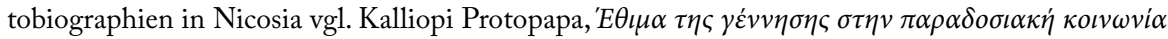
$\tau \eta \varsigma$ Kút $\rho \circ v$, Nicosia 2009, 400 ff. Zu den Amuletten gehören Metallgegenstände, Goldstücke, Se-

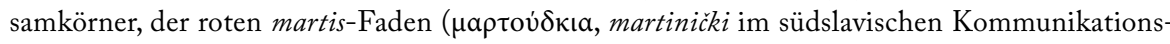
raum), gegen Dämonen auch Kreuzholzsplitter, Öl und Olive, Brot (für viele magische Belange,

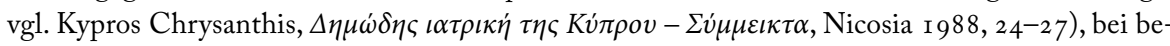
sonders hübschen Babies auch Strategien gegen den bösen Blick (Protopapa, op. cit., 4I 8-425): Verstecken von Mutter und Kind, um das Versiegen der Muttermilch zu verhindern, Amulette

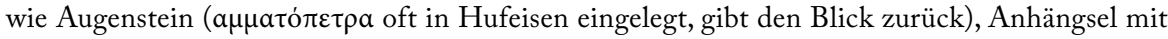
Schwert, Axt, Waffe oder Wassergefäß, auch Krebsschere, Kreuz usw., roter Faden (solche Amu-

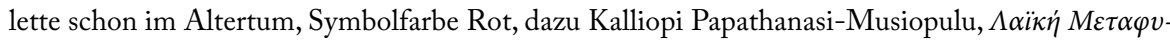
$\sigma \iota \kappa \eta \dot{~}$ Athen I98 I , 46); zum symbolischen Anspucken als Mittel gegen die baskania vgl. den Zwei-

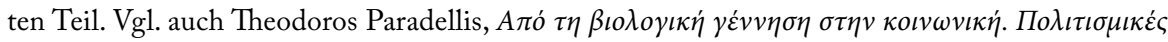

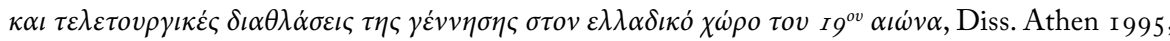
zur sozialen Geburt durch rites de passage wie Separation, Margination und Integration; PassageSymbole sind die Feuerstelle, Asche, das Feuer, aber auch das Sieb, der Nadelöhr-Ritus, ferner Stachelpflanzen, das Licht; als Sekundärpersonen gilt der Mann, die Hebamme, die Taufpaten; zur Dämonengefahr, der mit Amuletten und Prophylaxen begegnet wird, auch dem »Verstecken« der Schwangerschaft, treten auch Schwangerschaftsphantasien um die Teratogenese (vgl. auch Manolis

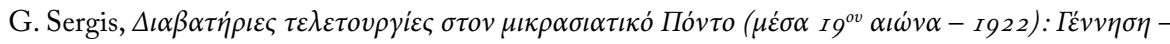

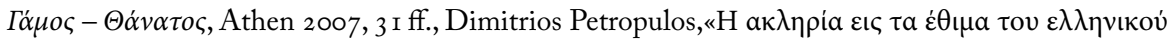

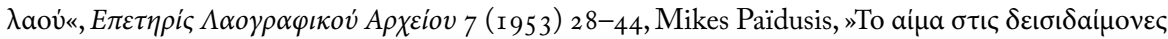

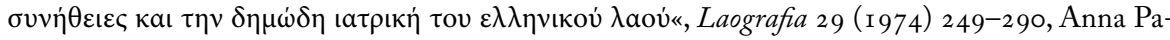
pamichael, Birth and plant symbolism. Symbolism and magical uses of plants in connection with birth in modern Greece, Athens I 975, Slobodan Vlahović, »Die Gebräuche bei der Geburt im traditionellen und gegenwärtigen Volksleben der Serben«, Lètopis ser. C (1982) 103-109 usw.

689 Protopapa, op. cit., 526 ff. Bei Koliken oder Augenkrankheiten wird ein Kringel in der Nacht an der Wegkreuzung vor dem Dorf gelegt (mit Umdrehverbot, Sprechverbot usw.), die Hunde fressen den Kringel und bekommen das Übel (transplantatio morborum); denselben Effekt haben Scheinverkauf und "Versklavung" des Kleinkindes bzw. der Nadelöhr-Ritus (Durchreichen des kranken Kindes durch einen engen Spalt, Loch usw., Krankheit bleibt da haften, bzw. durch einen großen Kringel an der Wegkreuzung, gebacken mit Mehl von sieben Familien, Teig mit einer Hand geknetet usw.); bei Schwierigkeiten beim Gehen und Sprechen bzw. bei Wachstumshemmung gehen drei kleine Mädchen auf Heischegang um Brot (ibid. 530 ff.), bekreuzen das Kind mit Steinen von der Wegkreuzung usw. Bei schwerer Krankheit besteht der Glaube an die Möglichkeit des Kindestausches; beim Rücktausch werden die Guten Frauen angerufen, es zurückzugeben (Xenofon

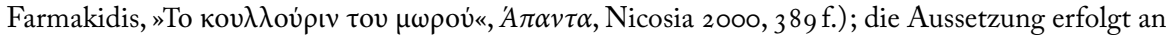
der Wegkreuzung, auf Brücken, dem islamischen Friedhof usw., eine andere Frau holt das Kind unter möglichst komplizierten Vorkehrungen zurück. Beim Befallen vom bösen Blick wird das Kind (Kleinkind, oder Mädchen bei der ersten Monatsblutung usw.) mit einem verbranntem Kleidungs-

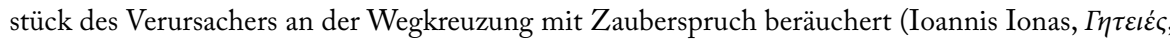
Nicosia 2007) oder als Apotropäum Asche vor die Tür gestreut bzw. das Kind mit unbesprochenem 
des Taufzuges durchaus performativen Charakter besitzen ${ }^{690}:$ r. die scheinbare Aussetzung an der Wegkreuzung vor dem Dorf - wer das Neugeborene findet, tauft es und gibt ihm seinen Namen (soziale Geburt, Identitätsänderung, Täuschung der Dämonen) ${ }^{691}$; 2. der Scheinverkauf des Babys im Geburtshaus: Eine der Frauen nimmt es in ihre Schürze und ruft: "Ich verkaufe ein Kind«, eine andere »kauft« es mit Silbermünzen und übergibt es der natürlichen Mutter mit Glückwünschen; 3. die »Versklavung« bzw. Weihung des kranken Kindes an einen Heiligen - das Kind dient jahrelang in der Kirche, bis es rituell von seiner Sklaverei (als Krankheitsprophylaxe) entbunden wird ${ }^{692}$; 4 . die Adoption mit kirchlicher Zeremonie vor der Panagia-Ikone - das Kleinkind wird durch das Hemd der adoptierenden Frau gereicht von der Halsöffnung bis zum Bodensaum (performativer Geburtsvorgang ${ }^{693}$. Dem liegen zwei fundamentale Glaubensvorstellungen zugrunde: die Existenz und Notwendigkeit, neben der biologischen eine gesellschaftliche Geburt mit scheinbarer Auflösung der Blutsbande (cognatio spiritualis, Taufpatenschaft) ${ }^{694}$ zu vollziehen (derselben Vorstellung liegt auch die couvade zugrunde) ${ }^{695}$, der Glaube an

Wasser besprengt. An religiösen Behandlungen sind vorgesehen: das dreimalige Gehen um die Kirche, Einreiben mit Öl von den Öllampen vor den Ikonen, das Aufhängen der alten Kleider des Kindes an Bäumen nahe der Kirche usw. Dazu noch mehr im der Folge.

69o Die folgenden Beispiele betreffen die Pontus-Griechen in Kleinasien vor 1922 (Manolis G. Sergis,

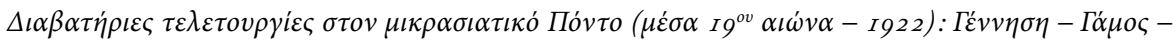
$\Theta \alpha \dot{v} \alpha \alpha \tau o \varsigma$, Athen 2007,84 ff.).

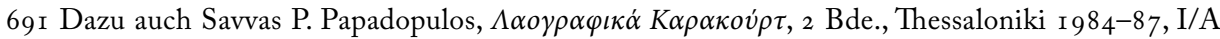

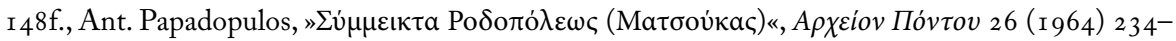
249, bes. 237. Zur Namensgebung allgemein Dimitrios V. Oikonomidis, »'

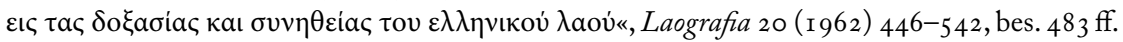

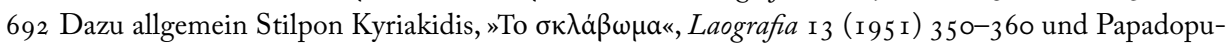

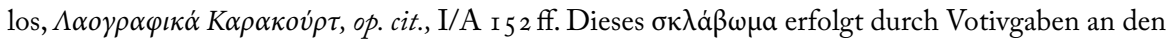
Heiligen: eine Kerze von der Größe des Kindes oder auch seinem Gewicht, gleichsam als Ersatz-

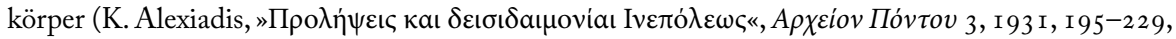
bes. 223 ff.); das Abmessen des Körpers des Kranken gehört auch zu den üblichen magischen Therapien. Auch Silber-Votive mit der Effigie des Kindes werden an die Ikone gehängt usw.

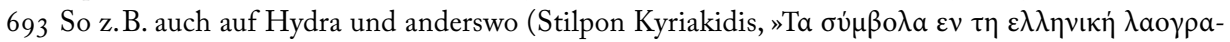

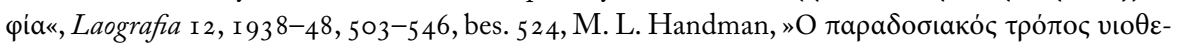

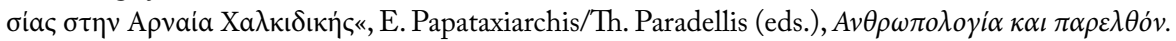

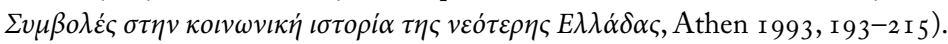

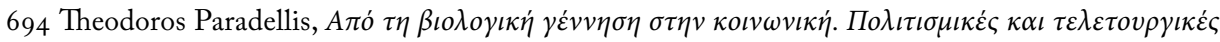

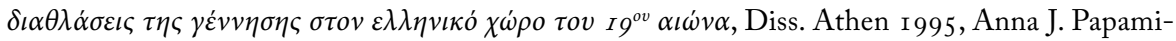
chael, Birth and plant symbolism: symbolic and magical uses of plants in connection with birth in modern Greece, Athens 1975, Vasiliki Chrysanthopoulou-Farrington, An analysis of rituals surrounding birth in modern Greece, M. Phil. thesis, University of Oxford 1984.

695 Zum Männerkindbett exisitert eine ausgedehnte Literatur. Vgl. hier bloß Dimitrios S. Lukatos,

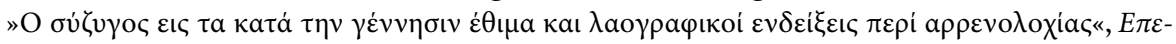


die Möglichkeit der Täuschung der Dämonen durch Wechselbalg-Taktik oder MutterErsatz (Fremd-Taufe, Verkaufen, Adoptieren).

Es besteht jedoch kein Zweifel, daß unter den Lebenslaufriten das Hochzeitszeremoniell im allgemeinen den höchsten Grad an Performativität besitzt. Dies betrifft, wie bereits erwähnt, nicht nur performative Riten und Maskierungen ${ }^{696}$, sondern auch den inszenierten Gesamtablauf mit seinen Prozessionen und Fahnen, die Eintrittsrituale als rite de passage, und besonders die zahlreichen Formen der Wegsperre ${ }^{697}$ und des spielhaften Brautraubs ${ }^{698}$, die versuchte Verhinderung und Verzögerung, die spielhaft überwunden werden müssen und die dem ganzen Ereignis den Charakter eines Schauspiels verleihen ${ }^{699}$. Besonders die Wegsperre des Braut- und Bräutigamzuges bei

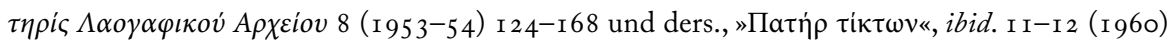
$27-42$.

$696 \mathrm{Zu}$ den oben erwähnten Arbeiten vgl. aus dem südslavischen Raum auch Radost Ivanova, »Svadbata kato maskarad «, Bălgarska Etnografija 3-4 ( 1 994) 35-40, Nikola Bonifačić-Rožin, »Svadbena dramatika u Dubračkovom primorju«, Narodna umjetnost 3 ( I 965) 39-74, ders., »Svadbena igra >Traženje ptice kod Valsavora i danas«, Narodno stvaralaštvo - Folklor I (I 962) 27-3 I, Milica Bošković-Matić, »Narodna drama u svadbenim običajima«, Rad X-og kongresa Saveza folklorsta Jugoslavije na Cetinju 1963. godine, Cetinje I 964, 329-332, Juraj Ćuk, »Svadbeni običaji i Krašiću nekada i danas«, Zbornik za narodni život i običaje južnih Slavena 40 (1962) 95-1o6, Franjo Miličević, "Ženidba (Broćanska župa u Hercegovini)«, Zbornik za narodni život i običaje južnih Slavena $20 / 2$ (1915) I 85-225, Stjepan Novosel, Prigorska svadba, Zagreb I 926, Zorica Rajković, »Dramski momenti u svadbenim običajima«, Dani bvarskog kazališta 2 (Split 1985) I77-196.

697 Dazu Dieter Dünninger, Wegsperre und Lösung. Formen und Motive eines dörflichen Hochzeitsbrauchs, Berlin 1967 .

698 Ján Komorovský, „Die Inszenierung eines Scheinkampfes um die Braut in der traditionellen slawischen Hochzeit«, Ethnologia Slavica 4 (I 972) I 59-1 78, William G. Lockwood, Bride Theft and Social Maneuverability in Western Bosnia«, Anthropological Quarterly 47 (I 974) 253-269, Helena Ložar-Podlogar, »Die Szene mit der `Falschen Braut in den südslawischen Hochzeitsbräuchen«, Ethnologia Slavica 3 (197I) 203-2 Io, Johannes Piprek, Slawische Brautwerbungs- und Hochzeitsgebräuche, Stuttgart I914, M. Smiljanić, »Die Spuren der Raub- und Kaufehe bei den Serben«, Internationales Archiv für Ethnographie I 5/2 (1 902) 4I-52, Eleftherios Alexakis, $H \sigma \eta \mu \alpha i \alpha \sigma \tau o ~ \gamma \alpha \dot{\alpha} \mu$.

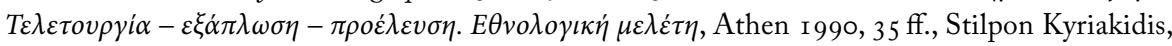

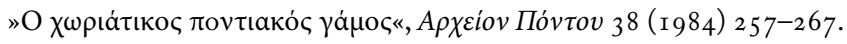

699 Besonders ausgebildet sind das Prozessionswesen und die Spielszenen bei den Ungarn. Neben den Brautwerbungsspielen gibt es eine ganze Abfolge von Prozessionen, wobei der erste Brautführer als Regisseur fungiert, er trägt die Verse vor bzw. der Beistand oder Trauzeuge für Braut und Bräutigam; daneben gibt es auch weitere kleine Brautführer. Brautführerverse gibt es auch in handschriftlicher oder gedruckter Form: Nach der Brautwerbung findet die Verlobung statt (heute mit Ring, früher ein Apfel mit Goldmünze, der Bräutigam mit Blumenstrauß am Hut). Das Verlobungsfest wird vorbereitet, Gäste bis zum 3-4. Verwandtschaftsgrad eingeladen, Honoratioren usw. (dies tragen die kleine Brautführer in Versform vor). Hochzeitsgeschenke werden am Vortag gebracht, wo 
der Abholung der Braut für die Trauungszeremonie und bei der Überführung in ihr neues Heim erlebt performative und spielhafte Ausformungen, wie z.B. bei der armenischen Hochzeit in Komotini, wo die Straße mit einem Strick gesperrt wird ${ }^{700}$. Der Bräutigamszug zum Haus der Braut ähnelt manchmal einem Hindernislauf mit laufender Mautentrichtung bzw. einer Sequenz von Prüfungen, in denen der Bräutigam, ähnlich wie in den südosteuropäischen Heldenliedern, seine Mannhaftigkeit beweisen muß ${ }^{701}$. Szenisch-theatralische Elemente mit satirischer Komik gibt es schon bei der

auch der Aussteuerumzug stattfindet: Brauttruhe, Brautbett, Möbelstücke, Bettzeug, Brautkleider usw. werden ins Haus des Bräutigams gebracht, der Zug des Bräutigams bricht zum Brauthaus auf, ihm wird jedoch der Weg versperrt; es kommt zu Verhandlungen, dem Brautbitter zeigt man zuerst eine alte bucklige Frau, dann einen als Braut verkleideten Burschen, dann eine Brautjungfer, endlich die Braut. Der Brautführer spricht die Abschiedsverse vom Vaterhaus im Namen der Braut, erst dann erfolgt die Hochzeitslamentation (dazu Puchner, Die Folklore Südosteuropas, op. cit., 78 f.), vor der Kirche wird getanzt; nach der Trauungszeremonie bleiben die beiden Hochzeitsgesellschaften getrennt, jede begibt sich ins eigene Haus. Nach dem Mittagessen erfolgt die inszenierte Abholungsszene: Abgesandte des Bräutigams kommen ins Haus der Braut, um sie zu abzuholen, jedoch vergeblich. Endlich kommt er mit vielen retardierenden theatralisch-spielerischen Elementen selbst, er muß seine Braut unter drei vermummten Gestalten herausfinden; es folgen lustige Verhandlungen von Brautführer und Beiständen. Endlich begibt man sich unter Spielen, Neckereien und Versen des Brautführers zum Haus des Bräutigams, wo das Abendessen mit festgelegter Sitzordnung stattfinden; die Speisenfolge wird angekündigt, die Köchin hat sich angeblich verbrannt und braucht Medikamente - Geldspenden; Maskierte kommen und spielen ein Scheinbegräbnis, sie werden auch bewirtet, mit Zigeunermusik geht es zum Tanz; beim Betten der Braut wird ihr Haar aufsteckt (statt Zöpfe Knoten) und spezielle Lieder gesungen, dann folgt der Brauttanz; auch Spielreste des Brautkaufs sind nachzuweisen (jeder kann gegen Entgeld mit der Braut tanzen, nach einer große Summe tanzt der Ehemann - das eingenommene Geld kommt dem junges Paar zustatten). Die Feierlichkeiten dauern etwa 2-3 Tage (Balassa/Ortutay, Ungarische Volkskunde, op. cit., 657 f.).

700 Vgl. die post-graduate Arbeiten im Department für Schwarzmeerstudien in Komotini Panagiotis

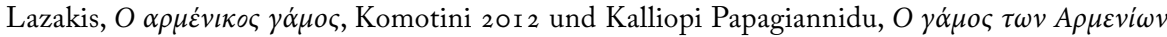

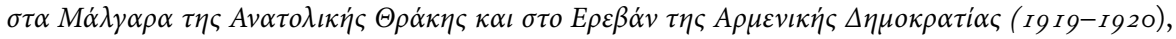
Komotini 2012.

70 r Zu dem Motiv in den Heldenliedern siehe Puchner, Die Folklore Südosteuropas, op. cit., I 9-3 I. Archaische Elemente sind bei der Hochzeit der Pontus-Griechen in Kleinasien vor 1922 nachzuweisen

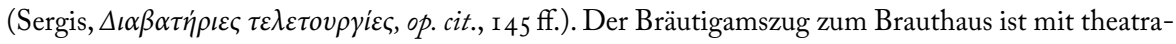
lischen Elementen bereichert und gleicht der spielhaften Belagerung einer Burg: Der Schwertwurf des Bräutigam über das Haus (bei Mißlingen schlechtes Omen) ist eine Prüfung seiner Mannhaftigkeit, das Brauthaus verweigert die Herausgabe der Braut, erst nach dem Versprechen von Gelagen seitens des anderen Lagers: Gebratenes Geflügel wird angeboten (Gänse als Symbole der Braut), mit ihrem Blut werden die Schuhe des Bräutigams bestrichen, die »Eroberer« ergehen sich in Diebstählen (Hühner, Löffel, Schnapsgläser, Teller) im Brauthaus, die ganze Szene ähnelt dem kriegerischen

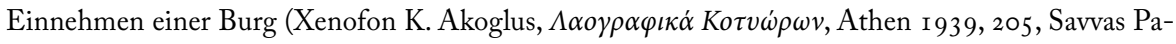

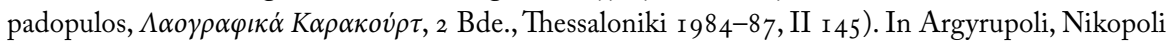




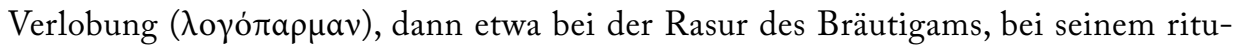
ellen Bekleiden, bei der Brautwerbung, beim Abholen der Braut usw. ${ }^{702}$ Doch bedarf der Gesamtablauf des spectacular event einer brauchhaft festgelegten Programmierung der traditionellen Szenensequenzen, für die der Terminus »Inszenierung« oder »Regie« adäquat erscheint ${ }^{703}$. Zu den traditionellen Hochzeitsfeierlichkeiten auf der Balkan-

usw. versperrt der Brautbruder mit einem Tisch mit gekochtem Geflügel oder Butterhonig dem Zug den Weg, der Trauzeuge kauft die Gaben und verteilt sie nach dem Einzug ins Brauthaus (N. La-

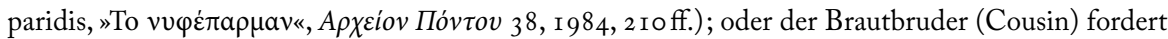
Geld für die Übergabe der Braut, bei zu hohem Preis kommt es zu Streitigkeiten, die Mitglieder des Bräutigamszuges müssen von Omelett und der Brathenne kosten, erst dann treten sie ins Haus

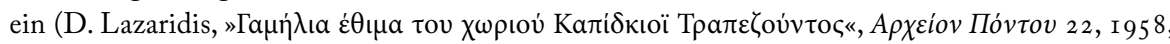
26I-264); oder die Brautgruppe hindert den Bräutigamszug am Eintritt ins Haus, der Bräutigam erscheint zu Pferd als Sieger. Die Symbolik der Mautentrichtung ist die Hindernisbildung, um die Schwierigkeit des Passage-Ritus zu demonstrieren, sowie ein spielhaftes Restelement des Brautkaufs

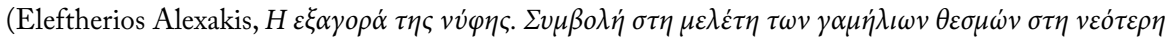

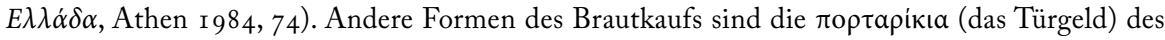
Bräutigams (oder Beistands) für den Eintritt ins Dorf oder ins Haus der Braut (Sergis, op. cit., 222).

702 Sergis, $\Delta \iota \alpha \beta \alpha \tau \dot{\eta} \rho \iota \varepsilon \varsigma \tau \varepsilon \lambda \varepsilon \tau o v \rho \gamma i \varepsilon \varsigma$, op. cit., I 23 f. Bei der Rasur des Bräutigams wird z.B. ein Teil des Gesichtes unrasiert gelassen, weil das Messer angeblich nicht schneidet usw.; der Bräutigam muß ein Gelage spendieren. Spielhafte Erweiterungen gibt es auch beim rituellen Bekleiden des Bräutigams (Kopftuch läßt sich nicht binden usw.). Die Hindernisse des Hochzeitszuges auf dem Weg zum neuen Haus sehen auch Seilsperren vor, dem Bräutigam wird der Fez gestohlen (erhält ihn gegen Lösegeld zurück), oder die Mitglieder des Zuges müssen gegen einen peblivan (professionellen ölbeschmierten Ringkämpfer) kämpfen und können sich durch Geldspenden von dieser Verpflichtung befreiten (das kann auch vom Brautvater vor der Brautübergabe gefordert werden). Inszenierte »Siege« des Bräutigams demonstrieren spielhaft den schwierigen Übergang, die vielfältigen Ritualhandlungen an der Hausschwelle die Initiation (Sergis, op. cit., I 5 8). Performative Elemente finden sich schon beim der Verlobung (入оүó Athen von Pontus-Griechen aus Kleinasien ein Dialog gespielt, wobei die Besucher die müden Wanderer darstellten: Sie erzählten ihre mannigfachen Abenteuer auf dem Weg, bis sie zufällig auf dieses Haus gestoßen seien, auf dem Weg habe sich der Bräutigam in ein Mädchen verliebt, das sie

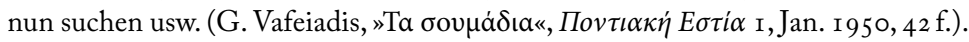

703 Dies konstatiert Buhociu auch für Rumänien (Die rumänische Volkskultur, op. cit., 44): Das Hochzeitsschauspiel ist vorprogrammiert, hat szenarischen Ablauf und folgt einer strengen BedeutungsHierarchie: An der Spitze steht das Brautpaar und der Hochzeitsbanner (zur Hochzeitsfahne

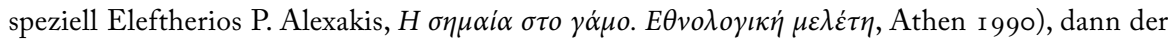
Anführer des Bräutigamzuges, der Brautführer als Zeremonienmeister, Altersgenossen, Trauzeugen, Eltern, helfende Mädchen, Instrumentenspieler/Sänger, die Mitglieder der Kommunität. Die Festivitäten dauern etwa eine Woche, Höhepunkt ist am Sonntag; die Zeremonie ist in Akte einteilbar wie bei einem Theaterstück. Zur Anwendung dieser Termini auf Phänomene der Volkskultur

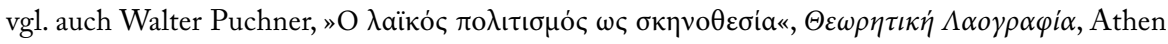

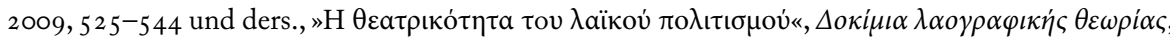


halbinsel gibt es eine ausgedehnte Bibliographie, von konventionellen volkskundlichen Arbeiten und beschreibenden Übersichten bis zu kultur- und sozialanthropologischen case studies, die eine enorme Fülle solcher theatralischer Spiel- und Schauelemente bereitstellt; es handelt sich jedoch meist um Fallstudien, die sich im besten Fall auf nationale Ebene erstrecken, sprach- und grenzübergreifende Arbeiten sind selten ${ }^{704}$.

Die Funeralprozession des Begräbnisses kann ebenfalls unter performativen Aspekten gesehen werden ${ }^{705}$, ebenso wie das traditionelle Lamentationsverhalten in mediter-

Athen 20 I I, 27-68. Die Tanz-Anthropologin Rena Lutzaki etwa hat das gesamte Hochzeitsze-

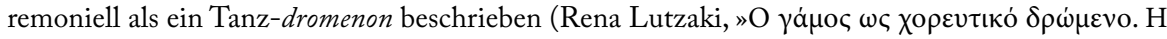

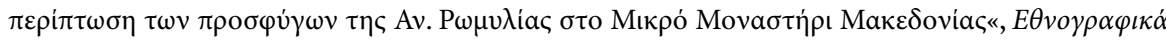
4-5, I $983-85$, I 43-I 76). Das Initiationsritual »Hochzeit« kann auch als Liedabfolge beschrieben

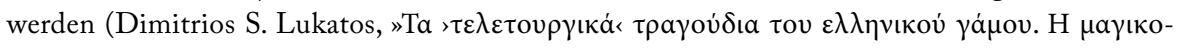

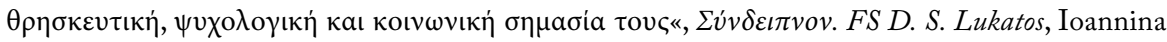

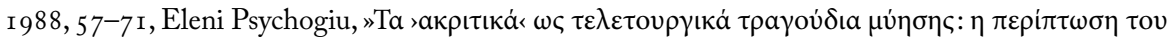

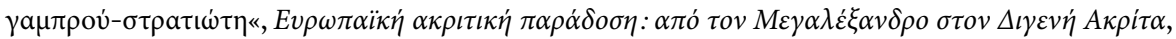
Athen 2004, I 5 2-I 85), als Demonstration der sozialen Geschlechterrollen (Nora Skuteri-Didas-

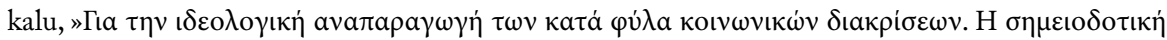

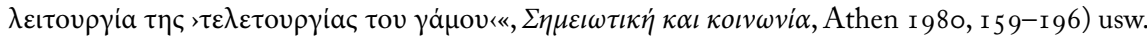

704 Z.B. Marcu Beza, »The Sacred Marriage in Roumanian Folklore«, The Slavonic Review 4/I I (I 925 ) 32 I-333, 5/I 5 ( I 927 ) 647-658, Catherine Brown, »Gypsy Wedding at Skoplje«, Folk-Lore 44 (1933) 305-308, Theodor Frings/Maximilian Braun, Brautwerbung, r. Teil, Leipzig 1947, Radost Ivanova, Traditional Bulgarian Wedding, Sofia 1987, Démétrios S. Loukatos, „Linvitation aux noces: sujet d'étude comparative chez les peuples balkaniques«, Die Kultur Südosteuropas, ibre Geschichte und Ausdrucksformen, Wiesbaden/München 1964, I6 I-I70; zur hebräischen Hochzeit in Ioannina Rachel Dalven, »Betrothal and Marriage Customs of the Jannina Jews«, Sephardic Scholars 3 (I973) 4I-60. In Auswahl aus dem griechischen Sprachraum: W. R. Halliday, "A Greek Marriage in Cappadocia«, Folklore 23 (I 1 I 2) 8 I-88, Magda H. Ohnefalsch-Richter, Griechische Sitten und Gebräuche auf Cypern, Berlin I 9 I3, Démétrios S. Loucatos, Religion populaire à Céphalonie, Athènes I950, Philip P. Argenti, The customes of Chios: their development from the XVth to the XXth century, London I953, Franz Dölger, "Hochzeit in Prosotsani «, Zeitscbrift für Balkanologie 2 (1964) 33-37, Maire-Elisabeth Handman-Xifaras, "Les noces à Pouri, Pélion «, L'Homme I6/2-3 (1976) 4I-67, Fotios K. Litsas, The Greek Folk Wedding: Preliminary Studies, Chicago I98 I, James Rennell Rodd, The Customs and Lore of Modern Greece, London

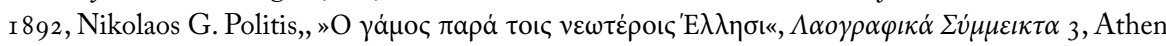
I93 I , 232-322, M. C. Couffin, Monde féminin et mariage en Epire grecque, Montpellier 1982, Eurydike

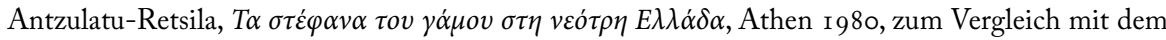
Altertum auch Philipp Sakellarios, Die Sitten und Gebräuche der Hochzeit bei den Neugriechen verglichen mit denen der alten Griechen, Diss. Halle a. S. ı88o, zu den Pontus-Griechen Manolis G. Sergis, $\Delta \iota \alpha-$

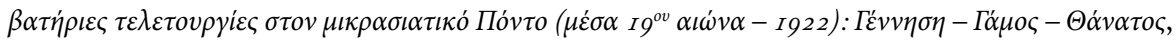
Athen 2007, I I 7-223, zu Zypern vgl. die enorme fast tausendseitige Matieralsammlung von Kalliopi

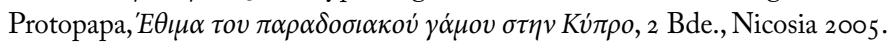

705 Rudolf Schenda, »Begräbnis«, Enzyklopädie des Märchens 2 ( (979) 28-4I mit umfangreicher Bibliographie. 
ranen und südosteuropäischen Regionen ${ }^{706}$, von der Beweinung des Leichnams über das Begräbnis, die mnemosyna/zadušnici-Messen und Seelengedenktage ${ }^{707}$, die Grabpflege und den Dialog mit dem Toten an der Grabplatte ${ }^{708}$ bis hin zur Exhumierung der Gebeine und ihrer Deponierung im Beinhaus (osteophylakion/kostnica) des Dorfes ${ }^{709}$. Dazu gibt es unzählige Übersichtswerke, Sammelstudien und Fallbeispiele, die z.T. enormes Informationsmaterial in großer Varianz vorlegen ${ }^{710}$, aber eigentliche performative Spiele gibt es bloß bei der Nachtwache an der aufgebahrten Leiche, wo vor allem im nördlichen Balkanraum auch Maskenspiele aufgeführt werden ${ }^{711}$. Aber allein schon die Vorstellung von den leiblichen Bedürfnissen des Toten, das Freilassen seines Platzes beim

706 Milenko S. Filipović, „Das Zerkratzen des Gesichts bei den Serben und Albanern«, Revue interna-

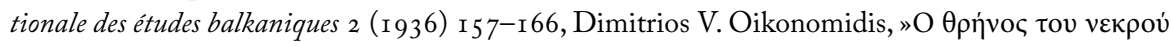

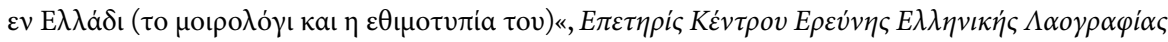
I 8-ı 9 ( 1965-66) I I-40, Ján Komorovský, »Kaukasische Parallelen der Begräbnis-Bräuche von Crna Gora (Montenegro)«, Ethnologia Slavica 2 (1 970) I 77-1 87.

707 Vgl. dazu die thematischen Abschnitte "Nekrolatria: Gedenkmesse, Grabbesuch und Speiseopfer» und »Allerseelen - das heortologische System der psychosabbata: liturgische Brotweihe, kollybaGabe und Hochzeitsorakel« in Puchner, Studien zur Volkskunde Südosteuropas, op. cit., 73-90. Dazu

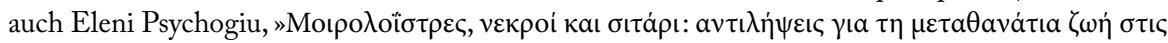

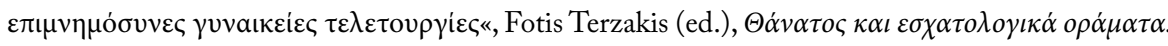

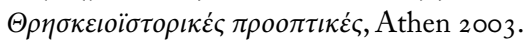

708 Marian Wenzel, »Graveside Feasts and Dances in Yugoslavia«, Folk-Lore 73 (1962) I-I 2, Matthias Murko, »Das Grab als Tisch", Worter und Sachen 2 ( I 9 го) 79-160.

$709 \mathrm{Zu}$ diesem zweiten Abschied und der Poetik der Lamentation vgl. vor allem Loring M. Danforth, The Death Rituals of Rural Greece, Princeton 1 982. Zu den Klageliedern Puchner, Die Folklore Südosteuropas, op. cit., 73-77.

7 Io Stichprobenartig für den hellenophonen Kommunikationsraum Bernhard Schmidt, »Totengebräuche und Gräberkultus im heutigen Griechenland «, Archiv für Religonswiss. 24 (I926) 28 I-3 I 8 ,

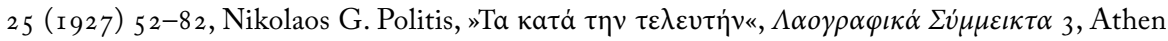
I 93 I , 323-362, Margaret Kenna, „Houses, Fields, and Graves: Property and Ritual Obligation on a Greek Island«, Ethnology I 5 ( 1976) 2 I-34, Jill Dubisch, »Death and Social Change in Greece«, J. Dubisch/L. Taylor (eds.), Special Issue of Anthropological Quarterly (on the Uses of Death in Europe)

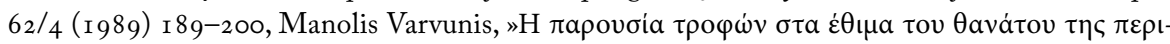

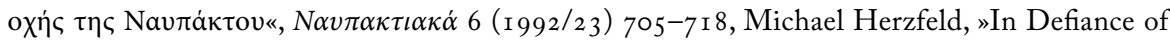
Destiny: The Management of Time and Gender at a Cretan Funeral«, American Ethnologist 20/2

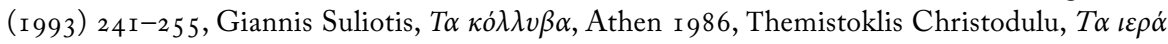

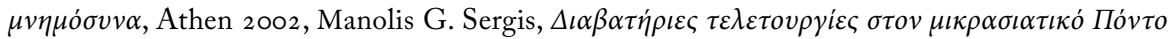

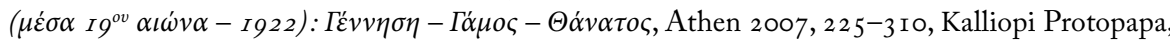

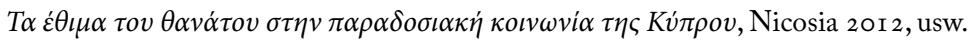

7 I I Z.B. in Rumänien und Ungarn. Bei den Ungarn ist der Klapperstock schon I 8 I 8 nachgewiesen: ein Bursch muß mit zugebundenen Augen erraten, wer ihn geschlagen hat. Anderswo wird Karten gespielt oder werden Witze erzählt (Balassa/Ortutay, Ungarische Volkskunde, op. cit., $672 \mathrm{ff}$.$) .$ 
Totenschmaus oder das Servieren von Speisen in der Totenkammer haben performative Aspekte, die einer näheren Untersuchung wert wären ${ }^{712}$.

Unter einem solchen weiter gefaßten Performativitätsbegriff könnte man dann auch noch andere Zeremonielle ekklesialer Natur ins Auge zu fassen, wie Teile der orthodoxen Messe mit deutlich darstellendem Charakter, etwa die Kreuzabnahme im Osterkreis, oder den Epitaphumzug, doch mag eine solche Expansion eher zu Unklarheiten und Mißverständnissen bezüglich der symbolischen Natur dieser Sakralhandlungen führen. Gesondert seien eventuell die rituellen ekklesialen Versteigerungen erwähnt, wo durch die höchste Geldspende das temporäre Besitzrecht eines ekklesialen Sakralgegenstandes erworben wird (das Tragen einer Ikone, von Hexapterygen, Bannern und Wimpeln, in der Kirche oder auf dem Dorfplatz, das Aufstellen des Kirchenkreuzes oder der Auferstehungsikone im eigenen Haus usw.). Dieser Brauch hat im Inselraum und dem östlichen Hellenentum manchmal deutlich theatralischen Charakter, wo der Prestigegewinn des Höchstbietenden öffentlich zur Schau gestellt wird ${ }^{713}$. Manchmal handelt es sich um Re-Innovationen von Kleinasienflüchtlingen ${ }^{714}$.

7 2 Mihai Pop, »Le mythe de `Grand voyage dans les chants des cérémonies funèbres roumaines«, To honor Roman Jakobson. Essays on the occasion of his 70 birthday, 2 Bde., The Hague/Paris I 967 , II r602-r6o9, Tioslav Matić, Totenkult bei den Serben, Diss. Leipzig r 940, Julius von Negelein, "Macedonischer Seelenglaube und Totenkultus«, Zeitschrift des Vereins für Volkskunde I 4 ( 1 904) I 9-35, Paul H. Stahl, „Le départ des morts. Quelques exemples roumaines et balkaniques«, Études rurales I05/I06 (I 987) 2 I5-24I, Philip V. R. Tilney, "Supernatural Prophylaxes in a Bulgarian

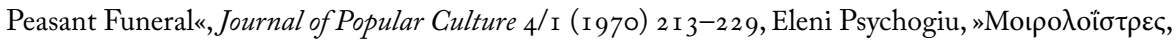

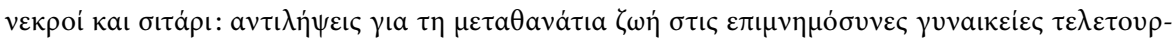

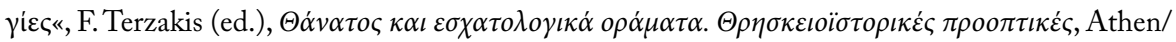

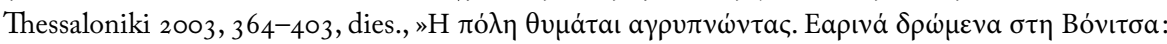

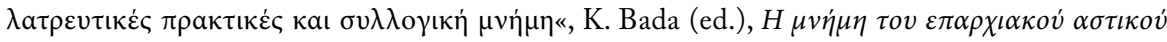

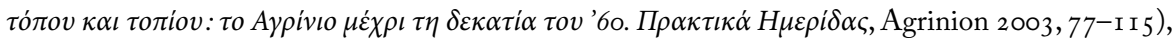
Josef Bauer, "Jenseits«, Enzyklopädie des Märchens 7 (1993) 524-533 usw.

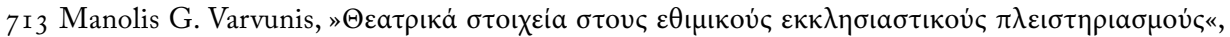

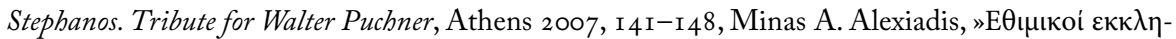

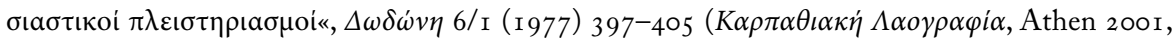

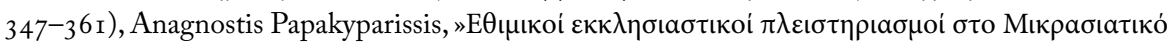

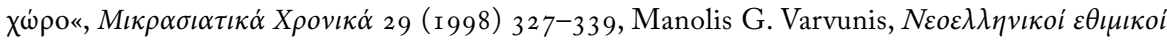

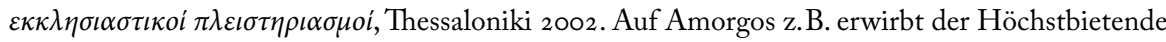
das Recht auf die Organisation des panegyri am Marienfest des I 5. Aug., anderswo zur Organisa-

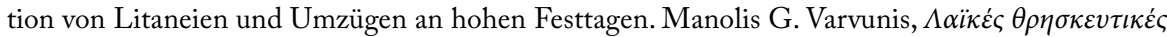

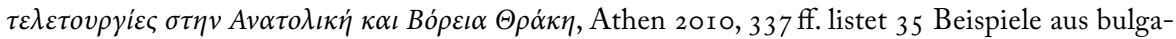
risch und türkisch Thrakien; es handelt sich um einen Sekundärritus mit dem Effekt der Gruppenstabilität, folkloristisch gebraucht für utilitaristische Ziele wie Geldsammlung für Kirche und gemeinnützige Zwecke (Verbreitungskarte S. 342).

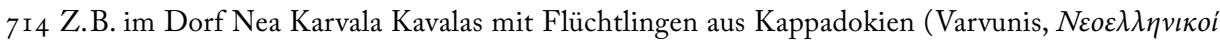


Der Vorgang theatralischer Schaustellung von Prestige und Macht ist freilich keineswegs auf die Oralkulturen der Unterschichten beschränkt, sondern bei den Elitekulturen dominant. Venedig hat in seinen Insel- und Küstenbesitzungen systematisch Gebrauch gemacht von Festivitäten und Veranstaltungen als Demonstration kultureller Überlegenheit und politischer Macht ${ }^{715}$. Dies wird uns an anderer Stelle noch zu beschäftigen haben; die vergleichbaren demonstrativen Schaustellungen unter dem Sozialismus fallen jedoch nicht mehr in den Rahmen dieser Untersuchung, die den traditionellen Oralkulturen gewidmet ist.

\subsection{PROFESSIONELLE SCHAUSTELLEREI}

Die professionelle oder semiprofessionelle Seite performativer Manifestationen in den Oralkulturen Südosteuropas umfaßt im wesentlichen die Instrumentenspieler und Musikanten, bei denen die Roma bekanntlich eine herausragende Rolle gespielt haben. Auf dem Sektor der Performanz im engeren Sinne als hauptberuflich organisierter Schaustellerei sind vor allem Puppen- und Schattenspieler zu erwähnen, nach Maßgabe der Tatsache, daß fahrende Spielgruppen mit improvisierten Theateraufführungen zumindest semiurbane Rezeptionsverhältnisse voraussetzen und vielfach auch eine existierende Theatertradition der Elitekultur, an der sie sich kontrapunktisch profilieren können. Die rituelle Bindung an Jahrestermine und Festtage sowie an Glaubensvorstellungen von der magische Effektivität der vorgeführten Handlungen sind nun nicht mehr gegeben, sondern Unterhaltungsbedürfnis auf der einen Seite und pekuniärer Erfolgszwang auf der anderen regulieren diese Aktivität nach den Marktgesetzen von Angebot und Nachfrage bzw. den vorgegebenen ästhetischen Normen der traditionellen Volkskultur, die sowohl für die Produktions- wie auch für die Rezeptionsseite Gültigkeit und Verbindlichkeit besitzen. Der Übergang von der Oralität zur szenischen Textreproduktion ereignet sich im weiten Variationsspielraum der Improvisationsmöglichkeiten, denen auch vorgegebene, sofern vorhanden, Textvorlagen unterliegen können.

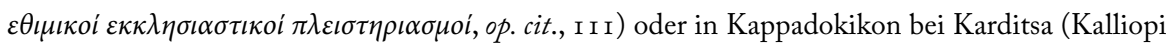

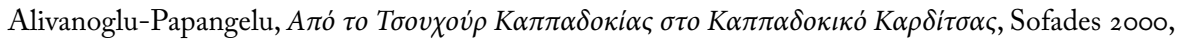
$52,55)$.

7 5 Vgl. z.B. zu diesem Macht-Theater der staatlichen Zeremonien und Feste im venezianischen Dubrovnik (Ragusa) Nella Lonza, Kazalište vlasti. Ceremonijal i državni blagdani dubrovačke Republike u 17 . i $_{\text {I }}$. stoljeću, Zagreb/Dubrovnik 2009. 


\subsection{Fabrende Komödianten}

Ambulante (Volks)Theatergruppen professionellen Zuschnitts hat es im Osmanischen

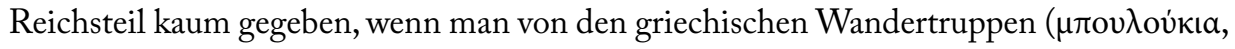
Haufen, Gruppe, türk. bülük) nach I 860 absieht, die im gesamten Ostmittelmeer und in der Schwarzmeerregion tätig waren; hier geht es zwar um Autodidakten, aber von Oralität und Improvisationstheater kann nicht die Rede $\operatorname{sein}^{716}$. Auf dem venezianischen Sektor Südosteuropas gibt es in den »Memorien« von Casanova die Nachricht, daß er um I745 als impresario eine commedia dell'arte- Truppe von Otranto nach Korfu geholt habe, die dort eine Saison ihre improvisierten Vorstellungen zum besten gegeben habe $^{717}$; möglicherweise gab es noch andere derartige Vorstellungen, denn die Einflüsse in der heptanesischen Dramatik im I 8. Jh. sind noch deutlich nachweisbar ${ }^{718}$. In den habsburgischen Bereichen Südosteuropas entstand ein ganzes Netz von fahrenden Komödianten, die die privilegierten deutschen Theater in den Provinzstädten der DonauMonarchie benutzten, doch handelt es sich eher um Manifestationen der Hegemonialkultur; näher am Begriff eines oral geprägten Volkstheaters waren etwa die wandernden Schauspieler in der Vojvodina mit ihrem serbokroatischen Spielplan oder die Gaukler und Schausteller in Ungarn ${ }^{719}$. Doch über Vorstadtheater und ex tempore, Affentheater, Hundetheater und andere Spektakel geben die Theatergeschichten ausreichend Auskunft $^{720}$.

Es gibt auch Fälle von Zusammenarbeiten von Berufsschauspielern mit Dillettanten, wie etwa der griechische Truppenprinzipal Michael Daniel, der r 909/ı in Georgien überwinterte und mit lokalen Laienspielgruppen zusammenarbeitete ${ }^{721}$. Doch auch hier

7 6 In Übersicht nun Walter Puchner, Hellenophones Theater im Osmanischen Reich (I600-1923), Wien/ Berlin 201 2, 83-159 (»Das lange I 9. Jahrhundert der Sultansrefomren. Griechisches Berufstheater und Laienspiel unter dem Halbmond und in den nationalstaatlichen Ausläufern«) mit der einschlägigen Spezialbibliographie.

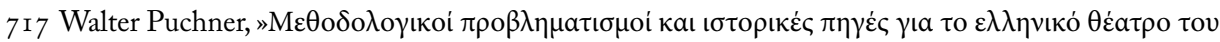

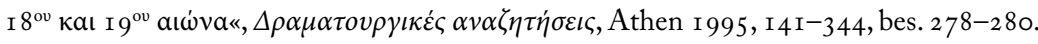

7 8 Walter Puchner, »Spuren der Commedia dell'arte im griechischen Theater des I 8. und I 9. Jahrhunderts«, Beiträge zur Theaterwissenschaft Südosteuropas und des mediterranen Raums II, Wien/Köln/ Weimar 2007, 31 7-322.

7 9 Alojz Ujes, »Das Publikum der wandernden Schauspieler in der Vojvodina im I 9. Jahrhundert«, Das Theater und sein Publikum, Wien I 977, 206-2 I 8, Hedwig Belitska-Scholz, „Gaukler und Wanderpuppenspieler in Ungarn«, Maske und Kothurn 2 I (1975) Io6-г 22.

720 Vgl. z.B. das klassische Werk von Otto Rommel, Die Alt-Wiener Volkskomödie, Wien 1952.

72 I In einem in der Odessaer griechischen Zeitung »Kosmos« Nr. 436 vom 8. 4. I 9 ro veröffentlichten Dankesbrief erwähnt der Truppenprinzipal, daß er drei Monate in Kars, Čiatura und Božomi verbracht und dort mit griechischen Laienspielern zusammengearbeitet habe (Irena Bogdanović/ 
geht es um Literaturtheater. Ähnliche Kontaktnahmen mit der Volkskultur gab es auch an den k.u.k. Provinzbühnen, wenn sich etwa die »Räuber« von Schiller in hippodromartige Kunstreitübungen auf der Bühne verwandeln ${ }^{722}$. Solche Hippodrom-Nummern wurde auch im Athen des bayerischen Königs Otto I. (1833-I 862) gezeigt, ähnlich wie das erste Theater der Stadt auch Seiltänzer und Akrobaten beherbergte ${ }^{723}$. Eine besonders beliebte Unterhaltung waren die Pantomimen ${ }^{724}$, denen später um die Jahrhun-

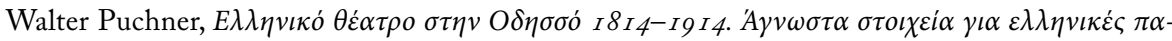

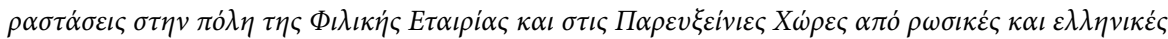

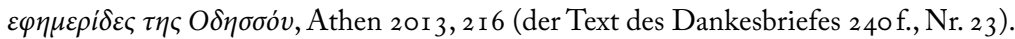

722 Z.B. bei Provinzaufführungen in Laibach und Zagreb (Peter v. Radics, Die Entwicklung des Bühnenwesens in Laibach, Laibach I 9 I 2, L. Duwan, „Die Beziehungen zwischen dem Laibacher und dem Wiener Vorstadttheater zwischen I 790 und I 848«, Maske und Kothurn I 2, I 966, 220-227, Blanka Breyer, Das deutsche Theater in Zagreb I780-I840, Zagreb I 938).

723 In Reiseberichten finden sich Angaben über die Art von Schaustellungen, die einige Jahre, nachdem I 830 Athen zur Hauptstadt Griechenlands erhoben wurde und I 833 der bayerische König Otto I. eingetroffen war (vgl. nun Ioannis Zelepos, Kleine Geschichte Griechenlands. Von der Staatsgründung bis heute, München 2014, 54 ff.), dort zu sehen waren. George Cochrane berichtet über eine Truppe aus Zante im Herbst I 835 : »The actors were, a man, his wife, and their two children; and the performance were merely those of a strolling company of the most limited class " Wanderings in Greece, 2 Bde., London I 837, I 202 f.). K. Schönwälder, Erinnerungen an Griechenland, Breig I 838, 263 erwähnt eine italienische Wandertruppe, die er in Patras gesehen habe, »welche das Publikum mit Farcen, Harlekinaden, Obscönitäten unterhielt« und gute Geschäfte machte. Ein anderer Reisender, C. O. I. von Arnim, Flüchtige Bemerkungen eines Flüchtig-Reisenden, Berlin I 837, 48 ff., bringt sogar den Wortlaut eines Theaterzettels vom 8. April I 836: „Heute stellt die Gesellschaft der Seiltänzer verschiedene neue Stücke vor, und sie hofft, daß die edelgesinnten Einwohner dieser Stadt mit ihrer gewohnten Freigiebigkeit ihre geringen Gaben belohnen werden. Um 4 Uhr fängt man an, sich zu versammeln, und um 5 Uhr zu spielen./Athen, den 8 ten April I 836/Vorstellungen./Tanz auf dem gespannten Seile./Pyramidalische Puppenspiele./Pyramiden./ Ein großer schwerer Sprung einer papiernen Puppe./Verschiedene Kunststücke auf dem schlaffen Seil,/und/eine mimische Vorstellung, genannt: die drei belebten Fässer«. Der Verfasser hat es allerdings vorgezogen, einen Spaziergang zu machen, und somit wissen wir nicht, was wirklich geboten wurde (eine Kombination von Akrobatik, Seiltanz, Puppenspiel und Pantomime?).

724 Diese Vorstellungen tauchen schon bald nach der Staatswerdung in allen größeren griechischen Städten auf, rekrutieren sich als ein separates Genre vor allem nach I 870 ; die Truppen sind manchmal italienischer Herkunft, aber auch autochthon; gespielt werden heroische Thematiken aus Antike, Byzanz oder dem Freiheitskrieg, mythologische, aber auch sentimentale Stoffe, die beliebten Räuberromane werden auf die Bühne gebracht wie auch aktuelle Themen. Um die Jahrhundertwende verfügen sie bereits über Musiknummern und phantasmagorische Bühnenbilder. Pantomi-

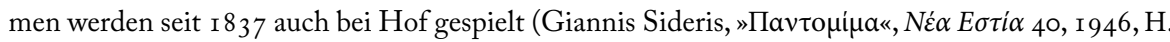

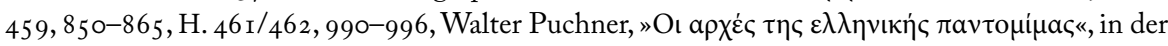

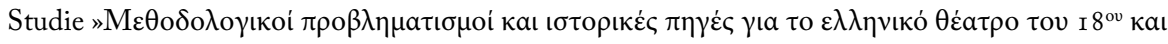

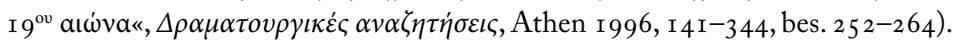




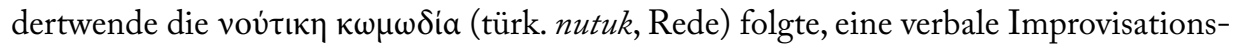
nummer am Ende einer Theatervorstellung ${ }^{725}$. Um diese Zeit brachten die griechischen Provinzbühnen auch Kunsttänzer, Akrobaten, Jongleure, Hypnotiseure, Zauberkünstler, Wunderdoktoren, Dompteure u.a. auf die Bühne ${ }^{726}$. Dieses Spektakelwesen setzt jedoch bereits einen urbanen Kontext voraus ${ }^{727}$, z.T. auch einen höfischen, wie etwa im phanariotischen Bukarest und in Iași, wo auch Seiltänzer, Jongleure, Clowns und Zauberer, italienische Affendompteure, deutsche Gewichtheber und türkische Feuertänzer zu sehen waren ${ }^{728}$.

Im allgemeinen handelt es sich um schwer einzugrenzende und zu dokumentierende Bereiche, die als paratheatralische Manifestationen z.T. auch von den regionalen Theatergeschichten behandelt werden ${ }^{729}$, deren Ergebnisse aber von der jeweiligen Quellenlage und dem Tiefengang ihrer Auswertung abhängig sind. Diese Phänomene einer städtischen Unterschichtenkultur gehören nur mehr teilweise der traditionellen oralen Kulturschicht an, da sie oft von fixierten Textvorgaben und Elite-Institutionen, von Ideen und Ideologien der Aufklärung und des Nationalismus überformt und geprägt sind.

\subsubsection{Panoramen}

Ähnlich wie die Pantomimen waren auch die Panoramen eine westliche Übernahme. In Städten wie Budapest und Bukarest waren sie vor allem in den Vorstädten zu sehen. In

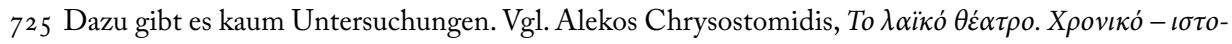
$\rho \iota \kappa o ́-\alpha v \alpha \mu \nu \eta \dot{\sigma \varepsilon \iota \varsigma, ~ A t h e n ~[1986], ~ I 64, ~ I 67 f . ~(w o ~ d e r ~ V e r f . ~ d i e ~ M e i n u n g ~ v e r t r i t t, ~ d a ß ~ d i e s e ~ G a t t u n g ~}$ aus den Pantomimen hervorgegangen sei).

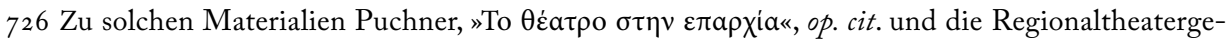

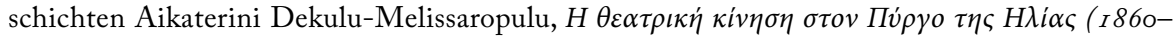

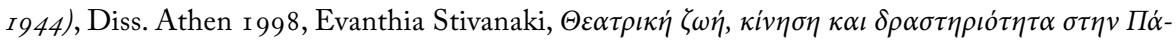

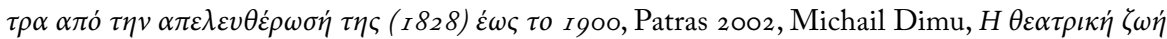

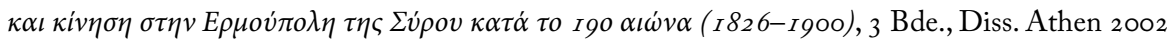
usw.

727 Vgl. Walter Puchner, »Theater und Stadtkultur: eine Typologie«, in der Studie: »Typologische Entwicklungsstrukturen der Theatergeschichte im südosteuropäischen Raum«, Beiträge zur Theaterwissenschaft Südosteuropas und des mediterranen Raums I, Wien/Köln/Weimar 2006, I3-72, bes. 56-72.

728 F. A. Costa, »Spectacole de divertisment la curțile domnești și boierești în epoca feudală«, Studii și cercetări ist. artei 5/2 (I 958) I 37-333, K. Berlogea, "Manifestations théâtrales à la cour voivodale valaque et moldave au Moyen Age «, Revue roumaine d'histoire de l'art. Série théâtre, musique, cinéma I 9 (1982) 29-35, A. M. Popescu, »Inceputurile teatrului cult în Țara Romînească«, Studii și cercetări ist. artei 5 (I958) $4 \mathrm{I}-57$.

729 Solche Materialien beinhalten auch die älteren rumänischen Theatergeschichten. 
Budapest wurde noch I 837 die Seeschlacht von Navarino (I 827 ), die zum Untergang der türkisch-ägyptischen Flotte durch die drei Großmächte geführt hatte sowie zum siegreichen Ende der griechischen Revolution, welche vorher schon in mehreren Versionen in London zu sehen war ${ }^{730}$, gezeigt, und zwar als Zugabe zur Aufführung des Theaterstückes »Der Pilger aus Moskau und der großmüthige Sultan«.

Der Programmzettel kündigt folgendes an: Zum Beschluß:/die Seeschlacht bei Navarin,/oder:/die Zerstörung der ägyptischen Flotte durch die russisch-englisch-französisch verbündete Flotte, den 20. Oktober I 827./So wie der Vorberg sich erhebt, erblickt man rechts die Festung Navarin, man sieht in der Morgenröthe die sich über das Meer verbreitet, schwimmend Delphine, Meerjungfern und andern Seethiere der Phantasie in lustigem Spiel vorüberschwimmen. Es wird allmählig Tag, man sieht die Schiffe kreuzen und eine Kanonade verkündet die Zusammenkunft der beiden Kriegsflotten. Die Alliierten bilden in der Ordnung der Schiffe einen halben Mond, so daß an beiden Ende die Franzosen, in der Mitte die Russen und Engländer stehen, und aus ibre Feuerschlunde Todt und Verderben unter die gegenden stehenden Türken senden. Die ägyptische weit größere Flotte erwiedert das Feuer der Kanonen eben so lebhaft auf ibre Feinde und bietet dem Auge einen schönen Anblick dar, die meisten

730 Die spektakuläre Schlacht wurde als Panorama-Nummer schon in die traditionelle Weihnachtspantomime von Covent Garden und im Surrey Theatre im Dezember I 827 aufgenommen (I. G.

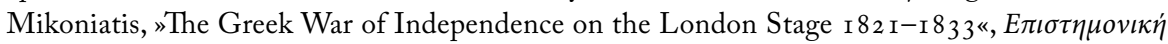

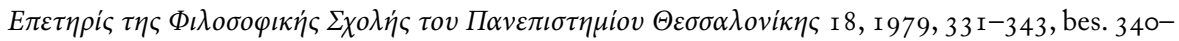
343); im ersten Falle als I 9. Szene der Serie »Harlequin and the number nip; of The Giant Mountain«, wo die Englische Flotte vom Einlaufen in das Mittelmeer durch die Engen von Gibraltar bis zum siegreichen Ende der Seeschlacht gezeigt wurde, im zweiten mit dem Titel »Harlequin and the Astrologer of Stepney; or The Enchanted Fish and Fated Ring «, wo die Englische Flotte zu Beginn noch im Hafen von Portsmouth liegt, Mikoniatis, op. cit., 34I). Ein anderes bewegliches Panorama von denselben Malern ging auf Tournee nach Holland und Deutschland (ebenso läßt sich ein solches Panorama für Paris I 83 I nachweisen, vgl. Hugh Honour, Romanticism, London 1979, 357). Aber es gibt auch andere Panoramen, die offenbar nicht beweglich waren: so hat sich eine "Descripition/of a/View of the Battle/of Navarin,/now Exhibiting at/the Panorama, Strand« erhalten, wo an die Zuschauer auch gedruckte »Erläuterungen« über die Vorgeschichte der Auseinandersetzung, ihre Entwicklung und ihren Ausgang verkauft wurden, mit Angaben zu Leben und Wirken von Flottenadmiral Sir E. Codrington sowie Auszüge von Augenzeugenberichten der

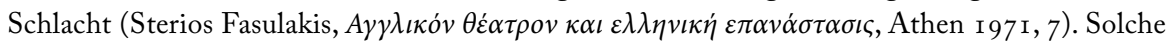
Panoramen mit eindrucksvollen Szenen aus dem hellenischen Orient mit wilden Naturlandschaften und authentischen Kostümen waren schon gleich nach dem Ausbruch der Revolution zu sehen. Eine gedruckte Beschreibung eines Panoramas in London I 822, zeigt z. B. folgendes: »descripition/ of the/Island and City of/Corfu,/with Part of the Coast of Greece, Epirus, and the Suliote/Chain of Mountains,/in the Distance, the Whole Representation Embellished, in the Foreground, with/a Variety of Costumes/Worn by the Greeks, Assembled on Fort Neuf to Celebrate the/Annual Religious Festival of `La Madonna< ...«(Fasulakis, op. cit., 6 f.). 
ihrer Schiffe werden zu Grund gerichtet. Deutlich unterscheidet man bei diesem, auf das Täuschendste nachgeahmten furchtbaren Ereigniße, eine Fregatte mit Rudersclaven besetzt sich näher an die Engländer heranziehen, sie erbält aber plötzlich mehrere volle Lagen, so daß die Mastbäume umstürzen, das Schiff in Brand gerath, der eine mehr um sich greift und die Pulverkammer zündet. Mit Krachen zersplüßet das Schiff und das brennende Wrack treibt auf dem Wasser umber, und schließt vollends mit dem Untergang der türkischen Flotte ... ${ }^{731}$

Derartige Schaustellungen mit Stadtansichten, Schlachtenszenen, Krönungen usw. waren in ambulanten Schaubuden auch in Bukarest ${ }^{732}$ und bei Jahrmarktsfesten auch in anderen Städten Rumäniens zu sehen (panarama); als Werbenummern und zur Anlockung von Zuschauern für das Panorama wurden auch improvisierte primitive Puppenspiele mit erotischen oder häuslichen Alltagsthemen gegeben (Vasilache și Marioara) ${ }^{733}$. Das führt uns allerdings schon zum folgenden Kapitel.

\subsubsection{Puppentheater}

Professionalismus im eigentlichen Sinne findet man jedoch vorwiegend bei Puppen- und Schattenspielern, die als Einzelgänger und one-man-show größere Überlebenschancen haben und überdies eine höhere Mobilität aufweisen ${ }^{734}$; dieser weitere Diffusionsradius betrifft vor allem den nordbalkanischen Raum, wo im weihnachtlichen Krippenspiel und dem »Herodeskasten « nicht nur Professionalismus und Laienspiel zusammentreffen, lebendige Schauspieler mit Puppen und Figuren, sondern auch mitteleuropäische, polnische, tschechische und ukrainische Kulturzonen mit ungarischen und rumänischen: Die Morphologie der ungarischen Krippenspiele und des tragbaren »Herodeskasten« ist nicht unbedeutend $^{735}$, dem entsprechen in Rumänien die vicleim-Spiele und das jocul papuşilor

73 I Photographie eines Programmzettels bei Hedwig Belitska-Scholtz, „Gaukler und Wanderpuppenspieler in Ungarn «, Maske und Kothurn 2 I (1975) I06-I 22, bes. I09.

732 Dies ist aus den Briefen des russischen Generals Kutuzov ersichtlich, veröffentlicht in der Revue de Paris, April I 835 (Ariadna Camariano, »Le théâtre grec à Bucarest au début du XIXe siècle«, Balcania 6, I 943, 38 I-4I6, bes. 38 2 f.). Zu den Panoramen von Matthias Brody vgl. D. C. Ollanescu, Teatrul la Români, București I 859, 30.

733 Horia Barbu Oprișan, »Das rumänische Volkspuppenspiel«, Österr. Zeitscbrift für Volkskunde 35/84 (1981) 84-106, bes. 87 .

$734 \mathrm{Zu}$ diesem Kapitel vgl. auch Walter Puchner, »Vergleichende Beiträge zum traditionellen Volkspuppenspiel auf der Balkanhalbinsel«, Beiträge zur Theaterwissenschaft Südosteuropas, op. cit., I 73-96,

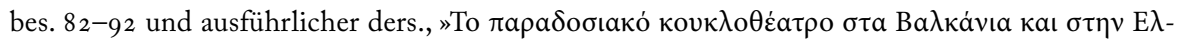

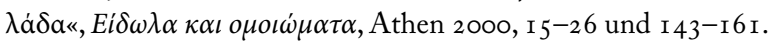

735 Dazu gibt es eine reichhaltige Bibliographie. In Auswahl: F. Schram, »Három történelmi bethlehemes játék«, Irodalomtörténeti Közlemények 1 964, 497-520, Gyula Ortutay, »Kérdőiv bethlehemes 
sowie das eher primitive Puppenspiel von Vasilache și Marioara ${ }^{736}$; vom Westen und Nordwesten beeinflußt zeigen sich die Puppenspielformen in Slovenien ${ }^{737}$, Šante i Pante und Verwandtes in Kroatien ${ }^{738}$, einfachere Formen finden sich in der Vojvodina ${ }^{739}$, im Banat ${ }^{740}$,

játekok gyüjtéséhez«, Ethnographia LXVIII (1956) 91-98, Jozsef Faragó, Betlehemezôk és kántálok Pusztakamaráson, Kolozsvar I 947, Lajos Vargyas, »Mimos elemek a magyar bethlehmes játékban«, Antiquitas Hungarie, Budapest I 95 5, I I 7 ff., Lázsló Földes, »A Budajenöre telepitett székelyek bethlehemezése«, Ethnographia 6o (I 958) 209-259, Robert Gragger, "Deutsche Puppenspiele aus Ungarn", Archiv für das Studium der neueren Sprachen und Literaturen I 48 (I 925 ) I6 I-I 80, Hedwig Belitska-Scholz, »Gaukler und Wanderpuppenspieler aus Ungarn«, Maske und Kothurn 2 I (1975) Io6-i 22, Ivan Balassa/Gyula Ortutay, Ungarische Volkskunde, München I 982, 699-702, L. Köldu, »Krippenspiel«, Ethnographia 69 (1958) 209-259, Ferenc Debreczeni (ed.), A Bábjátszás Magyarországon, Budapest I 955, 5-49, Dezso Szilágyi, Contemporary Hungarian Puppet Theatre, Budapest I 978, Klára Vamossy, A hazai Bábjáték, Budapest i 94I, Nora A. Tahy, Das theatralische Brauchtum des ungarischen Sprachbereichs, Frankfurt/M. etc. I 989, 26, É. Szacsvay, »A magyarországi bábtáncoltató betlehemézes«, Néprajzi Értesitô 60 (1978/82) 57-102, dies., Bábtáncoltató betleheméz Magyarországon és Közép-Klet-Europában, Budapest r 987 , E. v. Hlavats, Német Bábjátékosaink, Diss. Budapest I 940 etc.

736 Oprișan, »Das rumänische Volks-Puppenspiel«, op. cit., ders., Teatru fără scenă, București I 98 I , 26 f., 56-59.; Eugenia Popescu-Judetz, »L'influence des spectacles populaires turcs dans les Pays Roumaines", Studia et acta orientala 5-6 ( 1967 ) 337-355, Nicolae Rădulescu, "Musikalische Puppenspiele orientalischer Herkunft in der rumänischen Folklore«, Zeitschrift für Balkanologie I 4 ( 1978) 83-98, L. Nădejda, "Teatrul popular de papuși în secolul al XIX-lea«, Studii și cercetări de istoria artei 7, no I (I 960) 203-2I 5, Letiția Gîtză, »Le théâtre roumain de marionettes«, Revue roumaine d'histoire de l'art I ( I 964) I I 8-1 38, Johann Carl Schuller, Herodes. Ein deutsches Weihnachtsspiel aus Siebenbürgen, Herrmannstadt I 850, L. Alexandrescu, »Le Bethléem, un mystère paysan contemporain du nord de la Roumanie«, Estudios Escénicos 2 I (1978) I 49-I67, Simion Alterescu, Istoria Teatrului Leydiuturi pină la I848, București 1965 ; Letiția Gîtză, Teatrul de Papuși in Romînesc, București I 963, dies./I. Chimet/V. Silvestru, Teatrul de papuși in Romania, București I 968, Alfred Karasek-Langer, »Krippentheater und bewegliche Krippen im Sudetenraum«, Jabrbuch für ostdeutsche Volkskunde 8 (I 964) I 7 I-253, Nicolae Cartojan, Cărțile populare in literatura românească, Bd. 2, București 1938 (gedruckte vicleim-Texte) etc.

737 Niko Kuret, "Zanimiva oblika ljudskega lutkarstva na Slovenskem«, Slovenski Etnograf Io (1957) I I 3-I 24, ders., »Novo o 'naši tradicionalni lutki«, Slovenski Etnograf I 5 (I 962) I 57 - I66.

738 Nikola Bonifačić-Rožin, »Šante i Pante. Narodni ručne lutke u Hrvatkoj«, Slovenski Etnograf I 5 (1 962) I 35-1 56, Ivan Lozica, Folklorno kazaliste (Zapisi i tekstovi), Zagreb I 996, 349-36 г ; ders., Izvan teatra. Teatrabilni oblici folklora u Hrvatskoj, Zagreb I 99o, 264 ff., Nikola Bonifačić-Rožin, Narodne drame, poslovice i zagonetke, Zagreb I 963, I 28 - I 3 I.

739 Improvisierte Puppenspiele werden hier auch bei Hochzeit und Begräbnis aufgeführt (M. MatićBešković, »Lutka u običajima i verovanjima etničkih grupa u Vojvodini«, I 8. Zbornik kongresa jugoslovanskih folkloristor, Bovec 197 I, Ljubljana I973, I49-I 5 I).

740 T. Ferenc, "Die Wintervolkssitten im Nordbanat«, Makedonski Folklor I 5-I6 (I 975) I I I-I I 5 (I I 3 Hirtenspiel mit umherziehender Krippe). 
in Serbien, Bosnien und der Herzegovina ${ }^{741}$. Gegen Süden zu werden die Spieltraditionen etwas punktueller: Albanien ${ }^{742}$, der griechische fasulis ${ }^{743}$, Bulgarien ${ }^{744}$ sowie die Formenvielfalt des weithin unerforschten Puppenspieles in Kleinasien ${ }^{745}$. Mit den ungarischen Entsprechungen des Wiener Kasperls ${ }^{746}$ sowie dem griechischen, aus Italien importierten fasulis sind schon die Grenzen zu Übergangsformen zum Kunstpuppentheater überschritten $^{747}$.

Die nordbalkanischen Krippendarstellungen sind wie auch in Ostmitteleuropa mit den rituellen Weihnachtsumzügen verbunden ${ }^{748}$ und finden sich in verschiedenen Varianten als vertep, vertepaši, szopka, vicleim, betlejka, betlemaši, kriskindle usw.

74I Nikola Bonifačić-Rožin, »Tragom narodni ručnih lutaka u Hrvatskoj, Bosni, Hercegovini i Srbiji«, Traditiones 5-6 (I979) I9-30, Tvrtko Čubelić, Usmena narodna retorika i teatrologija, Zagreb I 970, I I 9-I 22, Nikola Bonifačić-Rožin, "Igre stri kraljaく i >vertepiく kod jednog dijela stanovništvo Hrvatske«, Rad XIV kongresa saveza udruženja folklorista Jugoslavije u Prizrenu 19-23. IX. 1967, Beograd I 974, 433-440.

742 S. Vaqari, »Teatri i kukllave ne«, Nëndori 2, I I (1955) I39-I 45.

743 Walter Puchner, Fasulis. Griechisches Puppentheater italienischen Ursprungs aus der zweiten Hälfte des 19. Jahrhundert, Bochum 1978 (Puppenspielkundliche Quellen und Forschungen 2), Maria Velioti,

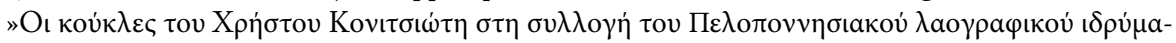

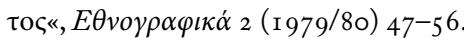

744 Rajna D. Kacarova, »Naroden kuklen teatăr", Radovi XII kongresa saveza folklorista Jugoslavije (Celje 1965), Ljubljana I 968, 385-410, dies., "Folk Puppet Theatre - Puppets made of plants«, The Folk Arts in Bulgaria. Papers from a Symposion, Pittsburgh, Pennsylvania 1976, 55-75, dies., "Za edin kuklar i negovite kukli čengii (About a puppeteer and his puppets)«, Etnografski i folkloristični izsledvanija, Sofija I 979, 292-305; Rajna Kacarova-Kukudova, »Naroden Kuklen teatăr. Kukli ot kărpi«, Izvestija na Etnografskija institut i muzej VI (1963) 409-424, Nadežda Atanasova, »Folklor i kuklen teatăr«, Chudožestvena samodejnost $\mathrm{I} 98 \mathrm{I} / 2,34 \mathrm{f}$.

745 Georg Jacob, »Das türkische Kukla ojunu. Aus den Briefen an Dr. Ritter«, Islam 9 (I 9 I 9) 248-250, Metin And, "Various species of shadow theatre and puppet theatre in Turkey", Estratto degli Atti del secondo congresso internazionale di arte Turca, Napoli i 965, Otto Spies, Türkisches Puppentheater. Versuch einer Geschichte des Puppentheater im Morgenlande, Emsdetten 1959 (Die Schaubühne 50), Ilhan Bașgöz, Earlier References to Kukla and Karagöz«, Turcica 3 (I 97 I) 9-2 I, Alessandro Bombaci, »On ancient Turkish Dramatic Performances«, D. Sinor (ed.), Aspects of Altaic Civilization, Bloomington I 962, 87-г I 7 , bes. I I , Herbert W. Duda, »Das türkische Volkstheater «, Bustan I 96 I $/ 2$, I I-I 9 .

746 Hedwig Belitska-Scholtz/O. Somorjai, Das Kreutzer-Theater in Buda (I794-I804). Eine Dokumentation zur Bühnengeschichte der Kasperlfgur in Budapest, Wien/Graz/Köln I 988.

747 Dies betrifft vor allem das Repertoire des Puppenspielers Christos Konitsiotis (vgl. jetzt Apostolos

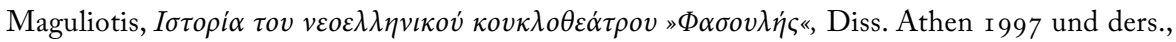

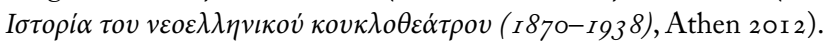

$748 \mathrm{Im}$ Sammelwerk Die österreichisch-ungarische Monarchie in Wort und Bild findet sich im Band zu Rumänien eine Beschreibung polnischer Weihnachtssänger und Puppenspieler (Bd. XI, 306 f.). 
von der Ukraine und Weißrußland, Polen und die Slowakei über Rumänien und Ungarn bis nach Slavonien und Serbien, ja sogar bis nach Skopje und Bitola im Sü$\operatorname{den}^{749}$; im dalmatinischen Küstenstreifen und in Slovenien bestehen hier noch $\mathrm{Zu}$ sammenhänge mit spätmittelalterlichen geistlichen Schauspielen (z.B. I6 I 5 wird in Šibenik ein Dreikönigsspiel mit Herodes gegeben, »dal libretto scritto in schiavo«) ${ }^{750}$. Unter morphologischen Gesichtspunkten stellt der derart weitverbreitete ambulante »Herodeskasten« aber einen Sonderfall dar, auch deshalb, weil er an den Zwölftentermin gebunden bleibt, was für das professionelle Puppenspiel nicht mehr üblich ist. Nach den Aufzeichnungen von Bonifačić-Rožin herrscht im südslavischen Raum ein zweifiguriger Spieltyp mit Stabpuppen vor, die in Kreuzform konstruiert sind, wobei der bedeckte Spieler auf der Erde (unter einer Bank) liegt und mit beiden Händen die Puppen hochhält ${ }^{751}$; aber auch Handpuppen, die mit drei Fingern gespielt werden, sind nachgewiesen. Die Spekulationen über die historische Herkunft dieser Primitivformen braucht hier nicht wiederholt zu werden ${ }^{752}$. Die Namensform beider

749 V. Antić, "Trojcata mudreci od istok i račanjeto na Isus Christos vo makedonskite narodni običai i pesni«, Makedonski Folklor I 5-i6 (1975) I 83-195 (die vertep-Krippe wird von drei Buben am Drei-Königs-Tag herumgetragen).

750 Franjo Fancev, „Liturgijsko obredne igre u zagrebačkoj stolnoj crkvi«, Narodna starina Io (Zagreb I 925), Niko Kuret, „Trikraljevske igre in Kolede na Slovenskom«, Slovenski Etnograf 3-4 ( I 95 I) 240-275. Zum geistlichen Schauspiel am dalmatinischen Küstenstreifen und im Hinterland Francesco Saverio Perillo, Le sacre rappresentazioni Croate, Bari 1975 und Nikola Batušić, Povijest Hrvatskoga Kazalista, Zagreb I978, I-25.

75 I Photographien in Bonifačić-Rožin, »Šante i Pante« (1962), op. cit., nach S. I 44 (S. I 37 jugoslavische Verbreitungskarte mit den hauptsächlichen Spieltypen; massiertes Vorkommen nur im zentralkroatischen Bereich).

752 Ich zitierte aus der deutschen Zusammenfassung seines Artikles in Traditiones (1979): »Aufzeichnungen aus Kroatien: i 964, Dorf Krvavac, Neretljanska krajina, Veranstaltung mit zwei Puppen, Spieler aus der Herzegowina; - 1967, Dorf Sušnjari, Požeška kotlina, Spiel mit zwei Puppen, von Hirten ausgeführt, Geplauder; - I 967, Dorf Studenci, Imotska krajina, Kinderspiel `Krizmar (die Firmung), in welchem der Bischof den Firmling mit der einen Hand an die Wange schlägt und dabei spricht: ,Šanti, panti, kad je krizma bilar. - ı 968, Babina Greda, Slawonien, Spiel mit zwei Puppen auf der Weide, man nennt sie strašilar (Gespenster). - I978, Ladinci, Umgebung von Križevci, Spiel mit zwei Puppen, die >Bartoli` genannt werden, aufgeführt bei einer Hochzeit. Der Puppenspieler liegt auf dem Rücken unter einer Bank. Aufzeichnungen aus der Herzegowina und aus Bosnien: 1 964, Dorf Osanići, Umgebung von Stolac. Beim abendlichen Treffen spielt um 1954 ein Spieler liegend, unter einer Decke, mit zwei Puppen; - 1964, Angaben, aufgezeichnet in Norinska Kula, über ein Spiel mit zwei Puppen im Dorf Trebižat bei Čapljina in der Herzegowina. Das Spiel mit volkstümlichen Puppen wurde nach Trebižat von einem Jungen gebracht, der beim Bau der Strecke Brčko-Banovići I 946 mitarbeitete. Dort sah er eine Puppenvorstellung, die Spieler waren aus einem Dorfe aus der Umgebung von Stolac. In Trebižat wurde das Puppenspiel zuerst auf der Bühne veranstaltet, nachher wurde es vom Volke übernommen und auf dem Felde während 
Puppen läuft meist auf Šante i Pante (mit Variationen) ${ }^{753}$,im Zwischenmurgebiet auch Gáspár i Melko ${ }^{754}$. Aus den bisher veröffentlichten Texte geht hervor, daß es sich um kurze improvisierte Dialoge verschiedensten Inhalts handelt ${ }^{755}$. Neuere Aufzeichnun-

der Ruhepause aufgeführt. Die Angaben über die Übernahme des Spiels mit zwei Puppen und liegendem Spieler wurden brieflich mitgeteilt. - 1976, Gundinci, Angaben über das Spiel der Hirten mit zwei Puppen, die Gespenstern ähnlich sind; der Spieler liegt und ist zugedeckt. Das Spiel wurde im Dorf Čardak bei Modrić aufgeführt. Die Angaben wurde von Zugewanderten übermittelt, die sich im J. 1952 aus dem bosnischen Čardak im slawonischen Gundinci angesiedelt hatten. Es wurde bei ihnen nicht mehr aufgeführt, doch wurde es von den Einheimischen nach dem Zweiten Weltkrieg auf der Weide gespielt./Aufzeichnungen aus Serbien: 1978, in Zagreb erhaltene Angaben. Von Einwohnern des rumänischen Dorfes Plavna bei Negotin wurde vor einigen Jahre bei der >Smotra folklora< (Folkloristische Veranstaltung) ein Puppenspiel aufgeführt, welches man auf rumänisch $>$ Natama ( = Anathema, Fluch) nennt./Aus den gesammelten Angaben geht hervor, daß die kroatischen und bosnisch-herzegowinischen Puppen ein Gestell aus zwei kreuzweise übereinander gelegten und befestigten Stäben haben. Mit zwei Puppen spielt immer ein Spieler, der auf dem Rücken liegt, bedeckt ist, die beiden Puppen in den Händen hält und in die Höhe hebt sowie an ihrer Statt mit abwechselnd verschiedener Stimme spricht. Im rumänischen Dorf Plavna bei Negotin in Serbien haben die Puppen kein Gestell in Kreuzform, der Spieler spreizt vielmehr seine Finger in Kreuzform auseinander, setzt den Puppenkopf auf die mittleren drei Finger und steckt den Daumen und den kleinen Finger in die beiden Ärmel. Für alle Puppen sind Zank und Schlägerei bezeichnend. Der Anlaß dafür ist verschieden: Grenze oder Liebe. Die Rumänen in Serbien führen das Puppenspiel >Natama dann auf, wenn im Dorf ein Diebstahl geschehen ist. Man will den Dieb entdecken. Während des Geplänkels der Puppen (eine ist gut, die andre böse), schweigt der Spieler, die Zuschauer aber verfluchen laut den Missetäter, der zugegen ist. Er wird davon beeindruckt und meldet sich von selbst. Die Leute verzeihen ihm gewöhnlich und tanzen mit ihm zuletzt ihren Rundreigen (`kolo $)$, froh, daß das Gute gesiegt hat./Die für die Puppen charakteristische Schlägerei entwickelt sich auch in den angeführten Beispielen zwischen der guten und der bösen Puppe, was besonders bei der rumänischen >Natama< hervortritt, wo der Fluch so sehr auf den Missetäter einwirkt, daß er seine Tat bereut und gesteht" (op. cit., 29 f.). Die bogomilische Herkunftstheorie braucht heute nicht mehr angeführt zu werden.

753 Francek i Vanček, Ante i Pante, Ivo i Ante, Prokop i Trivun, Prokop i Pétra, Ivica i Marica, Titić i Petrić usw. (Bonifačić-Rožin, »Šante i Pante« op.cit., I43).

754 Namensbeeinflussung durch Kasperl.

755 Bonifačić-Rožin notiert in seiner französischen Zusammenfassung I 962 : »Les scénarios des spectacles sont très variés. Au Medjimurje, comme en Slovénie, c'est à cause de la borne qu'on se querelle. Dans la Banija, on se bat à cause du bétail, ou bien ce sont deux soldats qui, à la frontière, livrent un combat. Quelque part, des ivrognes mettent leur force à l'épreuve. Ou bien on se bat à cause d'une jeune fille. Il y a aussi des scènes d'amour et des coutumes de noce. Il existe la tradition parmi le peuple selon laquelle l'une des marionettes doit représenter un personnage bon et naif, et l'autre un personnage méchant et fourbe. La querelle et la rixe entre eux est inévitable. Même, les mouton se frappent de leurs têtes. Les spectacles sont de brèves scènes qu'on donne aux veillées de filage, aux noces et très souvent au pâturage« (Bonifačić-Rožin, »Šante i Pante«, op. cit., I 55). Aufgrund der Verstreutheit der Belege nimmt Bonifačić-Rožin türkenzeitliche Herkunft an oder einen 
gen geben eine deutliche Vorstellung von der Rudimentarität dieser Dialoge und der »Aufführungen ${ }^{756}$ : »Klepetanje« (ohne Dialogtext), »Dva mladića«, »Dva strašila«, „Šante i Pante«, »Pijanci« (Dialog von Ivo und Ante oder Prokop und Trivun), »Gáspár i Melko«, »Ivica i Marica«, »Cica - Maca«, »Djed i Baka«, »Kata i Mato« usw. ${ }^{757}$ Hat die Verstreutheit und Inselhaftigkeit der Belege im südslavischen Raum zu Spekulationen um eine türkenzeitliche Übertragung aus dem Osten geführt, so lassen sich tatsächlich Parallelen im kleinasiatischen Raum ausmachen: Das bebek oyunu in Burdur in Anatolien geht ähnlich vor sich - der Spieler liegt auf dem Rücken und dirigiert mit jeder Hand eine Puppe, eine männliche und eine weibliche, die einander näherkommen und sich zu umarmen versuchen, doch durch das Anheben des Knies, an das eine große Puppe gebunden ist, werden beide wieder getrennt ${ }^{758}$. Doch sind gerade in Anatolien schon seit byzantinischer Zeit breite Populationsschichten aus dem Zentralbalkan angesiedelt, was sich an verschiedenen Brauchformen immer noch ablesen läß $\mathrm{t}^{759}$, so daß eine solche Übereinstimmung wenig aussagehältig ist. Zudem sind die Formen des traditionellen Puppentheaters in der Türkei nur sehr unzureichend erforscht. Dort ist etwa auch eine andere primitive Darstellungsform nachzuweisen: das Spiel $\grave{a}$ la planchette, wo zwei Puppen auf einem Seil aufgefädelt sind, das an das eine Bein des Puppenspielers gebunden ist und durch Kniebewegungen gelockert und gestrafft werden kann, was die Puppen in Bewegung (zum Tanz) bringt. Derselben Primitivtechnik begegnet man auch in Rumänien und Bulgarien ${ }^{760}$.

Am komplexesten ist die Situation wahrscheinlich in Rumänien, wo eine breite Übergangszone von darstellenden Umzugsbräuchen bis zu regelrechten Volkstheatervorstellungen nachzuweisen ist. Der Irod (Herodes) wird sowohl mit lebenden verkleideten Schauspielern als auch als Herodeskasten gespielt, beim Krippenspiel vicleim kommt es zu interessanten Mischformen ${ }^{761}$. Den primitiven Spieltyp vertreten die improvisierten

Zusammenhang mit mittelalterlichen dualistischen Sekten. Niko Kuret, der schon 1957 ähnliches Material veröffentlicht (Slovenski Etnograf ıo, I 957, I I 3-I 24), - auch ein Spieler mit zwei Holzkreuz-Puppen (Photos nach S. I 20, Herstellungstechnik S. I I 5), stellt sogar einen Zusammenhang mit der Kalogeros-Puppe in der ersten Szene des thrakischen Kalogeros-Brauches her, die allerdings nur ein in Tücher gewickeltes Holzstück ist, von Richard Dawkins aber mit dem Dionysos liknites (dem gewiegten) in Zusammenhang gebracht worden ist (vgl. wie oben).

756 Lozica, Izvan teatra, op. cit., 264-266 mit neuerer Literatur.

757 Lozica, Folklorno kazalište, op. cit., 349-36r (Nr. I55-169).

758 And, »Various species«, op. cit.

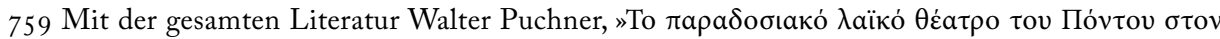

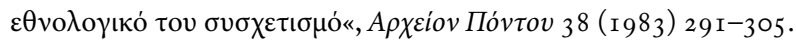

760 F. Ph. Kanitz, Donau-Bulgarien und der Balkan, Leipzig i 880, II 68 f. Der Faden läuft den beiden Puppen durch die Brust.

76r Zum Verhältnis Puppe - Schauspieler vgl. Petr Bogatyrev, »The interconnection of two similar se- 
Stücke um Vasilache și Marioara mit erotischen und häuslichen Alltagsthemen, die auch als prologartige Werbenummern bei den Panoramen in den rumänischen Städten auf einer Bühne aufgeführt wurden ${ }^{762}$. Oprișan nimmt an, daß diese Spielform von den durch Karagöz beeinflußten Puppenspielen, etwa den grotesken und phantastischen Puppen von Geamala und Hagi Ivat in den Bukarester Kaffeehäusern stammt ${ }^{763}$, doch will diese These aufgrund der grundlegenden Strukturunterschiede nicht recht überzeugen ${ }^{764}$.

Vergleichbare semiurbane Volkstheaterformen mit Puppenspiel scheint es zu dieser Zeit in Bulgarien noch nicht gegeben zu haben ${ }^{765}$, wohl aber in Griechenland, wo der Fasulis während der Karnevalszeit und in den Sommernächten im Freien gespielt wurde (meist im Rahmen eines Kaffeehausbetriebes), mit starkem Musikgebrauch und nasaler Stimmlage, als Stabpuppe oder mit drei Fingern bewegt, ähnlich häßlich wie Pulcinella, Vasilache und Petruschka (40-50cm groß, geschnitzter und bemalter Kopf, große Nase, einäugig), in einem kleinen improvisierten beleuchteten und geschmückten Bühnenhäuschen (2x3m), Bühnenbilder aus Karton und Leinwand, einen Arbeitstisch und Helfer. Das Spiel dürfte über die Ionischen Inseln (die italienischen Operntruppen wurden häufig auch von Puppenspielern und Schaustellern begleitet) ${ }^{766}$ nach I 850 nach Griechenland gekommen sein, der Name weist noch auf den fasulein in Bologna ${ }^{767}$, so-

miotic systems. The puppet theater and the theater of living actors«, Semiotica 47 (I 983 ) 47-68 und Henryk Jurkowski, »Transcodification of the sign systems of puppetry«, ibid. I 23-I46.

762 Oprișan, »Das rumänische Volkspuppenspiel«, op. cit. Neuere Forschung schließt sogar wegen der Ähnlichkeit mit Pulcinella eine italienische Herkunft nicht aus (John MacCormick/Bennie Pratasik, Popular puppet theatre in Europe, I800-I8I4, Cambridge I998, I I3). Die vergleichenden Skizzen zur Spieltechnik stellen allerdings auch eine Verwandtschaft zum russischen Petruschka her (I4I).

763 Beschreibung von D. C. Ollanescu, Teatrul la Români, București I 895, 27-29. Der zweite Name verweist mit Sicherheit auf das osmanische Schattentheater.

764 Oprișan, op. cit., 87 .

765 Nachweisbar sind hier auch andere Puppenformen, die ein gewisses individuelles künstlerisches Geschick erfordern: Puppen aus verkleideten Löffeln, Wasserkürbissen, Mais, Maiskolben, Blättern, Brot usw. (Kacarova, op. cit.).

766 Auf Korfu wird seit I 733 im Teatro San Giacomo italienische Oper gespielt (Platon Mavromusta-

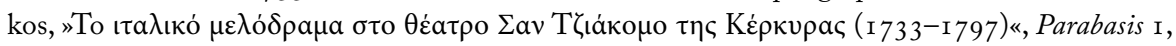
I995, I 47-192).

${ }_{767}$ Zum fagiolino oder fasulein aus Bologna existiert ausreichende Literatur. Grundlegend Alessandro Cervellati, Storia dei burattini Bolognesi (Fagiolino E C.), Bologna 1974 (Mc Cormick/Pratasik, op. cit., I I, 46, I I 9, I 22, I 24, I3 I, 227). "Enormously popular in Reggio Emilia, Fagiolino, despite a name that has been traced back to the Commedia dell'Arte, seems to belong with the group of late eighteenth-century figures. His distinguishing features are a log cap with a tassel, which flies around when he waves his head, and an exceptionally cheerfull disposition. His stock is used to set matters right and not as an instrument of aggression" (op.cit., I 22). Die fliegende Quaste wird im Griechischen auch als eine Art Helikopter benützt, womit er sich aus heiklen Situationen retten 
wie auch andere Namen noch italienisch sind ${ }^{768}$.

Ein Artikel von I 892 gibt folgende Beschreibung: Der Fasulis, vervollkommnet und mit der Zeit hellenisiert, wurde zum wahrhaftigsten Typ des Griechen. Mit ätzendem Spott ständig und jedermann belegend, ununterbrochen schimpfend, Schläge austeilend, wenn er seinem Gegner überlegen ist, und nicht selten Schläge von diesem einsteckend, seine Mietzahlung hinauszögernd und in ständigem Kriegszustand mit seinem Hausherrn befindlich, dessen Tochter nach ihm verrückt ist, ein leidenschaftlicher Politikaster und Müßiggänger..., gewaltiger Redner, wenn es darum geht, die Mutter seiner Geliebten zu überzeugen, daß sie die beiden allein läßt, ein Prabler zuweilen, der droht, mit seiner Pistole Unheil anzurichten, konzentriert er alle Tugenden und kleine Böswilligkeiten des echten Atheners in sich, auf welcher Charakterechtheit seine ungewöhnlich Volkstümlichkeit berubt ${ }^{769}$. Ähnlich erfolgreich sind auch die übrigen Typen seiner Komödie. Sein Hausherr Aurelios - der Name stammt noch aus dem Italienischen - wird stereotyp als sauertöpfischer und geiziger Alter dargestellt, der einen langen Bart und große Liebe zu seiner Tochter besitzt, ständiger Gegenstand des Spottes des schlauen Fasulis. Die Hausfrau Pandolfa - auch dieser Name italienisch - ist die ibrer Tochter bei ibren Liebesbeziehungen Beistand leistende, medisante Alte, die alle Geheimnisse der Nachbarschaft ausposaunt. Die Tochter Androfile, die den Haushalt versorgt, sieht sich am Ende gezwungen, Schneiderin zu werden. Perikles, der Diener des Fasulis, nimmt obne Murren die Schläge seines Herrn hin, rächt sich aber zuweilen, indem er Androfile einen Kuß

kann. In italienischen Arbeiten ist die Figur wortreich beschrieben und wird oft mit Bertoldo verglichen (Francesca Castellino/Italo Ferrari, Baracca e burattini, Torino s. a., I6 I ff.).

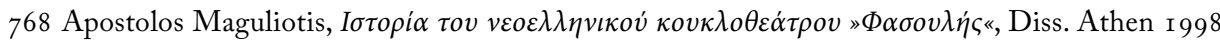
(Neufassung Athen 2012) hat in seiner Dissertation einen Versuch unternommen, die Figur aus der türkenzeitlichen Athener Karnevalstradition abzuleiten ( 86 ff.), was zumindest für die $\mathrm{Na}$ mensgebung (fasuli ist im Griechischen wie im Italienischen die Bohne) nicht unwahrscheinlich ist, allerdings werden in einer der frühesten ausführlichen Aufführungsbeschreibungen die übrigen Figuren als Facanapas, Arlekinos, Conte-Denios (Contadino?), Pulcinellas, Cassandros und Co-

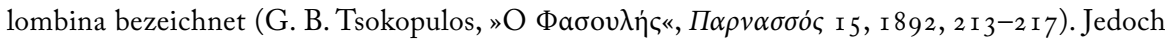
verfügen wir nun durch die Arbeit von Maguliotis über eine bessere Repertoire-Kenntnis, was die Beweiskraft dieser Namen einschränkt (es kann sich durchaus um eine Bearbeitung eines Bühneneinakters aus der italienischen Tradition handeln). Der Artikel von 1892 gibt auch einen Hinweis auf die Herkunft: Über die Ionischen Inseln sei das Spiel in den Jahren nach der Cholera (I 855 ) nach Kontinentalgriechenland gekommen. Wie die Repertoireanalysen von Maguliotis bestätigen, ist der Anteil an dramatischen Werken aus dem lebendigen Theater, das auf den improvisierenden Puppenbühnen zur Vorstellung kommt, nicht unbedeutend.

769 Die Übersetzung nach Puchner, Fasulis, op. cit., ro. Solche Urteile über den nationalen oder lokalen Autostereotyp sind in der Puppenspielliteratur gang und gäbe. Wenn man nach der erhaltenen Figur von Konitsiotis im Peloponnesischen Volkskundemuseum urteilen darf (vgl. dazu noch in der Folge), dürfte sein italienischer Kollege hübscher gewesen sein, vielleicht auch galanter, doch trügen die Abbildungen und generalisierende Pauschalbeschreibungen. 
stieblt, deren Treue etwas elastisch ist ${ }^{770}$. Manchmal stellt der Fasulis auch Dramen dar. Die ernsthaften Werke des hölzernen Theaters haben sehr seltsame Titel: "Frau Jannula und die Kanone des Krämers«, "Die drei Verbrecher von St. Sideras«, "Glaube, Hoffnung und Mitleid«, "Herr Manolis und sein Barbier«, "Die Hochzeit der Androfle«, ein Stück, das mehr Aufführungen zählt als alle griechischen Komidyllen zusammen; die Dramen aber... läßt Fasulis für die Fest- und Wobltätigkeitsveranstaltungen. Nach altem Usus kündigt er allein mit seiner nasalen und verstellten Stimme die nächste Vorstellung an, am Vorabend der Wobltätigkeitsvorstellung. Und wenn man um Mitternacht den umzäunten Platz betritt, der ihm als Theater dient, kann man ihn auf die Bühne kommen sehen, mit kreisender Mützenquaste als Zeichen, daß er etwas Ernsthaftes zu sagen habe, und man kannn ihn ausrufen hören: Das geehrte Publikum der Hauptstadt wird darauf hingewiesen, daß Fasulis morgen abend seine Wohltätigkeitsvorstellung gibt... Ruhe, das Klarinett, damit auch ich etwas sagen kann... Wir bitten also das verehrte Publikum, mit Familie zu kommen. Wir spielen die `Apokryphen des Generals Belisar' und singen auch Melodien aus der Plaka. Es gibt auch bengalische Lichter... brrr! $!^{771}$.

Das Repertoire bearbeitet Themen der Trivialliteratur und der Volkslesestoffe sowie Erfolge auf dem Theater, z.T. auch Stücke aus dem Schattentheater ${ }^{772}$. Diese Volksbelustigung, die ab I 890 die Konkurrenz des Schattentheaters erhält, hält sich bis zum Vorabend des Zweiten Weltkriegs ${ }^{773}$.

Die komplexesten Formen des traditionellen Volkspuppenspieles sind jedoch in $\mathrm{Ru}-$ mänien nachzuweisen, wo das jocul papuşilor oder papușile vor allem im I9. Jh. eine bedeutende Blüte aufweisen konnte ${ }^{774}$, wo sich im Zuge der weitverbreiteten weihnacht-

770 Puchner, op. cit., Iof. Deutlich ist hier die italienische komische Tradition zu erkennen. Doch gilt dies, wie gesagt, sicher nicht für das gesamte Repertoire.

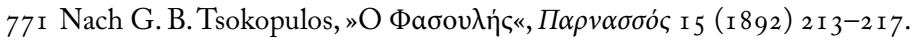

772 Im nachweisbaren Repertoire von Dimitrios Maridakis, Vasilios Bitunis, Ioannis Saridakis, Charilaos Patentas, Dimitrios Liaskopulos, Ioannis Kokkas, Athanasios Mutsos usw. finden sich mehrere griechische Bearbeitungen von Molière-Komödien, griechische Originalkomödien, komische Einakter und »romanhafte« Abenteuerdramen aus dem Repertoire der fahrenden Truppen im Zeitraum von r 870-г 9 Iо (Maguliotis, op. cit., 30I-306). Zu den vielgespielten Molière-Komödien in

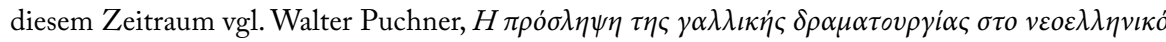

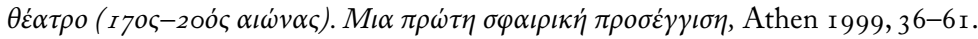

773 Die Blütezeit der Gattung liegt jedoch noch vor dem Ersten Weltkrieg. In der Zwischenkriegszeit hat das Schattentheater dem Puppenspiel den Rang abgelaufen (Walter Puchner, Das neugriechische Schattentheater Karagiozis, München 1975, I I6-г 43). Trotzdem haben Schattenspieler wie Evgenios Spatharis in ihrer Jugend auch Fasulis gespielt (Puchner, Fasulis, op. cit., I 4 f.).

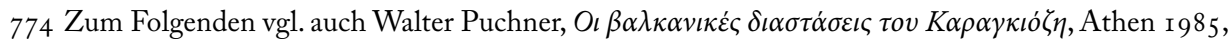
$55^{-60}$. 
lichen Bethlehem-Vorstellungen (vicleim im Rumänischen ${ }^{775}$, vertep im Ukrainischen ${ }^{776}$, szopka im Polnischen ${ }^{777}$ ), die wahrscheinlich über Siebenbürgen aus dem katholischen Westen gekommen $\operatorname{sind}^{778}$, wo sie in Ungarn und Ostzentraleuropa als Herodeskasten geläufig sind ${ }^{779}$, auch eine satirische Farce herausbildet, die nach der Vorstellung gegeben wird und gewisse Elemente des osmanischen Schattentheaters verarbeitet hat ${ }^{780}$. Für dieses satirische Puppentheater haben auch namhafte Schriftsteller des 19. Jh.s gearbeitet. Teodorescu hat schon I 874 einen solchen Spieltext veröffentlicht ${ }^{781}$. An der elaborierten Komödie beteiligen sich immerhin 16 Puppen: der Mos Ionică, ein alter Nachtwächter, der Iaurgiul, oltenischer Joghurtverkäufer, die Tochter des Moș Ionică, der Bragagiul, bulgarischer Hirsetrankverkäufer, die Cocoana Marița, »Dame« aus Bukarest, der russische Offizier, der Jäger Ghinda, der Bär, der Bärenführer als Zigeuner, der jüdische Händler, der Türke Hassan, der Russe, der Priester Macare, der Kirchensänger State, der Totengräber Stan und die alte Baba, die Frau des Moș Ionică ${ }^{782}$. Das Interessante und "Moderne« an dieser Farce ist die Tatsache, daß an dem Dialog auch zwei Schauspieler "außerhalb« der Bühne teilnehmen: Moșul di Vicleim, ein buckliger Alter mit Maske, Bart und umgedrehtem Schafspelz, und der Paiata (Bajazzo) mit buntem Flickenkostüm und Papphelm. Beide Figuren kommentieren satirisch das Bühnengeschehen und greifen häufig in den Dialog ein. Diese beiden Figuren hat man mit Karagöz und $H a-$ çivat verglichen und die rumänische Forschung nimmt hier einen Einfluß des osmanischen Schattentheaters $a^{783}$. Wie dem auch sei (das Flickenkostüm und der Name

775 Oprișan, „Volkspuppenspiel«, op. cit., $84 \mathrm{f}$.

776 Elizabeth Warner, The Russian Folk theatre, The Hague i 977, 8 I f. (mit weiterführender Literatur).

777 Ollanescu, Teatrul la Români, op. cit., IO2 f.

778 Moses Gaster, Literatura populară română, București I 883, 492.

779 Köldu, op. cit., Gragger, op. cit., etc.

780 Rădulescu, op. cit., 88.

78 I G. D. Teodorescu, Incercări critice asupra unoru credințe, datine și moravuri ale poporului românu, București i 874, 5 off.

782 Der Spieltext auch bei G. D. Teodorescu, Poesii populare române, București I 885, I 20-1 32, in französischer Übersetzung von M. Vulpescu in Revue d'ethnographie et des traditiones populaires, Paris I 926, 363-407. Eine »bearbeitete« Version auch im Buch dess., Irozii. Papusile. Teatrul taranesc al Vicleimului. Scaloianul și paparudele, București I 941, 49-92 (vgl. auch Ollanescu, op. cit., 95-101).

783 Die Literatur dazu ist ziemlich reichhaltig: Lazăr Șaineanu, »Jocul papușilor și raporturile en farsa Karagöz«, Lui Titu Maiorescu omagiu, București 1900, 28 I-287 (auch in Keleti Szemle I, Budapest $1900, \mathrm{I}_{40} \mathrm{O}-\mathrm{I} 44$ ), ders., Influență orientală asupra limbei și culturei Române I, București I 900, CLXX ff., ders., »Les marionettes en Roumanie et Turque«, Revue des traditiones populaires I6 (I 90I) 409-4I9, Letiția Gîtză, »Le théâtre roumaine de marionettes, art anciens et art modern«, Revue Roumain d'bistoire de l'art I ( I 964) i I 9-1 38, Viorica Dinescu, „La relation entre Karagöz oyunu et le théâtre populaire roumain de marionettes«, Résumées des communications, tom. 2, București I 974, 362 f., Eugenia Popescu-Judetz, »L'influence des Spectacles Populaires Turcs dans 
des zweiten Schauspielers deuten eher auf westliche Herkunft), es handelt sich um eine temporäre Anlagerung, strukturell deutlich abhebbar ${ }^{784}$, wie die gesamte Satire in ihrer Zusammensetzung konglomerathaften Charakter und ganz unterschiedliche Bauelemente aufweist: Der Mos ist als Ahn ein weitverbreiteter Verkleidungstyp der Winterumzüge (meist mit Ziege) ${ }^{785}$ und hat brauchtümliche Herkunft, Priester und Totengräber weisen auf karnevaleske Scheinbegräbnisse oder den Tod/Auferstehungs-Zyklus im Winterbrauchtum ${ }^{786}$, der Jäger und andere Figuren kommen aus den dramatischen Umzugsspielen, an denen Rumänien so reich ist und die sich zu richtigen Volkstheatervorstellungen entwickeln können ${ }^{787}$, der Moș und seine Baba finden ein Pendant in Vasilache und Marioara, während andere Typen den sozialen Kontext des rumänischen Stadtlebens im I 9. Jh. widerspiegeln. I9 5 veröffentliche Teodor T. Burada eine andere Version dieses Spiels ${ }^{788}$, doch eine spätere Kontrolluntersuchung I 932 in Tîrgu Jiu zeigt die Vorstellung bereits in Aufösung begriffen: Die lebendigen Schauspieler des Moș di Vicleim und Paiaț fehlen überhaupt, von den Puppen haben der Türke, der Priester, der Totengräber und ein Diener (der dem Moș Ionică entspricht) überlebt. Die »Handlung« der Vorstellung beschränkt sich auf die Köpfung des Türken und eine Begräbnisparodie $^{789}$. Neuere Untersuchungen zeigen ein völliges Aufgehen der Puppentheaterform, was Typen und Sujets betrifft, in die Verkleidungsformen der Weihnachtsumzüge ${ }^{790}$, die ja von Anfang an den strukturellen und funktionellen Rahmen dieser Puppentheaterform abgegeben haben.

Rumänien ist aber auch ein gutes Beispiel für Übergangsformen des traditionellen Puppenspiels zum Kunsttheater, doch hängt die Komplexität der Spielformen sowohl von gewissen Epochen wie auch bestimmten Persönlichkeiten ab. In der Blütezeit des jocul papusilor im I 9. Jh., zwischen I 8 I 8 und I 840, begann der Groß-Wornik Iordache Golescu (I768-i 848) sechs dramatische Puppenspiele zu schreiben, die die sozialen

les Pays Roumains«, Studia et Acta Orientala 5-6 (1967) 337-355, Nicolae Rădulescu, »Musikalische Puppenspiele orientalischer Herkunft in der rumänischen Folklore«, Zeitscbrift für Balkanologie I4 (1978) 83-98.

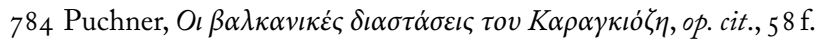

785 Olga Flegont, »The Moș in the Romanian popular theatrical art«, Revue roumain d' histoire de l'art III (I 964) I I9-I3 I (mit weiterer Literatur).

786 Vgl. wie oben.

787 Im Überblick Horia Barbu Oprișan, »Das volkstümliche rumänische Theater«, Österreichische Zeitschrift für Volkskunde 8 I (1978) I78-201.

788 Die Aufzeichnung stammt aus dem Jahr 1875 (Teodor T. Burada, Istoria Teatrului în Moldova, tom. I, Iași I 91 5, 36-44).

789 Constantin Brăiloiu/Henri H. Stahl, Sociologie românească I/I 2 (I936), angeführt bei Rădulescu, op. cit., 93 .

790 Rădulescu, op. cit. 
und politischen Zustände in der Walachei aufs Korn nahmen ${ }^{791}$. Die zentrale Figur, ein spaßmachender Zigeuner, ist dem Karagöz nachgebildet; die Spielakte werden perdele genannt. Das satirische Puppentheater erreicht im rumänischen I 9. Jh. eine solche Popularität und Kritikfähigkeit, daß es von Hașdeu mit Aristophanes verglichen wird ${ }^{792}$. Im Zeitraum von I 864 bis I 879 wird es in Iași polizeilich verboten, weswegen es der Komödiendichter Vasile Alecsandri in seinem Einakter »Ion Papușilor« I 864 auf die Theaterbühne bringt ${ }^{793}$. Auch in Bukarest gibt es Polizeiberichte aus dem Zeitraum von I 865-69, wo von Störung der öffentlichen Ordnung während der Aufführungen des Puppentheaters gesprochen wird ${ }^{794}$.

Übergangsformen zum Kunsttheater sind auch in Ungarn im I 9. Jh. anzutreffen, wo ganze Puppenspieldynastien das Gewerbe der fahrenden Künstler beherrschen ${ }^{795}$. Hier, ebenso wie in Korfu aus Italien kommend ${ }^{796}$, sind auch Marionettenspieler anzutreffen. Die ungarischen Puppenspieler stehen jedoch in Konkurrenz zu österreichischen und süddeutschen Wanderpuppenspielern. Das Kreutzer-Theater in Budapest war schon zu Beginn des I 9. Jh.s Pflegestätte des Wiener Kasperls ${ }^{797}$, dessen Einfluß im Gáspár deutlich ist, aber auch im Typ des Kis Bohóc (Kleiner Bajazzo). Die eigentlichen ungarischen Puppentypen sind Jancsi Paprika und Laszló Vitéz.

Paprika Jancsi ist eine großnasige, markante Maske eines Bürschchens mit hervorragendem Kinn, mit oder obne kleinem gewichsten Schnurrbart. Sein Kostüm: spitze rote Kappe mit Schelle an ibrer Spitze, roter Anzug mit einem roten, schellenverzierten, kaftanartigen Mantel. Seine Requisiten sind Stock, Kochlöffel, Stielpfanne oder irgendeine andere Prügelwaffe.

79I Perpessicius (pseud.), »Iordache Golescu lexilog și folklorist«, Studii și cercetări de istorie literară și folclor III (1954) 266.

792 Bogdan Petriceicu Hașdeu, Basme, poesii, păcălituri și gleicitori, adunate de I. C. Fundescu, București I $867, \mathrm{X}$.

793 Walter Puchner, Historisches Drama und gesellschaftskritische Komödie in den Ländern Südosteuropas im I9. Jahrhundert, Frankfurt/M. etc. I 994, Io6 f. (mit der einschlägigen Literatur). Vgl. auch ders., Die Literaturen Südosteuropas, op. cit., I 76, 2 I 7.

794 Rădulescu, op. cit., 95 .

795 Belitska-Scholtz, "Gaukler und Wanderpuppenspieler in Ungarn«, op. cit.

796 Vgl. einen Beleg, den Kapadochos veröffentlicht: Am 8. Io. I 857 sucht der italienische Marionettenspieler Marco Bartoli um Spielerlaubnis auf Korfu an (Dimitrios Chr. Kapadochos, To $\theta \dot{\varepsilon} \alpha \tau \rho o$

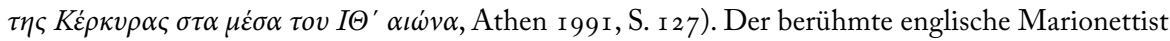
Thomas Holden hat allerdings fast alle größeren griechischen Städte bereist.

797 Hedwig Belitska-Scholtz/O. Somorjai, Das Kreutzer-Theater in Buda (I794-I804). Eine Dokumentation zur Bühnengeschichte der Kasperlfigur in Budapest, Wien/Graz/Köln I 988 . Zur Geschichte des Wiener Kasperls Otto Rommel, Die Alt-Wiener Volkskomödie, Wien 1952 mit weiterführender Literatur. 
Er ist ein schlauer und gefräßiger Kerl, frech und obne Achtung für jegliche Autorität. Sein Humor ist derb und oft saftig, aber er ist im Grunde herzensgut, ein Freund der Armen und Unterdrückten, ein unerbittlicher Verprügler aller Obrigkeit, sei es Gendarm, Nachtwächter, Polizist, Teufel, Hexenmeister oder gar der Tod selbst. [...] Aus dem Nachlaß der HinczFamilie stammt die älteste erhaltene ungarische Heldenfigur, die Handpuppe Vitéz-Laszló, eine Puppe mit typischer Narrenmaske, mit einer außerordentlich großen Nase, einem breiten, rotbemalten Mund und runden, naheliegenden Augen. Aus dem Nachlaß der KeményFamilie besitzen wir mehrere Vitéz-Laszló-Figuren, die Varianten der zehner-, zwanziger- und vierziger Jabre zeigen denselben Typ. Der Gesichtsausdruck aller Figuren zeugt von einer mit Einfalt gekoppelten Schlauheit, sie sind alle großnasige, schalkhafte Burschen. Ihre Kleidung besteht aus einer roten Hose und Jacke mit spitziger Mütze, in den Händen halten sie das unzertrennliche Schlaggerät, die Stielpfanne, »den Fächer der Großmutter aus ibrer Jungmädchenzeit«, den Knüppel oder die Mistgabel./Seine grundlegenden Eigenschaften sind: das rasche Erkennen der eigenen Interessen, seine eher der Feigheit und dem Zwang der bedrängten Situationen entsprungene Fäbigkeit zum schlagfertigen Handeln, Großmauligkeit, Gefräßigkeit, ständige Renitenz und Übermut - »wer denn sonst, wenn nicht ich!«-, eine überdurchschnittliche Menschenkenntnis, Hilfsbereitschaft - aber nur mit Maß -, Judizium und vor allem eine unbeschränkte und ständige Bereitschaft zur Prügelei ${ }^{798}$.

Jancsi Paprika kann ab 1843 nachgewiesen werden, Laszló Vitéz erst im letzten Drittel des I 9. Jh.s; zusammen mit Krumpli Miska, Teufel, Tod, Polizisten, Gendarmen, Einsiedlern, Barbier, Juden, Slowakischen Burschen, Kameraden Fritz usw. bestreiten sie die Stegreifstücke, von denen nur wenige Szenarien erhalten sind, und auch diese ohne die aktuell politische Satire ${ }^{799}$.

798 Belitska-Scholtz, op. cit., I I 9 f., I 2 I.

799 "Die Mehrheit der vom älteren Henrik Kemény hinterlassenen Vitéz-Laszló-Geschichten beruht auf der Tradition des I 9. Jahrhunderts. Das Wesen aller Geschichten ist das schnelle Aufeinanderfolgen der Dialoge und Aktionen, die von Szene zu Szene mitreißende Prügelei. Einen klassischen Typ stellt die Bravourszene der Verprügelung des Teufels in $>1-2-3$ : du folgst; $1-2-3$ : ich kommer. Hier verprügelt Vitéz Laszló die Teufel, aber in diese Grundsituation passen alle anderen aktuellen Varianten, z.B. die Szene von Vitéz Laszló mit den Gespenstern, dem Gendarmen, dem Polizisten oder mit dem Grundherrn. Dieselben Einfälle, herausgegriffenen Teile, bewährten Bonmots und Situationen kehren in den erhalten gebliebenen Stücken wieder. Beim Wanderpuppentheater mußte man, wie in den übrigen volkstümlichen Stegreiftheatern, mit einer Reihe der bewährten, erfolgreichen, von mehreren Generationen verfeinerten Kunstgriffen arbeiten, die samt den Puppen - neben den regelmäßig aufgeführten Stücken - zur spontanen Bühnenbearbeitung eines aktuellen Themas den Puppenspielern zur Verfügung stehen mußten. Die aus internationalen Motiven gesponnenen Wurstel-Puppenspielfabeln erschienen häufig mit aktuellem politischen Inhalt. Aus der Natur dieser Gattung folgt jedoch, daß eben diese für die Zeitgeschichte so wichtigen 
Was in Mittel- und Westeuropa zum typischen Erscheinungsbild des Puppentheaters vor allem im I 9. Jh. gehört, daß einzelne Puppenspieler oder Familien durch ihre Kunstfertigkeit berühmt werden ${ }^{800}$ und die Schwelle von der traditionellen Puppenspielform zum Kunsttheater überschreiten, ist in Südosteuropa seltener nachzuweisen und wurde von der allgemeinen historischen und kulturellen Situation nicht begünstigt. Ein herausragendes Beispiel ist freilich der Athener Puppenspieler Christos Konitsiotis, der eine Variante des Fasulis spielte, mit einer Figur, die er Paschalis nannte ${ }^{801}$. Seine Spieltätigkeit, auch in Tourneen durch die Provinz, ist von I 893 bis I 928 nachzuweisen. Sein Theater hatte er üblicherweise im Athener Nobelviertel Kolonaki aufgeschlagen, zu seinem $\mathrm{Pu}$ blikum zählte auch die "gute« Gesellschaft. Alle Quellen sprechen von seiner hervorragenden sprachlichen Improvisationsgabe. Improvisationstheater aus dieser Zeit ist heute nicht belegbar, doch vermag das nun erforschte Repertoire einen Eindruck von seiner künstlerischen Kapazität geben: Es umfaßt mehr als 200 Stücke, z.T. der Weltliteratur, vielfach der Trivialliteratur, oder eigene Erfindungen, in die improvisierend die aktuelle Politik und Gesellschaftsfragen sowie Publikumswünsche eingearbeitet wurden. Allein im Jahr I 895 trat er mit 38 neuen Stücken auf ${ }^{802}$. Zu den bevorzugten Themenkreisen gehörten: Liebe, Hochzeit, Tod, Teufel, Räuber, Verbrechen und Gerichtsprozesse, Irrenhaus, Berufe, Geschichte, Religion, Militär. Zu seinen improvisierten Literaturbearbeitungen zählen Schillers »Kabale und Liebe« ( I 90o), »Monsieur de Pourceaugnac» (I 895) von Molière, »Die Räuber« (I 903), "La Médecin malgré lui« ( I 895), „L'assomoir« ( I 9 I 5 ) von Émile Zola sowie eine Reihe von griechischen Komödien des I 9. Jh.s bzw. von zeitgenössischen Theatererfolgen. Die erhaltenen Textbruchstücke aus der Presse ${ }^{803}$ sowie die Inhaltsangaben ergeben freilich kein detailliertes Bild der Adaptationen; die Tonlage des Witzes dürfte sich von dem des Schattentheaters nicht grundlegend unterschieden haben.

\subsubsection{Schattentheater}

Das Schattentheater dürfte ursprünglich aus dem Handschattenspiel entstanden sein. Seine spezifische Technik sieht vor, daß auf eine von rückwärts beleuchtete Leinwand aus verschiedenen Materialien verfertigte zweidimensionale, meist durchscheinende (oft farbige) Puppenfiguren mit einem Haltestab gepreßt werden, so daß von der Zuschauerseite

aktuellen Szenen nicht überliefert wurden, da sie im Zuge der Ereignisse geboren, mit der Tagespolitik aktuell wurden und veralteten" (Belitska-Scholtz, op. cit., I 2 I f.).

800 Dazu jetzt mit der gesamten Literatur vergleichend McCormick/Pratasik, op. cit.

80 I Ob der Name mit Pasquale in Zusammenhang zu bringen ist, bleibt bisher ungeklärt.

802 Vgl. die statistischen Angaben bei Maguliotis, op. cit., $307 \mathrm{ff}$.

803 Maguliotis, op. cit., 323-339. 
die Silhouetten im Profil als Schatten auf der beleuchteten weißen Fläche zu erkennen sind. Der Schattenspieler imitiert die Stimmen der Figuren und führt die Körperbewegungen aus, welche von der Anzahl und Position der Gelenkösen abhängig sind. Diese Technik erlaubt bloß ein Minimum an illusionistischer Realistik, übt aber einen eigentümlichen ästhetischen Reiz aus ${ }^{804}$. Die Schattenspieltechnik wird sowohl im Kunsttheater (ombres chinoises, Théâtre Séraphin, Spielzeugtheater), als auch bei der traditionellen Schaustellerei verwendet. Historische und gegenwärtige Verbreitungsräume sind Ostund Südostasien (Java, Bali, Thailand, Malaysien, Kambodscha, China) ${ }^{805}$, Südindien, sowie der ostmediterrane Raum ${ }^{806}$. Nach älteren Genesetheorien soll das Schattenspiel aus dem ost- und südostasiatischen Raum, wo es heute noch gepflegt wird, auf dem Landweg in den Mittelmeerraum gekommen sein $^{807}$, wo zur Zeit der mittelalterlichen arabischen Kulturblüte in Ägypten ein hochentwickeltes Schattentheater nachzuweisen ist, dessen Stücke und Figuren allerdings mit dem heute bekannten Schattenspiel wenig zu tun haben $^{808}$. Die Kontinuitätsthesen aus dem Altertum, wo die Technik des Schattentheaters

804 Hetty Paërl, Schattenspiel und das Spielen mit Silhouetten, München r98 I, Günter Böhmer, Puppentheater, München I 969/76, 5 I-53, I 24-1 30, Franz Hadamowsky, »Das Puppentheater«, Martin Hürlimann (ed.), Das Atlantisbuch des Theaters, Zürich r 966, 920-944, bes. 934-938, 938-942, Olive Blackham, Shadow Puppets, New York 1960, Denis Bordat/Francis Boucrot, Les thêatre d'ombres, Paris 1956, Georg Jacob, Geschichte des Schattentheaters im Morgen- und Abendland, Hannover 1925, Grace G. Ransome, Puppets and shadows, A bibliography, Boston I 93 I, B. Sverne, Shadow Magic, The story of shadow play, New York 1959, Metin And, Dünyada ve Bizde Gölge Oyunu, Ankara 1977, Georg Jacob, Bibliographie über das Schattentheater, Erlangen 1902 usw.

805 Zur Bibliographie vgl. Walter Puchner, »Schattenspiel«, Enzyklopädie des Märchens I I/3 (Berlin, New York 2004, I 244-I 253.

806 Stathis Damianakos, »Karagöz turc et Karaghiozis grec, lectures comparatives«, Stathis Damianakos (ed.), Théâtres d'ombres. Tradition et Modernité, Paris I 986, I I 9-1 58, And, op. cit., 22 I-396, Walter

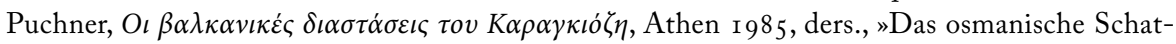
tentheater auf der Balkanhalbinsel zur Zeit der Türkenherrschaft. Verbreitung, Funktion, Assimi-

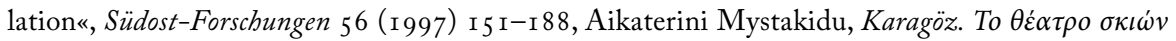

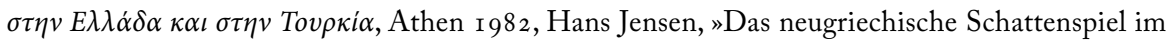
Zusammenhang mit dem orientalischen Schattentheater«, Johannes Irmscher/Hans Ditten/Marika Mineemi, Probleme der neugriechischen Literatur IV, Berlin I959, I98-208, Walter Puchner, „Osmanlı gölge tiyatrosunun. Yayılıș, ișlevi, asimilasyonu«, Toplumsal Tarih I 8 I (2009) 46-69 und ders., "Karagöz ve Balkanlar'da Osmanlı Gölge Oyununun Tarihi: Yayılma Alanı, İșlevleri ve Asimilasyon Örnekleri«, Peri Efe (ed.), Hayal perdesinde ulus, değișim ve geleneğin icad, İstanbul $2013,64-88$.

807 Georg Jacob, Das Schattentheater in seiner Wandlung vom Morgenland zum Abendland, Berlin I 90 I, Medjid K. Rezvani, Le théâtre et la danse en Iran, Paris 1962, I 23 ff., Otto Spies, Türkisches Puppentheater, Emsdetten 1959 .

808 Enno Littmann (mit Anhängen von Georg Jakob), Arabische Schattenspiele, Berlin r 9or, Georg Jacob, Al Muaijam, ein altarabisches Schauspiel für die Schattenbühne bestimmt von Muhammed Ibn Danijal, Erlangen i 9o I, Paul Kahle, Zur Geschichte des arabischen Schattentheaters in Egypten, 
unbekannt war ${ }^{809}$, aufgrund von thematischen Ähnlichkeiten mit der aristophanischen Komödie ${ }^{810}$ bzw. dem schwer nachzuweisenden byzantinischen Mimus ${ }^{811}$, brauchen heute

Leipzig I909, ders., »Islamische Schattenspielfiguren aus Egypten«, Der Islam I-2 ( I 9 I0-I I) I 43-1 95, 264-269, ders. "Das islamische Schattentheater in Aegypten", Orientalisches Archiv 3 (1913) I03-109, ders., "The Arabic Shadow Play in Egypt«, Journal of the Royal Asiatic Society I 939, 2 I-34, ders., "The Arabic shadow-play in medieval Egypt «, Journal of the Pakistan Historical Society 2 (1954) 85-I I 5, ders., »Huhammad Ibn Danijal und sein zweites arabisches Schattenspiel«, Miscellanea Academica Berolinensia II/2 (1950) I 5 I-I67, Josef Horovitz, Spuren griechischer Mimen im Orient. Mit einem Anhang über das egyptische Schattenspiel von Fr. Kern, Berlin I 905, Georg Jacob/Paul Kahle, Das orientalische Schattentheater. I. Band: Der Leuchtturm von Alexandria, Stuttgart 1930. Neuere englische Übersetzung von Safi Mahfouz/Marvin Carlson, Theatre from medieval Cairo. The Ibn Däniyāl Trilogy, New York 2013.

809 Die einzige Quelle, die mit Schattentheater in Zusammenhang gebracht werden kann, ist das berühmte Höhlengleichnis bei Platon (Politeia VII I ff.). Aber: "Platon hätte wohl kaum die ganze Erscheinung so ausführlich beschrieben, wenn er sie mit einem bereits damals existierenden und den Lesern bekannten Schattentheater hätte vergleichen können« (Růžena Dostálová-Jeništová, "Das neugriechische Schattentheater Karagöz. Einige Bemerkungen zu seiner weiteren Erforschung«, Johannes Irmscher et al. (eds.), Probleme der Neugriechischen Literatur, Bd. IV, Berlin 1959, I $85-197$, bes. I 85 ).

8 ro Diese wurden zuerst von klassischen Philologen unterstrichen: Cedric Whitman, Aristophanes and the Comic Hero, Cambridge/Mass. I 964, 28 I ff., Eric Walter White, "Greek shadow theatre ", Tribute to Benjamin Britten on his fifthieth birthday, London I 963, I 85-1 9o, J.-Th. Papademetriou, »IV. Echoes of the Aesop Romance in Greek Shadow Theatre", Aesop as an archtypical hero, Athens I 997, 73-84; vgl. auch Linda Myrsiades, "Aristophanic comedy and the modern Greek Karagiozis

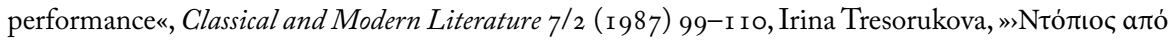

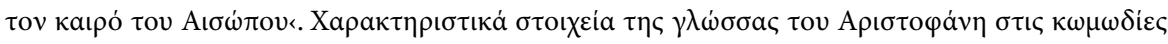

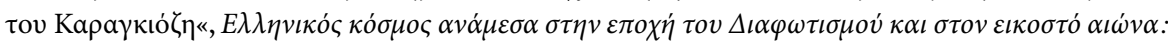

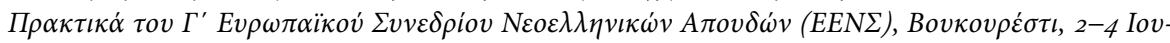
viov 2006, 3 Bde., Athen 2007, III I 87-I 94, Pierre Chuvin, "Karagöz entre Aristophanes et Platon", Sophie Basch/Pierre Chuvin (eds.), Pitres et pantines: Transformations du masque comique de l'antiquité au théâtre d'ombres, Paris 2007, 31 9-326.- Die These einer typologischen Vergleichbarkeit des komischen Sklaven bei Aristophanes mit Karagiozis war schon von Kostas Biris vertreten

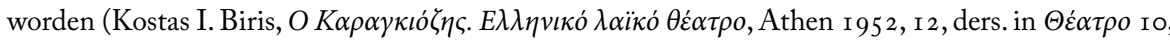
I963, 9).

8 I I Nach Hermann Reich, Der Mimus, Berlin 1903, 6 I 8 ff. (»Bis zu Konstantinopels Fall, vielleicht noch kurze Zeit darüber hinaus, existierte der byzantinische Mimus. [...] Der Karagöz schließt also unmittelbar an den byzantinischen Mimus an «, S. 30; dazu kritisch Walter Puchner, "Acting in Byzantine theatre: evidence and problems«, Pat Easterling/Edith Hall [eds.], Greek and Roman Actors. Aspects of an Ancient Profession, Cambridge 2002, 304-324). Die Ansicht von Reich wurde von einigen Forschern aufgegriffen: Jakob M. Landau, Studies in Arab theatre and cinema, Philadelphia I 958,47 , J. S. Tunison, Dramatic traditions of the dark ages, Chicago I907, I I 3, Metin And, Bizans tiyatrosu, Anakra 1962. Josef Horovitz (Spuren griechischer Mimen im Orient, Berlin 1905, 29 ff.) kommt diesbezüglich eher zu negativen Ergebnissen und es scheint sich ihm ein Zusammenhang 
nicht mehr diskutiert zu werden ${ }^{812}$. In neueren Theorien wird der Seeweg von Indien in die arabische Welt als Übertragungsmodus bevorzugt ${ }^{813}$. Von dort dürfte es im Zuge der Ausweitung des Osmanischen Reiches an den Bosporus gekommen sein, wo sich bis zum I 7. Jh. die gängigen komischen Figuren und das klassische osmanische Repertoire ausbil$\operatorname{den}^{814}$. Darauf verweisen indirekt auch die türkischen Ursprungslegenden.

über den arabischen Stimmkünstler hakija zum türkischen Märchenerzähler meddah zu ergeben (32).

8I 2 Der amerikanische Theaterwissenschaftler Marvin Carlson hat kürzlich die These aufgestellt, daß vor allem das dritte erhaltene Stück von Ibn Dāniyāl (I 3. Jh., dazu Li Guo, The Performing Arts in Medieval Islam: Shadow Play and Popular Poetry in Ibn Dāniyāl's Mamluk Cairo, Leiden 201 2) frappante Ähnlichkeiten mit den »Vögeln« von Aristophanes aufweise; die Bildungskontakte der Araber mit dem Schul- und Gelehrtenbetrieb in Byzanz, wo die Aristophanischen Texte weiterhin kopiert und studiert wurden, könnte die Kenntnis dieser Komödie vermittelt haben (Marvin Carlson, »The Arab Aristophanes«, Comparative Drama 47/2, 2013, I 5 I-I66). Diese These bedarf allerdings einer detaillierteren Prüfung.

8I 3 Dostálová-Jeništová, „Das neugriechische Schattentheater Karagöz«, op. cit., Günter Schnorr, "Aspekte der Puppen- und Schattenspielforschung", Quand les Marionette du Monde se donnent la Main, Liège 1958, I 57 ff., Pertev N. Boratav, "Karagöz«, The Encyclopedia of Islam, $2^{\text {nd }}$ ed., vol. 4 , Leiden I 990, 60I-603, Thodoros Hadjipantazis, »The Silk Route Blocked: Theories on the Origin of the Greek Shadow Theater«, Cultural and Commercial Exchanges between the Orient and the Greek World, Athens I 991, I 44 ff.

8 I 4 Zum osmanischen Schattentheater existiert eine umfangreiche Bibliographie. Vgl. in Auswahl: Metin And, A History of Theater and Popular Entertainment in Turkey, Ankara 1963-64, ders., Geleneksel Türk Tiyatrosu. Kukla, Karagöz, Ortaoyunu, Ankara i 969, ders., Karagöz. Turkish Shadow Theatre, Ankara 1975, Andreas Tietze, The Turkish Shadow Theater and the Puppet Collection of the L. A. Mayer Memorial Foundation, Berlin 1977, Selim N. Gerçek, Türk Temașasi. Meddah - KaragözOrtaoyunu, Istanbul 1942, Georg Jacob, Türkische Litteraturgeschichte in Einzeldarstellungen. I. Das Türkische Schattentheater, Berlin I900, Theodor Menzel, Meddah, Schattentheater und Orta Oyunu, Prag I94I, Alfred Thalasso, Molière en Turquie. Étude sur le théatre de Karagueuz, Paris I988, Ignác Kúnos, „Über türkische Schattenspiele«, Ungarische Revue 7 ( I 887) 425-435, ders., »Türkisches Puppentheater. Karagöz-Schaukelspiel«, Ethnologische Mitteilungen aus Ungarn 2 (I 892) I 48-I 58 , Felix von Luschan, "Das Türkische Schattenspiel«, Internationales Archiv für Ethnologie 2 ( ( 889) I-9, 8 I-90, I 25-I 43, Karl Süssheim, »Die moderne Gestalt des türkischen Schattenspiels (Qaragöz)«, Zeitschrift der Deutschen Morgenländischen Gesellschaft 63 (1909) 739-773, G. Bergsträsser, "Türkische Schattenspieler«, Orientalische Literaturzeitung 28 (I 925) 424-43 I, Theodor Menzel, "Türkische Schattenspiele«, Die Scene. Blätter für Bühnenkunst, Sept. 1925, I 78-1 82, Nicholas N. Martinovitch, The Turkish Theatre, New York 1935, Nejat An, Karagöz, Ankara 1959, Hellmut Ritter, »Karagöz«, Encyclopédie de l'Islam 2 (Paris 1925-26) 775-778, „Karagös«, Enciclopedia dello Spettacolo 6 (Roma 1959) 88 I-883, Metin And, "Various species of shadow theatre and puppet theatre in Turkey«, Estratto degli Atti del secondo congresso intern. di arte Turca, Napoli 1965 , Nureddin Sevin, Türk Gölge Oyunu, Istanbul 1968, Ahmet Borcakl1, Karagöz, Ankara 1970, Oral Ünver, Karagöz: Turkish shadow play, Ankara 2009. Weitere Bibliographie in: Ahmet Borcaklı/Gülter 
Die stereotypen dialektalen Spielfiguren spiegeln im wesentlichen den sozialen Horizont der traditionellen multiethnischen mahalle (Nachbarschaft) im alten Kostantiniyye/İstanbul und viele Stücke des klassischen Repertoires fußen auf tatsächlichen historischen Vorfällen ${ }^{815}$. Die Hauptfiguren sind der ithyphallische, ewig hungrige, dummschlaue, kahlköpfige, bucklige und abstoßend häßliche Karagöz (Schwarz-Auge), sein Freund und Handlungseinfädler, der gebildetere Opportunist Haçivat, der betrunkene Ordnungshüter Tuszuz Deli Bekir, dessen Eingreifen meist das brutale Ende der schwankartigen Stücke bildet, die verschlagene Dirne Zené, der westliche Sitten nachahmende Celebi, der verwachsene und debile Zwerg Beberubi, der Opiumraucher Tiryaki und die Dialekttypen: Baba Himmet aus Anatolien (mit Axt und größer als die anderen Figuren), der Laze von der Schwarzmeer-Küste, der Rumelili vom Balkan, der Kurde, Tartare, Zigeuner, Perser, Armenier usw., die sich durch das mangelhafte Beherrschen des Türkischen auszeichnen ${ }^{816}$.

Jede Aufführung gliedert sich in drei Teile: den Prolog (mukkademe), den Dialog (muhavere) und das eigentliche Stück (fasil). Die traditionellen Stücke bestehen aus zwei Kategorien: Karagöz übt einen Beruf aus und legt alle andere Figuren herein; am Ende wird er durch Prügel bestraft, oder es handelt sich um mythologische Erzählstoffe (wie z.B.»Ferhad und Schirin«). Als Beispiel sei die Beschreibung von Gérard de Nerval einer Aufführung in Kostantiniyye/İstanbul um I 85 I paraphrasiert (»Karagöz als Opfer seiner Keuschheit«):

Haçivat vertraut in seiner Abwesenheit seine Frau seinem Freund Karagöz an. Der ithyphallische Held beschließt sich zu tarnen, denn sobald sie seiner ansichtig werde, würde sie sich unsterblich in ihn verlieben. So legt er sich vor dem Hause seines Freundes über den Fluß und bildet eine Brücke. Auf seinen aufragenden Penis

Koçer, Cumburiyet Dönemi Türkiye Tiyatro Bibliyografyasi, Ankara 1973, 26-30, 246-255. Die bis jetzt umfangreichste Bibliographie findet sich in Vikton perdeyi eyledin vilan/Torn is the curtain, shattered is the screen the stage all in ruins: Yapı Kredi Karagöz KoleksiyonuYYapı Kredi Karagöz Collection (Collectif), Istanbul 2004 und Peri Efe (ed.), Hayal perdesinde ulus, değisim ve geleneğin icadi, Istanbul 20I 3, I 75-240 (von M. Sabri Koz mit 5 I handschriftlichen oder gedruckten Spieltexten, I7 I eigenständigen Publikationen und 282 Artikeln und Studien). Die umfangreichste Textsammlung, die die dreibändige von Hellmut Ritter, Karagösz. Türkische Schattenspiele, Hannover etc. 1924-53 ersetzt hat, die mehrbändige von Cevdet Kudret, Istanbul I 968-70 ist in einer einbändigen Ausgabe 2004 (Karagöz, İstanbul 2004, S. 1 339) nachgedruckt worden. Vgl. auch Saim Sakaoğlu, Türk gölge oyunu, Ankara 2003.

8I 5 Sabri E. Siyavusgil, Karagöz. Psiko-sosyolojik bir deneme, Istanbul I94I, ders., Karagöz, Son histoire, ses personnages, son esprit mystique et satirique, Istanbul I 95 I, ders., Karagöz. Its history, its characters, its mystic and satiric spirit, Ankara 1955.

8 I6 Altan Gokalp, »Les indigènes de la capitale et la kaléidoscope culturel ottoman: les figures rethniques` sur la scène du Karagöz turc«, in: Damianakos, Théâtres d'ombres, op. cit., I 85-1 98. 
binden die Kameltreiber ihre Tiere und junge Mädchen ihre Wäscheleinen. Karagöz läßt alles geduldig über sich ergehen, bis er einen schweren Wagen kommen hört und entsetzt die Flucht ergreift. Doch gerade in diesem Augenblick kommt Haçivats Frau aus dem Haus auf ihrem Weg zum öffentlichen Bad (hamam). Kaum wird sie seiner ansichtig, fühlt sie sich unwiderstehlich zu ihm hingezogen und nur der französische Botschafter mit seinem schweren Wagen vermag ihn aus der peinlichen Situation zu retten $^{817}$.

Das öffentliche Bad (hamam) ist eine häufig verwendete Konstellation: Karagöz bietet jeder der vorbeigehenden Frauen seine Dienste an und wird zum Schluß verprügelt. Unter den Berufen, die Karagöz ausübt, ist der Schreiber, Apotheker, Koch, Tavernenwirt usw., aber auch schwankartige Stücke wie der »Ausflug nach Yalova« (»Yalova safâsi«) um die Freier im großen Krug, die Tierverzauberung in der »Blutpappel« (»Kanlı Kavak«), die dämonischen Hexen (»câzûlar»), die Meeresreise in »Das Boot» (»kayık«) usw. bilden das klassische Repertoire. Die ersten Nachweise von Aufführungen an der Bosporus-Metropole fallen noch ins I6. Jh. ${ }^{818}$, ein Niedergang der Gattung ist nach der Jungtürkischen Revolution ( I 908), den Balkankriegen, dem Ersten Weltkrieg und in der republikanischen Zeit (I 923 ff.) zu verzeichnen ${ }^{819}$; Hauptgründe dafür waren die Obszönität des Schauspiels und das Verschwinden der multiethnischen mahalle in Istanbul, aus der Dialektfiguren ihre soziale Realität bezogen. Das anzügliche Karagöz-Spiel war überdies vorwiegend Palastunterhaltung und fast alle erhaltenen Text stammen daher; seine Verpflanzung in die traditionellen Cafés dürfte ein sukzessiver Vorgang sein, dessen zeitliche Grenzen im wesentlichen unbekannt sind. Erst in den letzten Jahren sind unter folkloristischen Vorzeichen gezielte Bemühungen unternommen worden, dieses »Kulturerbe $\mathrm{zu}$ reaktivieren ${ }^{820}$.

8I 7 Gerard de Nerval, Le Voyage en Orient, Bd. 2, Paris I 867, 44-52.

8 8 Nicht unanzweifelbar I 530 und 539 (Joseph v. Hammer, Geschichte des Osmanischen Reiches, 3 Bde., Pest I 828, I 99 und 213), sicherer ist die Nachricht von einer Vorstellung beim Beschneidungsfest des Sultansohnes 1582 (Nic. Haunoldt, Particular Verzeichnusz ... Frankfurt/M. I 590, 489; vgl. And, $A$ bistory, op. cit., 7). Für das I 7. Jh. vgl. M. Thévenot, Relation d'un voyage fait en Levant, Paris I665, 66-68, ders., Voyage de M. Thévenot tant en Europe qu'en Asie et en Afrique, Paris I689, 5 Bde., I I09-I I I.

8 9 Serdar Öztürk, »Karagöz Co-Opted:Turkish Shadow Theater of the Early Republic (I 923-1945)«, Asian Theatre Journal 23/2 (2006).

820 Zum Schicksal des Schattenspiels in der Nachkriegszeit vor allem Gayé Petek-Salom, Le théâtre traditionel turc de Karagöz. Vie, survivances, actualité, Paris 1972. Vgl. auch A. E. Uysal, „Some Specimens of wintergames in Turkey: a study based on observations in several ethnic communities«, Makedonski Folklor I 5-I6, I 975, I 47-I 5 I (»Unfortunately, the Turkish shadow theatre, which enjoyed great popularity until about 60 years ago, can no longer compete against the cinema and $\mathrm{TV}$, and therefore it is something like a historical curiosity« (I $47 \mathrm{f}$.). 
Von der Reichshauptstadt hat sich das Schattentheater jedoch relativ früh schon in praktisch alle größere Städte des Balkanraums verpflanzt: Ältere und vor allem neuere Forschungen aus Rumänien (Șainean ${ }^{821}$, Gaster $^{822}$, Burada ${ }^{823}$, Gîtză ${ }^{824}$, Di-

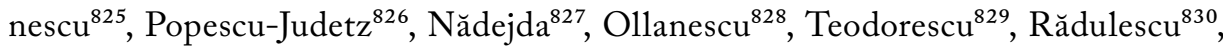
Oprișan ${ }^{831}$ ), Bulgarien (Ž ivkov $^{832}$ ), dem aromunischen Kommunikationsraum $\left(\mathrm{Marcu}^{833}\right.$, Papahagi $\left.{ }^{834}\right)$, den ehemaligen jugoslavischen Ländern (Nehring ${ }^{835}, \mathrm{Di}^{-}$ mitriadis $^{836}$, Tričkovićc ${ }^{837}$, Batušić ${ }^{838}$, Stefanovski ${ }^{839}$, Stefanović ${ }^{840}$, Vukanovićc ${ }^{841}$,

82 I Lazăr Șaineanu, "Jocul papușilor și raporturile sale en farsa Karagöz«, Lui Titu Maiorescu omagiu, București I 900, 28 1-287 (auch in Keleti Szemle I, Budapest I 900, I 40-I 44), ders., Influența orientală asupra libei și culturei Române I, București I 900, CLXXff., ders., »Les marionettes en Roumanie et Turque«, Revue des traditiones populaires I6 (I 901) 409-4I9.

822 Moses Gaster, Literatura populară română, București I 883, 492.

823 Teodor T. Burada, Istoria Teatrului în Moldova, Bd. I, Iași I 88 5 , I 5 .

824 Letiția Gîtză, "Le théâtre roumain de marionettes, art ancien et art modern «, Revue roumaine d'bistoire de l'art I (1964) I I 9-1 38 .

825 Viorica Dinescu, "La relation entre Karagöz oyunu et le théâtre populaire roumain de marionettes«, Résumées des communications, Bd. 2, București 1974, 362-363, dies., Teatrul de umbre Turc, București 1982.

826 Eugenia Popescu-Judetz, "L'influence des Spectacles Populaires Turcs dans les Pays Roumains«, Studie et Acta Orientala V-VI (1967) 337-355.

827 L. Nădejda, »Teatrul popular de papuși în secolul al XIX-lea«, Studii și cercetări de istoria artei 7/I (I 960 ) 203-2 I 5 .

828 D. C. Ollanescu, Teatrul la Români, București I 895, 27-28.

829 Gheorghe D. Teodorescu, Poesie populare române, București I 885, I $20-\mathrm{I} 32$.

830 Nicolae Rădulescu, „Musikalische Puppenspiele orientalischer Herkunft in der rumänischen Folklore«, Zeitschrift für Balkanologie I 4 (1978) 83-98.

83 I Horia Barbu Oprișan, „Das rumänische Volkspuppenspiel«, Österreichische Zeitschrift für Volkskunde 84 (1981) 84-106; ders., Teatru fără scena, București i 981, 56-59.

832 T. I. Živkov, »Za teatralnija charakter na folklornata obrednost«, Bălgarski Folklor 8/4 (1982) 47-52, bes. 49 .

833 L. Marcu, »Quelques aspects des anciennes coutumes d'hiver dans le vallé de Moglena«, Makedonski Folklor I 5-i 6 (I 975) 69-79, bes. 77 .

834 Perikle Papahagi, Megleno-românii, București I902, I I 4.

835 Karl Nehring, Adam Freiherr zu Herbersteins Gesandtschaftsreise nach Konstantinopel, München I 98 I , го I.

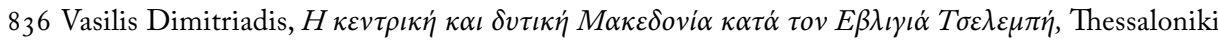
I973, 347.

837 R. Tričković, Beogradski pašalik, unveröff. Diss.,I 32.

838 Nikola Batušić, Povijest Hrvatskoga kazališta, Zagreb I 978, I 55 .

839 Risto Stefanovski, Teatarot vo Makedonija, Skopje 1976, 25.

840 V.T. Stefanović, »Stari Beograd«, Glasnisk I9 I (Beograd) I49.

84 I Tatomir Vukanović, »Studije iz balkanskog folklora«, Vranjski glasnik V (Vranje I 969) 337-339. 


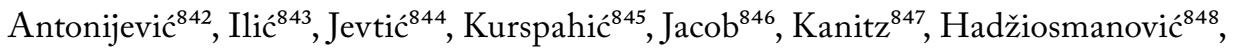
Bonifačić-Rožin ${ }^{849}$ ) und Griechenland (Fotiadis ${ }^{850}$, Simopulos ${ }^{851}$, Myrsiades ${ }^{852}$, Kalonaros $^{853}$, Kokkinis ${ }^{854}$, Sifakis ${ }^{855}$, Hatzipantazis ${ }^{856}$, Puchner ${ }^{857}$ ) haben entscheidend neues Material beigebracht ${ }^{858}$ und ergeben ein völlig neues Bild: Das Schauspiel war in praktisch allen größeren Städten zwischen den Transdanubischen Fürstentümern und Griechenland verbreitet, in Belgrad, Sarajevo und Skopje im I8. und I9., ja sogar noch im 20. Jh., im Donauraum schon im I7. Jh., am phanariotischen Hof in Bukarest bereits seit dem I8. Jh., in Ioannina zu Beginn des I9. Jh.s.

Der früheste Beleg für die Balkanhalbinsel fällt ins Jahr r6o8 und betrifft die Donaustadt Ilok (im heutigen kroatischen Teil von Syrmien) ${ }^{859}$, gefolgt von Hochzeitsfei-

842 Dragoslav Antonijević, „Karađoz«, Gradska kultura na Balkanu (XV-XIX vek), Beograd I 984 (Balkanološkog instituta SANU, 2 I) 395-4I 2.

843 Z. Ilić, »Jena zabrana izvočenja `Karađoz« pozorišta u Sarajevu«, »Politika«, 30. I. I 966, 20.

844 Borivoje Jevtić, Izabrana djela, Sarajevo I982, 357-36r.

845 Nemina Kurspahić, »Karađoz tursko pozorište senki«, Pozorište I-2 (Tuszla I98 I).

846 Georg Jacob, Geschichte des Schattentheaters im Morgen und Abendland, Hannover I 925 , I 30 ff.

847 F. Ph. Kanitz, Donau-Bulgarien und der Balkan, 2 Bde., Leipzig I 877, II I 9 r ff.

848 L. Hadžiosmanović, »Igra lutke i sjenke Karađoz«, Pozorište I-2 (Tuszla I98 I).

849 Nikola Bonifačić-Rožin, Narodne drame, poslovice i zagonetke, Zagreb I 963, I 28 ff.

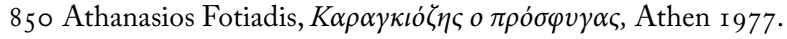

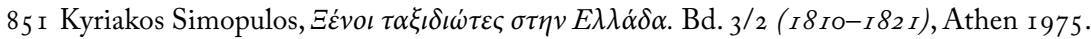

852 Linda Myrsiades, "The Karaghiozis Performance in Nineteenth Century Greece«, Byzantine and Modern Greek Studies 2 (1976) 83-97, dies., The Karaghiozis Tradition and Greek Shadow Puppet Theater: History and Analysis, Ph. D. diss. Indiana Univ. I 972, dies., "Nation and Class in the Karaghiozis History Performance«, Theatre Survey 9/I ( 1978 ) 49-62, Linda S. Myrsiades, »Oral composition and the Karaghiozis Performance«, Theatre Research International 5 (1980) I07-I 2 I, dies., "The Struggle for Greek Theater in Post-Independent Greece«, Journal of the Hellenic Diaspora 7/I (1980) 33-52, dies., "Theater and society: social context and effect in the Karaghiozis-performance", Folia neohellenica 4 (I982) I 37-I 45, L. S. \& K. M. Myrsiades, Karagiozis: Culture and Comedy in Greek Puppet Theater, Lexington 1992.

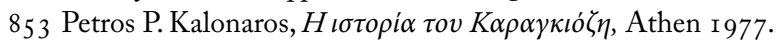

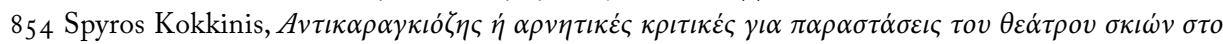

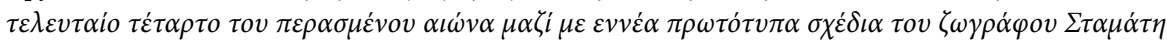

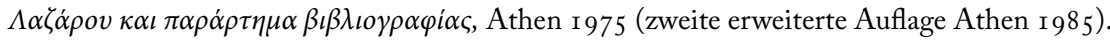

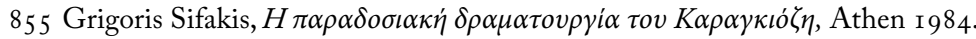

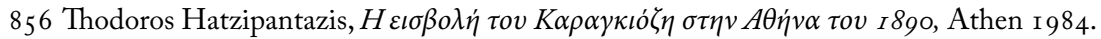

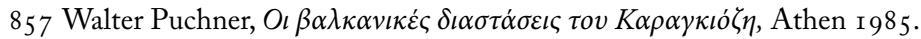

858 Vor allem die Studie von Antonijević, op. cit.

$859 \mathrm{Im}$ Jahre 1608 reiste der kaiserliche Botschafter Adam Freiherr von Herberstein, begleitet von Maximilian Brandstetter, mit dem Schiff die Donau hinab von Wien nach Konstantinopel zu einem offiziellen Besuch bei der Hohen Pforte; bei einem Reiseaufenthalt in Ilok (im heutigen 
erlichkeiten in Iaşi $1652^{860}$, den Handelsmarkt in Doliani (heute Banjsko südöstlich von Strumica) I $666^{861}$, das osmanisch besetzte Belgrad I $695^{862}$, den Fürstenhof der Walachei I 7 I $5^{863}$; dort sieht der Schweizer Franz Joseph Sulzer, Offizier der österreichischen

kroatischen Teil von Syrmien) lädt sie der türkische Pascha der Stadt ein, mit ihm den Abend zu verbringen und bietet ihnen zur Unterhaltung eine Vorstellung mit beweglichen »Marionetten« an, in der der Spieler männliche und weibliche Stimmen nachahmt. Der Passus des Reiseberichts lautet folgendermaßen: »Nach dem Essen hat der Ali Passa Chiai zu im geschickt, ob er was Kurtzweilig sehen wolte, das Ir Gnaden gewilliget und zu ime kommen. Da hat ein Gaukhler in einem verborgenen Gezehlt, bey einem Licht durch ein durchsichtig Tuch mit geschürtzten Weibl und Mändl allerley Possen getrieben, und er selbst auf allerley Arth von Mann und und Weib geredet« (Nehring, op. cit., Ior). Antonijević hat wohl zu recht vermutet, daß es sich um eine Schattentheateraufführung handelt (Antonijević, op. cit., 390).

860 Bei der Hochzeit zwischen Ruxandra, der Tochter des Hospodaren Vasile Lupu (I634-1653) und Timuș, dem Sohn des Bogdan Hmjelnizkij, Hatman der Kozaken von Saporoș, spielten vlachische und türkische Musikanten auf. Die Türken stellen auch »allerhand Frewdenspiel« vor (Bescbreibung der Solemniteten, so bey der Hochzeit des Chmielnizken Sohns, Timoszek mit des Hospodarn in Wallachey Tochter vorgegangen ... (Nicolae Iorga, Acte și fragmente en privire la Istoria Românilor, I, București I 895, 208-2 I4, bes. 2 I I). Iorga hat dies, nicht ohne eine gewisse Willkür, als Schattenspielaufführung interpretiert (»Celebrul Karagöz, de unde scaraghiosul nostru« (Iorga, op. cit., 2 I I, Anmerkungen). Seither wird dieser Vermerk in der rumänische Forschung als erster Nachweis des Schattentheaters in Rumänien zitiert (z.B. Rădulescu, op. cit., 83 ff.).

86 I Der bekannte türkische Reisende Evlija Çelebi hat den großen Jahrmarkt von Doliani besucht, wo er unter anderem auch »Puppentheater« und »Schattentheater« sieht; die Beschreibung ist sehr ausführlich, aber ebenso undeutlich, was die Details betrifft, und läßt gewisse Zweifel aufkommen an der Authentizität des »Augenzeugenberichtes« (Dimitriadis, op. cit., 347 f.). Die üblichen phantastischen Übertreibungen Çelebis in der Beschreibung fremder Örtlichkeiten erheben die Frage, ob er wirklich all das gesehen hat, was er hier anführt. Es gibt Indizien dafür, daß er auf seiner Reise gar nicht auf dem Jahrmarkt von Doliani gewesen sein kann; sollten diese Einwände stimmen, so gibt er einfach eine Liste der Schauspielformen von Kostantiniyye wieder, während er von dem Jahrmarkt auf seiner Durchreise bloß gehört hat.

862 Im Sommer des Jahres 1695 bringen türkische Händler anatolische Waren in das osmanisch besetzte Belgrad, worunter sich auch Karagöz-Figuren befinden, zusammen mit Kerzen, die zur Beleuchtung der Leinwand gebraucht werden (Tričković, op. cit., I 32, nach Antonijević, op. cit., 390). Im I8. Jh. werden im muslimischen Viertel von Skoplje Schattentheatervorstellungen in Kaffeeund Teehäusern gegeben (Stefanovski, op. cit., 25).

863 I 7 I 5 wohnt der Sekretär des Fürstenhofes der Walachei, Del Chiaro, einer Vorstellung mit »obszönen Farcen« bei (Anton-Maria del Chiaro, Istoria delle moderne rivoluzzioni della Valachia, Venezia I 8 I 7, 3), die zuerst in den Bojarenhäusern und im Fürstenpalast gespielt wurden, später auch in den Kaffeehäusern in Stadt und Land. Ein ausländischer Besucher der Transdanubischen Fürstentümer im I 8. Jh. vermerkt den zotenhaften Dialog zwischen den beiden Protagonisten einer Theateraufführung. Die rumänische Forscherin Popescu-Judetz hält diese Angaben für Nachweise der Existenz des Schattentheaters in Rumänien im I 8. Jh. (Popescu-Judetz, op. cit., 343). Die Sache ist freilich nicht so sicher, da, wie Sulzer später ausführlich beschreibt, auch »Komödien« mit lebendi- 
Armee, nach 1776 eine Schattentheatervorstellung ${ }^{864}$, die er folgendermaßen wiedergibt:

Man ist ibrer gleich müde [Vorstellung des orta oyunu, vgl. wie oben], und will eine Opera haben./Dieses türkische Schauspiel, welches die Griechen uns zu Gefallen Opera nennen, ist nichts anderes, als eine Art von Marionettenspiel und besteht darinn: Man verfinstert den Saal (wird es bey der Nacht aufgeführet, so ist diese Mühe erspahret), spannet vor eine Ecke, oder den einen Winkel desselben eine feine Leinwand, stellet hinter diese einen Tisch, und beleuchtet diesen also eingeschlossenen Winkel mit einigen Lichtern. In diesem engen Umfange steht hinter dem Tische ein einziger Tschausch, der gewisse flache Puppen, die aus Pappendeckel oder Kartenblättern verfertiget, und mit Schnüren zur Bewegung ibrer Gelenke versehen sind (nach welcher Art wir unsern Kindern zum Spielen den papiernen Hannswurst zu kaufen pflegen), auf dem Tische herum gehen, und nach den Worten, die er in walachischer und griechischer, grösstentheils aber in türkischer Sprache darzu sagen will, sich geberden lässt, so dass diese papiernen Figuren von dem Zuseher gleichsam im Schatten durch die Leinwand gesehen werden./Wie ein, mit so vielem Pöbelwitz redendes Schattenspiel (denn so glaube ich es nennen zu müssen) einmal gesehen, das zweytemal auch nur halbdenkende Menschen vergnügen könne, wird nur derjenige fragen, der von der tödtenden Langeweile der walachischgriechischen Höfe noch nicht unterrichtet ist ... ${ }^{865}$.

gen Schauspielern gegeben wurden (vgl. wie oben). In jedem Fall war das Schattenspiel in Hofkreisen bekannt, denn der gelehrte Dimitrie Cantemir (1673-1723) beschreibt es in seiner Geschichte des Osmanischen Reiches (Dimitrie Kantemir, Geschichte des osmanischen Reiches ..., Hamburg I 745, 377 ff.) und führt Karagöz in seiner Istoria Ieroglifică (dazu Puchner, Die Literaturen Südosteuropas, op. cit., 32, 35) als Maske mit schwarzen Augen an (Kara-göz = Schwarz-Auge) an (Rădulescu, op. cit., 84).

864 Sulzer, Offizier der österreichischen Armee und nachmals Beirat am Militärgericht, 1776 vom Fürsten Alexandros Ypsilantis nach Bukarest eingeladen, um hier eine juristische Schule einzurichten, bleibt bis zu seinem Tod I79I am phanariotischen Hofe der Walachei und beschreibt in seinem dreibändigen Werk unter anderem auch die Schaustellungen und Unterhaltungen am Hof; unter anderem gibt er eine ausführliche Deskription einer Schattentheatervorstellung. Diese Schaustellungen finden nach dem Essen zur Unterhaltung und zum Zeitvertreib des Hofes statt, oder bei Gelegenheit eines hohen Besuches. Sulzer sieht zwei Arten von Vorstellungen: zuerst eine improvisierte Komödie mit verkleideten Çaușen in »vlachischer«, griechischer und türkischer Sprache im zotigen Stil des Karagözspiels, die allerdings sehr kurz sind, nicht viel Gelächter hervorrufen und nur selten gegeben werden (vgl. dazu oben), und dann eine Schattentheatervorstellung.

865 Franz Joseph Sulzer, Geschichte des transalpinischen Daciens, das ist: der Walachey, Moldau und Bessarabiens, im Zusammenhange mit der Geschichte des übrigen Daciens als ein Versuch einer allgemeinen Geschichte mit kritischer Freyheit entworfen von ..., Zweeter Band, Wien I 78 I, 402 f. Wenige Jahre später schreibt ein Reisender aus Dalmatien (Raicevich, Osservazione storiche, naturali e politiche intorno la Valachie, e Moldavia, Napoli 1788 , 244) folgendes: "Nelle due Corti sogliono pure esservi 
Die Bekanntheit des Karagöz läßt sich auch vokabularisch in verschiedenen Balkansprachen dokumentieren ${ }^{866}$. Mit dem Ende der Phanariotenherrschaft in den Transdanubischen Fürstentümern I 82 I scheinen die Palastunterhaltungen auch in den Kaffeehäusern von Städten und Marktflecken nachgeahmt worden zu sein. So wird I 834 in Gimpulin papuși la perdea (Puppen der Leinwand) ${ }^{867}$ gespielt, und der moldauische Komödienautor Vasile Alecsandri bringt Karagöz selbst auf die Theaterbühne, in seiner Komödie »Iașii in Carnaval ${ }^{868}$. Auch in den Kaffeehäusern von Bukarest scheinen die

dei Chiause Turchi, specie di portieri che precedono il Principe con un bastone guarnito di sonagli d'argento. Per lo più sono uniti ad alcuni Armeni che fanno quest'Ufficio, e servono anche di Buffoni per divertire sua Altezza quando mangia, e rappresentare la Comedia in lingua Turca, che in realtà non è che una Farsa indecente se per gli atti, che per le parole. Costoro anno anche il talento di raccontare delle storie, o novellette molto usitate nei Caffè della Turchia per divertire gli Oziosi«. Der gleiche Autor bemerkt kritisch über die griechischen Fürsten: "Schauspiele, und Hazardspiele sind ihre liebsten Unterhaltungen" (Raicevich, Bemerkungen über die Moldau und Wallachey in Rücksicht auf Geschichte, Naturprodukte und Politik. Aus dem Italiänischen des Herrn von Raicewich, Wien I789, I3I).

866 Als Eigenschaftswort caraghios im Rumänischen, komisch, lächerlich (es existiert auch caraghioslic, das griechische караүкьо \ікє, abweichendes Verhalten im Sinne des Sich-lächerlich-Machens, sinnlose Handlung), als Hauptwort karagjoz auch im Bulgarischen, wo es die Fischart Else be-

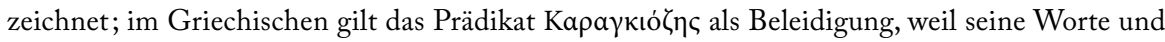

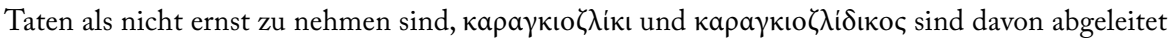
und bezeichnen lächerliche, nicht ernst zu nehmende Sachverhalte oder Personen. Caraghioz heißt auch der Lustigmacher beim Fest der rusaliile der Meglenorumänen (Marcu, op. cit., 77) wie auch beim Fest der eška der Aromunen im Bereich von Jenište-Vardar (Papahagi, op. cit., I I 4). Einen solchen Karagiozis gibt es auch bei Karnevalsverkleidungen in Nordgriechenland (bei den arugutshari in Briaza, A. J. B. Wace, »Mumming Plays in Southern Balkan«, The Annual of the British School at Athens 19, I 91 2 / I3 248 ff., bes. 254) sowie bei der »Hochzeit des Karagiozis« in Gonusa bei Kiato

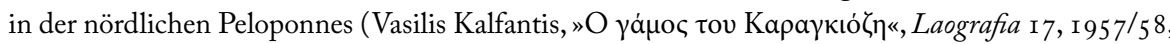
634 ff., vgl. wie oben). Trotzdem kann man nicht von einem »starken Einfluß des türkischen Karagöz auf die neugriechischen Fruchtbarkeitsbräuche« sprechen, wie dies Waldemar Liungman getan hat (Waldemar Liungman, Traditionswanderungen Euphrat-Rhein, Helsinki I 938 [FFC I I 9 ] 822;

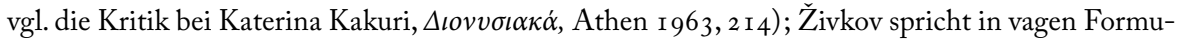
lierungen von einer »Bekanntschaft« bzw. einem »Ausborgen« von theatralischen Formen, wie dem Karagöz oder dem Puppentheater, durch die bulgarische Volkskultur (Živkov, op. cit., 49: „Vjarno e, ce našijat narod poznava ili po-skoro e zaimstvuvai čisto teatralni formi kato turskija teatăr na senkite >karagioz<, elementi na igrata e kukli i t.i.«).

867 Simion Alterescu (ed.), Istoria Teatrului în România, r. Bd. București I965, I 7 .

868 Akt 3, Szene 3 und 8. Zu Vasile Alecsandri vgl. Puchner, Die Literaturen Südosteuropas, op. cit., 50, I 3 I ff. In der Dobrudscha, die bis I 878 beim Osmanischen Reich verblieb, gab es Schattentheater bis zum Ende des I 9. Jh.s; der rumänische Theaterhistoriker und volkskundliche Feldforscher Teodor T. Burada trifft es da 1879 an, gespielt von Zigeunern; die Figuren stellen nach seinen Angaben Türken und Haremsfrauen dar (Teodor T. Burada, Calatorie în Dobrogea, Iași I 880, I 8). 
Schattenspielfiguren bekannt zu sein ${ }^{869}$. In Constanța an der Schwarzmeerküste und im Hinterland ist das Schattentheater im Zeitraum von I 895 bis I 9 I 3 nachzuweisen, und zwar sowohl auf Türkisch wie auch auf Griechisch und Armenisch ${ }^{870}$. Der rumänische Bojaren Costache Conache begann in der Moldau um I 806 kleine Stücke für das Schattentheater zu schreiben und in seinem Herrenhaus selbst aufzuführen ${ }^{871}$.

Zwischen I 820 und I 850 ist das Schattenspiel auch in den Kaffeehäusern von Bel$\operatorname{grad}^{872}$ und in den kosovarischen Städten Prizren, Peć und Priština anzutreffen, wo sich die Bewohner noch im 20.Jh. an diese Vorführungen erinnern. Gegen Ende des 19. Jh.s spielen türkische Karagözspieler aus Skopje am Amselfeld; in den Kaffeehäusern von Skopje werden Vorstellungen noch bis zum Vorabend des Zweiten Weltkrieges gegeben $^{873}$. Aber auch in makedonischen Städten wie Ohrid, Bitola, im montenegrinischen Veleš, im serbischen Štip usw. lebt das osmanische Schattentheater noch bis ins 20. Jh. ${ }^{874}$ Auch im bosnischen Sarajevo sind die derbzotigen Dialoge der Leinwandfiguren zu hören, so daß es I 868 wegen seiner Anstößigkeit für eine gewisse Zeit verboten wird ${ }^{875}$.

Derselbe Autor gibt für die Moldau Nachrichten über die Existenz einer »Komödie«, Hagi Ivat genannt, zu Beginn des I9. Jh.s; aus den eingeholten Informationen geht hervor, daß diese von zwei Spielern in Kaffeehäusern vorgeführt wurde, gewöhnlich von Armeniern oder Türken: einer habe ein Tambour gezupft, der andere verschiedene Witze zum besten gegeben, Szenen aus dem Alltagsleben vorgestellt, getanzt und rumänische und türkische Lieder gesungen (Teodor T. Burada, Istoria teatrului in Moldova, Bd. I, Iași I 91 5, 79 ff.). Trotz des Namens Haçivat scheint es eher um die pantomimischen Vorführungen eines Märchenerzählers zu gehen als um das Schattentheater.

869 Hier gibt es ein Spiel mit großen grotesken Puppen, die den Namen Geamale und Hagi Ivat haben und nach Ollanescu deutlich vom Schattentheater beeinflußt sind (D. C. Ollanescu, Teatrul la Români, București I 895, 27 f.).

870 Popescu-Judetz, op. cit., 35 I. Im Jahre 1905 kommt ein türkischer Schattenspieler aus Istanbul und gibt Vorstellungen im Ovidi-Viertel. Es gibt auch eine griechische Truppe (»Marika«, Vater und Sohn), die zwischen 1903 und 1908 in der Sommersaison griechischen Karagiozis spielen.

87 I Oprișan, »Volkspuppenspiele«, op. cit., 86. Schon zwanzig Jahre früher, I 786, ist in Dubrovnik/ Ragusa ein gewisser Josip Skubenta nachzuweisen, der eine Vorstellung mit ombre cinesi gibt, die er offenbar aus dem Hinterland der Hercegbosna kennt (Batušić, op. cit., I 55). I 798 ist in derselben Küstenstadt auch eine Schattentheatervorstellung »in platea propre Orlandum« nachgewiesen ( $Z$. Muljačić, »Dopune rad N. Beritić«, Prilozi 22, Beograd I 956, 84).

872 Stefanović, op. cit., I 49 .

873 Vukanović, op. cit., $337 \mathrm{ff}$.

874 Antonijević, op. cit., $39 \mathrm{I}$.

875 Ilić, op. cit., 20. Das öffentliche Publikum besteht hier aus Bauern und Angestellten. 1870 finden sich in der Presse von Sarajevo, ganz ähnlich wie in Griechenland zur selben Zeit, zwei Artikel, die Kritik an dem »anatolischen« Schauspiel üben; der Spieler ist ein Armenier aus Istanbul (Sarajerski conetik za I870 godini, 47, nach Antonijević, op. cit., 39I f.). In Sarajevo sieht auch Georg Jacob noch 1904 das Schattenspiel (Jacob, Geschichte, op. cit., I 30 ff., mit Photo), wie andere Reisende schon vor ihm (F. Ph. Kanitz, Donau-Bulgarien und der Balkan, 2 Bde., Leipzig I 877, II I 9 I ff.), im 
Das Schattentheater scheint die Grenzen des Osmanischen Reiches nur in Ausnahmefällen überschritten zu haben ${ }^{876}$.

Auch im hellenophonen Kommunikationsraum gibt es eine Reihe von Hinweisen darauf, daß der osmanische Karagöz bekannt gewesen ist ${ }^{877}$. Der englische Reisebegleiter von Lord Byron ${ }^{878}$, John Cam Hobhouse, sieht $\mathrm{I} 809$ in Ioannina in einem schmutzigen Kaffeehaus einen Hebräer zur Zeit des Ramadan Schattentheater spielen ${ }^{879}$ :

An evening of two before our departure from Ioannina, we went to see the only advance which the Turks have made towards scenic representations. This was a puppet-show, conducted by a Jew who visits this place during the Ramazan, with his card performers. The show, a sort of

Café des Hussein Pasalić, wo ein gewisser Samuel Gracijan seine Vorstellungen zum besten gibt (Kurspahić, op. cit., 42). Gerade für Sarajevo gibt es noch weitere Quellen (Jevtić, op. cit., $357 \mathrm{ff.}$ ).

876 Z.B. im Falle von Ragusa (vgl. wie oben). Das »Schattentheater«, das Bonifačić-Rožin für Kroatien beschreibt, ist eher ein Handschattenspiel als ein Figurenspiel (Bonifačić-Rožin, op. cit., I 28 ff.); bekannt dürfte die Spielgattung jedoch gewesen sein, denn Ivo Andrić, der in seiner Erzählung "Prokleta Avlija» (»Der verfluchte Hof«, Ausgabe Zagreb I 963) das Leben der Insassen eines Istanbuler Gefängnisses beschreibt, gibt dem Haupthelden der Erzählung, einem unmenschlichen Gefängniswärter, den Namen Karađoz; doch hier verbindet sich der Name nicht mit Lächlichkeit, sondern mit dämonischen, grotesken und sadistischen Charaktereigenschaften (Reinhard Lauer, "Das Osmanische Reich als Weltmodell. Zur parabolischen Struktur von Ivo Andrićs Erzählung ,Der verfluchte Hof «, Die Türkei in Europa. Südosteuropakongreß der AIESEE in Ankara 1979, Göttingen 1979, I 5 I-I66, Dagmar Burkhart, »Das künstlerische Weltmodell in der Prosaerzählung. Am Beispiel Ivo Andrićs >Prokleta Avlija«", Zeitschrift für Balkanologie I8/I, I 982, I-2 I sowie im Band Kulturraum Balkan. Studien zur Volkskunde und Literatur Südosteuropas, Berlin/Hamburg I989, 239-256).

877 Dies gilt auch für multiethnische Städte wie Thessaloniki, von denen bislang keine Quellen für das I9. Jh. erstellt worden sind (Menzel, op. cit., 59 führt erst für I 909 einen griechischen Karagöz-

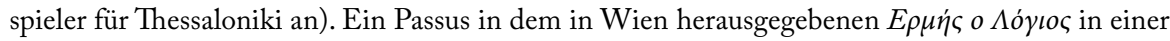
Reportage zum griechischen Laientheater in Odessa I 8 I 7 weist auf die Nützlichkeit desselben hin, ganz im Gegensatz zu den »unzüchtigen und obszönen Sachen«, die beim Karagöz-Spiel in Konstantinopel zu sehen wären (Beiheft I, I. I. I 8 I 7, S. 8, auch bei Georg Veloudis, Der neugriechische Alexander. Tradition in Berwahrung und Wandel, München 1968, 259 Anm. 2). Solche Hinweise auf

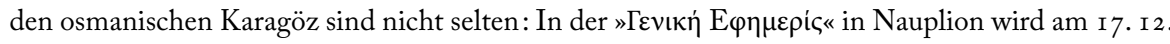
I 827 jemand als Karagiozis apostrophiert, mit einer erklärenden Fußnote, was der Karagöz in der

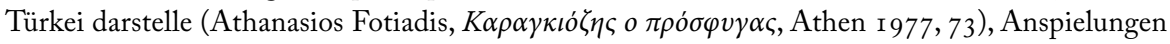
auf die Bekanntheit der Figur des Haçivat finden sich auch in anderen Schriften der Zeit (Mavro-

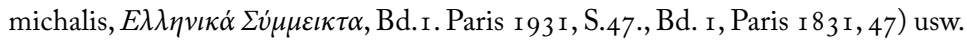

878 Zu Byrons Griechenlandaufenthalten nun Roderick Beaton, Byron's War. Romantic Rebellion, Greek Revolution, Cambridge I9I3.

879 John Cam Hobhouse, A Journey Through Albania, and Other Provinces of Turkey in Europe and Asia, to Constantinople, During the Years 1809 and 1810 , London I 8 I 3 , I 83 ff. 
ombre Chinoise, was fitted up in a corner of a very dirty coffee-house which was full of spectators, mostly young boys. The admittance was two paras for a cup of coffee, and two or three more of those small pieces of money put into a plate handed round after the performance. The hero of the piece was a kind of punch, called Cara-keus, who had, as a traveller has well expressed it, the equipage of the God of Gardens, supported by a string from his neck. The next in dignity was a droll, called Codja-Haivat, the Sancho of Cara-keus; a man and a woman were the remaining figures, except that the catastrophe of the drama was brought about the appearance of the Devil himself in his proper person. The dialogue, which was all in Turkish, and supported in different tones by the Jew, I did not understand; it caused loud and frequent bursts of laughter from the audience; but the action, which was perfectly intelligible, was too horrible to be described. If you have ever seen the morris-dancing in some countries of England, you may have a faint idea of it.IIf the character of a nation, as has been said, can be well appreciated by a view of the amusements in which they delights, this puppet-show would place the Turks very low in the estimation of any observer. They have none, we were informed, of a more decent kind ${ }^{880}$.

In Athen selbst sind Vorstellungen schon bald nach der Erhebung zur Hauptstadt Griechenlands nachzuweisen ${ }^{881}$. I 836 wird bekanntgegeben, daß die »öffentlichen Spiele« und »mobilen Theater« in Bezug auf ihre "Sittlichkeit« der Aufsichtspflicht der Po-

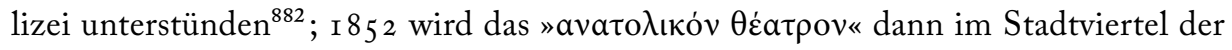
Plaka unter dem Akropolisfelsen nachgewiesen: Gespielt wird »Die Hochzeit des Karagiozis«; aus der etwas wirren, ironischen Beschreibung geht doch soviel hervor, daß es sich um den traditionellen osmanischen Karagöz gehandelt haben muß ${ }^{883}$. Auf die

880 Siehe auch Linda Myrsiades, »The Karaghiozis Performance in Nineteenth Century Greece«, Byzantine and Modern Greek Studies 2 (1976) 83-97. Die Spieltradition in Ioannina mag kontinuier-

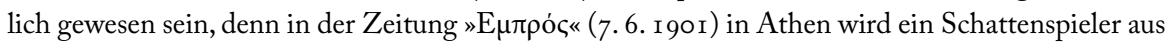
Ioannina angekündigt, der »in der Türkei Erinnerungen hinterlassen hat (Thodoros Hatzipantazis,

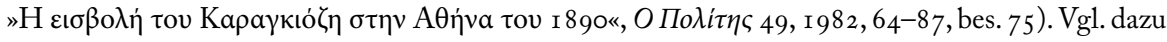
in der Folge.

88I Eine viel spätere Quelle berichtet über einen Schattenspieler nach I 834 in Athen, bei dem auch Höflinge und Botschafter verkehrt haben sollen; der österreichische Botschafter Prokesch-Osten

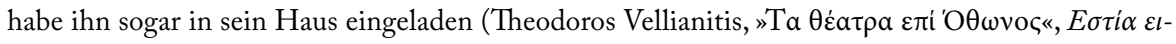

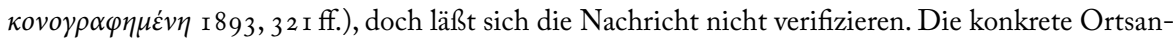

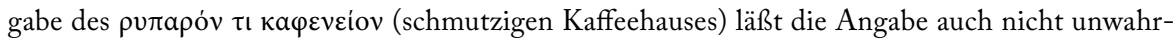

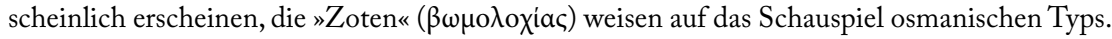

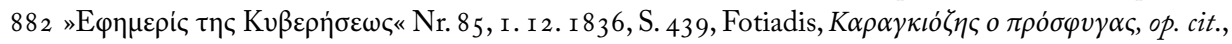
33 I.

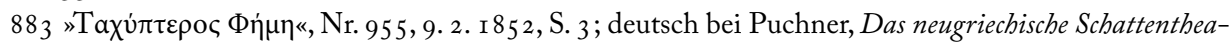
ter Karagiozis, München 1975, 66 f. Es dürfte sich um eine Variante von »Büyük Evlenme« handeln (And, History, op. cit., $5 \mathrm{I}$ ). 


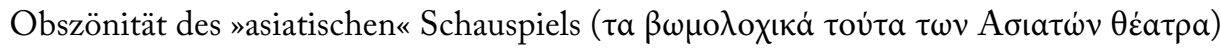
verweist ein Protestschreiben der guten Gesellschaft Athens an das Polizeiprädisium I $854^{884}$, in dem auf die öffentliche Gefahr für die Sitten hingewiesen wird, vor allem da die Gymnasialschüler zum ständigen Publikum dieser unanständigen Vorführungen zählten. Nach den Ursprungslegenden der griechischen Schattenspielergilde dürfte es ein gewisser Giannis Brachalis gewesen sein, der das Schattentheater in Griechenland heimisch gemacht hat ${ }^{885}$. Der chronologisch nächste Beleg führt in die euböische Hauptstadt Chalkida I $856^{886}$, woher auch ein Redaktionsbericht aus I 879 stammt $^{887}$. Bis Jahrhundertende gibt es noch weitere Notizen, die davon zeugen, daß der "anatolische« Typ der Vorstellung noch weiterhin, unter sich mehrenden Protesten gegen das groteske ithyphallische Schauspiel, gespielt wird ${ }^{888}$.

884 »Wir bedauern, die Leitung der Polizei hinnehmen zu sehen und zu entschuldigen die Vorstellung des sogenannten Karagiozis in irgendwelchen Kaffeehäusern, während diese früher streng verboten wurde. Uninformiert scheint der Herr Direktor zu sein, welche Szenen obszöner und unschicklicher Handlungen mit Hilfe von Marionetten in diesen possenreißerischen Theatern der Asiaten gezeigt werden, und welche Verderbnis hieraus in unsere ganze Gesellschaft sich ausgießt, nachdem eine unabsehbare Vielzahl verschiedener Kinder, ja sogar viele von den Schülern der Gymnasien und unserer übrigen Schulen, nicht aufhören ständig des abends an jenen Örtlichkeiten zu verkehren«

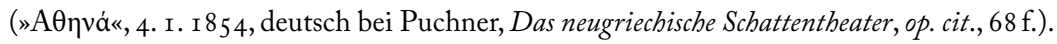

885 Zur teilweisen Historizität dieser oralen Ursprungssagen der Schattenspielergilde Thodoros Hatzi-

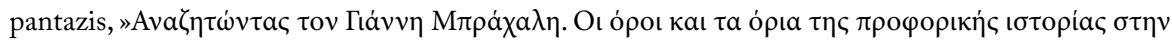

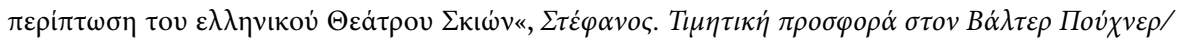

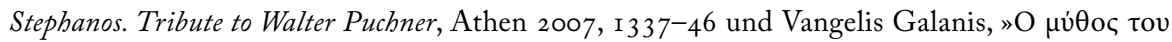

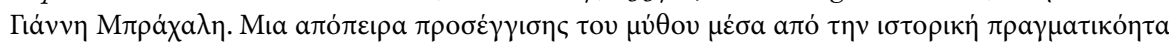

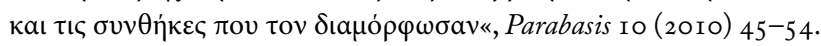

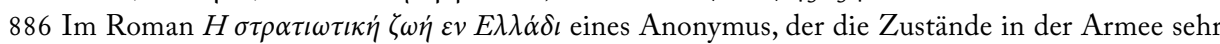

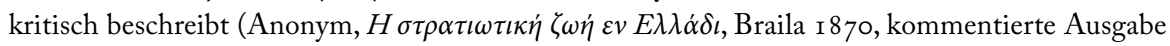
von Mario Vitti Athen 1970) wird ohne weitere Erklärung angegeben, daß der Erzähler in das »obere« Kaffeehaus gegangen sei, wo fast jeden Abend Schattentheatervorführungen stattgefunden hätten (I07).

887 Der Redaktor der Zeitung »Eúßoı « (Nr. I97, 24. Io. I879, Fotiadis, op. cit., 84) besucht die traditionelle Vorstellung "Hamam« und beschreibt sie folgendermaßen: die Vorstellung findet im jüdischen Viertel statt, vorgestern sei die »Schöne Sirene« gegeben worden (wahrscheinlich »Alexander d. Gr. und die verfluchte Schlange«). In der nächsten Nummer wird er Augenzeuge des $\mathrm{Pu}$ blikumszulaufes in den Nebelschwaden der Nargileh-Pfeifen, Männer aus allen gesellschaftlichen Klassen, auch Bauern, die zum erstenmal ein »Theater« sehen und fortwährend laut lachen, Türken, Juden und Christen; der Redaktor unternimmt einen eher ungenügenden Versuch, das Schauspiel zu beschreiben, denn die Rauchschwanden vertrieben ihn rasch aus dem »lehrreichen Schauspiel«

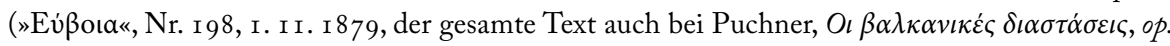
cit., 36-39).

888 I 864, im Jahre der Parlamentsauflösung, vermerkt die Athener Zeitung »Avүฑ่« (20. I I. I 864, Fo- 
Nach der Jungtürkischen Revolution und dem Auseinanderfallen des Großreiches setzt in den verschiedenen Provinzen des Osmanischen Reiches ein Verfallsprozeß der Schattentheatervorstellungen ein, der am Quellenbefund deutlich abzulesen ist. Die tieferen Ursachen für den Regreß liegen in der Tatsache, daß das Schattentheater nun, im 20. Jh., keinen Spiegel einer existierenden regionalsozialen Wirklichkeit mehr darstellt. Das betrifft vor allem die Länder der nordafrikanischen Mittelmeerküste des Maghrib (Ägypten, Libyen, Tunesien, Algerien), wo das osmanische Karagöz-Spiel im Laufe des I 8. und I9. Jh.s eingeführt wurde ${ }^{889}$; Karagöz war auch hier phallisch, bis ins 20. Jh. hatten die Vorstellungen intensiv politisch-satirische Funktion ${ }^{890}$. Charakteristisch ist eine Autopsie in Tripolis 1955: Die Leinwand ist nun klein $(50-70 \mathrm{~cm})$, von wenigen Kerzen beleuchtet, die Figuren sind nicht mehr farbig, die Vorstellung dauert bloß noch I 5 Minuten und wird ohne Musikbegleitung ausgeführt; Prolog und göstermelik (das kunstvolle Szenarium) fehlen, im Publikum sitzen nur noch Kinder ${ }^{891}$. Doch auch im rumänischen Puppentheater des vicleim, wo die Assimilation tiefer zu gehen scheint, sind die Zusatzfiguren mit lebendigen Schauspielern im 20. Jh. nicht mehr nachzuwei-

tiadis, op. cit., 84 f.) ironisch, daß die Hauptstadt noch ein zweites "Melodram« (neben der italienischen Oper) erhalten habe; die Eröffnung sei notwenig gewesen, weil das andere »Theater« (das Parlament) geschlossen worden sei, nämlich die Eröffnung des Karagöz-Theaters, wo »zuhöchst

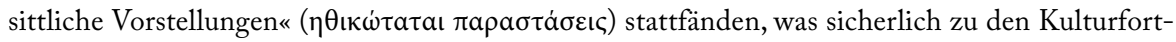
schritten des I 9. Jh.s zu rechnen sei.- Ein auf die Vergangenheit bezogener Artikel von Babis Anninos I 888 hebt die Obszönität des Schauspiels hervor und bezeichnet es als Erbe der Osma-

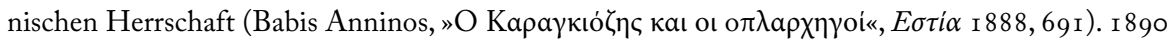
wird den Offizieren verboten, sogar in das im Vergleich völlig harmlose Puppentheater zu gehen

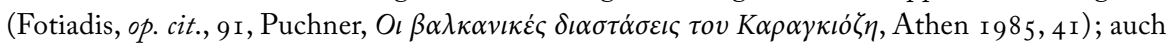
die Verbote der folgenden Jahre weisen darauf hin, daß Karagöz immer noch in der »unzüchtigen« Art gespielt wird (vgl. das Quellenmatrial bei Fotiadis, op. cit., 336 und Hatzipantazis, op. cit., 39 ff.). Erst die Reformen in Patras um I 890 entschärfen das obszöne Schauspiel durch die Abschaffung der phallischen Figurenteile und Witze.

889 Auswertung und Auflistung der Quellen in Walter Puchner, »Schwarzauge Karagöz und seine Geschichte auf der Balkanhalbinsel zur Zeit der Türkenherrschaft«, Beiträge zur Theaterwissenschaft Südosteuropas und des mediterranen Raums, 2 Bde., Wien/Köln/Weimar 2006/7, I 97-1 32, bes. I $20 \mathrm{f}$.

89 o So z.B. gebrauchte er sein überdimensionales Organ manchmal als Waffe gegen die Franzosen. Später ist dieses phallische Element nicht mehr nachzuweisen.

89. Wilhelm Hoenerbach, Das nordafrikanische Schattentheater, Mainz I959, 38 ff. Doch das Gravierendste ist die Aufweichung und Assimilierung der dialektischen Stereotypfiguren, die einen inneren Auflösungsprozeß markieren: Neben Karagöz und Haçivat erscheinen an Dialektfiguren nur der christliche Malteser, der Beduine, der Neger als Musikant, der Ägypter und einige andere; den brutalen Stückschluß der unilinearen Episodenreihe gibt Baba Hwaneb (funktionsgleich mit dem Tuszus Deli Bekir). Der osmanische Karagöz hat in der Region keine tiefere Integration erfahren und die Spuren der Assimilation bleiben oberflächlich und temporär. 
$\operatorname{sen}^{892}$. Als einzige Ausnahme im Niedergang des traditionellen osmanischen Schattenspiels nach dem Auseinanderfallen des osmanischen Großreiches steht der hellenische Kommunikationsraum da, dem es gelang, durch die Kreation von neuen Dialekttypen, die existierende soziale Realität widerspiegeln, Stückkategorien zu kultivieren, die die patriotische Mentalität des Publikums affiziert haben bzw. an autochthonen Traditionen wie die Sagen um Alexander den Großen und die Legenden um den H1. Georg anknüpfen sowie aktuelles Geschehen in die improvisierten Stücke einarbeiten.

Doch die Hellenisierung des osmanischen Spieltyps dürfte stufenweise vor sich gegangen $\operatorname{sein}^{893}$. Noch vor den entscheidenden Reformen von Mimaros in Patras um

$892 \mathrm{Vgl}$. wie oben.

893 Zur heute über I 200 items umfassenden Bibliographie des neugriechischen Schattentheaters vgl.

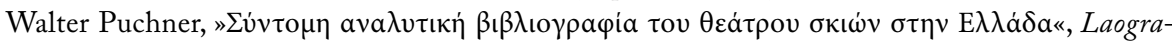

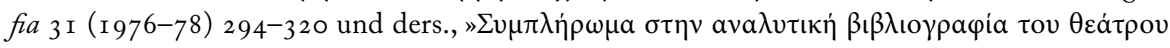

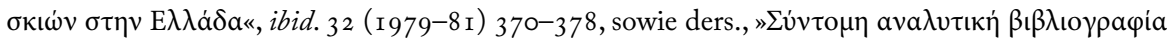

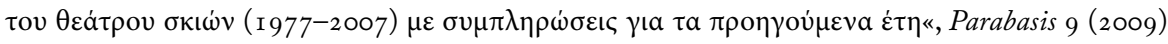
425-498. Vgl. auch die Bibliographie der gedruckten Spielheftchen, das Lexikon von I 45 namentlich bekannten Karagiozisspielern sowie das Stückrepertoire mit 264 Titeln in Walter Puchner, Das neugriechische Schattentheater Karagiozis, Diss. Wien 1972, dann München 1975 (Miscellanea Byzantina Monacensia 2 I) und mit neuer Einleitung, Nachwort und Bibliographie-Ergänzung sowie Register Wien 2014 (Don Juan-Archiv, Ottomania 2). In Auswahl: Louis Roussel, Karagheuz ou Le Théâtre d'Ombres à Athènes, 2 Bde., Athènes I 92 I, Giulio Caimi, Karagheuz ou la comédie grec

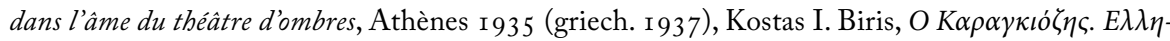

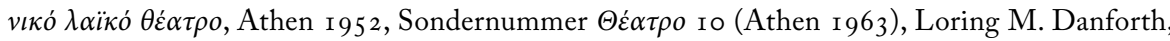
Greek Shadow Theatre: A Metasocial Commentary, Master's Thesis, Princeton I 974, ders., „Humour and Status Reversal in Greek Shadow Theatre", Byzantine and Modern Greek Studies 2 ( 1976) 99-

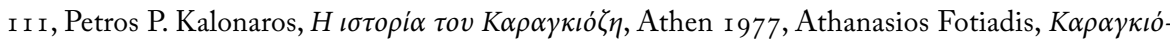

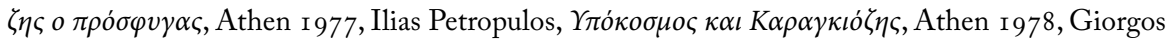

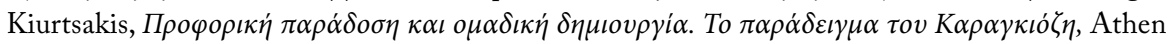

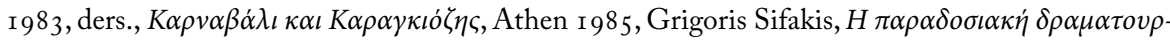

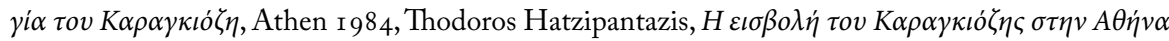
Tov I 890, Athen 1984, Loring M. Danforth, "Tradition and Change in Greek Shadow Theatre«, Journal of American Folklore 96/38 I ( I 983) 28 I-309 (auch in Damianakos, Théatre d'ombres, op. cit., I 59-I 88), Linda M. Myrsiades, »The Femal Role in the Karaghiozis Performance«, Southern Folklore Quarterly 44 ( 1980) I45-I63, dies., "Oral Composition and the Karaghiozis Performance", Theatre Research International 5 ( 1980) 107-1 2 I, dies., "Theatre and Society: Social Content and Effect in the Karaghiozis Performance«, Folia Neohellenica 4 (Amsterdam 1982) I 47-1 57, dies.,

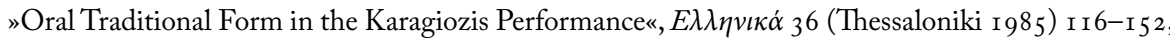
dies., "The Karagiozis Performance in Its Performative Context: the Rural/Urban Dichotomy», Modern Greek Studies Yearbook 4 ( I 988) 5 I-8 I, dies./Kostas Myrsiades, Karagiozis: Culture and Comedy in Greek Puppet Theater, Lexington 1992, Anna Stavrakopoulou, Variations on the Theme of Marriage in the Karaghiozis Recorded Performances of the Whitman-Rinvolucri Collection, Ph. d. Diss. Harvard Univ. Cambridge/Mass I994, dies., »Marriage: Recomposing a Ritual in Shadow 
I $890^{894}$ und der Erfindung der beliebten Figur des Barba-Giorgos durch Giannis Ru$\operatorname{lias}^{895}$, welche die Grundlage des enormen Erfolges des Schattentheaters in allen Bevölkerungsschichten in Griechenland von r 900-1 930 ausmachen ${ }^{896}$, nach der Annexion des südlichen Epirus an Griechenland, tauchen in west- und mittelgriechischen Städten Karagiozis-Spieler auf ${ }^{897}$, die einen unterschiedlichen Spieltypus pflegen als den »anatolischen« der Hauptstadt ${ }^{898}$. Im Verein mit der Entstehungslegende der griechischen Spieltradition durch den Hebräer Jakob am Hofe Ali Paschas ${ }^{899}$ entstand die These von der sogenannten epirotischen Tradition, die die erste Stufe der Assimilation des anatolischen Schauspiels an die neugriechische Tradition bilden soll ${ }^{900}$ : im noch osmani-

Theatre Performance«, in: Panagiotis Roilos/Dimitris Yatromanolakis (eds.), Greek ritual poetics, Washington, Center of Hellenic Studies 2005, 297-307, Moschos Morfakidis, Karaguiosis. El teatro des ombras griego, Granada I 999 usw.

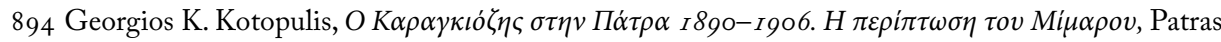

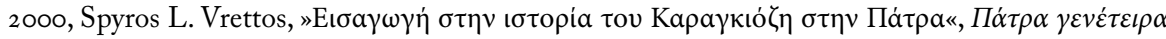

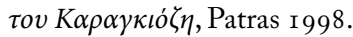

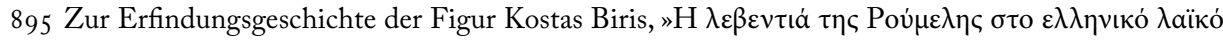

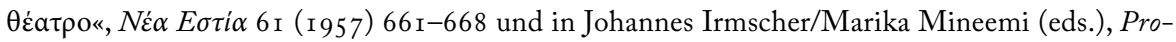
bleme der neugriechischen Literatur, Bd. IV, Berlin 1959, 209-222. Zur ambivalenten Funktion der Figur und den gemischten Gefühlen, die sie beim Publikum erweckt, zwischen Spott über das hinterwäldlerische Berglertum, die Naivität und Unangepaßtheit bezüglich der hauptstädtischen Sitten, und Bewunderung für die Mannhaftigkeit und Furchtlosigkeit des Rumelioten, der Verkörperung des Mannesideals der leventia, die als Kämpfer für den griechisch-türkischen Krieg von I 897 gebraucht werden, vgl. Puchner, Das neugriechische Schattentheater, op. cit., 84-87. Vgl. neuer-

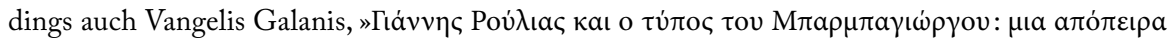

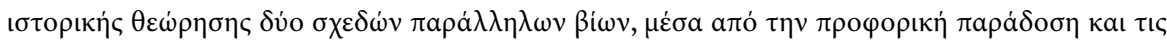

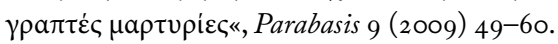

896 Vgl. Walter Puchner, »Greek Shadow Theatre and its Traditional Audience: a Contribution to the Research of Theatre Audience«, Stathis Damianakos (ed.), Théatres d'ombres. Tradition et Modernité, Paris 1986, 199-2 16.

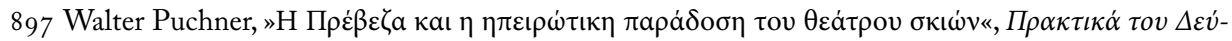

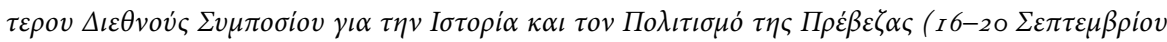
2009), Preveza 2010, 393-397.

898 In Arta, Metsovo, Amfilochia, Grevena und Farsala, aber auch weiter südlich in Agrinio, Meso-

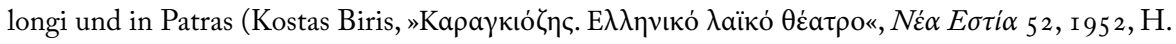
604, I 28 ff.). Unter diesen Spielern befindet sich der genannte Rulias sowie Liakos Prevezanos, der als erster die Vorstellung »Alexander der Große und die verfluchte Schlange« mit drei neuen Figuren spielte: Alexander dem Großen, Antiochos von Makedonien und Sirene, eine Neuerung, die die erste wesentliche Bindung des anatolischen Schauspiels an die neugriechische Volkskultur bildete.

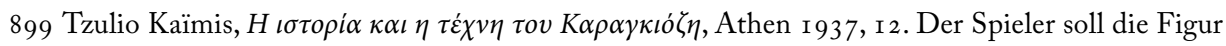
des legendären Paschas nach seinem Tod auf die Leinwand gebracht haben.

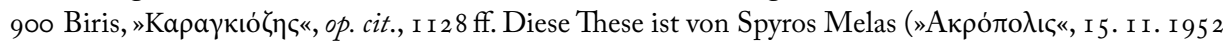


schen Epirus wird offenbar im Laufe des I 9. Jh.s der legendäre Pascha, der Aufstand der Sulioten und der ganze Themenzyklus um existente und imaginäre Waffenführer und Helden der Revolution von I 82 I auf die Bühne gebracht ${ }^{901}$. Die These scheint nicht ganz aus der Luft gegriffen zu sein, wenn man allein an die Literatur denkt, die den verhaßten und abtrünnigen Pascha umgibt, und die Tatsache, daß die Schattentheatervorstellungen auf der Balkanhalbinsel von Nicht-Muslimen, nämlich Roma, Hebräern, Armeniern und Griechen gegeben werden, die sich sprachlich an das jeweilige Publikum anpassen können. Die sogenannten »heroischen« Vorstellungen, wo die lustigen Figuren rund um Karagiozis und Hatziavatis nur eine Kontrafaktur-Handlung zur ernsthaften Haupthandlung bilden, die mit dem Martyrium eines der Revolutions-Helden enden, inspiriert von der Flut von patriotischen Dramen im Laufe des I 9. Jh.s ${ }^{902}$, dürften demnach einen Zwischentyp im Prozeß der Hellenisierung bilden ${ }^{903}$.

Vielleicht noch wesentlicher für den Integrationsprozeß der osmanischen Vorstellung in den griechischen Kulturhorizont war jedoch die Kreation der »mythischen« Vorstel-

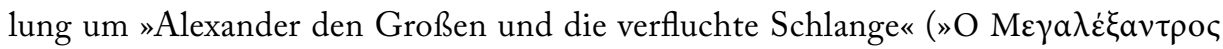

und Grigoris Sifakis (op. cit., I 8 f.) angezweifelt worden, weil ein solches Schauspiel nach dem gewaltsamen Tode von Ali Pascha nicht quellenkundig sei.

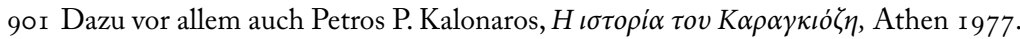

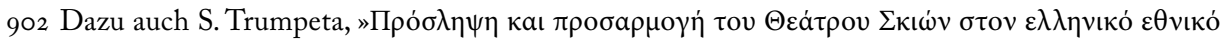

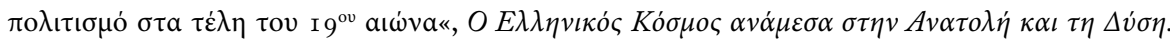

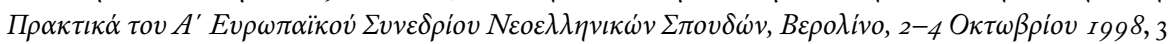
Bde., Athen I999, I 383-393. Zur patriotischen Dramatik Walter Puchner, Die patriotische Dramatik im I 9. Jahrhundert", Von Herodas zu Elytis. Studien zur griechischen Literaturtradition seit der

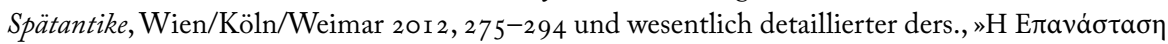

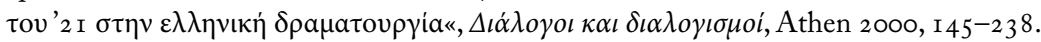

903 Diese Vorstellungen werden mit größeren Figuren gespielt, weisen eine komplexere Episodenreihe auf, die bereits die Dramatik nachahmt, verfügen meist über ein Finale mit bengalischen Lichtern und waren beim Publikum überhaus beliebt. Zur differenten Stückstruktur und den literarischen

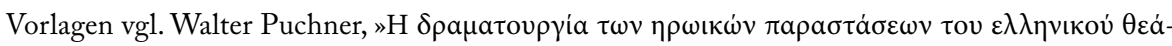

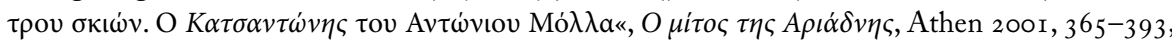

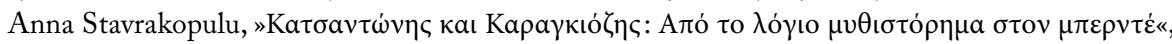

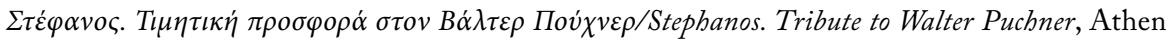
2007, I I73-I I 82. Zu diesen Vorstellungen auch Linda S. Myrsiades, "Nation and Class in the Karaghiozis History Performance«, Theatre Survey I 9/I (1978) 49-62, dies., »Traditional History and Reality in the View of the Karaghiozis History Performance «, Modern Greek Studies Yearbook I (I 985) 93-I07, dies., »Historical Source Material for the Karaghiozis Performance«, Theatre Research International Io/3 (1985) 2 I 3-225, dies./Kostas Myrsiades, The Karagiozis Heroic Performance in Greek Shadow Theater, Hanover 1988. 


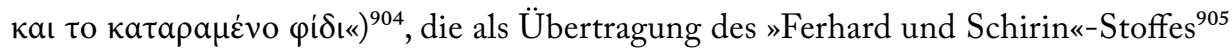
gleich mehrere Stränge der neugriechischen Volkstradition vereinigt: die schriftliche und mündliche Alexandersage in ihrer balkanischen Verbreitung ${ }^{906}$, das Märchen vom drachentötenden Helden (AT 300 $)^{907}$, der neben dem Königssohn auch anonym sein kann, und das H1. Georgslied ${ }^{908}$ und die orthodoxe Georgs-Ikone, die die Drachentötung darstellt ${ }^{909}$. Die Episodenstruktur des Stückes kreist um das Zentralmotiv des wasserabsperrenden Drachen (eine vielösige Schlangenfigur mit breiter morphologischer Ausgestaltungsmöglichkeit, nach Maßgabe der Tatsache, daß der Drache in der griechischen Volksdämonologie von der byzantinischen Ikonographie der Paradiesschlange beeinflußt ist ${ }^{910}$ und sowohl mit dem Draken als auch dem »Ungeheuer « im allgemeinen kontaminiert) ${ }^{911}$ :

Der Pascha läßt durch Hatziavatis ausrufen, daß derjenige, der das Ungeheuer tötet, seine Tochter zur Frau bekommt. Im Rachen des Ungeheuers verschwinden nach und nach alle Figuren des Ensembles, nur seinen Onkel Barba Giorgos warnt Karagiozis, daß er diese Schlange nicht einfach unter seinem Stiefel zerquetschen könne. Den dramatischen Höhepunkt bildet der Held Alexander, dessen Kopf schon zwischen den Bühnenzähnen des Monsters steckt, während er noch eine Hilfe-Arie an die Mutter

904 Ein Spieltext nun auch im Englischen zugänglich bei Linda Myrsiades, »The Alexander play in Greek shadow puppet theater", The Charioteer I 9 ( 1977) I 8 f. und die Textübersetzung von K. \& L. S. Myrisades, »M. Xanthos, The Seven Beasts and Karagiozis«, ibid., 20-49.

905 Herbert W. Duda, Ferbâd und Schîrîn. Die literarische Geschichte eines persischen Sagenstoffes, Prag r 933, Emmanuel Zakhos-Papazahariou, »Les Origines et Survivances Ottomanes au Sein du

Théâtre d'Ombres Grec«, Turcica 5 (1975) 32-39.

906 Vgl. Puchner, Die Folklore Südosteuropas, op. cit., 97.

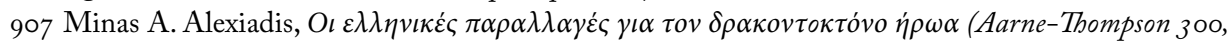
зо $A$ к $\alpha$ І зо I $B)$, Ioannina 1982 .

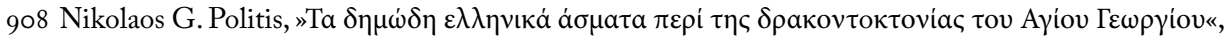
Laografia 4 (1 1 1 2/1 3) I 85-235, Karl Krumbacher, Der heilige Georg in der griechischen Überlieferung, München I 9 I I, J. B. Aufhauser, Das Drachenwunder des Heiligen Georg in der griechischen und lateinischen Überlieferung, Leipzig I 9 I I, Wolfgang Haubrichs, Georgslied und Georgslegende im frühen Mittelalter, Königstein/Ts. I980, T. Koleva, »Typologie de la fête de Saint-George chez les slaves du Sud«, Études balkaniques I 977/I, I66-I 2 I, Georgios Spyridakis, »Saint-George dans la vie populaire«, L'Hellénisme contemporain 6 (I 952 ) I 26-I 45, Gabriella Schubert, »Der H1. Georg und der Georgstag auf dem Balkan«, Zeitschrift für Balkanologie 2 I/I (1 985) 80-105.

909 Thomas Raff, „Der heilige Georg als Knabenretter«, Münchener Zeitschrift für Balkankunde 3 (I980) I 83-196, Leopold Kretzenbacher, Griechische Reiterheilige als Gefangenenretter, Wien I 983.

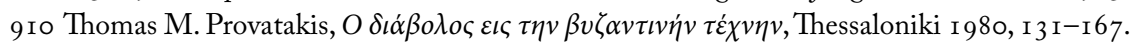

9I I Inez Diller, »Vom Draken, einer dämonischen Figur im griechischen Volksmärchen«, Vom Menschenbild im Märchen, Kassel I982, I I 7-I 20, Michalis G. Meraklis, „Drache und Drake. Zur Herkunft einer neugriechischen Märchengestalt«, Märchenspiegel 5/2 (1994) 5-8. 
Gottes singt, als ihm Karagiozis auf einer Leiter mit der Gießkanne zu Hilfe eilt und die Wut des Ungeheuers kühlt. Doch dann nimmt das Heldentum seinen konventionellen Lauf. Karagiozis gibt sich als Bezwinger des Ungeheuers aus und schlemmt bei der Siegesfeier im Serail. Es erscheint jedoch der richtige Held und verzeiht ihm großmütig ${ }^{912}$.

Diese meistgespielte Vorstellung bildet eine autochthone griechische Kreation, die mehrere traditionelle Quellenbereiche kombiniert, welche nicht nur der städtischen sondern auch der agrarischen Volkskultur angehören: vom Drachenmärchen und der Alexandersage bis zum Georgslied und der byzantinischen Ikonographie ${ }^{913}$.

Der neue Figurenkanon, den der Kirchensänger Dimitris Sardunis, genannt Mimaros, und andere um I 890 in Patras auf der Grundlage des osmanischen Karagöz kreiert hat ${ }^{914}$, wobei manche Dialektfiguren aus dem Komödienrepertoire des dramatischen Theaters des I 9. Jh.s stammen ${ }^{915}$, von wo auch manche thematischen Sujets stammen, stellt eine Art Sprachatlas der griechischen Dialektologie dar und reflektiert eine andere soziale Realität, nicht mehr in den Grenzen der traditionellen osmanischen multiethnischen mahalle, sondern in der Territorialität des im Laufe des r 9. Jh.s anwachsenden Nationalstaates Hellas. Aufgrund dieser unmittelbaren Spiegelfunktion wird das Schattentheater zur beliebtesten Volkstheaterform zwischen I 900 und I $930^{916}$. Neben dem sexuell »entschärften « Karagiozis ${ }^{917}$ und seinem Freund Hatziavatis, aus dem os-

91 2 Zum Motiv des falschen Drachenhelden und seiner Beweise Leopold Schmidt, »Sichelheld und Drachenzunge«, Fabula I (1958) 19-25, Wolfgang Hierse, Das Ausschneiden der Drachenzunge und der Roman von Tristan, Diss. Hannover 1969.

91 3 Zur Symbolbedeutung dieser Vorstellung auch Zakhos Siaflekis, »Transmission et transformation d'un symbol culturel dans le théâtre d'ombres grec: le cas d'Alexandre le Grand et le Dragon maudit«, Damianakos, Théatre d'ombres, op. cit., 229-247.

914 Zum Vergleich der osmanischen und griechischen Stücke vgl. Aikaterini Mystakidu, Karagöz. To

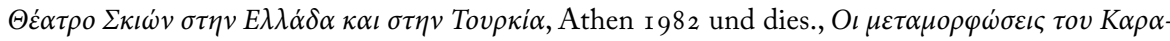

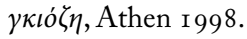

91 5 Zum Gebrauch der Regionaldialekte in der griechischen Komödie des I 9. Jh.s vgl. Walter Puch-

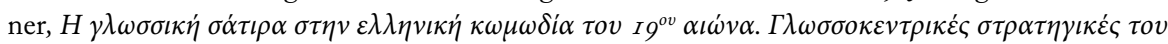

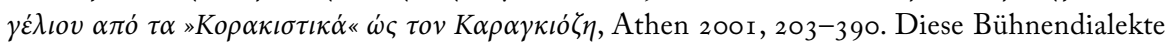
entsprechen nicht unbedingt den tatsächlich bestehenden regionalen Sprechgewohnheiten, sondern reproduzieren bloß gewisse charakteristische Merkmale, die für das Publikum Signalfunktion haben; die Tradition dieser »Theaterdialekte« wird von den Schattenspielern mehr oder weniger übernommen. Vgl. auch Walter Puchner, »Griechische Sprachsatire im bürgerlichen Zeitalter«, Von Herodas zu Elytis, op. cit., 295-422, bes. 348-4I 2.

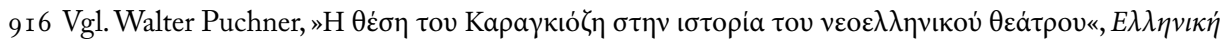

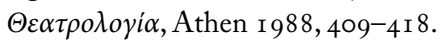

917 Zur Charakterisierung dieser Identifizierungsfigur des Schattentheaters seien die Worte eines der berühmtesten Spielers, Antonios Mollas, zitiert: „Er ist vollkommen der Typ des Mannes aus dem 
manischen Spieltyp übernommen, waren es vor allem Barba Giorgos aus dem gebirgigen Rumelien, unangepaßter Provinzler in der Stadt und zugleich Verkörperung des traditionellen Mannesideals, Stavrakas, der hasenherzige Macky Messer aus der Athener Unterwelt, Sior Dionysios oder Nionios von den Ionischen Inseln, der türkische Ordnungshüter Dervenagas, die Frau des Karagiozis Aglaia und seine drei Söhne (kollitiria), die den neuen sozialen Umraum widerspiegelten; weitere Dialektfiguren sind der Hebräer, der Kreter Kapetan Manusos, das Muttersöhnchen Omorfonios mit der riesigen Nase usw. Das stereotype Bühnenbild bildet weiterhin der türkenzeitliche Serail auf der einen und die windige Hütte des Karagiozis auf der anderen Seite. Pascha und Wezir sind ernsthaft und gerechte Figuren ${ }^{918}$. Viele der Stücke sind aus dem osmanischen Repertoire übernommen, zugleich werden aber auch neue kreiert, die auch zeitgenössische Aktualität verarbeiten, wie z.B. der Komet von Halley (I 9 I I), politische Satiren gegen Mussolini und Hitler, Karagiozis als Astronaut usw.; auch moritatenartige Motive wie Blutverbrechen werden erfolgreich bearbeitet (»Der Tod des Athanasopulos»

Volke. Die Hauptfigur der Schattenbühne, Witzbold, Sänger, gutes Herz, Patriot, Politiker, Etymologe, Verliebter des Schönheitswahns, während er in unvorstellbarem Grade häßlich ist. Einmal ist er reich, einmal ist er arm, einmal spielt er den Schwachkopf, einmal den Palikaren. Ein andermal führt ihn seine große Weisheit in den Wahnsinn, dann ist er naiv, dann wiederum ist er ein Betrüger und nachher beschützt er die Schwachen bis zur Aufopferung. Wo du willst, findest du ihn: im Serail, am Markt, in den Schlupfwinkeln der Verteidiger des Vaterlandes, in den Salons, in den Räuberhöhlen, auf der Straße, in Klöstern. Er wird Pascha, Sultan, Schiffbrüchiger, Soldat, Kriegsheld, Rechtsanwalt, Arzt, Diener, Koch, Diplomat. Der erste im Kampf, bei den Prügeln, in der Liebe. Der erste im Gefängnis, der erste in der Politik, der erste beim Hoch-Rufen, der erste beim Nieder-Rufen. Er ist überall, bei allen Bürgermeistern, bei allen Abgeordneten, bei allen Ministern. Einmal dagegen, ein andermal dafür. Aber trotz aller seiner Berufe, die er wechselt, ist er niemals satt, immer hungrig. Als man einmal wollte, daß er den Sultan spiele, fragte er: 'Essen die Sultane?' Er ist der vollkommene Typ des Romäers" (Walter Puchner, Das neugriechische Schattentheater Karagiozis, Wien 20I 4, 79). Es wird deutlich, daß Karagiozis weniger faktische als psychische Realität reflektiert. Seine Eigenschaften unterliegen einem ständigen Wechsel. Nur wenige Dinge bleiben gleich: sein Hunger, seine Untauglichkeit zu jeglicher Arbeit, obwohl er natürlich jegliche Arbeit annimmt. Aber auch sein Aussehen wechselt von Spieler zu Spieler, nur der Buckel, der riesige Kahlkopf mit der unbeschreiblichen Nase und dem funkelnden Schwarzauge ist unveränderbar. $\mathrm{Zu}$ seiner Unsterblichkeit und seiner Existenz als außergesellschaftliche life force vgl. auch Walter Puchner, »The Magic of Shadows. Small guide to Karaghizois«, Greek Shadow Theater: Light and history, Athens 2004, 17-27. Zu weiteren Charakterisierungsversuchen vgl. F. H. Aigner, Das neugriechische Schattentheater, Graz 1 963, 6 ff., Kaïmis, op. cit., 4, Evgenios Spatharis, »The comic substance of Karaghizois«, B. N. Sangh, Puppet theatre around the world, New Delhi 1960, I 57 f., Biris,

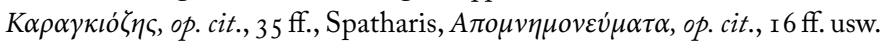

91 8 Nur in den sogenannten »heroischen« Vorstellungen um wirkliche und fiktive Anführer der griechischen Revolution von I 82 I bekommen die Türken feindliche Züge. 
um i 930). Die zu ergreifenden Berufe werden immer vielfältiger ${ }^{919}$, auch technische Verbesserungen sind zu beobachten ${ }^{920}$. Ab 1924 erscheinen auch die gedruckten Spielheftchen auf einem Druckbogen, die allerdings für ein Improvisationstheater eine zweifelhafte Quelle darstellen ${ }^{921}$. Der Zweite Weltkrieg bringt einen deutlichen Rückgang der Spieltätigkeit, die Wandlung des traditionellen Publikums durch das Vorherrschen von Kindern, Gebildeten und Touristen ${ }^{922}$ sowie Film und Radio führen zu Änderungen und Experimenten (antike Tragödien und Komödien, Karagiozis als pädagogisches Vorbild, Aufgeben der traditionellen Figuren ${ }^{923}$. Heute sind die Spieler in einer eigenen Vereinigung organisiert und bespielen auch außerhalb Griechenlands Zypern ${ }^{924}$, die Bundesrepublik, USA und Australien.

Die Detail- und Regionalforschung zu den seit I 900 über 200 namentlich bekannten Einzelspielern verzeichnet ein bedeutendes Forschungsdefizit ${ }^{925}$, das auf die Margina-

91 9 Die wichtigsten Stücksammlungen (auch Inhaltsangaben) sind: Louis Roussel, Karagheuz ou le Théâtre d'Ombres à Athénes, 2 Bde., Athènes I 92 I, Hans Jensen, Vulgärgriechische Schattenspieltexte,

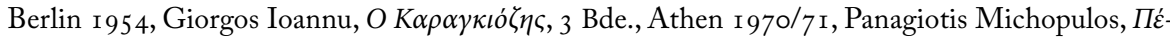

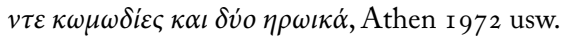

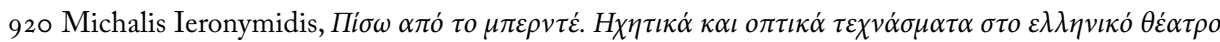

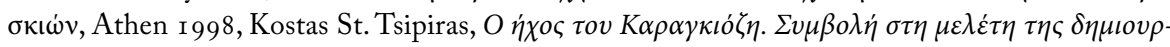

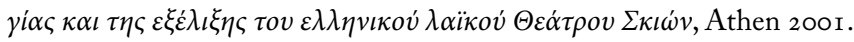

92 I Außer den ersten Serien und Reihen sind die Autoren meist auch keine Karagiozisspieler mehr. Zur Bibliographie veröffentlichter Stücksammlungen und Druckheftchen Linda Myrsiades, „Karagiozis. A bibliography of primary materials", Mantatoforos 2 I (Amsterdam 1983) I 5-42 und

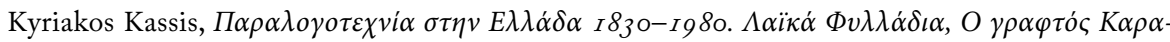

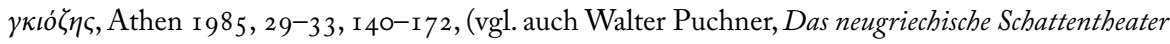
Karagiozis, München 1975, 22 I-236).

922 Walter Puchner, „Greek Shadow Theatre and its Traditional Audience: a Contribution to the Research of Theatre Audience«, in: Damianakos, Théâtre d'ombres, op. cit., I 99-2 I 6 und ders., "Le théâtre d'ombres grec et son auditoire traditionelle«, Cabiers de Littérature Orale 38 (I 995 ) I 25-I 43.

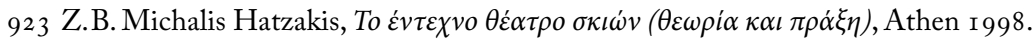

924 Wo sie auch auf türkische Spieler treffen (Mehmet Ortug, Gelenksel kıbris türk tiyatrosu, Birinci

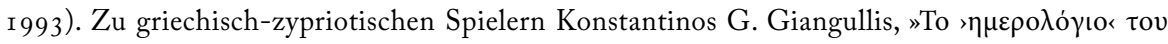

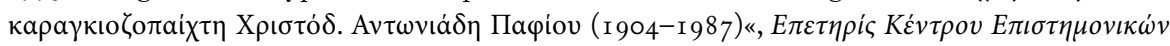

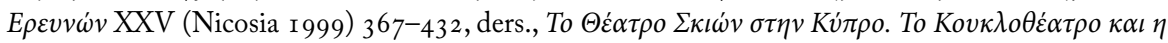

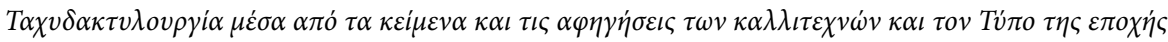

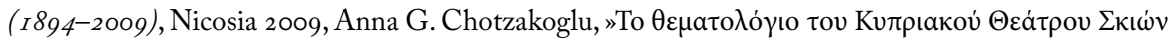

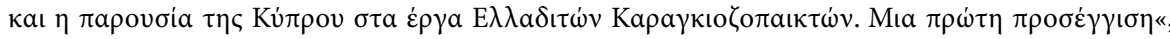

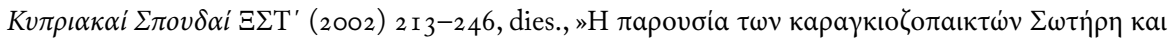

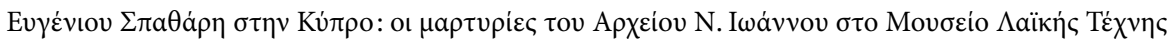

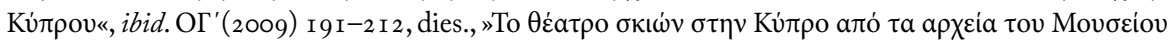

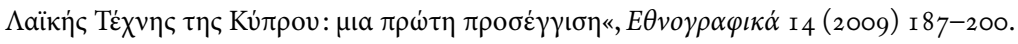

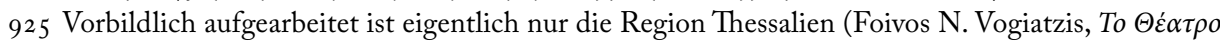


lität dieser prestigearmen Tätigkeit zurückzuführen ist, den niedrigen sozialen Status der Spieler, die Verachtung der Redakteure der Provinzpresse (die vielfach die einzige Quelle darstellt) für dieses fahrende Gewerbe, obwohl das soziologische Interesse an marginalen Unterschichten seitens der Intellektuellen und der Wissenschaft bedeutend gewachsen ist. Gewisse Themen wie die Reichweite der Varianz bei der gleichen Vorstellung (ev. auch beim gleichen Spieler) können wegen der beschränkten Anzahl an historischen Dokumentationen und des Mangels an Authentizität der rezenten Spieler kaum noch untersucht werden. Oralität ist zu einer kaum noch eruierbaren Rarität geworden.

\section{SONDERFORMEN DER PERFORMATIVITÄT A：SPIEL UND SPORT}

Der Spielbegriff als eine schwer einzugrenzende Fundamentalkategorie des menschlichen Handelns geht quer durch alle Kulturtheorien und Aktionssektoren ${ }^{926}$; sein Definitionsproblem ist aufzeigbar an dem schwer zu bestimmenden Gegenbegriff zum Spiel (Ernst, Handeln, Arbeit, Verantwortlichkeit, Konsequenzen, Utilitarismus usw. ${ }^{927}$. Die Dialektik von Spiel und Realität oszilliert zwischen Antithese und Synthese. Als eine ontologische Kategorie gefaßt $\mathrm{t}^{928}$ wird der Spielbegriff für die ethnologische Forschung mehr oder weniger unbrauchbar ${ }^{929}$. Heuristisch ist es sinnvoll, das Spiel im sozialpsycho-

$\Sigma \kappa \iota \dot{\omega} v \sigma \tau \eta \Theta \varepsilon \sigma \sigma \alpha \lambda i \alpha$, Karditsa 1995 und die Fortsetzung in $\Gamma v \dot{\omega} \sigma \eta \kappa \alpha \iota \Gamma v \dot{\omega} \mu \eta$ I 9, Karditsa 2006, I $73^{-260)}$.

926 Fast alle kulturtheoretischen Arbeiten zum Spielbegriff stehen in Auseinandersetzung mit dem schon vor dem Zweiten Weltkrieg entstandenen und epochemachenden Buch von Jan Huizinga, Homo ludens. Vom Ursprung der Kultur im Spiel, Hamburg 1956.

927 Ingeborg Heidemann, Der Begriff des Spieles und das ästhetische Weltbild der Philosophie der Gegenwart, Berlin I 968, 78. Resultat der Überlegungen ist, daß der Gegensatz zu Spiel nur ein gesetzter sein kann; »das Verhältnis von Spiel und Wirklichkeit impliziert, daß das Andere des Nicht-Spiels gesetzt ist « (78). »Spiel« umfaßt demnach die Wirklichkeit und ist gleichzeitig ihr Gegensatz. Zur Kritik dieses dialektischen Ansatzes siehe etwa Jürgen Hofmann, Theorie des Theatralischen als Wirkungskritik mimetischer Praxis, Diss. Wien I 970, XVIII.

928 Gadamer etwa (Hans-Georg Gadamer, Wabrheit und Methode. Grundzüge einer philosphischen Hermeneutik, Tübingen ${ }^{2}$ I 972, $97 \mathrm{ff}$.) berücksichtigt mehr den originär synthetischen als den antithetischen Aspekt. Das Spiel ist unabhängig vom Bewußtsein derer, die spielen. Es wird über die Spielenden Herr. »Das Subjekt des Spieles sind nicht die Spieler, sondern das Spiel kommt durch die Spielenden lediglich zur Darstellung« (98). Das Spiel spielt mit den Spielern und bringt zur Darstellung, was ist ( 107 f.) (siehe auch ders., „Verstehen und Spielen«, Kerygma und Mythos VI/I, Hamburg I 963, 69 ff.). Diese Gedanken hat Erika Fischer-Lichte in ihrer Performativitätstheorie der Theatervorstellung weiterentwickelt (Erika Fischer-Lichte, Ästhetik des Performativen, Frankfurt/M. 2004, dies., Performativität. Eine Einfübrung, Bielefeld 201 2).

929 Vgl. die Kritik der Ethnologie am homo ludens Huizingas. In Auswahl: Adolf E. Jensen, Mythos 
logischen Sinne von der ausdefinierten Alltagswirklichkeit der Erwachsenen im westlichen Kulturraum abzusetzen ${ }^{930}$ und ihm eigene Ordnungsfaktoren (Spielregeln) zuzugestehen; darüberhinaus ist es zielführend, organisierte Spielformen vom schöpferischen Alleinspiel des Kleinkindes zu unterscheiden ${ }^{931}$, wo die Bereiche Spiel und Wirklichkeit noch ineinander übergehen ${ }^{932}$. Die vor vielen Jahren versuchte und teilweise von der Forschung akzeptierte Definition des »konsequenzverminderten Probehandelns« weist in diese Richtung ${ }^{933}$; die Verminderung der Konsequenzen ist für Mitspieler und Zuschauer in die Spielkonvention, die Zeit und Raum aus der Alltagswirklichkeit wie beim Festritus heraushebt ${ }^{934}$, eingeschrieben und vom sozialen Kontext akzeptiert.

In den bisherigen Ausführungen war des öfteren von Spiel die Rede: Performanz, Kommunikation und Interaktion haben in den vorwiegend oralen Kulturschichten entweder praktisch-utilitaristischen Charakter in der Überlebensstrategie der Kommunität, rituellen oder spielhaften Charakter. Wenn man das einsame Kinderspiel der Philosophen (Heraklit) ${ }^{935}$ ausklammert, wo Wirklichkeiten aufgebaut und zerstört werden bzw. die Kommunikation nur über fiktive Interaktionspartner verläuft, wird es im Fol-

und Kult bei den Naturvölkern, Wiesbaden I95 I, 6 I-67, Roger Caillois, Die Spiele und die Menschen, Stuttgart I 960, 9 ff., und vor allem Volker Harms, Der Terminus "Spiel« in der Ethnologie, Diss. Hamburg I 969 , I ff., 43 ff., I 26 ff.

930 Peter L. Berger/Thomas Luckmann, Die gesellschaftliche Konstruktion der Wirklichkeit, Frankfurt 1 969, 28 ff. Spiel gehört aus dieser Sicht zu den »Inseln« in der Alltagswirklichkeit, wie Traum, Halluzination, Phantasie, Dichtung, ästhetisches und religiöses Erleben, philosophische Reflexion, Theater usw., wo die üblichen Verhaltensregeln, Normierungen und Denkmuster nur beschränkte Gültigkeit besitzen.

93 I Sozialpsychologie, Kinderpsychologie und Psychoanalyse haben z.T. emphatisch auf die Wichtigkeit des Spielens für Kind und Erwachsene hingewiesen (dazu Erik H. Erikson, Kindheit und Gesellschaft, Stuttgart ${ }^{4}$ I97 I, I 83 ff.). Beim Kind ist es Mittel der Ich-Beherrschung, beim Erwachsenen Abbau neurotischer Überidentifizierungen. »Das Spiel ist also eine Funktion des Ich, ein Versuch, die körperlichen und sozialen Prozesse mit dem Selbst in Einklang zu bringen« (206). "Kein Denker kann mehr tun und kein spielendes Kind weniger« (2 I 7 ).

932 Zur Ausfaltung des Spielbegriffes zwischen Möglichkeit und Wirklichkeit in Spiel und »Spiel«, einmal mit Einbeziehung der in der Kinderpsyche noch nicht ausgeformten und deshalb formbaren Alltagswirklichkeit der Erwachsenen und das anderemal in Kontrafaktur zu einer solchen vgl. Puchner, Brauchtumserscheinungen, op. cit., 347-35 I (mit weiterführender Literatur) und ausführli-

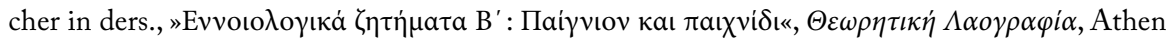
2009, 207-229.

933 Puchner, Brauchtumserscheinungen, op. cit., 347, aufgegriffen von Andreas Kotte, Theaterwissenschaft. Eine Einführung, Köln/Weimar/Wien 2005, 4I-43.

934 Vor allem Kerényi hat den Zusammenhang Kult - Spiel - Fest herausgestrichen (Karl Kerényi, »Vom Wesen des Festes«, Paideuma I, I 938-40, 59 ff.), zur Kritik W. Schmidt, »Spiele, Feste, Festspiele«, ibid. 4 ( I 950) I I-22.

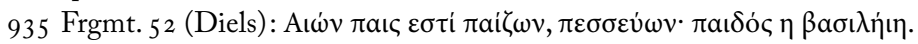


genden vorwiegend um Gruppenspiele mit Regelhaftigkeit und häufig körperlichem Einsatz gehen ${ }^{936}$, wobei die Möglichkeit des Zuschauens bzw. Mitspielens besteht und die Spieler der kompetitiven Beurteilung ihrer Leistung ausgesetzt sind. Eine spielhafte Komponente ist dabei vielen Performativakten eigen, ohne daß sie dabei ein »Spiel« im engeren Sinne konstituieren ${ }^{937}$.

Damit erweisen sich die organisierten Spielformen mit Gruppenbildung und spezifischer Regelhaftigkeit als eine Sonderform der Performativität, weil sich die Perspektiven des Spektators und des Akteurs, ähnlich wie in öffentlichen Kommunikationssituationen, aber ohne spezifische Regelbildung außerhalb der sozialen Wirklichkeit, überkreuzen: Mitspieler sind Zuschauer und Agierende zugleich, Produktion und Rezeption können zusammenfallen ${ }^{938}$. Unter den organisierten Spielformen sind die spezifischen Kinderspiele von den Erwachsenenspielen zu unterscheiden, welche vielfach eine sportliche und agonale Note besitzen. Dabei ist die Verwendung des Begriffes »Sport« ein bloßes Zugeständnis an den rezenten Sprachgebrauch, denn Sport im Sinne von Fitness, Körperhygiene und Gesundheitsstrategie bzw. als Leistungssport mit systematischer Vorbereitung und professionellem Training ist als Terminus und existierende Aktionsentität ein Phänomen des 20. Jh.s; in den Oralkulturen Südosteuropas ist das agonale Spiel vielfach noch an magische Glaubensvorstellungen rund um Fertilität und Eueterie (gutes Jahr) gebunden, neben den augenfälligen sozialen Funktionen der Unterhaltung und des Zeitvertreibs zu Festzeiten bzw. dem kommunalen Prestigegewinn der Sieger und eventuell der Performanz der Preisverleihung. Eine Sonderkategorie dieser sportlichen Darbietungen und Agonalspiele stellen die Reiterspiele dar, ob es nun um hippodromartige Pferdewettrennen geht, um Lanzenturniere wie giostra und barriera mit Kostümierung und einer gewissen Theaterhaftigkeit oder um Geschicklichkeitsläufe wie das Ringelstechen und correr all'anello.

Das überquellende Fallmaterial erlaubt nun nur noch in beschränkterem Umfang einen rein komparatistischen Zugang und eine konsequent sprachübergreifende Darstel-

936 Also weniger um Denkspiele, Rätselraten, Zungenbrecher, arithmetische Aufgaben, Zauberkunststücke, Glücksspiele, aber auch nicht um Kartenspiel und Brettspiele. Vgl. z.B. Tomas Malaby, Dealing in Indeterminacy: Gambling and Risk in Chania, Greece, Ph. D. diss. department of Anthropology, Harvard University 1997.

937 Als »Spiel« im weiteren Sinne wird in der einschlägigen Literatur auch jeder darstellende Brauch und performative Ritus bezeichnet, ähnlich wie in der anglophonen Sekundärliteratur der Ausdruck drama für ein sehr breites Phänomenspektrum eingesetzt wird.

938 Zur Überkreuzung von Zuschauer- und Darstellerperspektiven in alltäglichen Kommunikationssituationen vgl. Uri Rapp, Handeln und Zuschauen. Untersuchungen über den theatersoziologischen Aspekt der menschlichen Interaktion, Neuwied 1973, Erving Goffman, Self- Presentation in every day life, New York 1959 usw. 
lung, so daß eher auf systematisierende Kodifizierungen und selektive Übersichtsdarstellungen auf nationalsprachiger Ebene zurückgegriffen werden muß, was jedoch aufgrund der Typologisierbarkeit der Einzelerscheinungen methodisch gerechtfertigt erscheint.

Kinderspiel. Relative Einmütigkeit herrscht in der internationalen Fachliteratur über die sozialisierende Funktion des Kinderspiels und die Enkulturation durch den Prozeß des Erlernens der Spielregeln und ihrer Internalisierung ${ }^{939}$ (metaphorische Funktion) ${ }^{940}$; dieser Lernprozeß durch das Spielen reicht vom sozialen Rollenspiel bis zur Einübung von Lamentationsattitüden (vgl. wie oben) und religiösem Verhalten ${ }^{941}$. Hand in Hand damit geht die Beobachtung, daß der Kinderbrauch in vielen Fällen noch rituelle Manifestationen weitertradiert, die in der Welt der Erwachsenen eine Tendenz zur Regression bzw. zum völligen Verschwinden aufweisen ${ }^{942}$. Materialien liegen in einer weit verstreuten Fachliteratur aus ganz Südosteuropa vor ${ }^{943}$, auch gibt es einige Versuche einer Syste-

939 Charlotte Handman, »Can there be an Anthropology of Children«, Journal of the Anthropological Society of Oxford 4/I ( I 973) 85-99, John Newson/Elizabeth Newson, Toys and Playthings, Middlesex i 979, Helen Schwartzman, Transformations: the Anthropology of Children's Play, New York 1978, Brian Sutton-Smith, „Children's Folk Games as Customs«, Western Folklore 48/I ( 1 989) 33-42, A. James, Children's Games of Gender and Identity, University of Hull: Department of Sociology and Social Anthropology r 993, ders., Childhood Identities. Self and Social Relationship in the Experience of the Child, Edinburgh I 993, Katalin Horn, »Kind. Kinder«, Enzyklopädie des Märchens 7 (I 993) I 223-40, Uta Schier-Oberdorffer, Kinderspiel«, ibid. 7 (I 993) I 336-54, K. Rosengren/C. Johnson/P. Harris (eds.), Imagining the Impossible: Magical, Scientific and Religious Thinking in Children, Cambridge 2000 usw.

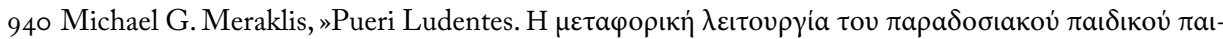

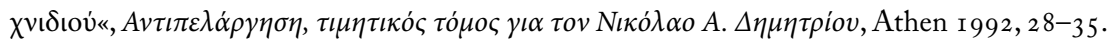

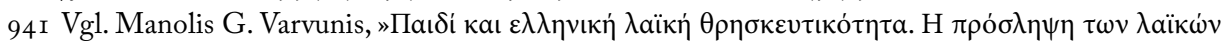

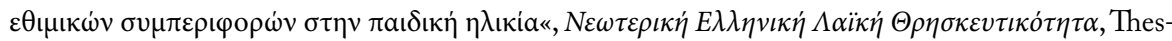
saloniki 2014,62 I-636.

942 So z.B. besteht die ungarische Pfingstkönigin-Wahl heute nur noch als Kinderspiel (Balassa/Ortytay, Ungarische Volkskunde, op. cit., 656).

943 Gyula Kerényi, Gyermekjdátékok, Budapest 195 I, Mária Kresz, A magyar gyermekjdáték-kututás, Budapest I 948, Paul G. Brewster, »Some Games from Southern Europe«, Midwest Folklore I (I 95 I) ı09-I I I, Paul G. Brewster/Jelena Milojković-Djurić, »Groups of Yugoslavic Games«, Southern Folklore Quarterly 20 (I956) I 83-I9I, Theodor Capidan, »Le jeu aux osselets chez les Roumains, les Slaves et les Albanais«, Revue internationale des études balkaniques I (I 934) 2 I I-23 I, Lazar Kostić, "Südslavische Volksschauspiele primitivster Art", Wissenschaftliche Mittheilungen aus Bosnien und der Hercegovina 3 (I 895) 533-538, Tihomir R. Đorđević, Srpske narodne igre, Beograd 1907, S. Zečević, Sprske narodne igre, Beograd I983, Marko K. Cepenkov, Makedonski narodni umotvorbi. Bd. ıо, Heft 9, Narodni veruvanja. Detski igri, Skopje r 972, Vesna Marjanović, Tradicionalne dečje igre u

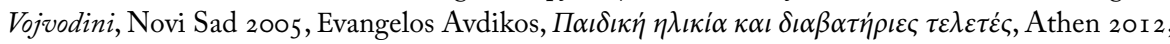
427-446, vgl. auch die Systematik der türkischen Kinderspiele von Pertev N. Boratav im 2. Band der Actes de bème Congrès d'Anthropologie, Paris 1964. 
matik, die jedoch an der schier uferlosen Phänomenologie und regionalen, ja individuellen Variabilität der Kinderspiele mehr oder weniger scheitern. Viele solcher Spielformen, wie etwa das Frühjahrsschaukeln der Mädchen ${ }^{944}$, das österliche Wasseranschütten ${ }^{945}$, der Orakelbrauch des klidonas zur Sommersonnenwende (Ziehen von Symbolgegenständen aus einem bedeckten Krug) $)^{946}$ oder die schon angeführten Dialogspiele, die auch agonalen Charakter haben, sind eng mit rituellen Handlungselementen und bezüglichen Glaubensvorstellungen an ihre magische Effektivität verbunden.

Stellvertretend für eine Systematik der südosteuropäischen Kinderspiele seien hier die einschlägigen griechischen Versuche zitiert ${ }^{947}$, von denen die Gruppenspiele besonderes Interesse aufweisen, da sie neben ihrer Performanz auch stereotype Strukturelemente enthalten (wie das Auslosen, verbales Spruchgut, das Abmessen von Distanzen, die Bestrafung der Verlierer ${ }^{948}$. Georgios A. Megas ${ }^{949}$ z.B. unterscheidet Solospiel

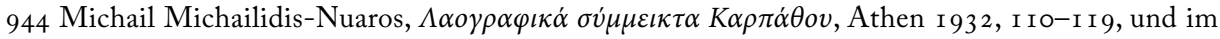

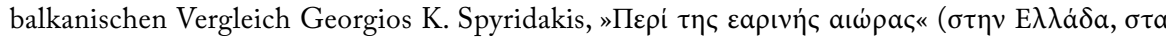

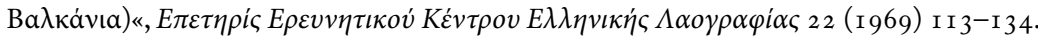

945 Von Ungarn bis Zypern. Vgl. auch das Regenmädchen (wie oben). Zu Zypern G. Cirili, »La fête

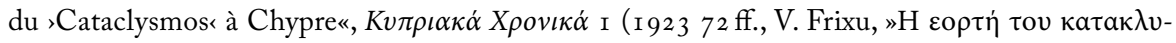

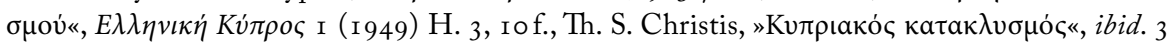

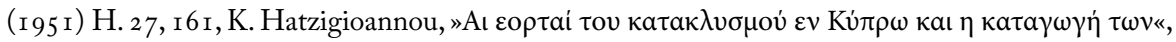

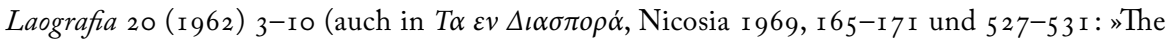

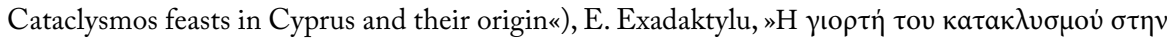

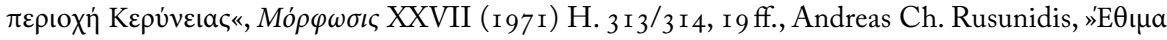

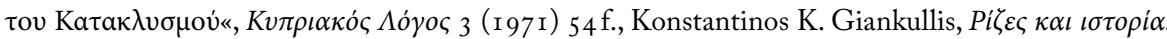

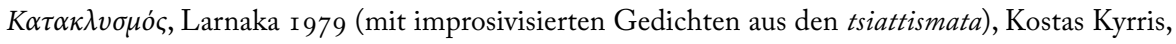

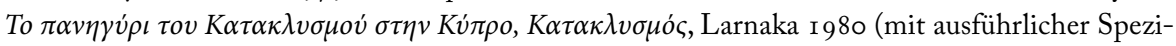

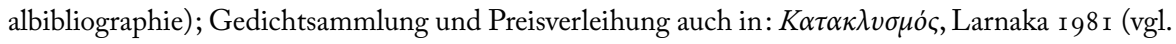
auch Maria Paraskevopoulou, Recherches sur les traditions des fêtes religieuses populaires de Chypre, $\mathrm{Ni}$ cosia I 978, 67-78). Zu den zypriotischen Volksdichtern (

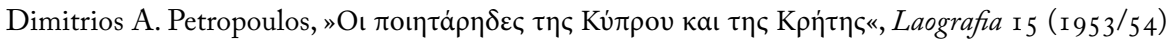

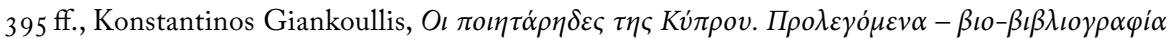

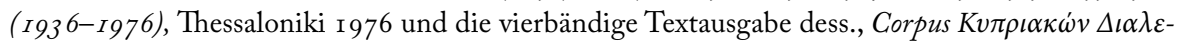

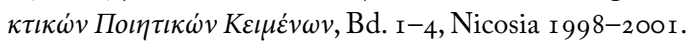

946 Vgl. im zweiten Teil.

947 Dimitrios Lukatos etwa unterscheidet nach dem Kriterium der Anzahl der Teilnehmer Einzelspiel (Drachensteigen, Puppe usw.) von Paarspielen (Ball, Schaukel, Ringen) und diese vom Gruppenspiel mit oder ohne Antagonismus (Sprung, Lauf, Rätsel, Schach, Steinschlacht), und separiert davon Formen sportlicher Disziplinen: Steinwurf, Ringkampf, Sprung, Lauf, Zielwurf (Zielschießen),

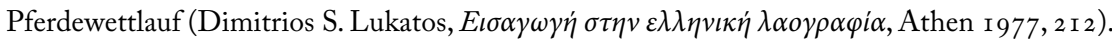

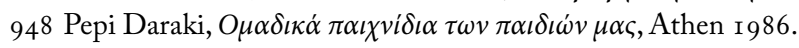

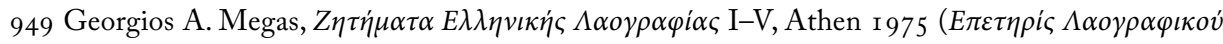
Apxeiov I939-49) I I 44-I 49. 
(Pferd, Kreisel, Adler, Kleinkinderspiel), von Gruppenspielen mit zwei oder mehr Teilnehmern (Puppenspiel ${ }^{950}$, performative Spiele ${ }^{951}$, Dialogspiele ${ }^{952}$ usw.) und davon antagonistische Spiele, wo entweder Muskelkraft oder Geschicklichkeit ausschlaggebend $\operatorname{sind}^{953}$. Die Gruppenspiele teilt er auch in Kategorien mit oder ohne Zielsetzung ein ${ }^{954}$. Diese Taxonomieversuche muten etwas hilflos an vor der unerschöpflichen Phantasie der Kinderspiele. Manche dieser Spielformen lassen sich schon im Altertum oder in Byzanz nachweisen ${ }^{955}$. Einschlägiges Fallmaterial ist in Arbeiten zur traditionellen Kinderkultur zu finden ${ }^{956}$, in Übersichten zum Kinderspiel ${ }^{957}$, regionale Arbeiten zur Kinderkultur ${ }^{958}$, in allgemeinen volkskundlichen Monographien zu Mikroregionen

950 Mit Thematiken wie Taufe, Heirat usw., Alltagssituationen in Haus, Hütte und Pferch u.a., Gebäude, Rollenspiele wie Mutter und Vater oder Taufpaten und Brautpaar, Situationen in Werkstatt und Geschäft (Krämer, Käufer und Verkäufer) usw.

95 I Die Kinder spielen Soldaten (Parade, Schlacht), Ente und Entlein, Huhn und Rabe, Schaf und Schäflein, Hinkender, Kreistanz usw.

952 Mit agonalen Elementen, z.B. »Wohin gehst du, Frau Maria? Du kommst nicht durch ...«, Spiele im Doppelkreis wie die oben in Epirus beschriebenen, Dialogspiele mit Repetition und Klimax, aber auch die Schaukel, traballa mit Liedern, körperliche Darstellungen wie der Schemel, das Schiff (Huckepack) usw.

953 Muskelkraft: Lauf, Sprung und Dreisprung, andere Sprünge, Steinwurf, Speerwurf, Schleuder, Ringkampf, Gewichtheben (Hände, Zähne), Tauziehen, Schwimmen und Spiele im Meer; Geschicklichkeit: Ballspiele, Zielschießen, Kugelspiele, Münzenwerfen, usw., aber auch Zungenbrecher, bis soo Zählen ohne Atemholen usw.; geistige Geschicklichkeit: Zahlen, Buchstaben, Fragespiele, Rätsel; Geschicklichkeit in der Nachahmung von Bewegungen oder der Bewegunglosigkeit (Stumm-Bleiben, Nicht-Lachen usw.).

954 Ohne Zielsetzung: Versteckspielen, Fangen, Blindenspiel, Katz und Maus usw.; mit Zielsetzung: z.B. Besiegen in der Steinschlacht.

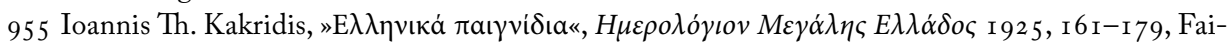

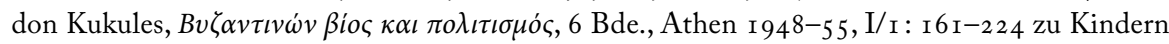
und Männern.

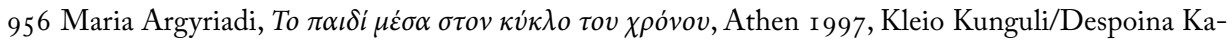

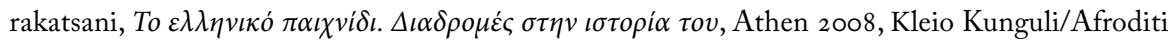

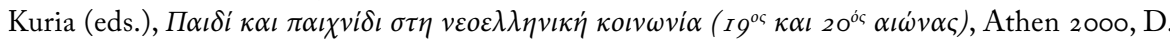
Makryniotis, Kó $\sigma \mu o \iota \tau \eta \varsigma \pi \alpha \iota \delta \iota k \eta ́ \varsigma ~ \eta \lambda \iota \kappa i \alpha \varsigma$, Athen ${ }_{2003}$, A. Chronopulu/K. Giannopulu (eds.), »To

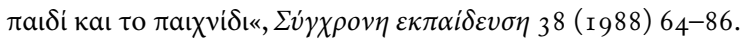

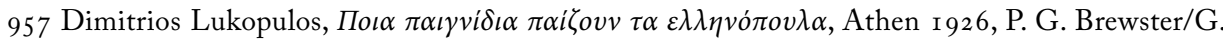

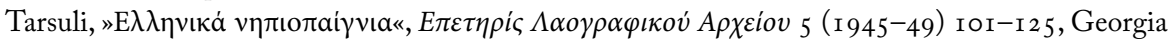
Tarsuli, $T \alpha \pi \alpha \iota \chi v i \delta ı \alpha \mu \alpha \varsigma$, Athen 1979.

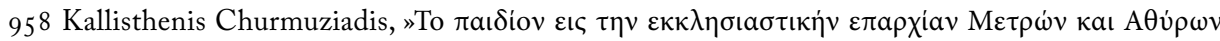

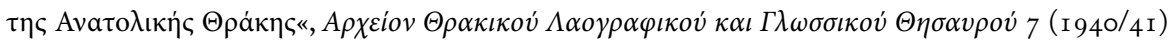

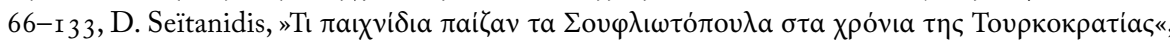

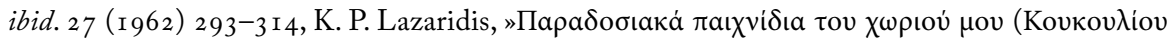

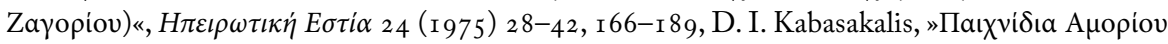


oder Orten ${ }^{959}$, viel Material ist auch in pädagogischen Zeitschriften und Sportperiodika gehortet. Dieses Material ist z.T. ungenügend aufgearbeitet und kodifiziert bzw. nach Kontext, Spielsituation, Regeln und Abweichungen, Namesformen und Lokalbezeichnung usw. untersuch $t^{960}$, so daß man immer wieder auf Spielformen trifft, die in den Übersichten nicht aufscheinen ${ }^{961}$. In diesen Arbeiten wird der Lernvorgang als Begleiteffekt des Spielens unterstrichen, das Kennenlernen der Natur (Pflanzen, Tiere), des näheren dörflichen Umraums, aber auch die Kultivierung des soziales Rollenspiels, vor allem beim Puppenspiel der Mädchen ${ }^{962}$. Diese ungenügend kodifizierte Morphologie läßt sich nun mutatis mutandis auch auf andere Regionen Südosteuropas übertragen ${ }^{963}$.

Agonales Spiel. In den Prolegomena seiner griechischen Übersetzung des Librettos "L'Olimpiade« von Pietro Metastasio (Wien i797) gibt der Visionär einer christlichbalkanischen Föderation der Untertanen des Osmanischen Reiches, Rigas Velestinlis, einen Hinweis auf das Weiterleben der Olympischen Spiele in der Volkskultur Südosteuropas: Von den olympischen Disziplinen sei noch der Wettlauf (mit oder ohne Pferd), der Ringkampf, der Steinwurf (Diskuswerfen), der (Drei)Sprung und das pankration (Kombination von Ring- und Faustkampf) in Thessalien und in ganz »Hellas« üblich ${ }^{964}$; mit Hellas ist nicht der heutige Staat Griechenland gemeint, sondern nach Maßgabe seiner berühmten Charta ein Großteil der Balkanhalbinsel ${ }^{965}$. Tatsächlich läßt sich diese

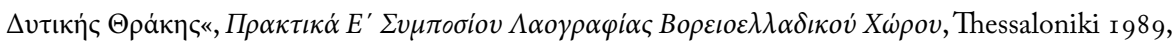
53-I04.

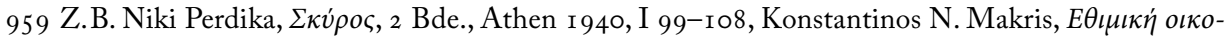

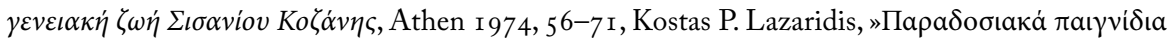

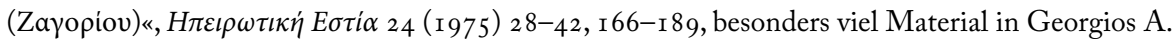

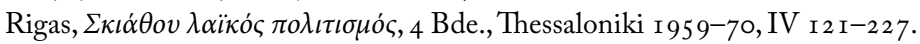

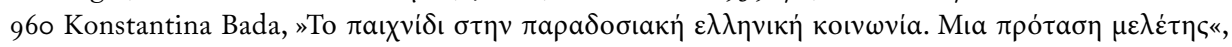

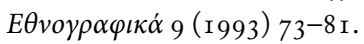

96r Z.B. Georg Eckert, Griechische Fadenspiele, Thessaloniki 1944.

962 Lazaridis, op. cit., I 86-г 88, Thanasis Kostakis, H Avakov́, Athen I963, I 25, Kukules, op. cit., I I 54 ,

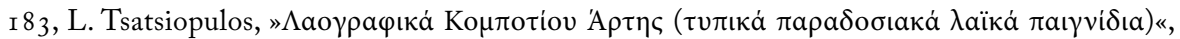

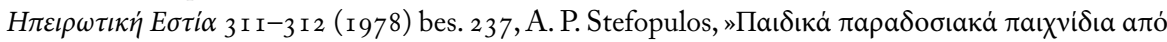

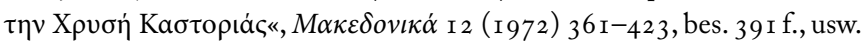

963 Balassa und Ortutay etwa führen für Ungarn Folgendes an: Spiele mit Rolle und Rollenwechsel, Fangspiele, Weiße Lilie, Blindekuh usw., auch Bewegungsspiele wie der ausschließende Kreis, die schreitende Kette mit Gefangennahme, Pfänderspiele usw. (Ungarische Volkskunde, op. cit., $650 \mathrm{off}$.).

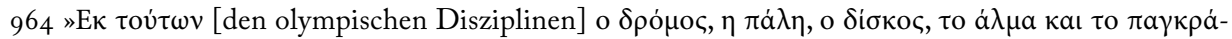

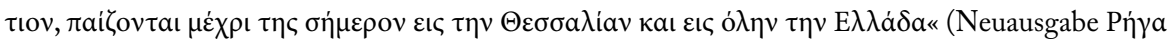

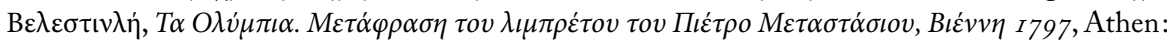
Urani-Stiftung 2000, ed. W. Puchner, S. I03).

${ }_{96}$ Zur Identifizierung der angeführten Städtenamen vgl. die Indices zur Charta von Dimitrios Kara- 
Diagnose quellenmäßig verifizieren: Formen des pentathlon und Einzeldisziplinen davon sind in komplexeren Performativritualen sequenzenartig integriert, wie z.B. beim köpek-bey im heute bulgarischen Ortaköy ${ }^{966}$ oder werden auch separat als Agonalspiele ausgetragen ${ }^{967}$, und zwar an verschiedenen Brauchterminen wie Zwölften, Karneval, am Sonntag des Ungläubigen Thomas ${ }^{968}$, am H1. Georgstag (23.4. . $^{969}$ und zu anderen Gele-

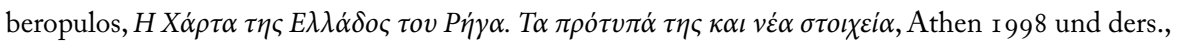

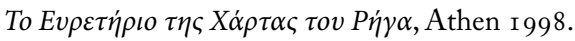

966 Am Ende des komplexen köpek-bey-Ritus werden fünfkampfartige Agone mit Jury ausgetragen: Weit- und Dreisprung, Steinwurf, Lauf, Ringkampf. Der Lauf wird dreimal auf einer kurzen Strecke wiederholt: An ihm nehmen nur der Araber und die kadina teil; sie gewinnt immer, weil sie ihn überlistet (früher wurden auch Pferderennen abgehalten). Im Ringkampf messen sich viele Paare. Zuletzt tritt ein Araber und die kadina an: Nach hartem Kampf wirft er sie auf den Rücken und schwängert sie vor allen Augen. Als Siegespreis kommen die Tücher, die der Bey gesammelt hat, zur Verteilung (N. Rodooinos, »Aтó $\tau \alpha$

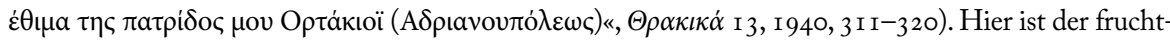
barkeitsmagische Kontext der Agone noch manifest. Zu diesem Ritus und seinen Agonen auch Mihail Arnaudoff, Die bulgarischen Festbräuche, Leipzig I9 7 7, 28 ff., ders., Folklore bulgare, Sofia 1936, I6 I ff., Richard Wolfram in R. Vogel (ed.), Die Volkskultur der südosteuropäischen Völker, München I 962, 66, Megas,

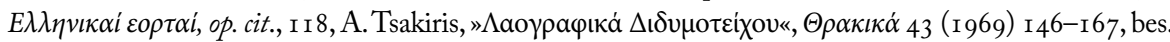

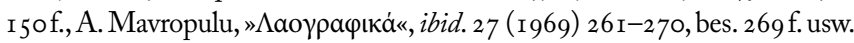

967 Dazu ein Beleg aus der Peloponnes um I796: „Der Faustkampf ist noch in Griechenland und in der ganzen Levante üblich; man sieht daselbst Leute, welche dem Publikum dieses Schauspiel für eine Belohnung geben. Sie legen ihre Kleider bis auf eine kurze lederne Hose ab, und bestreichen den Körper mit Oel, um von ihrem Gegner nicht so leicht gepackt werden zu können. Sie beginnen damit, sich drohende Gebärden zu machen; fassen sich darauf an den Armen, umklammern sich endlich und strengen alle Kräfte an, einer den anderen zu Boden zu werfen. Sie enthalten sich des Schlagens und thun sich selten Schaden. Die verschiedenen Stellungen, in denen sie erscheinen, bieten dem Künstler ein interessantes Schauspiel dar" (V.A. L. Castellans Briefe über Morea und die Inseln Cerigo, Hydra und Zante, Weimar I 809, I 78 f.).

968 In Nigrita im Raum Drama in Nordgriechenland werden am ersten Sonntag nach Ostern Wettkämpfe abgehalten: zuerst der Steinwurf (beliebig oft); der Sieger erhält ein Lamm; Seidentücher und Strümpfe werden für die folgenden Plätze vergeben. Der Lauf erfolgt über 5oom, der Ritt über 2oom. Als »Sprung« gilt der Dreisprung. An anderer Stelle werden die Ringkämpfe abgehalten: die Kämpfer sind nur mit Hose bekleidet, außer Schlägen ist alles erlaubt; verloren hat, wer auf dem Rücken zu liegen kommt ( $\eta$

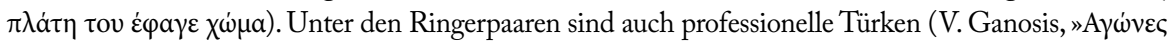

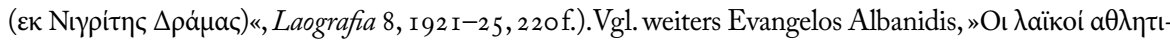

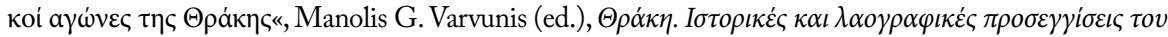

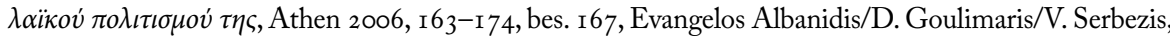
"Organization of Folk Athletic Games in Thrace«, Folklore 40 (2002) 87-Ioo, Manolis G. Varvunis, »Па-

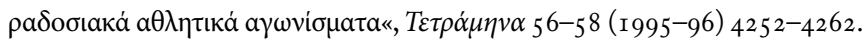

${ }_{969}$ Z.B. in Arachova, drei Tage lang: Am ersten Tag erfolgt der Lauf der Jungen, nach der Messe der Lauf der Alten; am 2. Tag wird am Dorfplatz gesprungen: Weitsprung und Dreisprung; am 3. Tag erfolgt der Speerwurf, der Ringkampf, das Steinstoßen und Gewichtheben (Hs der Laografischen 
genheiten ${ }^{970}$. Auch ölbeschmierte türkische professionelle Ringkämpfer (peblivan) ${ }^{971}$ aus Istanbu1 ${ }^{972}$ tragen solche Schaukämpfe aus. Für Zypern ist als Kraftprobe das Heben des Lüpfsteins ( $\delta \iota \mu i \tau \zeta v)$ typisch ${ }^{973}$. Der Austragung solcher Agonalspiele wird fertilitätspromovierender Charakter zugeschrieben ${ }^{974}$. Komplexere und vorinszenierte Kampfspiele sind auch beim Arvaniten-Waffentanz der Metzgerzunft im alten Istanbul nachgewiesen, wo angeblich auch die Schlacht Alexanders des Großen am Granikos pantomimisch dargestellt wurde ${ }^{975}$. Im allgemeinen ist das einschlägige Material bibliographisch schwer in den Griff zu bekommen ${ }^{976}$.

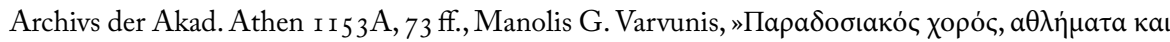

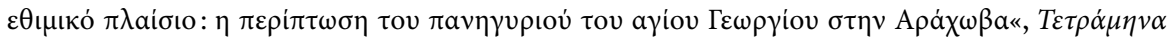
59-61, I 997/98, 4499-4509). - Ähnlich auch in Thrakien und anderswo (Thanasis Fotiadis, "Evac

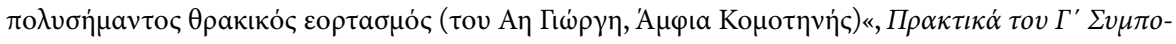

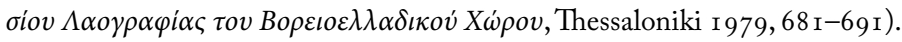

970 Nikolai I. Kolev, »Festive Customs and Ritual Games on St. Lazarus Day«, Journal of Popular Culture $\mathrm{I} 9 / \mathrm{I}(\mathrm{I} 985)$ I $43-\mathrm{I} 48$.

971 Z.B. in thrakischen Skopos (Üsküp, heute Europäische Türkei) an den Samstagen der Fastenzeit wurden solche Ringkämpfe von Einheimischen und Professionisten ausgetragen (Elli Kalokardu,

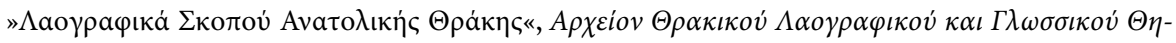

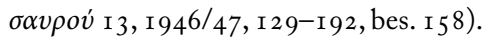

972 Am Käsemontag beim köpek-bey in Metaxades (heute Griechisch-Thrakien) wird am Ende der

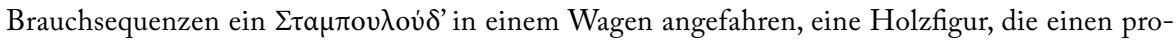
fessionellen Ringkämpfer aus Istanbul darstellt. Die Maskenfigur des Arabers fragt ihn nach dem Woher und Wohin und lädt ihn zum Ringkampf, der sich äußerst lustig gestaltet und den der

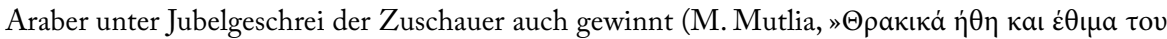

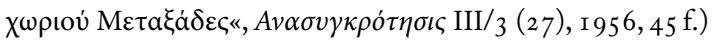

973 Vgl. das Widmungsheft der $\Lambda \alpha о \gamma \rho \alpha \varphi \iota k \dot{~ K u ́ \pi \rho o \varsigma ~ I ~} 3$ ( 1983 ) IO5 ff. I 83 ff., 22 I ff., 24 I ff., 275 ff. mit verschiedenen Beiträgen zum Steinheben und anderen Kraftproben sowie die analytische Biblio-

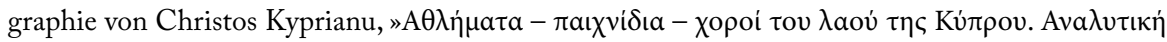

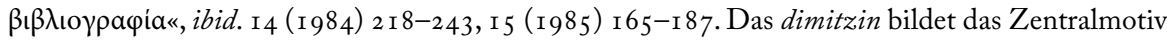

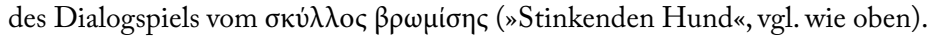

974 Im makedonischen Sarakina sind bei den surva-Umzügen die blutigen Zusammenstöße von Maskengruppen in Kampfspiele verwandelt: Sprung, Tauziehen, zuletzt Ringkampf, zuerst die Jüngeren,

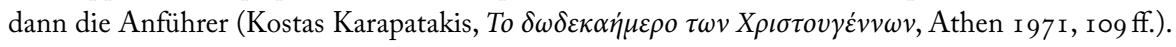
Das Tauziehen oder das Vor- und Zurückziehen der Räder des Königswagens ist auch bei den thrakischen Kalogeros-dromena evident. Zum fruchtbarkeitsmagischen Hintergrund vgl. auch Kalliopi

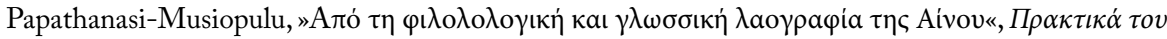

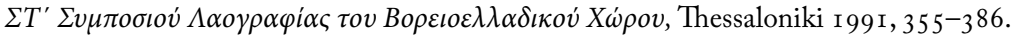

975 Im Byzanz bekannt als makellarikon hippodromion; der vom Sultan späterhin verbotene Waffen$\tan z$ wird auch »makedonischer« Tanz genannt. Zum Schwertertanz auch Leopold Schmidt in H. Gerndt/G. R. Schroubek (eds.), Dona Ethnologica. Beiträge zur vergleichenden Volkskunde, FS L. Kretzenbacher, München I $973,34 \mathrm{ff}$.

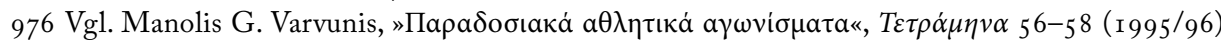


Reiterspiele. In der einfachsten Form geht es um Pferdewettrennen, die zu verschiedenen heortologischen Terminen ausgetragen werden, von Ungarn bis an die Schwarzmeerküste und die Ägäisinseln ${ }^{977}$. Eine besondere Rolle spielen hier die beiden Reiterheiligen Theodore sowie der H1. Demetrios und der H1. Georg. In Neon Suli bei Serres wird am 23. April der Kampf des Reiterheiligen Georg mit dem wassersperrenden Drachen nach der Georgslegende dargestellt ${ }^{978}$. Pferdeattrappen (Steckenpferde) spielen eine Rolle bei den pontischen momogeria und dem Dialogspiel vom Stinkenden Hund im zypriotischen Bergland sowie den rumänischen căluşarii ${ }^{979}$. Im Nord- und Zentralbalkan gibt es so etwas wie Reste eines Pferdekults: Am psychosabbato der H1. Theodore, dem ersten Fastensamstag der Quadragesima ${ }^{980}$, auch »Pferde-Ostern« (konski velikden) genannt ${ }^{981}$, werden zu Ehren des San Toader (das »Große Pferd«), dem Schutzheiligen der Blutsbrüder, Pferdewettrennen abgehalten ${ }^{982}$, ähnlich wie am Festtag der todorusale, genau in der Mitte der Seelenzeit zwischen Ostern und Pfingsten, wo in der kollektiven Imagination die Feen der rosaliile (rusalki, neraides) ${ }^{983}$ mit den săntoaderi,

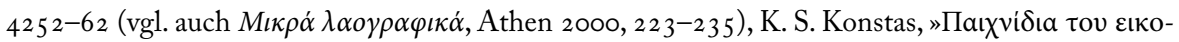

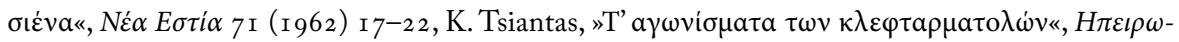

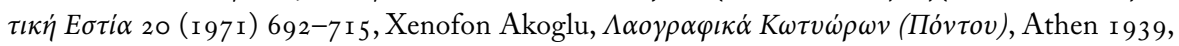

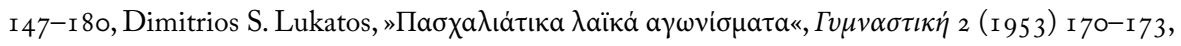

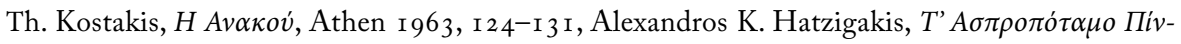

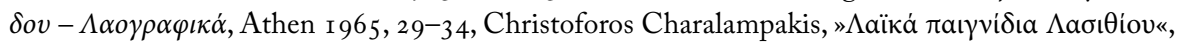
$A \mu \dot{\alpha} \lambda \theta \varepsilon ı \alpha 2$ (1971) 21 I-223. Viel einschlägiges Material findet sich auch in der Zeitschrift $E \lambda \lambda \eta$ -

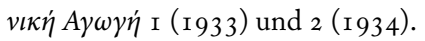

977 Balassa/Ortutay, Ungarische Volkskunde, op. cit., 656 (bei der Anführerwahl der Burschengruppen zu

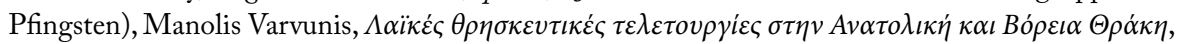
Athen $2010,{ }_{1}{ }_{3} \mathrm{ff}$.

978 Ein Bursche in rotem Mantel und mit Lanze reitet auf einem Schimmel durch die Zuschauermenge gegen die Quelle zu, wo nach oraler Tradition das Nest des Drachens gewesen sein soll, der dem Dorf das Wasser absperrt. Wenn der hl. Georg dort anlangt, wird aus einem kleinen Reservoir Wasser ausgelassen und ein dicker Wasserstrahl schießt mit Macht aus der Quellenrinne. In der

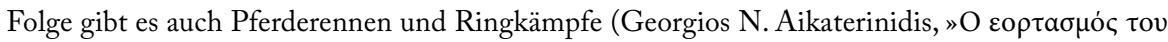

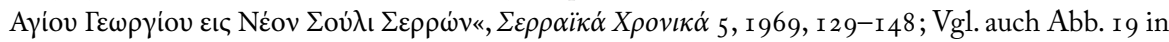
Puchner, Studien zur Volkskunde Südosteuropas, op. cit.).

979 Vgl. wie oben.

$980 \mathrm{Zu}$ dem Bündel von Brauchhandlungen an diesem Tag (kollyba-Segnung, Brotweihe für die Verstorbenen in der Kirche, „Erhöhungs«-Ritus (bypsoma) der beiden Heiligen, Almosen-Umzüge, Grabbesuch und Speisenverteilung, Gedenkmessen für »unrecht« Verstorbene, Arbeitsverbot usw., Puchner, Studien zur Volkskunde Südosteuropas, op. cit., 82 ff.

98 I Vakarelski, Bulgarische Volkskunde, op. cit., 32 I.

982 Vakarelski, op. cit., Buhociu, Die rumänische Volkskultur, op. cit., 66 ff., in der Moldau auch bei Hochzeiten (S. F. Marian, Nunța la români, București I 890, 6 Iof.).

${ }_{98} \mathrm{Zu}$ dieser Nixen- und Elfentypologie Charles Stewart, »Nymphomanie: Sexuality, Insanity and 
zentaurenaurtigen Pferdemenschen, die die sieben Söhne des hl. Theodor darstellen, zusammentreffen und erstere den schönen und gefährlichen Elfen nach Spiel und Tanz ein Heilkraut (todoruse, melites melissophylum) überreichen, das von der Besessenheit, die dieselben Feen für die Übertreter der Pfingstverbote hervorrufen, heilt ${ }^{984}$; dieser Heilprozess geschieht durch die akrobatische Tanztherapie der Trancetänzer căluşarii (»Pferdemenschen «, cal = Pferd) in der Ritualperiode der rusalii in der Vorpfingstwoche (Rusalienwoche) ${ }^{985} . \mathrm{Zu}$ diesen mythologischen Wesen in dem wilden zentaurenartigen Gefolge der săntoaderi gibt es auch Masken ${ }^{986}$, aber eine Realisation dieser imaginativen Vorstellung stellen die burschenbündischen Gruppierungen zwischen Siebenbürgen und der Moldau, zwischen Karpaten- und Balkangebirge selbst dar ${ }^{987}$.

In einen gänzlich anderen Kulturkontext führen die Formen der südosteuropäischen Turnierspiele zwischen der ritterlichen Brachialgewalt des Lanzenstechens und den Geschicklichkeitsübungen des Ringelreitens, die vor allem in den venezianischen Besitzungen in Südosteuropa und dem Ostmittelmeerraum quellenkundig sind ${ }^{988}$ und sich

Problems of Folklore Analysis«, Margaret Alexiou/Vasilis Lambropoulos (eds.), The Text and its Margins: Post-Structural Approaches to Modern Greek Literature, New York I 985, 2 I 9-252. 984 Mircea Eliade, »The Fairies and the Călușarii«, International Journal of Rumanian Studies 2 ( 1980 )

H. 3/4, 5-I 2, bes. I I f. (auch in The Journal of the Ancient Near Eastern Society of Columbia University 5, I973, II 5-I22).

985 Gail Kligman, Căluș. Symbolic Transformation in Romanian Ritual, Chicago I 98 r. Vgl. wie oben. 986 Romulus Vulcanescu, Măștile populare, București I 970, I72. Zu den Equidenmasken wie oben. 987 Vgl. wie oben.

988 Wie den großen umfassenden gesamteuropäischen Monographien von Leopold Kretzenbacher (Leopold Kretzenbacher, Ringreiten, Rolandspiel und Kufenstechen. Sportliches Reiterbrauchtum von heute als Erbe aus abendländischer Kulturgeschichte, Klagenfurt i 966) und Niko Kuret (Niko Kuret, Ziljsko štehvanje in njegov evropski okvir, Ljubljana 1963) zu entnehmen ist, folgt der Schaubrauch auch in der südosteuropäischen Tradition im wesentlichen den allgemeinen Entwicklungslinien: I) von der kampfsportlichen Disziplin des feudalen Ritterturniers mit lebensgefährlichen Zusammenstößen und ungewissem Ausgang zu kultivierteren, vorinszenierten und theatralisierten Spielformen in der Renaissance und in der Barockzeit, eine Entwicklung, die im höfischen Damenturnier als Gesellschaftsunterhaltung, im kunstvoll choreographierten Roßballett und in den getanzten theatralischen Schlachtenballetten mit großem Orchestereinsatz in Opern und Intermedien endet, und 2) vom selbstbewußten Größenwahn ritterlicher Selbstzelebrierung von Muskelkraft, Standfestigkeit, Reiter- und Waffengeschick über aristokratische Exklusivität der festlichen Selbstdarstellung an den prunksüchtigen Höfen des Absolutismus zu zunehmend volkstümlicheren und auch parodistischen Formen, in denen Reitersport, Kirchtagsbelustigung, Karnevalsparodie und Burschenfröhlichkeit zusammentreffen. Der unbekannte maskierte Fremde, der durch den Turniersieg die Hand der Königstochter gewinnt, einst stereotype Heroenfigur mittelalterlicher Ritter- und Minnekonventionen, reitet als eine nostalgische superman-Version eines verspäteten Don Quijotte noch viele Jahrhunderte durch Epen, Ritterromane und kavallereske Literatur vieler europäischer Nationalsprachen, auch zu einer Zeit, da Ritterideal und Feudalsystem längst keine 
heute noch eine letzte Fortsetzung in der theatralischen Darstellung des zweiten Teils des kretischen Versromans »Erotokritos «, das die giostra-Beschreibung betrifft ${ }^{989}$, im Dorf Skulikado auf Zante finden. Es handelt sich um eine Übertragung aus dem chevaleresken Westen zur Komnenen- und Palaiologenzeit nach Byzanz ${ }^{990}$, ohne daß das Osmanische Reich solcher Darstellungen völlig entbehrt hätte ${ }^{991}$. Doch gehäuft treten diese Reiterspiele am dalmatinischen Küstenstreifen ${ }^{992}$ und den Adria-Inseln ${ }^{993}$, auf den

einlösbaren Wirklichkeiten mehr darstellen. Für die Erhaltung der Tradition in Südosteuropa ist besonders die Venezianerherrschaft im Mittelmeer ausschlaggebend geworden, die der Festveranstaltung eine spezifische Funktion verliehen hat, nämlich die der greifbaren Schaustellung der politischen und kulturellen Übermacht der Serenissima in ihren Seeprovinzen (Puchner, "Giostra und barriera. Ostmediterrane Turnierspiele von Venedig bis Zypern in ihrer geschichtlichen Entwicklung und machtpolitischen Funktion", Studien zur Volkskunde Südosteuropas, op. cit., 2 I 3-252, bes. 2 I 5 f.).

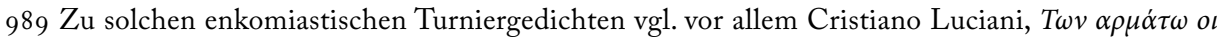

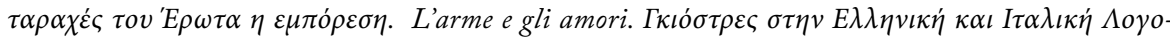

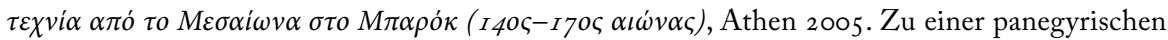
Turnierbeschreibung in Chania I 594 vgl. Gian Carlo Persio, La nobilissima barriera della Canea, poema cretese del 1594. Introduzione, testo critico e commento a cura di Cristiano Luciani, Venezia r 994 und zu einer »Herausforderung«/Einladung zu einem Karnevalsturnier in Candia (Heraklion) im Zeitraum von I637-1643, wobei man angeblich seine Kräfte mit einem fiktiven Turnierritter aus dem fernen Siebenbürgen zu messen habe, Alfred Vincent, „O入

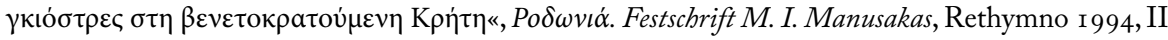
$62 \mathrm{I}-632$.

990 Dazu mit den einschlägigen Quellen und Indizien Peter Schreiner, «itterspiele in Byzanz«,Jahrbuch der Österreichischen Byzantinistik 46 (1996) $225^{-2} 39$.

99I Vgl. z.B. D. Petrović, »Das türkische Turnierspiel džilitanje in der Vergangenheit Serbiens und Bosniens«, Vernik Vojurg muzeja Jug. narodne armije 6/7 (Beograd I 962) I 35-I 44.

992 Z.B. das halka-Stechen in Sinj zur Erinnerung an die Türkenschlacht am I 5. August I7 I 5 (D. Nikolić, »Beitrag zum Studium des Ritterspiels von Sinj«, Narodno stvaralaštvo Folklor 3, 1964 , $807-8 \mathrm{r} 3)$.

993 Z.B. die wiederbelebte moreška auf der Insel Korčula. Vgl. die Aufführungsprospekte Moreška. Das Korčulaner Ritterspiel. Herausgegeben anläßlich der Dreißigjahrfeier der Erneuerung der Moreška (1 944-1 974), Korčula 1974 sowie M. Dupor, The Moreshka Story, Korčula (ca. 1974). An Studien in Auswahl: Ivan Ivančan, Narodni običaj korčulanskib kumpanija, Zagreb i 967, F. Pospisjl, „La moresca: studio comparato con particolare riguardo all' Italia settentionale«, Il folklore italiano IX, I-4 (r934) I ff., Jesna Čabo Žmegač, »Echoes of the Decapitation of an Ox in the Village Pupnat on the Island of Korčula: The Croats between Tradition and Modernity«, Narodna Umjetnost 37/2 (2000) 9-26, Zorica Vitez, »Revival and Local Meanings of Customs: Kumpanije on the Island of Korčula«, ibid., 27-46. Zum internationalen Vergleich der moresca-morris-Waffentänze John Forrest, The History of Morris Dancing, $145^{8-1750}$, Toronto/Cambridge 1999, Roberto Lorenzetti (ed.), La moresca nell'area mediterranea, Bologna i $99 \mathrm{I}$ usw. 
Ionischen Inseln, Kreta und Zypern ${ }^{994}$ auf ${ }^{995}$.

Die frühesten südosteuropäischen Belege fallen auf Konstantinopel I328 und Didymoteichon $1332^{996}$, in die Regierungszeit von Zar Stefan Dušan ${ }^{997}$, I 435 in Priština ein Lanzenstechen nach einem aufgehängten Handschuh, I440 ein Ringelreiten in Ragusa ${ }^{998}$. Auf Zypern ist das chevalereske Lanzenturnier schon vor seinem

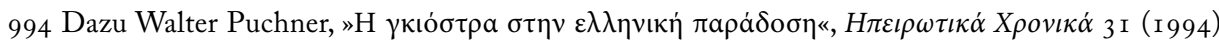

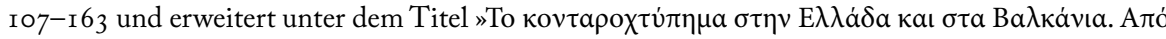

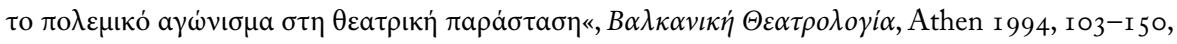
zurückgehend auf die Studie dess., »Südost-Belege zur sgiostra<: Reiterfeste und Lanzenturniere von der kolonialvenezianischen Adels- und Bürgerrenaissance bis zum rezenten heptanesischen Volksschauspiel«, Schweizer. Archiv für Volkskunde 75 ( 1979) I-27. Vgl. auch ergänzend ders., »To

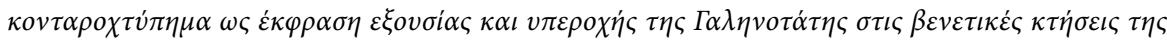

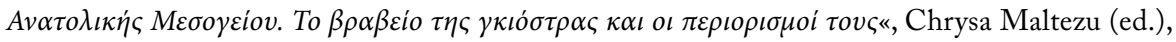

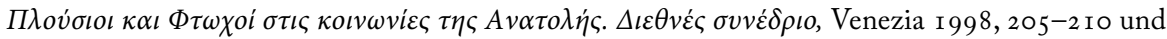

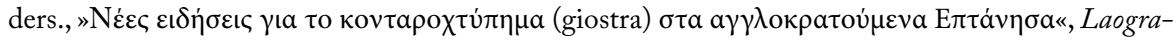
fia $40(2004-2006)$ 433-439.

995 Unter systematischen Gesichtspunkten sind verschiedene Disziplinen des Reiterkampfsports zu unterscheiden, wenn auch die Terminologie keineswegs einheitlich noch konsequent ist. Zunächst ist zwischen Truppen- und Einzelkämpfen, mit wirklichem oder fingiertem Feind, zwischen torneo (tournement) und giostra zu unterscheiden (Elena Povoledo, „Torneo«, Enciclopedia dello spettacolo 9, I 962, 991-999). Beide Arten können zu Fuß oder zu Pferd mit den verschiedensten Waffen ausgeführt werden, der Gruppenkampf (torneo) mit Schranken alla barriera oder in campo aperto, der Zweikampf (giostra) in verschiedenen Duellformen, abhängig von Lanzenart oder anderem Waffengebrauch. Zu den kultivierteren, spielhaften und sportnäheren Formen der giostra zählt I. die giostra all'anello, das Ringelstechen, wobei der Reiter aus vollem Lauf mit seiner Lanze einen auf einem Seil hängenden Ring aufspießen muß, und 2. die giostra alla quintana, wobei der Reiter eine mit ausgebreiteten Armen dastehende Figur in der Mitte (zwischen die Augen oder auf die Brust) treffen muß, da ihn sonst die rotierenden Arme treffen könnten; die Figur ist als Sarazene oder il moro bekannt, als Roland oder auch als "Türke«. Der Ausdruck quintana, in fast allen europäischen Sprachen geläufig, rührt aus den Schwertübungen der römischen Soldaten in der fünften Parallelstraße der via principalis im römischen Lager her, der quintana, wo der palus stand, an dem die Legionäre täglich ihre Waffengeschicklichkeit übten. Die Pfahlfigur des fiktiven Feindes ist in der ganzen mittelalterlichen Welt bekannt, oft auch als Sarazene, ebenso wie das Ringelstechen und das Turniermotiv (Brauterringung durch Turniersieg) in Epen und Ritterromanen.

996 Ältere Erwähnungen aus der Komnenenzeit vor der Lateinerherrschaft in Byzanz im I3. Jh. bleiben in ihrer Termininologie so vage, daß unklar ist, was wirklich vorgeführt wurde. Zur Heirat von Andronikos II. Palaiologos mit Anna von Savoyen 1328 und dem Geburtsfest ihres Sohnes im thrakischen Didymoteichon siehe die Belege bei Faidon Kukules, »A

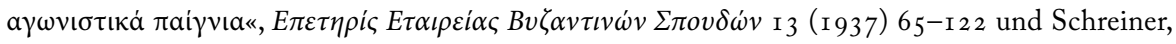
»Ritterspiele in Byzanz«, op. cit., $23 \mathrm{I}$ f.

997 r. H. I4. Jh. Mavro Orbini, Il regno degli Slavi, Pesaro r6 ro, 260.

998 Es handelte sich um vier schwere Silberringe (Kretzenbacher, op. cit., 66 f.); hier ist offenbar schon 
Fall an Venedig I 489 nachzuweisen ${ }^{999}$. Die Serenissima stiftet dann die Siegespreise, um die Bevölkerung zur Waffenschulung anzureizen, wobei auch das Adelsprivileg durchbrochen wurde ${ }^{1000}$. I 588 wird auf Kreta (Candia) eine barriera zu Ehren des provveditore Giovanni Mocenigo gegeben ${ }^{1001}$, I 594 in Chania zu Ehren des venezianischen

der direkte Einfluß der venezianischen giostra all'anello gegeben, die auf der piazza di San Marco in Venedig schon vor der Mitte des I 3. Jh.s einsetzt (Giuseppe Tassini, Feste, spettacoli e piacere degli antichi Veneziani, Venezia I 890 [Neudruck I96r] 29 ff.).

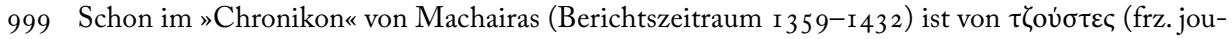
ste) gleich mehrfach die Rede (Leontios Makhairas, Recital concerning the Sweet Land of Cyprus entitled »Chonicle«, 2 vols., ed. with a translation and notes by Richard M. Dawkins, Oxford 1932 , Bd. I, S. 239/r 9-22, S. 266/2 und pass.) und »ioustes \& tournois« sind auch in der Beschreibung der Insel bei Estienne de Lusignan zu finden (Description de tovte l'isle du Cypre, et des Roys, Princes, et seigneurs, tant Payens que Chrestiens, qui ont commandé en icelle ... par R. Pere F. Estienne de Lusignan de la Royale maison de Cypre, Lecteur en Theologie, à Paris I 5 80, 22 I ff.).

I 000 Eine Petition der zypriotischen Lokalbehörden I 52 I (50 Jahre vor dem Fall an die Türken) an den venezianischen Senat enthält unter anderen Forderungen auch die Erneuerung der Abhaltung des Lanzenturniers und die Stiftung neuer Siegespreise, wobei auf die militärpädagogischen Ziele ausdrücklich verwiesen wird. Die Antwort des Senats war positiv; es wurde bloß die Bedingung gestellt, daß die giostra am 25. April, dem Nationalfeiertag der Lagunenrepublik

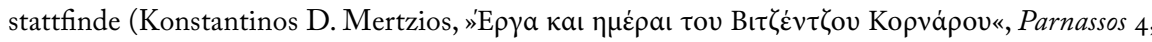

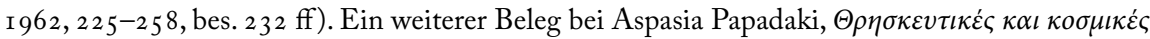

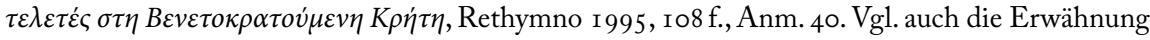

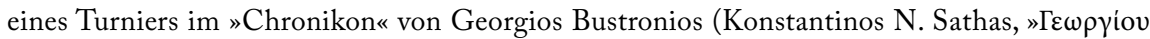

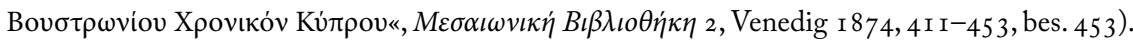

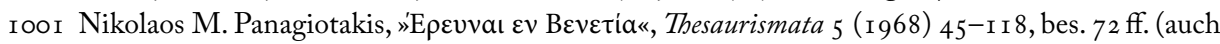

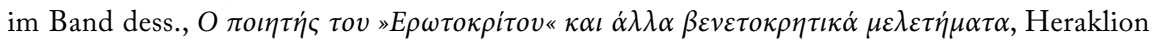
I 989, 5 I-I I I , bes. 78 ff.). Die detaillierte Beschreibung der »avventurieri cavallieri con vaghissime livree con ingeniose imprese et con motti dotissimi« zeigt schon die fortgeschrittene Entwicklungsstufe dieser giostra-Form an. Weitere Nachrichten zu Turnieren auf Kreta in F. Cornaro, Creta sacra, sive De episcopis utriusque ritus Graeci et Latini in insulae Cretae, Venetia I754, Bd. II, 336, 34 I ff. Daß es sich dabei um kein ungewöhnliches Schauspiel handelt, geht auch aus zwei Gedichten desselben Andreas Kornaros hervor, die im Cod. N. A. 435 der Zentralbibliothek von Florenz aufbewahrt sind: Nr. 370 "Per un cavaliero che comparse in una giostra fatta in Candia. Una donzella parla« und Nr. 37 I $P$ Per un altro cavaliero, che comparse similmente in un' altra giostra dentro una colonna di marmo, guidato da Giove et Marte et da une Reina che rappresentava Venetia. L'invention fu del cavalier proprio, e questo parlar fa una Ninfa marina (Nikolaos Pana-

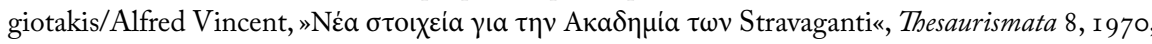

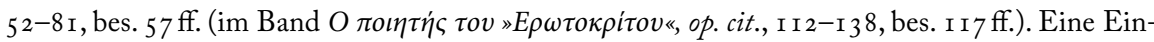
ladung zu einem fiktiven Quintana-Stechen zur Karnevalszeit findet sich zwischen I637-г643 (Text in Vincent, »O während der Belagerung von Candia (I645-r669) statt. 
bailo in Konstantinopel, offenbar in besonders theatralischer Form ${ }^{1002}$. Diese Turnierbeschreibung mag auch eine der Quellen für die giostra im zweiten Teil des Versromans »Erotokritos« aus den ersten Jahrzehnten des I7. Jh.s abgegeben haben ${ }^{1003}$. Das Turnier-Motiv findet sich auch mehrfach in der kretischen und heptanesischen Dramatik ${ }^{1004}$. Auf den Inseln Korfu, Kefalonia und Zante (I203, I500 und I483 an

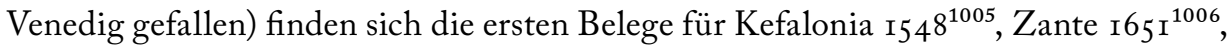

I002 Das langatmige panegyrische Gedicht in ariostischem Versmaß in 235 ottave rime mit eingestreuten Textpassagen in reimlosen Elfsilbern, beschreibt eine giostra I 594 in Canea (Chania): „La nobilissima barriera de la Canea posta in ottava rima da Gio: Carlo Persio«. Vgl. Cristiano Luciani,

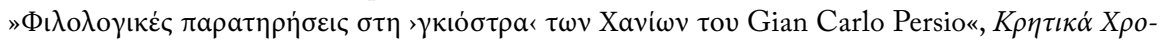

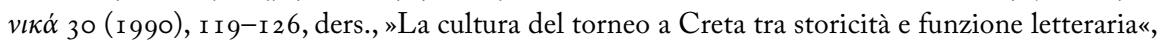
J.-M. Egea/J. Alonso (eds.), Prosa y verso en griego medieval. Rapports of the International Congress "Neograeca Medii Aevi« III Vitoria 1994, Amsterdam 1996, 2 I 9-225; kritische Ausgabe in Gian Carlo Persio, La nobilissima barriera della Canea, op. cit. Zur Inhaltsbeschreibung auch Rosemary E. Bancroft-Marcus, »Interludes«, in: David Holton (ed.), Literature and society in Renaissance Crete. Cambridge r 99I, I 59 ff., bes. I6of.

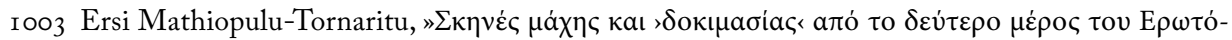

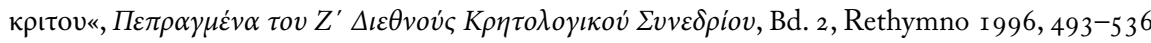
hat zuerst die These aufgestellt, daß es sich bei der Turnierbeschreibung im »Erotokritos« um ein ursprünglich selbständiges Turniergedicht handelt. Zur umfassenden Bibliographie zum kreti-

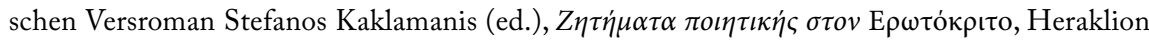
$2006,477-538$.

I004 Z.B. im religiösen Legendendrama "Eugena« von Teodoro Montselese (Venedig r646) auf Zante erscheint das Turnierspiel direkt auf der Theaterbühne selbst (Text in Mario Vitti, Teodoro Montselese, Evyév $\alpha$, a cura di Mario Vitti, Napoli 1965 und neuerdings Mario Vitti/Giuseppe

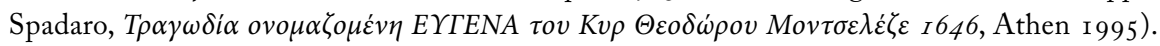
Zur Analyse und dem Turniermotiv Walter Puchner, »Raum- und Zeitprobleme in der Evyéva

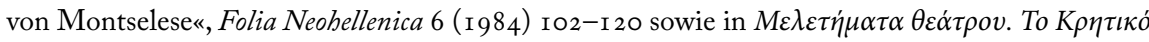
$\theta \varepsilon \dot{\varepsilon} \tau \tau \rho$, Athen 1991, 325-348.

I005 Es handelt sich um ein Dekret vom 22. April I 548, ausgestellt von Vincenzo Calbo, Sindicato e Avogadore dell' Oriente, das verordnet, die Ausgaben für die Siegespreise der giostra (palii) dürften künftig die 30 Dukaten nicht überschreiten (Text des Dokuments in Ermanno Lunzi, Della conditione politica delle isole Jonie sotto il dominio veneto, Venezia I 858, $482 \mathrm{ff}$.). Die Notwendigkeit der Kosteneindämmung kann aus einem Beleg um 1580 für Zante gut aufgezeigt werden, wo unter den regelmäßigen Ausgaben für die strattia (Kavallerie) ein Posten von 32 Dukaten für die Siegespreise der corse all'anello, des Ringelstechens, aufscheint; unter den außergewöhnlichen Ausgaben, die für drei Jahre berechnet wurden, für denselben Zweck sogar eine Summe von 43

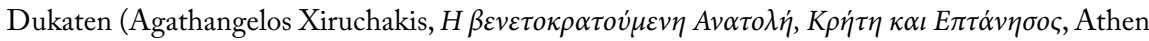
I934, I 86).

roo6 Am »Käsedonnerstag« des Karnevals fand auf der ruga der Stadt eine giostra statt; als maestro di campo fungierte der provveditore Giovanni Mocenigo, als Preis waren 32 Dukaten vorgesehen. Straßen und Häuser waren mit Teppichen und Blumen geschmückt, die Teilnehmerzahl 
Korfu I6 $62^{1007}$, während der Reiterbrauch im I8. Jh. zurückgeht ${ }^{1008}$.

Im Jahrhundert des Rückganges der Machtposition der Seebeherrscherin Venedig wird auch das Adelsprivileg gebrochen und die ersten parodistischen Volksformen des stolzen Reiterbrauches tauchen auf. Schon ${ }_{1} 6_{5} 2$ ist in Korfu die giostra dei stradiotti, der Garnisonsmannschaften im forte vecchio der Inselmetropole, die ihr eigenes Lanzenturnier abhielten, nachgewiesen ${ }^{1009}$. Im Zeitraum I 78 I bis 1798 ist die giostra degl'arlioti

der Reiter, durchwegs Adelssöhne der im libro d'oro verzeichneten Familien, durfte ein Dutzend nicht unterschreiten. Sowohl corsa dell'anello als auch corsa della quintana waren als Disziplinen vertreten; im letzteren Falle mußte eine Münze auf der Stirn eines Mohrenhauptes mehrfach aus vollem Lauf getroffen werden (Lunzi, op. cit., 384). Zweikampf und Verletzungsgefahr waren aus diesem Wettspiel eliminiert. Der Preis bestand in zwei Silbersporen oder -schwertern (ausführlichere Beschreibung auch in Puchner, Brauchtumserscheinungen, op. cit., I $47 \mathrm{f}$.)

I0०7 Die Regeln des Turnierspiel für Korfu sind in eigenen Statuten festgehalten, die im Archivio di Corfü bis ins 19. Jahrhundert hin aufbewahrt wurden (Lunzi, op. cit., 483 ff.). Die giostra wurde in der strada larga abgehalten, während das Richterkonzilium auf den Balkonen der flankierenden Häuser saß. In der zweiten Karnevalswoche r686 wurde eine giostra zu Ehren von Francesco

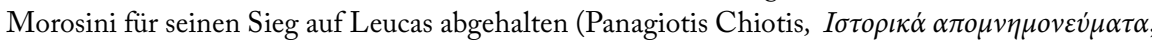
Bd. 3, Korfu i 863, 293).

Ioo8 Dies ist besonders an der Spieltätigkeit auf Zante abzulesen: Ein Senatserlaß vom 2 I. I. I703, die Insel Zante betreffend, schränkt die Ausgaben aus öffentlicher Hand für die giostra auf ıoo $\mathrm{Du}$ katen ein, ein weiterer Erlaß vom 8. I. I 7 I I drängt noch mehr auf Sparkurs (Spyridon de Viazis,

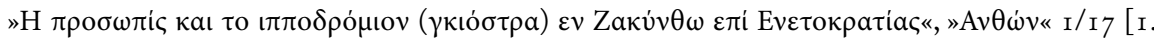
2. I890] 137). Nach der Ermordung eines venezianischen Syndicus am 2. I. I740 wird die Abhaltung der giostra nach jahrhundertelanger Übung auf der Insel überhaupt untersagt (Glykeria

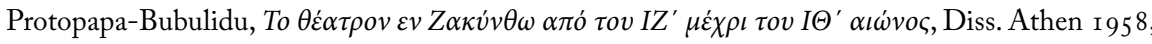
I 5 ff.). I 754 scheint noch ein gewisser Conte Venturo Kapnisis auf seinen Privatgütern im Dorf Agios Kirykas auf Zante eine giostra abgehalten zu haben, wie eine unveröffentlichte Inselchronik

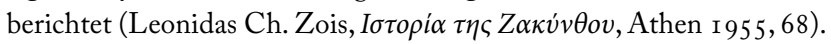

I009 Der provveditore Girolamo Foscarini berichtet in einer inedierten relazione folgendes: „Con che crederò d'haver terminato questo primo punto, raccordando humilmente di levar l'uso di far ogni anno l'ultima domenica di carnovale la giostra de' stradiotti nella fortezza vechhia, per evitare il concorso di gente che vi confluisce in giorno determinato, parendomi poco decente e meno sicuro l'haver in una volta sola tante persone nel recinto che superino la guarnigione, da che pure prese motivo la pubblica prudenza di trasportare l'istesso Domo in città, onde per mio umilissimo credere si potria far la stessa giostra o in spianada, ovvero nella strada, dove si fa anche quella dei cittadini, che corrono uguale pretio a quello de' stradiotti, cioè quattro brazza di roba d' oro donatale da Vostra Serenità annualmente, e questo a divertimento del concorso in fortezza vecchia, nella quale ho fatto sempre che sè potuto in absenza delli Eccellentissimi Signori Generali et in mancanza dell' armata, tener serrata la porta chiamata il portello, parendomi assai inconveniente, che altre l'introdurre senza niuna limitazione di numero, previo avvertimento, tutti chi vogliono entrare, si faci questo anche da più porte, non permesso mai in niuna fortezza di mediocre, non che di somma importanza» (Lunzi, op. cit. 485 ff.). 
bereits karnevaleske Volksbelustigung der Unterschichten ${ }^{1010}$. Der Niedergang der Machtposition der mythischen Fest- und Lagunenstadt hat auch unmittelbare Auswirkungen auf den dalmatinischen Küstenstreifen gehabt: In Zadar, wo das Ringelstechen seit I 409 nachgewiesen ist, unterliegt es I770 den Steuerbestimmungen und erlischt

Io Io Als arlioti werden die Nachfahren der Aristokratie von Nauplion im venezianischen »Königreich von Morea bezeichnet, die nach dem Fall der Peloponnes (I 7 I 5 die Einnahme Nauplions) nach Korfu kamen und hier auf die Anerkennung ihrer Adelstitel seitens der Republik warteten. Ihr sozialer »Abstieg« endete mit ihrer Eingliederung in die arbeitende Bevölkerung der Stadt. André Grasset Saint-Sauveur, der von I 78 I bis I798 auf Korfu gelebt hat, zuletzt als französischer Konsul, hat einen farbigen Bericht über das Reiterfest in den letzten Jahren der Serenissima gegeben: "De toutes les fêtes du carnaval, le plus brillante et en même-temps la plus intéressante, étoit la chiostra (ou course à cheval). J'ai déjà parlé de son institution. A-peu-près à la moitié du caranval, on préparoit la lice dans une des rues des plus larges, et qui communiquoit à l'esplanade; on y dressoit de chaque côté des amphithéâtres pour les spectateurs; une tribune pour le provéditeurgénéral qui devoit adjuger les prix aux vainqueurs; une seconde tribune était destinée pour les musiciens que célébroient leur victoire. Le jour de cette espèce de tournois, les concurrens, vêtus le plus magnifiquement qu'ils pouvoient, montant des chevaux richement enharnachés, précédés du mestre-de-champ ou juge, se rendoient à l'entrée de la carrière. Le général, in forma publica, accompagné d'un nombreux cortège, alloit se placer dans sa tribune; ses coureurs et seux des autres patrices vénitiens étoient aux ordres des athlètes, et couroient devant eux un moment avant qu'ils entrassent en carrière. Les cavaliers s'exerçoient d'abord à rompre des lances sur une figure en bois placée sur la droite de la carrière, près de la tribune des musiciens. Les trompettes donnoient enfin le signal; chaque cavalier partoit à son tour la lance en arrêt, visant à un petit cercle de fer partagé par plusieurs barres, et recouvert de papier; il étoit suspendu à une corde tendue des deux côtés de la rue: il falloit l'emporter trois fois de suite pour gagner le prix. Le mestre-de-camp marquois exactement, sous les yeux de général et des syndics de la ville, le coup de chaque cavalier. Les vainqueurs se présentoient au général, qui leur remettoit une lance à laquelle étoit attaché le prix. Ils étoient en suite accompagnés chez eux par leurs rivaux. Le bruit des trompettes, le son des instruments se mêloient aux acclamations, aux applaudissements des spectateurs. Le sénat de $\mathrm{Ve}-$ nise envoyoit lui-même des deux prix: le premier étoit ordinairement un habit complet richement brodé; le second, un pièce de drap d'or ou d'argent. Cette course étoit la chiostra publica, et les nobles du pays pouvoient seuls y disputer les prix./La lice demeuroit dans le même état de reste $\mathrm{du}$ carnaval. Tous les jours, des jeunes gens venoient y exercer leur adresse, souvent déguisée sous les vêtemens le plus grotesques: ce spectacle étoit extrêmement gai, et les concours très nombreux [...] Quelques jours après la chiostra publica, il s'en faisoit une seconde dans la forteresse vieille; elle se nommoit la chiostra degl' arlioti. Les artisans corfiotes étoient seuls admis à disputer le prix: c'étoit ordinairement une tasse d'argent donnée par le provéditeur de forteresse. Le ridicule de cette course, où la plupart des cavaliers montoient pour le première fois à cheval, attiroit une foule de spectateurs: on ne manquoit pas de bien applaudir aux chûtes fréquentes et à la bonne grace de concurrens: la victoire étoit lang-temps disputée: la vainqueur étoit ramené chez lui au bruit des tambours ..." (Voyage historique, littéraire et pittoresque dans les îles et possessions ci-devant vénetiennes du Lévant ..., À Paris VIII [= I 800] Bd. III, 2 I 2 f.). 
rund um I 820, auf Makarska enden die Turnierspiele I 832 und in Imotski im Hinterland halten sie sich bis $1830^{1011}$.

Das britische Protektorat des I 9. Jh.s (bis I 862) auf den Ionischen Inseln hat versucht, die venezianische Tradition nach der caduta di Serenissima wiederzubeleben ${ }^{1012}$, z.B. I 834 auf Korfu ${ }^{1013}$ und I 835 auf $Z_{\text {ante }}{ }^{1014}$, doch erst etwa ab der Mitte dieses

Io I I In Sinj bis nach dem Zweiten Weltkrieg (vgl. Kretzenbacher, op. cit., 72 f.). In Istrien endet die giostra alla Guintana mit dem Fall Venedigs 1797.

IOI 2 Schon I 8 I 4 beschließt der britische Senat auf Ionischen Inseln, zum Geburtstag des Vizekönigs eine giostra abhalten zu lassen (Gazette Ionienne 20. 8. I 8 I4); weitere Nachrichten der Presse beziehen sich auf die Jahre I 820, I 822, I 826 und I 827. In einem Brief des Private William Wheeler, Soldat im 5 r. Bataillon of King's Own Yorkshire Light Infantery vom 2. 5. I 823 wird zum Festtag des H1. Georg (23. April) zuerst das Maibaumklettern auf Korfu beschrieben, und sodann das correr all'anello: "The day passed off well, various were the games, viz. wrestling, boxing, running, jumping and many other games. The people assembled presented one of the most curious sights I ever saw, Greeks in the dress of the different Islands they belong to, Albanians, soldiers and sailors etc. all mingled together, each taking part and striving to be conquerers in the different games. Many surprizing feats were performed by the Greeks, who are a fine active robust race. Their riding at full gallop on horse back with a long lance and taking a ring on the point from a line over their heads, is an ancient game in which they excel. Our country may had but little chance with them./This amusement never takes place without much ceremony, it is announced by a proclamation from the General inviting the knights to enrol their names. The prices are of great value, an Adjutant General of the Game is appointed. Captain Wingat, $32^{\text {nd }}$, whose father lives on Portland place, held this office. A splendid stage is errected [sic] for the Lord High Commissioner and his staff, on each side of which are others richly decorated. From the principal stage the line runs across the ride. The knights having assembled at the starting post, each dressed in ancient costume, some representing the Templars, others in the costume of different ages, everything being ready a bugle sounds, off dashes one of the Knight at full speed with his lance errect [sic], as he approaches the ling the lance is brought down, at the same time he rises in his stirrups. If he succeeds in carrying of the ring, the Adjutant Genl. escorts him back to the Grand stand where the name of knight and the number of the prize is entered in a book (zu weiteren Details in dem

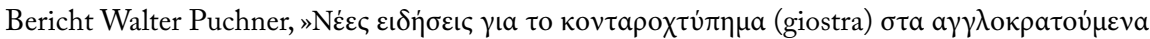

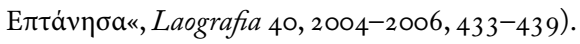

IOI 3 I 834 läßt der britische Generalgouverneur, Lord Granvill Nugget, Einladungen drucken und ruft die »Ritter« ins Feld der Ehre (Korfu, 26. April I 834). Wie Artikel Nr. 2 und 4 des Festprogrammes berichten, gehört es zu den Voraussetzungen der Teilnahme, für mittelalterliche Tracht und Waffen zu sorgen sowie sich einen geeigneten Ritternamen zuzulegen und geeignetes »Gefolge« mitzuführen. Nugget selbst nennt sich bescheiden Godefroy de Villehardouin. Die Festordnung sieht eine erste und zweite Einzugsprozession vor. Die Kampfregeln und das Punktesystem des

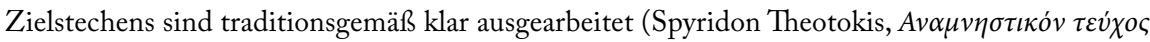

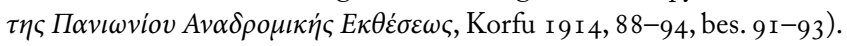

Ior4 Ein Jahr später, am 22. und 23. April I 835, wiederholt sich der seltsame Aufzug etwas außerhalb der Stadt von Zante unter dem sogenannten »Roten Felsen«; würdige englische Marineoffiziere 
Jahrhunderts ist der Reiterbrauch als dialogisches Volksschauspiel beim karnevalsken »Homilien«-Theater auf Zante (im Dorf Skulikado) nachzuweisen: Aufgeführt wird der zweite Teil des "Erotokritos«, die über 2.500 Verse lange giostra-Beschreibung mit Pferden, aufwendigen Kostümen (genau nach den Deskriptionen von Vincenzo Kornaros), Dialogen und einem Erzähler in einer bemerkenswerten verkürzenden und dialogisierenden Volksbearbeitung ${ }^{1015}$.

SONDERFORMEN DER PERFORMATIVITÄT B : MAGISCHE PRAKTIKEN UND EMPIRISCHE THERAPEUTIK

Eine andere Sonderform des performativen Handelns besteht in magischen Praktiken und empirischer Therapeutik der Ethnomedizin, die sowohl Verbalakte wie auch Symbolhandlungen in verschiedenen Kombinationen umfassen können. Zaubersprüche und Analogiehandlungen der »sympathetischen« Magie fußen beide auf Glaubensvorstellungen eines (prae)animistischen Weltbildes, die ihrerseits die imaginierte Möglichkeit

und nüchterne Verwaltungsbeamte mit kostümiertem Gefolge begeben sich im Wagenzug auf das Feld der Ehre, um in der Fiktion versunkener Ritterideale ihre handgreiflichen Verwaltungsschwierigkeiten mit der annexionswilligen, nationalistisch gesinnten griechischen Bevölkerung zu vergessen. Die Beeindruckung der popolari mißlingt jedoch gründlich: Das Schauspiel muß unfreiwillig komisch gewesen sein, und viel ätzender Spott hat sich von seiten der Bevölkerung über den naiven Romantizismus der »Mylords« ergossen, die so großspurig und tollpatschig die

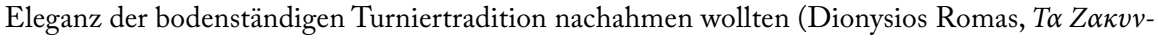
$\theta \iota v \alpha$, Athen 1957, 247 ff., 276 ff.).

IOI 5 Wegen der aufwendigen Vorbereitungen, die das ganze Dorf monatelang voll in Anspruch nehmen, findet die Aufführung nur ein- bis zweimal in jeder Generation statt. Die Organisation der Vorstellung ist ausschließlich diesem einen Dorf übertragen, die Rollen vererben sich von den Vätern auf die Söhne. Ausführliche Beschreibung der Aufführung im Jahr I 977 bei Puchner, "Südost-Belege zur >Giostra<: Reiterfeste und Lanzenturniere von der kolonialvenezianischen Adels- und Bürgerrenaissance bis zum rezenten heptanesischen Volksschauspiel«, Schweizer. Archiv für Volkskunde 75, 1979, I-27, bes. 23-26. Nach mündlichen Überlieferungen dürfte die erste Spieltätigkeit des Dorfes um die Mitte des I9. Jh.s fallen; bei der Aufführung des »Aretokritos« I 909 wurde der Kornaros-Text gemeinsam von den Spielern redigiert, die Probenleitung oblag dem Dorfschullehrer. I 925 wurde derselbe Text verwendet, über jeden individuellen Änderungsvorschlag wurde gemeinschaftlich abgestimmt. Zwischen Familien und Spielern entspann sich ein heftiger Antagonismus um die prächtigsten Kostüme und die besten schauspielerischen Leistungen. Die enorme Rolle des »Dichters«, die das professionelle Merkvermögen eines Schauspielers voraussetzt, ist als eine Art Herold gestaltet, der ankündigt und kommentiert; die Rollen werden bei den Feldarbeiten auswendig gelernt. 1935-1938 wird wieder gespielt: Der Erfolg der Darstellung ist naturgemäß von den Fähigkeiten der (Arbeits)Pferde abhängig. I 950 wurde die giostra und der »Große Krieg» (der 5. Teil des »Erotokritos«) gespielt; die Neuerung konnte sich jedoch nicht halten. 
einer Beeinflußbarkeit von Situationen und Fakten evozieren, welche das kollektive und individuelle Wohlbefinden bedrohen, aber jenseits des (vorwissenschaftlichen) menschlichen Wissens und damit der praktischen Manipulierbarkeit liegen; im Falle der praktischen Heilkunde stützen sich diese Strategien sowohl auf magische Vorstellungen wie auf übermitteltes medizinisches Schrifttum, aber auch auf persönliche Beobachtung und in der Oraltradition kumuliertes praktisches Heilwissen. In der empirischen Therapeutik treffen magisch-religiöse Strategien der Analogiebildung und assoziativen Verflechtung mit hochreligiös sanktionierten Abwehr-, Schutz- und Heilfunktionen von sakralen Instanzen (Heilige, Gottesmutter, Christus) und Orten (Kirche, Krankenwallfahrt) zusammen, aber auch die lokale Oraltradition mit der schriftlichen Überlieferung des Altertums, des arabischen und westlichen Mittelalters, der Apokryphik, Alchemie und Astrologie, und fahrende empirische Wunderdoktoren und Heilpraktiker mit den heilkundigen alten Frauen und Hebammen der Kommunität ${ }^{1016}$. Humanmedizinisch ließe sich die Prophylaktik und Diagnostik von den eigentlichen Therapieversuchen unterscheiden. Im zweiten Teil kommen diese imaginativen Vorstellungen, die hinter diesen Praktiken liegen, noch genauer zur Sprache.

Der in Frage stehende Bereich wird unterschiedlich bezeichnet, als Volksmedizin, Ethnomedizin, Sozio-Medizin, Zauber-Medizin, Vor-Medizin, auch Heilkulturwissenschaft ${ }^{1017}$ und umfaßt im allgemeinen Kapitel wie die Heilkundigen bzw. das Verhält-

ror6 Dazu auch Gabriella Schubert, „Die Frau in der Volksheilkunde auf dem Balkan«, Norbert Reiter (ed.), Die Stellung der Frau auf dem Balkan. Beiträge zur Tagung vom 3.-7. September 1985 in Berlin, Wiesbaden I 987, 2 I 9-23 I und Walter Puchner, „Frauenbrauch. Alterssoziologische Betrachtungen zu den exklusiv femininen Riten Südosteuropas«, Studien zur Volkskunde Südosteuropas und des mediterranen Raums, Wien/Köln/Weimar 2009, I 5 I-I 76.

Iог7 Den Begriff hat Helmut Vielhauer geprägt (»Volksmedizin - Heilkulturwissenschaft. Grundsätzliche Erwägungen anhand von Beispielen aus Niederösterreich«, Mitteilungen der Antbropologischen Gesellschaft in Wien 102, I973, I I4-136). Zur Ethnomedizin vgl. in Auswahl: Marcelle Bouteiller, Médicine populaire d'bier et d'aujourd'bui, Paris I966, Antonio Castillo de Lucas, Folkmedicina, Madrid I 958, Wayland D. Hand, Popular beliefs and superstitions from North Carolina, Durham i 964, ders., Magical Medicine. The Folklore Component of Medicin in the Folk Belief, Custom, and Ritual of the Peoples of Europe and America, Berkeley/Los Angeles/London I 980, Oskar von Hovorka, Geist der Medizin. Analytische Studien über die Grundideen der Vormedizin, Urmedizin, Volksmedizin, Zaubermedizin, Berufsmedizin, Wien/Leipzig I 91 5, ders./Adolf Kronfeld, Vergleichende Volksmedizin, 2 Bde., Stuttgart I 908/o9, Pavel Košir/Vinko Möderndorfer, "Ljudska medicina med koroškimi Slovenci«, C̆asopis za zgodovino in narodopisje 2 I (Maribor I 926) 85-I I2, deutsch in Elfriede Grabner, Volksmedizin. Probleme und Forschungsgeschichte, Darmstadt I 967, 27-7 (Kärntner Slovenen), Erwin Liek, Das Wunder in der Heilkunde, München I 930 (I93 I, I95 I), Clarence Meyer, American Folk-Medicine, Glennwood, Ill. I985, Vinko Möderndorfer, Ljudska medicina pri Slovencih, Ljubjana i 964, Adalberto Pazzini, La medicina popolare in Italia. Storia, Tradizione, Leggende, Triest I 948, Antonio Scarpa, Etnomedicina, Mi- 
nis zur Schulmedizin, die Krankheitsvorstellungen, Schutz- und Heilmittel (Amulette, Zauberpflanzen usw.) und Heilpraktiken (Analogiezauber usw.). ${ }^{1018}$. Diese empirischen Praktiken stehen im 20. Jh. in Südosteuropa vielfach im Übergang zum staatlich organisierten Gesundheitswesen der public health-Programme und der wissenschaftlichen Schulmedizin, wenn auch die alternativen Heilmethoden und älteren Praktiken parallel weiterhin existieren und keineswegs völlig verschwunden sind ${ }^{1019}$. Heilsprüche sind im allgemeinen mit performativen Handlungen kombiniert, die sich im positiven oder negativ-abwehrenden Sinne an die helfende oder verursachende Instanz wenden ${ }^{1020} . \mathrm{Zu}$

lano I980, M. Hoppá1/A. Törő, „Ethnomedicine in Hungary«, Orvostörténeti Közlemények 1975 usw.

Io 8 Elfriede Grabner, „Volksmedizin«, Rolf Wilhelm Brednich (ed.), Grundriss der Volkskunde. Einfübrung in die Forschungsfelder der Europäischen Ethnologie, Berlin 1988, 423-446. »Die dämonisch, jedenfalls irgendwie körperlich gefaßte Krankheit vertreibt man durch Vernageln oder Verbohren in einen Baum, durch Verpflanzen auf Bäume und Sträucher, durch Vergraben, Abmessen oder Abstreifen, durch Verfüttern an das Vieh, durch Wegwerfen, Verbrennen oder Wegschwemmen im fließenden Wasser, kurz durch Übertragung im vielfältigsten Sinn« (440). Diese therapeutischen Prinzipien haben im allgemeinen universelle Gültigkeit. Vgl. dies., Grundzüge der ostalpinen Volksmedizin, Wien I985, 232-24I, dies., "Das >Abbeten`. Magische Heilmethoden und Beschwörungsgebete in der Steiermark«, Zeitschrift des Historischen Vereins für Steiermark $53 / 2$ (1962) 359-370, dies., Volksmedizin. Probleme und Forschungsgeschichte, Darmstadt I 967.

Io 9 Vgl. den Feldforschungsbericht aus den 6oer Jahren von Richard \& Eva Blum, Health and Healing in Rural Greece. A Study of three Communities, Stanford California 1 965, dies., The Dangerous Hour. The Lore of Crisis and Mystery in Rural Greece, New York 1970. Vgl. auch Marlene Sue Arnold, Childbirth among Rural Greek Women in Crete: Use of Popular, Folk, and Cosmopolitical Medical Systems, $\mathrm{PhD}$ diss., University of Pennsylvania 1985 .

I020 Dazu einige Beispiele aus dem griechischen Fallmaterial (Laografia 4, I9 12/I 3, 37 f). Heilsprü-

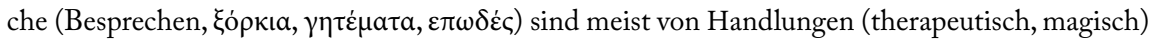
oder Objektberührung (über dem Kranken bewegt) begleitet; es handelt sich um ein Wissen zwischen empirischer Therapeutik, Magie, Superstition und religiösem Glauben, das nicht leicht weiterzugeben ist, gegen Bezahlung aktiviert wird, in Versform oder Prosa vorgetragen wird und auch bei Tieren und Pflanzen (Bäume) Anwendung findet. Die Zauberformeln sind von Handlungsanleitungen begleitet: z.B. für das Gerstenkorn im Auge: „Du nimmst einen Ring, füllst ein Glas mit frischem Wasser, wirfst den Ring hinein, bekreuzigst mit ihm dreimal das Auge und sagst folgende Worte (die mußt du auswendig lernen). Bei jedem Spruch bläst du auf das Auge«; darin besteht letztlich auch der therapeutische Effekt. Die magisch-religiösen Therapiesprüche sind oft in Wunschform ausgedrückt (»Komm, Christus und Panagia ...«) oder metaphorisch (»Ich, Gott und der Schluckauf ...«» Bannsprüche (»Christus und Panagia verfolgen dich, verschwinde ...«), sind narrativ oder dialogisch (»Die Gottesmutter und die Heiligen treffen den Kranken oder die Krankheit, der/die fragt sie und sie antworten und geben die richtige Lösung) und magisch-analogisch (Metaphern- und Wunschform: "So wie das Salz sich auflöst ...«), zielen auf Vertreibung ab (»Auf die Berge ins Gebirge ...«), oder auf Übertragung (»Nimm meine Pickel und gib sie einem anderen«), $a d y$ - 
den archaischen Schichten der Krankheitsvorstellungen gehört die Projektiltheorie ${ }^{1021}$, die das Befallen-Werden als Eindringen eines Fremdkörpers in den menschlichen Körper erklärt, der abgestreift oder ausgesondert werden kann; auf diese Vorstellung gründet sich eine ganze Reihe von Therapiemethoden.

$\mathrm{Zu}$ den am meisten verbreiteten prophylaktischen Praktiken gehört der Amulettgebrauch $^{1022}$, der sich bis ins Altertum zurückverfolgen läßt ${ }^{1023}$; z. B. die vom Blitz getroffenen Steine, die in Wasser über Nacht »unter die Sterne gelegt werden « ${ }^{1024}$ oder das Anziehen eines in einer Nacht von allen Frauen gemeinsam genähten Hem$\operatorname{des}^{1025}$. Prophylaxe und Therapiebemühungen gehen manchmal ineinander über, was vor allem bei Tierepidemien zu beobachten ist ${ }^{1026}$. Bei den diagnostischen Strategien

nata werden gefordert (»Zähle die Sterne am Himmel und die Blätter des Baums«), die helfende Instanz wird begrüßt (»Oh, gegrüßt seist du, neuer Mond ...«, Willkommen, willkommen die Schwalbe ...«); es gibt auch eine ganze Reihe von infantilen und spielhafte Formen, die Unverständliches artikulieren. Zum Spruch gehört fast immer auch die Aktion und ein Objekt (Salz, Kreuzblumen, Raute, Ring, Haar, Kohle usw.). Zu spezifischen Gebärden vgl. auch Herbert Fischer, »Heilgebärden«, Antaios 2 ( I 960) 3 I 8-347.

I02 I Lauri Honko, Krankheitsprojektile. Untersuchung über eine urtümliche Krankheitserklärung, Helsinki I 959 (FFC I 78 ).

1022 Siegfried Seligmann, Der böse Blick und Verwandtes, 2 Bde., Berlin I 9 Iо, ders., Die Zauberkraft des Auges und das Berufen, Hamburg 1922, ders., Die magischen Heil- und Schutzmittel aus der unbelebten Natur, mit besonderer Berücksichtigung der Mittel gegen den bösen Blick. Eine Geschichte des Amulettwesens, Stuttgart 1927. Zum evil eye vgl. vor allem den zweiten Teil.

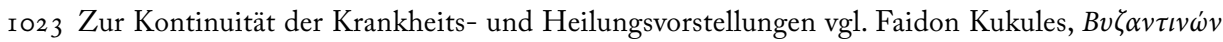

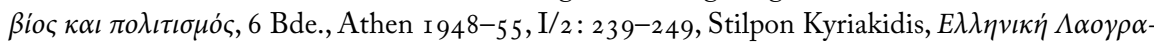

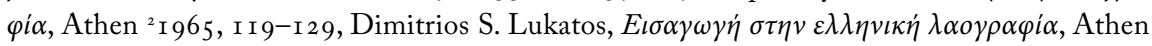

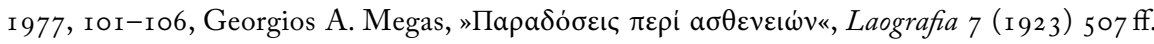
(Material in Laografia I-4, I 909-1913, Bd. 20, I 962, nach Krankheiten aufgeschlüsselt im Register in Laografia 23, I970, I85-189).

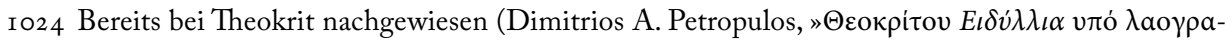

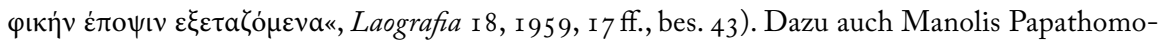

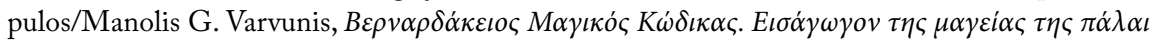
$\pi o \tau \dot{\varepsilon}$, Athen 2006, 349, 362 . In Thrakien werden damit Hautkrankheiten behandelt (Manolis G.

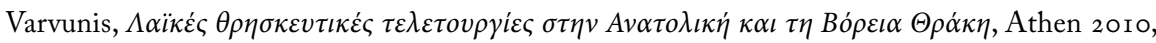
258).

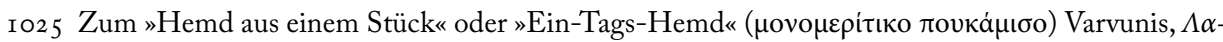

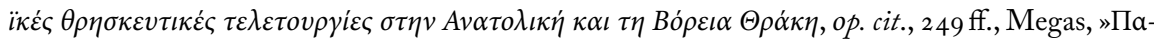

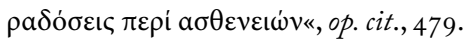

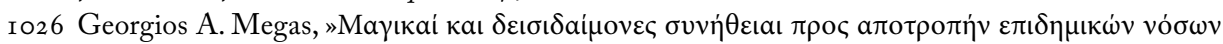

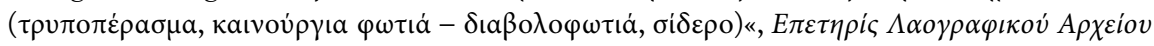
5-6 (I 943-44) 5-58 zusammen mit dem Nadelöhr-Ritus, dem Teufelsfeuer und der Eisenverwendung. 
wird auch die Traumdeutung herangezogen ${ }^{1027}$. Die spezifischen therapeutische Methoden erstrecken sich auf eine Vielfalt von Krankheiten ${ }^{1028}$ : Furunkel, Blutspukken, Blutfluß, Hämorrhoiden, Urinfluß, Mandelentzündung u. a. Halskrankheiten, Anämie, Blattern, Melanome, Schlaganfall, Atrophie, Mittelohrentzündung, Geschlechtskrankheiten, Krätze, Husten, Bronchitis, Grippe, Schlangen- und Insektenbiß (Auslutschen, Kräuterauflegen), Vergiftung, Diphtheritis, Darmverstopfung, Dysurie, Ekzeme, Malaria, Verdauungsstörungen, Epilepsie, Sodbrennen, Pocken, Blattern, Sonnenstich, Migräne, Gelbsucht, Masern, Ischias, Hühnerauge, Herzkrankheiten, Keuchhusten, Verkühlung, Erfrierung, Darmkoliken, Hautflechte, Ausschlag, Tollwut, Mumps, Brustwarzenentzündung, Hirnhautentzündung, Uterusbeschwerden, Nierenkolik, Zahnschmerzen, Ödem, Hodenentzündung, Augenentzündung, Scharlach, Nagelwurzen, Lungenfellentzündung, Lungenentzündung, Rachitis, Rheuma, Nasenbluten, Wurm/Bandwurm, Stomatitis, Schnupfen, Haarausfall, Typhus, Wassersucht, Lausigkeit, Tuberkulose, Nierensand, Krätze, Neuralgien, Hysterie, Ausbleiben der Monatsblutung) usw. ${ }^{1029}$

I027 Die Traumdiagnosen als Teil der Oneiromantik sind schon in der Antike bekannt. In Auswahl:

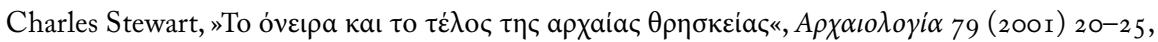
F. T. van Straten, „Daikrates' Dream: A Votive Relief from Kos, and some other Kat' onar De-

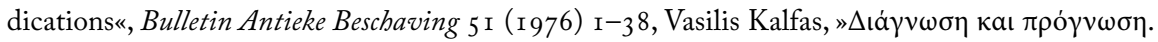

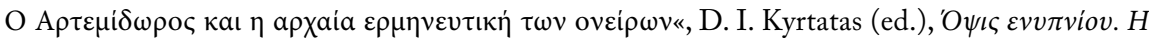

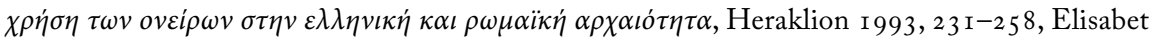

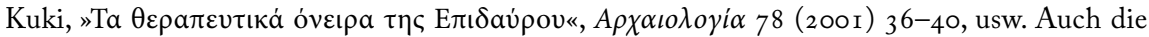
Laienastrologie kann eine solche Funktion einnehmen (vgl. z.B. Christoph Weisser, Studien zum mittelalterlichen Krankheitshunar. Ein Beitrag zur Geschichte laienastrologischer Fachprosa, Pattensen/ Hannover I982).

I028 Karl Jaberg, »Krankheitsnamen. Metaphorik und Dämonie«, Schweizer. Archiv für Volkskunde 47 (195 I) 77-г I 3, Ilmari Manninen, Die dämonistischen Krankheiten im finnischen Volksglauben, Helsinki $1922\left(\mathrm{FFC}_{45}\right)$.

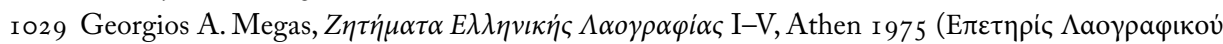
Apxzíov 1939-49) II r63-r 95. Die Systematik der empirischen Medizin umfaßt auch Krankheitsnamen und Terminologie, Symptomatologie, Sitz der Krankheit oder Ursache, euphemisti-

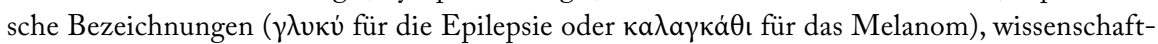
liche Bezeichnungen und ihre Verformung; ferner die Natur der Krankheiten im Volksglauben, die Ursachen: übernatürlich bzw. astral (Strafe, Prüfung, Magie, böser Blick; z.B. Epilepsie als Mondeinfluß oder Dämonenbesessenheit, Personifikation für Pest, Cholera usw., einschlägige Überlieferungen) oder natürlich (Verkühlung, Vergiftung, schlechte Säftemischung, Insektenbiß, Wurm). An anderer Stelle sind die dominanten Prozeduren der magischen Therapeutik thematisiert: Ausräuchern des Krankheitsdämons durch Verbrennen stinkender Sachen, Trinken oder Einreiben/Waschen mit verschiedenen Flüssigkeiten, Einkleiden mit Hemd (Kleidung) des Vaters, Lumpen aus einer gesunden und glücklichen Familie, das in einer Nacht genähte Hemd, Wälzen auf dem taufrischen Gras oder an der Wegkreuzung oder auf einem Grab, symbolische 
Unter den Therapiemethoden lassen sich einige Grundstrategien ausmachen: das

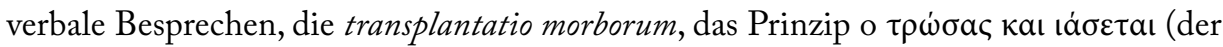
das Leiden Verursachende heilt es auch), similia similibus, Abmessen, Kräuterbehandlung, Berührung von Sakralgegenständen, Diäten, Rezepte der magischer Medizinbücher und -handschriften, chirurgische Eingriffe; dies gilt nicht nur für die Humanmedizin, sondern auch für die Veterinärmedizin.

Das magische Wort in seiner Wirkmächtigkeit, rhythmisch gesprochen, gesungen, geschrieben, aber auch stumm in innerlicher Deklamation, ist an sich ein Kommunikationsvorgang mit imaginären Adressaten ${ }^{1030}$. Folkloristisch gesehen gehört es zu Jolles »einfachen Formen ${ }^{1031}$. Die Sammlung von John Miles Foley aus dem serbischen Orašac und der Šumadija, entstanden aus der Formel- und oral poetry-Forschung von Parry und Lord, heute Teil der Milman Parry Collection, berücksichtigt auch die ethnographischen Kommunikationssituationen und die performative Dimension des Vorgangs ${ }^{1032}$. Neuere systematische Arbeiten zu den griechischen Heilsprüchen kommen jedoch zu dem Ergebnis, daß die Formelbildung des therapeutisch-magischen Spruchguts keineswegs den eisernen Regeln exakter Repetition unterliegt, um für wirksam gehalten zu werden, sondern bedeutenden Variationsspielraum aufweist, ganz wie alle anderen Manifestationen der Oralität auch, welcher den Glauben an die Effektivität des Sprechakts keineswegs herabmindert ${ }^{1033}$. Die Strukturierung der magischen Epode, ne-

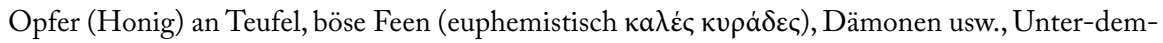
Epitaph-Durchgehen (Evangelium, Petrachelion des Popen), Berührung der Altargeräte, Rutenschlag usw. (ibid. II 97 ff.).

ro3o Stanley Tambiah, Magic, Science, Religion, and the Scope of Rationality, Cambridge 1990, ders., »The Magical Power of Word«, Man 3 (I 968) I 75-208, ders., »Form and Meaning of Magical Acts: a point of view«, R. Horton/R. Finnegan (eds.), Modes of Thought. Essays on Thinking in Western and non Western Societies, Great Britain 1 973, 199-229.

ro3 I André Jolles, Einfache Formen. Legende, Sage, Mythe, Rätsel, Spruch, Kasus, Memorabile, Märchen, Witz, Leipzig 1930.

I032 John Miles Foley/Barbara Kerewsky Halpern, "The Power of the Word. Healing Charms as an Oral Genre«, Journal of American Folklore 9I ( 1978 ) 903-924, bes. 904, John Miles Foley, »Epic Charm in Old English and Serbo-Croatian Oral Tradition«, Comparative Criticism 2 ( I 979) 7 I92, bes. 79 f., ders., Oral Formulaic Theory and Research, Garland 1985, 3-77, ders., »Word-Power, Performance, and Tradition«, Journal of American Folklore 105 (I 992) 275-30I, bes. $287 \mathrm{f}$.

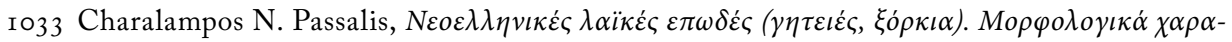
$\kappa \tau \eta \rho \iota \sigma \tau \iota \kappa \alpha ́ ~ \kappa \alpha \iota ~ \varepsilon \theta v o \gamma \rho \alpha \varphi \iota \kappa \varepsilon ́ \varsigma \kappa \alpha \tau \alpha \gamma \rho \alpha \varphi \varepsilon ́ \varsigma$, Diss. Thessaloniki 2000, $323 \mathrm{ff}$. Die Variationsbildung hängt hier besonders mit der lückenhaften Tradierung dieser (Geheim-)Texte zusammen, sowie auch mit der unvermeidlichen Varianz aufgrund der verschiedenen Kommunikationssituationen. Der Glaube an die Wirksamkeit des Zauberspruchs hängt nicht vom Gebrauch magischer Einzelwörter ab oder jener Dosis an Unverständlichkeit, die eine komplexe Syntax hervorrufen kann, sondern von der Kommunikationssituation mit der imaginären Instanz 
ben den Einleitungs- und Schlußformeln, äußert sich im Hauptteil entweder in ritualisierten Sprechformen oder narrativen Texten und verwendet appellartige Kategorien des Imperativs bzw. die zwingende Analogie der Parallelität (so - wie) ${ }^{1034}$. Als intendierter Kommunikationsakt mit imaginären Instanzen verbindet der Heilspruch drei verschiedene Adressaten: die personifizierten (oder nicht) Naturkräfte, den (magischreligiösen) Heilmythos und die sympathetische bzw. homöopathische Magie ${ }^{1035}$. In der verbalen Ausgestaltung der Heilsprüche fallen Archaismen aus der Kirchensprache auf, alliterative non-sense-Bildungen, Neologismen und künstliche Wortbildungen mit meist undefinierbarer Bedeutung ${ }^{1036}$, während Rhythmisierung, Repetitionen und KlimaxBildungen die erhöhte magische Wirksamkeit des Spruches garantieren ${ }^{1037}$. Häufig ist auch der Wechsel von Prosa und Versbildung bzw. der Gebrauch von Alliterationen und Binnenreimen, aber auch listenartigen Aufzählungen, Zahlenallegoresen und Farbanalogien (Gelb-Gelbsucht). Die therapeutische Wirkung des Heilspruchs ist auch anderen Formen des »wirkenden Worts« eigen: dem Gebet, dem Segen, der Beschwörung, dem Bannspruch usw. ${ }^{1038}$ Die Bibliographie zum magischen Heilspruchwesen ist aufgrund der antiken und byzantinischen Schrifttradition kaum zu überschauen ${ }^{1039}$. Einige

und dem Individuum des Sprechers. Der Sprechakt ist fast immer von Objektgebrauch begleitet. Die Liste der »besprochenen« Krankheiten aus dem gesamten griechischen Material zusammen mit der einschlägigen Bibliographie ist lang (70-92), gefolgt von psychologischen Streß-Zuständen (Angst 92 f.), Stech- und Bißtherapien (93-95), Kindbettkrankheiten (95 f.), Schwangerschaft, Säuglingspflege, landwirtschaftliche Prophylaktik (97 f.), Veterinärmedizin (IOO-IO2) usw.

I034 Im Versuch einer Taxonomie kommt Passalis zu folgenden Kategoriebildungen: I) Hauptteil des Spruchs subjektiv (Wunsch) als Bitte oder als Befehl, 2) Hauptteil des Spruchs objektiv als rituell gesprochenes Wort und Narration, 3) Hauptteil subjektiv und objektiv als verstärkte Befehlsform oder zwingende Analogie (Passalis, op. cit., 202).

I035 Vgl. dazu noch im Zweiten Teil.

I036 Passalis, op. cit., $28 \mathrm{I}-30 \mathrm{I}$.

I037 Emil Vrabie, »A Nineteenth-Century Incantation of Bulgarian Refugees in Romania«, Journal of American Folklore 9I (1978) 584-587.

I038 Irmgard Hampp, Beschwörung, Segen, Gebet. Untersuchungen zum Zauberspruch aus dem Bereich der Volksheilkunde, Stuttgart 196r, Ebermut Rudolph, Die geheimnisvollen Ärzte. Von Gesundbetern und

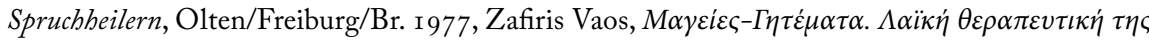
Mílov, Athen 1982.

I039 Eine gehaltvolle Zusammenstellung bei Passalis, op. cit., 325-352. Vgl. in Auswahl: Stilpon Ky-

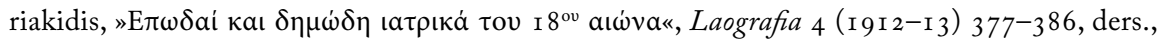

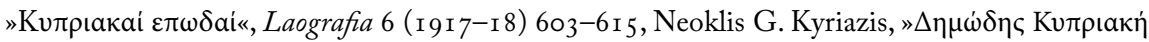

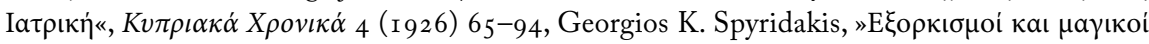

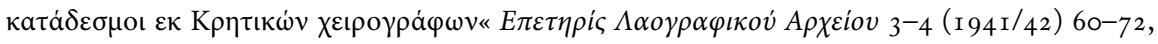

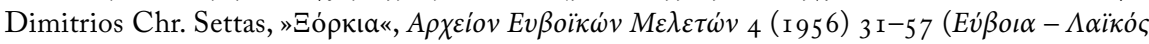


Beispiele aus dem Länderdreieck Thrakien: bei Ohrentzündung ein Pflaster von verschiedenen Kräutern auf die geschwollene Wange gelegt, dann mit dem Weihbrotstempel bekreuzigt, eine Anrufung an Christus und Maria und die Natur gesprochen (»wie die Sonne Licht verstreut auf Berge und Täler, so soll sie auch dieses Übel verstreuen«); bei Windpocken wird ein rotes Tuch aufgelegt ${ }^{1040}$. Bei Milzbrand bzw. Furunkel-Bildung wird ein Feuer entzündet: »verbrenn mich, daß ich dich verbrenne ${ }^{1041}$. In Madytos (bei Eceabat) wird bei Gerstenkorn das kranke Auge mit drei Gerstenkörnern aus den Roßäpfeln des Pferdekots bekreuzigt und folgender Bannspruch gesprochen: "wenn ich dich wieder einpflanze, gehst du mir aus dem Auge ${ }^{1042}$.

Eine der spektakulärsten Heilmethoden (spektakulär im Sinne der heutzutage auffallenden Irrationalität) ist die einseitige Übertragbarkeit der Krankheit durch die Kraft des Wortes, rituelle Praktiken oder Körperkontakt, die transplantatio morborum ${ }^{1043}$, eine Art Umkehrung des Ansteckungsvorganges: Wie die Krankheit durch Proxemik oder Berührung in den Körper gelangen kann, empirische Erfahrung jeder Pestepidemie seit Hippokrates, auf die gleiche Weise kann sie ihn auch wieder verlassen ${ }^{1044}$. Ein typi-

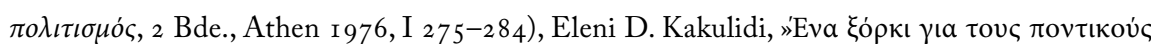

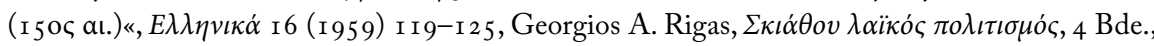

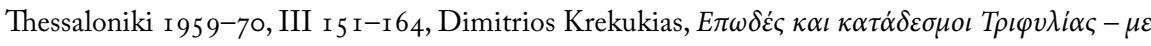

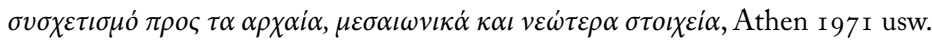

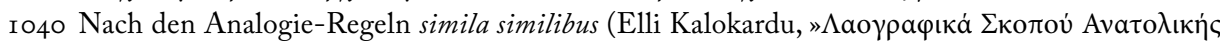

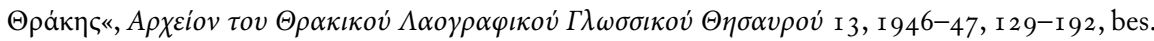
I74).

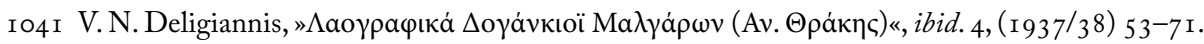

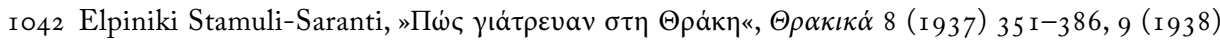
195-283, bes. 2 1 5. Vgl. auch Omiros Mavrides, Gesundheitsmagie in West-Thrakien. Ein Beitrag zur griechischen Volksmedizin, Diss. Universität Münster 1977.

I043 Elfriede Grabner, »Die >Transplantatio morborum` als Heilmethode in der Volksmedizin«, Österr. Zeitschrift für Volkskunde 70 (1967) I 78-1 95. Die Vorstellung von der Gegen-Übertragbarkeit der Krankheit ist sowohl in Antike wie Mittelalter anzutreffen. Vgl. Eduard Stemplinger, Antike

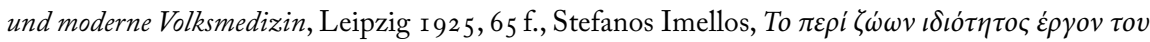

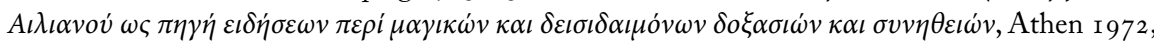
8 I f., Fritz Pradel, Griechische und süditalienische Gebete, Beschwörungen und Rezepte des Mittelalters, Giessen 1907, 376 f. Vgl. auch Michael Herzfeld, „Closure as Cure: Tropes in the Exploration of Bodily and Social Disorder«, Current Antbropology 27 ( (986) го7-г 20.

I044 Die transplantatio morborum gehört zu den fundamentalen Denkfiguren des vorwissenschaftlichen animistischen Weltbildes und ist fast allen voraufklärerischen Volks- und Völkerkulturen eigen, zusammen mit der Koexistenz antithetischer Glaubensvorstellungen, den Handlungsregulativen des do ut des, auch mit metaphysischen Instanzen, dem numinosum, der coincidentia oppositorum (z.B. Tod/Geburt), der Biophilie, pars pro toto und similia similibus, Proxemik und Kontagiosität als Übermittlungsmodalitäten von Identität, irrationale Kausalitäten (ätiologische Mythen), Dynamismus (universelle Kraftzirkulation, Vernetzung aller Dinge) und Animismus 
sches Beispiel dafür ist der »Nadelöhr-Ritus ${ }^{1045}$ : Ein krankes Kind etwa wird durch einen engen Fels- oder Erdspalt, ein Baumloch usw. hindurchgereicht, und mit diesem rite de passage bleibt die Krankheit an den Wänden des Spaltes haften. Ein ähnlicher Grundgedanke liegt der Übertragung durch das Waschwasser zugrunde: im thrakischen Malgara (Malkara) werden drei Weizenkörner von drei verschiedenen, erstmals verheirateten Frauen ins Waschwasser des kranken Kindes gelegt und dann den Hennen gegeben $^{1046}$.

Die Vorstellung von der Möglichkeit der Krankheitsübertragung durch Berührung oder Stoffe, die mit dem Kranken in Berührung gekommen sind, läuft parallel dazu und kontaminiert häufig mit einem anderen Grundprinzip des animistischen Weltbildes, der assoziativen und symmetrischen Analogie, eine Vorstellung die der »typologischen Übertragung « in der christlichen Theologie vergleichbar ist ${ }^{1047}$. Die Forschung hat dieses Prinzip mit similia similibus (curantur) umschrieben ${ }^{1048}$. Hier wird nach den Regeln der analogischen Magie gewöhnlich die Farbähnlichkeit eingesetzt: Bei Gelbsucht wird Eigelb auf die Stirn gestrichen ${ }^{1049}$, eine Goldmünze aufgelegt (Amulettfunktion

(Beseelung). Zu den Modalitäten der grundlegenden Denkfiguren in der Volkskultur Walter

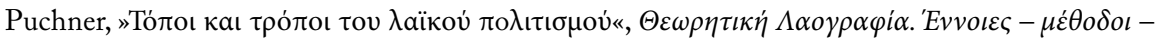

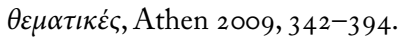

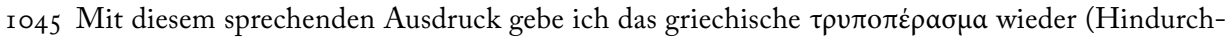

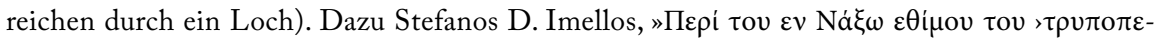

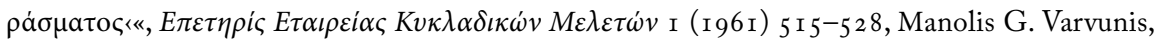

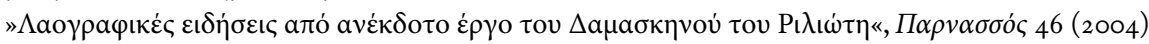

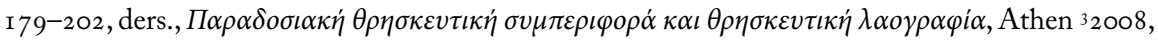
I 49, I 62 usw.

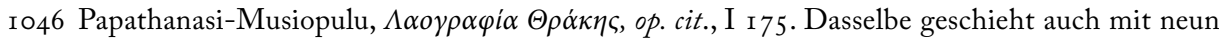
Gerstenkörnern und drei Zuckstücken; im allgemeinen werden für die tranplantatio morborum

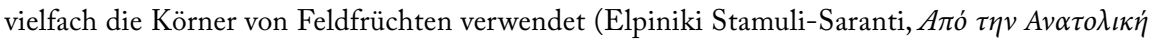

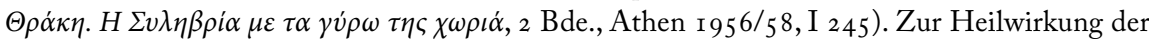
Waschungen vgl. auch Georgios Spyridakis, »The use of Baths during byzantine times«, The Origin of Medicin in Greece, Athens I 968, 5 I ff.

I047 $\mathrm{Zu}$ dieser in den kanonischen und apokryphen Schriften, der mittelalterlichen religiösen Dichtung und dem geistlichen Schauspiel anzutreffenden quasi-logischen Denkfigur Walter Puchner, Studien zum Kulturkontext der liturgischen Szene. Lazarus und Judas als religiöse Volksfiguren in Bild und Brauch, Lied und Legende Südosteuropas, 2 Bde., Wien I 99 I, I I I 6- I 2 I.

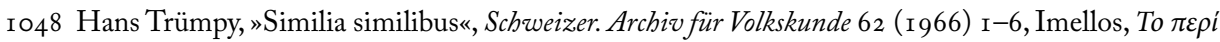

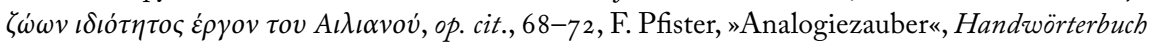
des Deutschen Aberglaubens I (1927) $385 \mathrm{ff}$.

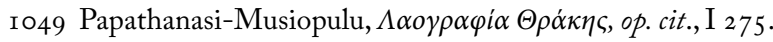


der Edelmetalle) ${ }^{1050}$, Zitronensaft aus reifen goldgelben Zitrusfrüchten verwendet ${ }^{1051}$, bei Blattern ein rotes Tuch aufgelegt ${ }^{1052}$; doch das Analogiedenken führt zu noch weit spektakuläreren Kuren: In Kallipolis (Gelibolu) an der Dardanellenenge verschluckt man bei fliegendem Puls das noch warme Herz einer geschlachteten Taube ${ }^{1053}$; aber auch Personifikationen der Krankheiten werden in das Netzwerk der Analogien miteinbezogen: Bei Masern (als Euphemismus »süß« genannt) stellt man einen Kübel mit Zuckerwasser vor die Tür oder Zucker wird in die Ecken des Hauses gelegt ${ }^{1054}$; oder prozeßhafte Vorgänge werden in den Dienst der Heilung gestellt: Der Ausschlag wird mit dem Morgentau des I. Mais behandelt - so wie der Tau verdunstet, soll auch der Ausschlag vergehen ${ }^{1055}$.

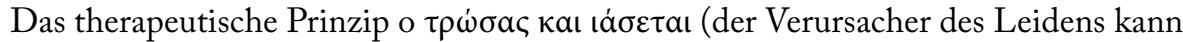
es auch heilen) ist seit dem Altertum bekannt ${ }^{1056}$ und wird vor allem bei Bissen und Stichen (Hund, Schlangen, Tausenfüßler, Insekten usw.) angewendet ${ }^{1057}$; es handelt

I050 In Kastanies (Kestanelik) an der Grenze zur Europäischen Türkei werden dem Gelbsüchtigen

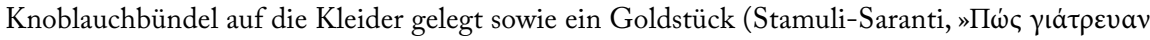

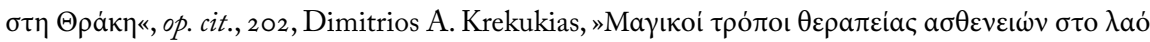

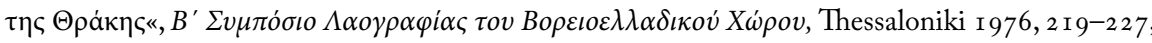

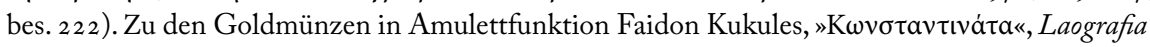
6 (1917-18) 216-220.

I05 I So in Madytos bei Eceabat (Apostolos E. Sitaras, H Mó $\delta v \tau o \varsigma$, Athen I 97 I , 284).

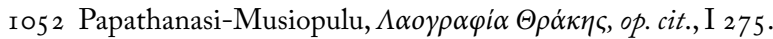

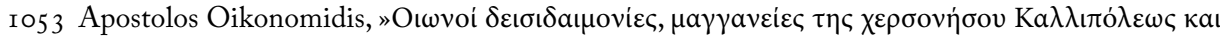

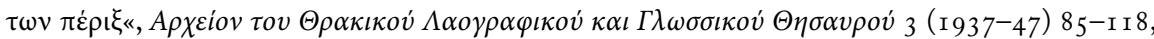
bes. 87 .

I054 Papathanasi-Musiopulu, $\Lambda \alpha o \gamma \rho \alpha \varphi i \alpha \Theta \rho \alpha \dot{\kappa} \eta \varsigma$, op. cit., I I 77. In Epivates am Marmarameer wird bei Krämpfen der Babies in den Kamin geschossen (gegen Dämonen).

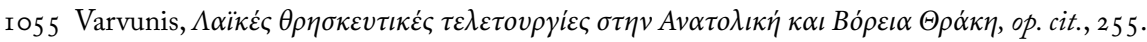

I056 Dimitrios Lukatos führt auch das gegenteilige Prinzip an: $\pi a \theta$ ó $\varsigma$ ı

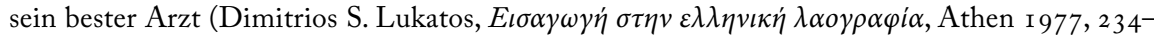
240) und bringt eine Reihe von Beispielen von empirischen Kuren: bei Verkühlung Einreiben mit rotem Pfeffer und Schnaps, Kamillentee trinken, bei Herzschmerzen Pulver von Muskatnuß in Wein trinken, bei Zahnschmerzen gebratenen Knoblauch auf den Zahn legen, auf Hühneraugen wird eine gebratene Tomate aufgelegt, auf offene Wunden legt man zwei zerdrückte Schnecken, bei Kopfschmerzen zerreibt man Brennesselsamen, mischt ihn mit Essig und streicht die Salbe auf dickes Papier, das auf die Stirn gebunden wird; bei Glatzköpfigkeit soll man Blutegel im Feuer verbrennen und das Pulver auf den Kopf streichen, bei Sonnenstich legt man das Kind nackt ins laue Badewasser (dazu Laografia 4, I 9 I $3-14_{4} 383$ ). Wie neuere medizinische Studien belegen, liegen diesen empirischen Kuren vielfach durchaus wissenschaftlich nachweisbare Beobachtungen zugrunde.

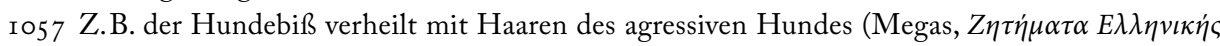

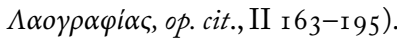


sich um ein Pflichtkapitel in den überlieferten Heilanleitungen ${ }^{1058}$. Neben klinischtherapeutischen Methoden ${ }^{1059}$ finden sich da auch magische Anleitungen, wie Abmessen, Abwägen, Übertragungen auf den Schatten, schamanenartige Praktiken wie bei den Heiltänzen der căluşarii, der anastenaria/nestinari usw. ${ }^{1060}$, aber vor allem pharmazeutische Heilkuren mit Naturstoffen (Kräuter, Säfte, menschliche und tierische Ausscheidungen, Metalle und Steine, Salben usw. $)^{1061}$. Unter den vielen verschiedenen Heilpflanzen ${ }^{1062}$ spielt in Südosteuropa vor allem die Alraune (mandragora) eine heraus-

I058 Adam Abt, Die Apologie des Apuleius von Madaura und die antike Zauberei, Gießen ${ }^{2}$ I967, I85,

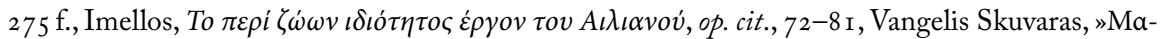

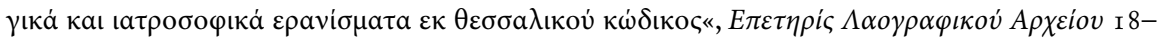

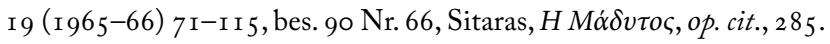

I059 Wie z.B. das Treten des Rückgrat des am Bauch Liegenden (vgl. auch den Bärentritt wie oben), das Nieren-Anheben durch Klebsalbe, Pflaster, Nabelschnüren, Auflegen heißer Ziegel, schweißtreibende Vorkehrungen, Einmassieren, Schröpfköpfe, Blutegel, Aderlaß, Einbände, Zäpfchen usw.

Io6o Dazu vor allem Loring Danforth, The Anastenaria: A study in Ritual Greek Therapy, Princeton 1978 , ders., »The Role of Dance in the Ritual Therapy of the Anastenaria“, Byzantine and Modern Greek Studies 4 (1979) I4I-I63.

I06 г Zu den Heilpflanzen systematisch Maria Miligu-Markantoni, $\Delta \dot{\varepsilon} v \tau \rho \alpha-\varphi v \tau \dot{\alpha}-\dot{\alpha} v \theta \eta \sigma \tau o v \lambda \alpha$ ¿їкó $\pi 0 \lambda \iota \tau \iota \sigma \mu o ́ ~ \tau \omega v v \varepsilon \omega \tau \varepsilon \dot{\varepsilon} \omega v E \lambda \lambda \dot{\eta} v \omega v$, Athen 2004 (alphabetisch geordnet), Evangelia K. Frangaki,

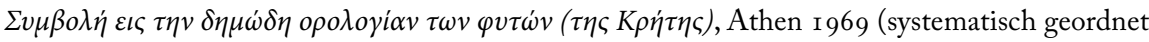

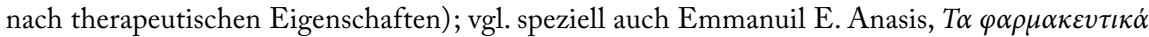

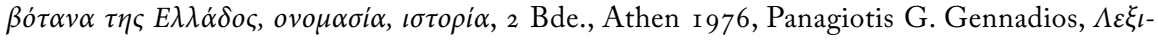

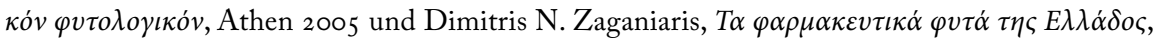
Athen I936. Bei den Heilpflanzen gibt es oft eine eigene lokale Terminologie und die spezifische therapeutische Kapazität ist von der Überlieferung festgelegt; Zeit und Weise der Kollektion sind nicht zufällig, ebenso wie die Anwendung und die Zubereitung. Unter den therapeutischen Eigenschaften dominieren: muttermilchfördernd und -hemmend, für die Monatsblutung, krampflösend, diuretisch, kathartisch, Schlafmittel, stärkend, gegen Fieber, gegen Inflammationen, schmerzstillend, giftig. Neben den Heilpflanzen spielen auch Speichel und andere Ausscheidungen eine Rolle wie Muttermilch, Tierhaut, Haare, Nägel, Galle, Fäkalien von Mensch und Tier, Urin, Unterwäsche mit Monatsblutung usw.

I062 Dazu in Auswahl: Lucia Djamo-Diaconița, »Une texte slavon de farmacoterapie populară din secolul al XVI-lea«, Romanoslavica I 4 ( 1967 ) 377-409, Stanoje M. Mijatović, »Narodna medicina Srba seljaka u Levču i Temniću«, Srpski etnografski zbornik I 3 ( I 909) 259-482, Jasna Belovic, Die Sitten der Südslawen, Dresden 1927, A. Mills, »Peasant Remedies from the Greek Islands«, Bulletin of the History of Medicine 22/4 (1948) 44I-450, Siegfried Seligmann, Die magischen Heil- und

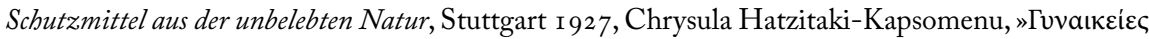

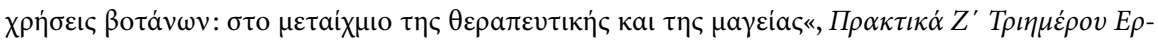

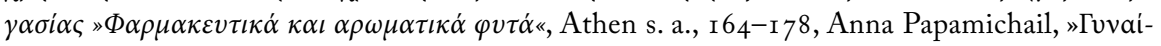

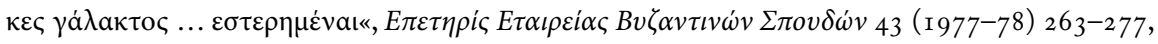

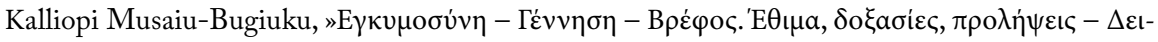


ragende Rolle ${ }^{1063}$. Daneben gibt es auch religiöse Heilpraktiken wie das Berühren von Sakralgegenständen (Priesterornat, Altartuch, Epitaphtuch oder Blumen vom Epitaph, wundertätige Ikone, Umhängen von Votivgaben) $)^{1064}$ oder bei den Krankenwallfahrten das Hinwegschreiten des Priesters mit dem Heiligtum über die am Boden liegenden und auf ein Heilungswunder hoffenden Kranken ${ }^{1065}$; in beiden Fällen geht es um dynamistische Kraftbindung durch Proxemik oder Kontagiosität ${ }^{1066}$.

$\mathrm{Zu}$ den fahrenden empirischen und selbsternannten Wunderdoktoren, Kurheilern und praktischen Chirurgen gibt es eine breite Bibliographie für Südosteuropa, da diese Profession noch bis tief ins 20. Jh. nachzuweisen ist ${ }^{1067}$. Besonders berühmt waren die

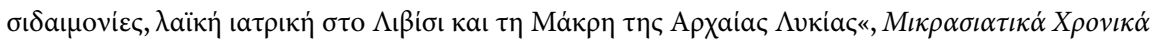
I 4 ( ( 970 ) 59-79, D. A. Krekukias, Il mondo vegetale nelle leggende tradizionali del popolo Greco e

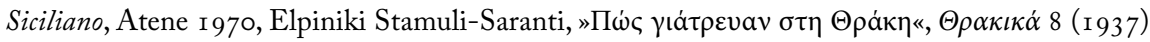

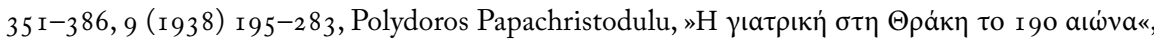

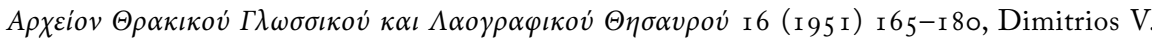

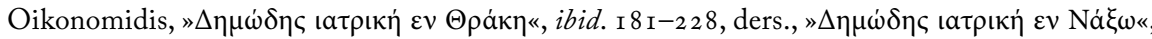

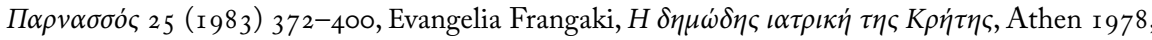

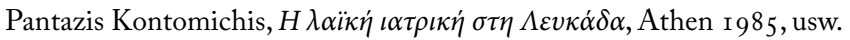

I063 Vagn Jørgensen Brøndegaard, Ethnobotanik. Pflanzen im Brauchtum, in der Geschichte und Volksmedizin, Berlin 1985, Anna Papamichael, Birth and Plant Symbolism. Symbolic and Magical Uses of Plants in Connection with Birth in Modern Greece, Athens 1975, pass., spezifisch P. G. Kritikos,

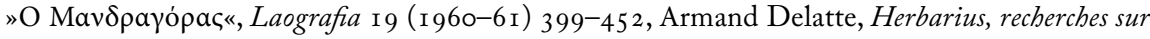
le cérémonial usité chez les anciens pour la cueilette des simples et des plantes magiques, Bruxelles I96 I, 40-45, I 8 I-I 86, Mircea Eliade, "Der Kult der Alraune in Rumänien«, Von Zalmoxis bis DschingisKhan, Köln/Lövenich 1 982, 2 I 5-234 (auch für Heiratsorakel der Mädchen).

ro64 Dazu gibt es viele Belege bereits seit der Antike (Otto Weinreich, Antike Heilungswunder, Giessen ${ }^{2}$ I 969, I 28). Eine besondere Heilpraktik mit Votivgaben ist in Thrakien nachgewiesen: der Kranke hängt ein Goldplättchen mit seiner Gestalt 40 Tage unter die Ikone, das er in der Folge

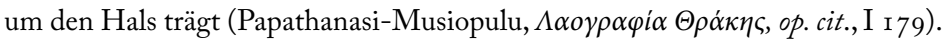

I065 Zur Fronleichnams-Prozession der katholischen Kirche auf Naxos im I7. Jh., wo die Monstranz über die querliegenden Kranken hinweggetragen wurde, die versuchen, das Altartuch zu küssen, bzw. die unter die Prozessionsteppiche gelegten Myrtenbüschel als Amulett und "geheiligte« Gegenstände gegen Krankheiten aller Art verwenden (auch für das Vieh und die Fruchtbarkeit

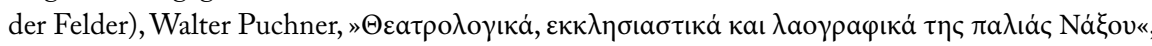

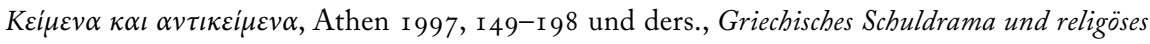
Barocktheater im ägäischen Raum zur Zeit der Türkenherrschaft (1580-1750), Wien 1999 (Österr. Akad. d. Wiss., phil.-hist. Klasse, Denkschriften 27) 78-87.

Io66 Oft treten auch Heilige als Therapeuten auf, vgl. G. A. Williamson, »Tutelary Saints of Medicine in the Greek Church«, Caledonian Medical Journal I4 (1 929) 94-ı04, z.B. Neoklis G. Kyriazis, $\Delta \eta \mu \omega ́ \delta \eta \varsigma \iota \alpha \tau \rho \iota \dot{~} \varepsilon v$ Kú $\rho \omega$, Larnaka 1926.

Io67 Vgl. in Auswahl: Bela Gunda, »Wandering Healers, Medicin Hawkers in Slovakia and Transylvania«, Southwestern Journal of Anthropology 5 (1949) I47-I50, Leopold Kretzenbacher, Teufelsbündner und Faustgestalten im Abendlande, Klagenfurt I968 (Kap. Io: „Garaboncziás- 


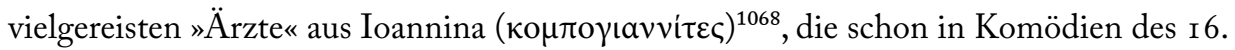
bis I 9. Jh.s satirisch aufs Korn genommen werden ${ }^{1069}$ und in der Novelle von Kostis Palamas, »Der Tod des Palikaren« (I 892) eine düster-dämonische Beschreibung erfahren haben $^{1070}$. Die Hauptquelle sind jedoch die zahlreichen magisch-religiös-medizinischastrologischen Heilanleitungen der iatrosophia, die im wesentlichen auf altägyptische Zauberpapyri und die antike Asklepios-Tradition zurückgehen, in Mittelalter und Neuzeit, Byzanz und Türkenzeit immer handschriftlich weiterkopiert und mit westlichen Rezepten, vor allem aus Italien, angereichert wurden ${ }^{1071}$. Padua war der tradi-

diák. Bettelstudent und „Wissender im Volksglauben der Ungarn«, Kap. I I : „Vom fahrenden Negromanten und Wetterzauberern bei Kroaten und Serben«, Kap. I2: „Der rumänische Solomonar, Erbträger alten Zauberwissens und Sternenglaubens«, Kap. I3 : „Die Slowenen erzählen vom sStudenten' der Schwarzen Schule von der Trenta«). Weiters: Dimitrios V. Oi-

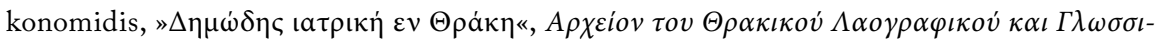

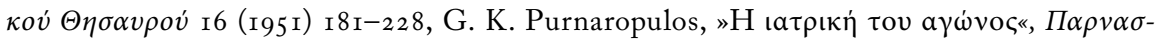

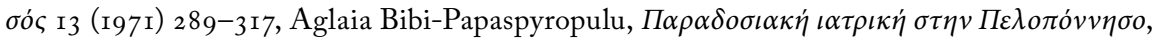

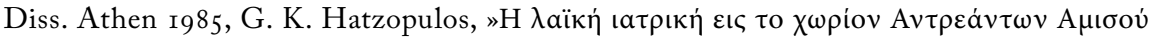

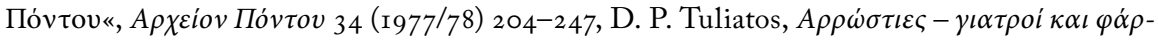
$\mu \alpha \kappa \alpha$, Athen I955, usw.

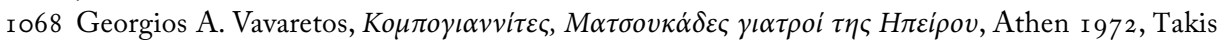

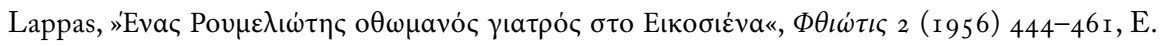

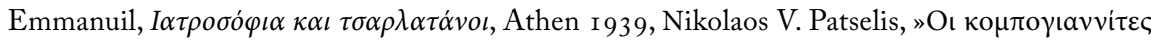

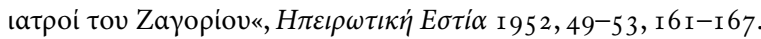

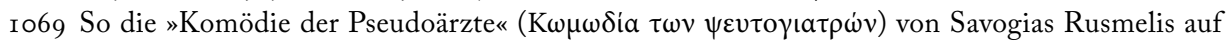
Zante 1745 . Zur Gestalt des komischen dottore als Arzt in der griechischen Dramatik vgl. Walter

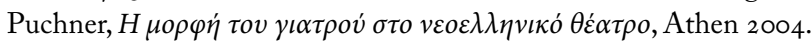

ı 70 Dazu Walter Puchner, »Der Tod des Pallikaren von Kostis Palamas (1891). Studien zur griechischen Dorfnovelle", Von Herodas zu Elytis. Studien zur griechischen Literaturtradition seit der

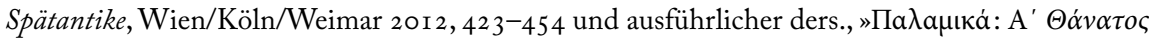

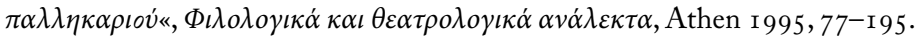

ı07 I Zur Bibliographie aller veröffentlichten und unveröffentlichten iatrosophischen Handschrif-

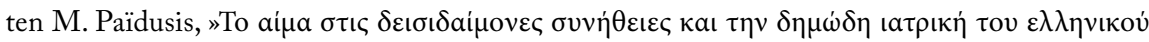

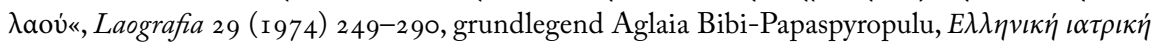
$\pi \alpha \rho \alpha ́ \delta o \sigma \eta, 2$ Bde., Athen 1989 vgl. auch Stefanos D. Imellos, »Griechische Volksmedizin«, Hes-

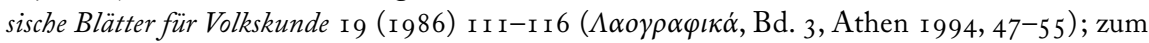
Altertum: Eduard Stemplinger, Antike und moderne Volksmedizin, Leipzig I 925, zur hellenistischen Periode: Iwan Bloch, Griechische Aerzte des dritten und vierten (nachchristlichen) Jabrbun-

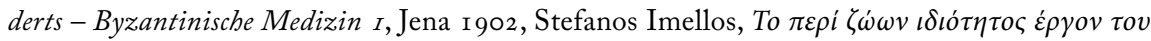

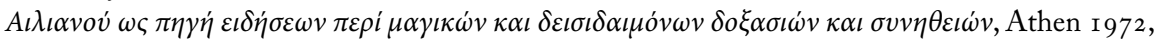

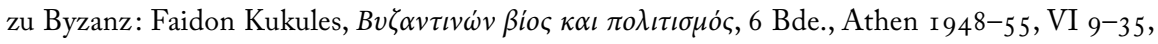
Robert Volk, Der medizinische Gehalt der Schriften des Michael Psellos, Münster 1990, Fr. Kudien, "Empirie und Theorie in der Harnlehre des Johnanes Aktuarios", Clio Medica 8/I (1973) I 9-30, Gudrun Schmalzbauer, »Medizinisch-Diätetisches über die Podagra aus spätbyzantinischer Zeit«, 
tionelle Studienort für Medizin im venezianischen Einflußraum in Südosteuropa. Die Abschriften und Kompilationen dieser Schrifttradition reichen noch bis ins I9. Jh. ${ }^{1072}$ Systematische Studien von medizinischer Seite haben dieses praktische Heilwissen in schriftlicher Tradition zusammengestellt, kodifiziert und auf ihre therapeutische Effizienz hin geprüft ${ }^{1073}$.

Neben pharmazeutischen Heilstrategien und magisch-religiösen Praktiken fehlen jedoch auch die chirurgischen Eingriffe nicht, Wundwaschung, Aufschneiden von Apostemen, Behandlung von Quetschungen, Brandwunden, Einrenken von Gelenken, Knochenbruch, Fistelbehandlung u.a. Ähnliches gilt für die Veterinärmedizin: Auch hier wird bei Geflügel, Schafen und Ziegen, Pferden, Eseln, Maultieren, Ochsen und Kühen, Schweinen und anderen Haustieren sowohl konservative Heilpraktiken mit Kräutern als auch magisch-religiöse Besprechungen wie auch chirurgische Eingriffe

Jahrbuch der Österr. Byzantinistik 23 (1974) 229-243, Ioanna Oikonomou-Agorastou, Kritische Erstausgabe des Rezeptbuches des Cod. Par. gr. 23 I6,f. 348-374, Köln I98 I, Alice-Mary M. Tal-

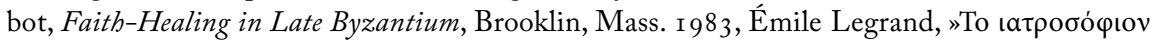

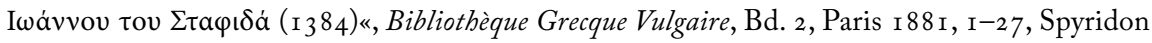

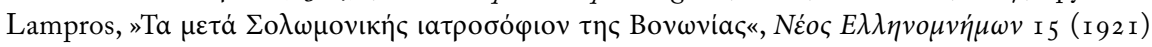

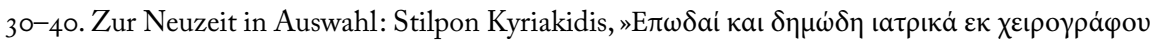

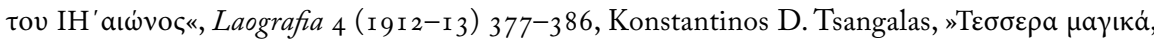

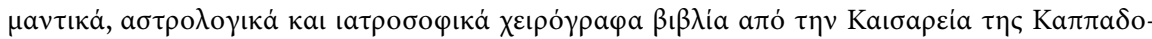

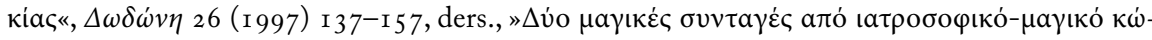

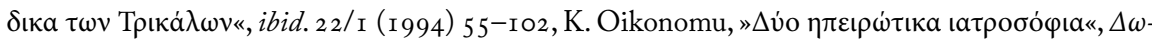

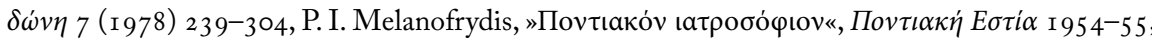

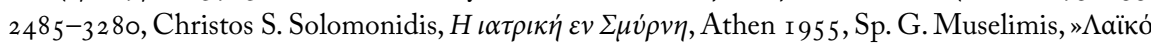

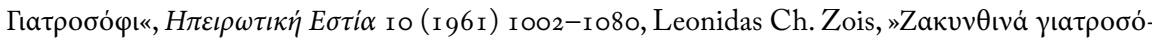

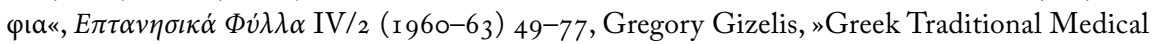
Practices as Revealed in a Manuscript from the Island of Levkas", Keystone Folklore I 8 ( 1973) I03-I 26, usw.

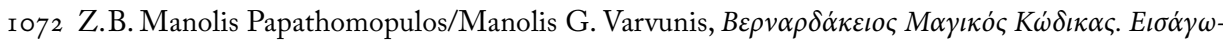

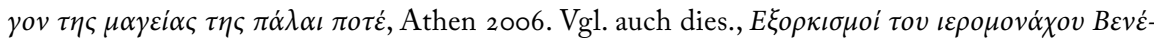

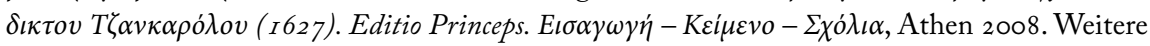

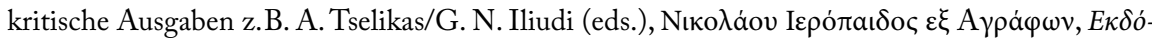

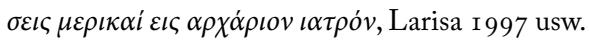

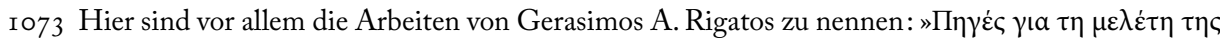

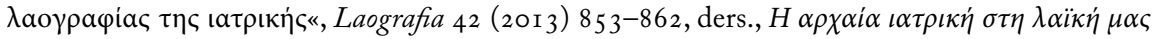

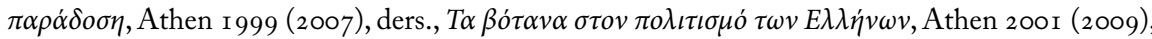

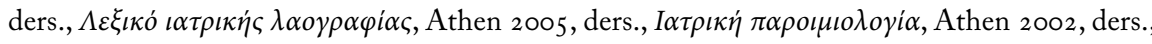

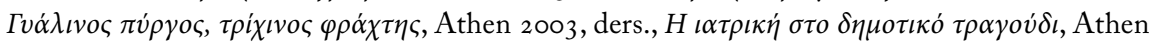

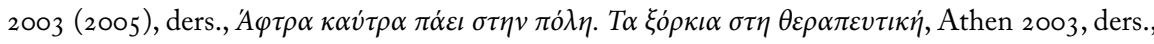

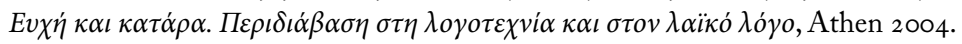


angewendet ${ }^{1074}$. Seuchen und Epidemien werden oft auf personifizierte Krankheitsdämonen zurückgeführt, wie die südslavische Pestfrau čuma ${ }^{1075}$.

Neben den grundlegenden Aktionen der Therapiebemühungen gibt es jedoch auch magische Verstärkungsmittel der Effektivität der Heilpraktiken durch die Einhaltung besonderer Vorschriften und die Kreation besonderer Umstände, wie die Nacktheit der Ausführenden ${ }^{1076}$,

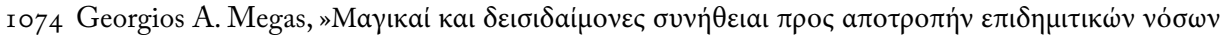

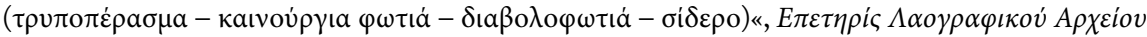
5 (I943-44) 5-58 (Laografia 25, I967, 48 I-533) für den thrakisch-bulgarischen Raum. Bei Tier-

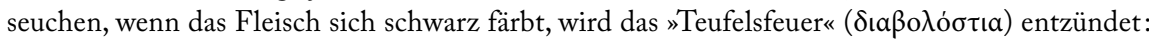
an der Wegkreuzung vor dem Dorf entzünden drei splitternackte Männer durch Holzreiben (komplizierte Technik, artifizielles Hindernis - besondere Effektivität) ein Feuer, über das man die kranken Tiere treibt; bei Büffelseuchen werden aus sieben verschiedenen Gegenden Eisenstücke von einem Schmied (nackt) zu einem Eisenstab geformt, der glühend den Tieren auf den Rücken oder unter den Schwanz gelegt wird; dieser magische Stab wird auch anderen Dörfern geliehen; bei Tollwut durch Hundbiß wird die Herde (der Treiber nackt) durch den Fluß getrieben oder über das Teufelsfeuer; auf diesem Feuer wird der Hund (oder das von Tollwut befallene

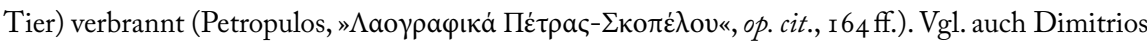

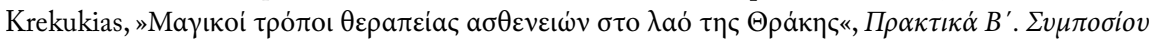

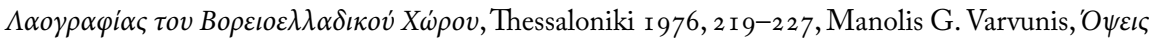

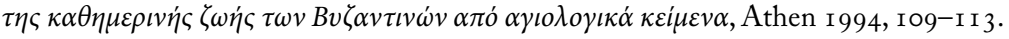

I075 Vakarelski, Bulgarische Volkskunde, op. cit., 235 f. Daneben gibt es die šarka für Pocken, Scharlach und Röteln, die navi für Kindbettkrankheiten, die červenka für Rotlauf, die bezsărnica für Schlaflosigkeit, den bolestčica für Schlaganfall usw. Zu solchen Glaubensvorstellungen personifizierter

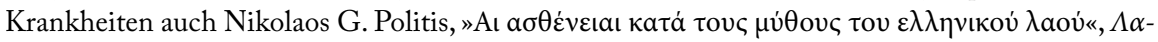

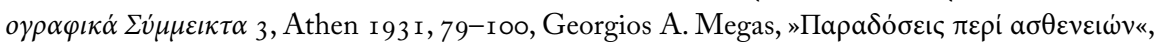

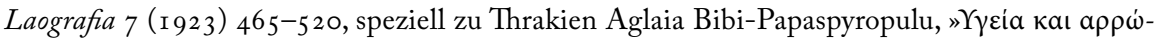

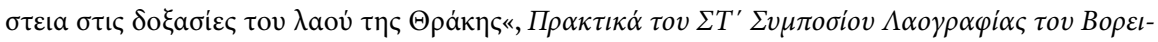

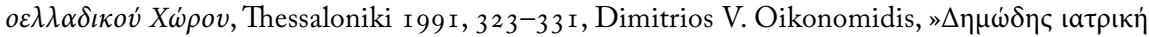

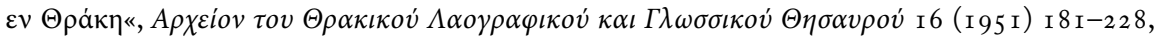

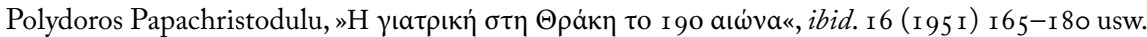

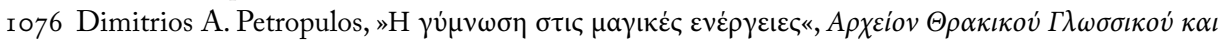

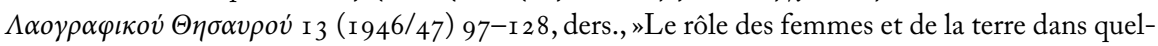
ques pratiques magiques", Mélanges Octave et Melpo Merlier, 2 Bde., Athènes I956, II 275-285. Z.B. bei Handlungen schwarzer Magie säen in Megara zwei nackte Frauen um Mitternacht Salz

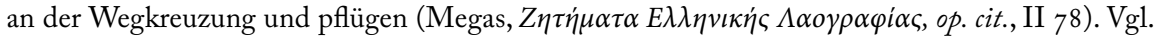
auch die Angaben zum thrakischen Teufelsfeuer. Zur magischen Kraft des weiblichen Hemdes,

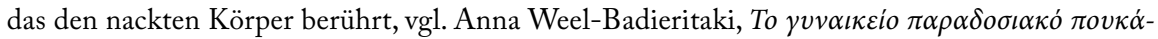

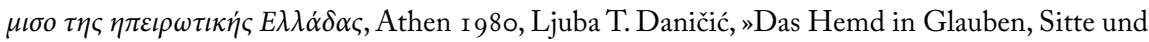
Brauch der Südslaven«, Anthropophyteia 7 (I9ro) 54-I 28, zum Zusammenhang der Schürze mit der Fruchtbarkeit dies., „Die Frauenschürze in Glauben und Sitten der Südslaven«, ibid. 9 ( I 9 I 2) 102-209. 
Schweigen, unbesprochenes Wasser ${ }^{1077}$, Unberührtheit ${ }^{1078}$, die Zahl $40^{1079}$, Opfer ${ }^{1080}$, Beschwörung ${ }^{1081}$ oder komplizierte Hindernisse in der Zusammenstellung und Zubereitung der Ingredienzien wie Fluch, Lüge, Diebstahl, Nicht-Umdrehen, verkehrt Anziehen, umgekehrt

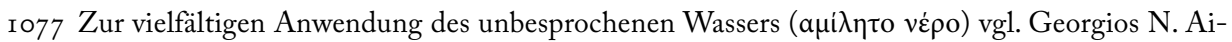

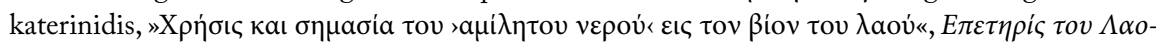

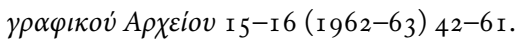

I078 Kirsten Hastrup, "The semantics of biology: virginity«, Sh. Ardener (ed.), Defining Females: The Nature of Women in Society, London 1978, 49-65, Eugen Fehrle, Die kultische Keuschheit im Altertum, Gießen r 9 I 0,63 f. Es handelt sich um ein konventionelles Element der Effektivitätssteigerung, z.B. Jungfrauen im Fruchtbarkeitszauber, beim Regenzauber usw. (Wilhelm Mannhardt, Wald- und Feldkulte, 2 Bde., Berlin I 905, I 328 f.), oder sie wälzen sich nackt im Flachs, damit er hoch wird (I 483 f.); Reste von Jungfernschaftskontrolle auch bei Lazarusumzügen (Puchner, Brauchtumserscheinungen, op. cit., 98 f.). Vgl. auch Wolfgang Brückner, »Keuschheit«, Enzyklopädie des Märchens 7 (1 993) I 2 I I-I 8. Zum Reinheitsprinzip auch Mary Douglas, Purity and danger. An analysis of concepts of pollution and taboo, London 1966.

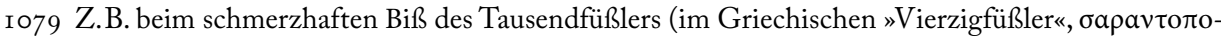

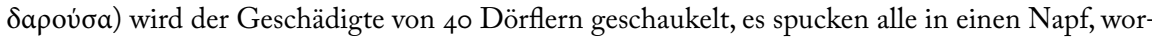
aus eine Salbe für die Bißwunde oder ein Heiltrank gemacht wird (Krekukias, Мaүıкоі тро́то«, op. cit., 225). Zu 40 als heiliger Zahl (Trauerperiode, Wochenbett usw.) Georgios K. Spyridakis, $O \alpha \rho \iota \theta \mu o ́ \varsigma \tau \varepsilon \sigma \sigma \varepsilon \rho \alpha \dot{\kappa} \kappa o v \tau \alpha \pi \alpha \rho \alpha \dot{\alpha} \tau o \iota \varsigma \beta v \zeta \alpha v \tau \iota v o i \varsigma \kappa \alpha \iota v \varepsilon \omega \tau \dot{\varepsilon} \rho o \iota \varsigma^{\prime} E \lambda \lambda \eta \sigma l$, Athen 1939, vgl. auch Max Wellmann, "Die Фvбıкá des Bolos Demokritos und der Magier Anaxilaos aus Larissa«, Abh. $d$. Preuss. Akad.d. Wiss. 7 ( 1928 22, Margaret H. Thompson, Textes grecs inédits relativs aux plantes, Paris I 965, I I3). Bei der Ikonenwaschung am Theophanietag in Ostthrakien (heute bulgarischtürkisch) sammeln die Frauen in einem ausgehöhlten Kürbis von 40 Meereswellen Wasser als

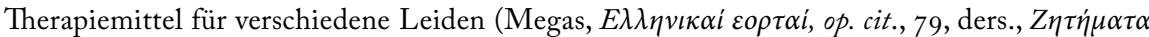
$\varepsilon \lambda \lambda \eta v ı \kappa \eta ́ \varsigma ~ \lambda \alpha о \gamma \rho \alpha \varphi i \alpha \varsigma$, op. cit., III 56). Vgl. auch Martin Ninck, Die Bedeutung des Wassers im Kult und Leben der Alten, Leipzig I 92 I, 4-7 usw. Zu anderen heiligen Zahlen wie 3, 7 und 72 vgl. Kypros Chrysanthis, "The Magic Numbers Three, Seven and Seventy-Two in Cypriote FolkMedicine «, Folklore 57 ( 1 946) 79-83. Vgl. auch Gilbert Dragon, "Troisième, neuvième et quarantième jours dans la tradition Byzantine: temps chrétien et anthropologie«, Colloques Internationaux du C. N. R. S. (Paris 9-I2 mars I98I). Le Temps chrétien de la fin de l'Antiquité au Moyen Age, IIIe-XIIe siècles, Paris I 984, 4 I 9-430.

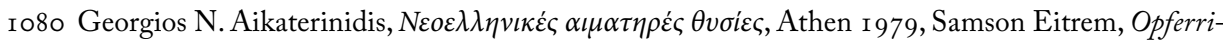
tus und Voropfer der Griechen und Römer, Kristiania I 9 I 4, F. Eckstein, "Speiseopfer «, Handwörterbuch des Deutschen Aberglaubens IX (1938/4I) 496-547. Vgl. den zweiten Teil.

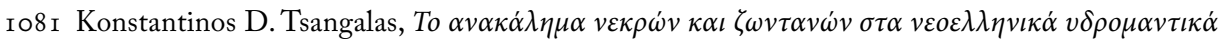

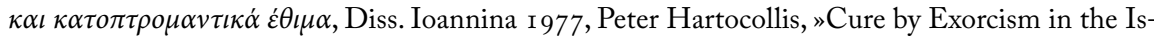
land of Cephalonia", Journal of the History of Medicine and the Allied Sciences I 3/3 (1958) 367-372,

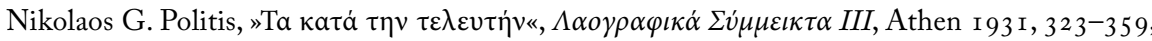
Paul Geiger, »Totenbeschwörung", Handwörterbuch des Deutschen Aberglaubens VIII ( I 936/37) I054-55, Irmgart Hampp, Beschwörung, Segen, Gebet, Stuttgart I 96 I, Theodor Hopfner, »Nekromantie«, Realenzyklopädie der Altertumswiss. XVI/2 (1935) 22 I 8-33, Walter F. Otto, Die Manen, oder von den Urformen des Totenglaubens, Berlin 1923. Vgl. den zweiten Teil. 
Schreiben (nach links), Heimlichkeit, Verhüllen, Nacht usw. ${ }^{1082}$. Damit ist jedoch der Übergang zum zweiten Teil bereits vollzogen.

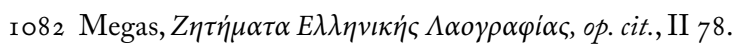


Bildtafeln 

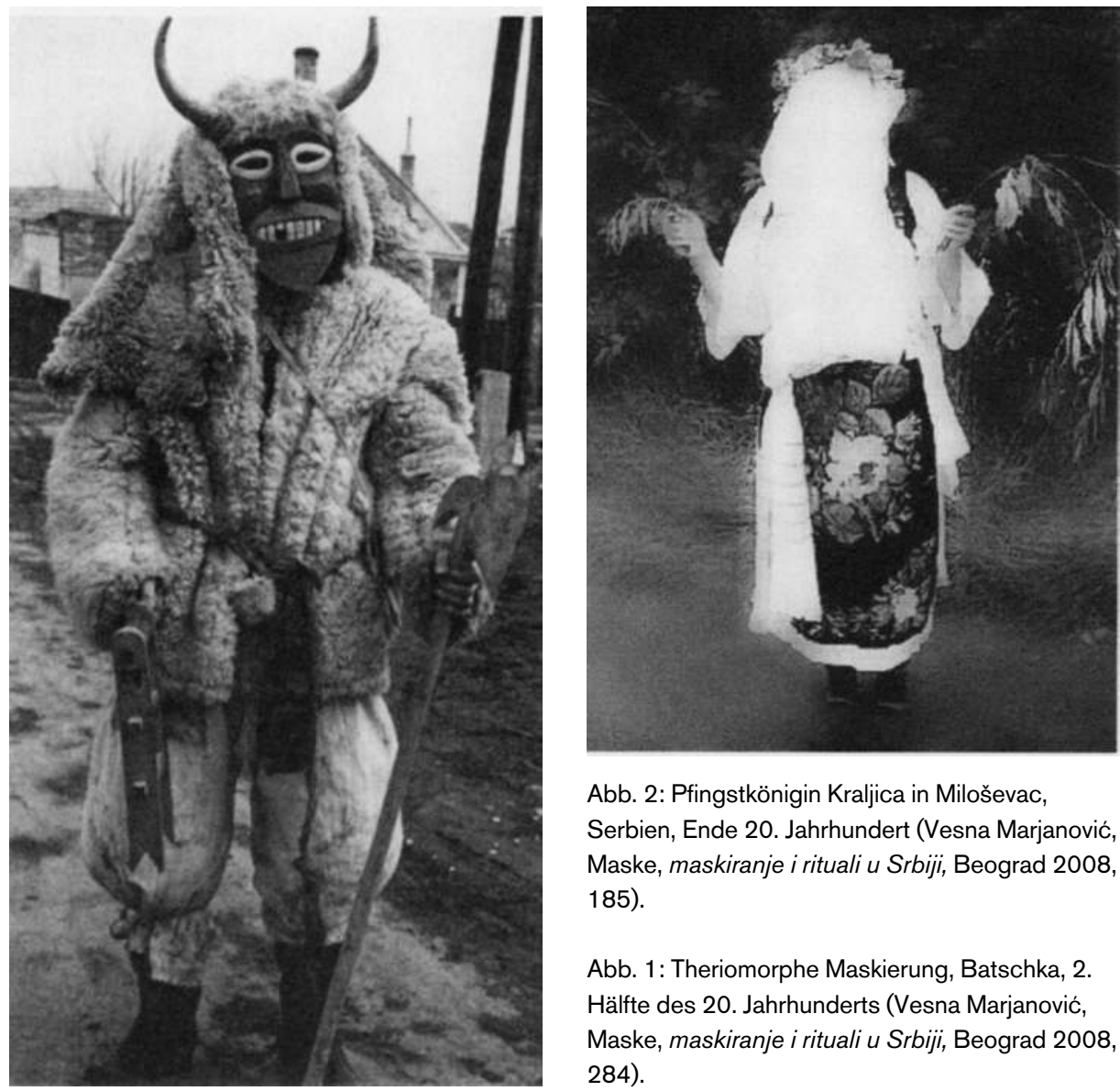

Abb. 2: Pfingstkönigin Kraljica in Miloševac,

Serbien, Ende 20. Jahrhundert (Vesna Marjanović, Maske, maskiranje i rituali u Srbiji, Beograd 2008, 185).

Abb. 1: Theriomorphe Maskierung, Batschka, 2. Hälfte des 20. Jahrhunderts (Vesna Marjanović, Maske, maskiranje i rituali u Srbiji, Beograd 2008, 284). 


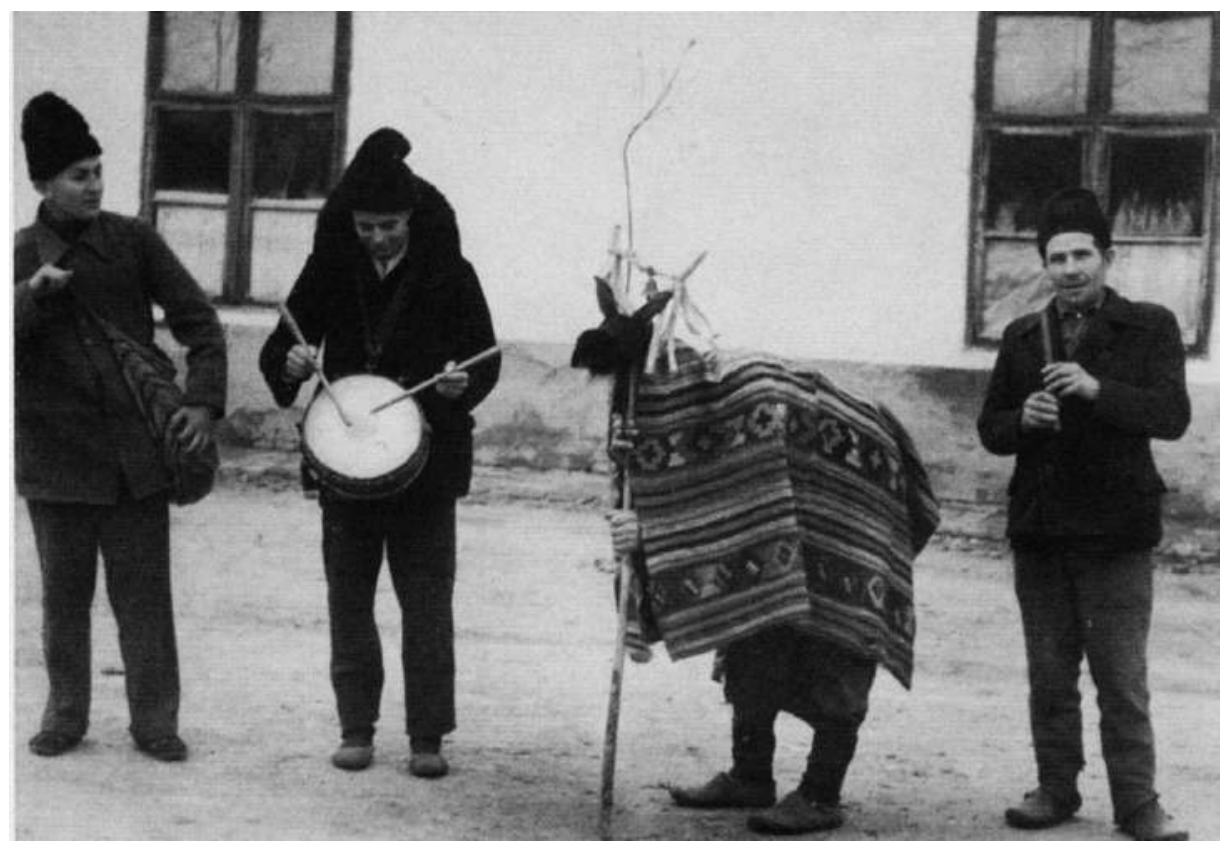

Abb. 3: Ziegenverkleidung der Winterumzüge mit Klappermaske, Jankov Most, rumänische Vojvodina (Robert Wildhaber (ed.), Masken und Maskenbrauchtum aus Ost- und Südosteuropa, Basel 1968, Abb. 37).

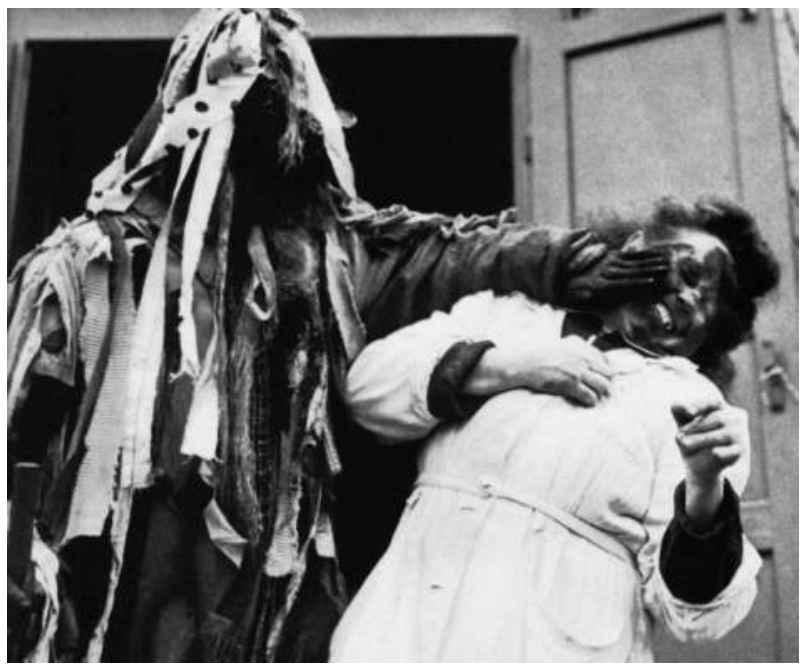

Abb. 4: Gesicht-Schwärzen bei den Karnevalsbräuchen in Moha (Bezirk Féjér) in Ungarn (Péter Korniss, Bräutigam des Himmels. Bilder ungarischer Volksbräuche, Budapest 1975, o. S.). 


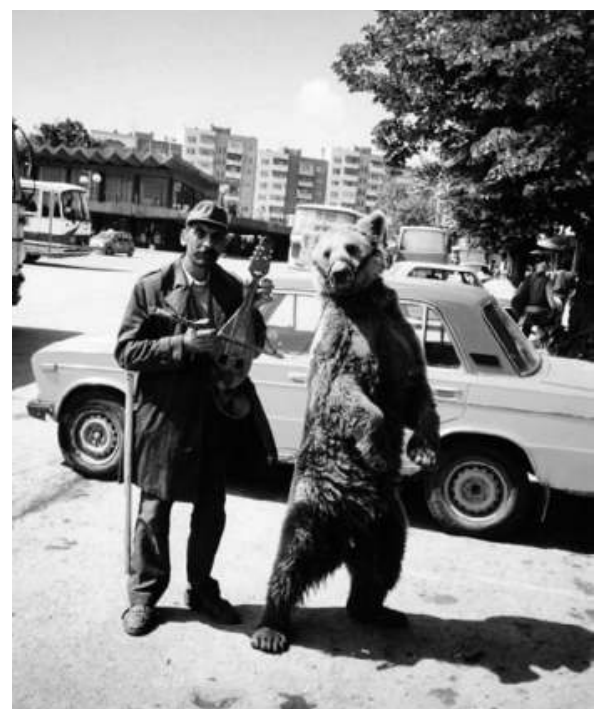

Abb. 5: das Vorbild der Bärenverkleidung: Tanzbär mit Zigeuner als Bärenführer, gadulka spielend, Varna, Bulgarien (Photoarchiv Thede Kahl).

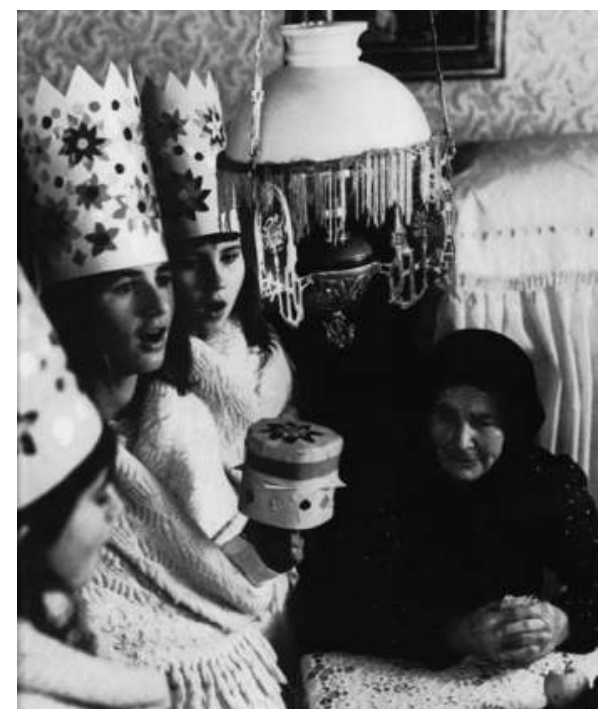

Abb. 6: Sternsingen in der Stube am HI. DreiKönigstag in Szakmár (Bezirk Bács-Kiskun) in Ungarn 1970 (Péter Korniss, Bräutigam des Himmels. Bilder ungarischer Volksbräuche, Budapest 1975, o. S.).

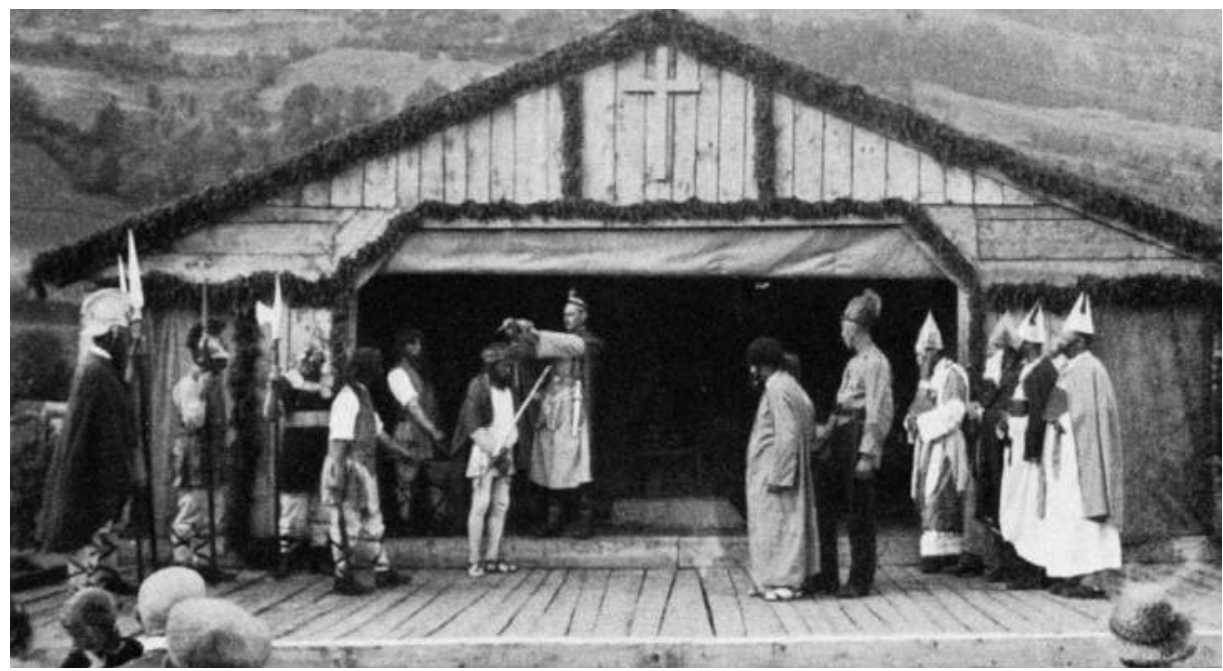

Abb.7: Die Dornenkörnung Christi aus dem theatralischen Passionsspiel in St. Lorenzen ob Murau, Steiermark 1937 (Leopold Kretzenbacher, Passionsbrauch und Christi-Leiden-Spiel, Salzburg 1952, Abb. 7). 


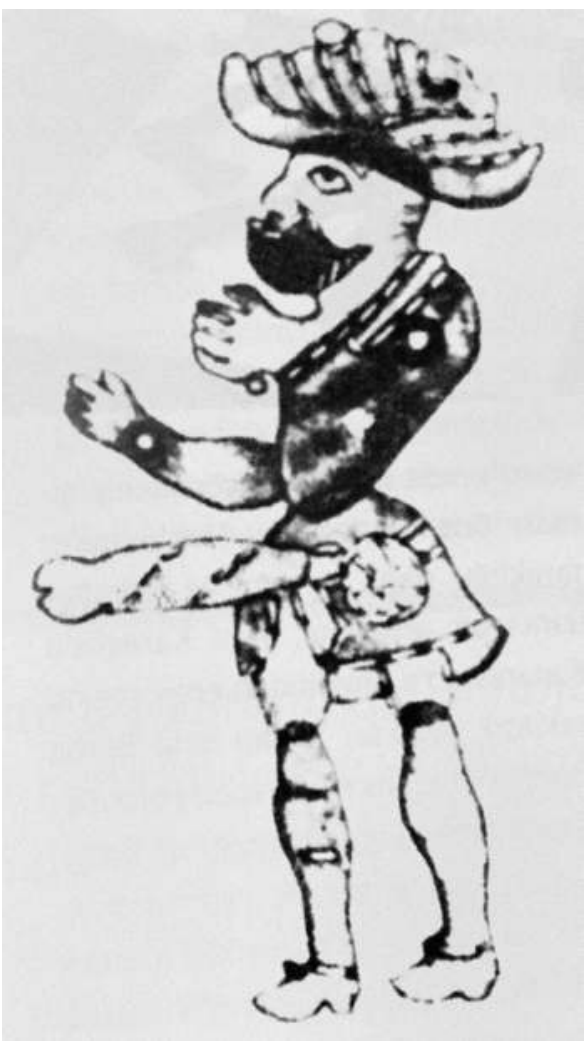

Abb. 8: Ithyphallische Karagöz-Figur aus der osmanischen Schattenspieltradition (Metin And, Karagöz. Théâtre d'Ombres Turc, Ankara 1977).

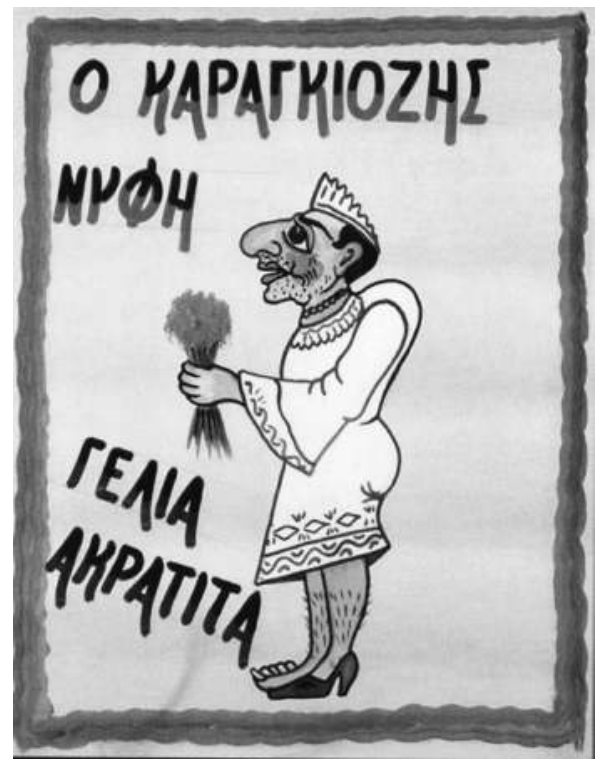

Abb. 9: Handgemaltes Reklameplakat einer griechischen Schattentheatervorstellung "Karagiozis als Braut" des Karagiozis-Spielers Fotis Plessas, das "haltloses Lachen" verspricht

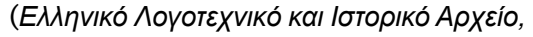

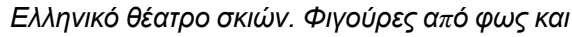
Iбторі́a, Athen 2004, Abb. 53). 


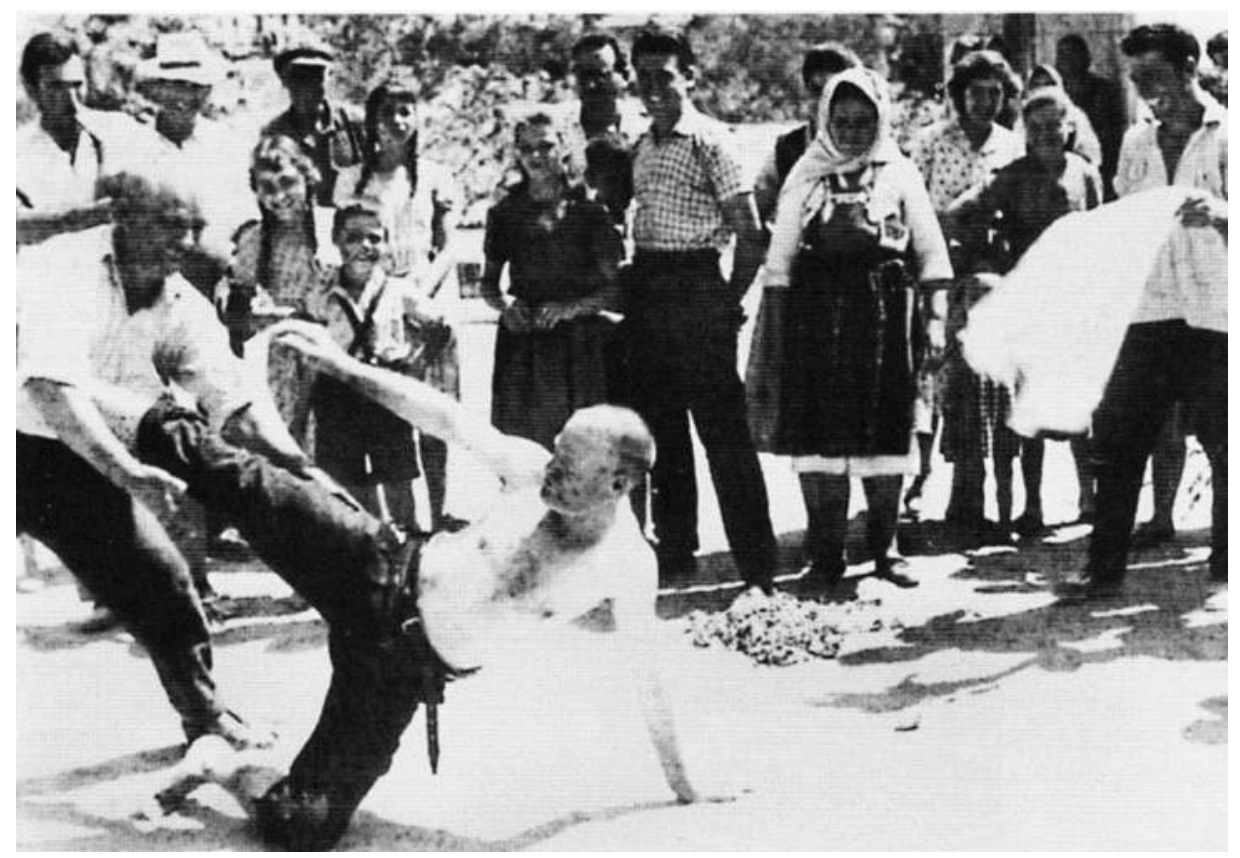

Abb. 10: Rituell-sportlicher Ringkampf bei einem Hochzeitsfest in Karoti bei Didymoteichon in Griechisch-Thrakien 1960 mit Dudelsack (gaida)-Begleitung, Photo G. N. Aikaterinidis (M. G. Varvunis,

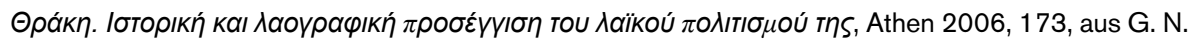

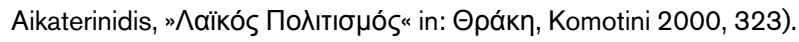




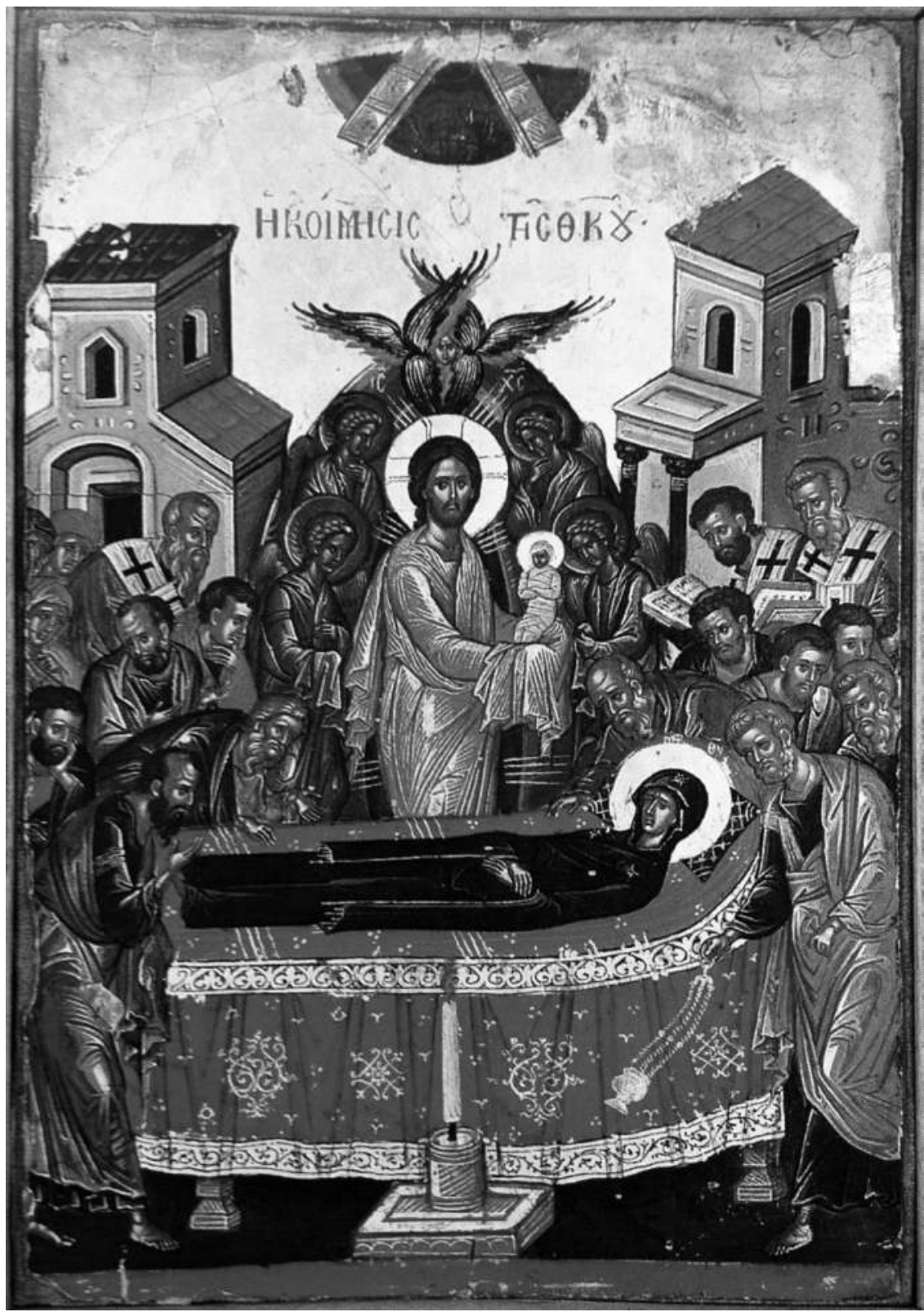

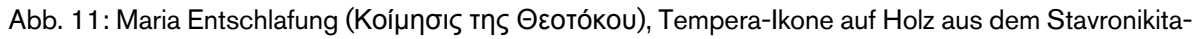

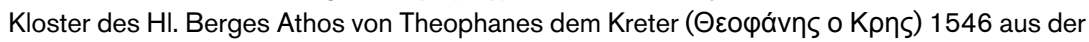
farbenfreudigen kretischen Schule; Christus hält die "Seele" der schon verstorbenen Mutter Gottes als Wickelkind im Arm (Onoaupoí rou Ayíou Opous, Thessaloniki 21997, 141 Nr. 2.72). 


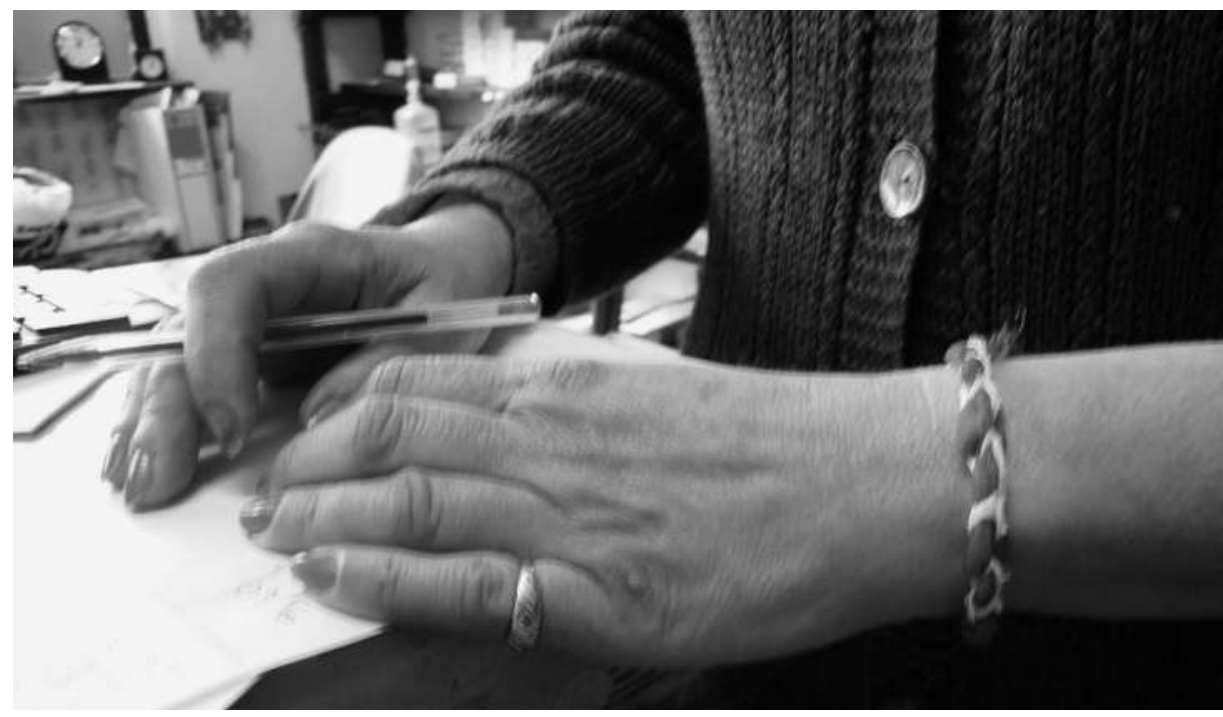

Abb. 12: Apotropäischer März-Faden (martis, martitsi, martinički) an der Hand einer Kassiererin in einem kleinen Lebensmittelgeschäft (bakaliko) im Dorf Pistiana im Gebiet der Tzumerka, Zentralpindus, Epirus (Photoarchiv Thede Kahl).

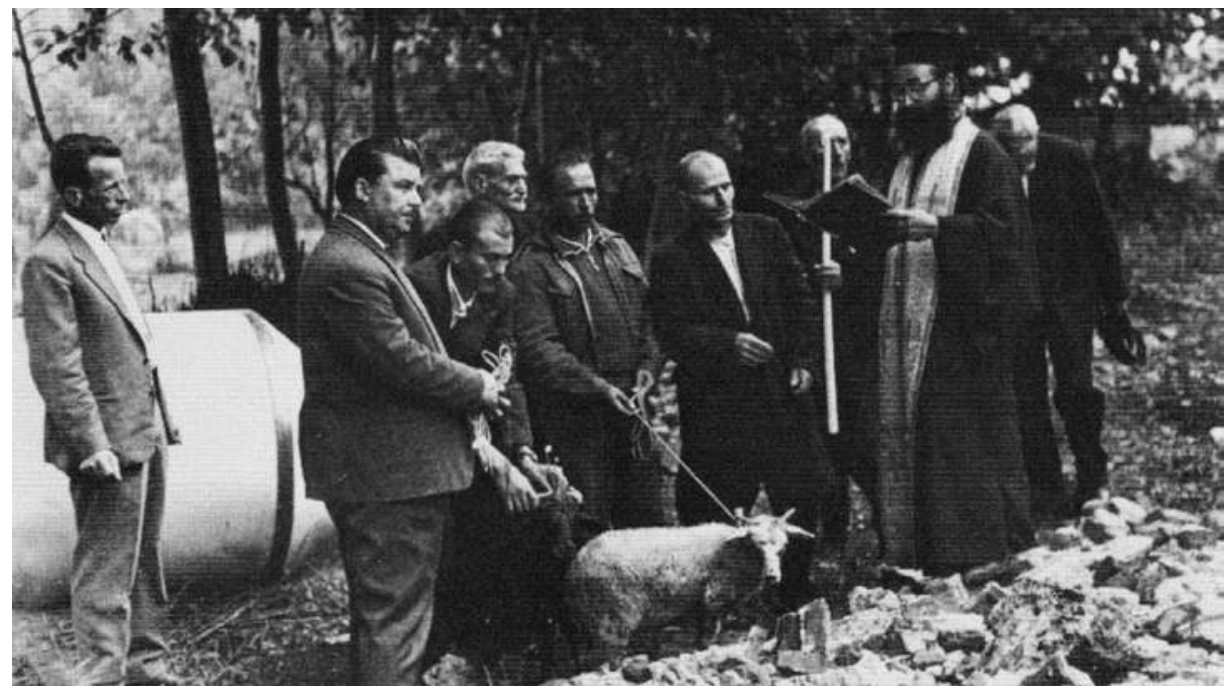

Abb. 13: Priesterliche Segnung eines Tieropfers: weißes und schwarzes Schaf mit aufgesteckten Kerzen auf den Hörnern, bei den rituellen Vorbereitungen des Feuerlaufs der anastenaria in Agia Eleni bei Serres, Griechisch-Makedonien, am 21. Mai 1963, Photo von G. K. Spyridakis und G. N. Aikaterinidis

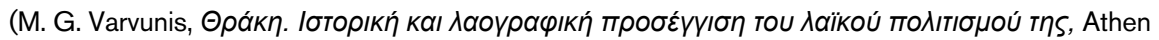
2006, 117). 

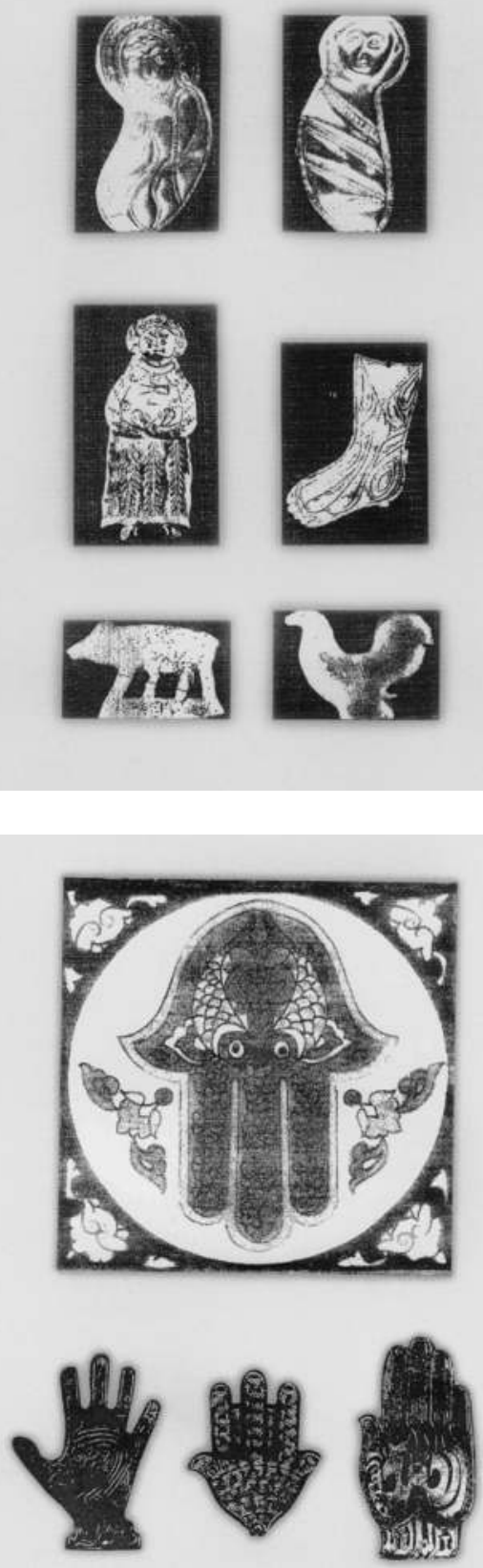

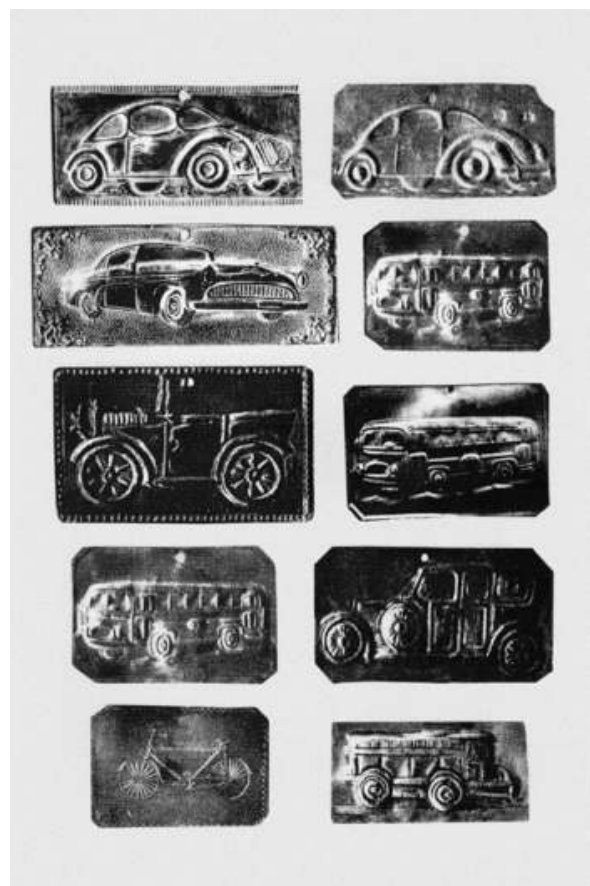

Abb. 14 (I.o.): Votivplättchen aus Serbien (Nikos

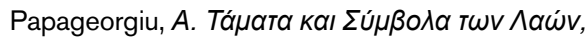
B. Z Athen 2011, 140).

Abb. 15 (l.u.): Das apotropäische Amulett "die Hand der Fatima" im islamischen Glaubensbereich (Nikos Papageorgiu, $A$.

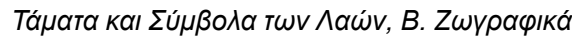

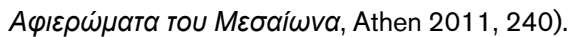

Abb. 16 (r.o.): Moderne Votivplättchen aus Griechenland (Nikos Papageorgiu, A. Támata кaı

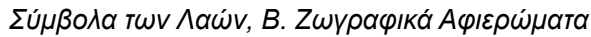

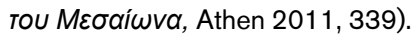


ZWEITER TEIL: IMAGINATION 


\section{Einleitung: Sakralität und Superstition}

War die Performanz als Interpretationsaspekt der rituellen oder spielerischen Handlung auf Kommunikation hin angelegt, so kann die Imagination von Mythos und Phantasie als Kommunikation mit imaginären Instanzen aufgefaßt werden. In gewissem Sinne wird das Gesagte und Gehandelte von einem dahinterliegenden Gedachten oder Geglaubten legitimiert und begründet, ungeachtet der Vorgängigkeitsfrage von Lebenspraxis und reflektierender oder spekulierender theoria (Schau). Das Weltbild der traditionellen Oralkulturen Südosteuropas baut gewöhnlich auf animistischen und dynamistischen Vorstellungen auf und ist von assoziativen und (pseudo)symmetrischen Analogiebildungen reguliert. Konsequenz dieses physischen und metaphysischen Interaktionssystems ist das Eingesponnen-Sein von Einzelindividuum, Familie und Kommunität in ein universales Netz von Abhängigkeiten, Verpflichtungen und Strategien der Bewältigung des Unbekannten, in ein kontinuierliches Gespanntsein, imaginären und realen Bedrohungen begegnen zu müssen, das Unvorhersehbare vorherzusehen, mit dem Übernatürlichen in Kontakt und Pakt zu treten, Verhandlungen des Unverhandelbaren zu führen, letztlich Geschäfte mit dem Schicksal zu machen und doch auch irgendwo den unverrückbaren Glauben zu besitzen, daß dies alles vergebens ist, aber man versucht es dennoch; schaden kann es nicht, vielleicht hilft es. Letzteres geschieht bereits in den Übergangsphasen zu einem wissenschaftlich rationalen Weltbild bzw. unter dem Druck von Dogmatik und Pastoralpraxis theologisch organisierter Religionen. Im Zuge der Industrialisierung, Verbürgerlichung und Mechanisierung der Produktion usw. ist der immense Druck des Alltäglichen und Nicht-Alltäglichen z.T. gewichen, doch die großen existentiellen Problemstellungen sind vielleicht noch größer geworden: Die magischen Praktiken auf dem landwirtschaftlichen Sektor mögen in der Zeit des Traktors und der künstlichen Bewässerung zurückgegangen sein, aber im persönlichen Seinsbereich haben sie eher noch zugenommen, mit neuen Formen der Mantik und Jagd nach dem Glück, in z.T. entritualisierter Form, denen der Zweifel als ständig irritierender Faktor der Suche nach Sicherheit und Geborgenheit schon von Anfang an einwohnt. Ersatzformen der Metaphysik erhöhen die innere existentielle Ausgesetztheit, obwohl auch die äußere keineswegs verschwunden ist (Armut, politische Verfolgung, Krieg, Vertreibung, Krankheit, Verkehrsunfall, usw.). Die Evozierung imaginärer Vorstellungen ist auch im rationalisierten Weltbild rezenter Massenkultur keineswegs zurückgegangen, bedient sich zwar anderer Medien, fußt aber vielfach auf traditionellen Praktiken der Manipulation und Verwaltung des Unvorhersehbaren und Strategien der Kompensation von physischem und sozialem Unrecht ${ }^{1}$.

I Emile Durkheim, Les formes élémentaires de la vie religieuse, Paris 2007 (I 9 I 2), Aron Gurevich, $M e-$ 
Im Dienst dieser Ausgleichungsvorgänge kollektiver und individueller psychischer Balance stehen sowohl die kontinuierliche religiöse Glaubensübung wie auch die okkasionellen magischen Praktiken; religiöse und parareligiöse Manifestationen unterscheiden sich in einer solchen funktionellen Hinsicht bloß durch den Grad der Institutionalisierung, dem Ausmaß der sozialen Akzeptanz und der dogmatischen Absicherung; der Kampf der Kirche gegen den Aberglauben (Paganismus und Idolatrie) ${ }^{2}$ kann nicht darüber hinwegtäuschen, daß beide Komplexe von Glaubensvorstellungen in den traditioneller Oralkulturen Südosteuropas die Schwachstellen in den Überlebensstrategien nicht-elitärer Populationsschichten ausfüllen, wenn auch mit differenten Mitteln und ganz unterschiedlicher Autorität. Die theologisch-religiösen Unterschiede zwischen Katholizismus/Protestantismus, Orthodoxie und Islam spielen auf der Ebene der Superstitionen eine geringere Rolle: Amulette, Heilmethoden, Gebärden, die Prophylaxe und Entzauberung vom Bösen Blick usw. sind ganz dieselben, vor allem zwischen Ostkirche und den muslimischen Balkanbereichen bestehen signifikante Kongruenzen ${ }^{3}$. Insofern ist eine schnittklare Grenzziehung zwischen hochreligiösen Manifestationen und abergläubischen Vorstellungen und Praktiken gar nicht zu ziehen; ein Blick auf die orthodoxe Pastoralpraxis der »Türkenzeit« genügt, um sich davon zu überzeugen (Tieropfer, kirchliche Einsegnung der Wahlbruderschaft, Blumenschmuck der Ikonen usw.). Der orthodoxen Glaubenszugehörigkeit ist übrigens der zahlenmäßig größte Bevölkerungsanteil Südosteuropas verpflichtet, und seit byzantinischer Zeit klafft eine große mentalitätsmäßige Lücke zwischen dem höheren und niederen Klerus, wobei letzterer der jeweiligen Volkskultur weit näher gestanden hat als die dogmatisch und theologisch Gebildeten ${ }^{4}$. Das Fehlen von Reformation, Gegenreformation und Aufklärung, wobei die letztere hier in anderer, weniger antiklerikaler Form stattgefunden hat, hat

dieval Popular Culture: Problems of Belief and Perception, Cambridge 1988, Gilbert Durand, Les structures anthropologiques de l'imaginaire, Paris 1992, Anthony Wallace, Religion: An Anthropologist View, New York 1966, Peter Berger, The Sacred Canopy. Elements of a Sociological Theory of Religion, New York 1967, Hartmut Lehmann (ed.), Religion und Religiosität in der Neuzeit, Göttingen I 996, Snežanja Zorić, »Ritual between anthropology and science of religion«, Narodna Umjetnost 33/I (I996) $233^{-247}$.

2 Walter Puchner, Akkommodationsfragen. Einzelbeispiele zum paganen Hintergrund von Elementen der frübkirchlichen und mittelalterlichen Sakraltradition und Volksfrömmigkeit, München 1997.

3 Vgl. den Sammelband von Thede Kahl und Cay Lienau (ed.), Christen und Muslime. Interethnische Koexistenz in südosteuropäischen Peripheriegebieten, Wien/Berlin 2009, Manolis G. Varvunis, „Christian and Islamic parallel cultural traditions in the popular culture of the Balkan people«, Journal of Oriental and African Studies 9 (1997-8) 53-74.

4

Dazu nun Ioannis Zelepos, Orthodoxe Eiferer im osmanischen Südosteuropa. Die Kollyvadenberwegung (I750-I820) und ibr Beitrag zu den Auseinandersetzungen um Tradition, Aufklärung und Identität, Wiesbaden 2012. 
den balkanischen Oralkulturen einen weit größeren Entfaltungsspielraum gestattet als in Mittel- und Westeuropa, was der Traditionierung älterer Kulturschichten bis in die nationalistischen Wirren der Unabhängigkeitskriege des I 9. Jh.s hinein und noch darüber hinaus zugute gekommen ist $\mathrm{t}^{5}$.

Das rationale (und im 20. Jh. dann auch ideologisierte) Weltbild hat dieses magischreligiöse Kosmos-Verständnis zum Großteil entzaubert, das jedoch als Inspirationsquelle für künstlerisches und schriftstellerisches Schaffen, in nostalgischen FolkloreDarbietungen und kulturpolitischen Diskussionen um Tradition und Fortschritt ${ }^{6}$, bei Glückspielen, Horoskopen, Traumdeutungen, Amulettverwendung, Entzaubern vom Bösen Blick und anderen abergläubischen Praktiken weiterlebt, zwar außerhalb der rationalen Vorzeige-Vitrine eines modernen europäischen Nationalstaates, aber unter breitester Akzeptanz und mit nahezu universeller Praktizierung bei umfassenden Populationsschichten ${ }^{7}$. Diese Glaubensvorstellungen unterliegen, wie fast alle Manifestationen der Oralkultur, den Existenzbedingungen der Varianz: Sie existieren nur in lokalen und regionalen Variationen, zeichnen sich daher durch beschränkte wissenschaftliche Kodifizierbarkeit aus, obwohl diese Variabilität aus der Kombination, Kontamination und Multiplikation weniger Grundprinzipien besteht (pars pro toto, assoziative Vernetzung, Similität und Kontagiosität als Identität, symmetrische Analogien und Parallelisierungen, aber auch coincidentia oppositorum, Synthese des Gegensätzlichen, Gleichzeitigkeit des Ungleichzeitigen usw.). Die christliche Hochkirche hat seit frühchristlicher Zeit und vor allem in der hochmittelalterlichen Dogmatik dieser zyklischen Vernetzung aller Dinge das quasi-logische System der typologischen Übertragung entgegengesetzt ${ }^{8}$.

5 Vgl. Walter Puchner, »Lateinisches Mittelalter und orthodoxer Südosten«, Studien zum Kulturkontext der liturgischen Szene. Lazarus und Judas als religiöse Volksfiguren in Bild und Brauch, Lied und Legende Südosteuropas, 2 Bde., Wien I 99 I (Österr. Akad. d. Wiss., phil.-hist. Klasse, Denkschriften 2 г6) I4-I6.

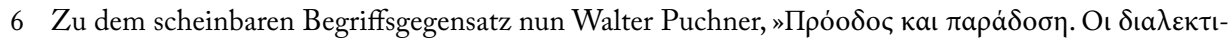

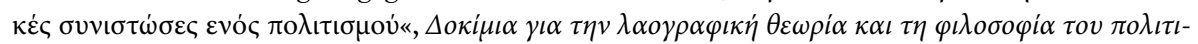
$\sigma \mu o \dot{v}$, Athen 2014, 87-I 26.

7 Ulrich Linse, Geisterseher und Wunderwirker: Heilssuche im Industriezeitalter, Frankfurt/M. I 996, José Casanova, Public Religions in the Modern World, Chicago/London 1994.

8 Der Terminus wurde von Theo Stemmler in die Mediävistik eingeführt (Theo Stemmler, Liturgische Feiern und geistliche Spiele. Studien zu den Erscheinungsformen des Dramatischen im Mittelalter, Tübingen r 970) und betrifft anfänglich Entsprechungen zwischen AT und NT (z.B. Christus bleibt drei Tage in der Unterwelt wie Jonas drei Tage im Bauch des Walfischs). Dazu Puchner, Studien zum

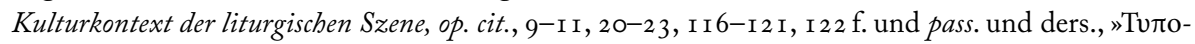

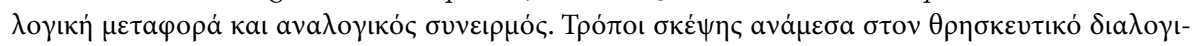

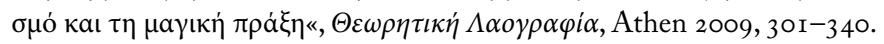


Ältere Volkskunde hat für diesen Gesamtbereich von Religion und »Aberglaube 9 den Ausdruck »Volksfrömmigkeit« geprägt. Doch die Konnotationen von »fromm« haben einen gewissen pietistischen Anstrich, der eher aus klerikaler Sicht kommt als aus empirisch-ethnographischer. Die griechische Volkskunde etwa, ohne den ideologischen Dirigismus der ehem. sozialistischen Regime Südosteuropas, verwendet einen eher neu-

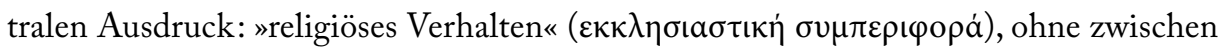
theologischer Dogmatik und Pastoralpraxis, Elite- und Volkskultur einen Unterschied zu machen, da eine soziale Differenzierung der Population eher ökonomischen Kriterien folgt als mentalitätsmäßigen, und die ethnographische Untersuchung auf das Sein und nicht auf das Sollen fokussiert ist, auf die praktizierenden Gläubigen und ihr Verhalten und nicht auf ev. Nichteinhaltungen der theologischen Vorgaben ${ }^{10}$.

Wollte man einen definitorischen Unterschied zwischen religiöser Sakralität und magischer Praktik wagen, so könnte man vielleicht darauf hinweisen, daß die magische Praxis eher zu einer instrumentalen und synkretistischen Metaphysik im Sinne des Erreichens eines ganz bestimmten Zieles mit allen Mitteln tendiert, wobei Teil dieser Strategie auch die Sakralinstanzen der jeweiligen Hochreligion sein können, während die religiöse Sakralität eher einen Transzendenzbereich von Glaubensvorstellungen betrifft, der nicht unmittelbar utilitaristisch geprägt ist, obwohl Anrufungen, Bittmessen und Litaneien, Votivgaben und Kerzenspenden gewöhnlich ganz spezifische Anlässe

9 Die etwas unglückliche pejorative Begriffsprägung für parareligiöse Phänomene aus der verächtlichen dogmatisch-elitären bzw. wissenschaftlichen Sicht der Theologie und der Aufklärung entspricht kaum der eigentlichen Bedeutung als Erklärungsversuche unbekannter Zusammenhänge und Taktiken aktiven Eingreifens zugunsten der Überlebensstrategien in einem vorwissenschaftlichen Zeitalter. Im »Aberglauben« manifestiert sich nicht sosehr ein bewußter Widerstand gegen die hochreligiösen Doktrinen (Gegen-Glaube), sondern als elitäre Gegenkonstruktion eher eine aggressive Attitüde der ekklesialen Institutionen für das, was außerhalb der sanktionierten Grenzen ihres Zuständigkeitsreviers passiert und vielfach mit paganistischen und idolatrischen Vorstellungen zu tun hat (vgl. die zahlreichen Attacken der Kirchenväter gegen die magischen Praktiken, aber auch das Märchen-Erzählen). Für die Aufklärer geht es um primitivistische Irrationalismen, Auswüchse einer hinterwäldlerischen Zurückgebliebenheit und schädliche Folgen von Analphabetismus und Bildungslosigkeit, die in dem Neuen Zeitalter der »Lichter« keinen Platz mehr hat. Erst viel später setzt sich die Erkenntnis durch, daß es sich in einer gewissen Weise um die "Wissenschaft « des vorwissenschaftlichen Zeitalters (»Vormoderne«) handelt, das nach dem Erkenntnisstand der damaligen Zeit durchaus seine eigene »Logik» besitzt und einer weiterreichenden Untersuchung und eines tieferen Verständnisses wert ist. Vgl. Eva Kreissl, Kulturtechnik Aberglaube, Bielefeld 2013, Gustav Friedrich Hartlaub, Das Unerklärliche. Studien zum magischen Weltbild, Stuttgart I 95 I, usw.

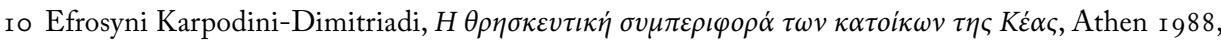

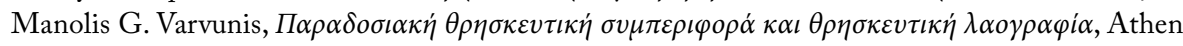

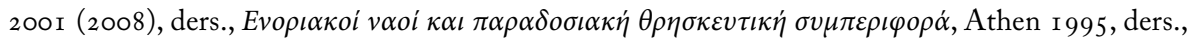

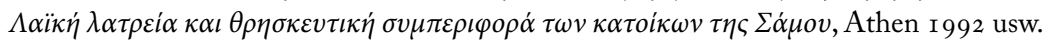


als Ausgangspunkt haben. Frömmigkeit (eusebeia) als eine abstrakt-allgemeine Lebenseinstellung ist vielfach aus einer persönlichen, familiären oder kollektiven Konkretheit einer bestimmten Situationskonstellation heraus zu begreifen ${ }^{11}$.

\section{SAKRALITÄT UND PROFANISIERUNG}

In einem religionsanthropologischen und sozialpsychologischen Ansatz hat Peter Weidkuhn die These aufgestellt, daß Sakralität einen hohen Ritualisierungsgrad des Kulturfeldes impliziere bzw. hervorrufe, das keine adiaphora erlaube und jeder Deviation von der Sakralvorschrift mit ungehemmter, wenn auch zeremoniell geregelter Aggression begegne, weil dies eine bewußte blasphemische Entweihung des Sakralraums darstelle; nach Maßgabe der graduellen Entschärfung des Sakralempfindens verwandeln sich jedoch die negativen Sanktionen des Sündenbock-Mechanismus von Ausstoßung und Lebensentzug in Bestrafungen und Ermahnungen, Bußübungen und reuige Wiedergutmachungen ${ }^{12}$. Das Fehlen der adiaphora (Zufälligkeiten) gilt für Opferplatz und Totempfahl, Heiligtum und Tempelbezirk, Kirchenraum und Moschee gleichermaßen und in einer semiotisch bedeutsamen Sinnzuweisung jedes Gegenstandes und jeder Aktion gewinnt der Sakralraum in seiner Gegenständlichkeit und seinen Akteuren und ihren Aktionen universelle Symbolhaltigkeit ${ }^{13}$. Im Zuge von

I I Vgl. z.B. meine Ausführungen zur orthodoxen Osterbotschaft, die im Gegensatz zur Westkirche weniger die Emphase auf das tragische Christusende am Kreuz legt, sondern auf die Befreiung der Menschheit vom Tod durch seinen Abstieg in die Hadeshölle (an sich ein apokryphes Motiv aus dem Nikodemus-Evangelium, das im Osten zur Anastasis-Ikone geworden ist) (Walter Puchner, ")Abgestiegen zur Hölle‘. Der descensus ad inferos als Keimzelle eines inexistenten orthodoxen Auferstehungs-Spiels«, Beiträge zur Theaterwissenschaft Südosteuropas und des mediterranen Raums, 2 Bde., Wien/Köln/Weimar 2006/7, I I 9 I-226).

I 2 Peter Weidkuhn, Aggressivität Ritus Säkularisierung. Biologische Grundformen religiöser Prozesse, Basel 1965 .

I3 Zur Symbolkonstruktion des christlichen Kirchenraums als »hierarchischem Vertikalsystem« vgl. in Auswahl: Joseph Sauer, Symbolik des Kirchengebäudes und seiner Ausstattung in der Auffassung des Mittelalters, Freiburg/Br. I902, Hans Sedlmayr, Die Entstehung der Kathedrale, Zürich 1950, Staale Sinding-Larsen, Iconography and Ritual, Bergen 1984, Christopher Walter, Art and Ritual of the Byzantine Church, London 1982, Karin M. Skawran, The Development of Middle Byzantine Fresco Painting in Greece, Pretoria 1982. Zum Symbolismus der byzantinischen Kirche als Abbild der wahren (jen-

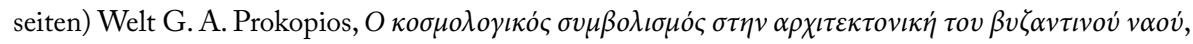
Athen 197 I, Günter Spitzing, Lexikon byzantinisch cbristlicher Symbole. Die Bilderwelt Griechenlands und Kleinasiens, München I 989. Zum Sakralraum als Abbild des Kosmos allgemein Mircea Eliade, "L'espace sacré et la sacralisation du monde«, Le Sacré et le Profan, Paris 1965, zur Zuordnung der Sakralzeit Alfred Gell, The Anthropology of Time. Cultural Constructions of Temporal Maps and Images, 
historischen, kulturellen und sozialen Mutationsprozessen kann dieses Symbolverständnis zurückgehen und einer teilweisen Profanisierung Platz machen; Konsequenzen dieser Lockerung des gruppendynamischen Zusammenhalts sind Entschärfung der Sanktionen, Toleranz gegenüber Outsidern, Unscharfwerden der Grenzen gegenüber dem Anderen, das Verschwimmen von Auto- und Heterostereotypen, Rationalisierung der Rituale, Elastizität des Wir-Bewußtseins usw. bis hin zu demokratischem Synkretismus, Mehrfachidentitäten und Hybridität ${ }^{14}$. Dies ist nicht unbedingt als eine kontinuierliche Entwicklung steigender Säkularisierung vorzustellen wie in westlichen Evolutionsmodellen der Kulturentwicklung seit der Aufklärung; in Südosteuropa sind aufgrund der dichten historischen Kontaktnahme vieler Populationsteile untereinander und der erhöhten Mobilität durch Fremdarbeit, Saisonpendler, Transhumanz, Merkantilität, Handelsmärkten, Kriegen usw. verschiedene Stufen zwischen Sakralität und Profanisierung im oben genannten Sinne in einem ständigen Auf und Ab der Intensitätsgrade gleichzeitig gegenwärtig ${ }^{15}$.

\section{I NUMINOSUM UND do ut des}

Von der Religiosität Südosteuropas in generellen Formulierungen zu sprechen geht nicht $\mathrm{an}^{16}$; zu groß sind die religiösen und konfessionellen Unterschiede, die histori-

Oxford/Providence 1992. Der hieros chronos umspannt symbolisch Anfang und Ende, den gesamten Jahreskreis, ist als kondensierte Zeit herausgehoben aus dem Alltagskontinuum. Zum zyklischen

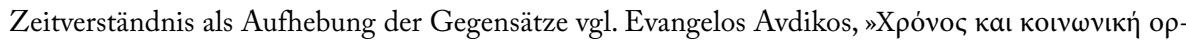

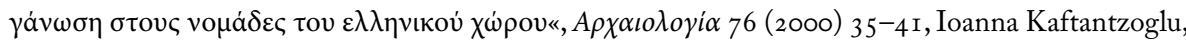

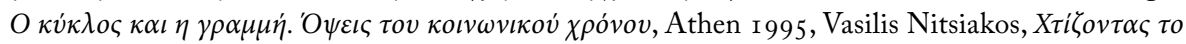

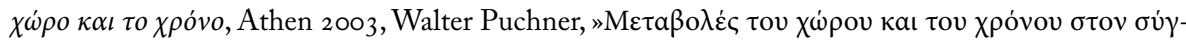

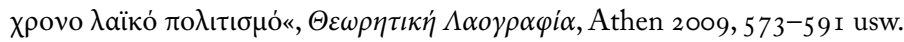

I 4 Danny Jorgensen, »Religion and Modernization: Secularization or Sacralization?«, I. Neusner (ed.), Religion and political orders, Atlanta 1996, I9-30, Jack Goody, »Religion and ritual: The definitonal problem«, British Journal of Sociology I 2 (I96I) I 42-I64, John Skorupski, Symbol and theory. A philosophical study of theories of religion in social antbropology, Cambridge 1 976. Zu Südosteuropa Manolis

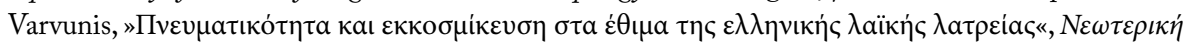

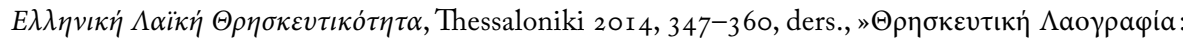

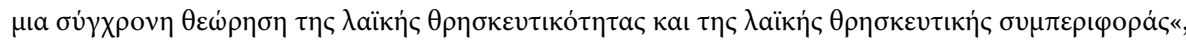

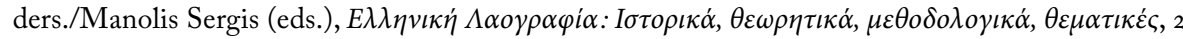
Bde., Athen 201 2, I 669-69I.

I 5 Károly Kocsis, »Changing religious pattern in the Carpathian Basin«, Ethnographica et Folkloristica Carpatbica 9-1o (I 998) 7 I-83, Galia Vălčinova, „Ethnographie et folklore du religieux en Bulgarie«,

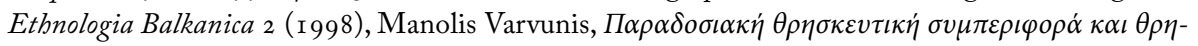

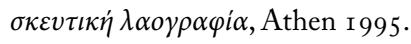

i6 Vgl. z.B. die spezifische Religiosität der Bektași. Dazu: John Kingsley Birge, The Bektashi order of 
schen Schicksale der Einzelregionen, der unterschiedliche Einfluß administrativer Lenkungseffekte und der regional unterschiedliche Impakt von Elite- und Schriftkulturen

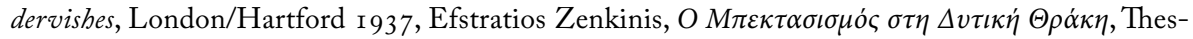
saloniki 988 (Institute for Balkan Studies 220), Hans Joachim Kissling, Dissertationes Orientales et Balcaniae collectae (ed. Brigitte Moser-Weithmann), I. Das Derwischtum (Vorwort Leopold Kretzenbacher), München 1986. Zur Stellung des Islams in Südosteuropa Franz Babinger, „Der Islam in Südosteuropa«, Völker und Kulturen Südosteuropas. Kulturhistorische Beiträge, München I 959, 2 I I-2 I 7, Smail Balić, »Der Islam in Bosnien. Ein Beitrag zu seiner Entstehungsgeschichte «, Österr. Osthefte 6/6 (I 974) 470-476, Paul Hidiroglu, Das religiöse Leben auf Kreta nach Ewlija Celebi, PhD. Diss. Bonn 1967. Oder die Religiosität von Minderheiten, wie etwa die Armenier in Komotini: Ma-

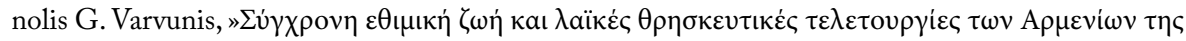

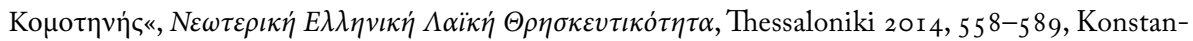

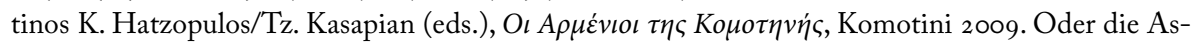
kenasen und Sefarden: Philip P. Argenti, The religious minorities of Chios: Jerws and Roman Catholics, Cambridge 1978, Benjamin Braude/Bernard Lewis (eds.), Christians and Jews in the Ottoman Empire. The Functioning of a Plural Society, vol. I: The Central Lands, New York/London I 982 ; oder die Krypto-Christen: Stavro Skendi, "Crypto-Christianity in the Balkan Area under the Ottomans«, Slavic Review 26 (1967) 226-246 (Balkan Cultural Studies, New York 1980, 233-257), Konstantinos Fotiadis, Die Islamisierung Kleinasiens und die Kryptochristen des Pontus, Diss. Tübingen 1985. Solche Fragen sind auch belastet von Theorien um das Weiterleben von religiösen Bewegungen wie Manichäismus und Bogomilentum, wozu ein zahlreiches Schrifttum unterschiedlicher Validität existiert. In Auswahl: Dimităr Angelov, Les Balkans au Moyen Age: la Bulgarie des Bogomiles aux Turcs, London 1978 (Sammelband), James M. George, The Dualistic-Gnostic Tradition in the Byzantine Commonwealth with Special Reference to the Paulician and Bogomil Movements, $\mathrm{PhD}$ thesis Wayne State 1979, Milan Loos, Dualistic Heresy in the Middle Ages, Prague/The Hague 1974, Dimitri Obolensky, The Bogomils. A Study in Balkan Neo-Manichaeism, Cambridge I 948, Alexander V. Soloviev, »Bogomilentum und Bogomilengräber in den südslawischen Ländern«, Völker und Kulturen Südosteuropas. Kulturhistorische Beiträge, München I959, I73-198, Georg Wild/Hannjost Lixfeld, »Bogomilen «, Enzyklopädie des Märchens 2 ( 1978 ) 580-586 (mit weiterer Literatur). Zu Fragen religiöser

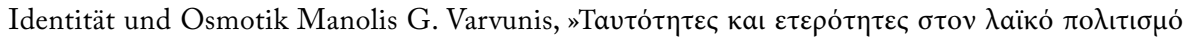

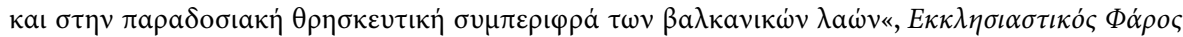
79 (2008) I 7-47 und ders., "A contribution to the study of influence of Christian upon Moslem

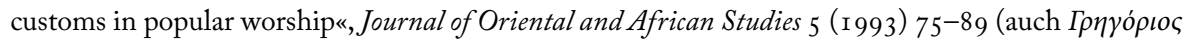
$o$ П $\alpha \lambda \alpha \mu \dot{\alpha} \varsigma$ 78, I 995, 805-8 I 4). Zu Formen des Synkretismus: Peter Bartl, »Kryptochristentum und Formen des religiösen Synkretismus in Albanien«, Grazer und Münchener balkanologische Studien, München 1967, I I 7-I 27, Milenko S. Filipović, »Volksglauben auf dem Balkan. Einige Betrachtungen", Südost-Forschungen I9 (1960) 239-262, Rudolf Kriss, "Volksglaube im Bereich des Islam (Aufgezeigt am Thema der Heiligenverehrung)«, Volkskunde-Kongreß Nürnberg 1958. Vorträge und Berichte, Stuttgart 1959, 40-53, Rudolf Kriss/Hubert Kriss-Heinrich, Volksglauben im Bereich des Islam. Bd. I: Wallfahrtswesen und Heiligenverehrung, Bd. 2: Amulette, Zauberformeln und Beschwörungen, Wiesbaden I 960/62, Rudolf Kriss, »St. Georg - al-Hard (Hadir, Hidr)«, Bayerisches Jabrbuch für Volkskunde I 960, 48-56, Paul H. Stahl, »Croyances communes des chrétiens et des musulmans balkaniques«, Buletinul Bibliotecii Române NS 7 (1979/80) 79-1 26. 
bzw. von institutionalisierten religiösen Instanzen. Trotzdem ergibt sich auf der Ebene der oralen Superstitionen und Glaubensvorstellungen, der religiösen Praxis und ihrer anwendungsorientierten Funktionalität eine Art Vergleichbarkeit, die sich auch auf anderen kulturellen Sektoren wie Kleidung und Architektur, Wertvorstellungen und Geschlechterrollen, Sprachmorphologie und Folklore mutatis mutandis bis zu einem gewissen Grad verifizieren läßt.

Dem absoluten Staunen vor dem Numinosen ${ }^{17}$, der Unfaßbarkeit der unbegreiflichen göttlichen Existenz in ihrer Unvorstellbarkeit, in seiner Bedrohlichkeit exemplifiziert in der prinzipiellen Unvorhersehbarkeit des Schicksals, das nur in völliger Hingabe meditativ zu imaginieren ist, steht der bemerkenswerte Realismus der Glaubensvorstellung von der Verhandelbarkeit von Ansprüchen an die metaphyischen Instanzen im Sinne des soziologischen Grundgesetzes von do ut des gegenüber, welches unausgesprochen und vielfach auch unbewußt hinter vielen Opferhandlungen steht ${ }^{18}$. Insofern hat religiöses Verhalten einen unmittelbareren Lebensbezug; die Unterwerfung unter das sakrale Diktat ist nicht so sehr Akt konventioneller Obrigkeitshörigkeit, sondern geschieht mehr im Vertrauen auf die zu erwartende und vorausgesetzte Gegenseitigkeit. Diese Erwartungshaltung erstreckt sich bis zu wunderbaren und übernatürlichen Vorkommnissen; Wunderberichte sind sprach- und religionsübergreifend, Manifestationen der Sehnsucht nach der Transzendierung einer erbarmungslos engen und bedrückenden Realität. Diese doppelte und gleichzeitig dialektische Seinsweise von Religiosität, auf der einen Seite die äußerste Hingabe als psychisches Ventil für die Pressionen des schwierigen Alltags, auf der anderen verbunden mit dem praktischen Realismus des Überleben-Müssens in einer feindlichen Umwelt (Naturkatastrophen, Bangen um den Erntesegen, Krankheiten, Epidemien, Kriege, sozialer Antagonismus), enthält auch Formen des Widerstands gegen metaphysische Instanzen, vergleichbar der balkanweiten traditionellen Widerstandskultur gegen behördliche und staatliche Obrigkeit jeglicher Provenienz, sobald diese als ungerecht empfunden wird, wie etwa im maniatischen Totenklagelied, das Gott selbst zur Rechenschaft zieht ${ }^{19}$, oder in Lamentationen, die die Existenz des Todes (und seiner Personifikation, Charos) als ein skandalon und Verbrechen gegen die Natur und das Leben bezeichnen ${ }^{20}$.

I7 Zum Begriff des Numinosen vgl. Helge Gerndt, »Numinoses«, Enzyklopädie des Märchens 1о (2000) I 54-1 59, Rudolf Otto, Das Heilige, Breslau I 91 7, ders., Das Gefühl des Überweltlichen (sensus numinis), München 1932 .

I 8 Speziell für Südosteuropa Minas A. Alexiadis, »Do ut des«, $\Delta \omega \delta \omega \dot{v} \eta$ r6/r (I 987 ) 253-265.

I 9 Vgl. den Band Die Folklore Südosteuropas, op. cit., 75-77.

20 Vgl. die luziden Ausführungen von Guy Saunier, "Adikia«. Le Mal et l'Injustice dans les Chansons

Populaires Grecques, Paris 1979. 
In der biophilen Grundlage der Devotionsformen der traditionellen südosteuropäischen Volksreligiosität ${ }^{21}$ ergibt sich vielleicht doch eine Art Differentialkriterium zu mittel- und westeuropäischem Frömmigkeitsempfinden, das durch Katechismus, Entpersönlichung und Rationalisierung hindurchgegangen ist und sich nun freiwillig der Aura der Sakralsprache entschlagen hat. Doch kann man über religiöses Empfinden und Verhalten nur in Beispielen sprechen, die in der Folge vor allem aus dem orthodoxen Raum stammen werden. Der griechische Revolutionsgeneral Makrygiannis (I 797-I 864) berichtet in einer vielzitierten Episode aus seiner Jugendzeit in seinen »Memoiren« von einem solchen »Geschäft « mit seinem Namensheiligen, dem H1. Johannes (24. 6.), das auf der einen Seite tiefer Religiosität entspringt ${ }^{22}$, auf der anderen Seite auf einem materiellen Gegenseitigkeitsdenken vom do-ut-des-Typ beruht: Im Pubertätsalter schließt er mit dem H1. Johannes einen Vertrag, wenn er ihm gute und silberne Waffen verschaffe und ausreichend Geld, um den demütigenden Hausarbeiten bei seinem Dienstherrn zu entgehen, wolle er ihm einen großen silbernen Leuchter machen lassen; nach Jahren hat er früh schon ein Vermögen zusammengetragen und löst sein Versprechen $\operatorname{ein}^{23}$.

2 I Paul Wiertz, »Zur religiösen Volkskultur der orientalischen und orthodoxen Kirchen - Volksglauben und Volksbrauch«, Handbuch der Ostkirchenkunde, Düsseldorf I 97 I , 569-632.

22 Makrygiannis ist immerhin Verfasser eines religiösen Tagebuchs »Visionen und Wunder« (Aus-

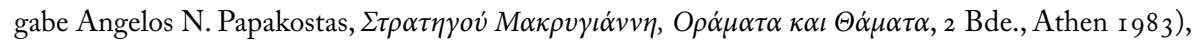
das seine häufige und ungehinderte Kommunikation mit metaphysischen Instanzen hinreichend dokumentiert. Berühmt geworden ist auch sein Brief an Gott in den »Memoiren«, drei Tage vor

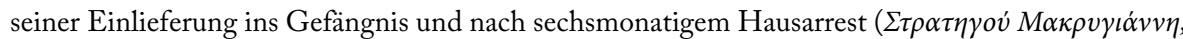

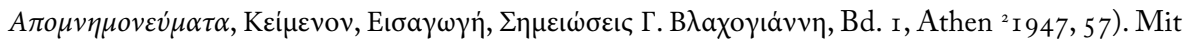
der gesamten umfangreichen Fachliteratur und zur Rezeptionsgeschichte vgl. Walter Puchner,»Vita exemplativa: die apologetischen Memoiren des griechischen Revolutionsgenerals Makrygiannis (verfaßt I 829-I 843)«, Studien zur Volkskunde Südosteuropas und des mediterranen Raums, Wien/Köln/ Weimar 2009, 565-590.

23 Anlaß war seine Liebe zu den Waffen: Im Alter von I4 Jahren hatte ihm sein Dienstgeber die Flinte zum Tragen gegeben, aus der er einen Schuß abgegeben hat, worauf der Dienstherr den Jungen vor allen Leuten verprügelte. »Nicht die Prügel schadeten mir so sehr als die Beschämung vor den Leuten. Alle aßen und tranken damals, und ich weinte. Für meine Beschwerde fand ich keinen Richter, dem ich (den Hergang) hätte erzählen können und der Recht spräche, und so hielt ich es für angebracht, zum H1. Johannes zu gehen, denn in seinem Haus ist mir dieses Unrecht und diese Schande widerfahren. Ich gehe in der Nacht in die Kirche und schließe die Tür und beginne zu weinen und zu schreien: Was ist das, was mir da zugestoßen ist, bin ich ein Esel, daß man mich schlägt? Und ich bitte ihn, mir Waffen zu geben, gute und silberne, und ${ }_{5}$ Säckel Geld und ich werde ihm eine große silberne Leuchte machen lassen. Mit vielen solchen Ausbrüchen schloß ich meinen Vertrag mit dem Heiligen«. Nach einigen Jahren, als Makrygiannis sein Vermögen zusammengetragen hat, geht er wieder zum H1. Johannes: „Und gut bewaffnet und zurechtgemacht nahm ich sie (die Leuchte) und ging zu meinem Patron und Wohltäter und wahren Freund, da ich mich an all die Mühe erinnerte,

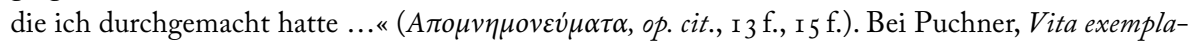




\subsection{AUFERSTEHUNG UND WIEDERGEBURT}

Wie oben ausgeführt, geht ein Großteil der panbalkanischen dromena und Verkleidungsformen in irgendeiner Form auf das Strukturmotiv Tod/Aufstehung (Thanatos/Anastasis) zurück, das in der Mythologie aller Agrarkulturen eine so große Rolle spielt, da es den Vegetationszyklus der Feldwirtschaft inkorporiert: Wie der Samen in das Reich der Toten, die Erde, eingegraben (gleichsam bestattet) wird und im Frühjahr als lebendiges Pflänzchen aus der Erde wieder aufsprießt, so ist der Tod nur der erste Akt eines zyklischen Dramas, auf den die Wiederbelebung erfolgt ${ }^{24}$. Die Idee des Lebens nach dem Tod ist fast allen Weltreligionen inhärent, und die Wiederbelebung der getöteten Gottheit ist sowohl der antiken Mythologie geläufig (z. B. Dionysos) ${ }^{25}$ wie auch Grundlage des christlichen Ostergeschehens. Das Paradoxon von Kreuzestod und Wiederaufstehung Christi ist in der orthodoxen Hymnik als mystische coincidentia oppositorum immer wieder besungen und als typologische Übertragung bis in die transzendentale Metaphysik und die reale Auferstehungshoffnung hineingetragen: Das vergängliche Leben als Vorspiel zum eigentlichen Sein im Jenseits und das Sterben als rite de passage zum Ewigen Leben. Der Tod Christi führt zur Abschaffung des Todes, wie es in der paradoxologischen Wortfigur der östlichen Osterhymnik besungen wird.

Daß die Dialektik des dogmatisch sanktionierten Paradoxons der coincidentia oppositorum von Tod und Auferstehung auf dem agrarmythologischen Zyklus des Vegetationsheros basiert, ist jedoch an der religiösen Volksfigur des Lazarus, als amicus Christi in typologischer Antithese zu dem proditor des Herrn, Judas Iskariotes, stehend, dessen Freitod zu keiner Anastasis geführt hat ${ }^{26}$, deutlicher zu belegen: Die suscitatio Lazari als tetrahemeros oder tetartaios (quatriduanus), der bereits vier Tage in der Unterwelt verweilt hat und dessen Verwesungsgeruch den zweiten Grabdiener auf den orthodoxen Bilddarstellungen der egersis Lazaru dazu bewegt, sich demonstrativ mit dem Ärmel

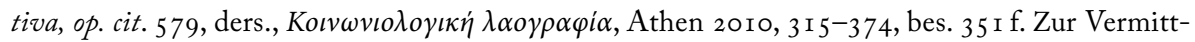
lungsrolle der Heiligen auch Bernhard Schmidt, Das Volksleben der Neugriechen und das hellenische Alterthum, Leipzig I 87 , 35-37.

24 "Saisondrama« nach Theodor Gaster, Thespis. Ritual, Myth and Drama in Ancient Near East, New York 1950 .

25 Vgl. die Theorie der antiken Tragödie als Passionsspiel für Dionysos, den die jeweiligen Heroen verkörpern (Gilbert Murray, »Excursus on the ritual forms preserved in Greek Tragedy«, Jane Harrison, Themis, New York I 962 [1912] 341-363).

$26 \mathrm{Zu}$ dieser typologischen Antithese Walter Puchner, Studien zum Kulturkontext der liturgischen Szene. Lazarus und Judas als religiöse Volksfiguren in Bild und Brauch, Lied und Legende Südosteuropas, 2 Bde., Wien I 99 (Österr. Akad. d. Wiss. phil.-hist. K1., Denkschriften 2 I 7 ) I 5 f. („Die Figurentopik: Freund und Feind des Herrn«). 
die Nase zuzuhalten ${ }^{27}$, ist ein Auferstehungsvorgang, der Christi Resurrektion in typologischer Analogie theologisch präfiguriert ${ }^{28}$ : Mit dem sabbato ante palmas setzt der gesamte Osterzyklus ein. Die meisten ikonographischen Figurierungen zeigen den bleichen Grabgesellen, in den Lazarusliedern oft als Schlafender, der aufgeweckt wurde, bezeichnet $^{29}$, in einer Mumienwicklung in Totenbinden (lazaromata) ${ }^{30}$, die der "geruchsempfindliche Grabknecht « mit der einen Hand loswickelt, während ein anderer den Grabdeckel abhebt. In der frühchristlichen Katakombenmalerei ist die vielpersonige Komposition mit Christus, Maria und Martha in Proskynese, den Juden- und Apostelgruppen auf eine kleine Grabmumie in einer aedicula reduziert, vor der Christus in der Kleidung eines antiken Magiers steht und ihn mit der Zaubergerte der virga thaumaturgica berührt ${ }^{31}$. Solche Lazarusstatuettchen wurden auch bei den geheimen Katakombenversammlungen der Zömeterialmessen noch ohne formverfestigten liturgischen Verlauf unter den Gläubigen als Zeichen der Auferstehungshoffung herumgereicht ${ }^{32}$.

Daran knüpfen sich nun mehrere typologische Übertragungsreihen von hoher Sinntiefe und großer zeitlichen Beständigkeit. I. Die Mumienwicklung entstammt antik-ägyptischem Totenbrauch und hat sich fast bis in die unmittelbare Gegenwart im orthodoxen Bestattungsritus erhalten, wo die Totenbinden immer noch lazaromata genannt werden und auf den bulgarischen und ägäischen Brotgebilden, zum Seelen-

27 Joh. I I, 38 : Herr, er riecht schon; denn er liegt schon vier Tage«. Zu dem Motiv auf den ikonographischen Abbildungen Puchner, Studien zum Kulturkontext der liturgischen Szene, op. cit., 23-3o, I4 I-I68. Zum Motiv des geruchsempfindlichen Grabknechts Klaus Wessel, „Erweckung des Lazarus«, Reallexikon zur byzantinischen Kunst, Bd. 2, Stuttgart I97 I, 388-4I 4.

${ }_{28} \mathrm{Zu}$ dieser Präfiguration vgl. speziell Sirarpie der Nersessian, »The homily on the Raising of Lazarus and the Harrowing of Hell«, Biblical and Patristic Studies in Memory of R. D. Casey, Freiburg/Br. I 963, 2 I 9-234, ders., "A homily of the raising of Lazarus and the harrowing of Hell«, Etudes Byzantines et Armeniennes/Byzantine and Armenian Studies I (1973) 457-467.

29 Puchner, Die Folklore Südosteuropas, op. cit., 65-68.

$30 \Lambda \alpha \zeta \alpha \rho \omega \omega \omega$ als Verb bedeutet heute noch »In die Totenbinden wickeln" (Aikaterini Chrysulaki,

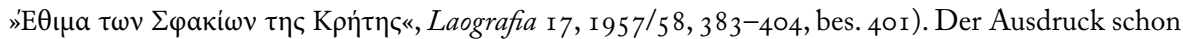
im Epos von »Digenes Akrites" (Erich Trapp, Digenis Akritas. Synoptische Ausgabe der ältesten Versionen, Wien I 97 I, 389- hier allerdings mit »in das Totenhemd kleiden« wiedergegeben). Vgl. auch Walter Puchner, »Lazarusbrauch in Südosteuropa«, Österr. Zeitschrift für Volkskunde 32/8 I ( I 979)

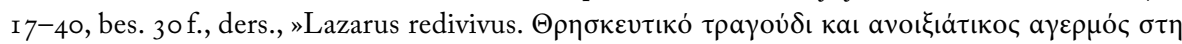

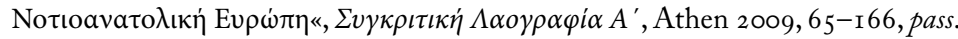

3I Die Einzelnachweise in Walter Puchner, "Christus als Magier«, Akkommodationsfragen. Einzelbeispiele zum paganen Hintergrund von Elementen der frühkirchlichen und mittelalterlichen Sakraltradition und Volksfrömmigkeit, München I 997, 25-28, 92-97.

32 Das Gesamtmaterial bei Raffaele Garrucci, Storio della Arte Cristiana nei primi otto secoli della chiesa, 6 Bde., Prato I 872-8 I, zum 4. Jh. bei Friedrich Wilhelm Deichmann, Repertorium der christlichantiken Sarkophage. I., Rom 1967. 
heil des amicus Christi bei den Lazarusumgängen verteilt, nachgeahmt werden ${ }^{33}$. 2. Das ikonographische Motiv »Christus als Magier«, als hellenistischer Wunderheiler mit der Zaubergerte der Berührungsmagie hält sich noch lange als ikonographisches Motiv ${ }^{34}$, bis es in den Befehlsgestus der ausgestreckten Hand mit dem weisenden Zeigefinger, ein Motiv aus der römischen Imperator-Ikonographie, umgewandelt wird ${ }^{35} \cdot 3$. Die kleine Mumiengestalt des Auferweckten, vor der größeren Christusfigur (Bedeutungsanalogie), erscheint häufig wie ein in Windeln gewickeltes Kleinkind, was kein Zufall ist, sondern drei unterschiedlichen, jedoch in sich kongruenten analogen Vorstellungskreisen entspricht: a) die traditionelle Wicklung der Babys und Kleinkinder entspricht tatsächlich der mumienartigen Wicklung der Totenbinden im Grabbrauchtum ${ }^{36}$,b) die agrarmythologische Vorstellung von Lazarus als Vegetationsheros und Blumenheld des Frühlings äußert sich im Lazarusbrauchtum, wenn die Lazarusmädchen den Auferweckten in Puppenform als Kleinkind wiegen ${ }^{37}$, und c) die orthodoxe Darstellungschiffre der Totenseelen in der Unterwelt entspricht dieser Similität der Mumienwicklung bei Kleinkindern und Toten, wodurch der bildlichen Seelendarstellung bereits die dialektische Dynamik von Gestorben-Sein und Ewigem Leben (Kleinkind als Lebenssymbol) einwohnt ${ }^{38}$. Des Lazarus zweites Leben war nach den Legenden jedoch keineswegs »ewig" ( 30 bzw. 40 Jahre als Nicht-Lachender) und hat zu existenzialistischer

33 Dazu Walter Puchner, »Anthropomorphe Brotgebilde in Südosteuropa und ihre Beziehungen zu byzantinischer Ikonographie«, Thede Kahl/Peter Maria Kreuter/Christina Vogel (eds.), Culinaria balcanica, Berlin 2015, 29-37 (mit den Einzelnachweisen).

34 Die Berührung mit der Zaubergerte als »Lebensrute« gehört zum Bildkreis antiker Wundervorstellungen: Der ursprünglich dem Hermes zugehörige Stab, mit dem er Seelen aus dem Hades heraufzaubert, wird als stehendes Wunderrequisit funktionsäquivalent eingesetzt (dazu Richard Reitzenstein, Hellenistische Wundererzäblungen, Darmstadt I 963 (2. Aufl., S. 4I Anleitungen zur Totenauferweckung), H. Preisker, »Wundermächte und Wundermänner der hellenistisch-römischen Kultur und die Auferweckung des Lazarus«, Wissenschaftl. Jahrbuch der Univ. Halle 2, I 952 2, 5 1 9-523).

35 In christlicher Umdeutung auch als Segensgeste bzw. mit der Buchrolle (Richard Delbrueck, Probleme der Lipsanothek in Brescia, Bonn I952, 29). Zum Befehlsgestus A. Pératé, „La Resurrection du Lazare dans l'art chretien primitif“, Mélanges d'archéologie et d'histoire, Paris I 892, Suppl. offert à J. B. Rossi, 272-279, bes. 272, Joseph Wilpert, I sarcofagi cristiani antichi, 5 Bde., Roma, Città di Vaticano I $929-32$, II 303 .

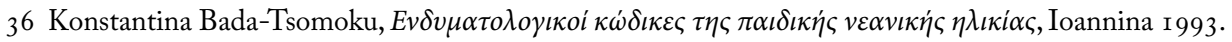

37 Bzw. der Eierkorb die Bedeutung von Wiege oder Grab des Lazarus annimmt (Puchner, Brauchtumserscheinungen, op. cit., I67, Verbreitungskarte S. 275).

38 Vgl. Puchner, »Die Mumienseelen«, Akkommodationsfragen, op. cit., 28-33, 97-105 (mit den Nachweisen). Vgl. z.B. Gertrud Schiller, Ikonographie der christlichen Kunst. III. Die Auferstehung und Erböbung Christi, Gütersloh I 97 I, 49, Hans Belting, Die Basilika dei SS. Martiri in Cimitile, Wiesbaden 1962, 74 f., Josef Strzygowski, Die Miniaturen des serbischen Psalters in der Königl. Hof- und Staatsbibliothek in München, Wien 1906, 85, Taf. LIX/I49. 
Skepsis Anlaß gegeben ${ }^{39}$. Doch ein anderes Beispiel der ikonographischen Chiffre für die Seelendarstellung findet sich in der Ikone von der Entschlafung Marias (кої

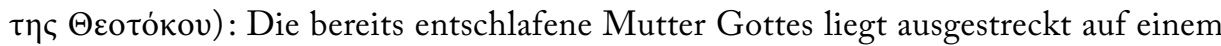
Bett mit den Aposteln in Lamentationshaltung und im Vordergrund das Motiv des sündigen Hebräers, dem der Engel die frevelnden Hände abschlägt (ein apokryphes Motiv, das vielfach auch fehlen kann ${ }^{40}$, und Christus aufrecht mit einem mumienartig in Windeln gewickelten Kleinkind im Arm, das nichts anderes als die Seele der bereits verstorbenen Gottesmutter darstellt ${ }^{41}$.

Die Auferweckung des Lazarus und die Resurrektion des Herrn fallen beide in den Frühlingsabschnitt und die assoziative Verbindung mit dem agrarmythologischen Vegetationsheros bzw. die Auferweckung/Auferstehung/Wiedergeburt als tatsächlichem Geburtsvorgang reiht sich bruchlos in das zyklische Jahreskreisdenken traditioneller Zeitvorstellungen ein. In der rituellen Performanz der Lazarusmädchen ist die Wiedererweckung des »Viertägigen« damit als reeller toketos mit einem Säugling gedacht, eine imaginative Interpretation, die auf den Denkfiguren des Agrarzyklus beruht. Das Wunder von der Wortmacht des Herrn, der seinen ersten Sieg über Thanatos und Hades erringt und seine eigene Auferstehung präfiguriert, wird deshalb nicht weniger wunderbar, wenn es sich dem Frühlingswunder des Vegetationszyklus einordnet ${ }^{42}$.

Und doch bleibt der Unterschied zweier verschiedener Denksysteme, denn das Analogie-System der quasi-logischen typologischen Übertragung folgt strengeren Entsprechungen. Dies läßt sich an der Marienmystik von der unbefleckten Empfängnis demonstrieren bzw. einer anderen ikonographischen Chiffre, der kline-artigen Berghöhle, in der Lazarus in seinem Grab zum Stehen kommt. Auf eine solche kline $e^{43}$ sind die

$39 \mathrm{Zu}$ den Legenden Puchner, Die Folklore Südosteuropas, op. cit., I 26-г 29. Zum existenzialistischen Drama "Lazarus« (1954) von Pantelis Prevelakis, das sein zweites Leben behandelt, vgl. Walter

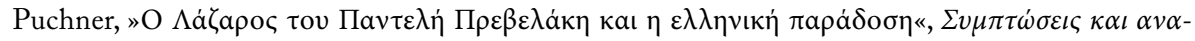

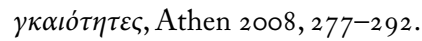

40 Dazu auch Leopold Kretzenbacher, Sterbekerze und Palmzweig-Ritual beim Marientod. Zu Apokry-

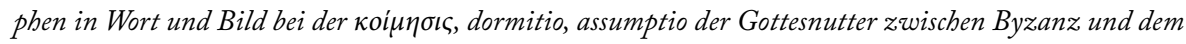
mittelalterlichen Westen, Wien I999, I3-I 5 .

4I Z.B. auf einem teilvergoldeten Speckstein aus dem ro. Jh. Ioli Kalavrezou-Maxeiner, Byzantine Icons in Steatite, 2 Bde., Wien I985, Abb.I, einer griechischen koimesis-Ikone aus dem I6. Jh. Walter Felicetti-Liebenfels, Geschichte der byzantinischen Ikonenmalerei, Olten/Lausanne 1956, I03.

42 Bereits der griechische Kirchenvater Johannes Chrysostomos hat in seiner Homilie "Auf den viertägigen Lazarus« in der Einleitung auf die Parallelität der Auferweckung/Auferstehung mit dem

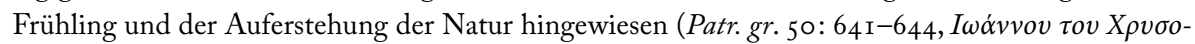

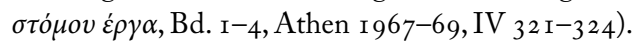

43 Zum byzantinischen Bildtopos der kline vgl. vor allem José Grosdidier de Matons, »Note sur le sens

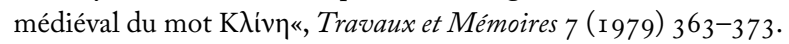


seitlich hingelagerten Apostel mit Christus bei den Abendmahlsdarstellungen plaziert, es gibt aber auch die kline, auf der Maria bei der Christgeburtsdarstellung liegt, die eine poetisch-dogmatische Metapher für die jungfräuliche Geburt darstellt ${ }^{44}$. Folgerichtig im Sinne dieser faszinierenden typologischen Übertragung wird die Hadeshöhle in der Anastasis-Ikone beim descensus ad inferos ebenso abgebildet, wo Christus Adam (und Eva) aus dem Sarkophag erhebt ${ }^{45}$. Der Bildtopos der kline-förmigen Geburts-/GrabesHöhle $^{46}$ ruft noch weitere Übertragungsreihen hervor: Die Geburtshöhle der jungfräulichen Gebärmutter ist in mariologischer Deutung auch das Paradies: »Nicht beschädigt wahrtest Du die Siegel, Christus,/aus dem Grabe wurdest Du erweckt, Du,/der Du in der Stunde Deiner Geburt/nicht verletztest der Jungfrau Schoß/und des Paradieses Tore/uns erschlossest ${ }^{47}$. Hadespforten und Paradiespforten werden hier analogisch verbunden, die Urelternvertreibung aus dem Paradies mit der Erlösung aus der Unterwelt parallelisiert. Die Verschlingung von Tod und Leben in einer mystischen Koinzidenz findet noch andere Ausdrucksformen: Auf Psalterillustrationen gibt es Darstellungen, die das Christuskind auf dem Schoß der Gottesmutter zeigen, wie es nach dem Typ der Anastasis-Ikone Adam und Eva zur Auferstehung die Hände reicht ${ }^{48}$. Anfang und Ende der christologischen Heilsgeschichte sind hier zu einer Bildkomposition von besonderer Sinntiefe zusammengespannt. In der Bildformel der berghöhlenartigen kline sind Uterus und Grab, Hades und Paradies zu einer antithetischen Einheit verschmolzen, die der Vorstellung der Einheit von Tod und Leben im zyklischen Denken des Agrarmythos und des Epochendramas entspricht. Damit sind freilich auch alte Welt-

44 Karl Onasch, Das Weibnachtsfest im orthodoxen Kirchenjahr, Berlin I958, I79 f.

45 Zur Entwicklung dieses Bildtyps vgl. Puchner, »Abgestiegen zur Hölle«, Beiträge zur Theaterwissenschaft Südosteuropas, Bd. I., op. cit., I 9 I-226, bes. 208-2 I 8.

46 Zum Grabhöhlentypus Hans Aurenhammer, Lexikon der christlichen Ikonographie, Bd. I, Wien I 959-67, 252 mit Nachweisen.

47 Ernst Benz/Hans Thurn/Constantin Floros, Das Buch der heiligen Gesänge der Ostkirche, Hamburg I 962 , $102 \mathrm{f}$.

48 Onasch, op. cit., I88, Strzygowski, op. cit., 86 f. Taf. LX/ I 54. Der auferstandene und der neugeborene Christus werden als gleichwertige Christustypologie erlebt. Babywickeln und Totenbinden werden schon im »Christus patiens« gleichgesetzt, wenn Christus in der Marienklage als $\varepsilon v \sigma \pi \alpha \rho-$

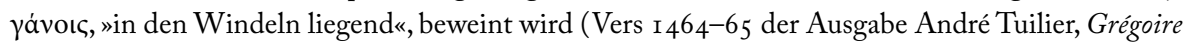
de Nazianze, La passion du Christ, Paris 1969), und noch deutlicher in einem slavisch-orthodoxen Ostersonntagshymnus, wo die drei Marien auf dem Gang zum Grabe die Leichentücher mit den Windeln explizit gleichsetzen: „Wir wollen gehen, laß uns eilen wie die Magier und die Proskynese geben und das Myron darbringen als Geschenk nicht dem in Windeln, sondern in der Plaščanica [Epitaph-Tuch] Gewickelten und lasset uns klagen und rufen: O Herr, stehe auf, der du darbringst den Gefallenen den Aufstieg“ (Alexios v. Maltzew, Fasten- und Blumentriodion nebst den Sonntagsliedern des Oktoichos der Orthodox-Katholischen Kirche des Morgenlandes, Berlin I 899, 69I). 
bildvorstellungen der hylozoistischen Philosophie im Altertum angesprochen. Doch der Spiritualisierung des kollektiven empirischen Wissens der Volkskultur in der Bild- und Wortmystik christlicher Theologie und Apokryphik kann die Oralkultur mit ihren performativen Umzügen und Ritualhandlungen nicht folgen; dennoch stößt die strenger gefaßte Assoziationsreihe der typologischen Übertragung aufgrund der Analogien mit dem Vegetationsdenken keineswegs auf Unverständnis.

\section{$3 \cdot 3$ DAS ZWISCHENREICH DER MAGIE}

Das Zwischenreich der Magie erstreckt sich von der Sakralsphäre des Religiösen bis in die gelebte Alltagswirklichkeit und kommt zur Anwendung in Krisensituationen des Individuums oder Kollektivs, gilt als empirisches Geheimwissen von Professionisten oder Zauberkundigen, das von zahlungswilligen Kunden evoziert oder zur Abwendung allgemeinerer Gefahren eingesetzt wird; Grundlage sind die Denkfiguren und Vorstellungen eines animistischen Weltbildes, der imaginative Wirkungsglaube an die angewendeten Praktiken, das klientelistische Abhängigkeitsverhältnis von einer »wissenden« Instanz (Magier, zauberkundige Frauen) und ein $»$ Kunde« in Krisensituation ${ }^{49}$. Das parareligiöse Ambiente der Pseudo-Sakralität und der inszenierten Autorität ist z.T. professionelle Vitrine, wobei der Glaubensgrad der Ausführenden selbst an die Effizienz ihrer magischen Praktiken nicht unbedingt eine entscheidende Rolle spiel ${ }^{50}$; das wissenssoziologische Gefälle von den Professionisten zu potentiellen und reellen Klienten hat vielfach auch eine merkantil-ökonomische Dimension, die den Marktgesetzen von Angebot und Nachfrage, Leiddruck der Hilfesuchenden und Berufsimage des Magiers unterliegt; daneben gibt es auch Anwendungsformen von weniger ausgeprägter Merkantilität und Professionalität, wo erfahrene und angesehene Personen der Kommunität entsprechende Hilfeleistungen auch ohne Gegenleistung vornehmen (z.B. die akrobatischen Heiltänze der călușarii oder die anastenaria/nestinari $)^{51}$.

49 Marcel Mauss, »Theorie der Magie« (1902/o3), Soziologie und Anthropologie, Bd. I, Frankfurt/M. I 989, 43-I 79, Christoph Daxelmüller, Zauberpraktiken. Die Ideengeschichte der Magie, Düsseldorf 2005 (Zürich 1993), Leander Petzoldt, „Magie«, Enzyklopädie des Märchens 9 (1999) 2-I 3, Heinz Huther, Zauberschwert und Teufelsmesser, Frankfurt/M. etc. 2013, Gottfried Korff, Simplizität und Sinnfälligkeit. Volkskundliche Studien zu Ritual und Symbol, Tübingen 2013, Michael Winkelman, "Magic: a theoretical reassessment«, Current Anthropology 23/r ( 1997) 37-66, usw.

50 Zur spezifischen Rolle der Roma Mlada Gospoja, »Bei der Zauberin Hamša Farina, einer Zigeunerin in Gorica«, Anthropophyteia 7 ( 1910 ) 407-4I 5 , Charles G. Leland, Gypsy Sorcery and Fortunetelling, New York 1962.

5 I Vgl. wie oben. 
Viele der magischen Praktiken beruhen auf der Glaubensvorstellung der Beeinflußbarkeit von Situationen und Prozessen aufgrund der assoziativen Vernetzung des gesamten Seinsbereiches durch Analogieketten, wobei die Schwierigkeit der auszuführenden Prozeduren, die Verstärker-Effekte der Wirksamkeit (Nacktheit, Nacht, Schweigen usw.) durch spezifische Bedingungen und das Zusammentragen der Ingredienzien unter besonderen erschwerenden Umständen eine Art pragmatische »Poetik» bilden, deren "Logik« ambivalent und polysemisch bleibt: so wie das Sakrale schützend aber auch gefährdend sein kann, können oft die gleichen Mittel (ähnlich wie in der Pharmazeutik), abhängig von Dosis oder Kontext, auch die gegenteilige Wirkung hervorrufen ${ }^{52}$. Die dienenden Geister sind nicht immer dienstbar. Ähnlich wie der Zauberspruch ist auch die magische Praktik ein Kommunikationsakt mit imaginären Adressaten, wobei ein Kundiger den Interaktionsvorgang leitet und die Vermittlung zu den »metaphysischen" Instanzen, die die gewünschte Wirkung erwirken sollen, herstellt. Doch die Spiritualität des Sakralen ist hier durch stofflich-materielle Mittel ersetzt; die magischen Praktiken sind nicht zur Gänze der gelebten Alltagswirklichkeit enthoben. Insofern bewegen sich Zauberei und Magie zwischen Parareligiosität und Einbildung bzw. Phantasterei, zwischen Transzendenz und Immanenz, zwischen Imagination und Realität. Freilich ist Imagination zugleich eine Art innere Realität, sowohl im individuellen wie auch im kollektiven Sinn, und deshalb im Sinne der Phänomenologie Teil der menschlichen Erfahrung und des Bewußtseins. Doch der immanente Zweifel an der Existenzwirklichkeit dieser angewandten "weltlichen Religion« mit ihren lebenspraktischen Zielen und Zwecken ohne eigentliche Transzendenz, hat magische Praktiken zu einem gewissen Grad immer schon von religiösem Glauben unterschieden. In den Überlebensstrategien der Oralkulturen Südosteuropas verblassen jedoch solche Differentialkriterien, Kirchliches und Weltliches, religiös Sanktioniertes und hybrides (Aber)Glaubensgut, außerhalb des institutionalisierten Kontrollbereiches der Hochreligion, von verschiedenem Alter und Herkunft, gehen in Pastoralpraxis und Lebensvollzug nichtelitärer Populationsschichten bemerkenswerte Legierungen und Kontaminationen ein, die theoretische Unterscheidungsversuche und Grenzziehungen zwischen religiös und magisch als akademische Konstruktionen erscheinen lassen.

Wer sind diese Zauberkundigen und Magierinnen, die in Mittel- und Westeuropa in Mittelalter und Neuzeit als Hexen und Teufelsbündner verbrannt worden $\operatorname{sind}^{53}$, und

52 Dies demonstriert auch die bedeutungsambivalente griechische Wurzel pharma-: farmako ist die Medizin, farmaki jedoch das Gift. Vgl. auch altgr. pharmakeia Vergiftung, ngr. farmakeion die Apotheke.

53 Hexenprozesse sind in Südosteuropa vor allem in Ungarn nachgewiesen (Balassa/Ortutay, op. cit. 72 If.). 
worin besteht ihre geheimnisvolle Tätigkeit? Wie kann man in deren apokryphes Wissen eingeweiht werden? Im multiethnischen Raum des historischen Thrakiens z.B. wälzen sich in der ersten Mainacht Frauen unbekleidet im Gras, um in die Geheimnisse der Magie eingeweiht zu werden ${ }^{54}$. Dort ergehen sich die maïstres (Magierinnen) in verschiedenen Ritualhandlungen zur Förderung ihrer eigenen Prosperität und verwünschen die fremde Ernte, Hab und Gut des Nachbarn, holen den Mond auf die Erde und melken Mondmilch; im allgemeinen entwickeln die hexenartigen Wesen eine eher asoziale Tätigkeit, helfen auch durch Schadenszauber in Erosbelangen ${ }^{55}$.

54 Berührung mit der Naturkraft Erde; auch die Übertragung des Wissens durch Speicheltausch ist

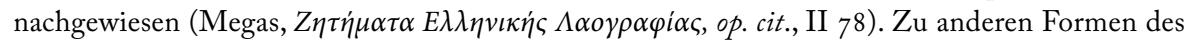
Wissenstransfers vgl. Dimitrios Benekos, "The initiation into magic according to the epirotic folk

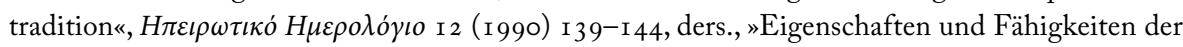
Magier und Hexen nach dem epirotischen Volksglauben «, Laografia 35 (1987-89) 223-234, Stilpon

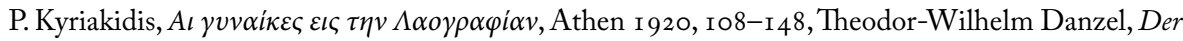
magische Mensch, Potsdam/Zürich I 928, 33-35, usw. Allgemein: Kalliopi Papathanasi-Musiopulu,

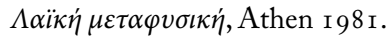

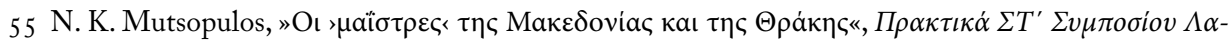

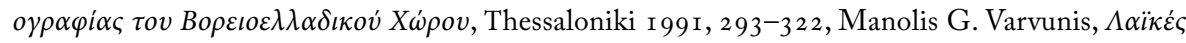

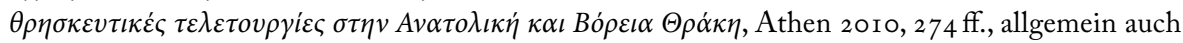
Démètrios A. Petropoulos, »Le rôle de femmes et de la terre en quelques pratiques magiques«, $M e ́-$

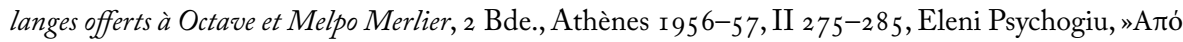

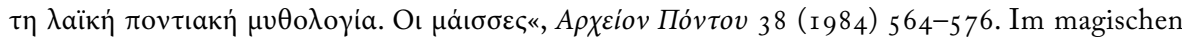

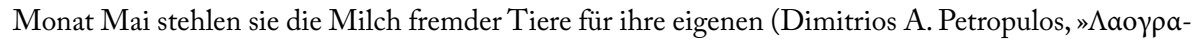

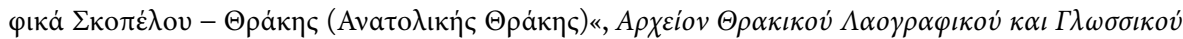
$\Theta \eta \sigma \alpha v \rho o v ́$ 8, I 94I/42, I 35-192, bes. I6 I f.), als Schadenszauber schneiden sie Holzsplitter von der

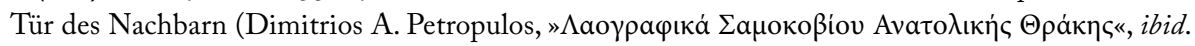
7, I 940-4I, I 45-223, bes. I66), sind im allgemeinen alt und häßlich, hinkend und verrunzelt, reiten

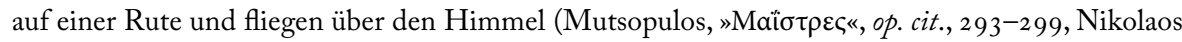

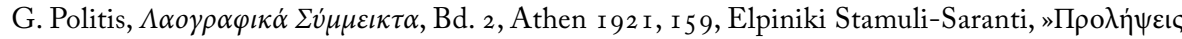

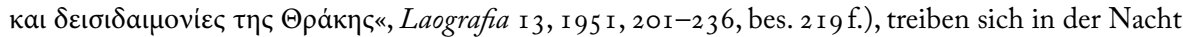
oft nackt an abgelegenen Orten außerhalb des Dorfes und auf Feldern herum, holen den Mond auf

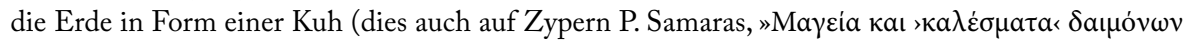

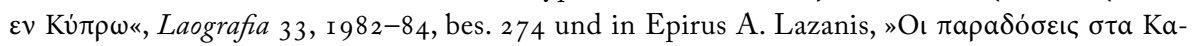

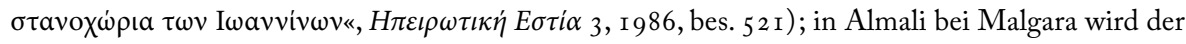
Mond als rote Kuh von Magiern gemolken, sie trinken Mondmilch und schlafen, durch Nase und Mund kriechen Reptile und Ungeziefer und trinken die Mondmilch, um nachher zu entweichen, lassen dem Zauberer aber einen Teil ihrer übernatürlichen Kräfte zurück (Nikolaos G. Politis, $\Lambda \alpha o-$

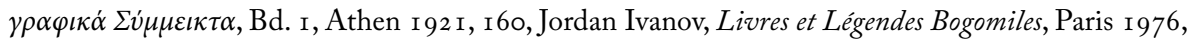

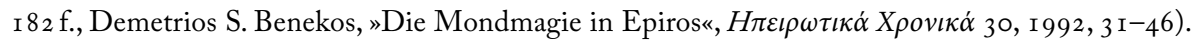
Im Zaubermonat Mai und zur Sommersonnenwende üben die Magierinnen auch Schadenszauber in Liebesdiensten: z.B. mit einer Seife, in die 40 Nadeln gestochen sind, am Brunnengrund (»wie die Seife zergeht, soll auch der/die zergehen, wenn er/sie mich nicht nimmt«); dies geschieht ge- 
Unter einem prozessualen Aspekt lassen sich passive Prophylaxe, Abwehr und Verhütung des Übels von den aktiven Eingriffen der magischen Praxis unterscheiden. Bei den apotropäischen Handlungen haben in Südosteuropa die magische Kreisziehung und der Amulettgebrauch dominante Bedeutung. Der Schutzzirkel hat eine ambivalente Doppelbedeutung ${ }^{56}$ : Abwehr des Übels durch die Vollkommenheit des geschlossenen Kreises und gleichzeitig Sakralisierung des geschützten Innenraums durch Ausstecken von Wegmarken in Kreisform, Gürten und Umgrenzen (beim Siedlungsraum geheiligte Stätten wie Kapellen, hagiasmata-Quellen, hypsoma-Bäume, proskynetaria-Ikonenschreine und Mini-Kapellen am Straßenrand, bei Kirchen oder Ikonen durch Faden-, Ketten- und Wachsgürtungen ${ }^{57}$. Bei den Schutz-Amuletten und Ta-

wöhnlich durch das rituelle Anbinden von Naturkräften oder Dämonen (Dimitrios S. Benekos, $H$

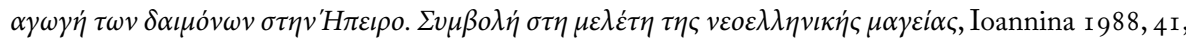

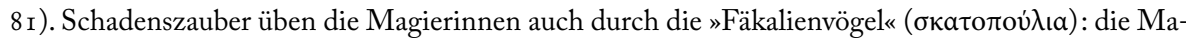
gierin hat 40 Vogeleier in einem Säckchen unter der Achsel 40 Tage lang, sie lacht nicht, singt nicht, blickt nicht auf die Seite; die ausgebrüteten magische Vögel entläßt sie mit Zaubersprüchen, sie fliegen durch den Rauchfang und bringen ihr die Feldfrüchte der Nachbarn; dieser Zauber bricht, wenn die Magierin von Speisen ißt, die ihr die Nachbarn darbringen, welche Fäkalien enthalten,

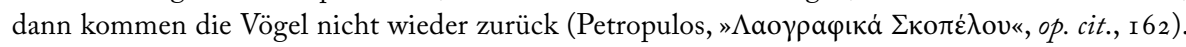

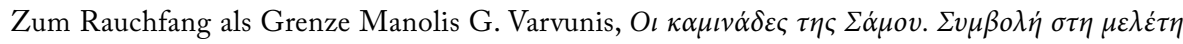

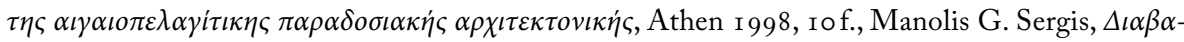

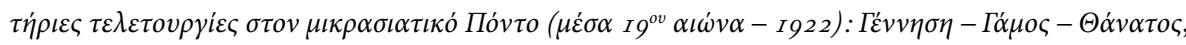

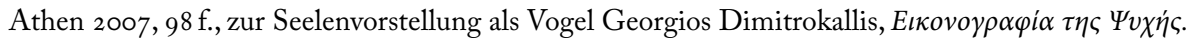
$H \psi v \chi \dot{\eta}-\pi o v \lambda i$, Athen $\mathrm{I}_{992}$, I 5 f. Als Gegenzauber malt man auch mit roten Ostereierschalen und

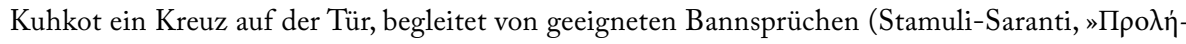

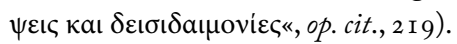

56 Dazu gehört der Großteil der Ritualumzüge, Bittlitaneien und Ikonen-Prozessionen (Dragoslav Antonijević, „Contribution à l'étude de la symbolique du cercle magique et la marche en rond autour du defunt «, Balcanica 3, I 972, 46 I-476, Charles Stewart, "Magic circles. An approach to Greek ritual«, Journal of the Anthropological Society of Oxford 25/I, I 994, 9 I-I I I, G. Nikolakakis, »La litanie dans le Lassithi, Crete«, Études et Documents Balkaniques et Méditerranéens I6, I992, 42-48, Geor-

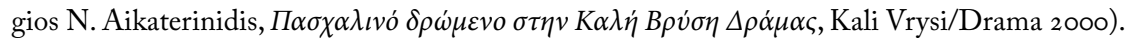

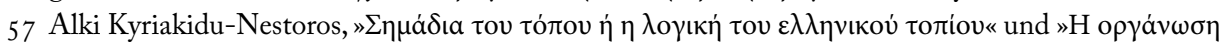

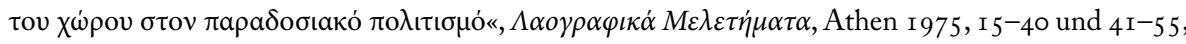
Lucia Nixon, Making a Landscape Sacred. Outlying Churches and Icon Stands in Sphakia, Southwestern

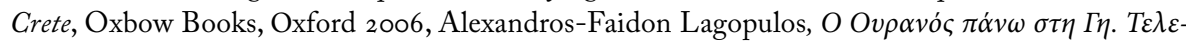

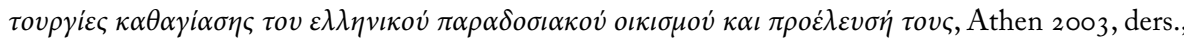

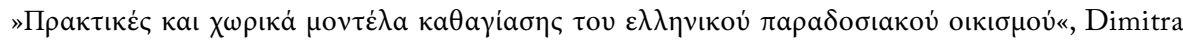

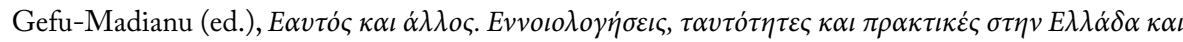

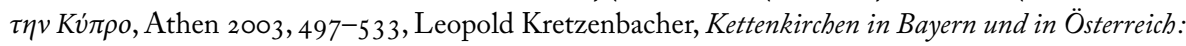
Vergleichend-volkskundliche Studien zur Devotionalform der "cinctura " an Sakralobjekten als kultisches Hegen und magisches Binden, München r 973. Zum magischen Zirkel in den Zauberbüchern und 
lismanen ${ }^{58}$ dominieren neben den Kreuzen die Edelmetalle an Halsketten (fylakto, хaï$\mu a \lambda$ i/hamayli), Ringe ${ }^{59}$, in der Kirche geweihte Silbermünzen ${ }^{60}$, rot gefärbte Eier (von schwarzer Henne am Gründonnerstag) ${ }^{61}$, Zettel mit Bibelzitaten an die Kleidungs-

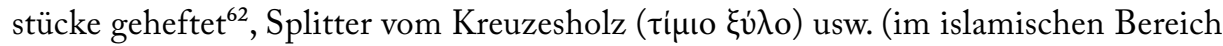
auch Halbmonde, Hörner, Fisch, Skorpion, Halsketten mit magischen Quadraten, In-

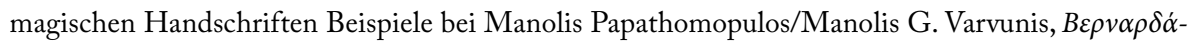

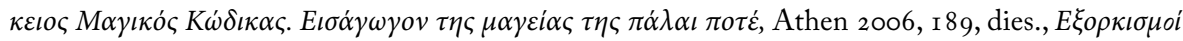

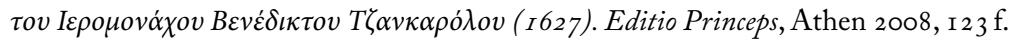

58 Dazu in Auswahl: W. D. Hand, »Abwehrzauber«, Enzyklopädie des Märchens I ( I 977) 48-52, Wolfgang Brückner, »Amulett«, ibid. I (I 977) 476-48 I, R. G. Alvey, »Eisen, eisern«, ibid. 3 (I98 I) I 294-I 300, Pfister, »Amulett«, Handwörterbuch des Deutschen Aberglaubens I (I 927 ) 377 ff., Lieselotte Hausmann/Lenz Kriss-Rettenbeck, Amulett und Talisman, München I 966, Leopold Schmidt, Heiliges Blei in Amuletten, Votiven und anderen Gegenständen des Volksglaubens in Europa und im Orient, Wien I 958, I 4-I 7, Gustave Schlumberger, »Amulettes byzantines anciens destinés a combattre les maléfices et maladies«, Revue des Études Grecques 5 (I 892) 73-93 (auch Byzantinische Zeitschrift 2, I893, I 87-I 91), Samson Eitrem/A. Fridrichsen, Ein christliches Amulett auf Papyrus, Kristiania I 92 I, V. Laurent, "Amulettes byzantines et formulaires magiques«, Byzantinische Zeitschrift 36 (I936) 300-3 I 5, Gregory Gizelis, »The Use of Amulets among Greek Philadelphians«, Pennsylvania Folklife 20/3 (I 97 I ) 30-37, Dragoslav Antonijević, "A contribution to the Study of Cults and Symbols of Balkan Cattle-Breeders«, Balcanica I 2 ( I 98 I) I09-I I6, Jeffrey Spier, "Medieval Byzantine Magical Amulets and their Tradition «, Journal of the Warburg and Courtauld Institutes 56 (I 993) 25-60, Ger-

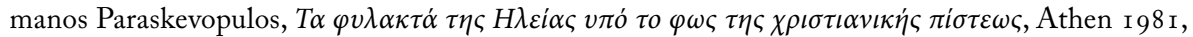
Wolfgang Brückner, »Christlicher Amulett-Gebrauch der frühen Neuzeit«, Frömmigkeit. Formen, Geschichte, Verbalten, Zeugnisse. FS L. Kriss-Rettenbeck, München I 993, 89-1 34, Mircea Eliade, The Forge and the Crucible, New York I 97 I, Ignaz Goldziher, „Eisen als Schutz gegen Dämonen«, Archiv für Religionswissenschaft Io (1 907) 4I-46, Siegfried Seligmann, Die magischen Heil- und Schutzmittel, Stuttgart 1927, I6I-I69, Wallis Budge, Amulets and superstitions, London r 930, etc.

59 Eisenring, auch gegen bösen Blick (Anna Papamichail, "X

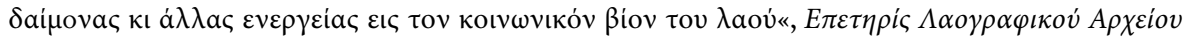

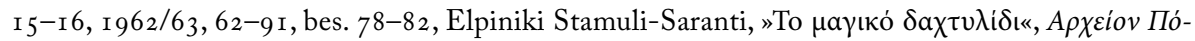
viov 19, 1954, 232-236), Silberring (Georg Salzberger, Die Salomosage in der semitischen Literatur, Berlin I 907, 93, Sofija Kostić, »Amajlije u narodnim verovanjima u Istočno Srbiji«, Glasnik Etnografskog muzeju u Beogradu 6o, I 966, 77-96), usw.

6o Votivgabe aus dem Gebiet des Kosovo (Nikos Papageorgiu, A. Tó $\mu \alpha \tau \alpha \kappa \alpha \iota \Sigma \dot{v} \mu \beta o \lambda \alpha \tau \omega \nu \Lambda \alpha \dot{\omega} v, B$.

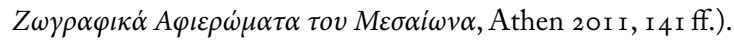

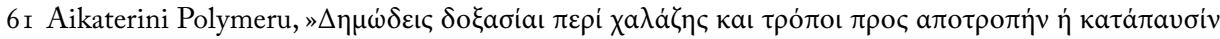

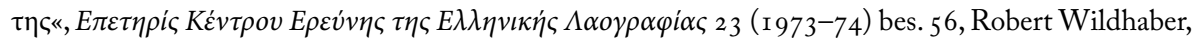
"Die Eierschalen im europäischen Glauben und Brauch«, Acta Ethnographica Academiae Scientiarum Hungaricae I 9 (1970) 435-457.

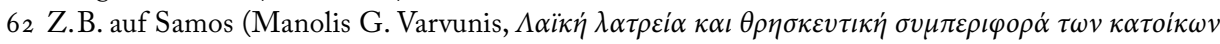

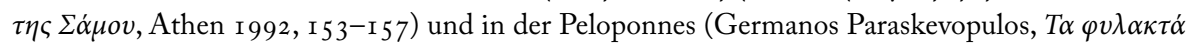

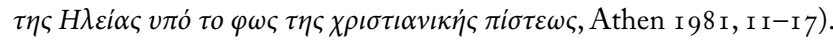


schriften, Gebetsketten etc. ${ }^{63}$ ), aber auch Formen des Bindezaubers und des Festmachens wie Fadenknoten, Verknüpfungen, Nägeleinschlagen usw. ${ }^{64}$, sowie ebenfalls spezifische Augenamulette gegen den Bösen Blick ${ }^{65}$, die heute noch als Auto- und Lastwagendekoration zu finden sind ${ }^{66}$.

Die Morphologie der prophylaktischen und apotropäischen Aktionen gegen Dämonen, schädliche Einflüsse und Übel jeglicher Art lassen sich kaum in irgendeine Form von Systematik pressen, da die Abwehrhandlungen vielfach bereits selbst aktive Eingriffe in eine gegebene Situation im Sinne der magischen Praktiken darstellen ${ }^{67}$ oder als Gegenzauber auf solche Eingriffe reagieren bzw. ihnen zuvorzukommen suchen ${ }^{68}$.

63 Josef Fr. v. Hammer-Purgstall, Talismane der Muslimen, Wien I9 14, Rudolf Kriss/Hubert KrissHeinrich, Volksglaube im Bereich des Islams, 2 Bde. I 960-62, II I-57.

64 Christoph Daxelmüller, »Festbannen«, Enzyklopädie des Märchens 4 (1984) I043-IO52, Will-Erich Peuckert, "Festmachen «, Handwörterbuch des Deutschen Aberglaubens 2, I 35 2-68, Isidor Scheftelowitz, Das Schlingen- und Netzmotiv im Glauben und Brauch der Volker, Gießen I 9 I 2, Paul Wolters, „Faden und Knoten als Amulett«, Archiv für Religionswissenschaft 8 ( ( 905) Beiheft I-23, usw.

65 Vgl. dazu noch in der Folge.

66 G. Tarsouli, »Décorations religieuses dans les moyen de transport«, Acted du premier congrès interna-

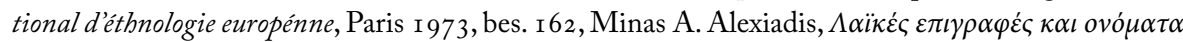

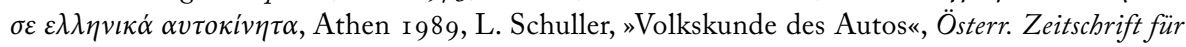
Volkskunde 73 (1970) I $52^{2-1} 73$.

67 So wird die Prophylaktik in manchen Übersichten zur Weißen Magie gerechnet: Die Abwendung von Übel (baskania, Krankheit, Dämonenbesessenheit, Feuer, Überschwemmung usw.) und die Herbeiführung von Glück (Gesundheit, Glücklichkeit, Freude, Erntesegen, Reichtum, Regen, Fruchtbarkeit usw.) gehen Hand in Hand und sind die zwei Seiten derselben Münze (Dimitrios S. Lukatos,

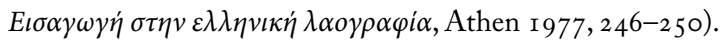

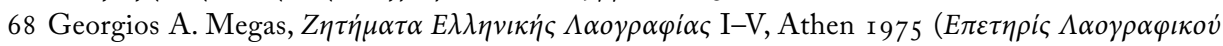

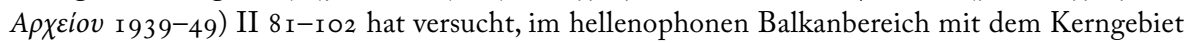
Thrakien in deskriptiver Form eine solche Morphologie der apotropäischen Prophylaktik gegen Dämonen und Übel jeglicher Art zu erstellen. Zu den Requisiten (I) dieser Handlungen gehören Gegenstände, Naturelemente, Gliedmaßen und Körperteile (z.B. Messer, Nadel, Schere, Huf, Schlüssel, Feuerzange, Pflugschar, Eisen oder anderes Metall, Wasser, Salz, Meerwasser, Feuer, brennende Fackel, glühende Kohle, Asche, Teer, Knoblauch, Hundszwiebel, Lorbeer, Raute u. a. Kräuter, Besen, Brot, Teig, Speichel, Muttermilch, Hemd, Netz, Horn, Hahn, Unterkiefer des Schweins, Schlange usw.), deren Wirkung verstärkt wird durch besondere Umstände wie Diebstahl, Sternenbeschau, Verfertigung in einem Tag, Galgenstrick usw., durch Zahlenmagie $(3,5,7,9)$, des nachts, zu bestimmter Stunde, an der Wegkreuzung oder Hausschwelle usw., mit bevorzugten Farben rot oder schwarz, mit Berührung eines Sakralgegenstands (z.B. Epitaphblumen, Lorbeerblätter der Osterliturgie, rote Eier usw.). Die Handlungen werden von Verbaläußerungen (2) begleitet (Anrufung sakraler Instanzen) oder von Symbolformen und Gesten (3): Pentalpha, Kreuz, Knoten, Phallus, Vagina, Fünf-Finger-Weisen usw., dazu auch Glockenleuten, Schläge, Gefäßzerschlagen, Schüsse, Lärm; besonders ist die magische Kreisziehung zu erwähnen (z.B. mit schwarzgriffigem Messer in der Erde) oder die Fadengürtung des Dorfes gegen Epidemien (der Faden wird in Thrakien von 
Im allgemeinen kann man das Analogie-Denken der magischen Praktiken in einen positiven und einen negativen Utilitarismus einteilen: Hilfe oder Schaden, Erringung von Properität, Glück und Fertilität oder Vernichtung, Verletzung und Unglück, Weiße und Schwarze Magie ${ }^{69}$. Der Schadenszauber als Haß- und Racheakt kann sich auch

unbekleideten Frauen in der Nacht gesponnen und an einem Schloß versperrt, vgl. Laografia VII, 472), die Umpflügung des Dorfes mit Zwillingsochsen, die Umzäunung des Pferchs mit Stachelsträuchern, die Zwölftenasche im Kreis streuen oder Feuer entzünden, die Ikonenprozession ums Dorf, Reliquien, Ikonen u.a. heilige und magische Objekte, das v́ $\psi \omega \mu \alpha$ (»Erhöhung«, Heiligung von Bäumen), das Aufstellen von Kreuzen mit brennenden Kerzen an den vier Horizonten in Kreuzform um das Dorf. Zu den apotropäischen Taktiken zählt auch das Täuschen des Dämons (4) durch das Sieb oder Weizenhalmbüschel hinter der Eingangstür oder an der Decke (er wird mit dem Zählen nicht fertig), aber auch die Vertreibung, das Anbinden und Durchstechen (5): Exorzismus, Annageln an Bäume und Mauern, symbolisches Anbinden und Fesseln (Knoten), Vertreibung in die Berge, Übertragung der Krankheit und des Übels auf andere (An-den-Baum-Hängen von Unterwäsche, Durchreichen des Kindes durch ein Zaunloch - die Hunde bekommen die Weinerlichkeit, Kinderhemd durch einen Felsspalt [siehe die Ausführungen zum Nadelöhr-Ritus]). Eine andere Strategie ist die Befreiung vom Übel durch Kathartik (6): Über-neues-Feuer-Halten (angezündet von Einäugigen, Linkshändigen, Nackten, Keuschen, Zwillingsbrüdern, usw. ohne zu sprechen, bei Viehherden verursacht durch Vampire, smerdaki, chamodraki usw.), durch Meerwasser (auf Ägäisinseln wird das Haus besprengt mit Wasser von 40 Wellen), durch Pharmakos-Riten (Eingraben des Übels; in Thrakien zündet man bei Viehseuche ein geteertes Schwein an, das über die Felder läuft und die Epidemie mit sich nimmt; Tieropfer), durch Nadelöhr-Riten ( Eisenring, Baumgabelung, Felsspalt, Erdriß, ärmelloses Hemd usw.); eine andere Taktik besteht in der Befreiung vom Übel durch Scheinverkauf (7) (auf Kreta z.B. »verkauft« die Mutter von verstorbenen Kindern in einer gespielten Dialogszene das letzte, dieserart "gefährdete« Kind an einer Frau mit vielen Kindern), durch Kleidertausch, Scheinbegräbnis usw. Zu den prophylaktischen Strategien gehören auch Euphemismen, das Verstecken von Fingernägeln oder abgetragenen Kleidern in Mauerlöchern, Amulette. Vgl. Gerald Alvey, "Euphemismus«, Enzyklopädie des Märchens 4 (I 984) 556563, Dimitrij K. Zelenin, Das Worttabu bei den Volkern Osteuropas und Nordasiens, Leningrad 1930.

${ }_{99}$ Der positive Effekt wird herbeigeführt durch Glücksobjekte (Fledermausknochen, Schlangenhaut, Brautschleier, Galgenstrick, Henkerschwert usw.) bzw. Analogiehandlungen (Auf-Eisen-Treten, Rechtswendungen, Honig für die Jungverheirateten beim Eintritt ins Haus, Zerschlagen des Gra-

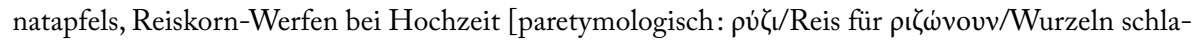
gen]), durch Rutenschlag oder Palmzweig (Olivenzweig, Kräuter) für Gesundheit und Fertilität, durch Tieropfer bei Hausbau (Brücke, Schiff usw.). Dem liegt die Grundidee des Einmauerns der

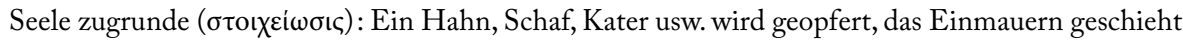
nur verbal, oder der Schatten fällt auf den Eckstein des Fundaments (oder Schattenmessen und Einmauern des Meßstocks; vgl. auch die Bauopferlegende und die Ballade von der Arta-Brücke in Puchner, Die Folklore Südosteuropas, op. cit., 45-49). Das Glück kommt auch durch Schatzfindung (Schatzhüter erscheint im Traum), durch das Beenden der Dürrezeit (perperuna) durch Anschütten von Menschen oder Idolen bzw. Ikonentaufe im Fluß, oder durch Litanei ( $\lambda \dot{\eta} \eta \sigma \eta)$ (meist an den

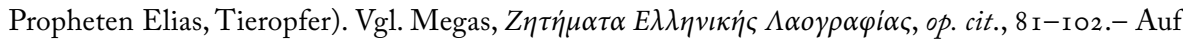
homöopathischen und sympathetischen Aktionen beruht auch das Analogie-Denken der Schwar- 
als versuchte Glücksverhinderung manifestierten (z.B. Bindezauber als Potenzverlust) und ruft Strategien der Neutralisierung auf den Plan (Lösung des Bindezaubers) ${ }^{70}$; der Liebeszauber bleibt trotz seiner Zielambivalenz nötigend ${ }^{71}$.

$\mathrm{Zu}$ den Basisstrategien der magischen Praktiken in Südosteuropa zählen der Bannspruch, die Beschwörung und der Exorzismus, Schwur und Fluch, das Besprechen bei therapeutischen Versuchen, der Bindezauber (katadesmos) und die Zahlenmagie. Dämonenbann und Exorzismus sind auch Aufgabe der institutionalisierten Kirche (bildet z.B. den historischen Hintergrund des Taufgeschehens) ${ }^{72}$ und wendet sich u.a. auch gegen die personifizierten

zen Magie: Schadenszauber durch Eingraben (ins Grab) eines Idols (Wachspuppe) des zu Schädigenden, Durchstechen der Rachepuppe (in Brunnen oder Meer geworfen), Zaubergegenstände an seine Schwelle gelegt, Bindezauber mit Faden und Stricken; dazu begleitende Fluchformeln, Magie mit kollyba (orthodoxe Totenspeise), abgebrannten Kerzen, Quecksilber usw.; auch Schadensziel durch Verhinderung der Fertilität, symbolischen Ernteraubs usw. (Megas, op. cit., II Io8 ff.). Zur Rachepuppe W. Müller-Bergström, »Rachepuppe «, Handwörterbuch des Deutschen Aberglaubens 7, 459463, vgl. weiters F. Ohrt, »Schadenzaubersprüche«, ibid. 7 ( I 935-36) 97 I-974, Gudrun Schwibbe, »Schadenzauber«, Enzyklopädie des Märchens I I (2004) I I 73-I I 79, G. Keil et al., »Zaubersprüche«, Lexikon des Mittelalters 9 ( 1999) 486-492, A. Wesselski, »Das Totbeten«, Sudetendeutsche Zeitschrift für Volkskunde I (1928) 82-102 usw. In Ungarn formt das sitzengebliebene Mädchen aus der Erde von den Fußspuren des Ungetreuen eine Fluchpuppe, die vergraben wird (Balassa/Ortutay, op. cit., 738 f.); der Fußabdruck gilt als Teil der Gesamtpersönlichkeit (Christoph Daxelmüller, »Fußspuren«, Enzyklopädie des Märchens 5, 1987, 6 1 $0-622$ bes. 6 1 8 ff.).

$70 \mathrm{Zu}$ den Strategien der Neutralisierung zählt die Aufhebung des Zaubers durch den Verursacher, die Anwendung von Gegenmitteln seitens des Geschädigten usw., was in einer Vielzahl von Handschriften und Anleitungen festgehalten ist. Die Lexika der Magie definieren auch die entsprechenden Anwendungssituationen: Eros, Impotenz, Dürre, Untreue, Verhexung durch bösen Blick, Dämonisierung, Todesfälle usw. (Lukatos, op. cit., 246 ff.). Vgl. auch Christoph Daxelmüller, "Sympathiezauber«, Enzyklopädie des Märchens I 3 (2010) Iо I-105. Zu den Abwehrstrategien des Schadenszaubers gehört auch das Abschneiden und sicher Aufbewahren der ersten Haarbüschel und Nägel des Kleinkindes, das heute noch geübt wird (das Haar gilt auch im Märchen als Sitz der Lebenskraft, vgl. Ulrich Kuder, »Haar«, Enzyklopädie des Märchens 6, I 988, 336-343, Sigrid Willer, Haar und Nagel in Magie, Religion und Volkskunde, Diss. Lübeck 1984).

7I Gewinnung der Zuneigung durch Elixiere und Filter (filtra) bzw. Verhinderung der Vereinigung (Potenzverlust, Verhinderung des Beischlafs bei Ehepaaren, Anbinden der Manneskraft - $\alpha \mu \pi$ ó$\delta \varepsilon \mu \alpha)$. Dieser geläufige Bindezauber geschieht meist durch Knotenknüpfen mit Zauberspruch, seine Abwehr durch ein schwarzgriffiges Messer oder Schlangenhaut, seine Lösung durch Auflösen der

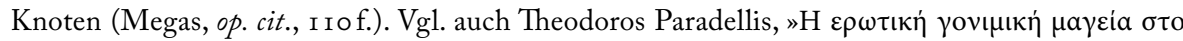

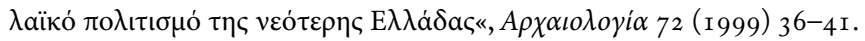

72 Christoph Daxelmüller, »Exorzismus«, Enzyklopädie des Märchens 4 (1984) 664-674, Dimitrios Pe-

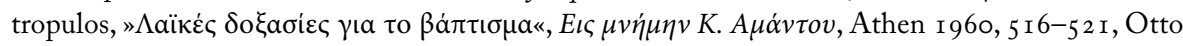
Böcher, Dämonenfurcht und Dämonenabwehr. Ein Beitrag zur Vorgeschichte der christlichen Taufe, Stuttgart etc. I970, 
Krankheitsdämonen bei volksmedizinischen Therapieversuchen ${ }^{73}$. Das Fluchrepertoire ist im mediterranen und balkanischen Raum besonders reichhaltig und verschont auch Sakralpersonen nicht ${ }^{74}$. Das Besprechen der Krankheit umfaßt neben der begleitenden Gestik ${ }^{75}$ eine große Formenvielfalt verbaler Manifestationen von Beschwörung, Segen und Gebet bis zu Exorzismusfomeln und Bannsprüchen ${ }^{76}$. Dominanter Anwendungsbereich von Formen des

73 Ljubinko Radenković, Narodna bajanja kod Južnih Slovena, Beograd I 996, Wilhelm Giese, „Der Bannspruch der albanischen Märchenerzähler«, Beiträge zur Südost-Europa-Forschung. Anläßlich des 2. Intern. Balkanologenkongresses in Athen 7. V.-13. V. 1970, München I970, 57-60, Charalampos N.

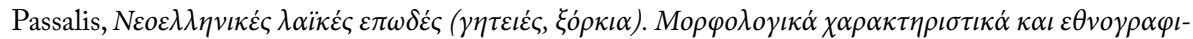

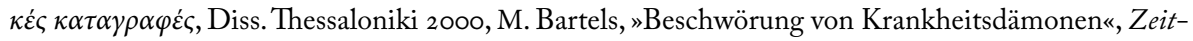
schrift für Volkskunde 5 (I 895) I-40, Manfred Geier, „Die magische Kraft der Poesie. Zur Geschichte, Struktur und Funktion des Zauberspruchs", Deutsche Vierteljahrsschrift für Literaturwissenschaft und Geistesgeschichte 56 (1982) 359-385.

74 Michael Belgrader, »Fluch, Fluchen, Flucher«, Enzyklopädie des Märchens 4 (I 984) I3 I 5-1 328, O. Mailand, »Der Fluch in der siebenbürgisch-rumänischen Volkspoesie«, Zeitschrift für Volkskunde 3 (I 89I 208-2 I 4, Michael Belgrader, "Magyarische Flüche«, Südostdeutsche Vierteljabresblätter 27/2 (1978) I 23-I 26, ders., »Rumanian Obscenities and Curses«, Maledicta 9 (1 985 ) usw.

75 Z.B. das Handauflegen (Christoph Daxelmüller, »Hand«, Enzyklopädie des Märchens 6, I 988,436 447, Rudolf Schenda, »Heilen, Heiler, Heilmittel«, ibid. 655-665).

76 Dazu existiert für Südosteuropa eine umfangreiche diachrone und synchrone Bibliographie. Vgl. auch im Ersten Teil und weiters in Auswahl: Otto Weinreich, Antike Heilungswunder, Gießen I 909, Oskar von Hovorka, Vergleichende Volksmedizin, 2 Bde., Stuttgart 1908/o9, Irmgard Hampp, Beschwörung, Segen, Gebet, Stuttgart I96 I, Mircea Eliade, "Kosmogonische Mythen und magische Heilungen", Paideuma 6 (1954/58) I 94-204, Stephan R. Delić, „Wie unser Volk denkt. I.: Der >Oganj< (Fieberausschlag) und seine Heilung", Wissenschaftliche Mittheilungen aus Bosnien und der Hercegovina 3 ( 1895 ) 558-565, Leopold Glück, »Skizzen aus der Volksmedicin und dem medicinischen Aberglauben in Bosnien und der Hercegovina«, ibid. 2 ( (1894) 392-454, ders., "Die Volksbehandlung der Tollwuth in Bosnien und der Hercegovina" 3 (1895) 539-55 I, ders., Medicinische Volksterminologie in Bosnien und der Hercegovina, unter Berücksichtigung der Nachbarländer, Sarajevo I 898, Mehmed F. Kolinović, „Volksaberglaube und Volksheilmittel bei den Mohammedanern Bosniens und der Hercegovina«, ibid. 7 ( 1900 ) 339-366, Josef Preindlberger, »Beiträge zur Volksmedicin in Bosnien«, ibid. 8 ( I 902) 2 I 5-229, Ćiro Truhelka, „Die Heilkunde nach volksthümlicher Überlieferung mit Auszügen aus einer alten Handschrift«, ibid. 2 (I 894) 375-39 I, Radmila Filipović-Fabijanić, "Folk Medicin in the Lištica Region", Wissenschaftliche Mitteilungen des bosnisch-herzegowinischen Landesmuseums 2 :B (1976) 235-244, Ute Dukova, „Gemeinsame Termini in der Folklore der Balkanvölker (Euphemistische Bezeichnungen der Bergfeen und der von ihnen hervorgerufenen Krankheiten)«, Balkansko ezikoznanie/Linguistique balkanqiue 23/2 (1980) 5-I 2, Nikola Gelenčir, Naturbeilkunde des Balkans, Steyr 1983 ( 78 Heilpflanzen), Andrijana Gojković, »Rusalje - an Ethnomusicological and Medical Problem«, Musik, Tanz und Kunst-Therapie 2/3 (1989) I 27-138, Salvator Israel, »Communautés et influences réciproques dans le domaine de la médicine des peuples balkaniques au cours de la période ottomane", Actes du premier congrès international des études balkaniques et sud-est européennes, Sofia 1966, Bd. 3, Sofia 1969, 829-834, Augustin Kristić, „Fragmente aus der Volksmedizin Bosniens und 
Bindeszaubers ist das Anbinden der sexuellen Manneskraft in der Erosmagie ${ }^{77}(\alpha \mu \pi o ́ \delta \varepsilon$ -

der Herzegowina«, Elfriede Grabner (ed.), Volksmedizin. Probleme und Forschungsgeschichte, Darmstadt I967, 345-36r, Wilhelm Lettenbauer, »Über Krankheitsdämonen im Volksglauben der Balkanslaven«, Serta Monacensia. FS F. Babinger, Leiden I952, I 20-I35, Gabriella Schubert, „Die Frau in der Volksheilkunde auf dem Balkan«, Norbert Reiter (ed.), Die Stellung der Frau auf dem Balkan, Wiesbaden 1987, 2 I 9-23 I, Maryan Udziela, „Ein Beitrag zur Volksthierheilkunde in Bosnien «, Zeitschrift für österr. Volkskunde 8 ( I 902) I05-I I 8, Joseph L. Conrad, »Magic Charms and Healing Rituals in Contemporary Yugoslavia«, Southeastern Europe 10/2 (1983) 99-1 20, ders., »Bulgarian Magic Charms: Ritual, Form, and Content«, Slavic and East European Journal 3 I/4 (1987) 548-562, Phyllis M. Kemp, Healing Ritual. Studies in the Technique and Tradition of the Southern Slavs, London 1935 (I940, reprint 1987), Barbara Kerewsky-Halpern/John M. Foley, "The Power of the Word: Healing Charms as an Oral Genre«, Journal of American Folklore 9I (I978) 903-924, dies., »Bajanje: Healing Magic in Rural Serbia«, P. Morley/R. Wallis (eds.), Culture and Curing. Anthropological Perspectives on Traditional Medical Beliefs and Practices, London/Pittsburgh, Penn. 1979, 40-56, Barbara KerewskyHalpern, »Talk, Touch and Trust in Rural Healing", Papers for the V. Congress of Southeast European Studies, Belgrade, September 1984, Columbus, Ohio 1984, 250-26 I (auch in Social Science and Medicin 2 I/3, I985, 3 19-325), dies., "Healing with Mother Metaphors«, Acta Ethnographica Academiae Scientiarum Hungaricae 34 (1 986-88) 245-265, C. McLean (ed.), Women as Healers. A Cross Cultural

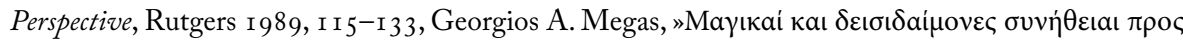

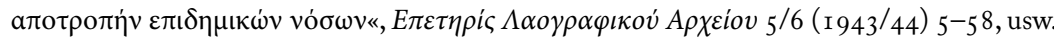

77 Christoph Daxelmüller, "Fernzauber«, Enzyklopädie des Märchens 4 (1984) 1025-1033, Ulrike Zischka, Zur sakralen und profanen Anwendung des Knotenmotivs als magisches Mittel, Symbol und Dekor, Diss. München I977, F. Byloff, „Nestelknüpfen und -lösen«, Archiv für Geschichte der Medizin I9 ( 1927 203-208, Franz Steinleitner, »Mittel aus dem Tierreich zum Anhexen der Impotenz und Heilen der angezauberten Mannesschwäche«, Zeitschrift für Volkskunde 42 (I 933) I 46-I63, Hanns Bächtold-Stäubli, »Impotenz", Handwörterbuch des Deutschen Aberglaubens 4 (I93 I-32) $676 \mathrm{ff}$. Zum Zauberwesen rund um die Sexualität in Südosteuropa vgl. Jasna Belović, Das Liebesleben auf dem Balkan, Dresden 1 927, Friedrich Salomo Krauss, »Die Skatologie der Südslaven«, John G. Bourke, Der Unrat in Sitte, Brauch, Glauben und Gewohnheitsrecht der Volker, Leipzig I 9I 3, 445-50 I, Michael Martischnig, "Erotik und Sexualität der unteren Volksschichten«, Zum 5o. Todestag von Friedrich Salomo Krauss, Wien 1989, 22-83, Bernhard Stern, Medizin, Aberglaube und Geschlechtsleben in der Türkei. Mit Berücksichtigung der moslemischen Nachbarländer und der ehemaligen Vasallenstaaten, 2 Bde., Berlin I 903, Friedrich Salomo Krauss, „Erotik und Skatologie im Zauberbann und Bannspruch «, Anthropophyteia 8 ( ( 907) I60-226, ders., "Nacktheitszauber«, ibid. 6 ( I 909) 206-2 I I, Tatomir P. Vukanović, »Obscene Objects in Balkan Religion and Magic«, Folklore 92 (I98I) 43-53. Zu weiterer Literatur siehe Paul Wolters, "Faden und Knoten als Amulett«, Archiv für Religionswissenschaft 8

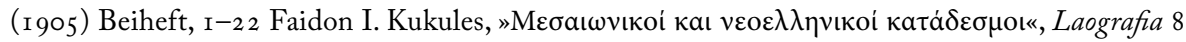

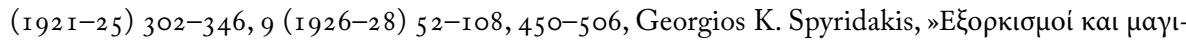

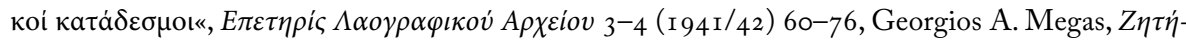

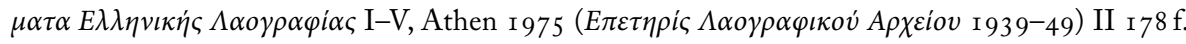
(ein Faden von der Länge des Toten oder seine Nägel und Haare werden versteckt, Charos wird durch ein Tuch ans Stiegengeländer gebunden, Nägeleinschlagen in die Erde, usw.). Vgl. auch Christine Shojaei Kawan, »Klebezauber (AaTh 57 I)«, Enzyklopädie des Märchens 7 (1993) I4 I 7-I 425. 
$\mu a)^{78}$. Der Glaube an die Bedeutung und magische Kraft von Zahlen (gerade und ungerade, 3, 7, I 2, 40 usw., I 3 als unglückbringend) ist auch heute weiterhin lebendig ${ }^{79}$.

Dieses magische Wissen wird von einer Schrifttradition gespeist, das in meist handschriftlicher Form bedeutendes Alter aufweist, auf die ägyptisch-griechischen Zauberpapyri zurückgeht ${ }^{80}$ und vom hellenistischen Synkretismus seinen Ausgang nehmend, über Byzanz, die arabische Welt und den Westen in medizinischem, astrologischem, alchemistischem, prophetischem, orakelhaftem (Traumdeutung) und anderem Schriftgut der Neuzeit übermittelt wird, wobei der südosteuropäische Traditionsstrang auf Byzanz und die arabisch/osmanischen Quellen zurückgreift ${ }^{81}$, vielfach aber angereichert durch

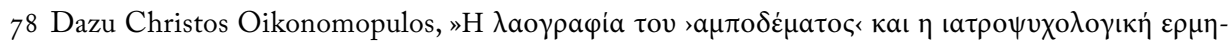

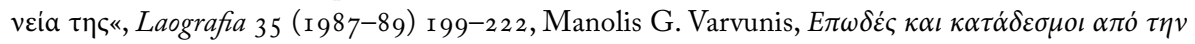

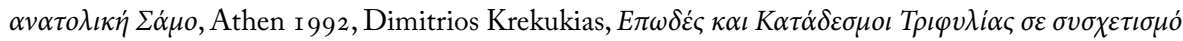

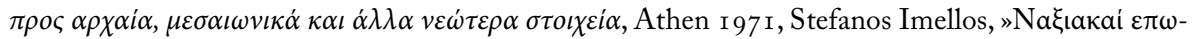

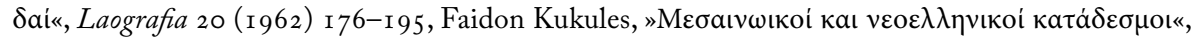

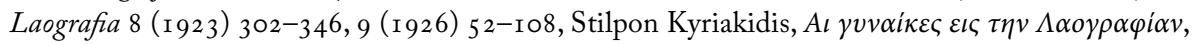
Athen $1920,108-148$.

79 Erich Bischoff, Die Mystik und Magie der Zablen, Berlin I920, Franz C. Endres/Annemarie Schimmel, Das Mysterium der Zabl. Zablensymbolik im Kulturvergleich, München ${ }^{4}$ I 988, Stilpon Kyriakidis,

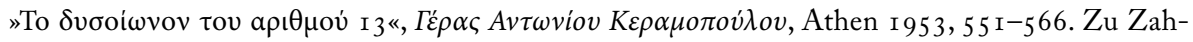
lenquadraten auch Hans A. Winkler, Siegel und Charakter in der muhammedanischen Zauberei, Berlin I930.

80 Fritz Graf, La magie dans l'antiquité gréco-romaine, Paris I 994, Theodor Hopfner, »OrientalischReligionsgeschichtliches aus den griechischen Zauberpapyri Aegyptens«, Archiv Orientâlni 3 (Praha I93 I) I I 9 - I 55, 327-358, ders., »Der religionsgeschichtliche Gehalt des demotischen Zauberpapyrus«, ibid. VII (1935) 89-I 20, Karl Preisendanz (ed.), Papyri graecae magicae. Die griechischen Zauberpapyri, 3 Bde., Stuttgart I 973, Carl Wessely, "Griechische Zauberpapyri von Paris und London «, Denkschriften der phil.-hist. Cl. der kaiserl. Akad. d. Wiss. in Wien 36 (г888) 27-1 5 I, ders., "Neue

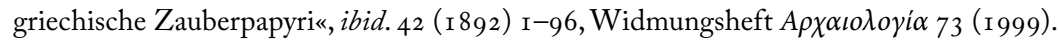

8I Dazu hat die Byzantinistik enormes Material zusammengetragen. Vgl. in Auswahl: Henry Maguire (ed.), Byzantine Magic, Washington D. C. 1995 (R. Greenfield, »A contribution to the study of Paleologican Magic«, I I 7-I 53), E. Riess, »Volkstümliches bei Artemidoros«, Rheinisches Museum 45 (I 894) I 77-I93, Umberto Benigni, »Una formula magica bizantina«, Bessarione 2 (I 897) 374-388, S. Pétridès, »Une formule magique byzantine«, Revue de l'orient chrétien 5 ( ( 900) 597-604, Dorothy de Abrahamse, "Magic and Sorcery in the hagiography of the middle byzantine period «, Byzantinische Forschungen 8 ( 1982 ) 3-17, Spyros N. Troianos, »Zauberei und Giftmischerei in mittelbyzantinischer Zeit«, Günter Prinzing/Dieter Simon (eds.), Fest und Alltag in Byzanz, München I 991, 37-52, J. Duffy, »Reactions of two Byzantine intellectuals to the theory and practice of Magic: Michael Psellos and Michael Italikos«, Henry Maguire (ed.), Byzantine Magic, Washington D. C. 1995, 83-97 (M. T. Fögen, »Balsamon on Magic: From Roman Secular Law to Byzantine Canon Law«, ibid. 99-I I 5), usw. 
den westlichen Traditionsstrang ${ }^{82}$. Neuere Textforschungen und archäologische Funde ${ }^{83}$ haben die einschlägige Bibliographie anschwellen lassen und bilden ein unabweisliches Indiz dafür, daß sich auf diesem Gebiet in Schrift- und Oraltradition, Elite- und Volkskultur in einer bedeutenden Langzeitkontinuität z.T. frappante Entsprechungen erhalten haben, die dafür plädieren, daß die Hilfsmittel der Magie mit ihren Techniken und Strategien zu den eher konstanten Kulturelementen des Alten Kontinents zäh$\operatorname{len}^{84}$. Sie leben denn auch in der Gegenwart in Form von Okkultismus, Apokryphik, Weissagungen des Mediums usw. ungebrochen fort ${ }^{85}$. Die assoziative Natur der Analogiebildungen führt zu immer neuen Möglichkeiten einer kreativen Vernetzung der Erscheinungen und kann selbst der unschuldigsten Alltagshandlung magisch-gefährliche Dimensionen verleihen ${ }^{86}$.

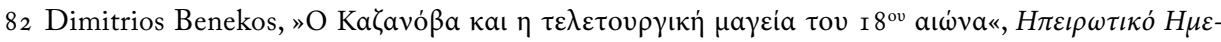

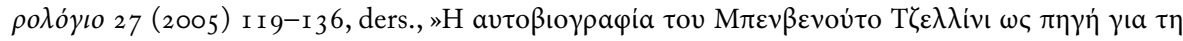

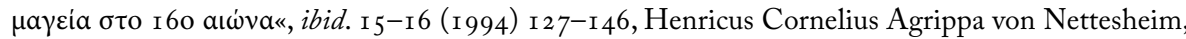
De occulta philosophia libri tres, s. 1. I 533, Bartholomaeus Anhorn, Magiologia, Basel I674, Johannes Bodin, De daemonomania magorum, Strassburg I591, Caesar Longinus, Trinum magicum (Tractatus Magicus), Francofurti r6 6 usw.

${ }_{3} \mathrm{Zu}$ den Inschriften in Auswahl: Armand Delatte (ed.), Anecdota Atheniensia I, Liège/Paris ${ }_{92} 7$, ders., »Un nouveau témoin de la littérature solomonique, le codex Gennadianus 45 d'Athènes«, Bulletin de la Classe des Lettres et des Sciences Morales et Politiques de l'Académie Royale de Belgique, $5 \mathrm{e}$ série, XLV (1959) 280-32 I, S. Giannobile, Un dialogo tra l'arcangelo Michele e il demone Abyzou in un inscrizione esorcistica cipriota «, Mediterraneo Antico 7/2 (2004) 727-750, D. Frankfurter, NNarrating Power: The Theory and Practice of the Magic Historiola in Ritual Spells«, M. Meyer/P. Mirecki (eds.), Ancient Magic and Ritual Power, Leyden/New York/Cologne 1 995, 457-476.

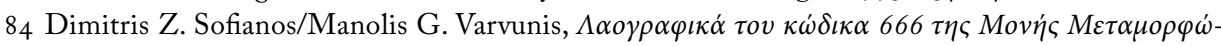

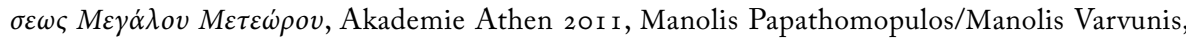

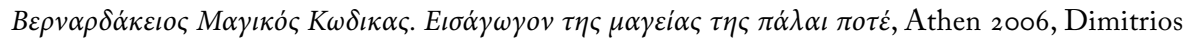

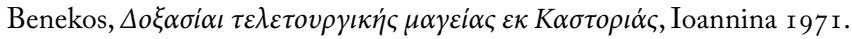

85 Dimitrios Benekos, »Magie und Okkultismus in der Industriegesellschaft«, Delphi ro/I (I 999) $28 \mathrm{ff}$.,

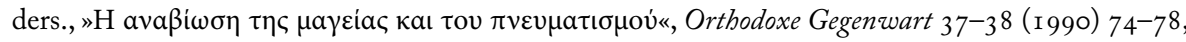

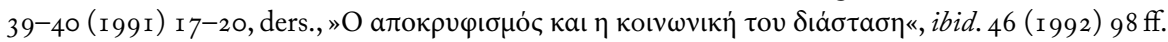

86 Dazu ein demonstratives Beispiel: In Adrianopel/Edirne vor der neuen Grenzziehung in den ersten Jahrzehnten des 20. Jh.s wurde einem Kunden beim Anpassen eines neuen Kleidungsstückes vom Schneider ein Eisenstück in den Mund gesteckt, solange er an dem angezogenen Kleidungsstück

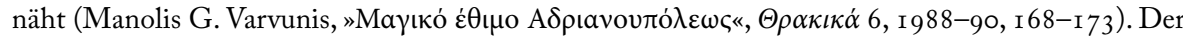
auf den ersten Blick unverständliche Zusammenhang steht jedoch in einem ganzen Netz von Entsprechungen. Die Eisenprophylaxe in Krisenmomenten in Amulettfunktion ist bekannt (z. B. bei

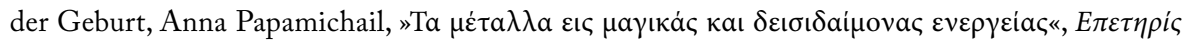

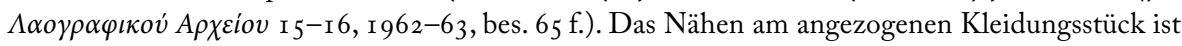
ein gefährlicher Moment, weil des Kunden Schicksal eingenäht werden kann (Laografia I 5, I 78 , 326); darüberhinaus bildet diese Phase eine Todesgefahr für den Nähenden (Ioannis Sp. Anagnosto- 


\section{$3 \cdot 4$ EKSTASE UND PROPHEZEIUNG}

Ekstase, Trance, Hypnose und Betäubung sind seit dem Altertum Voraussetzungen für das Orakelwesen und die Prophezeiungen ${ }^{87}$. Während des Pfingstrituals des Rosalienfestes der padalice bei den Aromunen in Duboka, im östlichen Bergland Serbiens, fallen die Frauen nach einem ekstatischen Tanz in einen Trancezustand (»Pfingstschlaf«), in dem sie die Zukunft prophezeien ${ }^{88}$. Solches hypnoseartiges Vorhersagen ist auch im

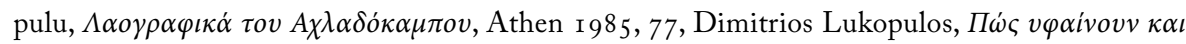

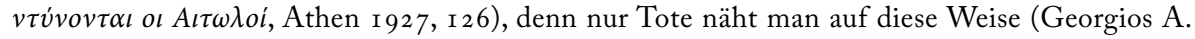

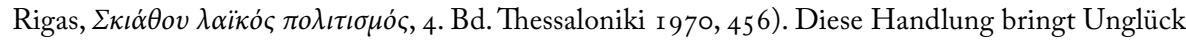
(Unglück, schlechtes Gedächtnis, Vergessen geliebter Personen usw., siehe Nikolaos I. Lyberis, $\Lambda \alpha o-$

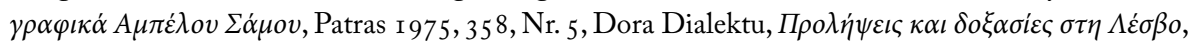

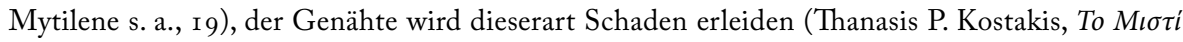

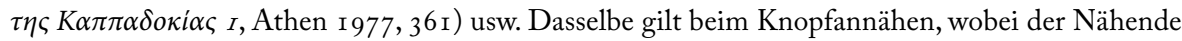

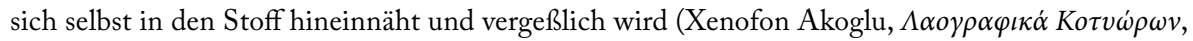
Athen 1939, 334). Dieser weit verbreitete Glaube basiert auf zwei Vorstellungen: I) das magische Einnähen von Glück, geistigen Fähigkeiten usw., 2) das Einnähen der Lebenskraft durch Binden,

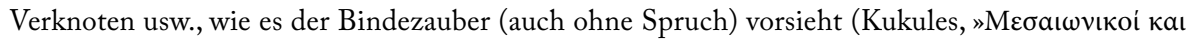

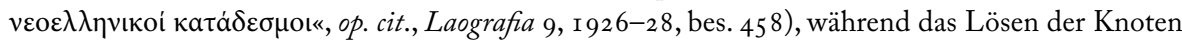
die Zielerreichung erleichtert. Nähen ist ein magischer Akt, Eisen gilt als Apotropäum (Leopold Schmidt, Heiliges Blei in Amuletten, Votiven und anderen Gegenständen des Volksglaubens in Europa und im Orient, Wien 1958, I4 f.). Diese Vorstellung von der Bindekraft des Knotens wird in der Volksmetaphysik auch in der schwarzen Magie angewandt: Ein rotes Seil mit Knöpfen bindet die Lebenskraft (Sergis, $\Delta \iota \alpha \beta \alpha \tau \dot{\rho} \rho \iota \varepsilon \varsigma \tau \varepsilon \lambda \varepsilon \tau o v \rho \gamma i \varepsilon \varsigma, ~ o p . ~ c i t ., ~ 53,234)$; mit derselben »Logik« kann man auch Verwünschung an ein Kleid annähen, oder Erde von Fußstapfen des Verfluchten als Schlamm in den Kamin schmieren: "wie das Feuer brennt, sollst auch du verbrennen« (Elpiniki Stamuli-

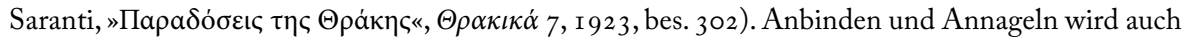
im Liebeszauber verwendet: So wird z.B. eine Fledermaus 40 Tage an die Tür genagelt (Kallisthenis

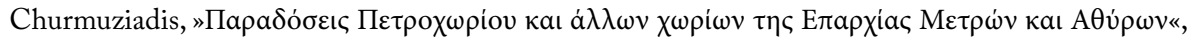

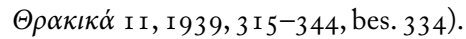

87 Die enorme Liteatur dazu sei hier übergangen. Vgl. Jürgen Beyer, »Prophezeiungen«, Enzyklopädie des Märchens Io (2000) I 4 I 9-I 432 mit weiterer Literatur (auch Rolf-Wilhelm Brednich, „Wahrsagen«, ibid. I 4, 20I I , 422-426).

88 »Überall wo die Rosalien vom Geist befallen werden, reden sie in Zungen. Die Menge lauscht andächtig ihren Äußerungen, da der Glaube allgemein ist, daß die Rosalien in die Zukunft schauen können. Ihre Äußerungen sind bald Schreien, bald Stammeln und Winseln, bald Hauchen. Nach einer Zeit konvulsivischen Ringens befällt sie eine Lähmung, die dann wieder durch Abwehr und Kraftausbrüche unterbrochen ist (Gustav A. Küppers, »Rosalienfest und Trancetänze in Duboka. Pfingstbräuche im ostserbischen Bergland «, Zeitschrift für Ethnologie 79, I 954, 2 I 2-224, bes. 223).

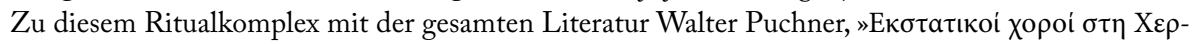

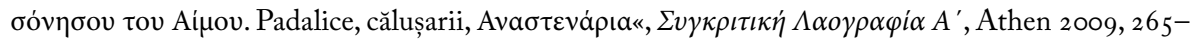
324, bes. 274-279. Vergleichend Dragoslav Antonijević, Ritualni trans, Beograd 1990 und Alois 
Kreis Timok und Krajina nachgewiesen sowie auch eine Magierin im Dorf Volenia, die zu allen hohen Festen in Trance verfällt und den Leuten ihr Schicksal prophezeit, Krankheiten vorhersieht, mit den Toten spricht und Heilkräuter verteilt ${ }^{89}$. Hier sind nun die Übergänge zum Professionalismus des Prophezeiens in Ekstase gegeben, wie dem ungarischen táltos, der auch mit Resten des Schamanismus in Zusammenhang gebracht worden ist, dem Schwarzkünstler und Totenbeschwörer garabonciás, den Hexe(r)n boszorkány, wissenden Hirten (túdos pasztor), Geisterseherinnen, Wahrsagern usw., die die ungarischen Glaubensvorstellungen parareligiöser Art bevölkern ${ }^{90}$. Prophezeiungen in Ekstasezustand sind jedoch auch bei den Feuertretern der anastenaria/nestinari in Thrakien und später in Makedonien (Agia Eleni im Raum Serres) nachgewiesen ${ }^{91}$. Professionelle Formen dieser Tätigkeit gibt es in Bulgarien und anderswo heute noch ${ }^{92}$.

Closs, »Südosteuropa als ethnologisches Untersuchungsfeld über ekstatisches Brauchtum«, Wiener Ethnohistorische Blätter 3 ( I 97 I) 3-22. Vgl. auch Cristea Sandu, »Les >Princesses` (craitzélé), culte païen d'origine dace, chez les Roumains (Valaques) de Serbie de N-E et de Bulgarie de N-O«, $M a-$ kedonski Folklor 6/I 2 (I973) 8 I-85 (Balcanica 5, I974, 33 I-336).

89 Tihomir Georgevici, Printre românii nostri. Note de călătorie, Bd. III, București I 943, 25-1 47, bes. 99. Zum Übergang von Hexenvorstellungen und Schadenszauber zur Heilkunde in den Händen der "wissenden Frauen« vgl. Walther Schönfeld, Frauen in der abendländischen Heilkunde vom klassischen Altertum bis zum Ausgang des 19. Jahrhunderts, Stuttgart I 947, Fritz M. Engel, ZauberpflanzenPfanzenzauber, Hannover 1978, Thomas R. Forbes, The Midwife and the Witch, New Haven/London I 966, W. D. Hand, Magical Medicine, Berkeley etc. I 980, Elfriede Moser-Rath, „Frau«, Enzyklopädie des Märchens 5 (1987) 100-I37, Rudolf Schenda, „Volksmedizin - was ist das heute?«, Zeitschrift für Volkskunde 69 (1973) I 89-2 Iо, usw.

90 Balassa/Ortutay, Ungarische Volkskunde, op. cit., 7 I 5-734. Der táltos muß zu seinen Prophezeiungen in Ekstase auf den Himmelsbaum klettern, seine Requisiten sind Hörner und Sieb (szita); in Tierverwandlung führt er auch Zweikämpfe mit anderen táltos aus (als Stier, Hengst, Feuerrad usw.). Dies ist mit bekannten schamanistischen Praktiken in Zusammenhang gebracht worden (Vilmos Diószegi, $A$ sámánhit emlékei a magyar népi múveltségben, Budapest 1958 , ders., „Die Überreste des Schamanismus in der ungarischen Volkskultur«, Acta Ethnographica Academiae Scientiarum Hungaricae 7, I 955, 97-I 35). Das Wahrsagen übt auch der garabonciás (von gramanzia, Nekromantik) aus, der/die boszorkány (auch baba genannt), mit Gegenspieler den túdos pasztor (wissender Hirt, auch Kutscher) usw. Zum ungarischen Hexenglauben auch V. Klein, »Der ungarische Hexenglaube«, Zeitschrift für Ethnologie 66 ( 1934) 374-402, Ákos Szendrey, "Hexen - Hexendruck «, Acta Ethnographica Academiae Scientiarum Hungaricae 4 (1955) I 29-I68 (schuld an Kleinkinderkrankheiten), Tekla Dömötör, »Die Hebamme als Hexe«, Lutz Röhrich (ed.), Probleme der Sagenforschung, Freiburg I 973, I 77-I 89, Éva Pócs, Fairies and Witches at the Boundary of South-Eastern and Central Europe, Helsinki 1989 (FFC 243).

91 Puchner, Brauchtumserscheinungen, op. cit., I75 (mit den Nachweisen). Vgl. auch Loring Danforth, The Anastenaria: A study in Ritual Greek Therapy, Princeton 1978.

92 Galina Vălčinova, Balkanski jasnovidki i proročici ot 20 vek, Sofija 2006, Ekaterina I. Anastasova/Irina Sedakova, »Across Boundaries: the Prophet Zor Alef, a Case of Transnational Mysticism«, Galina 
Daneben gibt es jedoch auch einen schriftlichen Traditionsstrang der Prophezeiungen als Nebenzweig der Prodigienliteratur ${ }^{93}$, die in Form von prognostischen Kalendarien bereits in byzantinischer Zeit bedeutende Verbreitung genossen hat ${ }^{94}$. Diese astrologische Kalenderliteratur hatte z.T. auch bedeutenden Einfluß auf die orale Tradition $^{95}$ und ist im christlichen wie im islamischen Bereich Südosteuropas gleichermaßen verbreitet ${ }^{96}$. Solche Prophezeiungen befinden sich in einer großen Anzahl von "Kleinchroniken« als Randnotizen oder eingeschobene Scholien in byzantinischen und nachbyzantinischer Handschriften jeglicher $\mathrm{Art}^{97}$.

Valtchinova (ed.), Region and Boundaries. Studies from the Balkans, Eastern Europe and Turkey, Istanbul 20Io, 33 I-349, Galina Vălčinova, »Constructing the Bulgarian Pythia: Intersecting religion, memory and history in the seer Vanga«, D. Kaneff/Fr. Pine/H. Haukanes (eds.). Memory, Politics and Religion: The Past Meets the Present in Contemporary Europe, Berlin/Wien 2004, I79-198.

$93 \mathrm{Zu}$ den Prodigien zählen Zeichen, Mirakel, Divinationen, Erscheinungen von Monstren, ungewöhnliche Ereignisse, Prophezeiungen, Kometen, Unwetter, Feuerbrände usw. (Jürgen Beyer, »Prodigien«, Enzyklopädie des Märchens Iо, 2000, I 378-1 388, Rudolf Schenda, „Wunderzeichen. Die alten Prodigien in neuen Gewändern. Eine Studie zur Geschichte eines Denkmusters«, Fabula 38, 1997, I4-32).

94 Dazu in Auswahl: Charles Gidel/Émile Legrand, Les oracles de l'empereur Léon le sage, expliqués, interprétés en grec vulgaire au XIIIe siècle et publiés pour la première fois d'après les manuscrits de la Bibliothèque nationale«, Annuaire 8 (I 884) I 50-1 92, Hans Eideneier, »Ein byzantinisches Ka-

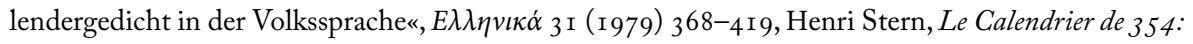
Étude sur son texte et ses illustrations, Paris I 953, Hans-Georg Beck, Vorbersehung und Vorherbestimmung in der theologischen Literatur der Byzantiner, Rom 1937, 65-84, zur Vorhersage von Kriegen: Utto Riedinger, Die Heilige Schrift im Kampf der griechischen Kirche gegen die Astrologie, Innsbruck 1956, 25-32; weiters: David Pingree, "Historical Horoscopes«, Journal of the American Oriental Society 82 ( 1962 ) 487-502, ders., "Gregory Chioniades and Palaiologan Astronomy«, Dumbarton Oaks Papers I 8 (1964) I 33-I60, ders., "The Astrological School of John Abramios«, ibid. 25 (I97 I)

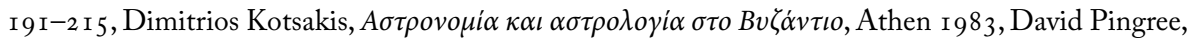
"Political horoscopes from the reign of Zeno«, Dumbarton Oaks Papers 30 (I 976) I 33-1 50, Giannis

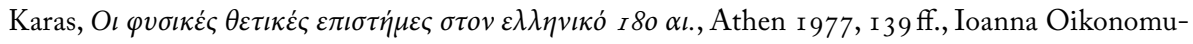

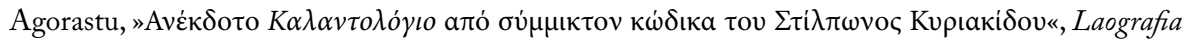
33 (1982-84) 247-256, usw.

95 Z.B. aus dem Munde von Volkspredigern, Asketen und respektierten lokalen »Alternativ«-Heiligen

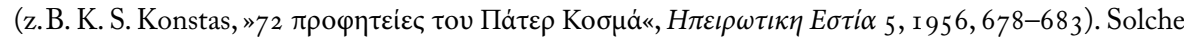
Prophezeiungen von Athos-Mönchen finden sich auch in den Tageszeitungen und im Internet.

96 Greville S. P. Freeman-Grenville, The islamic and christian Calendars, London 1995, Y. Dağli/C. Üçer, Tarih Chevirme Kilavuzu 3, Ankara 1997.

97 Dazu vor allem Peter Schreiner, Die byzantinischen Kleinchroniken, 3 Bde., Wien 1975-79. 


\subsection{MANTIK UND ORAKEL}

Die tagtägliche Begegnung und der Umgang mit dem Unbekannten und Ungewissen hat zu vermeintlich erfolgreichen Techniken im Erkennen des Uneinsichtigen geführt, die sich in der Vielfalt der Formen der Mantik manifestieren und praktisch in allen Kulturen anzutreffen sind. Unter systematischen Gesichtspunkten kann man die divinatio naturalis von der divinatio artificialis unterscheiden ${ }^{98}$. $\mathrm{Zu}$ ersterer zählen Physiognomik und Körperbeschaffenheit ${ }^{99}$, »bedeutende « akustische, optische und aktionelle Zeichen der Umwelt ${ }^{100}$, Begegnungen und Omen ${ }^{101}$, zufällige Begebenheiten, Fehlge-

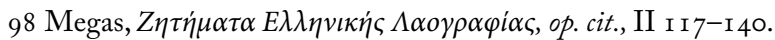

$99 \mathrm{Als}$ Interpretationkriterien gelten Muttermale, Augenform, Ohren (große - langlebig), Zähne (dichte - arm, weit auseinander - reich, oder Lügner auf Kreta), Stirn (große - faul wie ein Ochse, klein - Schwein, Epirus), Kopfform, Haar (rot und blaue Augen - diabolisch), Brauen, Körperbehaarung (dicht - gut, keine - böse), Handflächenlinien, Finger (nach außen gebogen - gebefreudig, nach innen - Geizhals), weiße Flecken auf Nägeln bedeuten Glück oder das Gegenteil, Gezeichnete (Bukkel, hinkend, dünnbärtig/bartlos, Krätze usw.), hervorstehendes Auge (links - schlecht, rechts - gut). Bedeutend sich auch Körperreaktionen wie Ohrensausen, Kratzen an Handfl̈̈chen, Nase, Wange, Hals, Rücken usw., Niesen (Wunsch, bei Begräbnis bringt Tod, zu Ostern - Krankheit), Schluckauf, Lachen. ıо Zu solchen Zeichen zählen z.B. ungewohnte Geräusche (Knarren des Daches, des Fußbodens, der Wände usw., was Übel oder Todesfall anzeigt), ähnlich das Zerspringen des Spiegels oder Glas, unabsichtliches Verschütten und Verstreuen (Wein, Öl, Salz), Stolpern, der Sturz vom Pferd, das Sich-auf-die-Zunge-Beißen, aufgebahrter Toter (hat er die Auge offen, so stirbt anderer), Brot läßt sich nicht backen (Todesfall) usw. Bei der Ikonenmantik ist es das Knacksen des Holzes, ihr Fall vom templum, das Vergießen des Öls aus dem Lampe, »Weinen« der Ikone usw., bei der Pyromantie das Knacken des brennenden Holzes, der Funkenregen bringt Geld, das Aufflammen gilt als Warnsignal, aufsteigender Rauch wird als gutes Omen interpretiert (vgl. für Thrakien Dimitrios V.

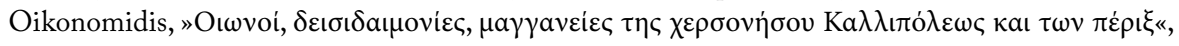

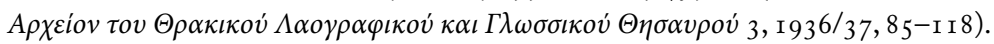

Iо I Als schlechte Begegnungen gelten Priester oder schwarze Witwen, glückbringend ist der Eintritt des ersten Besuchers (zu Neujahr, Monatsanfang usw.) über die Schwelle mit dem rechten Fuß (podariko), ambivalent der Beginn einer neuen Arbeit (cheriko); manche Personen gelten als Glücks-

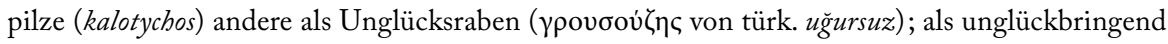
gelten ebenso Begegnungen mit Hasen, schwarzen Katzen, Schlangen nach Sonnenuntergang usw., im Gegensatz dazu befindet sich das Finden von Ring, Nadel, Huf usw. Als Omen gilt auch der Vogelruf: mit unterschiedlichen Bedeutungen Rabe, Krähe, der Einzug der Störche, Kuckuck, Eule, Turteltaube, Schwalbe, Hahnkrähen, Taube usw. Manche Vögel werden auch Totenvögel genannt, weil ihre Rufe einen Todesfall prophezeien. Solche Vorzeichen kann auch das Verhalten von Tieren, Haustieren und Insekten abgeben: Hund, Katze, Maus, Pferd/Maultier/Ochse, Schaf/Ziege, Schwein, Wolf/Fuchs/Schakal, Eidechse, Ameisen, Spinne, Biene/Wespe, Bremse, Käfer/Frauen-

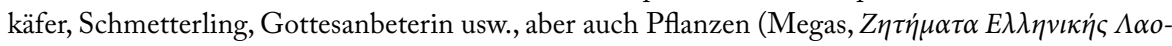

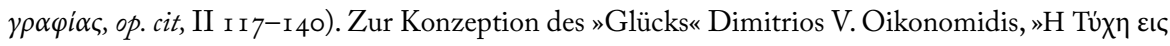

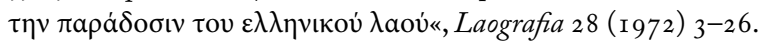


burten, Alpträume, Himmels- und Wetterzeichen usw. ${ }^{102}$ Im Weltbild des Animismus kann der gesamte Lebensraum in einer universalen Vernetzung von Dingen, Geschehnissen und (Vor)Bedeutungen mit exklusiv anthropozentrischer Fokussierung zum Omen werden. Zu den künstlich hervorgerufenen Divinationen ${ }^{103}$ zählen astrologische Horoskope $^{104}$, Eingeweideschau, Schulterblattorake ${ }^{105}$, Pyromantie ${ }^{106}$, klidonas $(\mathrm{Ob}-$ jekt-Ziehen aus bedecktem Krug mit Begleitliedern) ${ }^{107}$, Ei-Orakel, Bleigießen, Wachsorakel, Wasserorakel und Lekanomantie ${ }^{108}$, Aschen-, Mehl-, Sieb- und Ölorakel ${ }^{109}$,

I02 Z.B. das Brunnenorakel auf der Insel Amorgos. Dazu R. Hühnerkopf, Brunnen«, Handwörterbuch des Deutschen Aberglaubens I ( 1927) I672-85. Zu den Tierorakeln siehe auch Rainer Alsheimer, „Orakel«, Enzyklopädie des Märchens Iо (2000) 309-3 I2, L. Hopf, Thierorakel und Orakelthiere in alter und neuer Zeit, Stuttgart I 888, usw.

I03 Christoph Daxelmüller, »Divination«, Enzyklopädie des Märchens 3 (1981) 718-727; in zeitperspektivischer Hinsicht wird hier die auf die Vergangenheit gerichtete Retrokognition, von der gegenwärtigen Kryptoskopie bzw. dem Hellsehen unterschieden, während die Zukunft die Präkognition betrifft; bezüglich der Techniken ist eine induktive (künstlich herbeigeführte) Divination von einer intuitiven (durch Naturbeobachtung vollzogene) zu unterscheiden. Vgl. in Auswahl: William R. Halliday, Greek Divination. A Study of Its Methods and Principles, Oxford I 9 I 3 (Chicago 1968), Wilhelm Gundel, Sternglaube, Sternreligion und Sternorakel, Heidelberg 1959, Will-Erich Peuckert, Geschichte der Seherwissenschaften. I: Astrologie, Stuttgart I 960, Elfriede Moser-Rath, »Astrologie«, Enzyklopädie des Märchens I ( 1977) 928-93 I.

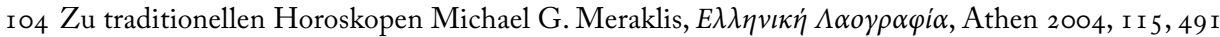

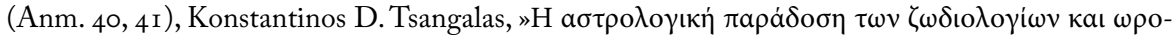

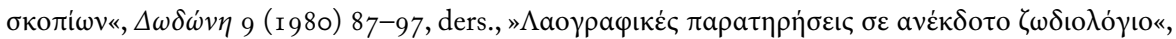

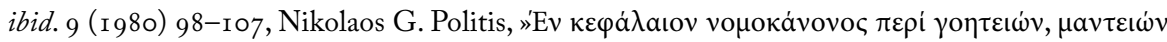

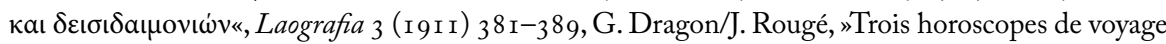
en mer", Revue des Études Byzantines 40 ( 1982 ) i I 7 - 133 usw.

I05 Georg Eckert/Araia Cuschan, Das Schulterblattorakel bei den Aromunen, Thessaloniki 1944, Geor-

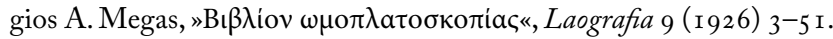

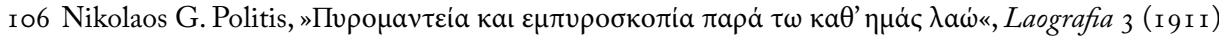
345-357. Z.B. werden Gerstenkörner ins Feuer geworfen und an ihrem Knall wird die Zukunft intepretiert.

I07 $\mathrm{Zu}$ dem in Südosteuropa und Kleinasien verbreiteten Sonnwendbrauch vgl. die Bibliographie in Puchner, Studien zur Volkskunde Südosteuropas, op. cit., $88 \mathrm{f}$.

I08 Fritz Boehm, »Lekanomantie«, Handwörterbuch des Deutschen Aberglaubens V (1932/33) I 205I 208, ders., "Hydromantie« ibid. IV (193 I/32) 548-574 (Realenzyklopäide der Altertumswissenschaften IX/I, I9I4, 79-86), Richard Ganschinietz, « François Cunen, La lécanomancie grecque, diss. Univ. de Liège 1950/5 r. Z.B. wird an einem dunklen Platz im Haus in ein Wasserschaff geschaut mit roten Tuch am Kopf (Papathanasi-Musiopulu, op. cit., I I 89 f.).

Io9 Theodor Hopfner, »Mittel- und Neugriechische Lekano-Lychno-Katoptro- und Onychomantien«, Studies presented to F. L. Griffith, London I 932, 2 I 8-232. 
Kaffeesud-Lesen ${ }^{110}$, Kartenaufschlagen, Spiegelorakel ${ }^{111}$, Ringorakel, Traummantik ${ }^{112}$, Gurkenschau, Blatt- und Blütenlesen, Brotorakel, Hahnenruf, Bild- und Schattenorakel $^{113}$, Nußorakel, Wünschelrutengehen ${ }^{114}$, Weizensäen, Psalterorakel ${ }^{115}$ usw. $^{116}$ Die Anleitungen und Interpretationsschemata dieser Orakeltechniken haben bereits im by-

I I $\mathrm{Zu}$ ähnlichen Praktiken schon in frühen Hochkulturen Johannes Hunger, Becherwabrsagung bei den Babyloniern. Nach zwei Keilschrifttexten aus der Hammurabi-Zeit, Leipzig 1903.

I I I Armand Delatte, La catoptromancie grecque et ses dérivés, Liège I932, Fritz Boehm, "Katoptromantie «, Handwörterbuch des Deutschen Aberglaubens IV (193 I/32) I099-1 107, L. Bieler, »Spiegel«, ibid. IX (1 938/4I) 547-577, E. Bälz, „Die sogenannten magischen Spiegel und ihr Gebrauch«,

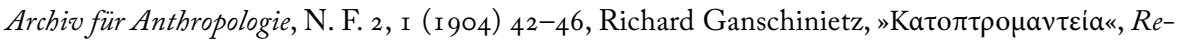
alenzyklopädie der Altertumswiss. XI/I (I 92 I) 27-29, H. Carrington Bolton, »A Modern Oracle and its Prototypes. A study in Catoptromancy", Journal of American Folk-Lore 6 (I893) 25-37, Karl Haberland, „Der Spiegel im Glauben und Brauch der Völker«, Zeitschrift für Völkerpsychologie und Sprachwissenschaft I 3 (I 882) 324-347, Géza Róheim, Spiegelzauber, Leipzig/Wien I 9 I 9, Herbert Silberer, "Zur Charakteristik des lekanomantischen Schauens", Zentralblatt für Psychoanalyse 3 (I 9 I 2) 73-98, ders., »Lekanomantische Versuche«, ibid. 2 (I 9 I I) 383-45 I, 5 I 8-53 I, 566-588, ders., "Mantik und Psychoanalyse«, ibid. 2 ( ( 9 I I ) $78-83$ usw.

I 2 Die Orakelträume der Mädchen (H1. Johannes 24. 6. und zu anderen Terminen) werden artifiziell hervorgerufen: durch den Verzehr von Salzkringel (künftiger Bräutigam gibt dem Mädchen im Schlaf zu trinken), Faschingsspaghetti (Käsewoche), den ersten Bissen von der vasilopitta, kollyba an einem Seelensamstag, durch Anrufung des Schicksals (moira), das Legen verschiedener Gegenstände unter den Kopfpolster, das Aussäen von Weizenkörnern oder kollyba, das Anbinden eines

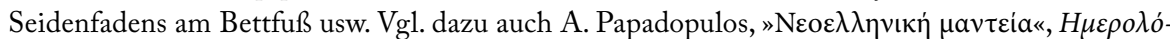

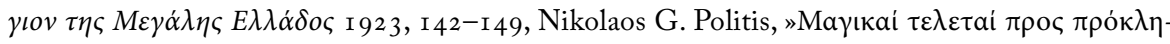

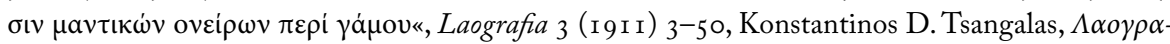

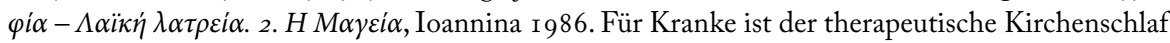
(Übernachten in der Kirche) mit seinen Heilträumen vorgesehen.

I 3 Julius von Negelein, »Bild, Spiegel und Schatten im Volksglauben«, Archiv für Religionswiss. 4 (I902) I -37 .

I 44 Hubert Knoblauch, „Vom Wünschelrutengehen zur Radiästhesie. Die Modernisierung der Magie«, Jahrbuch für Volkskunde I 9 (I 996) 22 I-240.

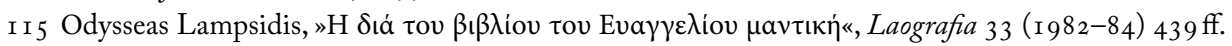
(zufälliges Aufschlagen einer Seite, erstes Wort).

I 6 Dazu auch Dimitrios S. Lukatos, Eı $\alpha \gamma \omega \gamma \eta \dot{\eta} \sigma \tau \eta v \varepsilon \lambda \lambda \eta v \iota k \eta \dot{~} \lambda \alpha o \gamma \rho \alpha \varphi$ í $\alpha$, Athen I977, 243-246 (fügt auch die psychische Mantik hinzu:Traum, Vorgefühl, Vorahnung, Visionen, Telepathie), Georgios

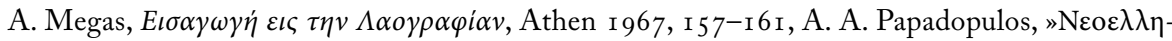

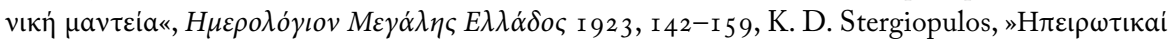

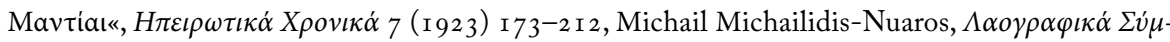

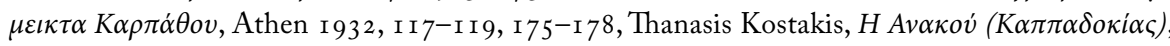

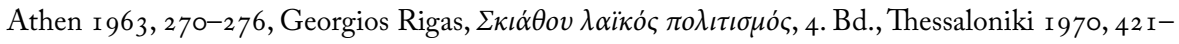
436, Alekos Florakis, Tívos, Athen I 97 I, 269-276, usw. 
zantinischen Schrifttum erstaunliches Ausmaß angenommen ${ }^{117}$, sind im allgemeinen aber wesentlich älteren Ursprungs ${ }^{118}$.

Eine besondere Stellung nimmt die Traumdeutung bis heute ein ${ }^{119}$, verbreitet im gesamten Ost- und Südosteuropa ${ }^{120}$, die in den oneirokritika-Anleitungen auch eine

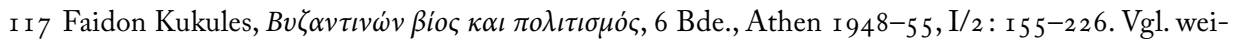
ters indizierend Herbert Hunger, Die hochsprachliche profane Literatur der Byzantiner, 2 Bde., München 1978, 22 I-260, Hans-Georg Beck, Geschichte der byzantinischen Volksliteratur, München I 97 I, 203 .

I 8 Z.B. Angelicus M. Kropp, Ausgerwäblte koptische Zaubertexte, 3 Bde., Bruxelles I930/3 I, Samson Eitrem, Orakel und Mysterien am Ausgang der Antike, Zürich 1947, Theodor Hopfner, „Die Kindermedien in den griechisch-ägyptischen Zauberpapyri«, Recueil d'études dédiées à la mémoire de Nikodim Pavlovic Kondakov, Prag 1926, 65-74.

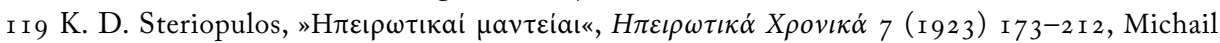

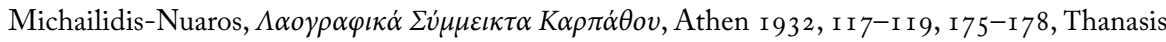

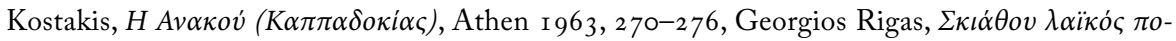

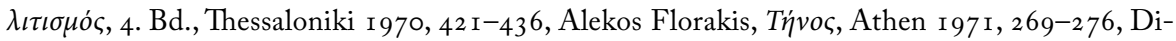

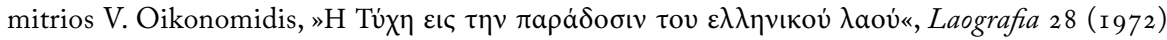

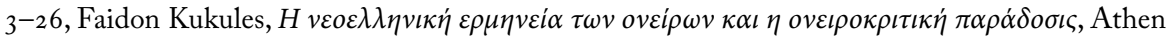

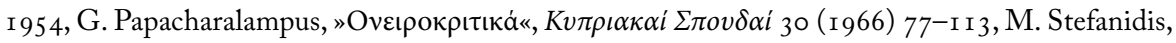

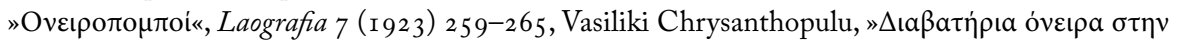

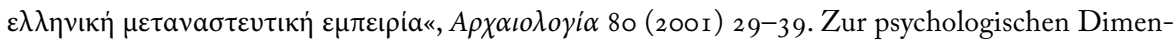
sion der Traumdeutung vgl. Iain Edgar, „Dream Imagery Becomes Social Experience: The Cultural Elucidation of Dream Interpretation«, S. Heald/A. Deluz (eds.), Anthropology and Psychoanalysis: An Encounter through Culture, London/New York 1994, 99-I I 3, ders., Dreamwork, Anthropology and the Caring Profession: A Cultural Approach to Dreamwork, Aldershot 1995, Maria E. WittmerBusch, Zur Bedeutung von Schlaf und Traum im Mittelalter, Krems I990, Wolfram Kurth, „Das Traumbuch des Artemidoros im Lichte der Freudschen Traumlehre«, Psyche 4 (I 95 I) 488-5 I 2, Roy G. d'Andrade, »The Effect of Culture on Dreams«, F. L. K. Hsu (ed.), Psychological Anthropology, Homewood I961, 308-332, S. G. M. Lee/A. R. Mayes (eds.), Dreams and Dreaming, Harmondsworth I973, I98-208, usw.

I 20 In Auswahl: Anatol Ančev, Dreams and folklore, Sofia I 995, ders., „Dreams in the folklore of the people from Bansko«, Bansko. Izsledvanija i materiali, Sofija I996, I 43-I69 (auch Bălgarski Folklor I 2/3, I 986, 62 ff., I 7/2, I 99 I , 42 ff.), T. Djakov, »The dream-interpretation on our traditional

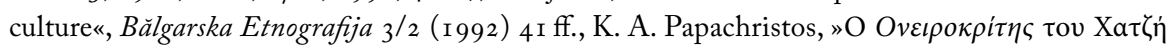
Гepaбinov (I 836)«, Laografia 34 ( I 985-86) 58-9 I, S. Bonsyak, »Mother should read it: notes on the people's interpretation of dreams", A Dunamenti népek hagyományes müveltsége, Budapest $199 \mathrm{I}$, 609 ff., J. Szabadfalvi, »Die Gestalt des `wissenden Imkers in der ungarischen Volksüberlieferung«, Ethnographica et Folkloristica Carpathica 7-8 (1992) 246-250; zu russischen Traumhandbüchern S. F. Karatov/G. P. Muravjova, Dreams and Fortunes, Moskva 1995, dies., The dreams and the fates. The fortune-telling and the sorcery on dreams, Moskva I996, J. Košelev, »The Smolensk's fortune tellings«, Kraj Smolenskij I I-I 2 ( I 996) 50-64, Annikki Kaivola-Bregenhoj, »Dreams as folklore«, Fabula 34 (I993) 2 I I-224, M. G. Grišina, The book of explanation of dreams. XVI-XX centuries, Moskva I 993 usw. Gesamteuropäisch Klaus Roth, »Traumbücher«, Enzyklopädie des Märchens I 3 (2010) 
bedeutende Schrifttradition seit der Antike besitzt ${ }^{121}$ und in Byzanz ${ }^{122}$ und im islamischen Bereich gleichermaßen verbreitet ist ${ }^{123}$. Der prophetische Traum wird auch durch verschiedene Techniken provoziert. Im Geflecht der Heiratsorakel der Mädchen nimmt die Trauminterpretation sogar eine dominante Position ein ${ }^{124}$. Ebenso signifikant sind

I0 I-I05, Felizitas Fuchs, Von der Zukunftsschau zum Seelenspiegel: Eine Studie zur Traumauffassung und Traumdeutung am Beispiel deutschsprachiger Traumbücher, Aachen 1987.

I 2 I Theodor Hopfner, »Traumdeutung", Realenzyklopädie der Altertumswissenschaften 6 (I 937) 2223-45, Roger A. Pack, Artemidori Daldiani Onirocriticon, Lipsiae 1963, D. del Corno, Graecorum de re oneirocritica scriptorum reliquiae, Milano 1968, C. Brillante, Studi sulla rappresentazione del sogno nella

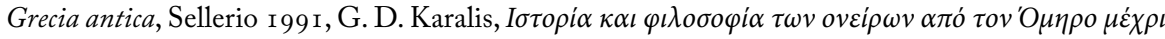

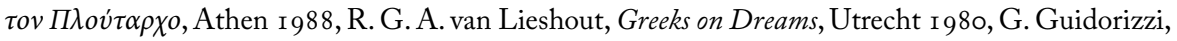
Pseudo-Niceforo. Libro dei sogni, Napoli 1980.

I 22 Steven M. Oberhelman, »Prolegomena to the Byzantine Oneirocritica«, Byzantion 50/2 (I 980) 487-503, ders., "The Interpretation of Dream-Symbols in Byzantine Oneirocritic Literature «, Byzantinoslavica 47 ( 1986 ) 8-24, ders., The Oneirocritic Literature of the Late Roman and Byzan-

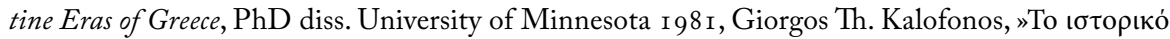

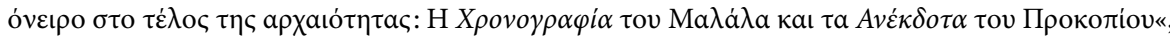

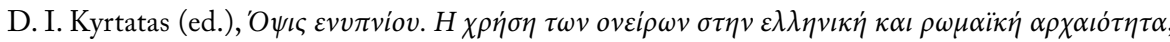
Heraklion I993, 283-322, ders., „Dream Interpretation: A Byzantinist Superstition?«, Byzantine and Modern Greek Studies 9 (1984-85) 21 5-220, Franz Drexl, »Das Traumbuch des Patriarchen Germanos", Laografia 7 ( 192 I-25) 428-448, usw.

I 23 Franz Drexl (ed.), Achmet, Oneirocriticon, Lipsiae I 925, ders., „Das anonyme Traumbuch des Cod. Par. gr. 25 I I «, Laografia 8 (1925) 346-375, ders., Achmetis Oneirocriticon, Lipsiae 1925, L. Massignon, »Thèmes archétypiques en onirocritique musulmane«, Eranos-Jahrbuch I 2 (I945) 24 I-25 I, Toufy Fahd, »Les songes et leur interprétation selon l'Islam«, Les songes et leur interprétation, Paris I 959, I 25-I 58, ders., »Le rêve dans la société islamique du Moyen age«, Roger Caillois/G. E. von Grunebaum (eds.), Le rêve et les sociétés humaines, Paris $1967,335-365$, dies., La divination arabe. Études religieuses, sociologiques et folkloristiques sur le milieu natif de l'Islam, Leiden I 966 (Paris 1987), Karl Brackertz (ed.), Das Traumbuch des Achmed ben Sirin, München 1986, Maria Mavroudi, The So-Called "Oneirocriticon of Achmet«: A Byzantine Book on Dream Interpretation and its Arabic Sources, PhD Diss. Harvard Univ. 1998.

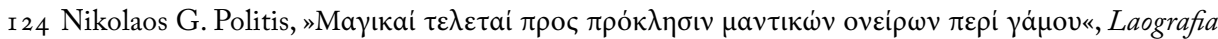
3 (I9I I) 3-50. Die üblichen Techniken des Heiratsorakeltraums sind das Salzkringelessen, das

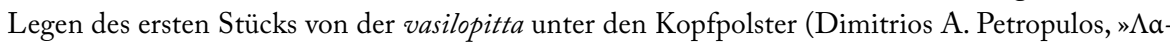

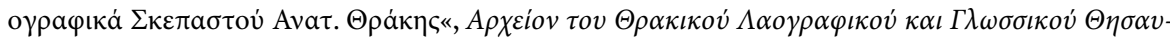

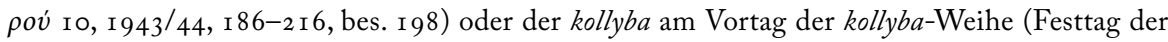
H1. Theodore, erster Seelensamstag der Fastenzeit, vgl. Politis, op. cit, I 35 ff., Anna Papamichail-

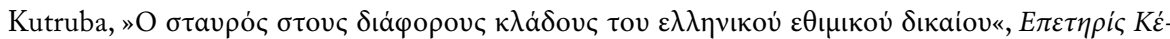

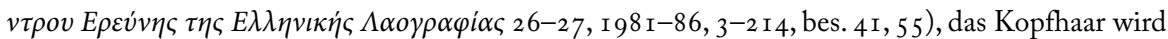
an einen Ring gebunden (wenn er sich bewegt, erfolgt die Verlobung rasch); ein Apfel wird rundherum abgeschält, die Schale in die Luft geworfen, aus der Form der Schale wird der Anfangsbuchstaben des Künftigen abgelesen (ebenso aus der Hautbildung am kollyba-Teig zu Weihnachten, aus der Hand gelesen usw.); Mädchen knüpfen im Mondlicht drei Knoten in ihr Kopftuch und 
auch die Zeichen der Voraussage von Sterbefällen ${ }^{125}$ bzw. die Techniken der Totenbeschwörung $^{126}$.

Das Bangen um den Ernteertrag ist zentrales Movens für die Wetterprognose und Bauernregeln der Volksmeteorologie ${ }^{127}$, die in einem System von vorausweisenden Zeichen wie Windrichtung, Regenfall, Regenbogen ${ }^{128}$, Erdbeben, Himmelskörper, Kometen, Mond- und Sonnenfinsternis usw. die Entwicklung des Lokalwetters vorherzusehen versuchen ${ }^{129}$. Auch auf diesem Sektor erfahren die Erfahrungswerte der lokale

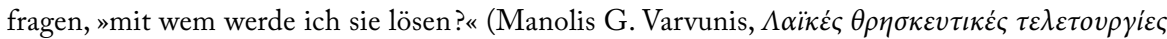

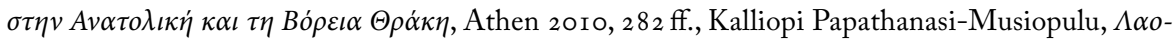

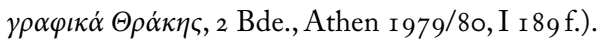

I 25 K. Jung, "Forecasting death and its omens in the traditions of the Hungarians in Yugoslavia«, Köznapok és legendák, Ujvidék I992, 70-77.

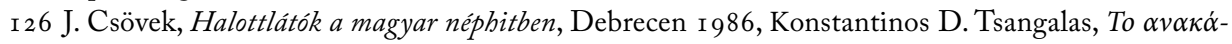

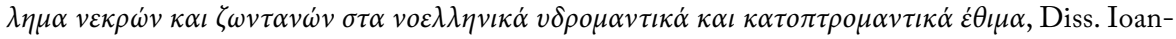
nina I 977. Allgemein: Lutz Röhrich, „Geist, Geister«, Enzyklopädie des Märchens 5 (I987) 909922, Gerda Grober-Glück, »Geistersichtig«, ibid. 939-944, K. Schmeling, Seher und Seherglaube, Darmstadt I 954, usw.

I 27 Dazu existierte eine enorme Regionalliteratur; in Auswahl aus dem hellenophonen Raum: Ch. P.

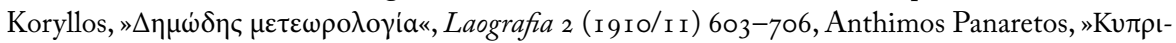

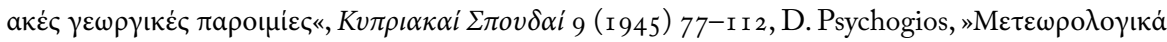

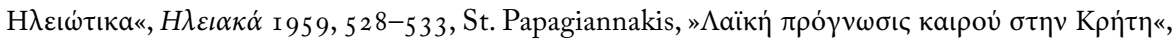

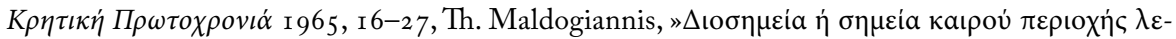

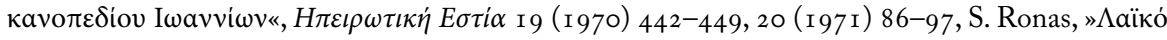

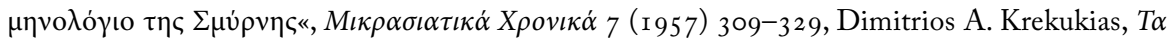

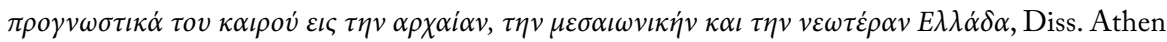
I 966 (Gli Uccelli nelle credenze e nelle tradizioni del popolo Greco e Siciliano, Atene 1970), usw. Allgemein: Jean Philippe Chassany, Dictionnaire de météorologie populaire, Paris I989, Horst Malberg, Bauern-Regeln. Ibre Deutung aus meteorologischer Sicht, Berlin I989, A. S. Ermolov, The popular weather knowledge, Moskva I995, Viera Gašparíkova, "Wettermacher «, Enzyklopädie des Märchens I 4 (201 I) 693-695, Ferdinand von Andrian, »Über Wetterzauberei«, Mitteilungen der Anthropologischen Gesellschaft in Wien 24 (1894) I-39, H. Berkusky, »Regenzauber«, ibid.43 (1913) 273-3 10, etc. I 28 Linda Sadnik, »Der Regenbogen in der Vorstellung der Balkanvölker «, Byzantinische Zeitscbrift 44 ( 95 I ) 482-486, dies., "Zur Herkunft der Wind-Vorstellungen und Wind-Bezeichnungen bei den Südslaven«, Wiener Slavistisches Jahrbuch I ( I950) I 3 I-I 33, Vasil Marinov, »Sur certains problèmes fondamentaux de l'astrologie de la Bulgarie«, Rivista di storia dell'agricultura 3 ( (1979) 47-6o, ähnlich in Acta Museorum Agriculturae I 5/I-2 (1980) 105-I I 2.

I 29 In einer Systematik der Wetterregeln und mythischen Interpretationen der Himmelserscheinungen sind folgende thematische Kreise angesprochen: die Sonne (Terminologie, mythische Erzählungen, Sonnenfinsternis, Beeinflussung des Menschen, Sprichwörter), Mond (Terminologie, Mondphasen, Neumond, Vollmond, Abnehmen, ätiologische Mythen, Mondfinsternis, Mondeinfluß: Hund bellt Mond an, Mondsüchtigkeit, Bedeutung für die Wettervorschau, Erntemantik), Sterne und Sternbilder (allgemein: Tierkreiszeichen, Sternzählen gilt als Übel, Annageln der 
Oralkultur einen bedeutenden Informationszufluß von astrologischer und astronomischer Schriftliteratur, die sich aus dem Altertum in östlicher und westlicher Traditionsbildung bis ins neuzeitliche Südosteuropa ergießt $\mathrm{t}^{130}$. Eine besondere Stellung in den Glaubensvorstellungen rund um das Wettergeschehen nimmt der Prophet Elias ein ${ }^{131}$,

Sterne als schwarze Magie, Einfluß auf den Menschen, Omen [rote Sterne - Übel], Prognostik des Wetters, Orientierung und Zeitplan, Einfluß auf Magie, Sprichwörter; im besonderen: Andromeda, Großer Bär, Aphrodite, Galaxie usw.); Kometen und Sternschnuppen; »unsägliche« Tage

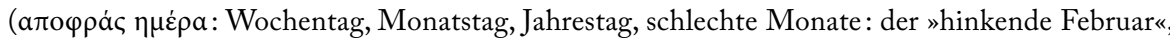
der März, der magische Mai, der kritische September [Ernte]); Schaltjahr; die böse Stunde (какท́ $\omega \dot{\omega} \rho \alpha)$, das "Kreuz des Mittags« mit den Neraidenerscheinungen. Prognostische Tage (Monatstage: jeder Tag bestimmt das Wetter eines Monats). Vorstellung von den bösen Augustfeen ( $\delta \rho i \mu \varepsilon \varsigma)$, die katastrophale Wettererscheinungen (Windhosen usw.) verursachen (an den ersten sechs Tagen des Augusts Arbeitsverbote, z.B. Waschen). Das Wetter ist auch von Datumszahlen (gerade, ungerade)

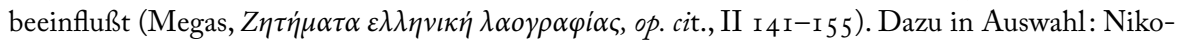

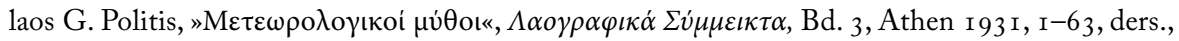

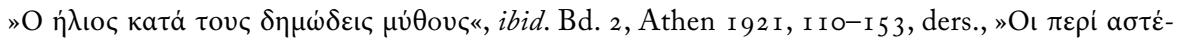

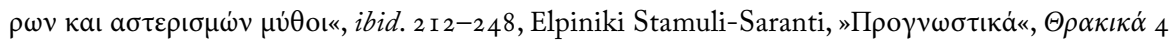
(1933) 234-239, usw. Zur Wetterprognose auch Lukatos, Eı $\sigma \alpha \omega \gamma \eta \dot{~ \sigma \tau \eta v ~ \varepsilon \lambda \lambda \eta v ı к \eta ́ ~} \lambda \alpha o \gamma \rho \alpha \varphi i \alpha$, op.

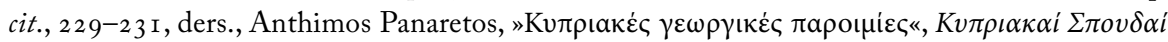

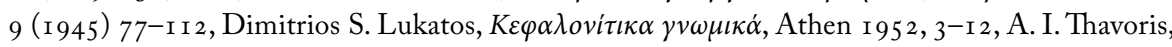

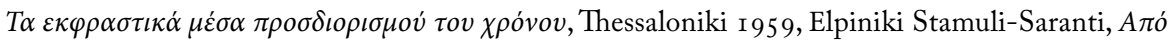

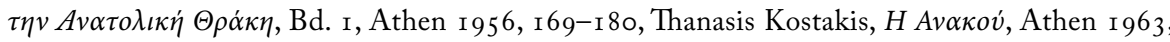
323-342. Manchmal greift die Wetterprognose auch zu ungewöhnlichen Mitteln: z.B. das Mil-

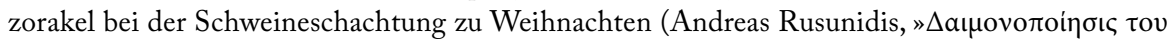

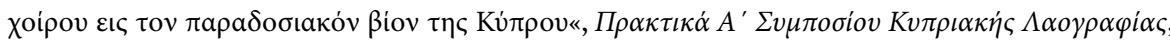
Nicosia I985, I83-I 89, Papathanasi-Musiopulu, op. cit., II 248 f.). Die gängigen Wetterregeln haben bedeutende Traditionstiefe. Z.B. bei Nebel zu Neujahr gibt es eine gute Ernte, rote Sonne im Westen bringt gutes Wetter, hat der Mond einen Hof gibt es Regen, bei Hahnenruf am Abend und Arbeitsruhe der Ameisen wird das Wetter schlecht, donnert es am Festtag des H1. Elias wird auch der restliche Sommer schlecht, ist der Rauch des Weihrauchs schwarz so kommt ein harter Winter

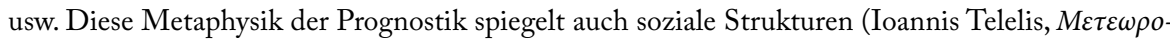

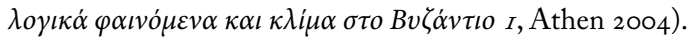

I 30 Julius L. Ideler, Meteorologia veterum Graecorum et Romanorum, Berolini I 832, Faidon I. Kuku-

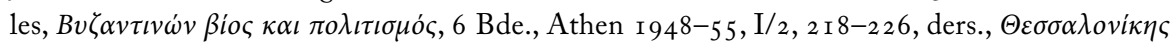

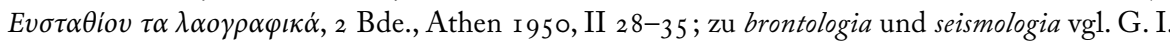

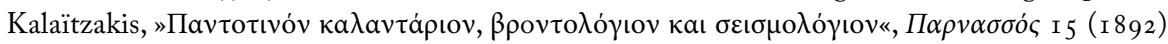
3 I 5-3 I 9, 795-800, Hans-Georg Beck, Byzantinische Volksliteratur, München I 97 I , 205, Ioanna

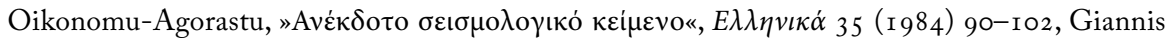

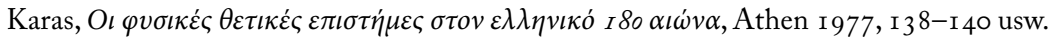

I 3 I Hier dominieren in Südosteuropa folgende Themen: Blitz und Donner (Terminologie, Glaubensvorstellungen: H1. Elias jagt Drachen am Himmel, Blitzabwendung: Hund aus dem Haus, Eisen aus dem Haus, Schweinskiefer an die Tür genagelt, bei Gewitter sitzt man nicht am Herdfeuer usw., Sprichwörter); Wolken/Regen/Hagel/Schnee/Tau/Nebel (Terminologie, ätiologische Mythen 
der mit seinem Sonnenwagen mit Blitz und Donner die Gewitterdrachen über den Himmel jagt ${ }^{132}$. Das (Un)Wetter, aber auch viele andere Katastrophen wie Epidemien, Kriege usw., wird freilich auch von den Konstellationen der astralen Himmelskörper beeinflußt, Vorstellungen, die ebenfalls bis in die Antike zurückreichen ${ }^{133}$.

[Regen fällt aus den Löchern des Himmels], Regenzauber: Litaneiprozession zum H1. Elias, perperuna usw., Aufhören des Regens); Regenbogen (Iris u.a. Namen, Überlieferungen, Sprichwörter, Farbenprognostik); Winde (Namen, Lokalbezeichnungen, Geräuschterminologie, Personifikationen der Winde, Bindezauber für Winde, Sprichwörter u. a.); Gewitter (Terminologie, Glaubensvorstellungen); Wirbelwinde (Terminologie, es tanzen die Neraiden, Abwehr: Anrufung der Neraiden, Messer in die Erde stecken, von der der Wirbelwind kommt); Saug-Windhosen (sifunas); elektrische Flämmchen auf den Schiffsmasten (als telonia-Geister interpretiert). Zeichen der Wettervorhersage: Tierrufe und -bewegungen (Katze, Hund, Hahn, Rinder, Pferde, Schafe, Spatzen, Krähen, Möwen, Enten, Schakale, Schlangen, Würmer, Kuckuck, Eule, usw.), Eingeweideschau, Schulterblattorakel usw., Beobachtung von Bäumen und Pflanzen, Himmelszeichen (Sonne, Mond, Sterne, Regenbogen, Wolkenbildung u.a.), Zeichen zur Wettersituation an bestimmten Jahrestagen: Meer, Feuer und Rauch, bezügliche Sprichwörter (Megas, op. cit., II I 55-I62).

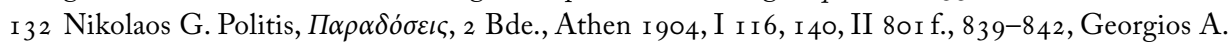

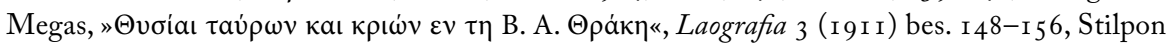

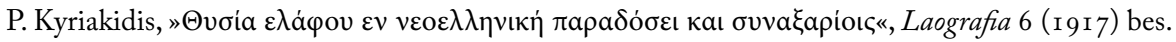

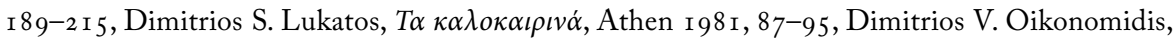

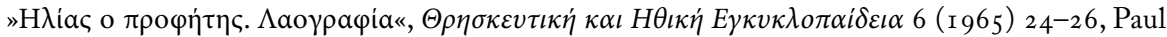
Sartori, »Elias", Handwörterbuch des Deutschen Aberglaubens 2 ( I 929/30) 748 ff., Manolis G. Var-

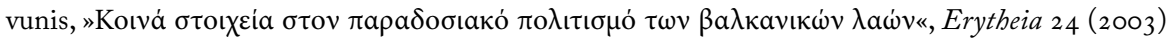
$24 \mathrm{I}-256$.

I 33 Vgl. J. D. Kowatscheff, »Bulgarischer Volksglaube aus dem Gebiet der Himmelskunde«, Zeitschrift für Ethnologie 63 (I 93 I ) 322-346. Zum Einfluß der Sternbilder auf die (Pest)Epidemienprognose

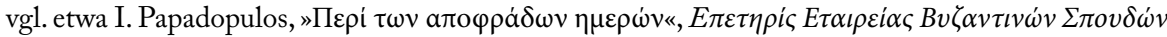

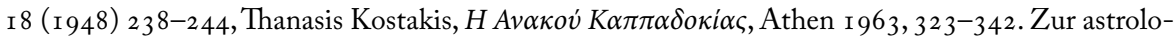
gischen Tradition in Auswahl: Catalogus codicum Astrologorum graecorum I-X, Bruxelles I 898-1 924, Wilhelm Gundel, Sterne und Sternbilder im Glauben des Altertums und der Neuzeit, Bonn/Leipzig 1922 (Hildesheim/New York I98 I), Will-Erich Peuckert, Astrologie. Geschichte der Geheimwissenschaften I, Stuttgart I 960, Franz Boll, Sphaera. Neue griechische Texte und Untersuchungen zur Geschichte der Sternbilder, Leipzig 1903 (Hildesheim I 967), Wilhelm \& H. G. Gundel, Astrologumena. Die astrologische Literatur in der Antike und ibre Geschichte, Wiesbaden I 966, Joseph Mogenet, "L'influence del'astronomie arabe à Byzance du IXe au XIVe siècles", Colloque d'histoire des sciences I (1972) et 2 (1973), Louvain 1976, 45-55, L. G. Westerink, "Ein astrologisches Kolleg aus dem Jahre 564", Byzantinische Zeitschrift 64 (1971) 6-2 I, P. Kunitzsch, »Die Unwettersterne und die `Geomantie des Zanati«, ibid. 60 ( I 967) 309-3 I 7, Joseph Mogenet, »Une scolie inédite du Vat. Gr. I 594 sur les rapports entre l'astronomie arabe et Byzance«, Osiris I 4 ( I962) I $98-22$ I, ders., »Les scolies astronomiques du Vat. Gr. I 29 I «, Bulletin de l'Institute Historique Belge à Rome 40 (1 969) 69-9 I, Arno Borst, Wie kam die arabische Sternkunde ins Kloster Reichenau?, Konstanz I 988, usw. 
Die zentrale Stellung des Ernteertrags in den Überlebensstrategien der traditionellen Kommunitäten führt auch zur Exekution von prophylaktischen und apotropäischen Riten der Landwirtschaft gegen Ernteschädlinge bzw. ein ganzes Bündel von abergläubischen Vorzeichen und Omen rund um die Produktionsvorgänge von der Saat ${ }^{134}$ bis zum Schnitt ${ }^{135}$ bzw. zur Weinlese ${ }^{136}$; den Feldfrüchten kommen überdies magische

I 34 Der Saattermin ist von außerordentlicher Wichtigkeit. Der Beginn der Aussaat wird nach dem Wochentag festgelegt (Montag, Mittwoch, Freitag), mit Gebeten, Wünschen, Kreuzschlagen usw. begibt man sich auf die Felder, keiner darf den Säern den Weg kreuzen (Dimitrios A. Petropulos,

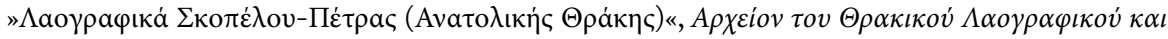

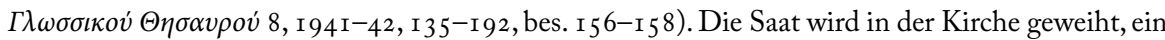
hagiasmos gegen Würmer und Mäuse wird vorgenommen, das Weihwasser in einer Flasche wird auf die Felder mitgenommen und mit Hilfe eines Basilikumkrauts versprengt.

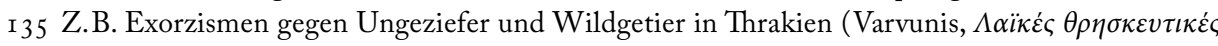

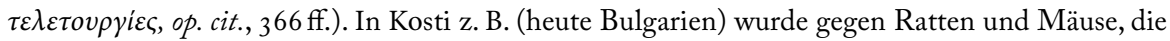
die Weizenfelder verwüsteten, als Innovation die symbolische »Mäusehochzeit« abgehalten, wo der Mäuserich mit der Maus verheiratet wird: ein Hochzeitszug mit dem Priester als Hochzeitsbeistand und dem gesamten Dorf in Festkleidung wird organisiert, nach der Segnung der Vereinigung läßt man die Mäuse frei und verwünscht sie mit einem Bannspruch; nach mündlichen Angaben wollte der Despot den Priester für dieses abergläubische Treiben bestrafen, doch die Dorfältesten ließen dies nicht zu; in Wirklichkeit hat der Pope nur den Bannspruch des H1. Tryphon gegen Ungeziefer verlesen. Drei Jahre lang soll es tatsächlich keine Mäuse mehr auf den Felder gegeben

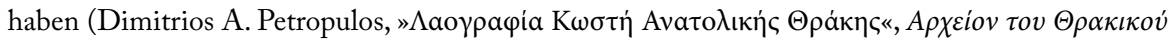

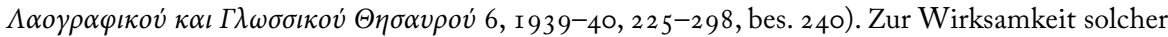

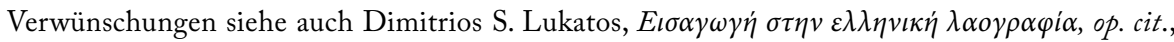

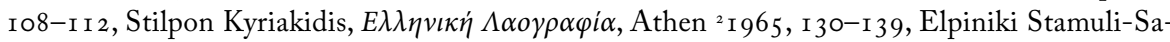

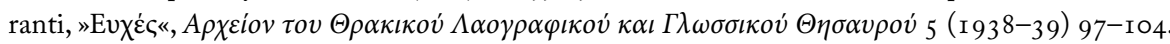
Es handelt sich um einen vereinzelten Fall der Innovation eines neuen Rituals, konstruiert aus traditionellem Material (Hochzeitsbrauch, Bannspruch gegen Ungeziefer). Zur Verschränkung von sakral und profan vgl. auch Mary Douglas, Purity and danger, London I 966, I5-I 7). Der Ritus sollte die Wiederherstellung der Balance zwischen menschlicher Kultur und der Natur bewirken. Die Erntebräuche verfügen über eine große Anzahl von Varianten, abhängig von den Eigenschaften der kultivierten Feldfrüchte (Alexandru Popescu, »Allgemeine und spezielle Charakteristiken der Erntebräuche in Südosteuropa«, Zeitschrift für Balkanologie 22, I 986, 89-93). In Thrakien darf z.B. am Dienstag, Donnertag u. Samstag nicht geerntet werden (Papathanasi-Musiopulu, op. cit., II I 38 ff.), die Bauern streicheln Schlangen, damit ihre Hände nicht schwitzen (eine Sekundärätiologie; Ernten bedeutet Eindringen in das Reich der Toten, vgl. E. Papamichail, »To $\varphi i \delta_{\iota}$, Laografia 3 , I 9 I I/I 2, 477 ff.), der Pflug wird beweihräuchert, die letzte Garbe unter die Ikonen gehängt, am 6. 8.

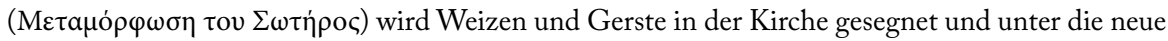
Aussaat gemischt, usw.

I 36 Für den Weinbau ist der H1. Tryphon (I. 2.) zuständig. An seinem Festtag werden Rebstöcke abgeschnitten und an die vier Ecken des Weinbergs gelegt (als Opfer und Abwehrhandlung, vgl.

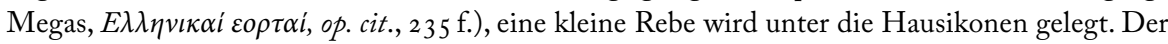


Eigenschaften zu, die auch bei den Therapiebemühungen der Volksmedizin eingesetzt werden $^{137}$. Darüberhinaus gibt es eine Reihe von Schutzheiligen der Agrarwirtschaft ${ }^{138}$.

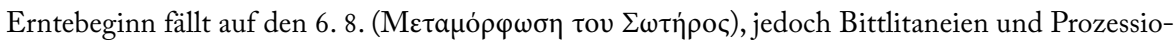
nen in die Weinberge sind schon ab der $\mu \varepsilon \sigma o \pi \varepsilon v \tau \eta$ кобтіं (Mitte zwischen Ostern und Pfingsten) nachzuweisen, die einen magischen Kreis um die Weinberge ziehen (Dimitrios S. Lukatos, »\ao-

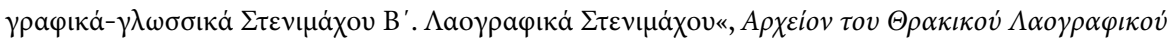

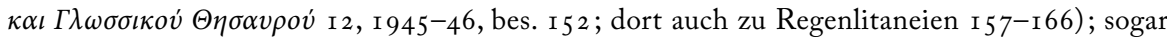

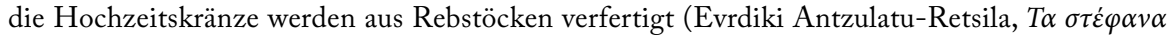

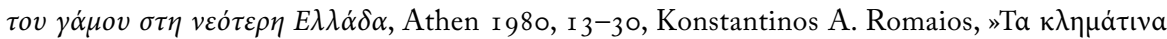

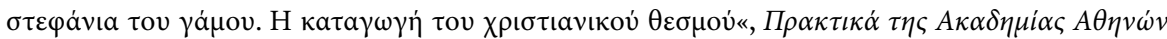

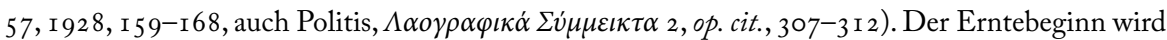
mit Musik gefeiert, Maultiere und Pferde werden mit Glocken behangen (Dimitrios S. Lukatos, T $\alpha$ $\varphi \theta \imath v o \pi \omega \rho \imath v \dot{\alpha}$, Athen 1 982, 23, für Stenimachos); die Rückkehr erfolgt mit Gesang, Hausschmükkung mit Reben, einem Festschmaus und nächtlichem Gelage.

I 37 Z.B. die Weizenkörner: Beim ersten Zahn des Kindes wird Weizen gekocht und an Verwandte und Nachbarn verteilt (damit die Zähne des Kindes leichter herauskommen); diese geben Silbermünzen,

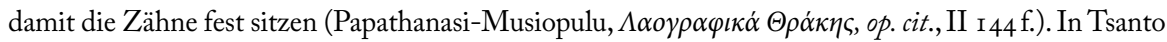
wird das Baby auf das Tischtuch gesetzt, rundherum ist Weizen gestreut, Münzen, ein Buch, eine Schere, usw.; welchen Gegenstand das Kind zuerst ergreift, hat zukunftweisende Bedeutung: den Weizen - er wird Bauer, Münzen - Reichtum, Buch - belesen, Schere - Schneider. In Tsakili wird zu Neujahr der Weizen ins Feuer geworfen, damit er so hoch wie dieses wird; die Großmutter holt Weizen, Münzen und unbesprochenes Wasser von geosteter Quelle: Münzen sind für den glückbringenden Eintritt der Mädchen ins Haus (podariko, Fußorakel), das Wasser wird mit dem Weizen auf die Felder verstreut für eine gute Ernte. Die mantische Eigenschaft des Weizens gründet in seiner chthonischen Eigenschaft als Symbol für Tod und Auferstehung der Vegetation und Sinnzeichen der Fruchtbarkeit

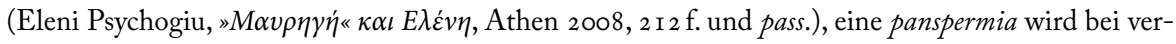
schiedenen Gelegenheiten gekocht und verzehrt bzw. in der Kirche gesegnet.

I 38 Für Hagelschutz steht die Hl. Eleni (2 I. 5.), der H1. Bartholomäos ( I r. 6.) gilt als Weinbergheiliger. In Thrakien werden gegen Hagelschlag auch drei Ostereier im Weinberg vergraben (Petropu-

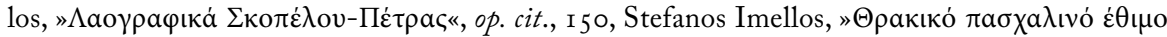

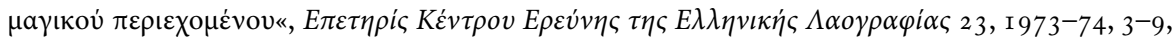

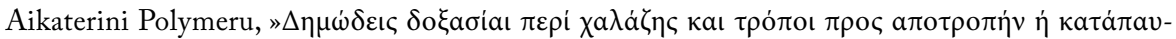
oiv $\tau \eta$ ««, ibid. 23, I 973-74, bes. 56, Robert Wildhaber, »Die Eierschalen im europäischen Glauben und Brauch «, Acta Ethnographica Academiae Scientiarum Hungaricae I 9, I 970, 435-457). Ein Ei von einer schwarzen Henne am Gründonnerstag besonders rot gefärbt gilt als Amulett (fylakto) gegen Hagelschlag; in Naimonas wird ein Pfannkuchen in Kreuzform mit vier Eiern an den Kreuzenden gebacken, nach Ostern werden Eier auf Weinbergen gegessen und die Schalen vergraben (ebenfalls

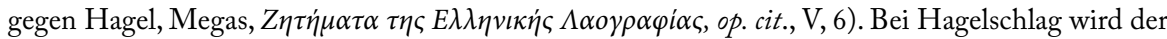

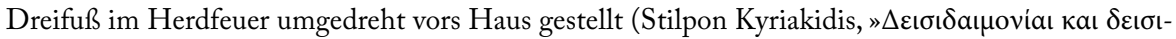

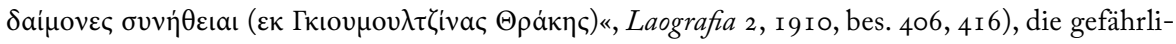

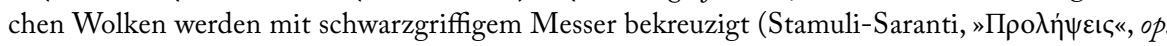
cit., 2 I 2 f.). Zu diesem in der Magie vielverwendeten Messer, das anziehend und zugleich abstoßend für Dämonen ist vgl. George Frederick Abbott, Macedonian Folklore, Cambridge 1903, 363, Faidon 
Flurprozessionen und Bittlitaneien sollen das Unwetter (Dürre, Hagelschlag) und den Ernteschaden (Epidemien, Heuschrecken) abwenden ${ }^{139}$. Erntedankfeste sind in praktisch allen Ackerbaukulturen nachweisbar ${ }^{140}$. Die Riten der Landwirtschaft und Viehzucht passen sich dem natürlichen Umraum an und reproduzieren ihn in einer für den Menschen günstigeren Variante; insofern handelt es sich um eine parallele Kosmogonie, wo Kultur und Kultivierung die »wilde« unbearbeitete Natur zu zähmen und für den Menschen fruchtbar zu machen versuchen.

\subsection{IM NETZWERK DER SUPERSTITIONEN}

Die praktisch unbeschränkte Ausdehnung und Dichte des assoziativen Gewebes von vermeintlichen Analogien im magisch-religiösen Weltbild des vorwissenschaftlichen

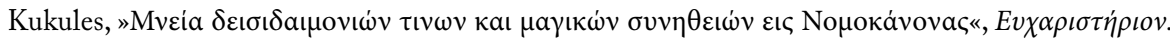

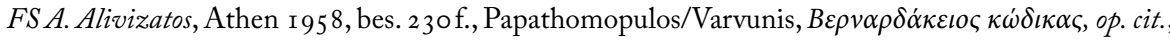
349, 362). Für den Herdenschutz der Viehzüchter gelten als Krisentage das Fest des H1. Georg (23. 4.) als Auftriebstermin und des H1. Demetrios (26. Io.) für den Abtrieb (Leopold K. Goetz,

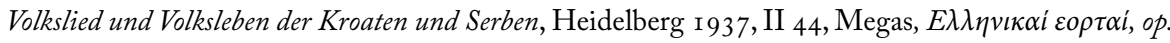
cit., 25 f., Angeliki Hatzimichali, $\Sigma \alpha \rho \alpha \kappa \alpha \tau \sigma \alpha \dot{v o l, ~ I / I, ~ A t h e n ~ 1957, ~} \rho \lambda \eta$ ', Démétrios S. Loukatos, »La St. Démètre (26 Oct.) jour de culte, de transhumances et de conventions automnales chez les pasteurs nomades ou semi-nomades en Grèce«, Symposium du 6-7 Nov. 1975 à Belgrade, Belgrade 1976 , 257-267). Als Schutzheilige der Herdentiere gelten der H1. Vlasios ( I I . 2.) und der H1. Athanasios (I 8. I. u. 2. 5.); an ihren Festtagen herrscht Arbeitsverbot, Schlachtopfer (kurbania) werden abgehalten, es erfolgt die Heilung der Tiere von baskania (böser Blick): ihnen werden Amulette umgehängt, sie werden mit hagiasmos-Weihwasser besprengt, eine wissende Frau zerschlägt ein Ei an ihrem Kopf, für milchlose Ziegen wird ein zerschlagenes Ei mit Salz und Kleie unter das Butterfaß gelegt und unverständliche Bannsprüche gesprochen (Papathanasi-Musiopulu, op. cit., II 230).

I 39 Ikonenumzüge und das Herumführen von Reliquien finden gewöhnlich in der Frühlings- und

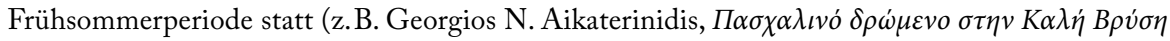
$\Delta \rho \alpha \dot{\mu} \alpha \varsigma$, Kali Vrysi 200o), die hagiasmos-Prozession am Theophanietag, die pompa von Stadtheiligen an ihrem Festtag (z.B. die Demetria in Thessaloniki). Solche Flurumgänge zu Monasterien, Feldkapellen und H1. Quellen können auch drei Tage lang dauern, wobei man die Tiere einsperrt und ohne Fressen läßt (G. Nikolakakis, »La litanie dans le Lassithi, Crete«, Études et Documents Balkaniques et Méditerranéens I6, I 992, 42-48). Die Deskriptionen und Analysen geben gewöhnlich die Prozessionsordnung an, die Stationen mit Gebeten und Litaneien (Niederknien), die Sakralrequisiten wie Kreuze und Hexapterygen, die Fastenvorschriften, usw. Zum »Kreuztragen« (krăstonoše) im südslavischen Raum vgl. Vakarelski, Bulgarische Volkskunde, op. cit., 33 I.

I 40 Gewöhnlich werden die ersten Feldfrüchte der Ernte in der Kirche geweiht, unter die Bilderwand (templum) gestellt und verteilt, bzw. zur Dorfquelle gebracht (Kreta, Makedonien, Thrakien usw.). Aus den ersten Weizenkörnern werden Kringel gebacken und bei der Quelle als Opfergabe aufgehängt; daraus bäckt man auch Weihbrote (prosfora, leiturgia), Wein, Olivenöl, Wachs und Weihrauch werden gespendet. 
Zeitalters der Vormoderne umgibt den Einzelnen, seine Familie und die Kommunität (bzw. auch größere kollektive Gruppierungen) unausweichlich und integriert sie in ein Netzwerk von prima vista uneinsichtigen Zusammenhängen, dessen Eng- oder Weitmaschigkeit und seine Verknüpfungsmodalitäten von der individuellen oder kollektiven Imagination und Phantasie bzw. der Intensität der Krisensituation und psychogenetischen Phobien abhängen. Trotz der Restriktionen der institutionalen Kirche (Reformation, Gegenreformation) bzw. der Rationalität des wissenschaftlichen Weltbildes der Aufklärung ergießt sich ein breiter Strom solcher Vorstellungen in die Moderne und die unmittelbare Gegenwart, denn das Unvorhersehbare bleibt trotz aller szientifischen und technologischen Errungenschaften weiterhin unvorhersehbar, das Unerklärliche füllt in beunruhigender Weise weiterhin die Leerstellen menschlicher Wissenslücken und die Modelle der Mikro- und Makrophysik ermangeln elementarer Vorstellbarkeit und sind für die Alltagspraxis des Durchschnittsmenschen mehr oder weniger irrelevant. Somit erhalten sich weiterhin Vorstellungsschichten, in Südosteuropa ganz dezidiert, die im Lichte aufgeklärter Vernünftigkeit eher zu den Schattenseiten der europäischen Kultur gezählt werden könnten, für die Kulturwissenschaften jedoch von unschätzbarem Wert sind, da sie die Organisationsformen von Wissen, Erleben und Erfahrungsanwendung im menschlichen Bewußtsein an seinen Grenzen erhellen, wo die Strategien im Umgang mit dem Unerklärlichen und Unvorhersehbaren in Frage stehen.

Die Morphologie »abergläubischer« Manifestationen ist in ihren Variationsmöglichkeiten schier endlos und in den Urbankulturen des heutigen Südosteuropa weiterhin gegenwärtig: Horoskop, Astrologie, Medium, Handlesen, Omen, Zahlenmagie (I 3), Okkultismus, der Böse Blick usw. dokumentieren das Weiterleben von Glaubensvorstellungen, die eigentlich dem animistischen Weltbild vorindustrieller Oralkulturen angehören $^{141}$. Dort kann praktisch jede zufällige Begebenheit eine bestimmte (oder auch ambivalente) Bedeutungszuweisung (Semiosis) erhalten, die aus dem unerschöpflichen Reservoir und dem universellen Netz von assoziativen Analogievorstellungen gespeist wird und deren quasi-logischer Konnex nicht immer leicht zu erkennen ist ${ }^{142}$. Dieses

I4I Genauso unerschöpflich ist die einschlägige Bibliographie bzw. die Materialzusammenstellungen.

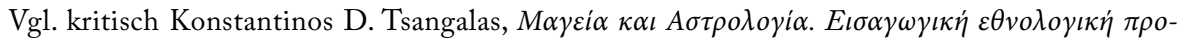

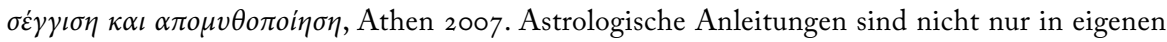
Fernsehsendungen zu sehen, sondern erfreuen sich auch weiterhin publizistischer Erfolge (z.B.

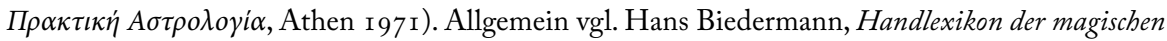
Künste, Graz 1973.

I42 Dazu einige Beispiele aus dem Bereich der traditionellen thrakischen Volkskultur: Öffnet sich die Eingangstür von alleine, so wird ein Freund ins Haus kommen; verschiedene Bedeutungen bekommen folgende Ereignisse: Wenn man irrtümlichweise mit zwei Gabeln ißt, Brot fällt zu Boden, man sieht ein Haar zu Boden fallen, man sieht eine Spinne usw. Der Nadelstich beim Anprobieren 
symbolische Kollektivwissen, das auch eine lange Liste von Verboten enthält ${ }^{143}$ und in das auch religiöse Institutionen miteinbezogen sind, reguliert und kanalisiert die Produktion und Reproduktion im sozialen Leben und festigt im allgemeinen gesellschaftliche Normen und Strukturen. Derartige Glaubensvorstellungen beruhen vielfach auch auf den Superstitionen bezüglich der Existenz und Aktivität von Dämonen ${ }^{144}$, aber auch auf den symbolische Bedeutungen, die dem Anfang und dem Ende einer Handlung beigemessen werden, wodurch das Kontinuum des Zeitflusses strukturiert wird ${ }^{145}$.

eines Kleides bedeutet, daß man es lange tragen wird, wenn die Schere der Schneiderin fällt, bekommt sie viel Arbeit; ein Sprung im Spiegel ist ein böses Omen, wer auf eine brennende Zigarette steigt, wird einem geliebten Menschen begegnen. Wenn die Wangen erröten, wird von einem gesprochen, Ohrenpfeifen gilt als Zeichen, daß man etwas zu hören bekommen wird, beißt das rechtes Ohr, wird man Geld geben, das linke - Geld bekommen. Wer Kaffee aus dem briki (ibrik)

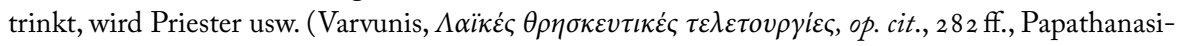

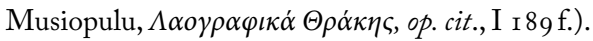

I43 Weitere Beispiele aus Thrakien: Mittags und nachts soll man nicht an Quellen wachen, weil sich dort die Neraiden aufhalten; man soll es vermeiden, die Monatstage zu zählen, aus Angst vor dem Sterben eines Verwandten; aus demselben Grund sagt man Kindernamen nicht; auf dem Weg zu den Gräbern begrüßt man sich nicht (nicht aus Pietät, sondern weil es ein schlechter Tag ist); aus der Pflanzenmagie: Die Knaben sollen keinen Mastix kauen, sonst bekommen sie keinen Schnurrbart. An den ersten Tagen des August (Erscheinung der $\delta \rho i \mu \varepsilon \varsigma)$ soll man kein Meerbad nehmen, sonst wird die Haut schuppig; welches Kind Brotrinden ißt, wird Priester (Mädchen - Popenfrau); man soll keine Brotkrumen übriglassen, sonst wird man von der Geliebten verlassen; bei Erntebeginn leiht man keine Geräte her, denn sonst verleiht man sein Glück; aus demselben Grund leiht man am Abend kein Salz oder Essig (sonst wird der Wein zu Essig). Die Arme zu kreuzen bedeutet, sich vor seinem Glück zu verschließen (eine Ruhehaltung, die bedeutet, daß man keine Arbeit hat); wenn Frauen viel lachen, werden sie viel weinen, wen die Nase beißt, der wird geschlagen werden; ein krankes Tier wird dreimal um die Kirche geführt, der Eulenschrei gilt als Omen für Pest oder Epidemien; noch schlimmer ist es, wenn die Eule am Hausdach sitzt: dann gibt es einen

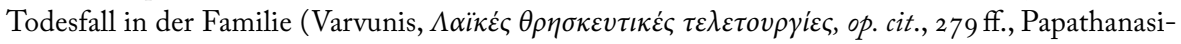
Musiopulu, $\Lambda \alpha o \gamma \rho \alpha \varphi \iota \kappa \dot{\alpha} \Theta \rho \alpha \dot{\alpha} \eta \eta$, op. cit., I I 9 I f.).

I 44 Z.B. das Pfeifen in der Nacht lockt die kalikantzaroi an, der wilde Feigenbaum ist der Sitz des

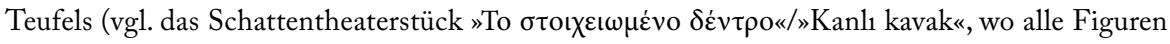
verzaubert werden, Walter Puchner, Das neugriechische Schattentheater Karagiozis, München I 975,

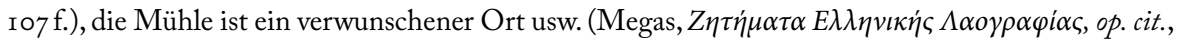
II II $3-$ II 6 ).

I 45 Auf dieser Zeitvorstellung gründen Vorstellungen wie das Eintreten des Glücks am Neujahrstag (podariko), der glückliche Anfang einer Aktion (cheriko, z.B. erster Gast in der Taverne, erster Käufer im Geschäft), Konzeptionen wie die »böse Stunde« (какท́ $\omega \rho \alpha$, wo schreckliche Dinge gleichsam ohne das Zutun der Akteure passieren, die bloß Ausführende des Schicksalswillens sind; so werden z.B. Gewaltverbrechen begründet), die Begrüßung von Sonne und Mond, der bieros chronos der Festzeit usw. Vgl. Venetia Newall, »Fest«, Enzyklopädie des Märchens 4 (1984) 1035-1043 (mit der

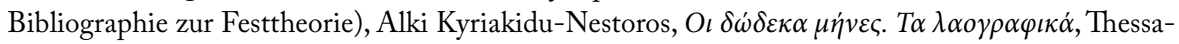


$\mathrm{Zu}$ Superstitionen im Balkanraum existiert eine unübersichtliche Bibliographie mit oft unstrukturierten kumulativen Materialsammlungen oder irrepräsentativen regionalen oder thematischen Spezialstudien ${ }^{146}$. Aber eine erschöpfende Bestandsaufnahme ist ohnehin gar nicht anstrebbar. Neben den parareligiösen Superstitionen im Marginalbereich der Sakralsphäre der institutionalisierten Hochreligion gibt es jedoch auch Manifestationen, die man unter dem Etikett »Reste naturkultischer Vorstellungen« subsumieren könnte: Dies betrifft die Naturelemente (Feuer, Wasser, Erde) ${ }^{147}$, aber auch Bäume, Felsen und Steine ${ }^{148}$ u.a.

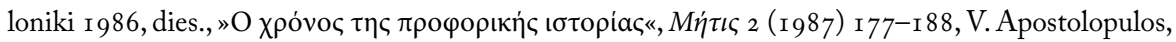

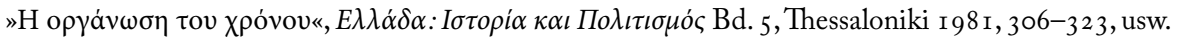
I46 Vgl. indizierend Anton E. Carić, „Volksaberglaube in Dalmatien «, Wissenschaftliche Mitteilungen aus Bosnien und der Hercegovina 6 (I 899) 585-608, Lukas Grgjić-Bjielokosić, „Volksglaube und Volksbräuche in der Hercegovina«, ibid. 6 (1899) 609-632, Georg Eckert/P. E. Formozis, Mazedonischer Volksglaube. Magie, Aberglaube und religiöse Vorstellungen in Saloniki und in der West-Chalkidike, Thessaloniki 1943, dies., Beiträge zur mazedonischen Volksmagie, Thessaloniki I 942, dies., Regenzauber in Makedonien, Thessaloniki r 943, Friedrich Salomo Krauss, "Sreća. Glück und Schicksal im Volksglauben der Südslaven«, Mitteilungen der Anthropologischen Gesellschaft in Wien I6 ( I 886) I02-162, ders., Volksglaube und religiöser Brauch der Südslaven, Münster I 89o, Momčilo Zlatanović, Narodne pesme i basme južne Srbije, Beograd I 994, Josef Matl, »Hölle und Höllenstrafen in den volksreligiösen Vorstellungen der Bulgaren, Serben und Kroaten«, Südslawische Studien, München I 965, I 59-179, Edmund Schneeweis, Grundriß der Volksglaubens und Volksbrauchs bei den Serbokroaten, Celje 1935, Gabriella Schubert, „Die Rolle der Frau im Volksglauben der Südslawen«, Slavica Gandensia 7/8 (1980/8I) I 57-179, Karl Dieterich, »Hellenistische Volksreligion und byzantinischneugriechischer Volksglaube", Angelos I (1925) 2-23 (Archiv für neutestamentliche Zeitgeschichte und Kulturkunde I, I 92 5, 2-3, 2, 1926, 69-73), Richard M. Dawkins, »Soul and Body in the Folklore of Modern Greece«, Folklore 53 (1 942) I 3 I-I 47, Leopold Kretzenbacher, »Heiliges Brot und Heilbrot. Gedanken zu einer neugriechischen Brot-Monographie«, Münchener Zeitschrift für Balkankunde 4 (198I-82) 26I-267, usw.

I 47 Feuer ist ein Apotropäum in vielen Kulturen. Während der Zwölften darf in Südosteuropa der "Christblock« nicht verlöschen, denn sonst kommen die Dämonen durch den Rauchfang ins Haus (vgl. wie oben); eine andere Vorstellung ist die des »Feuerengels«, der die schädlichen Zwölftengeister vertreibt. Ähnlich ist die Vorstellung vom Heiligen Licht, das niemals verlöscht. Die Herdstelle gilt als Zentrum des Hauses, in ihrem Feuer werden Öl- und Weinopfer dargebracht, Brotopfer im Backofen. Zu den Superstitionen rund um das Herdfeuer gehört auch, daß man in der Nacht kein Feuer herleiht, ebenso an Festtagen und wenn eine Frau im Kindbett liegt (Feuer als "Kraft« des Hauses). Dazu auch Donald Ward, »Feuer«, Enzyklopädie des Märchens 4 (1984) 1066-1083, Handbuch des Deutschen Aberglaubens 2 I 389-I 402. Dem Quellwasser werden magische Eigenschaften zugeschrieben (für leichte Geburt und gegen Kinderlosigkeit); es besteht auch die Vorstellung, daß das Wasser in der Nacht »schläft«. Die Münzopfer bei Quellen sind heute noch in Gebrauch; in das Quellwasser darf man nicht spucken noch urinieren (vgl. dazu noch in der Folge). Zum Erdkult der Ackerbaukulturen Donald Ward, »Erde«, Enzyklopädie des Märchens 4 (I 984) I 36 - 53.

I48 Die Vorstellung von Heiligen Steinen mit magischen Eigenschaften der Kraftübermittlung ist weit 
Besonders interessant ist die Vorstellung von alten und großen Bäumen als Sitz von Geistern: Daher ist es nicht ratsam, in ihrem Schatten zu schlafen, und beim Umschneiden sind spezielle Vorkehrungen gegen die Rache des Baumgeistes zu treffen ${ }^{149}$. Solche Vorstellungen gehen z.T. auf die Antike zurück ${ }^{150}$ und sind in Südosteuropa weit verbreitet ${ }^{151}$. Bei Fußwanderungen im Balkanraum oder auf den Ägäisinseln wird sich der Besucher vielleicht gewundert haben über Bäume und Sträucher, meist in unmittelbarer Nähe von eingefaßten Quellen (hagiasmata), die mit Stoff- und Kleiderfetzen über und über behangen sind. Diese $t$ zatzala ${ }^{152}$ sind Stoffteile von Kleidungsstücken von Kranken (Erwachsenen und Kindern), die nach dem Heilungsprinzip der transplantatio morborum der Naturpflanze die Krankheit übertragen (nach den Gesetzen der Berührungsmagie der Kontagiosität, wonach die Kleidung die Haut des Kranken berührt, ist das Kleidungsstück als pars pro toto ebenfalls Träger der Krankheit; die Krankheit, die von der Natur kommt, wird an die Natur zurückgegeben); diesen Effekt verstärkt noch die Sakralsphäre der H1. Quelle, in deren Wasser durch Waschungen eine ähnliche Therapie vorgenommen werden $\mathrm{kann}^{153}$.

verbreitet: Auf ihnen rutschen kinderlose Frauen, Kranke lassen ihre Kleider dort (transplantatio morborum) wie auf den Bäumen und Sträuchern nahe einer Quelle (vgl. dazu noch in der Folge); sie werden auch zur Heilung durch den Nadelöhr-Ritus benutzt (Konstantinos A. Romaios, »To

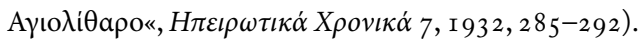

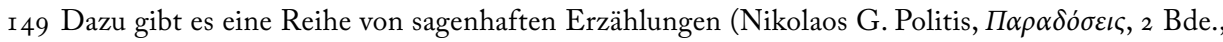

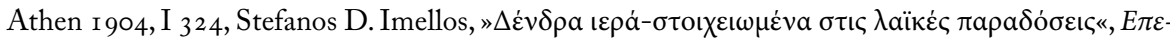

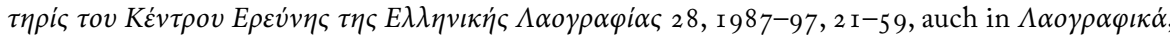
Bd. 4, Пoเкi $\alpha$, Athen 2003, 48-85).

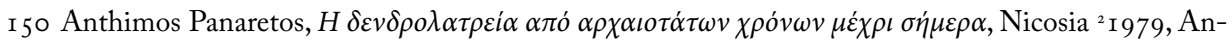

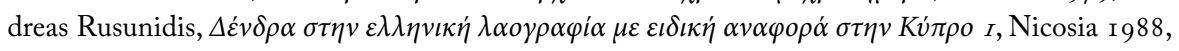
20.

I 5 I Leo Barbar, »Der Baumkult der Bulgaren«, Antbropos 30 (1935) 797-802, Wilhelm Lettenbauer, "Bemerkungen zur Baumverehrung in Volksglauben und Brauchtum der Südslaven", Südost-Forschungen I 7 (1958) 68-82, ders., Der Baumkult bei den Slaven. Vergleichende volkskundliche, kultur-

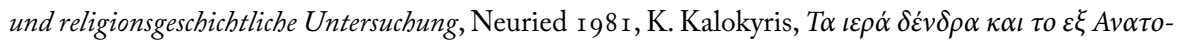

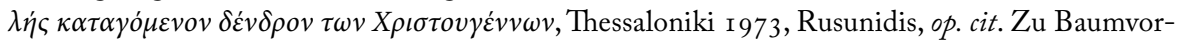
stellungen (axis mundi, genius loci, Metamorphosen, Feensitz, Lebensbäume, Sprossenwunder der dürren Zweige, gefährliche Schatten, verfluchte und gesegnete Bäume) vgl. Maria Miligu-Markantoni, $\Delta \dot{\varepsilon} v \delta \rho \alpha, \Phi v \tau \dot{\alpha}, A v \theta \eta \sigma \tau o v \lambda \alpha \ddot{\prime} \kappa o ́ ~ \pi o \lambda \tau \iota \sigma \iota \mu \dot{~} \tau \omega v v \varepsilon \omega \tau \dot{\varepsilon} \rho \omega v E \lambda \lambda \dot{\eta} v \omega v$, Athen 2006, $4 \mathrm{I}-\mathrm{I} 6_{3}$.

I 52 Der Name für die Kleiderfetzen (Lumpen usw.) düfte auf mittelgriech. tzantzalon (tzantzalos, der in Lumpen Gekleidete) zurückgehen mit ungewisser Etymologie (vielleicht ital. cencio von lat. cynici, womit die lumpengekleideten Philosophen der Kynischen Schule bezeichnet wurden; andere Lexika tippen auf arabische Herkunft.)

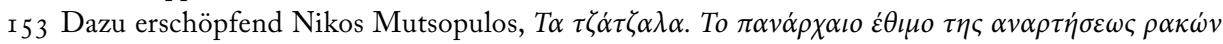
$\sigma \varepsilon \delta \varepsilon \dot{\varepsilon} \delta \rho \alpha, \pi \lambda \alpha^{\prime} \iota \sigma \varepsilon » \alpha \gamma \iota \alpha \dot{\alpha} \sigma \mu \alpha \tau \alpha$ « $\iota \alpha \tau \eta v i \alpha \sigma \eta \tau \omega v \alpha \sigma \theta \varepsilon v \dot{\omega} v$, Thessaloniki 2000. Das Verbreitungsgebiet ist vor allem Kleinasien, Thrakien, Makedonien, Epirus, Thessalien, Kreta, Ägäisinseln, Zy- 
pern, seltener in Festgriechenland und der Peloponnes (vgl. auch Miligu-Markantoni, op. cit., $94 \mathrm{ff}$.). Dazu einige Beispiele aus dem historischen Thrakien (heute Bulgarien, Europäische Türkei), wo der Brauch bei orthodoxen Christen und Muslimen gleichermaßen nachgewiesen werden kann

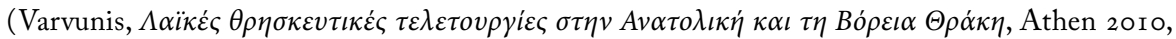
297 ff.). In Kosti und Viza (Bizye) werden Kleiderstücke von kranken Kindern mit dem Wasser der H1. Quelle benetzt und an bestimmten Bäumen in der Nähe aufgehängt (dies beschreibt der thra-

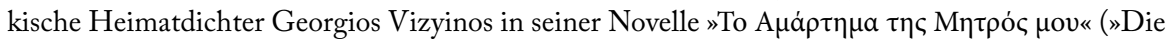

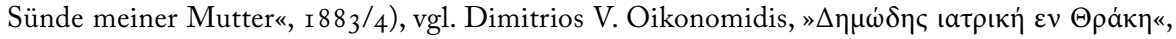

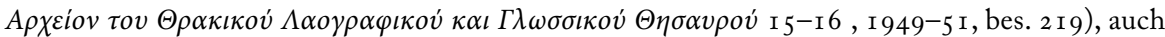
Fadenknoten als Bindezauber für die Krankheit werden ins Gras neben die H1. Quelle gelegt (E1-

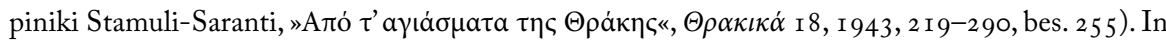
Kastanies gibt es gleich drei hagiasmata, die am Festtag der Transfiguration des Heilands (6. 8.) von Kranken mit Weihbroten und Geflügelopfer besucht werden: Ein trishagion wird für die Toten gelesen sowie die Bibelperikope Joh. 9, I 9 ff. über die Heilung des Blindgeborenen; gegen Fieber, Krämpfe und Kopfweh bekommen die Besucher ein Schlammkreuz auf die Stirn (Mutsopulos, T $\alpha$ $\tau \zeta \dot{\alpha} \tau \zeta \alpha \lambda \alpha$, op. cit., I 47 f.). Am Festtag der Entschlafung der Gottesmutter (I 5. 8.) werden kranke Kinder einer Waschung unterzogen, ihre Kleider zerrissen und in den Fluß geworfen. Am Festtag des H1. Johannes Prodromos (29. 8.) mißt ein Kranker mit spastischen Anfällen seine Körpergröße mit einem Baumwollfaden vor der Ikone des Heiligen ab, den er dann 40 Tage lang am Handgelenk angebunden trägt (Mutsopulos, $T \alpha \tau \zeta \dot{\alpha} \tau \zeta \alpha \alpha \alpha$, op. cit., 48 ); das Abmessen des Körpers gilt als eine Art somatischer Autotherapie. Die therapeutischen Riten umfassen meist drei Spielarten: a) Opfer an die Toten (um sie günstig zu stimmen, Tieropfer oder Votivgaben, auch ekklesiastische Riten), b) Wasserkontakt (trinken, besprengen, waschen), c) Stoffstück der Kleidung an Bäumen

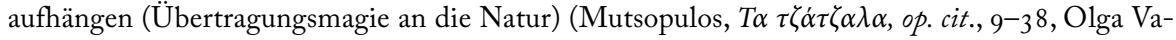

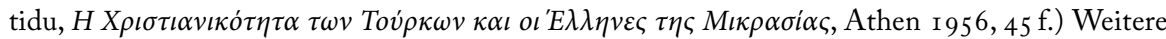

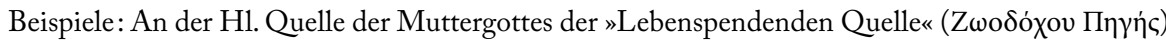
in Herakleia (Stamuli-Saranti, „A $\pi^{\prime} \tau \alpha$ a $ү ı \dot{\sigma} \sigma \mu \alpha \tau \alpha$ «, op. cit., 245) sind Proskynese, Wasserkontakt und Fetzenaufhängen kombiniert; am Festtag der Enthauptung des H1. Johannes Prodromos in

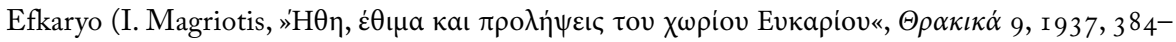
39I , bes. 386 f.) wird neben dem hagiasma ein großer Strauch über und über mit vielfarbigen Stoffetzen jeglicher Größe von Fieberkranken behängt. Im Raum Silivria trinken Kranke nach einer Fastenperiode von der H1. Quelle der Kapelle des H1. Johannes Theologos an seinem Festtag (8. 5.), waschen ihren Körper und die neue Kleidung, schneiden davon ein Stück ab und binden es an das Fenstergitter des Quellenhäuschens oder an einen Baum (Mutsopulos, $T \alpha \tau \zeta \dot{\alpha} \tau \zeta \alpha \lambda \alpha$, op. cit., I49). In Ganos werden am Festtag der H1. Paraskevi (26. 7.) Stücke von den Nähten oder dem

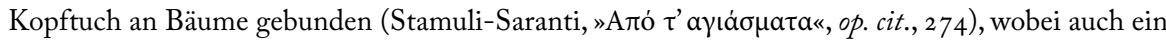
Umdrehverbot besteht (Gen. I7, I9) (der Blickkontakt ist an sich bereits ein Übertragungsmodus). In Kurvali bei Silivria üben auch die Muslime denselben Brauch am Festtag der H1. Paraskevi

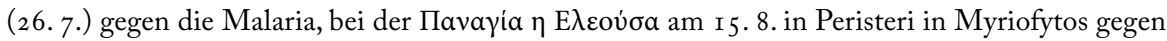
Lepra, wobei die Kleider mit Schlamm beschmiert werden, in Madytos 8. 5. (H1. Johannes Theologos), auch am i 7. 7. (H1. Marina), am Festtag des H1. Theodor Teron (I7. 2.) gegen Malaria und ansteckende Krankheiten mit einem Bannspruch (»ich binde dich, Kleid, damit du mir meine Ge-

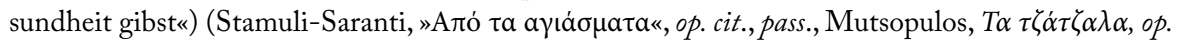


Ein anderer Ritus, der den Bäumen eine besondere Bedeutung beimißt, ist ihre »Erhöhung" (hypsoma), eine Weihung, die sie in den Status eines sakralen Schutz- und Grenzzeichens der Siedlung erhebt, Teil jenes magischen Zirkels von Kapellen, proskynetaria, H1. Quellen (hagiasmata), der den Siedlungsraum der Menschen ausgrenzt und gegen die dämonisch-wilde Natur schützt (Epidemien, Übel jeglicher Art) ${ }^{154}$. Der Ritus des hypsoma wird nach der Festliturgie in feierlicher Prozession der ganzen Gemeinde gewöhnlich in der Nachosterwoche vorgenommen, wobei der Priester ein Stück Rinde vom Baum abschneidet, ein Stück Weihbrot der Meßlesung in die Öffnung legt und den Rindenschnitt mit Wachs verklebt. Solche geweihten Bäume werden in jeder Himmelsrichtung aufgestellt, so daß sie kreisartig einen geistlichen Schutzwall rund um das Dorf bilden ${ }^{155}$.

Einen anderen Bestandteil des magischen Abwehrsystems und der zirkelartigen Konsekration des Siedlungsraumes bilden die heiligen Quellen (hagiasmata) und bachartigen Wasserläufe, oft eingefaßt und reguliert mit oder ohne Kapelle; Wasser gilt im weitesten Sinne als Sitz von Dämonen und ihm werden purifikatorische Eigenschaften

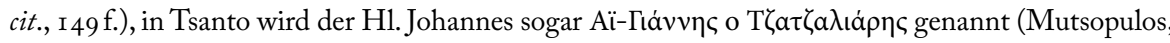
op. cit., I $5 \circ$ f.). Es gibt auch Fälle, wo die hl. Quellen mehr oder weniger in islamischer Hand sind, wenn z.B. das Wohnhaus des Imams gleich neben der Quelle steht; Krankheit kennt keine Dog-

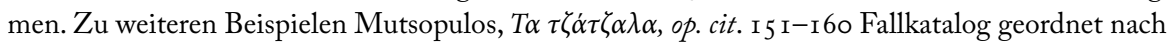

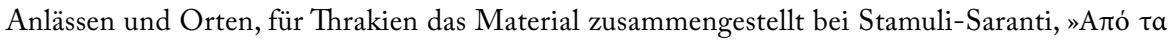

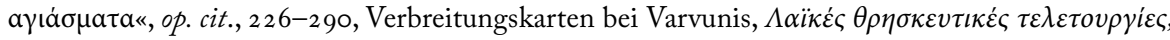
op. cit., 302-316 mit 2 Karten.

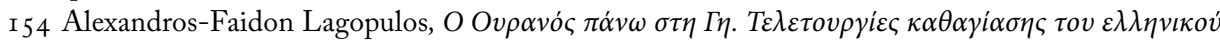

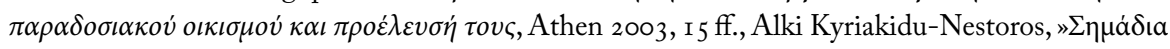

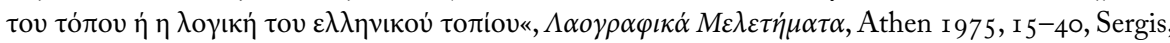

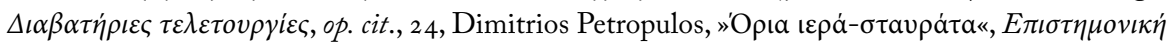

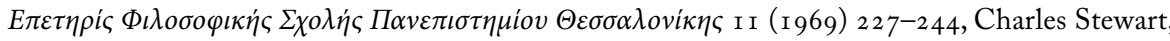
"Magic Circles: An Approach to Greek Ritual«, Journal of the Anthropological Society of Oxford 25 (i 994) 9i-ror.

I $55 \mathrm{Zu}$ den Details der Ritualhandlung Miligu-Markantoni, op. cit., I 53-I6o. Vgl. weiters Stefanos

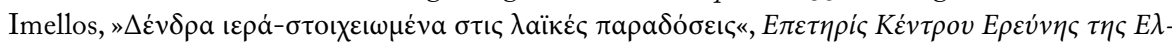

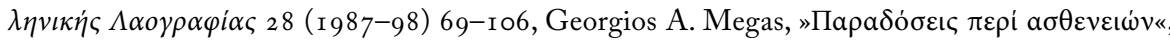
Laografia 7 (1923) 465-520, bes. 465-476, Dimitrios Koukopoulos, On the mountains of Katsantonis,

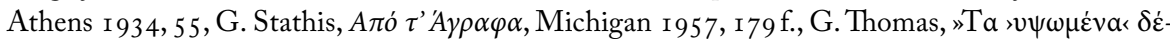

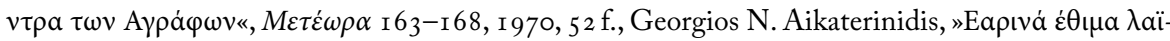

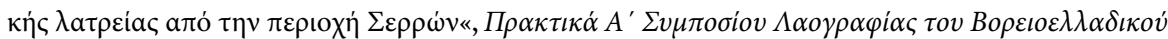

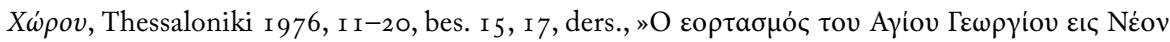

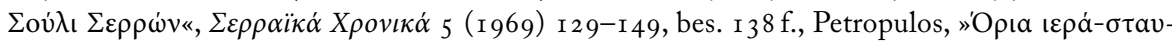

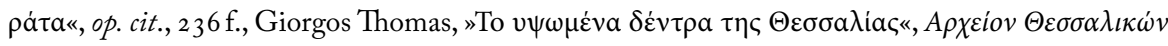
$M \varepsilon \lambda \varepsilon \tau \dot{\omega} v 7$ (1985) 207-225. 
zugeschrieben; solche Quellen sind meist einem bestimmten Heiligen gewidmet ${ }^{156}$. Die Sakralität und Heilkraft solcher Quellen gründet sich meist auf legendenartige Erzählungen, die gewöhnlich drei verschiedenen Typologien folgen: I. das wunderbare Entspringen der Quelle, 2. die Entdeckung der Quelle durch eine wunderbare Begebenheit und 3. die Entstehung der Quelle durch die Tätigkeit eines Heiligen, durch einen wunderbaren Hirschen oder eine wundertätige Ikone ${ }^{157}$. Solche Narrationen bilden die Grundlage für Riten, Feste und für die Übertragung der Sakralität auf den Umraum der Quelle und die Besucher ${ }^{158}$. Fast alle Heiligenfeste (panegyria) finden bei solchen bagiasmata statt, wobei die Festordnung neben der Festmesse, dem Symposium, Musik und Tanz, Ringkämpfen und anderen Agonen auch Tieropfer und das Aufhängen von Kleidungsstücken von Kranken an den H1. Bäumen in der Nähe der Quelle vorsieht ${ }^{159}$.

I 56 Für das historische Thrakien vgl. die systematische Studie von in Elpiniki Stamuli-Saranti, »Aтó

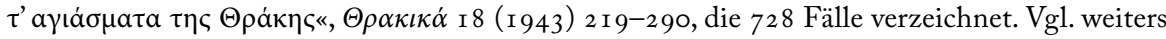

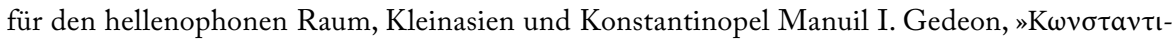

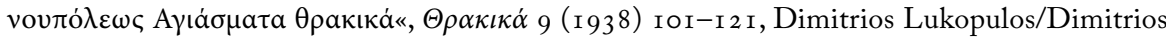

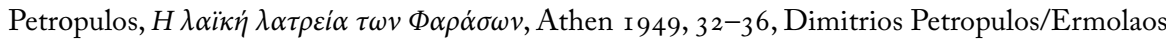

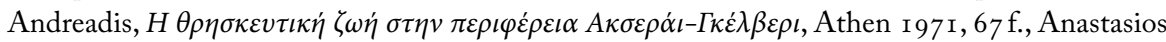

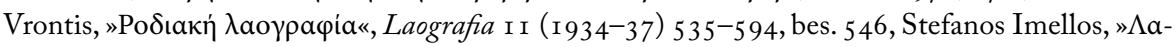

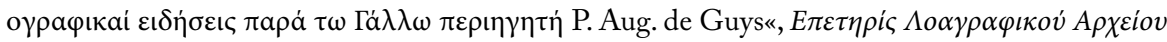

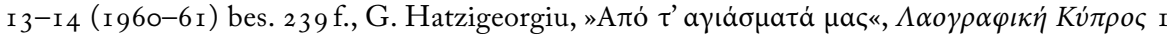

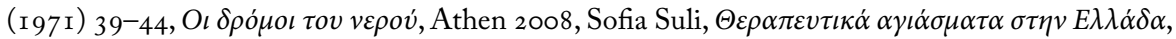

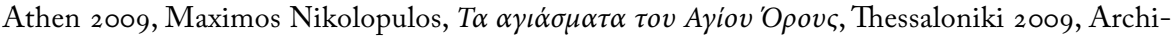

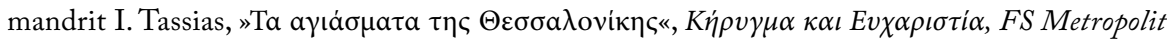

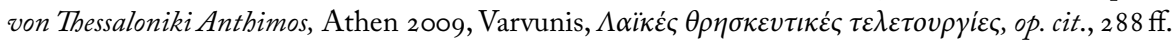
usw.

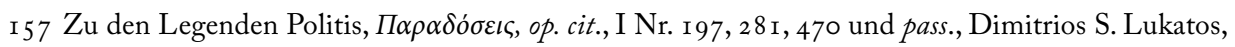

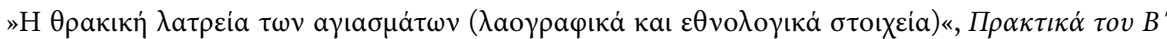

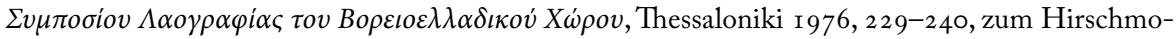
tiv ders., „Le motif de la chèvre decouvrant les lieux sacres en Grèce«, FS Matthias Zender, Bonn

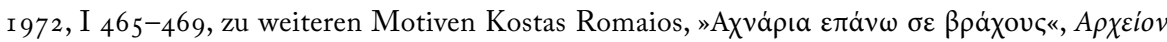

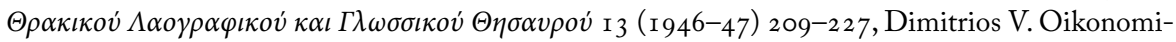

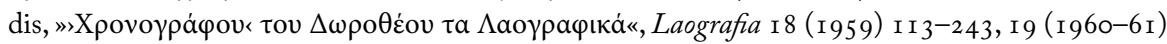
3-95, bes. 29 f.

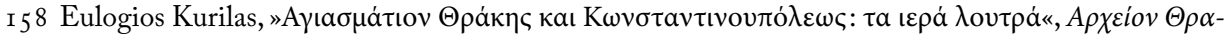

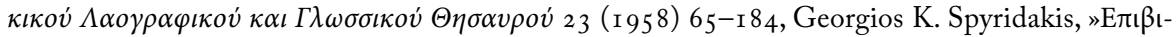

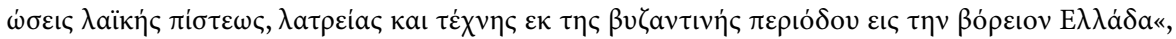

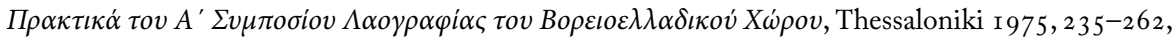
bes. $243,246$.

I 59 Einige Beispiele aus dem Raum des historischen Thrakien. In Madytos bei Eceabat wird die Quelle der Panagia auf der Hochebene von Kirtili am neunten Tag nach der Entschlafung der Gottesmutter (23. 8.) von vielen Leuten besucht. Die Festmanifestationen dauern drei Tage. Nach vielen 
Vorbereitungen (Essen, Decken, warme Kleider) treffen die Leute am Vortag beim hagiasma ein, das mit Übernachtungsstellen für die Familien, gezimmert aus Baumstämmen mit provisorischem Vorhang und überdacht mit Zweigen, ausgestattet ist. Kerzen werden angezündet, die Marienikone geküßt, man trinkt Wasser von der Quelle und wäscht sich das Gesicht, trägt die Namen derer ein, die bei der Bittmesse (paraklese) genannt werden sollen; beim Licht der Petroleumlampen dauern Tanz und Gesang bis Mitternacht, vor Sonnenaufgang findet man sich bei der Ikone ein und hört die Lesung, dann folgen wiederum Tanz und Musik, Frischvermählte nehmen mit gesamter Festkleidung teil (wechseln bei jedem Tanz), es gibt Geld für die Musikanten, damit weibliche Angehörige den Tanz anführen können, und alle Mädchen führen auf diese Art einen Tanz an; das Fest dient auch dem Kennenlernen der Jugend, es kommt zu Verlobungen usw. Am nächsten Tag findet

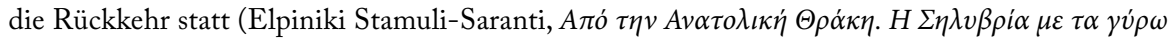
$\chi \omega \rho \iota \alpha ́$ $\tau \eta \varsigma, 2$ Bde. Athen I 956/58, I 232). Zu den Vorbereitungen der Proskynese zählen: Fasten, sexuelle Enthaltsamkeit, Gebet, Kommunion nach dem taximo (Gelübde, Weihung), die Weihbrote gesegnet und verteilt, das Entzünden von Kerzen (Seelenlicht), die Kommunion mit dem hl. Wasser (manchmal auch Kopfwaschung oder kranke Glieder und Körperstellen) (Konstantinos A.

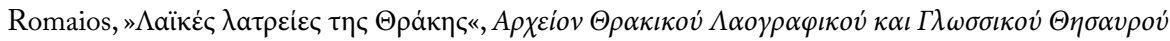

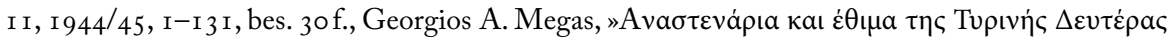

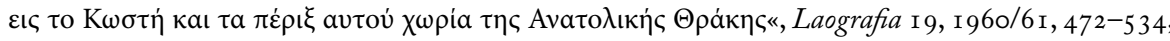
bes. $478,48 \mathrm{I}, 483$ ). Ziel dieser Besuche, meist verbunden mit dem Heiligenfest und seinem panegyri, ist der göttliche Segen und Beistand bzw. die Wunderheilung von Krankheit und Invalidität. Ein anderes Beispiel: Beim hagiasma der Entschlafung der Gottesmutter (I 5. 8.) in Kastania (Papathanasi-Musiopulu, op. cit., I 64f.) speist die Quelle ein Reservoir am Rande des Friedhofs; jede Frau bringt sechs Weihbrote (prosfora) mit, davon fünf für die Panagia, nach der Messe kommt es zur Prozession mit der Marienikone und eine parakletische Litanei wird psalmodiert, das Wasser wird geweiht, Kerzen werden entzündet, Münzen ins Reservoir geworfen, man besprengt einander mit Weihwasser, Gräber werden besucht, Tiere geschlachtet (zwei Schafe und Geflügel), das Fleisch gesegnet und bei einem Symposium gemeinschaftlich verzehrt, jeder Passant (auch Muslim) wird bewirtet, kranke Kinder werden mit Wasser begossen, ihre Kleider zerrissen und in den Fluß geworfen; für drei Tage besteht Fegeverbot, für neun Tage Waschverbot; im russischtürkischen Krieg des I9. Jh.s soll die Panagia das Dorf durch einfallenden dichten Nebel gerettet haben. Diese religiöse/weltliche Festivität ist auch ein Familienfest mit allgemeiner Teilnahme: Die Mutter sorgt für die Herstellung der Weihbrote, der Vater nimmt die Tieropfer vor, die Kinder werden mit Wasser begossen, jede Familie besucht ihre Toten und entzündet für sie eine Kerze (zu

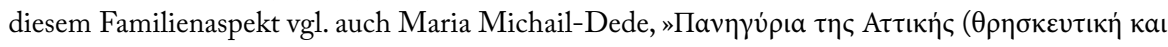

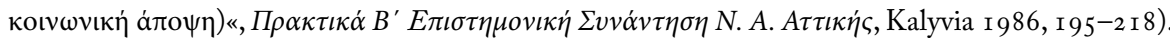
Das Weihwasser des hagiasma wird in Flaschen auch nach Hause gebracht, Kranke werden damit kommuniziert, neue Kleider besprengt, denn hagiasma gilt auch als therapeutisches Mittel (z.B.

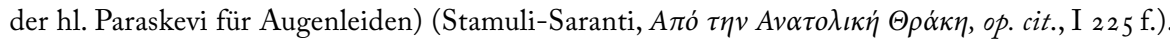
Manchmal finden diese Quellbesuche auch ohne geistlichen Beistand statt, z.B. beim hagiasma des H1. Eustratios in Skopos: Bei einer provisorischen Freilichtkapelle außerhalb der Stadt mit Granitplatte als Altar versammeln sich am Vorabend der Taxiarchen alte Frauen und Männer und bringen jeder einen Hahn (Fertilitätssymbol) mit, der unter Symbolgesten und mit prophetischem Gemurmel geschlachtet wird, während der Anführer die ganze Nacht Wache hält (ibid. 235). 
Charakteristischerweise werden solche Quell-Heiligtümer und Heil-Quellen in der gleichen Weise und zu demselben Zweck von muslimischen Glaubensangehörigen frequentiert $^{160}$.

\section{POPULARE DEVOTIONSFORMEN UND SUPERSTITION}

Zwischen institutionalisiertem und dogmatisch sanktioniertem Glaubensverhalten und dem, was im kirchlichen Umraum und in der Pastoralpraxis wirklich vor sich geht, ist in den traditionellen Oralkulturen Südosteuropas keine grenzscharfe Trennlinie zu ziehen, womit der grundsätzlichen Problematik einer klaren Scheidungsmöglichkeit von Sakralität und Profanität/Säkularisierung eine zusätzliche Schwierigkeit hinzugefügt wird, die, vor allem im orthodoxen Bereich, den Abstand der theologischen Maximen des höheren Klerus von der Praxis des niederen Klerus betrifft, eine Differenz, die sich bereits im byzantinischen Jahrtausend in verschiedenen Fragen bemerkbar gemacht hat. Die Dorfpfarrer und Kreispopen sind der theologischen Akkommodationstaktik der Hochkirche nicht in allen Punkten gefolgt ${ }^{161}$ und hatten Kompromisse mit Glaubensvorstellungen und Praktiken ihrer Gläubigengemeinde einzugehen, so daß in der lokalen Pastoralpraxis eine ganze Reihe von eigentlich "paganen« Riten trotz aller Verbote und Mahnungen des höheren Klerus und der ekklesialen Institutionen bis in die jüngste Vergangenheit weitergelebt haben, was vor allem im orthodoxen Kommunikationsraum durch das Fehlen von Reformation, Gegenreformation und einer weniger durchgreifenden Aufklärung bzw. durch das an Proselytismus grundsätzlich interesselose Verhalten der osmanischen Administration begünstigt worden ist. Insofern ist es eigentlich wenig zielführend, im religiösen Verhalten der Oralkulturen der nichtprivilegierten Unterschichten Südosteuropas pagane/idolatrische von christlichen Elementen unterscheiden zu wollen, magische Superstitionen von sanktionierten Glaubensinhalten, verdammens-

I60 Auch hier werden Waschungen vorgenommen, Kerzen entzündet, Geschenke ausgetauscht usw.; diese Manifestationen festigen den Gemeinschaftsgeist auch in gemischten Kommunitäten. Dazu Frederick William \& Margaret M. H. Hasluck, Christianity and Islam under the Sultans, 2 Bde., Oxford I 929, I 262-264, Olga Vatidu, H X

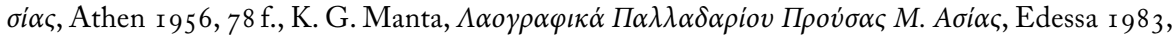

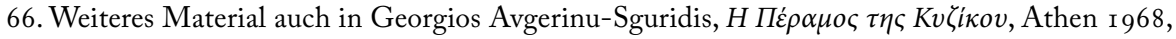

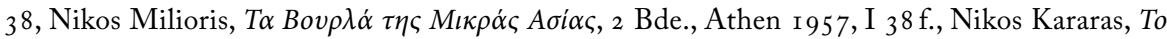

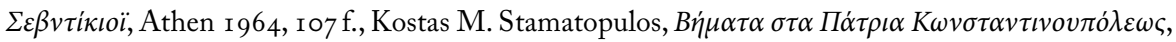
Athen r 989, 29 f., 69 usw.

I6 I Dazu Walter Puchner, Akkommodationsfragen. Einzelbeispiele zum paganen Hintergrund von Elementen der frühkirchlichen und mittelalterlichen Sakraltradition und Volksfrömmigkeit, München 1997. 
werte Praktiken, an denen die Lokalgeistlichen trotzdem teilnehmen, von dogmenkorrektem Verhalten. Die Orthodoxie hat gegenüber dieser byzantinischen oikonomia einer hinnehmenden Toleranz zu zeiten auch fundamentalistischen Eifer an den Tag gelegt, wie etwa an der Bewegung der Kollyvaden abzulesen ist ${ }^{162}$.

\section{I THEOLOGISCHE DOGMATIK UND GELEBTE PASTORALPRAXIS}

In der Folge seien einige Fälle solcher Differenzen näher beleuchtet, die Strukturkonstanten und Denkfiguren dieses hybriden Synkretismus magisch-religiöser Glaubensvorstellungen und -praktiken zu demonstrieren in der Lage sind. Das Assoziationsgewebe des Analogiedenkens im animistisch-dynamistischen Weltbild steht theologischen Dogmenbildungen vom Typus richtig/falsch eigentlich wesensfremd gegenüber, denn die lockeren Verknüpfungsformen des Denkens in Korrelationen aufgrund von Entsprechungen erlauben die Integration und Amalgamierung von schier unbegrenzbaren Glaubensinhalten, deren einziges Differentialkriterium die Tauglichkeit für die Überlebensstrategien der Kommunität ist. Insofern sind die sanktionierten Glaubensinhalte der Hochkirche wesentlichen Mutationen, Uminterpretationen und »Mißverständnissen« ausgesetzt, Mißverständnisse, die die Mentalität der Glaubens-Praktizierenden gar nicht als solche (an)erkennt, weil sie nicht dem Kreis ihres unmittelbaren Lebensinteresses angehören. Religiöses Verhalten in Südosteuropa ist daher ein Paradigmenkanon par excellence für die »Gleichzeitigkeit des Ungleichzeitigen«: Auf dem Traktor und dem Taxi-Wagen klebt neben dem Marienbild und dem hängenden Kreuz das Auge als Amulett gegen den Bösen Blick.

In der Phänomenologie der Volksfrömmigkeit gibt es nicht nur Bereiche, die mehr dem Aberglauben angehören als dem Glauben, sondern auch Manifestationen, die den kreativen Umgang mit den hochkulturellen Vorgaben der ekklesialen Sakralität dokumentieren: Dies ist im Bereich der Ästhetik nachzuweisen, aber auch im Bereich der Legendenbildung und der Bedeutungszuweisung von Heiligennamen durch paretymologische Auslegungen. Im ersten Fall ist es deutlich, daß sich die ästhetischen Präferenzen der nichtprivilegierten Unterschichten auch in Südosteuropa deutlich von den ikonographischen Vorgaben der Kirchenmalerei unterscheiden, die für den eigenen Gebrauch weniger die byzantinische und nachbyzantinische, gotische oder barocke Ikonenund Freskomalerei bevorzugen, sondern deutlich die süßlich romantisierenden Formen,

I62 Ioannis Zelepos, Orthodoxe Eiferer im osmanischen Südosteuropa. Die Kollyvadenberwegung (I750I820) und ibr Beitrag zu den Auseinandersetzungen um Tradition, Aufklärung und Identität im osmanisch-orthodoxen Kommunikationsraum $1750-1820$, Wiesbaden 2012. 
die dem Kitsch zuzurechnen sind, seien dies nun Andachtsbildchen, Papierikonen ${ }^{163}$, Hinterglasmalereien, Marienstatuen oder orthodoxe Heiligenikonen in Feldkapellen. Die Evozierung von Andachtsgefühlen und religiöser Bewegtheit scheint vom Grad der ästhetischen Qualität meditativer Gegenstände weitgehend unabhängig zu sein; die "Kunstlosigkeit« solcher Produkte des Wallfahrtswesens, der urbanen Heiligen- und Kirchweihfeste, der katechetischen Pastoralpraxis und des Massentourismus zu Sakralorten steht in keinem direkten Verhältnis zu ihrem Existenzstatus als Sakralobjekte. Hier eröffnet sich ein weites Feld religionspsychologischer und kunstwissenschaftlicher Untersuchungen, die in Südosteuropa vielfach noch in ihrer Beginnphase stehen ${ }^{164}$.

Der zweite Bereich, der an dieser Stelle bloß erwähnt sei, betrifft die kreative paretymologische Bedeutungszuweisung von Heiligennamen, die gleich auch ihre Eigenschaften und "Zuständigkeit« im Sinne der sprachlichen Analogiebildung festlegen: Der H1. Eleutherios ist für die Niederkunft zuständig ( $\varepsilon \lambda \varepsilon v \theta \dot{\varepsilon} \rho \omega \sigma \eta)$, der H1. Fanurios für

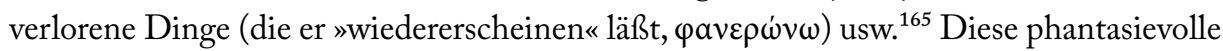
Verballhornung, die den Gesetzen der lautlichen Similität als semantischer Identität folgen, erstreckt sich auch auf andere Bereiche einer modifizierten Kirchensprache, die die Idiomatik und Terminologie der Glaubensmanifestationen umgibt ${ }^{166}$. Zur Phänomenologie der Volksfrömmigkeit gehört auch die Vermittlerrolle der Heiligen zur höchsten Sakralinstanz und ihre Schutzfunktion für Berufe und Städte bzw. ihre Zuständigkeit für bestimmte Krankheiten ${ }^{167}$ und ihre Beinamen ${ }^{168}$; vor ihren Ikonen muß immer eine

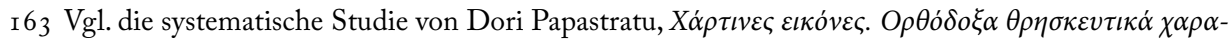

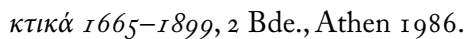

I64 Irina Nicolau/Ioana Popescu, »Le Kitsch comme tradition«, Revista de Etnografie și Folclor 30/2 (1985) I35-I4I, Paul Petrescu, »Les sources populaires et l'évolution de l'art contemporain dans le sud-est de l'Europe«, Revue des Études Sud-Est Européennes 25/ I ( I987) 3-9, Manolis G. Varvunis,

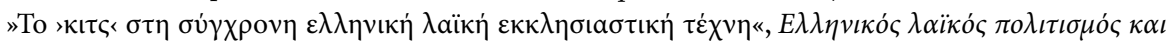

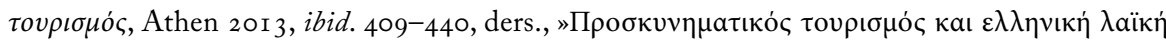

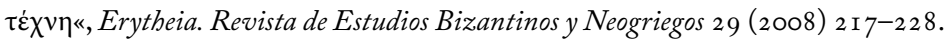

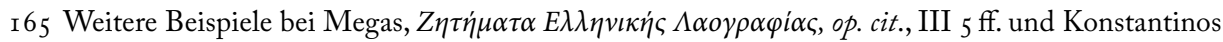

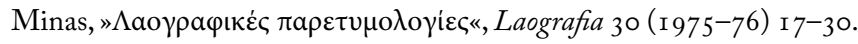

I66 Vgl. die Bibelsprichwörter (Puchner, Die Folklore Südosteuropas, op. cit., I 37).

I67 Was auf den Bildern vielfach zur Darstellung kommt. Vgl. dazu noch in der Folge.

I68 Dies gilt vor allem für die Gottesmutter. $Z u$ den weit über hundert Beinamen der Panagia vgl.

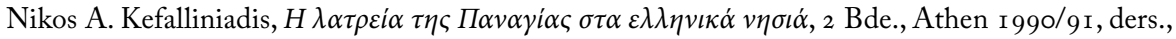

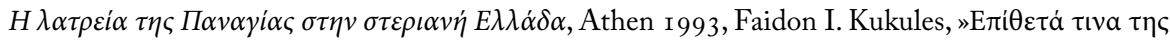

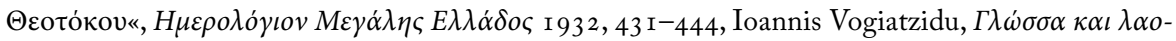

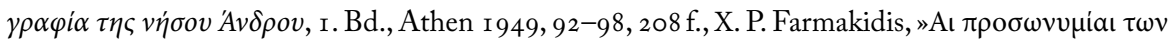

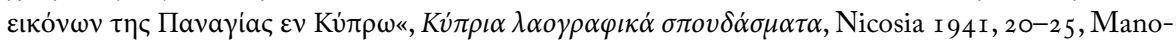

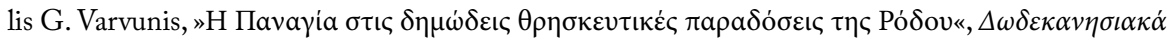
X 
Öllampe brennen. Ikonen zeigen häufig auch den Gründungsmythos der Kirche bzw. die Stifter ${ }^{169}$. Der Naos gilt als Haus des Heiligen, dem die Kirche gewidmet ist. Zu den Standardelementen der Volksfrömmigkeit gehören die Wunderikonen, die Reinigung und Verehrung der Ikonen auch im Haus, die Wasserweihe und der Handel mit dem hagiasma in Flaschen, Fastenzeiten und Kommunion, Arbeitsverbote und Strafen ${ }^{170}$.

\subsection{BILDERVEREHRUNG UND WALLFAHRTSWESEN}

Sakralität manifestiert sich in symbolischen Zwischenstufen zwischen Bildhaftigkeit und Bildlosigkeit. Judaismus, Islam und der frühchristliche Ikonoklasmus sind dafür eingetreten, daß das numinosum keinem konkreten Bildinhalt entsprechen kann, im ostkirchlichen Bereich wurde die Verehrung der Ikone im VII. Ökumenischen Konzil 787 beschlossen, allerdings unter den Restriktionen der theologischen Bilderlehre des H1. Johannes von Damaskus, in der die mystische Abbild-Urbild-Relation ausformuliert

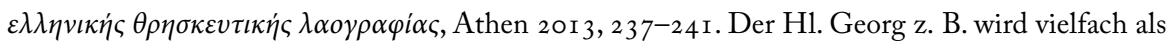
»der Reiter« bezeichnet, und Sagen über Wunderreisen des Heiligen für Hilfe oder Strafe sind im Umlauf (Leopold Kretzenbacher, »Sankt Georg mit dem Jüngling auf dem Streitross«, Münchener Zeitschrift für Balkankunde I, I 978, I 8 I-I 96, ders., Griechische Reiterheilige als Gefangenenretter, Wien I 983, 7-36, Thomas Raff, „Der hl. Georg als Knabenretter«, Münchener Zeitschrift für Balkankunde 3, I980, I1 $3-126)$.

r69 $\mathrm{Zu}$ den Gründungslegenden gehören Standardmotive wie: Die Ikonen zeigen den Platz, Bauverhinderung wenn der Platz dem Heiligen nicht gefällt, Sagen über die Benennung der Kirche, über Strafen beim Versuch des Abreißens der Kirche usw.

I70 Die thaumaturgische Eigenschaft einer Ikone äußert sich in Knistern, Transpiration usw. als Omen; ihr Auffindungsort erfährt eine Benediktion (kathagiasmos), die Kreuzeinweihung hat auch

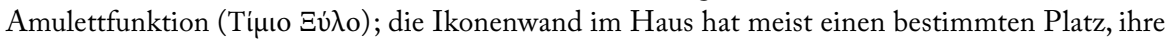
Reinigung und Verehrung ist datumsmäßig vorgesehen. Zum Kirchengebäude gehört vielfach auch das semantron (Stundentrommel) und der Glockenturm mit der Uhr. Es gibt heilige Quellen (hagiasmata), aber auch verwunschenes Wasser (anemoneria, Wohnort der Neraiden): Wasser von hagiasma wird als Medizin in Flaschen verkauft, hinter der Tür aufgehängt gegen Zauber; zu den Heiligenfesten bei Quellen vgl. oben und noch in der Folge. Fastentage sind Mittwoch und Freitag, Fastenzeiten die Quadragesima, die Fastenperiode vor dem I 5. August bzw. die Weihnachtsfasten; Fasten gilt auch als exzeptionelle Strafform; nur der Verzehr von Fastenspeisen ist erlaubt, drei Tage nach dem Fasching herrscht abolutes Eßverbot; Fasten ist auch ein Akt der Reinigung (als unrein gelten schwangere Frauen, Rückkehrende vom Begräbnis; dazu M. L. Arnott, »Ethnographic food habit research in Greece«, Ethnologia Europaea 5, I 97 I, 204-2 Iо, Chr. Enisleidis, O

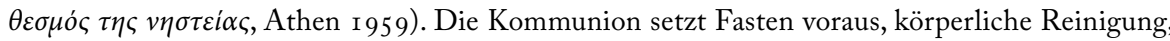
Beichte, Vergebung, Verbote; von ihr sind ausgeschlossen Schwangere nach Abort, Prostituierte, Paare, die in außerehelicher Symbiose leben. Das Verschütten des Meßweins gilt als schlechtes Omen. Zur Volksfrömmigkeit gehören auch die Arbeitsverbote an gewissen Festtagen und die

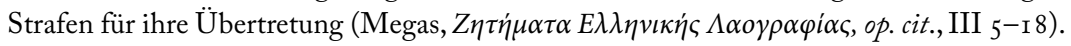


ist $^{171}$; als meditatives »Fenster « in die Schönheit der »anderen «, der eigentlichen Welt ${ }^{172}$, ist es nicht dem Zufall überlassen, was und wie auf einer Ikone abgebildet wird (was in den Malbüchern zu den einzelnen Ikonentypen festgehalten ist), die deshalb auch keine Entwicklung nach Maßgabe individuell-künstlerischer Eingebung aufweisen kann, wie sie für die nachgotische Kunst des westlichen Mittelalters charakteristisch ist. Als Symbolträger des Urbildes in mystischer Korrespondenz ist die Ikone aus sich gnadenemanativer Sakralgegenstand und wird im Osten geküßt wie das Kreuz und das Evangelium. Die feine theologische Scheidung zwischen (Ver)Ehrung ( $\tau \mu \eta \dot{)})$ und Anbetung ( $\lambda \alpha-$ $\tau \rho \varepsilon i ́ a)$ ist in der Glaubenspraxis jedoch kaum zum Tragen gekommen.

I7 I Zum »Geistcharakter« frühchristlicher Bildhaftigkeit vgl. Ernst Kitzinger, The Cult of the Images in the Age before Iconoclasm, Cambridge/Mass 1954, Heinz Skrobucha, Von Geist und Gestalt der Ikonen, Recklingshausen 196r. In der nachikonoklastischen Periode übernimmt die Ikonenverehrung schrittweise Funktionen des Reliquienkults (André Grabar, Martyrium. Recherches sur le culte des reliques et l'art chrétien antique, 2 Bde., Paris I 946, I 33 ff., II 343 ff.). Die Abbildbarkeit Christi wird in seiner Menschennatur begründet (Leonid Ouspensky/Wladimir Lossky, Der Sinn der Ikonen, Bern/Olten 1952, 28 f.). Zur theologischen Ikonenlehre Hans-Georg Beck, Kirche und theologische Literatur im byzantinischen Reich, München 1 959, 476 ff. Bildfeindliche und bildfreundliche Tendenz sind schon im sogenannten areopagitischen System (nach Dionysius Areopagites, 6. Jh.) verschachtelt, einem mystischen Zeichensystem zur Entschlüsselung des unsinnlichen Seins, wobei im »Apophatismus« die höchste Seinsstufe nur mehr negativ darstellbar ist; dazwischen gibt es jedoch verschiedene Symbolstufen sowie eine grundsätzliche Bedeutungsambivalenz der Zeichen. Insofern kann das Abbild mit dem Urbild nicht wesensidentisch sein (Gerhart Ladner, »The Concept of the Image of the Greek Fathers and the Byzantine Iconoclastic Controversy«, Dumbarton Oaks Papers 7, I 953, I-35) und der Betrachter der Ikone ist in ständiger Spannung dazu angehalten, die sinnlichen Zeichen und Bilder zu transzendieren, um die unsinnliche göttliche Welt imaginieren zu können. Der Sieg über die Bilderstürmer wird am ersten Fastensonntag, dem Sonntag »der Orthodoxie" gefeiert.

I72 Die Ikone ist demnach Objekt der Meditation, »Fenster« zum vergöttlichten Sein, »Lebensweg und ein Mittel; sie ist selbst Gebet. Daher ihre Hieratik, ihre majestätische Einfachheit, die Ruhe ihrer Bewegung; daher der Rhythmus ihrer Linien und die Freude ihrer Farben, die einer vollkommenen inneren Harmonie entfließen« (Ouspensky/Lossky, op. cit., 4I). Die kirchliche Kunst ist streng symbolisch, sie bildet die eigentliche Wahrheit ab, aber nicht illusionistisch, denn das Dargestellte entzieht sich von vornherein der menschlichen Faßbarkeit. „Der Sinn der kirchlichen Kunst besteht eben darin, daß sie diese zwei Wirklichkeiten, die Wirklichkeit Gottes und die der Welt, der Gnade und der Natur, wiedergibt, besser gesagt: indem sie darüber in sichtbarer Weise Zeugnis ablegt« (ibid. 37). Diese diffizilen theologischen Spekulationen werden im tatsächlichen Ikonenkult, der mit dem Heiligenkult in unmittelbarer Beziehung steht, freilich bald vergessen. Die Ikone wird selbst zum Idol, und ist nicht bloß Mittel zur Kommunikation mit dem Unsinnlichen; sie wird zum verehrungswürdigen Kultgegenstand aus sich selbst, und nicht nur weil sie dem dahinterstehenden Urbild entspricht (vgl. auch Hans-Georg Beck, Von der Fragwürdigkeit der Ikone, München 1977). Zu der ganzen Frage religiöser Bildhaftigkeit auch Hans Belting, Bild und Kult. Eine Geschichte des Bildes vor dem Zeitalter der Kunst, München ${ }^{2}$ I 99 I. 
Der griechische Religionssoziologe Demosthenes Savramis hat sich kritisch mit den »abergläubischen Mißbräuchen« des Bilderkults in Byzanz auseinandergesetzt und die Ikonenverehrung als nichtchristliche Tradition, die auf die Kaiserbildverehrung der Römerzeit zurückgeht, hingestellt ${ }^{173}$. Zu solchen »abergläubischen Mißbräuchen« zählen Wunderlegenden über Stadtrettung, Krankenheilung, Holz und Malfarbe der Ikonen als Talismane und Amulette, Blumenschmückung der Bilder, Versilbern und Vergolden der Ikone, angehängte Votivgaben usw. ${ }^{174}$ Die diffizilen Spekulationen um das apophatische System bildlicher Verkörperung des Unabbildbaren, greifbar etwa in den »nicht von Menschenhand gemalten Bildern « (ахعıротої $\tau \alpha)^{175}$, sind der Glaubenspraxis jedoch mehr oder weniger fremd geblieben, und die Ikonolatrie unterscheidet sich im Kultverhalten nur graduell von der Idolatrie. Insofern ist das Bildverständnis in Ost- und Westkirche (wo eine solche dogmatische Kontrolle der Ikonographie aufgrund des Fehlens der ikonoklastischen Auseinandersetzungen nicht anzutreffen ist) mehr eine Sache theologischer Dogmatik als gelebter Glaubenspraxis geblieben. Wunderikonen und Ikonenwunder sind in Ost und West gleichermaßen anzutreffen ${ }^{176}$, ebenso wie Gnadenorte und Wallfahrten zu heiligen Stätten. Ein greifbarer Unterschied besteht jedoch im Fehlen dreidimensionaler Darstellungen im Osten aufgrund des byzantinischen Skulpturverbots plastischer Figürlichkeit, das sich gegen die Anbetung von Götterstatuen in hellenistisch-römischer Zeit wendet ${ }^{177}$.

I 73 Demosthenes Savramis, „Der abergläubische Mißbrauch der Bilder in Byzanz«, Ostkirchliche Studien 9 ( 1960$)$ 1 $74-192$.

I74 Dieser an sich fruchtbare Ansatz wird allerdings auf dogmatisch-sterile Art abgehandelt, wenn der Autor meint, die Massen des Kirchenvolkes hätten das wahre religiöse Anliegen der Kirche verfälscht (Savramis, op. cit., I 75) und wenn der Volksglaube mit dem »Aberglauben« gleichgesetzt wird (ibid. I 80, Anm. 32). "Die theologische und philosophische Tiefe der Lehre von den Bildern, die die Kirche entwickelte, konnte aber nicht in das Volk eindringen und von den Massen verstanden werden« (ibid. I 8 I). Daß aber gerade diese Differenz von Intereesse für die Kulturforschung sein könnte, ist dem genannten Religionssoziologen nicht in den Sinn gekommen. Zu solchem »Aberglauben« vgl. u. a. Leopold Kretzenbacher, Das verletzte Kultbild, München 1977, ders., »Ikonotropie zu Kultbildern und Fresken in Südosteuropa«, Südost-Forschungen 29 ( 1970) 249-266.

I75 Ernst von Dobschütz, Christusbilder. Untersuchungen zur christlichen Legende, Leipzig I 899, Gilles G. Meersseman, »Leggende dell'Oriente cristiano nella letteratura e nell'arte figurativa del Medioevo«, Atti del convegno internazionale sul tema "L'Oriente cristiano nella storia della civiltà «, Roma I964, 239-250.

I 76 Wolfgang Brückner, »Heiligenbild«, Enzyklopädie des Märchens 6 ( I 988) 677-682, Hans Dünninger, »Ablaßbilder. Zur Klärung der Begriffe Gnadenbild und Gnadenstätte«, Jahrbuch für Volkskunde N. F. 8 ( I 985) 50-91, ders., "Gnade und Ablaß - Glück und Segen. Das Verhüllen und Enthüllen heiliger Bilder", ibid. го (1987) I 35-I 50, Wolfgang Brückner, Gnadenbild und Legende, Würzburg 1 978, Lenz Kriss-Rettenbeck, Bilder und Zeichen religiösen Volksglaubens, München 1962 (² 97 I), Wolfgang Brückner, »Bild, Bildzauber«, Enzyklopädie des Märchens 2 ( I 979) 319-326.

I 77 Ausnahmen bilden die Reliefikonen (vgl. z. B. Ioli Kalavrezou-Maxeiner, Byzantine Icons in Steatite, 2 Bde., Wien I985). 
Somit ergeben sich in den Lokalregionen Südosteuropas graduelle Abstufungen zwischen Bildhaftigkeit und Bildlosigkeit nach Maßgabe des Vorherrschens von Katholizismus, Orthodoxie oder Islam/Judaismus. Doch das Sakralitätszentrum einer Gnadenstätte mit Wunderheilungen, Votivgaben, Gelübden, Bußübungen usw. ist nicht nur eine thaumaturgische Ikone oder Vision, sondern auch das Vorhandensein von Reliquien von heiligen Personen ${ }^{178}$. Reliquienbesitz war im mittelalterlichen Kirchen- und Klosterwesen eine wesentliche Voraussetzung für Einfluß, Macht und Reichtum, und nach dem 4. Kreuzzug mit der Einnahme Konstantinopels durch die Lateiner I 204 wurden viele Reliquien nach dem Westen verschleppt ${ }^{179}$. Die frappante Streuweite und Nachweisdichte von Reliquien einer einzelnen Sakralperson an verschiedenen Orten in einem bedeutenden geographischen Radius ist Indikator und Pegelmesser für die wichtige religionssoziologische und kommerzielle Dimension des Reliquienbesitzes ${ }^{180}$.

Wallfahrten und Pilgertum sind religionsübergreifende Phänomene mit komplexen Implikationen für Kultur und Gesellschaft, die nicht nur den Ort der heiligen Stätte betreffen, sondern auch den Herkunftsbereich der Pilger, ihre Kommunität und Fami$\operatorname{lie}^{181}$. Pilgertum stellt auch eine frühe Form des Tourismus dar, eine Massenbewegung

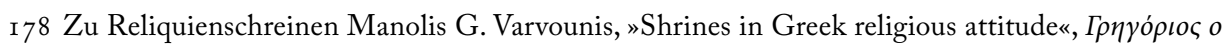

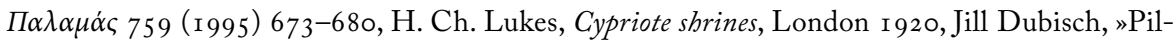
grimage and Popular Religion at a Greek Holy Shrine«, E. Badone (ed.), Religious Orthodoxy and Popular Faith in European Society, Princeton I 990, I I $3-1$ 36, usw.

${ }_{179} \mathrm{Zu}$ den Lazarusreliquien in Autun (von Konstantinopel aus) und den westlichen Legenden um sein zweites Leben als Bischof von Marseille vgl. Puchner, Die Folklore Südosteuropas, op. cit., I $26-$ I 29. Die H1. Demetrios-Reliquien fanden sich von Thessaloniki aus im italienischen Sassoferrato

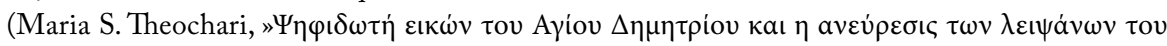

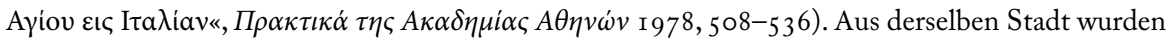
die Reliquien des Hosios David nach Pavia gebracht (Raymond-J. Loenertz, „Saint David de Thessalonique«, Revue des Études Byzantines I I , I 953, 205-223).

I 80 Zur Streuweite der Verbreitung von Reliquienteilen von Heiligen im Balkanraum vgl. Otto Meinardus, »A study of the Relics of Saints of the Greek Orthodox Church«, Oriens Christianus 54 (1970) I 30-275. Vgl. auch zur Verteilung der Reliquien: David Parin, »Ritual as spatial direction and bodility division«, Daniel de Coppet (ed.), Understanding Rituals, London/New York I 992, $\mathrm{I}_{3} \mathrm{ff}$.

I 8 I Bernhard Kötting, Peregrinatio religiosa. Wallfahrten in der Antike und das Pilgerwesen der alten Kirche, Münster I950, Hartmut Kühne et al., Europäische Wallfahrtsstudien, Frankfurt 2006 ff., Hans Dünninger/Wolfgang Brückner (eds.), Wallfahrt und Bilderkult, Würzburg I 995, Hans Dünninger, "Processio peregrinationis. Volkskundliche Untersuchungen zu einer Geschichte des Wallfahrtswesens im Gebiete der heutigen Diözese Würzburg 2«, Würzburger Diözesangeschichtsblätter 24 ( I 962) 52-г 88, Wolfgang Brückner, »Wallfahrten«, Enzyklopädie des Märchens I 4 (20 I I) 458-466, Alan Morinis, »Introduction: The Territory of the Anthropology of Pilgrimage«, ders. (ed.), Sacred Journeys. The Anthropology of Pilgrimage, Westport, Conn./London I 992, I-28, Victor \& Edith L. B. 
geographischer Mobilität, von der Karawansereien, Pilgerheime, Raststätten, Bruderschaften usw., aber auch Räuber und Piraten ihren Lebensunterhalt verdienen ${ }^{182}$. Die Fernwallfahrten nach Mekka, nach Palästina und nach Santiago di Compostella stellen vielfach auch einen Höhepunkt im Leben des peregrinus dar, oft verbunden mit einem Gelübde oder Schwur für empfangene divine Wohltaten oder in Erwartung von solchen $^{183}$. Ganze Regionen wie etwa der Kreuzfahrerstaat Zypern (unter venezianischer

Turner, Image and Pilgrimage in Christian Culture. Anthropological Perspectives, New York 1978, usw. I 82 Ellen Badone/Sharon R. Roseman (eds.), Intersecting Journeys. The Anthropology of Pilgrimage and Tourism, Urbana/Chicago 2004, Simon Coleman/John Eade (eds.), Reframing Pilgrimage. Cultures in Motion, London/New York 2004, Alphonse Dupront, »Tourisme et pélerinage: Réflexions de

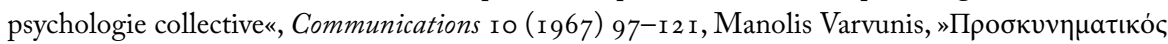

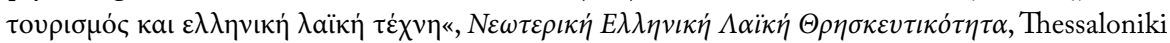

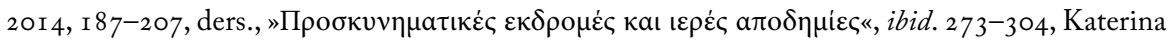

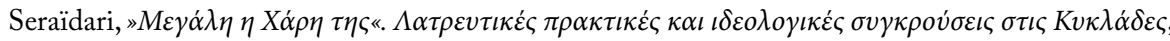

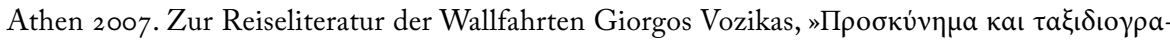

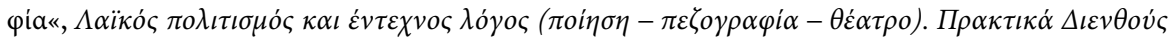

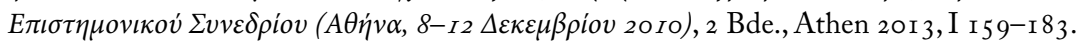

I 83 Bei der christlichen Bevölkerung im historischen Thrakien (heute Bulgarien, Europäische Türkei) wurde die aufgrund von Räubern und Piraten gefährliche Reise mit sorgfältig zusammengestellter Ausrüstung (Wegzehrung, Decken, Kleider, Geschenke an die Mönche an den H1. Stätten usw.) vor Weihnachten angetreten, mit erwarteter Rückkehr nach Ostern. Die Pilger trafen sich unter verschiedenen rituellen Vorkehrungen zu einem Abschiedsessen bei Verwandten (in Kleinasien

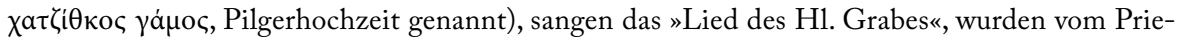

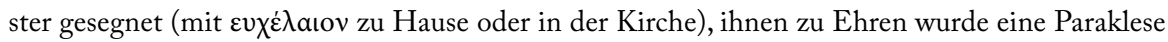
gelesen; der Abschiedszug von Verwandten und Freunden, mit hexapteryga, Priester im Ornat und Psalmensänger, begleitete die Pilger unter Glockengeläute bis vor das Dorf. Die Pilger-Karawanen wurden gewöhnlich von türkischen Soldaten begleitet wegen der Räuber. An den H1. Stätten besuchte man das H1. Grab, den Golgata-Hügel, Bethlehem, Gethsemane, das Mariengrab, Bethanien, das Lazarusgrab, den Jordanfluß usw.; man übernachtete in Klöstern, die Pilgerzüge im H1. Land fanden gewöhnlich unter Soldatenbegleitung statt. Vom Patriarchen erstand man Ablaßzettel ( $\sigma \nu \gamma \chi \omega \rho \circ \chi \alpha \dot{\rho} \tau \iota \alpha)$, man kaufte Tücher für Verwandte, Wachskreuze, Rosenkränze, Bet- und Spielketten (kombologia), Ikonen, Heiligenviten u.a. als Geschenke; ferner Fläschchen mit Jordanwasser, Erde vom H1. Grab, Kerzen vom H1. Licht, 33 Kerzen (Alter Christi), Kerzen für die Ikonen im Haus, Ikonen für die Kirche, Räucherwerk, Splitter vom Kreuzesholz usw. Die Verwandten wurden über den Rückkehrtag informiert und die Familie, Verwandte und Freunde empfingen die Pilger in Prozession mit Priester, Psalmensänger und hexapteryga vor dem Dorf. Die Prozession bewegte sich in Richtung Kirche, dort wurde eine Dankesmesse (doxologia) für den glücklichen Ausgang der Reise abgehalten; die Kirchengemeinde wurde im Haus des Pilgers empfangen, Geschenke verteilt, Begebnisse erzählt, Gefühlen Ausdruck verliehen und der Wunsch ausgesprochen, daß auch andere diese einzigartige Freude erleben können; denn nun sei man vorbereitet für die Reise ohne Rückkehr. Der soziale Status eines hatzis war außerordentlich; ihm wurde sogar die

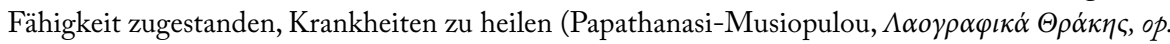


Herrschaft bis I 57 I) sind in ihrem Kulturprofil von dem Pilgerstrom aus dem Westen geprägt, da das Eiland der Aphrodite die letzte Station der Seereise ins Hl. Land bzw. die erst auf der Rückreise darstellte ${ }^{184}$.

Die Reise als rite de passage und Initiationsprozeß par excellence erhält in der Spielart der Wallfahrt noch eine zusätzlich spirituelle Funktion ${ }^{185}$. Im Balkanraum und in Kleinasien dominieren die islamischen Wallfahrten nach Mekka ${ }^{186}$ und die christlichen Pilgerreisen nach Palästina ${ }^{187}$, beide nach arab./türk. hac, hacı, hajjī, hadjdj usw. genannt (chadžii, $\chi \alpha \tau \zeta \zeta \dot{\eta} \delta \varepsilon \varsigma$ usw.), im slovenischen Raum auch die Jakobspilger nach Santiago di Compostella ${ }^{188}$. Die einschlägige Literatur zum Wallfahrtswesen Südosteuropas ist vor allem auf dem komparativen Sektor nicht allzu reichhaltig, was vielfach auch mit den politischen Entwicklungen des 20. Jh.s zu tun hat ${ }^{189}$; von herausragender Bedeutung

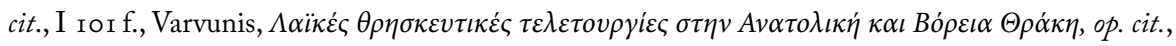
$364 \mathrm{ff}$.).

I 84 Die umfangreiche Literatur zum hybriden Charakter von Kultur und Gesellschaft Zyperns zwischen Ost und West im Zeitraum I I 9 I-I 57 r zusammengestellt bei Walter Puchner, H Kú $\pi \rho \circ \varsigma \tau \nu v$

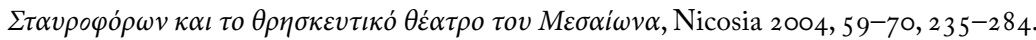

I 85 Richard P. Werbner, Ritual Passage Sacred Journey: the Process and Organization of Religious Movement, Washington/Manchester 1989, Edward D. Hunt, Holy Land Pilgrimage in the Later Roman Empire AD 312-460, Oxford I982, John Eade/M. Sallnow (eds.), Contesting the sacred: The anthropology of Christian pilgrimage, London/New York 199r, Fiona Bowie, The Anthropology of Religion. An Introduction, Oxford 2006, Victor Turner, „Liminal to liminoid in play, flow and ritual. An essay in comparative symbology «, Rice University Studies 60/3 (1974) 53-92, ders., "Pilgrimage and communitas«, Studia Missionalia 23 ( 1974) 305-327, ders., »Ritual, tribal and catholic«, Worship 50 (1976) 504-526, Victor Turner/Edith Turner, Image and Pilgrimage in Christian Culture, Columbia I 978, Émile Durkheim, The Elementary Forms of the Religious Life (transl. Karen E. Fields), New York 1995, 33-39, Don Handelman, Models and Mirrors: Towards an Anthropology of Public Events, Cambridge i 990 .

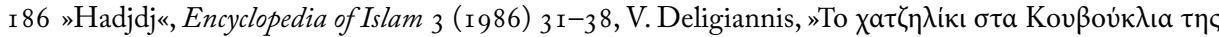

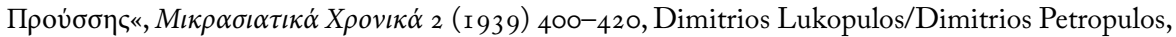

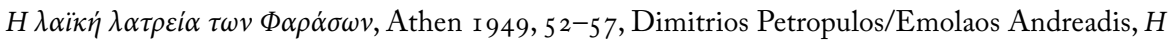

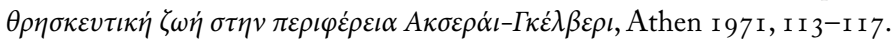

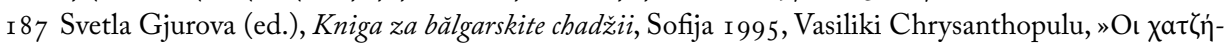

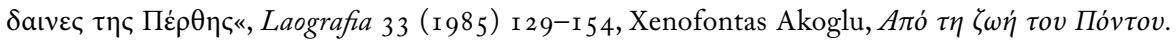

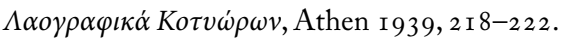

I 88 Vgl. die slovenischen Legendenlieder in Puchner, Die Folklore Südosteuropas, op. cit., 54-57.

I 89 Stefan S. Bobčev, "Notes comparée sur les Hadjis balkaniques«, Revue internationale des études balkaniques 2 (1936) I-I 2, Gábor Tüskés/Éva Knapp, »Mirakelliteratur als sozialgeschichtliche Quelle barockzeitlichen Wallfahrtswesens in Ungarn«, Schweizer. Archiv für Volkskunde 74 (1988) 79-103. Allerdings auch in Griechenland beginnt das Wallfahrtswesen erst in letzter Zeit Gegenstand intensiverer volkskundlicher Forschung zu werden (vgl. Manolis G. Varvounis, »Shrines in

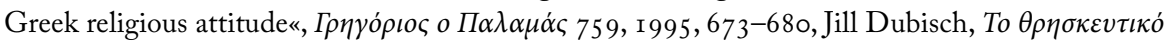


sind weiterhin die Monographien und Studien von Rudolf Kriss, Hubert Kriss-Heinrich und Lenz Rettenbeck ${ }^{190}$.

Nach Maßgabe der Reisedistanz kann man die Fernwallfahrten, die einmal im Leben vorgenommen werden, von den Regionalwallfahrten, zu denen man sich öfter entschließt, unterscheiden (z.B. zum schwarzen Marienbild in der Kirche der Szegeder Unterstadt, Csíksomlyó ${ }^{191}$, Siebenbürgen ${ }^{192}$, das slovenische Ruše/Maria Rast, Međugorje bei Mostar ${ }^{193}$, das berühmte Fresken-Kloster von Gračanica ${ }^{194}$, das bulgarische Rila-Kloster ${ }^{195}$, die Marienikone auf Tinos ${ }^{196}$, die Panagia als Ärztin auf dem Tay-

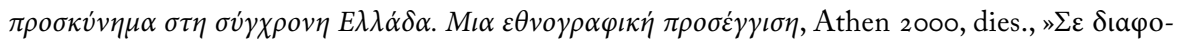

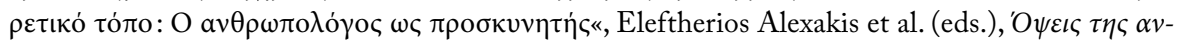

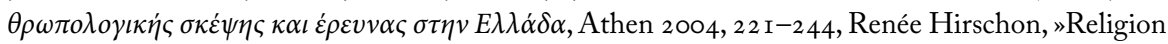
and Nationality: The Tangled Greek Case«, Rik Pinxten/Lisa Dikomitis (eds.), When God Comes to Town. Religious Traditions in Urban Contexts, New York/Oxford 2009, 3-16).

190 Rudolf Kriss/Hubert Kriss-Heinrich, Peregrinatio Neohellenika. Wallfahrtswanderungen im heutigen Griechenland und in Unteritalien, Wien I 955, dies., »Beiträge zum religiösen Volksleben auf der Insel Cypern mit besonderer Berücksichtigung des Wallfahrtswesens«, Rheinisches Jahrbuch für Volkskunde I 2 (196I) I 35-2 Iо, dies., Volksglaube im Bereich des Islams, 2 Bde. I 960-62, I 292-340, Rudolf Kriss, »Volksreligiöse Opferbräuche in Jugoslawien«, Wiener Zeitschrift für Volkskunde 35 ( 935 ) 49-63, ders., »Votive und Weihgaben des italienischen Volkes«, Zeitschrift für Volkskunde N. F. 2 (I 93 I) 249-27 I, Rudolf Kriss/Lenz Rettenbeck, Wallfahrten Europas, München 1950.

I9I Dorthin zieht die ganze katholische Bevölkerung des Szeklerlands mit Fahnen und Gesang, wird von den Dörflern umsonst oder billig beherbergt bzw. die Pilger schlafen in der Kirche (Balassa/ Ortutay, Ungarische Volkskunde, op. cit., I 2 I f.). Die griechisch-katholischen Uniierten haben Wallfahrtsorte auch in Máriapócs, in Andócs in Südwest-Ungarn, in Radna bei Szeged usw.

I 92 Constantina Cristescu, »Pilgrimage and pilgrimage song in Transylvania«, East European Meetings in Ethnomusicology I (1994) 3 I ff.

I93 Mart Bax, »The Seers of Medjugorje. Professionalization and Management Problems in a Yugoslav Pilgrimage Centre«, Ethnologia Europaea 20 ( I 990) I67-I 76, Pedro Ramet, »The Miracle at Medjugorje - A Functionalist Perspective«, The South Slav Journal 8/I-2 (I985) I 2-20.

I 94 Tatomir P. Vukanović, „Gypsy Pilgrimages to the Monastery of Gračanica in Serbia«, Journal of the Gypsy Lore Society, ser. 3, 45/I-2 (1966) i 7-26.

I 95 Zentralbalkanisches Wallfahrtszentrum für Bulgaren, Griechen, Aromunen und Sarakatsanen (E.

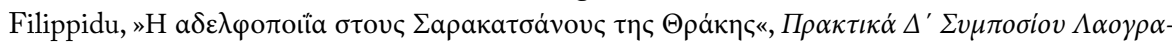

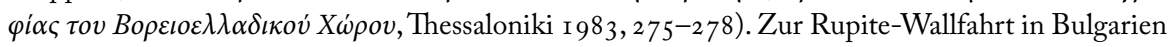
Galia Valtchinova, „Entre religion, politique et tourisme: le pelerinage de Rupite, en Bulgarie«, Ethnologie Française 3 (1998) 396-405.

I96 Dazu gibt es eine Fülle von Literatur. Die Anstiegstreppe zum Kirchenhügel wird meist auf den Knien oder bäuchlings erklommen. In Auswahl: Jill Dubisch, „Golden Apples and Silver Ships: An Interpretative Approach to a Greek Holy Shrine«, Journal of Modern Greek Studies 6 (I988) I I 7-I 34, dies., »Pilgrimage and Popular Religion at a Greek Holy Shrine«, Ellen Badone (ed.), Religious Orthodoxy and Popular Faith in European Society, Princeton I 990, I I 3-136, dies., "'Men's time and `women's time $<$ : History, Myth, and a Modern Greek Shrine«, Journal of Ritual Studies 
getos $^{197}$, der Berg Athos mit seinen 24 Klöstern ${ }^{198}$, die »Panagia des Charos« of Leip$\operatorname{sos}^{199}$, die Kykladeninseln ${ }^{200}$ usw.), die sich heute zu einer Art organisiertem religiösen Massentourismus entwickelt haben, von dem ganze Regionen profitieren. Daneben lassen sich Formen des »ökologischen« Pilgerwesens differenzieren, die zu Fuß in Prozessionsform vorgenommen werden. Die Motivationen und Organisationsformen sind unterschiedlich und komplex: brauchtümliche Begehung zu gewissen Jahresdaten, Prozessionsordnung mit Litaneien, Priestern und Sakralgegenständen, Gebeten und Liedern, Stationen und Bußübungen, individuelle Anreiseformen und Formung eines Pilgerkollektivs erst vor Ort, Initiationsriten und Anbetungsformen, Wunderberichte und Handel mit Broschüren, Andachtsbildern, Souvenirs, Flaschen mit Weihwasser, Heilkräutern, Heiligenviten, Rosenkränzen, Gebetsketten, Amuletten, Schutzbriefen, lokalen Agrarprodukten usw., aus persönlichen oder konventionellen Gründen, wie Gelübde, Krankenheilung, Bangen um den Erntesegen, Wunschverwirklichung usw., mit Votivgabe, Opferformen, Kerzenspenden, Geldgaben, Namensnennung während der parakletischen Bittmessen usw. ${ }^{201}$

5/I (I99I) I-26, dies., "The Church of Announciation of Tinos and the Domestication of Institutional Space«, Yearbook of Modern Greek Studies ro/ I I (1994/95) 389-4I 5 , dies., In a Different Place: Pilgrimage, Gender, and Politics at a Greek Island Shrine, Princeton 1995, Alekos E. Florakis, $H$

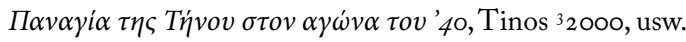

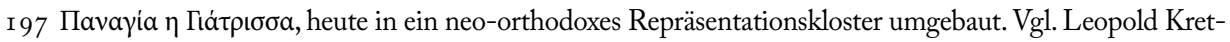
zenbacher, »Bergwallfahrt zur `Hochheiligen Ärztin auf dem Taygetos«, Ethnologia Europaea. Studienwanderungen und Erlebnisse auf volkskundlicher Feldforschung im Alleingang, München 1986, I07-I 5.

I98 Die umfangreiche Literatur dazu sei hier ausgespart.

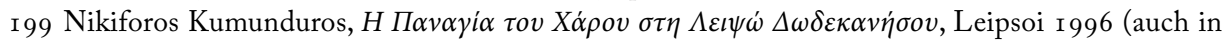

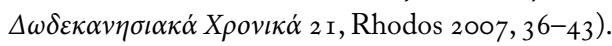

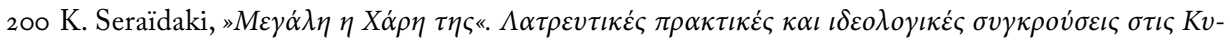
$\kappa \lambda \alpha \dot{\alpha} \delta \varepsilon$, , Athen 2007.

20r Eine der Hauptaktivitäten seitens der Pilger ist die Darbringung von Votiven und Weihgaben an die Ikone oder den Reliquienschrein, seitens der Sakralinstanz das Hinwegtragen des Gnadenbildes oder des Silberschreins mit den Reliquien in Prozession über die hingelagerten Kranken, die derart auf Heilung hoffen (zur Marienikone auf Tinos am Festtag der Verkündigung und der Entschlafung Marias 25.3. und I 5. 8. Kriss/Kriss-Heinrich, Peregrinatio neohellenika, op. cit., 32 ff., dem Schrein des H1. Gerasimos auf Kefalonia und des H1. Spyridon auf Korfu ibid. 55 ff.). In diesen Heilvorstellungen spielt die Berührungsmagie der Kraftübertragung aus dem Sakralgegenstand oder dem darunter befindlichen Altartuch bzw. das Weihwasser-Besprengen (hagiasmos) eine wesentliche Rolle. Denselben Brauch übten die Jesuiten schon im I7.Jh. auf Naxos (Walter Puchner, Griechisches Schuldrama und religiöses Barocktheater im ägäischen Raum zur Zeit der Türkenherrschaft (1580-I750), Wien I 999, 82-85). Der hagiasmos wird im allgemeinen auch bei Epidemien, bedrohtem Ernteerfolg usw. durchgeführt, zur Verstärkung mit den Reliquien aus dem nahen Kloster. Die Berührungsmagie zur Heilung des Kranken erfolgt auch durch das Auflegen des Petrachelions des Popen auf den Kopf des Leidenden, Bekreuzigung mit der H1. Lanze, Auflegen des Evangeliums, Berühren der Meßgewän- 
Neben solchen institutionalisierten Formen kollektiver proskynetischer Mobilität zu zentralisierten Orten der Andachtsübung und Heiligenverehrung mit bedeutendem Zulauf von Gläubigen und Pilgern gibt es jedoch auch mikroregionale Stätten der Devotionalität in einem Einzugsbereich von wenigen Kilometern: Das sind die sogenannten proskynetaria: Feld- und Bergkapellen, Straßenkreuze, kleine Ikonenschreine in aus Ziegeln oder mit Beton (früher aus Holz oder Eisen) gebauten Häuschen in Kuppelform auf einer erhöhten säulenartigen Basis am Straßenrand mit Ikone, Blumen, Weihrauch und Öllampe mit Feuerzeug hinter einer glasbedeckten Öffnung, die tagtäglicher Wartung bedürfen und von den Umwohnern regelmäßig frequentiert werden ${ }^{202}$. Diese Mini-Kapellen waren einst die Sakralzeichen der metaphysischen Geographie rund um den Siedlungsbereich, Marksteine des divinen Schutzes gegen die Dämonen der »wilden« Natur; nach dem Aufkommen des Automobilverkehrs sind sie meist Erinnerungsdenkmäler an einen Autounfall mit letalem Ausgang oder eine andere unglückliche Begebenheit und werden nicht von der Kommunität bzw. Pfarre errichtet, sondern von Privatpersonen, Verwandten und Leidtragenden. Die Morphologie dieser persönlichen und kollektiven Andachtsstätten dieser bescheidenen lieux de mémoire hat in den letzten Jahrzehnten stark zugenommen und zeigt in der Ausgestaltung zunehmend individuelle Züge ${ }^{203}$. Zu-

der usw. (vgl. auch Juliet Du Boulay, Cosmos, Life, and Liturgy in a Greek Orthodox Village, Limni, Evia 2009). Hier kommt auch das Prinzip der Proxemik zum Tragen, z.B. soll das gebückte Hindurchgehen durch den hochgehaltenen Epitaph-Baldachin in der Karfreitagnacht nach der zyklischen Epitaphprozession um das Dorf am Kircheneingang gegen Kreuzschmerzen helfen; zur symbolischen Bedeutung von Nähe und Ferne vom Sakralgegenstand bei Prozessionen vgl. auch Manolis G.

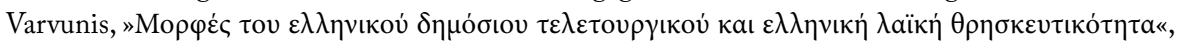

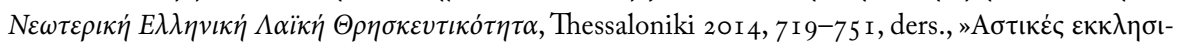

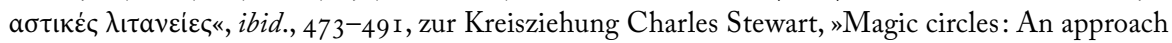
to Greek ritual«, Journal of the Anthropological Society of Oxford 25/I (I994) 9I-IoI, zum Anteil von Frauen und Bejahrten Renée Hirschon, „Women, the aged and religious activity: Oppositions and complementarity in an urban locality", Journal of Modern Greek Studies I (I983) I I 3-I 29.

202 Kalkweißen des »Gebäudes« zu Weihnachten und Ostern, Blumenwechsel, Ölnachfüllen, Kontrolle des Öllichts, Dochtschneuzen, Reinigung, Wiederanzündung, Ikonenwaschung usw. Diese Art der Devotion ist den umliegenden Privatpersonen überlassen bzw. den Stiftern der Andachtsstätte, die auch ohne kirchliche oder kommunale Genehmigung errichtet werden kann.

203 Dazu Ralph Hurlbutt, The Phenomenology of Proskinitaria, Hamline Univ. I985, N. Papadakis, $₫ \alpha-$

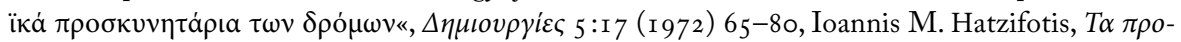

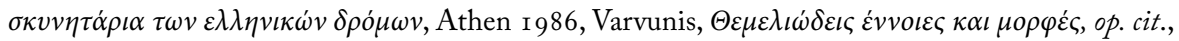

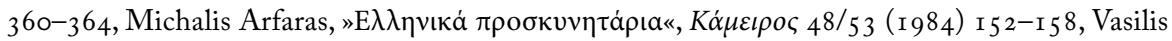

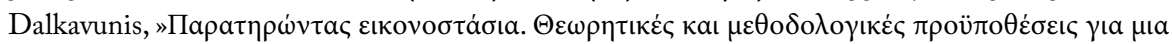

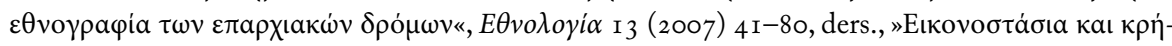

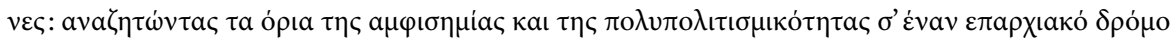

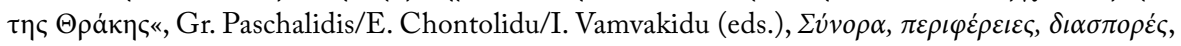


sammen mit den islamischen Brunnen und eingefaßten Quellen prägen sie das charakteristische Bild der südosteuropäischen Landstraße.

Die neuesten Entwicklungen auf dem Sektor des religiösen Tourismus mit Busreisen zu Heiligen Stätten betreffen nicht mehr nur die Pilger selbst, sondern auch fremdgläubige Touristen, die die Wallfahrt als touristische Attraktion erleben: im Internet wird eine Reise zum Bektași-Bergheiligtum Tomori südöstlich vom albanischen Berat angeboten, wo sich jährlich Ende August Tausende von Pilgern des muslimischen Ordens zum Kulmak-Tekke des Baba Ali Tomori auf I6oo Meter Höhe einfinden, während das eigentliche Pilgerziel, die Gedenkstätte zu Ehren des Abbaz Aliu von Kerbela auf dem Südgipfel des Tomori in 2.400 Metern Höhe liegt, was als reinigende Höhenwanderung angeboten wird; in entwaffnender Aufrichtigkeit gesteht das Gruppenreise-Angebot, daß damit keine religiösen Ziele verfolgt werden, stellt aber einen Bergführer, die Übernachtung im Zelt am Kulmak-Paß sowie vollwertige Verpflegung in der Höhe in Aus$\operatorname{sicht}^{204}$.

\section{$4 \cdot 3$ HEILIGENFESTE UND HANDELSM ÄRKTE}

Eine andere Form der Geselligkeit in gemischt sakral/profanem Rahmen sind die Heiligenfeste, Kirchweihfeste (Kirmes, Kirtag), Jahrmärkte und Handelsmärkte, mit einem

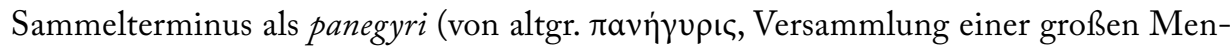
schenmenge) oder türk./slav. als pazar/bazar (Markt) bezeichnet ${ }^{205}$, einer Festivität mit der Ansammlung einer zu sakralen oder merkantilen Zwecken angereisten Menschenmenge, neben den ev. Transaktionen von Kauf und Verkauf auch mit deutlich unterhaltendem und kommunikativem Charakter, dem Austausch von Informationen und Geschichten, dem Kennenlernen der Jugend, Tanz und Musik, Brautschau und Demonstration der maskuliner Muskelkraft und Geschicklichkeit in Kampfspielen, sowie anderen Unterhaltungen und Spielen ${ }^{206}$. Bei manchen Festen bei den einem bestimmten Heiligen geweihten Kirchen und Kapellen kommt es auch zu einem bemerkenswerten

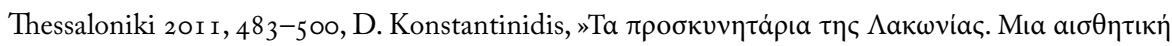

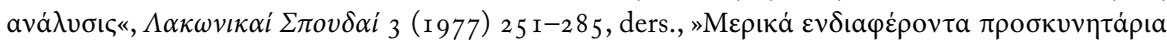

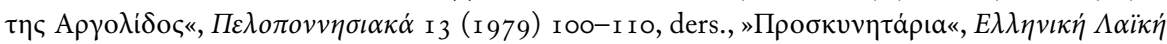
Tغ́x $v \eta$ I 3 (1973) 208-225, usw.

$204 \mathrm{http}: / / w w w / r e i s e n-i n-a l b a n i e n . d e / a l b a n i e n r e i s e / r e i s e b a u s t e i n e-3 /$ bekashifest.html

205 Der Ausdruck panegyri ist in anderen Balkansprachen nicht unbekannt, vor allem als panegirik,

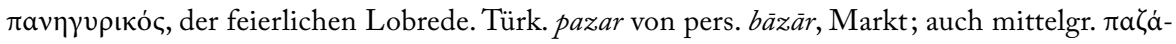
$\rho \mathrm{l}(\mathrm{o}) v$, sowohl Markt wie auch Verkaufsverhandlung.

$206 \mathrm{Zu}$ den sozialen Funktionen auch Edith Turner, Communitas. The Anthropology of Collective Joy, New York 2012. 
Synkretismus zwischen orthodoxer und muslimischer Bevölkerung, wie etwa beim H1. Georg und beim Propheten Elias, der im Sommer auf hochgelegenen Bergkapellen und Bergspitzen gefeiert wird, welche beide im sufisch-islamischen Heiligen Chadir kontaminieren $^{207}$, oder dem Bektași-Heiligen Sarı Saltuk, der dem H1. Nikolaos gleichgestellt ist, aber auch mit Georgios und Symeon kontaminiert ${ }^{208}$. Die großen Handelsmärkte

207 Der islamisch-sufische General-Heilige Chadir erscheint sowohl als H1. Georg als auch als Prophet Elias. Dazu Kriss/Kriss-Heinrich, Volksglaube im Bereich des Islam, op. cit., I I 54-164, Rudolf Kriss, »St. Georg - al Hadr Ihadir, Hidr«, Bayerisches Jabrbuch für Volkskunde I 96o, 48-56, ders. »Sanct Georg in der islamischen Welt", S. Metken et al. (eds.), Sanct Georg. Ritter mit dem Drachen, FreisingLindenberg/Allgäu 200 I, I 22 -I 25, C. Colpe, »Das samaritanische Pinehas-Grab in Awerta und die Beziehungen zwischen Hadir- und Georgslegende«, Zeitschrift des deutschen Palaestina-Vereins 85 ( 1969) I62-I96, H. S. Haddad, »Georgic Cults and Saint of the Levant", Numen I6 (1969) 2 I-39, Helmut Fischer, »H1. Georg«, Enzyklopädie des Märchens 5 ( I987) го30-ı039. Elias als Wettermacher wird bei Juden, Christen und Muslimen verehrt. Vgl. Haim Schwarzbaum, „Elias«, Enzyklopädie des Märchens 3 ( I 981) I 342-I353 (auch »Chadir (Hızır)«, ibid. 2, I 979, I 206-10), Frederick W. Hasluck, Christianity and Islam under the Sultans, 2 Bde. Oxford r 929, I 3 I 9-336 (vgl. auch das Legendenmotiv von Elias/Chadir als Engel oder Eremit [ATU 759] Haim Schwarzbaum, »The Jewish and Moslem Versions of some Theodicy Legends«, Fabula 3, I 960, I I9-169). Es handelt sich um eine Legendengestalt des islamischen Synkretismus, die Elemente aus dem Gilgamesch-Epos aufweist, der jüdischen Sage von Elias, Motive aus dem Alexanderroman (Zug zum Lebenswasser) und der Adam-Legende (Sohn des Kain, Vetter und Wesir Alexanders). Im modernen palästinensischen Volkskult gilt Chidar-Elias-H1. Georg (Mār Ğirğis) als Beschützer des Weideviehs. Vgl. S. Einsler, "Mār Eljās, el Chạ̣r und Mār Dschirjis«, Zeitschrift des deutschen Palaestina-Vereins I 7 (I 894) 42-55, Kriss/Kriss-Heinrich, Volksglaube im Bereich des Islam, op. cit., I I 54-I64, 244-248, I. Friedländer, "Zur Geschichte der Chadirlegende «, Archiv für Religionswissenschaft I 3 ( I 910 ) 92-1 10, ders. »Alexanders Zug nach dem Lebenswasser und die Chadirlegende«, ibid. I3 (I910) I6I-246, ders., Die Chadirlegende und der Alexanderroman, Leipzig/Berlin I9I3.

208 Sein Heiligtum in Kaliakra in der Dobrudscha wird sowohl von Muslimen wie von Christen verehrt. Zu seinen Drachenkampflegenden vgl. Puchner, Die Folklore Südosteuropas, op. cit., 94-ro4. Sein Grab soll in Sveti Naum am Ohrid-See liegen bzw. auf dem Berg von Kruja, oder auch auf Korfu, wo er mit dem H1. Spyridon gleichgesetzt wird (Kriss/Kriss-Heinrich, Volksglaube im Bereich des Islam, op. cit., I 335 f., Hasan Kaleshi, "Albanische Legenden um Sari Saltuk«, Actes du Premier Congrès Intern. des Études Balkaniques et Sud-Est Européennes, Sofia I 969, 81 5-828, H. T. Norris, Islam in the Balkans, London I 993, I 3 I f., I 46-I 57, Hasluck, Christianity and Islam, op. cit., 429435). Vor allem mit dem Bektaşi-Orden kommt es zu bedeutenden Überschneidungen: In Drymia bei Xanthi wird die H1. Georg-Kirche auch als tekke der Bektași-Sekte verwendet (Manolis G.

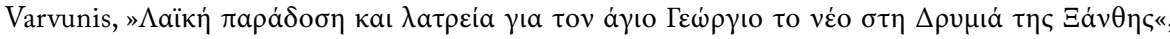

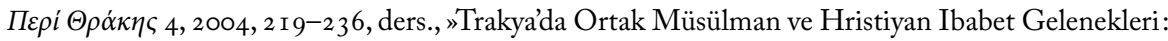
Xanti'den (Iskece) Örnek Bir Olay«, Yöre. Aylik Kültür Dergiși 8/85, 2007, 20-25). Ein anderes Beispiel bildet die H1. Mamas-Kirche in Mamasos in Kappadokien, die auch als islamische Moschee benutzt wurde; nach dem Bevölkerungsaustausch nach dem mißglückten griechischen Kleinasienfeldzug I 92 I/22 wurden die Reliquien des Heiligen von den lokalen Muslimen nicht herausge- 


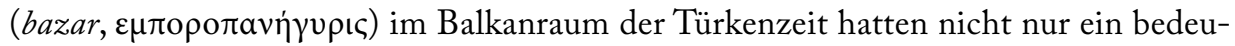
tendes geographisches Einzugsgebiet ${ }^{209}$, sondern unter den angebotenen Waren waren auch in Venedig gedruckte Bücher und populare Lesestoffe $\mathrm{zu}$ finden ${ }^{210}$ und Schaustel-

geben mit der Begründung, daß der H1. Mamas auch ihr Heiliger sei (Anna Marava-Hatzinikolau,

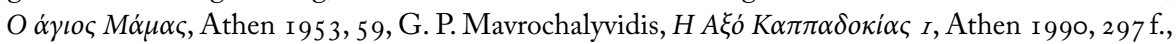

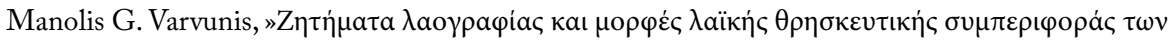

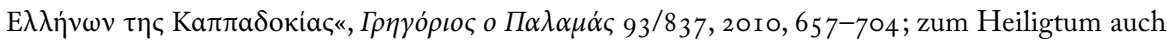
H. Carnoy/J. Nicolaides, Traditions populaires de l'Asie Mineure, Paris I 889, I 92 f.). Zum Synkretismus zwischen Orthodoxie und Bektași-Orden vgl. auch Manolis G. Varvounis, „Christian and Islamic Parallel traditions in the popular culture of the Balkan people«, Journal of Oriental and African Studies 9 (1997/98) 53-74, Hasluck, Christianity and Islam under the Sultans, op. cit., I 5-108,

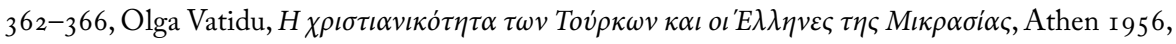
39 f., 45 f. Zum islamischen Heiligenkult vgl. allgemein Ignaz Goldziher, »Le culte des saints chez les Musulmans", Revue d'Historie des Religions 2 (I 880) $257 \mathrm{ff}$. und Kriss/Kriss-Heinrich, Volksglaube im Bereich des Islams, op. cit., I 3-52; sie wirken Wunder wie Totenerweckung, Wasserwanderung, Austrocknung des Meeres, Verwandlung (z.B. Wasser in Honig), Luftflug, sprechen mit Bäumen und Tieren, heilen Krankheiten, zähmen wilde Tiere, können gleichzeitig an verschiedenen Orten sein, besitzen die Gabe der Vorhersage usw. Vgl. auch Richard Gramlich, Die Wunder der Freunde Gottes. Theologien und Erscheinungsformen des islamischen Heiligenwunders, Wiesbaden 1987 , Gustav Mensching, Das Wunder im Glauben und Aberglauben der Volker, Leiden 1957.

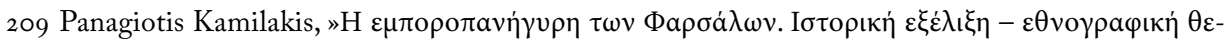

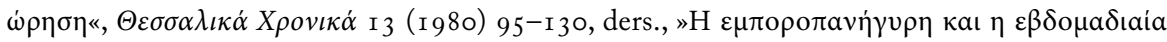

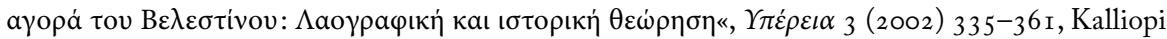

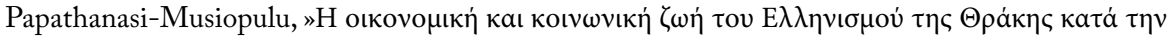

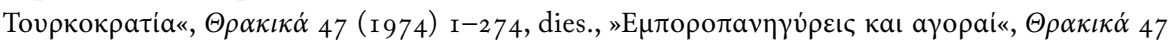

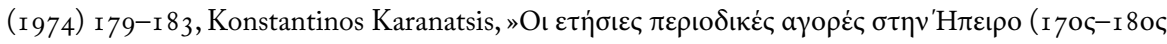

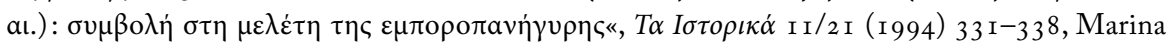

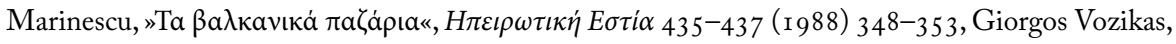

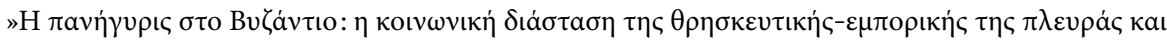

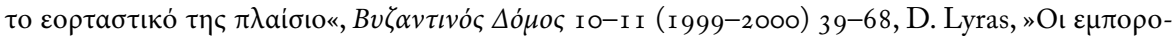

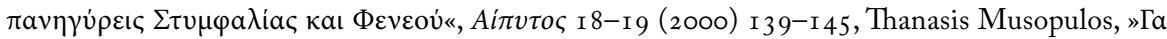

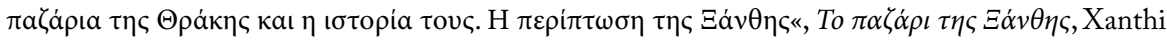

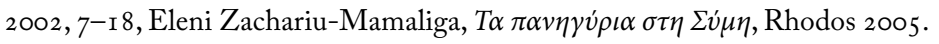

2 I0 I680 schreibt Michael Glykys von Ioannina aus an seinen Vater Nikolaos in Venedig, Inhaber des bekannten Druck- und Verlagshauses für griechische Bücher in der Serenissima, das von I670 bis 1854 die gesamte Balkanhalbinsel mit Kirchenbüchern und popularen Lesestoffen belieferte (Georg Veloudis, Das Druck- und Verlagshaus"Glikis« in Venedig (I670-1854). Das griechische Buch zur Zeit der Türkenherrschaft, Wiesbaden 1974), daß er für die Handelsmärkte in Zituni und Moscholuri im heutigen Bezirk Elasson in Nordthessalien Bücher zum Verkauf benötige, und zwar 40 Titel in insgesamt 1635 Exemplaren, davon 79\% ekklesiastische und didaktische Gebrauchs-

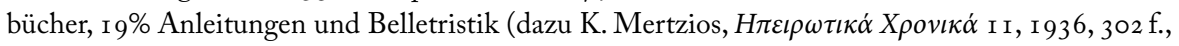
Veloudis, op. cit., I 37-I40, Léandros Vranoussis, L'Hellénisme postbyzantin et l'Europe. Manuscrits, livres, impriméries, Athènes I 98 I , 36 f., auch im Jahrbuch der Österreichischen Byzantinistik 32/ I, 
lungen verschiedener Art wurden vorgeführt ${ }^{211}$.

Das System der Heiligenkulte verteilt Festtermine über das gesamte jährliche heortologion $^{212}$, doch nicht alle werden mit einer eigenen Festivität gefeiert ${ }^{213}$. Besondere Aufmerksamkeit wird jenen Heiligen geschenkt, die aufgrund ihrer Zuständigkeit mit Landwirtschaft und Erntefragen verbunden sind oder deren Fest in einen kritischen Zeitabschnitt fällt, wie Herbst (Aussaat), Frühjahr und Sommer: Am Festtag des H1. Georgios (23.4.) wird auch der Regenbittgang durchgeführt ${ }^{214}$, ebenso wie am Festtag des Propheten Elias, dem Regen- und Wetterheiligen par excellence ${ }^{215}$, für den auch ei-

I982, 393-480). Diese Bücher kamen über die Karawanenwege von Botrinto und Ioannina in den Zentralbalkan südlich des Olymp. Zur Buchdistribution auf der Balkanhalbinsel vgl. Cornelia Papacostea-Danielopolu/Lidia Demény, Carte și tipar în societatea românească și sud-est europeană (secolele XVII-XIX), București I 985, Spyros Asdrachas, »Faits économiques et choix culturels: à propos du commerce de livres entre Venise et la Méditérrannée orientale au XVIIIe siècle«, Studi veneziani I 3 (I 97 I ) 587-62 I, Monika Skowronski/Marina Marinescu, Die "Volksbücher « Bertoldo und Syntipas in Südosteuropa. Ein Beitrag zur Kulturvermittlung in Griechenland und Bulgarien vom I7. bis 20. Jabrhundert, Frankfurt/M. 1992, I $25 \mathrm{ff}$.

2 I I Vgl. die Angaben über den Handelsmarkt von Doliani bei Evlija Çelebi (Vasilis Dimitriadis, $H$

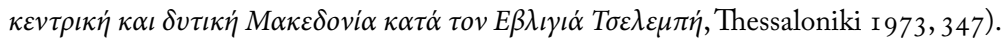

2 I 2 Konrad Kunze, »Heilige«, Enzyklopädie des Märchens 6 (1988) 666-677, Peter Brown, The Cult of Saints: Its Rise and Function in Latin Christianity, University of Chicago Press 1980, George Poulos, Orthodox Saints, 4 Bde., Brookline ${ }^{2}$ 1990, Mary Hamilton, Greek Saints and their Festivals, Edinburgh I 9 Iо, Angeliki Laiou-Thomadakis, »Saints and Society in the late Byzantine Empire", dies. (ed.), Charanis Studies: Essays in Honor of Peter Charanis, New Brunswick I980, 84-I I 4, Otto Meinardus, »A Study of Relics of Saints in the Greek Orthodox Church«, Oriens Christianus 54 (1970) I 30-278, ders., The Saints of Greece, Athens 1970.

2I 3 Dieser datumsstabile Festkalender der Menaien sieht in der Orthodoxie folgendermaßen aus (gereiht nach Festterminen): Basileios (г. r.), Johannes Prodromos (7. r.), Domna (8. r.), Antonios

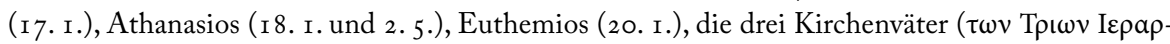
$\chi \dot{\omega} v$, 30. I.), Tryphon (I. 2.), Symeon (3. 2.), Charalampos (Io. 2.), Blasius (I I. 2.), Die vierzig

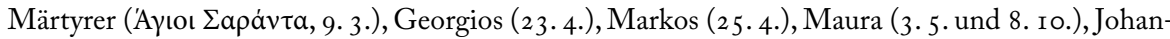
nes der Theologe (8.5. und 26. 9.), Konstantin (2 I. 5.), Elissaios ( 4 4. 6.), Johannes (der Theologe) $\gamma \varepsilon v \varepsilon \theta \lambda i \omega v$ (24. 6.), Petrus und Paulus (29. 6.), H1. Apostel (30. 6.), Kyriake (7. 7.), Bartholomäos (I I. 7.), Marina (I 7. 7.), Elias (20. 7.), Paraskeue (26.7.), Panteleimon (27.7.), Phanurios (27. 8.), Enthauptung des Johannes (29. 8.), Mamas (2. 9.), Euphemia (i6. 9.), Lukas (I 8. Io.), Artemios

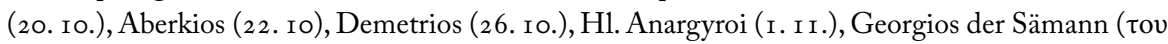
$\Sigma \pi$ $\rho \dot{\alpha} \rho \eta$, 3. I г.), Taxiarches (Erzengel Michael und Gabriel, 8. I r.), Menas (I I. I r.), Philippos (I 4. I r.), Platon ( 18. I r.), Aikaterina (25. I r.), Stylianos (26. I r.), Andreas (30. I r.), Barbara (4. I 2.), Sabbas (5. I 2.), Nikolaos (6. I 2.), Spyridon (I 2. I 2.), Eleutherios (I 5 . I 2.), Modestos (I8. I 2.),

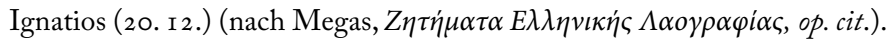

2 I 4 Miligu-Markantoni, $\Delta \dot{\varepsilon} v \delta \rho \alpha-\varphi v \tau \dot{\alpha}-\dot{\alpha} v \theta \eta$, op. cit., 275 f. Vgl. auch den ersten Teil.

2 I 5 Der Regenfall wird durch Bittlitanei, das verkleidete Regenmädchen, oder durch Tieropfer herbei-

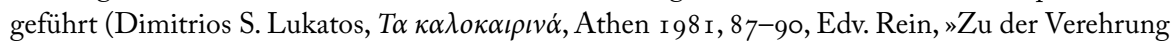


gene Feuer entzündet werden ${ }^{216}$. Wesentlich für den Erntevorgang ist auch die H1. Marina ( 7 . 7. $)^{217}$ und H1. Paraskevi (27. 7. $)^{218}$, ebenso wie der H1. Demetrios für die Aussaat (26. го. ${ }^{219}$; der Kampf der Heiligen gegen die Ernteschädlinge beginnt schon mit dem H1. Tryphon, zuständig vor allem für die Weinberge, am I. Februar ${ }^{220}$. Gerade mit diesem Heiligen wird das Thema der Arbeitsverbote an den Festtagen der Ernteschützer und die damit verbundenen Strafen für die Tabuübertreter angeschnitten ${ }^{221}$; rituelles

des Propheten Elias bei den Neugriechen«, Ovfersigt af Finsk Vetenskaps-Societetens Förhandlingar 47 (I 904-05) Nr. I, I-33, Stella Georgoudi, »Sant' Elia in Grecia«, Studi e materiali di storia delle religione 39, I968, 293-319).

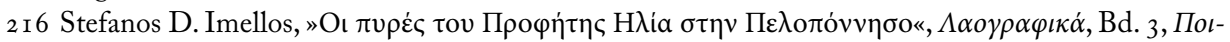

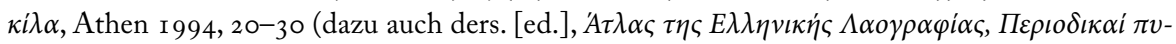
$\rho \alpha i$, Athen 1971).

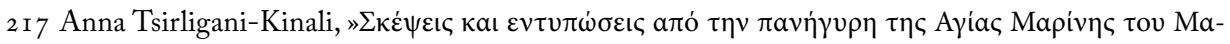

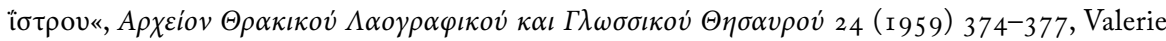

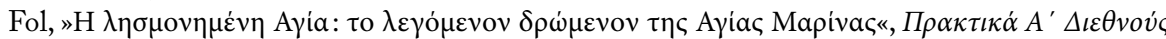

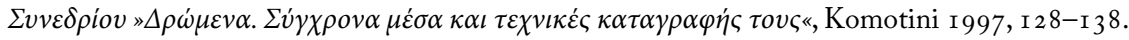

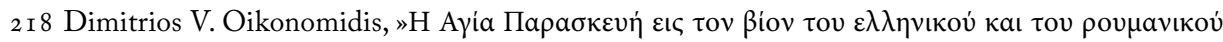

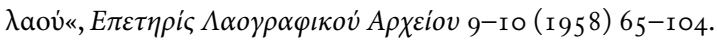

2 I 9 Vassilka Tăpkova-Zaimova, »Le culte de Saint Démétrius à Byzance et aux Balkans«, V. Gjuzelev/R. Pillinger (eds.), Das Christentum in Bulgarien und auf der übrigen Balkanhalbinsel in der Spätantike und im frühen Mittelalter. II. Internationales Symposium, Haskovo (Bulgarien), I0-I3 Juni I986, Wien I987, I39-I 46.

220 Miligu-Markantoni, $\Delta \dot{\varepsilon} v \delta \rho \alpha-\varphi v \tau \dot{\alpha}-\alpha \dot{\alpha} v \theta \eta$, op. cit., $296 \mathrm{f}$. An seinem Festtag wird auch ein hagiasmos der Felder gegen die Ratten durchgeführt. Weitere solche Rituale gegen Ernteschädlinge finden am Festtag des H1. Blasius ( I r. 2.) mit einer Bittlitanei gegen die Heuschreckenplage statt, gefolgt von den Lärmumzügen der Kinder am r. März, dem Feuersprung (Purifikation von Ungeziefer) und dem Schlangenbannspruch am Festtag das Hagioi Saranta (9.3.), der Ungeziefervertreibung am Gründonnerstag, ebenso am Festtag des H1. Georgios (23. 4.) und des H1. Markos (25. 4.), Lärmumzügen der Kinder am r. Mai, Litanei-Flurbegehungen zum Mittpfingstfest (Mrбo-

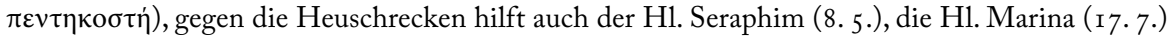
gegen Ungeziefer im allgemeinen.

22 I Zum Abschneiden der Nase des Feiertagsfrevlers vgl. wie oben. Neben christologischen und mariologischen Festen und Sonntagen (Leopold Kretzenbacher, »Sveta Nedelja - Santa Domenica Die hl. Frau Sonntag. Südslavische Bild- und Wortüberlieferungen zur Allegorie-Personifikation der Sonntagsheiligung mit Arbeitstabu«, Welt der Slaven 27, I982, 106-г 30) gilt das Arbeitsverbot auch für die Heiligenfeste (speziell der Schutzheiligen von landwirtschaftlichen Berufen). Dazu

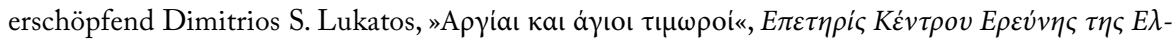

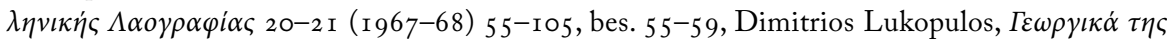
Poú $\mu \varepsilon \lambda \eta \varsigma$, Athen 1938, I64. Einige Beispiele: am 27. I., dem Festtag der Translation der Reliquien des H1. Joh. Chysostomos nähen die Frauen nicht, weil sie sonst dem H1. Kirchenvater in den Fin-

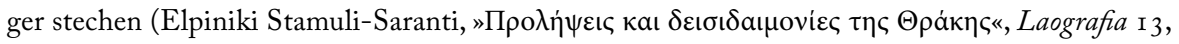

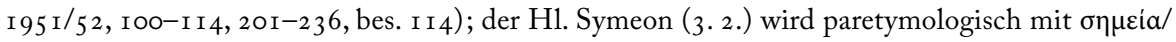


Nichtstun und Arbeitstabu stehen in unmittelbarem Konnex mit Totenkult und Purifi-

Zeichen und $\sigma \eta \mu \varepsilon \iota \omega \mu \varepsilon \dot{v}$ o/gezeichnet sein, verbunden: An diesem Tag greift man kein Arbeitswerkzeug an, kein Messer, keine Schere, keine Axt, denn die Zeichen der Schnitte erscheinen auf

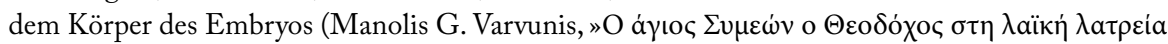

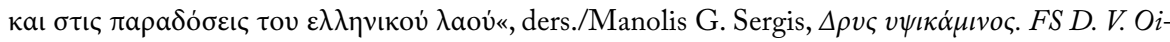
konomidis, Athen 2007, 83-9r); dazu gibt es viele Geschichten über gezeichnete Kinder (Papatha-

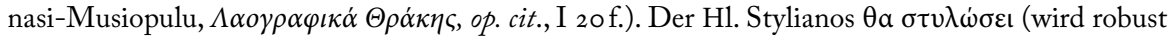

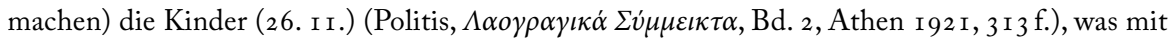
der hohen Mortalitätsrate der Kleinkinder zusammenhängt. Solche Paretymologien sind auch in anderen Sprachen üblich: Im Deutschen z.B. ist der H1. Augustin für die Augen zuständig (Carl L. P. Trüb, Heilige und Krankheit, Stuttgart I978, Lenz Rettenbeck, »Heiligengestalten im Votivbild«, Kultur und Volk, FS G. Gugitz, Wien I 954, 333-359). In Adrianopel/Edirne bürgt der H1. Eleuthe-

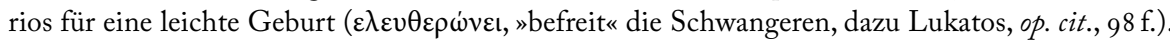
Am Festtag der 40 Märtyrer (9.3.) verfertigen die Mädchen 4o Fäden, 4o Schnäpse trinken die Männer, 40 weitere laden sie dazu ein, 40 Lügen sagen sie (Lukatos, ibid. 69). Am EvangelismosTag (25.3.) ist keine sexuelle Aktivität erlaubt, bei Tabuübertretung werden die Kinder gezeich-

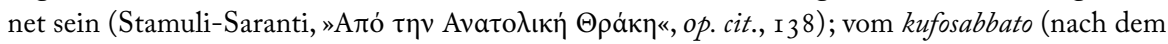

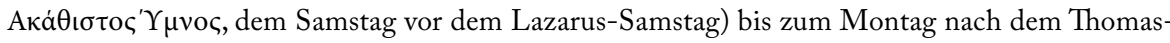

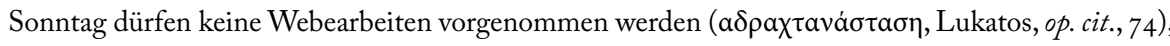
am Karmittwoch besteht Waschverbot, kein Seifengebrauch ist erlaubt. Am Kardonnerstag und

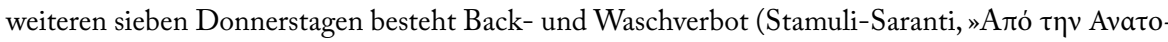

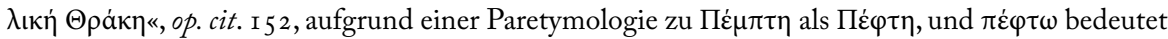
fallen, was mit Hagelgefahr u.a. Unglück in Zusammenhang gebracht wird). Am Karfreitag besteht Kochverbot. Für Hagelschlag ist der H1. Christophoros zuständig (Aikaterini Polymeru, $\mathrm{O}$ áyı

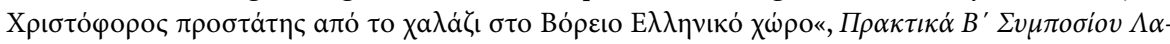

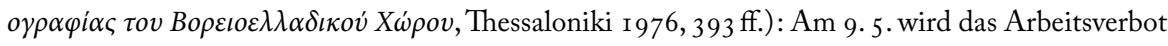
in Ostthrakien selbst von den Muslimen befolgt, die die Christen fragen, wann der Heilige seinen Feiertag hat, um nicht zu arbeiten (Lukatos, op. cit., 79). In der Mitte der Quadragesima (Пava-

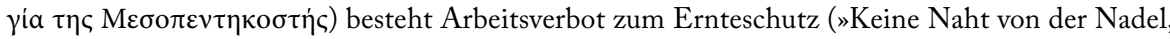
keine Ratte in der Tenne«), eine parakletische Litanei wird in den Weinbergen in Stenimachos/ Asenovgrad abgehalten, mit hagiasmos-Weihwasser besprengt man die Weinberge gegen Krankheiten und Hagel (Lukatos, op. cit., 79 f.). Im Zeitraum von Ostern bis Pfingsten (Anwesenheit der Seelen) darf man keine Reben schneiden (denn auf ihnen sitzen die Seelen), keine Hausarbeiten

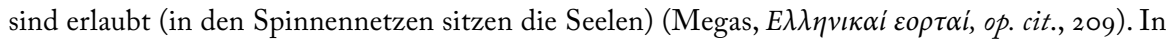
Ostthrakien erweist sich der Prophet Elias (20. 7.) als besonders rachsüchtig für Übertretungen des Arbeitsverbots an seinem Festtag: Stürme, Blitze, Donnerschläge und Hagel sind zu erwarten

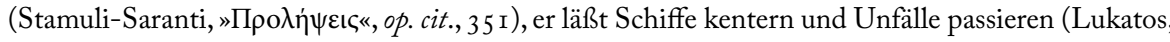
op. cit., 88). Am Festtag der Enthauptung des Joh. Prodromos (29. 8.), Schutzheiliger gegen Mala-

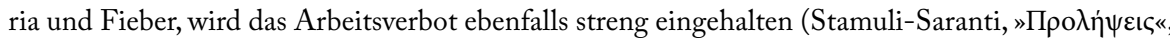

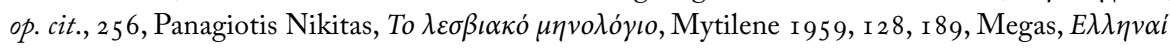

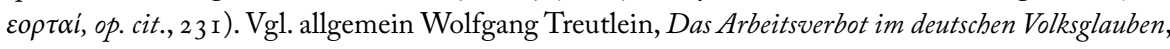
Bühl/Baden 1932, Lutz Röhrich, »Brauch«, Enzyklopädie des Märchens 2 (1979) 688-700. 
kation, dem Respekt vor dem hieros chronos der Festzeit ${ }^{222}$, und promovieren Gesundheit und Erntesegen. Die Begründungen und Erklärungen sind jedoch meist pseudorational und quasi-logisch bzw. stützen sich auf Paretymologien und lautliche Assonanzen zum Namen des spezifischen Heiligen ${ }^{223}$.

Derartige Kirchweih- und Heiligenfeste der Kirchensprengel werden auch in den Nachbarschaften der Urbanzentren gefeiert, selbst wenn der Bezug zu den Ernteerwartungen hier nicht mehr gegeben ist (z.B. das panegyri der H1. Marina im Vorort Heliupolis von Athen $)^{224}$; die merkantilen Transaktionen von Kauf und Verkauf, Angebot und Nachfrage sind in einen Bazar verwandelt, neue Medien werden eingesetzt wie etwa das Plakat $^{225}$. Eine andere Form festiven Verhaltens mit Anreise, das fast einer Wallfahrt gleicht, ist der Ausflug der Dorfvereine von den großen Städten bzw. aus dem Ausland zum Heimatdorf in der Osterzeit oder im Sommer ${ }^{226}$; dann kommt Leben in die un-

222 Neuere Literatur zur Festtheorie in Klaus-Peter Köpping, "Fest«, Christoph Wolf (ed.), Der Mensch. Handbuch Historische Anthropologie, Weinheim/Basel I 997, I048-65, Joachim Küchenhoff, "Das Fest und die Grenzen des Ich - Begrenzung und Entgrenzung im svom Gesetz gebotenen Exzeß««, Walter Haug/Rainer Warning (eds.), Poetik und Hermeutik XIV (München I 989), 99-г I 9 , Wolfgang Lipp, »Feste heute: Animation, Partizipation und Happening«, ders., Drama Kultur, Berlin $1994,523-547$.

223 Es gehört zu den Standardbeobachtungen der ethnographischen Literatur Südosteuropas, daß manche der weiblichen Heiligen noch Reste von Funktionen paganer Gottheiten besitzen, so z.B.

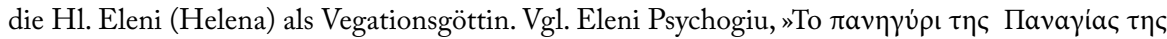

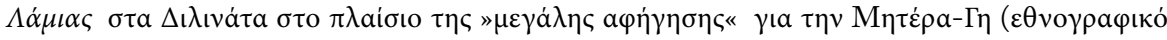

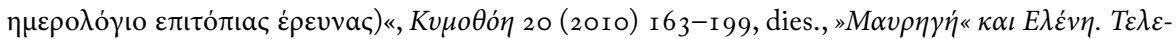

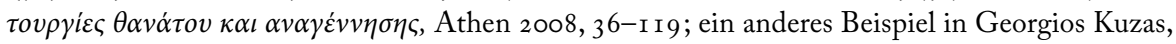

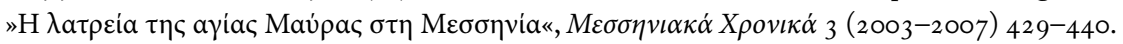

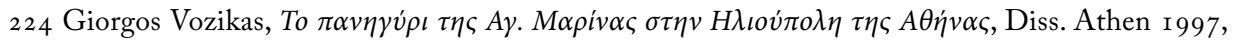

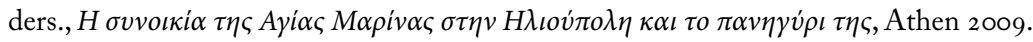

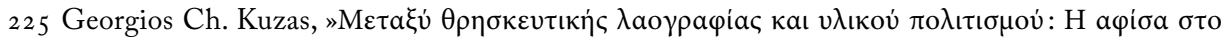

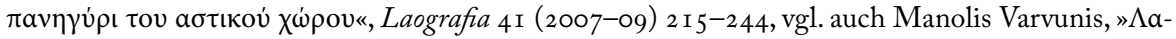

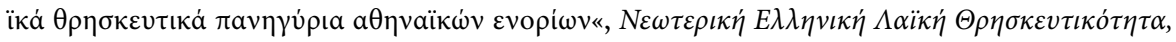
Thessaloniki 20I4, 99-I I I.

226 Anthony P. Cohen, The symbolic construction of community, London/New York I 985 , Eleftherios P.

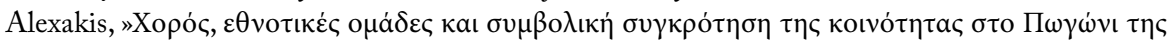

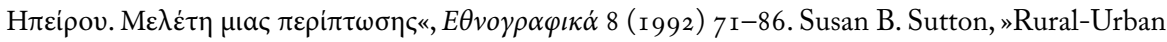
migration in Greece«, J. Kenny/D. Kertzer (eds.), Urban Life in Mediterranean Europe, Urbana I $983,225-249$, dies., "What is a villages in a nation of migrants«, Journal of Modern Greek Studies 4 (I 986) 2 I 7-243, Chrysoula Hadjitaki-Kapsomenou, „Folklore as Compensation: The Role of Local Cultural Associations in Folklorisation of Social Memory in the Contemporary Greek Context«, Migration, Minorities, Compensation, Issues of Cultural Identity in Europe, Brussels 200 I,

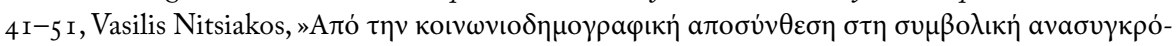

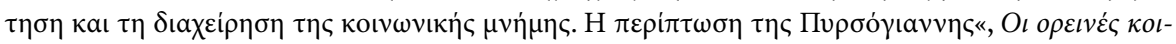


bewohnten "Geisterdörfer« der Gebirgszonen und Gemeinschaftsriten wie Festmesse, Rundtanz in Trachten, traditionelle Musik und lokale Volkslieder, Versteigerung des Tragerechts (»Besitz«) von Sakralgegenständen, Gemeinschaftsessen usw. konstituieren eine Art symbolischer Neugründung der Kommunität jedes Jahr und gehört zu den Zememoniellen um die lieux de mémoire ${ }^{227}$. Das Vereinswesen der Ausgewanderten bzw. von der Landflucht erfaßten Urbanbewohner ist ein wesentlicher Traditionsträger und stellt einen bedeutenden Faktor auch in Politik und Wirtschaft, Tourismus und Verkehr dar. Der organisierte kollektive Ausflug in die eigene Vergangenheit (Kinderzeit auf dem Dorf in der Heimat) mit intensiver Gefühlsstimulierung und gruppenstabilisierender Funktion hat ähnlichen Pilgercharakter wie die religiöse Wallfahrt mit öffentlichen oder privaten Verkehrsmitteln, die heute zum religiösen Tourismus gerechnet wird ${ }^{228}$.

Panegyrischen Charakter haben auch Sippen-, Familien- und Gildenfeste zu Ehren des Namens- oder Schutzheiligen wie die südslavische slava, der das griechische hypsoma (v่ $\psi \omega \mu \alpha$, Erhöhung) entspricht. Im ersten Fall versammelt sich die (Groß)Familie am Festtag des Sippenheiligen nach Kirche und Kommunion im Haus, wo der Pope die Brotweihung des slavski kolač und der koljivo zu Ehren der Toten vornimmt ${ }^{229}$. Die slava

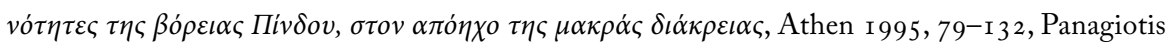

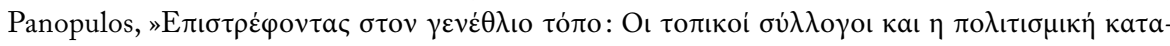

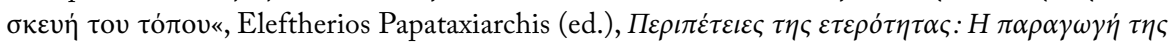

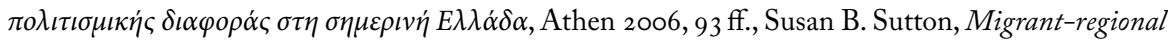
associations: An Athenian example and its implications, $\mathrm{Ph}$. D. diss. Chapel Hill 1978 (zu thrakischen

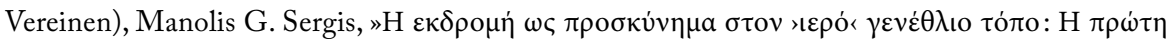

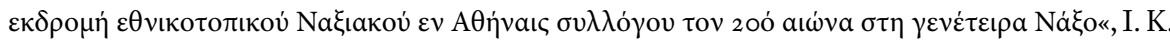

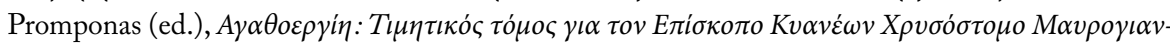

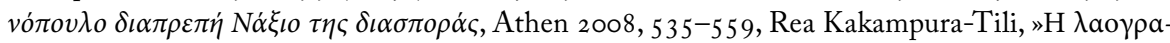

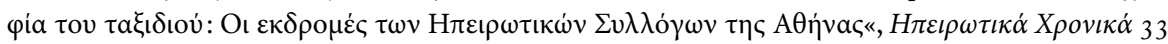
(I998-9) 20I-2 I6.

227 Zur Funktion und Morphologie der kollektiven und privaten Gedenkstätten Pierre Nora, Between memory and history: Les Lieux de Mémoire«, Representations 26 (1989) 7-25, ders., Realms of memory: rethinking French past, 3 Bde., New York 1 996-98. Zu den memory-studies vgl. auch die

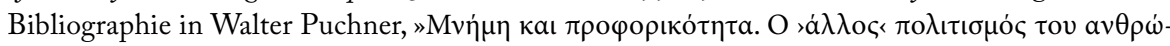

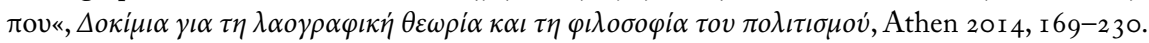

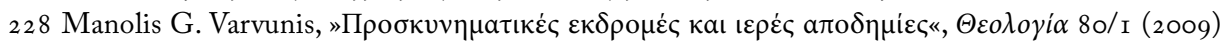
I9I-2II.

229 Dazu in Auswahl: Leopold Kretzenbacher, Brotweihe und Sippenfest der sslava in Serbien«, Ethnologia Europaea. Studienwanderungen und Erlebnisse auf volkskundlicher Feldforschung im Alleingang, München 1 986, I I 6- I 26, Ljubomir Pećo, »Das Sippenfest (Krsna slava, krsno ime) bei den Serben«, Zeitschrift für österr. Volkskunde I9 (I913) I I 7-1 20, David B. Rheubottom, »The Saint's Feasts and Skopska Crna Goran Social Structure«, Man I I ( I 976) I 8-34, Srboljub Zinanović, »The Origin of the Saint's feast in Macedonia«, Man (NS) I I ( 1976$) 575 \mathrm{ff}$. 
wird am Namenstag der häufigsten Heiligen vorgenommen und nicht nur von Familien, sondern vor allem in Serbien auch von ganzen Kommunitäten, Städten, Vereinen, politischen Parteien, Gesellschaften und Gilden gefeiert. Das griechische hypsoma ${ }^{230}$ des Heiligen erfolgt ebenfalls im Familienkreis (oder in der Kirche) durch das rituelle Hochheben des Tellers mit gekochten Weizenkörnern (Totenspeise) und Weihbrot (prosforo) und gleichzeitiger Segnung durch den Priester mit einer Lesung des spezi-

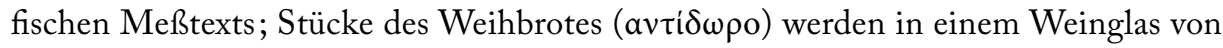
den Familienmitgliedern getrunken (Kommunion) ${ }^{231}$. Diese religiöse Ritualhandlung zu Ehren des Namensheiligen wird bei Einzelfamilien oder Gilden durchgeführt.

Will man nun eine Typologie eines traditionellen balkanischen panegyri erstellen, so ist a priori festzuhalten, daß in der Morphologie der Festmanifestationen kein grenzscharfer Unterschied zwischen Heiligenfesten, Kirmes, Jahrmarkt und Handelsmarkt zu ziehen ist. Alle Spielarten zwischen religiösem oder merkantilem Anlaß mit oder ohne Geschäftsabwicklung bedürfen der kollektiven Organisation: Ankündigung, Schaffung von Unterkunftsmöglichkeiten, Raumaufteilung, zeremonielle Festordnung usw. Die Heiligenfeste sehen auch Prozessionen mit spezifischer Prozessionsordnung mit Ikone und Reliquien ${ }^{232}$, Laternen und Fahnen, sowie dem Absingen/Psalmodieren von Litaneien, Gebeten usw. vor, die Versteigung des Tragerechts (Erlös kommt dem festlichen Gemeinschaftsessen oder anderen Zwecken zugute), Tieropfer und Symposia mit dem Fleisch der geschlachteten Opfer (oder auch nicht) ${ }^{233}$; der rituelle Festschmaus nach der Festmesse findet im Kirchenbereich oder unter großen Bäumen statt, manchmal gibt es auch eine vorbestimmte Sitzordnung der Familien, Trinksprüche werden vorgetragen

230 Zur »Erhöhung« der Bäume als sakrale Grenzzeichen des Siedlungbereichs vgl. wie oben.

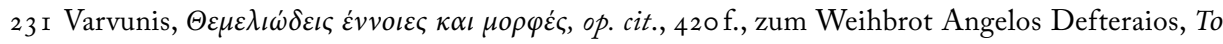

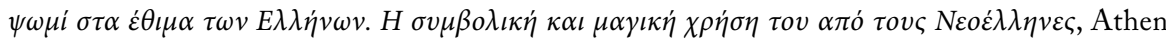
2000 .

232 In Limni auf Euböa besucht am 8. 9. eine Ikonenprozession auch mehrere Heilige (Laografia 3, 504 f.).

233 Auf einem Nebengipfel des Taygetos in Mani, Südpeloponnes, werden am Festtag des H1. Johannes des Theologen nicht weniger als 50 Schafe geschlachtet: Die Vorbereitungen beginnen bereits am Vorabend, der Priester verliest über dem Kopf jedes Tieres den Weihspruch, an der Kirchentür

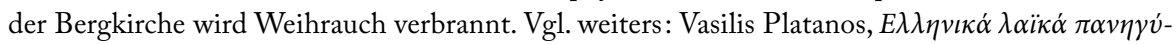
$\rho \iota \alpha$, Athen I963, Margaret Kenna, "Mattresses and Migrants: A Patron Saint's Festival on a Small Greek Island over Two Decades «, Jeremy Boissevain (ed.), Revitalizing European Rituals, London/ New York 1 992, I 55-1 72, N. Gabrielides, "Name Days and Feasting: Social and Ecological Implications of Visiting Patterns in a Greek Village of Argolid«, Anthropological Quarterly 47/I (1 974) 48-70, Anka Stahl, »Animal Sacrifices in the Balkans«, A. Bharati (ed.), The Realm of the ExtraHuman Ideas and Actions, The Hague I 976, 443-45 I, M. Gaussot, La panégyrie à Paros. Caractère plurifonctionnel de la fête populaire en Grèce, Thesis, Paris I 969. 
(manchmal in bestimmter Reihenfolge), es kommt zum Gemeinschaftstanz, Liedsingen und Kampfspielen (ev. mit Preisverleihung) ${ }^{234}$. Basiselemente der Heiligenfeste sind die Festmesse, Brotweihung als Kommunionsersatz, und die Unterhaltung; die Speiseopfer für die Toten, die an der Festivität teilnehmen: Restrukturierung der Gemeinschaft in der Festzeit (bieros chronos) in einer diachronischen Dimension ${ }^{235}$. Die Morphologie kennt in den Einzelheiten manche Variationen, die Typologie erstreckt sich jedoch auf Orthodoxe, Katholiken und Protestanten gleichermaßen ${ }^{236}$.

234 Das rituelle Gemeinschaftsessen nach der Festmesse ist besonders auch am Ostersonntag $(\Lambda \alpha-$

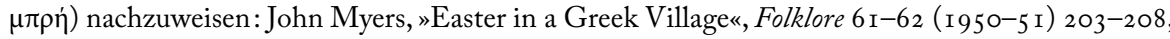
Edward L. Tilton, »Lenten Ceremony at Pylos in Greece«, ibid. 6 (г 895) 205 ff., K. J. Bonser, „Easter in Greece«, ibid. 75 ( I 964) 269 ff., Margaret Louis Arnott, Folk Customs surrounding the great days of Easter in Greece, M. A. thesis, Hartford Seminary Foundation 1953, Bernard Vonderlage, Das griechische Osterfest, Hamburg 1952, Angheliki Hadjimihali, „La Semaine Sainte et Paques chez les Saracatsans«, L'Hellénisme Contemporaine 2/5 (I95 I) I 3 I-I 36 usw.

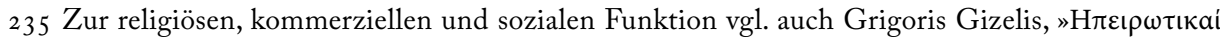

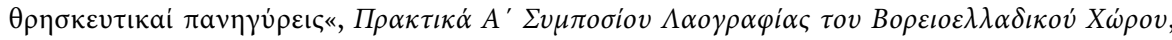
Thessaloniki 1975,2 I-33. Zur polyethnischen und multireligiösen Beteiligung an diesen Festivitäten vgl. ein Beispiel aus Thrakien: Am Festtag der H1. Paraskevi in Petra (26. 7.) erscheinen die Gläubigen schon am Vortag in Festkleidung, die Frauen geschmückt, beim hagiasma wird die Weihung gelesen, dann legen sich die Pilger zur Ruhe. Am Festtag treffen noch neue Pilger in Wagen ein, das semantron (die Stundentrommel) schlägt ununterbrochen, unter Psalmodieren wird eine Kuh geschlachtet und ${ }_{2-3}$ Schafe; davon werden auch Türken und Bulgaren bewirtet, die Leute tanzen zu Trommel und Dudelsack. Es gibt auch eine Wundererzählung über diese H1. Quelle: ein Türke soll dort am Festtag Holz geschnitten haben und wurde bestraft mit dem Tod seiner Kinder und Ochsen; seither kämen auch Muslime zum panegyri, wo sie Felle versteigern. Der Autor interpretiert diese ätiologische Straf-Geschichte als einen Versuch der Abgrenzung gegenüber dem

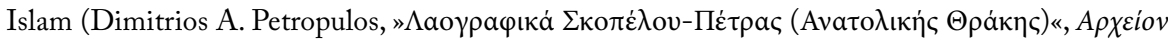

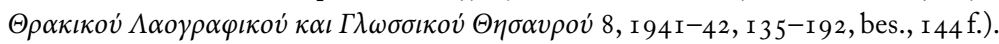

236 In Ungarn wird búcsú (Kirchweih, Kirmes) auch bei den Protestanten gefeiert, ebenfalls auch bei hl. Quellen (z.B. St. Anna See im Szeklerland), auch bei Heilquellen im Palotzenland. Vorwiegend weltlich sind hingegen Jahrmärkte und Handelsmärkte; die Heiligenfeste sind auch eine Art Brautschau und Heiratsmarkt; die Mädchen erscheinen in Trachten mit ihrer Aussteuer. Zu den Unterhaltungen zählen Karussel, Schaukeln, Schausteller, Paar- und Gemeinschaftstanz. Die Handelsmärkte sind vielfach spezialisiert: Viehmärkte, Getreidemärkte, ja selbst Glockenmärkte usw. (Balassa/Ortutay, Ungarische Volkskunde, op. cit., I 2 I ff.). Vgl. weiters: Manolis Varvunis, »H $\varepsilon \lambda$ -

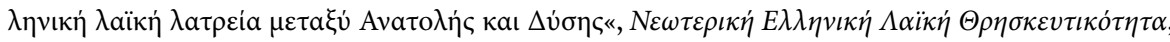
Thessaloniki 20I 4, 44I-472, Frank Kämpfer, »Der Kult des heiligen Serbenfürsten Lazar«, SüdostForschungen 3 I (1972) 8I-I39, Rudolf Kriss, "Volksreligiöse Opferbräuche in Jugoslavien«, Wiener Zeitschrift für Volkskunde 35 ( I 935) 49-68, Emilian Lilek, »Volksglaube und volksthümlicher Cultus in Bosnien und der Hercegovina«, Wissenschaftliche Mittheilungen aus Bosnien und der Hercegovina 4 (I 896) 40I-492, Manolis G. Varvounis, "Kult svetih u grckoj tradicijskoj kulturi«, Nikola Tasićl Mirjana Detelić (eds.), Kult svetib na Balkanu, Kragujevac 200 (Liceum 5), I75-I9o. 
Die historische Dimension der traditionellen panegyria läßt sich besonders deutlich am ehem. thrakischen Raum ablesen, wo die Festivitäten oft bis zu zwei Wochen gedauert haben, wobei das Gildenwesen eine besondere Rolle gespielt hat ${ }^{237}$; ganze Regionen

${ }_{237} \mathrm{Zu}$ Pfingsten wurde in Skopos/Üsküp ein dreitägiges panegyri abgehalten (Dimitrios A. Petropu-

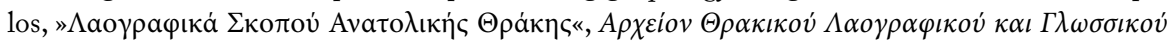
$\Theta \eta \sigma \alpha v \rho o v$ 5, 1938-39, 145-264, bes. I6of.). Die wichtigsten historischen panegyria im thrakischen Raum waren jedoch das von Uzunčiova bei Edirne, das vor I 878 am 29. 8. weitere acht Tage dauerte (mit der Eisenbahnlinie Wien-Konstantinopel [Orient-Expreß] ist seine Bedeutung zurückgegangen), in Marasia (am 3.7. und weitere I 5 Tage), in Syllimnos (29.5. und weiter I 5 Tage), Karnabas bei Edirne (Anfang März, 4 Tage), Arkadiupolis (Lule-Burgas) (r 3. 3., 6 Tage)

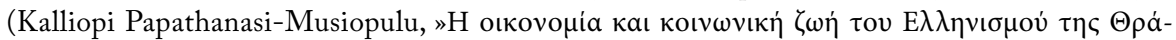

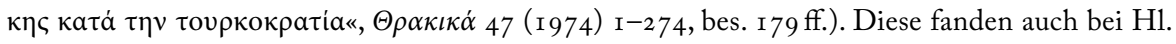
Quellen in Strandža für den H1. Georg statt (23. 4.) (Papathanasi-Musiopulu, $\Lambda \alpha o \gamma \rho \alpha \varphi \iota \kappa \dot{\alpha} \Theta \rho \dot{\alpha}-$ $\kappa \eta \varsigma$, op. cit., I 93): Allein 32 hagiasmata für den H1. Georg gab es in Thrakien, der der beliebteste Heilige war: An seinem Festtag gab es die Handelsmärkte der Viehzüchter, Unterhaltung für die Pilger, mit Petroleumlampen wurde bis tief in die Nacht getanzt und gesungen; in Silivri am Mar-

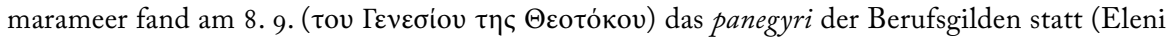

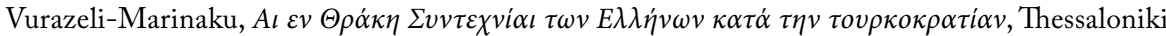
I950): Bei entlegenen Klöstern wurde gefeiert, Bauern und Pelzerzeuger zu Ehren des Propheten Elias, Geschirrmacher für den hl. Märtyrer Vlasios, die Schneider der dicken Hirtenmäntel für den H1. Johannes Prodromos, die Maurer zu Ehren des H1. Thomas, die Goldschmiede des H1. Spyridon usw.; nur Vertreter der Gilden konnten in der kleinen Kirche Einlaß finden, Schafe wurden gegrillt, die Brotweihe wurde im Freien vorgenommen, der gesamte Platz war mit Blättern ausgelegt für das Kinderspiel und das Picknick auf Tüchern; der Priester zerschnitt das geopferte Schaf und verteilte die Stücke (Papathanasi-Musiopulu, op. cit., I 97). Zu den dominanten Elementen

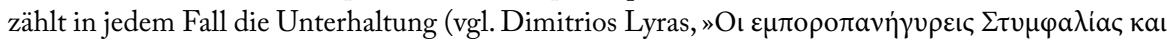

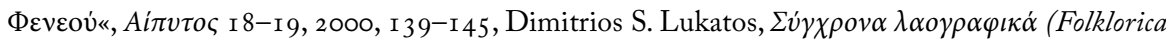
contemporanea), Athen 1963, 25 f.), auch der Verstorbenen, denen geopfert wird (das dritte Glas

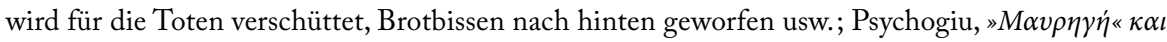

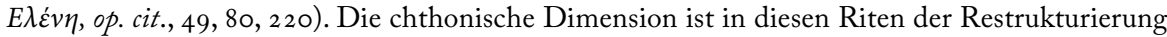
der Kommunität präsent; bei solchen Gelegenheiten wird auch das Schulterblatt der Opfertiere gelesen (Vergangenheit und Zukunft vereinen sich in der Festzeit). Im Raum Plovdiv kommt es bei den panegyria auch zum Ringkampf, Tücher werden für den Sieger auf einem Banner aufgesteckt: Die ölbeschmierten Ringkämpfer in ledernen Hosen treten zum Kampf an, Sieger ist der, der den Gegner dreimal auf den Rücken legen kann; unter Applaus knüpft er sich das Siegertuch um den Hals. Auch andere Agone (Hintergrund: Fertilität) aus bereits byzantinischer Tradition finden statt (Papathanasi-Musiopulu, op. cit., I 98 f.); der fertilitätpromovierende Sinnhintergrund ist auch bei anderen gemeinschaftsstabilisierenden Brauchhandlungen manifest wie dem balkan-

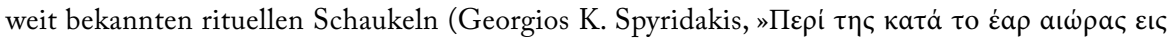

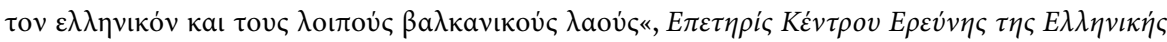

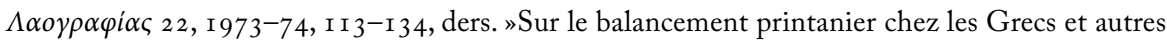
peuples de la péninsule balkanique«, Makedonski Folklor 6/I 2, I 973, I I 7-I 23,) und dem Abwiegen für Gesundheit (Stamuli-Saranti, A 
haben sich bei diesen Gelegenheiten getroffen ${ }^{238}$. In einem hybriden multifunktionellen Durcheinander vereinigen diese religiösen, kommerziellen und geselligen Treffen an feststehenden Heiligenfesten oder jährlich wiederholten Märkten mit ihren vielfältigen Manifestationen Jenseitiges und Diesseitiges, Geistiges und Materielles, Rituelles und Merkantiles in einem sozialen event von reichhaltigem emotionalem Angebot, Frömmigkeit und Vergnügen, Profitspekulation und Konsum, Warenabsatz und Feilschdialoge, notwendige Käufe und Vergnügungen, Spiritualität und Gastronomie, Gebet und Tanz, Informationsaustausch und Geselligkeit, ein Festtreiben, das zu den herausragenden Ereignissen für jede Kommunität und jede Region zählt und zu den charakteristischen Erscheinungen der traditionellen südosteuropäischen Volkskultur gehört ${ }^{239}$, heute angezeigt auf der Website jedes Dorfes ${ }^{240}$.

\subsection{IKONENKUSS UND BLUMENSCHMUCK}

Die theologische Unterscheidung zwischen Anbetung (Gott) und Verehrung (Heilige, Propheten, Sakralpersonen) verschwimmt mehr oder weniger in der alltäglichen Glaubenspraxis, wo die Heiligenikonen eigentlich nur ehrfurchtsvoll begrüßt werden sollten durch Bekreuzigung, Verneigung, Proskynese oder Kuß; gemäß der nachikonoklasti-

238 In Skepasto/Yenice im Raum Kırklareli fand am Festtag der Hl. Paraskevi, am 26.7., im gleichnamigen Kloster mit H1. Quelle ein großes Fest statt, an dem 360 Dörfer bis hinauf zur Donau teil-

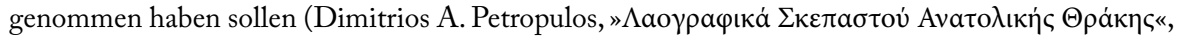

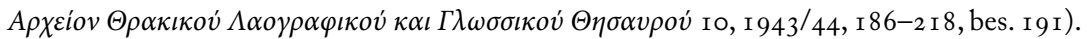

239 Die Bibliographie zu den Einzelerscheinungen ist schwer zu überschauen. Vgl. in Auswahl: Ekaterini Chalkea, »La fête dans les villages de Zagori«, Paul Stahl (ed.), Études et Documents Balkaniques et Méditerranéens 6 (Paris 1983) I-8, Margaret Kenna, „Mattresses and Migrants: A Patron Saint's Festival on a Small Greek Island over Two Decades«, Jeremy Boissevain (ed.), Revitalizing

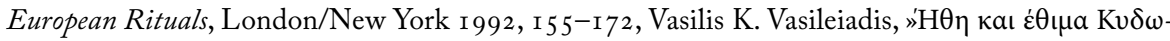

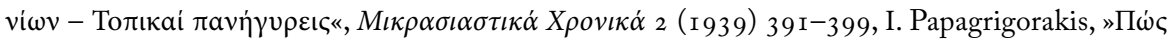

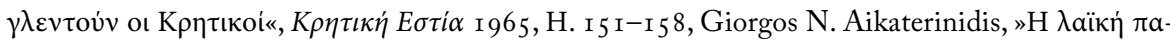

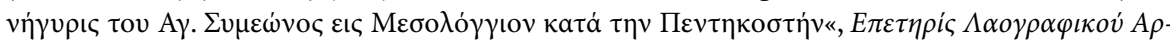

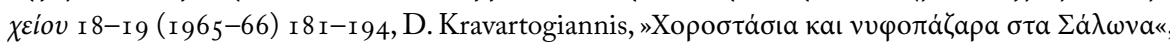

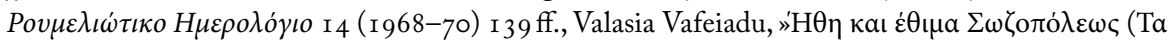

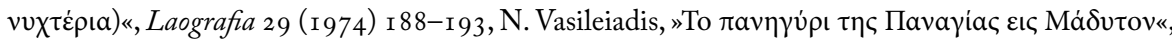

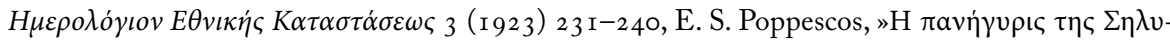

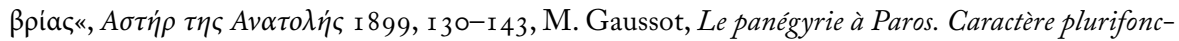
tionnel de la fête populaire en Grèce, Thesis, Paris I 969, Kyriaki P. Hadjijoannou, »The Cataclysmos

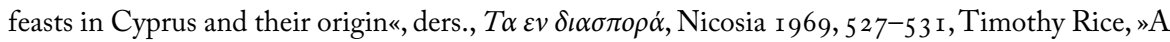
Macedonian Sobor: Anatomy of a Celebration«, Journal of American Folklore 93 (I 980 ) I I 3- I 28 , usw.

240 Katalogartig erfaßt und vorgestellt z.B. bei Terina Armenaki, Greek Folklore, Athens 2017. 
schen Ikonenlehre bezieht sich die Verehrung nicht auf ein auf Holz gemaltes Farbbild in seiner Gegenständlichkeit, sondern auf das Dargestellte ${ }^{241}$. Die Verehrung der Sakralpersonen in der Ikone findet durch eine ganze Reihe proskynetischer Handlungen statt: das Küssen der Ikone bei den Orthodoxen, der Blumenschmuck, das Kerzen-Anzünden, die Wachsgürtungen, die Votivgaben, die auf einer Schnur, einem Draht oder einer Kette unter der Ikone aufgehängt werden, und das Versilbern oder Vergolden von Teilen der Ikone, wobei nur das Gesicht der Sakralpersonen frei bleiben kann. In diesem Kapitel seien die beiden ersten Devotionsformen kurz behandelt.

Wie im ersten Teil ausgeführt, ist der aspasmos eine ehrfurchtsvolle Begrüßung, deren Lippenberührung oft nur angedeutet ist. Insofern ist der Judaskuß des proditor in der Ikonographie manchmal mißverstanden worden ${ }^{242}$. Dies gilt auch für das Ikonen-Küssen in der Ostkirche ebenso wie für das Küssen des Kreuzes oder des Evangeliums als gnadenemanativen Sakralobjekten; die Bedeutung der Berührungsmagie hält sich dabei mit hygienischen Überlegungen die Waage. Dieser Aspekt der Kontaktfrequenz ist auch bei den rituellen Ikonenwaschungen an Festtagen berücksichtigt. Der Verweischarakter der Ikonentheologie wird von den populären Glaubensvorstellungen jedoch im allgemeinen wenig berücksichtigt: die Ikone gilt als Haus des Heiligen in seiner Stofflichkeit, und die Wunderikonen haben ihr eigenes Leben: Sie können den Ort wechseln, Zeichen vermitteln durch Knacken, Schwitzen oder Tränen, Krankheiten heilen ${ }^{243}$ usw.

Wie der oben erwähnte Religionssoziologie Savramis ausführt, gehört der Blumenschmuck der Ikone, in besonders repräsentativer Form beim Blumenbaldachin des Epitaph-Umzuges am Karfreitag, zu den »abergläubischen Mißbräuchen« der Ikonentheo$\operatorname{logie}^{244}$. Doch gibt es zu diesem Faktum bereits Belege aus mittelbyzantinischer Zeit: In

24I Helmut Fischer, Von Jesus zur Christusikone. Petersberg 2005, Pavel Florenskij, Die Ikonostase. Stuttgart I988, Helmut Brenske, Ikonen, Tübingen 2004, Boris Rothemund, Handbuch der Ikonenkunst, 3. Aufl., München 1985, Ioann B. Sirota, Ikonographie der Gottesmutterikonen, Würzburg 1992, Abraham Karl Selig, Die Kunst des Ikonenmalens, Innsbruck 2006, usw.

${ }_{242} \mathrm{Zu}$ Abbildungen des Verräters und der Judaskußszene in der südosteuropäischen Ikonographie vgl. Puchner, Studien zum Kulturkontext der liturgischen Szene, op. cit., 7 I-82, 220-25 I (mit umfassender Bibliographie).

243 Mit Wachs werden Haare des Kranken angeklebt; die Farbe der Augen des Heiligen wird abgekratzt gegen Augenleiden usw. Zu den Wunderlegenden vgl. auch Puchner, Die Folklore Südosteu-

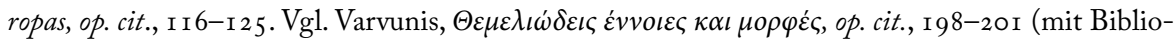

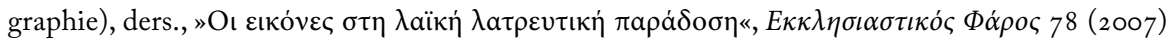
295-2 I0.

244 Demosthenes Savramis, „Der abergläubische Mißbrauch der Bilder in Byzanz«, Ostkirchliche Studien 9 ( I 960) 174-192, Paul Wiertz, "Zur religiösen Volkskultur der orientalischen und orthodoxen Kirchen - Volksglaube und Volksbrauch«, Handbuch der Ostkirchenkunde, Düsseldorf I 97 I, 569-632, Démétrios S. Loukatos, Fleurs et Plantes, dans les Églises Orthodoxes - Grecques: 
einer Rede von Johannes Mauropus, Metropolit im kleinasiatischen Euchaita im I I. Jh., auf den H1. Theodoros Teron ${ }^{245}$, die der bekannte Rhetor, Gelehrte und Schriftsteller (und Zeitgenosse von Michael Psellos) ${ }^{246}$ in der Kreisstadt Euchaita (an der Stelle des heutigen türkischen Dorfes Avkat oder Avhat) ${ }^{247}$, an der Heerstraße von Konstantinopel nach Amaseia, um I050 hielt ${ }^{248}$, wird eine solche Blumenwallfahrt beschrieben. Die damals nicht unbedeutende Stadt war kleinasiatisches Wallfahrtszentrum des Hl. Theodoros (des Teron, Rekruten ${ }^{249}$; seit dem 9. Jh. wird von ihm auch der H1. Theodoros Stratelates ${ }^{250}$

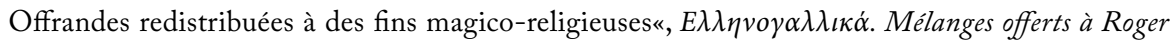
Milliex, Athènes I 990, 447-460, Katerina Seraïdari, Le culte des icons en Grèce, Toulouse 2005.

245 Logos, Nr. I 80 der Ausgabe Paulus de Lagarde/Johannes Bollig, Johannis Euchaitorum metropolitae

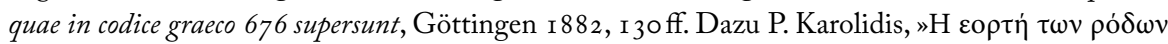
( Bemerkungen zu den alten kleinasiatischen Sprachen und Mythen, Straßburg I 9 I 3,178 ff. und pass.

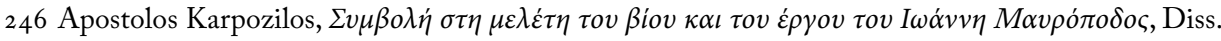
Ioannina 1982 (mit der gesamten älteren Literatur).

247 Henri Grégoire, „Géographie byzantine. I. Euchaita«, Byzantinische Zeitschrift 1 9 ( 1910) 59-62.

248 Karpozilos, op. cit., 29 ff. Mauropus bleibt insgesamt mit der kurzen Unterbrechung einer Konstantinopelreise bis 1075 in der kleinasiatischen Stadt und zieht sich dann als einfacher Mönch in das Prodromos-Kloster von Petra zurück. Mauropus hat in Euchaita fünf Reden geschrieben: Drei davon lassen sich in etwa datieren (Bollig/de Lagarde Nr. I79, I 80, I 84): Die eine wurde zu Ostern r $49 / 50$ gehalten, die beiden anderen zur selben Zeit oder kurze Zeit später (Karpozilos, op. cit., I 47 ff.).

249 In der ursprünglichen Ausformung besteht die Theodoros-Legende aus zwei Teilen: dem Martyrium und den zwölf Wunderberichten. Der Rekrut Theodoros wird im kleinasiatischen Amaseia als Christ vor Gericht gestellt und bekennt seinen Glauben; es wird ihm Bedenkzeit gegeben, den heidnischen Idolen zu opfern; statt dessen geht er in der Nacht hin und äschert den Magna-Mater-Tempel ein, bekennt sich selbst als Täter, wird gefoltert und dem Feuer übergeben (Richard Benz, Die Legende aurea des Jacobus von Voragine, Heidelberg I $975^{8}$, 859 f., F. M. Torrigio, Historia del martirio di S. Teodoro soldato, Roma I643, vgl. auch Bibliotheca Hagiographica latina antiquae et mediae aetatis, ediderunt socii Bollandiani, vol. II, Bruxelles r 898-1 90 I, I I70). Im Hymnus des Theodoros Studites († 826) wird der Drachenkampf vor dem Martyrium eingeschoben (vgl. die Versionen bei Hippolyte Delehaye, Les legendes grecques des saints militaires, Paris I 909, I 27-I 35, I 36-I 50, I 83-20 I etc.). Zum gesamten Legendenkomplex Karl Krumbacher, »Studien zu den Legenden des hl. Theodoros«, Sitzungsberichte der philos.-philolog. und histor. Klasse der Königl. Bayerischen Akademie der Wissenschaften I892, Heft II, München I 892, 2 I 7-379 sowie Willy Hengstenberg, »Der Drachenkampf des heiligen Theorodos«, Oriens Christianus N. S. 2 (I 9 I 2 ) 76-106, 3 (I9I3) $24 \mathrm{I}-280$.

250 Die Legenden um den hl. Theodoros, den Stratelaten (ein höherer byzantinischer Militärbeamtentitel), tauchen vor dem 9. Jh. auf und beziehen sich auf eine fingierte Märtyrerfigur des 4. Jh.s, die nichts weiter ist als eine Weiterbildung des H1. Theodoros Teron. Die beiden Heiligenviten sind sehr ähnlich. Als Ranghöherer überschattet der Stratelates den Teron schon ab dem 9. Jh. im Kult; beide Figuren verschmelzen zu einer Einheit (auch der Stratelates ist natürlich Drachentöter). Vgl. 
unterschieden; ersterer wird am I 7. Feb. gefeiert, zweiterer am 8. Feb. ${ }^{251}$ ), beide zusammen als Hagioi Theodoroi am Samstag der ersten Fastenwoche der quadragesima ${ }^{252}$, wenn auch der megalomartyr ursprünglich nur eine Person gewesen sein dürfte ${ }^{253}$, der nach der Lokalsage hier einen Stadt und Land verwüstenden Drachen überwältigt haben soll ${ }^{254}$ und Schutzheiliger (poliuchos) der nachdem aufblühenden Stadt, nach ihm »Theodorupolis « benannt, geworden ist ${ }^{255}$. Die Gebeine des Märtyrers sollen durch die Hosia Eusebia von Amaseia, dem Ort seines Martyriums im Jahre 306, nach Euchaita überführt worden $\operatorname{sein}^{256}$, deutlich auch in Zusammenhang mit dem erfolgreichen Drachenkampf ${ }^{257}$. Die

Hans-Georg Beck, Kirche und theologische Literatur im byzantinischen Reich, München I 959, 405. $\mathrm{Zu}$ späteren Versionen Delehaye, op. cit., I $5 \mathrm{I}-\mathrm{I} 67$, I68-1 82 usw. Der Stratelates als Reiterheld, der mit Lanzenstich das Untier tötet, bildet auch einen eigenen, dem H1. Georg sehr nahestehenden ikonographischen Typus (Helmut Lohse, Die Ikone des hl. Theodor Stratilat zu Kalbensteinsberg, München 1976, Bernd E. Scholz, „Die paarweise symmetrische Darstellung des H1. Georg und des Theodor Stratelates zu Pferde in der Kunst von Byzanz und Georgien im Io.-13.Jh.«,Jahrbuch der Österr. Byzantinistik 32/5 (1982) 243-253, Bernhard Kötting, Peregrinatio religiosa, Münster I 95 O, I6o-r 66 usw.).

25 I François Halkin, Bibliotheca Hagiographica Graeca, Bruxelles I $957^{3}$, vol. II, 277 f., 28 I f.

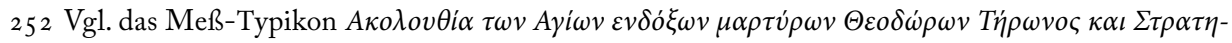
$\lambda \dot{\alpha} \tau o v$.

253 Beck vermerkt lakonisch: "Es handelt sich bei beiden (Theodor Tiro und Theodor Stratilat) um denselben Heiligen, und zwar um den Rekruten, den ein ehrgeiziger Hagiograph zum General beförderte" (Kirche und theologische Literatur, op. cit., 45). Vgl. auch Nikolas Oikonomides, "Le dedoublement de S. Théodore et les villes d'Euchaita et d'Euchaneia«, Analecta Bollandiana Io4 ( 1986 ) 327-335 und neuerdings Christopher Walter, The Warrier Saints in Byzantine Art and Tradition, Ashgate, Aldershot 2003, 44-66.

254 Die Zusammenstellung der Legendenversionen bei Hippolyte Delehaye, »Euchaita et la légende de St. Theodore ", Anatolian Studies presented to W. M. Ramsey, Manchester 1923, I 29-1 34 (wiederabgedruckt in Mélanges d'Hagiographie Grecque et Latin, Bruxelles I 966, 275-280).

255 Nach Zonaras XVII, 3, I7-1 8 und Skylitzes (ed. Thurn) 309, I9-33 unter Kaiser Tsimiskes. Vgl. auch Logos I 84, I 5-20 und I 80, I 32 von Mauropus.

256 Die translatio wird am 8. Juni im orthodoxen heortologion gefeiert. Schon im 5. Jh. wird hier in Euchaita eine Grabkirche errichtet (Hippolyte Delehaye, Les origines du culte des Martyrs, Bruxelles I $933^{2}$, i 69 f.).

${ }_{257}$ Zum Drachenkampf des H1. Theodoros in Euchaita siehe Delehaye, „Euchaita et le légende de S. Théodore«, op. cit., $276 \mathrm{f}$. und ders., Saints militaires, op. cit., 4 of. In den älteren Legendenfassungen (des. 5. Jh.s) fehlt die Drachenkampfepisode. Solche Drachenkampfmotive finden sich in den Synaxarien und Volkslegenden des H1. Georg, des H1. Nikolaos in Attika, des H1. Johannes auf Patmos, des H1. Donatus in der Peloponnes, des H1. Reginos auf Skopelos, ja sogar der H1. Paraskeue. Dazu Karl Krumbacher, Der hl. Georg in der griechischen Überlieferung, München I 9 I I, J. B. Aufhauser, Das Drachenwunder des bl. Georg in der griechischen und lateinischen Überlieferung, Leipzig I 9 I I, Nikolaos G. Politis, П $\alpha \alpha \delta o ́ \sigma \varepsilon \iota \varsigma$, Athen 1904, Bd. I, 75, Nr. I 4 I, 2 I 2, Nr. 379, 2 I 2 f., Nr. 380,2 I 3 f.,

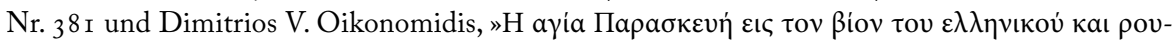


Legende will es nun, daß die Hosia Eusebia, die die Reliquientranslation durchgeführt haben soll, eben jene Jungfrau gewesen sei, die das Untier in seiner Gewalt hatte ${ }^{258}$ und die der pontische Reiterheilige und Nothelfer befreite. Während die Abspaltung des Stratelates, des Generals, vom Teron, dem gemeinen Rekruten, eine Art Rangerhöhung für die in Hoch- und Spätmittelalter so populären Reiterheiligen darstellt ${ }^{259}$, wird St. Theodor in Euchaita auch als Fußsoldat, als Schützer des Volkes und der Armen verehrt ${ }^{260}$.

Darüber und über andere Themen berichten als einzige Quelle die fünf euchaitischen logoi des sich hier in »Claudiopolis« in Bithynien fast wie in Verbannung fühlenden und nach der Polis sehnenden Mauropus ${ }^{261}$, der hier insgesamt wohl an die 25 Jahre verbracht haben dürfte. In der »Gedenkrede auf den H1. Großmärtyrer Theodor Teron oder

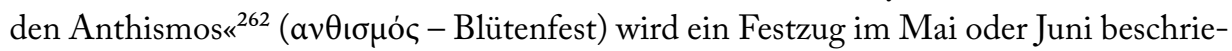
ben $^{263}$, bei dem die blumengeschmückte Ikone des Heiligen herumgeführt und mit Blumen beworfen wird; ein solcher anthismos, anthophoria oder rhodismos, wie es im Text ausdrücklich heißt, ist in byzantinischer Zeit auch für andere Heiligenikonen nachgewiesen $^{264}$. Das zusammenströmende Volk wird hier beschrieben, Opfergaben, Kreuze,

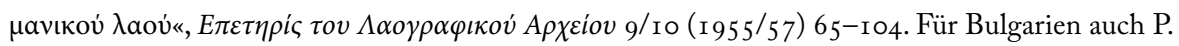
Stefanov, »Sveci zmeeborci v bălgarski folklor «, Bălgarski Folklor VIII/I ( I 982) 75-84.

258 Der Drache lebt mit der Frau zusammen, hat sie auf einem goldenen Bett. Die Drachenepisode exisiert auch unabhängig von der synaxarischen Theodoros-Vita als Lokalsage von Euchaita (Delehaye, Saints militaires, op. cit., 37 f., Nikolaos G. Politis, »Ta $\delta \eta \mu \omega \dot{\delta} \eta \varepsilon \lambda \lambda \eta \eta v \iota \alpha \dot{~ a ́ \sigma \mu a \tau a ~ \pi \varepsilon \rho i ~ \tau \eta ऽ ~}$

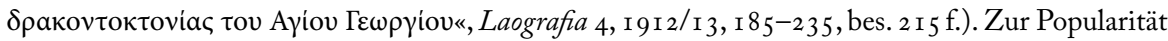
des Drachentötungsmotivs in Hochbyzanz vgl. auch die Akritenlieder, wo das Motiv im Gegensatz

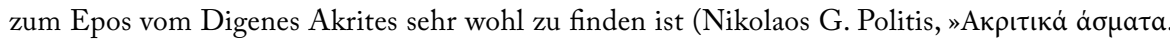

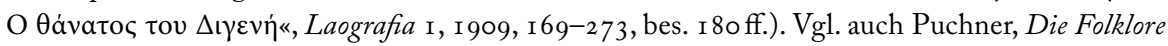
Südosteuropas, op. cit., 29-3 I.

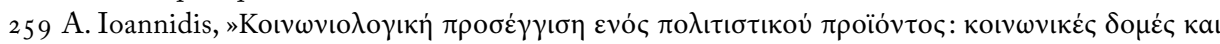

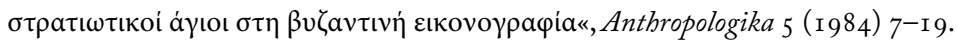

260 Mauropus, Logos I 89 auf den "H1. Theodor den Fußsoldaten« (Karpozilos, op. cit., I 52 ff.). Es dürfte sich auch um einen kappadokisch-pontischen Lokalkult mit großem Fremdenzulauf handeln. Die Vorbereitungen der volkstümlichen Festlichkeiten am Samstag der »Mittpfingsten« scheint von einer religiösen adelphotis getragen worden zu sein. Sonst ist über den Sonderkult des

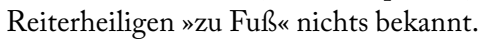

26I Vgl. auch die Gedichte von Mauropus: Joannes Mauropus', Erzbischofs von Euchaita, Gedichte, ausgewählt und metrisch übersetzt von A. Berndt, Plauen i. V. I 887.

262 Bollig/de Lagarde, Nr. I 80, I 30 f., Karpozilos, op. cit., I 5 of.

263 Karolidis nennt ohne ersichtlichen Grund den 9. oder 24. Juni (Bemerkungen, op. cit., I 45). Aus der Rede selbst läßt sich bloß Frühlingsende bzw. Sommeranfang erschließen (Karpozilos, op. cit., I 50 ). ${ }_{26} 64$ So im Kult des hl. Nikolaos und des hl. Johannes. Vgl. Gustav Anrich, Hagios Nikolaos: Der heilige

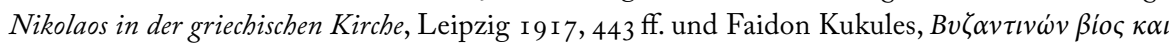
$\pi 0 \lambda \iota \tau \iota \sigma \mu o ́ s, 6$ Bde., Athen I 948-55, II, 29 ff. 
Blumen- und Blütenkränze tragend, Blüten auf die Wallfahrtsikone streuend; das Ende des Frühlings und der Einzug des Sommers wird in rhetorisch gewandten Satzperioden beschworen, der "Gekränzte« (stephanites) fast wie ein Vegetationsheros besungen ${ }^{265}$. Die Blumenwallfahrt des St. Theodor von Euchaita, von der wir sonst keine Nachricht haben, geschieht, wie ausdrücklich erwähnt, zum Segen von Feldern und Haus ${ }^{266}$.

Vom Blumenschmuck der frühchristlichen Märtyrergräber über den anthismos der byzantinischen Heiligenikonen bis zum Blumenbaldachin der rezenten Epitaphprozessionen in der orthodoxen Karfreitagsnacht läuft eine Konstante, die die Blumen mit dem christlichen Kultritual verbindet. Blumen als Grabbeigaben sind darüberhinaus in der griechischen Tradition von der Antike bis heute geläufig ${ }^{267}$. Die Verbindung der christlichen Glaubensmanifestationen des heortologions mit dem Vegetationszyklus, im Frühlingsabschnitt mit dem Aufblühen der Natur als Parallelereignis zu der Auferstehung Christ und der Aufweckung des Lazarus, ist nicht nur seit der Kirchenväterzeit stehender topos, sondern auch eingebettet in der Pastoralpraxis popularer Devotionsformen, zu denen auch Ritualhandlungen gehören, die deutlicher dem GegenseitigkeitsPrinzip des do ut des folgen.

\section{$4 \cdot 5$ VOTIVGABEN UND TIEROPFER}

Opferhandlungen mit verschiedenen Motivationen (Dank, Erwartung, Wunsch, Konvention), ausgehend jedoch fast immer von dem ungeschriebenen Gesetz der Gegenseitigkeit, sind in fast allen Kulturen nachzuweisen und bilden einen wesentlichen Bestandteil der devotionalen Glaubensaktivität der ekklesialen Praxis ${ }^{268}$. Die magische Gleichung von

265 Bollig/de Lagarde, op. cit., I 35. »Derart treibt der Gerechte in den Höfen Gottes unter Psalmgesang Blüten wie eine Palme, wie eine Zeder, und wächst und vermehrt sich, vergißt nicht, seine Geschenke an alle zu vermehren; und dieser wird derart von jenen nicht ohne Grund `Blütengeschmückter<, oder einfacher `Blumenverzierter genannt, sei es wegen seines blühenden und schönen Aussehens ... oder sei es, daß sie auf die Zeit anspielen und die jetzige Blütenpracht, daher wird der Tapfere so benannt. Möge deshalb auch das Fest >Blütenfest< [anthophoria] benannt sein, wie es schon von manchen auch >Rosenfest [ rhodismos] oder >Blütenfest [anthismos] genannt worden ist « (die Übersetzung in Walter Puchner, »Im Namen der Rose. Zum Nachleben des Rosalienfestes auf der Balkanhalbinsel«, Studien zur Volkskunde Südosteuropas und des mediterranen Raums, Wien/Köln/ Weimar 2009, 47-ro6, bes. 58, Anm. 74).

266 Bollig/de Lagarde, op. cit., I79 f.

267 Z.B. Margaret Alexiou, The ritual lament in Greek tradition, Cambridge 1974, 39 und pass.

268 Marco Frenschkowski/Lutz Röhrich, »Opfer«, Enzyklopädie des Märchens го (2000) 28 I-306, Henri Hubert/Marcel Mauss, »Essai sur la nature et la fonction du sacrifice« (I 899), Marcel Mauss, Euvres I, Paris 1968, 193-307, D. Stonus, »Do ut des«. Herkunft und Funktion eines Erklärungsbegriffs«, Jahrbuch für Volkskunde, N. F. I 9 (1996) 4I-59, Gerardus van der Leeuw, »Die do-ut-des- 
Gabe und Gegengabe mit einer Dosis von inhärenter ökonomischer Rationalität ${ }^{269}$ reicht jedoch in ihrer Materialität vom Tieropfer bis zur Geldspende und ist keineswegs nur auf den Sakralbereich kirchlichen Gläubigenverhaltens beschränkt, sondern auch in verschiedenen Sektoren der landwirtschaftlichen Produktion anzutreffen; dies betrifft z.B. die ersten und die letzten Erntefrüchte ${ }^{270}$. In der Interaktion mit den metaphysischen Instanzen im Kirchenbereich der Pastoralpraxis ist das Opferverhalten Teil der Überlebensstrategien von Individuum, Familie und Kommunität, womit alltäglichen und umstandsgebundenen Bedrohungen begegnet bzw. versucht wird, auf die unbekannte $\mathrm{Zu}$ kunft einen gewissen Einfluß zu bekommen. Darüberhinaus sind die sakrifizialen $\mathrm{Ob-}$ jekte auch »interesseloser« Ausdruck der Frömmigkeit und des Glaubens, Gegenstände, deren Seinszweck ein funktionaler und kein ästhetischer ist: Wachsopfer ${ }^{271}$, Kerzenwachs, Ö1, Weihrauch, Blumen als Ikonenschmuck, heptazyma, prosfora (Weihbrote) ${ }^{272}$, Pfannkuchen, Gebildbrote, Schmuck, Stoffe und Stickereien, Grundstücke, Tieropfer, Ikonen und

Formel in der Opfertheorie«, Archiv für Religionswissenschaft 20 (I $920-2 \mathrm{I}$ ) 24I-2 53, F. Eckstein, "Speiseopfer«, Handwörterbuch des Deutschen Aberglaubens 9 (Nachträge) (I 938-4I) 496-547, Michael Müller-Wille, Opferkulte der Germanen und Slaven, Stuttgart 1999, Guy Rosolato, Le Sacrifice, Paris 1987 .

269 Werner Wunderlich, »Gabe«, Enzykopädie des Märchens 5 (г 987) 625-637, Minas A. Alexiadis, "Do ut des«, $\Delta \omega \delta \omega \dot{v} \eta$ r6/I (1987) 253-265.

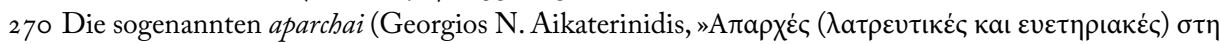

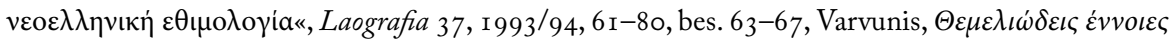

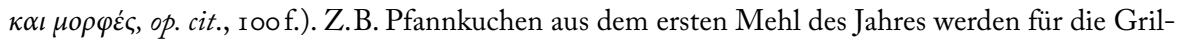
len gebacken, Saatkörner in die Tenne geworfen, ein Feldstück wird nicht abgeerntet (Naturopfer)

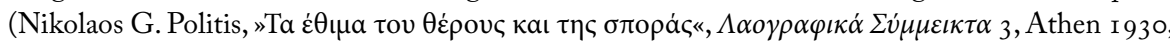

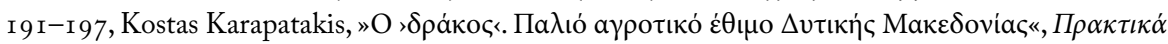

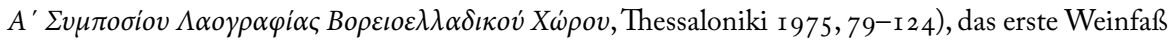
der neuen Ernte wird vom Priester gesegnet und im ganzen Dorf verteilt (im ostthrakischen Petra,

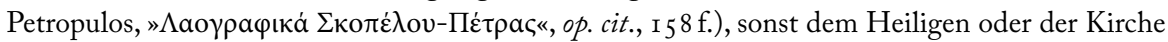

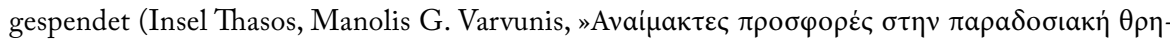

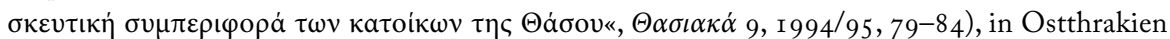
werden auch die ersten Trauben am Festtag der Hl. Paraskevi (26. 7.) oder dem Festtag der Transfiguration des Herrn (6. 8.) in der Kirche geweiht und verteilt (Kappadokien, Dimitrios Lukopulos/

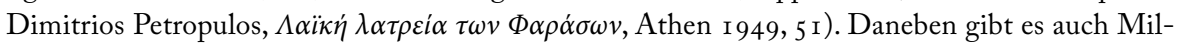
chopfer an den Fluß, Brotopfer an Quellen, Münzenopfer, Honigopfer an Heilige oder die Feen der neraides, an die Schicksalsfrauen (moires), an Dämonen, auf Zante auch an die Hausschlangen, auf Leros an die Hausgeister. Aber auch die Gabe von Blüten, Blumenkränzen, Zweigen zählt dazu, die Epitaphschmückung, die Kirchenschmückung mit Myrthenbüschel, Lorbeerzweigen usw.

27I Besonders Wachsopfer im Eigengewicht, was einem symbolischen Selbstopfer gleichkommt.

272 Im kollektiven Notfall geschieht die Herstellung auch mit den magischen »Verstärkern« der Wirksamkeit: Die Jungfrauen kneten den Teig und backen in der Kirche ein prosforo in der Nacht, das dann vom Priester geweiht wird (Kastoria, Koroni). 
das Versilbern und Vergolden von Ikonen ${ }^{273}$, das Gürten der Ikone ${ }^{274}$, Altargerät, Kelche, Evangelien, hexapteryga, Reliquienschreine, Kerzenständer, Manuale, Ikonenwände, stasidia, goldbestickte Ornate, Votivgaben als Metallplättchen (gepreßt oder gegossen), eikonostasia (Ikonenschreine, proskynetaria) am Straßenrand usw. ${ }^{275}$ Diese Opferspenden nehmen manchmal auch komplexe Ritualformen an, wie etwa bei der Dedikation eines kranken Kindes an einen Heiligen und seine Ikone ${ }^{276}$. Diese Kultspenden stellen eine z.T. bedeutende ökonomische Einnahmsquelle von Kirchen und Klöstern dar und es ist auch eine gewisse Spezialisierung der Sakralinstitutionen auf bestimmte »Dienstleistungen« vor allem in den letzten Jahrzehnten festzustellen ${ }^{277}$.

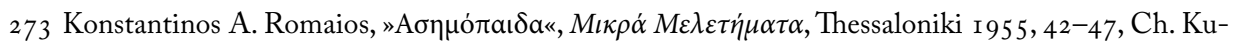

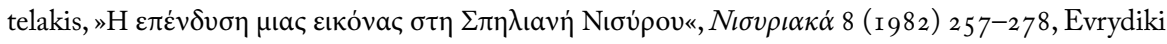

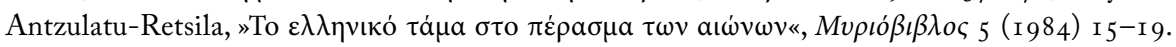
Der Brauch wurde bereits in Byzanz geübt.

274 Den Faden im Ausmaß der Ikone bindet sich der Spender an den Gürtel.

275 Evrydiki Antzulatu-Retsila, in Nikos Papageorgiu, A. Tó $\mu \alpha \tau \alpha \kappa \alpha \iota \Sigma \dot{v} \mu \beta o \lambda \alpha \tau \omega \nu \Lambda \alpha \omega \dot{v}, B$. Z $\omega \gamma \rho \alpha-$

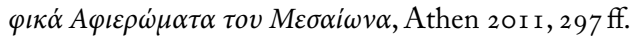

276 Vgl. auch wie oben im Ersten Teil. Z.B. wird das kranke Kind vor der Ikone abgewogen und dem Heiligen wird Wachs oder Öl im Ausmaß des Körpergewichtes des Kindes gespendet. Das »versklavte« Kind bekommt einen Silberring um den Hals, der nach Jahren zu den Votivgaben der Ikone kommt. In Sparta und auf den Ionischen Inseln werden kranke Kinder zu »Mönchen/Nonnen" gemacht und dem Heiligen geweiht; sie werden in schwarze Kutten gekleidet, nicht beim Namen genannt und nach der verflossenen Frist in Weiß gekleidet, wobei die Kutten in der Kirche bleiben. Im historischen Thrakien sind viele Auffindungslegenden von Marienikonen anzutreffen, und Versklavungen und Weihungen ( $\tau \dot{\alpha} \xi \xi \mu \mathrm{o})$ von kranken Kindern sind häufig nachzuweisen $(\mathrm{Pa}-$

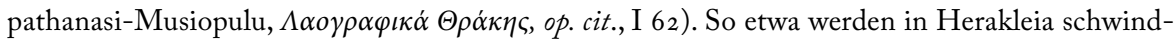

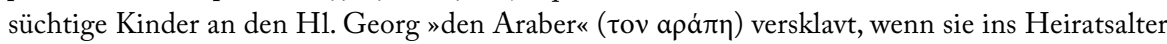
kommen, werden sie freigekauft mit Ö1 oder Geld (ibid. I 76); das sklavoma wird mit ritueller Ankündigung in der Kirche bekanntgemacht, das Kind bekommt für 40 Tage einen Eisenring um den Hals, der in der Folge dann auf die Ikone gehängt wird; der Heranwachsende muß in sexueller Reinheit leben, die Fasten einhalten, in Frömmigkeit der Kirche dienen, dann sorgt die Panagia oder der Heilige auch für Gesundheit, Schadlosigkeit und sein Überleben (der Brauch bestand

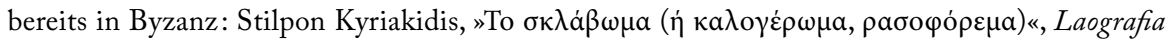

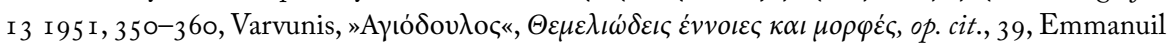

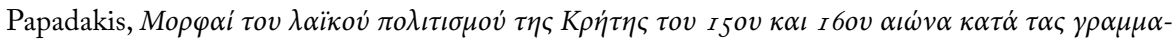

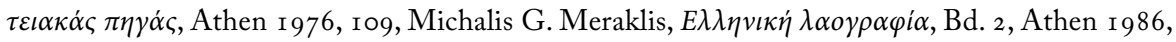

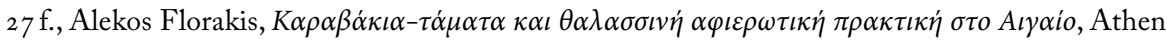
r 982, 93 f.); die Lösung des dedikativen Zustands und der Freikauf vom Heiligen erfolgt mit einer vereinbarten Geldsumme und Zeremonie; wie bei der Heirat (jetzt Fruchtbarkeits-Dimension)

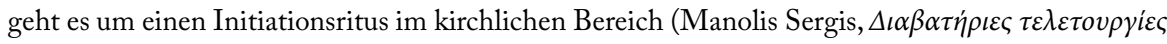

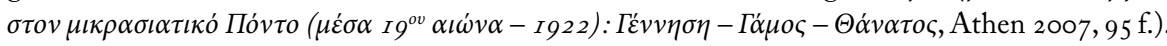

277 So z.B. der »Apfel der Fruchtbarkeit« im Kloster der H1. Irene Chysovalantu in Metamorphosis in Attika, in Spata bei Athen wird an gewissen Sonntagen die Weihe der neuen Autos vorgenommen 
Votiv- und Weihegaben sind seit den frühchristlichen Jahrhunderten nachgewie$\operatorname{sen}^{278}$; im Vor- und Frühmittelalter existiert auch eine ganze Verbotsliteratur, wo die Opferdarbringung bei Quellen, Steinen, Bäumen, Weggabelungen usw. untersagt wird $^{279}$. Die Dedikationsformel »ex voto« ist schon im 3. Jh. n. Chr. nachgewiesen ${ }^{280}$

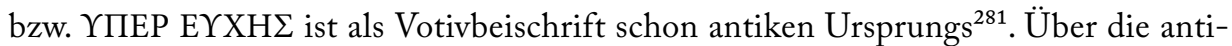
ken Weihgaben für Asklepios und in anderen Kulten bestehen fundierte Übersichten ${ }^{282}$. Aufgrund des byzantinischen Verbots der Vollplastik fehlen in der Orthodoxie Südosteuropas die sonst üblichen figürlichen Votiv-Plastiken ${ }^{283}$, wodurch sich die Morphologie des Votivwesens grundsätzlich vom lateinischen Westen unterscheidet ${ }^{284}$. Ansonsten

usw. Bedeutende Wallfahrtszentren wie die Panagia Megalochari in der Evangelistria-Kirche auf Tinos hat organisierte Prozeduren der Verwaltung der z.T. wertvollen Opfergaben entwickelt: Sie bleiben drei Jahre in den Tresoren der Griechischen Handelsbank und werden dann versteigert (Margaret Kenna, "Icons in Theory and Practice«, History of Religions 24/4, I 985, 345-368).

278 Vgl. die Belegzusammenstellung bei Lenz Kriss-Rettenbeck, Ex voto. Zeichen, Bild und Abbild im christlichen Votivbrauchtum, Zürich/Freiburg 1972, $87 \mathrm{ff}$.

279 Kriss-Rettenbeck, op. cit., Io7 (mit Quellen).

280 Auf einem Mosaik in Ostia (Abb. 49 in Arnold Toynbee, Auf diesem Felsen. Das Christentum Grundlagen und Weg zur Macht, Wien/München 1 970).

28 I Henri Leclercq, Dictionnaire d'Archéologie Chrétienne et de Liturgie V ro39ff., Bernhard Kötting, Peregrinatio religiosa. Wallfahrten in der Antike und das Pilgerwesen der alten Kirche, Regensburg/ Münster 1 950, I 85, 395 ff., Ernst Lucius/G. Anrich, Die Anfänge des Heiligenkultes in der christlichen Kirche, Tübingen I 904, 288 f., Adolph Franz, Die kirchlichen Benediktionen im Mittelalter, 2 Bde., Freiburg I 909, II 439 f., $456 \mathrm{f}$.

282 In Auswahl: Emil Reisch, Griechische Weihgeschenke, Wien I 89o, William H. D. Rouse, Greek votive offerings, Cambridge I 902, Rudolf Herzog, Die Wunderheilungen von Epidaurus, Leipzig I 93 I, Georg Karo, Weihgeschenke in Epidaurus, Stuttgart 1937, Ludwig \& Emma Edelstein, Asklepios, Baltimore 1945, Ulrich Hausmann, Kunst und Heiltum. Untersuchungen zu den griechischen Asklepiosreliefs, Potsdam I 948, Carl Roebuck, The Asklepeion and Lerna, Princeton I 95 I usw.

283 Materialzusammenstellungen bei Rudolf Kriss/Hubert Kriss-Heinrich, Peregrinatio neohellenika. Wallfahrtswanderungen im heutigen Griechenland und in Unteritalien, Wien 1955, Georg Eckert/P. E. Formozis, Beiträge zur mazedonischen Volksmagie, Thessalonike 1942, dies., Mazedonischer Volksglaube. Magie, Aberglaube und religiöse Vorstellungen, Thessalonike 1943.

284 Kriss-Rettenbeck, Ex voto, op. cit., Rudolf Kriss, Volkskunde der altbayerischen Gnadenstätten, 3 Bde., München I 953-56, Rudolf Kriss/Lenz Kriss-Rettenbeck, Wallfahrten Europas, München 1950, Lenz Kriss-Rettenbeck, Bilder und Zeichen religiösen Volksglaubens, München I 963 . Ausnahmen in dieser relativen Einförmigkeit gibt es nur in Form von Votiv-Ikonen unter westlichem Einfluß (Kriss/Kriss-Heinrich, Peregrinatio neohellenica, op. cit., 24 f.), der Votiv-Bäume und -schiffe (bzw. Augenamulette) aufTinos, der vollplastischen Wachsvotive und Votivbilder unter venezianischem Einfluß auf den Ionischen Inseln, Vogelvotive von Türken, Votiv-Schiffe und dergleichen auf der Dodekanes, Steinreliefs mit angeklebten Münzen in Konstantinopel (ibid. 32 f., 55 f., I I 4 f, I 69 f.

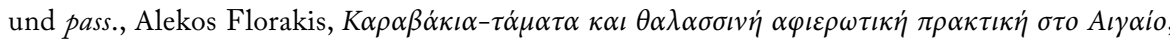
Athen 1982). 
hat das Votiv (tama, anathema, afieroma, taximo) die Form von kleinen Täfelchen aus dünnem Silberblech oder anderem Metall, zuweilen auch aus Gold, mit eingepreßten figürlichen Darstellungen als Ganzfiguren oder Halbfiguren en face und im Profil sowie Körperteilen und Organen, heute in serienmäßiger Erzeugung. Die Umrisse der Votivfiguren sind in punktierten Linien angegeben; sie stehen des öfteren in der antiken Adorantenhaltung mit geöffneten, erhobenen Armen ${ }^{285}$ oder in Beteuerungsgesten mit einer Hand auf der Brust ${ }^{286}$. Die Votivplättchen werden gewöhnlich an einer Messingstange, Schnur oder Seil unter dem Heiligenbild aufgereiht oder direkt über die Ikone als "Halskette« gezogen; ältere Votive werden auch in Holzkästen zur Schau gestellt. Zu den Votivgaben zählt auch das Versilbern bzw. Vergolden von Ikonen bzw. Wachs- und Kerzenopfer ${ }^{287}$.

$\mathrm{Zu}$ diesen Votivgaben gibt es internationale Sammlungen und Studien ${ }^{288}$. In einer der umfangreichsten ${ }^{289}$ sind für den südslavischen und hellenophonen Kommunikationsraum in Südosteuropa folgende Thematiken festgehalten: Menschenfiguren, Herz, Burschen, Mädchen, Frauen, Männer, Hochzeitskränze, Augen, Ohren, Füße, Brust, Arme, Beine, Hände, Magen, Nieren, Lunge, Zähne, Rumpf, Häuser, Dankspruch, Pferde, Esel, Maultiere, Ziegen, Autos, Autobus, Fahrräder, Kreuze, Schiffe, Anker, Nähmaschine, Flugzeug, Krone, Schlüssel, Hufeisen, Medaillen usw. ${ }^{290}$ Für den südsla-

${ }_{28}{ }_{5}$ Klassische griechische Gebetsgebärde, die in einer Ausbreitung und Erhebung der Arme nach oben bestand (Paul Stengel, Die griechischen Kultusaltertümer, 2. Auf., München 1920, 80) und in die christliche Meßfeier eingegangen ist (Thomas Ohm, Die Gebetsgebärden der Völker und das Christentum, Leiden 1948, 259).

286 Seltener mit gekreuzten Armen oder Hängenlassen derselben (Eckert/Formozis, Volksmagie, op. cit., 66). Die Hand auf der Brust ist schon in der antiken und frühchristlichen Kunst nachzuweisen (Georg Weise/Gertrud Otto, Die religiösen Ausdrucksgebärden des Barocks und ibre Vorbereitung durch die italienischen Kunst der Renaissance, Stuttgart 1938, 48 f.).

287 Die Kerzenopfer haben in der berühmten Wallfahrtskirche der Panagia Evangelistria auf Tinos solche Ausmaße angenommen, daß sie zum Schutz der Fresken im Kirchennaos untersagt werden mußten (1994). Die Kirche ist erst I 822 nach einer Wundervision entstanden und hat massiv an-

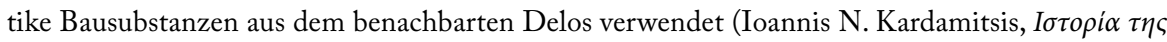

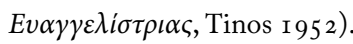

288 Vgl. wie oben. Dazu auch Wolfgang Brückner, »Volkstümliche Denkstrukturen und hochschichtliches Weltbild im Votivwesen «, Schweizer. Archiv für Volkskunde 59 (1963) I 86-203.

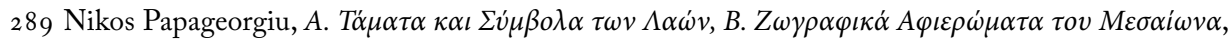
Athen 20 I I, ist eine der größten weltweiten Sammlungen von Votivgaben aus allen fünf Kontinenten mit hunderten von Abbildungen, die der von der UNESCO beauftragte Ethnologe in zahlreichen Feldforschungs-Expeditionen zusammengetragen hat. Vgl. auch seinen ähnlich strukturierten,

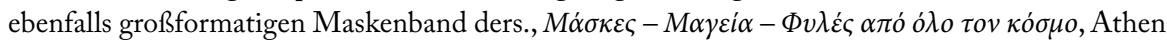
2013 .

290 Papageorgiu, op. cit., 293-296. Dazu kommen noch flammende Herzen als Zeichen der Hingabe, 
vischen Raum können 93 thematische Typen dieser Metallplättchen, aber auch Votive aus Holz und Wachs, Stick- und Webwaren ausgemacht werden; in Serbien sind die Metallplättchen auf den Dörfern nicht üblich, sondern nur in den Städten und Monasterien $^{291}$. Zum Votivwesen Südosteuropas gibt es vorwiegend regionale Bibliographie, die auch die Diaspora umfaßt ${ }^{292}$.

Im islamischen Glaubensbereich der Balkanhalbinsel ist diese Art der Opferspende nicht so verbreite ${ }^{293}$, wohl aber das kurban bajram (nach hebr. korban), das blutige Tieropfer, das im orthodoxen griechisch-südslavischen Kommunikationsraum unter dem

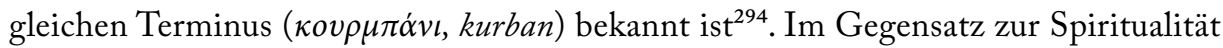

Brautkränze als Bitt- oder Dankopfer für die Heirat, Personengruppen, Scheren usw. (vgl. auch Puchner, Akkommodationsfragen, op. cit., 53 f.).

29I Gordana Blagojević in Papageorgiu, op. cit., I4I-I43. Themen sind u.a. Wickelkinder, Füße, ein Schwein, ein Hahn, die groznica (das Fieber in Form eines Frosches) usw. Adressaten dieser Opfer und Dankopfer sind in den ehem. jugoslavischen Ländern die Heiligen Johannes, Nikolaos, Georgios und Parakevi mit anthropomorphen Abbildungen, zoomorphen und hagiographischen (auch im serbischen Athos-Kloster Hilandar). Bei Kinderwunsch werden auch Wachspuppen als Kleinkinder auf dem Friedhof begraben (Scheinopfer). Im Marienkloster von Sokolica bei Kosovska Mitrovica ist die Marien-Ikone behangen mit Stoffen, Tüchern und Schmuck, in Kosovo verehrt auch von muslimischen Frauen (Kinderwunsch); im Falle der Fremdarbeit (pečalba) wird eine Silbermünze in der Kirche geweiht und als Amulett getragen. In Perovaradin in der Vojvodina feiert die Tekija-Kirche (Crkva na Tekijama) mit dem berühmten Tekija templom am 5 . Aug. und 26. Juni ein panegyri unter Beteiligung von Orthodoxen, Römisch-Katholischen, Protestanten und Griechisch-Katholischen; von den einstigen Wachsopfern ist allerdings wenig erhalten.

292 Neben den Arbeiten von Kriss und Kriss-Heinrich (vgl. wie oben) Z. Mihail, »Symbols populaires de la reconnaissance dans l'aire mediterranéenne et Sud-Est-européenne«, M. Mandalà (ed.), La Sicilia, il Mediterraneo, i Balcani: Storie, culture, lingue, popoli, Palermo 2006, I 23-I47, Stavro

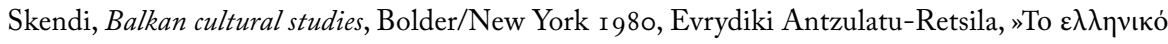

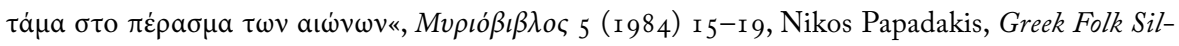
ver Votive Offerings: Iconographical Citation from the Anonymous Art of Greek People, Athens I 97 I, Robert-Thomas Teske, Votive Offerings among Greek Philadelphians, New York 1980 (PhD diss.,

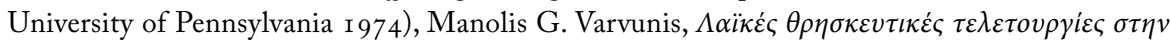

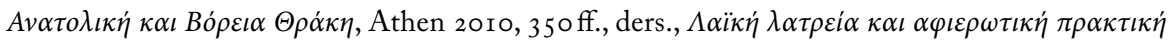

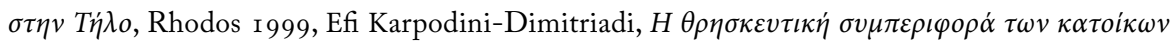

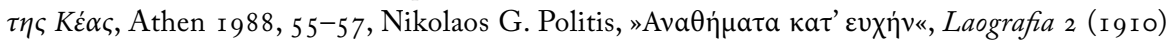

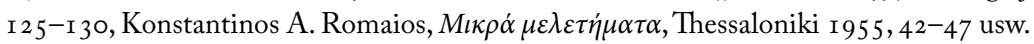

293 Vgl. Kriss/Kriss-Heinrich, Volksglaube im Bereich des Islam, op. cit., 292-340, wo der Nadelöhr-Ritus, das Fetzenopfer bei Quellen, Reiterspiele, Baumheiligtümer, Votivgaben usw. angeführt sind im Zuge des Synkretismus der Mevlevi und der Bektași mit der Orthodoxie (bes. 336-340).

294 Zur Parallelität dieser Opferkonventionen vgl. Manolis G. Varvounis, „Christian and Islamic parallel traditions in the popular culture of the Balkan people«, Journal of Oriental and African Studies 9 ( 1997-98) 53-74, Frederick N. Hasluck, Christianity and Islam under the Sultans, Oxford I929,

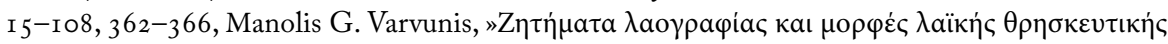


der Votivgaben scheint das Tieropfer Ausdruck primitiver Stofflichkeit zu sein ${ }^{295}$, das jedoch in der orthodoxen Pastoralpraxis in Südosteuropa mit Priestersegnung und teilweise in der Kirche bis in die unmittelbare Gegenwart hinein stellenweise noch anzu-

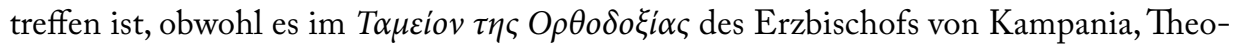
philos (Venedig I 780) in einem eigenen Kapitel als barbarischer und heidnisch-paganer Brauch (»hellenisch«) verurteilt wird ${ }^{296}$. Das Auseinanderklaffen von Pastoralpraxis und Verdikten des höheren Klerus wird uns in der Folge noch weiter beschäftigen.

Obwohl der Konnex zu den antiken Opferbräuchen auf der Hand zu liegen scheint ${ }^{297}$, gibt es jedoch eine Reihe von signifikanten Unterschieden zu den südosteuropäischen Tieropfern der Neuzeit ${ }^{298}$. In einer auf 736 Fallstudien beruhenden Mo-

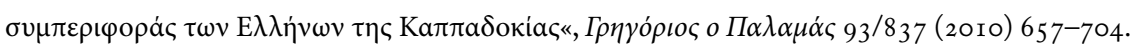

295 Die gestempelten Kultbrote (prosfora) sind mit der Symbolik von Christi Leib ihrer Stofflichkeit entkleidet, der bei der koinonia gespendete Meßwein steht für Christi Blut. Paulus hat in seinen Briefen mehrfach versucht, die Blutsymbolik Christi mit den jüdischen Reinigungsopfern in $\mathrm{Zu}$ sammenhang zu bringen (Kor. I0.I 8-I 9, 2 I-22, Hebr. 9.I3-I4). Im AT spielt die Blutbesprengung als Purifikationsritus eine wesentliche Rolle (der Gläubigen Exod. 24,8, des neuen Priesters Levit. 8,30, des Altars Exod. 29, r6, Levit. I,5; 4,7; 5,9 usw.). Auch in frühchristlicher Zeit wurde das Märtyrerblut als Amulett verwendet (Andreas I. Fytrakis, $\Lambda \varepsilon i \psi \alpha v \alpha \kappa \alpha \iota \tau \dot{\alpha} \varphi \circ \iota \mu \alpha \rho \tau \dot{v} \rho \omega v$, Athen 1955, 35-38). Der Zusammenhang zwischen den Agape-Festen im Kirchennaos, den Festen an den

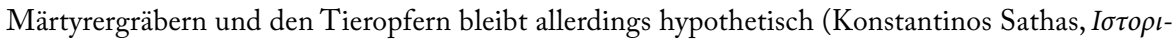

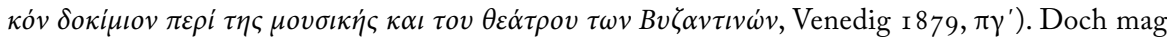
es sein, daß die Spiritualität der christlichen Blutmystik (als Sitz der Seele schon in der Antike), Christi Blut als Unsterblichkeitsgarant, das Märtyrerblut, die Rot- und Rosensymbolik usw. in der Volksfrömmigkeit auch stofflichere, weniger sublimierte Ausformungen gekannt hat, wenn man etwa an die Materialhaftigkeit des Reliquienkultes denkt (die gegenständliche Verehrung von Knochen und Schädeln, vgl. Otto Meinardus, »A Study of Relics of Saints in the Greek Orthodox Church«, Oriens Christianus 54, I970, I 30-278), die fast »kannibalischen« Wallfahrtshysterien um den Reliquienbesitz im Mittelalter (Leopold Kretzenbacher, »Besitz-Streit um den Leib des `Heiligen«", Österr. Zeitschrift für Volkskunde LXIV/95, I 992, 46 I-48 I) und den vielfach bezeugten Heilglauben an die körperliche Berührung mit dem »Kraftträger« (vgl. wie oben).

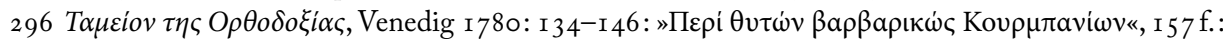

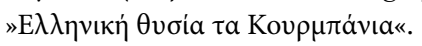

297 Démétrios Petropoulos, »Survivances de sacrifices d'animaux en Grèce«, Papers of the International Congress of European and Western Ethnology (Stockholm 195I), Stockholm 1956, I 20-I 25, Stella Georgoudi, »L'égorgement sanctifié en Grèce moderne: les `Kourbaniar des saints«, Marcel Detienne/ Jean-Pierre Vernant (eds.), La cuisine du sacrifice en pay grec, Paris 1979, 27 I-307.

298 Walter Burkhart, Homo necans. The Anthropology of Ancient Greek Sacrificial Ritual and Myth, Berkeley/Los Angeles/London 1983 (deutsche Version Berlin 1972), Margaret Alexiou, »Reappropriating Greek Sacrifice: homo necans or $\alpha \dot{\alpha} \theta \rho \omega \pi ⿻ \varsigma \theta v \sigma i \alpha \dot{\zeta} \omega \nu \ll$, Journal of Modern Greek Studies 8/I (1990) 97-I 23. Diese Unterschiede bestehen nicht nur in der Anwesenheit des christlichen Priesters, der Kreuzeinritzung in die Stirn des Opfertiers, dem Kerzenaufstecken auf die Hör- 
nographie zu den blutigen Tieropfern im griechischen Kommunikationsraum (davon allein $173 \mathrm{im}$ historischen Thrakien und den thrakischen Flüchtlingssiedlungen in Griechisch-Makedonien $)^{299}$ ist festgehalten ${ }^{300}$, daß die meisten Opfer zu einem bestimmten heortologischen Termin (Heiligenfest) ${ }^{301}$ mit kirchlichem Zeremoniell (daneben gibt es Privatopfer mit magischem Blutgebrauch, Opfer bei Grundsteinlegungen $^{302}$, als Apotropäum von Krankheit und Übel ${ }^{303}$ usw.) stattfinden; das Opfertier ist, im Gegensatz zum Altertum, nach Art und Farbe selten streng festgelegt (Stiere z.B.

ner und der Beweihräucherung (Anka Stahl, »Animal Sacrifices in the Balkans«, A. Bharati (ed.), The Realms of the Extra-Human Ideas and Actions, The Hague 1976, 443-45 I), sondern vor allem im Fehlen eigener Blutrituale bei der Opferung (Royden K. Yerkes, Le Sacrifice dans les religions grecque et romaine et dans le judaisme primitif, Paris 1955, I69, Stengel, Griechische Kultusaltertümer, op. cit., I I 6 f.), in der relativen Bedeutungslosigkeit des Schlachtvorgangs, der Häutung und der Fleischverteilung, während der Sinnakzent der Opferhandlung auf dem Fleischverzehr gelegen hat (Yerkes, op. cit., I 35). Im Gegensatz dazu wird in dem aufgelisteten Fallmaterial oft betont, daß die Opfer nur um des Blutes willen vorgenommen werden (vgl. auch Puchner, Akkommodationsfragen, op. cit., 54-56).

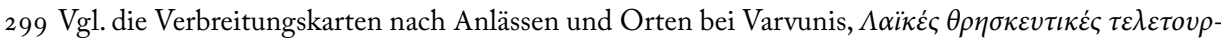

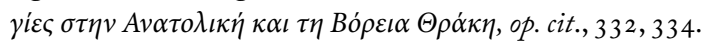

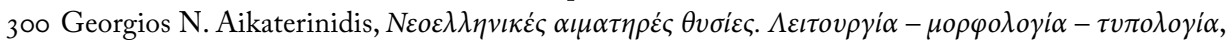
Athen 1979 .

30r Dazu zählen die Heiligen Athanasios, Demetrios, Tryphon, Georgios, Nikolaos, Charalampos, Konstantinos, Johannes Theologos, der Prophet Elias usw. Vgl. Ivanička Georgieva, "Le fen et la croix: un rite en l'honneur de saint Constantin«, Ethnologie Française 3 I (200I) 25 I-26o, Tatiana Koleva, »Sur l'origine d'un groupe de coutumes et rites dans la région balkano-carpathique. La fête

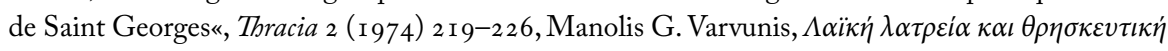

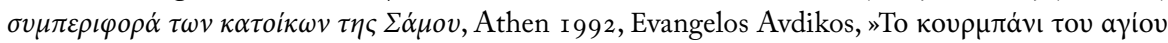

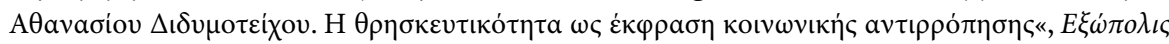

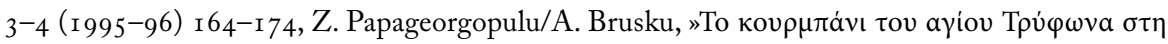

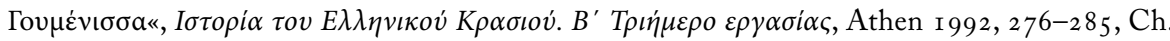

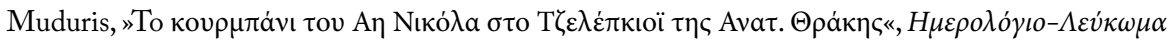

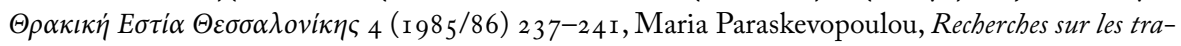
ditions des fêtes religieuses populaires de Chypre, Nicosia I 978, usw.

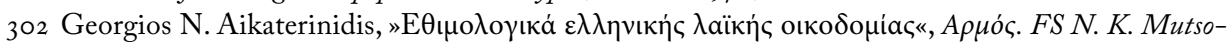

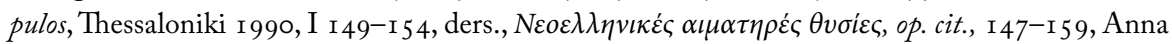
Papamichael-Koutroubas, »The laying of Sacrifices under the foundation of buildings e. t. c. «, $\mathrm{Ne}-$

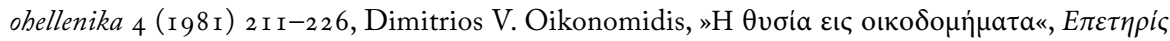

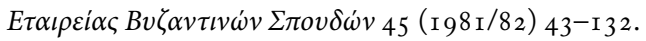

303 Im Krankheitsfall wird das Tier auf der Kirchenschwelle getötet, während der Priester den Weihespruch verliest; Fleischstücke werden an die Kleidung des Kranken gebunden. Kollektive Tieropfer werden bei Epidemien oder Mißernten im Kirchenhof oder am Hauptplatz vorgenommen (Politis,

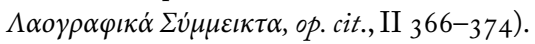


nur bei den anastenaria und auf Lesbos) $)^{304}$, meist Schafe, Ziegen und Böcke, Schweine zu Weihnachten und im Karneval, Hähne bei Hausbau und bei der Hochzeit (auch für den Erzengel Michael) ${ }^{305}$; die Schlachtung findet im Kirchhof, am Portal, beim Glokkenturm, am Hausfundament statt oder auch im Kirchennaos selbst (daneben auch in Höhlen und unter Bäumen); der Schlächter ist ein Verwandter, Mitbewohner oder auch Fremder oder der Meistbietende bei Versteigerungen, früher scheint auch der Priester eine wesentliche Rolle gespielt zu haben ${ }^{306}$; bei den öffentlichen Opferhandlungen ist seine Anwesenheit die Regel, gilt das Tieropfer doch trotz aller Verbote als Ausdruckszeichen höchster Frömmigkeit ${ }^{307}$; die Schlachtung findet während der Liturgie oder am Vortag statt, so daß das Opferfleisch am Festtag gesegnet werden kann. Zum öffentlichen Zeremoniell gehören die Schmückung des Tieres und die Prozession (es darf nicht ermüdet werden $)^{308}$; die Schlachtung erfolgt mit dem Kopf gegen Osten, das Blut fließt in eine eigens ausgehobene Grube, oder, je nach Umständen, ins Kirchen- oder Hausfundament, unter die Heiligenikone, auf die Hausschwelle, den Hürdeneingang, die Bootsbretter usw.; mit dem Blut wird den Anwesenden ein Kreuz auf die Stirn gemalt, auf Hauseingänge und Ställe, es wird im Ikonenschrein des Hauses aufbewahrt oder als Amulett getragen usw. ${ }^{309}$ Das Fleisch wird nach der Messe roh oder gekocht verteilt oder im Kirchenraum bzw. an einem sonstigen vorbestimmten Ort verzehrt; an dem Schmaus nimmt die gesamte Kommunität und auch Ortsfremde teil; wesentlich ist, daß das Opferfleisch noch am Festtag verzehrt wird, die Reste (und das Blut) werden aufbewahrt, den Kopf (oder das Rückenteil) bekommt der Priester. Zahlreiche Opferlegenden berichten von der Rettung mancher Dörfer von Seuchen durch solche Tieropfer, die gewissen Heiligen geweiht sind, andere berichten von der Übertretung solcher Gelübde, wo das dem Heiligen bestimmte Tier überhaupt nicht oder ein anderes an seiner Stelle geschlachtet wurde, und von den verheerenden Folgen dieser Tat ${ }^{310}$.

Tierschutzvereine, aufgeklärte Rationalität und Verdikte von seiten der offiziellen Kirche haben es bisher nicht vermocht, diese Opferpraktiken gänzlich zu unterdrücken; ganz im Gegensatz zu den kirchlich gesegneten Bluts- und Wahlbruderschaften, die

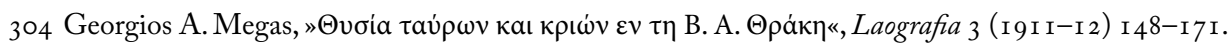

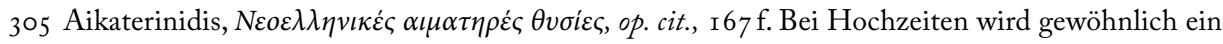
Schaf, ein Hahn oder Geflügel geschlachtet und die Hausschwelle mit Blut bestrichen.

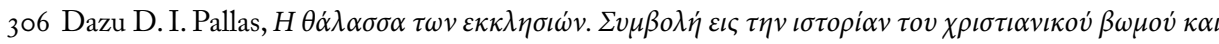

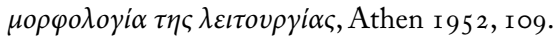

307 Aikaterinidis, op.cit., 9I, I 55 und I70.

308 Das Ideal des Opfertieres ist ohne Fehl und kommt freiwillig zur Schlachtung (zu Legenden um den Hirsch, der freiwillig zum Opfer kam, Laografia III I 55, I6o, VI I 89 f.).

309 Aikaterinidis, op. cit., I 7 I.

3 Io Ibid. I63, I72. 
bereits seit byzantinischer Zeit verboten waren, deren Eliminierung jedoch erst im 20. Jh. vor sich gegangen ist. Populare Devotionsformen folgen anderen Notwendigkeiten, die sich fern der theologischen Dogmatik bewegen, und die Absenz dieses jahrhundertealten Kirchenbrauchs ist nicht den patriarchalen Erlässen zuzuschreiben, sondern den geänderten Lebensbedingungen der nicht-privilegierten Unterschichten.

\section{SONDERFORMEN DER PASTORALPRAXIS}

In diesem Abschnitt werden stellvertretend zwei Beispiele von Glaubensübungen der Pastoralpraxis untersucht, wo der Übergang zwischen ekklesial sanktioniertem Ritus und dogmatisch dubiosen Praktiken, in manchen Fällen von patriarchalen Dekreten und synodalen Verdikten ausdrücklich verboten, wie etwa die animalen Blutopfer mit kirchlicher Segnung, nicht mehr eindeutig festzulegen ist, die sich jedoch in der Pastoralpraxis weiter erhalten haben, oft bis in die unmittelbare Gegenwart hinein. Ein Fall betrifft den Ritus der Wahlbruderschaft mit ekklesialer Benediktion in der südosteuropäischen Orthodoxie, wo sich die patriarchalen Erlässe und die episkopalen Verordnungen erst im 20. Jh. durchgesetzt haben, ein anderer die Bittprozessionen mit Litaneien und eigenen parakletischen Liturgien, die in den euchologia als spezifische Akoluthien (Meßordnungen) zu verschiedenen Notsituationen festgehalten sind, welche das Kirchenvolk bewegen und beschäftigen, aber mit den eigentlichen Glaubensinhalten der Hochreligion wenig zu tun haben (z.B. Trockenperioden).

\section{I WAHLBRUDERSCHAFT MIT EKKLESIALER BENEDIKTION}

Zwei Grundtypen der Wahlbruderschaft bzw. Blutsbrüderschaft sind zu unterscheiden: I. die eigentliche Blutmischung der Verbrüderten (durch Aufeinanderlegen der Schnittwunden, Blutsaugen, Bluttrunk oder Ersatz durch Rotwein) bzw. ihre »sublimierten« Formen durch Händeverbindung, Treueschwur, aspasmos ${ }^{311}$, Geschenktausch usw. und 2. die kirchliche Segnung im Beisein des Priesters, der Durchführung eines einfachen Symbolrituals und der Psalmodierung von Hymnen bzw. dem Aussprechen von Gebeten und Segnungen, entweder festgehalten in eigenen "Akoluthien " (vor allem in älteren umstandsgebundenen euchologia) oder vom Geistlichen improvisiert (nach Maßgabe der geltenden Pastoralpraxis). Beide Grundtypen sind auch in vielfachen Kombinationen bzw. auch im sukzessiven Nacheinander oder im simultanen Ineinander anzutreffen. Die »magische« Bindung der Blutkommunion (»Blutsbrüderschaft«) als sekundärem

3 I Vgl. dazu im Ersten Teil. 
Verwandtschaftssystem, dem in besonderen Situationen spezifische strategische Funktionen zukommen, dürfte praktisch weltweit verbreitet gewesen $\operatorname{sein}^{312}$, die kirchliche

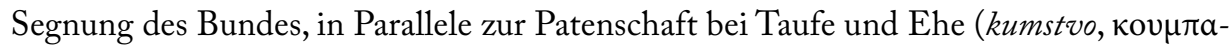

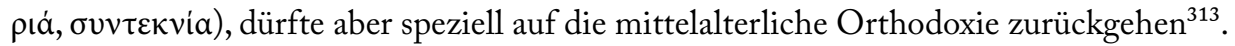
Die Wahlbruderschaft steht als cognatio spiritualis in Kontrast zu allen Formen des leiblichen Bruderverhältnisses und im Übergang zur Milchbruderschaft oder Taufbruderschaft $^{314}$. Säkularisierte Formen stellen die Städteverschwesterungen und Institutsver-

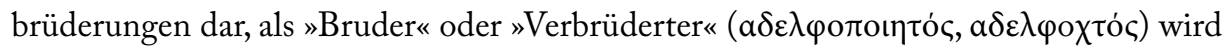
auch der Angehörige einer gleichen Gemeinschaft (Orden, Geheimbund) oder einfach der Vertraute und intime Freund bezeichnet.

Die cin bratotvorenja ist keineswegs eine vorwiegend südslavische Domäne, wie in der älteren Literatur zu lesen ist ${ }^{315}$, sondern auch im hellenophonen Kommunikationsraum

3 I 2 Dazu J. Kohler, »Studien über künstliche Verwandtschaft«, Zeitschrift für vergleichende Rechtswissenschaft V (I883) 4I 5-440, bes. 436-440, Albert H. Post, Grundriss der ethnologischen Jurisprudenz, O1denbourg/Leipzig I89 I, Bd. I, 94 ff., Harry Tegnaeus, Blood-Brothers, Stockholm I 952 (in der französischen Ausgabe La Fraternité de sang, étude ethnosociologique des rites de la fraternité de sang notamment en Afrique, Paris 1954), K. Weibust, »Ritual Coparenthood in Peasant Societies«, Ethnologia Scandinavica I 972, IOI-I 44, Leopold Hellmuth, Die germanische Blutsbrüderschaft. Ein typologischer Vergleich mit völkerkundlichen Gegenstücken, Wien 1975. Weitere Literatur im Artikel »Blutsbrüderschaft« von M. Belgrader in der Enzyklopädie des Märchens II (Berlin/New York 1977) 523-528. Ältere Rechtsliteratur

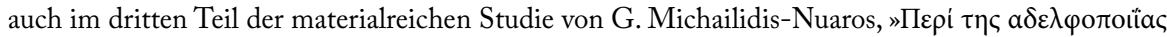

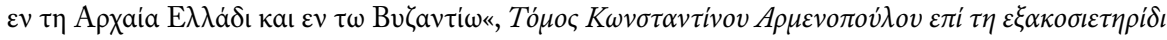

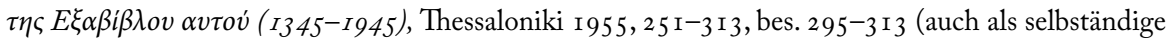

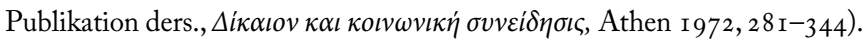

3 I 3 Zur kumstvo vgl. die Literaturangaben bei Leopold Kretzenbacher, Geheiligtes Recht. Aufsätze zu einer vergleichenden rechtlichen Volkskunde in Mittel- und Südosteuropa, Wien/Graz/Köln I 988 ,

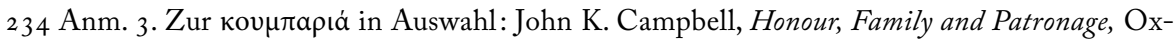
ford I 964, 2 1 3-262, Ernestine Friedl, Vasilika. A Village in Modern Greece, New York 1962, 72 ff., Margaret Kenna, »The Idiom of Family«, John Peristiany (ed.), Mediterranean Family Structures, Cambridge 1976, 347-362 (im selben Band auch Julian Pitt-Rivers, »Ritual Kinship in the Me-

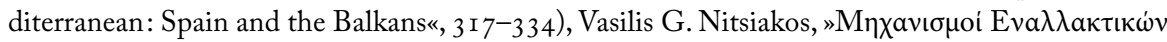

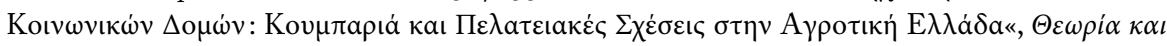
Kolvwvia 2 (1990). Ausführlich auch in Paul Sant Cassia/Constantina Bada, The Making of Modern Greek Family. Marriage and Exchange in Nineteenth-Century Athens, Cambridge r 992, I 55 ff.

3 I 4 "Brustbrüder « ( $\beta \nu \zeta \alpha \delta \dot{\varepsilon} \lambda \varphi \iota \alpha)$ werden sie im Raum Florina und Kastoria genannt (Georgios Spy-

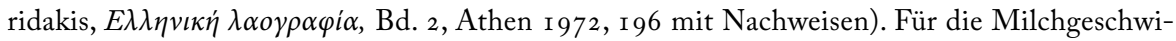

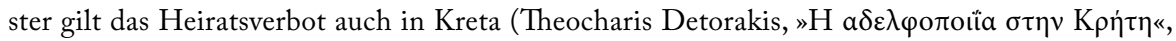

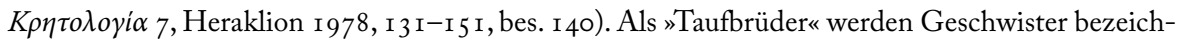
net, die zu gleicher Zeit im selben Taufbecken getauft worden sind oder denselben Taufpaten ha-

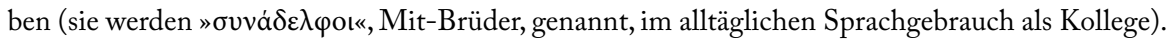

3 I 5 Z.B. Stanislaus Ciszewski, Künstliche Verwandtschaften bei den Südslaven, Diss. Leipzig I 897. 
und anderswo in Südosteuropa gang und gäbe ${ }^{316}$. Leopold Kretzenbacher hat in einer Reihe aufeinanderfolgender Studien ${ }^{317}$ das Phänomen der pobratimstvo in erlebter Feldforschung (Kruševac 1966, 1977), in Geschichte, Theologie und Literatur gründlich untersucht ${ }^{318}$, und ein neuerliches Aufgreifen der Thematik meinerseits konnte das Funk-

3 r6 Vgl. dazu Walter Puchner, »Griechisches zur adoptio in fratrem«, Südost-Forschungen 53 ( 1994 ) I 87-224 und modifiziert ders., "Adoptio in fratrem. Kirchliche Segnung der Wahlbruderschaft zwischen theologischem Verdikt und gelebter Pastoralpraxis«, Studien zur Volkskunde Südosteuropas, op. cit., 353-384.

3 I 7 Zuerst im Aufsatz Leopold Kretzenbacher, "Gegenwartsformen der Wahlverwandtschaft spobratimstvo bei den Serben und im übrigen Südosteuropa«, Grazer und Münchener Balkanologische Studien-Beiträge zur Kenntnis Südosteuropas und des Nahen Orients, Bd. 2, München 1967, r67 ff., sodann in der Monographie Rituelle Wablverbrüderung in Südosteuropa. Erlebniswirklichkeit und Erzählmotiv, Bayerische Akademie der Wissenschaften, phil.-hist. Klasse, Sitzungsberichte I97 I/I, München I97 r. Hierauf griff der Aufsatz »Serbisch-orthodoxe ,Wahlverbrüderung« zwischen Gläubigenwunsch und Kirchenverbot von heute«, Südost-Forschungen 38 (1979) I63-I 83 dieselbe Thematik unter einem anderen Aspekt (den der Kirchenerlässe und erneuter Feldforschung in Kruševac) wieder auf. Das Erlebnis der kirchlichen Wahlverbrüderung bzw. -verschwesterung in Kruševac erfuhr im Aufsatz »Volkskundliche Feldforschung im europäischen Südosten«, Saga och Sed. Kungl. Gustav Adolf Akademiens Arsbok. Hrsg. von Lennart Elmevik (= Annales Academiae Regiae Gustavi Adolphi), Uppsala 1983, 33-48 nochmals eine eindringliche Darstellung und wurde im Kapitel ıо »Kirchlich eingesegnete Wahlverbrüderung in Südosteuropa«, im Band Ethnologia Europaea. Studienwanderungen und Erlebnisse auf volkskundlicher Feldforschung im Alleingang, München 1986, I 27-I 34 nachgestaltet. Der materialreiche Aufsatz von 1979 ist nochmals abgedruckt im Band Leopold Kretzenbacher, Geheiligtes Recht. Aufsätze zu einer vergleichenden rechtlichen Volkskunde in Mittel-und Südosteuropa, Wien/Graz/Köln I 988, 233-252.

3 I 8 Ausgehend vom Erlebnis der serbisch-orthodoxen kirchlichen Segnung einer pobratimstvo im serbischen Kruševac i 966 (Kretzenbacher I97 I, op. cit., 3 ff., ders. I 967, op. cit.) bietet er eine gründliche Aufarbeitung der liturgiegeschichtlichen und byzantinisch-rechtlichen Quellen zu diesem von der Hochkirche immer mit einem gewissen Mißtrauen betrachteten Brauch (ders. I 988,239 ff.) sowie eine Weiterverfolgung dieser Institution "geistiger « Verwandtschaft in Volksliteratur und Hochliteratur (ders. I 97 I, I 5 ff.). Diese insgesamt umfassende Darstellung von der byzantinischen Kaiserprophetie und der Danielis-Episode in der Legenden-Biographie des Kaisers Basileios (868-886) (ders. I97 I , 7 ff. nach Hans-Georg Beck, Byzantinisches Gefolgschaftswesen, München I 965, Ioff. und Gyula Moravcsik, »Sagen und Legenden über Kaiser Basileios I.«, Dumbarton Oaks Papers XV, I 95 I, 59 ff.) führt über glagolithische und altkirchenslavische Ritualbücher zur $a \delta \varepsilon \lambda$ фолої̈ (nach P. Simić, „Pobratimstvo u liturgiči i crkvenom pravu«, Pravoslavna misao XI/I-2, Beograd I 968, 85-I0I), dem entsprechenden Literaturmotiv in der Ragusaner Renaissance- und Barockliteratur (nach Milovan Gavazzi, „Vitalnost običaja pobratimstva i posestrimstva u Sjevernoj Dalmaciji «, Radovi Instituta Jugoslavenske Akademije znanosti in umjetnosti u Zadru I I, I955, I 7 ff. und Belegstellen in Tomo Maretić, Rječnik hrvatskoga ili srpskoga jezika, Bd. го, Zagreb I 93 I, I 44 f. pobratim) sowie Nachweisen aus dem Reiseschrifttum über Dalmatien im I 7. und I 8. Jahrhundert (ders. I 967, I 8 I f. nach Alberto Fortis, Viaggio in Dalmazia, Venezia I774, Bd. I, 58 f. und Ivan Lovrić, Osservazioni di Giovanni Lovrich sopra diversi pezzi del viaggio in Dalmazia del 
tionsspektrum des Nothilfebrauchs noch um andere Funktionen des Reagierens auf eine Krisensituation erweitern ${ }^{319}$. Die kirchlich-rituellen Segnungen des Bundes in den Euchologie-Handschriften und Akoluthien-Drucken zwischen dem I I. und I 7. Jh. ${ }^{320}$

Signor Abate Alberto Fortis ... In Venezia I 776, го4 f.) zu jüngeren Studien über Kroaten, Serben, Bulgaren und Albaner (Gavazzi, op. cit., N. A. Nacovi, "Za pobratimstvo«, Periodičesko spisanie na bălgarskoto knjižovno družestvo Sredeci I 895, IX-XI 32-72, LI 375-403, LII-LIII 443-506, Johann Georg Hahn, Albanesische Studien, Bd. I, Jena I 854, I 78, Eqrem Çabej, »Albanische Volkskunde«, Südost-Forschungen 25, 1966, 333 f., bes. 350; zu katholischen Geistlichen, die sich mit islamischen beïraktars durch Bluttausch »verbrüdern" Ernst Jäckh, Im türkischen Kriegslager durch Albanien, Hannover I 9I I, 48; vgl. ebenfalls Ciszewski, op. cit., Giovanni Tamassia, L'affratellamento ( $\alpha \delta \varepsilon \lambda$ фолої $\alpha$ ). Studio storico-giuridico, Torino I 886, Emil Schneeweis, Serbokroatische Volkskunde, Berlin I 96 I, I 76 f., Galaba Palikruševa, »Kumstvoto i pobratimstvoto na Sveti Jovan«, Makedonski Folklor I 5/I6, I 975, und weitere Literatur bei Kretzenbacher 1988, 25 I Anm. 37), dem Nachweis des Motivs der vila posestrima, der Wahlschwester-Fee, im Kosovo-Zyklus und in bulgarischen Teufelspakt-Legenden (ders. I 97 I, 8 f., B. A. Strauß, Bulgarische Volksdichtungen, Wien/Leipzig I 895, 53, Max Lambertz, Die geflügelte Schwester und die Dunklen der Erde. Albanische Volksmärchen, Eisenach I 952, 2 I ff.), aber auch als "patriarchalischer« Brauch im Heimatroman von Janko Veselinović (Kretzenbacher I 97 I, I 5 f.), im Roman »Unreines Blut« von Borislav Stanković (ibid. I6-ı 8., Erstausgabe Beograd I910, deutsche Übersetzung 1922 und München I935) und letztlich im Roman „Freiheit oder Tod« von Nikos Kazantzakis (»Kapetan Michalis«) (ibid. I 9-2 I, in der griechischen Ausgabe, Athen I 955, 25 ff,, in der deutschen Übersetzung, Berlin-Grunewald s. a. [1954], 27 ff.). Diese umfassende Darstellung findet ihren Abschluß in den neuerlichen Abfragungen in Kruševac I 977, die die Übertretung des "geistigen Bundes« durch Heiratschließung ans Licht brachte (ders. I 979 und r 988, bes. 247 ff.), und die negative Stellungnahme der offiziellen serbisch-orthodoxen Kirche (ders. I 979, I 988, 236 f. nach einem Auskunftsbrief vom 8. I 2. I 977). Der Synodalentscheid wurde aufgrund der Studie von Simić, op. cit., sowie auf dessen Betreiben gefällt.

3 I 9 Zur psychischen Schutz- und Stützfunktion für Alte, Kranke und Hilfsbedürftige im weiteren Sinne vgl. die Beispiele, die Kretzenbacher bringt ( 1988,246 und ders. I 967, I 72 f.): Die Kranken kommen im Morgengrauen zur Lazarica-Kirche in Kruševac, um sich »einen Bruder zu suchen« und sprechen den Erstbesten diesbezüglich an. $\mathrm{Zu}$ solchen Not-Wahlbrüderschaften im südlichen Moravatal Dragutin M. Đorđević, „Život i običaji narodni u Leskovačkoj Moravi«, Srpski Etnografski Zbornik LXX/3 (Beograd I958) $524 \mathrm{f}$. Zum mißbräuchlichen Einsatz als soziale Aufstiegshilfe und Schutzsicherung durch Einflußreiche vgl. den byzantischen Legendenroman um Basileios I. (Kretzenbacher I97 I, Io ff.). Doch neben diesen Funktionen dient der Brauch auch der gezielt eingesetzten psychischen Festigung der Kampfgemeinschaft in Krisenzeiten (z.B. Kreta der Türkenzeit), fungiert als ergänzende Strategie verwandtschaftlicher Vernetzung in Kleingemeinden, oder ist einfach akzentuierte Ausdrucksform intimer Freundschaft. Vgl. Walter Puchner, »Griechisches zur adoptio in fratrem«, Südost-Forschungen 53 ( ( 994) I 87-224 und verkürzt in ders., "Adoptio in fratrem. Kirchliche Segnung der Wahlbruderschaft zwischen theologischem Verdikt und gelebter Pastoralpraxis«, Studien zur Volkskunde Südosteuropas und des mediterranen Raums, Wien/Köln/Weimar 2009, 353-384.

320 Zusammenstellung solcher Texte bei Jacobus Goar, Evxoló yıov sive rituale Graecorum, Paris I647, Teil VII, in der Ausgabe Venedig I 730 (Reprint Graz i 960) 706-709 und Aleksej Dmitrievskij, 
weisen den Brauch von vornherein in den Status des ausgeprägt Institutionellen; als juridischer Problemkreis findet sich die adoptio in fratrem denn auch zuerst im römischen (und byzantinischen) Ehe- und Erbrecht ${ }^{321}$. Das Erbproblem für den frater adoptivus taucht zum erstenmal im Codex Justinianus auf, als rescriptum eines Erlasses von Kaiser Diokletian (3. I 2. 285), der der Verbindung jegliche Rechtskraft abspricht ${ }^{322}$, und wird

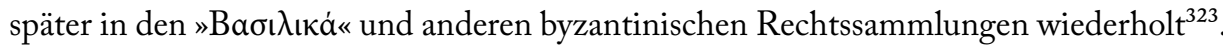
Die weite Verbreitung der »Wahlverbrüderung« in Byzanz spiegeln sowohl die Quellen der kirchlichen Rechtsprechung wie die Gesetzeskompendien ${ }^{324}$, aber auch historische

Opisanie liturgitseskich rukopisej. II. Evxoló I . Kiew I 90 I (reprografischer Nachruck Hildesheim I 965) 3 I f., I 22 f., I 79 f., 2 I 5, 466 f., 569, 743 f. und ro5 I (Fußwaschung). Zusammenstellung der altkirchenslavischen Texte bei Simić, op. cit., $92 \mathrm{ff}$.

32 I Die Kirchenrechtserlässe zusammengestellt bei Georgios A. Rallis/Michail Potlis, $\Sigma v ́ v \tau \alpha \gamma \mu \alpha \theta \varepsilon i \omega v$

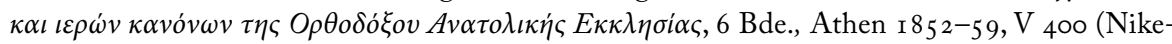
phoros Chartophylax) und VI I $27 \mathrm{ff}$. (Matthaios Blastares). Vgl. auch P. I. Panagiotunakis, $\Sigma \dot{v} \sigma \tau \eta \mu \alpha$

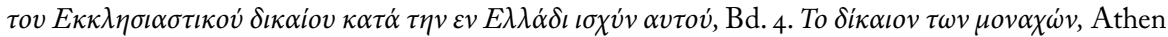
I 957, 258 Anm. 2 (wo der Brauch verurteilt wird). Unter dem Namen $a \delta \varepsilon \lambda \varphi$ o

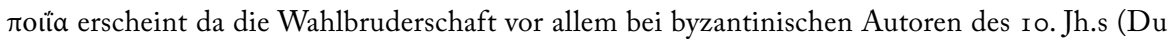
Cange, Glossarium ad scriptores mediae et infimae graecitatis, Bd. I, I688, 23 f., Michailidis-Nuaros, op. cit. und F. Dölger, П $\alpha \rho \alpha \sigma \tau \rho \rho \alpha ́$, Ettal I 96 I, I 97 Anm. I 2). Im »Testamentum« des Theodoros

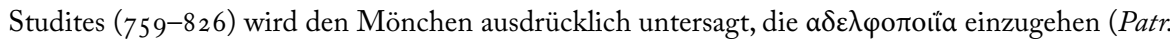
gr. 99: г 82०B, 8). Zu weiterem Material aus byzantinischer Zeit vgl. nun E. A. R. Brown, BBrotherhood in Byzantium. Introduction«, Traditio 52 (1997) 26I-384, bes. 26 I ff. und Claudia Rapp, "Ritual brotherhood in Byzantium", ibid. 285-326.

322 Cod.J. VI, 24, 7. Beim Ableben des Wahlverbrüderten hat der "frater adoptivus« nichts zu erben.

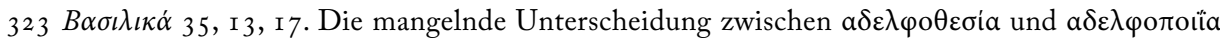
hat in der Folge zu mannigfachen Rechtskontroversen Anlaß gegeben (Michailidis-Nuaros, op. cit., 275-282, Zacharias von Lingenthal, Geschichte des griechisch-römischen Rechts, Berlin I 892 (3. Auf.), I I 8-I 20; die Rechtssammlungen bibiographisch zusammengestellt bei Karl Krumbacher, Geschichte der byzantinischen Litteratur, München I 897, 605 ff.). In Byzanz wird das Dekret des Diokletian für die Wahlbruderschaft im engeren Sinne ausgelegt und als Verdikt für die offen-

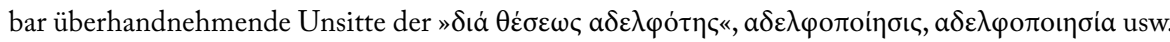
eingesetzt und nicht zu Unrecht u.a. als Erbschleicher-Strategie und Leitfaden für rasche soziale Vertikalkarriere interpretiert. Die nachfolgende Heirat von heterosexuellen Wahlverbrüderten bzw. -verschwesterten ist ausdrücklich untersagt (Lingenthal, op. cit., I I 9). Das Verbot für Mönche und Laien ist auch in den Klostertypika festgehalten (Philipp Meyer, Die Haupturkunden für die Geschichte der Athosklöster, Leipzig I 894, I I 3, I 46, 208). Die späteren Rechtskompilationen werden nicht müde, immer neue Gründe für die Existenzberechtigung des geltenden Verbots zu erfinden,

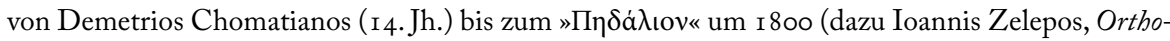
doxe Eiferer im osmanischen Südosteuropa. Die Kollyvadenberwegung (I750-1820) und ibr Beitrag zu den Auseinandersetzungen um Tradition, Aufklärung und Identität, Wiesbaden 20 I 2).

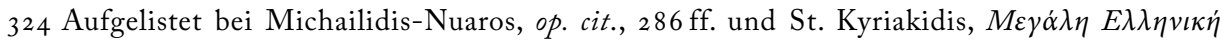

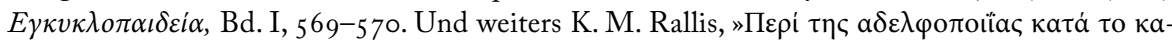


und literarische Quellen ${ }^{325}$ und die Euchologien- und Akoluthien-Sammlungen für den speziellen kirchlichen Ritus ${ }^{326}$ noch bis tief in die nachbyzantinische Zeit. Als Rechtsfolgen des "geistigen « Bundes werden Solidarität und Hilfeverpflichtung angegeben sowie die Konsequenz des Heiratsverbotes für die Verbrüderten bzw. Verschwesterten und ihre Verwandten ${ }^{327}$. Byzantinische und vor allem postbyzantinische Quellen lassen darauf schließen, daß diese Verpflichtungen durchaus nicht immer eingehalten worden $\operatorname{sind}^{328}$. Die eigenartig ambivalente Stellung dieser artifiziellen Verwandtschaftsinstitu-

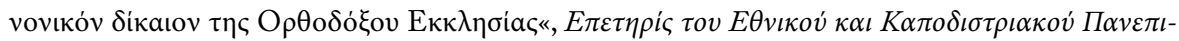

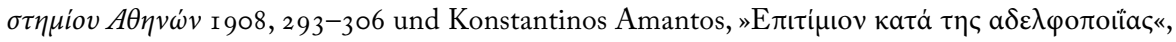

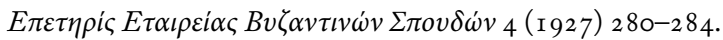

325 Erste Zusammenstellung bei Du Cange, Glossarium ad scriptores mediae et infimae graecitatis, Bd. I (I688) 23 f. Pseudo-Kodinos berichtet, daß Justinian und Strategios Wahlbrüder gewesen seien (Bonn, I33), Leon Grammatikos berichtet von der Wahlbruderschaft von Basileios mit einem angehenden Mönch (Bonn, 234, Text auch bei Michailidis-Nuaros, op. cit., 288), Georgios Kedrenos erzählt die schon angeführte Danielis-Episode bei der Kaiserwerdung von Basileios (weitere Bei-

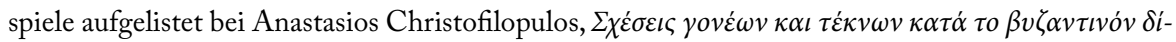

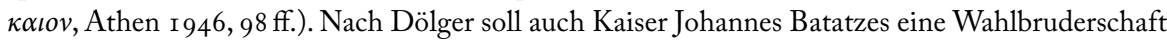
mit seinem Minister Demetrios Tornikes eingegangen sein (Byzantinische Zeitschrift 27, 303 Anm.

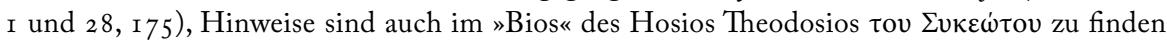

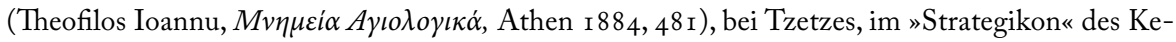
kaumenos (49, I I) usw. (vgl. Amantos, op. cit., 283). Niketas Choniates (Bonn, 536) berichtet von Wahlverbrüderungen zwischen Byzantinern und Sarazenen mit Blutmischung und Nikephoros Gregoras berichtet in seinem Brief an Joseph den Philosophen (zwischen I 322 und I 325 ), daß sich die Bewohner von »Karmania« (am Persischen Golf) zur Bekräftigung ihrer Freundschaft Adern im Gesicht öffneten (Rodolphe Guilland, Correspondance de Nicéphore Gregoras, Paris 1927, 2).

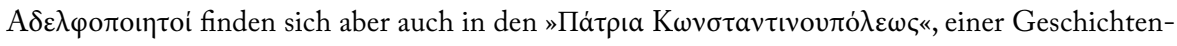
sammlung des 9.-ro. Jh.s (Theodorus Preger, Scriptores originum Constantinopolitanarum I, Lipsiae I 90 I, 74-ro8, bes. 79 Zeile I) sowie in der Chronik des Symeon Magistros aus dem ro. Jh. (Bonn, 656 Zeile I 2).

326 Vgl. Goar, op. cit. ( 1730,706 ff.) und Dmitrievskij, op. cit., pass. Auch Christofilopulos, op. cit., Ioo Anm. 2.

327 Michailidis-Nuaros, op. cit., 289 f.

328 Im »X die Griechen des Despotats geführt, daß ihnen die Wahlbruderschaft bloß zu List und Betrug

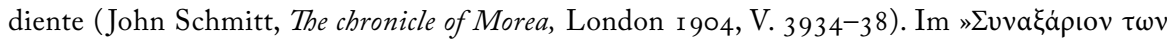

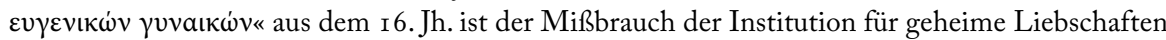
deutlich formuliert (Karl Krumbacher, Ein vulgärgriechischer Weiberspiegel, München 1905, 4I 2). Von Wahlverbrüderten, die nachher geheiratet haben, weiß auch Manuel Malaxos in seinem »No-

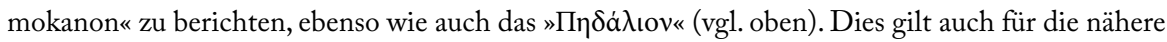
Vergangenheit (vgl. Kretzenbacher 1 988, op. cit., 244f.). Aus dieser Erfahrung heraus befragte der serbische Pope 1966 in Kruševac dreimal die jungen Leute, ob sie auch wirklich bereit seien, immerzu nur als Bruder und Schwester zu leben; die Reaktionen auf den Bruch der Bindung, die 
tion zwischen offizieller Nichtanerkennung und weithin geläufiger sozialer Praxis zieht sich auch im nachbyzantinischen Südosteuropa noch bis ins 20. Jh. hin. In den unsicheren Jahrhunderten der Türkenherrschaft nimmt die Intensität des Brauches sogar noch zu: Er gehört wie die Kinderehe ${ }^{329}$ und die Großfamilien-Formen zu den sozialen Schutz- und Überlebensstrategien der Einzelfamilie in der Kleingemeinde; in der langen Kette der Aufstände gegen das Osmanische Reich ${ }^{330}$ wird das Verbrüderungsritual auch zum emotionellen Zusammenschweißen der mobilen Kampfgruppen angewendet, ja sogar für geheimbündische Organisationsformen, deren Ziele nicht immer nur patriotische gewesen sind (z.B. in Kreta des späten I 9. Jh.s). Hier geht es meist um Gruppenverbrüderungen; daneben aber bleibt zu betonen, daß bei diesen Formen der "geistigen Verwandtschaft« ethnische und religiöse Grenzen keine definitive Rolle zu spielen scheinen $^{331}$.

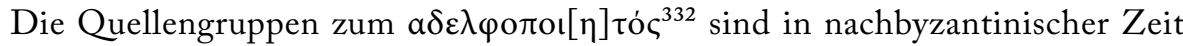
in etwa die gleichen: Rechtskompendien, spezifische Meßrituale, aber auch zuneh-

beim zweiten Besuch Kretzenbachers 1977 ans Tageslicht kam, waren dementsprechend heftig (ibid. 247).

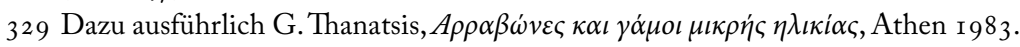

330 Olga Katsiardi-Hering, »Von den Aufständen zu den Revolutionen christlicher Untertanen des osmanischen Reiches in Südosteuropa (ca. I530-1821). Ein Typologisierungsversuch «, SüdostForschungen 68 (2009) 96-1 37 .

33 I So berichtet schon Niketas Choniates in spätbyzantinischer Zeit von Griechen, die mit Lateinern (»Franken«) Wahlbruderschaft eingegangen seien (Bonn, 536). Mehrere namhafte Waffenführer der griechischen Revolution von I 82 I waren mit von der Hohen Pforte abtrünnigen Türken verbrüdert: So war z.B. der Großvater von Theodoros Kolokotronis Wahlbruder des Großvaters von Ali Farma-

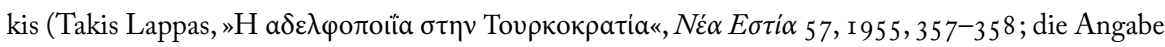
stammt aus den Memoiren von Theodoros Kolokotronis, Georgios Tertsetis, 'A $\pi \alpha \tau \tau \alpha$, Bd. 3, Athen I 953, 46); auch Ali Pascha von Tepeleni war durch diese Bande an einen griechischen Waffenführer gebunden: Er war Wahlbruder mit Kapetan Andrutsos, dem Vater des berühmten Waffenführers von I 82 I, Odysseas Andrutsos (Lappas, op. cit.). Was Kazantzakis in seinem Roman »Freiheit oder Tod»

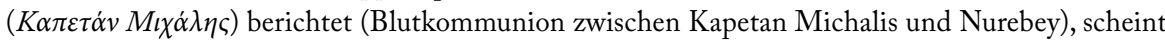

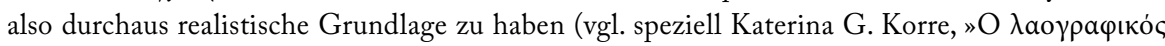

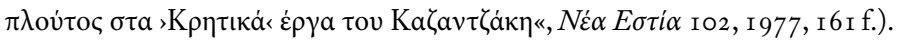

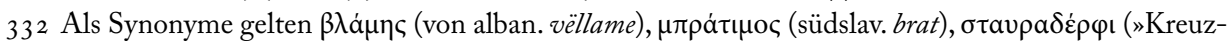

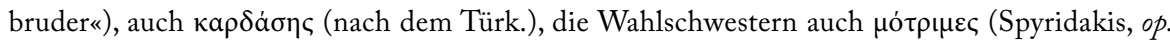
cit., I 87) u.a. Diese Terminologie wird aber in verschiedenen Gegenden auch metaphorisch für den engen Freund und Vertrauten, den Gesinnungsgenossen, der "wie ein Bruder« ist, gebraucht. Im Hochzeitsritual bezeichnet man mit diesem Ausdruck vor allem in nordgriechischen Gegenden auch Braut- und Bräutigamführer, Verwandte oder Freunde des Paares, kleine Kinder mit spezifischen Funktionen im Ablauf der Feierlichkeiten, oder auch Hochzeitshelfer jeglicher Art.

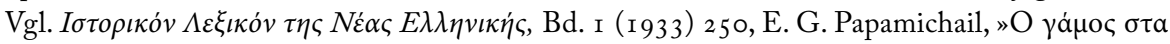


mend kirchliche Verdikte, Literaturquellen, Chroniken $^{333}$, in steigendem Maße nun auch Volkslieder und Sprichwörter, Augenzeugenberichte und volkskundliche Feldforschungen ${ }^{334}$. Im Gefolge der Verdikte von Matthaios Blastares (das alphabetische Handbuch des Kirchenrechts um 1335) und Nikephoros Chartophylax ${ }^{335}$ finden sich die gleichen Satzungen auch im »Nomokanon« von Manuel Malaxos (gest. ca. I 58 I $)^{336}$, ein Synodalbeschluß von r 685 verkündet wortreich die Auflösung des Ehe-

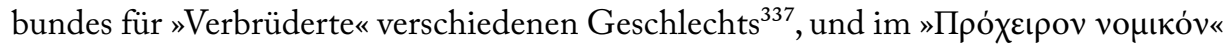
von Theophilos Papafilu, Bischof von Kampania (bei Thessaloniki, ca. I 7 I 5-nach I 793) ist neuerlich die Ungültigkeit der Ehe für Wahlgeschwister festgehalten: Der ausführende Priester wird temporär seiner Pastoralpflichten enthoben ${ }^{338}$. Und in einem feurigen, in volkstümlichem Sprachduktus gehaltenen Patriarchatserlaß des I 8. Jh.s ist von »Gesetz- und Gehirnlosen « die Rede, die diesen Unfug anstellten ${ }^{339}$. Einer der ersten Erlässe des Gouverneurs Ioannis Kapodistrias im befreiten Griechenland

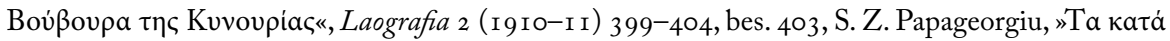

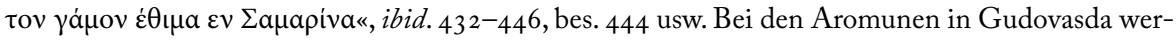
den Bräutigamsbegleiter und Brautbegleiter als $\mu \pi \rho a \tau i \mu o l ~ u n d ~ » f a r t a t i «$ bezeichnet (V.I. Vikas,»O

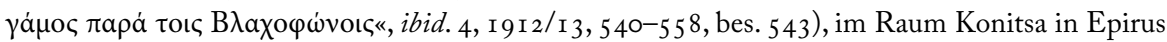
wird der Ehrentitel den Helfern und Organisatoren der Hochzeit verliehen (G. A. Anagnostopulos,

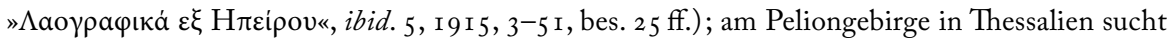

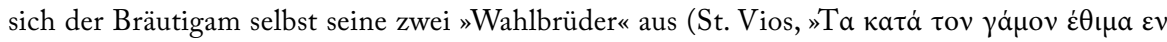

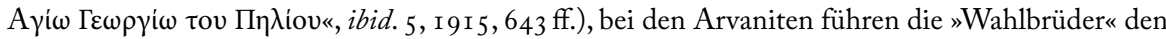

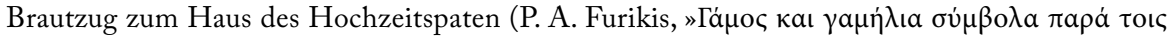

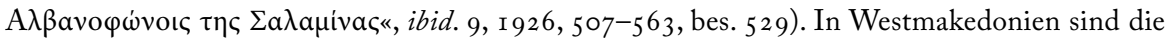
$\alpha \delta \varepsilon \lambda \varphi \circ \varphi \tau \varepsilon \dot{\varsigma} \varsigma$ verwandte Mädchen des Bräutigams, die bei der Organisation der Hochzeitsfeierlich-

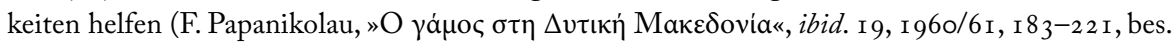

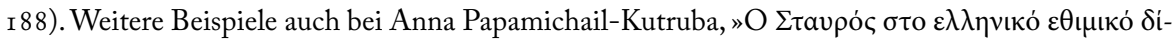

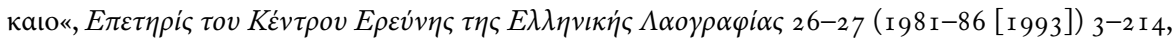
speziell $80 \mathrm{f}$.

333 Auch im Kreuzfahrerstaat Zypern (Richard M. Dawkins, Leontios Makhairas. Recital concerning the Sweet Land of Cyprus entitled»Chronicle«. vol. I-2, Oxford I 932, 84 Zeile 5 ; Konstantinos N. Sathas,

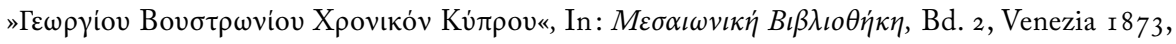
4I I-543, bes. 47 I).

334 Vgl. Michailidis-Nuaros, op. cit., Lappas, op. cit.

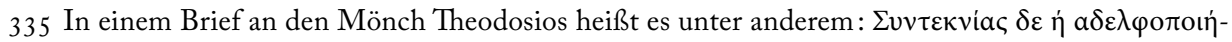

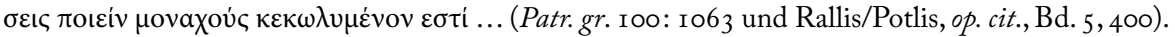

336 Kap. r62. Nachweise bei Michailidis-Nuaros, op. cit. 285.

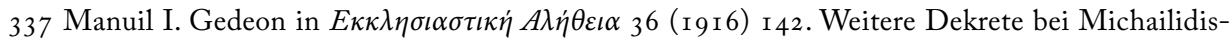
Nuaros, op. cit., 290 Anm. 3.

338 Michailidis-Nuaros, op. cit., 290 f. Zum Verf. Gerhard Podskalsky, Griechische Theologie in der Zeit der Türkenherrschaft I453-I82 I, München I 988, $354 \mathrm{ff}$. (mit weiterer Bibliographie).

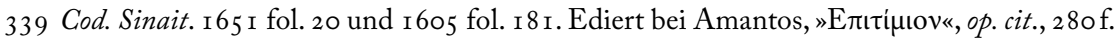


vor I 830 war das Verbot von »Geheimgesellschaften« sowie die Empfehlung, keinen Gebrauch mehr von der sogenannten » $\alpha \delta \varepsilon \lambda \varphi$ oлolïa « zu machen ${ }^{340}$. Zwischen solchen "Geheimbünden« und der "Wahlbruderschaft« besteht ein tieferer Zusammenhang, der mit den Erhebungsbewegungen gegen die Osmanische Herrschaft zu tun hat ${ }^{341}$. In dem juridischen Sammelwerk von Ludwig Maurer zum brauchtümlichen Recht in

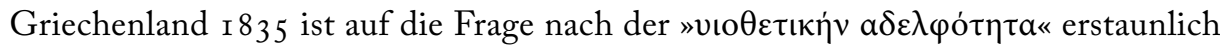
wenig Material eingelaufen ${ }^{342}$. Ein tatsächlicher Rückgang des Brauches ist jedoch nicht anzunehmen, denn um I 860 erfolgen gleich drei Enzykliken der H1. Synode der autokephalen Kirche Griechenlands (Nr. 5706 am i r. 6. I 859, Nr. 13385 am 26. 9. I 862 und Nr. 278 am I I. I. I 863), die den Priestern die Lesung der speziellen akoluthia untersagen, im Weigerungsfalle den Klerikern strenge Strafen androhen und den Laien empfindliche Bußen ${ }^{343}$. Unter dem Druck dieser restriktiven Kirchenpoli-

340 Der Sekretär Nikolaos Dragumis berichtet in seinen Memoiren, daß er selbst diesen Erlaß $25 \mathrm{mal}$

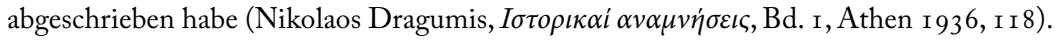

34I Rigas Velestinlis selbst hat griechische Kleften und islamische Abtrünnige der Hohen Pforte durch Wahlbruderschaft verbunden, die im übrigen seit dem I7. Jh. zwischen Griechen, Albanern und Türken nachgewiesen ist. Die Verbrüderung zwischen Griechen und Türken in Festgriechen-

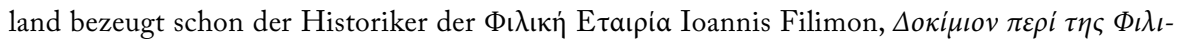

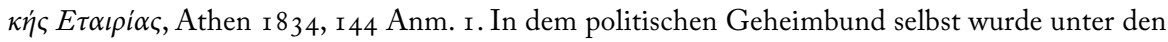
„Verbrüderten« zwischen Griechen, Türken und Albanern wenig Unterschied gemacht (vgl. auch Takis Kandiloros, $H \Phi \iota \lambda \iota \kappa \eta ́ ~ E \tau \alpha \iota p i \alpha ~(I 8 I 4-I 82 I)$, Athen 1926, 96 ff.). Der französische Reisende Pierre August de Guys trifft den Brauch nach der Mitte des I 8. Jh.s im ägäischen Inselarchipel und auf Zypern an (P. Aug. de Guys, Voyage littéraire de la Grèce, ou lettres sur les Grecs, anciens et modernes, avec un parallele de leurs mours, Paris I77 I, zweite Auflage I776, die besagte Stelle in

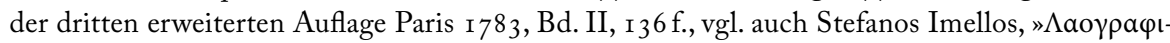

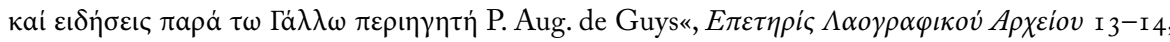

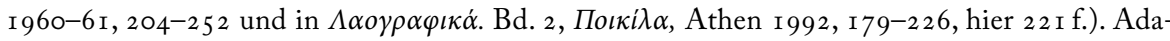

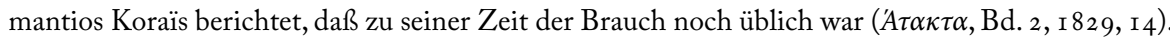

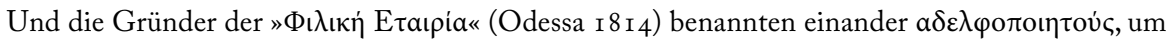
die Aufmerksamkeit der Osmanen, denen der Brauch bekannt war, von den politischen Zielen des Geheimbundes abzulenken (nach Filimon, op. cit., I 44 f.).

342 Vgl. Ludwig von Maurer, Das griechische Volk in öffentlicher, kirchlicher und privatrechtlicher Beziehung vor und nach dem Freiheitskampfe ... Heidelberg I 835, Bd. I, 257 , 3 I I f., 324 . Zu Persönlichkeit und Werk von Ludwig von Maurer vgl. Walter Puchner, Biographisches Lexikon zur Geschichte Südosteuropas, Bd. III (München I 978) I I 9 f. (mit weiterer einschlägiger Literatur). Das hängt vermutlich mit der Tatsache zusammen, daß die Formulierung der Fragestellung von den Vertretern der Lokalbehörden nicht verstanden worden ist (Christofilopulos, op. cit., IO2 Anm. I).

343 Texte bei Rallis/Potlis, op. cit., VI 300 f. Es versteht sich, daß für die Untermauerung des Verbotes dieses gesellschaftlichen Schaden verursachenden Kirchenbrauchs immer wieder die byzantinischen Kirchenrechtserlässe herangezogen wurden. 
tik verschwindet die akoluthia aus den ekklesialen »Euchologien ${ }^{344}$ und die lokalen Kirchenbehörden halten den niederen Klerus dazu an, den Brauch auch bei Laienwunsch nicht auszuführen ${ }^{345}$.

Wie sieht nun eine solche kirchliche Wahlbrudersegnung aus ? ${ }^{346}$ Hier stehen die zur Verbrüderung Bereiten vor dem vierbeinigen Evangelien-Lesepult und legen ihre Hände auf das Evangelium, während sie in der anderen Hand eine brennende Kerze halten ${ }^{347}$. Dann psalmodiert der Priester das Troparium des Tages, verliest die Fürbitten, wendet sich im Gebet an den Pantokrator, daß die beiden Brüder würden wie die Märtyrer Sergius und Bacchus ${ }^{348}$, er solle ihnen unverwandelbaren Glauben schenken, unverstellte wahre Liebe, sie sollen ihr Leben lang frei von Haß und Versuchung $\operatorname{sein}^{349}$. Nach anderen Akolutbien küssen die »Brüder« das Evangelium und einander (aspasmos), als Vorbilder der »Brüderlichkeit im Geiste« werden neben Sergius und Bacchus noch

344 Während die verschiedenen Versionen der Gebete und Segnungen (die ersten in einer Sianitischen Handschrift aus dem ı. Jh.) im Evхoגó yıov von Jacobus Goar (Paris I647) aufgelistet sind, die sich in der Ausgabe Venedig I 730 noch unverändert nachgedruckt finden (Reprint von der Akademischen Druck- und Verlagsanstalt Graz i 960), fehlen sie im heutigen Evxoló (Athen 1986), das auf eine unverändert nachgedruckte Vorlage aus Venedig I 862 zurückgeht, wo sie offenbar schon eliminiert sind. Zur Editionspolitik des Wahlbruder-Segens in den venezianischen und slavischen Drucken vgl. auch Kretzenbacher 1988, op. cit., 249.

345 Die serbisch-orthodoxe Kirche erließ diesbezüglich noch I975 ein offizielles Verbot (vgl. wie oben); trotzdem erschien 1982 in Athen eine kleine Abhandlung über "Die Wahlbruderschaft aus kanonischer Sicht« vom Protopresbyter Dr. Evangelos K. Mantzuneas, Sekretär des Synodalausschusses für kanonische Fragen und Doktor der Rechtswissenschaften, der nach einer kurzen aber objektiven Darstellung der Brauchgeschichte im römischen und byzantinischen Recht und dem Abdruck von zwei »Akoluthien« aus Goar keinen Grund zu einem Verdikt sieht, ja sogar noch Beispiele der Brauchübung aus jüngster Vergangenheit (Epirus) bringt und darauf hinweist, daß die ganze Frage eigentlich bereits der Geschichte angehört (Evangelos Mantzuneas, $H \alpha \delta \varepsilon \lambda \varphi \circ \pi \circ i \eta \sigma \iota \varsigma$ $\varepsilon \kappa \kappa \alpha v o v ı \kappa \eta ́ \varsigma \alpha \pi o ́ \psi \varepsilon \omega \varsigma$, Athen 1982).

346 Es mag sein, daß die altkirchenslavischen, serbischen und russischen Festtypika und Liturgiebücher zur cin bratotvorenja etwas detaillierter ausgestaltet sind als die griechischen (Kretzenbacher I 988, op. cit., 242 f.), doch gilt dies bloß für begleitende Einzelheiten, denn zumeist handelt es sich um Übersetzungen jener Vielfalt von Akoluthien, die von Goar und Dmitrievskij stellvertretend herausgegeben worden sind (Jacobus Goar, Euchologion sive rituale Graecorum. Unveränderter Abdruck der 1730 in Venedig erschienenen Ausgabe [2. Ausgabe]. Graz, Akademische Druck- und Verlagsanstalt 1960, 706-709, Aleksej Dmitrievskij, Opisanie liturgitseskich rukopisej. II. Evхoגóyıx. Kiew I 90 I [Reprographischer Nachdruck Hildesheim, Georg Olms Verlagsbuchhandlung I 965] 3 I f., I 22 f., I 79 f., 2 I 5, 466 f., 569 , 743 f.).

347 Goar, op. cit., $706 \mathrm{f}$.

348 Z.B. im Sinaitischen euchologion Nr. 958 (Dmitrievskij, op. cit., 3 I f.).

349 Auch Mantzuneas, op. cit., I I. 
Kosmas und Damian, Kyros und Johannes ${ }^{350}$, manchmal auch die Apostel Philippos und Bartholomäos genannt ${ }^{351}$. Neben der Apostelsendung und der Aufforderung zur Nächstenliebe ist zuweilen auch von der Bewahrung vor bösen Dämonen die Rede. In

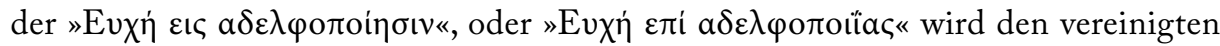
Händen der »Brüder« auch das Handkreuz aufgelegt ${ }^{352}$, Petrus und Paulus angerufen;

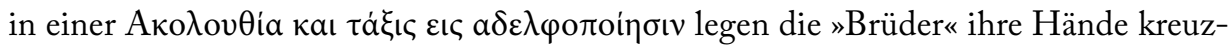
weise übereinander auf das Evangelium an der Vorderseite des Opferaltars ${ }^{353}$. Anderswo ist von Handwechsel die Rede, am Ende küssen sie das Evangelium und einander ${ }^{354}$. Die Textgruppe zeigt zwar einen gewissen gleichbleibenden Sinnkern, der sich auch in stereotypen Formulierungen manifestiert, ist aber doch nicht unbedeutenden Schwankungsmöglichkeiten unterworfen. Diese sind noch deutlicher bei den »Massenverbrüderungen« im türkenzeitlichen Balkan, wo die Funktion der Einrichtung nicht mehr der Gläubigenwunsch zur psychischen Festigung im sozialen Kontext ist, zur Nothilfeleistung und Dienststellung bei Kranksein und genereller Hilfsbedürftigkeit, sondern den geheimbündischen Kampfgruppen zum Schutz der Gemeinden und zur Vorbereitung militärischer Guerilla-Operationen gegen die osmanischen Lokalbehörden als rituelle Solidaritätsdarstellung (Treueschwur) in ihrer Angewiesenheit aufeinander dient $^{355}$. Hier stellen sich die Männer (manchmal ist auch ein einzelnes Mädchen dabei) rund um den Priester auf, binden jeder sein Tuch an den Kuttengürtel des Geistlichen oder gürten sich alle mit diesem zusammen, und leisten den Eid auf das Evangelium. In diesem Fall sind die Segnungen und Wünsche des Priesters rein improvisiert und

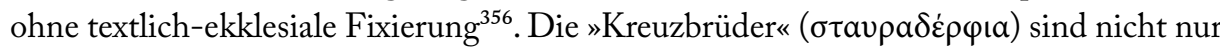
bis in den Tod aufeinander eingeschworen, sondern müssen auch die Aussteuer für die Schwestern der Verbrüderten aufbringen und für ihre Verheiratung sorgen ${ }^{357}$. Solche

350 Dmitrievskij, op. cit., I 22 f.

35 I Z.B.im euchologion des Athanasios dem Athoniten (op. cit., I79 f.)

352 Sinaitisches euchologion Nr. 973 (Dmitrievskij, op. cit., I 22).

353 Sianitisches euchologion Nr. 960 (op. cit., 2 I 5 ).

354 Dmitrievskij, op. cit., 466 f. In einer anderen Akoluthie werden auch die Reiterheiligen Georgios, Demetrios und die beiden Theodore angerufen; die Akoluthie kann auch um eine Messe erweitert werden (Konstantinopolitanisches Euchologion aus dem Jahr I 522 , Dmitrievskij, op. cit., 743 f.).

355 Solche Massenverbrüderungen waren weit verbreitet. Vgl. Giannis Vlachogiannis, A $\chi x \varepsilon i o v ~ \sigma \tau \rho \alpha-$

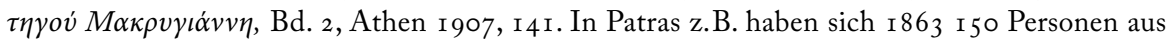

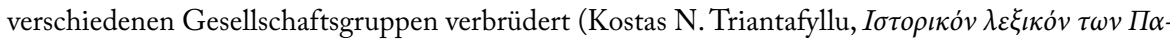
$\tau \rho \omega \dot{v}$, Patras 1959,45$)$.

356 Mantzuneas, op. cit., 8. Hier finden sich auch Spuren der Blutkommunion: Rotwein mit oder ohne Blutbeimischung wird getrunken, gestocktes Blut in einem Tuch wird der Ikone des H1. Georg, Demetrios oder Nikolaos (bei Seefahrern) geweiht (Lappas, op. cit., 357 f.).

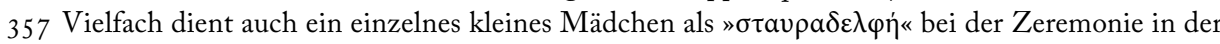


»Massenverbrüderungen« zu militärischen Zwecken sind von verschiedenen Reisenden beobachtet worden ${ }^{358}$.

Im allgemeinen ist die Verbrüderung (Verschwesterung) als Privatbund oder öffentliche Konspirationsform zwischen der primitiven Blutmischung und der kirchlichen Einsegnung mit einem eigenen Meßritual großer Varianz unterworfen ${ }^{359}$ und es handelt sich in Südosteuropa um ein grundsätzlich ethnisch und sogar religionsmäßig sprachübergreifendes Phänomen ${ }^{360}$, das jedoch vor allem in neuerer Zeit bei den Orthodoxen

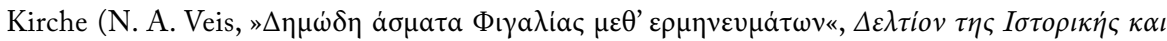

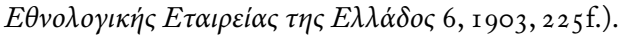

358 Beim Waffenführer Markos Botsaris François Ch. H. L. Pouqueville, Histoire de la régénération de la Grèce, vol. 4. Paris I 824, 205, Pashley dasselbe im gebirgigen Westkreta im Jahre I 82 I, dem Ausbruchsjahr des griechischen Befreiungskampfes (Robert Pashley, Travels in Crete, vol. II, London I 837, 248).

$359 \mathrm{Zu}$ weiteren Materialien Puchner, »Adopto in fratrem«, op. cit., Papamichail-Kutruba, op. cit., I 9 ff., 3 I ff. Letztere versucht eine Typologie der Zeremonie zu geben: I) die eigentliche Blutsbrüderschaft durch Blutmischung, 2) kirchliche Segnung und Schwur, 3) durch Geschenk- und Waffentausch, seltener der Waffengang zur Kirche, Relikt- und Mischformen. Bei der Blutmischung wird ein Schnitt in die Handwurzel gemacht, in den kleinen Finger mit Aussaugen des Blutes, in die (rechte) Hand; das Bluttrinken erfolgt auch aus einer Schüssel und wird vom Waffentausch begleitet. Komplexer ist der kirchliche Eid, mit oder ohne Beisein des Priesters. Im ersten Falle wird I) die Benediktion gesprochen und aus dem Evangelium gelesen, das geküßt wird, worauf der Treueschwur erfolgt, oder 2) die Teilnehmenden werden mit dem H1. Gürtel gegürtet, oder auch einem gewöhnlichen, mit einem Strick, Band usw., wobei der Taufsegen gesprochen oder dreimal rund um die Kirche gegangen wird, ein Teil der Trauungsmesse zum Vortrag kommt, oder auch der hesperinos des österlichen Agape-Festes usw., oder 3) sie scharen sich im Kreis um den Priester, um der Benediktion zu lauschen, oder werden 4) mit dem petrachelion des Geistlichen bedeckt, 5) der Schwur wird mit der Hand auf dem Evangelienbuch geleistet, 6) auch vor der Panagia-Ikone, wobei manchmal auch die Blutmischung stattfinden kann. Den Kombinationsmöglichkeiten scheint in der ars combinatoria, der »Poesie« dieser Zeremonielle, kaum Grenzen gesetzt zu sein. Im Falle des Kirchgangs ohne Priester wird der Eid vor einer Heiligenikone geleistet, manchmal in voller Bewaffnung. Zu den Schwundstufen gehören der bloße Kleider- und Waffentausch, Händedruck, kreuzweises Küssen usw.

360 Von solchen Wahlbruderschaften zwischen griechischen Sarakatsanen, Serben, Bulgaren und Pindus-Vlachen im Rila-Kloster berichtet eine thrakische Quelle (E. Filippidu, »H $\alpha \delta \varepsilon \lambda \varphi$ oлolï

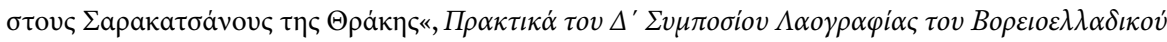
X́́pov, Thessaloniki $1983,275^{-2} 78$, bes. 278). »Fremde waren sie und sind eine Verwandtschaft (бóı) geworden, ein Blut, mit dem Segen des Priesters und den geheiligten Zeichen«, berichtet ein bejahrter Hürdenbesitzer über die Zeremonie um I 9 Iо. Als er I 8 Jahre alt war, hat er sich mit zwölf anderen Burschen aus umliegenden Hürden zusammengetan und die Gruppe ist zum Heiligenfest ins Rila-Kloster am 29. August gezogen, nach seelischer Vorbereitung mit Beichte, Fasten und Buße, in Festbewaffnung und mit den besten Pferden. Der Abt habe sie rund um das Evangelium aufstellen lassen und mit dem heiligen Gürtel gegürtet. Alle hätten das Haupt unter das 
nachgewiesen werden $\mathrm{kann}^{361}$. Im 20. Jh. hat sich der Brauch noch im isolierten InnerMani und auf Kreta erhalten. An der Südspitze der Peloponnes in seiner primitiven

Petrachelion gebeugt und sich kreuzweise, wie eine Kette, an den Schultern gehalten. Der Priester habe mit leiser Stimme die Segenswünsche gesprochen und sie hätten mit der Hand auf das Evangelium geschworen, im Glauben treu zu sein, den Wahlbrüdern zu helfen wie Brüder, untereinander keine Schwagerschaft einzugehen bis ins neunte Glied, keinen Schwur zu tun, nicht zu fluchen und nicht zu verraten. Daraufhin habe ihnen der Hegumenos mit dem Messer die Handflächen aufgeschnitten und ihnen mit dem Blut ein Kreuz auf die Stirn gemacht. Sie hätten sich die Hände gegeben, damit das Blut zwischen ihnen zirkuliere. Dann hätten sie sich umarmt und geküßt und kommuniziert. Zum Schluß habe ihnen der Hegumenos noch ein Stück heiligen Gürtel mitgegeben, ein geweihtes Amulett gegen Krankheiten von Mensch und Tier. Im Klosterhof hätten sie ihre Familien erwartet, der Ikone des H1. Johannes seien in der Folge Schafe geopfert worden, die Männer hätten sie auf Spießen gebraten, die Frauen hätten feierlich die Speisen ausgebreitet, es sei gesungen worden und getanzt, man feierte die neuen Wahlbrüder. »Könnte man mir jene Jahre geben und die jetzigen verbrennen«.

36 I Im Raum Preveza am Ambrakischen Golf werden die vlamides und motrimes (nach der albanischen Terminologie) sinngemäß beim "Liebesfest « (Aүárๆ) am Ostersonntag in der Kirche »verbrüdert" und »verschwestert«. Es handelt sich um Jünglinge und Mädchen. »Sie müssen ungefähr in gleichem Alter sein und dürfen keine Verwandtschaft untereinander besitzen. Mit einem roten Ei in der Hand stellen sie sich in der Mitte der Kirche auf und der Priester verliest den Segenswunsch und psalmodiert dreimal das `Christ ist erstanden«. Er faßt sie an den Händen wie das Brautpaar an den Brautkronen und führt sie rund herum von rechts nach links und psalmodiert das $>$ Hoaïa

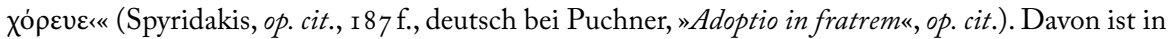
den »Euchologien« nichts zu finden. Hier wird also getreu das kirchliche Trauungszeremoniell für den Verbrüderungsritus eingesetzt. »Statt des Ringes wechseln sie das rote Ei. Dann wünscht ihnen der Priester, sie mögen in Liebe bis zum Tode leben, und sie geben ihm ein wenig Geld für die Mühe. Von da an werden sie svlamides` genannt und die Mädchen `motrimes‘. Sie stehen einander in Freud und Leid bei und erzählen einander alle Geheimnisse. Bei der Hochzeit des Jünglings steht der svlamis` rechts neben dem Bräutigam. Im Hause der Braut, die zum Trauungsgang abgeholt wird, gibt der svlamis` der Braut die Geschenke des Bräutigams, die Schuhe und das Halskreuz. Den ıvlamis muß er mit allen Mitteln unterstützen. Selbst Meineide muß er schwören, um ihn zu retten, und sollte dieser sich ein Mädchen rauben wollen, um es zur Frau zu nehmen, sowie auch in jedem anderen Fall, so muß er ihm beistehen«. An anderen Feiertagen wird das »Christ ist erstanden« bei der Verbrüderungszeremonie durch das Troparium des Festtages ersetzt. Manchmal gibt es auch so etwas wie einen »Verbrüderungszeugen«, ein Mädchen, das zu diesem Zweck in die Kirche geholt wird und der Zeremonie beiwohnt. Dieses gilt als ehrenhafte Person und wird als $\sigma \tau \alpha v \rho \propto \delta \varepsilon \lambda \varphi \eta \dot{~(» K r e u z s c h w e s t e r «) ~ b e z e i c h n e t, ~ d i e ~ V e r b r u ̈ d e r t e n ~ m u ̈ s s e n ~ f u ̈ r ~ i h r e ~ A u s s t e u e r ~ s o r g e n ~}$ und sie verheiraten. Aus diesem Quellenmaterial geht auch hervor, daß es zu verschiedenen Legierungen zwischen den beiden Grundtypen kommen kann: So gehen in Epirus die "Wahlbrüder« zuerst in die Kirche und kommunizieren, bevor sie sich Schnittwunden an den Handgelenken zufügen, das Blut in ein Glas fließen lassen, das sie beide trinken und vor Zeugen schwören, einander

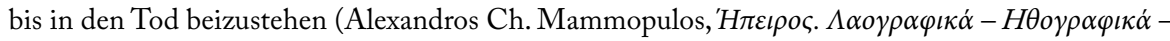

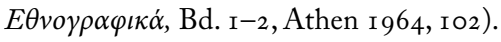


Form $^{362}$, ab ca. I 935 abgelöst von Brauch der »Verschwesterung « von Frauen, die keine Fehdeverpflichtung mit sich bringt ${ }^{363}$.

Auf Kreta lassen sich zwei andere Sonderfunktionen beobachten: Der Übergang von der revolutionären Kampftruppe der »Verbrüderten« zu unkontrollierten Geheimbünden, die die Bevölkerung terrorisieren, und der Einsatz des Brauches als zusätzliches Schutzelement des »Synteknien«-Systems (Patenschaft) zur Eindämmung des phasenweise überhandnehmenden Viehdiebstahls, der für die kretischen Berghirten zur »Poetik des Mann-Seins « ${ }^{364}$ gehört wie die Waffe zum Heldenideal ${ }^{365}$. Nach I 850 nehmen

362 Die Verbrüderten sind zumeist gute Freunde aus verschiedenen Dörfern, werden vor der Zeremonie den Sippenverwandten vorgestellt, tauschen Geschenke aus (Pistolen, Messer, Gürtel u. a.), nehmen den Segen der Eltern oder Sippenälteren entgegen, verlassen dann das Dorf für zwei drei Tage und leben ungesehen in einer Berghöhle von der Jagd. Die Blutmischung geschieht durch

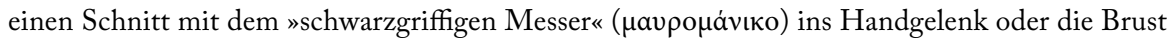
und das Beschmieren der eigenen Wunde mit dem Blut des »Bruders«; diese Art der »Blutsverwandtschaft« gilt als heilig (»der Wahlbruder ist besser als der Herzbruder«; als »Herzbruder« wird

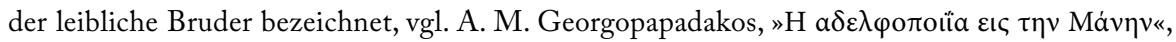
Laografia I3, 1950/5 I, 28-32, bes. 30 ff.). Der Bruch der Bindung zieht einen Bannfluch nach sich. Nach der Rückkehr ins Dorf wird gefeiert, oder man läßt die Bindung noch vom Priester einsegnen, der dazu allerdings nicht das »Euchologion« benützt, sondern den Segenswunsch improvisiert

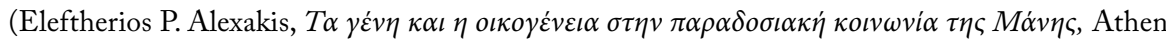
I 980, 260 f.). In selteneren Fällen wird die Institution auch gezielt von den schwächeren Clans ( $а \chi \propto \mu \nu \nu \dot{\mu \varepsilon \rho o \iota) ~ z u r ~ V e r b i n d u n g ~ m i t ~ d e n ~ s t a ̈ r k e r e n ~ S i p p e n ~(~}$ verpflichtung zu erlangen oder eine Fehdeverpflichtung zu übertragen, zu deren Ausführung man allein nicht in der Lage ist.

${ }_{363}$ Die Frauen können auch im gleichen Dorf leben, wo die Zeremonie auch in »sublimierter« Form stattfindet durch Umarmung und Kuß, Gabentausch, einem bloß mehrstündigen Verschwinden aus dem Dorf und ohne Festgelage nach ihrer Rückkehr. Die kirchliche Einsegnung des Bundes ist eher selten. Statt dessen wird auch eine Ikone verwendet, die von einem kleinen Kind gehalten wird: Die »Wahlschwestern« küssen die Ikone und das Kind, das auch zum »Wahlbruder« gemacht wird.

364 Vgl. den Titel der einschlägigen Monographie von Michael Herzfeld, The Poetics of Manhood: Contest and Identity in a Cretan Mountain Village, Princeton 1985.

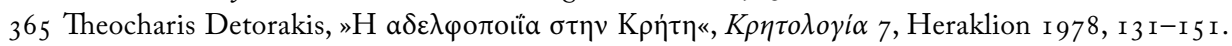
Die Wahlbrüder oder "Kreuzbrüder« sind schon vor der Blutmischungsszene zwischen Nurebey und Kapetan Michalis im bekannten Roman von Nikos Kazantzakis vom französischen Reisenden Louis Félix Bourquelot I86 I beschrieben worden (Louis Félix Bourquelot, Huits jours dans l'île de Candie en I 86r. Moeurs et paysages, Paris I 863, 62). Verbrüderungen zwischen Christen und Türken, wie sie Kazantzakis schildert, dürften schon im Zeitraum I 868-I 878, trotz der vielen Aufstände und ihrer Niederwerfung im I 9. Jh., üblich gewesen sein. Die Blutmischung geschieht durch Saugen an der Schnittwunde des anderen (am kleinen Finger) oder durch Aufeinanderlegen der Schnittwunden am Handgelenk. Die kirchliche Segnung geschieht zumeist beim Agape-Fest am Ostersonntag mit Heiligenikonen und dem Evangelium. Bei Verbrüderungen unter I 2 Perso- 
die Wahlverbrüderungen Massencharakter an. Da Kreta nicht der autokephalen Kirche Griechenlands untersteht, sondern direkt dem Patriarchat von Konstantinopel, erließ das Ökumenische Patriarchat auf Betreiben der Hohen Pforte, die zu Recht hinter den Verbrüderungen verschwörerische Ziele witterte, I 865, also kurz vor dem berühmten Aufstand, der mit dem Holocaust des Klosters Arkadi bei Rethymno endete, ein Dekret, dessen Inhalt erhellend ist ${ }^{366}$ : Hier wird der Metropolit von Kreta, der Klerus und die Dorfvorsteher aufgefordert, die von der Kirche untersagte $\alpha \delta \varepsilon \lambda \varphi\rangle_{0}$ oit $\alpha$ zu unterbinden, da alle Christen bereits "Brüder in Christo« seien, die Mitglieder dieser Verbindung oft Schaden und Unordnung anrichteten und moralisch und politisch dafür verantwortlich seien; daher sei dieses »absurde System « zu verurteilen und jegliche Wahlbruderschaft als nicht geschehen zu betrachten; Zuwiderhandelnde lüden »Seelensünde und Hölle« auf sich und verstrickten sich "moralisch und psychisch in schadhafte Schuldigkeit«; wer trotzdem an dieser antichristlichen Gewohnheit festhalte, sei den Kirchenbehörden anzuführen, damit diese drastischere Maßnahmen ergreife ${ }^{367}$. Doch der große Aufstand von I 866-69 führte zu weiteren Massenverbrüderungen, vor allem nach i 867, als das Kampfethos der Untergrundgruppen zu sinken begann ${ }^{368}$. Im Zeitraum bis zum nächsten Aufstand I 878 vervielfältigen sich die bruderschaftartigen Geheimbünde und Splittergruppen, deren Tätigkeit nur mehr schwer zu kontrollieren ist. In den Jahren I 877 und I 878 erreichen auch die Viehdiebstähle ihren Höhepunkt ${ }^{369}$. Die Hohe Pforte veranlaßt neuerlich das Ökumenische Patriarchat, ein Verdikt für diese Organisationen auszustellen, wobei der Patriarch Joachim III. am ıо. 3. I 877 die $\alpha \delta \varepsilon \lambda \varphi$ олоїа neuerlich untersagt ${ }^{370}$. Die Kampfbruderschaften breiten sich beim Aufstand von I 878, der

nen formen die Kandidaten einen Kreis um den Geistlichen und binden jeder sein Tuch in dessen Gürtel, während sie das Zipfelende in der Hand halten. Nach den Segenswünschen des Priesters wird der Eid von allen nachgesprochen, am Ende küßt man Kreuz und Evangelium und umarmt

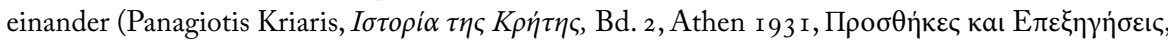
${ }_{9}$ f.). Bei den zahlenmäßig beschränkteren Wahlverbrüderungen nahm manchmal auch ein Mädchen mit Namen Maria teil (als Symbol der Gottesmutter), das zur »Wahlschwester« der Verbrüderten wurde, als echte »Schwester« ihrem Schutz anbefohlen war, das keiner heiraten durfte und für deren Aussteuer man zu sorgen hatte.

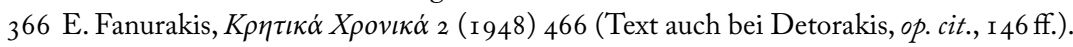

${ }_{3} 67$ Dieses Verdikt folgt also gleich auf die griechischen Kirchenverbote von i 859 -1 863.

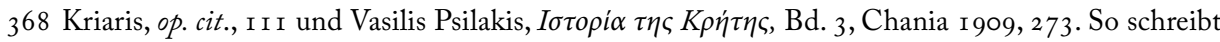
etwa der Waffenführer Emmanuel Kraniotakis I 868 an den russischen Subkonsul in Heraklion, daß er eine Kampfgruppe von 200 Mann aufzustellen gedenke, um der Revolution beizustehen, die er durch Schwur und Wahlbruderschaft untereinander binden wolle (Nikolaos Stavrinidis, $O$

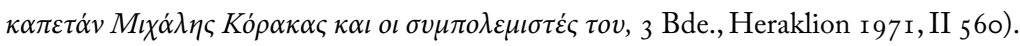

369 Stavrinidis, op. cit., III I $048 \mathrm{ff}$.

370 Teile des Erlasses bei Amantos, op. cit., 284. 
sich gegen den Vertrag von Berlin richtet, welcher die osmanische Oberhoheit über Kreta anerkennt, über die gesamte Großinsel aus ${ }^{371}$. Doch die Zersplitterung führte letztlich zu einer Spaltung der Aufstandsbewegung und zu ihrer raschen Niederschlagung $^{372}$. In der gleichen Funktion findet man die Wahlbruderschaft noch in den Revolutionen von I 889 und I 897 , die Kazantzakis als Kind noch selbst miterlebt hat ${ }^{373}$. Im 20. Jh. und unter den geänderten Bedingungen des Endes der Türkenherrschaft auf der Großinsel (I9I3) ersetzt die Patenschaft, die synteknia, weitgehend die Funktionen der Wahlbruderschaft. Sie ist vor allem unter den Hirten zu beobachten, als Schutz für den überhandnehmenden Viehdiebstahl ${ }^{374}$. I 930 haben sich Berghirten im Raum Sfakia in

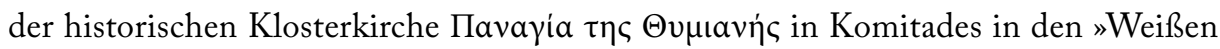
Bergen« versammelt, um Wahlbruderschaft zu schließen und den Schwur zu tun, für vier Jahre lang die Herden der anderen schonen zu wollen. I930-34 war tatsächlich kein einziger Viehdiebstahl in der Region zu verzeichnen ${ }^{375}$. Dies war auch die letzte belegte Gruppenverbrüderung auf Kreta.

37 I Die Zersplitterung der Kampfverbände in geheime Minigruppen wurde in diesem Fall von den Türken auch gefördert, denn so gelang es, die Einheitlichkeit der Aufstandsbewegung zu untergraben und die Wortführer durch Verrat in die Hand zu bekommen. Besonders in Mesara im Raum Heraklion kam es zu heftigen Auseinandersetzungen der Kampfbruderschaften gegen den Waffenführer Michalis Korakas (Stavrinidis, op. cit., III ro 7 f. mit den einschlägigen Dokumenten). Die Verbandsgruppen bildeten sich anfänglich aus Protest gegen die Steuereinhebung durch die aufständischen Guerillatruppen und die Verwendung der Hilfsgüter und Gelder aus Griechenland, die für die leidende Bevölkerung gedacht waren, für ihre eigenen Zwecke, schreckten aber in der Folge nicht vor bürgerkriegsartigen Übergriffen zurück. In dieser Phase sind sogar Geistliche zu "Wahlbrüdern« geworden. Die »Wahlbrüder« bildeten Aktionszellen mit streng geregelten Funktionen (Ausschuß, Kassier usw.), die als Widerstandsgruppen der Unterschlagung der Hilfsgüter entgegenwirken sollten, von den militärischen Aufstandsorganisationen aber als Konterrevolutionäre deklariert wurden, wobei man versuchte, diese »Wahlverbrüderungen« zu verhindern (Detorakis, op. cit., I 49).

372 Das historische Volkslied zum Ruhme von Michalis Korakas rechnet mit den »Wahlbrüdern« in paradigmatischer Weise ab (Text bei Stavrinidis, op. cit., III ro24).

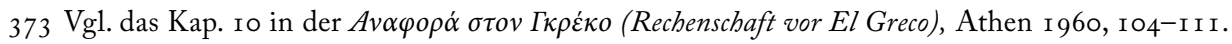

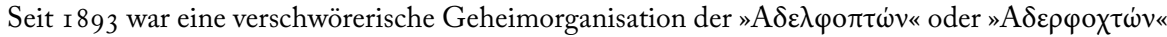
gegründet worden, die in der kritischen Phase von I 895 bis 1898 aktiv war (Theocharis Detorakis,

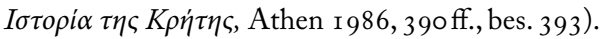

374 Herzfeld, The Poetics of Manhood, op. cit. Zum brauchtümlichen Schafe-Stehlen auch E. Tachatakis,

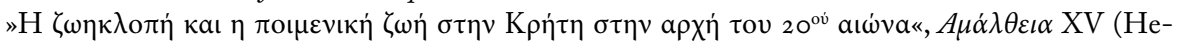
raklion I984) H. 58-59, I 59-I 76 .

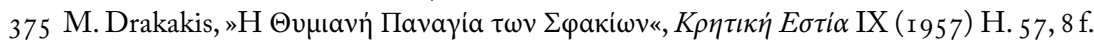


Die Wahlbruderschaft ist nach dem Zweiten Weltkrieg kaum noch nachzuweisen ${ }^{376}$. Dafür sind die wirtschaftlichen und demographischen Umwälzungen, die die Notwendigkeit von solchen »alternativen Sozialstrukturen herabmindern $^{377}$, ebenso verantwortlich zu machen wie die negative Haltung der Kirche ${ }^{378}$. Die einstigen Verbote sind dem niederen Klerus nun geläufig. Dazu ein autobiographischer Bericht eines Popen: »Ich selbst habe keine solche Zeremonie durchgeführt, aber es ist nichts, ist eine Lüge. Ich bin selbst ` im Dorf Aspropotamos bei Trikala, und der Pfarrer hat einen Gürtel gebracht, wie den, den sie bei der Messe tragen, und weil der nicht für uns alle gereicht hat, hat der Pfarrer noch ein Seil dazugebunden, denn wir waren zehn und mit der бovpáta [Wahlschwester] elf. Er hat eine Fürbitte gelesen, eine Evangelienstelle, irgendeine, wir haben einander geküßt und sind Wahlbrüder gewesen, ein Schwindel. In der damaligen Zeit haben die Menschen gestohlen und gemordet, es ist zu Exkommunikationen gekommen; da hat sich ein dynamischer Pfarrer gefunden, damit nicht der A den B umbringt. Da hat er die Zeremonie gemacht, damit nicht einer gegen den anderen kämpft und ihn umbringt, und damals stand der Wahlbruder in höherem Wert als der Bruder. Es ist aber absolut nichts. Es steht nichts davon im Alten und Neuen Testament, in den >Kanones der Kirche, alles ist ein Schwindel. 1937 ging ich zum Bischof von Larisa Dorotheos und habe ihm die Frage nach der Zeremonie gestellt, und er hat mir gedroht, was für ein Priester das sei, der die Christen zum Besten halte und ihnen Zaubereien vormache, davon stehe nichts im Kanon der Kirche, und wenn ein Pfarrer dies tue, dann sei ihm das zu verbieten ${ }^{379}$.

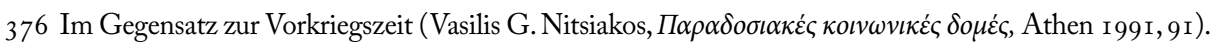

377 Die soziale Notwendigkeit von zusätzlichen Verwandtschaftsrelationen als Vernetzung von Verbindungen und Beziehungen in der geschlossenen Gruppe der Agrargemeinde hat durch Mobilität, Verbürgerlichung (Landflucht) und nicht zuletzt durch das politisch-parlamentarische Klientelsystem der regionalen gewählten Abgeordneten und ihrem engen Verhältnis zu ihrer Stimmträgerbasis (wobei das Taufpatentum und das Hochzeitspatentum wieder eine stabilisierende und symbolisch überhöhende Funktion als Darstellung nicht der Parteitreue, aber der Personenabhängigkeit bilden) abgenommen. Zu dem politischen und wirtschaftlichen Klientelsystem paradigmatisch Karl Heinz Pfeffer/Irma Schaafhausen, Griechenland. Grenzen wirtschaftlicher Hilfe für den Entwicklungserfolg, Hamburg 1959.

378 In Griechenland ist es zwar zu keinem synodalen Verdikt gekommen wie in Serbien (vgl. die positive Haltung der Kommission für kanonische Fragen der H1. Synode), doch war dies wahrscheinlich auch gar nicht mehr notwendig. Mantzuneas betont in seiner Abhandlung, daß die Frage bereits der Geschichte angehöre (op. cit.).

379 Zitiert nach Nitsiakos, op. cit., 93 f. (nach einem handgeschriebenen Brief vom 5. I. I 979 des Pfarrers Konstantinos Nitsiakos aus dem Dorf Kalochori im Raum Larisa, 92 Jahre alt), deutsch bei Puchner, »Adoptio in fratrem«, op. cit., $38 \mathrm{I}$ f. 


\section{$5 \cdot 2$ BITTPROZESSIONEN}

Im Gegensatz zu den rituellen Einsegnungen der Wahlbruderschaft (mit oder ohne Blutmischung), die trotz aller Verdikte über tausend Jahre lang Bestandteil der lokalen Pastoralpraxis gewesen sind, haben sich andere Formen ekklesialer Riten in Not- und Krisensituationen der Kirchengemeinde weiterhin erhalten. Diese haben mit den kollektiven und persönlichen Lebensumständen der Gläubigen zu tun, mit Krankheit, Epidemien, Erntegefährdung, Unwetter usw. Das große euchologion der orthodoxen anatolischen Kirche ${ }^{380}$ sieht heute noch Bittmessen und parakletische Akoluthien in folgenden Fällen vor: die Exorzismen des H1. Basileios für Dämonenbesessene und gegen andere Krankheiten (zusammen mit Segenssprüchen des H1. Johannes Chrysostomos) ${ }^{381}$, eine parakletische akoluthia für Kranke, die von unreinen Geistern befallen sind und geplagt werden ${ }^{382}$, ein Segensspruch für Kranke, die an Schlaflosigkeit leiden ${ }^{383}$, eine taxis gegen Brunnenverschmutzung ${ }^{384}$, eine taxis gegen die Verunreinigung des Weines oder Honigs oder anderer Flüssigkeiten durch einen unreinen Gegenstand, der in das Gefäß gefallen ist ${ }^{385}$, Segen für die Druschtenne und die Weinstockpflanzung, die Weinlese und Segnung des ersten Weins, der ersten

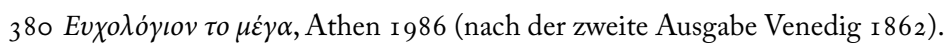

38 I Ibid., I 47-1 52 (drei Gebete), I 5 2-1 56 (vier Gebete).

382 Ibid., $382-387$, bestehend aus einem trishagion, einem parakletischen Kanon an Christus, die Theotokos, die Engel, die Apostel und alle Heiligen in neun Oden, unterbrochen von den theotokia (Anrufungen an die Gottesmutter) und ein Troparium; gegen Ende wird der Kranke mit einem Öldocht bestrichen und ein Bittgebet gesprochen.

383 Ibid. 387 f. Nach zahlreichen Anrufungen wird die Forderung nach ruhebringendem, körperlichem, gesunden und rettenden Schlaf für den Kranken gefordert.

384 Ibid. 488 f. Vor dem Gebet, das die Reinigung der Wasser durch das Kreuz erbittet, gibt es folgende Anleitung: mit dem Brunnenkübel sei der Schacht trockenzulegen und das verschmutzte Wasser wegzuschütten; dann habe der Priester Kerzen anzuzünden und den Brunnenschacht in Kreisform zu beweihräuchern; sodann gieße er Weihwasser vom großen hagiasmos am Theophanietag kreuzweise dreimal in den Schacht; und nach Osten gewendet solle er das nachfolgende Gebet sprechen.

$385 \mathrm{Ibid} .48 \mathrm{~g}$ f. Vor dem Gebet ist folgende Anleitung zu befolgen: Der verschmutzende Gegenstand sei zu entfernen und wegzuwerfen, der Wein in einen anderen Krug zu gießen bzw. das Olivenöl in eine andere Kanne umzuschütten; das verschmutzte Gefäß sei innen und außen sorgfältig zu waschen; der Priester solle mit dem kapnisterion (Räucherfaß) das gereinigte Gefäß innen und außen beweihräuchern und Weihwasser vom großen hagiasmos des Theophanietages in Kreuzform dreimal hineingießen; sodann sei der Wein oder das Öl zurückzugießen, neuerlich zu beweihräuchern und das nachfolgende Gebet zu sprechen. Nach dem Gebet, das die Segnung des Weines oder Öls erbittet, habe der Geistliche von der Flüssigkeit zu kosten und auch den männlichen Mitgliedern des Hauses anzubieten. Sollte der unreine Gegenstand weiterhin im Gefäß verblieben sein und verfaulen, so sei die Flüssigkeit (Wein oder Olivenöl) wegzuschütten. - Dies sind durchwegs praktische Anweisungen, wie man mit dem Problem umzugehen habe. 
Trauben usw. ${ }^{386}$, taxis gegen Ungeziefer oder andere Schädlinge im Weinberg oder Gemüsegarten ${ }^{387}$, der Exorzismus des H1. Tryphon gegen Ernteschädlinge ${ }^{388}$, ein Segen für den Hirten ${ }^{389}$, Fleischsegen zu Ostern, Segen für Käse und Eier ${ }^{390}$, für den Schiffsbau, die Fischernetze, das Graben eines Brunnenschachts ${ }^{391}$; gleich mehrere Bittmessen sind für die Beendigung der Dürrezeit (anombria) und für Regenfall vorgesehen ${ }^{392}$, aber auch aus

386 Ibid. $496-499$.

387 Ibid. 499 f. Eine Bittmesse ist notwendig, eine hängende Öllampe (candela) vor der Ikone des Hl. Tryphon oder des H1. Eusthatios bzw. des H1. Julianos des Libyers oder allen zusammen sei anzuzünden. Nach der Bittmesse begebe sich der Priester mit dem Öl aus den Öllampen und Weihwasser vom hagiasmos des Theophanietages zu dem Feld oder Weinberg oder Hausgarten, das kreuzweise zu besprengen ist, wobei nachfolgendes Gebet zu psalmodieren sei.

388 Ibid. 500-503. Der H1. Tryphon ist eigentlich zuständig für die Weinberge, doch der Bannspruch wird auch auf Feldern und in Hausgärten gesprochen. Da werden namentlich genannt: Raupen, Würmer, Wurmraupen, Käfer, Heuschrecken, Ameisen, Flöhe, Wanzen, Schnecken, Pilze und alles was den Trauben und dem Gemüse schädlich sein könnte; man schickt sie in die wilden Berge, zu den fruchtlosen Bäumen, wo Gott ihnen ihr tägliches Brot gegeben habe; in unerschlossene Gegenden, wasserlose und fruchtlose Einöden. Auf bebautem Land hätte das Ungeziefer nichts zu suchen.

389 Ibid. 503 mit Schutzspruch gegen den Teufel, andere Menschenrassen und Feinde, gegen Pest und Epidemien, die Herde möge sich zu Tausenden vermehren, von Engeln beschützt gegen Krankheit und Neid, gegen Vergiftung und Zauber und anderem Teufelswerk. Damit ähnelt das Bittgebet eigentlich dem Loblied auf den Hirten der kalanda-Sänger in der Mittwinterzeit (vgl. Puchner, Die Folklore Südosteuropas, op. cit., 59-63).

390 Ibid. 504 f.

39I Ibid. 505 f. Der Schiffsbauer wird mit Noah und seiner Arche verglichen, die himmlischen Mächte mögen die Passagiere beschützen; der Brunnenbauer möge reichlich harmloses Wasser finden, um den Durst des Volkes zu löschen.

392 Ibid. 5 I6-532. Im ersten Fall handelt es sich um einen Dialog zwischen Diakon und Priester, wo der Herr der Wolken und der Wasser beschworen wird, einen "friedlichen« Regen zu senden, das Gras für Mensch und Vieh wachsen zu lassen, diese Stadt und jede andere von Pest und Hunger, Erdbeben, Überschwemmung, Feuer, Schwert, Heuschrecken, Hagel, Einfall von Feinden, Bürgerkrieg und plötzlichem Tod zu verschonen. In einem kanon biketerios in Form von neun Oden in Akrostichis (unterbrochen von den theotokia) wird um das Himmelswasser gebeten, Gott möge seinen Zorn wegen der Sünden der Menschheit besänftigen und Wolken schicken, damit die Feldfrüchte wachsen. Es folgen sechs Bittgebete des Patriarchen Kallistos von Konstantinopel mit reicher poetischer Bildsprache: Da wird die vertrocknete Erde mit der Mutterbrust verglichen, die vertrocknet sei und keine Milch, sondern dem Säugling Tod spende, so auch die vertrockneten Regenrinnen, die kein Grün sprießen lassen, und die Hitze gleiche dem Fieber, das alles Lebendige dahinraffe. Auch hier wird Noah zitiert, die Brotvermehrung usw. Es folgt noch ein Bittgebet desselben Autors um Regen und Änderung der Winde (529f.), sowie ein weiteres Bittgebet um die Abwendung der Dürre (530-532). Allein die Anzahl und der Umfang der ekklesialen Texte um Regenfall zeigen die zentrale Bedeutung, die diesen Bittmessen, Gebeten, Litaneien und Prozessionen gegen die Trockenheit in der Pastoralpraxis zukommen. 
Furcht vor Erdbeben ${ }^{393}$, ein Kanon an die H1. Dreifaltigkeit gegen die Bedrohung durch ansteckende Krankheiten ${ }^{394}$, ein Bittgebet gegen die Pest ${ }^{395}$, zwei gegen tödliche Krankheiten (thanatikon) ${ }^{396}$, die Anflehung Gottes (euche hiketerios) in Zeiten von Pest und Hunger $^{397}$, ein Bittgebet für die Abwendung von Donner und Blitz ${ }^{398}$, gegen unmäßige Winde und Seesturm ${ }^{399}$ usw. $^{400}$

Es ist demnach kaum eine Übertreibung festzuhalten, daß diese ekklesialen kanonisierten Texte, Segens- und Bannsprüche, Bittgebete und Akklamationen, Litaneien und Paraklesen, Akoluthien und Meßordnungen, z.T. mit praktischen Anleitungen für den Popen, den entstandenen Schaden zu beheben, einen einigermaßen getreuen Spiegel des Alltagslebens einer traditionellen Kommunität in Südosteuropa zu zeiten der Osmanischen Herrschaft bilden, mit all den Unbilden und Bedrohungen von Leib und Leben, Hab und Gut, dem ständigen Bangen um den Ernteertrag und das Wetter, Kummer und Sorgen, denen durch die ansteigenden Hygienemaßnahmen, das staatlich organisierte Gesundheitswesen und die wissenschaftliche Medizin, die Antibiotika und die Entwicklung der Pharmazeutik, durch die Mechanisierung der Landwirtschaft und die systematische Schädlingsbekämpfung zum Großteil der Stachel entzogen ist. Das hat einerseits zum Rückgang der traditionellen Dämonologie und ihrer Prophylaktik geführt, andererseits zu einer höheren Internalisierung der Existenzunsicherheiten, die sich nun in Orientierungslosigkeit, Landflucht, Wertvakuum, Flucht in die Disko und in Drogen, Alkoholismus usw. manifestieren. Das Leben auf dem Lande ist leichter geworden, aber auch reizloser und sinnentleerter.

Im Sinne der rezenten Entwicklungen spiegeln diese ekklesialen Texte bereits eine historisch gewordene Wirklichkeit der Vergangenheit und kommen heute weniger zum

393 Ibid. 532-543. Zuerst ein Kanon mit neun Oden in Form von Akrostichis (unterbrochen von den theotokia) mit stichera proshomoia und stichera idiomela und einem Troparium. In einem nachfolgenden Bittgebet wird der Herr der Welt angefleht, die Erde nicht zittern zu lassen, die Berge sollen nicht rauchen, die Fundamente des Himmels nicht beben und seine Säulen nicht wanken; er solle seine Schöpfung stützen, die Erde stabilisieren usw. Es folgen noch zwei umfangreichere Bittgebete mit Lesungen aus den Briefen von Paulus an die Hebräer und dem Evangelium (Matth. 8,23).

394 Ibid. 543-547. Es geht um einen Kanon mit neun Oden (unterbrochen von den Anrufungen an Maria - theotokia).

395 Ibid. 548-553

396 Ibid. $553-556$.

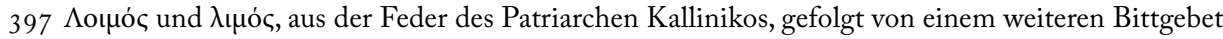
(ibid. 557 f.).

398 Als Zorn Gottes interpretiert, wegen der Sünden der Menschheit (ibid. 558 f.).

399 Ibid. 559-56r.

400 Gegen feindliche Einfälle (ibid. 56 I f., 567 ff.), Pest ( $572-576$ ), Marienmesse gegen Seelenschmerz (580-587), für das Antreten einer Reise ( $587-590$, Seereise 590), für Adoption (603 ff.) usw. 
Vortrag als früher. Manche sind allerdings prekär geblieben: Die Wettervorhersage kann auch keinen Regen herbeizaubern, der trotz aller Bewässerungssysteme weiterhin bitter nötig ist, und Erdbeben sind nach wie vor, trotz aller antiseismischen Bauweise, ein Schrecken, der den Bewohnern seismogener Zonen in den Knochen steckt. Und doch haben diese Texte nicht das gesamte Spektrum individueller und kollektiver Phobien gedeckt und den magischen Praktiken weiten Spielraum gelassen, welche sich z.T. pseudoreligiöser Terminologie und Phraseologie bedient. Mögen die Flurumgänge und Bittprozessionen des Frühjahrs- und Sommerabschnittes etwas von der Atmosphäre der nackten Existenzangst verloren haben, so sind sie jedoch keineswegs abgekommen, sondern werden weiterhin gefeiert, allerdings mit einer gewissen Funktionsverschiebung: Ähnlich wie bei Ritualhandlungen der dromena in der Phase, wo der Glaube an die magische Effizienz des Praktizierten nicht mehr gegeben ist und dieses Aktionsmaterial gleichsam befreit von der Last der Zwangswiederholung zu einem frei verfügbaren Darstellungs- und Handlungskanon wird, der ästhetisiert, theatralisiert, den Zwecken der Unterhaltung, Schaustellung und lokalen Selbstpräsentation untergeordnet werden kann, kommt es auch bei diesen ekklesialen Begehungen, oft schon traditionell verbunden mit einer Festivität (panegyri), Gemeinschaftsessen, Tanz und $\mathrm{Mu}-$ sik, Kampfspielen usw., zu einer Transmutation der Teilnahme-Motivation, wobei nun sekundäre Ideologisierungen wie folkloristisches Bewußtsein und Traditionspflege im lokalen, regionalen oder nationalen Rahmen, aber auch gemeinsames Festerleben fern der Alltags- und Arbeitsroutine usw. eine führende Rolle spielen. Die Prozession wird zur organisierten Wanderung, die Wallfahrt zum gemeinschaftlichen Ausflug Gleichgesinnter. Das Stichwort vom »religiösen Tourismus« spiegelt diese Haltungsänderung. Brauch ohne Glaube ${ }^{401}$.

Die gleitenden Übergänge zu pseudoreligiösen oder pagan-magischen Praktiken bleiben jedoch erhalten. Neben dem offiziellen Regenbittgang des »Kreuz-Tragens« (krstonoše) ${ }^{402}$ hat sich der Umzug des perperunal dodola-Regenmädchens weiterhin erhalten ${ }^{403}$, organisiert nun von der Schule und/oder lokalen Kultur- und Traditionsvereinigungen, die die Organisation und Kultivierung des »althergebrachten Brauchtums« übernehmen. Beide Bittprozessionen, die ekklesiale und die »pagane«, bestehen nebeneinander und interferieren: Die Bittlitanei des Regenmädchens (als einziges religiöses

\footnotetext{
40I Das slogan stammt von Leopold Schmidt, Brauch obne Glaube, Würzburg 1977.

$4 \mathrm{O} 2$ Vakarelski, Bulgarische Volkskunde, op. cit., 33 r. Zur Beschreibung eines solchen Umzugs in Kreta

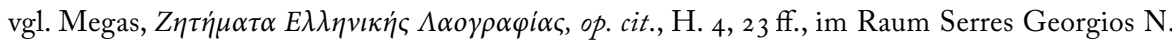

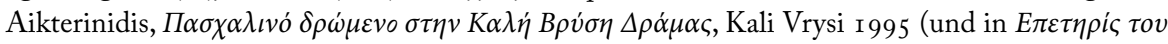

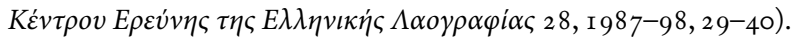

403 Vgl. im Ersten Teil. Zum Regenbittlied Puchner, Die Folklore Südosteuropas, op. cit., 63-65.
} 
Volkslied, das sich direkt an Gott als höchster sakraler Instanz wendet), verwendet nicht nur die Melodie eines Kirchenliedes ${ }^{404}$, sondern auch die religiösen Litaneien der Bittprozessionen fordern genau das gleiche von Gott, einen »sanften« und reichhaltigen Regen, damit die Feldfrüchte gedeihen. Die homöopathische Grünverkleidung und das analogiemagische Anschütten mit Wasser und Abtropfen der Blätter auf dem (nackten) Körper des Regenmädchens, so als hätte es wirklich geregnet, wird in den kirchlichen Paraklesen auf eine verbale Ebene als deskriptive bikesia an die Sakralinstanz übertragen; die sympathetisch-magische Darstellung des Erwünschten und Herbeigesehnten ist der ekklesialen Symbolgestik als idolatrische Restform nicht gestattet. In Bildsprache und $Z$ weckbindung sind beide Texte jedoch funktionsgleich; der Gang von Haus zu Haus und die Prozession zu Feldkapellen, Klöstern und hagiasmata rund um die Siedlung führt die gleiche symbolische Kreisziehung aus ${ }^{405}$, ist zyklisches Begehen des durch die sakralen Zeichen begrenzten Lebensraums der Kommunität. Das kleine, arme, patschnasse Regenmädchen in seinem buschartigen Blätterwald und den Münzen als Gegengabe führt im wesentlichen genau das gleiche aus wie der Pope in seinem gestickten Ornat, mit den Kruzifixen und hexapteryga, eventuell auch den Ikonen und Reliquien, den Diakonen und Psalmensängern sowie im Prozessionszug mit der gesamten Dorfbevölkerung, mit den Stationen, Gebeten und Litaneien, Klosterbesuchen und Feldmessen.

Die Entsprechungen auf volksmagischer und hochreligiöser Ebene, so sehr sie sich auch unterschiedlicher Mittel bedienen, sind durch die Lebenspraxis der Kommunität gegeben. Auf diese (Über)Lebensbedingungen geht auch die Pastoralpraxis ein und wird in ihren einzelnen Ausfaltungen zu einem hohen Grad von ihr bestimmt. Dies mag den höheren ekklesialen Instanzen, der theoretischen Theologie und Dogmatik, die die Glaubensinhalte verwaltet und bestimmt, nicht immer genügend bewußt gewesen sein, so daß die Pastoralpraxis in regionalem Ausmaß Abweichungen aufweisen kann, die sich theologisch nur schwer rechtfertigen lassen und doch gebräuchliches »Recht« der Kirchengemeinde dargestellt haben, das sich zäh durch die Jahrhunderte erhalten hat.

Darüberhinaus gibt es auch freilich grundlegendere Übereinstimmungen, die die Volksmagie mit der Hochreligion verbinden, wie etwa der Geisterglaube, Dämonenvorstellungen, die Umtriebe des Teufels usw. Verfolgt man etwa die Entwicklung der

404 Vgl. Walter Puchner, Studien zum griechischen Volkslied, Wien I 996, 90-I 24.

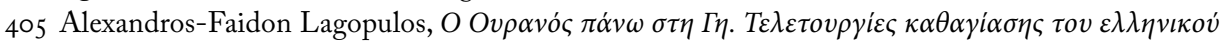

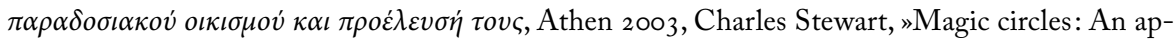
proach to Greek ritual«, Journal of the Anthroplogical Society of Oxford 25/I (I994) 9I-IOI. 
Teufelsvorstellung in den mittelalterlichen und nachmittelalterlichen Passionsspielen ${ }^{406}$, die auch im südosteuropäischen Raum ihre pendants aufweisen können ${ }^{407}$, so ist eine Wandlung vom Schrecken des Dämonischen zu Komik und Klamauk festzustellen ${ }^{408}$, zu Geschichten um den dummen Teufel ${ }^{409}$ oder niedliche verspielte Teufelchen, die keine ernsthafte Bedrohung mehr darstellen ${ }^{410}$. Dies dürfte allerdings eine latente Dynamik des Sakralen in seiner Negativausprägung darstellen, das in dieser Entwicklungsphase manifest geworden ist.

\section{DIE KEHRSEITE DES HEILIGEN : KOMIK UND TERROR}

Der Faszination und dem Schrecken der Erscheinung des Numinosen (numinosum tremens $)^{411}$ scheint eine Dialektik einzuwohnen, die auf den ersten Blick schwer zu erklären ist: Dem Sakralen dürfte die Aufhebung seiner selbst in Satire und Parodie inhärent sein, ja sogar Voraussetzung für seine Stabilität und Unhinterfragbarkeit. Die temporäre und okkasionelle Travestierung seiner Erscheinungsform und seiner Riten scheint die Effizienz der Gläubigkeit nicht zu unterminieren sondern im Gegenteil noch zu verstärken; die komische Karikierung ein unabdingbarer Gegensatz-Partner letzter Ernsthaftigkeit zu sein. Das Heilige wäre demnach eine dynamische Synthese von Glaubensvorstellungen und ihrer spielhaften In-Frage-Stellung durch die Parodie. Für die Annahme einer solchen inhärenten Dynamik der Gegensätze in der Sakralsphäre gibt es eine Reihe von Beispielen, die sonst schwer zu erklären sind.

Eine unterschiedliche Antithetik bewegt sich auf der Ebene ethischer und aletischer Glaubensvorstellungen: die Theodizee-Frage um Gut und Böse, welche als Leitbegriffe eines dichotomisierten Weltbildes aufeinander angewiesen sind und in vielen kosmogonischen Mythologien ihren Niederschlag gefunden haben. Die animistischen Denkfi-

406 Puchner, Studien zum Kulturkontext der liturgischen Szene, op. cit., I 23 f., 295-297.

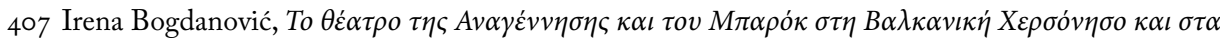
$v \eta \sigma \iota \alpha \dot{~} \tau \eta \varsigma$, Diss. Athen $20 \mathrm{I} 2$.

408 Z.B. in der dämonischen Gegenhandlung in der chiotischen und kykladischen Barockdramatik der Jesuiten und Orthodoxen (Walter Puchner, Griechisches Schultheater und barocke Ordensdramatik im ägäischen Raum zur Zeit der Türkenherrschaft (1580-I750), Wien 1999 (Österr. Akad. d. Wiss., phil.-hist. K1., Denkschriften 277) 39-r46).

409 Bei Aarne/Thompson/Uther zusammengefaßt in einer eigenen Schwankkategorie.

4IO So der kleine clevere Leviathan im Spiel um die Drei Knaben im Feuerofen aus Chios (2. H. I7.

Jh.) und das Ballett der Kinder-Teufelchen im ebenfalls chiotischen David-Spiel (Anfang I 8. Jh.).

Vgl. Puchner, Griechisches Schultheater, op. cit., I I6-I I 9, I 22 f.

4I I Rudolf Otto, Das Heilige, Breslau i 9 I 7. 
guren der Oralkulturen kennen demnach gute und helfende metaphysische Kräfte und bedrohliche und schädliche Dämonengestalten ${ }^{412}$. Die Abstraktionen und Dogmen der Hochreligion um Seelenheil, Jenseitsschicksal, Sündenschuld usw. werden in den Oralkulturen in die Überlebensstrategien und die Alltagspraxis der Kommunität integriert, wodurch Heilige und Dämonen ihre spezifischen Schutz- und Schadens-Funktionen zugewiesen bekommen. Der Terror der Dämonologie auf dieser Welt und in diesem Leben überschattet vielfach das metaphysische Bangen um das Einzelschicksal in jener Welt nach dem Tode. Auf diesem Sektor weisen Ost- und Westkirche nicht unbedeutende Unterschiede auf.

\section{I PARODIE UND SAKRALITÄT}

Die coincidentia oppositorum von Sakralität und Profanisierung, Heiligkeit und Entheiligung, Anbetungswürdigkeit und Parodisierung, die der Oralkultur etwa in den satirischen Karnevalsmanifestationen geläufig ist, scheint auch der institutionalisierten ecclesia nicht ganz fremd zu sein. Die westkirchlichen Erscheinungsformen der mittelalterlichen und nachmittelalterlichen Periode, wie Eselfeste, Kinderbischof usw. sind Gemeingut der Mediävistik, doch gibt es analoge Erscheinungen auch in der Hagia Sophia am Bosporus zu byzantinischen Zeiten, woran sich der Klerus selbst aktiv beteiligt hat ${ }^{413}$. Dort ist auch von Mönchsverkleidungen und mimetischen Spielen im Kirchenraum selbst die Rede ${ }^{414}$.

In noch offensichtlicherer Weise ist die Popenfigur travestiert in den karnevalesken improvisierten Hochzeitsparodien ${ }^{415}$, wo Pseudopriester mit Kuhmist räuchern, Zoten psalmodieren und die ganze Zeremonie der Krönung des Ehepaars ins Lächerliche ziehen $^{416}$. Ähnliches gilt für die Begräbnisparodie, wo vor allem die sexuellen Vorzüge des »Verstorbenen « gerühmt werden ${ }^{417}$. Meßparodien gibt es jedoch bereits seit byzantinischer Zeit, z.B. die Parodie auf den »unheiligen und ziegenbärtigen Spanos«, die in ihrem in der Erfindungskunst von Schimpfkanonaden kaum zu übertreffenden skato-

4I 2 Charles Stewart, Demons and the Devil: Moral Imagination in Modern Greek Culture, Princeton I99.

4I 3 Zu diesen Quellenberichten in Übersicht Walter Puchner, Acting in Byzantine theatre: evidence and problems", Pat Easterling/Edith Hall (eds.), Greek and Roman Actors. Aspects of an Ancient Profession, Cambridge 2002, 304-324.

4I 4 Materialzusammenstellung auch bei Franz Tinnefeld, "Zum profanen Mimos in Byzanz nach dem

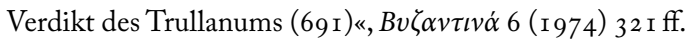

4I 5 Vgl. den entsprechenden Abschnitt im Ersten Teil.

4I6 Puchner, Brauchtumserscheinungen, op. cit., 237-239, $254 \mathrm{f}$.

4I 7 Ibid., 225, 239-24I, 267-269. 
logischen und sexuellen Vokabular eines der meistgelesenen »Volksbücher« der Neuzeit gewesen ist ${ }^{418}$.

Unter den speziellen Lobliedern der kalanda-Sänger auf den Geistlichen finden sich auch satirische auf den eingeschlafenen Priester, der die Messe versäumt und den man wecken muß ${ }^{419}$, ja sogar im großen euchologion findet sich eine Bußmesse, die der eingeschlafene Priester für sein Vergehen lesen muß ${ }^{420}$. Bei den balkanischen Schwankerzählungen ist der Pope ${ }^{421}$, aber vor allem seine Frau, die ihre Gelüste nicht zu zähmen imstande ist ${ }^{422}$, eine beliebte Figur. Auch Mönche und Nonnen entgehen dieser satirischen Entheiligung im Pfaffenschwank nicht, der sich auch eines entsprechenden deftig-derben Vokabulars bedient ${ }^{423}$, und dem monasterischen Alkoholismus ist im nachbyzantinischen "Krasopateras" (Säufermönch) ein rabelais-artiges Denkmal absurder Übertreibungen gesetzt ${ }^{424}$. Eine derartige Enttabuisierung ethisch-moralischer Vorgaben in Bezug auf Ehre, Scham und Schande, die in der Alltagswirklichkeit peinlich genau eingehalten werden, da in einer geschlossenen Dorfgemeinschaft eben nichts verborgen bleibt, findet auch in den karnevalesken satirischen Liedern der gamotraguda statt ${ }^{425}$, wo die Dinge ohne Umschweife beim Namen genannt werden in einer geradezu traumatischen Realistik, die in der Karikierung der Debilität und Vertierung auch vor dem Inzesttabu nicht halt macht ${ }^{426}$.

Der mundus reversus des Karnevals mit seiner spielhaften und temporären Außerkraftsetzung aller gültigen Restriktionen der Alltagsordnung offenbart jedoch auch noch eine tiefere Beziehung zwischen Verbot und Übertretung: Erst das Überschreiten

4I 8 Hans Eideneier, SPANOS: eine byzantinische Satire in der Form einer Parodie, Berlin/New York 1977 (griechische Ausgabe Athen 1990).

4I 9 Puchner, Die Folklore Südosteuropas, op. cit. 84.

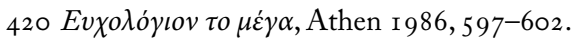

42 I Friedrich Salomo Krauss, Volkserzäblungen der Südslaven: Märchen und Sagen, Schwänke, Schnurren und erbauliche Geschichten, Raymod L. Burt/Walter Puchner (eds.), Wien/Köln/Weimar 2002, $43 \mathrm{I}-448$.

422 Puchner, Die Folklore Südosteuropas, op. cit., 84.

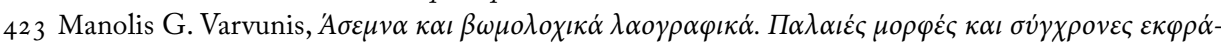

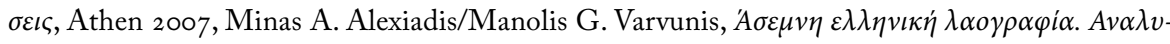
$\tau \iota \kappa \dot{\eta} \beta \iota \beta \lambda \iota о \gamma \rho \alpha \varphi i \alpha$, Athen 2013.

424 Der zwischen dem I6. und I8. Jh. vielfach abgeschriebene Text ist voll von monströsen Adynata, wie der Weinbecher, der bis zum Himmel reicht, der Berg Sinai oder Olymp als Weinfaß usw. (Hans Eideneier [ed.], Krasopateras. Kritische Ausgabe der Versionen des I 6.-I8. Jahrbunderts, Köln I988).

425 Vgl. dazu Puchner, Die Folklore Südosteuropas, op. cit., 83-84.

426 Puchner, »Schwank und \Pornographie im griechischen Karnevalslied«, Studien zum griechischen Volkslied, Wien 1996, 2 I 3-222. 
der Grenze macht diese (wieder) bewußt und wirksam, der paradigmatische Fall des Unerlaubten und der nachfolgenden Sanktionen, in sovielen Lehrlegenden exemplifiziert, festigt das gesetzte Gebot. Die Spielhaftigkeit des Als-Ob in der Karnevalsperiode im Probehandeln des temporär gestatteten Tabubruchs konstituiert seine Gültigkeit und Unübertretbarkeit aufs Neue; übertragen auf die Sakralität und ihre Parodierung bedeutet dies, daß die an sich unstatthafte Relativierung der institutionalisierten Heiligkeit in Form von Satire und Karikatur ihre Wirkungsmacht im Bewußtsein der Gläubigen nur noch verstärkt. Jenseits der Funktion einer psychischen Ventilhandlung aufgrund der Untragbarkeit des Numinosen, daß sich in der Sakralität offenbart, in das Gegenteil der Faszination, die als Vorgang nicht dauernd anhalten kann, die Lächerlichmachung, erweist sich die fundamentale Dialektik von Sakralität und Profanität: der eine Begriff und die eine Wirklichkeit kann ohne die andere nicht auskommen. Es handelt sich um zwei Seiten desselben Phänomens ${ }^{427}$.

\subsection{DÄMONOLOGIE UND PROPHYLAKTIK}

Eine Typologie der Dämonenvorstellungen der Oralkulturen Südosteuropas geben zu wollen, ist an sich ein Unding, weil sich diese Wesen der kollektiven Imagination und individuellen Phantasie gleichsam per definitionem einem systematischen Zugriff entziehen und jeglicher Kodifizierung als generalisierendem Abstraktionsvorgang widerstehen. Im Gegenteil: Ein charakteristisches Merkmal der Existenz und Aktivität von Dämonen ist die Ambivalenz in ihrer Beziehung zum Menschen (schädlich/helfend), ihre gleitende Morphologie und variable körperliche Ausstattung sowie ihr ungewöhnliches Verhalten. Gemessen an der Idealnorm der menschlichen Somatik kann ihr Aussehen mit einem »Zuviel« oder "Zuwenig « beschrieben werden (Riesen, Zwerge, Hinkende, Einäugige, Blinde, Häßlichkeit, übernatürliche Kräfte und Wissen, Hexen, Zauberer usw.), wobei ihre Monstrosität als reversiertes Heldenideal noch auf die menschliche Formbeschaffenheit der Anthropomorphie zurückzuführen ist ${ }^{428}$; eine andere Wurzel des Geisterwesens ist die Thanatophobie und die Angst vor der Wiederkehr der Toten (Vampirismus, Wiedergängertum, Nachzehrer) oder auch die sexuellen Phantasien und ihre Unterdrückung in der Männerwelt, die die große Gruppe der ambivalenten Feengestalten hervorgebracht hat, ihr libertinistisches Verhalten, aber umgekehrt auch die

427 Peter Weidkuhn, Aggressivität Ritus Säkularisierung. Biologische Grundformen religiöser Prozesse, Basel 1965 .

428 Vgl. dazu das akritische Lied des »Porfyris«, der als Heros auch kannibalische Züge tragen kann (Puchner, Die Folklore Südosteuropas, op. cit., 22). Auf die Bachtinsche Karnevalstheorie sei hier bloß verwiesen. 
Möglichkeit, eine Ehe mit ihnen einzugehen ${ }^{429}$. Die anthropozentrische Grundlage der phantasierten Gestaltmorphologie ist in jenem Augenblick nicht mehr gegeben, wenn es sich um Tierdämonen handelt (Drache, Ungeheuer) oder um Kombinationen von Mensch und Tier (Zentauren, Hundsköpfige, zmej). Die gleitenden Übergänge zwischen anthropomorpher und zoo- oder theriomorpher Existenz weisen noch auf die ursprüngliche Identität von Heros und Ungeheuer in den kosmogonischen Mythen vom uranfänglichen »Herrn der Güter « ${ }^{430}$.

Ausgehend von der conditio bumana und der Vorstellung vom normierten menschlichen Idealkörper könnte man den Ansatz wagen, daß somatische Dysplasie, psychische »Anomalie« und mentaler Defekt im animistischen Weltbild Ausdruck der gleichen innerlich/ äußerlichen Deviation vom geltenden Normideal sind, die die gleichen negativen Sanktionen und Negativaffekte hervorrufen (Verachtung, Lächerlichkeit, in Ambivalenz dazu bei Dämonisierung auch Furcht und Schrecken) und auf die gleichen Ursachen (Sünde ${ }^{431}$, Schlechtigkeit, Bösartigkeit, Schlauheit usw.) zurückgeführt werden können ${ }^{432}$. Schon die Frühkirche hat sich bemüht, diesen idolatrischen »Aberglauben« des Altertums in seiner schier unerschöpflichen Reichhaltigkeit der Dämonologie zu beschneiden ${ }^{433}$, doch die

429 Charles Stewart, „Nymfomania: sexuality, insanity and problems in folklore analysis«, Margaret Alexiou/Vasilis Lambropoulos (eds.), The Text and its Margins, New York I 99 I, 2 I 9-252.

430 Vgl. Puchner, Die Folklore Südosteuropas, op. cit., 29-3 I.

43 I Wobei diese Sünde sich von den Eltern auf die Kinder vererbt (vgl. Joh. 9,2).

432 "Solche seit dem Altertum bekannten Einstellungen wirken bis heute nach" (Hans-Jörg Uther, Enzyklopädie des Märchens 3, I981, Sp. I 83 f.). Vgl. dazu in Auswahl: Reinhold Kretschmer, Geschichte des Blindenwesens vom Altertum bis zum Beginn der allgemeinen Blindenbildung, Ratibor 1925 , Albert Esser, Das Antlitz der Blindheit in der Antike, Giessen 1939 (196r), Michael E. Monbeck, The Meaning of Blindness. Attitudes Toward Blindness und Blind People, Bloomington I973, und zu Behinderten und Gebrechlichen im allgemeinen: Hans Schadewaldt, „Die Einstellung der Gesellschaft zum Behinderten im Laufe der Geschichte«, Der behinderte Mensch und die Eugenik, Neuburgweier 1970, 29-43 und Hans-Jörg Uther, Bebinderte in populären Erzäblungen. Berlin/New York I98I.

433 Die griechischen Kirchenväter warnen wiederholt vor dem Erzählen von Märchen und »helle-

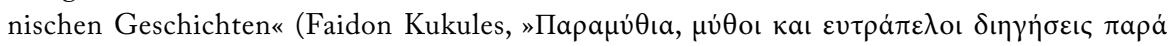

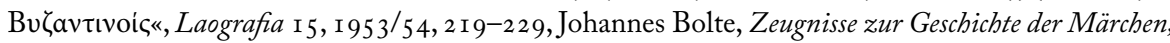
Helsinki r 92 I, 6 und 9). Johannes Chrysostomos verwirft die Begegnungs-Omen mit Hinkenden als »Teufelswerk« und der Evangelist Johannes legt in der Perikope zur Heilung des Blindgeborenen Jesus die Worte in den Mund: »Weder dieser hat gesündigt noch seine Eltern«, als ihn die Jünger fragen, wer denn gesündigt habe, daß er blind geboren sei (Joh. 9,2). Gebrechen ist Erbschuld, gottgewollt, schicksalsverhangen (vgl. auch die Beispiele bei Uther, Behinderte in populären Erzäblungen, op. cit., 7 f.). Schon das neutestamentarische Christentum hat sich gegen diese Auffassung gewandt, genauso wie gegen die ähnlich mitleidlosen Dämonenvorstellungen. Christus heilt Lahme und Blinde, treibt Dämonen aus. Doch diese Vorstellungen leben weiter bis tief in die Neu- 
"Monstersucht ${ }^{434}$ der Oralkulturen, noch in Mittelalter und Neuzeit bis zur Aufklärung hin lebendig, lebt in science fiction-Filmen, Computerspielen und der Spielzeugindustrie ungebrochen weiter ${ }^{435}$.

Dämonengestalten treten da in Erscheinung, wo reelle oder phantasierte Gefahren bestehen, wie etwa für Schwangerschaft, Neugeborenes und Mutter im Wochenbett ${ }^{436}$; die Mortalitätsraten der damaligen Kindersterblichkeit sind heute kaum vorstellbar. Davon ist letztlich das Christuskind als Zwölftengeborener selbst betroffen und eine

zeit hinein, ja in der ekklesialen Tradition selbst: Viele Reste des antiker Mythenwesens sind in die Synaxarien und Heiligenviten, die byzantinischen Chroniken und Wunderlegenden eingegangen und im Synkretismus der Vorstellungen orthodoxer Volkskultur der Türkenzeit greifbar, wie der hundsköpfige H1. Christophoros (Leopold Kretzenbacher, Kynokephale Dämonen südosteuropäischer Volksdichtung. Vergleichende Studien zu Mythen, Sagen, Maskenbräuchen und Kynokephaloi, Werwölfen und südslawischen Pesoglavii, München 1 968, 58 ff.), die hochmittelalterliche Anlagerung der Drachentötung an die Hl. Georgs-Vita und vieles andere.

434 Dazu in Auswahl: Margaret Robinson, Fictitious Beasts. A Bibliography, London r 96 I, Angus Hall, Bestien, Scheusale und Monster, Frankfurt/Berlin/Wien 1979 (englisch 1975), Rudolf Schenda, "Die deutsche Prodigiensammlungen des I6. und I 7. Jahrhunderts«, Archiv für Geschichte des Buchrwesens 4 ( 1 963) 637-7 1o (z.B. Georg Stengel, De monstris et monstrosis [...], Ingolstadt r647). Weitere Angaben bei Uther, op. cit., Sp. I I 9 I f.

435 Dazu Walter Puchner, »Groteskkörper und Verunstaltung in der Volksphantasie. Zu Formen und Funktionen somatischer Deformation", Innovation und Wandel. Festschrift für Oskar Moser, Graz 1994, 337-352 und erweitert in ders., Studien zur Volkskunde Südosteuropas und des mediterranen Raums, Wien/Köln/Weimar 2009, 54I-556.

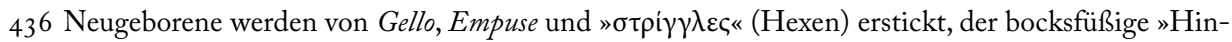

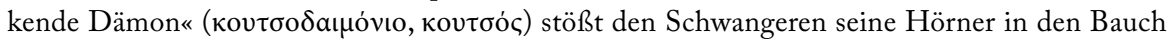
und verursacht derart Aborte und Frühgeburten. Zu diesem gefährlichen Dämon vgl. Nikolaos

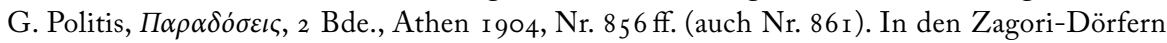
nördlich von Ioannina ist er auch einfach als »Hinkender« im Umlauf, vgl. Laografia 4 ( I 917) 666

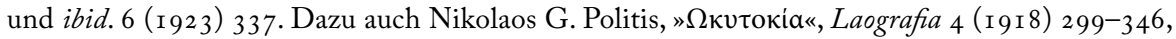
bes. 337 und Bernhard Schmidt, Das Volksleben der Neugriechen und das hellenische Altertum, Leipzig I 87 I, I 53. Die ungetauften oder zwölftengeborenen Kinder können leicht zu den miasmatischen und schädlichen Zwölftendämonen werden, deren »reelles« Erscheinungsbild zwischen Kakerlaken und Fledermäusen schwankt (zu einem solchen mißglückten Versuch, ein reelles Erscheinungsbild für diese phantasierten Dämonengestalten zu finden, vgl. Christos Th. Oikonomopulos, »H a arouv-

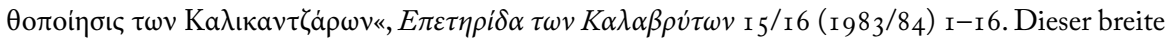
Vorstellungsbereich kontaminiert auch mit Vampirglaube und Werwolfsphantasien. Zur Gello vgl. Maria Patera, »Gylou, démon et Sorcière de Monde byzantine au Monde néogrec«, Revue des Étu-

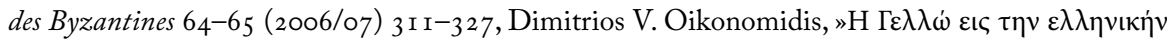

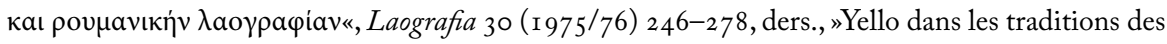
peuples hellénique et roumaine«, ibid. 22 (1965) 328-334. Zur Empuse J. Vaser, „Empousa«, RealEnzyklopädie der Alterthumswissenschaften 5 (1905) 2540-43. Ähnliche Schwangerschaftdämonen zirkulieren auch im islamischen Bereich. 
neuere Entstehungstheorie der kalikantzaroi kombiniert die panbalkanischen Zwölftendämonen mit der Gefährdung, der das Neugeborene ausgesetzt ist ${ }^{437}$. Insofern handelt es sich bei der Dämonologie um innerpsychische Projektionen nach außen, die den gemischten Gefühlen zwischen Furcht und Grauen, im Falle der gelungenen Abwehr auch Lächerlichkeit und Spott, beschreibbare Gestalt da verleihen, wo die Ungewißheit sich jeder Erklärungsmöglichkeit entzieht. Name und Gestalt des Dämons und ein ungefähres Wissen um seine Tätigkeit und Funktionen sind selbst bereits ein Akt der Prophylaktik und des Krisenmanagements, doch geht es nicht um faktisch gesichertes Wissen, sondern eher um Vermutungen, die großen Schwankungen unterworfen sind. Namensgebung und Benennung sind erste Akte der Beherrschung und Machtausübung ${ }^{438}$.

Damit ist das bis zu einem gewissen Grad ungewisse Wesen der Dämonengestalten bereits umrissen und auch die prinzipielle Schwierigkeit, sie auf bestimmte allgemeine Charakteristika festzulegen. Dazu kommt noch die regionale und lokale Varianz, die ähnlich wie die antike Mythologie kaum Verallgemeinerungen zuläßt und einer deskriptiven Variabilität großen Spielraum einräumen muß. Die Existenz dieser imaginierten immateriellen Wesen beruht überdies auf Erzählungen über sie, eine Folklore, die ihre eigenen Gesetze der Variierung kennt: Diese Geschichten existieren nur in verschiedenen lokalen Versionen, aus denen sich eine einheitliche Narrative bloß unter Abzug der Details als ein noetisches abstractum konstruieren läßt. Dies ist auch die Schwäche der meisten wissenschaftlichen Übersichtsdarstellungen zur Dämonologie ${ }^{439}$, die in Südosteuropa aufgrund des antiken Erbes besonders reichhaltig auftritt ${ }^{440}$.

Übersichten zur Dämonologie gibt es in Südosteuropa gewöhnlich länderweise oder auch nach Sprachgruppen, seltener auch vergleichend (und dann häufig im Rekurs auf

437 Vgl. wie im ersten Teil. Insofern ist es kein Zufall, daß das Hebammenfest am Ende der Zwölftenperiode gefeiert wird.

438 Lutz Röhrich, »Der Dämon und sein Name«, Paul und Braunes Beiträge zur Geschichte der deutschen Sprache und Literatur 73 (I 95 I) 456-468, ders., "Dämon«, Enzyklopädie des Märchens 3 (I98 I) 223237, Christoph Daxelmüller, »Dämonologie«, ibid. 3 ( I 98 I) 237-259, Herbert Haag, Teufelsglaube, Tübingen r 974, Eugen Fehrle, Zauber und Segen, Jena 1926, Gotthilf Isler, Die Sennenpuppe, Basel I97 I, Robert Müller-Sternberg, Die Dämonen, Bremen r 964, usw.

439 Dies gilt vor allem auch für ältere Sammelwerke wie Nic. Remigius, Daemonolatreiae libri tres, Lugduni 1595 .

440 Hans Georg Gundel, Weltbild und Astrologie in den griechischen Zauberpapyri, München 1968, Hans Herter, »Böse Dämonen im frühgriechischen Volksglauben«, Rheinisches Jahrbuch für Volkskunde I (I 950) I I 2-I 43, Theodor Hopfner, Griechisch-ägyptischer Offenbarungszauber, Amsterdam I 974, Hans Lewy, Chaldaean Oracles and Theurgy. Mysticism, Magic and Platonism in the Later Roman Empire, Leiden 1978, usw. 
urslavische, dakische, thrakische u. a. Gottheiten und Mythen) ${ }^{441}:$ Albanien $^{442}, \mathrm{Un}^{-}$ garn $^{443}$, Serbien ${ }^{44}$, Rumänien ${ }^{445}$, Bulgarien und Makedonien ${ }^{446}$, Griechenland ${ }^{447}$,

44I Petra Himstedt-Vaid, »Volksglaube auf dem Balkan«, Uwe Hinrichs/Thede Kahl/Petra HimstedtVaid (eds.), Handbuch Balkan, Wiesbaden, Harrassowitz 2014, 69 I-732, Georges Drettas, »Le cavalier glouton - Contribution à l'étude de la théorie populaire du vampirisme balkanique«, De la voûte céleste au terroir, du jardin au foyer - Textes offerts à Lucien Bernot, Paris 1 987, 7 I 9-746, Milenko Filipović, „Die NAVI bei den Balkan-Slaven«, Das heidnische und christliche Slaventum, Wiesbaden I 969, I05-I I 3, Friedrich Salomo Krauss,, »Südslawischer Geisterglaube«, Globus 6 I (1892) I 54-1 58, Mark Kulikowski, A Bibliography of Slavic Mythology, Columbus, Ohio I989, Louis Leger, La mythologie slave, Paris I 90 I, Norbert Reiter, »Mythologie der Alten Slaven«, H.W. Haussig (ed.), Worterbuch der Mythologie, Stuttgart I 973, II I65-208, ders., „Der Pferdemythos bei den Slaven«, Slavica Gandensia 7/8 (I980/8I) I 3 I-I46, Slobodan Zečević, »Die Personifikation des Windes in der serbischen Mythologie«, Zeitschrift für Balkanologie I 9 (1983) 2 1 7-223, Eqrem Çabej, »Kult und Fortleben der Göttin Diana auf dem Balkan«, Leipziger Vierteljahresschrift für Südosteuropa 5 (194I) 229-24I, Ivanitchka Georgieva, "Survivances de la religion des Thraces dans la culture spirituelle du peuple bulgare", Le Monde Thrace. Actes du IIe Congrès International de Thracologie, Bucarest 1976, Paris etc. 1982, 348-352, Gh. Mușu, »Motifs mythiques du substrat thrace et leurs correspondances avec ceux de Dionysos«, ibid. 353-356 usw.

442 Maximilian Lambertz, »Mythologie der Albaner«, Worterbuch der Mythologie, Stuttgart 1969, 457-

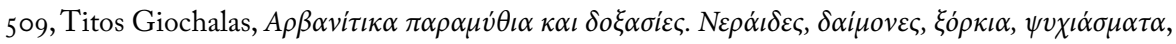
Athen 1997.

443 Géza Róheim, Magyar néphit és népszokások, Budapest I925, Ákos Szendrey, A magyar néphit kutatása, Budapest 1948, Zoltán Ujváry, »Theriomorphe Korndämonen in der ungarischen Volksüberlieferung«, Acta Ethnographica Academiae Scientiarum Hungaricae I6 (1967) 35-53, ders., »Anthropomorphe mythische Wesen in der agrarischen Volksüberlieferung Ungarns und Europas«, ibid. I7 ( I 968) 63-I I 9, János Balázs, »Über die Ekstase des ungarischen Schamanen«, Glaubenswelt und Folklore der sibirischen Volker, Budapest 1963 , Éva Pócs, »Binde- und Lösungszauber im ungarischen Volksglauben", Acta Ethnographica Academiae Scientiarum Hungaricae 1967, dies., Fairies and Witches at the Boundary of South-Eastern and Central Europe, Helsinki 1989 (FFC 243).

444 Slobodan Zečević, "Heidnisch-christliche Symbiose einiger mythischer Wesen der serbischen Volkstradition «, Das heidnische und christliche Slaventum, Wiesbaden I969, I 20-I 25.

445 G. P. Klepikova, »Motiv dviženija-poleta v semantike karpato-balkanskogo striga (štriga)«, Balkanskije ćtenija 3. Lingrvo-etnokul'turalno istorija Balkan i vostočnoj Jevropy. Tezisy i materialy simpoziuma, Moskva 1994, 94-99.

446 Tanas Vražinovski, Narodna demonologija na makedoncite, Skopje 1995, Ute Dukova, „Die Bezeichnung der Dämonen im Bulgarischen«, Balkansko ezikoznanie/Linguistique balkanique 26/4 (1983)

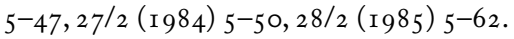

447 John L. Tomkinson, Haunted Greece. Nymphs, Vampires and other Exotica, Athens 2004, Theodoros Vlachos, »Geister- und Dämonenvorstellungen im südosteuropäischen Raum griechischer Sprachzugehörigkeit«, Österr. Zeitschrift für Volkskunde 25 (197I) 2 I 7-248, Charles Stewart, »The >Exotikar: Greek Values and Their Supernatural Antithesis«, ARV (Scandinavian Folklore Archives) 4I (1985) 36-64, ders., Demons and the Devil. Moral Imagination in Modern Greek Culture, Princeton I 99 I . 
Rußland ${ }^{448}$, das byzantinische Reich ${ }^{49}$ und das osmanische Reich $^{450}$, Minderheiten ${ }^{451}$. Nikolaos Politis hat zu Beginn des 20. Jh.s eine Zusammenstellung lokaler Dämonensagen aus Griechenland vorgenommen, die als Beispiel einer solchen reichhaltigen Übersicht hier kurz analysiert sei ${ }^{452}$. Dabei unterscheidet er folgende Kategorien: amorphe und nicht näher beschriebene Ungeheuer ${ }^{453}$, Drachen und Schlangen ${ }^{454}$, Dra-

448 Ol'ga A. Čerepanova, Demonologičeskaja leksika severnorusskih govorov, Leningrad I975, dies., Mifologičeskaja leksika russkogo Severa, Leningrad 1983.

449 Enrico V. Maltese, Dimensione bizantine: Donne, Angeli e Demoni nel medioevo greco, Torino I995, Richard P. H. Greenfield, Traditions of Belief in Late Byzantine Demonology, Amsterdam 1988, Otto Waser, Charon, Charun, Charos. Mythologisch-archäologische Monographie, Berlin I 898, Franz Boll, "Griechische Gespenster", Archiv für Religionswiss. I 2 (1909) I05-I 22, Paul Perdrizet, Negotium perambulans in tenebris. Études de démonologie gréco-orientale, Strasbourg 1922, Dirk C. Hesseling, Charos. Ein Beitrag zur Kenntnis des neugriechischen Volksglaubens, Leiden/Leipzig I 897, ders., "Charos rediens", Byzantinische Zeitschrift 30 (1 929/30) I 86-I 91, ders. "Le Charon Byzantin", Neophilologus I6 (I 93 I) I 3 I-I 35, Gyula Moravcsik, »Il Caronte Bizantino«, Studi Bizantini e Neoellenici 3 ( I 930) 37-68 (separatum Roma i930), Karel Svoboda, La démonologie de Michel Psellos, Brno I 927 , Armand Delatte/Ch. Josserand, »Contribution à l'étude de la démonologie byzantine«, Annuaire de l'Institute de Philologie et d'Histoire Orientales 2 (1 933/34) 207-232, Perikles P. Ioannou, "Les croyances démonologiques au XIe siècle à Byzance ", Actes du VIe Congrès International des Études Byzantines, Bd. I, Paris I 950, 25 2-271, ders., Démonologie populaire - démonologie critique au XIe siècle, Wiesbaden r 971, John Chryssavgis, »The Monk and the Demon: The Demonology of the Byzantine Fathers«, Theologia 57 ( 1986) 753-764.

450 Anatole de Meibohm, Démons, derviches and saints, Paris I 956, Paul A. Eichler, Die Dschinn, Teufel und Engel im Koran, Leipzig I 92 8, T. Fahd, „Anges, démons et djinns en Islam«, Sources orientales 8 ( I 97 I ) I 53-2 I 4, Ernst Zbinden, Die Djin des Islam und der altorientalische Geisterglaube, Berlin/Stuttgart 1953, Rudolf Kriss/Hubert Kriss-Heinrich, Volksglaube im Bereich des Islams, 2 Bde. I $960-62$.

45 I Elwood B. Trigg, Gypsy Demons and Divinities: The Magic and Religion of the Gypsies, New York I 973 .

452 Nikolaos G. Politis, П $\alpha \alpha \delta \delta$ ó $\varepsilon \iota \varsigma, 2$ Bde., Athen 1 904. Der erste Band bringt die Texte der über tausend Erzählungen, der zweite die Kommentare zu etwa der Hälfte der Narrationen (ein dritter Band, der die Kommentierung zu Ende führen sollte, ist nie erschienen). Zu den Dämonensagen vgl. auch Puchner, Die Folklore Südosteuropas, op. cit., I I о-1 I 3 .

453 I 205 ff. Nr. 368-373, II 954-964. Dazu rechnet er auch die bei Sachlikis (Kreta, I 4. Jh.) beschriebenen Hundsköpfigen (962 f.). Zu den Kynokephalen und ihren Sagen auch Walter Puchner,

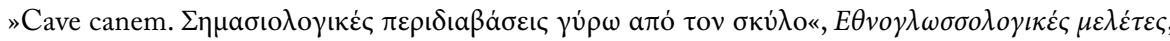
Athen $20 \mathrm{I}_{3}, \mathrm{I} 7-84$.

454 I 208-2 I 8, Nr. 374-388, II 966-990. Dazu auch die Drachentötermärchen Minas A. Alexiadis, Oı

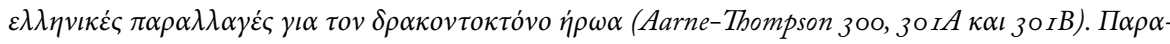
$\mu v \theta 0 \lambda o \gamma \iota \kappa \eta \dot{~} \mu \varepsilon \lambda \dot{\varepsilon} \tau \eta$, Ioannina 1982. 


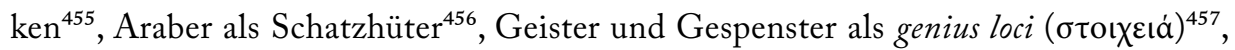
Meereswesen ${ }^{458}$, chamodrakia ${ }^{459}$, kalikantzaroi ${ }^{460}$, anaskelades $^{461}$, Neraiden $^{462}$, lamies $^{463}$, Hexen (stringles) ${ }^{464}$, Teufel ${ }^{465}$, Geister ${ }^{466}$, der Alb (vrachnas) ${ }^{467}$, Krankheiten wie die

455 I 2 I 9-229, Nr. 389-403, II 990-I002. Zum drakos, seiner Frau drakaina und den Kindern drakopula, dem anthropomorphen menschenfressenden ogre, manchmal in den Märchen auch mit dem Drachen (drakontas) verwechselt, vgl. auch Michael G. Meraklis, »Drache und Drake. Zur Herkunft einer neugriechischen Märchengestalt«, Märchenspiegel 5/2 (1994) 5-7. Der drakos, keineswegs immer riesenhaft, aber ein stupider Kannibale mit übermenschlichen Fähigkeiten entspricht dem dev des Vorderen Ostens (Msia Čačava, »Dev«, Enzyklopädie des Märchens 3, I 98 I , 569-573), als dew, div, diw, dif usw. in persischen, georgischen, armenischen, türkischen und albanischen Überlieferungen, ein riesenhafter ogre, der in Höhlen wohnt, Frauen raubt, dumm, aber mit übernatürlichen Fähigkeiten begabt. Vgl. Manuk Abeghian, Der armenische Volksglaube, Leipzig I 899, I I -- I I 3, Max Lambertz, Albanische Märchen, Wien I 92 2, 44-46, Arthur Christensen, Persische Märchen, Düsseldorf I 95 8, 289-291, usw. Vgl. auch Thomas Geider, Ogre«, Enzyklopädie des Märchens 10 (2000) 235-249.

456 I 229-249, Nr. 404-446, II 1003-I05 I. Der riesenhafte Schwarze hat durchaus ambivalente Züge: Als Schatzhüter ist er guter Hausgeist, aber auch Menschenfresser, der Frauen beschläft und tötet. Daneben gibt es auch die arapissa, deren Unterlippe die Erde berührt, die Oberlippe den Himmel (Michael G. Meraklis, Studien zum griechischen Märchen, Wien I 992, I 53 ).

457 I 250-306, Nr. 447-549, II I05 I-I I 64.

458 Wie gorgona, Sirenen, Nixen und Wassermänner I 307-3 I 2, Nr 550-559, II I I 64-I 2 I I.

459 Zusammen mit dem smerdaki Herdendämonen, behaarte Schaffresser in satyrhafter Bocksgestalt, oder eine behaarte Kindesfigur, die die Tiere beschläft und bespringt und dabei Krankheiten überträgt (I 3 I 4-330, Nr. 560-589, II I 2 I I-I 240). Dazu auch Pan. S. Codellas, »Greek Folklore of the Present Day: the Smerdaki«, Journal of American Folklore 58 (I 945) 236-244.

460 Auf die noch zurückzukommen sein wird (I 33 I-38 I, Nr. 590-644, II I 240-I 345).

46 I Tierdämon in Eselsgestalt, die immer größer wird, wenn sie beritten wird ( $\left.\mathrm{I}_{3} 82-386\right)$.

462 I $387-490, N r .65$ I-804. Zu den anziehenden, aber auch gefährlichen Feen noch in der Folge.

463 Schlanke loreleihafte Frauengestalten, die ihr langes Haar kämmen, manchmal auch vielfüßig erscheinen (I 49I-499, Nr. 805-82 I). Charakteristisch für die morphologische Ambivalenz solcher Vorstellungen ist die Tatsache, daß die lami(j)a im zentralbalkanischen Raum als gewitterbringender Himmelsdrachen gedacht wird.

464 I $500-506$, Nr. $822-832$.

465 I 5 I 4-542, Nr. 840-542. Vgl. auch Spyros Troianos, "Der Teufel im orthodoxen Kirchenrecht«, Byzantinische Zeitschrift 90 (1997) 97- I I .

466 I 543-548, Nr. 887-897.

467 Ein kindhafter Brustsitzer oder Aufhocker (I $55 \circ$ f., Nr. 898-900), der auch als Frauengestalt erscheint (mora). Vgl. auch Friedrich Salomo Krauss, »Das Alpdrücken«, Am Urquell NS 2 (I89I) I03-105. 
Pest (panukla $)^{468}$, die alten Schicksalsfrauen (moires) ${ }^{469}$, die Totenseelen ${ }^{470}$, die Vampire (vrikolakes und andere Bezeichnungen wie katachanas, teloni usw. ${ }^{471}$. Vergleicht man diese repräsentative Übersicht einer Kodifizierung der morphologischen Vielfalt der Dämonenvorstellungen im hellenophonen Kommunikationsraum der Balkanhalbinsel mit neueren einschlägigen Arbeiten, so wird eine Tatsache augenfällig, die jeglichen weiteren Taxonomie-Versuch in seiner Aussagehältigkeit untergräbt: Namen und Inhalte gehen oft verschiedene Wege; unter der gleichen Nomenklatur verbergen sich verschiedene Dämonengestalten, und die gleichen imaginierten Wesen können unter verschiedenen Namen erscheinen ${ }^{472}$. Dies ist zur ethisch-moralischen Labilität und prinzipiellen Unberechenbarkeit dieser Wesen noch hinzuzurechnen; der Übergang zwischen guten Feen und bösen Hexen ist ein gleitender ${ }^{473}$.

Häufiger und schwieriger zu überblicken sind die Darstellungen zu Einzeldämonen ${ }^{474}$, wo auch komparative Ansätze sprachübergreifend in jenen Fällen zu verorten sind, wo eine Dämonengestalt größere Regionalverbreitung aufweist und in mehreren Sprachen vertreten ist. Eine Grundschwierigkeit all dieser Untersuchungen ist jedoch die variable Lokalterminologie ${ }^{475}$ mit ihren phonetischen und morphologischen $\mathrm{Ab}$ -

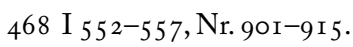

469 I 559-563, Nr. 916-922, die manchmal auch jung und schön sein können. K. Krikos-Davis, »The

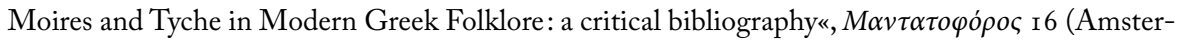
dam i 980) 47-53. Dazu auch Rolf-Wilhelm Brednich, Volkserzäblungen und Volksglaube von den Schicksalsfrauen, Helsinki 1964 (FFC 193) und ders., »Schicksalsfrauen«, Enzyklopädie des Märchens I I (2004) I395-I 404. Zur balkanischen Nomenklatur der ursitori, orisnici, sudice usw. Norbert Reiter, »Die Schicksalsfrauen«, Wolfgang Dahmen/Petra Himstedt-Vaid/Gerhard Ressel (eds.), Grenzüberschreitungen. Traditionen und Identitäten in Südosteuropa. FS Gabriella Schubert, Wiesbaden 2008, 5 IO- 5 I 2 .

470 I $565-572$, Nr. 923-932. Vgl. dazu noch in der Folge.

47 I I 573-608, Nr. 933-977.

472 Dieses Ergebnis überrascht nicht. Ganz genau die gleiche Feststellung konnte beim Nachzeichnen der verschlungenen Traditionsfäden beim Nachleben des Rosalienfestes in Südosteuropa festgestellt werden (Walter Puchner, »Zum Nachleben des Rosalienfestes auf der Balkanhalbinsel«,

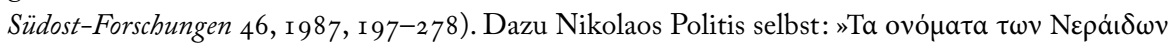

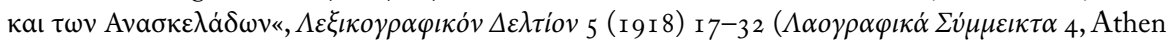
1980-85, 489-503).

473 Éva Pócs, Fairies and Witches at the Boundary of South-Eastern and Central Europe, Helsinki 1989 (FFC 243).

474 Z.B. Mihail Arnaudov, »Der Familienschutzgeist im Volksglauben der Bulgaren. Folkloristische Skizze«, Zeitschrift für Balkanologie 5 (1967) I 29-1 37.

475 Vgl. z. B. Dämonengestalten mit vereinzelten Namensformen wie bei Dimitrios P. Paschalis, »Av-

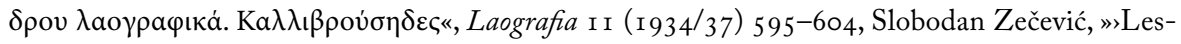
nik - the Forest Spirit of Leskovac in South Serbia«, Ethnologia Slavica I ( 1969) I 7 I-I 83, usw. 
weichungen sowie die Unmöglichkeit einer klaren Grenzziehung zwischen den Einzelgestalten, ihrem Aussehen und ihrer Tätigkeit. Gesondert zu behandeln sind die vielgestaltigen Vampirformen, der zmej, die Zwölftendämonen und verwandte Gestalten, Hexen und Pestfrauen, sowie der breite Bereich von Feenformen mit jenen ambivalenten Konsequenzen, die die faszinierende weibliche Schönheit für die Menschen hat.

Blutsaugende Vampire, Wiedergänger und Nachzehrer werden zwar im einschlägigen Schrifttum säuberlich getrennt, befinden sich allerdings im bibliographisch kaum zu überblickenden erfaßten Fallmaterial in einer hybriden Gemengelage, die die Gelehrten daran erinnert, daß es sich um imaginierte Phantasiegestalten handelt. Der Vampirismus und seine Prophylaktik haben schon die kirchliche Rechtsprechung seit byzantinischen Zeiten beschäftigt ${ }^{476}$. Die Exhumierung und Verbrennung bestatteter Leichen als Prophylaxe war schon in den byzantinischen nomokanones verboten ${ }^{477}$, über Morphologie, Ätiologie, Aktivität (wann, wo) und Schutzakte ist viel Tinte geflossen ${ }^{478}$. Eine lesbare Übersicht gibt die Monographie von Perkowski ${ }^{479}$, aus kulturanthropologischer Sicht sind die Artikel von Georges Drettas geschrieben ${ }^{480}$, unersetzlich ist nach wie vor die materialreiche Studie von Dagmar Burkhart ${ }^{481}$, die einen bleibenden Ein-

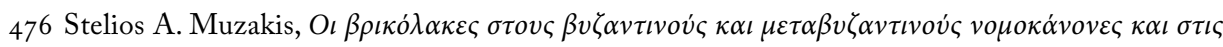

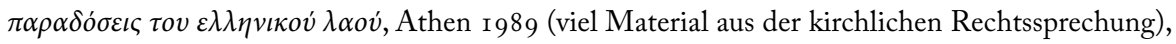

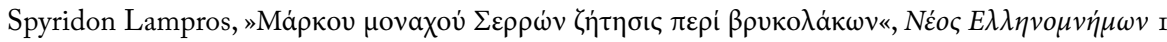

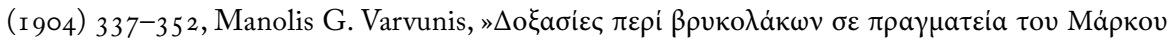

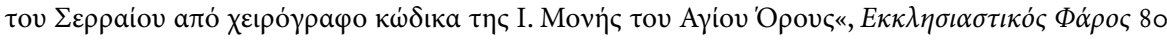

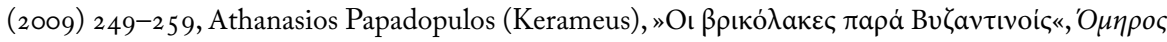

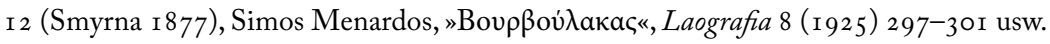

477 So auch im Gesetzbuch des Zaren Dušan I 349 (Mehmed Begović, Zakonik cara Stefana Dušana, Beograd I98 I, § 2 I). Zur Prophylaktik in Ungarn und Rumänien vgl. Oskar Hovorka/Adolf Kronfeld, Vergleichende Volksmedizin, Stuttgart I 908, 429 ff., noch im I 9. Jh. wurde diese Praktik in Serbien geübt (Tihomir Đorđević, Iz Srbije Kneza Miloša, Beograd I 924, 2 Iof.), ja sogar noch im 20. Jh. ( 1 934) (ders., »Vampir i druga bića«, Srpski Etnografski Zbornik 66, I 953, 3 ff.).

478 Vampirismus wurde sogar bei Tieren diagnostiziert (Adolf Strauß, Die Bulgaren, Leipzig I898, I 89).

479 Jan L. Perkowski, Vampires of the Slavs, Cambridge/Mass. 1976, ders., The Darkling. A Treatise on Slavic Vampirism, Columbus, Ohio 1989.

480 Georges Drettas, »Questions de vampirisme«, Études Rurales 97-98 (I985) 20 I-2 I 8, ders., »Le cavalier glouton - Contribution à l'étude de la théorie populaire du vampirisme balkanique ", De la voûte céleste au terroir, du jardin au foyer - Textes offerts à Lucien Bernot, Paris I 987, 7 I 9-746, ders., "Aspects de l'hémophilie vampirique«, Revue des études slaves 64/4 (1994) 73 I-742, ders., »Les che-

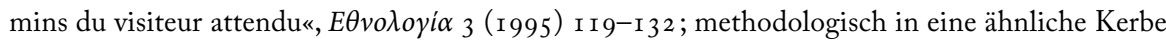
schlägt Juliet Du Boulay, »The Greek Vampire: A Study of Cyclic Symbolism in Marriage and Death «, $\operatorname{Man}$ (n. s.) I7 (1982) 2 19-238.

48 I Dagmar Burkhart, „Vampirglaube in Südosteuropa«, Kulturraum Balkan. Studien zur Volkskunde 
druck von der assoziationslogischen »Chaotik« dieser Vorstellungen vermittelt, der ars combinatoria von Namen und Sachen, die letztlich auch ein Darstellungsproblem impliziert. Als Ursprungsregion wird das östliche und südöstliche Slaventum angenommen, was allerdings auch eine Frage der Quellen bzw. Quellenkenntnis sein kann. Beim Definitionsproblem ${ }^{482}$ wird festgehalten, daß der Vampir ein wandelnder Leichnam sei, kein Dämon, ein wiederkehrender Toter, der den Lebenden Blut aussaugt. Das Fallmaterial hält sich jedoch keineswegs an solche Kategorienbildungen ${ }^{483}$, denn dort finden sich diese gefährlichen Totengestalten, zusammen mit Werwölfen, Alpgeistern, Zwölftendämonen, Hexen, Drachen, kannibalischen Riesen, Würgegeistern, Krankheitsdämonen usw. in einem unentwirrbaren Synkretismus in assoziativer Vernetzung, als Gefahr und Bedrohung des Menschen, auf der Grundlage der Gefühlambivalenz zu den Toten, die als Totenseelenvorstellungen vielfach das Fundament für diese Dämonologie bilden. Voda Dracula und den Toten Bruder aus der balkanischen Lenorenballade scheidet demnach nur die gute und böse Absicht ${ }^{484}$.

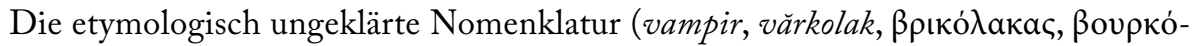
$\lambda \alpha \kappa a \varsigma)^{485}$ weist möglicherweise auf ein geflügeltes Seelentier ${ }^{486}$, verfügt über bedeu-

und Literatur Südosteuropas, Berlin/Hamburg 1 989, 65-108. Zu dem etwas zu kurz gekommenen

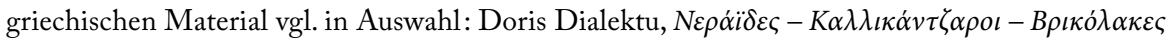

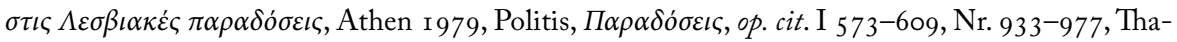

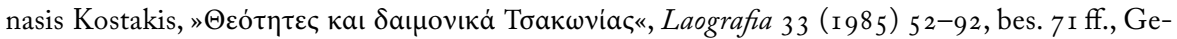
org Eckert/P. E. Formozis, Geister und Dämonenglaube im Pontus, Thessaloniki 1943, Doroth Lee, "Greek Accounts of the Vrykolakas", Journal of American Folklore 55 (I 942) I $26-$ I 32.

482 Perkowski 1976 , op. cit., I36.

483 Der Wiedergänger stellt an sich eine Dachkategorie des Vampirismus dar (auch ohne Blutkonsum), als es offene Rechtsverhältnisse zu den Lebenden sind, die ihn nicht zur Ruhe kommen lassen (Alfred Wopmann, Grundformen der Vorstellungen vom Leben nach dem Tode. Eine kultursoziologische Untersuchung der » Totenseelenvorstellungen « in Mythen, Märchen und Sagen, Diss. Wien I 96 I).

484 Vgl. Puchner, Die Folklore Südosteuropas, op. cit., I ro-I I 3.

485 Bulg. vampir, vapir, vepir, văpir, serb. vampir, aromun. vombir gilt als Fledermaus (Gustav Ludwig Weigand, Die Aromunen, Leipzig I 894/95 II I 22, Theodor Capidan, Meglenoromănii, București I 925,37 ). Vărkolak ist eigentlich die Werwolfsbezeichnung. Zu älteren Etymologieversuchen z.B.

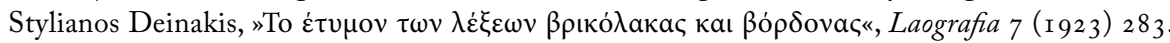
Man hat auch versucht, das Zentrum des Herkunftsbereiches auf Makedonien und Westbulgarien festzulegen (Kazimierza Moszyński, Kultura ludowa Stowian, 2 Bde., Krakow i934, II 666).

486 Eine Fliege, eine Fledermaus, einen Schmetterling usw. Zur Vorstellung der Seele als Vogel vg1.

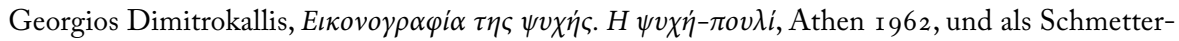

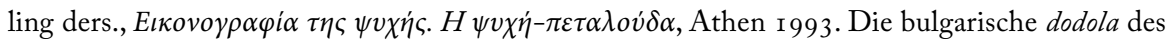
Regenbittganges "fliegt« zu Gott, um Regen zu erbitten (vgl. Puchner, Zur Folklore Südosteuropas, op. cit., 63-65). Zu der Totenseelenvorstellung als etwas Zartem und Verletzlichem (Arbeitsverbote) vgl. noch in der Folge. 
tende Varianz und umfaßt auch ganz andere Bezeichnungen ${ }^{487}$. Gegenspieler sind

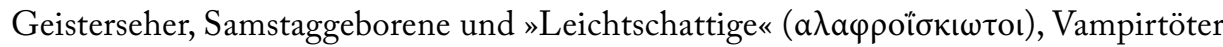
die Kinder aus einer Semi-Vampirehe ${ }^{488}$ wie der Drachensohn Zmaj Ognenji Vuk im südslavischen Heldenlied ${ }^{489}$. Verwandte Wesen sind die Nachzehrer und Wiedergänger, aber auch Menschenfleischfresser wie der drakos und andere ogre-Formen; auch als Tierverwandlung in Vogelform ${ }^{490}$, als Herdentiere reißender Werwolf ${ }^{491}$, Mahr, Alp (der Würgetod auch bei Vampiren), lugat (alb. $)^{492}$, karakondžule, karakondžeri (makedon.), karakondžo (bulg. Hockauf) ${ }^{493}$, als Hausgeist talasăm, talaso(r)n, talasum ${ }^{494}$; die weibliche Alpdruckgestalt der Mahr: mora (bulg., serbokroat.), morina, morica (serbokroat.), morava (bulg.) usw. befindet sich im Übergang zum Vampir (und zu anderen weiblichen Dämonen wie lamia, empusa, gello, striges [strix] und zur Hexe $)^{495}$ und zeigt große Ver-

487 Friedrich Salomo Krauss, Slavische Volksforschungen, Leipzig 1908, I 24, Edmund Schneeweis, Serbokroatische Volkskunde, Berlin I 96 I, 9, Johann v. Hahn, Albanesische Studien, I-3, Jena I 854, I I 63, Max Lambertz, Albanische Märchen, Wien 1922, 23, John C. Lawson, Modern Greek Folklore and Ancient Greek Religion. A Study in Survivals, Cambridge I 9 I o, 38 I ff. usw.

488 Die pirdžii, džindžii, văperari, vampiradžii, glogove, usw. (Hristo Vakarelski, Etnografija Butgarii, Wrocław I 965, 229) oder vampirovici (Edmund Schneeweis, Serbokroatische Volkskunde I. Volksglaube und Volksbrauch, Berlin I 96 I, 9) bzw. der Sohn eines lugat, alban. bir i lugats (Max Lambertz, Albanische Märchen, Wien I 922, 22f.), aromun. abraši (Weigand, op. cit., I 22 f.).

489 Der Held ist als zmej (bulg.), zmaj (serb.), pozoj (kroat.), drangue (alb.) charakteristiert, d. h. selbst ein semianthropomorpher Dämon, der den Gewitterdrachen lamja, chala (bulg.), lamnja, ala, aždaha (serbokroat.), lamia (gr.), ku(l)shedra, lamia (alban.) bekämpft, manchmal auch als guter Lokalgeist kr(e)snik oder obilnjak (slov., norddalm., Maja Bošković-Stulli, Istarske narodne priče, Zagreb 1959, 232), der mit dem Nachbargeist kämpft, wenn er siegreich ist, gibt es für den Ort eine gute Ernte; ähnlich auch der Schlafgeist (v)jedogonja (montenegr., hercegov.), auch als zdubač (obwohl zduhaći eigentlich Berggeister sind, vgl. Vuk Karadžić, Život i običaja naroda srpskoga, Wien I 867, 2 I 5 ). Vgl. dazu noch in der Folge.

$490 \mathrm{Als}$ navi(je), navjaci (bulg., ostlsav.), nekrštenci (serb.), nevidinčići, nevidmići (kroat.) usw. Vgl. Schneeweis, op. cit., 5, Dimitar Marinov, Narodna vjara i religiozni narodni običai, Sofija I 9 I4, 22 I f. 49 I Ursprünglich eine Verkörperung der Seuche (ustrel im Bulg.).

492 Eqrem Çabej, »Sitten und Gebräuche der Albaner«, Revue International des Études Balkaniques I ( I 935$) 225 \mathrm{ff}$.

493 Dazu noch in der Folge.

494 Mak., bulg., südserb., nach Vakarelski, Bulgarische Volkskunde, op. cit. $238 \mathrm{f}$. von griech. telonia (?), nach Krauss (Friedrich Salomo Krauss, "Vampire im südslawischen Volksglauben«, Globus 6I/20, I 892, 325-328) ein Würgegeist im Übergang zum Werwolf.

495 Die Hexe veštica (bulg.), v(j)estica/v(j)estac, vedarec (serbokroat.), vešča/vedomec (slov.) erscheint auch als Nachtfalter (T. Đorđević, »Veštica i vila u našem narodomverovanju i predanju«, Srpski Etnografski Zbornik 66, I 953, 5-55); ihre Bezeichnung wird auch vom männlichen čar/Zauberer als čarovnica/čarodeec (bulg.), čarovnica/čarovnik (serbokroat.) abgeleitet, für Hexe steht auch vražalica (bulg. Heilkundige), biljarka (Kräuterzauberin), brodnica (hält sich am Wasser bei Vilen und Teu- 
wandlungsfähigkeit ${ }^{496}$, auch als Krankheitsdämon wie kukúdhi, karkanxhol (alb., Wiedergänger und Pestgeist) oder eingemauerte Schatten (bulg. sjanka, seništa), der die Hausbewohner dauernd krank sein läßt ${ }^{497}$. Besonders auffallend ist in Südosteuropa die große Verwandschaft des Vampirismus mit Werwolfsvorstellungen, in die oft gleich die Zwölftendämonen auch integriert werden ${ }^{498}$. Diese vampiroiden Glaubensvorstellungen sind grundsätzlich religionsübergreifend ${ }^{499}$.

Es war vom zmej die Rede ${ }^{500}$, jenem semizoomorphen Wesen mit Flügeln in den Achselhöhlen und schuppigem Schwanz (alban. drangue) aus der südslavisch-albanischen Oralepik, zuständig für die Regenfälle, aber Gegenspieler des Gewitterdrachens

feln auf), verschiedene euphemistische Bezeichnungen, štriga (kroat.), štrija/strigon (slov.), shtriga (alb.), striglă (aromun.), stringla (gr.), strigoi (rum.) (ital. strega, latein. strix die blutsaugende Ohreule) (in Istrien dem vukodlak gleichgesetzt). Vgl. auch Pócs, op. cit.; es handelt sich um ein ganzes Sammelbecken von Namens- und Erscheinungsformen, wo der Vampirismus mit der Zauberei eng verbunden ist.

496 Schneeweis, op. cit., 23.

$497 \mathrm{Zu}$ den positiven Konnotationen des zazidan (Einmauerns) vgl. Marinov, op. cit., 2 I $9 \mathrm{f}$.

498 Sowohl bei Südslaven wie auch bei Griechen, Albanern und Rumänen. Zur Namensvarianz: vurkolak (Wolfshaar), vărkolak, vălkolak usw. (bulg.), vukodlak, vukedlak (serbokroat.), vurko(l)ak,

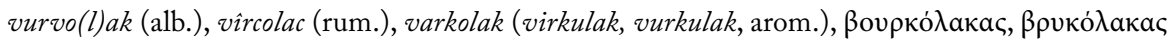
(gr.), vurkolak (türk.), usw. Die Vorstellung vom Wolf als Stammesahn und Schutzgeist der Sippe ist praktisch überall verbreitet (von altgr. $\lambda$ úкоৎ Lyceum usw.); als Rest dieser Vorstellung gilt der Wolf noch als Taufpate (Jasna Belović, Die Sitten der Südslaven, Dresden I 927, 5 I f., was sich in Namensformen wie Vuk, Vukac usw. äußert); meist fallen die Bedeutungen des Vampirs und Wer-

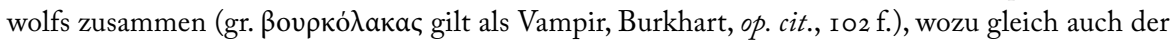
kalikantzaros gerechnet wird (Bernhard Schmidt, Das Volksleben der Neugriechen und das hellenistische Altertum, Leipzig I 87 I, I 44, leitet aus dem türk. karakondjolos ab, auch Arnaudov und Çabej, op. cit., 234, John C. Lawson, Modern Greek Folklore and Ancient Greek Religion. A Study in Survivals, Cambridge I 9 Iо, 2 I 4 f., schlägt ein griechisches etymon vor, Vakarelski, Bulgarische Volkskunde, op. cit., 228 tippt auf türk. korkunc). Zu der Frage noch in der Folge. Der Zwölftengeist an den »heidnischen« Tagen poganski dene (bulg.) und nekršteni dani (serb.) wird manchmal auch von Forschern als Werwolf aufgefaßt (Burkhart, op. cit., I03 nach R. Bernard, »Le Bulgare karakondžo ssorte de loupe garou< et autres formes bulgares issues du turc karakoncolos«, Izsledvanija v čest na akademik Mihail Arnaudov, Sofija I 970, 477-486), was der Vermischung der Vorstellungen im Forschungsfeld entspricht: karakondžula (serb., mak., gilt als Wiedergänger, Alpgeist, Krankheitsdämon und Vampir), karakondžul, karakondžar, karakončo (bulg.), karkanzhól (alban.), pricoliciu (rum., im Banat auch mit Hundeschweif, manchmal auch hundsköpfig). Damit hat man jüngst auch den Brauch der »Hunderfolter « am Reinen Montag in Zusammenhang gebracht (Manolis G. Sergis, »Dog Sacrifice in Ancient and Modern Greece: from the Sacrifice Ritual to Dog Torture (kynomartyrion)«, Folklore. Electronic Journal of Folklore 45, 2010, 6 I-88).

499 Markus Köhlbach, »Ein Fall von Vampirismus bei den Osmanen«, Balkan Studies 20 (1979) 83-90. 500 Vgl. auch Puchner, Die Folklore Südosteuropas, op. cit., 29. 
( hala, lamja, ažder usw. $)^{501}$, der aber auch schöne junge Mädchen raubt, als Gegenspieler der epischen Helden auftreten kann, welcher sich jedoch auch in einen zmej verwandeln $\mathrm{kann}^{502}$. Diese Metamorphosen dokumentieren die ursprüngliche Einheit von Dämon und Heros. Hier ergeben sich wiederum Übergänge zum geflügelten Drachenungeheuer, dem menschenfressenden drakos, dem monströsen div und frauenraubenden arapin sowie ogre-Formen in jeglicher Ausführung.

Zur Onomatologie der Zwölftendämonen ${ }^{503}$ liegen nun die erschöpfenden Studien von Emmanuella Moser-Karagiannis vor, die hunderte von griechischen Versionen des kalikantzaros zusammenstellt ${ }^{504}$ und auf ihre Etymologie hin untersucht. Während die griechischen Ableitungen bisher kaum eine tragbare Lösung angeboten haben ${ }^{505}$, bleiben drei Argumente, die die Diskussion in eine andere Richtung führen: I. die erste Anführung dieser Bezeichnung findet sich in der Schrift »Graecorum hodie quorandum opiniationibus« (Amsterdam I645) des griechischen Bibliothekars im Vatikan aus Chios, Leon Allatios (Leo Allacci) ${ }^{506}$, während in Byzanz der Ausdruck unbekannt

50 I Vgl. vor allem Milena Benovska-Săbkova, Zmejat v bălgarskija folklor, Sofija 1992 (1995) und Dagmar Burkhart, Untersuchungen zur Stratigraphie und Chronologie der südslavischen Volksepik, München I 968, 463-486. Weiters Radoslav Katičić, "Nachlese zum urslawischen Mythos vom Zweikampf des Donnergottes mit dem Drachen«, Wiener Slavistisches Jahrbuch 34 ( I 988) 57-75, ders., "Weiteres zur Rekonstruktion der Texte eines urslawischen Fruchtbarkeitsritus«, ibid. 35 ( I 989) $57-98$.

502 In Auswahl: E. Karanov, "Zemat (ažder) i zmijata (zămja) v bălgarskata narodna poezija«, Periodičesko spisanie na Bălgarskoto knižovno družestvo 9 (г884) I 29 ff., Marko Kitevski, "Zmijata vo makedonskite mitološki narodni pesni«, Zbornik radova 35 kongresa Saveza udruženja folklorista Jugoslavija, Rožaje, 26-29 sept. 1988, Titograd I 988, 262-267, Radost Ivanova, "Archaični čerti v obraza na južnoslavjanskija epičeski geroj«, Slavjanska filologija 20 ( I 988) I62-I72, Plamen Bočkov, "Zoomorfni čerti v obraza na epičeskija geroj-junak", Vtori meždunaroden kongres po bălgaristika I 5 (Sofija I988) 205-2 I5, Mark Tirtja, »Des stratifications mythologiques dans l'Épopées légendaires«, Culture populaire albanaise, Tirana 1985, 9 1 -102, Myzafere Mustafa, „Kuçedra«, Gjurmime albanologjike, Seria folklor dhe etnologji 20 (1990) I49-I69, Drita Statovci, „Elemente mitologjike dhe demonologjike në doke e zakone të lindjes«, ibid. I 8 ( I988) I 73-г 92.

503 Vgl. auch im Ersten Teil.

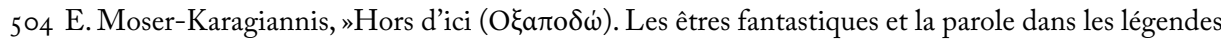
populaires grecques. I. Xotika (Anaskelades, Arapides, Chamodrakia (Smerdakia Telonia), Drakoi, Gorgones, Kalikantzaroi, Néraïdes, Stoicheia, Vrachnades). A. Le Kalikantzaros«, Littérature orale de la Grèce moderne. Revueil d'études, Athènes 2005, 263-450 und dies., "Quelques remarques sur les appellations du Kalikantzaros«, $\Lambda \varepsilon \xi ı \kappa o \gamma \rho \alpha \varphi \iota \kappa o ́ v ~ \Delta \varepsilon \lambda \tau i o v ~ 24$ (2002-2003) I6 I-I 97.

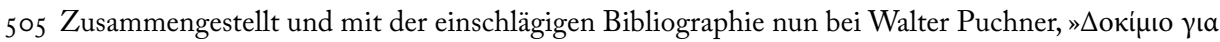

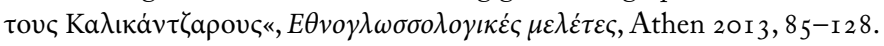

506 Zur Bedeutung dieser Schrift nun Karen Hartnup, On the Beliefs of the Greeks. Leo Allatius and Popular Orthodoxy, Leiden/Boston 2004. 
ist $\mathrm{t}^{507}$, 2. die Entsprechungen dieser Bezeichnung in den anderen Balkansprachen (alb. karkanzhól, bulg. karakondžo usw.) folgen grosso modo den Ausdehnungsgrenzen des Osmanischen Reichs ${ }^{508}$, und 3. die türkische Folklore kennt den karakonçolos als Mittwintergeist mit unterschiedlichem Aussehen und Funktionen ${ }^{509}$. Insofern ist die osmanische Herkunft keineswegs auszuschließen, auch wenn die Zwölftenperiode als Seelentermin im Islam unbekannt is ${ }^{510}$. Daneben existieren jedoch noch eine ganze Reihe von anderen Bezeichnungen. Wie dem auch sei, die Morphologie bietet eine geradezu unüberschaubare Varianz: Diese Wesen sind sehr groß oder sehr klein, schwarz, behaart, hinkend, ziegenfüßig, drei- bzw. einbeinig, haben rote Augen, sind einäugig, haben Hauer, lange gebogene Krallen usw. ${ }^{511}$ In Nordserbien kontaminieren sie mit Hexenvorstellungen, karakondžuli sind auch weibliche Krankengeister ${ }^{512}$, in Griechenand auch mit dem hinkenden Dämon (katsipodis, kutsodaimonas) ${ }^{513}$, in Serbien mit der Mahr ${ }^{514}$. $\mathrm{Zu}$ ihrer miasmatischen Funktion gehört das Urinieren ins Feuer (das als »Christblock«

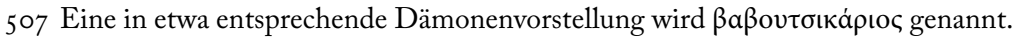

508 Albanien, Montenegro, Südserbien, Hercegbosna, Makedonien, Bulgarien, Aromunen und Turkophone.

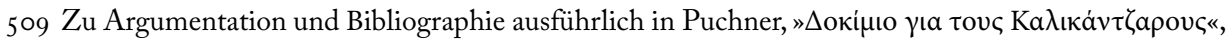
op. cit.

5 Io Dies ist z.T. auch von älterer Bibliographie unterstützt worden, z. B. Elard H. Meyer, Indogermanische Mythen, Wien I883, Bd. I, I68, ders., Etymologisches Worterbuch der albanesischen Sprache, Strassburg I89 I, I79, Bernhard Schmidt, Das Volksleben der Neugriechen und das hellenische Alterthum, I. Teil, Leipzig I 871, I $42-152$.

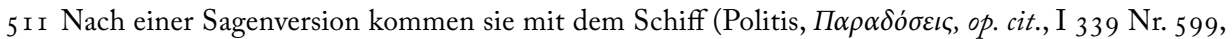
Apostolos E. Sitaras, H Mó $\delta v \tau o \varsigma$, Athen I97 I, 2 I 2); sie bleiben auf der Oberwelt von Malka Koleda bis Vodica ( $\Phi \omega \dot{\tau} \tau)$, oder von Ignažden 2. r. bis babin den 2 I. I. (je nach dem alten oder neuen Kalender): Manchmal haben sie Zentaurenform (Dimităr Marinov, Narodni vjara i religiozni narodni običai, Sofija I 914, 304 f.), ein andermal sind sie nackte, einäugige, einfüßige, behaarte oder mit Dornen übersäte Menschenfresser (P. Mandžarov, »Poganoto (pogani din) văv vjarvanijata i bita na strandžanskite sela«, Bălgarski Folklor 8/4, I 982, 9 I-IOI mit älterer Literatur).

5 I 2 Bei den Slavomakedonen werden karakondžul die Weihnachtskringel genannt, die man auf den Pflug legt und nächstes Jahr als Arznei verwendet (Stevan Tanović, Sprski narodni običaji u Đevđelijskoj kazi, Beograd/Zemun I 927, 79 f., 85).

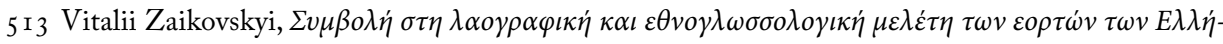

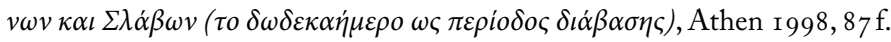

5 I 4 Stanoje M. Mijatović, „Narodna medicina Srba seljaka u Levču i Temniću «, Etnologska i etnografska grada I 3 ( I 909) 259-482, bes. 338, Veselin Čajkanović, Sabrana dela iz srpske religije i mitologije u pet knjiga, Beograd 1994 (reprint), V 3 I 2, Slobodan Zečević, Mitska bića srpskih predanja, Beograd I98 I, I68 (i 7 I auch andere Mahrgestalten: der Alte). Solche Alpgeister stellen Menschen Rätsel (auch die Feen der rusalki). Sie können auch bloß Straffunktion haben und sind nicht schädlich für Fleißige (sekundäre Ordnungsfunktion der Überlieferung). Vogelgeister stehlen in den Zwölften auch Neugeborene (nekrštenci, wie die Hexe striga usw.). 
nicht erlöschen darf $)^{515}$, aber auch in Wasser, Wein, Öl usw.; doch sofort stellt sich auch eine Bedeutungsambivalenz ein, denn den Urin umgibt eine gewisse sakrale Aura, er gilt in der Volksmedizin als kinderbringend ${ }^{516}$.

Damit kommen wir zu den weiblichen Dämonen: auch hier ist der Übergang zwischen Menschen mit besonderen Fähigkeiten und imaginierten Phantasievorstellungen ein gleitender: Hexen und Pestfrauen, Magierinnen und Krankheitsdämonen. Den bösen Blick kann sogar jeder haben, der Übles will. Die Hexenvorstellung ist durch ihre kirchliche Überformung ein Sammelbecken für sehr Unterschiedliches ${ }^{517}$. Neben ihrer allgemeinen magischen Tätigkeit des Schadenszaubers ${ }^{518}$ wird ihr die Fähigkeit zur Krankheitsübertragung zugeschrieben ${ }^{519}$; die häufigen und verheerenden Pestepidemien haben die imaginäre Gestalt der Pestfrau hervorgebracht ${ }^{520}$.

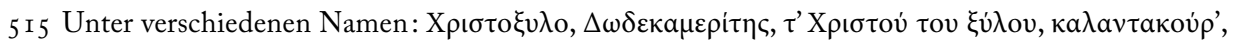
bădnikăt, bădnik, bădnjak, prikadnik, babka, dednik, stari bog, stari bădnjak usw. In Bulgarien wird

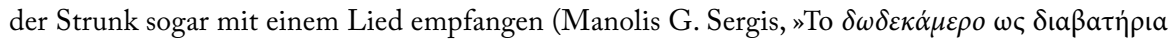

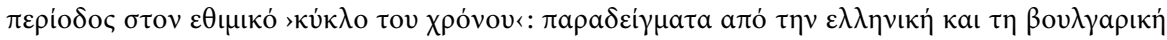

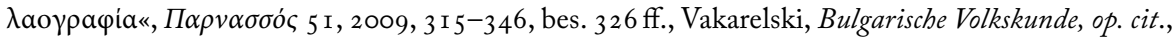
3 I4). Vgl. auch im ersten Teil.

5 I6 Vgl. das Trinken des Morgenurins von Pferden als Arznei für kinderlose Frauen (auch den Märchentyp ATU 30I). Ähnlich gilt der Furz als glückbringend, in den Erweckungsszenen der pontischen momogeria ist er sogar lebenspendend (vgl. den ersten Teil).

5 I 7 Catia Galatariotou, »Holy Women and Witches: Aspects of Byzantine Conceptions of Gender«, Byzantine and Modern Greek Studies 9 (I 984-85) 55-94, Marjeta Tratnik Volasko/Matevž Košir, Caroviene: predstave, procesi, pregoni i evropskih in slovenskib deželah, Ljubljana I 995, Agron Xhagolli, »Shtriga në mite, rite e besime të shiptarë«, Kultura popullore I-2 (I993) 6I-70, ders., »The witch in myths, rites and beliefs of the Albanians«, Studia albanica I-2 (1 994) 93-I04, Éva Pócs, Fairies and Witches at the Boundary of South-Eastern and Central Europe, Helsinki 1989 (FFC 243), Démètrios A. Petropoulos, "Le rôle des Femmes et de la Terre en quelques Pratiques Magiques«, Mélanges offerts à Octave et Melpo Merlier, 2 Bde., Athènes I 956-57, II 275-285.

5 r 8 Vgl. wie oben. Dazu auch Arne Runeberg, Witches, Demons and Fertility Magic, Helsinki 1947, Wolfgang Brückner, »Überlegungen zur Magietheorie. Vom Zauber mit Bildern«, Leander Petzoldt (ed.), Magie und Religion, Darmstadt I978, 404-4I 9.

5 I 9 Leander Petzoldt, „Besessenheit in Sage und Volksglauben«, Rheinisches Jabrbuch für Volkskunde

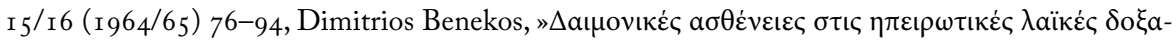

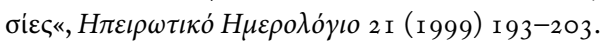

520 Kyprou Chrysanthis, »The Personification of Plague and Cholera According to the Cypriots«, Folklore 56 (1 945) 259-266, K. L. Lübeck, »Die Krankheitsdämonen der Balkanvölker«, Zeitschrift des Vereins für Volkskunde 8 (I 898) 24I-249, 379-389, 9 (I 899) 58-68, I94-402, 295-304, Peter Dinzelbacher, »Die tötende Gottheit. Pestbild und Todesikonographie als Ausdruck der Mentalität des Spätmittelalters und der Renaissance«, Analecta Cartusiana I I 7 ( 1986) 5-1 38, Neihard Bulst, "Pest«, Enzyklopädie des Märchens Iо (2000) 772-782, Michael W. Dols, The Black Death in the Middle East, Princeton 1977, Jacque Rouffié/Jean-Charles Sournia, Die Seuchen in der Geschichte der 
Über die ambivalente panbalkanische Feengestalt der vila-samovila (mak. westbulg.), vila (serbokr., slov.), samodiva, diva, diva-samodiva (zentral-, ostbulg.), juda, samojuda (südbulg. mak.), neraida (griech.), zina, iana, rosali (il)a (rumän.), ora, zana, zanë (alban.), rusalka (russ.) usw. ist viel geschrieben worden ${ }^{521}$. Ihre z.T. widersprüchlichen Eigenschaften und Tätigkeiten (helfend, schädlich) sind katalogfüllend: Sie tauchen in Glaubensvorstellungen und der Dämonologie, in Heldenliedern und Balladen, in Märchen und Sagen

Menschheit, Stuttgart 1987, I7-65 (zu Hexen), zur Vorstellung vom Abschießen magischer Gegenstände, die die Haut durchdringen und Krankheiten verursachen Lauri Honko, Krankheitsprojektile, Helsinki 1967 (FFC I78).

52 I Jordanka Koceva, »Samovila«, Enzyklopädie des Märchens I I (2004) I Io5-I I Io, Gabriella Schubert, »Die bulgarischen Samovila und ihre balkanischen Schwestern«, T. I. Živkov/ G. Georgiev (eds.), Dokladi. Bălgarskata kultura i vzaimodejstvieto i săs svetovnata kultura, Sofija I983, 372-394, Puchner, Studien zur Volkskunde Südosteuropas, op. cit., 90-102, Milena Benovska-Săbkova, "Za rusalkite v bălgarkija folklor Bălgarski folklor I 7/I (I 99I) 3-I4, Edmund Schneeweis, Serbokroatische Volkskunde. I. Volksglaube und Volksbrauch, Berlin I 96 I, 6-8, Johann Georg von Hahn, Albanesische Studien, Jena I 854, I62, Tihomir Đorđević, »Veštica i vila u našem narodnom verovanju i predanju «, Srpski etnografski zbornik LXVI (1953) 57-I I 9, B. Angelov, »Samovilite v bălgarskata narodna poezija«, Izvestija na Seminara po Slavjanska filologija pri universiteta v Sofja 3 (I9 I I) I-66, Milenko S. Filipović, »Volksglauben auf dem Balkan. Einige Betrachtungen« Südost-Forschungen I 9 ( 1 960) 239-262, Hristo Vakarelski, "Za samovilite - orisnici«, Izvestija na Narodnija etnografski muzej I 2 ( 1 936) 32 ff., Mark Kulikowski, A bibliography of Slavic mythology, Bloomington I 989, Špiro Kulišić, Sprski mitološki rečnik, Beograd I 970, Maximilian Lambertz, »Die Mythologie der Albaner«, Hans Wilhelm Haussig (ed.), Worterbuch der Mythologie, I. Abt. Bd. II. Götter und Mythen im Alten Europa, Stuttgart 1973, 455-509, ders., Die Volksepik der Albaner, Halle 1 95 8, I 55-1 57, Ndani Stojnev (ed.), Bălgarska mitologija, Enciklopedičen rečnik, Sofija 1994, Mark Tirtja, „Figures mythologiques albanaises et rencontres balkaniques«, Studia albanica I-2 (I 992) I I 9-I 25, ders., »Figures de la mythologie albanais et concordances balkaniques«, Thraco-Dacica I6 (I 995) 26 I-266, Eqrem Çabej, »Život i običaji arbanasa«, Knjiga o Balkanu I (Beograd I936) 303-329, ders. »Albanische Volkskunde«, Südost-Forschungen 35 (1 966) 333-387, bes. 373, Theodoros Vlachos, "Geister- und Dämonenvorstellungen im südosteuropäischen Raum griechischer Sprachzugehörigkeit«, Österreichische Zeitschrift für Volkskunde 25 ( I 97 I) 2 I 7-248, Tanas Vražinovski, Narodna demonologija na makedonite, Skopje/Prilep I 995, Romulus Vulcănescu, Mitologie română, București I 985, Ion Popinceanu, Religion, Glaube und Aberglaube in der rumänischen Sprache, Nürnberg 1 964, 46 f., Svetla Petkova, »Tipove vaveždane v njakoi mitičeski narodni pesni«, Ezik i poetika na bălgarskija folklor 5 ( 1980) 68-79, G. Il'inskij, "Juda. Stranička iz slavjanskoj mifologii«, Sbornik Miletić I 933, 467-474, Milena Benovska-Săbkova, »Rusalkite i samodivite v bălgarskata tradicija «, Medievistika i kulturna antropologija, FS D. Petkanova, Sofija I998, 345-40 I, Ute Dukova, „Die Bezeichnungen der Dämonen im Bulgarischen«, Linguistique balkanique 26/4 (1983) 5-46, dies., »Gemeinsame Termini in der Folklore der Balkanvöker (Euphemistische Bezeichnung der Bergfeen und von ihnen her-

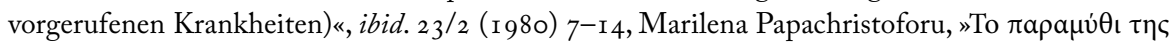

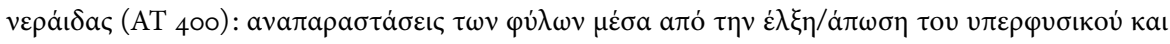

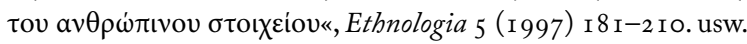


auf, verursachen Sturm und Wirbelwind, sperren das Wasser, als kriegerische Amazonen sind sie auch helfende Wahlschwestern für den epischen Helden ${ }^{522}$, besitzen allerdings den versteinernden Blick (Medusa, Gorgona), schenken umgekehrt aber auch Gesundheit und Kraft, Glück, Schönheit und Reichtum, bei Tabuübertretung (Namensnennung, Verbotsübertretung) verursachen sie Krankheiten, Epilepsie, Depressionen ${ }^{523}$ usw. Ihr orgiastischer Tanz ${ }^{524}$ und die Vilenheirat mit Sterblichen durch Entwendung der Flügel (des Kleides, Kopftuchs, Kranzes) ist ein beliebtes Sagen- und Balladenmotiv ${ }^{525}$. Ihre

522 R. Angelova et al. (eds.), Bălgarski junaški epos, Sofija I 97 I, Nr. I 46-I 50, Nr. I69 ff., L. Bogdanova, "Pregled na motivite na bălgarskite junaški pesni i na proizvedenijata v proza za geroite na junaškija epos«, Sbornik za narodni umotvorenija i narodopis 53 (1971) 849-944, bes. 865 Nr. I90 a, b, Dagmar Burkhart, Untersuchungen zur Stratigraphie und Chronologie der südslavischen Volksepik, München 1968, 378-409, A. Popova, „Une Société féerique d'amazones. Les Samodivi«, J.-C. Payen, Le conte de fées en Normandie, Noireau I 986, 276-296, Ljubinko Radenković, Narodna bajanja kod južnih slovena, Beograd I 996, 48-50, I. Marazov, »Amazonkata i samodivata«, Mitologija, izkustvo, folklor, Sofija I 985, 90-I I 7, V. Čajkanović, „Stara srpska religija i mitologija«, Sabrana dela iz srpske religije i mitologije, Bd. 5, ed. V. Đurić, Beograd I 994, 228-247, bes. 243, 246 ff., T. I. Živkov/S. Bojadžieva (eds.), Bălgarskite narodni baladi i pesni s mitičeski i legendarni motivi, Sofija I 993/94, Nr. 53-55, 59, 60, 67-69, J. Ivanov, Bălgarski narodni pesni, Sofija I959, I64-I 7 I, Branislav Krstić, "Ženitba čoveka vilom«, Prilozi proučavanju narodne poezije 4 (I 937) 99-I I I, ders., Indeks motiva narodnih pesama balkanskih slovena, Beograd I 984, 60 I ff., Maja Bošković-Stulli, Istarske narodne priče, Zagreb I959, I64, N. Milošević-Đorđević, Zajednička tematsko-sižejna osnova srpskohrvatskih neistoričeskih pesama i prozne tradizie, Beograd I 97 I, 5 I-75, D. Todorov, »Samodivi«, ders. (ed.), Kapanci. Bit i kultura na staroto bălgarsko naselenie v severoiztočna Bălgarija, Sofija 1985, 27 I ff., Charles Stewart, »Nymphomania: sexuality, insanity and problems in folklore analysis«, Margaret Alexiou/Vasilis Lambropoulos (eds.), The text and its margins, New York I 99 I , 2 I 9-252, Andrijana Gojković, »Rusalje - an Ethnomusicological and Medical Problem«, Musik, Tanz und Kunst-Therapie 2/3 (1989) I 27-138.

523 Die die căluşarii in ihren akrobatischen Trancetänzen in der Vorpfingstwoche zu heilen versuchen. Vgl. im Ersten Teil.

524 St. Džudžev, Bălgarska narodna horeografija, Sofija I 974, 50.

525 In Kurzform läuft die Geschichte folgendermaßen: Sobald sie dieses Gegenstandes habhaft werden kann, verläßt sie Mann und Kind; in Langform: Der Mann sucht seine Frau und die Ehe wird fortgesetzt (ATU 400, 465). Dazu Branislav Krstić, Indeks motiva narodnih pesama balkanskih slovena, Beograd I 984, 8-I 8 (A 5.I-5.7), Ivanička Georgieva, Bălgarska narodna mitologija, Sofija I 983 (2 I 993) I 33 ff., Dejan Ajdačić, "O vilama u narodnim baladama«, Studia mythologica Slavica 4 (200 I) 207-224, Benovska-Săbkova, "Za rusalkite v bălgarskija folklor «, op. cit., Hahn, Albanesische Studien, op. cit., I62, George Frederick Abbott, Macedonian Folklore, Cambridge 1903, 242-249, Popinceanu, Religion, Glaube und Aberglaube in der rumänischen Sprache, op. cit., $46 \mathrm{ff}$., V. Angelov, "Samovilite v bălgarskata narodna poezija«, Izvestija na Seminara po Slavjanska filologija 3 ( I9 I I) I 5 ff., B. Angelov, „Bălgarskata narodna balada (Baladi za samovili - samodivi)«, Izvestija na narodnija Etnografski muzej I 2 (1936) I-29, Slobodan Zečević, Mitska bića sprskib predanja, Beograd I98 I, 39-49, Tihomir Đorđević, »Veštica i vila u našem narodnom veruvanju i predanju«, Srpski etnografski zbornik 66 
feenhafte Schönheit verbirgt die ursprüngliche Drachengestalt ${ }^{526}$. Als sublimiertes und ästhetisiertes kosmogonisches Ungeheuer und weiblicher Dämon ist sie auch Gegenstand von Spekulationen um Matriarchatsreste (umgeformt im patriarchalischen Heldenlied), ein thrakisch/protobulgarisches bzw. urslavisches Substrat usw. geworden ${ }^{527}$. Häufig anzutreffen ist ihre spezifische Beziehung zum Wasser (Aufenthalt, Absperren) ${ }^{528}$ und zur Dialektik von Leben und Tod ${ }^{529}$. Als Paradebeispiel einer kaum eingrenzbaren Erscheinungsvielfalt in verschiedenen Textkategorien und Glaubensvorstellungen ist die balkanische Feengestalt mit praktisch allen ethnologischen Theorien in Zusammenhang gebracht worden $^{530}$. Die häufige literarische Ausgestaltung dieses gefahrenvollen fascinosums hat die Analysierbarkeit dieser Glaubensvorstellung noch weiter kompliziert ${ }^{531}$.

(1953) 58-ı I 9, Najden Gerov, Rečnik na bălgarskija ezik, Bd. 5, Plovdiv I 904 (Sofija I 978 ) I I 2-I I 5 , Dimităr Marinov, Narodna vjara i religiozni narodni običai, Sofija I 9 I 4 ( ${ }^{2}$ I 994$)$ 292-298, Hr. Vakarelski, Etnografija na Bălgarija, Sofija I 974, I I 2, N. I. Kolev, »Narodni predstavi i vjarvanija za vichruškata«, V. Chadžinikolov (ed.), Văprosi na etnografijata i folkloristikata, Sofija 1 980, 77-86 usw. 526 Zora D. Zimmerman, $»$ The Changing Roles of the >Vila< in Serbian Traditional Literature«, Journal of the Folklore Institute I6 (1979) I67-I 75, Leopold Geitler, „Die Juda in den Mythen der Balkanvölker«, Mitteilungen der Anthropologischen Gesellschaft in Wien 10 (I88 I) 199-202. In sublimierten Versionen des Drachenkampfthemas wird ihr das Flügelkleid weggenommen und sie bietet dem Helden die Wahlbruderschaft an. Im westbulgarischen Raum wird das Lied auch als Weihnachtsoder Oster-Ansingelied gesungen. Die vila in Drachenfunktion stellt eine Stufe der Entmythologisierung des Ungeheuers dar. In manchen Versionen erscheint sie auch als verräterische Schankwirtin (krimarica), - eine weitere Stufe der Anthropomorphisierung (Burkhart, Untersuchungen, op. cit., 378-409). Vgl. auch Puchner, Die Folklore Südosteuropas, op. cit., 29-3 I.

527 Josif Moroz, Ženski demonični obrazi v bălgarskija folklor i vjarvanija, Sofija 1989, 22-105, Jordan Ivanov, Bălgarski narodni pesni, Sofija I953, I 5 I , B. Angelov, Samodivite v bălgarskite narodni pesni, Sofija I 9 I I , E. Teodorov, Trakijsko nasledstvo v bălgarskija folklor, Sofija I972, I 8, G. Mihajlov, "Trakijski i drugi drevni elementi v geroičeskija epos«, Vekove 5 ( I 976) 27-3 I, usw.

528 Bea Lundt, "Wassergeister«, Enzyklopädie des Märchens 14 (20 I I) 5 I 9-526, R. Goossens, "Les fem-

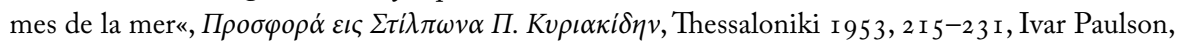
„Die Wassergeister als Schutzwesen der Fische im Volksglauben der finnisch-ugrischen Völker«, Acta Ethnographica Academiae Scientiarum Hungaricae I 5 (I 966) I 8 I-I 94.

529 Manchmal tritt sie auch zoomorph auf als Hindin (J. Moroz, „Elenat v bălgarskija folklor i vjarvanija«, Bălgarski Folklor 3, I98 I) oder als Stute (vgl. die klocalica-Maske in Serbien).

530 Amazonismus und Matriarchat, Schamanismus und dionysische Kultreste. Vgl. Ivanička Georgieva, Bălgarska narodna mitologija, Sofija I983, P. Ljubenov, Samovili i samodivi, Sofija I891, G. Iljinskij, "Juda«, Sbornik v čest na L. Miletič, Sofija I 933, 473, K. Šapkarev, Rusalii, Plovdiv I 884, Hr. Vakarelski, Etnografija na Bălgarija, Sofija I 974, 508, usw. Zur Erscheinung im Heldenlied Burkhart, Untersuchungen, op. cit., I 2 ff. (juda), I 06 ff. (wassersperrender Dämon), I 23 ff. (čuma), I 26 ff., I 32 ff. (veštica), I4 I ff. (orisnica) usw. Vgl. auch Puchner, Die Folklore Südosteuropas, op. cit., 29.

53 I Katharine Briggs, The Fairies in Tradition and Literature, London 1967. 
Damit ist auch Dialektik und Ambivalenz des Dämonischen in seinem ethischen und ästhetischen So-Sein angesprochen: Dämonen sind nicht nur monströse Ungeheuer, deren schlimmes Treiben Tod und Krankheit, Leid und Übel verursachen. Positives und Negatives kann sich auch die Waage halten, freilich in jedem Augenblick reversierbar, ebenso wie nicht alle dieser Phantasiewesen häßlich oder monströs sind, sondern auch reizvoll und lieblich sein können. Doch der Schein trügt: wie Rilke dies in den »Duineser Elegien« so unvergleichlich festgehalten hat - die Kehrseite des Schönen ist das Schreckliche.

\subsection{Totenseelen und Jenseitsglaube oder die Implikationen der invisiblen Präsenz}

Ein Großteil dieser Phantasiegestalten der kollektiven Imagination in den Oralkulturen Südosteuropas scheint, ähnlich wie Teile der Verkleidungs- und Maskenformen, auf die Vorstellung der Anwesenheit der Totenseelen aus dem Jenseits oder der Unterwelt in gewissen Perioden des Jahreskreises zurückzugehen. Bei der Festlegung dieser Perioden, die in der Vorzeit die Sonnenwenden betraf, haben in den Ackerbaukulturen die kritischen Phasen der Aussaat, der Vegetationsbelebung im Frühjahr und der sommerlichen Ernte eine Rolle gespielt, welche später dann vom hellenistisch-römischen Festkalender aufgesogen wurden, um dann in den Akkommodationsstrategien der christlichen Frühkirche in ein neues heortologion übergeführt zu werden. Diese Anwesenheitsphasen der Totenseelen auf der Oberwelt betreffen den Zwölftenabschnitt ${ }^{532}$, das System der psychosabbata (Seelensamstage: in der Karnevalszeit, am ersten Samstag der quadragesima, Pfingstsamstag oder Rusaliensamstag) bzw. den Zeitabschnitt der fünfzig Tage zwischen Ostern und Pfingsten, wo nach der Legende Christus auf Bitten der Gottesmutter hin den Totenseelen eine Straferleichtung in Form von Höllenurlaub erteilt ${ }^{533}$. Nach Meulis grundlegender Theorie sind diese Seelenzeiten auch Dämonentage und Maskenzeiten, weil nach dieser Hypothese die Toten in der kollektiven Imagination der Oralkulturen die Gestalt von Dämonen annehmen und diese sich in Maskierungen und Verkleidungen materialisieren und daher auch beeinflußbar gemacht werden können ${ }^{534}$.

Dabei wird die Totenseele in ihrer materiellen Erscheinung keineswegs nur als monströser Dämon in Form von »Alten« dargestellt ${ }^{535}$ oder als gefährliche Wasserfeen und

532 Vgl. den ersten Teil.

533 Dazu Walter Puchner, Studien zur Volkskunde Südosteuropas und des mediterranen Raums, Wien/ Köln/Weimar 2009, 78-90.

534 Karl Meuli, »Bettelumzüge im Totenkultus, Opferritual und Volksbrauch«, Schweizer. Archiv für Volkskunde 28 ( I 928) I-38 und ders., „Maske, Maskereien«, Handwörterbuch des deutschen Aberglaubens $5($ I $932 / 33)$ I $744-1852$.

535 Niko Kuret, »Die >Alten in den Maskenumzügen Südosteuropas«, Etnografski folkloristični izsledvanija, FS Chr. Vakarelski, Sofija I 979, 2 I 5-225. 
Nixen wie die rusalki ${ }^{536}$, wie die Maskenformen und Feensagen nahelegen würden, sondern auch als etwas Zartes und Zerbrechliches wie ein Insekt oder ein kleiner Vogel. Die Totenvorstellung als eines Individuums mit leiblichen Bedürfnissen ist bei der persönliche Totenpflege und dem Grabbesuch evident ${ }^{537}$. Die Totenseele bedarf noch vieler Fürsorge, bis sie zur Ruhe kommt ${ }^{538}$. Dazu gehören die mnemosyna-Gedenkmessen am dritten, neunten, vierzigsten Tag, nach drei, sechs und neun Monaten, nach einem $\mathrm{Jahr}^{539}$, wo nach der Messe geweihte Kultbrote und kollyba an alle (auch zufällig) Anwe-

536 Wilhelm Tomaschek, »Über Brumalia und Rusalia«, Sitzungsber. der phil.-hist. Classe der Kayserlichen Akad.d. Wiss. 6o (Wien I 869) 35 I-404, Franz Miklosich, „Die Rusalien. Ein Beitrag zur slavischen Mythologie«, ibid. 46 (Wien I 864) 386-405, Paul Perdrizet, »Les rosalies«, Bullétin de Correspondance Hellénique XXIV (1 900) 299 ff, K. Šapkarev, Russalii, dreven i tvărde interesen bălgarskij običaj, zapazen i do dones v južna Makedonija, Plovdiv I884, 7-20, Mihail Arnaudov, »Kukeri i Rusalii«, Sbornik za Narodni Umotverenija i Narodopis XXXIV (Sofija 1924) I-242, bes. I 38 ff., F. Tailliez, »Rusaliile, les Rosalies et la Rose«, Cahier Sextil Puşcariu I/2 (Roma I 952) 30 I-3 I 7.

537 Am Grab wird Wein oder Wasser ausgegossen, ein Tongefäß zertrümmert, manchmal wird auch eine Puppe mit ins Grab gelegt (zur Vorstellung der Puppen als Totenseele vgl. auch die kukla-ähnlichen Frauengrabkreuze; sie werden auch kukli genannt; Christo Vakarelski, Bulgarische Volkskunde, Berlin 1969, 308; zu kukla-förmigen Gebildbroten in Bulgarien auch I. Željaskov, »Obrednite chljabove ot Elchovsko«, Folklor $i$ istorija, Sofija I 982, 259-262), Funeraltänze werden abgehalten, Kranke werden am Grab geheilt, auf das Grab wird geweihtes oder gestempeltes Kultbrot (prosforo) oder kollyba/koljiva geworfen, auf und am Grab werden Kultbrote (nekropsoma) und kollyba verteilt, oder auch der Totenschmaus gehalten ( $\sigma v \chi \omega \dot{\omega} ı$, $\mu \alpha \kappa \alpha \rho \dot{\alpha})$, der sonst im Hause des Verstorbenen

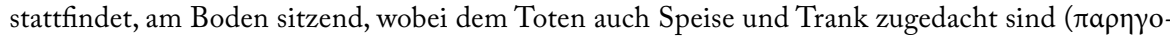
plá, die $\pi \varepsilon \rho i \delta \varepsilon ı v v a$ der Antike; G. Ch. Papacharalampous, »Perideipna in Cyprus«, Neo-Hellenika I, I 970, 55-67, Vakarelski, Bulgarische Volkskunde, op. cit., 308). Die Einzelnachweise in Puchner, Studien zur Volkskunde Südosteuropas, op. cit., 73-78.

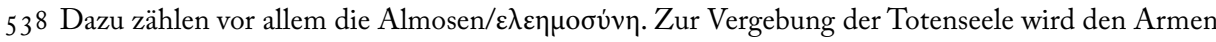

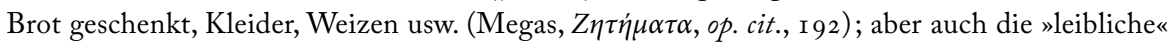
Fürsorge für die Totenseele während der Trauerzeit: In Thrakien wird in der Totenkammer noch drei Tage lang Wasser, Brot und Totenkerze aufgestellt; in Ätolien schüttet man noch drei Tage lang Wasser auf das Grab, damit der Tote nicht dürstet; in Sfakia auf Kreta richtet die Frau oder Mutter des Verstorbenen noch 40 Tage lang sein Essen her und zündet eine Kerze an (zur Weih-

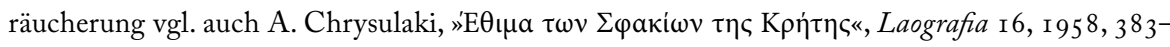
404, bes. 402 f.); in Sinope im Pontusgebiet trägt man am nächsten Tag Früchte auf den Friedhof und verteilt sie an die Armen; auf Naxos kehrt man drei Tage das Haus nicht, um der Totensseele

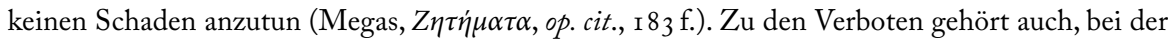
Totenwache, dem Begräbnis und den Gedenkmessen nicht zu niesen, weil man dann selbst oder ein Familienangehöriger des Niesenden bald sterben wird (dazu P. Leventis, »To $\varphi \tau \dot{\alpha} \rho v ı \sigma \mu \alpha «, ~ K v \pi \rho \iota \alpha \kappa \alpha ́ \alpha$

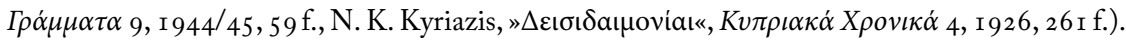

539 Diese Gedenkmessen werden oft gleich nach dem Datum benannt, ähnlich wie die trita, enata und triakostia des Altertums, als trita/tretini, niata/devetini, saranta (Vakarelski, Bulgarische Volkskunde,

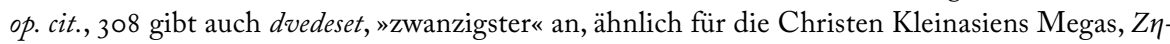


sende verteilt werden. Es folgt der Besuch am Grab, wo man dem Toten »Gesellschaft« leistet, ihn segnet, ihm Speise und Trank darbringt, seiner gedenkt ${ }^{540}$. Auch an hohen

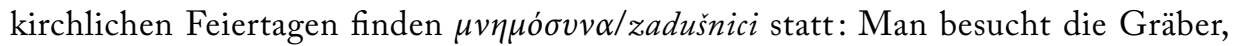
spricht Gebete, bringt Speise- und Trankopfer, verteilt kollyba, zündet Kerzen an, legt Blumen aufs Grab ${ }^{541}$. Diese stellvertretende Fürsorge endet erst mit der Exhumierung der Gebeine; die Schädel werden dann im osteophylakion/kostnica des Friedhofs aufbewahrt; damit ist das Grab als Kommunikationsort mit dem Jenseitsaufenthalt des Verstorbenen aufgelöst: der Tote ist in einer Weise »heimgekehrt«, in einer anderen auf ewig »hinweggegangen « ${ }^{542}$. Das »Gespräch « am Grab (verbal, rituell, emotionell) ist verstummt; das $\mu \nu \eta \mu \varepsilon$ íov ist wieder eine bedeutungslose Grube.

Jenseits dieser persönlich-familiären Grabbesuchstermine gibt es aber auch »Allerseelen«, an denen die Totenseelen auf der Oberwelt anwesend gedacht werden und das gesamte Dorf zum ovxẃpıo (zur Lossprechung, Vergebung) der Seelen auf den Friedhof zieht und an den Gräbern ißt und trinkt wie beim Totenmahl. Solche Gräbergelage (manchmal auch nur mehr symbolisch durchgeführt) finden bevorzugt am Rusaliensamstag zu Pfingsten statt und am Samstag der hl. Theodore in der ersten Fastenwoche, wo in der Kirche das Andenken an das kollyba-Wunder ${ }^{543}$ gefeiert wird.

Der Sabbath gilt im balkanischen Volksglauben als Tag der Magie und der Kontakte mit dem Überirdischen ${ }^{544}$. Als Seelensamstage, an denen Seelenmessen für alle Toten gelesen werden, gelten vier: der Samstag der »Fleischwoche« (

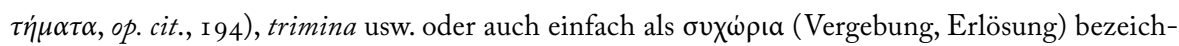
net. Diese Gedenkmessen sind in der Dogmatik der Orthodoxen Kirche verankert (Panagiotis

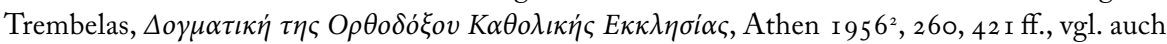

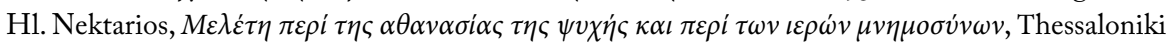
I $973^{2}$, I I 3 ff.).

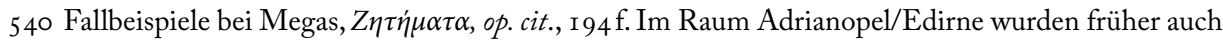
Tieropfer (kurban) am Grab vorgenommen (Vakarelski, op. cit., 308 f.).

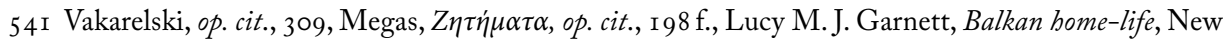
York I 9 1 7, I 25 ff. Dies geschieht im allgemeinen zu Weihnachten, Neujahr, am Karfreitag, zu Ostern, Christi Himmelfahrt und am Kreuzerhöhungstag ( 14 . Sept.) (auch am Tag von Mariä Himmelfahrt,

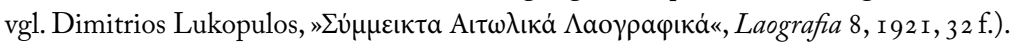

$542 \mathrm{Zu}$ dieser Ambivalenz vor allem Loring Danforth/A. Tsiaras, The death rituals in rural Greece, Princeton I 982 , i 77 ff.

543 Die kollyba-Körner werden auch in der Regenmagie oder zur Abwehr von Hagel verwendet. In Thrakien hob man die kollyba-Körner vom St. Theodorstag auf und warf sie bei Hagelschlag aus

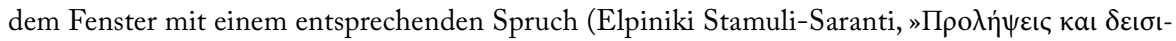

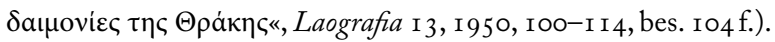

544 Dies gilt z.B. auch für magische Handlungen wie Bindezauber und dergleichen. Zu solchen

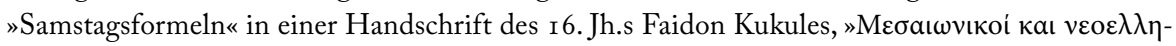

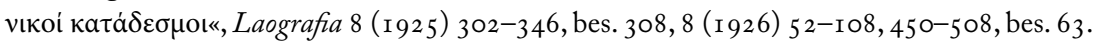




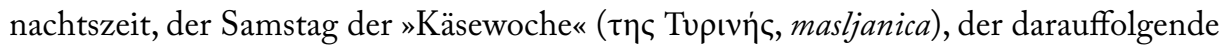

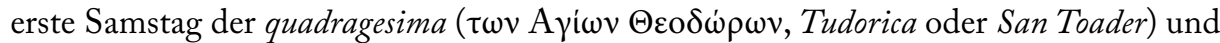
der balkanweit so genannte Rusaliensamstag vor Pfingsten/pentekoste ${ }^{545}$. Die ersten beiden psychosabbata fallen in die Allerseelenzeit der Fastnacht, der Festtag der heiligen Theodore gilt als Totentag, da an diesem Tag das kollyba-Wunder des hl. Theodor Teron gefeiert wird, der Samstag der Rusalien-Woche endlich ist der Tag, an dem die Seelen nach ihrem fünfzigtägigen Aufenthalt auf der Oberwelt - Christus befreit sie bei der österlichen Überwindung der Höllenpforten und die Panagia erwirkt ihnen in ihrer Rolle als mediatrix gratiarum Straferleichterung und Hadesurlaub ${ }^{546}$, ein Legendenmotiv, das auf den apokryphen »Gang Mariae zu den Höllenqualen « zurückgeht ${ }^{547}$ - wieder in die Hadeshölle zurück müssen ${ }^{548}$.

Das Handlungssystem der psychosabbata unterscheidet sich nicht wesentlich von den familiengebundenen mnemosyna, ist bloß etwas komplexer und die Beteiligung universeller ${ }^{549}$.

545 Daneben gibt es freilich noch andere Termine, wo Grabbesuch und Umzüge unter dem Namen rusalia stattfinden (Puchner, Brauchtumserscheinungen, op. cit., I77).

$546 \mathrm{Zu}$ solchen Orallegenden Puchner, Studien zum Kulturkontext der liturgischen Szene, op. cit., I 86I 88, Anm. 5 I 8-520, zur Straferleichterung »ot văzkresenje do pentikost« ibid. IO2 f. Vgl. auch V. Stojčevska-Antić, »Od eschatologiškite apokrifi za Bogorodica i nivniot odsiv vo narodnoto tvorčestvo na Južnoslovenskite narodi«, Makedonski Folklor 2 ( ( 969) 207-2 I 8 und Dimitrios

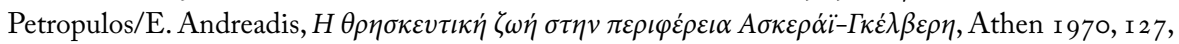
wo auch der Seelen-Termin der Zwölften auf dieselbe Weise erklärt wird.

$547 \mathrm{Zu}$ dieser apokryphen Legende in Südosteuropa vgl. Leopold Kretzenbacher, Südost-Überlieferungen zum apokryphen »Traum Mariens«, München 1975, I I 9 ff., Felix Karlinger, Einführung in die romanische Volksliteratur, München 1969, 32, ders., Der Gang Mariens zu den Qualen. Ein rumänisches Volksbuch des I 6. Jh.s, Salzburg I 976, L. Müller, „Die Offenbarung der Gottesmutter über die

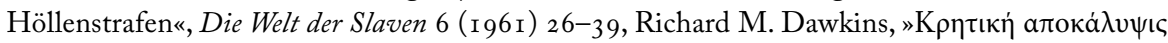

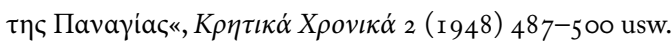

548 Die üblichste Version zu dieser Überlieferung ist, daß die Straferleichterungsperiode mit dem Gründonnerstagstermin einsetzt und bis zum Pfingstsamstag dauert (dazu noch im Folgenden), manchmal aber auch schon am Faschingssamstag (»Fleischsamstag«) beginnt und so beide Seelenzeiten verbindet. Bei den Russen zählt auch deshalb der Gründonnerstag zu den Totentagen (und nicht nur, weil er einen einstigen Neujahrstermin bezeichnet, siehe Dmitrij Zelenin, Russische Volkskunde, Berlin 1927, 364), dasselbe bei den Ukrainern (Bohdan G. Mykytiuk, Die ukrainischen Andreasbräuche und verwandtes Brauchtum, Wiesbaden I979, гог).

549 Bei den Seelensamstagen der Karnevalsperiode kontaminieren die Inhalte auch mit den Fastnachtsaktivitäten bzw. sind auf die Sonntage und auch auf den »Reinen Montag« (Ka $\theta \alpha \rho \eta \dot{~} \Delta \varepsilon v$ $\tau \dot{\varepsilon} \rho a)$ verlagert. Anders am Theodors-Samstag: Im Zentrum der Brauchhandlung steht die kollybaSegnung und Brotweihe für die Verstorbenen in der Kirche, der »Erhöhungs«-Ritus (v่ $\psi \omega \mu \alpha)$ der beiden Heiligen, die Almosen-Umzüge, Grabbesuch- und Speisenverteilung, auch Gedenkmessen für die eines »unrechten« Todes Gestorbenen. Es besteht strenges Arbeitsverbot, teilweise auch Waschverbot (Details in Puchner, Studien zur Volkskunde Südosteuropas, op. cit., 78-90). 
Am balkanweit so genannten Rusaliensamstag ${ }^{550}$ werden an den Gräbern Kerzen entzündet, Seelengebete (trishagia) gesprochen, Wein wird ausgegossen, kollyba und Speisen verteilt ${ }^{51}$.

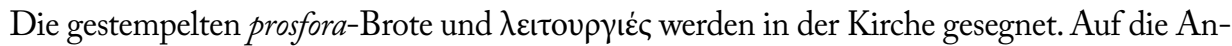
wesenheit der Seelen, die von ihren Verwandten Abschied nehmen vor ihrer Rückkehr in die Unterwelt, bezieht sich eine ganze Reihe von Verboten: neben dem allgemeinen Arbeitsverbot ein spezifisches Waschverbot (mit Seife), Nähverbot (um den Totenseelen nicht die Augen auszustechen), untersagt ist auch das Schneiden von Weinreben und Zweigen (die Seelen sitzen darauf), das Kämmen, Spinnen, Weben usw. ${ }^{552}$ Der Pfingstsonntag, H1.-Geist-

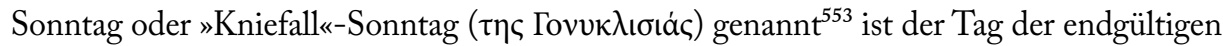

550 F. K. Litsas, »Rousalia: The Ritual Worship of the Dead «, A. Bharati (ed.), The Realm of the ExtraHuman, The Hague/Paris I 975, 447-465, bes. 453), Mihail Arnaudov, "Kukeri i rusalii«, op. cit., 207 f. usw. Rusalien-Woche wird auch die gesamte Vorpfingstwoche genannt (Vakarelski, op. cit., 326 f.), rusalii in Rumänien (Gail Kligman, Căluş. Symbolic Transformation in Rumanian Ritual, Chicago/London I98 I, pass.), sămbati di Rsalja für die Aromunen, ršaë für die Albaner (Laografia 4, I 9 I 4, 749), ruzičalo oder rusalna nadelja in den einstigen jugoslavischen Ländern.

55 I Bei »Vlachen« und Aromunen im r 9. Jh.: »Zu Pfingsten tauschen die Frauen auf den Gräbern Kuchen untereinander aus. Man glaubt, daß an diesem Tag alle Toten satt werden. In Monastir [Bitola] gehen die Frauen zu Pfingsten mit Bratfischen, Sauermilch, Brot, Kuchen, Käse, Milchreis, Wein u. a. beladen auf den Friedhof, wo sie viel weinen, essen und trinken. In der Woche vor Anfang der Osterfastenzeit werden auf dem Friedhof Kuchen und Brathühner verteilt. Gefragt, warum diese wahre Verschwendung mit Speisen, antworten die Südrumänen, daß die verteilten Speisen eigentlich den Toten zugute kommen" (Victor Lazar, Die Südrumänen der Türkei und der angrenzenden Länder, Bukarest I9 IO, I 7 I). In Vonitsa werden die »Seelenbrote« in Wein getaucht, von einem Kinderumzug in die Häuser getragen, wobei sie den Vergebungswunsch für die Toten sprechen (Laografia I 2, I 938-48, 599). Im Raum Verbiani besucht man auch die Verwandten des

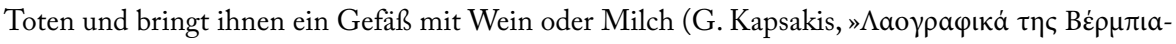
vๆ५«, Laografia 4, I9I 4, 403-4I 3, bes. 407).

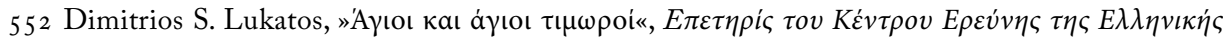
$\Lambda \alpha o \gamma \rho \alpha \varphi i \alpha \varsigma_{20 / 2}$ I (1967/68) 55-105. Aus all dem geht hervor, daß die Seele nach diesen Vorstellungen etwas Kleines, Zartes und Zerbrechliches sein muß. In der Südwestpeloponnes soll man an diesem Tag das Wasser meiden, keine großen Feuer entzünden, nicht pflügen und ackern, nicht spinnen (Litsas, op. cit., 455 f.); alte Leute müssen wachen, denn während sie schlafen, könnten die Toten auch ihre Seele gleich mitnehmen (zum Schlafverbot auch Leopold Kretzenbacher, Ethnologia Europaea. Studienwanderungen und Erlebnisse auf volkskundlicher Feldforschung im Alleingang, München I 986, 99). Zu den »körperlichen« Seelenvorstellungen vgl. auch Richard M. Dawkins, "Soul and body in the Folklor of Modern Greece«, Folk-Lore 53 (I942) I 3 I-I 47.

553 Reminiszenzen an die ganze Rusalien-Woche (rusalska sedmica, Vakarelski, op. cit., 324 f.) bestehen auch in der Südwestpeloponnes: »Also from the mountainous Triphylia comes information that years before, the celebration of Rousalia Day was a great fair, eight or ten days long, and was performed with songs, dance and amusement. People dressed in their best attire, would roast meat, every family would kill a special lamb called the Rousalites ...«(Litsas, op. cit., 455 Anm. I4). 
Trennung von den Seelen. In den Kirchen kniet man auf Nußblättern, unbeweglich mit gesenktem Blick, denn in diesem Augenblick ziehen die Seelen vorüber ${ }^{54}$ und müssen über die "Haarbrücke« ins Jenseits ${ }^{555}$. Nach der Messe geht man an die Gräber und verteilt kollyba und Speisen. Ähnliches geschieht auch am Dreifaltigkeits-Tag (Hagia Triada), dem Pfingstmontag $^{556}$.

Die Gleichung: Anwesenheit der Totenseelen=Dämonenzeit=Maskenumgänge geht allerdings in Bezug auf Festtermine, imaginäre Dämonenmorphologie und Maskenformen nicht ganz auf, sondern ist eine wissenschaftliche Erklärungskonstruktion, die der Wirklichkeit nur unter Abstrichen entspricht und im »Feld« auch gar nicht abfragbar ist; doch gilt eine solche Unschärferelation für einen großen Teil der Manifestationen einer Oralkultur. Dies ist freilich auch ein Ergebnis kultureller Überformung durch die Geschichte und dem individuellen und lokalen Ermessensspielraum, der allen assoziationslogischen Vernetzungen durch Analogie und Entsprechungen anhaftet.

\subsection{ZAUBER UND GEGENZAUBER ODER DIE MODALITÄTEN DES} ANIMISMUS

Will man nun eine Art Zwischenbilanz ziehen über die Möglichkeiten der Beeinflußbarkeit von Gegebenheiten, die die magischen Praktiken und Vorstellungen im Rahmen des animistischen Weltbildes anbieten, so sieht man sich mit der Schwierigkeit konfrontiert, ein assoziatives Beziehungsgebilde auf die Denkmuster einer pseudorationalen Kausalität bringen zu müssen, was dem Denken in Analogien und Entsprechungen in seiner Seinsweise eigentlich fremd ist; die strenge Ursache/Wirkung-Klammer einer

554 Vgl. Laografia 4 (г 9 14) 749, ibid. 5 (I916) 652, ibid.6 (I9r8) 465 f. Die Seelen wollen nicht zurückkehren, werden von den Engeln aber zusammengetrieben; der gesenkte Blick deshalb, damit sie nicht gesehen werden.

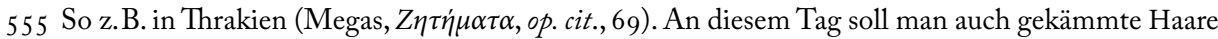
in die Luft streuen, damit die Toten (über die »Haarbrücke«) besser ins Jenseits zurückgelangen (Litsas, op. cit., 454 ff.). Wenn man sich bewegt, erschrecken die Seelen und fallen von der Haarbrücke. Zur Vorstellung der Haarbrücke Peter Dinzelbacher, Die Jenseitsbrücke im Mittelalter, Wien I 973. Die Nußblätter haben verschiedene Verwendung (z.B. gegen Ungeziefer in Schränken); man

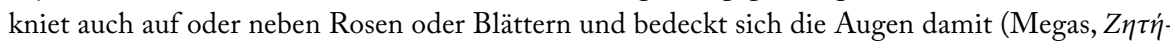
$\mu \alpha \tau \alpha$, op. cit., 69, Litsas, op. cit., 456). Ein Stein im Rücken soll gegen Kreuzschmerzen helfen; man nimmt auch Erde mit in die Kirche, damit die Obstbäume besser wachsen usw. Die Ikonen werden mit Blumen geschmückt, man bringt Milchkuchen mit in die Kirche.

556 An den Gräbern wird Milchreise und Sauermilch angeboten, der Priester psalmodiert das trishagion an den Gräbern und verteilt Nußblätter und Blüten in der Kirche; es herrscht Schlafverbot, man darf sich nicht im Meer waschen, nicht auf die Bäume klettern (Xenofontas Akoglu, $\Lambda \alpha o \gamma \rho \alpha-$ $\varphi \iota \kappa \dot{~} K \omega \tau v \omega \dot{\omega} \rho \omega v$, Athen I939, 266). 
Kausalbeziehung kann die lockere und »kreative« Verbindung von gleich oder ähnlich Scheinendem auf verschiedenen Wirklichkeitsebenen nur ungenügend wiedergeben, da das magische Analogiehandeln und die Vorstellung der Existenz universaler Entsprechungen, die man im Zauberhandeln für sich fruchtbar machen kann, auf imaginativen Vorgaben der Phantasie beruhen und jederzeit auch den Fall des Versagens der Methode miteinschließen. Im magischen Denken ist der Grad der zu erwartenden Effektivität nicht im gleichen Maße gesichert wie bei Kausalmodellen, die sich auf harte Fakten und nachgewiesene Beziehungen stützen.

Der Seinsweise der »schwankenden Gestalten« der Dämonologie und der keineswegs gewissen, sondern bloß possiblen Wirkungserwartung magischer Strategien könnte man aus der Sicht positivistischen Systemdenkens und faktischen Handelns einen gewissen Hypothese-Charakter zusprechen, unter Abstrich freilich der rationalen Argumentationsführungen, die die verantwortliche Hypothesenbildung voraussetzt. Dem Verwobensein der Dinge in ihren Symbolbeziehungen entspricht das integrale Schaffenspotential des Kunstwollens in der Ästhetik eher als szientifische Abhängigkeitsgeflechte, die auf Beweisbarkeit und Ergebnissicherung hin angelegt sind.

Einen besseren Verständniszugang mag etwa die Kinderpsychologie abgeben, wo die Symbolbedeutungen der Dinge noch nicht eindeutig festgelegt sind durch die Alltagswirklichkeit der Erwachsenen und jeder Gegenstand ein vielbedeutendes Zeichen darstellt, dessen Sinn nicht thetisch vorgegeben sondern kreativ formbar ist. Im Konzept des künstlerischen Zeichens, wo die Konnotationen über die Denotationen überwiegen ${ }^{57}$ und die semiosis (der Vorgang, wie die Zeichen ihre Bedeutung erhalten) ein keineswegs irreversibler, sondern offener und revisierbarer Vorgang ist, der in seiner Polysemie durch den Interpretationsvorgang zu keinem definitiven Ende kommen muß, ist ein Begriffsinstrument geschaffen, das dem magischen Analogie-Denken und den Kreationsweisen der Phantasie-Gebilde der Dämonologie näher kommen mag als der wissenschaftliche Diskurs. Dieser poetisch-ästhetische Aspekt der Kreativität in den Glaubensvorstellungen der Oralkulturen ist von der Ethnologie nur selten angesprochen worden ${ }^{55}$, was seine Ursachen bei der Ethnologia europaea in der wertenden Begrifflichkeit rational-aufgeklärter Bürgerlichkeit haben mag, bei der außereuropäischen Ethnologie und Sozialanthropologie in den abstrakten Konstruktionen der strukturalfunktionalen Schule, die als wissenschaftlicher Administrationszweig des Imperialismus völlig fremden und scheinbar "geschichtslosen« Kulturen gegenüberstand.

Die Entzauberung der Magie durch die Wissenschaft hat ihre Abwertung zur Folge; als »Aberglaube« figuriert sie im weiten Bereich der parareligiösen Manifestationen,

557 Erika Fischer-Lichte, Semiotik des Theaters, 3 Bde., Tübingen I $983 / 84$.

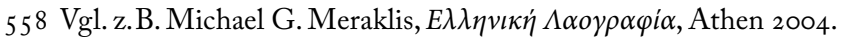


von Kirche und Aufklärung gleichermaßen als Teufelswerk, rückständiges Hinterwäldlertum und naive Simplizität der Ungebildeten gebrandmarkt. Dieses tiefere Unverständnis für eine historische Denkweise, nach deren Leitprinzipien sich die menschliche Kultur viele Tausende von Jahren ausgerichtet und organisiert hat, ist manchen der wissenschaftlichen Datenerfassungen und Erklärungsmodellen immer noch inhärent, eine Denkweise, die erst in irrationalen Strömungen des 20. Jh.s, aber auch durch Romantik und Psychoanalyse eine neue Aufwertung erfahren haben. Magie läßt sich nur teilweise in ein System bringen, ihre Verweisformen sind nicht »logisch«, ähnlich wie Erklärungsmodelle von Kindern oder Interpretationsmöglichkeiten von Kunstwerken.

Dem Zauber kann man an sich nur durch Gegenzauber begegnen; dies ist trotz aller Anleitungen ein kreativer Vorgang, der Verständnis der Mittel und der intendierten Ziele erfordert sowie Glaube an die Effektivität des Praktizierten. Oder man kann sich verzaubern lassen. Ein solcher Gedanken-Gang durch das Reich der Magie und der Imaginationen ohne vorgegebenes Methoden-Paradigma ist vielleicht einer der angezeigtesten Wege durch die Labyrinthe der Analogien, aus deren Netzwerken wir selbst nicht auszuschließen sind. Die in der new anthropology zu beobachtende Inklusion der Subjektivität der untersuchenden Instanz (der Feldforscher als Teil des zu untersuchenden Feldes) ist auch im Weltbild des Animismus gegeben: Von den qualitativen Tiefeninterviews der Soziologie bis zum kreativen Umgang mit Symbolen und ihren Verflechtungen in Ästhetik, Psychoanalyse und Religionswissenschaft ist das Subjekt mit seinen geistigen, psychischen und gesamtkörperlichen Voraussetzungen unabdingbarer Bestandteil der Beobachtung und des Verständnisses. Und dies gilt in besonderem Maße auch für Südosteuropa, wo die zeitliche, historische und mentalitätsmäßige Verschichtung in der Gleichzeitigkeit des Ungleichzeitigen zusammen mit dem hybriden Synkretismus von Sprachen, Religionen und Kulturschichten ein Erkenntnisfeld darstellen, das besonders hohe und spezifische Ansprüche stellt.

\subsection{DER BÖSE BLICK ODER DIE DOMINANZ DER DURCHSCHNIT TLICHKEIT}

Das non plus ultra magischer und imaginativer Vorstellungen stellt die nonverbale Kommunikation dar, mit der dieser Band begonnen hat: Doch geht es nun nicht um bloße Verständigung (eben durch Gesten), sondern um massive Einflußnahme mit unabsehbaren negativen Folgen: Verzauberung; bloß durch den Blickkontakt, ja sogar durch das einseitige Ansehen. Über die Kraft des Blicks ist viel geschrieben und spekuliert worden $^{559}$ und die Ausdrucksmöglichkeiten des Auges und ihre Bedeutungszuweisun-

559 Otto Koenig, Urmotiv Auge. Neuentdeckte Grundzüge menschlichen Verhaltens, München 1975. 
gen entziehen sich letztlich einer wissenschaftlichen Kodifizierung ${ }^{560}$. Die psychische Grundlage für die Glaubensvorstellung vom Bösen Blick als der am weitesten verbreiteten Form des Schadenszaubers dürfte das Neidgefühl darstellen, mit dem alles Bemerkenswerte, Außerordentliche, Schöne, Bewunderswerte bewußt oder unbewußt bedacht wird; oder anders gesagt: die Dominanz der Durchschnittlichkeit in der Alltagswirklichkeit. Daneben gibt es freilich noch andere Motivationen wie Haß, Rachegefühle, Feindschaft und dergleichen mehr. Das Auge ist Teil der Physiognomik, deren Charakteristika traditionellenweise Gegenstand von semantischen Interpretationen bezüglich von Charaktereigenschaften der Trägerperson gewesen sind; der Blick hingegen, vielfach das lange und intensive Anblicken, ist eine energetische Aktion, die negative Kraftübertragung im Sinne des Prinzips der transplantatio morborum ${ }^{561}$ impliziert $^{562}$. Die Träger des Bösen Blicks werden machmal als "gezeichnet « apostrophiert, was sich allerdings charakteristischerweise auf sehr viele und sehr verschiedene Körpermerkmale und Blickformen beziehen $\mathrm{kann}^{563}$. Die praktisch globale Verbreitung und die zahlreichen popularwissenschaftlichen und psychologisierenden Darstellungen haben zu einem ausufernden Schrifttum geführt, das teilweise sogar aus dem Internet herunterzuladen ist ${ }^{564}$.

560 Paul Ekman, Unmasking the Face, Englewood Cliffs, New York 1975, W. Schule, Audruckswahrnehmung des Gesichts. Experimentelle Untersuchungen, Frankfurt/M. 1976.

56r Vgl. wie im ersten Teil.

562 Das offene Auge und die Fähigkeit des Sehens als Voraussetzung des Bösen Blicks ist jedoch nicht immer gegeben: Auch Schlafende, Blinde, Glasäugige und Tote können diese Übertragung vornehmen; daher werden dem Verstorbenen die Lider geschlossen, die Braut trägt als Schutzvorhang den Schleier und dem Hinzurichtenden werden die Augen verbunden. Diese Prophylaxen scheinen darauf hinzudeuten, daß es nicht nur um die Sehkraft des Verursachers geht, sondern auch um den Anblick dieses Auges durch das Opfer und den Glauben an die Möglichkeit der Schadensübertragung, also eine Projektion einer psychischen Phobie aus Anlaß einer ungewöhnlichen Kommunikationssituation (Blickkontakt). Umgekehrt ist aber auch der Fall häufig, daß der Geschädigte von dem Blickzauber keine Ahnung hat und erst an den Symptomen merkt, daß er durch einen Bösen Blick verzaubert ist. Auch hier erweist sich wiederum die Relativität jeglicher Kategorienbildungen im Bereich der Magie, die vielfach szientifische Kausalfiktionen bleiben und deren Verallgemeinerung sofort auf eine Reihe von Gegenbeispielen stößt.

563 In der einschlägigen Bibliographie sind somatische Dysplasie und Invalidität genannt, Hypertrichose bis zur Vollbehaarung, Magerkeit, schlaff-welke Haut, Kopfwackeln, struppige rote Haare, bärtige Frauen usw., Schielen, Augenzittern, ungewöhnliche Augenfarbe (bei beiden Augen verschieden), deformierte Pupillen, vorstehende oder tiefliegende, große oder kleine Augen, zusammengewachsene Augenbrauen usw.

564 Siegfried Seligmann, Der böse Blick und Verwandtes. Ein Beitrag zur Geschichte des Aberglaubens aller Zeiten und Völker, 2 Bde., Berlin I 9 1о (Nachdruck in einem Band Hildesheim etc. 1985), M. Djeribi, »Le Mauvais œil et la lait«, L'Homme Io5 ( I 988) 35-47, Amica Lykiardopoulos, »The Evil 
Der heute abfragbare Bestand dieser Glaubensvorstellung umfaßt den mediterranen Raum, Südosteuropa, den Vorderen und Mittleren Orient, die islamische Welt und Nordafrika sowie Ibero-Amerika durch die Kolonialisierung; der Verbreitungsraum dürfte in der Voraufklärung jedoch viel größer gewesen sein. Kulturkreisartige Thesen um Ursprung und Herkunftsregionen können hier umgangen werden, da es sich wahrscheinlich um eine prähistorische und polygenetische Vorstellung handelt, die bereits auf Keilschrifttexten der Sumerer und Babylonier um 3000 v. Chr. auch als Terminus zum erstenmal auftaucht. Das mediterrane malocchio, mal de ojo und mau-olhado, griech. mati oder matiasma (baskania), ist im Osten als nazar (türk., Indien, Pakistan), ayn alhasüd (arab.), áyin hā-rá (hebr.), char atchk (armen.), chashm zakhm (pers.), cheshim mora (afghan.) usw. bekannt, in Südosteuropa als uroklivjo oko (serb.), uroklivo oko (bulg.mak.), syri i keq oder syni keq (alb.), gonosz szem oder szemmelverés (ungar.), deochi (rumän.), nazar boncuğu oder nazar takımı (die »Blick-Perle« des blauen Auges) als Amulett für kem göz (türk.) usw.

Als faktisch global verbreitetes Standardelement menschlichen Verhaltens und Interpretationsmuster für nonverbale Interaktionen ist plausiblerweise eine polygenetische Entstehung anzunehmen, was auch die Verbreitung in Kulturen, die miteinander niemals in Kontakt gekommen sind, nahelegt. In Europa besteht eine lange Tradition der Beschäftigung mit dem Bösen Blick, angefangen mit einer ganzen Reihe von antiken Schriftstel$l^{\text {lern }}{ }^{55}$, die meist mit Plutarch die unheilvolle Wirkung des Blicks dem Neid und der Mißgunst zuschreiben ${ }^{566}$. Das Christentum hat diese Ansichten z.T. übernommen ${ }^{567}$. Schon

Eye: Towards an Exhaustive Study«, Folklore 92 ( 198 I) 22 I-230, Thomas Hauschild, Der böse Blick: Ideengeschichtliche und sozialpsychologische Untersuchungen, Hamburg I 979 ( ${ }^{2}$ I 982$)$, Alan Dundes (ed.), The Evil Eye: A Casebook, New York 198 I (Madison 1992), Edward S. Gifford, The Evil Eye: Studies in the Folklore of Vision, New York 1958, Pierre Bettez Gravel, The Malevolent Eye. An Essay on the Evil Eye, Fertility and the Concept of Mana, New York etc. 1995, Siegfried Seligmann, „Die Angst vor dem Blick", Zeitschrift für Augenheilkunde 3 I (1914) 34 I-347, 5 I 3-5 I 9, ders., Die Zauberkraft des Auges und das Berufen. Ein Kapitel aus der Geschichte des Aberglaubens, Den Haag 1980 (Hamburg 1922), Clarence Maloney (ed.), The Evil Eye, New York 1976, Christina Veïku, Kakó

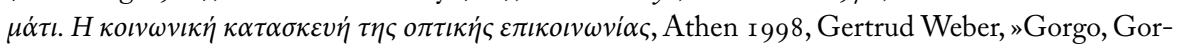
gonen «, Enzyklopädie des Märchens 5 ( 1987 ) I404-I409, usw.

${ }_{5} 65$ Zusammenstellung der einschlägigen Stellen bei Frederick Thomas Elworthy, The Evil Eye: The Classic Account of an Ancient Superstition, New York 2004 (London I 895).

566 Plutarch hat eine ganze Theorie aufgestellt, wie der Neid im Körper schädliche Ausdünstungen entwickelt, die dann aus den Augen treten (Mathew W. Dickie, »Heliodorus and Plutarch on the Evil Eye«, Classical Philology 86, I99 I, I 7-29).

${ }_{5} 67$ Im NT spricht Mark. 7,22 von blemma poniron, und apotropäische graffiti dürfte es bereits in frühchristlicher Zeit gegeben haben (Henri Grégoire, Recueil des incriptions grecques-chrétinnes d'Asie Mineur, Paris 1922, I Abb. 230, zitiert bei Thede Kahl, »Der Böse Blick. Ein gemeinsames Ele- 
die griechische Patristik setzt sich mit der Frage auseinander ${ }^{568}$ und byzantinische Traktate zur Magie, wie in den Schriften von Michael Psellos, gehen auf das imaginative Phänomen ein ${ }^{569}$, das von der protobyzantinischen Zeit bis zur Ära der Palaiologen mit seinen prophylaktischen Amuletten ${ }^{570}$ einen Bestandteil der Alltagspraxis dargestellt ${ }^{571}$ und seine Spuren sogar in der Ikonographie und Freskomalerei hinterlassen hat ${ }^{572}$. Trotz der Verbote von Magie und Orakelwesen (Cod. Theodos. 9.16,4-6) sah sich die Kirche gezwungen, im Rahmen ihrer Akkommodationsstrategien ${ }^{573}$ in der Pastoralpraxis Zugeständnisse zu machen; so gibt es im »Mikron Euchologion« der orthodoxen Kirche heute noch eine Segnung gegen die baskania (Verzauberung durch den Bösen Blick) ${ }^{574}$.

ment im Volksglauben von Christen und Muslimen«, Thomas Wünsch (ed.), Religion und Magie in Ostmitteleuropa. Spielräume theologischer Normierungsprozesse in Spätmittelalter und Früher Neuzeit, Münster 2006, 32 I-336, bes. 324). Zu apotropäischen Zaubergegenständen gegen den Bösen Blick auch James Russel, »Anemurium: the Changing Face of a Roman City", Archaeology 33/5 (r 980 ) $3 \mathrm{I}-4 \mathrm{O}$, ders., »The Archaeological Context of Magic in the Early Byzantine Period«, Henry Maguire (ed.), Byzantine Magic, Washington D. C. 1995, 35-50.

568 Matthew W. Dickie, »The Fathers of the Church and the Evil Eye«, Maguire (ed.), Byzantine Magic, op. cit., 9-34, Vasiliki Limberis, »The Eyes Infected by Evil: Basil of Caesarea's Homily«, The Harvard Theological Review 84/2 (I99I) I63-I 84.

569 So in der »Chronographia« von Psellos (го 8-ca. 1080): Salvatore Impellizzeri et al. (eds.), Michel Psello, Imperatori di Bizanzio, 2 Bde., Roma 1984 , VI 3, dazu John Duffy, »Reactions of Two Byzantine Intellectuals to the Theory and Practice of Magic: Michael Psellos und Michael Italikos«, Maguire (ed.), Byzantine Magic, op. cit., 50-97. Sogar der Fall von Konstantinopel 1453 ist schon dem Bösen Blick zugeschrieben worden (Louis Bréhier, »Constantine et la Fondation de Constantinople«, Revue Historique I I9, I 9 I 5, 248).

570 Tatiana Matantséva, »Les amulettes byzantines contre le mauvais œil du Cabinet des Médailles«, Jahrbuch für Antike und Christentum 37 (I 994) I IO-I 2 I, Sergio Giannobile, »Medaglioni magicodevozionali della Sicilia tardoantica", Jahrbuch für Antike und Christentum 45 (2002) I70-201.

57 I James Russel, »The Evil Eye in early Byzantine Society«,Jahrbuch der Österreichischen Byzantinistik 22/2 (1 972) 537-547, Richard P. H. Greenfield, "A Contribution to the Study of Palaeologan

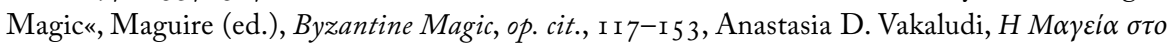

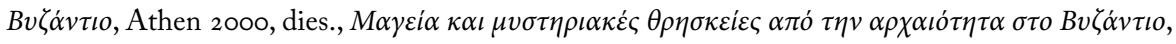

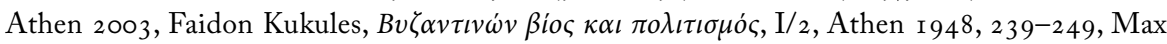
Marwick, Witchcraft and Sorcery, Harmondsworth I 970, I I-I3, P. K. Velissaropulos, »To $\varphi \omega \varsigma$ kaı o

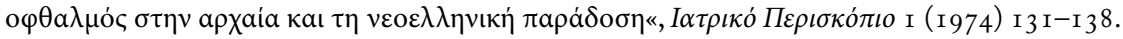

572 Z.B. Vassiliki Foskolou, »The Virgin, the Christ-child and the evil eye«, Maria Vassilaki (ed.), Images of the Mother of God. Perceptions of the Theotokos in Byzantium, Aldershot 2005, $25 \mathrm{I}-262$.

573 Walter Puchner, Akkommodationsfragen. Einzelbeispiele zum paganen Hintergrund von Elementen der frübkirchlichen und mittelalterlichen Sakraltradition und Volksfrömmigkeit, München 1997.

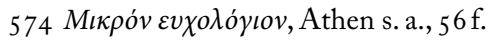


Dieselbe Vorstellung ist auch im AT und der rabbinischen Literatur anzutreffen ${ }^{575}$ sowie im Islam ${ }^{576}$, wo der blaue Augenstein und die abweisende Hand heute noch als Amulett angeboten werden ${ }^{577}$. Somit waren es in Südosteuropa sowohl die orthodoxe wie die islamische Tradition, die die Vorstellung bis in die unmittelbare Gegenwart getragen haben ${ }^{58}$, bestärkt noch durch Popen und Imame, die religiöse Abhilfe bereitstel1 len ${ }^{579}$; der Böse Blick war jedoch auch im Westen nicht unbekannt ${ }^{580}$.

Auch für Südosteuropa gibt es eine ganze Reihe von Spezialuntersuchungen, von allgemeinen lexikalischen, philosophischen, semiotischen, soziologischen oder sozialpsychologi-

575 Rivka Ulmer, The Evil Eye in the Bible and in Rabbinic Literature, Hoboken, New Jersey 1994.

576 Sure ro9-i I 4. Vgl. auch den Spruch Mohammeds über die Macht von Blick und Stimme (Frank Bliss, Islamischer Volksglaube der Gegenwart, Bonn 1 986, 36 ff.). Weiters Lidia Eissler, „Das böse Auge «, Zeitschrift der Deutschen Morgenländischen Gesellschaft I 2 ( I 889) 200 ff., Wallis Budge, Amulets and superstitions, London I930, James Robson, "Magic cures in popular Islam«, Moslem World 24 (1934) $33 \mathrm{ff}$.

577 Rudolf Kriss/Hubert Kriss-Heinrich, Volksglaube im Bereich des Islams, 2 Bde. I 960-62, II I-57, bes. I 5 ff. Die abweisende Hand (Hand der Fatima) sowie die mit gespreizten Fingern (griech. muntza) haben demnach die gleiche apotropäische Wirkung (op. cit., 5 , auch Seligmann, Der böse Blick, op. cit., II r 68), zuweilen verstärkt auch durch die Fluchformel fünf in dein Auge«. Dieses Handamulett ist auch auf Autos usw. zu finden (Abb. I eine Amuletthand aus Sarajevo); viele Geschichten über den Bösen Blick I 5 ff. Vgl. auch Bernhard Stern, Medizin, Aberglaube und Geschlechtsleben in der Türkei, 2 Bde., Berlin I 903, Josef Fr. v. Hammer-Purgstall, Talismane der Muslimen, Wien I 9 I 4 , Anton Hangi, Die Moslims in Bosnien und Herzegowina, Sarajevo I 907.

578 Klaus Roth, Osmanische Spuren in der Alltagskultur Südosteuropas«, Hans Georg Majer (ed.), Die Staaten Südosteuropas und die Osmanen, München I 989, 3 I 9-332, Thede Kahl, »Interethnische Beziehungen von orthodoxen Christen und Muslimen. Fragen und Methoden der Erforschung interreligiöser Koexistenz in Südosteuropa«, Astrid Hörsperger/Fritz Kirsch (eds.), Stadt und Ethnizität, Wien 2005, 67-102.

579 Kahl, Der Böse Blick«, op. cit., 333 ff.

580 In Auswahl: Bernhard D. Haage, Der »böse Blick«. Beobachtungen zu einem Motiv in der deutschen Literatur des Mittelalters, St. Ingbert 2002, 5 I-67, Karl Meisen, »Der böse Blick, das böse Wort und der Schadenzauber durch Berührung im Mittelalter und in der neueren Zeit«, Rheinisches Jabrbuch für Volkskunde 3 (1952) I69-225, Toivo Vuorela, Der böse Blick im Lichte der finnischen Überlieferung, Helsinki I 967 (FFC 20I) usw. 
schen Darstellungen ${ }^{581}$, vergleichenden Übersichten ${ }^{582}$ bis zu Länderstudien für Ungarn ${ }^{583}$, Ex-Jugoslavien ${ }^{584}$, Rumänien ${ }^{585}$, Griechenland ${ }^{586}$, Türkei $^{587}$ usw. oder Regionalstudien ${ }^{588}$ sowie

58 I Tache Papahagi, Mic dicționar folkloric, București r 979, 362-368 (ochiu), Konstantinos A. Roma-

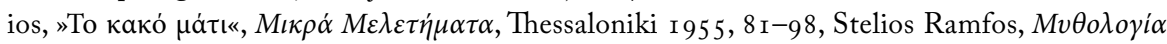

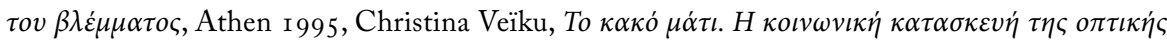

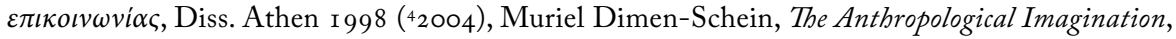
New York etc. I 977, I 37 ff., Michael Herzfeld, »Meaning and Morality: A Semantic Approach to Evil Eye Accusations in a Greek Village «, American Ethnologist 8 (I98 I) 560-574, Margaret Kenna, "Saying >No in Greece: Hospitality, gender, and the evil eye «, Stathis Damianakos/Marie Elisabeth Handman (eds.), Les amis et les autres: mélanges en l'honneur de John Peristiany, Athens 1995.

582 Petru Caraman, Descolindatul în orientul și sud-estul Europei, Iași I 997 (Diss. I 939), Lake Evelyn F. Coote, »Some Notes on the Evil Eye round the Mediterranean Basin«, Folklore 44 (1933) 9398, Thede Kahl, „Der Böse Blick. Ein gemeinsames Element im Volksglauben von Christen und Muslimen«, Thomas Wünsch (ed.), Religion und Magie in Ostmitteleuropa. Spielräume theologischer Normierungsprozesse in Spätmittelalter und Früher Neuzeit, Münster 2006, 32 I-336, Petra Himstedt-Vaid, »Volksglaube auf dem Balkan«, Uwe Hinrichs/Thede Kahl/Petra Himstedt-Vaid (eds.), Handbuch Balkan, Wiesbaden, Harrassowitz 2014 4, 69I-732.

583 Árpad Csiszár, »Szemmelverés és igéséz«, Jósa András Múz. Évk. I I (I968) I6 I-I 70, Ivan Balassa/ Gyula Ortutay, Ungarische Volkskunde, Budapest/München I 982, 736, 739 .

584 Edmund Schneeweis, Serbokroatische Volkskunde. Erster Teil: Volksglaube und Volksbrauch, Berlin I 96 I, I68-i 70.

585 Radu Răutu (ed.), Antologia descântecelor populare românești, București 1998.

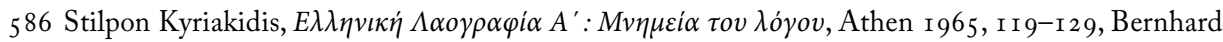
Schmidt, »Der böse Blick und ähnlicher Zauber im neugriechischen Volksglauben«, Neue Jahrbücher

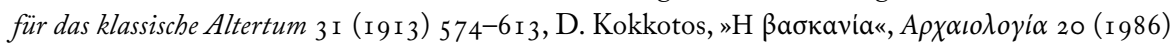
45 ff., Louis Arnaud, "La Baskania ou le mauvais œil des Grec Modernes«, Échos d’Orient I 5 (I 1 I 2) 385-394, J. K. Gubbins, »Some Observations on the Evil Eye in Modern Greece«, Folklore 57 (194647) I95-I98, Aranca, Christos Anesti«. Osterbräuche im heutigen Griechenland, Zürich I 968, 42 f., $108 \mathrm{f}$.

587 Müyesser Tosunbaș, "Çukurova'da Nazar ve Nazardan Korunma Pratikleri«, Türk Folklor Araștırmaları, İstanbul I 976, $7807 \mathrm{ff}$.

588 George Frederick Abbott, Macedonian Folklore, Chicago ${ }^{2}$ I969, I4I-I46, Margaret M. Hardie (Mrs. F. W. Hasluck), »The Evil Eye in some Greek Villages of the Upper Haliakmon Valley in West Macedonia", Journal of the Royal Anthropological Institute of Great Britain and Ireland 53 ( 1923) I60-I72, S. Knecht, "Matiasma - der böse Blick. Diagnose und Therapie auf Kreta«, $M e-$ dizinische Welt 4/4 (I 968) 2455-6I, Richard and Eva Blum, The Dangerous Hour. The Lore of Crisis and Mystery in Rural Greece, London 1970 (Nordgriechenland), Regina Dionisopoulos-Mass, »The Evil Eye and Bewitchment in a Peasant Village«, Clarence Maloney (ed.), The Evil Eye, New York

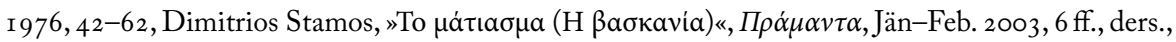

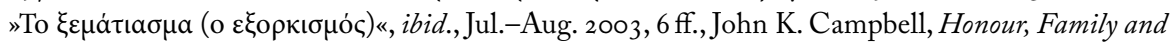
Patronage. A Study of Institutions and Moral Values in a Greek Mountain Community, Oxford I964,

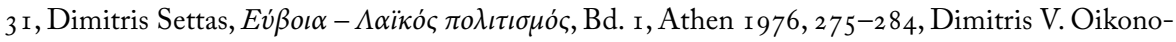


auch etwa für die Diaspora-Griechen in Australien und Amerika ${ }^{589}$. Der baskanos ophthalmos (oculus malus, invidiosus) oder baskania im Altgriechischen ${ }^{590}$ ist im Neugriechischen zu matiasma bzw. als Gegenzauber xematiasma ${ }^{51}$ geworden, zuzüglich einer ganzen Reihe von Lokalbezeichnungen, darunter besonders interessant $\varphi \theta$ óvoc (Neid) auf Zypern ${ }^{592}$. Dem intensiven Blick als Schadenszauber entspricht auch eine verbale Variante: das $\gamma \lambda \omega \sigma \sigma o \varphi \alpha ́ \gamma \omega \mu \alpha$ (»mit der Zunge fressen« - jemanden dauernd im Munde führen), das ebenso unheilvolle Wirkung haben kann ${ }^{593}$.

Wer hat den Bösen Blick und wer sind seine Opfer? In einer griechischen Gesamtübersich ${ }^{594}$ ist die Rede von zusammengewachsenen Augenbrauen, großen Brüsten und hervorstehenden Augen, von denjenigen die zu viel Muttermilch getrunken haben (Kreta), Besitzer von schwarzen oder blauen Augen usw. Anfällig für den Schaden sind besonders Kinder, aber auch Erwachsene, besonders schöne Menschen (Kreta), Jäger und Fischer, Weberinnen, Herdentiere (Käse stockt nicht), Schweine, fruchtreiche Bäume, Käse, Seidenraupen usw. ${ }^{595}$ Wie kann man sich schützen? Die am weitesten verbreitete Prophylaxe ist das schon im Altertum nachzuweisende symbolische (sich selbst) (Be)

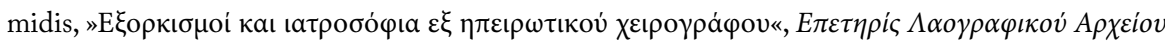
8 (1953-54) г4-40.

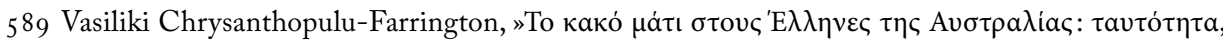

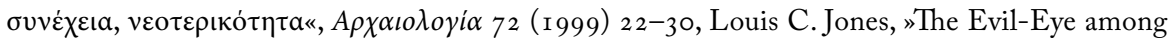
European-Americans«, Western Folklore ro (I 95 I) I I-25, R. Georges, »Matiasma: Living Folk Belief", Midwest Folklore I $2 / 2$ (1962) 69-74.

590 Davon die Verben ophthalmizein oder als Gegenzauber apophthalmizein, bzw. baskanein.

59I Von mati (Auge, omma[ti]) statt ophthalmos.

592 Auf Kreta $\varphi \theta \alpha \rho \mu o ́ \varsigma$ (von $\varphi \theta \varepsilon i \rho \omega$, schaden) oder $\lambda \dot{\alpha} \beta \omega \mu \alpha$ (Verwundung), $\alpha \rho \mu \varepsilon \dot{v i}$ เa $\mu \alpha$ in Thessalien (die Armenierinnen spielen als Hexen eine bedeutende Rolle in den griechischen Volksvorstellungen) usw. Vgl. auch Kahl, »Der Böse Blick«, op. cit., 326.

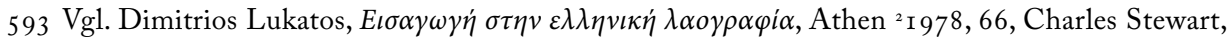
Daemons and the Devil, op. cit., $232-237$.

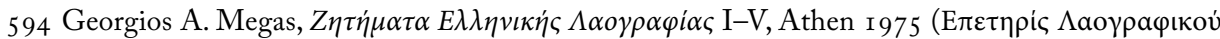
Apxziou 1939-49) II 8I-86.

595 Kahl fügt aus der Feldforschung hinzu: Glückliches Ehepaar, das kinderlos geblieben ist (Neid einer Unverheirateten, türkisch aus Medgidia, Rumänien), berittener Arzt auf Schimmel wird mit H1. Georg verglichen und fällt gleich vom Pferd (ungewollt, Igumenitsa, Westgriechenland), Pope diagnostiziert die Verzauberung bei einer Schwangeren (aromunisch aus Distrato, Epirus), plötzlicher Tod eines Widders, der als besonders potent gerühmt wurde (Tsepelovo, Zagori-Dörfer, Epirus), Lob einer Alten läßt Garten verwelken (aromunisch, Plasa, Albanien), negative Vorhersage läßt einen hinderlichen Steinblock beim Brunnengraben zerbersten (pomakisch, Tepeköy, Türkei) (Kahl, »Der Böse Blick«, op. cit., 326 ff.). Die angeführten Beispiele zeigen den gleitenden Übergang zur glossofagia (Lob aus neidischem Mund) und auch die sinngemäße Umkehrung (Vorhersage der Aussichtlosigkeit führt zum glücklichen Ausgang eines schwierigen Unternehmens). 
Spucken mit dem entsprechenden apotropäischen Bannspruch; es geht an sich um ein Täuschungsmanöver: Die Schandhandlung deklariert den Bespuckten als Minderwertigen, der keinen Neid erregen kann ${ }^{596}$. Hilfreich sind auch die religiösen Symbole: die Anrufung Gottes, der Panagia oder Allahs, Ikonen, Kreuze, an sich jeder von der Kirche gesegnete Gegenstand, Beweihräuchern ${ }^{597}$, aber auch Paganes wie Schlüssel-Talismane aus Edelmetall ${ }^{598}$, Münzen, Schädelknochen vom Esel, Unterkiefer vom Schwein, der rote Märzfaden (martinički) für Kinder ${ }^{599}$, die multifunktionalen Knoblauchgebinde ${ }^{600}$, und vor allem das Augenamulett: als blaue Perle (Souvenir in der Türkei), als Talisman für kleine Kinder, als offenes blaues Auge aufgemalt oder aufgeklebt an Autos und Lastwagen $^{601}$, oder als erschreckende Larve und Fratze als Ornament an Häusern und anderen Gebäuden der traditionellen Architektur ${ }^{602}$. Der magische Grundgedanke ist hier die Abschreckung und Retournierung des Bösen Blicks. Solche Augen-Amulette ${ }^{603}$ gibt es für Kleinkinder, Tiere, Häuser, Ställe, Bäume, Felder, Blüten, ja sogar Seidenraupen usw. ${ }^{604}$

Die klinische Symptomatologie der Schädigung ist eher untypisch: Abfragbar sind z.B. Kopfschmerzen, seltener schwerere somatische oder psychische Störungen (z.B. angezauberte Impotenz) oder gar Todesfälle ${ }^{605}$. Es geht eher um eine Art Unwohlsein, das Gefühl, daß irgendetwas nicht stimmt und dergleichen ${ }^{606}$, wobei man mit der über-

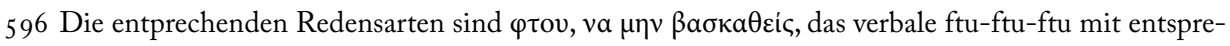
chender Lippenbewegen, $\mu \eta$ $\sigma \varepsilon \mu \alpha \tau \dot{\alpha} \sigma \omega$, ptiu ptiu să nu te deochi usw. Speichel gehört überdies zu den therapeutischen Körpersäften. Die gleiche Funktion hat das Anziehen alter Kleider für kleine Kinder (Bliss, Islamischer Volksglaube, op. cit., 37).

597 Balassa/Ortutay, Ungarische Volkskunde, op. cit., Abb. 3 I o Räuchern gegen bösen Blick.

$598 \mathrm{Im}$ Altertum vor allem phallische Amulette; auch phallische Gestik (Thomas Hauschild, »Abwehrmagie und Geschlechtssymbolik im mittelmeerischen Volksglauben«, Baessler-Archiv 28, I980, 73-I04, bes. 84).

599 Aber auch für Kühe am Schwanz angebunden, oder für Herdenvieh als Rotfärbung des Fells (Campbell, Honour, Family and Patronage, op. cit., 30), Gebetszettel ins angebohrte Horn des Hammels usw. (Schneeweis, Serbokroatische Volkskunde, op. cit., I 68 ff.).

600 Kahl, »Der Böse Blick«, op. cit., 328 f. Heute noch in Geschäften und Wohnungen zu sehen.

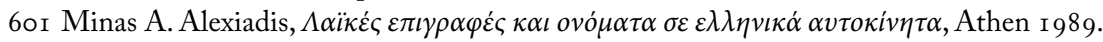

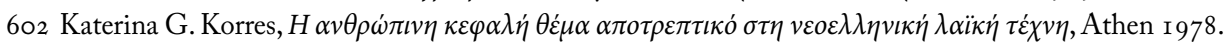

603 Vgl. Rudolf Kriss/Hubert Kriss-Heinrich, Peregrinatio neohellenika. Wallfahrtwanderungen im heutigen Griechenland und in Unteritalien, Wien I 955, Abb. 52.

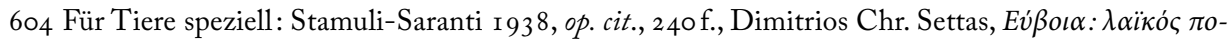

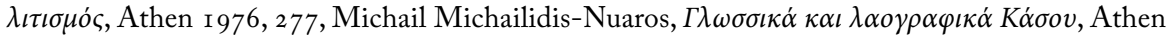

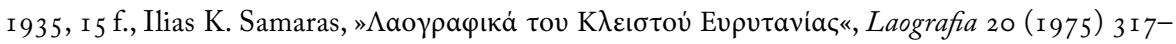
34I, bes. 33 I, usw.

605 Kahl, Der Böse Blick«, op. cit. 326. Dort allerdings auch das eindrucksvolle Zitat einer serbischen Bäuerin, daß mehr Leute am Bösen Blick gestorben seien als an Krankheiten (323).

606 Geschädigter errötet im Gesicht, ist bedrückt (Kastoria) usw. Dazu wird in dem einschlägigen 
all geglaubten und allen einleuchtenden Diagnose gleich bei der Hand ist. Hilfreich für die Therapie ist jedoch zuerst die Identifizierung des Schädigers: Hier gibt es verschiedene Praktiken, z.B. eine glühende Kohle ins Wasserglas werfen und den Namen des vermuteten Schädigers aussprechen: Landet die Kohle am Boden des Glases, dann ist die Antwort positiv ${ }^{607}$. Im Falle der unbewußten Schädigung ist der Verursacher auch die geeignetste Person, den Schadenszauber wieder aufzuheben ${ }^{608}$.

An Personen, die die Verzauberung durch den Bösen Blick heilen können, ist kein Mangel; praktisch jede erfahrene Frau kennt sich in diesen Dingen aus. $\mathrm{Zu}$ den Bannsprüchen und Beschwörungsliedern gibt es umfangreiche Sammlungen ${ }^{609}$, obwohl diese Texte als Heilwissen eigentlich geheimgehalten werden. Als assistierende Objeke der "Besprechung« gelten Salz, Öl, Wasser, Tücher und Kohle. Eine der grundlegenden Symbolhandlungen ist das Be(weih)räuchern mit Kohle aus den Kapnisterien (kirchlichen Räucherfässern) bzw. das Streuen von Salz ins Wasser (Analogiehandlung der Auflösung mit Bannspruch), das Tragen des kranken Kindes über das Herdfeuer (Feuer als Reinigung), das Besprengen oder Begießen mit Wasser (mit einer glühender Kohle, aufgelöstem Salz oder Öl von der Öllampe, aber auch Erde vom Spurentritt des Schädigers oder drei seiner Haare; weiters Asche,

Schrifttum noch angeführt: Nervosität, Fieber, Ohnmacht, Schlaflosigkeit, Übelkeit, Impotenz, Unfruchtbarkeit, Gewichtsverlust, Anämie, aber auch Pechsträhne.

6o7 Derselbe Diagnoseritus wird auch mit Öltropfen in Wasser vorgenommen, Salzstreuen ins Feuer

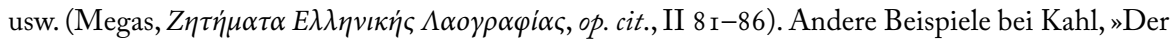
Böse Blick«, op. cit., 332.

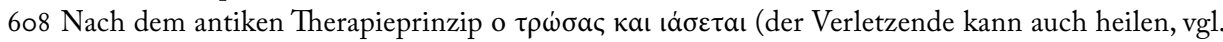
wie im Ersten Teil). Dazu ein Beispiel: In Maistro in der Europäischen Türkei wird die Diagnose des Bösen Blicks mit drei kleinen Holzkreuzen bewerkstelligt, womit man das Kind bekreuzt und diese in das Wasser, in dem man die Kirchenkerzen löscht, wirft; wenn Blasen aufsteigen, ist das Kind tatsächlich befallen; als Theraphie ist der Verursacher ausfindig zu machen, von dessen Kleidung man ein Stoffstück verbrennt (oder Epitaphblumen); Rauch bringt den Zauber zu ihm zurück; effektiv ist auch das Anspucken vom Verursacher des Schadens mit dem Spruch: "von mir

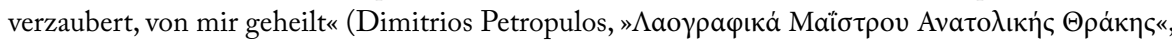

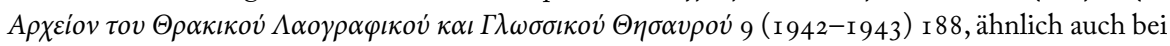

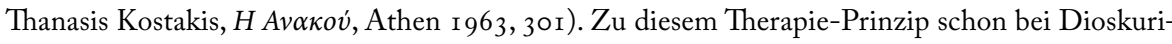

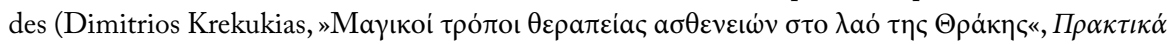

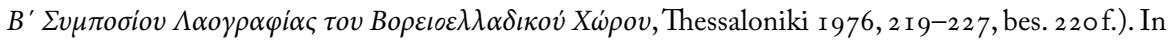
der Türkei und im Mittleren Osten wird für die Eruierung des Verursachers auch das Ei-Orakel eingesetzt: Der Personenname wird auf die beiden Enden des Eis geschrieben, und dieses zum Platzen gebracht; damit ist der Zauber gelöst. Vgl. auch M. L. Lechner, »Ei, Eier«, Enzylopädie des Märchens 3 (I 98 I) I I07-i I I 8, bes. I I I f. (Ei als magischer Gegenstand).

609 Caraman, Descolindatul, op. cit. aus dem gesamten südosteuropäischen Raum, Răutu, Antologia, op. cit., für Rumänien. 
ein Elfenbeinkreuz oder Knochen) ${ }^{610}$, die Bekreuzigung mit Salz, Salzessen oder Salzwasser trinken (Auflösungs-Symbolik), die Bekreuzigung mit Olivenblättern, Palmzweigen oder dem schwarzgriffigen Messer, das Bestreichen mit Speichel oder Speicheltrinken, das Zählen von I bis 9 oder 9 bis I (Körperöffnungen?) mit Ausspucken, die verbale Verbannung in die Berge und andere Analogiehandlungen ${ }^{611}$.

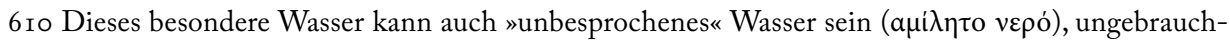
tes, oder Wasser, das unter dem Sternenhimmel die Nacht über draußen gestanden hat; es wird aus einem ganz bestimmten Gefäß gegossen. $\mathrm{Zu}$ den z.T. umfangreichen verbalen Bannsprüchen (Epoden) vgl. auch den Ersten Teil zu den therapeutischen Methoden.

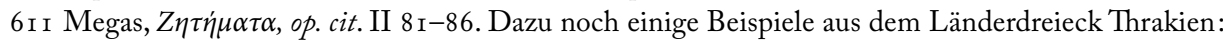
Babys werden dadurch entzaubert, daß die wissende Frau in einen Napf mit frischem Wasser drei Salzkörner wirft, den Napf mit einer geöffneten Schere bekreuzigt und einen langen narrativen Bannspruch deklamiert; mit dem Wasser besprengt sie das Kind und den Rest verschüttet sie an der Wegkreuzung vor dem Dorf (Krekukias, »Мaүıкоі тро́ло«, ор. cit., 226). Hier ist Bindezauber mit der transplantatio verbunden: frisches Wasser, sich auflösendes Salz, die offene Schere (die geschlossene bindet), die Wegkreuzung als magischer Knotenpunkt (hier entscheidet es sich, ob das Übel ins Dorf kommt oder nicht, vgl. Martin Scharfe, »Wegkreuzung «, Enzyklopädie des Märchens I4, 20I I, 540-544), das Wegschütten desselben Wassers, mit dem das Kind in Berührung gekommen ist (dazu auch Sergis, $\Delta \iota \alpha \beta \alpha \tau \dot{\eta} \rho \iota \varepsilon \varsigma \tau \varepsilon \lambda \varepsilon \tau o v \rho \gamma i \varepsilon \varsigma$, op. cit., 8o-86). In Ainos und Umraum: Der Böse Blick wird besonders im März übertragen, von Blauäugigen und Samstaggeborenen; der Priester verliest einen Segen für den Befallenen, nachdem ein Test durch Salzorakel im Feuer (ob der Kranke wirklich matiasmenos ist) vorgenommen worden ist - eine alte Frau legt eine kleine Ikone ins Wasser und erhitzt es: Steigen Blasen aus den kleinen Löchern der Ikone, so ist die Diagnose positiv; die Heilung erfolgt durch Teig in eine Schale »unter die Sterne « gelegt und in Weihwasser dem nüchternen Kranken zu trinken gegeben; eine andere Methode besteht im Blumenverbrennen in Kerzenflamme (mit dem Spruch: "ist's das Auge, so komm' es raus, ist's der Wind, soll er vorbeiwehen, zu denen die dir übel wollen«). Bei Kindern wird das chaimali-Amulett (türk, hamail, im Gegensatz zu fylakto, das meistens kirchlichen Ursprungs ist) als Prophylaxe angewendet; die Diagnostik sieht Öl von der Kirchenlampe im Wasserglas vor, bei Auflösung ist der Betreffende

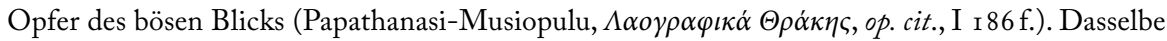
geschieht auch mit Wasser und Olivenöl, zusammen mit Teig und Brot (Teigkneten und Brotbakken als symbolischer Geburtsvorgang; siehe Marie-Christine Couffin, Monde feminin et marriage en Epire grecque, Montpellier 1982). Als Prophylaxe werden an den Pflug Glocken gehängt (Pe-

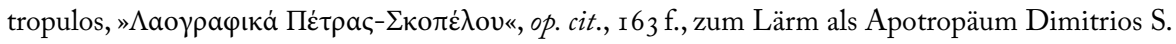

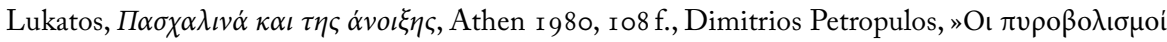

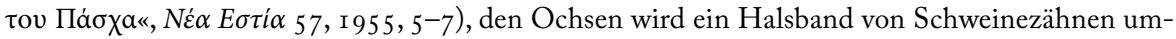
gehängt oder ein Amulett-Säckchen; zur Entzauberung wird von kundigen Frauen ein Ei an der Stirn des erkrankten Tiers zerschlagen und geheime Zaubersprüche gemurmelt (wenn sie bekannt werden, verlieren sie ihre Heilkraft), Salzkörner mit Bannsprüchen besprochen, dann in Wasser zu trinken gegeben (auch von drei Frauen, wobei jede andere Bannsprüche spricht), auch Öltropfen in Wasser. Als Apotropäum gilt die Farbe Schwarz, Lärm, Gestank, Amulette, das Schwein, das Ei usw. Es handelt sich um ein puzzle und eine ganze Kombination von Symbolelementen und 
Vielfach werden ganz dieselben Prinzipien angewendet wie bei der Therapie von Krankheiten ${ }^{612}$.

Der detaillierte Vorgang des xematiasma-Ritus findet sich auch in einer griechischen Dialektkomödie des I9. Jh.s, »Der Karpather oder der eingebildete Verliebte« (»O Ka $\rho$ -

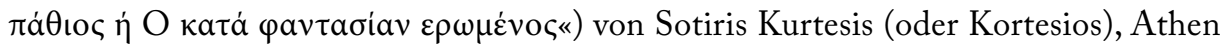
I 862 (und I 886 noch einmal von seinem Sohn herausgegeben) ${ }^{613}$, wo einer der ewig betrunkenen, verliebten und mantinades mit Lyrabegleitung grölenden Maurermeister aus Karpathos Unruhe in ein gutgesittetes Athener Bürgerhaus bringt und dafür bestraft wird ${ }^{614}$. In einer der einaktigen Erstfassung (um I 858) hinzugefügten genre-Szene

Symbolhandlungen. Weitere Materialien zu Thrakien in Kalliopi Papathanasi-Musiopulu, »Aтó

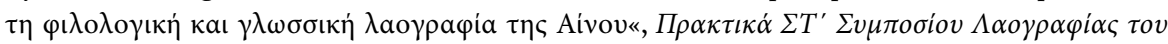

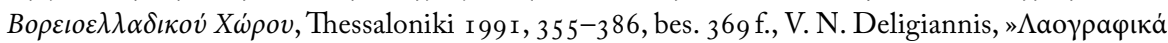

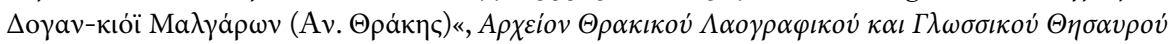

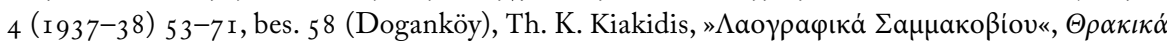

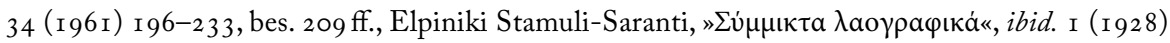

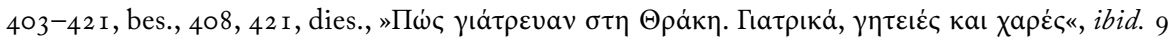
(1938) I 95-286, bes. 223,235 f., 238 f. 240 f.,

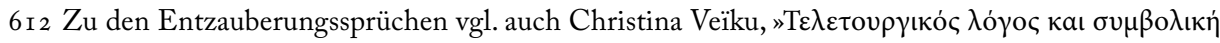

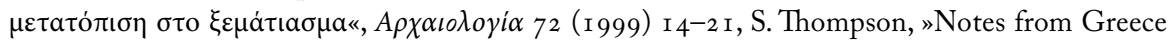
and the Aegean. Evil Eye Charms«, Folklore I 9 ( 1908 ) 469-470, Maria V. Asvesti, »Maүıкаi каı

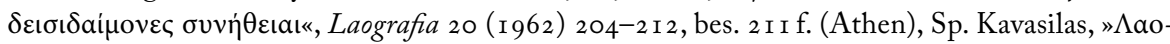

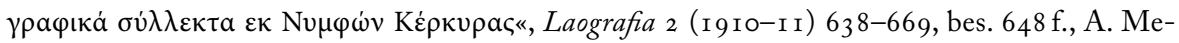

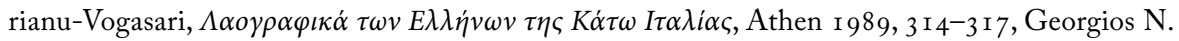

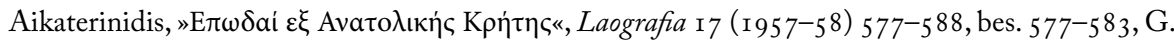

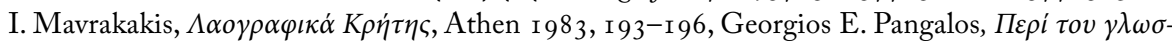

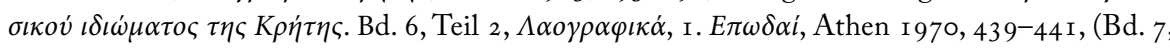

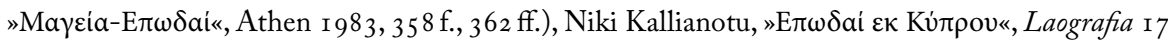

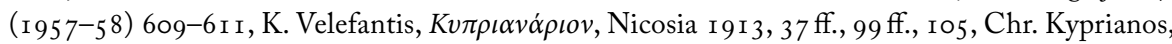

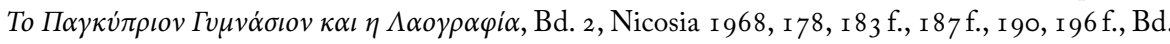

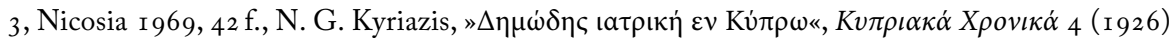

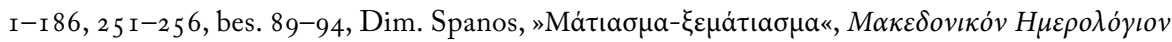

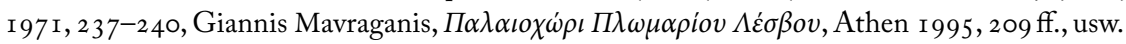

6r 3 Der Titel ist dem molièrischen "Le malade imaginaire« ironisch nachgebildet; zur intensiven Molière-Rezeption in Griechenland bereits seit dem Ende des I 8. Jh.s vgl. Walter Puchner, $H$

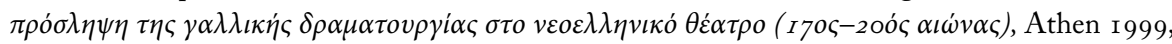
36-6o. Zu dem Folgenden vgl. auch Walter Puchner, »Strategien zur Entzauberung vom Bösen Blick in Südosteuropa. Anhand einer griechischen Dialektkomödie aus dem i 9. Jahrhundert«, Zeitscbrift für Balkanologie 5 I/2 (2015) 225-235.

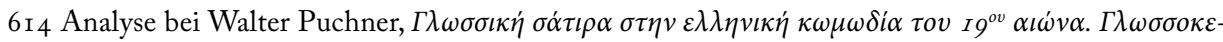

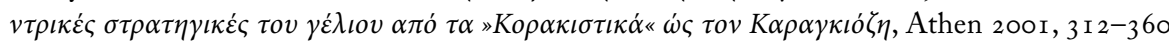
und ders., »Griechische Sprachsatire im bürgerlichen Zeitalter«, Von Herodas zu Elytis. Studien zur griechischen Literaturtradition seit der Spätantike, Wien/Köln/Weimar 20 I 2, 295-422, bes. 389-40 I. 
im Bürgerhaus taucht neben anderen Dialekttypen auch die alte Kassu auf, die das AltAthener Idiom (eigentlich ein Inseldialekt) spricht und unter anderem auf der Bühne eine solche Entzauberung vom Bösen Blick an einer Freundin des Hauses vornimmt. Neben dem Bannspruch gibt es die Bekreuzigung mit Salzprisen, das Gähnen, Abschlecken des Gesichtes der Befallenen, das Salzorakel im Feuer und ein Ei, das »unter die Sterne gelegt« wird zur nachherigen Begutachtung der Effektivität der Therapiehandlung ${ }^{615}$. Es handelt sich um eine eher freie Kombination von Elementen, für deren

6I 5 Der Passus des Dialekttextes sei hier übersetzt. Die Kassu nimmt drei Prisen Salz und setzt sich der Befallenen gegenüber; anwesend ist auch die Hausherrin Aspasia, die als gute Bürgerstochter verheiratet werden soll. In der Folge bekreuzt sie sich dreimal und spricht: „Die schwarze Kuh hat geworfen, ein schwarzes Kalb geboren; aaah - aaah -aaah (gähnt). (Die Aspasia niest). Zum Wohl, aber wirklich, sag ich (fährt [in der Behandlung] fort); es ist zum Bazar hinabgestiegen, da haben es auch andere Kühe gesehen und neidisch angeblickt [to 'matiakane], aaah - aaah -aaah (es gähnen alle drei). Die haben dir das Herz ausgesogen, mein Kind, die Lichtverbrannten [Dämonen, Teufel]; es kommen mir Tränen in die Augen, mein Gott [eig. Sohn; Redensart]. (Sie fährt fort [mit dem Entzauberungsritus]). Da hat sich die Kuh niedergebeugt und ihr Kalb abgeschleckt, das ist gleich gesund geworden. So schlecke ich auch meine Aspasia ab, damit sie gesund wird (sie schleckt sie dreimal im Gesicht ab). Verkehrt bist du reingekommen, verkehrt; und verkehrt gehst du wieder raus (dreimal). Das Übel soll in die Berge gehen, ins Gebirge, dort wo die Sonne, aaah - aaah -aaah (es gähnen alle drei), das Brot bäckt und das Meer das Salz; hinter die Sonne, und in meinen ersten Schuh, aaah - aaah -aaah (es gähnen alle drei). Och! meine Herzblätter tun mir weh, mein Gott [Sohn]. Ach! mein Kind, du bist damit eingeschlafen; siehst du nicht, wie mir die Augen laufen; vai, vai, mein Gott. (Sie fährt fort). Komm, Panagitsa, meine Frau; das Übel von mir verbannt und von der Panagia geheilt. (Sie reibt sich die Augen und gähnt). Nimm jetzt das Salz, meine Tochter, und wirf es in das Feuer, damit das Übel zerplatzt, und am Abend schlag ein Ei in einen Becher, und leg es draußen unter die Sterne, und am Morgen komme ich und sehe es

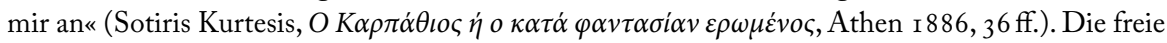
Kombination der Elemente des Entzauberungsritus mag, zusammen mit den interpolierten Kommentaren, Seufzern und Beteuerungen körperlichen Mitleidens der alten Kassu im Alt-Athener Idiom, das um die Jh.mitte des I 9. Jh.s dem Publikum noch geläufig sein mußte, den komischen Bühneneffekt noch erhöht haben, wenn man sie isoliert betrachtet, scheinen sie jedoch authentische Elemente des magischen Kontextes zu sein: die Salzprisen, die ins Feuer geworfen werden (Orakel und Purifikation, Knallen und Knistern als Lärm-Apotropäum), die Narration mit dem Kalb, das die Analogiehandlung vorbereitet (wie - so), Speichel als therapeutisches Mittel (auch gegen den Bösen Blick - Speichelbestreichen der Stirn von Kleinkindern, Speicheltrinken), originell scheint das ansteckende Gähnen als Kontakthandlung für die Anwesenden, Augentränen und Herzschmerzen als Mitleiden der Therapeutin, das hypnotische Einnicken der Befallenen nach dem vielen Gähnen, die Diagnose des dämonischen Einflusses, der Exorzismus der Verbannung des Übels in die Berge (Erwähnung der Naturkräfte Sonne und Meer) und in kosmische Bereiche (hinter die Sonne) bzw. in die Vergangenheit (die ersten Schuhe, die es nicht mehr gibt), die Anrufung der Gottesmutter als Heilerin vom Übel, und dann noch das angekündigte Ei-Orakel, das aufgeschlagen in einen Becher »unter die Sterne« zu legen sei und das am Morgen auf seine 
Authentizität der Schauspieler-Autor nicht unbedingt zur Verantwortung zu ziehen ist (ähnlich wie sich die gebrauchten Dialekte als Bühnenidiome keineswegs unbedingt mit den realen Sprachgewohnheiten der angegebenen Gegenden decken) ${ }^{616}$. Solche genreSzenen mit folkloristischem Kolorit werden nach I 880 dann in der Prosaliteratur und auf dem Theater gang und gäbe ${ }^{617}$.

Die kreative Imagination (Einbildung und Erfindung) ist unabdingbarer Bestandteil des magischen Denkens in Assoziationen und Analogien, um mit inneren Projektionen und hypothetischen Mutmaßungen in existenzielle (medizinische, wirtschaftliche, kommunikative, kollektive und persönliche, psychische und soziale) Gegebenheiten einzugreifen bzw. Vorkommnisse begreiflich zu machen, wo das wirkliche Wissen um die bewirkenden Ursachen fehlt und die kumulierte Erfahrung nicht ausreicht, um die Dinge zu erklären; die angestrebten Interventionen dieser Alternativ-»Wissenschaft" in die physische und metaphysische Umwelt sind fast immer von den allumfassenden Überlebensstrategien der Kommunitäten und Menschengruppen der traditionellen Gesellschaftsformen diktiert, in ihrer Effizienz jedoch keineswegs unfehlbar. Magische Praktiken sind auch Probehandlungen, die ohne die erwünschten Ergebnisse bleiben können. Der Glaube an den Bösen Blick ist überdies ein getreuer Spiegel der fragilen Komplexität kommunikativer Interaktionsformen in traditionellen Gesellschaften, wo die Interpretation des Übermittelten zwar konventionell festgelegt ist, der Ermessensspielraum des Interpretanten jedoch die gesellschaftliche Normierung der Zeichen und ihrer Bedeutungen immer in einer Gleitlage hält, die letztlich keine unverrückbaren Sicherheiten zuläßt ${ }^{618}$.

Aussagekräftigkeit bezüglich der gelungenen oder mißlungenen Entzauberung begutachtet werden wird. Kurtesis, der noch andere Bühnenwerke verfaßt hat, die durchaus der Aktualität der Zeit entsprechen, greift demnach gesellschaftsübliche magische Praktiken auf und verbindet sie zu einer Kombination, die Lachen hervorrufen soll, bemüht sich jedoch, wie auch in der Sprachführung und Wiedergabe der verschiedenen Dialekte, den Eindruck des Authentischen zu erzeugen.

6I6 Der Dialekt des Karpathers bewegt sich übrigens an der Grenze des für ein Athener Publikum des I 9. Jh.s noch Verständlichen. Dazu Puchner, $H \gamma \lambda \omega \sigma \sigma \iota \kappa \dot{~} \sigma \alpha \dot{\tau} \iota \rho \alpha$, op. cit., 3 I 2-360 und zur

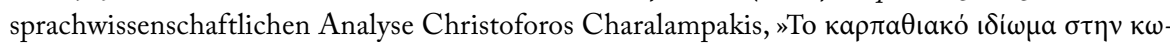

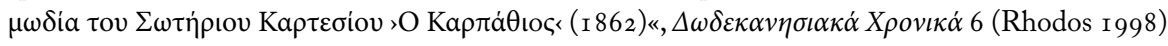
377-391.

6 7 Vgl. die sogenannte »ethographische« Bewegung der Literaturgeneration von r 880, die auch die Heimatnovelle und den Dorfroman pflegt (dazu Puchner, "Der Tod des Pallikaren von Kostis Palamas (I 89r). Studien zur griechischen Dorfnovelle«, Von Herodas zu Elytis, op. cit., 423-454, bes. 425 ff.).

6r 8 Dazu nur der Hinweis, daß dies auch in nicht-traditionellen Gesellschaftsformen der Fall ist, wenn man z.B. an den Blickkontakt beim Flirt denkt: Der Antwortblick in seiner Vieldeutigkeit kann Ja bedeuten, oder auch Nein, Noch nicht, Nicht jetzt, Warum nicht, Lieber nicht, Vielleicht usw. Aber 


\section{TYPOLOGISCHE ÜBERTRAGUNG UND ASSOZIATIVE VERNETZUNG ODER DENKFIGUREN ZWISCHEN SCHRIFT- THEOLOGIE UND ORAL-KULTUR}

Mehrfach war die Rede von »Hochreligion« und »Volkskult«, theologischer Dogmatik und Pastoralpraxis, der Differenz zwischen höherem und niedrigem Klerus, den wohlüberlegten Akkommodationstaktiken der Frühkirche und dem heimlich oder auch offenen Weiterleben von Paganität und Idolatrie, von der Ikonentheologie nach der Besiegung des Ikonoklasmus und dem »Mißbrauch« der Bilder in Byzanz, von Synodalverdikten und Patriarchatserlässen gegen Praktiken und Rituale, die »von oben« eigentlich verboten sind, jedoch zum traditionellen Bild der balkanischen Dorfkirche gehören, von synkretistischen Verehrungsformen und hybriden Heiligen zwischen Ostkirche und dem Islam usw., immer mit einem deutlichen Verweis auf die Kluft zwischen Hochkirche und Glaubenspraxis, die mutatis mutandis auch als Differenz zwischen Schriftkultur und Oralkultur interpretiert werden kann. Das mündliche Wort in seiner akustischen Flüchtigkeit steht dem unwandelbaren »Es steht geschrieben« in seiner Quasi-Ewigkeit gegenüber, der variable Zauberspruch dem Bibelwort.

Doch die Art des Kommunikationsmediums umfaßt nicht nur das Verhältis des Worts zur Zeit, sondern impliziert auch differente Denkfiguren und Existenzweisen von Sprachtexten. Der Unterschied zwischen Sprechen und Lesen ist fundamental: Nicht nur aufgrund der Interaktionssituation (wenn man vom Vorlesen vor Hörern absieht) ist das alleinige Lesen eine Pseudo-Kommunikation ähnlich wie das Schreiben, während die Rede als Sprechakt aber eine Handlung ist, die einen Partner voraussetzt; umgekehrt ist die Formulierung des Augenblicks eine zwar wiederholbare, aber auch variable Handlung, während das Geschriebene feststeht und nur reproduziert werden kann, wenn auch in stimmlicher Interpretation und deklamatorischer Sinnverlagerung. Dem geschriebenen und gesprochenen Wort liegen unterschiedliche Denkmodalitäten zugrunde, wenn auch in den historischen (Volks)Kulturen des alten Kontinents Literarität und Oralität in einer gemeinsamen Tradition ständig interferieren ${ }^{619}$. Für Südosteuropa wurde im ersten Band dieser balkanologischen Trilogie ein spezifisches Modell konzentrischer Ringe um den vorwiegend oralen inneren Balkanraum ausgearbeitet ${ }^{620}$.

die Dinge gestalten sich noch komplizierter, wenn das Spiel mit den Bedeutungsnormen jegliche sichere Interpretation untergräbt: Wenn die Ja-Signale ein Nein bedeuten können, das konventionelle Nein ein eigentliches Ja usw. Literatur dazu halte ich an dieser Stelle nicht für notwendig.

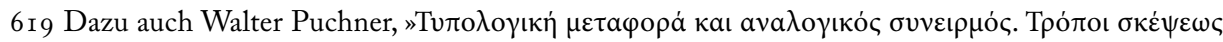

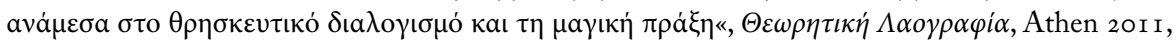
30I-340.

620 Puchner, Die Literaturen Südosteuropas, op. cit., I 2 f., I 5 f., 2 I , 68, I 64 f., 178 f. 
$\mathrm{Zu}$ den spezifischen Charakteristika der Oralkulturen zählt, daß ihre Textzeugnisse als Aufzeichnungen nur in Varianten und Variationen existieren, die sich zwar thematisch gruppieren lassen, aber keine archetypische Urform zu besitzen scheinen ${ }^{621}$. Die Existierweise in der Varianz bildet eine der größten methodologischen Schwierigkeiten im Umgang mit der Folklore; dieselben Eigenschaften besitzen jedoch auch die Akte der Performanz und die Gestaltbildungen der Imagination. Mit der schriftlichen Fixierung, dem Kopier- und Druckprozeß, dominiert automatisch das Modell der Reproduzierbarkeit eines Urtextes, der bei dem Kopieren von Handschriften zwar gewissen Änderungen unterworfen ist, aber Autorenname, Originalität und geistige Besitzrechte sind moderne Konsequenzen dieser einmaligen Festlegung. Die Unwandelbarkeit und Gültigkeit des geschriebenen Wortes wird im Falle von Sakraltexten zu einem Dogma, die Auslegung des heiligen Wortes zu einem heißumstrittenen Thema, das in der Vergangenheit viele Kriege und Ströme von Schrifttum provoziert hat. Zwar steht für die traditionelle Mentalität nichtprivilegierter Unterschichten vorwiegend oralen $\mathrm{Zu}$ schnitts die Zukunft auch im Buch des Schicksals mit unaustilgbaren Lettern geschrieben, doch niemand hat in diesem je lesen können. Bibel, Talmud und Koran aber, wie die heiligen Bücher der meisten Religionen, sind lesbar und werden gelehrt; ihr Inhalt selbst und die Gültigkeit ihres Wortes stehen jedoch außerhalb der Zeit.

Auf diesen Heiligen Schriften bauen die Religionen ihre Schrifttradition auf, die vielfach der Auslegung und Anwendung des bieros logos gewidmet ist. Im Falle des Christentums war es die Patristik, Homiletik, Hymnik, die Predigten und Meßordnungen, Monatsbücher und Heiligenviten, Segnungen und Ritualvorschriften, die kodifizierte Texte und Handlungsanleitungen dem Klerus vorlegen und die vom Kirchenvolk anzuhören sind. Erst die Sonntagspredigt und andere kerygmatische Okkasionen fallen in den formulierbaren Ermessensspielraum des Geistlichen. Theologische Traktate und dogmatische Abhandungen wenden sich jedoch an insider der ekklesialen Tradition. Im Sakralbereich des Ekklesialen ist also mit einer extrem hohen Fixiertheit von Wort (Psalmodierung, Gesang), Symbolakten, Abbildungen (Ikonographie, Freskomalereien) und Raumstruktur (Narthex, Naos, Heiligtum) zu rechnen, in extremem Gegensatz zur hohen Varianz der Elemente, die in den magischen Praktiken als Verbalspruch, Symbolakt und assistierenden Objekten zur Anwendung kommen. Im Wortmedium gibt es dennoch indirekte Beziehungen: So wie das magische Wort geheim, unverständlich und rätselhaft sein kann (muß, um wirksam zu sein), umgibt auch das Sakralwort das

62 I Zur Varianz als Grundform der Existenz von Erscheinungen der Folklore und allgemein der

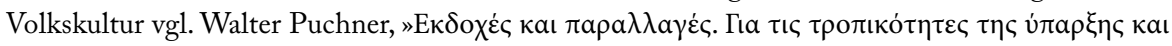

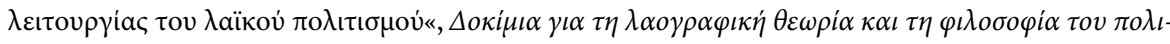
$\tau \iota \sigma \mu o v$, Athen 2014, I $27-\mathrm{I} 68$. 
Geheimnis des Unfaßbaren und die Aura des Fremdartigen, ob es sich nun um Latein, Altkirchenslavisch oder Bibelgriechisch handelt ${ }^{622}$.

Die systematischen Akkommodationsstrategien des ersten Jahrtausends, mit der Scheidung von kanonischen und apokryphen Schriften, der Etablierung der Ikonentheologie und der Kodifizierung von Meßordnungen statt der formlosen Gebetsfolge in den geheimen Katakomben-Versammlungen hat ein streng aufeinander abgestimmtes Verweissystem von Wort, Bild und Ritus installiert, aus dem alle adiaphora eliminiert sind und pagane Restformen der hellenistischen Zeit spirituell umgedeutet und vertieft werden $^{623}$. Daß dieser kontinuierliche Reformprozeß nicht überall erfolgreich war, dafür gibt es genügend Beispiele ${ }^{624}$. Fundamentale Denkfigur dieses Verweisprozesses ist die typologische Übertragung als ein quasi-logisches Referenznetz, das zuerst in der Bibelexegese exemplifiziert wurde durch die Vorausweisung der Propheten und Vorväter des AT auf die Ereignisse des NT, die dann in der Exegetik als schon im AT vorhergesagt dargestellt werden; in ähnlicher Weise wurde allerdings auch in der Patristik ein bedeutender Teil der philosophischen Tradition des Altertums durch spirituelle Umdeutung in die ekklesiale Tradition des Christentums integriert und bildet seither den Grundstock der gemeineuropäischen Kultur. Die typologische Übertragung bildet ein strenges Verweissystem von Analogien, deren gemeinsame Elemente jedoch einen gewissen Mystizismus beinhalten, der kausallogischer Rationalität nicht standhalten kann und eine hohe Glaubensbereitschaft voraussetzt ${ }^{625}$. Mit dieser Methode sind in der Exegese

622 Insofern war die Abschaffung des Lateinischen bei den Katholiken unter einem gewissen Aspekt ein rational-aufklärerischer Akt, der frömmigkeitspsychologisch durchaus hinterfragbar ist. Das Kirchengriechische war den Analphabeten der Türkenzeit zwar nicht völlig unzugänglich, doch wie manche Bibelsprichwörter zeigen, mit Mißverständnissen behaftet. Die Rumänen hatten ihre Messen noch bis ins I7. Jh. in Altkirchenslavisch; und das Slavenoserbische der serbischen Kirchentradition war von der Sprechsprache des Kirchenvolkes ebensfalls weit entfernt. Die Aura und Würde des Heiligen Wortes bedarf einer gewissen sprachlichen Gewandung, die von der Alltagssprache distinktierbar sein soll.

623 Vgl. die Beispiele in Walter Puchner, Akkommodationsfragen. Einzelbeispiele zum paganen Hintergrund von Elementen der frühkirchlichen und mittelalterlichen Sakraltradition und Volksfrömmigkeit, München 1997 .

624 Vgl. etwa den descensus ad inferos, der als topos der antiken Hadesfahrt (nekyia) erst im apokryphen Nikodemusevangelium (Acta Pauli) im 2. Jh. n. Chr. ausformuliert und schriftlich festgelegt wurde und trotzdem zur kanonisierten Anastasis-Ikone der Ostkirche geworden ist (Walter Puchner, "Abgestiegen zur Höller. Der descensus ad inferos als Keimzelle eines inexistenten orthodoxen Auferstehungsspiels«, Beiträge zur Theaterwissenschaft Südosteuropas und des mediterranen Raums, 2 Bde., Wien/Köln/Weimar 2006/o7, I I 91-226).

625 Die »Logik« der typologischen Übertragung der Höllenfahrt Christi, der wie Jonas im Bauch des Walfisches drei Tage in der Unterwelt weilte, bezieht sich bloß auf die (magische) Zahl drei und den dunklen und ungewöhnlichen Ort des Aufenthalts. 
immer neue Seinsbereiche und Wissensgebiete in den biblischen Kontext integriert worden und die Legendenbildung, die eher nach den Gesetzen der Oralität funktioniert, konnte durch eine strengere Reglementierung im quasi-logischen Verweissystem der Analogie der typologischen Übertragung kontrolliert, kanalisiert und in ihrer theologischen Glaubwürdigkeit besser fundiert werden.

Diese mystischen Entsprechungen der theologischen Typologie gehen den oralen Erzählungen und magischen Praktiken im Assoziationsnetz der Analogien des animistischen Weltbildes ab, wo die energetische Imagination und die phantastischen Kombinationen magisch-symbolischer Entsprechungen durch keine kontrollierbare Typologie in Grenzen gehalten wird und die weltbildmäßige Vernetzung aller Dinge untereinander auch kreative und originelle Zusammenstellungen erlaubt, die nur mehr sehr ungefähr miteinander zu tun haben und einen ausufernden Gesamtkontext bilden, der praktisch ohne Grenzen ist. Doch genau dieses Charakteristikum der latenten Grenzenlosigkeit entspricht der Varianz und Freiheit der Oralität, ihrer Kreativität und »Poetik«, wo in der jeweiligen Symbolik kollektive Konvention und individuelle Gestaltungsphantasie zusammentreffen. Letzlich geht es um institutionelle Kontrolle (kirchliche Kanonisierung), die aber auch den Manifestationen der Volkskultur keineswegs abgeht: Was nicht akzeptiert wird, verschwindet wieder ${ }^{626}$, und letztlich unterliegt alles Tun und Denken den Überlebensstrategien der Kommunität.

Diese Differenzen in den Verknüpfungsmodalitäten und Denkfiguren der Analogie (Typologie bzw. Assoziation) konnte für die magisch-religiösen Vorstellungen im südosteuropäischen Raum in zwei Modellen exemplarisch vorgestellt werden, die einerseits den symbolischen Kirchenraum betreffen und das, was sich in ihm abspielt, andererseits die orale Folklore und ihre Entwicklungsmodalitäten, untersucht am Beispiel zweier biblischer Gestalten, Lazarus und Judas (Freund und Feind des Herrn), die die Volksphantasie des Balkanraums in bedeutendem Maße angeregt und beschäftigt haben ${ }^{627}$ :

626 Als Beispiel seien hier die osmanischen und hellenischen Schattenspielfiguren und Dialekttypen angeführt, die weit zahlreicher gewesen sind als die, die letztlich überlebt haben; jede Vorstellung ist durch die Eingreifensmöglichkeit des Publikums in das improvisierte Spiel in Form von Kundgebungen der Zustimmung oder Ablehnung bzw. aufgrund der Erfolgsabhängigkeit der Spieler zugleich ein Selektionsprozeß, der von den Erwartungshaltungen des Auditoriums abhängt und den Spieler mehr oder weniger zum Exekutor des kollektiven Publikumswillens macht (dazu Walter Puchner, Das griechische Schattentheater Karagiozis, München 1975, neue erweiterte Ausgabe Wien 20I4). Ähnliche Kontrollprozesse für die Produktionen der Volkskultur gibt es auch auf anderen Sektoren, wie etwa dem Volkslied (vgl. Die Folklore Südosteuropas, op. cit., I 7-I 9).

627 Walter Puchner, Studien zum Kulturkontext der liturgischen Szene. Lazarus und Judas als religiöse Volksfiguren in Bild und Brauch, Lied und Legende Südosteuropas, 2 Bde., Wien I99 (Österr. Akad. d. Wiss., phil.-hist. Klasse, Denkschriften 2 I 7 ). 
das Sternmodell und das Netzmodell. Ersteres demonstriert, wie Bild, Wort und Symbolhandlung der Meßordnung im symbolischen Kirchenraum aufeinander abgestimmt sind und alles Gesagte (Gesungene)/Gehörte und Gesehene durch das Analogie-Scharnier der typologischen Übertragung in möglichst hoher Kontrolle zusammengehalten wird; alle Ausdrucksmedien der Messe rekurrieren direkt auf das kanonisierte (und apokryphe) Glaubensfundament, wobei sich jedoch Wort, Bild und Symbolhandlung z.T. ungleichmäßig entwickelt haben bzw. in unterschiedlichem Maße pagane Reste ausscheiden bzw. uminterpretieren konnten, phasenweise auch unabhängig voneinander (vor allem im ersten Jahrtausend), bis erst das theologische System der typologischen Übertragung die Feinabstimmung der Einzelmedien des Meßgeschehens aufeinander vorgenommen hat ${ }^{628}$.

Im Gegensatz dazu unterliegen die Manifestationen der Volksreligiosität der Oralkultur auch einer querverlaufenden Vernetzung der Einzelmedien (Wort, Bild, Symbolhandlung, Glaubensvorstellung), die ebenfalls auf den ekklesialen Quellenbereich rekurriert, aber keineswegs ausschließlich, sondern unmittelbar auch von einem nicht sanktionierten Seinsbereich beeinflußt wird. Dies ist bildlich eher mit einem Spinnennetzmodell darzustellen ${ }^{629}$. Der hybride Bereich von Magie und Volksreligosität macht

628 »Das dogmatische Denkschema der typologischen Übertragung aus dem sanktionierten Daten`Fundus«, wo der Anlagerungs- und Expansionsprozeß in den einzelnen liturgischen Ausdrucksmedien unabhängig voneinander vor sich geht, läßt sich etwa durch ein Stern-Modell exemplifizieren, während es bei den assoziationslogischen Bezugsnetzen, auch schon innerhalb der reinen Sakralkunst, zu einer gegenseitigen Abhängigkeit und Verknüpfung der Ausdrucksmedien kommt, was man etwa in einem Spinnennetz veranschaulichen kann. [...]. Diese Modelle sind freilich nur Konstruktionen, die der Vorstellbarkeit komplizierter Prozesse in den Kontextstrukturen zur liturgischen Szene dienen sollen; sie beanspruchen keinerlei Wahrheitswert jenseits dieser Veranschaulichungsfunktion. Sie kommen auch nicht rrein vor, sondern stellen Tendenzen dar, denen sich in der mittelalterlichen Theater->Entwicklung gewisse Stilschichten zuordnen lassen. [...] Die liturgischen Ausdrucksmedien sind einerseits durch ihre Bibelgrundlage im >Gesamtkunstwerk der Messe aufeinander abgestimmt, andererseits unabhängig in ihren Anreicherungsschüben und `Entwicklungsgeschwindigkeiten, die medienspezifisch bleiben (Fig. I) und erst in einer zweiten Phase (Fig. 2) durch querverlaufende Übernahmen ausbalanciert werden, die im volksfrommen Bereich, nicht mehr nur in der Bibel fußen. Erst die Dialektik beider Modelle der Unabhängigkeit und Abhängigkeit der liturgischen Ausdrucksmedien voneinander ergibt, in verschiedenen Dosierungen und Mischungen, historische Wirklichkeit« (Puchner, Studien zum Kulturkontext der liturgischen Szene, op. cit. I I 9 f.).

629 Das Spinnennetzmodell »deutet an, daß die entsprechenden Ausdrucksmedien (die volksfrommen Medien Brauch, Lied, Überlieferung/Legende, Sprichwort) nicht mehr ausschließlich auf die christliche Schriftgrundlage rekurrieren. [...] Waren die assoziativen (statt der typologischen) Denkmuster in den liturgischen Audrucksmedien in nuce schon angelegt (Fig. 2), vor allem was die Apokryphen betrifft und jene Traditionsstränge, die sich zeitweise der dogmatischen Kontrolle entziehen konnten (also etwa die synaxarischen Legenden, die Buchmalerei usw.), so kommen sie 
keinen Unterschied zwischen sanktionierten und nicht sanktionierten Quellengruppen, sondern benutzt das gesamte in der Umwelt und Tradition zur Verfügung stehende Hilfsinstrumentarium, um seine persönlichen und kollektiven Ziele zu erreichen. Die Verbote der Magie sind anderer Natur als die Verdikte der institutionalisierten Religion. Die Hochreligion bekämpft den »Aberglauben«, weil er sich der dogmatischen Kontrolle entzieht; der Aberglaube aber benutzt die spirituellen Hilfsmittel und sakralen Schutzfunktionen der Hochreligion, um seine Ziele zu verfolgen. Diese Dynamik von Exklusion und Inklusion ist der südosteuropäischen Pastoralpraxis deutlich inhärent. Die strenge Ausschließlichkeit der organisierten Sakralität in den monotheistischen Religionen mag den hybriden Seinsbereich der magischen Praktiken als Profanation oder Säkularisierung, ja als verwerfliche Paganität und Idolatrie deklarieren, doch aus der Sicht der Alltagsmenschen wird diese Abstufung nicht allzu häufig nachempfunden, weil Religiosität jenseits der traditionellen Kulturkonvention ganz unterschiedliche psychische oder ideologische Motivationen beim Einzelindividuum haben kann; in der Notsituation oder als metaphysische Zukunftsvorsorge greift der Mensch zu jedem habhaften Hilfsmittel ohne Ansehen seiner Herkunft. Derart ist auch der Synkretismus zwischen Gläubigen der Ostkirche und des Islams, die hybride Attitüde der Roma in Religionsfragen oder die traditionelle dreigespaltene Glaubenszugehörigkeit der Albaner zu erklären. Oder die animalen Blutopfer im geheiligten Kirchenraum mit priesterlicher Segnung; oder der Segensspruch gegen den Bösen Blick, den sich der vermeintlich Befallene vom Popen oder Imam einholt, wenn die anderen Entzauberungsmethoden versagt haben.

in der Pastoralpraxis (vor allem in Südosteruopa), als gelebte historische Wirklichkeit der kirchlichen Tradition inmitten der Volkskultur, voll zur Entwicklung. Das Verständnis der Dynamik beider Kontextstrukturen, die auf zwei unterschiedlichen Denkmodellen, Verknüpfungsweisen von Daten zu Reihen, Ketten und Netzen im Dienste der Weltbilderstellung, beruhen, scheint das Verständnis der Morphologie mittelalterlichen religiösen Theaters und neuzeitlichen religiösen Volksschauspiels zu erleichtern, das in seinen Ausformungen in unterschiedlichen Legierungen beider Kontextstrukturen verpflichtet ist. [...] Während die mittelalterliche Theologie in der Scholastik die typologische Methode perfektioniert, stellen diese Szenenagglomerate handgreiflich Weltgeschichte vor, auch Heilsgeschichte, aber immanent, realistisch, assoziativ, kumulativ, amalgamierend, alles Bestehende zu einer pluralistischen Einheit verknüpfend. Das selektierende, quasi-logische Sieb von bestätigten Vorhersagen, typologischen Übertragungen, geschlossenen Symbolsystemen, Abbild/Urbild-Relationen, dogmatisch kontrollierten Sinnzuweisungen, und in ihrer Dekadenz juridisch-spitzfindigen Ableitungen wird hier aufgebrochen und ersetzt durch ein grobmaschiges Netz von Realanalogien, Affinitäten und assoziativ-schöpferischen Innovationen, das Immanenz und Transzendenz gleichermaßen einfängt, Menschliches und Göttliches, auch Allzumenschliches, Weltgeschichte, Heilsgeschichte und persönliches Einzelschicksal, das ein anderes, in aller Grausamkeit und Naturalistik aber doch lebensbejahendes Christentum darstellt" (Puchner, Studien zum Kulturkontext der liturgischen Szene, op. cit., I 20 f.). 


\section{Schlußwort}

Über die methodologischen Vorentscheidungen, die in diesem Band getroffen wurden, gibt die Einleitung detaillierte Auskunft; dies braucht hier nicht wiederholt zu werden. Vielmehr fällt dem Schlußwort in diesem Band die Aufgabe zu, auch den Epilog zu der gesamten Trilogie zu bilden. Das logische Band der Aufeinanderfolge der Thematiken in den drei Bänden ist ebenfalls der Einleitung zu entnehmen. War der zweite Band schon voluminöser als der erste, nach Maßgabe der Tatsache, daß die orale Literatur im Balkanraum in Bezug auf die Textanzahl nicht nur umfangreicher (auch aufgrund der Varianz natürlich) sondern nach manchen Ansichten z.T. auch bedeutender gewesen ist, so ist der dritte noch stattlicher als der zweite, was seine Ursache in der Tatsache hat, daß die Verbalität eben nur einen Teil der Gesamtkultur darstellt, auch in Kulturen, wo die Oralität vorherrscht. Das Nichtgesagte kann bedeutender sein als das Ausgesprochene.

Performanz und Imagination sind Bereiche, die sich methodisch schwieriger erfassen lassen als gesprochene oder geschriebene Texte. Performativität durchzieht alle Gesellschaftsbereiche und ist gerade in den geschlossenen Dorfgesellschaften des Balkanraums omnipräsent, äußert sich allerdings in vielen und verschiedenen Manifestationen, von Riten und Bräuchen bis zur professionellen Schaustellerei und vom Rollenspiel des Alltags bis zur institutionalisierten Theateraufführung. Der Imagination hingegen sind noch schwieriger zu erfassende Phänomene anheimgestellt, wie die Glaubensvorstellungen der Dämonologie und die magischen Praktiken, die noch weite Teile der popularen Religiosität durchziehen und in einer kreativen ars combinatoria die vermeintliche Effizienz von Methoden der Intervention in mißliche Gegebenheiten gleichsam in Laborversuchen und Implementierungs-Tests prüfen; der Übergang zur eigentlichen Religiosität der Sakralinstitutionen hat sich als gleitend erwiesen.

Im ersten Teil des Bandes konnte ich auf meine langjährigen Studien und Arbeiten zu performativen Riten und ersten Theaterformen auf der Balkanhalbinsel sowohl in einem komparativen wie auch in einem entwicklungstheoretischen Ansatz zurückgreifen, im zweiten Teil hingegen war ich vorwiegend auf die Sekundärliteratur und meine Feldforschungserfahrung angewiesen, so daß hier die hellenophone Bibliographie ein gewisse Dominanz erhält; als Beispielraum wurde wiederholt das polyethnische und multireligiöse historische Thrakien herangezogen, aufgrund der günstigen Quellenlage durch die vielen Berichte der Aussiedler über die Zustände vor den Balkankriegen. Dieser Teil, der die Magie und Dämonologie betrifft, konnte ohnehin nur mehr oder weniger stichprobenartig vorgestellt werden. 
Desgleichen scheint es wenig Sinn zu haben, nochmals aufzuzählen, was in diesem Band trotz seines Titels nicht behandelt werden konnte. $\mathrm{Zu}$ ausgedehnt ist der geographische Bereich und zu weit die chronologischen Eckdaten, um Vollständigkeit zu implizieren, zu verstreut die bibliographischen Daten und Einzelstudien und zu groß die Forschungslücken, die regionenweise oder länderspezifisch bestehen; zu intensiv ist auch die Gleichzeitigkeit des Ungleichzeitigen, wo noch für Phänomene des 20. Jh.s ihr Alter bis in die hellenistische Zeit zurückreichen kann und im Bereich der Magie und Astrologie mit den ägyptischen Zauberpapyri sogar noch weiter. Insofern war das Hineinarbeiten in den Bereich der Byzantinistik unumgänglich, sollte aber auch nicht dominant werden, obwohl die Dinge hier vielfach besser aufgearbeitet sind als für die nachbyzantinische Zeit.

Im Bereich der (Volks)Religiosität wurde der Schwerpunkt auf die orthodoxe Ostkirche gelegt, wo viele Dinge der Pastoralpraxis anders gelagert sind als in den balkanischen Bereichen der Westkirche, und vor allem auch Wert gelegt auf synkretistische Phänomene in bezug auf den Islam. Das ist sicherlich ein Gebiet, in dem es noch viel aufzuholen gilt; der Großteil des südosteuropäischen Raums hat immerhin über mehrere Jahrhunderte dem Osmanischen Reich angehört. Die Komplexität und Kompliziertheit der südosteuropäischen Geschichte in der postbyzantinischen Periode ist sicherlich eine ständige methodische Belastung, weil die militärischen Auseinandersetzungen, die administrativen Gegebenheiten und die wechselnden kulturellen Einflüsse die Rahmenbedingungen abgegeben haben für Phänomene wie Performanz und Imagination. Auf der anderen Seite bewegen sich Vorstellungsbereiche wie Magie und Dämonie, Heilwissen und Volksreligiosität in einer gewissen Weise z.T. außerhalb der Geschichte und ihren Wechselfällen, sind sprachübergreifend und zu einem gewissen Grad auch religionsunabhängig, so daß Phänomene la longue durée wie etwa in der Volksmedizin oder beim Schadenszauber nicht weiter überraschen. Die Verflechtung von Schriftlichkeit und Mündlichkeit ist auch in diesem Bereich intensiv, wobei aufgrund des byzantinischen Jahrtausends das Griechische die dominante Überlieferungssprache geblieben ist.

Das thematische Ausufern war in diesem Band weniger zu umgehen als im ersten oder auch im zweiten Band und konnte nicht immer in Exkursen aufgefangen werden. $\mathrm{Zu}$ umfangreich sind die Detailangaben etwa zur Dämonologie, empirisch-therapeutischen Methoden, zur Magie und Formen der Pastoralpraxis. Konnte im ersten Teil noch ein repräsentativer Überblick gegeben werden über die Hauptformen der Performativität im in Frage stehenden Gesamtraum, so war dies im zweiten Teil nicht mehr in demselben Maße möglich, vor allem auch durch die Tatsache, daß für die theoretischen und methodischen Implikationen dieser Fragebereiche umfangreichere Erläuterungen notwendig waren. $\mathrm{Zu}$ unterschiedlich ist die Denkweise und Mentalität des animisti- 
schen Weltbildes der Volkskulturen, um einem heutigen Leser ohne weiteres zugänglich oder verständlich zu sein. Der rezenten utilitaristischen Rationalität eines szientifisch geprägten Weltbildes ist sowohl das quasi-logische Verweissystem der typologischen Übertragung in der christlichen Theologie unverständlich wie auch der assoziationslogische Verknüpfungsmodus von hypostasierten Analogien in der Totalvernetzung der Dinge im animistischen Weltbild.

Mit dem Abschluß dieses Bandes ist der Versuch einer vergleichenden Darstellung eines bedeutenden Teils der kulturellen Grundlagen der traditionellen Gesellschaften des südosteuropäischen Raums zu einem Ende gekommen. Dies gilt allerdings nur für den Verfasser dieser Zeilen, denn, wie zu hoffen bleibt, werden sich Nachfolger finden, die balkanologische Komparatistik auf dem einen oder anderen Sektor weiter voranzutreiben. Eine umfassende Darstellung, die alle Kultursparten umfaßt, ähnlich wie dies für die Geschichte des südosteuropäischen Raums vorliegt, ist trotz des sechsbändigen Regensburger Projekts, in dem Band 3 und ${ }_{4}$ Sprache und Kultur Südosteuropas umfassen, noch für längere Zeit nicht möglich, weil der Forschungsstand in den einzelnen Ländern zu unterschiedlich ist, zu verschieden auch von Kultursparte zu Kultursparte, und die Komparatistik aufgrund der Sprachschwierigkeiten und der Literaturbeschaffung in manchen Fragen noch in den Kinderschuhen steckt. Das wird sich in Zukunft aufgrund von internationalen Projekten, bilateralen Zusammenarbeiten, der Transzendierung streng nationalgeschichtlicher Forschungstraditionen und der zu erwünschenden Stabilität der zuständigen administrativ-staatlichen Instanzen in der Europäischen Gemeinschaft sicherlich bessern, aber eine systematische Editionsserie zur Komparation der einzelnen Kultursparten des südosteuropäischen Raums, ihrer Geschichte, Traditionalität und die heutigen Entwicklungen berücksichtigend, ist sicherlich noch für lange Zeit Zukunftsmusik.

Trotzdem bleibt zu hoffen, daß mit dieser Trilogie eine Art Grundstein für eine solche Entwicklung gelegt ist, die zwar fragmentarisch bleiben muß, weil ein Einzelforscher eine solche Synthese nicht mehr zu leisten imstande ist, die sich aber programmatisch der übergreifenden Komparation verschrieben hat, was auch weiterhin das vordringlichste desideratum bleibt. Sprachwissenschaftler und Historiker haben hier bereits den Weg gewiesen. Nach der Lektüre der über tausend Seiten dieser drei Bände wird der Leser mit dem Autor überzeugt sein, daß es sich bei Südosteuropa um einen teilhomogenen Kulturraum besonderer Prägung handelt, der trotz der vielen unterschiedlichen Sprachen, Religionen und Konfessionen, Staatszugehörigkeiten und einer komplizierten Historie fundamentale Gemeinsamkeiten aufweist, die ihn vom übrigen Europa unterscheiden, aber in den umfassenden Europa-Begriff des 2r. Jh.s zu intergrieren sind, sollte der Einigungsprozeß zu einem erfolgreichen Abschluß kommen wollen. Zum Erkennen der Alterität dieses geographisch und demographisch umfangreichen 
Bereichs, der in der Vergangenheit nicht immer mit den positivsten Pauschalurteilen belegt wurde (Pulverfaß Europas, Balkanisierung), jenseits der Flut von journalistischen Tagesberichten und popularwissenschaftlichen Verlagsangeboten, ist es notwendig, die unterschiedlichen traditionellen Grundlagen dieser Gesellschaften kennenzulernen, ihre Kulturleistungen in Vergangenheit und Gegenwart zu estimieren, ihre unterschiedliche Mentalität in ihren Spielarten jenseits der üblichen Heterostereotype zu begreifen und sich letztlich faszinieren zu lassen von einem differenten Europa "vor der Haustür«, von dem in unseren Schulbüchern wenig zu lesen ist.

Für das Einarbeiten in gewisse Fachbereiche wurde eine kommentierte Bibliographie in allen drei Bänden angeboten, Fachleute finden reiche bibliographische Angaben in den Fußnoten, aufgeschlüsselt auch in den Registern und in Auswahl angeboten in einer Bibliographie am jeweiligen Bandende. Für den Autor selbst ist mit dieser Trilogie auch eine lebenslange Beschäftigung mit der vergleichenden Balkanologie zum Abschluß gekommen, die er als Theaterwissenschaftler, Volkskundler/Ethnologe und Gräzist (Byzanz und Neugriechenland) ausgeübt hat. Denselben Anstoß für eine zukünftige Balkankomparatistik auf verschiedenen Sektoren der Kulturtätigkeit haben auch die Studienbände Beiträge zur Theaterwissenschaft Südosteuropas und des mediterranen Raums, 2 Bde., Wien/Köln/Weimar 2006/o7 (zusammen 800 Seiten) und Studien zur Volkskunde Südosteuropas und des mediterranen Raums, Wien/Köln/Weimar 2009 (738 Seiten) gegeben. Mit der nun vorliegenden Trilogie bilden sie zusammen ein weiteres Triptychon, das insgesamt einen massiven Impetus für die Forschung darstellt, der sicherlich nicht ohne Respons bleiben wird. 


\section{A. KOMMENTIERTE BIBLIOGRAPHIE}

Die Erforschung der performativen Aspekte der südosteuropäischen Volkskultur und der kollektiven Imaginationen folgt vorwiegend nationalen Forschungstraditionen. Grenzübergreifende Synthesen führen in den ersten Stadien der Materialkollektion über die allgemeinen Bibliographien wie die Südosteuropäische Bibliographie des Südostinstituts in München (5 Bde., München 1959-82, Berichtszeitraum 1945-70), über allgemeine volkskundliche Bibliographien wie die seit 1927 herausgegebene, $200 \mathrm{I}$ aber eingestellte Internationale Volkskundliche Bibliographie/International Folklore Bibliography/Bibliographie Internationale d'Ethnologie, zuletzt Bonn, die Zusammenfassungen der Zeitschrift Demos. Ethnographische und folkloristische Informationen, Berlin I 960-2000, die die sozialistischen Länder Europas betreute, nach der Wende jedoch alle Kleinsprachen des Alten Kontinents, oder aber über die persönlichen Publikationslisten herausragender Persönlichkeiten der Ethnologia Europaea, die dem Balkanraum besondere Aufmerksamkeit geschenkt haben, wie Leopold Kretzenbacher (I 9 1 2-2007): Helge Gerndt/Georg R. Schroubek, Vergleichende Volkskunde. Bibliographie Leopold Kretzenbacher, München/Würzburg 1 977, Gerda Möhler, Vergleichende Volkskunde. Bibliographie Leopold Kretzenbacher II, München I 989, und Leopold Kretzenbacher, Vergleichende Volkskunde Europas. Gesamtbibliographie mit Register 1936-1999, Münster etc. 2000 sowie Hermann Hummer, "Bibliographie Leopold Kretzenbacher 1999-2002«, Österr. Zeitschrift für Volkskunde LVI/I05 (2002) 403-405.

Neben den Nationalbibliographien ${ }^{1}$ bzw. den spezifisch volkskundlichen Bibliographien oder Bibliographien zu Sprachgruppen sowie den Bibliographien zur nationalen Volkskunde ${ }^{2}$ finden sich auch wörterbuchartige Kompilationen, wie Robert Elsie, $A$ Dictionary of Albanian Religion, Mythology, and Folk Culture, London 2001 oder Magyar Néprajzi Lexikon, 5 Bde., Budapest 1978-82 mit umfangreichen und systematischen bibliographischen Angaben. Von besonderem Nutzen sind auch bibliographische $\mathrm{Zu}$ sammenstellungen fremdsprachiger Literatur in den europäischen Hauptsprachen, wie die von Klaus Roth zu den orthodoxen slavophonen Ländern des Balkanraums (South Slavic Folk Culture. A Bibliography of Literature in English, German, and French on Bos-

I Z.B. Odile Daniel, Albanie, une bibliographie historique, Paris 1985.

2 Vgl. den bibliographischen Teil in Walter Puchner, Die Folklore Südosteuropas, Wien/Köln/Weimar 2016. 
nian-Hercegovinian, Bulgarian, Macedonian, Montenegrin and Serbian Folk Culture, compiled and edited by Klaus Roth and Gabriele Wolf with the cooperation of Tomislav Helebrant, Columbus, Ohio r 994, mit 7654 items) sowie die von Walter Puchner zu Griechenland, Zypern, Kleinasien und der griechischen Diaspora (Greek Folk Culture. A Bibliography of Literature in English, French, German, and Italian on Greek Folk Culture in Greece, Cyprus, Asia Minor (before I922), and the Diaspora (up to 2000), compiled and edited by Walter Puchner, with the collaboration of Manolis Varvounis, Athens 20 I I, mit 7820 items).

Ein weiterer Zugang führt über die generellen Einführungen in nationale Volkskulturen wie die von Iván Balassa und Gyula Ortutay in die ungarische Volkskultur (Ungarische Volkskunde, Budapest/München 1982) oder von Christo Vakarelski in die bulgarische (Bulgarische Volkskunde, Berlin 1969 ausführlicher Bălgarski folklor, Sofija 1974), Robert Elsie, Handbuch zur albanischen Volkskultur. Mythologie, Religion, Volksglaube, Sitten, Gebräuche und kulturelle Besonderheiten, Wiesbaden 2002 (englisch 2001), Adrian Fochi (ed.), Bibliografia generală u etnografiei și folclorul românesc I (I800-I89I), București 1968 und die Forschungsberichte von dems., »Recherches et folklore comparée sud-est européen en Roumanie (XIX ${ }^{\mathrm{e}}$ siècle première moitié du XX $\mathrm{XX}^{\mathrm{e}}$ siècle)«, Revue des études sud-est européennes 6 ( ( 1968 ) I I 3-I 42, 7 (1969) 367-396. Dazu treten spezifischere Übersichten zu Sektoren der Volkskultur, die für diesen Band von besonderer Relevanz sind, wie z.B. die von Geza Róheim, Néphit és Népszojások, Budapest 1925 zu Volksglaube und Volksbrauch, oder Edmund Schneeweis, Serbokroatische Volkskunde. I. Volksglaube und Volksbrauch, Berlin I96r. Zu spezifischeren thematischen Bibliographien vgl. die kommentierten Bibliographien zum Ersten und Zweiten Teil in der Folge. Vergleichende Ansätze finden sich allerdings auch in spezifischen grenzübergreifenden

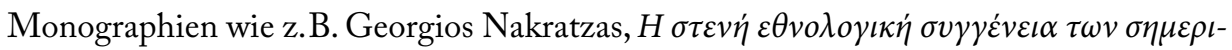

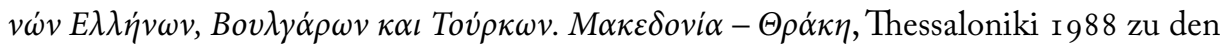
historischen Kulturlandschaften Makedonien und Thrakien.

\section{KOMMENTIERTE BIBLIOGRAPHIE ZUM ERSTEN TEIL}

Auf dem Sektor der Masken- und Volksschauspielforschung liegen aufgrund des Vorhandenseins älterer Forschungstraditionen auch großräumigere Vergleiche in Form von Sammelbänden oder Einzelmonographien vor, ließen sich die Phänomene der ritualhaften Verkleidung und die rudimentäre Darstellung archetypischer Szenen doch als survivals altthrakischer, dakischer, dionysischer, altslavischer oder altgriechischer Herkunft in die nationalen Geschichtsmythologeme in indizierender Funktion integrieren. Dem entsprach im mittel- und westeuropäischen Bereich die Interessensdominanz an Ursprungsfragen vor und nach der Jahrhundertwende von I 900, die dann später von 
einer horizontal-flächendeckenden balkanologischen Komparatistik abgelöst wurde, als sich in Sprachwissenschaft und Historiographie Südosteuropa als eigenständiger Kommunikationsraum etabliert hatte. Aufgrund der historischen Bindungen waren hier vor allem mitteleuropäische Forschungstraditionen am Werk. Hier ist zu erwähnen der Sammelband von Robert Wildhaber (ed.), Masken und Maskenbrauchtum in Ost- und Südosteuropa, Basel 1968 mit Übersichtsbeiträgen aus vielen südosteuropäischen Ländern, der auch nach Osten ausgreifende Sammelband von Leopold Schmidt, Masken in Mitteleuropa, Wien 1955; Beiträge aus dem Südosten finden sich auch im Sammelband dess. (ed.), Le théâtre populaire Européen, Paris 1965 . Neueren Datums ist die Übersicht von Walter Puchner, »Performative Riten, Volksschauspiel und Volkstheater in Südosteuropa. Vom Dromenon zum Drama«, Studien zur Volkskunde Südosteuropas und des mediterranen Raums, Wien/Köln/Weimar 2009, 253-298 (sowie auch andere Kapitel in diesem Studienband) sowie mehrere Kapitel aus der zweibändigen Studienkollektion Beiträge zur Theaterwissenschaft Südosteuropas und des mediterranen Raums, 2 Bde., Wien/ Köln/Weimar 2006/o7, die performative Riten, Maskenwesen und Volksschauspiel betreffen. Komparative Versuche kommen jedoch auch aus dem südosteuropäischen Raum selbst, wie z.B. das Buch von Dragoslav Antonijević, Dromena, Beograd r 997: unter dromena mit Maske (27-108) bringt er aus Griechenland das Kalogeros-Spiel, die Glockenverkleidung auf Skyros u.a., aus Serbien die koledari und arapi, aus Makedonien die Čamalari, aus Bulgarien die kukeri und survakari, verschiedene Maskenformen aus Rumänien; bei den verbalen dromena (Iog ff.) dominieren die Lazarinen-Umzüge mit Puppe und das Schattentheater; unter dem Titel »Semiotische dromena« ( 175 ff.) wird die hypothetische Strukturentwicklung zum Theater hin reproduziert, die ich seinerzeit vorgelegt hatte ${ }^{3}$. Eine ähnlich komparative Zusammenstellung von Material hatte schon Ritualni trans, Beograd I 992 gebracht, wo die Feuertänzer der griechisch-bulgarischen anastenaria/nestinari vorgestellt werden, die ekstatischen Bräuche der serbisch/aromunischen padalice/kraljice sowie die akrobatischen Trancetänze der rumänischen căluşarii ${ }^{4}$. Vgl. auch den von ihm herausgegebenen Sammelband Folklorni teatar u balkanski i podunavskim zemljama, Beograd 1984.

Verschiedenen Aspekten der südosteuropäischen Volkskultur ist die Monographie von Walter Puchner, Studien zum Kulturkontext der liturgischen Szene. Lazarus und Ju-

3 Das reproduzierte Graphem zuerst in Walter Puchner, Brauchtumserscheinungen im griechischen Jahreslauf und ibre Beziehungen zum Volkstheater. Theaterwissenschaftlich-volkskundliche Querschnittstudien zur südbalkan-mediterranen Volkskultur, Wien 1977 (Veröffentlichungen des Österr. Museums

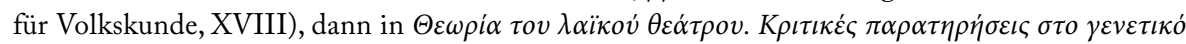

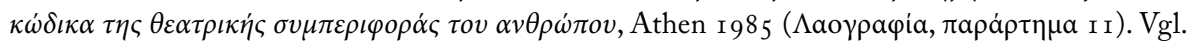
auch meine Anzeige in Laografia 40 (2004-2005) I I08-I I I I. 
das als religiöse Volksfiguren in Bild und Brauch, Lied und Legende Südosteuropas, 2 Bde., Wien r 99I (Österr. Akad. d. Wiss., phil.-hist. Klasse, Denkschriften 2 I6) gewidmet sowie die Bände 2 und 3 der volkskundlichen Serie dess., $\Sigma v \gamma \kappa \rho \iota \tau \iota \kappa \eta ่ ~ \Lambda \alpha o \gamma \rho \alpha \varphi i \alpha$, Athen $2009^{5}$. Materialien aus verschiedenen Teilen des Balkanraums finden sich auch in ethnographischen Autopsien vor dem Zerfall des Osmanischen Reiches, wie z.B. in den Arbeiten von A. J. B. Wace, "North Greek Festivals and the Worship of Dionysos", The Annual of the British School in Athens 16 (r 909/ro) 232 ff., ders., "Mumming Plays in Southern Balkan", The Annual of the British School in Athens I9 (1912/13) $248 \mathrm{ff}$. und A. J. B. Wace/M. S. Thompson, The Nomads of the Balkans, London I 9 I 4. Vgl. auch P. Caraman, Obręzed kolędowania u Stowien i u Rumunów, Kraków 1933 und manche Kapitel aus Waldemar Liungman, Traditionswanderungen Euphrat-Rhein, 2 Bde., Helsinki I 937 (FFC I I 8, I I 9). Sprachübergreifend sind auch manche Spezialbibliographien, wie die zum Feuerlauf der anastenaria/nestinari (Walter Puchner, »Beiträge zum thrakischen Feuerlauf (Anastenaria/Nestinari) und zur thrakischen Karnevalsszene (Kalogeros/ Kuker/Köpek Bey). Anmerkungen zur Forschungsgeschichte und analytische Bibliographie«, Zeitschrift für Balkanologie I 7, I 98 I , 47-75) oder zum osmanischen und griechischen Schattentheater in Südosteuropa (Vikton perdeyi eyledin vilan/Torn is the curtain, shattered is the screen the stage all in ruins: Yapı Kredi Karagöz Koleksiyonu/Yapı Kredi Karagöz Collection (Collectif), Istanbul 2004, Peri Efe [ed.], Hayal perdesinde ulus, değisim

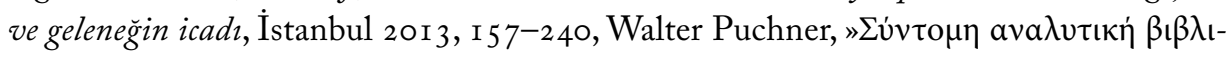

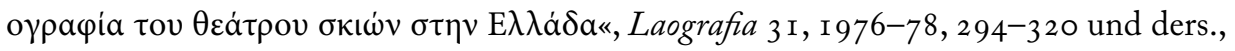

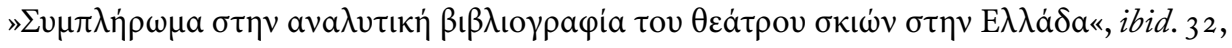

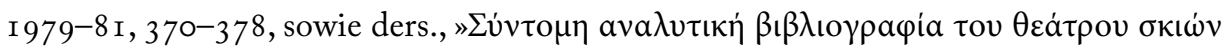

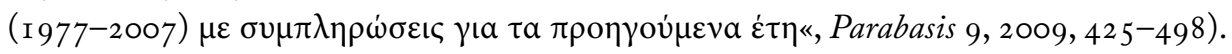
In Einzelmonographien von Leopold Kretzenbacher finden sich ganze Kapitel, die Performanz und Imagination südosteuropïascher Länder betreffen; indizierend seien an dieser Stelle erwähnt: Kynokephale Dämonen südosteuropäischer Volksdichtung. Vergleichende Studien zu Mythen, Sagen, Maskenbräuchen und Kynokephaloi, Werwölfen und südslawischen Pesoglavi, München r 968, Teufelsbündner und Faustgestalten im Abendlande,

5 Balkankomparative Studien enthalten jedoch auch die anderen Bände: zur theoretischen Volks-

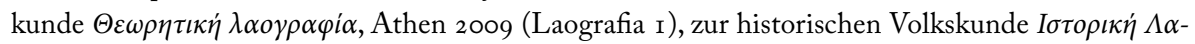

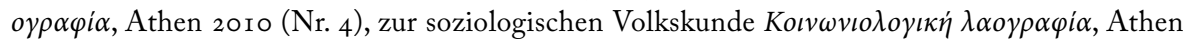

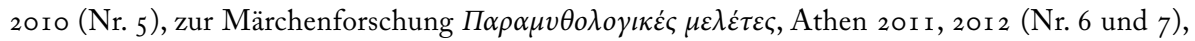

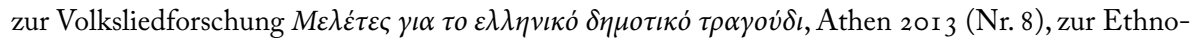

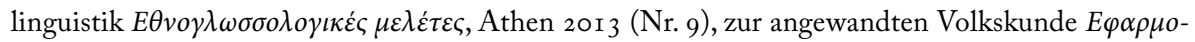

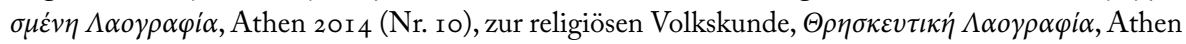

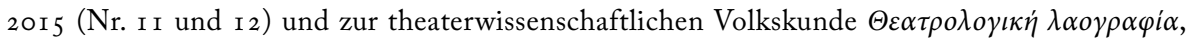
Athen 2016 (Nr. I3 und 14 ). 
Klagenfurt I 968, Rituelle Wablverbrüderung in Südosteuropa, München I 97 I, Ethnologia Europaea. Studienwanderungen und Erlebnisse auf volkskundlicher Feldforschung im Alleingang, München 1 986, Geheiligtes Recht. Aufsätze zu einer vergleichenden rechtlichen Volkskunde in Mittel- und Südosteuropa, Wien/Graz/Köln r 988. Auch einzelne Spezialstudien haben grenzübergreifend-komparativen Charakter, wie z. B. Walter Puchner, "Improvisierte Gerichtsspiele und karnevaleske Schauprozesse in der Volkskultur des Zentralbalkans und des hellenophonen Mittelmeerraums", Südost-Forschungen 63/64 (2004/05) 2 I I-23I.

Dennoch verbleiben die meisten Arbeiten im Rahmen nationaler Grenzziehungen und dominanzsprachlicher Kommunikationsräume. Einer der am besten erforschten Sprachräume in Bezug auf Verkleidung und Volksschauspiel ist der magyarische Bereich. Vgl. die vergleichenden Übersichten von Tekla Dömötör, A zujkori szinjátzsás kialakulása kelet-Európában, Budapest I 964, dies., A népi szinjátsás Európában, Budapest I 966, die volkskundlichen Einführungen von Gyula Ortutay, Kleine ungarische Volkskunde, Budapest I 963 (ungarisch I 958), Thekla Dömötör, Ungarische Volksbräuche, Budapest 1972 und Ivan Balassa/Gyula Ortutay, Die ungarische Volkskunde, Budapest/ München I 982 ; spezifischer ist die mehr theaterwissenschaftlich orientierte Monographie von Nora A. Tahy, Das theatralische Brauchtum des ungarischen Sprachbereichs, Frankfurt/M. I989, die zweibändige Materialsammlung zu Volksbräuchen und Schauspielen von Zoltán Ujváry, Népszokások és szinjátétok, 2 Bde., Debrecen I 979/8 I, sein dreibändiges Maskenbuch Játék és maszk, 3 Bde., Debrecen I 983, zu Kalenderfesttagen und Volksschauspiel von Tekla Dömötör, Naptári ünnepek - népi színjátzsás, Budapest I 979, Jahreslaufkaleidoskope wie das von Sándor Bálint, Az esztendö néprajza, Budapest I 942 und ders. Ünnepi kalendárium, 2 Bde., Budapest 1977 usw. In Ungarn gibt es jedoch auch eine Reihe von Arbeiten, die performative Ritualformen unter dem Aspekt der Schauspielkunst und der Dramatik untersuchen: Linda Dégh, A magyar népi szinjátszásról, Budapest I 939, dies., A szinjátszás kutatása, Budapest i 947, Ferenc Hont, Az eltünt magyar szinjátszás, Budapest ı 940, Tibor Kardos/Tekla Dömötör, Régi magyar drámai emlékek, 2 Bde., Budapest I 96o, historisch orientiert Zsolt Alszeghi (ed.), Magyar drámai emlékek a középkorbol Benneyeig XVI-XVIII. szászad, Budapest I 9 I4, Sammelanleitungen zum Volksschauspiel János Manga, Tájékosztato szinjátékszerü népszokások gyüjtéséhez, Budapest I 953, ältere Materialkompilationen wie Resö Ensel, Magyarországi népszokások, Pest I 866 und István Volly, Népi játétok, Budapest I 938, aber auch ästhetisch-theoretische Ansätze wie Vilmos Voigt, „A folklor esztétikája«, $A$ magyar folklor, Budapest 1979 .

Vielfältig sind die Arbeiten auch im südslavischen Bereich. Für Slovenien sind die systematischen Monographien von Niko Kuret weiterhin ausschlaggebend: Maske slovenskib pokrajin, Ljubljana I 984 und Slovenska koledniška dramatika, Ljubljana I986; 
vgl. auch die komparative Monographie Ziljsko štehvanje in njegov evropski okvir, Ljubljana 1963. Für Binnenkroatien und den dalmatinischen Küstenbereich mit reichem Feldforschungsmaterial theoretisch überarbeitet Ivan Lozica, Izvan teatra. Teatrabilni oblici folklora u Hrvatskoj, Zagreb $1990^{6}$, die systematische Bestandsaufnahme von Karnevalsformen einst und jetzt in ders., Hrvatski karnevali, Zagreb r 997 und zu Formen des Volksschauspiels (mit Texten), Folklorno kazaliste (Zapisi i tekstovi), Zagreb 1 $996^{7}$. Vgl. daneben auch Tvrtko Čubelić, Usmena narodna retorika i teatrologija, Zagreb 1970 und die älteren Brauchzusammenstellungen bei Milovan Gavazzi, Godina dana brvatskih običaja, 2 Bde., Zagreb 1939 sowie Nikola Bonifačić-Rožin et al., Narodne drame, poslovice $i$ zagonetke, Zagreb 1963 .

Für Serbien dominieren nach der Bestandsaufnahme von Vuk Stefanović Karadžić, Život i običaji naroda srpskoga, Beč I 867 (Beograd I957), die neueren Arbeiten, wie die von Mile Nedeljković, Godišnji običaji u Srba, Beograd i 99o. Besonderer Erwähnung bedarf jedoch die ausgezeichnete systematische Monographie (mit Verbreitungskarten, älteren und rezenten Photographien, Bibliographie usw.) von Vesna Marjanović, Maske, maskiranje i rituali u Srbiju, Beograd 2008, die unveröffentlichte Materialien aus dem ethnographischen Museum der Vojvodina in Novi Sad bringt sowie unveröffentlichte Photographien aus der Photothek, die Maskierungsformen bis in die Gegenwart verfolgt (Studentenproteste, Kinderball) und theoretische und semiotische Analyseansätze aufweist. Eine der repräsentativsten Arbeiten für Bulgarien ist die von Stojan Rajčevski/ Valerija Fol, Kukerăt bez maskata, Sofija 1993 (engl. summary), rezente Erhebung von Daten der 7oer und 8oer Jahre, wobei sich das »ohne Maske« auf das Fehlen von Holzmasken bezieht ${ }^{8}$. Vgl. auch Georg Kraev, Bălgarski maskaradni igri, Sofija 1996. Ältere Materialsammlungen und Überblicke sind die von K. Šapkarev, Russalii, dreven i tvărde interesen bălgarskij običaj, zapazen i do dones v južna Makedonija, Plovdiv I 884, Dimităr Marinov, Narodna vjara i religiozni narodni običai, Sofija I9I4, Mihail Arnaudoff, Die bulgarischen Festbräuche, Leipzig I 9 I 7 usw.

Besser systematisiert präsentiert sich die rumänische Masken- und Volksschauspielforschung: vgl. z.B. das einschlägige Lexikon von Ion Ghinoiu, Obiceiuri populare de peste an. Diç̦ionar, București 1997. Unmethodisch ist Horia Barbu Oprișan, Teatru fără scenă. Evocări ale unor spectacole, personaje și interpreti ai teatrului popular românesc, $\mathrm{Bu}-$ curești 198 I, der aus älteren Arbeiten exzerpiert (vor allem D. C. Ollanescu, Teatrul la

6 Vgl. meine Anzeige in Südost-Forschungen 53 (1994) 487-489.

7 Vgl. die Anzeigen in Österreichische Zeitschrift für Volkskunde LIII/IO2 (I 999) 239-243. Vgl. auch ders., Poganska baština, Zagreb 2002.

8 Die Ausführungen zum Rekurs der Maskierungen auf ein altthrakisches Substrat muten heute etwas antiquiert an (vgl. meine Anzeige Südost-Forschungen 53, 1994, 534-536). 
români, partea I, București I 895/96 und Theodor T. Burada, Istoria teatrului în Moldova, I, Iași I 9 I 5) und Aufführungstexte fragmentarisch wiedergibt (vor allem das Herodesspiel, »Irod«, aus Tudor Pamfile, Sărbătorile la români, Crăciunul, București I 9 I 4 und G. Dem. Teodorescu, Poesii populare române, București I 885); die etwas impressionistische Darstellung umfaßt sowohl colinde-Umzüge mit und ohne Verkleidung, Maskenfiguren wie auch Rollenparts und Dialoge aus elaborierten populären Theatervorstellungen. Ähnlich unmethodisch auch Mihail Vulpescu, Irozii, papuşile, teatrul țărănesc al vicleimului, caloialului și paparudele, București I 94I. Grundlegend ist weiterhin Vasile Adăscăliței, Teatrul folkloric, Iași I 969 sowie der materialreiche Artikel von Gheorghe Vrabie, »Teatrul popular romînesc", Studii și cercetări de istorie literară și folclor 6/3-4 ( 957 ) 485-562 und die Monographie von Romulus Vulcănescu, Măștile populare, București i 970 .

Für Griechenland grundlegend sich die Einführungen von Georgios A. Megas, E $\lambda$ -

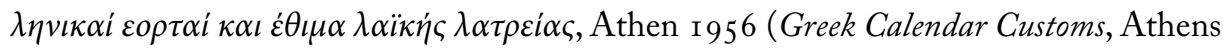

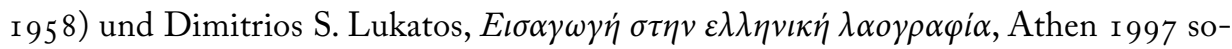

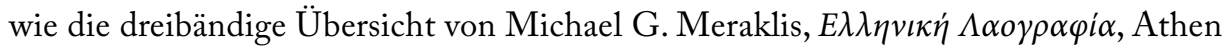
I 985-92 (einbändig 2004); weiters die Materialsammlung und Systematik von Geor-

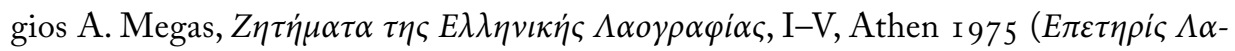

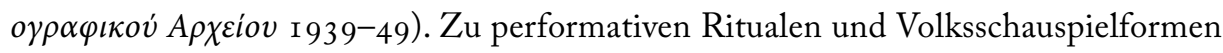
unter theatertheoretischen Aspekten Walter Puchner, Brauchtumserscheinungen im griechischen Jahreslauf und ibre Beziehungen zum Volkstheater. Theaterwissenschaftlich-volkskundliche Querschnittstudien zur südbalkan-mediterranen Volkskultur, Wien 1977 (Veröffentlichungen des Österr. Museums für Volkskunde, XVIII). Zur Türkei vgl. vor allem Metin And, A history of theatre and popular entertainment in Turkey, Ankara 1963/64.

Speziell zum Puppen- und Schattentheater vgl. die Darstellung von Metin And, $K a-$ ragöz. Turkish Shadow Theatre, Ankara 1975 und vergleichend Dünyada ve Bizde Gölge Oyunu, Ankara I 977. Zum balkanisch-osmanischen Karagöz den materialreichen Artikel von Dragoslav Antonijević, »Karađoz«, Gradska kultura na Balkanu (XV-XIX vek), Beograd I 984 (Balkanološkog instituta SANU, 2 I) 395-4I 2, zum griechischen Karagiozis Walter Puchner, Das neugriechische Schattentheater Karagiozis, München 1975 (erw. Neuausgabe Wien 20I4). Zu Blüte und Verfall des osmanischen Schattentheaters in Südosteuropa vgl. Walter Puchner, Oı $\beta \alpha \lambda \kappa \alpha v \iota \kappa \varepsilon ́ \varsigma \delta \iota \alpha \sigma \tau \alpha \dot{\sigma \varepsilon \varepsilon \iota \varsigma ~ \tau o v ~ K \alpha \rho \alpha \gamma \kappa \iota o ́ \zeta \eta, ~ A t h e n ~}$ I 985 und ders., „Das osmanische Schattentheater auf der Balkanhalbinsel zur Zeit der Türkenherrschaft. Verbreitung, Funktion, Assimilation«, Südost-Forschungen 56 ( I 997) I 5 I-I 88. Zu Maskenwesen und Volksschauspiel auf der Balkanhalbinsel auch ders., $\Lambda \alpha$ -

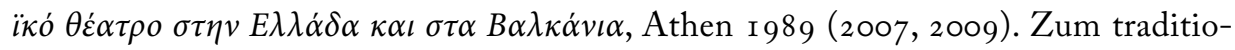
nellen Puppentheater speziell die einschlägigen Kapitel bei John MacCormick/Benny Pratasik, Popular puppet theatre in Europe, I800-I8I4, Cambridge I 998, zu rituellen 
Vorformen Walter Puchner, »Primitividole und Idolbestattung auf der Balkanhalbinsel (zur rituellen Frühgeschichte des Puppentheaters)«, Acta Ethnogaphica Academiae Scientiarum Hungaricae 34 (1986-88) 229-244. Zum nordbalkanischen Krippenspiel und Herodeskasten indizierend L. Köldu, »Krippenspiel «, Ethnographia 69 (I958) 209-259, zum griechischen Fasulis Walter Puchner, Fasulis. Griechisches Puppentheater italienischen Ursprungs aus der zweiten Hälfte des I9. Jahrhundert, Bochum I 978 (Puppenspielkundliche Quellen und Forschungen 2).

Zum Abschnitt »Spiel und Sport« vgl. die einschlägigen Kapitel zum Reiterbrauch bei Leopold Kretzenbacher, Ringreiten, Rolandspiel und Kufenstechen. Sportliches Reiterbrauchtum von heute als Erbe aus abendländischer Kulturgeschichte, Klagenfurt I 966 sowie Walter Puchner, »Südost-Belege zur sgiostra : Reiterfeste und Lanzenturniere von der kolonialvenezianischen Adels- und Bürgerrenaissance bis zum rezenten heptanesischen Volksschauspiel«, Schweizer. Archiv für Volkskunde 75 (I 979) I-27 und ders., »Zum Ritterspiel in griechischer Tradition«, Byzantinische Zeitschrift 9I (I 998) 435-470.

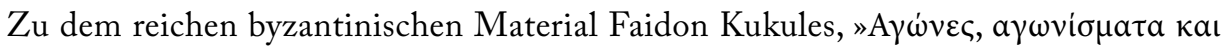

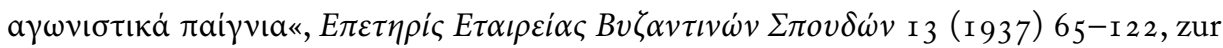
griechischen Bestandsaufnahme des Kinderspiels Dimitrios Lukopulos, Пoı $\pi \alpha \iota \gamma v i \delta \iota \alpha$

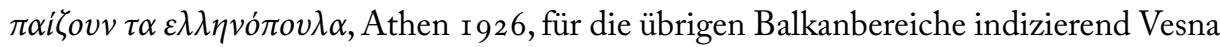
Marjanović, Tradicionalne dečje igre u Vojvodini, Novi Sad 2005.

Zum Abschnitte "Magische Praktiken und empirische Therapeutik« existieren auch

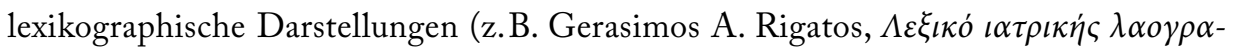
pias, Athen 2005) und großräumige Übersichten (z.B. Phyllis M. Kemp, Healing Ritual. Studies in the Technique and Tradition of the Southern Slavs, London I 935, I940, reprint I 987 , Petra Himstedt-Vaid, „Volksglaube auf dem Balkan«, Handbuch Balkan, ed. Uwe Hinrichs, Thede Kahl, Petra Himstedt-Vaid, Wiesbaden 2014, 69 I-723), kulturanthropologische Feldstudien (John Miles Foley/Barbara Kerewsky Halpern, »The Power of the Word. Healing Charms as an Oral Genre«, Journal of American Folklore 91, I 978 , 903-924, dies., "Bajanje: Healing Magic in Rural Serbia«, P. Morley/R. Wallis (eds.), Culture and Curing. Anthropological Perspectives on Traditional Medical Beliefs and Practices, London/Pittsburgh, Penn. I 979, 40-56), sprachnationale Darstellungen (z.B. J. L. Conrad, "Magic Charms and Healing Rituals in Contemporary Yugoslavia", Southeastern Europe 10/2, I983, 99-1 20, ders., "Bulgarian Magic Charms: Ritual, Form, and Content «, Slavic and East European Journal 3 I/4, I 987, 548-562) oder auch geographisch begrenztere Fallstudien, die den Übergang zur wissenschaftlichen Medizin und dem staatlichen Gesundheitswesen dokumentieren (z. B. Richard \& E. Blum, Health and Healing in Rural Greece. A Study of Three Communities, Stanford I965, dies., The Dangerous Hour. The Lore of Crisis and Mystery in Rural Greece, London 1970). Von besonderem Interesse und Materialreichtum sind die Studien aus Rückzugsgebieten wie Hercegbosna 
(in Auswahl: M. F. Kolinović, »Volksaberglaube und Volksheilmittel bei den Mohammedanern Bosniens und der Hercegovina«, Wissenschaftliche Mittheilungen aus Bosnien und der Hercegovina 7 ( I 900) 339-366, K. L. Lübeck, »Die Krankheitsdämonen der Balkanvölker«, Zeitschrift des Vereins für Volkskunde 8, [I 898] 24 I-249, 379-389, 9 [I 899] 58-68, I 94-204, 295-304, vgl. auch den übersetzten Nachdruck, A. Kristić, „Fragmente aus der Volksmedizin Bosniens und der Herzegowina «, Elfriede Grabner [ed.], Volksmedizin. Probleme und Forschungsgeschichte, Darmstadt I967, 345-36r), aber auch Serbien (Stanoje M. Mijatović, »Narodna medicina Srba seljaka u Levču i Temniću«, Srpski etnografski zbornik I 3, I 909, 259-482) und weiteren Gebieten des ehem. osmanischen Balkans (Berhard Stern, Medizin, Aberglaube und Geschlechtsleben in der Türkei. Mit Berücksichtigung der moslemischen Nachbarländer und der ehemaligen Vasallenstaaten, 2 Bde., Berlin I 903). Neuere Darstellungen mit differenter Methodologie gehen dabei auch der Geschichte dieser Praktiken nach (z. B. Alice-Mary M. Talbot, Faith-Healing in Late Byzantium, Brooklin, Mass. I 983) und betreffen geographische Bereiche von Slovenien bis Griechenland (Vinko Möderndorfer, Ljudska medicina pri Slovencih, Ljubjana I 964, Ljubinko Radenković, Narodna bajanja kod Južnib Slovena, Beograd i 996, Omiros Mavrides, Gesundheitsmagie in West-Thrakien. Ein Beitrag zur griechischen Volksmedizin, Diss.

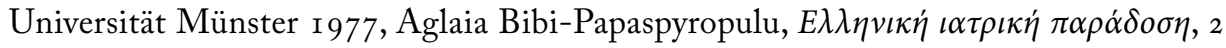
Bde., Athen 1989); dabei wird oft die spezifische Rolle der Frau unterstrichen (Gabriella Schubert, "Die Frau in der Volksheilkunde auf dem Balkan«, Norbert Reiter (ed.), Die Stellung der Frau auf dem Balkan, Wiesbaden I 987, 2 I 9-23 I) oder es werden auch systematische semiotisch-strukturelle Analysen der Heil- und Zaubersprüche angestellt (z.B.

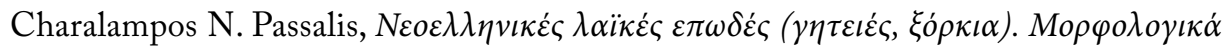

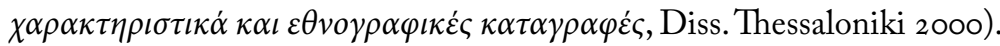

KOMMENTIERTE BIBLIOGRAPHIE ZUM ZWEITEN TEIL

Bezüglich magischer Vorstellungen und Zauberpraktiken, Mantik, Prophezeiung und Orakel, Dämonologie und Prophylaktik, und der von der Theologie oft abweichenden Pastoralpraxis und ihren Sonderformen existieren auch systematische Darstellungen vor allem bezüglich altslavischer Mythologie in Form von Enzyklopädien und Bibliographien, die wegen ihrer Hypothetik manchmal mit Vorsicht zu benützen sind: Mark Kulikowski, A Bibliography of Slavic Mythology, Columbus, Ohio I 989, Anani Stojnev (ed.), Bălgarska mitologija, Enciklopedičen rečnik, Sofija I 994, Svetlana M. Tolstoj/Ljubinko Radenković, Slovenska mitologija, Enciklopedijski rečnik, Beograd 200 I, Špiro Kulišić, Srpski mitološki rečnik, Beograd I 970, sowie die materialreiche Darstellung von Max Lambertz, »Die Mythologie der Albaner«, Hans Wilhelm Haussig (ed.), Wörter- 
buch der Mythologie, I. Abt. Bd. II. Götter und Mythen im Alten Europa, Stuttgart I 973, 455-509, dort auch Norbert Reiter, "Mythologie der alten Slaven«, ibid. I65-208 (in neuerer erweiterter Fassung ders., Das Glaubensgut der Slawen im europäischen Verbund, Wiesbaden 2009); vgl. auch Romulus Vulcănescu, Mitologie română, București I 985 usw. In ihrer Intention, die nichtchristliche Seite der rezenten Volkskultur herauszustreichen, umfassen sie oft auch weite Teile kollektiver Imaginationen der Dämonologie, die allerdings in einer hybriden Gemengelage mit der Volksfrömmigkeit und der dörflichen Pastoralpraxis anzutreffen sind (vgl. z.B. Paul Wiertz, »Zur religiösen Volkskultur der orientalischen und orthodoxen Kirchen - Volksglauben und Volksbrauch«, Handbuch der Ostkirchenkunde, Düsseldorf I 97 I, 569-632). Diese Gemengelage ist etwa bei den vom Priester gesegneten blutigen Tieropfern im Kirchenbereich gegeben (dazu die vor-

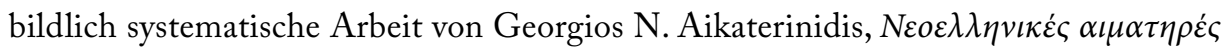

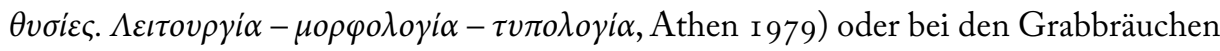
(zur konstanten Tradition seit der Antike vgl. die klassische Monographie von Margaret Alexiou, The ritual lament in Greek tradition, Cambridge i 974, erw. Aufl. von Dimitrios Yatromanolakis und Panagiotis Roilos, Lanham/Boulder/New York/Oxford 2002). Unschätzbar sind die älteren Arbeiten von Friedrich Salomo Krauss, Volksglaube und religiöser Brauch der Südslaven, Münster I 890 und Slavische Volksforschungen, Leipzig I 9o8, da sie vormoderne kollektive Imaginationen aufnehmen und beschreiben.

Zur Dämonologie gibt es eine ganze Reihe von Arbeiten (in Auswahl: Milena Benovska-Săbkova, Zmejat v bălgarskija folklor, Sofija I 992 [I 995], Tanas Vražinovski, Narodna demonologija na makedoncite, Skopje I 995, P. Ljubenov, Samovili i samodivi, Sofija I 89 I, Josip Moroz, Ženski demonični obrazi v bălgarskija folklor i vjarvanija, Sofija

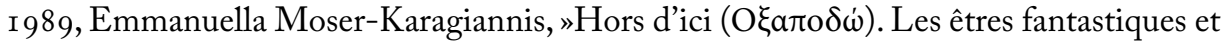
la parole dans les légendes populaires grecques. I. Xotika (Anaskelades, Arapides, Chamodrakia (Smerdakia, Telonia), Drakoi, Gorgones, Kalikantzaroi, Néraïdes, Stoicheia, Vrachnades). A. Le Kalikantzaros", Littérature orale de la Grèce moderne. Revueil d'études, Athènes 2005, 263-450, Éva Pócs, Fairies and Witches at the Boudary of South-Eastern and Central Europe, Helsinki 1989 (FFC 243), vergleichend Dagmar Burkhart, „Vampirglaube in Südosteuropa«, Kulturraum Balkan. Studien zur Volkskunde und Literatur Südosteuropas, Berlin/Hamburg I 989, 65-ıо8, Ute Dukova, „Die Bezeichnung der Dämonen im Bulgarischen«, Balkansko ezikoznanie/Linguistique balkanique 26/4 (I983) 5-47, 27/2 [1984]5-50, 28/2 [1985]5-62, Wilhelm Lettenbauer, »Über Krankheitsdämonen im Volksglauben der Balkanslaven«, Serta Monacensia. FS Franz Babinger, Leiden I 952, I 20-I 35, Ivanička Georgieva, Bălgarska narodna mitologija, Sofija I 983 [2 ${ }^{2}$ 993], zur Metamorphose des altgriechischen Charon zum neugriechischen Charos Dirk C. Hesseling, Charos. Ein Beitrag zur Kenntnis des neugriechischen Volksglaubens, Leiden/Leipzig I 897, zur byzantinischen Dämonologie Perikles-Petros Ioannou, Dé- 
monologie populaire - démonologie critique au XIe siècle, Wiesbaden I 97 I, zu den ein-

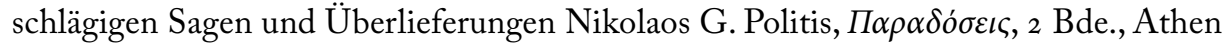
I 904 sowie Einzelkapitel in den Miszellen dess., $\Lambda \alpha o \gamma \rho \alpha \varphi \iota \kappa \dot{\alpha} \Sigma v ́ \mu \mu \varepsilon \iota \kappa \tau \alpha, 3$ Bde., Athen I 920/2 I und I93 I, zu neueren methodischen Ansätzen vgl. Charles Stewart, Demons and the Devil: Moral Imagination in Modern Greek Culture, Princeton I 99 I, zu Abwehr-

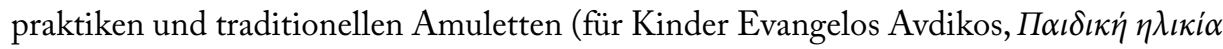
$\kappa \alpha \iota \delta \iota \alpha \beta \alpha \tau \dot{\eta} \rho \iota \varepsilon \varsigma \tau \varepsilon \lambda \varepsilon \tau \varepsilon \dot{\varepsilon}$, , Athen 20 г 2, Joseph Freiherr v. Hammer-Purgstall, Talismane der Muslimen, Wien I 9 I4), ebenso wie zu allen Formen der Zauberei und Mantik (Veselin Čajkanović, Sabrana dela iz srpske religije i mitologije u pet knjiga, Beograd I 994, Sreten Petrović, Mitologija, magija i običaji, Beograd r 992, Henry Maguire [ed.], Byzantine Magic, Washington D. C. I995).

Reichhaltige Literatur existiert auch zu rezenten Vorstellungen wie dem Bösen Blick (zu den parallelen antiken Vorstellungen Frederick Thomas Elworthy, The Evil Eye: The Classic Account of an Ancient Superstition, New York 2004 [London I 895], Petru Caraman, Descolindatul în orientul și sud-estul Europei, Iași I 997 [Diss. I 939], Christina

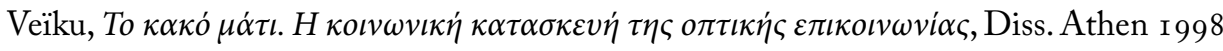
[42004] usw.), aber auch zum Wallfahrtswesen (z.B. zur Tinos-Wallfahrt Jill Dubisch, In a Different Place: Pilgrimage, Gender, and Politics at a Greek Island Shrine, Princeton I 995, Svetla Gjurova (ed.), Kniga za bălgarskite chadžii, Sofija I 995, zu den Mini-Kapel-

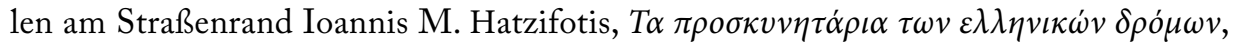
Athen r 986; unverzichtbar sind immer noch die Feldforschungsarbeiten von Rudolf Kriss und Hubert Kriss-Heinrich, Peregrinatio Neohellenika. Wallfabrtswanderungen im heutigen Griechenland und in Unteritalien, Wien 1955, Volksglauben im Bereich des Islam. Bd. I: Wallfahrtswesen und Heiligenverehrung, Bd. 2: Amulette, Zauberformeln und Beschwörungen, Wiesbaden I 960/62 und »Beiträge zum religiösen Volksleben auf der Insel Cypern mit besonderer Berücksichtigung des Wallfahrtswesens«, Rheinisches Jabrbuch für Volkskunde I 2, I 96 I, I35-2 10).

Besonders interessante Kulturlandschaften wie das historische Thrakien (heute auf drei Länder aufgeteilt) und Kleinasien (vor der Etablierung der türkischen Republik) sind aufgrund der Flüchtlingsvolkskunde Gegenstand erschöpfender Studien geworden

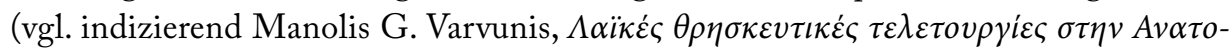

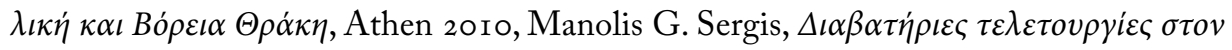

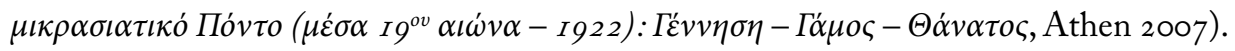
Zahlreiche Studien existieren auch zu den Sonderformen der Pastoralpraxis (z.B. zu kirchlich eingesegneten Wahlbruderschaft vgl. Leopold Kretzenbacher, Rituelle Wablverbrüderung in Südosteuropa. Erlebniswirklichkeit und Erzäblmotiv, München I 97 I, ders., "Serbisch-orthodoxe >Wahlverbrüderung`zwischen Gläubigenwunsch und Kirchenverbot von heute«, Südost-Forschungen 38, I979, I63-I 83, Walter Puchner, „Grie- 
chisches zur adoptio in fratrem«, Südost-Forschungen 53 (I 994) I 87-224 und modifiziert ders., "Adoptio in fratrem. Kirchliche Segnung der Wahlbruderschaft zwischen theologischem Verdikt und gelebter Pastoralpraxis«, Studien zur Volkskunde Südosteuropas, Wien/ Köln/Weimar 2009, 353-384) sowie dem balkanischen Heiligenkult (z. B. T. Tasić/M. Detelić [eds.], Kult svetih na Balkanu, Kragujevac 200 I).

\section{B. AUSWAHLBIBLIOGRAPHIE ZUM VORLIEGENDEN BAND}

An dieser Stelle werden nur Monographien und Studien genannt, die mehrfach zitiert worden sind oder herausragende Bedeutung für die Darstellung des behandelten Themas besitzen bzw. von übergreifender Themenstellung sind.

Abbott, C. F., Macedonian Folklore, Cambridge i 893.

Adăscăliței, V., »Jocul Cerbului în Moldova«, Revista de Etnografie și Folclor I 968,42 I438.

Adăscăliței, V., Teatru folcloric din județele Bacău Neamt,, Bacău I 968.

Adăscăliței, V., Teatrul folkloric, Iași I 969.

Adăscăliței, V./L. Çireș, »Mocănașii«. Datina - spectacol«, Revista di Etnnografia și Folclor I 5 (I 970) 323-333.

Adăscăliței, V./I. Ciubotaru, Teatru folcloric din județul Iași, Iași I 969.

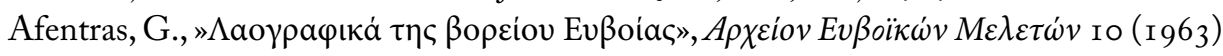
$223-365$.

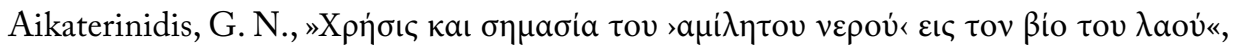

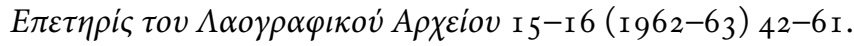

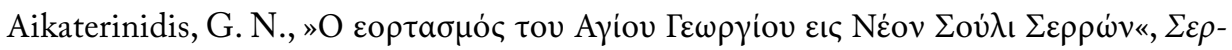

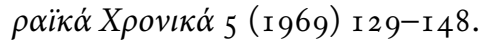

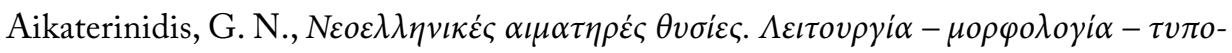

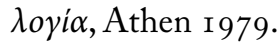

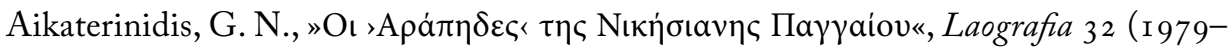
8 I) 2 I 5-226.

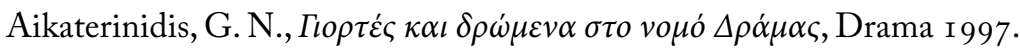

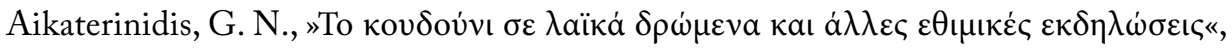

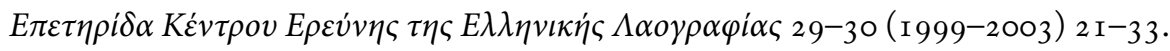

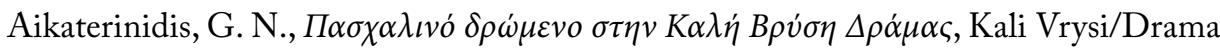
2000.

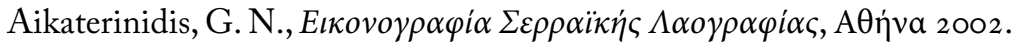

Ajdačić, D., »O vilama u narodnim baladama«, Studia mythologica Slavica 4 (2001) 207224 . 


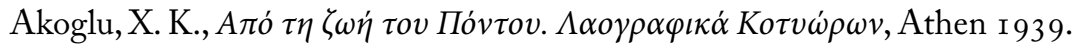

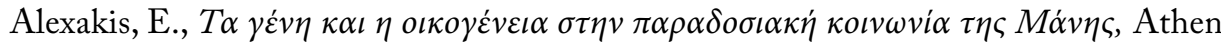
I 980 .

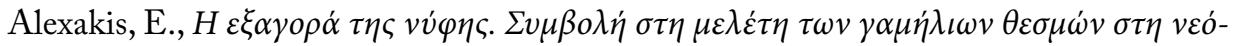
$\tau \varepsilon \rho \eta E \lambda \lambda \alpha \dot{\alpha} \alpha \alpha$, Athen 1984.

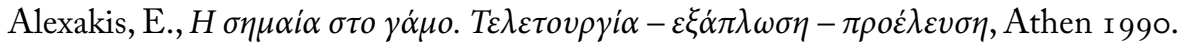

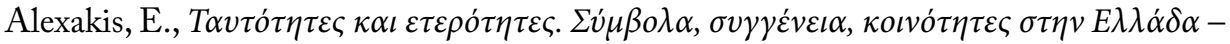
$B \alpha \lambda \kappa \alpha \dot{v} \iota \alpha$, Athen $200 \mathrm{I}$.

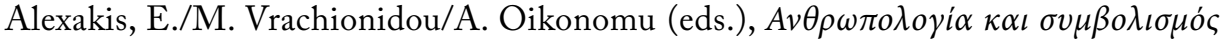
$\sigma \tau \eta v E \lambda \lambda \dot{\alpha} \delta \alpha$, Athen 2008.

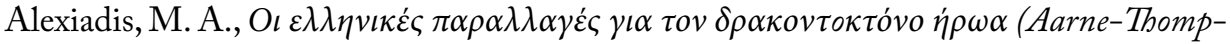
son 300, зо $A$ $\kappa \alpha$ เ зо I $B)$, Ioannina 1982 .

Alexiadis, M. A., »Do ut des«, $\Delta \omega \delta \omega \dot{v} \eta$ i6/ I (I987) 253-265.

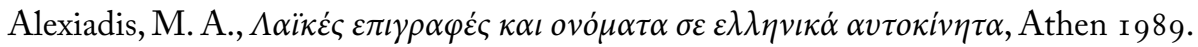

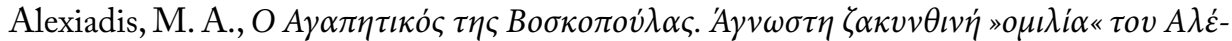
$\kappa o v \Gamma \varepsilon \lambda \alpha \delta \dot{\alpha} . \Sigma v \mu \beta o \lambda \eta \dot{~ \sigma \tau \eta v ~ \varepsilon ́ \rho \varepsilon v v \alpha ~ \tau o v ~ \zeta \alpha \kappa v v \theta ı v o v ́ ~ \lambda \alpha i ̈ \kappa o v ́ ~ \theta \varepsilon \alpha ́ ~} \tau \rho o v$, Athen I 990.

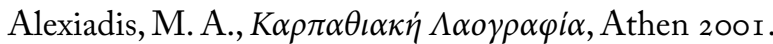

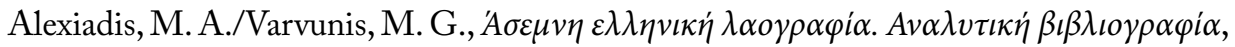
Athen 2013.

Alexiou, M., The ritual lament in Greek tradition, Cambridge I 974 (erw. Aufl. von D. Yatromanolakis und P. Roilos, Lanham/Boulder/New York/Oxford 2002).

Alexiou, M., "Reappropriating Greek Sacrifice: homo necans or $\alpha \dot{v} \theta \rho \omega \pi \circ \varsigma \theta v \sigma \iota \dot{\alpha} \zeta \omega v \ll$, Journal of Modern Greek Studies 8/I (1990) 97-1 23.

Alterescu, S., Istoria Teatrului Leydiuturi pină la I848, București I 965 .

An, N., Karagöz, Ankara I959.

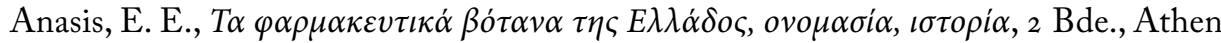
I 976.

Anastasiadou, I. I., „Deux cérémonies de travestissement en Thrace: le jour de Babo et les Caloyeri«, L'Homme r6 (i 976) 89-ior.

Ančev, A., Dreams and folklore, Sofia 1995.

And, M., Dances of Anatolian Turkey, New York I 959.

And, M., Kirk Gün Kirk Gece, Istanbul 1959.

And, M., Dionisos ve Anadolu Köylüsü, Istanbul I 962 .

And, M., A history of theatre and popular entertainment in Turkey, Ankara 1963/64.

And, M., "Various species of shadow theatre and puppet theatre in Turkey«, Estratto degli Atti del secondo congresso internazionale di arte Turca, Napoli i 965.

And, M., „Wie entstand das türkische Orta Oyunu (Spiel der Mitte)?«, Maske und Kothurn I6 (I 970) 20 I-2 I 6. 
And, M., Karagöz. Turkish Shadow Theatre, Ankara 1975.

And, M., Dünyada ve Bizde Gölge Oyunu, Ankara 1977.

Angelov, B., »Samovilite v bălgarskata narodna poezija«, Izvestija na Seminara po Slavjanska filologija pri universiteta $v$ Sofija 3 (I I I I) I-66.

Angelov, B., »Bălgarskata narodna balada (Baladi za samovili - samodivi)«, Izvestija na narodnija Etnografski muzej I 2 (1936) I-29.

Angelov, D., Les Balkans au Moyen Age: la Bulgarie des Bogomiles aux Turcs, London 1978.

Angelov, V., »Obrednata maska«, Bălgarskija etnografija 3-4 (I 994) 28-34.

Angelova, R., »Kukerski igri-običai za plodorodie i zdrave i naroden teatăr«, Teatăr 2 (1956) 95-106.

Anguélova-Georguéva, R., "La culture théâtrale folklorique chez les Slaves du sud à travers leurs coutumes et leurs jeux d'hiver en travestis et avec masques«, Makedonski Folklor I 5-I6 (1975) 353-36r.

Antić, V., „Trojcata mudreci od istok i račanjeto na Isus Christos vo makedonskite narodni običai i pesni«, Makedonski Folklor I 5-16 (1975) I 83-1 95.

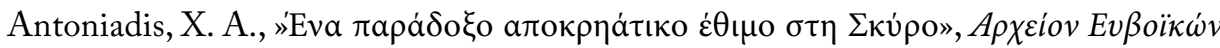

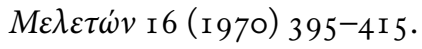

Antonijević, D., »Contribution à létude de la symbolique du cercle magique et la marche en rond autour du defunt«, Balcanica 3 (1972) 46I-476.

Antonijević, D., "Đurđevdanski folklor kao obeležje specifičnosti i zajednice etnički grupa prizrena«, Rad XIV kongresa saveza udruženja folklorista Jugoslavije u Prizrenu I0.-13. IX. 1967, Beograd 1974, 193-202.

Antonijević, D., „Vizantijske brumalije i savremene maskirane prvorke balkanskich naroda«, Balcanica ro (1979) 93-I 29.

Antonijević, D., »A contribution to the Study of Cults and Symbols of Balkan CattleBreeders«, Balcanica I2 (1981) ro9-I I6.

Antonijević, D. (ed.), Folklorni teatar u balkanski i podunavskim zemljama, Beograd I 984. Antonijević, D., „Karađoz«, Gradska kultura na Balkanu (XV-XIX vek), Beograd 1984 (Balkanološkog instituta SANU, 2 I) 395-4I 2.

Antonijević, D., »Some theatrical elements in carnival rites of the Balkan people«, Balcanica $\mathrm{I} 6-\mathrm{I} 7$ ( (1985-86) I 59- 166.

Antonijević, D., »Igre pod maskami u svetlu komparacije i kontinuiteta«, Glasnik Etnografskog muzeju u Beogradu 54-55 (1991) 165-I78.

Antonijević, D., Dromena, Beograd I 997.

Antonijevic, D. et al., Ritualni trans, Beograd 1990.

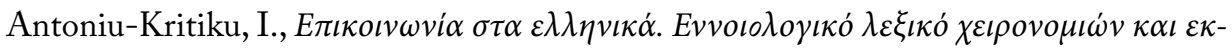
$\varphi \rho \alpha \dot{\sigma \varepsilon} \omega v$, Athen 2008.

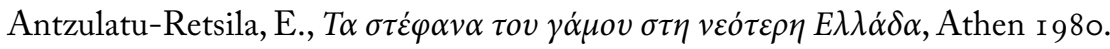


Appendini, F. M., Notizie istorico-critiche sulle antichità, istoria e letteratura de' Ragusei, 2 Bde., Dubrovnik I 802/3.

Aranud, A., "La Baskania ou le mauvais œil des Grec Modernes«, Échos d'Orient I 5 (I 9I 2) 385-394.

Ardalic, V., »Bucovica (nastavak), Godišnji običaji: domaći (kućni) običaji kod svetkovanja«, Zbornik za narodni život i običaje južnih Slavena 7/2 (I 902) 237-294.

Argenti, P. P., The customes of Chios: their development from the XVth to the XXth century, London I 953.

Argenti, P. P., The religious minorities of Chios: Jews and Roman Catholics, Cambridge I 978 .

Argenti, P. P./A. J. Rose, The Folk-Lore of Chios, Cambridge I 949.

Arnaudov, M., Die bulgarischen Festbräuche, Leipzig i 9 I 7.

Arnaudov, M., »Kukeri i rusalii«, Sbornik za narodni umotvorenija i narodopis 34, Sofija I $920, \mathrm{I}-242$.

Arnaudov, M., Očerki po bălgarski folklor, Sofija I 934.

Arnaudov, M., "Der Familienschutzgeist im Volksglauben der Bulgaren. Folkloristische Skizze«, Zeitschrift für Balkanologie 5 ( I 967) I 29-1 37.

Arnaudov, M., »Babinden văv Velingradsko«, Văprosi na etnografijata i folkloristikata, Sofija I980, 92-roo.

Arnold, M. S., Childbirth among Rural Greek Women in Crete: Use of Popular, Folk, and Cosmopolitical Medical Systems, PhD diss., University of Pennsylvania 1985.

Atanasova, K., »Obreda rolja i značenieto na trapezata v kolednite praznici na bălgarii i rumănci«, Etnografski problemi na narodnata duhovna kultura, Bd. 3, Sofija I 994, 48-79.

Asdrachas, Sp., „Faits économiques et choix culturels: à propos du commerce de livres entre Venise et la Méditérrannée orientale au XVIIIe siècle«, Studi veneziani I 3 ( I 97 I) 587-62 I.

Avdeev, A. D., Proizchoždenie teatr, Moskva I 969.

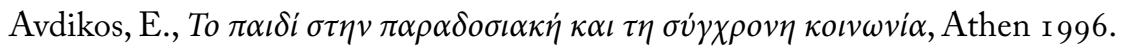

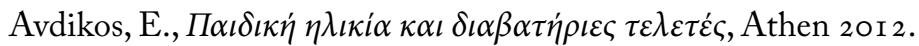

Babinger, F., „Der Islam in Südosteuropa«, Volker und Kulturen Südosteuropas. Kulturbistorische Beiträge, München I 959, 2 I I-2 I 7.

Balassa, I./G. Ortutay, Die ungarische Volkskunde, Budapest/München I 982.

Bálint, S., Ünnepi kalendárium, 2 Bde., Budapest 1977.

Bandić, D., »Šamanistička komponenta rusalijskog rituala«, Carstvo zemaljsko i carstvo nebesko, Beograd i 997, 203-224.

Barbar, K., »Der Baumkult der Bulgaren«, Anthropos 30 (I 935) 797-802.

Basch, S./P. Chuvin (eds.), Pitres et pantines: Transformations du masque comique de l'antiquité au théâtre d'ombres, Paris 2007. 
Bax, M., »The Seers of Medjugorje. Professionalization and Management Problems in a Yugoslav Pilgrimage Centre«, Ethnologia Europaea 20 ( I 990) I67-r 76.

Bonifačić-Rožin, N., »Šante i Pante. Narodni ručne lutke u Hrvatkoj«, Slovenski Etnograf I 5 (I 962) г 35-I 56.

Bartl, P., »Kryptochristentum und Formen des religiösen Synkretismus in Albanien«, Grazer und Münchener balkanologische Studien, München I 967, I I 7-I 27.

Bașgöz, I., »Earlier References to Kukla and Karagöz«, Turcica 3 ( I 97 I) 9-2 I.

Basić, O., Etnokoreologija, Beograd 2004.

Batušić, N., Povijest Hrvatskoga Kazališta, Zagreb 1978.

Bauman, R., Story, Performance, and Event, New York 1986.

Beck, H.-G., Kirche und theologische Literatur im byzantinischen Reich, München 1959.

Beck, H.-G., Von der Fragwürdigkeit der Ikone, München I 977.

Begović, M., Zakonik cara Stefana Dušana, Beograd i 98 I.

Belaj, V., »Običaji vučara u Južnih Slavena i pokušaji njegova interpretiranja«, Zbornik za narodni život i običaji južnih slavena 49 (Zagreb r 983) 73-94.

Belgrader, M., »Magyarische Flüche«, Südostdeutsche Vierteljabrsblätter 27/2 (1978) I 23I 26 .

Belgrader, M., »Rumanian Obscenities and Curses«, Maledicta 9 (I 985 ).

Belitska-Scholz, H., »Gaukler und Wanderpuppenspieler aus Ungarn«, Maske und Kothurn 2 I (1975) ro6-I 22.

Belitska-Scholtz, H./O. Somorjai, Das Kreutzer-Theater in Buda (I794-I804). Eine Dokumentation zur Bühnengeschichte der Kasperlfigur in Budapest, Wien/Graz/Köln I 988.

Belović, J., Das Liebesleben auf dem Balkan, Dresden 1927.

Belovic, J., Die Sitten der Südslaven, Dresden I 927.

Belting, H., Bild und Kult. Eine Geschichte des Bildes vor dem Zeitalter der Kunst, München ${ }^{2}$ I 99 I.

Ben-Amos, D./K. S. Goldstein (eds.), Folklore: Performance and Communication, The Hague I 975 .

Benc Bošković, K., Pokladne maske iz zbirki Etnografskog muzeja u Zagrebu i muzeja u Mohaču, Mohács/Zagreb I 973.

Benedek, A./L. Vargyas, Az istenesi székelyek betlehemes játéka, Kolozsvár I 943.

Benekos, D., „Eigenschaften und Fähigkeiten der Magier und Hexen nach dem epirotischen Volksglauben", Laografia 35 ( 1987-89) 223-234.

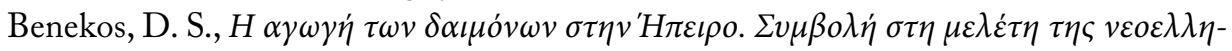
$v \iota \kappa \dot{\zeta} \varsigma \mu \alpha \varepsilon \dot{\alpha} \alpha \varsigma$, Ioannina I 988.

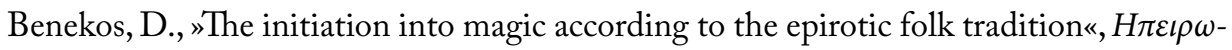

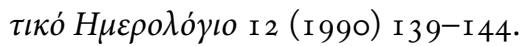

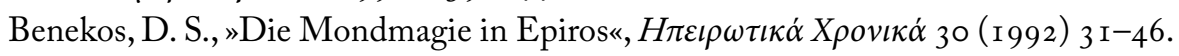




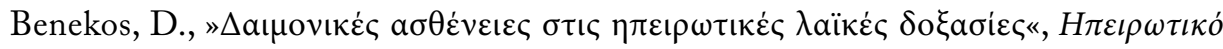

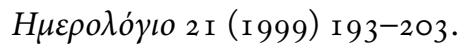

Benovska, M., »Nabljudenija vărchu simbolikata v obreda za dăžd >peperuda««, Folklor, ezik i narodna sŭdba, Sofija I979, I42-I 53.

Benovska, M., »Š̌̌šnost i estetičeski izmerenija na obreda German«, Obredi i obreden folklor, Sofija I 98 I, 235-256.

Benovska-Săbkova, M., "Za rusalkite v bălgarkija folklor « Bălgarski folklor I 7/I ( I 99I) $3^{-\mathrm{I} 4}$.

Benovska-Săbkova, M., Zmejat v bălgarskija folklor, Sofija I 992 (I 995 ).

Benovska-Săbkova, M., "Bălgarskata maskaradna obrednost v konteksta na evropejskata tradicija«, Bălgarskija etnografija 3-4 (I 994) 3-I 5.

Benovska-Săbkova, M., »Rusalkite i samodivite v bălgarskata tradicija«, Medievistika i kulturna antropologija, FS D. Petkanova, Sofija I 998, 345-40 I.

Benyovsky, K., Die Oberuferer Weihnachtsspiele, Pressburg I 934.

Bernard, R., »Le Bulgare karakondžo ssorte de loupa garou< et autres formes bulgares issues du turc karakoncolos«, Izsledvanija v čest na akademik Mibail Arnaudov, Sofija I 970, 477-486.

Berze Nagy, J., Baranyai magyar népszokások, Pécs I 940.

Beza, M., »The Sacred Marriage in Roumanian Folklore«, The Slavonic Review 4/I I (I 925 ) 32 I-333, 5/ I 5 (I 927 ) 647-658.

Beza, M., Paganism in roumanian folklore, London 1928.

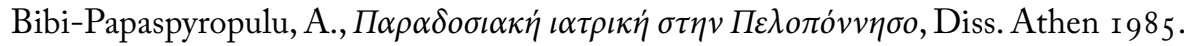

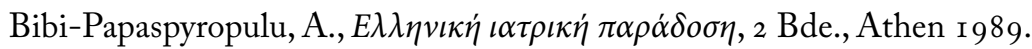

Bihalji-Merin, O., Maska, ritual i pozorište, Beograd 1970.

Bihalji-Merin, O., Maske sveta, Beograd/Ljubljana I970.

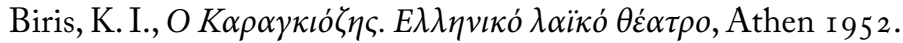

Bliss, F., Islamischer Volksglaube der Gegenwart, Bonn 1986.

Blum, R. \& E., Health and Healing in Rural Greece. A Study of Three Communities, Stanford 1965 .

Blum, R. \& E., The Dangerous Hour. The Lore of Crisis and Mystery in Rural Greece, London 1970.

Bobčev, S. S., „Notes comparée sur les Hadjis balkaniques«, Revue internationale des études balkaniques 2 ( I936) I-I 2.

Bočev, M., »Kukerski igri. Kukeri. Kukeri maski«, Problemi na izkustvoto 3 (1 976) 27-34.

Bocev, V., "Maskiranjeto i običaite pod maski vo Makedonija«, Etnolog 3 (Skopje I 993) I I 4-I 24.

Bočkov, P., "Zoomorfni čerti v obraza na epičeskija geroj-junak«, Vtori meždunaroden kongres po bălgaristika I 5 (Sofija I 988) 205-2 I 5. 
Bogdani, H. G., »Valle në festat kalendarike të ripërtëritjes së natyrës«, Kultura Popullore I-2 (Tirana I 994) I 59-i67.

Bokova, I., »Festivalăm - tradicija i săvremenost «, Maska i ritual, Sofija I 999, I I 7-I 3 I . Bombaci, A., »Ortaoyunu«, Wiener Zeitschrift für die Kunde des Morgenlandes 56 ( I 960) 285-297.

Bombaci, A., »On ancient Turkish Dramatic Performances«, D. Sinor (ed.), Aspects of Altaic Civilization, Bloomington r 962, 87- I 7 .

Bombaci, A., »Rappresentazioni drammatiche di Anatolia«, Oriens I6 (I963) I 7 I-I 93.

Bonifačić-Rožin, N., Hrvatski narodni običaji, priče i pjesme iz kotara Rijeka, Zagreb I 952 .

Bonifačić-Rožin, N., Hvratske narodi običaji iz kotara Pazin, Zagreb I 959.

Bonifačić-Rožin, N., Folklorna građa Petrinje i okolice, Zagreb i 960.

Bonifačić-Rožin, N., Narodne igre (Vocin i Čačinci), Zagreb I 960.

Bonifačić-Rožin, N., "Svadbena dramatika u Dubrovačkom primorju «, Narodna umjetnost 3 ( ( $964 / 65$ ) 38-74.

Bonifačić-Rožin, N., "Pokladne maškare u Konovlima«, Narodna Umjetnost 4 ( ( 966) I $53-$ I 73 .

Bonifačić-Rožin, N., "Narodna drama i igre u Sinjkog krajini«, Narodna Umjetnost ${ }^{-6}$ ( I 968 ) 5 I $7-578$.

Bonifačić-Rožin, N., »Folkloruv kazalište in južnom dijelu Hrvatskog zagorja«, Narodna umjetnost ro (1973) 2 I 7-258.

Bonifačić-Rožin, N., »Igre `trikralja i ıvertepi` kod jednog dijela stanovništa Hrvatske«, Rad XIV kongresa saveza udruženja folklorista Jugoslavije u Prizrenu Io.-13. IX. 1967, Beograd i 974, 433-440.

Bonifačić-Rožin, N., »Maškare i njihove dramski igre na otoku Braču«, Narodna umjetnost I I-I 2 (I 975) 365-396.

Bonifačić-Rožin, N., »Tragom narodni ručnih lutaka u Hrvatskoj, Bosni, Hercegovini i Srbiji«, Traditiones 5-6 (1979) I 9-30.

Bonifačić-Rožin, N. et al., Narodne drame, poslovice $i$ zagonetke, Zagreb i 963.

Boratav, P. N., »The Negro in Turkish Folklore«, Journal of American Folklore 64 (I95 I) $83-88$.

Boratav, P. N., »Les Noirs dans le folklore turc et le folklore des Noirs de Turquie (Notes)«, Journal de la Société des Africanistes 28 ( I 958) 7-23.

Borcakl1, A., Karagöz, Ankara I970.

Bosić, M., Božićni običaji Srba u Vojvodini, Novi Sad/Beograd 1985.

Bosić, M., „Glavni elementi svadbenih običaja Srba u Vojvodini«, Glasnik Etnografskog muzeja 54-55 (I991) I 85-201.

Bosić, M., Ženidbeni običaji Šokaca - Hrvata u Bačkoj, Novi Sad I 992. 
Bosić, M., Godišnji običaji Srba u Vojvodini, Novi Sad I 996.

Bošković-Stulli, M., »Darstellerische Aspekte des Erzählen«, Fabula 26 (I 985 ) 58-7 I.

Bošković-Stulli, M., »O folklorizmu«, Zbornik za narodni život i običaje Južnih Slavena 45 (I 986$) 3$ I -57 .

Braude, B./L. Bernard (eds.), Christians and Jews in the Ottoman Empire. The Functioning of a Plural Society, vol. I : The Central Lands, New York/London 1982.

Brednich, R.-W., Volkserzählungen und Volksglaube von den Schicksalsfrauen, Helsinki I 964 (FFC I93).

Brewster, P. G., »Some Games from Southern Europe«, Midwest Folklore I (I95 I) Io9I I .

Brewster, P. G./Jelena Milojković-Djurić, "Groups of Yugoslavic Games«, Southern Folklore Quarterly 20 (1956) i 83-i9i.

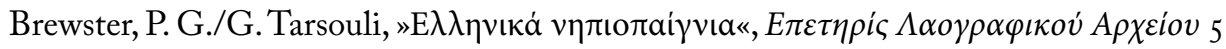
(1945-49) roi-I25.

Breyer, B., Das deutsche Theater in Zagreb I780-1840, Zagreb I 938.

Buhociu, O., Die rumänische Volkskultur und ibre Mythologie, Wiesbaden 1974.

Buhociu, O., Le folklore roumain de printemps, Thèse, Paris I 957.

Buhociu, O., »Die Feiertage des Sommers und Herbstes in Rumänien«, Zeitschrift für Balkanologie 6 (1968) 3-39.

Burada, T. T., Istoria teatrului in Moldova, Bd. I, Iași I 9 I 5 .

Burkhart, D., Untersuchungen zur Stratigraphie und Chronologie der südslavischen Volksepik, München I968.

Burkhart, D., „Der rote Schleier. Zur traditionellen Brautausstattung bei den Türken und Bulgaren«, G. Völger/K. v. Welck, Die Braut. Geliebt, verkauft, getauscht, geraubt, Bd. 2, Köln I 985, 450-455.

Burkhart, D., »Vampirglaube in Südosteuropa«, Kulturraum Balkan. Studien zur Volkskunde und Literatur Südosteuropas, Berlin/Hamburg I 989, 65-ı 08.

Burkhart, D. (ed.), Körper, Essen und Trinken im Kulturverständnis der Balkanvölker (Beiträge zur Tagung vom 19.-24. Nov. 1989 in Hamburg), Berlin I 99 I.

Burkhart, W., Homo necans. The Anthropology of Ancient Greek Sacrificial Ritual and Myth, Berkeley/Los Angeles/London I983.

Çabej, E., "Sitten und Gebräuche der Albaner«, Revue International des Études Balkaniques I (I 935$) 225 \mathrm{ff}$.

Çabej, E., "Život i običaji arbanasa«, Knjiga o Balkanu I (Beograd r936) 303-329.

Çabej, E., »Kult und Fortleben der Göttin Diana auf dem Balkan«, Leipziger Vierteljahresschrift für Südosteuropa 5 (I 94I) 229-24I.

Çabej, E., "Albanische Volkskunde«, Südost-Forschungen 35 ( I 966) 333-387.

Caimi, G., Karagheuz ou la comédie grec dans l'âme du théâtre d'ombres, Athènes 1935. 
Čajkanović, V., Sabrana dela iz srpske religije i mitologije u pet knjiga, Beograd I 994.

Campbell, J. K., Honour, Family and Patronage, Oxford 1964.

Capidan, Th., "Le jeu aux osselets chez les Roumains, les Slaves et les Albanais«, Revue internationale des études balkaniques I ( 1934 ) 2 I I-23 I.

Caraman, P., Obręzed kolędowania u Stowien i u Rumunów, Kraków 1933.

Caraman, P., Descolindatul în orientul și sud-estul Europei, Iași I 997 (Diss. I 939).

Carić, Anton E., "Volksaberglaube in Dalmatien«, Wissenschaftliche Mitteilungen aus Bosnien und der Hercegovina 6 (I 899) 585-608.

Carolidis, P., Bemerkungen zu den alten kleinasiatischen Sprachen und Mythen, Straßburg I9I3.

Carnoy, H./J. Nicolaïdes, Traditions populaires de Constantinople et de ses environs. Contributions au Folklore des Turcs, Chrétiens, Arméniens, etc., Paris I 892.

Carnoy, H./J. Nicolaïdes, Folklore de Constantinople, Paris I 894.

Cepenkov, M. K., Makedonski narodni umotvorbi. Bd. Io, Heft 9, Narodni veruvanja. Detski igri, Skopje I 972.

Chalkea, E., "La fête dans les villages de Zagori«, P. Stahl (ed.), Études et Documents Balkaniques et Méditerranéens 6 (Paris I 983) I-8.

Chiaro Fiorentino, A. del, Istoria delle moderne rivoluzioni della Valachia. III. Riti de' Valachi, Venezia I 7 I 8.

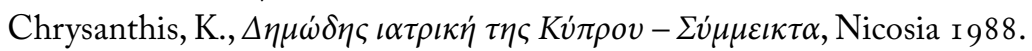

Chrysanthopoulou-Farrington, B., An analysis of rituals surrounding birth in modern Greece, M. Phil. thesis, University of Oxford I 984.

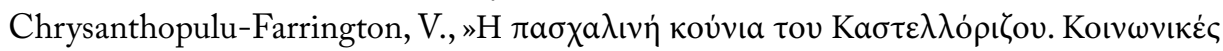

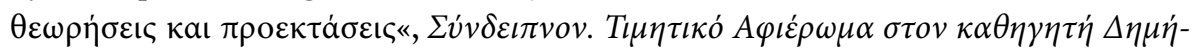

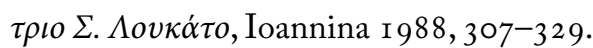

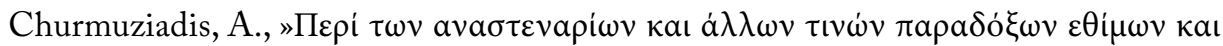

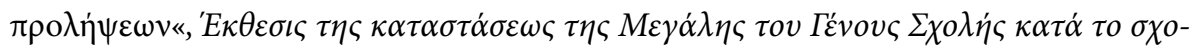

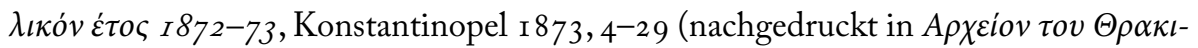

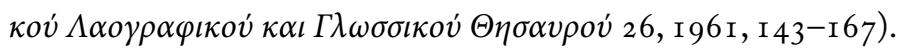

Ciszewski, St., Künstliche Verwandtschaften bei den Südslaven, Diss. Leipzig I 897 .

Closs, A., "Südosteuropa als ethnologisches Untersuchungsfeld über ekstatisches Brauchtum«, Wiener Ethnohistorische Blätter 3 ( I 97 I) 3-22.

Codellas, Pan. S., "Greek Folklore of the Present Day: the Smerdaki«, Journal of American Folklore 58 (1945) 236-244.

Colpe, C., "Das samaritanische Pinehas-Grab in Awerta und die Beziehungen zwischen Hadir- und Georgslegende«, Zeitschrift des deutschen Palaestina-Vereins 85 (1969) r62-196. 
Conrad, J. L., "Magic Charms and Healing Rituals in Contemporary Yugoslavia«, Southeastern Europe 1o/2 (1983) 99-1 20.

Conrad, J. L., "Bulgarian Magic Charms: Ritual, Form, and Content«, Slavic and East European Journal 31/4 (I987) 548-562.

Constantin, M., "Les coutumes dans les cortèges à masques chez les roumains et chez les peuples balkaniques", Makedonski Folklor 8/ I 5-I6 (I 975) 335-345.

Coote, F., »Some Notes on the Evil Eye round the Mediterranean Basin«, Folklore 44 ( I 933) 93-98.

Costa, F. A., »Spectacole de divertisment la curțile domnești și boierești în epoca feudală«, Studii și cercetări ist. artei 5/2 (I958) I 37-333.

Couffin, M. C., Monde féminin et mariage en Epire grecque, Montpellier I 982.

Coulentianou, J., The goat-dance of Skyros, Athens 1977.

Cristescu, C., "Pilgrimage and pilgrimage song in Transylvania«, East European Meetings in Ethnomusicology I (r 994) 3 I ff.

Csalog, J., Busójárás, a mohácsi sokácok ünnepe, Pécs I 949.

Csávásy, A., »Tuskohuzás a Hienzeknél«, Ethnographia 33 (I922) 91 ff.

Csiszár, Á., »Szemmelverés és igéséz«, Jósa András Múz. Évk. i I ( 1968) I6 I-I 70.

Csövek, J., Halottlátók a magyar néphitben, Debrecen 1986.

Čubelić, T., Narodno dramsko stvaralaštvo, Zagreb i 964.

Čubelić, T., Usmena narodna retorika i teatrologija, Zagreb 1970.

Ćuk, J., "Svadbeni običaji i Krašiću nekada i danas«, Zbornik za narodni život i običaje južnih Slavena 40 (1962) 95-106.

Čulinović-Konstantinović, V., "Dodole i prporuše«, Narodna Umjetnost 5 (1963) 73-96.

Ćupurdija, B., Agrarna magija u tradicionalnoj kulturi Srba, Beograd I 982.

Cvetanovska, J., Igre po smrti, Skopje I 999.

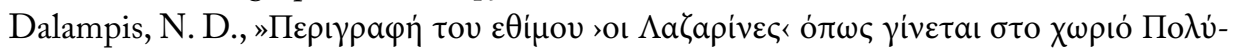

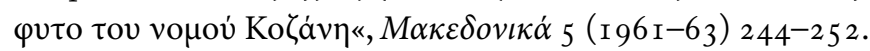

Dalven, I. R., »Betrothal and Marriage Customs of the Jannina Jews«, Sephardic Scholars 3 (I 973) 4 I-6o.

Damianakos, St. (ed.), Théâtres d'ombres. Tradition et Modernité, Paris I 986.

Danforth, L. M., "Humour and Status Reversal in Greek Shadow Theatre”, Byzantine and Modern Greek Studies 2 (I 976) 99-I I I.

Danforth, L. M., The Anastenaria: A study in Ritual Greek Therapy, Princeton 1978.

Danforth, L. M., »The Role of Dance in the Ritual Therapy of the Anastenaria«, Byzantine and Modern Greek Studies 4 (I979) I 4 I-I63.

Danforth, L./A. Tsiaras, The death rituals in rural Greece, Princeton 1982.

Daničić, L. T., "Das Hemd in Glauben, Sitte und Brauch der Südslaven«, Anthropophyteia 7 (I9IO) 54-I 28. 
Daničić, L. T., »Die Frauenschürze in Glauben und Sitten der Südslaven«, Anthropophyteia 9 (I9I2) 102-209.

Dawkins, R. M., "A visit to Scyros«, The Annual of the British School in Athens I I (I 904/05) $72 \mathrm{ff}$.

Dawkins, R. M., »The modern Carnival in Thrace and the Cult of Dionysos«, Journal of Hellenic Studies 26 ( I 906) I 9 I-206.

Dawkins, R. M., »Soul and body in the Folklor of Modern Greece«, Folk-Lore 53 (I 942) I 3 I-I 47 .

Daxelmüller, Chr., Zauberpraktiken. Die Ideengeschichte der Magie, Düsseldorf 2005 (Zürich I993).

Debreczeni, F. (ed.), A Bábjátszás Magyarországon, Budapest 1955.

Dede, A., Bati Trakya Türk Folkloru, Istanbul I 975.

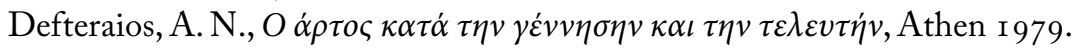

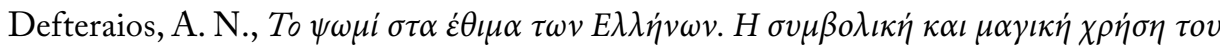

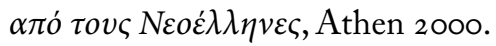

Dégh, L., Narratives in Society. A Performer-Centered Study of Narration, Helsinki I 995 (FFC 255).

Delatte, A., La catoptromancie grecque et ses dérivés, Liège 1932.

Delić, St. R., »Wie unser Volk denkt. I.: Der >Oganj` (Fieberausschlag) und seine Heilung", Wissenschaftliche Mittheilungen aus Bosnien und der Hercegovina 3 (I 895) 558565 .

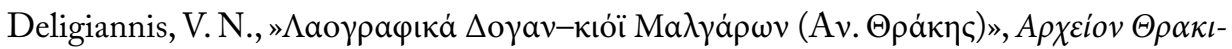

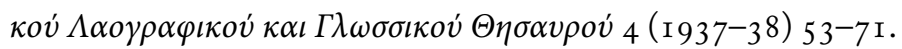

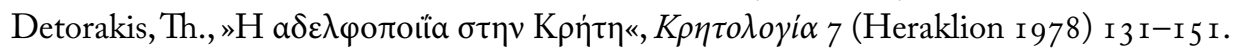

Djamo-Diaconița, L., »Une texte slavon de farmacoterapie populară din secolul al XVIlea«, Romanoslavica I 4 ( I 967) 377-409.

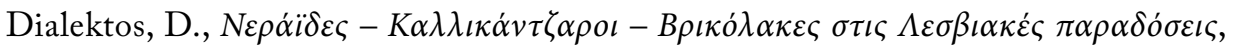
Athen 1979 .

Dieterich, K., »Hellenistische Volksreligion und byzantinisch-neugriechischer Volksglaube«, Angelos I (1 925) 2-23.

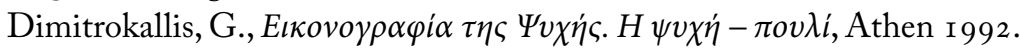

Dinekov, P., Bălgarski folklor, Sofija 1972.

Dinescu, V., Teatrul de umbre Turc, București I 982.

Dionisopoulos-Mass, R., »The Evil Eye and Bewitchment in a Peasant Village«, C. Maloney (ed.), The Evil Eye, New York I 976, 42-62.

Dioszégi, V., »Die Überreste des Schamanismus in der ungarischen Volkskultur», Acta Ethnographica Academiae Scientiarum Hungaricae 7 (1955) 97-1 35.

Diószegi, V., A sámánhit emlékei a magyar népi müveltségben, Budapest 1958. 


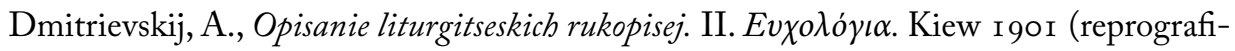
scher Nachruck Hildesheim i 965).

Domonkos, P. P., »A moresca Europában és a magyar hagyományban«, Filologiai Közlönyi (1958) $202 \mathrm{ff}$.

Domonkos, P. P., »Der Moriskentanz in Europa und in der ungarischen Tradition«, Studia Musicologiae ro ( I 968) 229-3 I I.

Dömötör, T., »Erscheinungsformen des Charivari im ungarischen Sprachgebiet «, Acta Ethnographica Academiae Scientiarum Hungaricae 6 (1 957) 72-89.

Dömötör, T., "Literatur and folklore. Problems of reseach in old Hungarian dramatic art«, Annual Universitatis Scientiarum Budapestensis, Sectiones Philologiae I ( 957 ) 53-65.

Dömötör, T., »Regelő`-Monday (The First Monday after Epiphany)«, Acta Ethnographica Academiae Scientiarum Hungaricae 8 (1959) I-2 5.

Dömötör, T., A zujkori szinjátszás kialakulása kelet-Európában, Budapest I 964.

Dömötör, T., A népi szinjátsás Európában, Budapest I 966.

Dömötör, T./E. Eperjessy, »Dodola and other slavonic folk-customs in county Baranya (Hungary)«, Acta Ethnographica Academiae Scientiarum Hungaricae I6 (I967) 399408.

Dömötör, T., »Népi színjatéktípusok«, Müveltség és Hagyomány 1o ( I 968) I 6 I-I 74.

Dömötör, T., »Zur Frage der sogenannten Kausalfiktionen», IV. Intern. Congress for Folknarrative Research in Athens, Laografia 27 ( 1968 ) 88-93.

Dömötör, T., „Das Blochziehen in Rábatótfalu I 968 - eine ungarische Variante eines interethnisch verbreiteten Faschingsbrauches«, Kontakte und Grenzen. Probleme der Volkskultur-und Sozialforschung, Göttingen I 969, 385-392.

Dömötör, T., »Die Hebamme als Hexe«, L. Röhrich (ed.), Probleme der Sagenforschung, Freiburg 1973, 177-189.

Dömötör, T., Ungarische Volksbräuche, Budapest 1972.

Dömötör, T., A népszokások költészete, Budapest 1974.

Đorđević, D. T., Život i običaji narodni u leskovačkom kraju, Leskovac I 985.

Đorđević, T., Srpske narodne igre, Beograd I 907.

Đorđević, T., Iz Srbije Kneza Miloša, Beograd I 924.

Đorđević, T., »Veštica i vila u nasem narodomverovanju i predanju«, Srpski Etnografski Zbornik 66 (I953) 5-55.

Đorđević, T., Deca u verovanjima i običajima našega naroda, Beograd/Niš I 990.

Dostálová-Jeništová, R., „Das neugriechische Schattentheater Karagöz. Einige Bemerkungen zu seiner weiteren Erforschung«, J. Irmscher et al. (eds.), Probleme der Neugriechischen Literatur, Bd. IV, Berlin I959, I 85-1 97.

Drettas, G., »Questions de vampirisme«, Études Rurales 97-98 (I 985 ) 20 I-2 I 8. 
Drettas, G., "Le cavalier glouton - Contribution à l'étude de la théorie populaire du vampirisme balkanique«, De la voûte céleste au terroir, du jardin au foyer-Textes offerts à Lucien Bernot, Paris I 987, 7 I 9-746.

Drettas, G., »Aspects de l'hémophilie vampirique«, Revue des études slaves 64/4 (1994) $73 \mathrm{I}-742$.

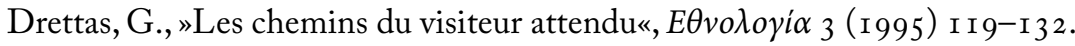

Drexl, F. (ed.), Achmet, Oneirocriticon, Lipsiae i 925.

Du Boulay, J., »The Greek Vampire: A Study of Cyclic Symbolism in Marriage and Death«, Man (n.s.) I7 (1982) 2 19-238.

Du Boulay, J., Cosmos, Life, and Liturgy in a Greek Orthodox Village, Limni, Evia 2009.

Dubinskas, G. A., »Ritual on Stage: Folklore Performance as Symbolic Action«, Narodna Umjetnost, Special issue: Folklore and Oral Communication, Zagreb I 98 I, 93-ro6.

Dubisch, J., „Golden Apples and Silver Ships: An Interpretative Approach to a Greek Holy Shrine «, Journal of Modern Greek Studies 6 (I 988) i I 7-I 34.

Dubisch, J., »Death and Social Change in Greece«, J. Dubisch/L. Taylor (eds.), Special Issue of Anthropological Quarterly (on the Uses of Death in Europe) 62/4 (1989) I 89-200.

Dubisch, J., »Pilgrimage and Popular Religion at a Greek Holy Shrine«, E. Badone (ed.), Religious Orthodoxy and Popular Faith in European Society, Princeton r 990, I I 3-1 36.

Dubisch, J., "»Men's time « and `women's time Shrine«, Journal of Ritual Studies 5/I (I99I) I-26.

Dubisch, J., "The Church of Announciation of Tinos and the Domestication of Institutional Space«, Yearbook of Modern Greek Studies Io/I I (I 994/95) 389-4 I 5.

Dubisch, J., In a Different Place: Pilgrimage, Gender, and Politics at a Greek Island Shrine, Princeton I 995 .

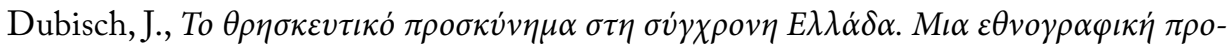
$\sigma \dot{\varepsilon} \gamma \gamma \iota \sigma \eta$, Athen 2000.

Dukova, U., »Gemeinsame Termini in der Folklore der Balkanvölker (Euphemistische Bezeichnungen der Bergfeen und der von ihnen hervorgerufenen Krankheiten) «, Balkansko ezikoznanie/Linguistique balkanqiue 23/2 (I 980) 5-I 2.

Dukova, U., »Die Bezeichnung der Dämonen im Bulgarischen«, Balkansko ezikoznaniel Linguistique balkanique 26/4 (I983) 5-47, 27/2 (I984) 5-50, 28/2 (I985) 5-62.

Dundes, A. (ed.), The Evil Eye: A Casebook, New York r 98 r (Madison r 992).

Dünninger, D., Wegsperre und Lösung. Formen und Motive eines dörflichen Hochzeitsbrauchs, Berlin I 967.

Dünninger, H./Wolfgang Brückner (eds.), Wallfahrt und Bilderkult, Würzburg 1995 .

Džudžev, St., Bălgarska narodna horeografija, Sofija I 974.

Eckert, G., Griechische Fadenspiele, Thessaloniki I 944. 
Eckert, G./Cuschan, A., Das Schulterblattorakel bei den Aromunen, Thessaloniki 1944.

Eckert, G./P. E. Formozis, Beiträge zur mazedonischen Volksmagie, Thessaloniki 1942.

Eckert, G./P. E. Formozis, Geister und Dämonenglaube im Pontus, Thessaloniki I 943.

Eckert, G./P. E. Formozis, Mazedonischer Volksglaube. Magie, Aberglaube und religiöse Vorstellungen in Saloniki und in der West-Chalkidike, Thessaloniki 1943.

Eckert, G./P. E. Formozis, Regenzauber in Makedonien, Thessaloniki 1943.

Efe, P. (ed.), Hayal perdesinde ulus, değișim ve geleneğin icad, İstanbul 2013.

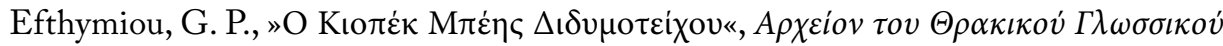

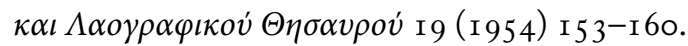

Eichler, P. A., Die Dschinn, Teufel und Engel im Koran, Leipzig I 928.

Elçin, S., Anadolu köy osta oyunlari, Ankara I 964.

Eliade, M., »Kosmogonische Mythen und magische Heilungen«, Paideuma 6 (I 954/58) I 94-204.

Eliade, M., »The Fairies and the Căluşarii«, International Journal fo Rumanian Studies 2 ( 1980 ) H. 3/4, 5-1 2.

Eliade, M., "Schamanismus` bei den Rumänen?«, Von Zalmoxis zu Dschingis-Khan. Religion und Volkskultur in Südosteuropa, Köln I 982.

Elworthy, F. Th., The Evil Eye: The Classic Account of an Ancient Superstition, New York 2004 (London i 895).

Emeritzy, A. E., »Das Volksschauspiel Südosteuropas«, Karpathen-Jahrbuch 30 ( I 979) I $23-\mathrm{I} 46$.

Ernyey, J./G. Karzai-Kurzweil/L. Schmidt, Deutsche Volksschauspiele aus den oberungarischen Bergstädten, Bd. 2, Budapest 1938.

Fahd, T., »Les songes et leur interprétation selon l'Islam«, Les songes et leur interprétation, Paris I 959, I 25-I 58 .

Fahd, T., »Le rêve dans la société islamique du Moyen age«, R. Caillois/G. E. von Grunebaum (eds.), Le rêve et les sociétés humaines, Paris I 967, 335-365.

Fahd, T., La divination arabe. Études religieuses, sociologiques et folkloristiques sur le milieu natif de l'Islam, Leiden I 966 (Paris I987).

Fahd, T., "Anges, démons et djinns en Islam«, Sources orientales 8 (I 97 I) I 53-2 I 4.

Faragó, J., Betlehemezők és kántálok Pusztakamaráson, Kolozsvár I 947.

Fehrle, E., Feste und Volksbräuche im Jahreslauf europäischer Völker, Kassel 1955.

Ferenc, T., »Die Wintervolkssitten im Nordbanat«, Makedonski Folklor I 5-I6 (I 975) I I I-I I 5 .

Ferenczi, I./Z. Ujváry, »Farsangi dramatikus játétok Szatmárban«, Múveltség és Hagyomány 4 (I962) 3-I 5 .

Ferenczi, I./Z. Ujváry, »Népi dramatikus játétok alkalmai és tipusai az Alföldön«, Müveltség és Hagyomány 8 ( I 966) I 8 I-i 96. 
Filipović, M. S., »Das Zerkratzen des Gesichts bei den Serben und Albanern«, Revue internationale des études balkaniques 2 (1936) I 57-166.

Filipović, M. S., „Volksglauben auf dem Balkan. Einige Betrachtungen«, Südost-Forschungen i 9 ( I 960) 239-262.

Filipović, M. S., „Die NAVI bei den Balkan-Slaven«, Das heidnische und christliche Slaventum, Wiesbaden I 969, 105-I I 3 .

Filipović-Fabijanić, R., "Folk Medicin in the Lištica Region«, Wissenschaftliche Mitteilungen des bosnisch-herzegowinischen Landesmuseums $2: \mathrm{B}$ (I 976) 235-244.

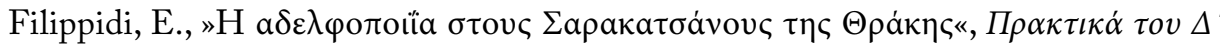

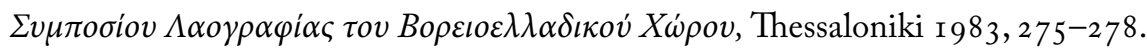

Finnegan, R., Oral traditions and the verbal arts: a guide to research practice, London/New York r 992/

Fischer-Lichte, E., Ästethik des Performativen, Frankfurt/M. 2004.

Fischer-Lichte, E., Performativität. Eine Einführung, Bielefeld 2012.

Flegont, O., Istoria Teatrului în România, București I 965.

Flegont, O., »The Moș in the Romanian popular theatrical art«, Revue roumain d'bistoire del'art 3, I 966, I I 9-I 3 I.

Fligier, C., Ethnologische Entdeckungen im Rhodope-Gebirge, Wien I 879.

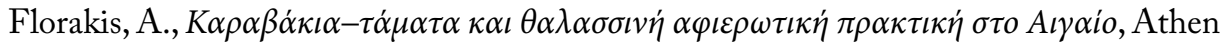
I 982.

Florenskij, P., Die Ikonostase, Stuttgart I 988.

Focşa, G., "Le village roumain pendant les fêtes religieuses d'hiver«, Zalmoxis 3 (I 94042) 6I-IO2.

Födes, L., »A Budajenöre telepitett székelyek bethlehemezése«, Ethnographia 69 ( 1958 ) 209-259.

Foley, M. J./B. Krewsky Halpern, »The Power of the Word. Healing Charms as an Oral Genre«, Journal of American Folklore 9I (1 978) 903-924.

Foley, M. J., „Epic Charm in Old English and Serbo-Croatian Oral Tradition«, Comparative Criticism 2 ( 1979) 7 I-92.

Foretić, V., »Prilozi o moreški u dalmatinskim gradovima«, Zbornik za narodni život $i$ običaje južnih Slavena 42 (I964) I 55-182.

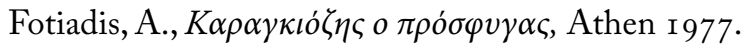

Fotiadis, K., Die Islamisierung Kleinasiens und die Kryptochristen des Pontus, Diss. Tübingen 1985 .

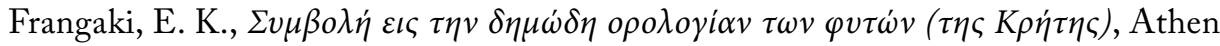
I 969.

Friedl, E., Vasilika. A Village in Modern Greece, New York 1962.

Friedländer, I., Die Chadirlegende und der Alexanderroman, Leipzig/Berlin I 9 I 3. 
Gaćnik, A., Moć tradicije, Kurentovanje in karneval na Ptuju, Ptuj 2000.

Galatariotou, C., »Holy Women and Witches: Aspects of Byzantine Conceptions of Gender", Byzantine and Modern Greek Studies 9 ( I 984-85) 55-94.

Gălușcă, T., »Mocanii - un Joc dramatic al românilor din Dobrogea«, Annarul Arbivei de Folclor 7 (1945) I 2-34.

Garnett, L. M. J., Balkan home-life, New York I 9 I 7.

Gavazzi, M., „Vitalnost običaja pobratimstva i posestrimstva u Sjevernoj Dalmaciji«, Radovi Instituta Jugoslavenske Akademije znanosti in umjetnosti u Zadru I I (I 955) I 7 ff.

Geitler, L., „Die Juda in den Mythen der Balkanvölker«, Mitteilungen der Anthropologischen Gesellschaft in Wien Iо (I 88 I) I 99-202.

Gelenčir, N., Naturheilkunde des Balkans, Steyr I 983.

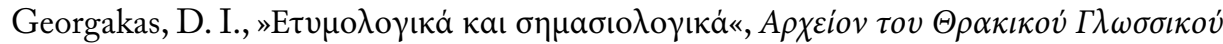

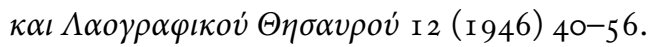

Georgevici, T., »Printre Români nostri. Note de călătorie«, ed. C. Constante, Români din Timoc, Bd. 3, București I 843, 25-I 47.

Georgieva, I., »Survivances de la religion des Thraces dans la culture spirituelle du peuple bulgare«, Le Monde Thrace. Actes du IIe Congrès International de Thracologie, Bucarest 1976 , Paris etc. 1982, 348-352.

Georgieva, I., Bălgarska narodna mitologija, Sofija I983 ( ${ }^{2}$ I993).

Georgieva, I., "Le fen et la croix: un rite en l'honneur de saint Constantin«, Ethnologie Française 3I (200I) 25 I-26o.

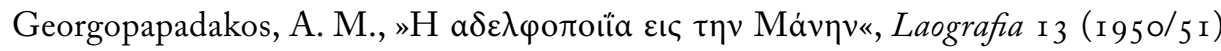
28-32.

Georgoudi, S., »Sant' Elia in Grecia«, Studi e materiali di storia delle religione 39 (I 968) 293-3 I 9.

Georgoudi, S., »L'égorgement sanctifié en Grèce moderne: les >Kourbania des saints«, M. Detienne/J. P. Vernant (eds.), La cuisine du sacrifice en pay grec, Paris I 979, 27 I307 .

Gerçek, S. N., Türk Temașasi (Meddah - Karagöz - Orta oyunu), Istanbul I 942.

Gerndt, H./G. R. Schroubek (eds.), Dona Ethnologica. Beiträge zur vergleichenden Volkskunde, München 1973.

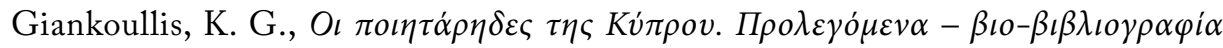
(1936-1976), Thessaloniki I 976.

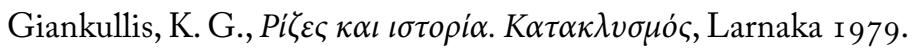

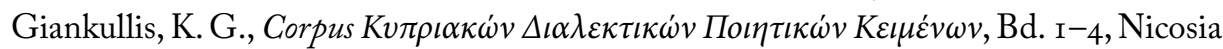
I 998-200I.

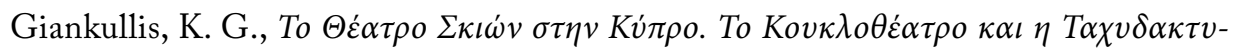




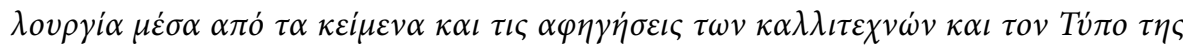

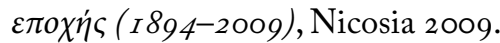

Giochalas, T, $A \rho \beta \alpha v i \tau \iota \kappa \alpha \pi \alpha \rho \alpha \mu v \dot{\theta} \iota \alpha \kappa \alpha \iota \delta o \xi \alpha \sigma i \varepsilon \varsigma$, Athen 1997.

Gîtză, L., Teatrul de Papuși in Romînesc, București i 963.

Gîtză, L., "Le théâtre roumain de marionettes«, Revue roumaine d'bistoire de l'art I (1964) i I 8-i 38 .

Gîtză, L./I. Chimet/V. Silvestru, Teatrul de papuși in Romania, București 1968.

Gjurova, S. (ed.), Kniga za bălgarskite chadžii, Sofija I 995.

Glück, L., »Skizzen aus der Volksmedicin und dem medicinischen Aberglauben in Bosnien und der Hercegovina«, Wissenschaftliche Mittheilungen aus Bosnien und der Hercegovina 2 ( I 894) 392-454.

Glück, L., »Die Volksbehandlung der Tollwuth in Bosnien und der Hercegovina«, Wissenschaftliche Mittheilungen aus Bosnien und der Hercegovina 3 (I 895) 539-55 I.

Glück, L., Medicinische Volksterminologie in Bosnien und der Hercegovina, unter Berücksichtigung der Nachbarländer, Sarajevo I 898.

Goar, J., Evxoגó 1 ıov sive rituale Graecorum, Paris I 647.

Goetz, L. K., Volkslied und Volksleben der Kroaten und Serben, 2 Bde., Heidelberg 1937.

Gospoja, M., »Bei der Zauberin Hamša Farina, einer Zigeunerin in Gorica«, Antbropophyteia 7 (I9I0) 407-4I5.

Gragger, R., »Deutsche Puppenspiele aus Ungarn«, Archiv für das Studium der neueren Sprachen und Literaturen I 48 (I925) I6 I-I 80.

Gramlich, R., Die Wunder der Freunde Gottes. Theologien und Erscheinungsformen des islamischen Heiligenwunders, Wiesbaden I 987.

Grgjić-Bjielokosić, L., »Volksglaube und Volksbräuche in der Hercegovina«, Wissenschaftliche Mitteilungen aus Bosnien und der Hercegovina 6 (I 899) 609-632.

Greenfield, P. H., Traditions of Belief in Late Byzantine Demonology, Amsterdam 988.

Gundel, W., Sterne und Sternbilder im Glauben des Altertums und der Neuzeit, Bonn/ Leipzig I 922 (Hildesheim/New York I 98 I).

Gušić, B., Ljelje - Kraljice kao historijski spomenik, Zagreb I967.

Hadjitaki-Kapsomenou, Chr., »Folklore as Compensation: The Role of Local Cultural Associations in Folklorisation of Social Memory in the Contemporary Greek Context«, Migration, Minorities, Compensation, Issues of Cultural Identity in Europe, Brussels $200 \mathrm{I}, 4 \mathrm{I}-5 \mathrm{I}$.

Hahn, J. G. von, Albanesische Studien I-III, Jena I 854.

Haiding, K., Von der Gestensprache des Märchenerzäblers, Helsinki I 959 (FFC I 55 ).

Hajtov, N. A., Asenovgrad, Sofija I963 (Thessaloniki i 964).

Håland, E. J., »Rituals of Magic Rain-Making in Modern and Ancient Greece. A 
Comparative Research «, Cosmos. The Journal of the Traditional Cosmology Society I 7/2 (2005) I 97-25 I.

Håland, E. J., Greske Fester, Moderne of Antikke. En Sammenlignende Undersøkelse av Kvinnelige og Mannlige Verdier, Kristiansand 2007 (Greek Festivals, Modern and Ancient. A Comparison of Femals and Male Values).

Håland, E. J., „Greek Women, Power and the Body. From Fieldwork on Cults Connected with the Femals Sphere Towards a Deconstruction of Male Ideologies, Modern and Ancient", Mediterranean Review 3/I (2010) 3 I-57.

Håland, E. J., »From Modern Greek Carnivals to the Masks of Dionysos and Other Divinities in Ancient Greece «, Narodna Umjetnost 49/I (20 I 2 ) I I 3-I 30.

Halliday, W. R., "A Greek Marriage in Cappadocia«, Folklore 23 ( I 9 I 2) 8 I-88.

Halliday, W. R., Greek Divination. A Study of Its Methods and Principles, Oxford I 9 I 3 (Chicago r 968).

Hammer-Purgstall, J. Fr. v., Talismane der Muslimen, Wien I 9 I 4.

Handman-Xifaras, M.-E., »Les noces à Pouri, Pélion«, L'Homme I6/2-3 (I 976) 4I-67. Hangi, A., Die Moslims in Bosnien und Herzegowina, Sarajevo I 907.

Hardie, M. M. (Mrs. F. W. Hasluck), »The Evil Eye in some Greek Villages of the Upper Haliakmon Valley in West Macedonia«, Journal of the Royal Anthropological Institute of Great Britain and Ireland 53 (1923) I60-I 72.

Harms, V., Der Terminus »Spiel in der Ethnologie, Diss. Hamburg I 969.

Hartnup, K., On the Beliefs of the Greeks. Leo Allatius and Popular Orthodoxy, Leiden/ Boston 2004 .

Hasluck, F., Christianity and Islam under the Sultans, New York 1973.

Hasluck, M., »The Basil-cake of the Greek New Year", Folklore 38 (I 927 ) I 43-I 77.

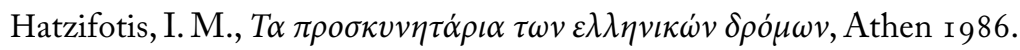

Hatzimichali, A., $\Sigma \alpha \rho \alpha \kappa \alpha \tau \sigma \alpha \dot{v} o$, Athen 1957.

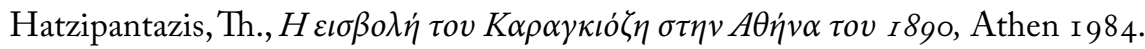

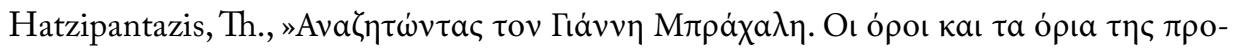

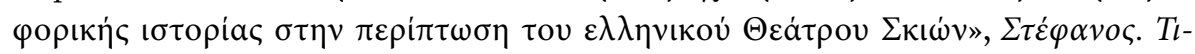

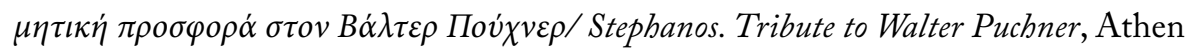
2007, I $337-46$.

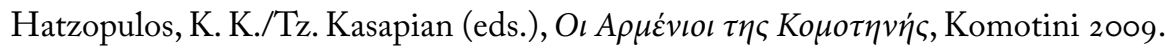

Hauschild, Th., Der böse Blick: Ideengeschichtliche und sozialpsychologische Untersuchungen, Hamburg I979 ( ${ }^{2}$ I982).

Hausmann, L./L. Kriss-Rettenbeck, Amulett und Talisman, München 1966.

Herrman, J./H. Köpstein/R. Müller (eds.), Griechenland-Byzanz-Europa, Berlin I 985 . Herter, H., „Böse Dämonen im frühgriechischen Volksglauben«, Rheinisches Jahrbuch für Volkskunde I (1950) i I 2-I43. 
Herzfeld, M., »Meaning and Morality: A Semantic Approach to Evil Eye Accusations in a Greek Village", American Ethnologist 8 (I98 I) 560-574.

Herzfeld, M., The Poetics of Manhood: Contest and Identity in a Cretan Mountain Village, Princeton 1985.

Hesseling, D. C., Charos. Ein Beitrag zur Kenntnis des neugriechischen Volksglaubens, Leiden/Leipzig I 897.

Hesseling, D. C., »Charos rediens«, Byzantinische Zeitschrift 30 (1 929/30) I 86- I 9 I .

Hesseling, D. C., »Le Charon Byzantin«, Neophilologus I6 (I 93 I) I 3 I-I 35 .

Hirschon, R., „Women, the aged and religious activity: Oppositions and complementarity in an urban locality«, Journal of Modern Greek Studies I (I 983) I I 3-I 29.

Hirschon, R., »Religion and Nationality: The Tangled Greek Case«, R. Pinxten/L. Dikomitis (eds.), When God Comes to Town. Religious Traditions in Urban Contexts, New York/Oxford 2009, 3-i6.

Honko, L., Krankheitsprojektile. Untersuchung über eine urtümliche Krankheitserklärung, Helsinki I 959 (FFC I78).

Hopfner, Th., »Mittel- und Neugriechische Lekano-Lychno-Katoptro- und Onychomantien«, Studies presented to F. L. Griffith, London I 932, 2 I 8-232.

Hopfner, T., Griechisch-ägyptischer Offenbarungszauber, Amsterdam I 974.

Hoppál, M./Törő, »Ethnomedicine in Hungary“, Orvostörténeti Közlemények I 975.

Hovorka, O. von, Vergleichende Volksmedizin, 2 Bde., Stuttgart I 908/o9.

Huizinga, J., Homo ludens. Vom Ursprung der Kultur im Spiel, Hamburg 1956.

Hurlbutt, R., The Phenomenology of Proskinitaria, Hamline Univ. I 985.

Huziak, W., Zeleni Juraj, Zageb i 957.

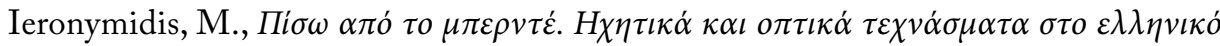

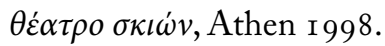

Ilić, M., »Klocalica, šerbulj ili curka - jedna maska u običajima Srba i Rumuna u Banatu«, Rad vojvočanskib muzeja I 2-I 3 (Novi Sad I 964) 45-68.

Ilijin, M./O. Mladenović, „Narodne igre okolini Beograda«, Zbornik radova Etnografskog instituta $\mathrm{SANU}_{4}$ (1962) i $72-\mathrm{I} 78$.

Il'inskij, G., »Juda. Stranička iz slavjanskoj mifologii«, Sbornik Miletić I 933, 467-474.

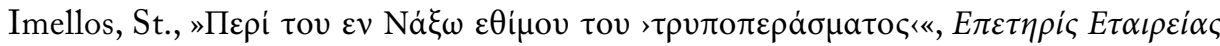
$K v \kappa \lambda \alpha \delta \iota \kappa \omega \dot{v} v \varepsilon \lambda \varepsilon \tau \dot{\omega} v$ I (I96I) 5 I 5-528.

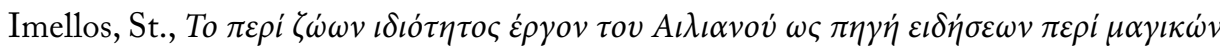
$\kappa \alpha \iota \delta \varepsilon \iota \sigma \iota \delta \alpha \iota \dot{v} v \omega v \delta o \xi \alpha \sigma \iota \omega ́ v \kappa \alpha \iota \sigma v v \eta \theta \varepsilon \iota \omega \dot{v}$, Athen 1972.

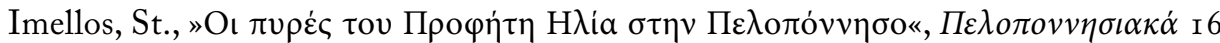
(I985/86) 34I-350.

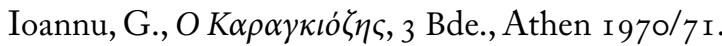

Ioannou, P., Démonologie populaire - démonologie critique au XIe siècle, Wiesbaden I 97 I. 


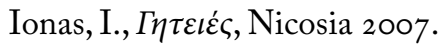

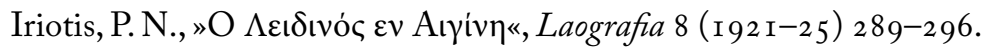

Ivančan, I., Narodni običaj korčulanskih kumpanija, Zagreb I 967.

Ivănescu, G., »O influență bizantînă sau slavă în folclorul românesc și în limba românească. Caloianul«, Folklor Literar I (1 967) I 3-23.

Ivanova, J., Kalendarnje običai i obrjady v stranach zarubežnoj Evropy, Moskva 1978.

Ivanova, R., Traditional Bulgarian Wedding, Sofia 1987.

Ivanova, R., "Archaični čerti v obraza na južnoslavjanskija epičeski geroj«, Slavjanska filologija 20 (I988) I62-I72.

Ivanova, R., »Svadbata kato maskarad«, Bălgarska Etnografija 3-4 (I 994) 35-40.

Ivanović, M., »Poklade u okolinu Beograda«, Etno-kulturološki zbornik I I (Svrljig 1996) IO2-I IO.

Jacob, G., Das Schattentheater in seiner Wandlung vom Morgenland zum Abendland, Berlin I 90 . I.

Jacob, G., Geschichte des Schattentheaters im Morgen- und Abendland, Hannover 1925.

Janeva, St., Ritual Loaves. Bulgarian Folk Customs and Rituals, Sofia 1983.

Jensen, H., Vulgärgriechische Schattenspieltexte, Berlin I 954.

Jensen, H., "Das neugriechische Schattenspiel im Zusammenhang mit dem orientalischen Schattentheater", Joh. Irmscher/H. Ditten/M. Mineemi, Probleme der neugriechischen Literatur IV, Berlin 1959, I 98-208.

Jolles, A., Einfache Formen. Legende, Sage, Mythe, Rätsel, Spruch, Kasus, Memorabile, Märchen, Witz, Leipzig I 930.

Jordanova, L., "Za običaja lazaruvane v Bălgarija«, Izvestija na Etnografskija institut $i$ mиzеj 9 (1966) го7-162.

Jovanović, B., Magija sprskih obreda, Niš 200 I.

Jung, K., »Forecasting death and its omens in the traditions of the Hungarians in Yugoslavia«, Köznapok és legendák, Ujvidék I 992, 70-77.

Kacarova, R., »Naroden kuklen teatăr«, Radovi XII kongresa saveza folklorista Jugoslavije (Celje 1965), Ljubljana 1968, 385-4Io.

Kacarova, R., »Kukeri v s. Vresovo, Ajtosko, i v s. Asparuchovo, Provadijsko«, Izsledvanija v čest na akad. M. Arnaudov, Sofija I970, 433-454.

Kacarova, R., "Folk Puppet Theatre - Puppets made of plants«, The Folk Arts in Bulgaria. Papers from a Symposion, Pittsburgh, Pennsylvania 1 976, 55-75.

Kacarova, R., »Derviši«, Bălgarsko muzikoznenija 4 (I 978) 73-96.

Kacarova, R., »Za edin kuklar i negovite kukli čengii (About a puppeteer and his puppets)«, Etnografski i folkloristični izsledvanija, Sofija I979, 292-305.

Kacarova-Kukudova, R., Bălgarski tancov folklore, Sofija 1955. 
Kacarova-Kukudova, R., »Naroden Kuklen teatăr. Kukli ot kărpi«, Izvestija na Etnografskija institut i muzej VI (1963) 409-424,

Kahl, Th., »Der Böse Blick. Ein gemeinsames Element im Volksglauben von Christen und Muslimen«, Thomas Wünsch (ed.), Religion und Magie in Ostmitteleuropa. Spielräume theologischer Normierungsprozesse in Spätmittelalter und Früher Neuzeit, Münster 2006, 32 I-336.

Kahl, Th./C. Lienau (eds.), Christen und Muslime. Interethnische Koexistenz in südosteuropäischen Peripheriegebieten, Wien/Berlin 2009.

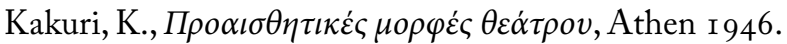

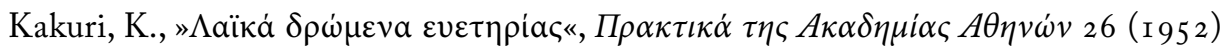
2 I $6 \mathrm{ff}$.

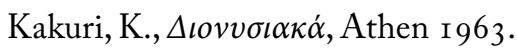

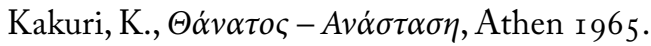

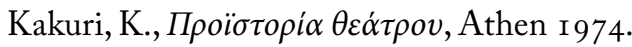

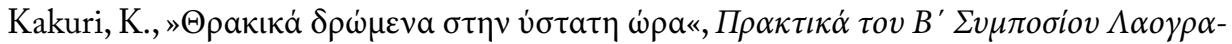

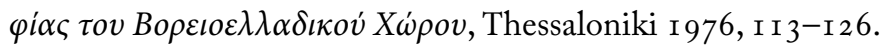

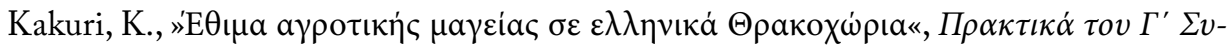

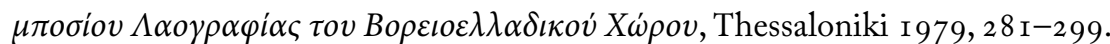

Kaleshi, H., "Albanische Legenden um Sari Saltuk", Actes du Premier Congrès Intern. des Études Balkaniques et Sud-Est Européennes, Sofia i 969, 8 I 5-828.

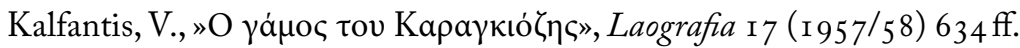

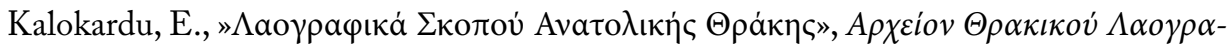

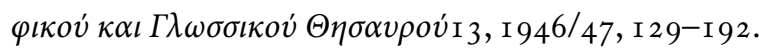

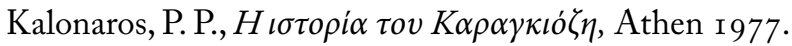

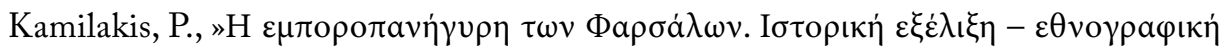

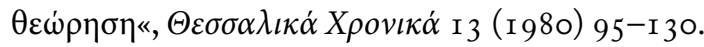

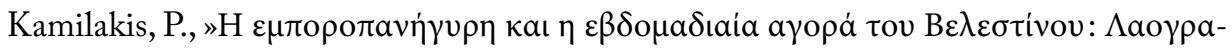

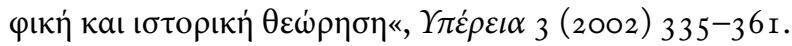

Kämpfer, F., »Der Kult des heiligen Serbenfürsten Lazar«, Südost-Forschungen 3 I (I 972) 8I-I39.

Karadžić, Vuk, Život i običaji narodna srpskog, Beč i 867 .

Karanov, E., "Zemat (ažder) i zmijata (zămja) v bălgarskata narodna poezija ", Periodičesko spisanie na Bălgarskoto knižouno družestvo 9 (I 884) I 29 ff.

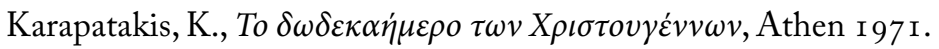

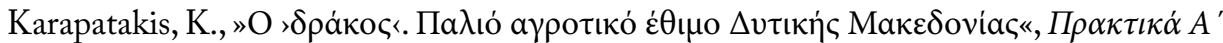

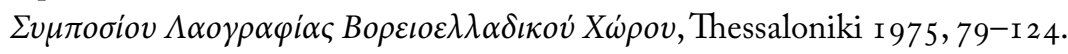

Karasek, A., Das deutsche Volksschauspiel in der Schwäbischen Türkei, Marburg I 974. 
Karasek, A. /K. Horak, Das deutsche Volksschauspiel in der Batschka, in Syrmien und Slawonien, Marburg I 972.

Karavelov, I., Pamjatniki narodnogo bjita bolgar, Moskva I 86 I.

Kaser, K., »Die Mannfrau in den patriarchalen Gesellschaften des Balkans und der Mythos vom Matriarchat«, L'Homme. Zeitschrift für feministische Geschichtswissenschaft 5 (I 994) 59-77.

Kaser, K./S. Gruber/R. Pichler (eds.), Historische Antbropologie im südöstlichen Europa. Eine Einfübrung, Wien etc. 2003.

Katičić, R., "Nachlese zum urslawischen Mythos vom Zweikampf des Donnergottes mit dem Drachen«, Wiener Slavistisches Jahrbuch 34 ( 1988) 57-75.

Katičić, R., »Weiteres zur Rekonstruktion der Texte eines urslawischen Fruchtbarkeitsritus«, Wiener Slavistisches Jahrbuch 35 (I 989) 57-98.

Katsiardi-Hering, O., »Von den Aufständen zu den Revolutionen christlicher Untertanen des osmanischen Reiches in Südosteuropa (ca. I 530-I 82 I). Ein Typologisierungsversuch«, Südost-Forschungen 68 (2009) 96-г 37.

Katzarova, R., »Derwisch-Karnevalsspiele im Dorf Lessitschevo - Kreis Pasardschik«, A. Mauerhofer (ed.) Musikethnologisches Kolloquium. Die Südosteuropäische Volkskultur in der Gegenwart. Referate der 4. Internationalen Balkanologentagung, Graz I983, 97-I I 4 .

Kaufman, K., »Oplakvaneto na >German« u kapancite. Ot plač kăm pesen«, Izvestija na Instituta za Muzika I 3 (1969) I 55-175.

Kazarow, G., »Karnevalsbräuche in Bulgarien«, Archiv für Religionswissenschaft I I (I 908 ) 407-409.

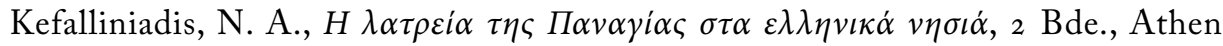
I 990/9I.

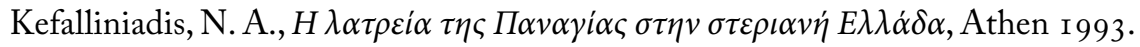

Kemp, Ph. M., Healing Ritual. Studies in the Technique and Tradition of the Southern Slavs, London I935 (I940, reprint I987).

Kenna, M., »Houses, Fields, and Graves: Property and Ritual Obligation on a Greek Island «, Ethnology I 5 ( I 976) 2 I-34.

Kenna, M., "Icons in Theory and Practice«, History of Religions 24/4 (I 985 ) 345-368.

Kenna, M., "Mattresses and Migrants: A Patron Saint's Festival on a Small Greek Island over Two Decades«, Jeremy Boissevain (ed.), Revitalizing European Rituals, London/New York I 992, I 55-172.

Kenna, M., "Saying >No in Greece: Hospitality, gender, and the evil eye«, St. Damianakos/M. E. Handman (eds.), Les amis et les autres: mélanges en l'honneur de John Peristiany, Athens I 995.

Kerényi, G., Gyermekjdátékok, Budapest I 95 I. 
Kerewsky-Halpern, B., »Talk, Touch and Trust in Rural Healing", Papers for the V. Congress of Southeast European Studies, Belgrade, September 1984, Columbus, Ohio 1984, 250-26 I (auch in Social Science and Medicin 2 I/3, 1985, 3 19-325).

Kerewsky-Halpern, B., »Healing with Mother Metaphors", Acta Ethnographica Academiae Scientiarum Hungaricae 34 (1 986-88) 245-265.

Kerewsky-Halpern, B./J. M. Foley, "The Power of the Word: Healing Charms as an Oral Genre«, Journal of American Folklore 9I (I 978) 903-924.

Kerewsky-Halpern, B./J. M. Foley, »Bajanje: Healing Magic in Rural Serbia«, P. Morley/R. Wallis (eds.), Culture and Curing. Antbropological Perspectives on Traditional Medical Beliefs and Practices, London/Pittsburgh, Penn. 1979, 40-56.

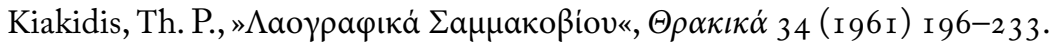

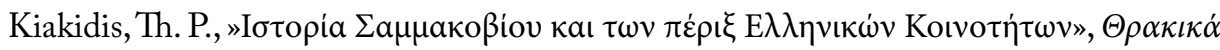
33 (1960) 3-147.

Kissling, H.J., Beiträge zur Kenntnis Thrakiens im 17 . Jahrhundert, Wiesbaden 1956.

Kissling, H. J., „Das islamische Heiligenwesen auf dem Balkan, vorab in Thrakien«, Zeitschrift für Balkanologie I (1962) 46-59.

Kissling, H. J., Dissertationes Orientales et Balcaniae collectae (ed. Brigitte Moser-Weithmann), I. Das Derwischtum (Vorwort L. Kretzenbacher), München 1986.

Kitevski, M., "Zmijata vo makedonskite mitološki narodni pesni«, Zbornik radova 35 kongresa Saveza udruženja folklorista Jugoslavija, Rožaje, 26-29 sept. 1988, Titograd I $988,262-267$.

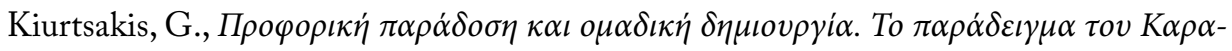
$\gamma \kappa i o ́ \zeta \eta$, Athen 1983.

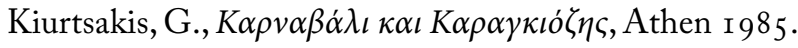

Klein, V., »Der ungarische Hexenglaube«, Zeitscbrift für Ethnologie 66 (I 934) 374-402.

Klepikova, G. P., »Motiv dviženija-poleta v semantike karpato-balkanskogo striga (štriga)«, Balkanskije čtenija 3. Lingro-etnokul'turalno istorija Balkan i vostočnoj Jevropy. Tezisy i materialy simpoziuma, Moskva I994, 94-99.

Kličkova, V., Les coutumes de pâques dans la région de Poretch, Macédonie, Skopje 1957.

Klier, K. M., Das Bockziehen. Ein Faschingsbrauch von der Südostgrenze Österreichs, Eisenstadt 1953 .

Kligman, G., Căluş. Symbolic Transformation in Romanian Ritual, Chicago I98 I .

Knecht, S., »Matiasma - der böse Blick. Diagnose und Therapie auf Kreta«, Medizinische Welt 4/4 (I968) 2455-6r.

Kneževic, M. V., »Svadbeni običaji kao obred i inscenacija«, Zbornik kongresa saveza udruženja folklorista Jugoslavije v Celju 1965, Ljubljana I 968, I 9 I-194.

Kocsis, K., »Changing religious pattern in the Carpathian Basin«, Ethnographica et Folkloristica Carpathica 9-10 (1998) 71-83. 
Köldu, L., »Krippenspiel«, Ethnographia 69 (I 958) 209-259.

Kolev, N., »Narodni predstavi i vjarvanija za vichruškata«, V. Chadžinikolov (ed.), Văprosi na etnografijata i folkloristikata, Sofija I 980, 77-86.

Kolev, R., „Varianti na obredite Peperuda i German«, Bălgarski Folklor I 2/3 (I 986) 4758.

Koleva, T. A., »Sur l'origine de la fête de Saint-Georges chez les Slaves du Sud«, Ethnologia Slavica 6 (I974) I 47-I 73.

Koleva, T. A., »Sur l'origine d'un groupe de coutumes et rites dans la région balkanocarpathique. La fête de Saint Georges«, Thracia 2 (I 974) 2 I 9-226.

Koleva, T. A., „Vestiges de rites d'initiation dans les coutumes de printemps des jeunes filles bulgares«, Études balkaniques Io/ I ( 1974) 65-85.

Koleva, T., »Bolgari«, Kalendarnie običai i obrjadi v stranach zarubežnoj Evropi. Verenni prazdniki, Moskva I977, 69-i I I.

Kolinović, M. F., »Volksaberglaube und Volksheilmittel bei den Mohammedanern Bosniens und der Hercegovina", Wissenschaftliche Mittheilungen aus Bosnien und der Hercegovina 7 ( I 900) 339-366.

Komorovsky, J., »Kaukasische Parallelen der Begräbnis-Bräuche von Crna Gora (Montenegro)«, Ethnologia Slavica 2 ( 1970) I 77-1 87.

Komorovský, J., »Die Inszenierung eines Scheinkampfes um die Braut in der traditionellen slawischen Hochzeit", Ethnologia Slavica 4 (I 972) I 59-i 78.

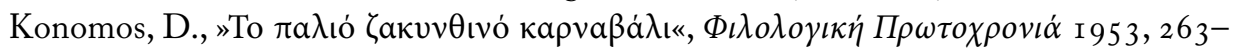
275 .

Korff, G., Simplizität und Sinnfälligkeit. Volkskundliche Studien zu Ritual und Symbol, Tübingen 2013 .

Korniss, P., Bräutigam des Himmels. Bilder ungarischer Volksbräuche, Budapest 1975 .

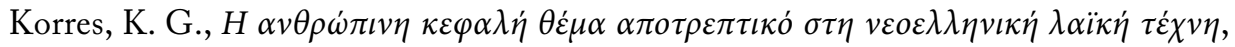
Athen 1978.

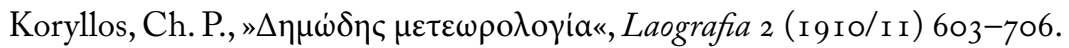

Košir, P./V. Möderndorfer, "Ljudska medicina med koroškimi Slovenci«, Časopis za zgodovino in narodopisje 2 I (Maribor I926) 85-I I 2.

Kosswig, L., »Hochzeitsgebräche in Anatolien«, Oriens I 3/I 4 (I 960/6 I) 240-250.

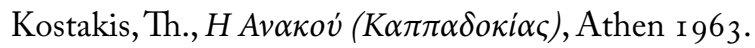

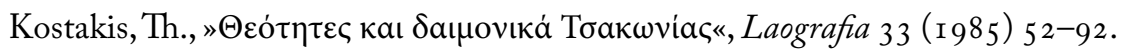

Kostić, L., »Südslavische Volksschauspiele primitivster Art«, Wissenschaftliche Mittheilungen aus Bosnien und der Hercegovina 3 ( 1895 ) 533-538.

Kostić, P., »Godišnji običaji u okolini Zaječara«, Glasnik etnografskog muzeja 42 ( ( 978 ) 399-44I.

Kostić, P., »Lazarice u Surlici«, Glasnik Etnografskog muzeja 46 ( I982) 9-39. 
Kostić, P., »Godišnji običaji, Cjeničko-pešterska visoravan«, Glasnik etnografkog muzeja 52-53 (I 988-89) 73-I23.

Kostić, S., »Amajlije u narodnim verovanjima u Istočno Srbiji«, Glasnik Etnografskog muzеju u Beogradu 6o (i 966) 77-96.

Kostov, St. L., »Kultăt na Germane u bălgarite«, Izvestija na Bălgarskoto archeologičesko družestro v Sofija 3 (1913) ro8-1 24.

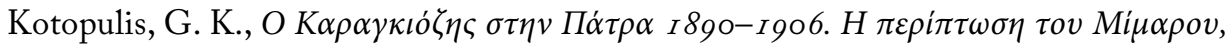
Patras 2000.

Kötting, B., Peregrinatio religiosa. Wallfahrten in der Antike und das Pilgerwesen der alten Kirche, Münster I 950.

Kovač, S., Maska kao znak, Beograd I 996.

Kovačević, I., »Dodola - intergrationi pristup proučavanju običaja«, Glasnik Etnografskog instituta SANU 25 (I976) 67-88.

Kovačević, I., Semiologija rituala, Beograd I 985.

Kovačević, I., Semiologija mita i rituala I-III, Beograd 200 I.

Kowatscheff, J. D., »Bulgarischer Volksglaube aus dem Gebiet der Himmelskunde«, Zeitschrift für Ethnologie 63 (I 93 I) 322-346.

Kraev, G., "Tipologija na Kategoriajata parodija v Kukerskija obred«, Folklor, ezik $i$ narodna sădba, Sofija I 979, I 54-I65.

Kraev, G., Bălgarski maskaradni igri, Sofija I 996.

Kraev, G., »Obredno i dramatično dejstvo«, Maska i ritual, Sofija I999, Io I-I I 3.

Kraev, G., Maska i bulo, Sofija 2003.

Krauss, F. S., »Sreća. Glück und Schicksal im Volksglauben der Südslaven«, Mitteilungen der Anthropologischen Gesellschaft in Wien I6 ( I 886) го2-I 62.

Krauss, F. S., Volksglaube und religiöser Brauch der Südslaven, Münster I 890.

Krauss, F. S., »Vampire im südslawischen Volksglauben«, Globus 6 I/20 (I 892) 325-328.

Krauss, F. S., „Erotik und Skatologie im Zauberbann und Bannspruch«, Antbropophyteia 8 (1907) I60-226.

Krauss, F. S., Slavische Volksforschungen, Leipzig I 908.

Krauss, F. S., »Die Skatologie der Südslaven«, John G. Bourke, Der Unrat in Sitte, Brauch, Glauben und Gewohnheitsrecht der Volker, Leipzig I 9 I 3, 445-50 I.

Kreissl, E., Kulturtechnik Aberglaube, Bielefeld 2013.

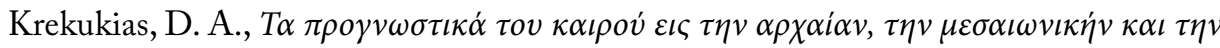
$v \varepsilon \omega \tau \varepsilon \dot{\varepsilon} \rho \alpha v E \lambda \lambda \dot{\alpha} \delta \alpha$, Diss. Athen 1966.

Krekukias, D. A., Il mondo vegetale nelle leggende tradizionali del popolo Greco e Siciliano, Atene 1970 .

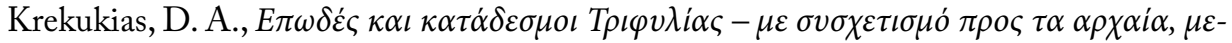

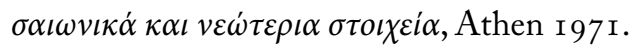




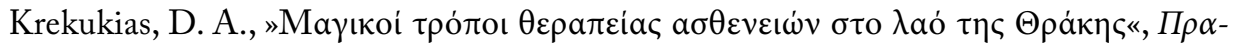

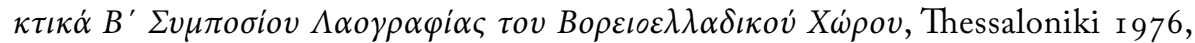
2 I $9-227$.

Kretzenbacher, L., Passionsbrauch und Christi-Leiden-Spiel in den Südost-Alpenländern, Salzburg I 952.

Kretzenbacher, L., Santa Lucia und die Lutzelfrau. Volksglaube und Hochreligion im Spannungsfeld Mittel-und Osteuropas, München 1959.

Kretzenbacher, L., »Rusa und `Gambela< als Equiden-Masken der Slowenen«, Lares I $965,49-74$.

Kretzenbacher, L., Ringreiten, Rolandspiel und Kufenstechen. Sportliches Reiterbrauchtum von heute als Erbe aus abendländischer Kulturgeschichte, Klagenfurt I 966.

Kretzenbacher, L., Kynokephale Dämonen südosteuropäischer Volksdichtung. Vergleichende Studien zu Mythen, Sagen, Maskenbräuchen und Kynokephaloi, Werwölfen und südslawischen Pesoglavci, München r 968.

Kretzenbacher, L., Teufelsbündner und Faustgestalten im Abendlande, Klagenfurt 1968.

Kretzenbacher, L., Rituelle Wablverbrüderung in Südosteuropa, München I 97 I.

Kretzenbacher, L., »Heiliges Brot und Heilbrot. Gedanken zu einer neugriechischen Brot-Monographie«, Münchener Zeitschrift für Balkankunde 4 (I 98 I-82) 26I-267.

Kretzenbacher, L., »Sveta Nedelja - Santa Domenica - Die hl. Frau Sonntag. Südslavische Bild- und Wortüberlieferungen zur Allegorie-Personifikation der Sonntagsheiligung mit Arbeitstabu«, Welt der Slaven 27, I982, 106-1 30.

Kretzenbacher, L., Griechische Reiterheilige als Gefangenenretter, Wien I 983.

Kretzenbacher, L., Ethnologia Europaea. Studienwanderungen und Erlebnisse auf volkskundlicher Feldforschung im Alleingang, München 1986.

Kretzenbacher, L., Geheiligtes Recht. Aufsätze zu einer vergleichenden rechtlichen Volkskunde in Mittel-und Südosteuropa, Wien/Graz/Köln I 988.

Kretzenbacher, L., Sterbekerze und Palmzweig-Ritual beim Marientod. Zu Apokryphen in

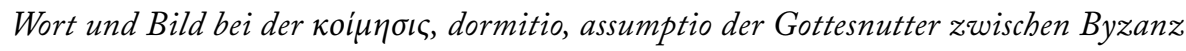
und dem mittelalterlichen Westen, Wien 1999.

Krikos-Davis, K., »The Moires and Tyche in Modern Greek Folklore: a critical biblio-

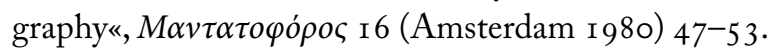

Kriss, R., „Votive und Weihgaben des italienischen Volkes«, Zeitschrift für Volkskunde N. F. 2 (I93 I) 249-27I.

Kriss, R., »Volksreligiöse Opferbräuche in Jugoslawien«, Wiener Zeitschrift für Volkskunde 35 (I935) 49-63.

Kriss, R., »Volksglaube im Bereich des Islam (Aufgezeigt am Thema der Heiligenverehrung)«, Volkskunde-Kongreß Nürnberg 1958. Vorträge und Berichte, Stuttgart I 959, $40-53$. 
Kriss, R., »St. Georg - al Hadr (Ihadir, Hidr)«, Bayerisches Jahrbuch für Volkskunde I 960, 48-56.

Kriss, R./H. Kriss-Heinrich, Peregrinatio Neohellenika. Wallfahrtswanderungen im heutigen Griechenland und in Unteritalien, Wien 1955.

Kriss, R./H. Kriss-Heinrich, Volksglauben im Bereich des Islam. Bd. I: Wallfahrtswesen und Heiligenverehrung, Bd. 2: Amulette, Zauberformeln und Beschwörungen, Wiesbaden $1960 / 62$.

Kriss, R./H. Kriss-Heinrich, „Beiträge zum religiösen Volksleben auf der Insel Cypern mit besonderer Berücksichtigung des Wallfahrtswesens«, Rheinisches Jabrbuch für Volkskunde I 2 (196I) I 35-2 io.

Kriss, R./Rettenbeck, L., Wallfahrten Europas, München I950.

Kriss-Rettenbeck, L., Bilder und Zeichen religiösen Volksglaubens, München I 962 ( ${ }^{2}$ I 97 I).

Kriss-Rettenbeck, L., Ex voto. Zeichen, Bild und Abbild im christlichen Votivbrauchtum, Zürich/ Freiburg I 972.

Kristić, A., „Fragmente aus der Volksmedizin Bosniens und der Herzegowina«, Elfriede Grabner (ed.), Volksmedizin. Probleme und Forschungsgeschichte, Darmstadt I 967, 345$36 \mathrm{I}$.

Krstić, B., "Ženitba čoveka vilom«, Prilozi proučavanju narodne poezije 4 (I 937) 99-I I I.

Krstić, D., »Svadbeni običaji u selu Ošljane«, Pirotski zbornik 25-26 (Pirot 2000) 6 I-78.

Kudret, C., Orta Oyunu, Ankara 1973.

Kudret, C., Karagöz, İstanbul 2004.

Kuhar, B., "Ceremonial Masks in Yugoslavia«, Walter W. Kolar (ed.), The Folk Arts of Yugoslavia, Pittsburgh, Penn. I 976, 89-102.

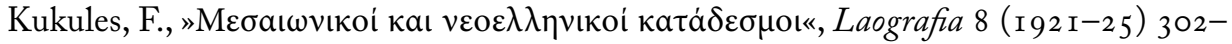
346, 9 (1926-28) 52-108, 450-506.

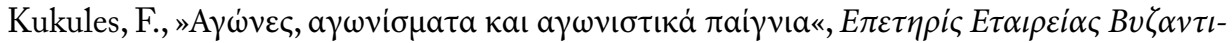
$v \omega \dot{v} \Sigma \pi 0 v \delta \omega \dot{v}$ г 3 ( I937) 65-г 22.

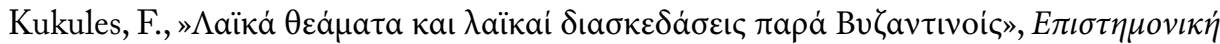

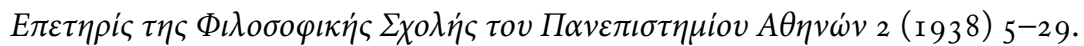

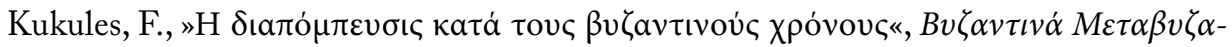
$v \tau \iota v \alpha ́$ I (I 949) 75-гог.

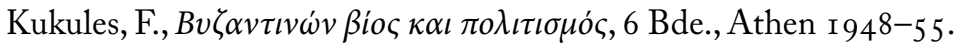

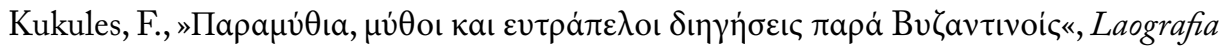
I 5 (I953/54) 2 I 9-229.

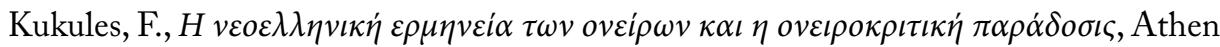
I 954 .

Kulikowski, M., A Bibliography of Slavic Mythology, Columbus, Ohio I 989.

Kulišić, Š., Srpski mitološki rečnik, Beograd I 970. 


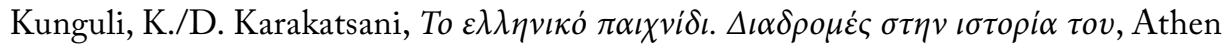
2008.

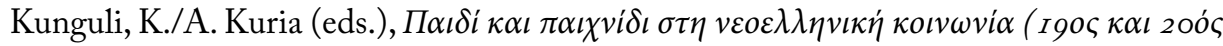
$\alpha \iota \omega \dot{v} \alpha)$, Athen 2000.

Kúnos, I., »Türkisches Volksschauspiel Orta Ojun«, Keleti Szemle 8 ( I 907) I-93, 262263.

Kúnos, I., Das türkische Volksschauspiel - Orta Ojun, Leipzig I 908.

Küppers, G. A., »Rosalienfest und Trancetänze in Duboka. Pfingstbräuche im ostserbischen Bergland«, Zeitschrift für Ethnologie 76 (I 954) 2 I 2-224.

Küppers-Sonnenberg, G. A., "Bei den Feuertänzern (Nestinari) im bulgarischen Strandschagebirge «, Zeitschrift für Ethnologie 8 I (I 956) I I 8-i 23.

Küppers-Sonnenberg, G. A., »Balkanisches Festtagsbackwerk (Gebildbrot). Ornamentik, Symbolik, Stellung im Festbrauch«, Zeitschrift für Ethnologie 87 ( I962) 93-I I 4.

Kuret, N., Igra o Kristusovem trplenju, Ljubljana I 937 (Ljudske igre, Nr. I7).

Kuret, N., »Trikraljevske igre in Kolede na Slovenskom«, Slovenski Etnograf 3/4 (I 95 I) 240-275.

Kuret, N., »Zanimiva oblika ljudskega lutkarstva na Slovenskem«, Slovenski Etnograf ıо (I957) I I 3-I 24 .

Kuret, N., »Ljubljanska igra o paradizu in ujen evropsky okvir«, Razprave $S A Z U_{4}$ (I958) 204-252.

Kuret, N., » Baba žagajor. Slovenske oblike pozabljenega obredja in njegove evropske paralele (Scier le vieille. Formes slovenes et parallèls européennes d'une cérémonie oubliée)«, Slovenski Etnograf I 8 ( I 960) i I 5 ff.

Kuret, N., »Novo o >naši tradicionalni lutki«, Slovenski Etnograf I 5 ( I 962) I 57-i66.

Kuret, N., Ziljsko štehvanje in njegov evropski okvir, Ljubljana I 963.

Kuret, N., »Ljudsko gledališče pri Slovenich«, Slovenski Etnograf 3 (I 965) I 26-I 42.

Kuret, N., »Die Mittwintersfrau der Slowenen (Prehta baba und Torka)«, Alpes Orientales 5 (Ljubljana I 969) 209-239.

Kuret, N., Praznično leto Slovencev. Starosvetne šege in navade od pomlade do zime, Celje I 970.

Kuret, N., »Frauenbünde und maskierte Frau«, Schweizer. Archiv für Volkskunde 68/69 (1972/73) 334-347.

Kuret, N., »Die >Alten` in den Maskenumzügen Südosteuropas«, Etnografski folkloristicni izsledvanija, FS Chr. Vakarelski, Sofija I 979, 2 I 5-225.

Kuret, N., Maske slovenskih pokrajin, Ljubljana I 984.

Kuret, N., Slovenska koledniška dramatika, Ljubljana 1986.

Kuret, N., »Sredozimske maske: Poglavje iz primerjalnega narodopisja«, Etnolog 5 (LVI) (I 995) I 3-49. 


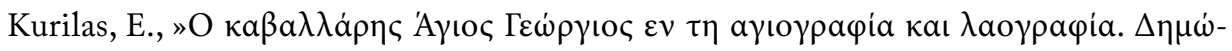

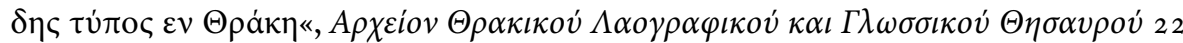
(г957) г7-г 36.

Kuzmanova, V., »Za sistemnija charakter na proletnite obredi«, Obred i obreden folklor, Sofija I98 I, I I 5-I 45 .

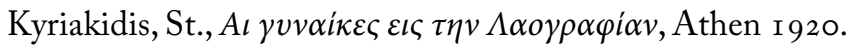

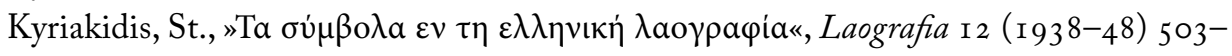
546.

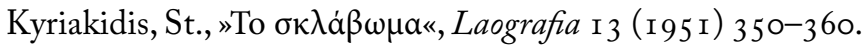

Kyriakidu-Nestoros, A., $\Lambda \alpha o \gamma \rho \alpha \varphi \iota \kappa \dot{\alpha} \mu \varepsilon \lambda \varepsilon \tau \dot{\eta} \mu \alpha \tau \alpha$, Athen $\mathrm{I} 975$.

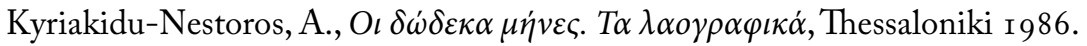

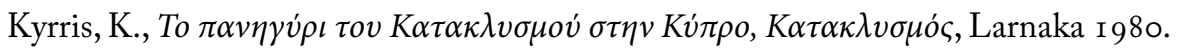

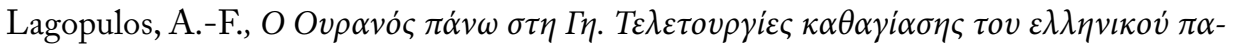

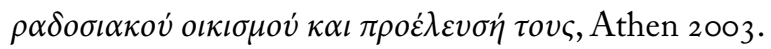

Lájos, Á., Este a fonoban, Budapest 1974.

Lambertz, M., »Die Mythologie der Albaner«, H. W. Haussig (ed.), Wörterbuch der Mythologie, I. Abt. Bd. II. Götter und Mythen im Alten Europa, Stuttgart I 973, 455-509.

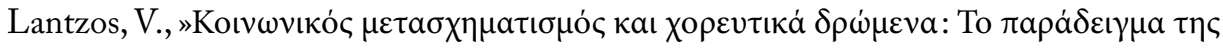

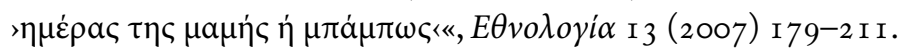

Lawson, J. C., »A beast dance in Scyros«, The Annual of the British School in Athens 6 (I 899/ г 900) I $25 \mathrm{ff}$.

Lawson, J. C., Modern Greek Folklore and Ancient Greek Religion, Cambridge i 9 I.

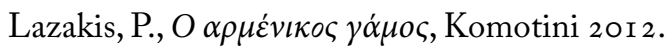

Lazar, V., Die Südrumänen der Türkei und der angrenzenden Länder, Bukarest I 9 I 0.

Lechner, Z., "Buše - pokladni običaj baranjskih Hrvata«, Etnološki prilozi I ( 1978) I 59I 74 .

Leeuw, G. van der, »Die do-ut-des-Formel in der Opfertheorie«, Archiv für Religionswissenschaft 20 ( I 920-2 I) 24I-253.

Lesky, A., "Abwehr und Verachtung in der Gebärdensprache«, Anzeiger der phil.-bist. Klasse der Österreichischen Akademie der Wissenschaften 106 (I 969) I 49-I 57.

Lettenbauer, W., »Über Krankheitsdämonen im Volksglauben der Balkanslaven«, Serta Monacensia. FS F. Babinger, Leiden I952, I 20-I35.

Lettenbauer, W., »Bemerkungen zur Baumverehrung in Volksglauben und Brauchtum der Südslaven «, Südost-Forschungen I 7 ( 1958 ) 68-82.

Lettenbauer, W., Der Baumkult bei den Slaven. Vergleichende volkskundliche, kultur-und religionsgeschichtliche Untersuchung, Neuried I 98 I .

Lilek, E., „Volksglaube und volksthümlicher Cultus in Bosnien und der Hercegovina", Wissenschaftliche Mittheilungen aus Bosnien und der Hercegovina 4 ( I 896) 40 I-492. 
Litsas, F. K., »Rousalia: The Ritual Worship of the Dead«, A. Bharati (ed.), The Realm of the Extra-Human, The Hague/Paris I 975, 447-465.

Litsas, F. K., The Greek Folk Wedding: Preliminary Studies, Chicago I 98 I .

Liungman, W., Traditionswanderungen Euphrat-Rhein, 2 Bde., Helsinki I 937 (FFC I I 8, I I 9).

Liungman, W., »Das Kukeri-Spiel in Hagios Georgios und zwei damit zusammenhängende Namensreihen«, Byzantinisch-neugriechische Jabrbücher I 5 (I 939) 2 I-29.

Ljubenov, P., Samovili i samodivi, Sofija I 89 I.

Lockwood, W. G., »Bride Theft and Social Maneuverability in Western Bosnia«, Anthropological Quarterly 47 ( I 974) 253-269.

Lodge, O. C., "Fire-Dances in Bulgaria - I 939«, The Slavonic and East European Review $26($ I $947 / 48) 467-483$.

Lorinț, F./C. Eretescu, »Moșiiく în obiceiurile vieții familiale«, Revista de Etnografie și Folclor I 2 ( 1 967) 299-308.

Loukatos, D. S., „L'invitation aux noces: sujet d'étude comparative chez les peuples balkaniques«, Die Kultur Südosteuropas, ibre Geschichte und Ausdrucksformen, Wiesbaden/ München I964, I6I-i70.

Loukatos D. S., »La St. Démètre (26 Oct.) jour de culte, de transhumances et de conventions automnales chez les pasteurs nomades ou semi-nomades en Grèce«, Symposium du 6-7 Nov. I975 à Belgrade, Belgrade I 976, 257-267.

Loukatos, D. S., »Fleurs et Plantes, dans les Églises Orthodoxes - Grecques: Offrandes

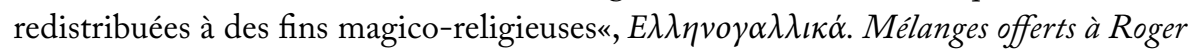
Milliex, Athènes r 990, 447-46o.

Loutzaki, R., Dance as a cultural message. A study of style among the Greek from nothern Thrace in Micro Monastiri, Neo Monastiri and Aeginion, Belfast I 989.

Ložar-Podlogar, H., „Die Szene mit der `Falschen Braut ‘ in den südslawischen Hochzeitsbräuchen«, Ethnologia Slavica 3 (I 97 I) 203-2 Io.

Lozica, I., »Teatralnost, teatrabilnost, i folklorni teatar«, Gradina 3 (Niš I 980) 79-9 I.

Lozica, I., »Dva karnevala«, Narodna umjetnost 25 ( I 988) 87-I I 3.

Lozica, I., »Customs Staged as Theatrical Performance«, Narodna umjetnost 25 ( 1988) I 8 I-I 90 .

Lozica, I., Izvan teatra (Zapisi i tekstovi), Zagreb I 990.

Lozica, I., "From Ritual to Theater and Back: The Lastovo Island Carnival«, Narodna Umjetnost 32/I (I 995) I 55-I 79 .

Lozica, I., Hrvatski karnevali, Zagreb 1997.

Lozica, I., Poganska baština, Zagreb 2002.

Lübeck, K. L., „Die Krankheitsdämonen der Balkanvölker«, Zeitschrift des Vereins für Volkskunde 8 (I 898) 24I-249, 379-389, 9 (I 899) 58-68, I 94-204, 295-304. 


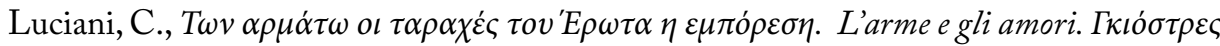

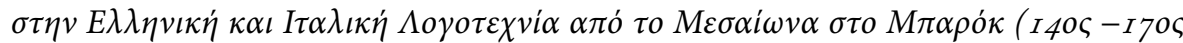
$\alpha \iota \omega \dot{v} \alpha \varsigma)$, Athen 2005 .

Luciani, C., Gian Carlo Persio, La nobilissima barriera della Canea, poema cretese del 1594. Introduzione, testo critico e commento a cura di Cristiano Luciani, Venezia I 994.

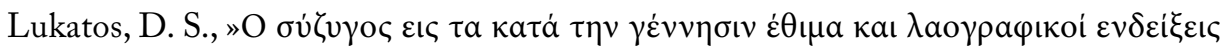

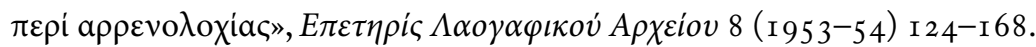

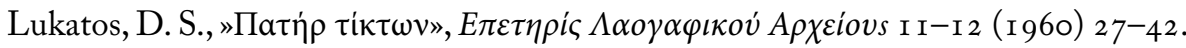

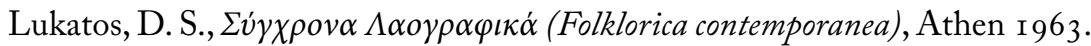

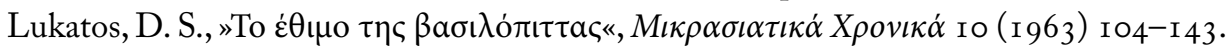

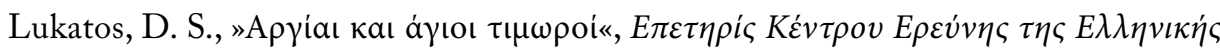
$\Lambda \alpha о \gamma \rho \alpha \varphi i \alpha \varsigma$ 20-2 I (I 967-68) г 5-105.

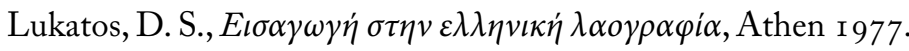

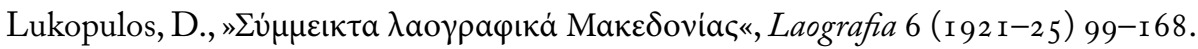

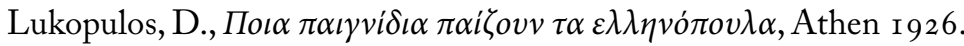

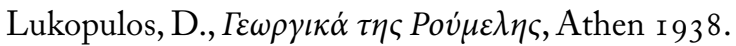

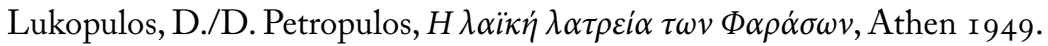

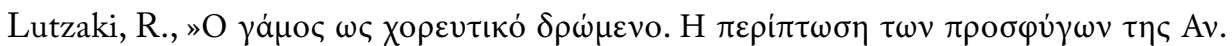

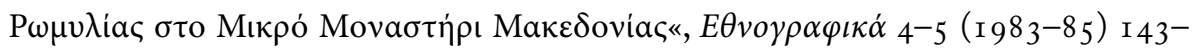
I 76 .

MacCormick, J./B. Pratasik, Popular puppet theatre in Europe, I80o-I8I4, Cambridge I 998.

Maguire, H. (ed.), Byzantine Magic, Washington D. C. I995.

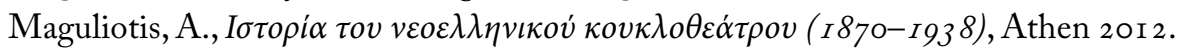

Mailand, O., »Der Fluch in der siebenbürgisch-rumänischen Volkspoesie«, Zeitschrift für Volkskunde 3 (I 89 I) 208-2 I 4.

Majzner, M., »Dubočke Rusalije«, Godišnjica N. Čupica 34 (Beograd I 97I) 226-257.

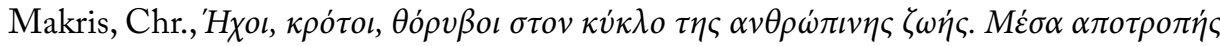

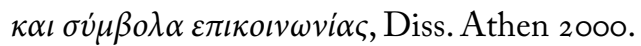

Maluckov, M., "Klocalica kod Srba i Rumuna u Banatu“, Posebni otisak, Radovi Simposijuma o juslovensku-rumunskim uzajamnostima u oblasti narodne književnosti, Pančevo I $972,34 \mathrm{I}-356$.

Maluckov, M., Rumuni u Banatu, Novi Sad I 985.

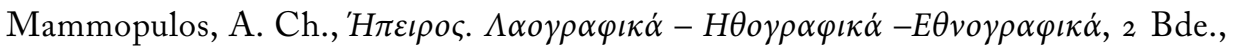
Athen I964.

Mándoki, L., Busójárás Monácson, Pécs I 963.

Mandžarov, P., »Poganotor (pogani din) văv vjarvanijata i bita na strandžanskite sela«, Bălgarski Folklor 8/4 (1982) 91-ıо . 
Manga, J., Tájékosztato szinjátékszerü népszokások gyüjtéséhez, Budapest 1953.

Mango, J., »Die Hochzeitsbräuche der Paloczen und ihre slowakischen Analogien«, Acta Ethnographica Academiae Scientiarum Hungaricae I 9 ( I 970) 247-279.

Mansel, A. M., Trakya'nin Kültür Taribi, Istanbul 1938.

Marazov, I., »Amazonkata i samodivata «, Mitologija, izkustvo, folklor, Sofija I 985, 90-I I 7.

Marian, S. F., Nunta la români, București I 890.

Marian, S. F., Inmormântarea la Români, București I 892.

Marinov, D., Narodna vjara i religiozni narodni običai, Sofija I 9 I 4 (Sbornik za Narodna Umotvorenija XXVIII).

Marinov, V., »Sur certains problèmes fondamentaux de l'astrologie de la Bulgarie«, Rivista di storia dell'agricultura 3 ( ( 979) 47-6o.

Marjanović, V., Maske u tradicionalnoj kulturi Vojvodine, Novi Sad I 992.

Marjanović, V., »Pokladne maske i povorke«, Glasnik etnografkog muzeja 67-68 (2004) I 55-I 76 .

Marjanović, V., Tradicionalne dečje igre u Vojvodini, Novi Sad 2005.

Marjanović, V., Maske, maskiranje i rituali u Srbiju, Beograd 2008.

Markov, L. V., Bolgary Kalendarnye obyčai i obrjady v stranach zarubežnoj Evropy, Moskva I 978 .

Martischnig, M., »Erotik und Sexualität der unteren Volksschichten«, Zum 5o. Todestag von Friedrich Salomo Krauss, Wien I 989, 22-83.

Matantséva, T., »Les amulettes byzantines contre le mauvais œil du Cabinet des Médailles«, Jahrbuch für Antike und Christentum 37 (I 994) I I O-I 2 I.

Matić, T., Totenkult bei den Serben, Diss. Leipzig I 940.

Matl, J., »Hölle und Höllenstrafen in den volksreligiösen Vorstellungen der Bulgaren, Serben und Kroaten«, Südslawische Studien, München I 965, I 59-1 79.

Maurer, L. v., Das griechische Volk in öffentlicher, kirchlicher und privatrechtlicher Beziehung. vor und nach dem Freiheitskampfe ... 3 Bde., Heidelberg I 835 .

Mavrides, O., Gesundheitsmagie in West-Thrakien. Ein Beitrag zur griechischen Volksmedizin, Diss. Universität Münster I 977.

Mavroudi, M., The So-Called»Oneirocriticon of Achmet «: A Byzantine Book on Dream Interpretation and its Arabic Sources, PhD Diss. Harvard Univ. I 998.

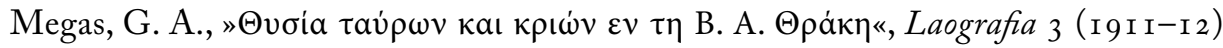
I $48-$ I 7 I.

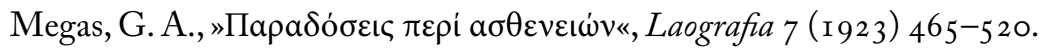

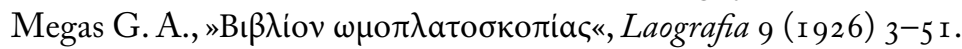

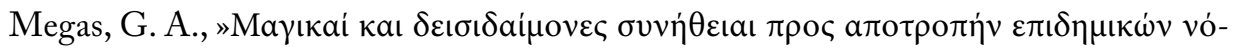

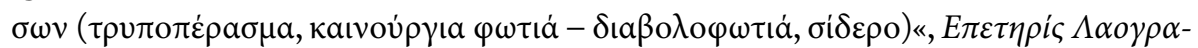

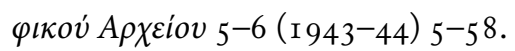




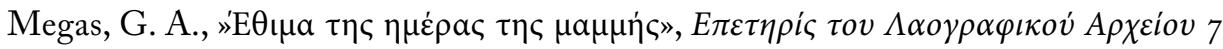
(1952) 3-27 (Laografia 25, I967, 534-556).

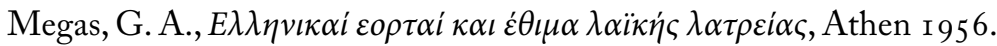

Megas, G. A., Greek Calendar Customs, Athens 1958.

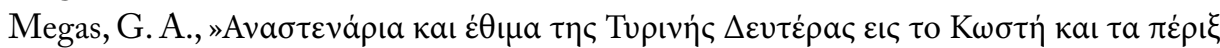

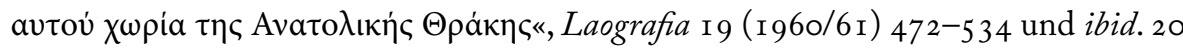
(I 962$) 552-557$.

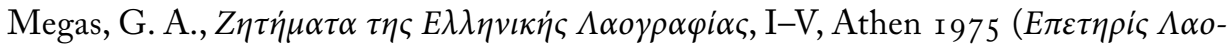

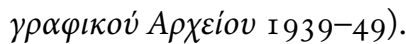

Meinardus, O., "A study of the Relics of Saints of the Greek Orthodox Church«, Oriens Christianus 54 (1970) I 30-275.

Meițoiu, I., Spectacol nunților, București i 969.

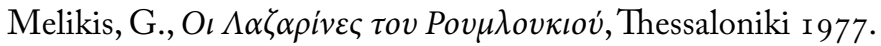

Menzel, Th., Meddah, Schattentheater und Orta Oyunu, Prag I94I.

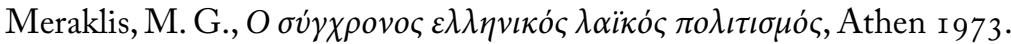

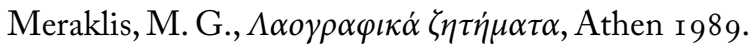

Meraklis, M. G., Studien zum griechischen Märchen, Wien 1992.

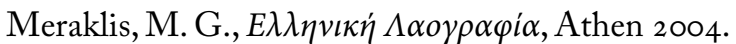

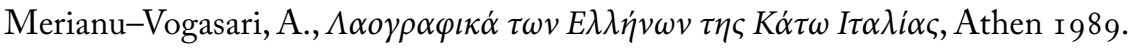

Meuli, K., »Bettelumzüge im Totenkultus, Opferritual und Volksbrauch«, Schweizer Archiv für Volkskunde 28 (I928) I-38.

Meuli, K., »Maske, Maskereien«, Handwörterbuch des deutschen Aberglaubens 5 (1932/33) I 744-I 852 .

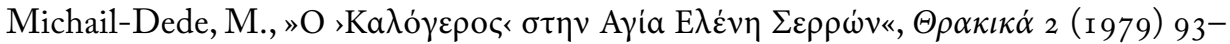
I 26 .

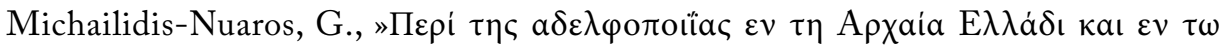

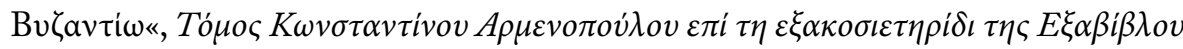

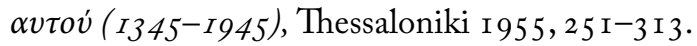

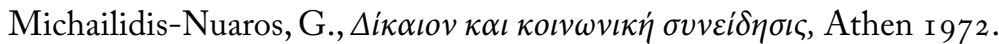

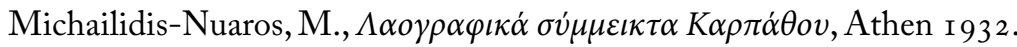

Michailidis-Nuaros, M., $\Gamma \lambda \omega \sigma \sigma \iota \kappa \dot{\alpha} \kappa \alpha \iota \lambda \alpha o \gamma \rho \alpha \varphi \iota \kappa \dot{\alpha} K \alpha \dot{\alpha} \sigma o v$, Athen 1935.

Mihail, Z., "Symbols populaires de la reconnaissance dans l'aire mediterranéenne et Sud-Est-européenne«, M. Mandalà (ed.), La Sicilia, il Mediterraneo, i Balcani: Storie, culture, lingue, popoli, Palermo 2006, I 23 - 47 .

Michailova, G., »Kăm problema za semantikata na vestite v patriarchalnija svjat na Bălgarina«, Folklor, ezik i narodna sădba, Sofija I 979, I I 7-I 25.

Mihailović, S., »Svadbeni običaji u Nišavu«, Glasnik Etnografskog muzeja 34 (I97 I) 85IO3. 
Mijatović, St. M., „Narodna medicina Srba seljaka u Levču i Temniću«, Srpski etnografski zbornik I 3 (I 909) $259-482$.

Mikov, L., "Kăm problema za tipologijata na materialnata kultura v obreda«, Folklor, ezik i narodna sădba, Sofija I 979, I $26-\mathrm{I} 34$.

Mikov, L., Părvomartenska obrednost (Bălgarski praznici i običai), Sofija I 985 .

Mikov, L., "Ženska antropomorfna plastika v dva obreda za dăžd ot Jambolski okrăg“, Bălgarski Folklor I I/4 (1985) i 9-27.

Milčetić, I., Koleda u južnih slavena, Zagreb i 9 I 7.

Miličević, F., "Ženidba (Broćanska župa u Hercegovini)«, Zbornik za narodni život $i$ običaje južnih Slavena 20/2 (I 91 5) I 85-225.

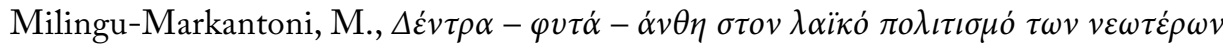

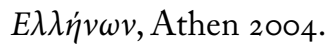

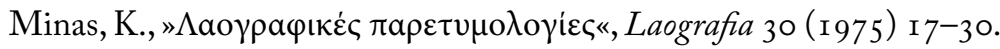

Mitova-Džonova, D., »Naj-rannijat komponent na kukerskite igri«, Annali. Spisanie za istorija, klasičeska kultura i izkustvoznanie 2 (I 995) 39-63.

Mladenović, O., "Narodne igre ćerdapskog stanovništva«, Zbornik radova Etnografskog instituta 7 (1974) 9I-ro8.

Möderndorfer, V., Ljudska medicina pri Slovencib, Ljubjana I 964.

Moldoveanu-Nestor, E., »Date inedite privind practicile folclorice tradiționale de Anul Nou în zona Buzău«, Revista de Etnografie și Folclor I 97 I, 307-325.

Moravcsik, G., »Il Caronte Bizantino«, Studi Bizantini e Neoellenici 3 ( 930 ) 37-68 (separatum Roma i 930).

Morfakidis, M., Karaguiosis. El teatro des ombras griego, Granada I 999.

Morinis, A, (ed.), Sacred Journeys. The Anthropology of Pilgrimage, Westport, Conn./London 1992 .

Moroz, J., Ženski demonični obrazi v bălgarskija folklor i vjarvanija, Sofija I 989.

Moser, D.-R., Fastnacht - Fasching - Karneval. Das Fest der »verkehrten Welt«, Grazl Köln/Wien I 986.

Moser-Karagiannis, E., »Quelques remarques sur les appellations du Kalikantzaros«, $\Lambda \mathcal{E}$ -

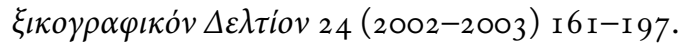

Moser-Karagiannis, E., »Hors d'ici $(\mathrm{O} \xi \alpha \pi \circ \delta \omega \dot{)})$. Les êtres fantastiques et la parole dans les légendes populaires grecques. I. Xotika (Anaskelades, Arapides, Chamodrakia (Smerdakia, Telonia), Drakoi, Gorgones, Kalikantzaroi, Néraïdes, Stoicheia, Vrachnades). A. Le Kalikantzaros«, Littérature orale de la Grèce moderne. Revueil d'études, Athènes 2005, 263-450.

Moszyński, K., Kultura ludowa Stowian, 2 Bde., Krakow I 934.

Murko, M., „Das Grab als Tisch«, Wörter und Sachen 2 (I 910) 79-160. 
Mustafa, M., "Kuçedra", Gjurmime albanologiike, Seria folklor dhe etnologji 20 (I 990) I $49-$ - 69 .

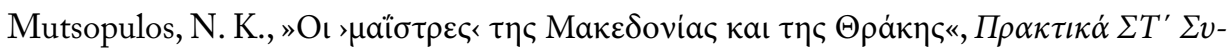

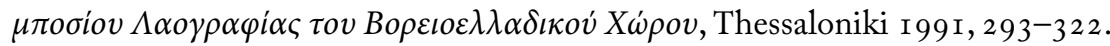

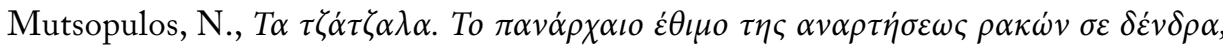

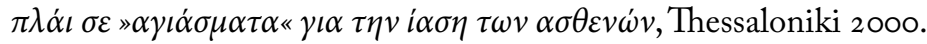

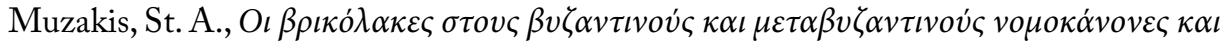

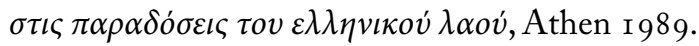

Myrsiades, L. S., "The Karaghiozis Performance in Nineteenth Century Greece«, Byzantine and Modern Greek Studies 2 (1976) 83-97.

Myrsiades, L. S., »Nation and Class in the Karaghiozis History Performance«, Theatre Survey $19 /$ I (1978) 49-62.

Myrsiades, L. S., "Oral composition and the Karaghiozis Performance«, Theatre Research International 5 (1980) 107-I $2 \mathrm{I}$.

Myrsiades, L. S., »Theater and society: social context and effect in the Karaghiozis-performance«, Folia neohellenica 4 (I982) I 37-I 45 .

Myrsiades, L. S., »Historical Source Material for the Karaghiozis Performance«, Theatre Research International $\mathrm{IO} / 3$ ( 1985 ) $213-225$.

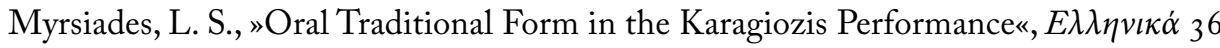
(I985) I I6-I52.

Myrsiades, L. S., »Traditional History and Reality in the View of the Karaghiozis History Performance«, Modern Greek Studies Yearbook I (1 985) 93-го7.

Myrsiades, L. S., "The Karagiozis Performance in Its Performative Context: the Rural/ Urban Dichotomy«, Modern Greek Studies Yearbook 4 ( I 988) 5 I-8I.

Myrsiades, L. S. \& K. M., Karagiozis: Culture and Comedy in Greek Puppet Theater, Lexington 1992.

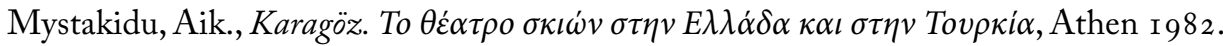

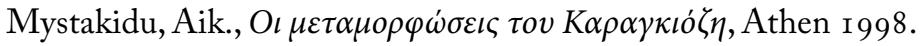

Nacovi, N. A., "Za pobratimstvo«, Periodičesko spisanie na bălgarskoto knjižovno družestvo Sredeci I 895, IX-XI 32-72, LI 375-403, LII-LIII 443-506.

Nădejda, L., »Teatrul popular de papuși în secolul al XIX-lea«, Studii și cercetări de istoria artei 7, no I (1960) 203-215.

Nedeljković, M., Godišnji običaji u Srba, Beograd 1990.

Negelein, J. v., »Bild, Spiegel und Schatten im Volksglauben«, Archiv für Religionswiss. 4 (I902) I-37.

Negelein, J. v., »Macedonischer Seelenglaube und Totenkultus«, Zeitschrift des Vereins für Volkskunde 14 (1904) I9-35. 
Nersessian, S. der, "The homily on the Raising of Lazarus and the Harrowing of Hell«, Biblical and Patristic Studies in Memory of R. D. Casey, Freiburg/Br. 1963, 2 I 9-234.

Nersessian, S. der, "A homily of the Raising of Lazarus and the Harrowing of Hell«, Études Byzantines et Armeniennes/Byzantine and Armenian Studies I (1973) 457-467.

Nicolau, I./Ioana Popescu, »Le Kitsch comme tradition«, Revista de Etnografie și Folclor 30/2 (I 985 ) I35-I4I.

Nikolakakis, G., »La litanie dans le Lassithi, Crete«, Études et Documents Balkaniques et Méditerranéens I6 (I 992) 42-48.

Nikolić, D., »Beitrag zum Studium des Ritterspiels von Sinj«, Narodno stvaralaštvo Folk$\operatorname{lor}_{3}$ ( I 964) 807-8 I3.

Nikolić-Stojančević, V., Vranjsko Pomoravlje, Beograd I 974.

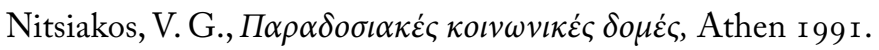

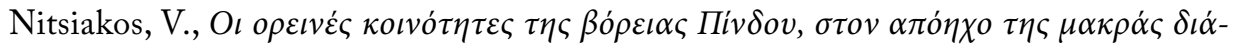
$\kappa \rho \varepsilon ı \alpha$, , Athen I 995 .

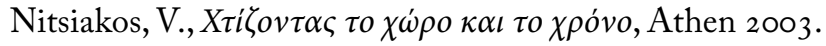

Nixon, L., Making a Landscape Sacred. Outlying Churches and Icon Stands in Sphakia, Southwestern Crete, Oxford 2006.

Nodilo, N., Stara vjera Srba i Hrvata, Split I 98 I.

Norris, H. T., Islam in the Balkans, London 1993.

Novosel, S., Prigorska sbatba, Zagreb I 926.

Nutku, Ö., »Die Verfremdung im Orta Oyunu«, Maske und Kothurn I6 (I 970) 2 I 7-22 8.

Oberhelman, S. M., "Prolegomena to the Byzantine Oneirocritica«, Byzantion 50/2 (I 980 ) 487-503.

Oberhelman, S. M., The Oneirocritic Literature of the Late Roman and Byzantine Eras of Greece, $\mathrm{PhD}$ diss. University of Minnesota $\mathrm{I} 98 \mathrm{I}$.

Oberhelman, S. M., »The Interpretation of Dream-Symbols in Byzantine Oneirocritic Literature«, Byzantinoslavica 47 (I986) 8-24.

Ohnefalsch-Richter, M., Griechische Sitten und Gebräuche auf Cypern, Berlin I 9 I 3.

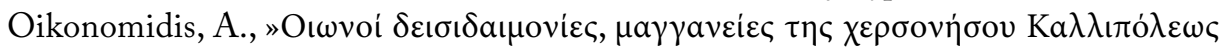

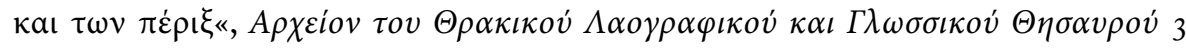
(1937-47) 85-i i 8 .

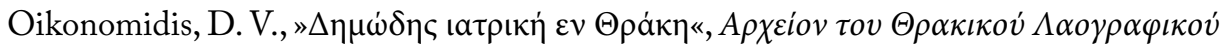

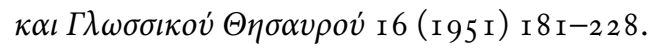

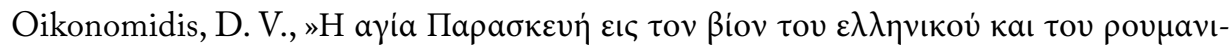

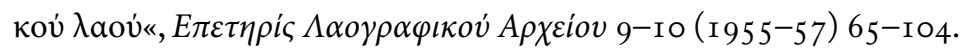

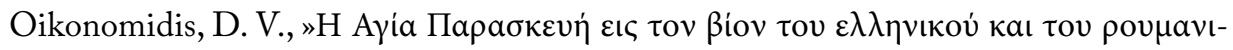

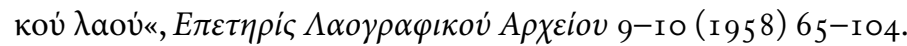




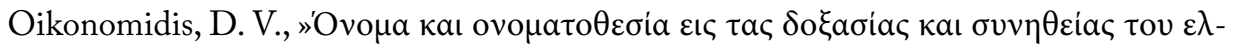

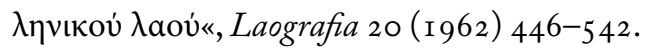

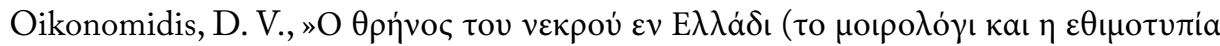

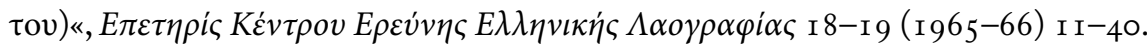

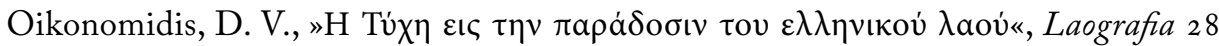
(I 972 ) 3-26.

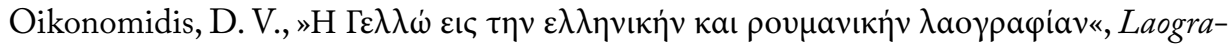
fia $30($ I $975 / 76) 246-278$.

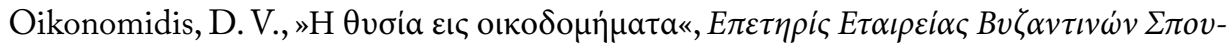
$\delta \omega \dot{v} 45$ ( I 98 I/82) $43-\mathrm{I} 32$.

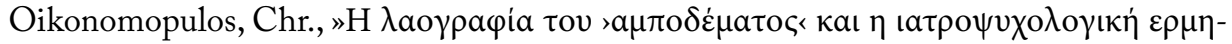

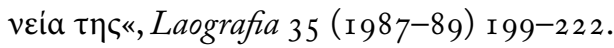

Ollanescu, D. C., Teatrul la români, Bd. I, București I 898 .

Onasch, K., Das Weihnachtsfest im orthodoxen Kirchenjahr, Berlin 1958.

Oprișan, H. B., Călușarii, București I 969.

Oprișan, H. B., Jienii. Teatru popular haiducesc, București 1974.

Oprișan, H. B., »Das volkstümliche rumänische Theater«, Österr. Zeitschrift für Volkskunde 8 I (1978) I 78-20I.

Oprișan, H. B., »Das rumänische Volks-Puppenspiel«, Österreichische Zeitschrift für Volkskunde XXX/84 (198 I) 84-106.

Oprișan, H. B., Teatru fără scena. Evocări ale unor spectacole, personaje și interpreti ai teatrului popular românesc, București I $98 \mathrm{I}$.

Ortug, M., Gelenksel kıbrıs türk tiyatrosu, Birinci I 993.

Ortutay, G., »Kérdőiv bethlehemes játekok gyüjtéséhez«, Ethnographia 68 (I 956) 91-98.

Ortutay, G., Kleine ungarische Volkskunde, Budapest 1963.

Ouspensky, L./W. Lossky, Der Sinn der Ikonen, Bern/Olten I 952.

Öztürk, S., »Karagöz Co-Opted: Turkish Shadow Theater of the Early Republic (I 923I 945)«, Asian Theatre Journal 23/2 (2006).

Païdusis, M., »To aí

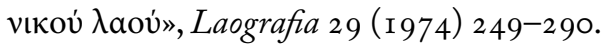

Pamfile, T., Sărbătorile de văra la Români, Bucureşti i 9 Iо.

Pamfile, T., Sărbătorile la români. Crăciunul, București i 9 I 4.

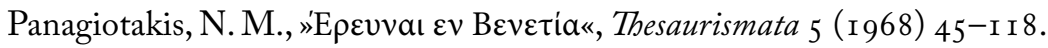

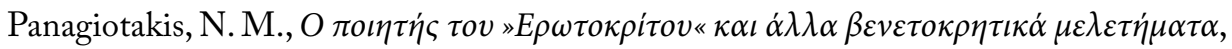
Heraklion 1989.

Pantelić, I., »Ženidbeni običaji na teritoriji opštine Zaječar«, Glasnik Etnografskog muzeja 42 (I 978 ) 355-382.

Papacharalampous, G. Ch., »Perideipna in Cyprus«, Neo-Hellenika I (1970) 55-67. 


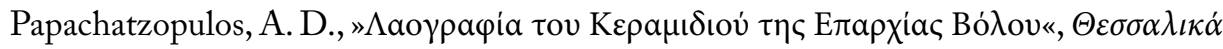
X

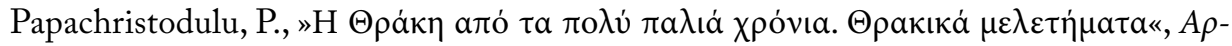

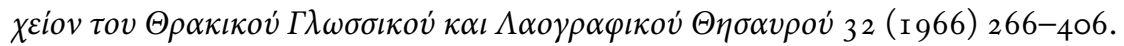

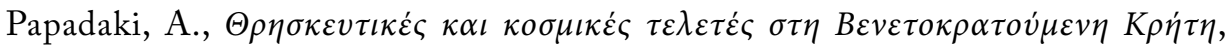
Rethymno I 995 .

Papacostea-Danielopolu, C./L. Demény, Carte și tipar în societatea românească și sud-est europeană (secolele XVII-XIX), București I 985 .

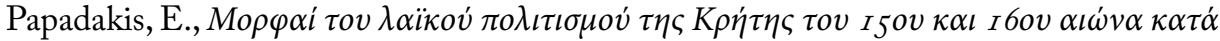
$\tau \alpha \varsigma \gamma \rho \alpha \mu \mu \alpha \tau \varepsilon \iota \alpha \kappa \alpha \dot{\alpha} \varsigma \pi \eta \dot{\alpha} \varsigma$, Athen 1976.

Papadakis, N., Greek Folk Silver Votive Offerings: Iconographical Citation from the Anonymous Art of Greek People, Athens I 97 I.

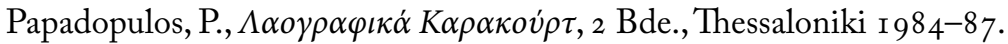

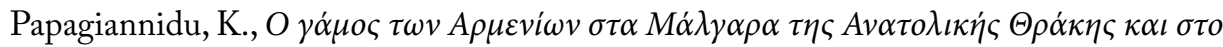

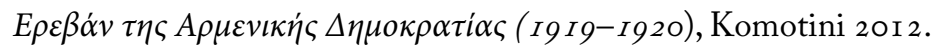

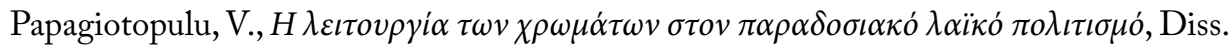
Athen I 996.

Papahagi, P., Basme Aromâne, și glosar, București I 905.

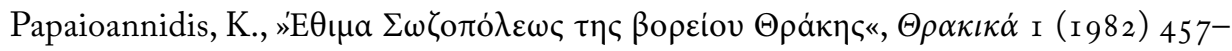
500.

Papamichael, A., Birth and plant symbolism. Symbolism and magical uses of plants in connection with birth in modern Greece, Athens 1975 .

Papamichael-Koutroubas, A., "The laying of Sacrifices under the foundation of buildings e.t.c.", Neohellenika 4 (I98 I) 2 I I-226.

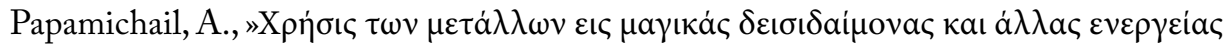

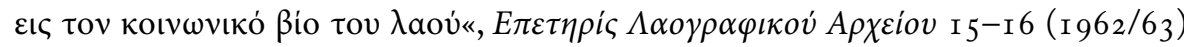
62-9I, I7 (I964) 53-I I 4.

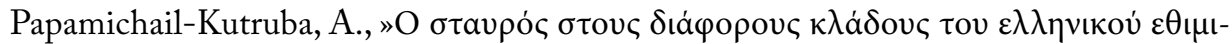

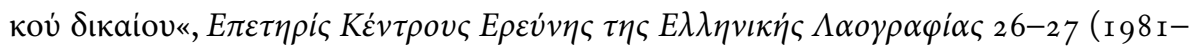
86) 3-2 I 4 .

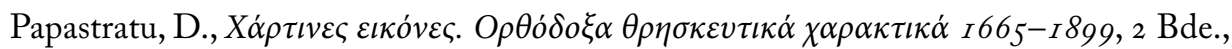
Athen 1986.

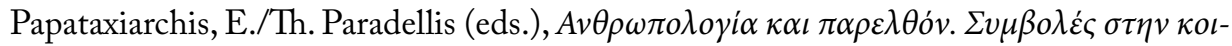

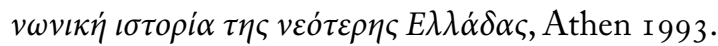

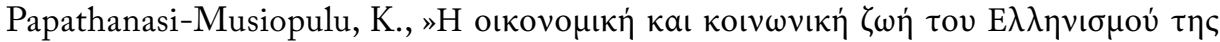

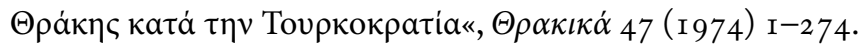

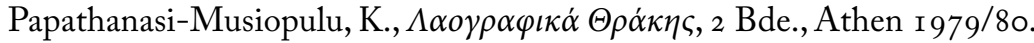

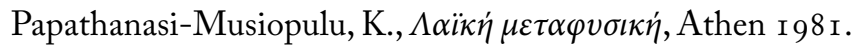




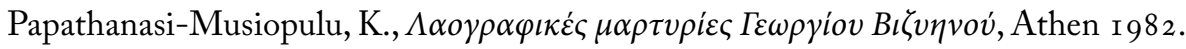

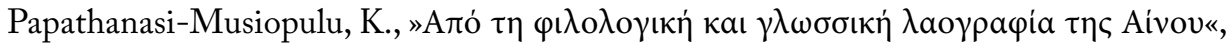

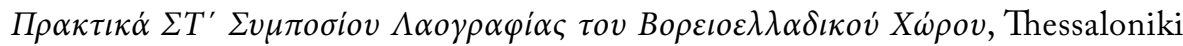
I 99 I, 355-386.

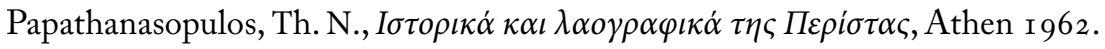

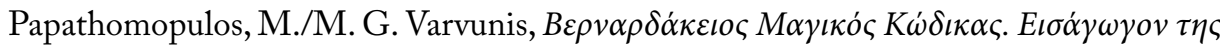
$\mu \alpha \gamma \varepsilon i \alpha \varsigma \tau \eta \varsigma \pi \dot{\alpha} \lambda \alpha \iota \pi o \tau \dot{\varepsilon}$, Athen 2006.

Papathomopulos, M./M. G. Varvunis, Eל

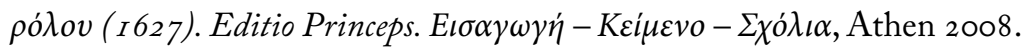

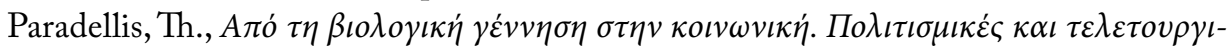

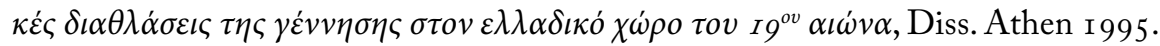

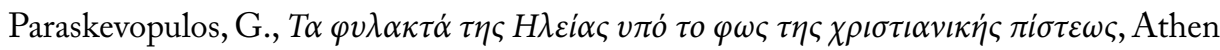
I 98 I.

Paraskevopoulou, M., Recherches sur les fêtes religieuses populaires de Chypre, Nicosie 1978.

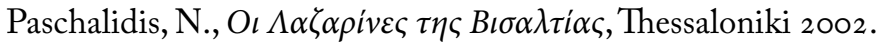

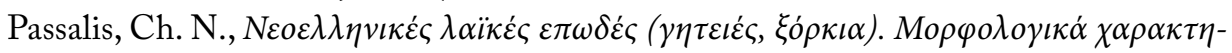

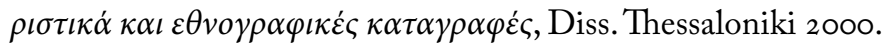

Patera, M., "Gylou, démon et Sorcière de Monde byzantine au Monde néogrec«, Revue des Études Byzantines 64-65 (2006/07) 3 I I-327.

Pavković, N./S. Haumović, »Fașancu la Grebenat,: Folklorizam simboličke strategije i etnički identitet rumunske nacionalne manjine u Banatu«, Popožaj manjina Saveznoj Republici Jugoslaviji, Beograd i 996, 697-708.

Pećo, L., „Das Sippenfest (Krsna slava, krsno ime) bei den Serben«, Zeitschrift für österr. Volkskunde I9 (I9I3) I I 7-I 20.

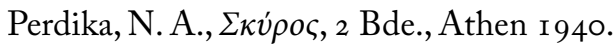

Peristiany, J. (ed.), Mediterranean Family Structures, Cambridge I 976.

Perkowski, J. L., Vampires of the Slavs, Cambridge/Mass. 1976.

Perkowski, J. L., The Darkling. A Treatise on Slavic Vampirism, Columbus, Ohio I 989.

Petek, G., Le théâtre traditionel turc de Karagöz. Vie, survivances, actualité, Paris 1972.

Petrescu, P., »Les sources populaires et l'évolution de l'art contemporain dans le sud-est de l'Europe«, Revue des Études Sud-Est Européennes 25/I ( I987) 3-9.

Petropoulos, D., »Survivances de sacrifices d'animaux en Grèce «, Papers of the International Congress of European and Western Ethnology (Stockholm I95 I), Stockholm I 956, I 20-I 25 .

Petropoulos, D. A., "Le rôle des femmes et de la terre dans quelques pratiques magiques«, Mélanges Octave et Melpo Merlier, 2 Bde., Athènes I 956/57, II 275-285.

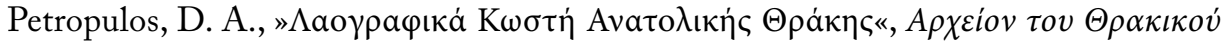

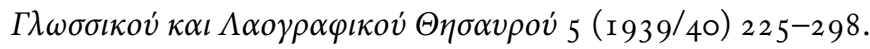




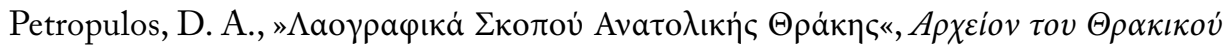

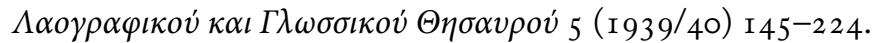

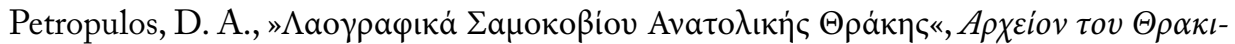

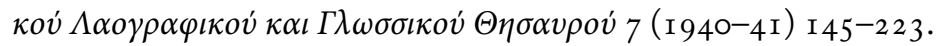

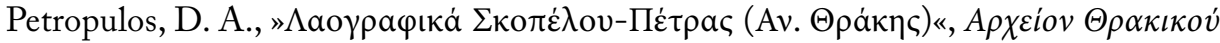

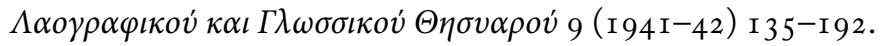

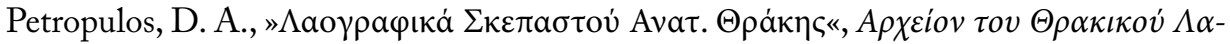

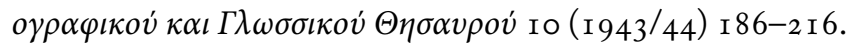

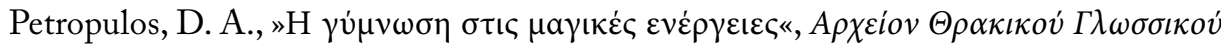

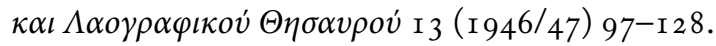

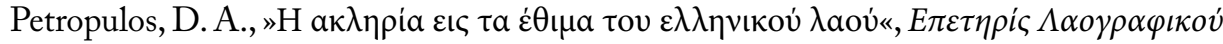
A $x$ zióv 7 (1953) 28-44.

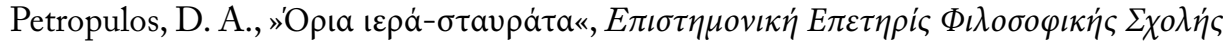

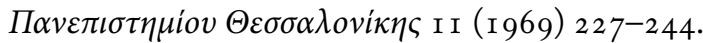

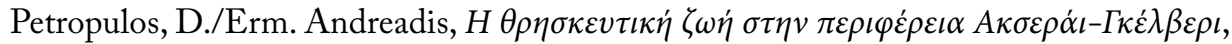
Athen I97I.

Petrov, P. A., »Kukeri v s. Pădarevo, Burgasko«, Sbornik za narodni umotvorenija i narodopis 50 (1963) 345-368.

Petrović, D., „Das türkische Turnierspiel džilitanje in der Vergangenheit Serbiens und Bosniens«, Vernik Vojurg muzeja Jug. narodne armije 6/7 (Beograd I 962) I 35-I 44.

Petrović, P. Ž., Život i običaji narodni u Gruži, Beograd 1948.

Petrović, S., Mitologija, magija i običaji, Niš 1992.

Piprek, J., Slawische Brautwerbungs- und Hochzeitsgebräuche, Stuttgart I 9 I 4.

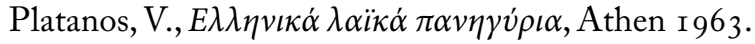

Plotnikova, A. A., »Roždjestvjenskaja simvolika v terminologii obrjadovogo hljeba u sjerbov«, Simvoličeskij jazyk tradicionnoj kul'tury. Balkanskite čtenija II, Moskva I 993, $37-62$.

Pócs, É., »Binde- und Lösungszauber im ungarischen Volksglauben«, Acta Ethnographica Academiae Scientiarum Hungaricae I 967.

Pócs, É., Fairies and Witches at the Boudary of South-Eastern and Central Europe, Helsinki I 989 (FFC 243).

Podskalsky, G., Griechische Theologie in der Zeit der Türkenherrschaft I453-I82 I, München 1988 .

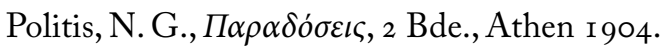

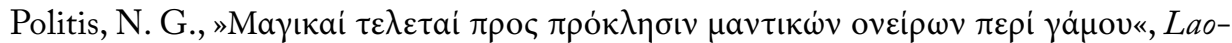
grafia 3 (I 9 I ) 3-50.

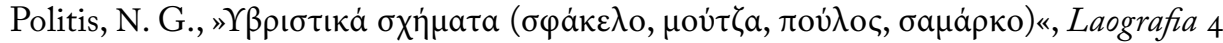
(г 9г2-г3) 6or-669. 


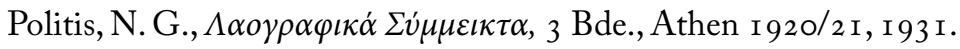

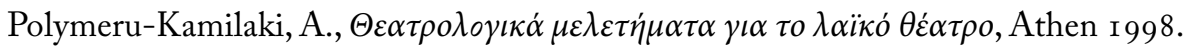

Pop, M., »Bräuche, Gesang und Spiel zu Neujahr in der heutigen rumänischen Folklore «, Festschrift W. Steinitz, Berlin I 965, 3 I 4 ff.

Pop, M., »Considerații etnografice şi medicale asupră Căluşului oltenesc«, Despre medicină populară românească, Bucureşti I 970, 2 I 3-223.

Pop, M., »Căluşul: Lectura unui text«, Revista de Etnografie şi Folclor 20 (I 975) I 5-32.

Pop, M./P. Ruxandoiu, Folklore literar romînesc, București I 976.

Popa, I., "Les cortèges aux masques chez les Roumains et chez les Bulgares de Banat«, Makedonski Folklor 4/7-8 (I 97 I) I 59-i 64 .

Popescu, A., »Allgemeine und spezielle Charakteristiken der Erntebräuche in Südosteuropa«, Zeitschrift für Balkanologie 22 ( I 986) 89-93.

Popescu-Judetz, E., "L'influence des spectacles populaires turcs dans les Pays Roumaines«, Studia et acta orientala 5-6 (1 967) 337-355.

Popinceanu, J., Religion, Glaube und Aberglaube in der rumänischen Sprache, Nürnberg I 964 .

Popov, R., Peperuda i German, Sofija I 989.

Popov, R., »O jednoj varianti karnevalske svadbe kod Bugara«, Svadba 3 (Beograd I998) Iо3-I Iо.

Popova, A., »Ni chair, ni poisson: Tryphon le coupé«, Cahiers de littérature orale 3 ( I977) I 5-69.

Popova, A., »Une Société féerique d'amazones. Les Samodivi«, J.-C. Payen, Le conte de fées en Normandie, Noireau i 986, 276-296.

Popvasileva, A., »Lazarskite pesni v Kosturskoto Popolje (egejska makedonija)«, Makedonski Folklor I (1 968) I 55-i 66.

Poulos, G., Orthodox Saints, 4 Bde., Brookline ${ }^{2}$ I 990.

Pradel, Fr., Griechische und süditalienische Gebete, Beschwörungen und Rezepte des Mittelalters, Giessen I 907.

Preindlberger, J., »Beiträge zur Volksmedicin in Bosnien«, Wissenschaftliche Mittheilungen aus Bosnien und der Hercegovina 8 ( I 902) 2 I 5-229.

Preisendanz, K. (ed.), Papyri graecae magicae. Die griechischen Zauberpapyri, 3 Bde., Stuttgart 1973 .

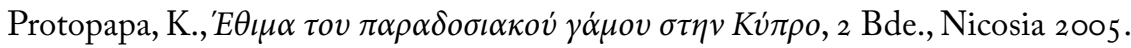

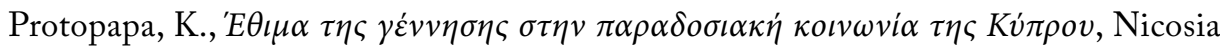
2009.

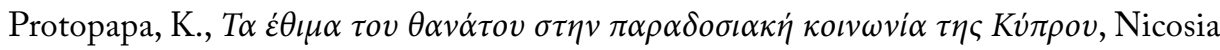
2012.

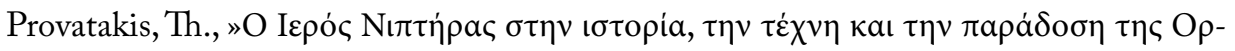




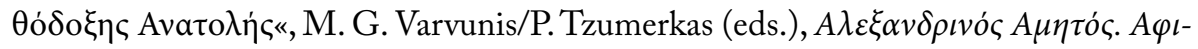

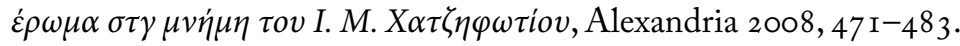

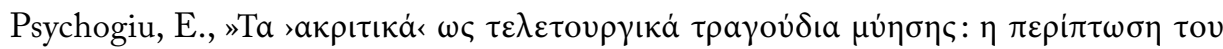

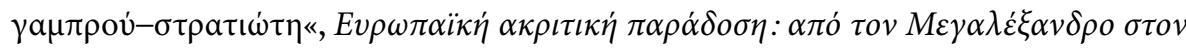

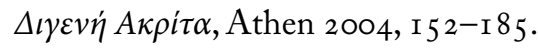

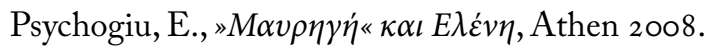

Puchner, W., Das neugriechische Schattentheater Karagiozis, München 975 (erw. Neuausgabe Wien 2014).

Puchner, W., »Kretische Renaissance- und Barockdramatik in Volksaufführungen auf den Sieben Inseln«, Österr. Zeitschrift für Volkskunde XXX/79 (I 976) 232-242.

Puchner, W., Brauchtumserscheinungen im griechischen Jabreslauf und ibre Beziehung zum Volkstheater. Theaterwissenschaftlich-volkskundliche Querschnittstudien zur südbalkanmediterranen Volkskultur, Wien 1977.

Puchner, W., Fasulis. Griechisches Puppentheater italienischen Ursprungs aus der zweiten Hälfte des I9. Jahrbunderts, Bochum I 978 (Puppenspielkundliche Quellen und Forschungen 2).

Puchner, W., »Lazarusbrauch in Südosteuropa. Proben und Überblick«, Österreichische Zeitschrift für Volkskunde XXXII/8 I ( I 978) I 7-40.

Puchner, W., »Südost-Belege zur sgiostra<: Reiterfeste und Lanzenturniere von der kolonialvenezianischen Adels- und Bürgerrenaissance bis zum rezenten heptanesischen Volksschauspiel«, Schweizer. Archiv für Volkskunde 75 (1979) I-27.

Puchner, W., »Beiträge zum thrakischen Feuerlauf (Anastenaria/Nestinari) und zur thrakischen Karnevalsszene (Kalogeros/Kuker/Köpek Bey). Anmerkungen zur Forschungsgeschichte und analytische Bibliographie«, Zeitschrift für Balkanologie I 7 ( I98 I) 47-75.

Puchner, W., »Die thrakische Karnevalsszene und die Ursprungstheorie zum altgriechischen Drama. Ein Beitrag zur wissenschaftsgeschichtlichen Rezeptionsforschung «, Balkan Studies 24/ I ( 1983 ) ro7-1 22.

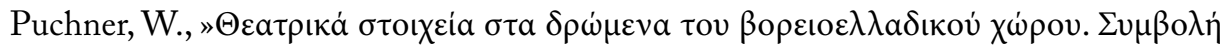

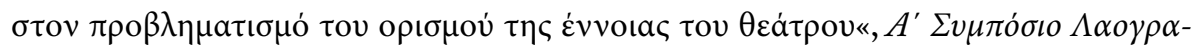

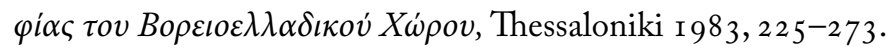

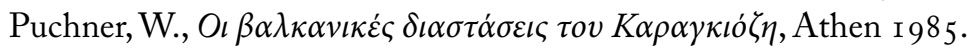

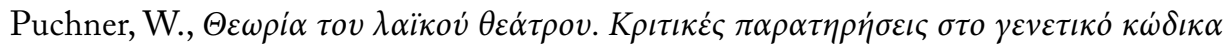

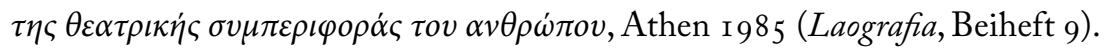

Puchner, W., »Primitividole und Idolbestattung auf der Balkanhalbinsel (zur rituellen Frühgeschichte des Puppentheaters)«, Acta Ethnogaphica Academiae Scientiarum Hungaricae 34 (I 986-88) 229-244.

Puchner, W., »Zum Nachleben des Rosalienfestes auf der Balkanhalbinsel«, Südost-Forschungen 46 ( 1987 ) I97-278. 


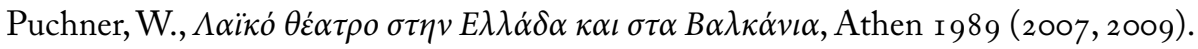

Puchner, W., Studien zum Kulturkontext der liturgischen Szene. Lazarus und Judas als religiöse Volksfiguren in Bild und Brauch, Lied und Legende Südosteuropas, 2 Bde., Wien I 99 I (Österr. Akademie der Wissenschaften, phil.-hist. Klasse, Denkschriften 2 I6).

Puchner, W., „Griechisches zur adoptio in fratrem«, Südost-Forschungen 53 (1994) I 87224.

Puchner, W., Historisches Drama und gesellschaftskritische Komödie in den Ländern Südosteuropas im I9. Jahrbundert, Frankfurt/M. etc. I 994.

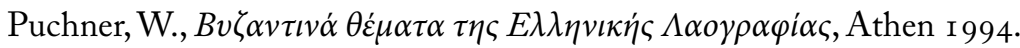

Puchner, W., "Le théâtre d'ombres grec et son auditoire traditionelle«, Cabiers de Littérature Orale 38 (I 995) I 25-I 43.

Puchner, W., Studien zum griechischen Volkslied, Wien 1996.

Puchner, W., Akkommodationsfragen. Einzelbeispiele zum paganen Hintergrund von Elemente der frübkirchlichen und mittelalterlichen Sakraltradition und Volksfrömmigkeit, München I 997 .

Puchner, W., »Das osmanische Schattentheater auf der Balkanhalbinsel zur Zeit der Türkenherrschaft. Verbreitung, Funktion, Assimilation«, Südost-Forschungen ${ }_{5} 6$ (I 997) I 5 I-I 88.

Puchner, W., Griechisches Schuldrama und religiöses Barocktheater im ägäischen Raum zur Zeit der Türkenherrschaft (1580-1750), Wien I 999 (Österr. Akad d. Wiss., phil.-hist. Klasse, Denkschriften 277).

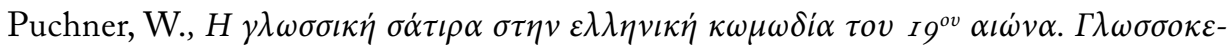

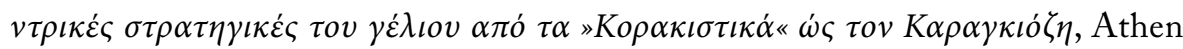
2001.

Puchner, W., »Improvisierte Gerichtsspiele und karnevaleske Schauprozesse in der Volkskultur des Zentralbalkans und des hellenophonen Mittelmeerraums«, SüdostForschungen 63/64 (2004/05) 2 I I-23 I.

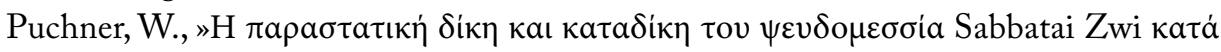

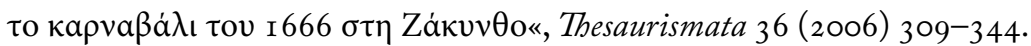

Puchner, W., Beiträge zur Theaterwissenschaft Südosteuropas und des mediterranen Raums, 2 Bde., Wien/Köln/Weimar 2006-07.

Puchner, W., Studien zur Volkskunde Südosteuropas und des mediterranen Raums, Wien/ Köln/Weimar 2009.

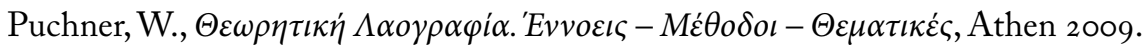

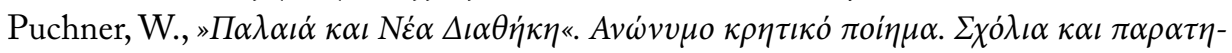
$\rho \dot{\sigma \varepsilon \varepsilon \iota \varsigma, ~ V e n e d i g ~} 2009$.

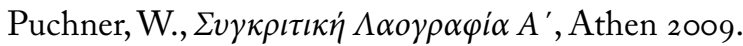


Puchner, W., »The Forgotten Fiancée. From the Italian Renaissance Novella to Modern Greek Fairy Tales«, Fabula 5 I (2010) H. 3/4, 20 I-2 I 6.

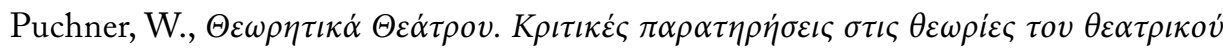

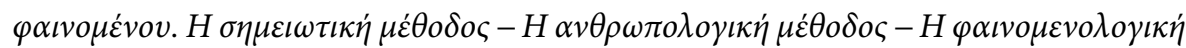
$\mu \dot{\varepsilon} \theta o \delta o \varsigma$, Athen 20 io.

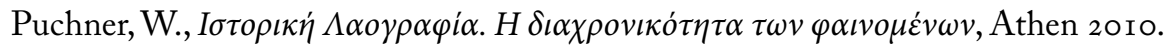

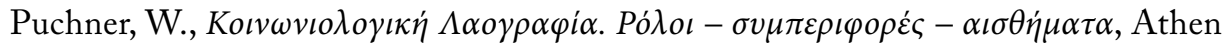
2010.

Puchner, W., Greek Folk Culture. A Bibliography of Literature in English, French, German, and Italian on Greek Folk Culture in Greece, Cyprus, Asian Minor (before 1922) and the Diaspora (up to 200o). Compiled and edited by Walter Puchner with the collaboration of Manolis Varvounis, Athens 2o I I (Laografia, Suppl. I 5).

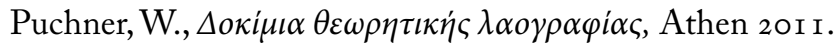

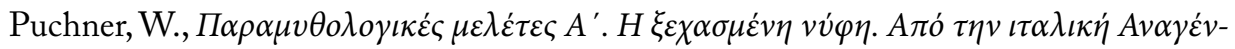

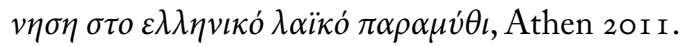

Puchner, W., Von Herodas zu Elytis. Studien zur griechischen Literaturtradition seit der Spätantike, Wien/Köln/Weimar 2012.

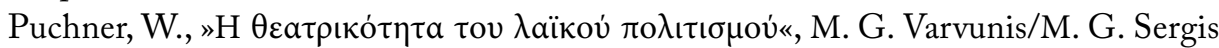

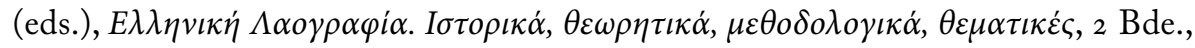
Athen 20I 2, II 339-378.

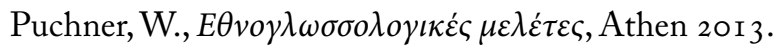

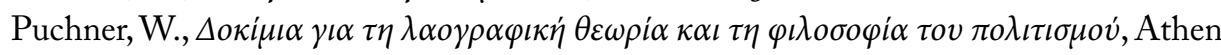
2014.

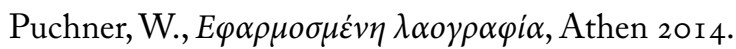

Puchner, W., Die Literaturen Südosteuropas (15. bis frühes 20. Jahrhundert). Ein Vergleich, Wien/Köln/Weimar 2015.

Puchner, W., Die Folklore Südosteuropas. Eine komparative Übersicht, Wien/Köln/Weimar 2016.

Radenković, L., Narodna bajanja kod Južnib Slovena, Beograd I 996.

Rădulescu, N., »Musikalische Puppenspiele orientalischer Herkunft in der rumänischen Folklore«, Zeitschrift für Balkanologie I 4 ( 1 978) 83-98.

Rajčevski, St./Fol, V., Kukerăt bez maskata, Sofija I 993.

Rajković, Z., "Dramski momenti u svadbenim običajima«, Mogućnosti 32 (I985) I 32I 46 (Dani bvarskog kazališta 2, Split I 985, I77-196).

Rakovski, G. S., Gorski Pătnik, Sofija I 857.

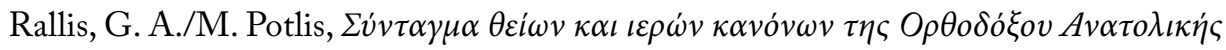

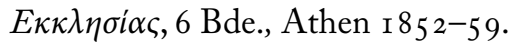


Ramet, P., »The Miracle at Medjugorje - A Functionalist Perspective«, The South Slav Journal 8/I-2 (I985) I 2-20.

Răutu, R. (ed.), Antologia descântecelor populare românești, București 1998.

Régő Ensel, S., Magyarországi népszokások, Pest i 867.

Rein, E., »Zu der Verehrung des Propheten Elias bei den Neugriechen«, Öfversigt of Finska Vetenkaps-societetens förhandlingar $47($ I 904/5) I-33.

Reiter, N., »Mythologie der Alten Slaven«, H. W. Haussig (ed.), Wörterbuch der Mythologie, Stuttgart I973, II I65-208.

Reiter, N., „Der Pferdemythos bei den Slaven«, Slavica Gandensia 7/8 (I980/8 I) I 3 II 46.

Reiter, N. (ed.), Die Stellung der Frau auf dem Balkan. Beiträge zur Tagung vom 3.-7. September 1985 in Berlin, Wiesbaden 1987.

Reljić, L., »Običaji i verovanja vezani za životni ciklus - poćenje, brak i smrt«, Glasnik Etnografskog muzeja 62 (I998) 50-86.

Reljić, L., »Žensko slavje«, Zbornik Etnografsko muzeja u Beogradu, I9o I-20o I, Beograd 200I, 56-86.

Rešetar, M., »Der Hochzeitsschwank im ragusanischen Liederbuch vom Jahr I 507«, Archiv für slavische Philologie 22 ( I 900) 6 I 3 ff.

Rheubottom, D. B., »The Saint's Feasts and Skopska Crna Goran Social Structure«, Man I I ( I 976) I 8-34.

Rice, T., »A Macedonian Sobor: Anatomy of a Celebration«, Journal of American Folklore 93 (I 980$)$ I I 3-I 28.

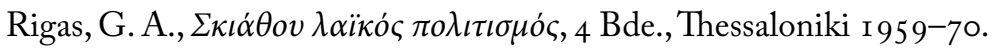

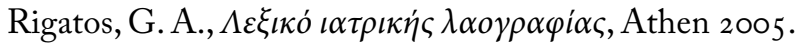

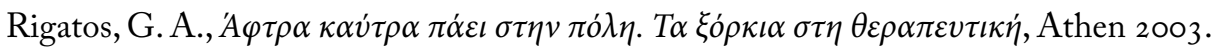

Ristovski, V., »Makedonskite dodolski i drugi običai i pesni za dožd«, Makedonski Folklor I 9-20 ( I 977) 37-63.

Ritter, H., Karagösz. Türkische Schattenspiele, Hannover etc. I 924-53.

Riznić, M. S., »Lazarice«, Bratstvo 4 (Beograd I 890) 43-52.

Rnjak, D., »Od kulta do pozorišta«, Antički teatar na tlu Jugoslavije, Novi Sad I 979, I3$4 \mathrm{I}$.

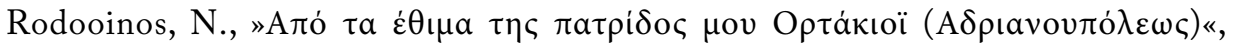
Thrakika I 3 ( I 940) 3 I I-320.

Róheim, G., Magyar néphit és népszokások, Budapest 1927.

Róheim, R., »Hungarian Shamanism«, Psychoanalysis and Social Sciences 3 (I 95 I) I 3 I-I69.

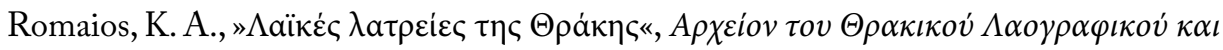

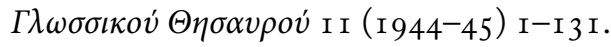

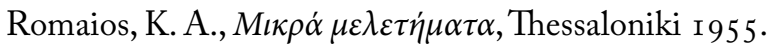


Roth, K., »Osmanische Spuren in der Alltagskultur Südosteuropas«, H. G. Majer (ed.), Die Staaten Südosteuropas und die Osmanen, München I 989, 3 I 9-332.

Roth, K./Wolf, G., South Slavic Folk Culture: a Bibliography of Literature in English, German, and French, on Bosnian-Hercegovian, Bulgarian, Macedonian, Montenegrin and Serbian Folk Culture, compiled and edited by Klaus Roth and Gabriele Wolf with the collaboration of Tomislav Helebrant, Columbus, Ohio 1993.

Roussel, L., Karagheuz ou Le Théâtre d'Ombres à Athènes, 2 Bde., Athènes 192 I.

Rožin, N. R., »Svadbena dramatika u Dubrovačkom primorju «, Narodna Umjetnost 3 (I $964-65)$ 38-74.

Rožin, N. R., »Pokladne maškare konavlima«, Narodna Umjetnost 5 ( I 966) I 53-I 74.

Russel, J., »The Evil Eye in early Byzantine Society“, Jahrbuch der Österreichischen Byzantinistik 22/2 (I972) 537-547.

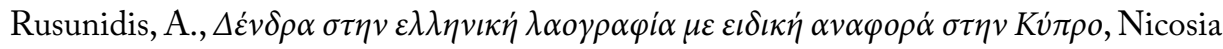
I 988.

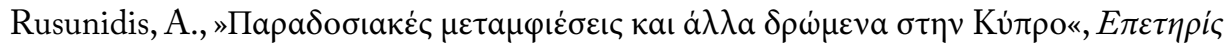

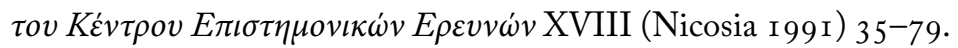

Sadnik, L., "Zur Herkunft der Wind-Vorstellungen und Wind-Bezeichnungen bei den Südslaven«, Wiener Slavistisches Jahrbuch I ( I 950) I 3 I-I 33 .

Sadnik, L., »Der Regenbogen in der Vorstellung der Balkanvölker«, Byzantinische Zeitschrift 44 ( I 95 I) $482-486$.

Șaineanu, L., »Jocul papușilor și raporturile en farsa Karagöz«, Lui Titu Maiorescu omagiu, București r 900, 28 I-287.

Sakaoğlu, S., Türk gölge oyunu, Ankara 2003.

Saminova-Semova, A., Maskata v čoveškata civilizacija i v teatăra, Sofija 2000.

Samokovlieva, M., »Teritorialno razprostranie na njakoi tipove kalendarno obredi pesni v Severna Bălgarija«, Bălgarski Folklor 4/4 (I 978) I 5-33.

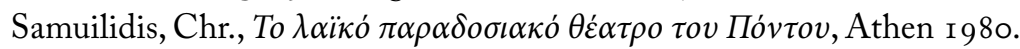

Sandu, C., »Les >Princesses` (craitzélé), culte païen d'origine dace, chez les Roumains (Valaques) de Serbie de N-E et de Bulgarie de N-O«, Makedonski Folklor 6/ I 2 (I 973) 8I-85 (Balcanica 5, I974, 33 I-336).

Sant Cassia, P./C. Bada, The Making of Modern Greek Family. Marriage and Exchange in Nineteenth-Century Athens, Cambridge 1992.

Šapkarev, K., Russalii, dreven i tvărde interesen bălgarskij običaj, zapazen i do dones v južna Makedonija, Plovdiv I 884 .

Saunier, G., "Adikia«. Le Mal et l'Injustice dans les Chansons Populaires Grecques, Paris I 979 .

Savramis, D., „Der abergläubische Mißbrauch der Bilder in Byzanz«, Ostkirchliche Studien 9 (1960) I74-192. 
Scheftelowitz, I., Das Schlingen- und Netzmotiv im Glauben und Brauch der Völker, Gießen I9I2.

Schenda, R., „Wunderzeichen. Die alten Prodigien in neuen Gewändern. Eine Studie zur Geschichte eines Denkmusters«, Fabula 38, 1997, I4-32.

Schlumberger, G., "Amulettes byzantines anciens destinés a combattre les maléfices et maladies«, Revue des Études Grecques 5 (1 892) 73-93.

Schmidt, B., Der Volksglaube der Neugriechen und das hellenische Alterthum, Leipzig I 87 I.

Schmidt, B., »Der böse Blick und ähnlicher Zauber im neugriechischen Volksglauben«, Neue Jabrbücher für das klassische Altertum 3 I (1913) 574-6 I 3.

Schmidt, B., »Totengebräuche und Gräberkultus im heutigen Griechenland «, Archiv für Religionswissenschaft I 4 (I926) 28 I-3 I 8 und I 5 (I 927) 62-82.

Schmidt, L., »Der Oberuferer Spielkreis«, Sudetendeutsche Zeitschrift für Volkskunde 7 (I 934) I 45-I 57 .

Schmidt, L., »Der Eselsreiter von Moschendorf. Seine Stellung im mitteleuropäischen Umzugsspiel und Maskenbrauch“, Österr. Zeitschrift für Volkskunde 3/52 (I 949) 7798.

Schmidt, L. (ed.), Masken in Mitteleuropa, Wien 1955 .

Schmidt, L., Heiliges Blei in Amuletten, Votiven und anderen Gegenständen des Volksglaubens in Europa und im Orient, Wien 1958.

Schmidt, L. (ed.), Le théâtre populaire Européen, Paris I 965.

Schmidt, L., Volksglaube und Volksbrauch, Berlin 1966.

Schmidt, L., Brauch obne Glaube, Würzburg 1977 (Ethnologia Bavarica 5).

Schneeweis, E., Die Weibnachtsbräuche der Serbokroaten, Wien I 925.

Schneeweis, E., Grundriß des Volksglaubens und Volksbrauchs der Serbokroaten, Celje I 935.

Schneeweis, E., Serbokroatische Volkskunde. I. Volksglaube und Volksbrauch, Berlin I 96 I .

Schram, F., »Három történelmi bethlehemes jaték«, Irodalomtörténeti Közlemények I 964, 497-520.

Schreiner, P., »Ritterspiele in Byzanz«, Jahrbuch der Österreichischen Byzantinistik 46 (I996) 225-239.

Schubert, G., »Die Rolle der Frau im Volksglauben der Südslawen«, Slavica Gandensia 7/8 (I980/8I) I 57-I 79.

Schubert, G., »Die bulgarischen Samovila und ihre balkanischen Schwestern«, T. I. Živkov/G. Georgiev (eds.), Dokladi. Bălgarskata kultura i vzaimodejstvieto i săs svetovnata kultura, Sofija I983, 372-394.

Schubert, G., »Der H1. Georg und der Georgstag auf der Balkan«, Zeitschrift für Balkanologie 2 I/I ( I985) 80-ro5.

Schubert, G., »Die Frau in der Volksheilkunde auf dem Balkan«, Norbert Reiter (ed.), Die Stellung der Frau auf dem Balkan, Wiesbaden I 987, 2 I 9-23 I. 


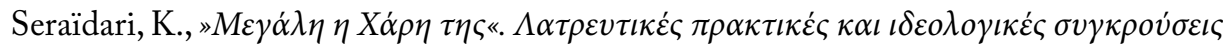
$\sigma \tau \iota \varsigma, K v \kappa \lambda \dot{\alpha} \delta \varepsilon \varsigma$, Athen 2007.

Sekulić, A., Narodni život i običaji bačkih Bunjevaca, Zagreb I 986.

Seligmann, S., Der böse Blick und Verwandtes, 2 Bde., Berlin I 9 го.

Seligmann, S., Die Zauberkraft des Auges und das Berufen, Hamburg 1922.

Seligmann, S., Die magischen Heil-und Schutzmittel aus der unbelebten Natur, mit besonderer Berücksichtigung der Mittel gegen den bösen Blick. Eine Geschichte des Amulettwesens, Stuttgart I 927.

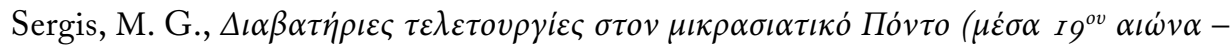

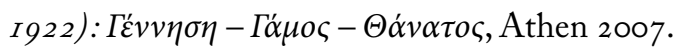

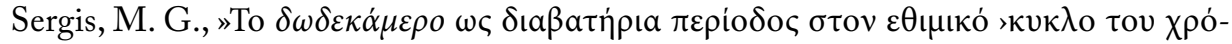

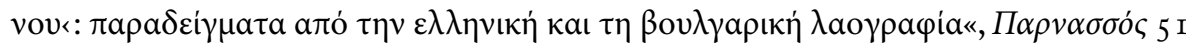
(2009) 3 I 5-346.

Sergis, M. G., »Dog Sacrifice in Ancient and Modern Greece: from the Sacrifice Ritual to Dog Torture (kynomartyrion)«, Folklore. Electronic Journal of Folklore 45 (2010) $6 \mathrm{I}-88$.

Sevastos, E., Nunta la Români, București I 889 .

Sheffler, J., »Mask Rituals of Bulgaria: The Pernik Festival, r 980«, K. K. Shangriladze/E. W. Townsend (eds.), Papers for the V. Congress of Southeast European Studies, Belgrade, September 1984, Columbus, Ohio I984, 338-36r.

Siampanopulos, K., Oı $\Lambda \alpha \zeta \alpha \rho i v \varepsilon \varsigma$, Thessaloniki 1973.

Sieber, F., Deutsch-slawische Beziehungen in Frühlingsbräuchen, Berlin 1968.

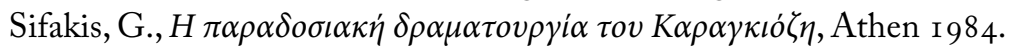

Sikimih, B., Sveci creva motaju, Kult svetih na Balkanu, Kragujevac 200 I.

Simić, P., »Pobratimstvo u liturgiči i crkvenom pravu«, Pravoslavna misao XI/I-2, Beograd i 968,85 -Ior.

Siyavusgil, S. E., Karagöz. Its history, its characters, its mystic and satiric spirit, Ankara I 955 .

Škarić, M., "Život i običaji >Planinacar pod Fruškom gorom«, Srpski etnografski zbornik 24 (I 939) I-275.

Skendi, St., "Crypto-christianity in the Balkan area under the Ottomans", Slavic Review 26 ( I 967) 227-246.

Skendi, St., Balkan cultural studies, Bolder/New York I 980.

Skowronski, M./M. Marinescu, Die »Volksbücher« Bertoldo und Syntipas in Südosteuropa. Ein Beitrag zur Kulturvermittlung in Griechenland und Bulgarien vom I7. bis 20. Jahrbundert, Frankfurt/M. I 992.

Skurativs'kyj, V., Rusalii, Kyjiv 1996. 
Smiljanić, M., »Die Spuren der Raub- und Kaufehe bei den Serben«, Internationales Archiv für Ethnographie I 5/2 (I 902) 4I-52.

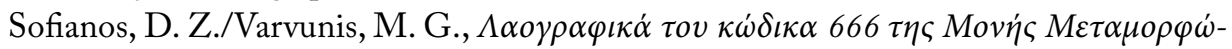

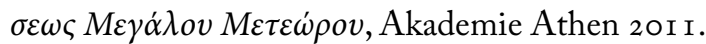

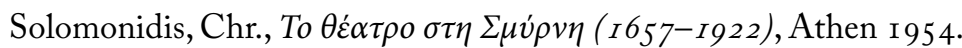

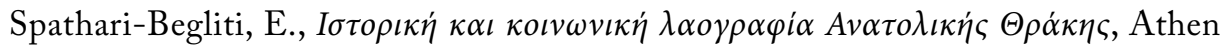
I 997.

Spyridakis, G. K., »Saint-Georg dans la vie populaire«, L'Hellénisme Contemporaine 6 (I952) I $26-145$.

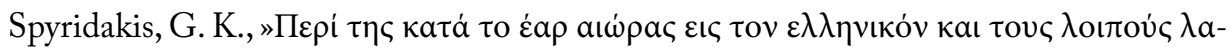

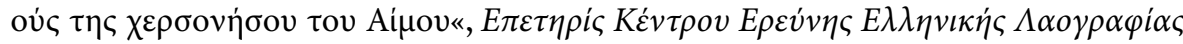
22 (I 973) I I 3 -I 34.

Stahl, A., »Animal Sacrifices in the Balkans«, A. Bharati (ed.), The Realm of the ExtraHuman Ideas and Actions, The Hague I 976, 443-45 I.

Stahl, H. H., Nerej, un village d'une region archaique, monographie sociologique. Vol. II, Les manifestations spirituelles, Bucharest I 939.

Stahl, P. H., „Croyances communes des chrétiens et des musulmans balkaniques«, Buletinul Bibliotecii Române NS 7 ( I 979/80) 79-1 26.

Stahl, P. H., »Le départ des morts. Quelques exemples roumaines et balkaniques«, Études rurales I05/106 (I 987) 21 5-24I.

Spies, O., Türkisches Puppentheater. Versuch einer Geschichte des Puppentheater im Morgenlande, Emsdetten r 959 (Die Schaubühne 50).

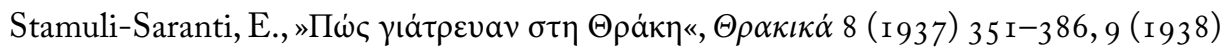
I 95-283.

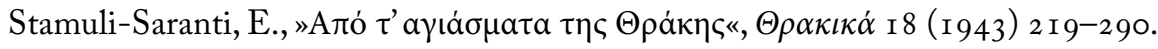

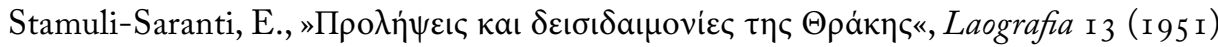
$201-236$.

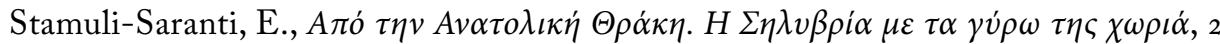
Bde., Athen I 956/58.

Statovci, D., »Elemente mitologjike dhe demonologjike në doke e zakone të lindjes«, Gjurmime albanologjike, Seria folklor dhe etnologji I 8 ( I988) I73-1 92.

Stavrakopoulou, A., »Marriage: Recomposing a Ritual in Shadow Theatre Performance«, in: P. Roilos/D. Yatromanolakis (eds.), Greek ritual poetics, Washington, Center of Hellenic Studies 2005, 297-307.

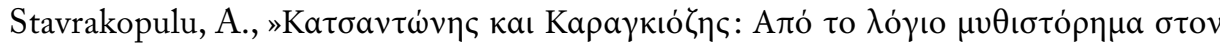

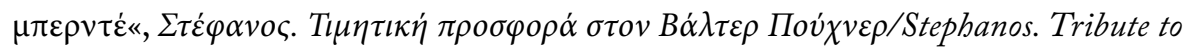
Walter Puchner, Athen 2007, I I 73-I I 82.

Stefanov, P., »Sveci zmeeborci v bălgarski folklor«, Bălgarski Folklor VIII/I (I 982) 75-84. 
Stefanovski, P., Teatarot vo Makedonija, Skopje 1976.

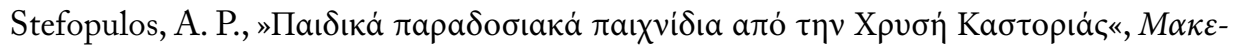

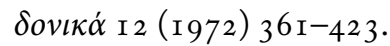

Steinleitner, F., »Mittel aus dem Tierreich zum Anhexen der Impotenz und Heilen der angezauberten Mannesschwäche«, Zeitschrift für Volkskunde 42 (1933) I 46-163.

Stern, B., Medizin, Aberglaube und Geschlechtsleben in der Türkei. Mit Berücksichtigung der moslemischen Nachbarländer und der ehemaligen Vasallenstaaten, 2 Bde., Berlin I 903.

Stewart, Ch., »The >Exotika<: Greek Values and Their Supernatural Antithesis«, $A R V$ (Scandinavian Folklore Archives) 4I (I985) 36-64.

Stewart, Ch., Daemons and the Devil: Moral Imagination in Modern Greek Culture, Princeton I99I.

Stewart, Ch., »Nymfomania: sexuality, insanity and problems in folklore analysis«, $M$. Alexiou/V. Lambropoulos (eds.), The Text and its Margins, New York I 99 I, 2 I 9-25 2.

Stewart, Ch., »Magic circles. An approach to Greek ritual«, Journal of the Anthropological Society of Oxford 25/I (I 994) 9I-Ior.

Stoica-Vasilescu, L., »Paparuda«, Revista de Etnografie și Folclor I 5 ( 1970) 375-394.

Stojčevska-Antić, V., »Od eschatologiškite apokrifi za Bogorodica i nivniot odsiv vo narodnoto tvorčestvo na Južnoslovenskite narodi«, Makedonski Folklor 2 ( I 969) 2072 I 8.

Stojanović, L., »Dramski elementi u pokladnim običajima Slavonije i Baranje«, Osiječki zbornik I 8-19 (1987) 245-258.

Stojnev, N. (ed.), Bălgarska mitologija, Enciklopedičen rečnik, Sofija I 994.

Stonus, D., " Do ut des«. Herkunft und Funktion eines Erklärungsbegriffs«, Jahrbuch für Volkskunde, N. F. I9 (I 996) 4I-59.

Strauß, A., Die Bulgaren, Leipzig I 898.

Süssheim, K., »Die moderne Gestalt des türkischen Schattenspiels (Qaragöz)«, Zeitschrift der Deutschen Morgenländischen Gesellschaft 63 ( I 909) 739-773.

Sutton, S. B., »Rural-Urban migration in Greece«, J. Kenny/D. Kertzer (eds.), Urban Life in Mediterranean Europe, Urbana I983, 22 5-249.

Sutton, S. B., »What is a >village in a nation of migrants«, Journal of Modern Greek Studies 4 ( I 986$) 2$ I 7-243.

Svoboda, K., La démonologie de Michel Psellos, Brno 1927.

Sykora, G., "Ruinenstädte und Feuertänzer am bulgarischen Pontus«, Slavische Rundschau 5 (I 933) 389-397.

Szabadfalvi, J., »Die Gestalt des 'wissenden Imkers` in der ungarischen Volksüberlieferung", Ethnograpica et Folkloristica Carpathica 7-8 (1992) 246-250.

Szacsvay, É., "A magyarországi bábtáncoltató betlehemézes«, Néprajzi Értesitő 60 (I978/82) 57-IO2. 
Szacsvay, É., Bábtáncoltató betleheméz Magyarorszagon és Közép-Klet-Europában, Budapest 1987 .

Szendrey, Á., A magyar néphit kutatása, Budapest 1948.

Szendrey, A., »Hexen - Hexendruck«, Acta Ethnographica Academiae Scientiarum Hungaricae 4 (I955) I 29-I 68.

Szendrey, A., "Die Vorbereitung der Hochzeit und der Abschluss des Ehevertrags bei den Ungarn«, Acta Ethnographica Academiae Scientiarum Hungaricae 6 ( I 957) 37 I-434.

Szilágyi, D., Contemporary Hungarian Puppet Theatre, Budapest 1978.

Tahy, N. A., Das theatralische Brauchtum des ungarischen Sprachbereichs, Frankfurt/M. etc. I 989 .

Tailliez, F., »Rusaliile, les Rosalies et la Rose«, Cabier Sextil Puşcariu I/2 (Roma I 952 ) 3OI-3I 7 .

Talbot, A.-M. M., Faith-Healing in Late Byzantium, Brooklin, Mass. I 983.

Tamassia, G., L'affratellamento ( $\alpha \delta \varepsilon \lambda \varphi$ өлоіi $\alpha$ ). Studio storico-giuridico, Torino I 886.

Tanovic, St., Sprski narodni običaji u Đevđelijskoj kazi, Beograd/Zemun 1927.

Tansung, S., "Jeux populaires masqués de villages Turcs«, Le Masque dans la Tradition Européenne, Catalogue, Binche 1975, 301-3 Iо.

Tăpkova-Zaimova, V., »Le culte de Saint Démétrius à Byzance et aux Balkans«, V. Gjuzelev/R. Pillinger (eds.), Das Christentum in Bulgarien und auf der übrigen Balkanhalbinsel in der Spätantike und im frühen Mittelalter. II. Internationales Symposium, Haskovo (Bulgarien), ro-13 Juni 1986, Wien 1987, I39-146.

Tasić, N./M. Detelić (eds.), Kult svetih na Balkanu, Kragujevac 200 I.

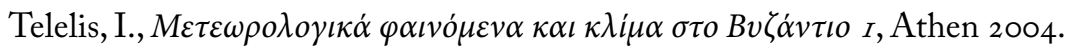

Teodorov, E., Trakijsko nasledstvo v bălgarskija folklor, Sofija I 972.

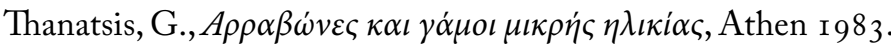

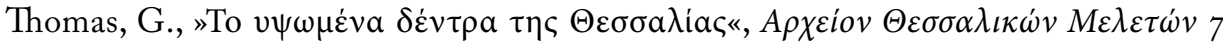
(I985) 207-225.

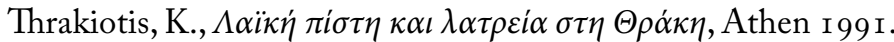

Tilneu, P. V. R., »Supernatural Prophylaxes in a Bulgarian Peasant Funeral«, Journal of Popular Culture 4/I (I 970) 2 I 3-229.

Tirta, M., "Des stratifications mythologiques dans l'Épopées légendaires«, Culture populaire albanaise, Tirana 1985, 91-I02.

Tirta, M., »Figures mythologiques albanaises et rencontres balkaniques«, Studia albanica I-2 (I 992) I I 9-I 25.

Tirta, M., »Figures de la mythologie albanais et concordances balkaniques«, Thraco-Dacica I6 (I 995) 26 I-266.

Tirtja, M., »Les cultes de l'agriculture et de l'élevage chez le peuple albanais«, Ethnographie albanaise 9 ( I 979) $20 \mathrm{I} \mathrm{ff}$. 
Todorov, D., Kapanci. Bit i kultura na staroto bălgarsko naselenie v severoiztočna Bălgarija, Sofija I 985 .

Tolstoj, S. M./Lj. Radenković, Slovenska mitologija, Enciklopedijski rečnik, Beograd $200 \mathrm{I}$.

Tomkinson, J. L., Haunted Greece. Nymphs, Vampires and other Exotica, Athens 2004.

Török, K., Magyar lakodalmi szokások az Alföldön, Pest i 864.

Trigg, E. B., Gypsy Demons and Divinities: The Magic and Religion of the Gypsies, New York I 973 .

Troianos, Sp. N., »Zauberei und Giftmischerei in mittelbyzantinischer Zeit«, Günter Prinzing/Dieter Simon (eds.), Fest und Alltag in Byzanz, München I 99 I, 37-52.

Trojanović, S., „Glavni srpski žretveni običaji«, Srpski etnografski zbornik I 7 ( I 9 I I) I-239.

Truhelka, Ć., »Die Heilkunde nach volksthümlicher Überlieferung mit Auszügen aus einer alten Handschrift «, Wissenschaftliche Mittheilungen aus Bosnien und der Hercegovina 2 ( I 894) 375-39I.

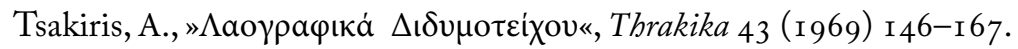

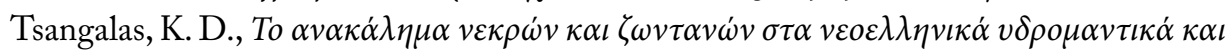

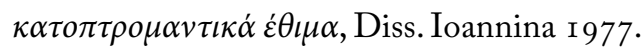

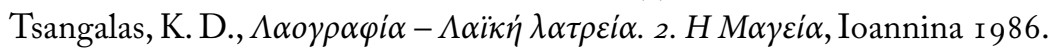

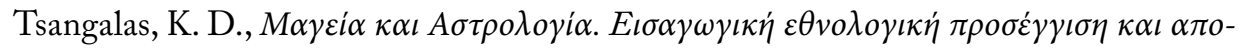
$\mu v \theta$ oлoin $\eta$, Athen 2007.

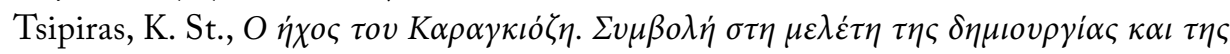

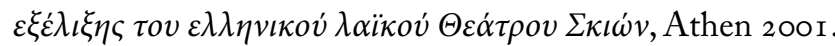

Turner, E., Communitas. The Anthropology of Collective Joy, New York $20 \mathrm{o} 2$.

Turner, V., From Ritual to Theater. The Human Seriousness of Play, New York 1982.

Turner, V., The anthropology of performance, New York 1986.

Turner, V. \& E. L. B., Image and Pilgrimage in Christian Culture. Anthropological Perspectives, New York 1978.

Tüskés, G./E. Knapp, Mirakelliteratur als sozialgeschichtliche Quelle barockzeitlichen Wallfahrtswesens in Ungarn«, Schweizer Archiv für Volkskunde 74 (1988) 79-103.

Udziela, M., »Ein Beitrag zur Volksthierheilkunde in Bosnien«, Zeitschrift für österr. Volkskunde 8 (I902) 105-I I 8.

Ujes, A., »Das Publikum der wandernden Schauspieler in der Vojvodina im I 9. Jahrhundert", Das Theater und sein Publikum, Wien I 977, 206-2 I 8.

Ujváry, Z., »Une coutume des Slavs du Sud: la >Dodola«", Publicationes Instituti Philologiae Slavicae Debreceniensis 38 ( 1963 ) I 3 I-I 40.

Ujváry, Z., "Das Begräbnis parodierende Spiele in der ungarischen Volksüberlieferung", Österreichische Zeitschrift für Volkskunde 69/XX (1966) 267-278. 
Ujváry, Z., "Theriomorphe Korndämonen in der ungarischen Volksüberlieferung ", Acta Ethnographica Academiae Scientiarum Hungaricae 16 (1967) 35-53.

Ujváry, Z., »Anthropomorphe mythische Wesen in der agrarischen Volksüberlieferung Ungarns und Europas«, Acta Ethnographica Academiae Scientiarum Hungaricae I7 (i g68) 63-i i 9 .

Ujváry, Z., »A ló az alföldi falvak dramatikus néps zokásaiban «, Müveltség és Hagyomány I 5-16 (1972-74) 299-340.

Ujváry, Z., »Probleme der zoomorphen Dämonen in den ungarischen Agrarriten«, Müveltség és Hagyomány I 5-I6 (1972-74) I $29 \mathrm{ff}$.

Ujváry, Z., »A temetést parodizáló szinjátékszerü szokások kérdéséhez«, Szolnokmegyei Muzeumi Évkönyve 1973, 22 I-230.

Ujváry, Z., A temetés paródiája, Debrecen 1978.

Ujváry, Z., Játék és maszk, 3 Bde., Debrecen 1983.

Ujváry, Z./I. Ferenczi, »Farsangi dramatikus«, Mû́veltseg és Hagyomány 4 (I g62) 3-1 5.

Ünver, O., Karagöz: Turkish shadow play, Ankara 2009.

Uplegger, H., „Das Volkschauspiel«, J. Deny et al. (eds.), Philologiae Turcicae Fundamenta,

2 Bde., Wiesbaden 1959-64, Bd. 2, I 47-168.

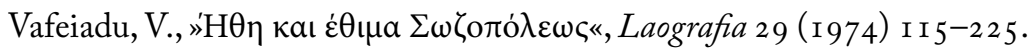

Vakarelski, Chr., Etnografija Butgarii, Wrocław 1965.

Vakarelski, Chr., »Altertümliche Elemente in Lebensweise und Kultur der bulgarischen

Mohammedaner«, Zeitschrift für Balkanologie 4 (1966) I 49-I 72.

Vakarelski, Chr., Bulgarische Volkskunde, Berlin I 969.

Vakarelski, Chr., »Jeux et coutumes théâtrales chez les Bulgares«, Ethnologia Slavica I (I 969) I 2 I-I 42.

Vakarelski, Hr., Etnografija na Bălgarija, Sofija 1977.

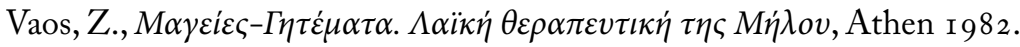

Vaqari, S., »Teatri i kukllave ne«, Nëndori 2, I I (1955) I39-I45.

Vargyas, L., »Mimos elemek a magyar bethlehmes játékban«, Antiquitas Hungarie, Budapest I 955, I I 7 ff.

Valsavor, J. V., Die Ehre des Herzogthums Crain, Nürnberg 1689.

Varvounis, M. G., »A contribution to the study of influences of christian upon moslem customs in popular worship", Journal of Oriental and African Studies 5 (1993) 75-89.

Varvounis, M. G., »Balkan dimensions and Moslem variations at the custom of Tzamala in Thrace«, Journal of Oriental and African Studies I 2 (2003) 53-6r.

Varvounis, M. G., »Historical and Ethnological influences on the traditional civilization of Pomaks of the Greek Thrace«, Balcanica 34 (2003) 267-283.

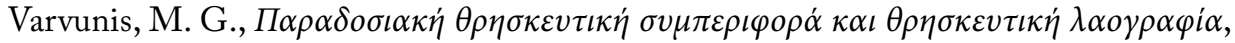
Athen 1995 ( $\left.{ }^{3} 2008\right)$. 


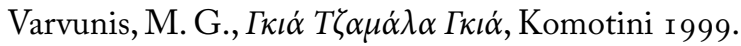

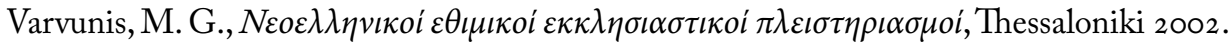

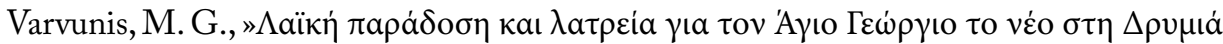

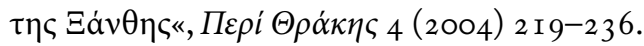

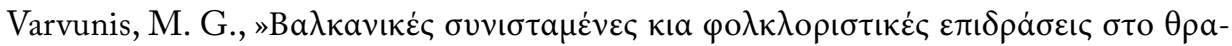

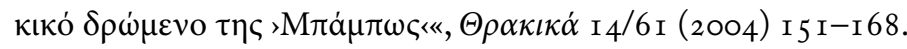

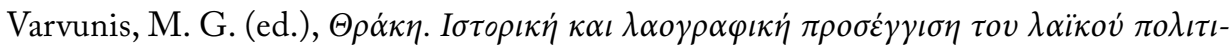

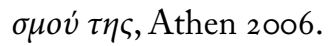

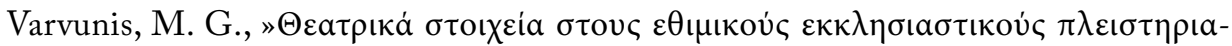

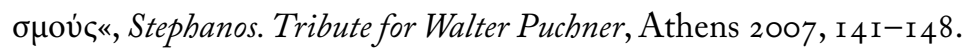

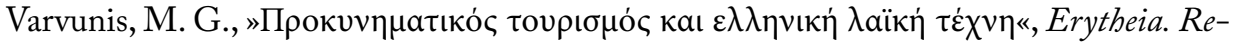
vista de Estudios Bizantinos y Neogriegos 29 (2008) 2 I 7-2 28.

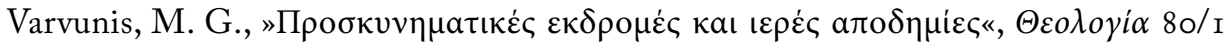
(2009) I9I-2 I I.

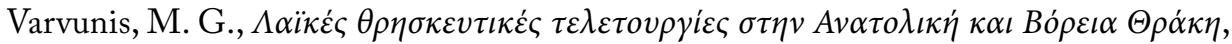
Athen 2010.

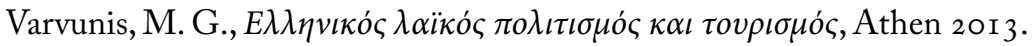

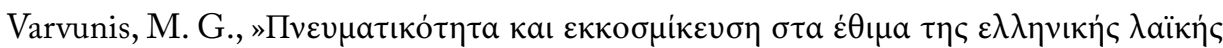

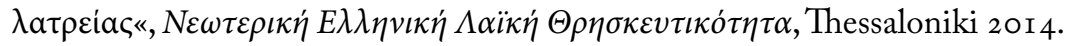

Vasileva, M., Lazarouvane: Bulgarian Feasts and Customs, Sofia I 982.

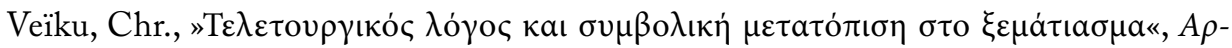

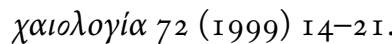

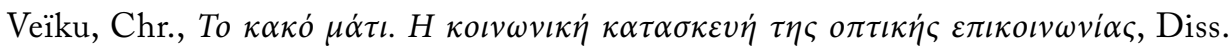
Athen I998 (42004).

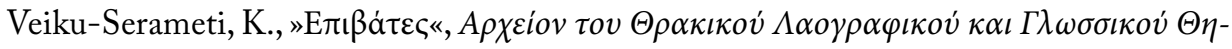

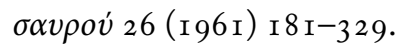

Veleckaja, N. N., Jazyčeskaja simbolika slavjanskich archaičeskich ritualov, Moskva I 978.

Veleckaja, N., »Rudimenty indoevropejskich i drebne balkanskich ritualov v slavjano balkanskoj obrjadnosti mediacii sil privadu (dodola - peperuda - german)«, Makedonski Folklor 23 ( I 979) 87-roo.

Velin, S., "Obnovljeni pokladnii običaji Šokaca u Santovu«, Etnografija Južnih Slovena u Mađarskoj, Budimpešta I 982, 2 I 5-237.

Veloudis, G., Das Druck- und Verlagshaus »Glikis« in Venedig (I670-I854). Das griechische Buch zur Zeit der Türkenherrschaft, Wiesbaden I 974.

Veselinović, J. H., »Lazarice«, Bratstvo 4 (Beograd I 890) 66-94.

Videnov, M., »Godečkaja džamala«, Bălgarska Etnografija 3-4 (I 994) 4I-53.

Vinogradova, L. N., Zimnjaja kalendarnaja poezia zapadnyb $i$ vostočnyh slavjan. Genezis i tipologija koljadovanija, Moskva I 982. 
Vlachos, Th., »Geister- und Dämonenvorstellungen im südosteuropäischen Raum griechischer Sprachzugehörigkeit«, Österr. Zeitschrift für Volkskunde 25 (I97 I) 2 I 7-248.

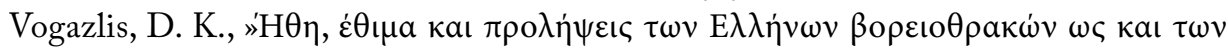

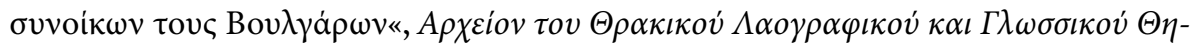

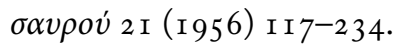

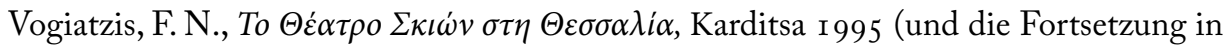

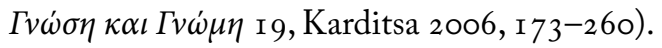

Volasko, M. T./Košir, M., Čaroviene: predstave, procesi, pregoni i evropskih in slovenskih deželah, Ljubljana r 995 .

Vonderlage, B., Das griechische Osterfest, Hamburg 1952.

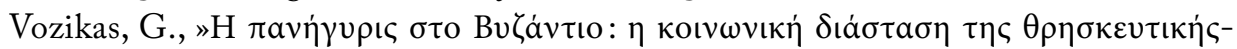

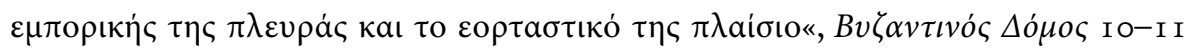
(г 999-2000) 39-68.

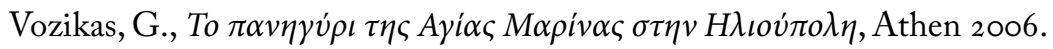

Vrabie, E., "A Nineteenth-Century Incantation of Bulgarian Refugees in Romania«, Journal of American Folklore 9I (1978) 584-587.

Vrabie, G., »Teatrul popular romînesc«, Studii și cercetări de istorie literară și folclor $6 / 3-4$ (I957) 485-562.

Vrabie, G., Folclorul. Obiect, principii, metodă, categorii, București I 970.

Vražinovski, T., Narodna demonologija na makedoncite, Skopje I 995.

Vsevolod-Gherngross, V. N., Russkaja ustnaja narodnaja drama, Moskva 1959.

Vuletić-Vukasović, V., Narodni običaji na otoku Korčuli, Zagreb I 891.

Vuia, R., »Originea jocului de călușari«, Dacoromania 2 (I92 I-22) 2 I 5-254 (Wiederabdruck in Studi de Etnografie şi Folclor I 975, I IO-I 40 und englische Übersetzung I 4 I-I 54).

Vukanović, T. P., »Gypsy Bear Leaders in the Balkan Peninsula«, Journal of the Gypsy Lore Society ser. 2, 38 (1959) I06-I 27.

Vukanović, T. P., »Gypsy Pilgrimages to the Monastery of Gračanica in Serbia«, Journal of the Gypsy Lore Society, ser. 3, 45/I-2 ( I 966) i 7-26.

Vukanović, T. P., »Obscene Objects in Balkan Religion and Magic«, Folklore 92 (I 98 I) 43-53.

Vukanović, T., Srbi na Kosovu, 2 Bde., Vranje I 986.

Vulcănescu, R., Măștile populare, București i 970.

Vulcănescu, R., Mitologie română, București I 985 .

Vulcănescu, R., »Ritual Masks in European Cultures«, M. Eliade (ed.), The Encyclopedia of Religion, vol. 7-8, New York/London I 993, 270-276.

Vulpescu, M., Irozii, papușile, teatrul țărănesc al vicleimului, caloialului și paparudele, $\mathrm{Bu}-$ curești I 94I. 


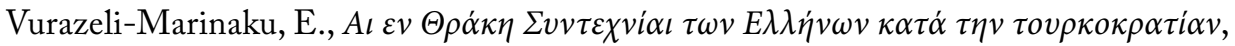
Thessaloniki I 950.

Wace, A. J. B., "North Greek Festvals and the Worship of Dionysos", The Annual of the British School in Athens I 6 ( I 909/ro) $232 \mathrm{ff}$.

Wace, A. J. B., "Mumming Plays in Southern Balkan«, The Annual of the British School in Athens 19 (1912/13) $248 \mathrm{ff}$.

Wace, A. J. B./M. S. Thompson, The Nomads of the Balkans, London I 9 I 4.

Weidkuhn, P., Aggressivität Ritus Säkularisierung. Biologische Grundformen religiöser Prozesse, Basel I 965 .

Wenzel, M., »Graveside Feasts and Dances in Yugoslavia«, Folk-Lore 73 (I962) I-I 2.

Werbner, R. P., Ritual Passage Sacred Journey: the Process and Organization of Religious Movement, Washington/Manchester I989.

Wiertz, P., "Zur religiösen Volkskultur der orientalischen und orthodoxen Kirchen Volksglauben und Volksbrauch«, Handbuch der Ostkirchenkunde, Düsseldorf I 97 I, $569-632$.

Wildhaber, R. (ed.), Masken und Maskenbrauchtum in Ost-und Südosteuropa, Basel I 968.

Wildhaber, R., "Die Eierschalen im europäischen Glauben und Brauch", Acta Ethnographica Academiae Scientiarum Hungaricae I 9 (1970) 435-457.

Williamson, G. A., »Tutelary Saints of Medicine in the Greek Church«, Caledonian Medical Journal I 4 ( 1929) 94-ro4.

Winkler, H. A., Siegel und Charakter in der mubammedanischen Zauberei, Berlin I 930.

Wolfram, R., »Altersklassen und Männerbünde in Rumänien«, Mitteilungen der Anthropologischen Gesellschaft in Wien 44 (1934) I I 2-I 28.

Wolfram, R., Brauchtum und Volksglaube in der Gottschee, Wien I 980.

Xhagolli, A., »Shtriga në mite, rite e besime të shiptarë«, Kultura popullore I-2 (I 993) $6 \mathrm{I}-70$.

Xhagolli, A., »The witch in myths, rites and beliefs of the Albanians«, Studia albanica I-2 (r 994) 93-ro4.

Zachariev, J., »Lazaruvane v Kamenitsa (Kjustendilstvo)«, Izvestija na narodnija etnografski muzej v Sofija Io-I I (I 932) I 87-202.

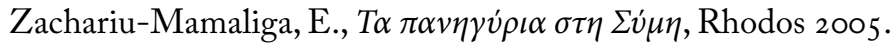

Zajkovskaja, T., »Momoery-novogodnije rjaženyje u grekov Adžarii«, Polevyje issledovanija, n. s. I (Moskva r 993) 94-го5.

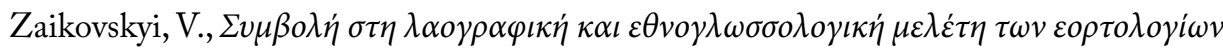
$\tau \omega v E \lambda \lambda \dot{\eta} v \omega v \kappa \alpha \iota \Sigma \lambda \dot{\alpha} \beta \omega v(\tau o \delta \omega \delta \varepsilon \kappa \alpha \eta \dot{\eta} \mu \rho \rho \omega \varsigma \pi \varepsilon \rho i o \delta o \varsigma \delta \iota \dot{\alpha} \beta \alpha \sigma \eta \varsigma)$, Diss. Athen 1998.

Zakhos-Papazahariou, E., "Les Origines et Survivances Ottomanes au Sein du Théâtre d'Ombres Grec», Turcica 5 (I 975) 32-39. 
Žatko, R., »Svadba u Slovákov v Mad'arsku«, Národopisny Sbornik 9 (Bratislava I950) I $72-197$.

Zbinden, E., Die Djin des Islam und der altorientalische Geisterglaube, Berlin/Stuttgart 1953.

Zečević, S., »Predanja o rusalijski grobljima u Istočnoj Srbiji«, Narodno stvaralaštvo folklor I (Beograd I962) 235-243.

Zečević, S., »Heidnisch-christliche Symbiose einiger mythischer Wesen der serbischen Volkstradition«, Das heidnische und christliche Slaventum, Wiesbaden I 969, I 20-I 25.

Zečević, S., Elementi naše mitologije u narodnim obredima uz igru, Zenica 1973.

Zečević, S., Mitska bića srpskih predanja, Beograd I $98 \mathrm{I}$.

Zečević, S., Kult mrtvih kod Srba, Beograd 1982.

Zečević, S., Sprske narodne igre, Beograd I 983.

Zečević, S., »Die Personifikation des Windes in der serbischen Mythologie«, Zeitschrift für Balkanologie 19 (1983) 217-223.

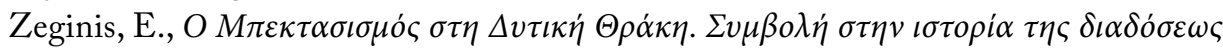

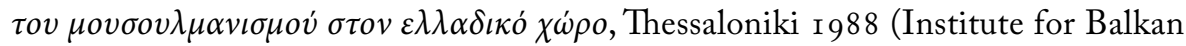
Studies 220).

Zelenčuk, V. S./J. V. Popović, »Antropomorfnye obrazy v obrjadach plodorodija u vostočnoromanskich narodov (XIX - načalo XX veka)«, Balkanskie issledovanija. Problemi istorii i kultury, Moskva 1976, 195-201.

Zelepos, I., Orthodoxe Eiferer im osmanischen Südosteuropa. Die Kollyvadenbewegung (I750-I820) und ibr Beitrag zu den Auseinandersetzungen um Tradition, Aufklärung und Identität, Wiesbaden $20 \mathrm{I} 2$.

Željaskov, I., „Obrednite chljabove ot Elchovsko«, Folklor i istorija, Sofija I 982, 259-262.

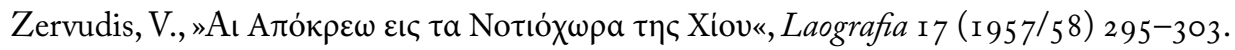

Zimmerman, Z. D., »The Changing Roles of the $>V$ Vila in Serbian Traditional Literature «, Journal of the Folklore Institute I6 (1979) I67-I 75.

Zischka, U., Zur sakralen und profanen Anwendung des Knotenmotivs als magisches Mittel, Symbol und Dekor, Diss. München 1977.

Živkov, T. I., »Obrednost i obredno izkustvo«, Obredi i obreden folklor, Sofija I 98 I , 7-28.

Zlabadnik, B., Od zibelke do groba, Čelovec 1982.

Zlabadnik, B., Volksbrauchtum der Kärntner Slowenen, Klagenfurt 1992.

Zlatanović, M., Narodne pesme i basme južne Srbije, Beograd I 994.

Zlatanović, S., »Značenjski sklop tradicijske svadbe«, Etnologija 4 (Sofija 2oor) 7-50.

Zlatković, D., »Mesto i uloga neveste u svadbenom obredu staroplaninskih cela u Srbiji«, Etnologija 4 (Sofija 200I) 5 I-85.

Zlatkovskaja, T. D., »O proizchoždenii nekotorich elementov kukerskogo v bolgar (k voprosu o frakijskich tradicijach u narodno jugo-vostočnoj Evropi)«, Sovjetskaja Etnografija I967, H. 4, 3 I-46. 


\section{Abbildungsverzeichnis}

Abb. I : Theriomorphe Maskierung, Batschka, 2. Hälfte des 20. Jahrhunderts (Vesna Marjanović, Maske, maskiranje i rituali u Srbiji, Beograd 2008, 284).

Abb. 2 : Pfingstkönigin Kraljica in Miloševac, Serbien, Ende 20. Jahrhundert (Vesna Marjanović, Maske, maskiranje i rituali u Srbiji, Beograd 2008, I85).

Abb. 3: Ziegenverkleidung der Winterumzüge mit Klappermaske, Jankov Most, rumänische Vojvodina (Robert Wildhaber (ed.), Masken und Maskenbrauchtum aus Ostund Südosteuropa, Basel i 968, Abb. 37).

Abb. 4: Gesicht-Schwärzen bei den Karnevalsbräuchen in Moha (Bezirk Féjér) in Ungarn (Péter Korniss, Bräutigam des Himmels. Bilder ungarischer Volksbräuche, Budapest I 975 , o. S.).

Abb. 5: das Vorbild der Bärenverkleidung: Tanzbär mit Zigeuner als Bärenführer, $g a-$ dulka spielend, Varna, Bulgarien (Photoarchiv Thede Kahl).

Abb. 6: Sternsingen in der Stube am H1.Drei-Königstag in Szakmár (Bezirk Bács-Kiskun) in Ungarn 1970 (Péter Korniss, Bräutigam des Himmels. Bilder ungarischer Volksbräuche, Budapest I 975 , o. S.).

Abb. 7: Die Dornenkörnung Christi aus dem theatralischen Passionsspiel in St. Lorenzen ob Murau, Steiermark 1937 (Leopold Kretzenbacher, Passionsbrauch und CbristiLeiden-Spiel, Salzburg 1952, Abb. 7).

Abb. 8: Ithyphallische Karagöz-Figur aus der osmanischen Schattenspieltradition (Metin And, Karagöz. Théâtre d'Ombres Turc, Ankara 1977).

Abb. 9: Handgemaltes Reklameplakat einer griechischen Schattentheatervorstellung »Karagiozis als Braut« des Karagiozis-Spielers Fotis Plessas, das »haltloses Lachen«

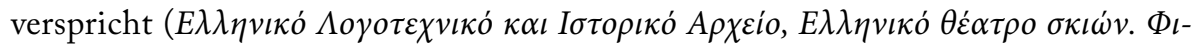

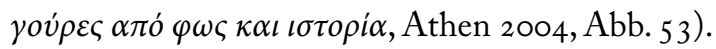

Abb. ro: Rituell-sportlicher Ringkampf bei einem Hochzeitsfest in Karoti bei Didymoteichon in Griechisch-Thrakien I 960 mit Dudelsack (gaida)-Begleitung, Photo G. N.

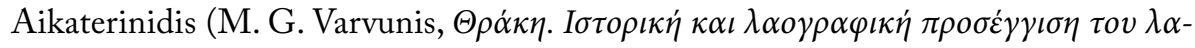

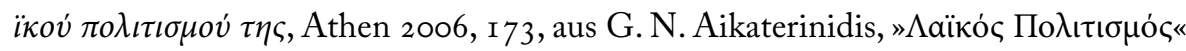
in: $\Theta \rho \alpha \dot{\kappa} \kappa \eta$, Komotini 2000, 323).

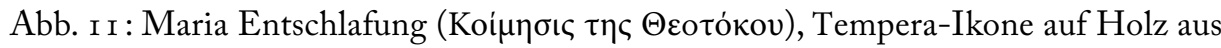
dem Stavronikita-Kloster des H1. Berges Athos von Theophanes dem Kreter ( $\Theta \varepsilon o-$

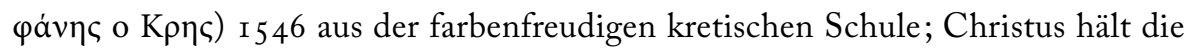
"Seele« der schon verstorbenen Mutter Gottes als Wickelkind im Arm ( $\Theta \eta \sigma \alpha v \rho o i$

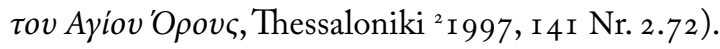


Abb. I 2 : Apotropäischer März-Faden (martis, martitsi, martinicki) an der Hand einer Kassiererin in einem kleinen Lebensmittelgeschäft (bakaliko) im Dorf Pistiana im Gebiet der Tzumerka, Zentralpindus, Epirus (Photoarchiv Thede Kahl).

Abb. 13: Priesterliche Segnung eines Tieropfers: weißes und schwarzes Schaf mit aufgesteckten Kerzen auf den Hörnern, bei den rituellen Vorbereitungen des Feuerlaufs der anastenaria in Agia Eleni bei Serres, Griechisch-Makedonien, am 2 r. Mai I963,

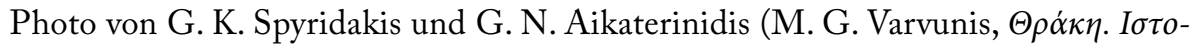

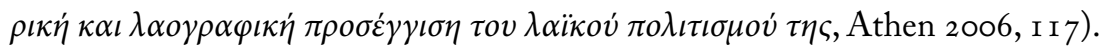

Abb. I4: Votivplättchen aus Serbien (Nikos Papageorgiu, A. Tó $\mu \alpha \tau \alpha \kappa \alpha \iota \Sigma \dot{u} \mu \beta 0 \lambda \alpha \tau \omega v$

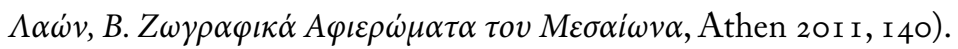

Abb. I 5 : Das apotropäische Amulett »die Hand der Fatima« im islamischen Glaubens-

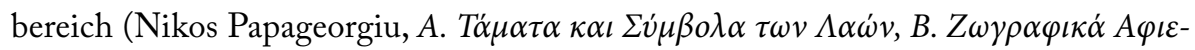

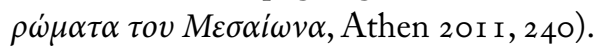

Abb. I6: Moderne Votivplättchen aus Griechenland (Nikos Papageorgiu, A. Tó $\mu \alpha \tau \alpha$

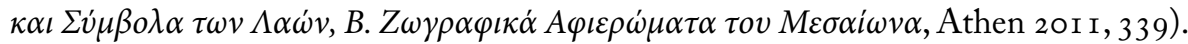




\section{Kartenverzeichnis}

Nr. I : Physische Übersichtskarte Südosteuropas, Ing. Büro für Kartographie J. Zwick, 35394 Gießen, Entwurf K. Clewing / P. M. Kreuter, Lexikon zur Geschichte Südosteuropas, Red. K. Clewing, Hgg. E. Hösch, Wien/Köln/Weimar, Böhlau-Verlag, 2004. S. 3 I.

Nr. 2 : IEG-MAPS Server für digitale historische Karten / A. Kunz 2009, Karte 7 I 2 , Titel: Südosteuropa 2008, Bearbeiter: A. Kunz / R. Moeschl, Kartographie: Joachim Robert Moeschl, Herausgeber: Andreas Kunz. http://www.ieg-maps.uni-mainz.de/ mapsp/mappEu2008_SE.htm 


\section{NAMEN UND PERSONEN}

Abbaz Aliu von Kerbela 359

Abbott, G. F. I23, I28, 425, 588, 468

Abeghian, M. 4I 5

Abrahamse, D. de 323

Abt, A. 279

Adam 3 I 2, 360

Adamantiu, A. 49

Adăscăliței, V. 69, 82, I 35, I 37, I 9 If., 463, 468

Adonis II 7

Afentras, G. 60, I05, I61, 468

Ahrens, Chr. 3 If.

Aigner, F.H. 249

Aikaterinidis, G. N. 44,48, 50, 6 I, 77, I I 3 , I $23-$ I $25,260,284,293,295,3$ I $6,338,344,370,376$, $382 f$., $444,466,525$ f.

Ajdačić, D. 425, 468

Akoglu, X. K. I I 2, 205, 250, 260, 325, 432, 469

Albanidis, E. 258

Alecsandri, V. 226, 238

Alexakis, E. P. 3 I, 48, I 3of., 204, 206, 355, 365, 397,460

Alexander d. Gr. I Io, 244-248, 259, 360

Alexandrescu, L. 2 I 6

Alexandru, T. 32

Alexiadis, K. 203

Alexiadis, M. A. 22, 66, 97, 195, 209, 247, 306, 3I $8,376,408,44 \mathrm{I}, 469$

Alexidis, I. I 27

Alexieva, M. 64

Alexiou, M. 33, I I 7, 26 I , 375, 38 I , 4 Iо, 466, 469, 5 I7

Ali Pascha 245f., 390

Alivanoglu-Papangelu, K. 2 Iо

Allacci, L. 42 I

Allah 4I I

Allatios, L. 42 I

Allenby, J. 3 I

Alonso,J. 265
Alsheimer, R. 329

Alszeghi, Z. 46I

Alterescu, S. 68, 82, I91, 216, 238, 469

Alvey, R. G. 3I7, 3 I 9

Amanshauser, H. I 89

Amantos, K. 389, 391, 398

Ambrosetti, R.J. 29

Ampelakia, E. 126

An, N. 23I, 469

Anagnostopulos, G. A. 39I

Anagnostopulu, I. Sp. 324

Anasis, E. E. 279,469

Anastasiadou, I. I. 97, 469

Anastasova, E. I. 326

Ančev, A. 33I, 469

And, M. 76, 91 I I 54, I 73, I97, 2 1 7 , 230f., 233, 463,469 f.

Andrade, R. G. d' 33 I

Andreadis, E. 345, 355, 430, 507

Andrian, F. Freiherr von 89, 333

Andrić, I. 240

Andriopulos, D. 108

Andronikos II. Palaiologos 263

Andrutsos, O. 390

Anfert'ev, A. N. I 28

Angelis, P.I. 73

Angelov, B. 424-426, 470

Angelov, D. 305, 470

Angelov, V. 104, 425, 470

Angelova, G. 68

Angelova, R. 68, I 5 I , I70, 42 5, 470

Anguélova-Georguéva, R. I06, 470

Anhorn, B. 324

Anna von Savoyen 263

Anninos, B. 243

Anogeianakis, F. 84

Anoyanakis, F. 3 I

Anrich, G. 374, 378 
Anthony, A. 4I

Antić, V. I49, 2 I 8, 470

Antoniadis, L. I 84

Antoniadis, X. A. I I 3,470

Antonijević, D. I3, 65, 69f., 95, I05f., I 42, 235 f., 239, 3 I6f., 325, 459, 463, 470

Antoniu-Kritiku, I. 33, 37, 470

Antzulatu-Retsila, E. 207, 337, 377, 380, 470

Aphrodite I I 9, 202, 334, 355

Appendini, F. M. 80, 47 I

Apostolopulos, V. 34I

Aranca 4I, I6I, 439

Ardalic, V. 140, $47 \mathrm{I}$

Ardener, Sh. 284

Arfaras, M. 56, 358

Argenti, P. P. 62, I I 8, I 77, 207, 305, 47 I

Argis, A. 60

Argyriadi, M. 256

Aristophanes 226, $230 \mathrm{of}$.

Arnaud, L. 439

Arnaudoff, M. 60, 85, 91, 104, I64, 258, 462, 47 I

Arnaudov, M. 40, 48f., 57, 90, 97, I08, I I 5, I 23 , I69f., $4 \mathrm{I} 6,42 \mathrm{O}, 428,43 \mathrm{I}$

Arnim, C. O.I.v. 2 I 2

Arnold, M. S. 271, 47 I

Arnott, M. L. 4I, 350, 368

Artemis 86

Asdrachas, Sp. 362, 47 I

Askari, M. 32

Asklepios $28 \mathrm{I}$

Asvesti, M. V. 444

Atanasova, K. 48, 104, 47 I

Atanasova, N. 217

Athanasiadis, E. 173

Athanasiadis, P. I 25

Athanasiadis, St. $\quad$ I 73

Aufhauser, J. B. $\quad 247,373$

Aurel, I. I 5 I

Aurenhammer, H. 3 I 2

Ausländer, P. 32

Austin, J. L. 27

Avdeev, A. D. 69, $47 \mathrm{I}$

Avdikos, E. G. I 25, I 30, 254, 304, 382, 467, 47 I

Averof, G. A. 3I, I 83

Avgerinu-Sguridis, G. 347
Avrasoglus, D. I 25

Baba Ali Tomori 359

Babinger, F. 305, 322, 466, 47 I, 496

Bacchus 393

Bachofen,J.J. 20

Bachtin, M. 5 I, 409

Bächtold-Stäubli, H. 322

Bada, C. 385, 5 I 3

Bada, K. 209

Bada-Tsomoku, K. 3 iо

Badone, E. 353 f., 356,480

Bakalaki, A. 97

Balašov, M. 69

Balassa, I. 40, 6I, 93, I 33f., I 48f., 20 I, 205, 208, 2 I 6, 254, $257,260 \mathrm{~m} 3$ I $4 \mathrm{~m} \mathrm{320,326,356,44} \mathrm{I,}$ $458,46 \mathrm{I}, 47 \mathrm{I}$

Balázs, J. 73, 4I 3

Balić, S. 305

Bálint, S. I 33, 46 I, $47 \mathrm{I}$

Bälz, E. 330

Bancroft-Marcus, R. E. 265

Bandić, B. I 42, $47 \mathrm{I}$

Bandinus $15 \mathrm{I}$

Barbar, L. 342, 47 I

Barkan, Ö. L. I 68

Bartels, M. 32 I

Bartholomäos 337, 362, 394

Bartl, P. 305, 472

Bartok, B. 3 I

Bartoli, M. 226

Basch, S. 230, $47 \mathrm{I}$

Başgöz, I. 2 I 7, 472

Basić, O. 472

Basileios I. 386f., 389

Batatzes, Joh. 389

Batušić, N. 80, I 49, I 93, 2 I 8, 234, 239, 472

Bauer, J. 209

Bauman, R. 28, I 70, 472

Baumel,J. 85

Bausinger, H. 43

Bax, M. 356, 472

Beck, H.-G. 327, 334, 35 I, 373, 386, 472

Begović, M. 4I7, 472

Bekiaris, K. 52 
Belaj, V. 80, 88, 472

Belgrader, M. 32 I, 385, 472

Belitska-Scholz, H. I 48, 2 I I, 2 I 6, 472

Bell, C.M. 29

Bellosics, B. 75

Belovic, J. 94, 279, 322, 420, 472

Belting, H. 3 Io, 35 I , 472

Belzić, J. 3 I

Ben-Amos, D. 27, 472

Benc Bošković, K. I04, 472

Benedek, A. I 33, 472

Benekos, D. 3 I 5 f., 324, 423, 472 f.

Benigni, U. 323

Benovska, M. 68, 78, I 5 I, I 70, 473

Benovska-Săbkova, M. ı o6, 424f., 466, 473

Bent, J.T. I99

Benyovsky, K. I 90, 473

Benz, E. 3 I 2

Benz, R. 372

Beranek-Wolf, H. I 89

Berger, P. 300

Berger, P. L. I 8f., 252

Bergsträsser, G. $23 \mathrm{I}$

Berking, H. 43

Berkusky, H. 333

Berlogea, K. 2 I 3

Bernard, L. 475

Bernard, R. 420, 473

Berndt, A. 375

Bernea, E. I 5 I

Bertram, O. I 56

Berze Nagy, J. I 33, 473

Beyer, J. 325, 327

Beza, M. I I 5, I 35, 207, 473

Bezić-Božanić, N. I93

Bharati, A. 367, 382, 43 I , 497, 5 I 6

Bibi-Papaspyropulu, A. 28 I, 283, 465, 473

Biddle, B.J. 66

Biedermann, H. 339

Bieler, L. 330

Bihalji-Merin, O. 65, 69, I05, 473

Birge, J. K. 304

Biris, K. I. 230, 244f., 249, 473

Bischoff, E. 323

Bitunis, V. 223
Blackham, O. 229

Blagojević, G. 380

Blastares, M. 388, 390

Bleichsteiner, R. 59, 100

Bliss, F. 438, 44I, 473

Bloch, E. 43

Bloch, I. $28 \mathrm{I}$

Bloland, S. 3 I

Blum, E. 44, 464

Blum, R. 44, 464

Bobčev, S. S. 355, 473

Bočev, M. I 5 I, 473

Bocev, V. I04, 473

Böcher, A. 320

Bočkov, B. 42 I, 473

Bodin, J. 324

Boehm, F. $329 f$.

Bogatyrev, P. 66, 220

Bogdani, H. G. I o5, 474

Bogdanova, L. 425

Bogdanović, I. I73

Böhmer, G. 229

Boissevain, J. 367, 370, 489

Bojadžieva, S. 425

Bokova, I. I07, 474

Boll, F. 335, 4I 4

Bollig, J. 372, 374f.

Bolte, J. I 9o, 4 IO

Bombaci, A. 80, I 73, I 97, I 99, 2 I 7, 474

Bonifačić-Rožin, N. 69, 82, 89, I 40, I 93f., 200, 204, 2 I 6-2 I 9, I 35, 240, 462, 472, 474

Bonser, K. J. 368

Bonsyak, S. 33 I

Boratav, P. N. 9I , I 73, 23 I , 254, 474

Borcakl1, A. 23 I, 474

Bordat, D. 229

Borst, A. 335

Bosić, M. 40, 78, 93, 95, I04, I 4 If., I 57, 474f.

Bošković-Matić, M. 204

Bošković-Stulli, M. 34, 69, I06, I 94, 41 9, 425, 475

Botsaris, M. 395

Boucrot, F. 229

Bourquelot, L. F. 397

Bourke, J. G. 322, 492 
Bouteiller, M. 270

Bowie, F. 23, 355

Boyer, P. 23

Brachalis, G. 242

Brackertz, K. 332

Braid, D. $27 f$.

Brăiloiu, C. 225

Brandl, R. M. 32

Brandstetter, M. 235

Brandt, H. I 89

Braude, B. 305, 475

Braun, H. 32

Braun, M. 205

Brednich, R. W. 27I, 325, 4I 6, 475

Bréhier, L. 437

Brenske, H. $37 \mathrm{I}$

Brewer, W. D. 34

Brewster, P. G. 254, 256, 475

Breyer, B. 2 I 2, 475

Briggs, K. 426

Brillante, C. 332

Broby-Johansen, R. 66

Brody, M. 2 I 5

Brøndegaard, V.J. 280

Brown, C. 29, 207

Brown, E. A. R. 388

Brown, P. 362

Browne, R. B. 29

Bruckner, J. I I 4

Brückner, W. 57, 284, 3 I 7, 35 2f., 379, 423, 480

Brusku, A. 382

Bucşan, A. I 5 I

Buday, G. 3 I

Budge, W. 317,438

Buhociu, O. 40, 82, 94, I 35, I 37f., I 56, 206, 26o, 475

Bulst, N. 423

Bünker, K. I 88

Bünker, R. I 87

Burada, T.T. 82, I 37, I 5 I, I 91 , 225, 234, $238 f$., 463

Burkhart, D. 32, 46, 95, 240, 4I 7, 420f., 425f., 466, 475

Burkhart, W. $38 \mathrm{I}$

Burt, R. L. 408
Bustronios, G. 264

Byloff, M. 322

Byron, Lord 240

Çabej, E. 387, 4I 3, 4I 9f., 424, 475

Čačava, M. 4I 5

Caduff, C. 29

Caillois, R. 252

Caimi, G. 244, 475

Čajkanović, V. 47, 42 5, 467, 476

Calbo, V. 265

Călin, C. 94

Camariano, A. 2 I 5

Campbell, J. K. 385, 439, 44I, 476

Candrea, I. A. I I 5

Cange, Du $388 \mathrm{f}$.

Cantemir, D. 80, I 36, I 5 I, 277

Capidan, Th. 254, 4I 8, 476

Caraman, P. 45, 94, 439, 442, 476

Carayon, A. I 49

Carić, A. E. 34 I

Carlson, M. I6, 27, 23 of.

Carnoy, H. I 22, 36 I, 476

Carolidis, P. 372,476

Carrington Bolton, H. 330

Cartojan, N. 2 I 6

Casanova 2 I I

Casanova, J. 30I

Castellan, V. A. L. 258

Castellino, F. 222

Castillo de Lucas, A. 270

Çelebi, E. 232, 236, 305,362

Cepenkov, M. K. 254, 476

Čerepanova, O.A. 4 I 4

Čerkezova, M. M. I 5 I, I 70

Cernea, G. I67

Cervellati, A. 22 I

Cervenka, E. C. 33, 283

Chadžinikolov, V. 426, 49I

Chalkea, E. 370, 476

Charalampakis, Chr. 260

Chartophylax, N. 388, 39I

Chassany, J. P. 333

Chelcea, E. I38

Chiaro, A. M. del 236 
Chiaro Fiorentino, A. del 8o, 476

Chimet,I. 2 I 6, 484

Chiotis, P. 266

Chomatianos, D. 388

Choniates, N. $389 f$.

Chontolidu, E. 359

Chortatsis, G. I 80, I 94-196

Christensen, A. 4 I 5

Christis, Th. S. 255

Christodoulou, St. I 24

Christodulu, Th. 208

Christofilopulos, A. 389,392

Christomanos, K. Iо7

Christudis, P. 99, 104

Chronopulu, A. 256

Chrysanthis, K. 202, 284, 423, 476

Chrysanthopoulou-Farrington, B. 203, 476

Chrysanthopulu-Farrington, V. I30, 440, 476

Chrysostomidis, A. 2 I 3

Chrysostomos, Joh. 70, 3 I I, 4O I, 4IO

Chryssavgis, J. 4I 4

Chrysulaki, A. 309, 428

Churmuziadis, A. I04, I64, 476

Churmuziadis, K. 84, I 26, 325

Chuvin, P. 230, $47 \mathrm{I}$

Çireș, L. I00, 468

Cirili, G. 255

Ciszewski, St. 385,387

Ciubotaru, I. 82, I9I, 468

Christus 44, 47, 50, 63, 7of., I 27 , 27 of., 276, 294, 301, 303, 309-3 1 2, 35 2, 37 I, 40 I, 4I of., 427, 430,525

Clewing, K. I 3,527

Closs, A. 326, 476

Cochrane, G. 2 I 2

Codellas, P. S. 41 5, 476

Codrington, E. 2 I 4

Cohen, A. P. 365

Cohen, Ph. R. 27

Coleman, S. 354

Čolić, J. 88

Colpe, C. 360,476

Conache, C. 239

Conrad,J.L. 322, 464, 477

Constante, C. 94,483
Constantin, M. I42, 477

Coote, L. E. F. 439, 477

Coppet, D. de 353

Cornaro, F. 264

Cornaro, V. I 80

Corno, D. del 332

Costa, F. A. 213, 477

Costa, H. I 87

Couffin, M. C. 207, 443, 477

Coulentianou, J. I I 4, 477

Cowan, J. K. 31, I06

Cristescu, C. 356, 477

Critchley, M. 33

Crum, D. 3 I

Csalog,J. I03, 477

Csávásy, A. I 56, 477

Csiszár, Á. 439, 477

Csövek, E. 333, 477

Čubelić, T. 69, 2 I 7, 462, 477

Ćuk,J. 204, 477

Cuulinović-Konstantinović, V. 76f., 477

Cunen, F. 329

Ćupurdija, B. 76, 477

Cuschan, A. 329, 48 I

Cvetanovska,J. I 42,477

Dağli, Y. 327

Dahmen, W. $4 \mathrm{I} 6$

Dahrendorf, R. 66

Dalampis, N. D. 95, 477

Dalkavunis, V. $35^{8}$

Dalven, R. 4I, 207, 477

Damian 394

Damianakos, St. 229, 232, 244f., 248, 250, 439, 477

Dancov, N.I. 97

Danev, G. I70

Danforth, L. M. I I 7, 208, 244, 279, 326, 429, 477

Daničić, L.T. 283,477 f.

Daniel, M. 2 I I

Daniel, O. 457

Dāniyāl, Ibn 23 of.

Danzel, Th. W. 3 I 5

Daraki, P. 255

David, L. 106 
Davis, T.C. 28

Dawkins, R. M. 98, I I 3 , I 50, I63, I66-г69, 220, 264, 34I, 39I, 43of., 478

Daxelmüller, Chr. 3I3, 3 I 8, 320-322, 329, 4I 2 , 478

Debeljković, D. 95, I4If.

Debreczeni, F. I 48, 2 I6, 478

Dede, A. 478

Dede, M. 49f., 97

Defteraios, A. N. 46, I 29, 367,478

Dégh, L. 28, 68, 46 I , 478

Deichmann, F.W. 309

Deinakis, St. 4I 8

Dekulu-Melissaropulu, A. 2 I 3

Delatte, A. 280, 324, 330, 4I 4, 478

Delbrueck, R. 3 Io

Delehaye, H. $372 \mathrm{f}$.

Delić, S. R. 32 I , 478

Deligiannis, B. N. 49

Deligiannis, V.N. $276,355,444,478$

Deluz, A. 33 I

Demény, L. 362, 505

Demeter I 24

Detelić, M. $368,468,5$ I 8

Detienne, M. 38 I, 483

Detorakis, Th. 385,478

Dialektu, D. 325, 4I 8

Dickie, M.W. $436 f$.

Dieterich, K. 34I, 478

Dikomitis, L. 356

Diller, I. 247

Dimen-Schein, M. 439

Dimitriadis, V. 234, 236, 362

Dimitrijević, S. Iо5

Dimitriu, N.A. I 77

Dimitrokallis, G. 3 I6, 4I8, 478

Dimu, M. 2 I 3

Dinekov, P. I 3, I 23, I63, 478

Dinescu, V. 224, 234, 478

Dinzelbacher, P. 423, 432

Diokletian, Kaiser 388

Dionisopoulos-Mass, R. 439, 478

Dionysius Areopagites $35 \mathrm{I}$

Dionysos 43, I63, I67, 220, 308

Dioskurides 442
Dioszégi, V. I 5 1, 326, 478

Dirksmeier, P. 27

Ditten, H. 229, 487

Djakov, T. 33 I

Djamo-Diaconița, L. 279,478

Djenev, K. 3 I

Djeribi, M. 435

Dmitrievskij, A. 387, 389, 393f., 479

Dobruški 163

Dobschütz, E.v. $35^{2}$

Đokić, R. 65

Dölger, F. 207, $388 \mathrm{f}$.

Dols, M.W. 423

Domonkos, P. P. I 50, 479

Dömötör, T. 66, 68, 73, 75, 79, 93, I I 4 , I 33 f., I 54 , I 56, 20I, 326, 46 I, 479

Don Quijotte 26I

Donkov, I. 3 I

Dorbarakis, B. Ch. 50

Đorđević, D. 76, 8I, I57

Đorđević, D. M. 387

Đorđević, D.T. 95, I4I, 479

Đorđević, T. R. 44, 57, I4I, 254, 4I 7, 4I 9, 424, 479

Döring, J. 27

Dörrer, O. I 89

Dostálová-Jeništová, R. 23 of., 479

Douglas, M. 284, 336

Drăgoi, S. V. 137

Dragon, G. 284, 329

Dragoumis, M. Ph. 32

Dragumis, N. 392

Drakakis, M. 399

Drakos, I. E. I. I 27

Drandakis, L. I 7 I

Drettas, G. 4I3, 479 f.

Drexl, Fr. 332, 480

Driesch, G. C. von der 199

Du Boulay, J. 357, 4I 7, 480

Dubinskas, F. A. 60, 79, 480

Dubisch,J. 20, 208, 353, 355f., 480

Duda,H.W. 197, 217,247

Duffy,J. 323, 437

Dukova, U. 32 I , 4I 3, 424, 466, 480

Dumont, A. 87 
Dundes, A. 436,480

Dünninger, D. 56, 204, 480

Dünninger, H. 353

Dupor, M. 262

Dupront, A. 354

Durand, G. 300

Đurić, V. 425

Durkheim, E. 299, 355

Dušan, St., Zar 263, 4I 7

Duwan, L. 2 I 2

Džudžev, St. I $70,425,480$

Eade, J. 354f.

Easterling, P. 67, 230, 407

Eckert, G. 74, 257, 329, 34I, 378f., 4I 8, 480

Eckstein, F. I 26, 284, 376

Edelstein, E. 378

Edelstein, L. 378

Edgar, I. 33 I

Egea,J.-M. 265

Efe, P. 232, $48 \mathrm{I}$

Efron, D. $33 \mathrm{f}$.

Efthymiu, G. K. 50

Efthymiu, G. P. I68, I 7 I

Eichler, P. A. 4I 4, 48 I

Eideneier, H. 327,408

Einsler, E. 360

Eissler, L. 438

Eitrem, S. 284, 3 I 7, 33 I

Ekman, P. 33, 435

Elçin, S. I73, $48 \mathrm{I}$

Elefterescu, E. I 5 I

Eliade, M. 86f., I 104, I 5 I, 26 I, 280, 303, 3 I 7, 32 I, $48 \mathrm{I}, 522$

Elias, N. 33

Elsie, R. 457 f.

Elworthy, F.Th. 436, 467, 48 I

Emeritzy, A. E. I 90, 48 I

Emmanuil, E. 279, 281, 377

Endres, F. C. 323

Engel, F. M. 326

Enisleidis, Chr. $35^{\circ}$

Ensel, R. 75, 46 I, 5 I 2

Eperjessy, E. 75, 479

Erdeljanović,J. 93
Eretescu, C. 74, 76, 90, I 7 I, 497

Erikson, E. H. 252

Ermolov, A. S. 333

Ernyey, J. Iо3, I 89, 48 I

Eroz, M. I 23

Erzengel Gabriel I 32, 362

Erzengel Michael I 23, 362

Esser, A. 4IO

Estocq, H. L. 89, I 87

Euripides I63

Eva 3 I 2

Evangelatos, Sp. A. I 94

Exadaktylu, A. 62

Exadaktylu, E. 255

Faber, R. 43

Fahd, Th. 332, 4I 4, 48 I

Faltaits, K. 96

Faltaits, M. I I 3

Fančev, F. I49, I 93

Fanurakis, E. 398

Faragó, J. I 48, 2 I 6, 48 I

Faraklas, D. I 77

Farca, V.I. I 38

Farmakidis, X. P. 72, 202, 349

Farmakis, A. 390

Fasulakis, S. 2 I 4

Fehrle, E. 4O, 46, 75, I 2 I , 284, 4I 2, 48 I

Felicetti-Liebenfels, W. 3 I I

Ferenc, T. 2 I 6, 48 I

Ferenczi, I. 88, I 54, 48 I

Fermore, P. L. I60

Ferrari, I. 222

Fiedler, K. G. I 23

Filimon, I. 392

Filipović, M. S. 44f., 75, 95, 208, 305, 4I 3, 424, 482

Filipović-Fabijanić, R. 32 I, 482

Filippidu, E. 356, 395

Finnegan, R. 29, 274, 482

Firth, R. 33

Fischer, E. I I 5

Fischer, H. 272, 360, 37 I

Fischer-Lichte, E. I 5-I 7, 27, 25 I, 433, 482

Fischer-Wellenborn, G. I 90 
Flegont, O. 69, 8I, I 7 I , I9I I, 225, 482

Fligier, C. I 22, 482

Florakis, A.E. 33of., 357, 377f., 482

Florenskij, P. 37 I, 482

Floros, C. 3 I 2

Fochi, A. $45^{8}$

Focșa, G. I3 8 , I 5 I, 482

Fögen, M.T. 323

Fol, V. I 42, 363, 462, 5 I I

Földes, L. I03, I 48, 2 I 6

Foley,J.M. 28, 274, 322, 464, 482

Forbes, T. R. 326

Foretić, V. I 40, 482

Formozis, P. E. 74, 34I, 378f., 4I 8, 48 I

Forrest, J. 262

Fortis, A. $386 f$.

Foscarini, G. 266

Foskolou, V. 437

Fostiropulos, A. I $72 \mathrm{f}$.

Foteas, P. 97

Fotiadis, A. 235, 240-244, 482

Fotiadis, K. 305

Fotiadis, Th. 259

Fragulis, D. II 3

Frangaki, E. K. $279 f ., 482$

Frankfurter, D. 324

Franz, A. 378

Franziszi, F. I 88

Frazer, J. G. I64

Fredrich, C. I 3

Freeman-Grenville, G. S. P. 327

Frenschkowski, M. 375

Fridrichsen, A. 3 I 7

Friede, S. I05

Friedl, E. 20, 385, 482

Friedländer, I. 360,482

Friesen, W. F. 33

Frings, Th. 207

Fritsch, J. 32

Frixu, V. 255

Frudić, N. 69

Fuchs, F. 332

Fuchs, R. 8I

Fundescu, I. C. 226

Furikis, P. A. 39I
Furlas, D. V. 60

Fürst, K. E. I 87, r 89

Fytrakis, A.I. $38 \mathrm{I}$

Gabrielides, N. 200, 367

Gaćnik, A. 105, 483

Gadamer, H.-G.

Galanis, V. 25 I

Galatariotou, C. 423,483

Gălușcă,T. 82, 89, 483

Ganosis, V. 258

Ganschinietz, R. $329 f$.

Garnett, L. M.J. 429, 483

Garrucci, R. 309

Gašparíkova, V. 333

Gaster,M. 224, 234

Gaster, Th. 308

Gaussot, M. 367, 370

Gavazzi, M. 69, 76, 386f., 462,483

Gearing, F. I06, I 29

Gedeon, M.I. 345, 39I

Gefu-Madianu, G. 3 I 6

Geider,Th. 4I5

Geier, M. 32 I

Geiger, P. I 88, 284

Geitler,L. 426

Gelenčir, N. 32 I, 483

Gell, A. 303

Genčev, St. 76, I I 5

Gennadios, P. G. 279

Georgakas, D. I. I62, 483

George,J.M. 305

Georges, R. 440

Georgevici, T. 94, 326, 483

Georgiev, G. 424, 5 I 4

Georgieva, I. 382, 4I 3, 425, 466, 483

Georgopapadakos, A. M. 397, 483

Georgoudi, S. 363, 483

Georgulas, S. G. I 53

Geramb, V.von 83, I87

Gerçek, S. N. 197, 231, 483

Gerholm,T. 29

Germidis, A. I 25, I 28

Gerndt, H. 83, 259, 306, 457, 483

Gerov, N. 426 
Gherman, T. 64, I 5 I

Ghinoiu, I. 462

Giankullis, G. K. 255, 483

Giannobile, S. 324, 437

Giannopulu, K. 256

Giannutsos, K. 75

Gidel, Ch. 327

Giese, W. 32 I

Gifford, E. S. 436

Ginčev, C. II 5

Giochalas, T. 45, 4I3, 484

Gîtză, L. 2 I6, 224, 234, 484

Giurchescu, A. 31, I5 I

Giurescu, A. I 5 I

Gizelis, G. 282, 3 I 7, 368

Gjorgjevic, T. R. 75

Gjurova, S. 355, 467, 484

Gjuzelev, V. ${ }_{36} 6_{3}, 5$ I 8

Glaser,J. I 93

Glück, L. 32 I

Glykys, M. 36I

Glykys, N. $36 \mathrm{I}$

Goar,J. 74, 387, 389, 393, 484

Goetz, L. K. 383, 484

Goffman, E. 253

Gojković, A. 32 I, 425

Gokalp, A. 232

Goldstein, K. S. 27, 472

Goldziher, I. 31 7, 36 I

Golescu, I. 225 f.

Göney, S. 201

Goody,J. 20, 304

Goossens, R. 426

Gospoja, M. 313, 484

Goulimaris, D. 258

Grabar, A. 35 I

Graber, G. 81, 89, I87f.

Grabner, E. 27of., 276, 322, 465, 494

Gracijan, S. 240

Graf, F. 323

Gragger, R. I48, 216, 224, 484

Gramlich, R. 36I, 484

Grammatas, Th. 63, I5o

Grammatikoglu, E. I68f.

Grammatikos, L. 389
Gravel, P. B. 436

Grbić, S. 44,48

Greenfield, R.P.H. 323, 4I 4, 437, 484

Grégoire, H. 372, 436

Gregoras, N. 389

Grgjić-Bjielokosić, L. 34I, 484

Grigoriadis, G. I73

Grišina, M. G. $33 \mathrm{I}$

Grober-Glück, G. 333

Grosdidier de Matons, J. 3 I I

Gruber, S. I9, 499

Grunebaum, G. E.v. 332, 48 I

Gubbins, J. K. 439

Guidorizzi, G. 332

Guil, A. I3 I

Guilland, R. 389

Gulaki-Vutira, A. 32

Gunda, B. 280

Gundel, H. G. 4I 2

Gundel, W. 329, 335, 484

Guo, L. 23 I

Gurevich,A. 229

Gušić, B. 93, 484

Gusios, A. 9I

Guys, P.A.de 345, 392

Györffy, I. I 5 I

Haage, B. D. 438

Haberland, K. 330

Hadamowsky, F. 229

Haddad, H. S. 360

Hadjijoannou, K. P. 370

Hadjimihali, A. 368

Hadjipantazis, Th. 23I

Hadjitaki-Kapsomenou, Chr. 365, 484

Hadžiosmanović, L. 235

Hagioi Saranta 363

Hagioi Theodoroi 373

Hahn, J. G. von 40, 45, 59, 61, 4I 9, 424f., 484

Haiding, K. 34, 484

Hain, R. K. 52

Hajtov, N. A. I 22, 484

Halaçoğlu, Y. I 22

Håland, E.J. 79, I96, 484

Halimi, K. I4I 
Hall, A. 4I I

Hall, E. 67,407

Hall, F. 3 I

Halliday, W. R. 329, 485

Hamilton, M. 362

Hammer, J. 233

Hammer-Purgstall, J. F.v. 3I $8,438,467,485$

Hampe, R. 90

Hampp, I. 275, 284, 32 I

Hand,W.D. 317, 326

Handelman, D. 355

Handleman, H. 65

Handman, C. 254

Handman, M. L. 203

Handman-Xifaras, M.-E. 207, 439, 485, 489

Hangi, A. 438,485

Hardie, M. M. 439, 485

Harms, V. 252, 485

Harris, P. 254, 308

Harrison, J. 308

Hartlaub, G. F. 302

Hartmann, A. I 89

Hartnup, K. 42 I, 485

Hartocollis, P. 284

Hașdeu, B. P. 226

Hasluck, F. W. I 23, 347, 360f., 380, 439, 485

Hasluck, M. M. 48, г 26

Hastrup, K. 284

Hatzakis, M. 250

Hatzifotis, I. M. $358,467,485$

Hatzigakis, A. K. 260

Hatzigeorgiu, G. 345

Hatzigioannou, K. 255

Hatziiosif, Chr. 72

Hatzipantazis, Th. 235, 24I, 243 f, 485

Hatzitaki-Kapsomenu, Chr. 22, 279

Hatzopulos, G. H. 82

Hatzopulos, G. K. $28 \mathrm{I}$

Hatzopulos, K. K. 305, 485

Hatzopulos, K. N. 126

Haubrichs, W. 247

Hauffen, A. I 88

Haug, W. 365

Haukanes, H. 327

Haumović, S. 106, 506
Haunoldt, N. 233

Hauschild, Th. 436, 44I, 485

Hausmann, L. 3 I 7, 485

Hausmann, U. 378

Haussig, H.W. 4I 3, 465, 496, 5 I 2

Heald, S. 33 I

Hegyesi, A. 75

Heidemann, I. 25 I

Hl. Aberkios 362

H1. Aikaterina 362

H1. Anargyroi 362

H1. Andreas 132,362

H1. Anton 48

H1. Antonios 362

H1. Artemios 362

H1. Athanasios 338, 362,382, 394

H1. Augustin 364

H1. Barbara 127,362

H1. Bartholomäos 337,362, 394

H1. Basileios 4I, 48, 59f., IO I, 362, $40 \mathrm{I}$

H1. Blasius 128

H1. Chadir 360

H1. Charalampos I $28,362,382$

H1. Christophoros I3 I, 364, 4I I

H1. Chrysostomos 70, 40I, 4 IO

H1. Demetrios 42, I 24, 260, 338, 353, 362f., 382 , 394

H1. Domna 362

H1. Domnike 4I, 49

H1. Donatus 373

Hl. Drei Könige 4If., I 32

H1. Eleni 337,365

H1. Eleutherios $349,362,364$

H1. Elissaios 362

H1. Euphemia 362

H1. Eustratios 346

H1. Euthemios 362

H1. Familie 44

H1. Fanurios 349

H1. Georg 4I, 5 2f., 92, I 23, I3 of., I 40, 244, 247 , $258,260,268,338,360,362 \mathrm{f} ., 369,373,380$,

394, 4 I I

H1. Gerasimos 357

H1. Germanos I I 6

H1. Ignatios 362 
H1. Irene 377

H1. Johannes 42, 53, I 24, I 3 I, 307, 344, 362 , 373f., 394, 396, 40 I

H1. Johannes der Täufer 50, 56

H1. Johannes Prodromos 343, 362, 369, 380

H1. Johannes Theologos 343, 382

H1. Johannes von Damaskus 350

H1. Julianos der Libyer 402

H1. Konstantinos 382

Hl. Kyriake 362

Hl. Mamas 36o-362

H1. Marina I 3 I, $362 \mathrm{f}$.

Hl. Markos $362 f$.

Hl. Maura 362

Hl. Menas 362

H1. Minas I 32

H1. Modestos I 28

H1. Nektarios 429

H1. Nikolaos 42, I 27, 362, 373f., 380, 382, 394

H1. Panteleimon 362

H1. Paraskeue 362

H1. Paraskevi I 3 I, 343, 346, 363, 368, 370, 376

H1. Paulus 362, 38I, 394

H1. Petrus 362

H1. Phanurios 362

H1. Philippos 362,394

Hl. Platon 362

Hl. Reginos 373

Hl. Sabbas 362

H1. Seraphim 363

Hl. Spyridon I 27, 357, 360, 362, 369

H1. Stefan 48

H1. Stylianos 362, 364

H1. Symeon I $28,360,362$

H1. Theodor(e) 4I, I39, 26of., 373f., 394, 429f.

H1. Theodor(os) Stratelates 372

H1. Theodor(os) Teron 343, 372, 374

H1. Thomas 4I, I 38, $258,364,369$

H1. Tryphon I 28, 336, 362f., 382, 402

H1. Vlasios I 28, 338, 369

Heinzel, M. I 89

Helbrecht, I. 27

Helebrant, T. 20, 458, 5 I 3

Heliodor 83

Hengstenberg, W. 372
Heraklit 252

Hermes 3 Io

Hellmuth, L. 385

Herberstein, A. F. v. 235

Herrman, J. 4I, 485

Herter, H. 4I 2, 485

Herzfeld, M. 52, 208, 276, 397, 399, 439, 486

Herzog, R. 378

Hesseling, D. C. 466, 486

Hidiroglu, P. 305

Hierse, W. 248

Himstedt-Vaid, P. 4I 3, 4I6, 439, 464

Hinrichs, U. 4I 3, 439, 464

Hippokrates 276

Hirschon, R. 20, 356, 358, 486

Hitler, A. I92, 249

Hlavats, E.v. 148

Hmjelnizkij, B. 236

Hobhouse, J. C. 240

Hoenerbach, W. 243

Hoerburger, F. 3 If.

Höfler, M. 47

Hofmann, J. 25 I

Holden, R. 3 I

Holden, Th. 226

Honko, L. 272

Honour, H. 2 I 4,476

Hont, F. 68, 46 I

Hopf, L. 329

Hopfner, Th. 284, 323, 329, 33 If., 4I 2, 486

Hoppál, M. 27 I, 486

Horak, K. I 90, 489

Horger, A. I 50

Horn, K. 254

Horovitz, J. 230

Hörsperger, A. 438

Horton, R. 274

Hosia Eusebia 373

Hosios David 353

Hosios Lukas 362

Hosios Theodosios 389

Hovorka, O.v. 270, 32 I, 4I 7, 486

Hsu, F. L. K. $33 \mathrm{I}$

Hubert, H. 375

Hughes-Freeland, F. 28 
Hühnerkopf, R. 329

Huizinga, J. 25 I, 486

Hummer, H. 457

Hunger, H. $33 \mathrm{I}$

Hunger, J. 330

Hunt, E. D. 355

Hurlbutt, R. $35^{8,486}$

Hürlimann, M. 229

Huther, H. $3 \mathrm{I} 3$

Huziak, V. 70, 486

Hymes, D. 27

Ideler, J. L. 334

Ieronymidis, M. 250, 486

Ilić, M. 88, 486

Ilić, Z. 235

Ilić, Ž. 69

Ilieva, A. 95

Ilijin, M. I06, 486

Il'inskij, G. 424, 486

Iljinskij, G. 426

Iliudi, G. N. 282

Imellos, St. 45, 84, I 28 , I 3 If., I 77, $276 f, 279,28$ I, 3 I 9, 32 I, 337, 342, 344f., 392, 486

Impellizzeri, S. 437

Ingold, T. 28

Ioannidis, A. 374

Ioannou, P. P. 4I 4 4 466, 486

Ioannu, G. 250, 486

Ioannu, Th. 389

Ionas, I. 202, 487

Iorga, N. 236

Iriotis, P. N. I I 7, 487

Irmscher, J. 229 f., 245, 479, 487

Isler, H. 4I 2

Israel, S. 32 I

Ivančan, I. 272, 487

Ivănescu, G. I I 5, 487

Ivanov, J. 31 5, 426

Ivanova, J. 76, 487

Ivanova, R. I 57, 204, 207, 42 I, 425

Ivanović, M. 106

Jaberg, K. 273

Jäckh, E. 387
Jacob, G. 229, 23I, 235, 239, 487

Jakobson, R. 34, 209

Jaković, L. 94

Jakovljević, V. 94

James, A. 254

Jancsó, B. 75

Janeva, St. 46, I 5 I 487

Jankó,J. 75

Janković, D. S. 3 I , 8 I, 93, I 4 I

Janković, L. S. 3 I , 8 I, 93, I 42

Jardas, I. 89

Jensen, A. E. $25 \mathrm{I}$

Jensen, H. 229, 250, 487

Jenssen, Ch. I 89

Jevtić, B. 235, 240

Joachim III., Patriarch 398

Joas, H. 66

Johannes I 45

Johnson, C. 254

Jolles, A. 274, 487

Jonas 301, 449

Jones, L. C. 440

Jordanova, L. 98, I I gf., 487

Jorgensen, D. 304

Joseph der Philosoph 389

Josserand, C. H. 4I 4

Jovanović, B. I 57

Judge, R. 70

Jung, K. 333, 487

Jurkowski, H. 22 I

Justinian, Kaiser $388 f$.

Kabasakalis, D. I. 256

Kacarov, G. I63

Kacarova, R. 21 7, 221, 487

Kacarova-Kukudova, R. I 70, 2 I 7, 488

Kaftantzoglu, I. 304

Kahane, M. I36

Kahl, Th. I 20, I 22, 29I, 295, 300, 3 Io, 4I 3, 437$442,464,488,525$ f.

Kahle, P. 22 ff.,

Kaivola-Bregenhoj, A. 33 I

Kaïmis, Tz. 245, 249

Kakampura-Tili, R. 366

Kaklamanis, St. 265 
Kakridis, I. Th. 256

Kakulidi, E. D. 276

Kakuri, K. 65, 69, 73, 77, I08, I I6f., I 20, I 25 , I3 I, I $53-\mathrm{I} 55, \mathrm{I} 67, \mathrm{I} 7 \mathrm{I}-\mathrm{I} 73, \mathrm{I} 78,238,488$

Kalaitzakis, G.I. 334

Kalavrezou-Maxeiner, I. 3 I I , 352

Kaleshi, H. 360, 488

Kalfantis, V. I6 If., 238,488

Kalfas, V. 273

Kallianotu, N. 444

Kallistos, Patriarch 402

Kalofonos, G. Th. 332

Kalogiras, A. I6 I

Kalokardu, E. I 25, 259, 276, 488

Kalokyris, K. 342

Kalojan, Zar I 16

Kalonaros, P. P. 235, 244, 246, 488

Kämpfer, F. 368, 488

Kandilaptis, G. I 72

Kandiloros, T. 392

Kanellakis, K. N. I77

Kanellon-Thanasoulas, A. I 24

Kaneff, D. 327

Kanitz, F.Ph. 220, 235, 239

Kapadochos, D. Chr. 226

Kapnisis, V. 266

Kapodistrias, I. 39I

Kapsakis, G. 43I

Karaberopulos, D. $257 \mathrm{f}$.

Karadžić, V. 75, 93, 419, 462, 488

Karakasis, S. I68f., I7 I

Karakatsani, D. 256

Karalis, G. D. 332

Karanastasis, T. A. 37

Karanatsis, K. 36I

Karanov, E. 421, 488

Karapatakis, K. 48, 60, 84, 89, 99f., го4, I 23, I 73, 259, 376, 488

Kararas, N. 347

Karas, G. 327, 334

Karasek, A. 190, $488 \mathrm{f}$.

Karasek-Langer, A. I 90, 2 I 6

Karatov, S. F. 33 I

Karavelov, I. 75, 489

Kardamitsis, I. N. 379
Kardos, T. 46I

Karlinger, F. I 3, 430

Karo, G. 378

Karolidis, P. 372, 374

Karpodini-Dimitriadi, E. 302

Karpozilos, A. 372, 374

Karzai-Kurzweil, G. I 89, 48 I

Kasapian, Tz. 305, 485

Kaser, K. I gf., 489

Kassis, K. 250

Katičić, R. 42 I, 489

Katsaros, V. 50

Katsarova, R. 3I

Katsiardi-Hering, O. 390, 489

Katzarova, R. 88, 489

Kaufman, K. I I 5 f., 489

Kavasilas, Sp. 444

Kazantzakis, N. 387, 390, 397, 399

Kazarow, G. I08, I64, 489

Kazazis, I. N. 37

Kedrenos, G. 389

Kefalliniadis, N.A. 349,489

Keil, G. 320

Keiter, E. 86

Kekaumenos 389

Kekez,J. 69

Kemp, Ph. M., 32 2, 464, 489

Kenna, M. I 45, 208, 367, 370, 378, 385, 439, 489

Kenner, H. 5 I

Kerényi, G. 254, 489

Kerényi, K. 86, 252

Kerewsky-Halpern, B. 274, 322, 464, 490

Kiakidis, Th. K. I I I , I 25, 490

Király, E. 107

Kirchner, Th. 56

Kirsch, F. 438

Kiss, L. 201

Kiss, M. 45

Kissling, H.J. I 22, 305, 490

Kitevski, M. 57, 42 I, 490

Kitzinger, E. $35 \mathrm{I}$

Kiurtsakis, G. 244, 490

Klein, H. I 89

Klein, V. 326, 490

Klepikova, G. P. 433, 490 
Kličkova, V. 44, 52, 490

Klier, K. M. 86, I 56, 490

Kligman, G. 53, 94, I 5 I, 26 I, 43 I, 490

Knapp, E. 355, 5 I 9

Knecht, S. 439, 490

Knežević, M. V. 200, 490

Knoblauch, H. 318,330

Koblar, F. 57

Koçer, G. 232

Koceva,J. 424

Kocsis, K. 304, 490

Koenig, O. 434

Köhlbach, M. 420

Kohler, J. 385

Kokkas, I. 223

Kokkinis, Sp. 235

Kokkotos, D. 439

Kolar, W.W. 3 I , I 42, 494

Kolaxizelis, St. P. I 45

Köldu, L. I48, 2 I 6, 224, 464, 49 I

Kolesch, D. I6

Kolev, N. I. 259, 426, 49 I

Kolev, R. 76, 49 I

Koleva, T. A. 70, 1 70, 247, 382, 49 I

Kolinović, M. F. 32 I , 465, 49 I

Kollárov, M.I. 75

Kolokotronis, Th. 390

Komorovský,J. 204, 208, 49I

König, R. 65

Konitsiotis, Chr. 2 I 7, 222, 228

Konomos, D. I07, I 54, I6 I, I96, 49 I

Konstas, K. S. I 96, 260, 327

Konstantinidis, D. 359

Konstantinidis, G. K. 125

Konstantinidis, M. I I 3

Konstantinov, N. I70

Kontomichis, P. 280

Köppen, W. I 89

Köpping, K. P. 365

Köpstein, H. 4I

Korais, A. 36, 392

Korakas, M. 399

Koren, H. I 88

Korff, G. 3 I 3, 49 I

Korre, K. G. 390
Koryllos, Ch. P. 333, 49 I

Kornaros, A. 264

Kornaros, V. 269

Korniss, P. 104, I 33f., 29of., 49I

Koromilas, D. 195

Korres, K. G. 44I, 49I

Kortesios, S. 444

Koșay, H.Z. 173

Koschier, F. 188

Košelev, J. 33 I

Košir, P. 270, 423, 49 I

Kosmas 394

Kosswig, L. 92, 49I

Kostakis, Th. 257, 260, 325, 330f., 334f., 4I 8, 442, 49I

Kostić, L. 254, $49 \mathrm{I}$

Kostić, P. 5O, 95, IO4, I4I, 492

Kostić, S. 3 I 7

Kostov, St. L. I I 5, I63, 492

Kotopulis, G. K. 245, 492

Kotsakis, D. 327

Kotsi, E. 95

Kotte, A. 28, 252

Kötting, B. 353, 373, 378, 492

Koukopoulos, D. 344

Kovač, S. I06, 492

Kovačev, Chr. P. I63

Kovačević, I. 65, 76, I 42, 492

Kovács, J. 73, I I 4

Kowatscheff, J. D. 335, 492

Koz, M. S. 232

Kozarac, V. I4I

Košir, M. 270, 423, 49I

Kraev, G. 49, 65, 97, IO4f., I 2 I I 5 I , I 70, 462 , 492

Kraniotakis, E. 398

Krauss, F. S. 94, 322, 34I, 408, 4I 3, 4I 5, 4I 9, 466, 492

Kravartogiannis, D. 370

Kreinath,J. 29

Kreissl, E. 302, 492

Krekukias, D. A. 276, 278, 280, 283 f., 323, 333, 442f., $492 f$.

Kremenliev, B. A. 32

Kresz, M. 254

Kretschmer, R. 4 IO 
Kretzenbacher, L. I 3, 3 I , 46, 49, 75, 8of., 83, 89, I I6, I 22, I 35, I4 I, I 87f., 247, 259, 26 I , 263 , 268, 280, 29 I, 305, 3 I I , 3 I 6, 34 I, 350, 352, 357 , 363, 366, 38 I , 385-387, 389f., 393, 4 I I , 43 of., $457,460,464,467,490,493,525$

Kriaris, P. 398

Krikos-Davis, K. 4I6, 493

Kriss, R. I 3 I , 305, 3 I 8, 35 6f., 36of., 368, 380, 4 I 4, 438, 44I, 467, 493f.

Kriss-Heinrich, H. I 3 I, 3 I 8, 356f., 36of., 380, 4I 4, 438, 44I, 467, 494

Kriss-Rettenbeck, L. 33, 3 I 7, 35 2, 378, 485

Kristić, A. 32 I, 465, 494

Kritikos, P. G. 280

Kronfeld, A. 270

Kropp, A. M. 33 I

Krstić, B. 425, 494

Krstić, D. I 57

Krumbacher, K. I I6, 247, 372f., $388 f$.

Krystallis, K. 84, 108

Ktenidis, D. 61, 83

Küchenhoff, J. 365

Kuder, U. 320

Kudien, Fr. $28 \mathrm{I}$

Kudret, C. I 97, I 99, 232, 494

Kufis, P. 47

Kuhar, B. I 42, 494

Kuki, E. 273

Kukules, F. $35,83,85,87$, I 28 , I 30, 256 f., 263 , 272, 278,28 I, 322f., 325, 33 I, 338f, 374, 4I O, $429,437,464,494$

Kuleris, A. B. 97

Kulikowski, M. 4I 3, 424, 465, 494

Kulišić, Š. 424, 465, 494

Kuližić, Z. I I 6

Kumbatovič, K. I 89

Kumer, Z. I 3

Kumunduros, N. 357

Kunguli, K. 256, 495

Kunitzsch, P. 335

Kúnos, I. I 97, I 99, 23 I, 495

Kunze, K. 362

Küppers, G. A. 46, 94, 495

Küppers-Sonnenberg, G. A. I 24, 32 5, 495

Kuret, N. 40, 48, 5 I, 65, 8of., 83, 90, 94, 96, roo,
I09, I 2 I, I 40f., I 49, I 87-I 89, I 93, 2 I 6, 2 I 8, 220, 26 I, 427, 46 I, 495

Kuria, A. 256, 495

Kurilas, E. I 3 I, 496

Kurspahić, N. 235, 240

Kurtesis, S. 444-446

Kurth, W. 33 I

Kurtidis, K. G. 125

Kurzweil, G. I 89, 48 I

Kusios, M. 75

Kutelakis, Ch. 377

Kutsuradi, P. 48

Kutuzov, Gen. 2 I 5

Kuzas, G. Ch. 365

Kuzmanova, V. 94, 496

Kyparissis, V. 74

Kyprianos, Chr. 444

Kyriadzis, St. 72

Kyriakidis, St. P. 62, I 28, 203f., 272, 275, 282, 3 I 5 , $323,335-337,377,388,439,496$

Kyriakidu-Nestoros, A. 22, 47f., 54, 3 I 6, 340, 344, 496

Kyriazis, N. G. $275,280,428,444$

Kyros 394

Kyrris, K. 4I, 255, 496

Kyrtatas, D. I. 273,332

Labridis, I. 75

Ladas, St. $\quad$ 22

Ladner, G. 35 I

Lagarde, P. de 372, 374f.

Lagopulos, A.-F. 54, 56, I 28, 3 I 6, 344, 405, 496

Laiou-Thomadakis, A. 362

Lájos, Á. I 33, 496

Lakidis, Th. 164

Lambek, M. 65, I 26

Lambertz, M. 387, 4I 5, 419, 424, 465, 496

Lambropoulos, V. 26 I, 4IO, 425, 5 I 7

Lampros, Sp. 282, 4I 7

Lampsidis, O. I 73, 330

Landau, J. M. 230

Lange, H. I 87

Lantzos, V. 63, 97, 496

Lanz, J. I90

Laparidis, N. 206 
Lappas, T. 28 I, 39of., 394

Lauer, R. 32, 240

Laurent, V. 3 I 7

Laušević, M. 32

Laver,J. 66

Lawson, J. C. 35, 85, I I3, 4 I 9 f. 496

Lazakis, P. 205, 496

Lazar, V. 43I, 496

Lazaridis, D. 206

Lazaridis, K. P. 2566 .

Lazarus I 7, 58, 60-64, 70-72, 92, 94f., I I If., I I 4 , I I 8-I 20, I 29, I 35, I 44, I 88f., I 92, 308-3 I I, 353 f., $364,375,45$ o, 5 I 0,542

Lechner, M. L. 442

Lechner, Z. I04, 496

Leclercq, H. 378

Lee, D. 4I 8

Lee, S. G. M. 3 I I

Leeuw, G. van der 375, 496

Leger, L. 4I 3

Legrand, É. 282, 327

Lehmann, H. 300

Leibman, R. H. 3 I

Leland, C. G. 3 I 3

Leonidas, I. IoI, I48,

Lesk, M. I 24

Lesky, A. 35, 496

Lettenbauer, W. 322, 342, 466, 496

Leventis, P. 428

Lewis, B. 305

Lewy, H. 4I 2

Liaskopulos, D. 223

Liek, E. 270

Lienau, C. I 22,300, 488

Lienhardt, G. 65, I 26

Lieshout, R. G. A. van 332

Lilek, E. 368, 496

Lillis, G. I 2

Limberis, V. 437

Lingenthal, Z.v. 388

Linse, U. 30I

Lipp, W. 365

Lisac, J. 194

Lisician, S. 80, 82

Litsas, F. K. 207, 43 If., 497
Littmann, E. 229

Liungman, W. 85, 108, 167, 238, 460, 497

Lixfeld, H. 305

Ljubenov, P. 426, 466, 497

Lockwood, W. G. 204, 497

Lodge, O. C. I24, 497

Loenertz, R.W. 353

Lohse, H. 373

Longinus, C. 324

Lonza, N. 2 Io

Loos, M. 305

Lord, A. B. 274

Lorenzetti, R. 262

Lorinț, F. 90, 497

Lossky, W. 35 I, 504

Loucatos, D. S. 207

Loukatos, D. 207, 338, 371, 497

Loutzaki, I. 3 I

Loutzaki, R. I 24, 497

Lovretić,J. 93

Lovrić, I. 386

Ložar-Podlogar,H. 204, 497

Lozica, I. 54, 64f., 69, 8 I, I04, Io6f., I 2 I, I 33 , I 40-I 42, I 94, 2 I 6, 220, 462, 497

Lübeck, K. L. 423, 465, 497

Luciani, C. $262,265,498$

Lucić, H. 194

Lucius, E. 378

Luckmann, Th. I 8 f., 252

Lukatos, D. S. I 3,63 , I 23 - I 29, I 3 If., I 45, I 7 I, 203, 207, 25 5, 260, 272, 278, 3 I 8, 320, 330, $334-337,362,364,369,43$ I, 440, 443, 463, 498

Lukes, H. Ch. 353

Lukopulos, D. 62, 75, 99, 104, 256, 325, 345, 355, $363,376,429,464,498$

Lundt, B. 426

Lunzi, E. $265^{-267}$

Lupu, V. 236

Luschan, F. v. $23 \mathrm{I}$

Lusignan, E. de 264

Lutzaki, R. 206f., 498

Lyberis, N.I. 177,325

Lydaki, A. I 45

Lykiardopoulos, A. 435

Lykuris, Ch. V. I I 7 
Lyras, D. 361, 369

Machairas, L. 264

Machin, B. 70

MacCormick, J. 22 I, 463, 498

McLean, C. 322

Magriotis, I. 343

Maguire, H. 323, 437, 467, 498

Maguliotis, A. 21 7, 222f., 228, 498

Mahfouz, S. 230

Mailand, O. 32 I, 498

Majer, H. G. 438,5 I 3

Majzner, M. 94, 498

Makedonski, D. I63

Makris, Chr. I 28, 498

Makris, K. N. 257

Makrygiannis, G. 307

Makrymichalis, St. I. I I 7

Makryniotis, D. 256

Malaby, Th. 253

Malaxos, M. 389, 39 I

Maldogiannis, Th. 333

Malliaras, N. 32

Maloney, C. 436, 439

Maltese, E. V. 243, 4I 4

Maltzew, A. 3I 2

Maluckov, M. 78, 88, I 4I , 498

Mammopulos, A. Ch. I I 2, 396, 498

Manakas, D. 6I, I $7 \mathrm{I}$

Mandalà, M. 380, 500

Mándoki, L. I03, 498

Mandžarov, P. 422, 498

Manga,J. 73, I I 4, 46I, 499

Mangiuca, S. I 35

Mango,J. 200, 499

Mannhardt, W. 45, 86, 284

Manninen, I. 273

Mansel, A. M. I 22, 499

Manta, K. G. 347

Mantzuneas, E. K. 393f., 400

Manusakas, M.I. I 80, 262

Mār Ğirğis 360

Marakis, B. I 24

Marava-Hatzinikolau, A. 36I

Marazov, I. 425, 499
Marcu, L. 234, 238

Maretić, T. 386

Maria Muttergottes 343

Marian, S. F. I 35f., 208, 2I 5, 260, 499

Maridakis, D. 223

Marinatos, Sp. I 30

Marinescu, M. 36If., 5 I 5

Marinis, K. I05

Marinov, D. 44, 5O, I I 5, I 63, 4I 9f., 42 2, 426, 462 , 499

Marinov, V. 333, 499

Marjanović, V. 65, 77f., 90, 93, 95f., 105-107, 109, I 4 If., I 49, I 57, 254, 289, 462, 464, 499, 525

Marko Kraljević i ıо

Markov, L. V. I I 5, 499

Marrou, H. 50

Martin, G. $3 \mathrm{I}$

Martinovitch, N. N. I97, 23 I

Martischnig, M. 322, 499

Marušić, L. 57

Marwick, M. 437

Masinski, K. I I 5

Massignon, L. 332

Matantséva,T. 437, 499

Mathiopulu-Tornaritu, E. 265

Matić,T. 209, 499

Matić-Bešković, M. 2I6, 499

Matl,J. 34I, 499

Mauerhofer, A. 32, 80, 88, 489

Mauksch, H.J. 32

Maurer, L.v. 392, 499

Mauropus, Joh. 372-374

Mauss, M. 33, 3 I3, 375

Mautner, K. I 88

Mavraganis, G. 444

Mavrakakis, G. I. 444

Mavrides, O. 276, 465, 499

Mavrochalyvidis, G.P. $36 \mathrm{I}$

Mavroeidis, Th. 60

Mavromichalis 240

Mavromustakos, P. 22 I

Mavropulu, A. 258

Mavroudi, M. 332, 499

May, K. 20

Mayes, A. R. 33 I 
Meersseman, G. G. 352

Megas, G. A. 40, 45, 48f., 56, 62-64, 72-76, 82, 84, 90, 96f., I05, I08-I Iо, I I 7, I 2 I, I 28, I 3 I, I 44, I 54, I6 I , I65, I67, I 7 I , I 73, 255, 258 , $272 f ., 278,283-285,315,318-320,322,328-$ 330, 334-338, 340, 344, 346, 349f., 362, 364 , $383,404,428 f$ f., 432, 440, 442f., 463,499

Meibohm, A. D. $4 \mathrm{I} 4$

Meinardus, O. 362, 381, 500

Meinecke, M. I97

Meisen, K. 438

Meițoiu, I. 200, 500

Melanofrydis, P. I72, 282

Melas, Sp. 245

Melikis, G. 60, I 29, 500

Menardos, S. 4I 7

Menzel, Th. I97, 23I, 240, 500

Meraklis, M. G. I3, 22, 48, 97, I 27, I94, 200, 247, $254,329,377,4$ I $5,433,463,500$

Merianu-Vogasari, A. 444, 500

Mertzios, K. D. 264, 36I

Metalleidis, M. I73

Metastasio, P. 257

Metaxas, K. Ch. 73

Metaxotos, N. G. I05

Metken, S. 360

Meuli, K. 43, 427, 500

Meyer, C. 270

Meyer, E.H. 422

Meyer, G. 36

Meyer, M. 324

Meyer, Ph. 388

Michaelis, A. 29

Michail-Dede, M. 49f., 97, I 72, 346, 500

Michailidis-Nuaros, G. 385, 388f., 391, 500

Michailidis-Nuaros, M. 255, 33 I, 44I, 500

Michailova, G. I70, 500

Mihail, Z. 380, 500

Mihajlov, G. 426

Mihailović, S. I 57, 500

Michopulos, P. 250

Mijatović, St. M. 279, 422,465, 50 I

Miklosich, F. 428

Mikoniatis, I. G. 2 I 4

Mikov, L. 6I, 76, I70, $50 \mathrm{I}$
Milavonić, B. 32

Milčetić, I. IO4, I93, 5 O I

Miličević, F. 204. 5 OI

Milićević, M. I42

Miligu-Markantoni, M. I 29, I 32, 279, 342-344, $362 f$.

Mills, A. 279

Milojković-Djurić,J. 254, 475

Milosavljević, M. 96

Milošević-Đorđević, N. 425

Mimaros 244

Minas, K. I 28, 349, 5 o I

Mineemi, M. 229, 245, 487

Minotu, M. I95

Mirecki, P. 324

Misailidis, D. I I7

Mitova-Džonova, D. I 5 I, 5 OI

Mitrevski, G. G. I 24

Mladenov, M. I04

Mladenović, O. 31, 94, I06, 486, 5 O I

Mocenigo, G. $264 \mathrm{f}$.

Möderndorfer, V. 270, 465, 49I, 5 O I

Mogenet, J. 335

Mohammed 438

Möhler, G. 457

Moldoveanu-Nestor, E. I35, 5 O I

Molière 223, 228, 23 I, 444

Mollas, A. 248

Molnar, I. 74

Monbeck, M.E. 4IO

Monogios, E. I. 120

Montselese, T. I 94, 265

Moore, S. F. 29

Moravcsik, G. 386, 4I 4, 5 O I

Morfakidis, M. 245, 5 O I

Morgan, J. 27

Morley, P. 322, 464, 490

Moro, F. 89

Morosini, F. 266

Moroz,J. 426

Morris, D. 34 f.

Morvay, P. I 54

Moschidis, Th. 84

Moser, D.-R. 5 I, 5 O I

Moser, H. I 89 
Moser, O. 8I, 87, 4I I

Moser-Karagiannis, E. 90, 42 I , 466

Moser-Rath, E. 326, 329

Moser-Weithmann, B. 88, I 22, 305, 490

Moszyński, K. 4I 8, 5 OI

Moutsos, D. G. 36

Muduris, Ch. 382

Muljačić, Z. 239

Mullas, P. I96

Müller, A. I 30

Müller, G. 34

Müller, L. 430

Müller, R. 4I, 485

Müller-Bergström, W. 320

Müller-Sternberg, R. 4I 2

Müller-Wille, M. 376

Muraj, A. 76

Muratidis, E. L. 173

Muravjova, G. P. 33 I

Murrais-Veludios, Th. I 24

Murray, G. 308

Musaiu-Bugiuku, K. 279

Mușlea, I. I36, I 38

Musopulos, Th. I 24, 36 I

Mussolini 249

Mustafa, M. 42 I, 502

Mușu, Gh. 4I 3

Mutlia, M. I7 I, 259

Mutsopulos, N. 3 I 5, 342-344, 502

Mutsopulos, N. K. 31 5, 342-344, 502

Mutsos, A. 223

Muzakis, St. A. 4I 7, 502

Myerhoff, P. G. 29

Myers, J. 369

Mykytiuk, B. G. 430

Mylonakos, St. A. 105

Mylonopulos, Sp. I95

Myrsiades, K. M. 235

Myrsiades, L. 230, 235, 24 I, 244, 246f., 250, 502

Mystakidu, A. 229, 502

Nacovi, N.A. 387,502

Nădejda, L. 2 I 6, 234, 502

Nadoeanu, G. I 92

Nakratzas, G. 458
Nedeljković, D. 70

Nedeljković, M. 50, 93, I04, 462, 502

Negelein, J.v. 209, 330, 502

Nehring, K. 234, 236

Nersessian, S. der 309, 503

Nerval, G. de 233

Nestler, S. 22

Netolitzky, R. I 89

Nettesheim, H. C. A. v. 324

Neusner, I. 304

Newall, V. 340

Newson, E. 254

Newson, J. 254

Nicolaides, J. 36 I

Nicolaïdes, J. I 22, 476

Nicolau, I. 349,503

Nicoloff, A. 60

Niculiță-Voronca, E. I36

Niemčić, I. 96

Nikas, K. I 78

Nikitas, P. 48,364

Nikočević, L. I 40

Nikolakakis, G. 3 I 6, 338, 503

Nikolić, D. 69, 262, 503

Nikolić, V. 50

Nikolić-Stojančević, V. 95, I 57, 503

Nikolopulos, M. 345

Nilsson, M. I30

Ninck, M. 284

Nitsiakos, K. 400

Nitsiakos, V. 304, 365, 385, 400, 503

Nitsos, N. 52

Nixon, L. 316, 503

Noah 402

Nodilo, N. I42, 503

Nora, P. 366

Norris, H.T. 360,503

Novak, S. P. 70

Novaković, St. I 94

Novosel, S. 204, 503

Nugget, G. 268

Nutku, Ö. I 97, I 99, 503

Oakes, D. 3 I

Oberhelman, S. M. 332,503 
Obolensky, D. 305

Ohm, Th. 379

Ohnefalsch-Richter, M. 72, I I 9, 207, 503

Ohrt, F. 320

Oikonomides, N. 373

Oikonomidis, A. 278,503

Oikonomidis, D. I. I 72

Oikonomidis, D. V. 73f., 76, I I 6, I 27, I 3 I, 203, 208, 280j., 283, 328, 335, 343, 345, 363, 374, $382,4 \mathrm{II}, 503 \mathrm{f}$.

Oikonomopulos, Chr. Th. 323, 4I I, 504

Oikonomou-Agorastou, I. 282

Oikonomu, A. 48, 469

Oikonomu, I. 327, 334

Oikonomu, I. K. 74

Oikonomu, K. 282

Olejar,J. I4I

Ollanescu, D. C. 68, I91 , 21 5, 22 I, 224, 234, 239, 462, 504

Onasch, K. 31 2, 504

Oprișan, H. B. 85, I 20, I38, I 5 I I I 9 I-I 93, 2 I 5 f., 22 I, 224f., 234, 239, 462, 504

Orbán, B. 73

Orbini, M. 263

Ortug, M. 250, 504

Ortutay, G. 40, 6 I , 93, I I 7, I 33f., I 48f., 20of., $205,208,2 \mathrm{I} 6,257,260,3 \mathrm{I} 4,320,326,356,44 \mathrm{I}$, $458,46 \mathrm{I}, 47 \mathrm{I}, 504$

Ottitsch, R. I 87

Otto, G. 379

Otto, R. 306, 406

Otto, W.F. 284

Otto I. 2 I 2

Ouspensky, L. 35 I, 504

Öztürk, S. 233, 504

Păcală, V. I 39

Pack, R. A. 332

Paërl, H. 229

Païdusis, M. 202, 28I, 504

Palamas, K. 28I

Palikruševa, G. 70, 387

Pallas, D. I. 383

Pamfile, T. I 36, I 5 I, 463, 504

Panagiotakis, N.M. I 96, 264, 504
Panagiotunakis, P. I. 388

Panaretos, A. I 96, 333f., 342

Pangalos, G. E. 444

Pankova, V.J. 46

Panopulos, P. 95, 366, 5 I 5

Pantelić, N. I I6, I 57, 504

Papacharalampous, G. Ch. 428, 504

Papacharalampus, G. Ch. I06, 33 I

Papachatzopulos, A. D. 99, I01, I47, 505

Papachristodulu, P. I 7 I , 280, 283, 505

Papachristoforu, M. 424

Papachristos, K. A. 33I

Papacostea-Danielopolu, C. 362

Papadaki, A. 264, 505

Papadakis, E. 377

Papadakis, N. 380

Papademetriou, J.-Th. 230

Papadia-Lala, A. I44

Papadimitriu-Politsaki, S. I 25

Papadopoli, Z. 108

Papadopulos, A. 203, 330

Papadopulos (Kerameus), A. 4I 7

Papadopulos, A. A. I72, 330

Papadopulos, D. K. I I 7 , I 72

Papadopulos, I. 335

Papadopulos, N. V. 127

Papadopulos, P. 505

Papadopulos, S. P. 203

Papadopulos, Th. I 25

Papafentidu, A. 100

Papafilu, Th. 39I

Papageorgiu, A. I 3

Papageorgiu, N. 296, 31 7, 377, 379f., 526

Papageorgiu, S.Z. 391

Papageorgopulu, Z. 382

Papagiannakis, St. 333

Papagiannidu, K. 205, 505

Papagiotopulu, V. 505

Papagrigorakis, I. 370

Papahagi, P. I 35, I 5 I , 234, 238, 505

Papahagi, T. 439

Papaioannidis, I. 96, 505

Papaioannu, G. G. 75

Papaïoannu, K. D. I 25

Papakonstantinu, Th. 97 
Papakostas, A. N. 307

Papakostas, N. Ch. 196

Papakyparissis, A. 209

Papamichael, A. 202, 280, 505

Papamichael-Koutroubas, A. 382, 505

Papamichail, A. I30, 279, 3 I 7

Papamichail, E. G. $336,390,505$

Papamichail-Kutruba, A. 39I, 395

Papanaum, D. N. 60

Papanikolau, F. 39I

Papanis, P.E. I 45

Papanutsopulu, K. 50

Papapanagiotu, G. 85

Paparussopulu, A.P. 48

Papas, W. 34

Paraskevopoulou, M. 48, I32, 255, 382, 506

Papastergiu, A. 57

Papastratu, D. 349, 505

Papataxiarchis, E. 203, 366, 505

Papathanasi-Musiopulu, K. I 23f., г 26, г 28-г 32, I 72, 202, 259, 277f., 280,329 , 333f., 337f., 346, 36r, 369, 443f., 505 f.

Papathanasiu, Th. 6I

Papathanasopulos, Th. N. I05, I6 I, 506

Papatheodoru, K. I05

Papathomopulos, M. 272, 31 7, 324, 338, 506

Papatriantafyllu, A. I 25

Paradellis, Th. 202f., 320,505 f.

Paraskevopulos, G. 31 7, 506

Paraskevopoulou, M. 48, I32, 255, 382, 506

Paredes, A. 28

Parin, D. 353

Parry, M. 274

Pasalić, H. 240

Paschalidis, Gr. 359, 505

Paschalis, D. P. $4 \mathrm{I} 6$

Paschaludis, N. 60, I69

Pashley, R. 395

Passalis, Ch. N. 274f., 32 I, 465, 506

Patentas, Ch. 223

Patera, M. 4I I, 506

Patković, M. I 93

Patselis, N. V. 62, 28I

Paulson, I. 426

Pauly-Wissowa 83
Pavel, Á. 74, 76, 270,37 I

Pavković, N. I06, 506

Payen,J. C. 264, 425, 508

Pazzini, A. 270

Pećo, L. 47, 366, 506

Pefanis, G. P. 146

Penn, M. 3 I

Pératé, A. 3 Io

Perdika, N. A. I I 3, 257, 506

Perdrizet, P. 4I 4, 428

Perillo, F. S. 2 I 8

Peristiany, J. G. I06, I 29, 385, 439, 489, 506

Perkowski, J.L. 4I 7f., 506

Persio, G. C. 262, 265, 498

Pesovár, E. $3 \mathrm{I}$

Petek-Salom, G. 233

Petkova, S. 424

Petrescu, E. 349, 506

Pétridès, S. 3I 3

Petrides, Th. 3 I

Petropoulos, D. A. 75, 255, 31 5, 38 I, 423, 506

Petropulos, D. 62, I 23, I 25, I 27 , I 30, I66, I68, I 7 I , 202, 272, 283, 3 I 5f., 320, 332, 336, 344f., $355,368,370,376,430,442,498,506$

Petropulos, I. 244

Petrov, P.A. I70, 507

Petrović, A. 45

Petrović, B. 93

Petrović, D. 262, 507

Petrović, P. 44

Petrović, P. Ž. I Io, I I6, I 42

Petrović, S. $44,46,467$

Petruțiu, E. I 5 I

Petzoldt, L. 31 3, 423

Peuckert,W.-E. 318, 329, 335

Pezo, E. I 3

Pfaff-Czernecka, J. 29

Pfeffer, K. H. 400

Pfister, F. 277, 317

Philippos 362, 394

Pichler, R. I9, 489

Picken, L. 32, 62

Pillinger, R. 363,5 I 8

Pine, Fr. 327

Pingree, T. 327 
Pinxten, R. 356

Piprek, J. 204, 507

Pitiș, I. G. I 37 f.

Pitt-Rivers, J. 385

Platanos, V. 98, I 28, I 44, 367, 507

Platon 22 I, 230, 362, 4I 2

Plotnikova, A. A. 46, 50, 9I, 507

Plutarch 436

Pócs, É. 89, 326, 356, 4I 3, 4I 6, 420, 423, 466

Podskalsky, G. 391, 507

Polheim, K. I 87

Politis, N. G. 35 f., 42, 44, 46f., $63,75,85,90$, 107, I 2 I, I 29 f., I 39, I64, 207f., 2 10, 226 f., 243,247 , 240, 283 f., 299, 301, 31 5, 329f., 332, 334f., 337, $342,345,355,364,367,373$ f., $376,380,382$, 392, 398, 400, 4I I , 4I 4, 4 I 6, 4I 8, 42 2, 467, 507

Pollack, M.E. 27

Polymeru, A. I3 I, 3 1 7, 337, 364

Polymeru-Kamilaki, A. I45, I 77, I95f., 508

Pop, M. 74, 76, I 5 I, I 7 I, I92, 508

Popa, I. I42, 508

Popescu, A. 336, 508

Popescu, A. M. 2 I 3

Popescu, I. 349, 503

Popescu-Judetz, E. I 7 I, 2 I 6, 224, 234, 236, 239

Popinceanu, I. 424f., 508

Popov, R. 64, 76, I 57

Popova, A. I 28, 425

Popović, J.V. II 5

Poppescos, E. S. 370

Popvasileva, A. I I 9, 508

Porfyris, K. 195, 409

Pospisjl, F. 262

Post, A. H. 385

Potlis, M. 388, 39If., 5 I I

Poulos, G. 508

Pouqueville, F. Ch. H. L. 395

Povoledo, E. 263

Pradel, Fr. 276, 508

Pratasik, B. 22 I , 228, 463, 498

Preger, Th. 389

Preindlberger,J. 32 I, 508

Preisendanz, K. 323, 508

Preisker, H. 3 Io

Prevelakis, P. 3 I I
Prevezanos, L. 245

Priakis, Ch. K. I03, I 48

Prinzing, G. 323, 519

Prokesch-Osten, A. v. 24I

Prokopios, G. A. 303

Promponas, I. K. 366

Prophet Elias 42, I 23, I3 I, 27 I, 3 I 9, 334, 360, 363f., $369,382,5$ I 2

Prosić, M. 65

Prošić-Dvornić, M. I05, 109

Protopapa, K. 4I, 202, 207f., 508

Protopapa-Bubulidu, G. I 54, I 96, 266

Provatakis, Th. M. I 29, 247, 508

Psalti, E. I 26

Psaltis, St. I 26

Psathas, A. D. 126

Psatha-Mitrakli, V. 126

Psellos, M. 372, 437

Pseudo-Kodinos 389

Psilakis, V. $39^{8}$

Psychogios, D. 333

Psychogiu, E. 207-209, 3I 5, 365, 369, 509

Puchner,W. I5-23, 28-33, 35-42, 44-47, 49-54, 56-64, 67-71, 73f., 76-78, 80-85, 87, 9 of., 93-95, 97f., 100-IO2, I05-I I 4, I I 6-I 2 I, I 23 f., I 27 , I $29 f$., I 32 , I 35, I $39 f .$, I $42-$ I 47 , I 49 f., I 52, I 55 , I $58-169$, I 7 I-I 76, I 78-I 8 I, I 83 , I 85f., I 86, 192-I 97, 200, 205f., 208f., 2 I I-2 I 3, 215 , 217 , 220, 222 f., 225 f., $229 f$., 230,235 , 237 f., 24 I-250, 25 2, 257, 260, 262 f., 265 f., 268 , 270, 277, 28 of., 284, 300f., 303f., 307-3 I 2, 3 I 9 , 325 f., 329, 340, 347, 349, 353, 355, 357, 36o, 366, 37I , 374f., $380,382,386 f$., 392, 396, 400, 402, 404, 4I I , 4I 4, 4I 6, 4I 8, 420-422, 424, $426-428,430,437,444,446-45^{2}, 457-46 \mathrm{I}, 463$, $464,467,485,509-5$ I I

Puljar d'Alessio, S. 96

Purnaropulos, G. K. 28 I

Račeva, I. 95

Račeva, M. 44

Radenković, L. 94, 32 I, 42 5, 465, 5 I9

Radics, P.v. I 89, 2 I 2

Rădulescu, N. 2 I6, 224-226, $236 f$., 5 I I

Raecke, J. 20 
Raff, Th. 247, 345

Raftis, A. I I

Raicevich 237 f.

Rajčevski, St. I06, I 42, 462, 5 I I

Rajković, Z. 69, 200, 204, 5 I I

Rakovski, G. K. 97

Rakovski, G. S. I63, 5 I I

Rallis, G.A. 388, 39 If., 5 I I

Ramet, P. 356, 5 I 2

Ramfos, St. 439

Ransome, G. G. 229

Rapp, C. 388

Rapp, U. 253

Raptis, D. 60

Răutu, R. 439, 442, 5 I 2

Régó Ensel, S. 75, 5 I 2

Reich, H. 230

Rein, E. I 3 I, 362, 5 I 2

Reineck,J. S. 3 I

Reinhard, K. 240

Reisch, E. 88, 378

Reiter, N. 4I3, 4I 6, 466, 5 I 2

Reitzenstein, R. 3 10

Reljić, L. 96, I 57, 5 I 2

Remigius, N. 4I 2

Rešetar, M. 80, I93, 5 I 2

Ressel, G. 4I6

Rettenbeck, L. 364

Rezvani, M. K. 229

Rheubottom, D. B. 386, 5 I 2

Ribeyrol, M. 44

Rice, T. 370

Rice, T.T. 83

Richter, D. 4I, 5 I, IO5

Riedinger, U. 327

Riess, E. 323

Rigas, G. A. 276, 325, 33 of.

Rigas Velestinlis 257,392, 5 I 2

Rigatos, G. A. 282, 464, 5 I 2

Rilke, R.M. 427

Risi, C. 27

Ristovski, B. 76, 5 I 2

Ritter, H. 23 If., 5 I 2

Riznić, M. S. 95, 5 I 2

Rizos Rangavis, A. I6 I
Rnjak, D. 65, 5 I 2

Robinson, M. 4I I

Robson, J. 438

Rodd,J.R. 207

Rodooinos, N. I68f., I 7 I , 258, 5 I 2

Roebuck, C. 378

Róheim, G. I 5 of., 330, 4I 3 , 45 8, 5 I 2

Röhrich, L. 326, 333, 364, 375, 4I 2, 479

Roilos, P. 33, 245, 466, 469, 5 I 6

Romaios, K. 345, 5 I 2

Romaios, K.A. 49, 63, 97, I00, I02, I04, I 54, I62, I $67,337,342,346,377,380,5$ I 2

Romas, D. 269

Rommel, O. 2 I I , 226

Ronas, S. 333

Roosevelt, G. 192

Rose, A.J. 62, I I 8, I 77, 47 I

Roselt,J. 27

Roseman, S. R. 354

Rosengren, K. 254

Rosolato, G. 376

Roth, K. 20, 3 If., I 2 I , 33 I, 438, 457f., 5 I 3

Rothemund, B. $37 \mathrm{I}$

Roubin, L.A. I 28

Rouffié,J. 423

Rougé, E. I 29

Rouse, W.H.D. 378

Roussel, L. 244, 250, 5 I 3

Rožin, N. R. 193, 513

Rudolph, E. 275

Rulias, G. 245

Runeberg, A. 423

Rusmelis, S. 28I

Russel,J. 437, 5 I3 3

Russopulos, Chr. I 25

Rusunelos, D. 48

Rusunidis, A. Ch. I 26, I 83 f., 255, 334, 243, 5 I 3

Ruxandoiu, P. 76, 508

Săbotinova, D. I70

Sachlikis, St. 4I 4

Sadnik, L. 333, 5 I 3

Șaineanu, L. 224, 234, 5 I 3

Saint-Sauveur, A. G. 267

Saitz, R. L. 33 
Sakaoğlu, S. 232, 5 I 3

Sakellarios, Ph. 207

Sakellariu, A. I 84 f.

Salamangas, D. 84, I 96

Sallnow, M. 355

Salome 49

Salzberger, G. 3 I 7

Samaras, I. K. 44I

Samaras, P. 3 I 5

Saminova-Semova, A. 65, 5 I 3

Samokovlieva, M. 76, 5 I 3

Samothrakis, D. A. I 25

Samsaris, P. I 25

Samuilidis, Chr. 82, I I 7, I 72, I 8 I, 5 I 3

San Toader I 39, 26of., $430,55^{\circ}$

Sándor, S. 34, I33, 201, 46 I

Sandu, C. 326, 5 I 3

Sangh, B. N. 249

Sankt Nikolaus 48

Sant Cassia, P. 385, 5 I 3

Šapkarev, K. 426, 428, 462, 5 I3

Sardunis, D. 248

Sar1 Saltuk 360

Saridakis, I. 223

Sarros, D. M. 73, I I 6 f.

Sartori 187,335

Sathas, K. 264, 38I, 39I

Sauer, J. 303

Saunier, G. 306, 5 I 3

Saussey, E. I 97

Savramis, D. 352, 37 I , 5 I3

Scarpa, A. 270

Schaafhausen, I. 400

Schadewaldt, H. 4 IO

Scharfe, M. 443

Schechner, R. 27

Scheftelowitz, I. 3 I 8, 5 I 4

Scheider, F. I 30

Schenda, R. 207, 32 I, 326f., 4I I , 5 I 4

Schieffelin, E. 28

Schier, B. I 90

Schier-Oberdorffer, U. 254

Schiller, F. 2 I 2, 228

Schiller, G. 3 I

Schimmel, A. 260
Schlossar, A. 80, I 56, I 87

Schlumberger, G. 317, 5 I 4

Schmalzbauer, G. 28 I

Schmeling, K. 333

Schmidt, B. 35, 46, I I 7, 208, 308, 4I I , 420, 422 , 439, 5 I 4

Schmidt, L. 36, 69, 8of., 83, 85f., 89, I 87-190, I $96,248,259,3$ I $7,325,404,48$ I

Schmidt, T. 137

Schmidt, W. 252

Schmitt, J. 389

Schneeweis, E. 40, 45, 59, 74f., 34I, 387, 4I 9f., $424,439,44$ I , 458, 5 I 4

Schnorr, G. $23 \mathrm{I}$

Scholz, B. E. I48, 2 I I , 2 I 6, 373, 472, 529

Schönfeld, W. 326

Schönwälder, K. 2 I 2

Schram, F. I48, 2I 5, 5 I 4

Schreiner, P. 32, 262 f., 327, 5 I 4

Schröer, K. J. I 89

Schroubek, G. R. 83, 259, 457, 483

Schubert, G. 53, 70, I 22, I 30, 247, $270,322,34 \mathrm{I}$, 4I $6,465,5$ I 4

Schule, W. 435

Schuller,J. C. 216

Schuller, L. 3 I 8

Schwartzman, H. 254

Schwarzbaum, H. 360

Schwibbe, G. 320

Searle, J. L. 27

Sebestyén, G. 133

Sedakova, I. 326

Sedlmayr, H. 303

Seitanidis, D. 256

Sekulić, A. I 42, 5 I 5

Selig, A. K. $37 \mathrm{I}$

Seligmann, S. 272, 279, 3I 7, 435f., 438, 5 I 5

Sembdner, H. I 89

Seraïdari, K. 354, 372, 5 I 5

Serbezis, V. 258

Sergis, M. G. 4I, 68, I 22, I 28 , 202f., 205-208, $304,316,325,344,364,377,420,423,443,467$, 5 I I

Sergius 393

Settas, D. Chr. 275, 439, 44I 
Sevastos, E. I36, 5 I 5

Sevengil, R. A. 197

Sevin, N. 23I

Shangriladze, K. I07, I 5 I

Shay, A. 3 I

Sheffler,J. I07, 5 I 5

Shojaei Kawan, Chr. I07, 5 I 5

Siaflekis, Z. 248

Siampanopulos, K. 95, 5 I 5

Sideris, I. P. I 53,2 I 2

Sieber, F. 74, I I 4, I 7 I , 5 I 5

Sifakis, G. 235, 244, 246, 5 I 5

Sikimih, B. I 42, 5 I 5

Silberer, H. 330

Silvestru, V. 216,484

Simić, P. $386-388,5$ I 5

Simmel, G. 65

Simon, D. 323, 5 I 9

Simon, F. 20I

Simopulos, K. 235

Sinding-Larsen, St. 303

Sinor, D. 217,474

Siontis, K. Ch. 62

Sirota, I. B. $37 \mathrm{I}$

Sitaras, A. E. 74, I 25,278 f., 422

Sittl, C. 36, 24I, 243

Siuts, H. 54

Šivačev, St. I 63

Šivačov, S. K. I63

Siyavusgil, S. E. 232, 5 I 5

Skandalidis, M. 106

Škarić, M. 93, I05, 5 I 5

Skawran, K. M. 303

Skendi, St. I 22, 305, 380, 5 I 5

Skordelis, V. 6of., 96, 104

Skorupski,J. 304

Skovran, O. 3 I

Skowronski, M. 362, 5 I 5

Skrbić Alempijević, N. 96

Skrobucha, H. 35 I

Skubenta,J. 239

Skurativs'kyj, V. I 42, 5 I 5

Skuteri-Didaskalu, N. 207

Skuvaras, V. 279

Skylitzes 373
Slavejkov, R. I70

Slivka, M. 69

Smiljanić, M. 204, 5 I 6

Snoek, J. 29

Sofianos, D.Z. 324, 5 I 6

Sokolova, B. K. 46

Solokov, J. M. 193

Solomonidis, Chr. S. I 99, 282, 5 I 6

Soloviev, A. V. 305

Solymos, E. I05

Somogyi, G. 75

Somorjai, O. 21 7, 226, 472

Sournia, J. C. 423

Sp.,J. 74

Spadaro, G. 265

Spanos, D. 407f., 444

Spathari-Begliti, E. I 22 f., 5 I 6

Spatharis, E. 223, 249

Spatharis, S. 249

Speranția, T. 152

Spier, J. 3 I 7

Spies, O. 197, 21 7, 229, 5 I 6

Spitzing, G. 303

Spyridakis, G. K. 45, 52, 61, 70, I I 4, I 30, 247, $255,275,277,284,295,322,345,369,390,396$, 5 I 6,526

Stahl, A. 8I, 219, 367, 382

Stahl,H.H. 8I, 225

Stahl, P. H. 209, 305, 370

Stakias, D. Ch. I 55

Stalin 192

Stamatiadis, E. I 77

Stamatopulos, K. M. 347

Stamos, D. 439

Stamuli-Saranti, E. I I 7, I 23, I 25, I 28, 276-278, 280, 3 I 5-3 I 7, 325, 334, 337, 343-346, 363 f., $369,44 \mathrm{I}, 444,5 \mathrm{I} 6$

Stanek, H. I 87

Stanković, B. I 87

Stathis, G. 344

Statovci, D. 42 I, 5 I 6

Stavrakopoulou, A. 244, 5 I 6

Stavrakopulu, A. 246, 5 I 6

Stavrinidis, N. $398 \mathrm{f}$.

Stefanidis, M. I29, I3 I 
Stefanov, P. 374, 5 I 6

Stefanović, V.T. 234, 239

Stefanovski, R. 234, 236, 5 I 7

Stefopulos, A. P. 257,5 I 7

Stegemann, V. I 89

Steinleitner, F. 322, 5 I 7

Steinmetz, F. I07

Stemmler, Th. 301

Stemplinger, E. 276, $28 \mathrm{I}$

Stengel, G. 4I I

Stengel, P. 379, 382

Stergiopulos, K. D. 330

Stern, B. 322, 438, 465, 5 I 7

Stern, H. 327

Sternhell, Z. 19

Stewart, Ch. 260, 273, 3I 6, 344, 358, 405, 407, 4IO, 4I 3, 42 5, 440, 467, 5 I 7

Stivanaki, E. 2I 3

Stoaneva, I. 76

Stockmann, D. 32

Stockmann, E. 32

Stoica, G. I 5 I

Stoica-Vasilescu, S. 76, 5 I 7

Stoilov, A. P. I43, I70

Stojanović, L. I05, 5 I 7

Stojčevska-Antić, V. 430, 5 I 7

Stojnev, A. 424, 465, 5 I 7

Stöffelmayer, K. 87

Stonus, D. 375,5 I 7

Storey, J. 29

Straten, F.T. van 273

Strausberg, M. 29

Strauß, A. 4I 7, 5 I 7

Strauß, B. A. 387

Strzygowski, J. 3 I 0 , 3 I 2

Studites, Th. 372, 388

Stylianu, P. I 83

Suliotis, G. 208

Sulițeanu, G. 32, I 5 I

Sulzer, F.J. I 5 I, I98f., 236 f.

Sumcov, N. F. 46

Supek, O. 69

Supek-Zupan, O. 69

Süssheim, K. 23 I, 5 I 7

Sutton, S. B. 366, 5 I 7
Sutton-Smith, B. 254, 365

Sverne, B. 229

Sv. Jeremija 142

Sv. Lucija 89, I4I

Sv. Lucije I4I

Sv. Nikole I4I

Sv. Varvare I4I

Svinu, L. I68f., I 7 I

Svoboda, K. 4I 4, 5 I 7

Sykora, G. I 24, 5 I 7

Szabadfalvi, J. 33 I, 5 I 7

Szacsvay, É. I 48, 2 I6, 5 I 7 f.

Szendrey, A. 200, 326, 4I 3, 5 I 8

Szilády, S. 90

Szilágyi, D. I48, 2 I6, 5 I 8

Tachatakis, E. 399

Tacit, D. 82

Taft, R. 56

Tahy, N. A. 38, 58, 62, 8 I , 86f., го3f., го9f., I I 4 , I 48, I 50, I 55-I 57, I 77, I 91, 2 I 6, 46 I, 5 I 8

Tailliez, F. 428,5 I 8

Talbot, A.-M.M. 83, 465, 5 I 8

Tamassia, G. 387, 5 I 8

Tambiah, S. J. 29, 274

Tanović, St. 422

Tansung, S. I05, 5 I 8

Tăpkova-Zaimova, V. I70, 363, 5 I 8

Tarsouli, G. 3I 8, 475

Tarsuli, G. 256

Tasić, T. $368,468,5$ I 8

Tassias, I. 345

Tassini, G. 264

Taxiarches 131,362

Taylor, L. 208, 480

Tecer, A. K. I 73

Tegnaeus, A.H. 385

Tektonidis, E. Ch. 126

Telelis, I. 334, 5 I 8

Teodorescu, G. D.

Teodorov, E. 224, 234, 463

Tertsetis, G. 390

Terzakis, F. $208 f$.

Teske, R.-Th. 380

Thalasso, A. $23 \mathrm{I}$ 
Theochari, M. S. $353,385,397,399$

Theokrit 272

Theophilos, Erzb. v. Kampania 39I

Theotokis, Sp. 268

Theotokos 49, 437

Thévenot, M. 233

Thielmann, T. 27

Thilo, J. C. 49

Thomas, E.J. 66

Thomas, G. 344, 5 I 8

Thompson, M.H. 284

Thompson, M. S. 9I, 98

Thompson, S. 406, 4I 4, 444

Thomson, G. 86

Thrakiotis, K. 49, 97, I 23, I 25, 5 I 8

Thrift, N.J. 27

Thurn, H. 3I 2

Tichova, A. I70

Tietze, A. $23 \mathrm{I}$

Tilney, Ph. V. R. 6r, 209

Tilton, E. L. 368

Tinnefeld, F. 407

Tirtja, M. 76, 5 I 8

Tittelbach, E. 77

Tobas, A. 126

Todorov, D. 425, 5 I 9

Tolis, D. St. I05

Tolstoj, N.I. 88

Tolstoj, S. M. 94, 465, 5 I 9

Tomaschek, W. 428

Tomić, P. 95

Tomkinson, J. L. 4I3, 5I 9

Tomov, A. 97

Toporkov, A. L. 9I

Topuzis, G. 85

Tornikes, D. 389

Törő, A. 271, 486

Török, K. 201, 5 I 9

Torp, L. 3 I

Torrigio, F.M. 372

Tosunbaș, M. 439

Townsend, E.W. I07, 5 I 5

Toynbee, A. 378

Trapp, E. 309

Tratnik Volasko, M. 423
Trembelas, P. 429

Tresorukova, I. 230

Treutlein, W. 364

Treutsch, J. 150

Triantafyllu, K. N. I 25, 394

Tričković, R. 234, 236

Trigg, E. B. 4I 4, 5 I 9

Troianos, S. N. 323, 41 5, 5 I 9

Troili, F. F. v. I 78 f.

Trojanović, S. 48, I04, I 42, 5 I 9

Trüb, C. L. P. 364

Truhelka, Ć. 32 I, 5 I 9

Trumpeta, S. 246

Trstenjak, A. I 89

Trümpy, H. 277

Tsakiris, A. I 7 I , 258, 5 I 9

Tsaknakis, A. Th. 74

Tsangalas, K. D. 282, 284, 329f., 333, 339, 5 I 9

Tsatsiopulos, L. 257

Tselikas, A. 282

Tsiantas, K. 260

Tsiaras, A. 429, 477

Tsimiskes, Kaiser 373

Tsipiras, K. St. 250,5 I 9

Tsirligani-Kinali, A. 363

Tsiropina, St. 60

Tsokopulos, G. B. $222 \mathrm{f}$.

Tsurkas, K. 62

Tsvetkova, Chr. 76

Tulbure, V. I 37

Tuilier, A. 3 I 2

Tuliatos, D. P. $28 \mathrm{I}$

Tunison, J. S. 230

Turner, E. 353f., 359, 5 I 9

Turner, T. 29

Turner, V. 29, 353-355, 5 I 9

Tüskés, G. 355, 5 I 9

Tzartzanu, A. 57

Tzetzes, I. 389

Tzukalas, G. I 26

Tzumerkas, P. 60, 129, 509

Tzunis, T. V. 84, 97, r $26 f$.

Üçer, C. 327

Udziela, M. 322, 5 I 9 
Uglien, A. E. ${ }^{4} 42$

Ujes, A. 2I I, 5 I 9

Ujváry, Z. 65, 75, 79, 8 I , 85f., 88, I I 7, I 2 I, I 54, 4I 3,46 I , 48 I, 5 I 9 f.

Ulmer, R. 438

Umathum, S. I6

Ünver, O. 520

Uplegger, H. 197, 520

Ureche, V.A. I 5 I

Uther, H.-J. 4Iof.

Uysal, A.E. 233

Vafeiadis, G. 206

Vafeiadu, V. I 25, I 29, 370, 520

Vagiakakos, D. V. 33

Vakalopulos, K. A. I 22

Vakaludi, A. D. 437

Vakarcs, K. 74

Vakarelski, Chr. 4of., 49, 52, 6o, 63, 68, 74-76, 78, $85,87,8$ ff., 95, I04, I08, г 10, I I 5 f., I 2 I-I 24 , I 4 I , I 43f., I 62, 260, 283, 338, 404, 4I 9, 428f., $43 \mathrm{I}, 458,520$

Vakarelski, Hr. 44f., 48, 50, 97, Ioo, I 70, 4I 9, 424, $427,495,520$

Valaoras, V. G. I6 I

Vălčinova, G. 304, $326 f$.

Valsavor,J.W. 57, 200, 204, 520

Valtchinova, G. 327, 356

Vamossy, K. I48, 2 I 6

Vamvakidu, I. $35^{8}$

Vaos, Z. 275, 520

Vaqari, S. 217,520

Vargyas, L. I 33, I 48, 2 I6, 472, 520

Varvounis, M. G. 20, 63, 85f., 96, I 23, I 26, 353 , $36 \mathrm{I}, 368,380,458,5$ I I, 520

Varvunis, M. G. 60, 66, 68, 97, I 22-I 24, I28-I 3 I, I 77, 208f., 254, 258-260, 272, 277f., 282 f., 295 , 300, 302, 304f., 31 5-3 I 7, 323f., 333, 336, 338, 340, 343-345, 349, 355, 358, 36of., 364-367, 37I, 376f., $380,382,408,4 \mathrm{I} 7,467,469,506$, 509, 5 I I , 5 I 6, 5 20f., 525 f.

Vaser, J. 4I I

Vasić, O. 31, 77, 95

Vasileiadis, N. 370

Vasileiadis, V. K. 370
Vasileva, M. 50, 52, I I9, I 70, 508, 52 I

Vassilaki, M. 437

Vatidu, O. 347, 36r

Vavaretos, G. A. $28 \mathrm{I}$

Veïku, Chr. 439, 444, 467, 52 I

Veiku-Serameti, K. 84, 436

Veis, N.A. 395

Veleckaja, N. N. 76, I I 5, 52 I

Velefantis, K. 444

Velestinlis, Rigas 257,392

Velin, S. I04, 52 I

Velioti, M. 2 I 7

Velissaropulos, P. K. 437

Vellianitis, Th. 24I

Veloudis, G. 240, 36I, $52 \mathrm{I}$

Vernant, J. P. 38I, 483

Vernardu, F. 48

Verveniotis, A. I07

Veselinović,J. 387, 52 I

Veselinović,J.H. 95

Viazis, Sp. de 266

Viciu, A. ${ }_{3} 8$

Videnov, M. 85, 52 I

Vielhauer, H. 270

Vikas, V.I. 59, 62, 75, 78, 39I

Villehardouin, G. de 268

Vincent, A. 108, 262, 264

Vinogradova, L. N. 43, 47, 52 I

Vios, St. 39I

Vita, Z. 8I

Vitez,Z. 262

Vitti,M. I94, 242, 265

Vizyinos, G. I64-I66, 343

Vlachogiannis, G. 394

Vlachos, Th. 4I 3, 424, 522

Vlahović, S. 202

Vlahović, V. I 57

Vogazlis, D. K. 6of., 87, 99, I05, I 25, 522

Vogel, Chr. 46, I 20, 3 10

Vogel, R. 258

Vogiatzidu, I. 349

Voigt, V. 46I

Völger, G. 95, 475

Volk, R. $28 \mathrm{I}$

Volly, I. I4I, 46I 
Vonderlage, B. 4I, 368, 522

Vouras, M. 3 I

Vozikas, G. I 3 I, 354, 36 I, 365, 522

Vrabie, E. 275, 522

Vrabie, G. I37, I91, 463

Vrachionidu, M. 48

Vranoussis, L. 36 I

Vražinovski, T. 4I 3, 424, 466, 522

Vrčević, V. I42

Vrettos, Sp. L. 245

Vrontis, A. 345

Vsevolodskij-Gherngross, V.N. 8I

Vuia, R. I 36, I 5 I, 522

Vukanović, T. I05, I41, 234, 239, 522

Vukanović, T.P. $87,322,356,522$

Vulcănescu, R. 65, 85, 87, 89, I 04, I 2 I, I 24, I 7 I, 26 I, 424, 463, 466, 522

Vuletić-Vukasović, V. I 40, 522

Vulpescu, M. I91, 224, 463, 522

Vunas, Chr. I08, I6 I

Vuorela, T. 438

Vurazeli-Marinaku, E. 369, 523

Vutsopulos, K. G. I I I, I6 I

Wace, A.J. B. 73, 75, 91, 98, 101, 104, I 47, 238, 460,52 I

Wackernell, J. I87

Wallace, A. 300

Wallis, R. 322, 464, 490

Walter, Chr. 303, 373

Ward, D. 34 I

Warner, E. 224

Warning, R. 365

Warstat, M. I6

Waser, O. $4 \mathrm{I} 4$

Weber, G. 436, 440

Weel-Badieritaki, A. 283

Wehse, R. 33

Weibust, K. 385

Weidkuhn, P. I 8, 303, 409, 523

Weidlein, J. 88

Weigand, G. L. 4I $8 f$.

Weihe, R. I05

Weinhold, K. I 87

Weinhold, R. I 89
Weinreich, O. 280, $32 \mathrm{I}$

Weisser, Chr. 273

Welck, K.v. 95, 475

Wellesz, E. 32

Wellmann, M. 284

Werbner, R. P. 355, 523

Wessel, K. 309

Wesselski, A. 320

Wessely, C. 323

Westerink, L. G. 335

Wheeler, W. 268

Whitman, C. 230, 244

White, E.W. 230

Wild, G. 305

Wildhaber, R. 65, 69, 75-77, 8I, 93, I 70, 290, 3 I 7 , $337,459,523,525$

Wiertz, P. 307, 371, 466, 523

Willer, S. 320

Williamson, G. A. 280, 523

Wilpert, J. 3 Io

Wilshire, B. 66

Winder, A. 90

Winkelman, M. 3 I 3

Winkler, H. A. 323,523

Wirth, U. 28

Wittmer-Busch, M.E. 33I

Wohlstand, L. I 90

Wolf, G. 20, I 2 I , 456, 5 I 3

Wolfram, R. 3I, 53, 87, I35-I 37, I 87, 258, 523

Wolters, P. 3I 8, 322

Wonisch, O. I 88, 2 I 9

Wopmann, A. 4I 8

Wulf, Chr. I 6

Wunderlich, W. 376

Wundt, W. 33

Wünsch, Th. 437, 439, 488

Wurdack, K. I 88

Xhagolli, A. 423,523

Xiruchakis, A. 265

Yatromanolakis, D. 33, 245, 466, 469, 5 I6

Yerkes, R. K. 382

Yönetken, H. B. I 73

Ypsilantis, A. 237 
Zachariev, J. 95, 523

Zachariu-Mamaliga, E. 36I, 523

Zaganiaris, D. N. 279

Zajkovskaja, T. I72, 523

Zaikovskyi, V. 44-49, 422, 523

Zakhos-Papazahariou, E. 247, 523

Žatko, R. 200, 524

Zbinden, E. 4I 4, 524

Zečević, S. 44f., 69, 93-95, I05, I IO, I I 5, I 4 Iff., $254,4 \mathrm{I} 3,4 \mathrm{I} 6,422,425,524$

Zeginis, E. I 22, 524

Zelenčuk, V. S. I I 5,524

Zelenin, A. 430

Zelenin, D. K. 3 I 9

Zelepos, I. 2 I 2, 300, 348, 388, 524

Željaskov, I. 428, 524

Zender, M. 75, 345

Zenkinis, E. 305

Zeno, F. I96

\section{ORTE}

Abdera 84

Adramyttio 155

Adria-Inseln I 39, 262

Adrianopel 80, I30, I68, 324, 364429

Ägäis 57, 62, I09, I I 4 , I 32, I 49, I 5 5, 260, 280 , 309, 3 I 9, 342, 357, 392, 406, 5 IO

Ägäisinseln 57, 260, 342

Agia Eleni I 66, I72, 295, 326, 369, 430, 526

Ägina 63, I09, I I 7 f.

Agiasos I45

Agioi Theodoroi 100

Agiopigi 100

Agios Kirykas 266

Agrinio 245

Ägypten 44, I 79, 229, 243

Ainos I 28, 443

Aitoško I63

Albanien 32, I 29, I 40, I 44, 21 7, 305, 359, 387, 4I $3,422,440$

Algerien 243

Algier 179

Almali 3I5
Zervudis, V. I 53, 524

Zerzelidis, G. 173

Ziegler, S. 32

Zimmerman, Z.D. 426

Zinanović, S. 366

Zischka, U. 322, 524

Živkov,T.I. 68, 234, 238, 424f., 5 I 4, 524

Zlabadnik, B. I 40, 524

Zlatanović, M. 34I, 524

Zlatanović, S. I 57

Zlatković, D. 157,524

Zlatkovskaja, D.T. 524

Žmegač, J. Č. 262

Zois, L. Ch. 195, 249, 266, 282, 3 I 3

Zola,É. 228

Zonaras 373

Zorić, S. 300

Zwi, S. I79
Almyros I00, I02
Altthrakien I09, I 25
Amaseia 372,373
Ambrakischer Golf 396
Amfilochia I96, 245
Amisos 63, I73
Amorgos 209, 329
Amselfeld 239
Anakasia 99
Anatolien 91, 220, 232
Andócs 356
Ano Amisos 63
Arabische Länder 34
Arapovo I63
Argeș I36
Argolis I53
Argyrupoli 205
Arkadien 86
Arkadiupolis 369
Armenien 80,82
Arta I96, 245, 319
Asenovgrad I 22, 364 
Aspropotamos 400

Aspropyrgos 84

Athen 107, 166, 21 2, 22 2, 228, 247, 249, 32 1, 377

Athos 294, 327, 357, 380, 388, 525

Ätolien 428

Ätoloakarnanien 176

Attika 373, 377

Australien $97,250,440$

Autun 353

Avhat 372

Avkat 372

Babalio ${ }^{7} 76$

Babina Greda 2 I 8

Bali 229

Balıkesir 155

Balkan 20, 91 I I2, 2 I 2, 270, 300, 31 8, 322, 394

Balkanhalbinsel 40, 73, 87, I08, I 2 I, I 36, I 76, I $97,207,229,235,380,4 \mathrm{I} 6$

Balkanraum I I-I 3, 52, 67, 8 г, г o3, I 26, I39f., I 44, I62, I 74, I93, 208, 2 I 5, 234, 34If., 353, 453,460

Banat rogf., I35f., I 89, 2 I 6, 420

Banjsko 236

Banovići 218

Baranya 75, I40, 479

Batschka 93, 96, I08, I 89, 289, 489, 525

Batumi I72f.

Belevren I43

Belgrad 235f., 322

Belikesir 92

Berat 359

Berlin 199, 399

Bessarabien I I 5 , I 70, I 89

Bethanien 354

Bethlehem 49, 354

Bihar I 34

Binnenkroatien 139,462

Bithynien 374

Bitola I49, 2 I 8, 329, 43 I

Bizye 343

Bjala Voda I 43

Blaca 143

Bliznak I43

Bohinj I 40
Bologna 22 I

Bosnien 44, 47, 2 I 7

Bosporus 231, 233, 407

Botrinto 362

Božomi 2 II

Brașov I36, I38, I 50

Brauron 86

Brčko 2 I 8

Briaza 238

Brodilovo I 43

Brodivo I7I

Bucovica 140

Budapest 21 3 f., 226

Bukarest I98, 2I3, 2I 5, 22 I, 224, 226, 237f.

Bukowina $\mathrm{I} 34$

Bulgari I 43

Bulgarien 34, 57, 62f., 73, 78, 82, 85, 87f., 92, 94 , I I 4, I I 6, I 20, I 40-I 42, I 66, I 70, 2 I 7, 22 of., 234, 238, 29I, 326, 336, 343, 354, 362, 4I 3, 4I 8, 422 f., $459,462,525$

Bulgarisch-Thrakien 97,99

Bunahisar I 70

Burdur 220

Burgas I63, I70, 369

Burgenland $187, \mathrm{r} 89$

Byzanz 35, 6I , 7 I , I 28, I 44, 2 I 2, 23 I, 256, 259, 262 f., 28 I , 323, 332, 373, 377, 388, 42 I , 447, 456

Canea 265

Candia 262, 264

Čapljina 2 I 8

Čardak 2 I 9

Chalki 62

Chalkida 242

Chalkidike I I9, 229, 34 I, 48 I

Chania 262, $264 \mathrm{f}$.

Chiliodendri 6I

China 229

Chios 57, 6o, 62f., I09, I I 7f., I 55, I 77, 406, 42 I

Čiatura 2 II

«Claudiopolis» 374

Cluj I34, $_{3} 38$

Constanța 239

Crna Gora 45, 78, 208

Csíksomlyó 356 
Dalmatien 34, 237, 386

Dalmatinischer Küstenstreifen 89, I39, I49, I93, 200, 2 1 8, 262, 267

Damaskinia 62

Dardanellen 278

Delos 379

Demirköy I I

Dervitsani I I 3

Deutschland 2 I4

Didymoteicho 83, I68, 263, 293

Distrato 440

Dobrudscha 50, I43, I70, I 89, 238, 360

Dodekanes 85, I 20, I 7 I, 378

Doganköy 444

Doliani 48, 236, 362

Domeniko 99

Donau 64, 96, I 7 I, I 89, 370

Donau-Monarchie 2 I I

Donaubecken 138

Donauraum 132, 235

Drăguș 137

Drama 50,258

Drymia 360

Duboka 94, 325

Dubrovnik I40, 239

Dumanll I73

Eceabat I 29, 276, 278, 345

Edirne 80, I30, I68, 324, 364, 369, 429

Edremit 155

Efkaryo 343

Elasson 87,91, 36 I

England $192,24 \mathrm{I}$

Epirus 52, 64, 73, I I 6, I 20, I40, I 84, I 96, 2 I 4 , 245f., 256, 295, 31 5, 328, 342, 391, 393, 396, 440,526

Epivates 84,278

Eptachori 147

Erekler I 43

Euböa I6I, 367

Euchaita $372-375$

Europa 150,456

Europäische Türkei 62, 78, 84, I Iо, I63, I68, 259, $278,343,354,442$

Euxinischer Pontus 8I
Evros I7 I

Evrostini 50

Farasa 62

Farsala 245

Festgriechenland I6I, 343

Florenz 264

Florina 47, 89, 385

Fohnsdorf 83

Frankreich 192

Galanovrysi 6I

Galata 57, I 49

Ganos 343

Gelibolu 278

Georgien I72, 21 I, 373

Gethsemane 354

Gevgelija 44

Gibraltar 2 I4

Gimpulin 238

Giresun 173

Gjirokastër I I I, I I 3

Glykomilea 99

Gomati I 9

Gonusa 238

Gornja Pšinja 95

Gornica 50

Gračanica 356

Gramatikovo I43

Granikos 259

Grevena 245

Griechenland 32f., 24, 45, 62, 78, 84, I44f., I6I, I 72, I 96 , 200, 2 I 2, 22 If., 235, $238,240,245$, 250, 257 f., 296, 343, 355f., 39 If., 398f., 4 I 3 f., 439f., 444, 456, 45 8f., 463,465

Griechisch-Makedonien 49, 95, 97, ror, I65f., I 72, 295, 382, 526

Griechisch-Thrakien 83, 99, 250, 293, 525

Grintades 62

Gruža I Io

Gudovasda 73, 39 I

Gundinci 219

Hagios Georgios I 50

H1. Land 55, 354 
Heliupolis 365

Hellas 248, 257

Heptanesos 194

Herakleia 343,377

Heraklion 262, 399

Hercegbosna 239, 422, 464

Herzegovina 217

Hilandar 380

Hispano-Amerika 35

Holland 2 I 4

Hunedoara 137

Hvar 194

Hydra 203

Iaşi 213,226

Ibero-Amerika 436

Igumenitsa 440

Iliolusto IOI

Ilok 235

Imotski 268

Indien 229, 23I, 436

Indže Vojvoda 143

Innerösterreich 68, I39, I 87

Inselraum I08, I 55, 209

Ionische Inseln I 53, I6 I , I 80, I 94, I 96, 22 If., $249,263,268,377 f$.

Ioannina 4I, 84, I08, I I 2, I 84, I 97, 235, 24 of., $28 \mathrm{I}, 36 \mathrm{I}-362,4 \mathrm{II}$

Ipolydamazsd 73

Istanbul I68, I99, 233, 239f., 259

Istrien I 40, I 93, 268, 420

Italien 34, I 78, 2 I 2f., 2 I 7, 22 I-223, 226, 28 I , 356

Izmir 199

Java 229

Jenište-Vardar 238

Jordan 43, I 27, 354

Jugoslawien 20, 88

Kalambaka roo

Kali Vrysi 50

Kaliakra 360

Kallipolis 278

Kalochi 99

Kalochori 400
Kambodscha 229

Kamenica I 43

Kappadokien 48, 60, 62, 209, 360, 376

Karancs 96

Karditsa I02, I 96, 2 I0

«Karmania» 389

Karnabas 369

Kärnten 8I, 86, I $87 f$.

Karpaten I32, I34, I38

Karpatenbogen I32, I 50, I 89, 26I

Karpatenraum 39

Karpathos 153, 444

Karpenisi 196

Kars I73, 2 I I

Kasavštin I40

Kastania 73,346

Kastanies 84, 278, 343

Kaštel Starom 109

Kastoria 48, 6I, I 47, 376, 385, 44I

Kaukasus Ioo

Kavala I00, 209

Kefalonia I07, I 45, I6I, I 94, 265, 357

Keppekklisia 176

Keramidi 99, I0I

Kerasus 173

Kestanelik 278

Kiato I6I, 238

Kilkis $\mathrm{I} 76$

Kırklareli 370

Kirtili 345

Kition $7 \mathrm{I}$

Klausenburg 138

Kleinasien 34, 54, 83, 82, 85, 87, 9 I, I I 2, I I 4, I I 7, I 32, I 54, I 72 f., 203, 205f., 209, 2 I 7, 329, 342, 345,354 f., $428,458,467$

Kokkotoi IoI, I 47

Kolonaki 228

Komitades 399

Komotini 205,305

Kondolovo I43

Konitsa 39I

Konstantinopel 83, I49, I68, I79, 230, 235, 265, $345,353,369,372,378,398,402,437$

Kontinentalgriechenland 222

Korčula 140,262 
Korfu 21 I, 22 I, 226, 265-268, 327, 360

Korinth 50

Korinthischer Golf 196

Kornofolia 99

Koroni 376

Kos 273

Kosovo 95, I40, 239, 380, 387

Kosovska Mitrovica 380

Kostantiniyye 232, 236

Kosti I30, I 43, I64, I66, I 7 I, 343

Kotyora I I 2, I 73

Kozani 62

Kragujevac 108, I4I

Krajina 21 8, 326

Kreta 57, 74, 90, I07, I I 4, I 54, I 79, 263 f., 305, 31 $9,328,338,342,387,390,395-399,404,4 \mathrm{I} 4$, $428,439 f$., 490

Križevci 2 I 8

Krk I4O

Kroatien 39, I09, I32, I39f., 2 I6, 2 I 8, 240, 462

Kruja 360

Kruševac 386f., 389

Krvavac 2 I 8

Kulata 143

Kurvali 343

Küstendil I Io

Kykladen 357

Kyparisia 158

Ladinci 2 I 8

Laibach 2 I 2

Lankadas I7I

Larisa 61, 282, 400

Larnaka 7I, I I 9

Lastovo 96, I40

Lefkada 196

Lefkogia 154

Leipsos 357

Lemessos 182

Lesbos I 45, I 55, 383

Lesičevo 170

Leucas I96, 266

Limni 367

Ljubljana 57

Lobor 140
London 2 I 4

Lozengrad I63, I70

Lule-Burgas 369

Lumnitsa 98

Lunxhëri II I

Lupida 84

Libyen 243

Lygaria 100

Lykudi 6I, I47

M. Tărnovo I70

Maçka I73

Madytos I 29, 278, 343, 345

Madžura I43

Maghrib 243

Magnesien I47

Maistro 442

Makarska 266

Makedonien 98-IOO, I I 5, I35, I 40, 326, 338, $342,4 \mathrm{I} 3,4 \mathrm{I} 8,422,458 \mathrm{f}$.

Malaysien 229

Malăk Samokov I43

Malgara 84, 277,3 I 5

Malkara 277

Malta 34

Mamasos 360

Mani 33, 396

Maramureș 138

Marasia 369

Maria Rast 356

Máriapócs 356

Marmarameer 278

Marpissa 146

Marseille 353

Matsuka 173

Mazia I84, I 86

Medgidia 440

Međugorje 356

Megara 283

Mekka 55, 354f.

Meliki I65, I7 I

Mesara 399

Mesolongi 196

Metalliko 176

Metamorphosis 377 
Metaxades 259

Metsovo 245

Mihai Bravu 192

Miloševac 93, 289, 525

Mitteleuropa 80, I 29, I56, I 87, 2 I 7

Mittelmeer 34, 42, I 44, I 78, 2 I 4, 229, 243, 262

Mittelmeerraum 35, I I 8

Mittlerer Osten 424

Modrić 2 I 9

Mohács Io3f.

Moldau 8I, I32, I 35f., I38, I50, 239, 26 of.

Moldauwalachei 192

Monastir 43I

Monodendri I I 2

Monokklisia 49, 84, 97

Montenegro I4O, 208, 422

Morava 387

Moscholuri 36I

Mostar 356

München I 3

Muntenien 138

Mykonos I 7

Myriofytos 343

Mytilene 85, I 45, I 55

Naimonas 337

Nauplion 240, 267

Navarino 2 I 4

Naxos 57, 280

Nea Karvala 209

Neapel 34

Negotin 219

Neon Suli 260

Nicosia 183,202

Nigrita 258

Nikisiani 100

Nikopoli 205

Niš 77

Nordafrika 35, 243, 436

Nordalbanien I4O

Nordbalkanraum 94

Nordbulgarien 80

Nordgriechenland 45, 78, 84, I 44, I 72, 238,258 , 439

Nordostserbien 50
Nordpeloponnes 73, I 53, I6 I, I 85

Nordthessalien 87, 99, 36 I

Nordwestbalkanraum 89

Norinska Kula 2 I 8

Novi Sad 96

Novo Vinodolski 140

Nymfaio 62

Oberufer I $89 f$.

Odessa I73, 211, 240, 392

Ohrid 239, 360

Olib I40

Oltenien 136

Olymp 362, 408

Olympoi 177

Olympos 153

Orašac 274

Ordu I I 2, I 73

Orestiada I68f.

Ortakioi 168

Ortaköy 168

Osanići 218

Ostalpenvorland 89

Ostasien 229

Ostbulgarien 95

Österreich 69, I 92

Ostia 378

Ostmitteleuropa I 29, I4I, I 87, 2 I 7 ,

Ostmittelmeer 57, I 99, 2 I I , 26I

Ostserbien 50

Ostthessalien 147

Ostthrakien 284,364,376

Otranto 2II

Padua 28I

Pag I40, 193

Pakistan 436

Palästina $\mathrm{I} 78,354 \mathrm{f}$.

Paliokastro 99

Palotzenland 368

Pangaion 9I

Pannonischen Tiefebene 8I, I 50

Paros 146

Pasardžik 88, I 70

Patmos I 45, 373 
Patras I08, 21 2, 243f., 248

Pavia 353

Peć 239

Peliongebirge I44, 39I

Peristeri 343

Perivolia 147

Perovaradin 380

Persischer Golf 389

Petra 368, 372, 376

Petrusa I 24

Philippopel I 26

Piatra Neamț 192

Pieria 100

Pindus 98, 295, 305, 526

Pisoderi 99

Plaka 223, 24I

Plasa 440

Platanos 98

Plavna 2 I 9

Plovdiv I 26, 369

Pogoniani II 2

Polen I49, 2 I 8

Polyfyto 95

Pontus 80-82, I I 2, I 50, I 72, I 76, I 8 I, 20I, 205-207, 428

Portsmouth 214

Priština 263

Prizren 95, 239

Pylias 177

Rábatótfalu ${ }_{5} 6$

Radna 356

Radošić I 40

Ragusa 80, 2 10, 239f., 263, 386

Regensburg IIf.

Rethymno I54, I94, 398

Rhodopen 163

Rila 356, 395

Rilji 108

Rize 173

Rizus 173

Rupčosko I63

Rupite 356

Ruše 356

Rußland 5O, 4I4
Sammakovi I Io

Samobor 140

Samos 47, I77, 3 I 7

Samsun 373

Santa 173

Santa Maura 196

Santiago di Compostella 55, 354f.

Santorini 109

Saporoș 236

Sarajevo 45, 107, 235, 240

Sarakina 259

Sassoferrato 353

Schwarzmeer 4If., IOO, I I 2, I I 7 , I 22, I 28, I 72 , 205, 2 I I , 232, 239

Serbien 78, 90, 94, 96, I I 5, I 36, I 40f., I 49, I 57 , I 92, 2 I 7-2 I 9, 262, 289, 296, 325, 366f., 380, $400,4 \mathrm{I} 3,426,459,462,526$

Serenissima I39, I44, 262, 264, 267f., 36I

Serfije 98

Serres 49, 84, 97, 260, 295, 326, 404, 526

Sfakia 399,428

Siatista IOI

Šibenik I49, I 93, 2 I 8

Siebenbürgen I32, I35, I 37, I 92, 224, 26 If., 356

Siğırc1 92

Silistra 170

Silivri I 29, 343, 369

Silivria I 29, 343

Sinemorec 143

Sinai 39I, 393f., 408

Sinj 262, 268

Sinope 428

Sizilien 34

Skepasto 370

Škofja Loka 57

Skopelos 373

Skoplje 149,236

Skopos 259, 346, 369

Skulikado 262, 269

Skyros I I 3 f., I 83,459

Slavonien 88, 93, I 49, I 93, 2 I 8

Slivarovo I 43

Slovenien 39, 48, 80, 83, 85, 94, 96, I32, I39, I 49, 200, 2 I 6, 2 I 8,46 I, 465

Slowakei I 49, 2 I 8 
Smederevo I09

Smilovo ro9

Sokolica 380

Sozopol 129

Sparta 377

Spata 377

Split I4O

Srebren $\mathrm{I}_{3}$

St. Anna See 368

St. Gotthard 156

Steiermark 80, 86, 29I , 525

Stenimachos 337,364

Štip 239

Stoilovo I43

Stolac 2 I 8

Strandža 369

Strumica 236

Studenci 2 I 8

Stymphalia 73

Südalbanien 32, I 29, I 44

Südindien 229

Süditalien 34

Südmakedonien ıоo

Südostalpen 87

Südostasien 229

Südostbulgarien $\mathrm{I} 70$

Südosteuropa I If., I 5, I 7-2 I. 23, 30-33, 37-39, 4If., 46,49 f., $52-67,69$ f., $73-75,77,80-83$, 87-91, 93-96, I00, I02, I08-I Iо, I I 4, I I 7I 29, I 22 , I 27 , I $29 f$., I 32, I 35 f., I 39 f., I 43, I 46 , I 55, I65, I 70-I 73, I 80, I 89f., I 92-I 94, 205, 207f., 2 I of., 2 I 3 , 2 I 5, 226, 228 , 237f., 240, 243 , 247,253 f., $257,260-263,27$ of., 277,279 f., 282 , 290, 299-3 I 2, 3 I 4, 3 I 6, 3 I 9-322, 326f., 329, 33 I , 334, 336, 339, 34If., 347-349, 35 2f., 355, 36o, 362, 365, 374f., 379-38 I, 385f., 388, 390, $395,403,4 \mathrm{I} 2,420,428,43 \mathrm{O}, 434,436,455,459$, 463,489

Südpeloponnes 367

Südrumänien I I $4, I_{3} 8$

Südserbien 48, 8I, 422

Südwesteuropa 2 I

Südwestpeloponnes $43 \mathrm{I}$

Südwest-Ungarn 356

Suli 196
Šumadija 109, 274

Sušnjari 2 I 8

Sveti Naum 360

Syllimnos 369

Symi 85

Syra 153

Syrmien 235 f.

Szabolcs 20I

Szeged 73, I I 4, 356

Szék I 34

Szeklerland 356,368

Țara Oltului $136 f$.

Taygetos 357,367

Tbilisi 173

Tepeköy 440

Tepeleni 390

Thailand 229

Thasos 376

Theben I6o

Theiß I I 4

Thessalien 48, 62, 73, 91, 99-102, I 40, I 47, 25 O, 257, 342, 361, 391, 440

Thrakien 62f., 83f., or, 97-99, I I 7, I 22, I 3 of., I 63 , I68, 209, 259, 272, 276, 283, 3I 5, 3 I 8f., 326, $328,336-338,340,342-345,354,368 f$., 377 , $382,428 f ., 432-434,453,458,467$

Tiflis 173

Timok 326

Tinos $145,356,378 f$.

Tîrgu Jiu 225

Tolnar $\mathrm{I} 34$

Tomori 359

Transdanubische Fürstentümer 235

Transylvanien I 38, I 92

Trapezunt $\mathrm{I} 73, \mathrm{I} 75$

Trebižat 2 I 8

Trikala 73,400

Triphylia $43 \mathrm{I}$

Tripolis 243

Trogir 193

Tsakili 84,337

Tsanto 337,344

Tsepelovo 440

Tunesien 243 
Türkei 220, 24I , 439-442, 463

Tutraka 170

Tyrnavos 62, 109

Ukraine 8I, I I 7, I49, I 93, 2 I 8, 430

Ungarn 39, 42, 6rf., 73, 78, 8of., 87, 93, I04, I I3, I 32, I 34, I 4 of., I 48 f., I 5 I, I 54, I 56, I 76, I 87 , I 89, 204, 208, 2 I I , 224, 226, 255, 257, 260, 29of., 3 I 4, 320, 356, 368, 4I 7, 439, 46 I

Unteritalien 178

Untersteiermark 85

USA $25^{\circ}$

Üsküp 259,369

Uzunčiova 369

Vágfarcasd I 50

Valtos i $68 \mathrm{f}$.

Varoš 88

Vatikan 42 I

Vavyloi I 55

Veleš 239

Venedig 42, 65, 90, I79, 2 10, 262, 264-266, 268, $361,387,391$

Verbiani $43 \mathrm{I}$

Veroia 98

Vetren 163

Viden 170

Vincovici 76

Viza 343

Vize I Iо

Vizye I Iо, 343

Vlachogianni 6I

Vlčany I 50

Vojvodina 78, 93, I 4 I , 2 I I , 2 I 6, 290, 380, 462

Volenia 326

Volos 199

\section{SACHEN, TITEL UND BEGRIFFE}

Abbild-Urbild-Relation $35^{\circ}$

Aberglaube 300, 302, 348, 410, 433

Ablaßzettel 354

Abmessen 203, 255, 27I, 274, 343

abraši 4I 9
Vonitsa 43 I

Vorderer Orient 436

Vorderer Osten 4I 5

Walachei 80, $226 f$.

Weißrußland I 49, 2 I 8

Westbulgarien 85,4 I 8

Westeuropa 23, 35, 228, 30I, 3I 4

Westgriechenland I 45,440

Westkreta 395

Westmakedonien I7I, 39 I

Westpeloponnes I47, 43 I

Westungarn 88, I 89

Wien I3, 21 7, 226, 240

Windischdorf 156

Xanthi 84,360

Xirokampos 99

Yenice 370

Zabernovo 143

Zadar 267

Zagori-Dörfer I I 2, 4I I , 440

Zagreb 2 I 9

Zante 90, I07, I 45, I 79f., I 94-I 96, 2 I 2, 258, 262, 265 f., 268 f. 28 I, 376

Zentralasien 2I, 35

Zentralbalkan 64, 87, I I3, I 29, I38f., I44, I 7 I, 260, 356, 362, 4I 5, 46 I

Zentralbalkanraum 89

Zituni 36I

Zwischenmurgebiet I4O, 2 I 9

Zypern 4If., 62, 7 If., 90, I I 9, I32, I 50, I 7 I I I 78, I $83,207,250,255,259,262,263,315,355$, 39rf., $449,45^{8}$

Abwägen I30, 279

accommodatio $5 \mathrm{I}$

Adam i Eva 189

Adam-Legende 360

»Adela und der König« I 92 
adelphotis 374

adiaphora 303, 499

adoptio in fratrem I 35, 388

Adoption 403

Advent 42, I49

adynata 408

aedicula 309

afieroma 379

Agape-Fest 4I, 381, 395, 397

Aga-Spiel I77

Aglaia 249

Agon 52, 59, I6o, I69, I 84f., 253, 345

Agonales Spiel $256 f$.

Agonalspiele $258 \mathrm{f}$.

aiditsa 82

$a k b a b a$ I 8 I

Akklamationen 403

Akkommodation 347, 427, 437, 449

akolutbia 392f., $40 \mathrm{I}$

Akoluthien 384, 387, 389, 393, 401, 402

Akritenlieder 374

Akrostichis $402 \mathrm{f}$.

ala 4I9

Alaiuri I9I

Alb 4I9

Albaner 387,392, 420, 43 I, $45^{2}$

Alchemie 270

"Alexander d. Gr. und die verfluchte Schlange« $245 \mathrm{f}$.

Alexanderroman 360

"Allerseelen« 208

Allerseelenzeit 430

Almosen 86, 260, 428, 430

Alogas I74-I76

Altertum 2I, 33, 35, 202, 207, 229, 256, 270, 272, 278, 28 I, 3 I 3, 325 f., 334f., 382, 4 I of., 428, 44of., 449

Amateurtheater 30, 39, I56, I 86, I9 I

Amazonismus 426

Amulett 2if., 35, 45, 87, 202, 27 I, 277f., 280, 296, 30of., 3 I6-3 I 9, 324, 337f., 348, 350, 35 2, 357, $378,443,467$

Analogie I8, 2 If., I46, I 50, 270, 275-278, 299, 30 I, 309f., 3 I 3f., 3 I 9, 338f., 348f., 432, 434, 446, $449-45^{2}, 455$
Analogiehandlungen 74, 78, I 27, 200, 269, 433, $442 f ., 445$

Analogiezauber $27 \mathrm{I}$

anaskelades 4I 5, 42 I, 466, 5 O I

Anastasis 308

Anastasis-Ikone 37, 3 I 2, 449

anastenaria I04, I 24, I30, I63, I66, 279, 295, 3 I3, $326,383,495 \mathrm{f}$.

anathema 54, 219,379

Anbinden 61, 3 16, 3 19f., 322, 325, 330

anemoneria $35^{\circ}$

Animismus 256, 276, 329, 432, 434

anombria 402

"Anul Nou și Anul Vechi« r 9I

Anschwärzen 36, I 33

Ansingelieder 50, 54, 59, IOI, I 9 I

Ante $i$ Pante 2 I 9

anthismos 374

Anthomorphie 70

anthophoria $374 \mathrm{f}$.

Antike 2 I, 3 I, 43, 52, 86, I06, I 24, 250, 275, 28of., 308, 3 I о, 332, 335, 342, 353, 375, 378f., 38 I, 4I If., 428, 436, 442, 449, $466 f$ f.

Apokryphik 270, 313, 324

"Apophatismus« $35 \mathrm{I}$

Apotropäum 22, 45-48, 68, 90, I30, I 52, I 55, 202, 325, 34I, 382, 443, 445

Araber 2 I, 23 I

"Araber«(Maske) 84, 88, 9of., 93, 98, ıoof., ı03, Io9, I I I, I 23, I 44, I 47, I 49, I 53 f., I 58 , I 6o, I69, I 76, I 8 I, I 9 I , I 97, 25 8f., 377, 4I 5

arap oyunu $9 \mathrm{I}, \mathrm{I} 54$

arapi I08, I 43, 459

arapides $90,42 \mathrm{I}, 466,5 \mathrm{OI}$

arapin 90, $42 \mathrm{I}$

arapis 90

arapissa 4I 5

arapki $\mathrm{IOO}$

arapkoi 102

arapul 90

Arbeitsverbote 44, 5 I, 53, 334, 350, 363

Arcașii I 34

"Aretokritos« 269

»arktos« 86

arlioti $266 f$. 
Armenier 140, 199, 232, 239, 305, 440 arnăutii I I $\mathrm{O}$

Aromunen 50,62, 78, 94, 98, I35, I42, 238, 325, 356,391

ars combinatoria $22,395,418,453$

arugutshari 98,238

Arvaniten 98, I IO, 259, 39 I

Arzt (Maske) 67, 84, 99-103, I Iof., I I3, I44, I 47 f., I 5 O, I $52-$ I 55 , I 58 , I 60, I68, I 72, I 74 , I 76, 249, 278, 28I, 440

Arztparodie 158

Asche 36, 45, 47, 67, 85, I03, I Iо, I I3, I64f., 202, 31 8 f., 329

"Aschenfrau" I00

Aschensack 91, I04, I6If.

Aschermittwoch 4I, I32

Askenasen 305

aspasmos $37,37 \mathrm{I}, 384,393$

Assoziation I 8, 40, I47, 31 3, 4I 8, 446, 45 of., 455

Ästhetik I 2, I7f., 37, 5 I, 79, 348, 433f.

Astrologie 270, 327, 339,4I 2, 454

Aufklärung 39, 2 I 3, 300, 302, 304, 339, 347f., 388, 4I I , 434, 524

Augenamulett 3I8, 44I

Augenstein 202, 438

Ausrufen der Altjungerfern I 33f., I 39, I 49, 223 , 247

Aussetzung 202

axis mundi 342

áyin hā-rá 436

ayn al-hasūd 436

aždaha 4I 9

ažder 42 I, 488

baba 46, 89, I00, 109, I 40, 143, 224f., 232, 243, 326,359

Baba Himmet 232

Baba Hwaneb 243

baba-seh I I I

babaiurdes 102

babajurdes I02, I 47

babice 50

babin den 49, 63, 96f., 109, I 23, 422

babingün 49,63,96

babine rubi 50 babka 45,423

babo 108, I64, I66

baboerides 102

babogeri 90

babogeroi 9I

babska Paska 50

babski velikden 50

babugeri $\mathrm{I}_{43}, \mathrm{I} 63$

babugeroi 108

babušar 82

babusarari 108, I 43

babušaria 90

Babylonier 330, 436

"Bădica Traian« I 9I

bădnik 45, 423

bădnikăt 423

badnjak 45

bădnjak 423

badnjeg dan I4I

bailo 265

baïraki $\mathrm{I} 30$

bajazzo I I If., 224, 226

Bak-Husar I 34

bakira $\mathrm{I} 82$

Balkanisierung 456

balkanizacija 20

Balkanliteratur I 5

Balkanologie 27-3 I

Balkanpatriachalismus $20 \mathrm{I}$

Balkanpatriarchat I9

Bannsprüche 46

Barba-Giorgos 245

barbutes I08

Bärenführer 87, I00, IO2, I Iо, I44, I68, 224, 29 I, 525

Bärenjagen 87

Bärenmaskierung 86

barjaktar(uše) 93

Barock I78, 261, 348

Barockdramatik 406

Barocktheater 280

barriera $253,263 \mathrm{f}$.

basilti 59

baskania 2 I, 33, 202, 3 I 8, 338, 436f., 440 
baskanos ophthalmos 440

baubo-Kult I 24

"Baumerhöhung" 55

Bauopferlegende 3 I 9

bauta 107

bazar 359, 361, 365, 445

bebek oyunu 220

Beberubi 222

Begräbnis 4I, I I 5-I I 8, I34, I 59, 207f., 328, 350, 428

Begräbnis des Karnevals I I 4, I 54

Begräbnisparodie I 49, I 52, I 54, I 60, I67, 407

Begräbnisritual I 54

beïraktars 387

Bektași I 22f., 304, 359-36r, 380

bele babe ro8f.

Belletristik I I, I 5, I 8, 36 I

Benediktion 350, 378, 384, 395

berigln 89

Bertoldo 222,362

Beschwörung 271, 275f., 320, 442

Besprechen 271, 274, 32 of.

Bethlehemspiele I 90

betlehemari I4I

betlejka I49, I 93, 2 I 7

betlemaši I 49, I 93, 2 I 7

Betyaren I 9of.

Betyaren-Spiele I9o

Betyarenlieder I 90

Beweihräuchern 55. I 26, 50 I, 44I

bey I60, I63, I68f., I 7 I

Bibel 3 I 7, 343, 447-449, 45 I

Bibelsprichwörter 349

bibliographie raisonnée I 2

Bibliographien I 2 I, 457 f., 460

Bilderverehrung 350

biljarka 4I9

Bindezauber 61, 3 I 8, 320, 325, 335, 343, 429

Biophilie 276

bir i lugats 4 I 9

birău 136

Bittlitanei 54, 57, 78, I3 I, 3 I6, 337f., 362f., 404

Bittmesse 302, 346, 357, 40If.

Bittprozessionen 384, 401, 404

Blasiustag I 33 blaženo drvo 45

blemma poniron 436

"Blick-Perle« 436

Blochziehen 86, I 29, I33f., I 56

Blutsbrüder 260, 384

Blutsbrüderschaft I 35, I 38, I 52, 395

boeniško boro 95

Bogomilentum 305

Boritzen-Waffentanz I 50

Böser Blick 33, 273, 338

Boul 33, I92

božićar 48

božja liturdijica 44

boszorkány 326

brat 390

Brauch I 5, 22, 28, 36, 39f., 43, 52, 55, 63, 73, 77, 90, 92, 96, 98, I I I, I I 5-I I 7, I 2of., I 39, I 46, I60, I62, I64, I66, I68-I 7 I, I 73, I 93, 209, 220 , $25^{8-260,269,329,343,369,377,38 ~ I, ~ 386, ~ 388, ~}$ 390, 393, 396f.

Brauchtum 109, 261, 280

Braut 45, 47, 56, 63, 94, 99f., I 24, I 57, I 59, I6 If., I 95,435

»Braut«(Maske) 77, 93, 96, 98, ro2f., го9, i I I, I 43, I 48-I 50, I 5 2-I 54, I 74-I 76, 205, 256

Bräutigam (Maske) 98, I 8 I

Brautpaar 67, 92, I Io, I4I, I 56, I 58, I65, 256, 396, 391, 396

Brautraub I I , I 47, I 55, I60, I72, I 83, I 97, 204

Brautschau 359, 368

Brautwerbedialoge 200

Brautwerbung 201, 206

brezaiă 80

brezaja 88

briki 340

brodnica $4 \mathrm{I} 9$

brontologia 334

Brot 50, 78, 84, I65, I67, 202, 208, 260, 3 I 8, 328 , 339f., 343f., 402, 43 I

Brotorakel 330

Brotweihe 366, 368f., 430

Brunnenorakel 329

»Brustbrüder« 385

bubaroi 147

bubucheria Io8 
bubunes $\mathrm{I} 28$

bucium 138

búcsú 368

Budelmutter 89

buenec 95, I 20

bugani dni 44

»Bujor« I 9 I

buklijaš I 57

bules I08, I 47, I 85

Bulgaren 48, I 70, 365, 368, 387, 395

bülük $22 \mathrm{I}$

burani rogf.

»Burani« 62

Burschenhaus 58, I34, I36

Burschenschaft I $34-$ I 38 , I77, I 9 I

buše Io9

Busó I03

Bußmesse 408

»Büyük Evlenme« 24I

buzdugan I 36

buzeštini $\mathrm{I} 4 \mathrm{O}$

Byzantinistik 323,454

calendae 43, 59

caloianul i I 5 f., I $9 \mathrm{I}$

călușarii 53, 62, 85, I I о, I 34, I36, I 38, I 5 I , 26 of., 279,425

Čamalari 459

cămilă 85

candela 402

căpitanul I Io

capră $79 f$.

„Capra cu Împerăti« I 9I

căprari $\mathrm{I} 38$

car I IO, I 44

car 4 I 9

cara Lazara 95

cărăbiț 94

caracandzali I 35

caraghios 236,238

caraghioslic 238

caraice 93

caraice $\mathrm{I} 42$

carodeec $4 \mathrm{I} 9$

carojice $\mathrm{I} 4 \mathrm{O}$ čarownica 4I9

caroonik 4I 9

case studies 2 I, 207, 309

čauš I I O, I 57

čauši I I

cavud I 57

"câzûlar« 233

Celebi 232, 236, 362

çem I 23

Cerbarul I92

cerbut I 37

cerbutul I 37

chadżii 355

chaimali 443

chala 4 I 9

chamodrakia 4I5

char atchk 436

charačari 143

charivari $\mathrm{I} 33$

Charon 466

Charos 306, 322, 357,466

Charta 257

chashm zakhm 436

cheriko 328,340

cheshim mora 436

cioc 152

chamodraki 3 I 9, 4I 5, 42 I, 5 O I

„Chasis« I 94

chizesi 138

choro I43

Christblock 45, I 26, I 4 I, 34 I, 422

Christen I 22, I 79, 242, 343, 364, 397f., 400, 428, 438,448

Christentum 378, 410, 439, 449, $45^{2}$

Christgeburtsspiel I 89

Christi Himmelfahrt 94, I 30, I 38, 429

»Christus patiens« 3 I 2

"Chronographia« 437

»Chrysavgi« I80, I95

chuchuti ro8

„Cica-Maca« 220

cigančica 44

cigani Io8

cigánybál Io7

cin bratotvorenja 385 
cîneru I 36

circusant $\mathrm{I} 57$

cisti ponedelnik 63, 128

Cocoana Marita 224

Codex Justinianus 388

cognatio spiritualis 203,385

coincidentia oppositorum 276, 301, 308, 407

colăceri $\mathrm{I} 38$

colida 43

colinda 59, 80, I 35 , I 37

colindat $\mathrm{I} 34$

colindători $\mathrm{I} 35$

colinde 43 , I 34

colindet I 35

colindeți I 36

Commedia dell'arte I 94f., I 99, 2 I I, 22 I

"Constantino Brîncoveanu“ I 9I

corna 36

Corpus Christi 57

correr all'anello 253,268

corse all'anello 265

corse alla quintana 90

couvade 203

craite 152

Crkva na Tekijama 380

Csángómagyaren 150

csárdás I 34

cuca $\mathrm{I} 5 \mathrm{O}$

cuci I $7 \mathrm{I}$

culinda 59

čuma 283, 426

cununa grîului I 34

Dachgleiche-Riten I 33

dada I 4 I

dames 98

Dämonen $44-47,5$ I , 54, 67, 79, 88-90, I 39, 202-204, 274, 278, 3 I 6f., 320, 337, 34 of., 344, 376, 394, 405, 409, 4I I , 4I 6, 4I 9, 422-427, 432, 445,460

Dämonenbesessenheit 273, 3 I 8, 40 I

Dämonensagen 4I4

Dämonologie 90, 247, 403, 407, 409f., 4 I 2, 4I 8, $424,433,453 \mathrm{f}$., $465 \mathrm{f}$.

Das Jüngste Gericht I 89
»Das Opfer Abrahams« I 95

debele babe Io9

ded i baba 47

deda I4I

Deda Mraz I4I

dedica I4I

dedice IIO

dedici $\mathrm{I} 43$

dednik 45, 423

deesis I $3 \mathrm{I}$

deilino I I 8

Demetria 338

Demetrius-Ikone I 6

Demetrius-Legende I 6

deochi 436, 44 I

„Der grüne Tisch« I 92

„Der Karpather oder der eingebildete Verliebte« 444, 446

„Der Liebhaber der Schäferin« I 95

»Der Pilger aus Moskau und der großmüthige

Sultan« 2 I 4

»Der Tod des Athanasopulos« 249

"Der Tod des Palikaren« $28 \mathrm{I}$

Dervenagas 249

derviši $\mathrm{I} 43$

Derwisch 88, I 10, I 22f., 305

descensus ad inferos 56. I 46, 303, 3 I 2, 449

»Despo« I 95

dev 4I 5

deve bași 92

dever rogf., I 43

devetini 428

devojki $\mathrm{I} 43$

dew 4I 5

Diagnostik 270, 443

Dialektkomödie 444

Dialektologie 248

Dialog i ff., 30, 39, 59, 86f., го3, I го, I 20, I 44I 46, I 48, I 56, I 58, I 93, I 97 f., 200, 208, 2 I 9 f., $224,227,232,236,269,402,463$

Dialogspiele I 52, I 58, I 78, I 8of., I 84-I86, 20 I, 206, 255 f., 259 f., 3 I 9

diapompeusis 35

didi 82,89, I09

didici 82,89 
"Die Hochzeit des Karagiozis» I6 I, 238

„Die Sünde meiner Mutter« 343

„Die unglückliche Liebe« 195

dif 4I 5

»Digenes Akrites« I69, 309, 374

dikolon $\mathrm{I} 74 \mathrm{f}$.

Dionysoskult 43, I06, I63, I67, I 70

Diskuswerfen 257

ditzimin $\mathrm{I} 82$

div $4 \mathrm{I} 5$

diva 424

diver 93

divinatio artificialis 328

divinatio naturalis 328

diw 4I 5

"Djed i Baka« 220

do-ut-des 54, 307, 375, 496

dodola 74, 78, I I6, 404, 4I 8

"Doppelkypros« 9I

dottore $28 \mathrm{I}$

doxologia 354

Drache I42, I 94, 255, 334f., 360, 372-374, 4IO, 4I 4f., 4I 8, 42 I

Drachentöter 87,247

Drachentötermärchen 248

Drachentötung 374

Dracula 4I 8

drakaina $4 \mathrm{I} 5$

Drake 247

drakopula 4I 5

drakontas $4 \mathrm{I} 5$

drakos 44, I 27, 4I 5, 4I 9, 42 I

drakusi $\mathrm{I} 43$

drangue $4 \mathrm{Igf}$.

Dreifaltigkeits-Tag 432

Dreikönigsspiel I 4 of., I 49, I 88, I93, 2 I 8

Dreisprung I 8, I69, 256, 258

Dromedar 82

dromenon 28, 59, 71, 92, I 50, I65, 207

dübelek $9 \mathrm{I}$

dumutsi 60

duszas 90

"Dva mladića 220

"Dva strašila《 220

dvedeset 428 dvorkinja 93

dyligaroi $\mathrm{I} 23$

Dynamismus 276

Dysplasie 4IO, 435

džamala 84,89 , I $23 \mathrm{f}$.

džamalacka 84

džamalari 85, I02, I08, I Iо, I 43

dzhamalari 98

džindžii $4 \mathrm{I} 9$

ecclesia 407

Efe ve Kadi oyunu 154

Ei-Orakel 329

Eingeweideschau 48,329, 335

Eintrittsritual 204

Einzug Christi in Jerusalem $187 f$.

Ekstase I34, I 52, 325f., 4I 3

Elitekultur 23, 32, I 44, 2 IO

Empirische Therapeutik 30, 269, 271, 273,464

Empuse 4II

enata 106,428

Epiphanie 42

"Epirotisches Glockenbrett« 64, I I 4, I 20

Epitaph 37, I 29, 274, 280, 3 I 2, 3 I 8, 35 8, 442

Epitaphumzug 52, I 45, 209, $375 \mathrm{f}$.

Epode $167,274,443$

Equidenmaske 79, 83, 26I

Erbsenbär 86

Erkennungsverbot II 3

„Erofile« I45, I80, I94-I96

"Erotokritos« I 80, 195, 262, 265, 269

Erzählforschung 37

Eselfeste 407

eškari 102, 108, 143

»Esme« I 93, I 95

Ethnochoreologie 30

Ethnolinguistik 49

Ethnologia Europea I 2 I

Ethnologie 25 I, 433

Ethnomedizin 269f.

Ethnomusikologie 32

euche hiketerios 403

euchologion 393f., 397, 40I, 408, 437

euchologia 384

Eueteria I3 I 
Eueterie 59, 90, 254

"Eugena" 194, 265

Euphemismus 22, 278, 319

eusebeia 303

Evangelismos 364

evil eye $33,35,277$

"Evolution« 38

Exhumierung 208, 417, 429

Exorzismus 319-321, 402

faček $8 \mathrm{I}, 83$

fagiolino $22 \mathrm{I}$

„Fäkalienvögel« 3 I6

farsang 5 I, I09, 133

farsangkönszöntes $\mathrm{I} 32$

"fartati« 39I

fašanek $\mathrm{I} 4 \mathrm{O}$

fašange 109

Fasching 43, 5 I, 73, I03, I05, I08f., I 40, I 56, I 76,

I $83, \mathrm{I} 95,330,350,430,479,490$

Faschingsbegräbnis II 4, I I 7, I 29

Faschingsfeuer I I 2

Faschingskönig I7 I

fasil 232

faskela 36

Fastnachtsspiel I90

fasulein $22 \mathrm{I}$

fasulis $2 \mathrm{I} 7,22 \mathrm{I}-223,228$

Faustkampf 257 f.

Feen 53, 89, 26of., 274, 334, 342, 376, 409, 4I 5$4 \mathrm{I} 7,422,424,426-428,480$

Fehdeverpflichtung 397

»Ferhad und Schirin« 232, 247

Festkleidung 39, 64, 68, 77, 92, I09, I 37, I6o, 336,368

»Feuerhochzeit« 45

Figurentheater 148

filipovicice 76

filtra $\mathrm{I} 20$

"Fiorentinos und Dolcetta" I 80

Fleischwoche 4I, 49, I 53, I 77, 429

Fluch 219, 284, 320f., 396f., 438

Flüchtlingsvolkskunde I 25,467

Flurprozessionen 134,338 focari 136

Folklore I I , 23, 32, 42, 76, 94, I07, I 2 I, I 52, I 94, $30 \mathrm{I}, 306,4 \mathrm{I} 2,448,450$

Folklore-Theater 28, 30

Folklorismus 66, 68, I I 2, I 2 I, I 93

Folkloristik 27, I2 I

forte vecchio 266

Francek i Vanček 219

„Frankos« I I 3

frater adoptivus 338

Frauenbrauch 49

„Freiheit oder Tod « 387,390

Fronleichnam 55, 57, 280

Frühlingslieder 94

Funeralprozession 73, 207

fuskodentri 73, I I 7

Fußwaschungsszene 145

fustanella 98f., , I02, I I If., I 53

futadis 102

fylakto 3 I 7, 337, 443

gaitani 98

gajda 9I, I43

gajdar $\mathrm{I} 43$

gambela $82 \mathrm{f}$.

gamotraguda 408

"Gang Mariae zu den Höllenqualen" 430

garabonciás 326

gărmež I I 6

Gáspá 2 I 9

Gáspár i Melko 2 I 9

"Gáspár i Melko« 220

Gaukler 2 I I

Geamala 22 I

Gebärden I 5, I7, 30, 32f., 35-37, I 53, I64, 258 , 272, 300

Geburt 20, 4If., 44, 67, 202f., 263, 276, 324, 34I, 364,443

Geburtsparodie I 53, I 58, I 79

Geburtstagsparty 200, 263, 268

Gegen-Aufklärung 19

Gegenreformation 187, 193, 300, 339, 347

Gegenzauber 316, 3 I 8, 432, 434, 440

Gello 4I I, 4I 9

gender roles $5 \mathrm{I}$ 
gender studies 20

genius loci 342, 4I 5

"Genoveva de Brabant" I9I

Gerichtsspiel 87, 93, I 45, I 59 f., I 7 If., I $74-$ I 76 , I 78 , I 8 of., I 83 , I 95

german 64,73 , I09, I I 5 f.

germančo II 5

geroi $\mathrm{IO} 8, \mathrm{II} 3, \mathrm{I} 83$

Geschlechtswechselverkleidung 43, 5 I, 93, I I 2

Gesichtsmasken 91, 98

Gesten I 5, I 7, 32-34, 38, I 75, 3 I 8, 346, 434

Gewichtheben 256, 258

geyik oyunu $\mathrm{I} 54$

Gilgamesch-Epos 360

giostra 55, 90, 262, 265, 269

giostra all'anello 264

giostra alla quintana 268

giostra degl'arlioti 266

giostra dei stradiotti 266

girafă 85

Glaubensvorstellung I 2, I6, I 8, 78, I 26, I 58, 203,

$253,255,276,283,300 f ., 306,3$ I 4 , 326, 334,

$34 \mathrm{O}, 37 \mathrm{I}, 406,42 \mathrm{O}, 426,433,435$ f., 45 I

glogove $4 \mathrm{I} 9$

glossofagia 440

glumac 157

goagă $\mathrm{I} 37$

godenice 95

"Golfo« 195

gonosz szem 486

gorgona $4 \mathrm{I} 5,425$

göstermelik 243

Grabbesuch 47, 208, 260, 428-430

graćenici ro9

graffiti 436

Granatapfel 46, 6I, I 26

Gregoriustag 133

Griechen 3 I , 33, 36, 86, 91 , 98, I I 2, I I 9, I 78 f., I 8 I, I 99, 203, 205-207, 222, 237, 246, 284, $389 f ., 420$

grosi 165, I 82

Großfamilie 390

groznica 380

"Gruia lui Novac« I9If.

Gründonnerstag 4I, 70, 31 7, 337, 363, 430
Gründungslegenden $35^{\circ}$

Grünverkleidung 73,405

Gynaikokratie 97

"Haarbrücke« 432

Habergeiß 79

hac 355

haci 355

Haçivat I 98, 232f., 239 f., 243

Hades 56, 303, 3 10-3 I 2, 430

Hadesfahrt i i $6 f ., 449$

badjdj 355

Hagel 48, 55, I3 I, I 34, 334, 337f., 364, 402, 429

Hagi Ivat 22 I, 239, 357

Hagia Sophia 407

Hagia Triada 432

hagiasmata 56, I 24, 316, 342-345, 350, 369, 405

bagiasmos 56, I28, I38, 336, 338, 350, 357, 364, 4 oIf.

baiduci 192

Hajduken 190

hajjī 355

bakija $23 \mathrm{I}$

hala $42 \mathrm{I}$

balka-Stechen 262

bamail 443

hamam 233

"Hamam« 242

bamayli 3I7

»Hamsa«-Amulett 35

"Hand der Fatima« 35

Handelsmärkte 304, 359-36r, 368-370

Handpuppen 218

Handschattenspiel 228, 240

Hans-Wurst-Streit 199

hanumissa 84

harapis 90

Harapu I9I

Hatman 236

Hatziavatis $246-248$

hatzis 354

Hebamme 49f., 63, 84, 97, I09, I 53, I 58, 20 If. 270

Hebammenfest 4I, I 23, 4I 2

Hebräer I 79, I 99, 24O, 245f., 249, 3 I I, 403

Hegemonialkultur I9, 2 I I 
Hegumenos 396

Heilanleitungen 279, $28 \mathrm{I}$

Heilige(r) 7 I , I I6, I 28, 203, 270f., 280, 308, 343, 349f., 359-36r, 363, 365, 367, 369, 37 г, 376f., 380, 383, 395, 397, 406f., 4 I I , 4I 3, 447

Heilige Quellen 344

Heiligenfeste 42, I 24, I 2 7, 346, $368,370,382$

Heiligenkult 305, 35 of., $358,362,378$

H1. Basileios-Tag 59, ro I

H1.-Geist-Sonntag 43 I

Hl. Georgstag 258

Heilkulturwissenschaft 270

Heilpraktiken I 52, 27of., 280, $282 \mathrm{f}$.

Heilspruch 275

Heiltänze 53, I 5 I, 279, 313

Heirat 42, 56, 8I, 256, 263, 368, $380,3_{3} 87$ f.

Heiratsorakel 280,332

Heiratsparodie I Io

Heiratsverbot 385,389

Heldenlied 93, 205, 419, 424, 426

hemiplegia 152

heortologion 39, 42, I I 8 , I 20, I 35, I 44, 200, 373, 375,427

»Herodeskasten« I 48f., 2 I 5, 2 I 8 , 2 20, 224, 464

Herodesspiel 192

hesperinos 395

Heterochronie I I I

Hexapterygen $57,209,358$

Hexen 227, 233, 3 I 4f., 326, 409, 4I I , 4I 5f., 4I 8, $422-424,440,472$

Hexenmaskierung 89

Hienzen ${ }_{5} 6$

bieros chronos 52, 304, 340, 365, 368

hieros logos 448

bikesia 405

„Hinkende« I 84

»Hinkender Dämon « 422

Hippodrom 35, 85, 87, I 39, I68, 2 I 2, 22 25, 259

"Hirschkuh« 82

Hirschmaskierung 80

Hirtenspiel I49, I 83, I 88

Hochzeit 20, 4I, 45-47, 55, 67, 8I , 84, 86, 92, I 27 ,

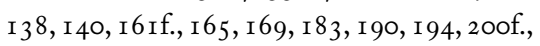
205, 207, 21 18, 228, 236, 293, 319, 337, 379, 383 , 391,396
»Hochzeit des Kutrulis« I6 I

Hochzeitsbräuche 6I, I I I, I 26, I 36

Hochzeitsfahne 137

Hochzeitsführer 93, ro9

Hochzeitslamentation 205

Hochzeitslieder 94

Hochzeitsorakel 208

Hochzeitsparodie 94, IO I, I 34, I 5 2, I 55-I 57 , I65, 407

Hochzeitstravestie I Io, I 58 f., I 67

Hochzeitszeremonie I60, I93, 204, 207, 235, 390

Hodscha 102, I60

Höllenfahrt Christi 449

Holzmaske 80, 90, I03, I 37, I42, I 50, I 93

Homiletik 448

Homilie 70, 3 I I

»Homilien«-Theater I 45, I 80, I 94, I 96, 269

horă I 38

"Hora« I9I

"Hora Unirii« I 9 I

Horoskop I9, 21, 23, I68, 301, 329, 339

Humanismus 140

Hunde-Bey I08, I63, I68

»Hunde-Montag" I 29

»Hundebursch" 94, I36

Hundsköpfige 4I of., 4I 4

Hymnik 308, 447

Hypertrichose 435

hypsoma 54, 56, I29, 316, 344, 367

iana 424

"Iașii in Carnaval« 238

iatrosopbia 2 I, 28 I

ibrik 340

Idol 52, 6 г , 63, 73, I09, I I 4-I I 6, I I 8, г 20, 3 I 9f., 35 I, 372

Idolatrie $300,302,347,352,405,410,447,45^{2}$

Idolbegräbnis 64 , I I 7, I 35

Ignažden 422

Ignatul porcilor 48

Ikone 42, 6 I , I I 6, I 26, 203, 209, 247, 280, 294, 300, 303, 3 I If., 3 I 9, 336, 343, 345f., 348, 35 O$354,356-358,367,374,377,394-397,402,405$, $432,44 \mathrm{I}, 443,525$

Ikonenkuß 370 
Ikonenlehre $37 \mathrm{I}$

Ikonenmantik 328

Ikonentheologie 447,449

Ikonenumzüge 55,338

Ikonenverehrung $35 \mathrm{I}$

Ikonenwand 350,377

Ikonenwaschung I 27, 284

Ikonographie 247f., 3 10, 35 2, 423, 437, 444

Ikonoklasmus $35 \circ, 447$

Ikonolatrie $35^{2}$

il moro 90

Imagination I 2, I 7-I 9, 22, 27f., 43, 79, 260, 3 I 4, $322,339,409,427,434,446,448,450,453$ f., $457,460,466 \mathrm{f}$.

Imam $344,438,452$

impresario 2 I I

Improvisationstheater 2I I, 228, 250

incantatores $\mathrm{I} 5 \mathrm{I}$

infamus digitus 35

Initiation 70, I34, I38, 206f., 355, 357, 377

Instrumentenspieler 33, 96, I 74, 206, 2 IO

Interaktives Rollengeflecht 105, I46

"Ion Papușilor« 226

"Irod« I 9 If., 220

ishk'nari 98

Islam 202, 296, 300, 305, 31 7, 327, 332, 344, 350, $353,355,35$ 9f., $368,380,387,392,4$ I I , 42 2, $447,452,454$

Islamisierung $2 \mathrm{I}$

Ivica i Marica $2 \mathrm{I} 9$

"Ivica i Marica« 220

Ivo i Ante 219

Jahresfeuer 45

Jahreslauf 39f., 8 I , I 20, 46 I

Jahreszyklus 40

Jahrmärkte I 83, 359, 368

Jancsi Paprika 2266 .

jankele $\mathrm{I0} 3$

jatagana 93

Jenseitsglaube 427

Jesuiten 57, I09, I 49, 357, 406

»Jianu" I $9 \mathrm{I}-\mathrm{I} 93$

"Jocul del mare« 192

jocul papusilor 215, 223-225, 234 jouste 264

juda 424

Judaismus 350,353

Judas I 29, I 45, I 78, 308

Judaskuß 58, 37 I, $45^{\circ}$

Judaspuppe I I 4, I I 8, I 79

Judasverbrennung 63, I I 9 , I 24

jude $\mathrm{I} 34$

judia $\mathrm{I} 34, \mathrm{I} 37$

Jugendkultur I 39

Jungfernschaftskontrolle 284

Jungtürkischen Revolution 233

Junii $\mathrm{I} 34, \mathrm{I} 38$

juzi $\mathrm{I} 37$

"Kabale und Liebe« 228

kadı $\mathrm{I} 72$

kadi I6o, I69, I72, I74-I 77

kadija $\mathrm{I} 43$

kadina $\mathrm{I} 69,258$

"Kaiserul« I9I

k'alanda 59

k'alandoba 59

kalanda 43, 49, 55, 5 9f., 79, 98, го०, го5, г 20, І 26 , I 36, I 47, I 74f., I 93,402

kalanta 59

kalindrades I02, I47

kal'katzar 102

kalikantzaroi 43f., I02, I I I , 340, 4I 2, 4I 5, 42 I

kalinarke I4I

kalkagan oyunu $\mathrm{I} 54$

kallinitsa I 24

kollitiria 249

kalogeroi $\mathrm{I08,}$ I64f.

kalogeros 82, 98, I24, I 50, I60, I62, I64-I68, I $7 \mathrm{I}$, 220, 259, 459 f.

kalojan IO9, II 5 f.

kalotychos 328

kalugeri $\mathrm{I}_{42}$

Kamel 79f., 83, II 3, I53, I60, I72, I 82, 233

Kamel-Spiel 183

kamela 80

kamelce 80

Kamelopard 82

Kamelverkleidung I 23f., I 9 I

kamila 85 
kamile ro9

Kampfspiele I 52, I 85, 259, 359, 366, 404

kamu(d)zelles 108

„Kanlı Kavak« 233, 340

kannavos I I 7

kannavuri 63, I I 7

kanon hiketerios $402 \mathrm{f}$.

kapa $\mathrm{IO} 3$

kapetan I I O, I 53, I60, 390

Kapetan Manusos 249

»Kapetan Michalis« 387,397

kapetanareoi 102

kapetane I00, I47

kapetanios 99

kapetanissa I 53

kapistras I66

kapnisterion $40 \mathrm{I}$

Kapuziner 57

karababa I 8 I

Karagiozis I6 I, 223, 238, 239f., 242, 244-246, $248-250$

karagjoz 238

Karagöz I 98, 22 I, 224, 232-234, 237-24I, 243, 248, 292, 463

karakandžula 44

karakantzalia 102

karakonio 420

karakonçolos 422

karakondjolos 420

karakondžar 420

karakondžeri 4 I 9

karakondžo 4I 9

karakon(d)žovi dni 44

karakondžula 44, 420

karakondžule 4I 9

karakondžuli 422

karakotzadoi I76, I8 I

Karfreitag 4I, 52, 56, 6I , 63, 70, I I 8, I 46, 358, $37 \mathrm{I}, 375,429$

karkanxhol 420

karkanzhól 420, 422

karnavalia 102, , 08

Karneval 36, 39, 4I-43, 49, 5 I, 54, 62-67, 79, 84f., 88f., 92, 96, 98, IO I, I03, I05, IO7-I IO, I I 2, I I 4, I 2 I, I 28 , I 32-I 35, I 37, I 39f., I 43-I 45,
I 53f., I 57, I62-г69, I 7 If., I 74, I 76f., I 79f., I 85 f., I 93, I 97, 22 If., $225,238,26$ If., 264-267, 269, 290, 383, 407-409, 460

Karnevalsverkleidungen I 24

Karsamstag 4I

karuala $\mathrm{I} 43$

Karwoche 4I, I I I, I 29

Käsewoche 4I, I Io, 330, 430

Kasperl 21 7, 21 9, 226, 472

"Kata i Mato« 220

katabasis $\mathrm{I} 45$

katachanas $4 \mathrm{I} 6$

katadesmos 320

Katakombenmalerei 309

kathagiasmos 350

Katholiken 57, I40, 368, 449

katsipodis 422

Kavuklu I97f.

»kay1k" 233

Keilschrifttexte 436

kem göz 436

Kinderbischof 407

Kinderehe 390

Kinderkarneval Io6

Kinderkrankheiten 201, 326

Kinderkultur 256

Kinderpsychologie I 5, 252,433

Kinderspiele I33,253-256

Kinderumzüge 56, I33, I36

Kindestausch 202

kiopek-bey Io8

Kiralesa I9 I

Kirchweihfeste 349,359

Kis Bohóc 226

kisze 166

kizir I74f.

kjopek bej I 43

Klagelied I I6, 208, 306

Klageverhalten I 6

"Kleinchroniken« 327

"Klepetanje 220

klidonas 42, 53, I 24, I 3 I, 255, 329

Klientelsystem 400

kline 3 I I

kljunk I43 
klocalica 88,426

Klostertypika 388

klutsa 60

»Kniefall»-Sonntag 43 I

koimesis-Ikone 3 I I

koinonia $38 \mathrm{I}$

Koitusparodie 109

"kokkala« 85

kokkinos $\mathrm{I} 23$

koleda 59, I05, I 26

koledari 89, I02, I4I, 459

koledarski kolač I4I

koledžane I 43

kolendra 59

koljiva $\mathrm{I} 26,428$

koljivo $\mathrm{I} 32,366$

kolo I03, 219

kollyba 47, I I 7, I 26-I 28, I 32, I39, 208, 260, 320 , $330,332,428-432$

Kollyvaden 348, 388, 524

kombologia 354

komboloi II I

komendijaš I08, I 57

komendijaši 108

komendije 108

Kommunikation I If., I 5-I 8, 20, 27 f., 29f., 32-35, 37-39, 65, 86, I03, I09, I 25, I 32, I 46 f., I 84 , I 9 I, 202, 208, 234, 240, 244, 25 2f., 274 f., 299, 307, 314, 347f., 35 I, 380, 382, 385, 400, 4I6, $429,435,447,459,46$ I

Komnenenzeit 263

Komödianten 2 I I

Komödie 40, I09, I61, I68, I 88, I98, 222-224, 228, 23of., 236, 238 f., 248, 250, 28 I , 444

»Komödie der Pseudoärzte« $28 \mathrm{I}$

konjar I 43

»konsequenzvermindertes Probehandeln« I 8

konski velikden $\mathrm{I} 39$

köpek-bey 108, I 24, I68, $258 \mathrm{f}$

Kopulationsparodie Io9, 158

Koran 448

koranti 8I, I09

korban 380

korelles II 3 korkunc 420

Körpersprache I7, 33, 35

köse oyunu $\mathrm{I} 54$

Kosmogonie 338

kostnica 208, 249

košuta 80

köy tiyatrosu $\mathrm{I} 73$

Kozaken 236

kralj 94

kraljica 289

kraljice 53, 93f., I 42, 289

kraljitarji $\mathrm{I} 4 \mathrm{O}$

Krankenheilung I 2, 332, 357

Krankenwallfahrten 280

Krankheit 2of., 4I, 50, 53-55, 80, 87, I 52 , 2OI-203, 273, 275-278, 280, 299, 306, 3 I 8, 326, $328,342-344,346,349,354,36$ I, 37 I , 382, 396, 4OI-4O3, 4I 5, 424f., 427, 44I

Krankheitsdämonen 283, 32 If., 4I 8, 420, 423

Krankheitsprophylaxe 203

Krankheitsvorstellungen $27 \mathrm{If}$.

krantonellos 63, I I 7

"Krasopateras« 408

krăste 57

krăstonoše 57

Krauthinkl 79,88

krimarica 426

Kreuzerhöhung II 8, 429

Kreuzerhöhungstag 429

Kreuzigungsspiel I46

»Kreuztragen" 42, 57, 74, 94, 338

»Krinos" I 80, 195

"Krinos und Anthia" 195

Krippenspiel I 33, I 4I, I 48, I 93, 2 I 5, 220, 464

kriskindle $\mathrm{I} 49, \mathrm{I} 93,2 \mathrm{I} 7$

$k r(e)_{\text {snik }}$ 4I 9

Krumpli Miska 227

Krypto-Christen 305

Kryptoskopie 329

kuç kuçura II 7

kuchkutera II 7

kudunates 108

kufosabbato 364

kuka I 80 
kukeri 46, 90, I 08, I 24, I 42-I 44, I 5 I, I 60, I62f., I 68-i 7 I, 459f.

kukerski igri $\mathrm{I} 43$

kukla I 20,428

kukli $2 \mathrm{I} 7,428$

kukove $\mathrm{I} 43$

kukúdhi 420

kukugeroi 108

kukuti ro8

kukuvci I 43

Kulmak-Tekke 359

kumbaros 127

kumpanija I40

kumstvo 385

kurban 380, 429

kurban bajram 380

kurbania 338

ku(l)shedra 4 I 9

kušle 44

kutsodaimonas 422

Kynokephale 4I I, 4I 4

"L'assomoir« 228

"L'Olimpiade« 257

"Le Médecin malgré lui« 228

lagatsiaraioi $\mathrm{IO} 2$

Laienspiel I73, 2 I I, 2 I 5

Lamentation 33, 63, 73, I I6, 208, 306

Lamentationsverhalten I I 7, 207, 254, 3 I I

lamia 4 19

lami(j)a 4I 5

lamja 4I9, 42 I

lamies $4 \mathrm{I} 5$

lamnja 4 I 9

Lanzenstechen 90, 26I, 263

lapatas I 24

Lärminstrument 6o, 84, I 36

larfa го9

larva I03

Laszló Vitéz $226 \mathrm{f}$.

Lateinerherrschaft I44, 263

lätureni $\mathrm{I} 35, \mathrm{I} 37 \mathrm{f}$.

Lauf I69, 255f., 258

lavipedium 129

lazar 94 lazari I 20

lazarica 94, I42, 387

lazarice 94

lazarines 94

lazarka $\mathrm{I} 20$

lazarki 46, 94

lazarkite 46

lazaromata 309

lazarovden 94

Lazarus 62, 70, 72, 92, 95, I I I, I I 8, I 35, I 44, I 92, $284,308,3$ Iof., 353 f., 375,450

"Lazarus"

Lazaruslied 94, I I 2, 309

Lazarusmädchen 58

Lazaruspuppe 6I, I I 4, I I 9, I 20

»Lazarussamstag« 4I, I 29, 364

Lazaruswiegen 64

lažlja $\mathrm{I} 57$

»Le malade imaginaire« 444

»Le Médecin malgré lui« 228

Legenden I9 I, 23 I, 244, 265, 3 I of., 348, 350, $353,355,360,37 \mathrm{I}-373,377,383,386,409,4 \mathrm{II}$, 430,45 I

"Leichtschattige« 449

leidinos 63, ro9, I I 7 f.

leiturgia 338

Lekanomantie 329

Lenorenballade 4 I 8

leventia 245

Libretto I 49, I 93, 2 I 8, 257

libro d'oro 266

Liebeslieder I 30

Lieder 22, 58, 73, 78, 85, 96, I I of., I3 I, I3 8, I 77, I $92,239,256,357$

lieux de mémoire 358, 366

ligučari 102

ligutshari 98

Litanei 23, 42, 53-55, 57, 74f., 78, I 3 I, 209, 302, 3 16, 3 19, 335, 337f., 357, 362-364, 384, $402-405$

liukantzaria $\mathrm{I} 0 \mathrm{0}$

Loblieder 43, 94, IO2, I I 2, I 34, I4 I, I 93, 408

lorfe rog

luat din rusalii $\mathrm{I}_{5} 2$

lucija 89, I40f. 
lugat 4I 9

Lumpen(ver)kleidung 66, 85, 92, I 53, I 59

Lutzelfrau 89, I4I

Luzientag I33

mackare ro6

maestro di campo 265

Magie I 2, I 5, I 9, 2 I , 40, 66, I00, I I 7, I 27, I36, I 53, I 55, I 58, 269, 27I, 273, 275-277, 283, 3 I 3-3 I6, 3 I 8-320, 322, 324-326, 334, 337, 339-343, 357, 37 I, 378f., 405, 433-435, 437, 439, 44I , 45 I-454, 465, 478

Magier(in) 20I, 284, 309f., 423

Magische Praktiken I 5, 2 I, 23, 30, 75, 79, 260, 299f., 302, 3 г 3f., 3 I 8-320, 404, 432, 446, 448, $450,452 \mathrm{f} ., 464$

maballe $232 \mathrm{f}$., 248

Maibaumklettern 268

"Maikugeln« 62, I 24, I 3 I

maiopulo 73

maïstres 3 I 5

majka I4I, I43

makellarikon hippodromion 259

mako 147

Malanka 94

Malbücher $35 \mathrm{I}$

Malka Koleda 422

mal de ojo 436

malocchio 436

mammi 84

manak 6I

mandatum I 29

mandragora 279

Manichäismus 305

Männerbünde I34-I 36

Männerkindbett 203

Mantik 43, 48, I 24, 299, 328, 465, 467

mantinades I 54, 444

Märchen I 9, 22, 37, 47, 49, 87, I35, I 80, 23 I, 239, 247f., 274, 302, 32 I, 387, 4I 5, 424, 460

Mariä Himmelfahrt I 3 I, 429

Mariä Verkündigung 52,357

Marienklage 52, I 29, 3 I 2

Marienmädchen 93

Marionettenspieler 226 martenica $6 \mathrm{I}$

martinički 6I, 202, 295, 44I, 526

martis 6I, 526

martis-Faden 202, 295, 526

März-Faden 526

măš 82

maškara Io9

maškarada Io6

Maske I 5, 22f., 30, 55, 58f., 64, 67f., 79, 83, 89, 92, 96, 98-IO5, IO7-I I 2, I 20, I 26, I 37-I 40, I 42, I 45, I 48f., I 53, I 57 f., I 67, I 72, I 74-I 76, I 90-I92, I 97, 224, 226, 237, 259, 26 I, 379, 427 f., 460

masken-bal ro6

Maskenforschung I43, 458

Maskentermine I4I

Maskentheorie 65

Maskenumzug 84, 87, I I 3, I68, 432

Maskenzeit 42, I35, I 44

Maskierung 2 I, 39, 43, 49, 55, 58f., 65, 67, 77, 79f., 86, 88-90, го2, го6, I 32, I 36, I 38-I4 I, I $43, \mathrm{I} 47, \mathrm{I} 5 \mathrm{O}, \mathrm{I} 67,200,204,289,427,462$

maskirani 106, Io8

maskirci 109

masljanica 4I, 430

matahala $\mathrm{I} 5 \mathrm{O}$

mati 436

matiasma 436

matiasmenos 443

Matriarchat 20,426

matsuki 6o

mau-olhado 436

»Mäusehochzeit« 336

mé̌eško horo 87

mecka I43

mečkar I43

meckari Io9

meddah $23 \mathrm{I}$

mediatrix gratiarum 430

Mediävistik 301,407

Medium I 9, 22, 324, 339, 447f.

Medusa 425

medved 90

medvjed 87

megalomartyr 373 
Meglenorumänen 238

melites melissophylum 26 I

memory-studies 366

Menaien 362

"Messer»-Tanz I 83

Meßparodien 407

Metonymie $73,77,84$

Mevlevi 380

miklavž 140

Milchbruderschaft 385

Milchgeschwister 385

Mimus I99, 230

"Mircea și Baiazid« I 9 I

Mittelalter 5 I , 70, I 20, I 40, I 49, I 87, I 93, 2 I 8 , 220, 229, 247, 26I , 263, 268, 270, 273, 276f., 28 I, 300f., 309, 3 I 4, 347, 35 I, 353, 374,378, 38 I, 385, 406f., 4I I , 423, 437-439, 449, 45 If., 448 ,

Mittwinterverkleidungen 67, I04, I 29

mlad I Io

mlada $\mathrm{I} 57$

mladožena I Io

mnemosyna $47,208,428,430$

mocanii 82

Mohrenkopf 90

moira 330

moires 3I I, 376, 4I6

mokos 44

momci 143

mome 95

momi I 43

momice 95

momoeria 85

momogeria I 50, I72, 260, 423

momogeroi $\mathrm{I0} 8, \mathrm{I} 72$

momogeros 82

"Monsieur de Pourceaugnac» 228

"Monstersucht« 4I I

mora 4I 5, 4I 9

morava 4I9

moresca $150,262,479$

moreška $\mathrm{I} 4 \mathrm{O}, 262$

moreška-Spiel I 40

morica $4 \mathrm{I} 9$

morina 4I 9 morris 24I, 262

moș 8 If., 225

MoșAjun I $9 \mathrm{I}$

"Moș Ajunul« I 36

Moș Begu 193

Moș Ionică 224

mosii 89

moša 50

Moșul di Vicleim 225

motcoși 136

mrăsni(ci) dni 44

mitsunes 108

muchtar $\mathrm{I} 82$

mubavere 232

mukkademe 232

mundus reversus 43, 5 I, 64, 92, 408

muntza 35,438

Musik I 2, 3of., 5 I, 96, 98, г 1 о, г 30, I 36, I 38, I 44, I 57 , I65, I 76 f., 2 IO, 2 I 2, 22 I, 236, 243, 337, 345f., 359,366

Musikinstrument 9I

muškarac ${ }_{5} 57$

Muslime 85, I 22, I 40, 246, 300, 343, 360, 364 , 368,437

mut $\mathrm{I} 52$

mutul I 52

mutsunarides 108

mutsunes I I 2

muza 35

"Myrtilos und Daphne« 195

Mythologie I 9, 29, 40, 82, I 35, 308, 406, 4I 2

Mythos 20, 29, 42, 104, 275, 350

Nachosterwoche 4I, 50, 56, I 29, 344

Nadelöhr-Ritus 202, 272, 277, 342, 380

Naos 350, 379, 38 I, 383, 448

Narthex 448

"Natama« 2 I 9

navi 283

navi(je) 4I 9

navjaci $4 \mathrm{I} 9$

nazar 436

nazar boncuğu 436

nazar takım 436

nekrăsteni dni 44 
nekrštenci 4I 9, 422

nekrolatria 4I 7, I3 I, 208

nekropsoma 428

nekršteni dani 44,420

nekyia 449

neonati 44

neraida 424

Neraiden 334f., 340, $35^{\circ}$

neraides 260

nestinari I04, I 24, I30, 279, 3 I 3, 459

Neujahr 4If., 48, 6or., 82, 87, 98, гоo, I26, I33,

I 37, I47, I74, I76, I 9 I, 328, 334, 340, 429f.

Neujahrsspiel I9I

nevesta $\mathrm{I} 43$

nevidincici $4 \mathrm{I} 9$

nevidmići $4 \mathrm{I} 9$

new anthropology 434

niata 428

Nikodemus-Evangelium 303

Nikolaustag I $37 f$.

Nikolausumzüge I4I

Nionios 249

nipter I 29, I 45

Nixen 260, 4I 5, 428

nomokanones $4 \mathrm{I} 7$

norocosi $i$ 38

Novelle I66, I 80, 238, 28 I, 343, 446

Numinosum I 8, 276, 304, 350, 460

numinosum tremens 406

Nunta țigănească I $9 \mathrm{I}$

nutuk 2 I 3

obilnjak $4 \mathrm{I} 9$

oblicje ro9

obraz Io9

„Octavius und Valeria« I 95

oculus malus 440

oculus invidiosus 440

ogre 4I 5, 4I 9, 42 I

oikonomia 348

ombres chinoises 229

Omorfonios 249

oneirokritika $33 \mathrm{I}$

Oneiromantik 273

Oper 22 I, 243
Opfer 43, 59, 62, I 55, I76, 232, 274, 284, 295, 303, 306, 336, 338, 356f., 374, 377f., 383, 394, 435,440

ora 424

Orakel 2 I, 42f., 47f., 53, I 3 I, 208, 280, 323 , $328-332,334 f ., 337,442 f, 445,465$

Orakelträume I 29

Orakelwesen 325,437

oral poetry-Forschung 274

Orale Tradition I 5, 260, 324

Oralerzählung 36

Oralkultur I If, I 5f., 2 If., 29f., 32, 38, 54, 69, I 32 , 2 I0, 253, 300f., 3 I 3f., 334, 339, 347, 407, 409, 4I I , 427, 432f., $447 \mathrm{f}$.

Ordensspiele $57, \mathrm{I} 87$

orisnica 426

orisnici $4 \mathrm{I} 6$

orta oyunu I73, I97, I99, 237

Orthodoxe I40, 368, 37 I, 406

Orthodoxie I 9, 21 , 37, 40, 52, 56, 74, 94, I I 9, I 34f., I 4 I, I 46, I 56, I 87, 200, 247, 300, 303, 307-3 го, 3 I 2, 320, 343, 347-349, 357, 360, 373 , 375, 38of., 386f., 393, 395, 4O I, 4 I I , 4I 5, 429, 437f., 449, 457

Osmanen 83, 392

Osmanisches Reich I49, I73, I 92, I 99, 2 I I , 23 I, 237, 240, 257, 262, 390, 4I 4, 45 4, 460

osteophylakion 208, 429

Osterfasten 89, I08, 43 I

Ostergericht I 39

Ostern 52f., 6 I, I I 7, I $29 f$., I 33f., I 39, 258, 328 , $337,358,364,372,402,427,429$

Ostersonntag 4I, 3 1 2, 368, 396, 397

»ot văzkresenje do pentikost« 430

oteporci I 40

oyun $\mathrm{I} 73$

padalice $142,325,459$

Paganismus 300

pagano 44

paganus 44

Paiața 244f.

Palaiologenzeit 262

palanka I97

palii 265 
Palikare I I I, 249, 28 I

Palmsamstag 62, 94

Palmsonntag 4I, 6I, I 29

palóc I 33

Palotzen 133,368

palus 263

"Panagia des Charos« 357

Panagia-Ikone 203,395

panarama 215

"Panaratos" II 6

panegyri 42, 55, I 24, I45, 209, 345, 359, 368f., 380,404

pankration 257

Panoramen 2I3-3I5, 22 I

panspermia I 27, I32, 337

Pantomime 56, 85, IOI, I 59, I67, I 83, I 94 , 2 I $2-2$ I 4

panukla 4I6

Papierikonen 349

pappus I 47

papusi la perdea 238

papusile I91, 234, 463

Paradeisspiel 80, I4I, I 88

paraklese $346,354,403,405$

Paretymologien I 28, $364 \mathrm{f}$.

Parodie I 8, 39, 63, 92, I09-I I I, I I 7, I 34, I 44, I 49, I 52-I62, I65, I 67, I 82f., 26 I , 406-409 pars pro toto 301,342

Paschalis 228

Passionsspiele I87,406

pastir I4I

Pastoralpraxis 54, 299f., 302, 3 I 4, 347-349, 375f., $38 \mathrm{I}, 384-387,402,437,447,452,454,465-45^{8}$

Patristik 437, 448f.

pazar 359

pečalba 380

pečenica 48

pefti 49

peblivan 206

pebtra baba 140

pentathlon 258

pentekoste 430

Perchten 8I, 89

perdele 226

peregrinus 354 performance $\mathrm{I} 6,27$

Performanz IIf., I 5f., I 8 , 25, 27-29, 93, I32, 2 Iо, 253, 255, 299, 3 I I , 448, 453 f., 460

Performative Riten I 5 f., 2 I , 30, 38, I32, I 72, 200, 204,453

performative turn I7, 27-3 I

Performativität $\mathrm{I} 5-\mathrm{I} 7,27,30,38,59,200,204$, 209, 25 I, 253, 453

perperuna 74, 78, I I6, 319, 404

pesi ponedelnik 63

Pest I 28, I 52, 273, 335, 340, 402f., 4I 6f., 420, 423

Pestepidemien 276

Pestfrau 283, 4I7, 423

Petrachelion 274, 357, 395f.

Petruschka 22 I

peraciuce 93

Pfaffenschwank 408

"Pferde-Ostern« I 39, 260

"Pferdeknecht« I43

Pferderennen I34, I 39, I69, 258, 260

Pferdeverkleidung 8I, I4I

Pferdewettrennen I 28, I 36, 253, 260

Pfingsten 52f., I I 7, I 30, 260, 337.364, 369, 374, 427, 429-43 I

Pfingstköniginnen $93 \mathrm{f}$.

Pfingstmontag 432

Pfingstsamstag 42, 427,430

Pfingstsonntag $73, \mathrm{I} 38,43 \mathrm{I}$

Phanariotenherrschaft 238

Phanariotenzeit $\mathrm{I} 32$

pharmakos I76, 319

Phyllomorphie 70

Physiognomik 435

"Pijanci« 220

Pilgertum 353

piperi-Tanz I I 2,159

pirdžii 4I 9

pirgarul mare $\mathrm{I} 37$

pirgarul mic I 37

pîrgari I 37

Pișekâr I 97f.

piterades I Io

pitarei $\mathrm{I} 35$

plugusor I 35

plugusorul I4I 
pobratimstvo 386

podariko 45, 337, 340

poganoto dni 44

poganski dene 420

poklade $5 \mathrm{I}$

pokladi svatovi I Io

pokrăsti 57

polaznik 45

poliuchos 373

Polysemie r6, I36, 433

pompa 338

pompe I67

Pontusgriechen I I 2

pop I 43

popolari 269

Popularkultur 29

»Porfyris« 409

pozoj 4I 9

Präkognition 329

Prangerumzug 85

predatel I I 8

preličnici ro9

prerušenci ro9

pricoliciu 420

prikadnik 423

primicer I35f.

pristavi I 37

privacy 30

Prodigien 327

Prodigienliteratur 327

proditor I I 8, 308, 37 I

Profanisierung 303-305,407

Projektiltheorie 272

"Prokleta Avlija« 240

Prokop i Pétra 2 I 9

ProkopiTrivun 2 I 9

Prophezeiungen 21, 8I, 325-327

Prophylaktik 43, 201, 270, 275, 318, 403, 409, 4I 7,465

Prophylaxe 22, 35, 5 I, 202f., 272, 300, 3 I 6, 324, 4I 7, 435, 440, 443

prosfora $338,346,376,38$ I, 43 I

prosforo $367,376,428$

Proskynese 37, 309, 3 I 2, 343, 346, 370

proskynetaria 358,377

\section{prosopades 108}

Protevangelium des Jacobus 49

provedittore I 79

provodos I I I

Proxemik 2if., 33, 40, I 28, 276, 280, 358

Prozession 2I, 30, 35, 42, 52-59, 67, 72f., 75, 95 , I02, I05, I I If., I33-I36, I 42, I 56, I 77, 200, 204, 207, 268, 280, 3 I 6, 3 I 9, 335, 338, 344, 346, 354, 357 f., 367, 383f., 40 I, 404f.

prperudata 46

Pseudopope I Io

Psychoanalyse 252,330, 434

psychopompoi I $3 \mathrm{I}$

psychosabbata 4I, 47, 208, 427, 430

Pulcinella 22 If.

Puppe 30, 6r , 63f., 73, 75f., 8 I, 83, 88, ro4, I I4I I 6, I I 9f., г 33f., I 48f., I 59, I 79, г 88, г 91-г 93, 2 I 5-229, 237-24I, 255, 257, 3 IO, 320, 428, 459

Puppenspieler 2 I of.

Puppentheater 192, 224, 226, 228, 236, 243

pustovi ro9

Pyromantie 45, I 29

Quadragesima 4I, 52, 89, I 28, I 35, I 37, I 54, 260, $350,364,373,430$

Quintana-Stechen 264

rabvagas 176

Rachepuppe 320

ramadan $\mathrm{I} 98,240$

»Räuber« 55, I 90, 2 I 2, 249, 354

„Räuberschlachten« I 76

Realitätshältiges Rollengeflecht I 46

Reformationszeit 187

Regenbittlied 74, 78,404

Regenbitt-Messe 74

Regenbitt-Riten 73

Regenlitanei 53, 78, 337

Regenmädchen 53,74-76, 78, r 24, 255,362, 404f.

Regenmagie I I 7,429

Regenzauber 74f., 284, 335

regös $\mathrm{I} 33$

Reigentänze 93

»Reiner Montag« 4 I, I o9, I 28, I 53-I 56, I 59 f., 420,430 
Reiterheilige 260, 374, 394

Reiterspiele 253, 260, 262, 380

Reliefikonen 352

Religion I 8, 53, I 70, 22 8, 299, 302, 308, 3 I 4, 452, 455

Religionswissenschaft 3 I 7 f., 434

Religiosität 38, 300, 304-307, 453f.

Reliquien 37,55,319,338,360,367,405

Reliquienkult 35 I, 38 I

Reliquienschrein 357,377

Reliquientranslation 363,374

Renaissance I45, I 80, 26I, 386

Renaissancedramatik 195

Renaissancetheater I93f.

Reritualisierung I 8,64, I67

Retrokognition 329

rhodismos $374 \mathrm{f}$.

rîndaș 136

Ringkampf I 30, I69, 255-259, 293, 369, 525

Ringelreiten 261, 263

Ringelstechen 253,263,265,267

rite de passage 29, 43, 202,355

Ritual I 2, I 8, 28f., 39, 42f., 53, 66f., 93-96, I I 7, I 24, I 30-I33, I 5 If., I 74, I 9 I, 207, 304, 3 I I, $377,382,390,404$

Ritualität 2of., 3 I 4

Ritus I 7, 28, 38f., 56, 68, 73f., г о9, г I 3, I I6, г 33f., I 45, 202, 206, 209, 25 2f., 258, 260, 277, 309, 3 I 9, 336, 342, 344, 38of., 384, 389, 396, 409, 430, 442, 444f., 449

roata de foc $\mathrm{I} 34 \mathrm{f}$.

"Robinja« I40, I93

Robinja-Spiel I43, I93

rogač 82

rogatsia 90,102

rogatsiaria I08, I 47

"Roland und Hildegunde" I 95

Rolle I 5, I7, 20, 39f., 48, 62, 64, 66f., 74, 77, 80, 92f., 95-97, 99, го3, го5, го9, г I 3, I I6, I I 9f., I 35 , I 39, I 4 I, I 43-I 45, I 50, I 55, I 57, I 76, I 98 , 207, 2 I0, 260, 269, 279, 306

Rollenfigur 58f., I47, I 58

Rollenspiel 30, I 45f., I64, 254, $256 f$.

Rollentheorie 66

Roma I 40, 2 IO, 246
Romanioten 140

rosali(il)a 424

rosaliile $53, \mathrm{I} 52,260$

Rosalienfest 4I, 67, I 43, 4I6

Rosalien-Woche 42

Rosen-Mädchen I 34

rozos 60

ršä 43 I

ruga 265

rugatsaria 99

rugatsiari 98

rugatsiaria 90

rugatsiaris 102

rugatsiarus 99

rukantzaria 102

"Rumana« I85f.

Rumänen 78, 93f., I 34, I36, I 4 I, 2 I 9, 238, 420, 43 I , 449

Rumelili 232

Rumelioten 245

Ruralkarneval ıo9, I54

rusa 8of.

Rusalien 53, 26I, 429f.,

rusalii I 52, 26I

rusalija $\mathrm{I}^{42}$

rusalije 94

rusalka 424

rusalki 422, 428

rusalksa sedmica 53

rusalna nadelja $43 \mathrm{I}$

ruzičalo $43 \mathrm{I}$

Russen 214, 430

Rußschwärzen 35,90

Sabbath 429

sabbato ante palmas 7 I, 309

sablje 93

sădija I 43

Sagen 27, 29, 242, 244, 247, 350, 4I I , 4I 4, 422, $424 \mathrm{f}, 428,467$

»Saisondrama« 308

Sakralität I 8, 58, г 27, 299, 304, 3 I 3, 347f., 350, $353,407,409,452$

Sakralmalerei 37

Sakralprozession 55 
Säkularisierung I 8

sămbati di Rsalja $43 \mathrm{I}$

Sammelumzüge 53, 58,62, I 66

samodiva $424 \mathrm{f}$.

samojuda 424

samovila 424

samovilski denovi 44

Samstaggeborene 429, 443

"Samstagsformeln« 429

Šante i Pante 2 16,2 I $9 f$.

San Toader I39, 26 of., 430

santoaderi $\mathrm{I} 39$

Sarakatsanen 63, I08, I I 8, I 59, 356, 395

Sarakosti 154

saranta 363,428

sarka 283

Satire I8, 39, 5 I, I09, I 27, I 47, I 54, I 57-I60, I 62, I 74, 22 5, 22 7, 248f., 406, 409

scalojan 64,73 , I 16

Scaraoschi I 9 I

Schadenszauber I9, 2 I, 20I, 3 I 5 f., 3 I 9 f., 326, 423, $435,440,442,454$

Schamanismus 94, 326, 426

Schandritt 85, I60, I68

Schattenmessen 319

Schattenspieler 2 IO, 2 I 5, 223, 229, 239, 24If., 248

Schattentheater 30, I6 If., I 97-I99, 22 I, 223 f., 228-231, 234-237, 239f., 242-246, 248-250, 262, 340, 450,459 f., 463

Schaustellerei 29 f., 38 f., 4 I , 43, 2 IO, 453

Scheinbegräbnis $63,158,205,225,319$

Scheinhochzeit IOI, I 40, I 43, I 53, I 55, I 59, I 83

Scheinkämpfe 9I, Io I

Scheinobrigkeit I38, I69, I 7 If.

Scheinobrigkeitsrecht I69, I7 If.

Scheinpflügung 63,86 , I35, I4 I, I 43 f., I 56 , I67f., I 7 I

Scheinverkauf 203,3 I9

Schicksalsfrauen $376,4 \mathrm{I} 6,475$

Schokatzen I04

»Schöne Sirene« 242

Schreckmasken 80, I04

Schulmedizin $27 \mathrm{I}$

Schulterblattorakel 48,329, 335
Schutzheiliger 48, I 33, 364, 373

Schwalbenidol 6I

Schwalbenumzug 4I, 6I, I30

Schwärzen 32, 35f., 43, 67, 84f., 90, I 33, 290, 525

Schweineschlachten 4I, 44, 48, I 77

Schwertertanz 259

Schwundstufe 29, 53, 103, 395

Schwur I 20, 354, 385, 394-396, $398 \mathrm{f}$.

scobicei $\mathrm{I} 36$

Seelensamstag 4I, I 29f., 330, 332, 427, $429 f$.

Sefarden 140,305

seimenides I IO

seismologia 334

semantron 350,368

šeme 89 , I09, I 40

šemen 89

Semiosis $15,339,433$

Semiotik 16, 27,65, 106

senista 420

Sexualität $\mathrm{I} 59,322$

sfakela 36

shtriga 420

Sieb 46, 78, 92, II 3 , I 55, 202, 3 I 9, 326

sifunas 335

silivestri 191

similia similibus 22, 274, $276 f$.

similludkia 72

Sior Dionysios 249

Sirenen $4 \mathrm{I} 5$

sirni ponedelnik 164

sirnica 94

sirovari $\mathrm{I} 4 \mathrm{I}$

sito 78

sjanka 420

skalojan I I 5

sklavoma 377

skylareoi 106

slava 46, 96, 200, 366

slavski kolač 366

Slovenen 80, 89, I89, 270

sluškinja 93

smerdaki 319, 4I 5, 42 I

Sokácok rozf.

Šokci 104

Solotanz 87 
Șoimii Carpatilor I 34, I 38

Sonntag des Ungläubigen Thomas 4I, 258

Sonnwendfeuer I3 I

sorcova I9I

Sozialanthropologie I 9, 433

Soziologie 65, 3 I 3, 37 I, 434

Sozialismus 2 Io

spatial turn 27

Spätmittelalter I40, I 49, 2 I 8, 374, 423, 437, 439, 488

Speerwurf 256,258

Speiseopfer 47, I32, 208, 386

sphakelos 35

Spiel I 8, 96, IOI, I32-I34, I42, I 50, I67, I $70-$

I 93, I 96, 20I, 207, 2 I 7, 26 I, 447

Spiel à la planchette 220

Spiel vom armen Lazarus I $88 f$.

Spiel von St. Sebastian I88f.

Spielzeugtheater 229

Spinnstube 5 I , 58, 62, 8 I, 86-88, I IO, I 32, I34, I $55^{-1} 57$, I 90

Sport 30, 25 I, 257, 26I, 263, 464

Sprechakt-Theorie 27

Sprechverbot 44, 60, I I3, 202

Sprichwort 22, 34, 45 I

Sprung I 8, I69, 2 I 2, 256-259, 363

spyria I 28

Stabpuppen 2 I 8

starci IO8-I IO, I 43, I63

staribog 423

stari bădnjak 423

staric I4 I

stašca I4 I

Stavrakas 249

steag 152

Steckenpferd 79, 85, I36, I 74, I 82, 260

„Štefan cel Mare« I 9 I

"Steffl von Neuhausen« I 90

Stegreiftheater 227

Stehlrecht 9I

Steinstoßen 258

Steinwurf $169,255^{-2} 5^{8}$

stephanites 375

Sterberitual 42

Sternsingen I33, I 4 I, I 48, I 88, I 93, 29 I, 525 stichera idiomela 403

stichera proshomoia 403

St. Lucia I4 I

strada larga 266

strašila 109, 2 I 8, 220

»Strategikon« 389

strattia 265

strega 420

striga 4I 3, 420, 490

strija 420

striglă 420

strigoi 420

strigon 420

strigarea pesta sate $I_{3} 8$

striges $4 \mathrm{I} 9$

stringla 420

stringles 4I 5

strînsul feciorilor I 37

strix 4I9f.

Strohbär 86

Strohpuppe I I4, I33

strojnik 45

Stubenspiel I 54

Strukturalismus I6

stubo 60

subra $6 \mathrm{I}$

sudice $4 \mathrm{I} 6$

Südslaven $37,45,98$

Sulioten 246

sultaris $\mathrm{I} 47$

Sumerer 436

Superstition 5 I, I 26, 27 I, 299, 306, 34 I

surovari 60

surva 61, 87, I 23, I 27, I 91, 259

survački $\mathrm{I} 4 \mathrm{I}$

survakari 459

survaknici 6o, I4I

survari 102

suscitatio-dromenon $7 \mathrm{I}$

suvra $6 \mathrm{I}$

Sv. Lucija (Maske) 89

svadbari rog

svatovi rogf.

Symbolhandlungen 54, 442, 444

Synaxarien 4II 
Synkretismus I 22, 304f., 323, 348, 360, 380, 4I I, 4I $8,434,452$

synteknia 399

"Synteknien« 397

syni keq 436

syri ikeq 436

Székelys I33

Szekler 73, I33, I56, 368

szemmelverés 436

szimki $\mathrm{I} 5 \mathrm{O}$

szita 326

szopka $\mathrm{I} 48,2 \mathrm{I} 7,224$

tableaux vivants I07

Tabu 19, 3 I9, 363f., 408f., 425

talasăm 4I 9

talaso(r)n $4 \mathrm{ro}$

talasum $4 \mathrm{I} 9$

Talisman 3I7f., 352, 44I

Talmud 448

táltos 326

tama 379

Tanz I 2, 32, 55, 73, 75, 77f., 80, 82, 84, 94-96, 98-IO3, I I 2 , I 23 f., I 3 I , I 33 , I 36 -I 4 O, I 43 f., I 48 , I 5 O, I 5 2f., I $57-$ I60, I62, I65, I 67, I 74 f., I 77, I 86, I 88, 205-207, 2 I 2 , 2 I $9,239,255$ f., 26 I, 29 I, 32 I, 325, 335, 345f., 349, 356f., 259 , 366, 368-370, 396, 404f., 425

Tanzbär 86f., I Iо, I66, I 72, 525

Tanzhaus 58, I 34, I 76

"Tanz der Einheit" I 9 If.

»Taufbrüder" 385

Taufbruderschaft 385

Taufpatenschaft 203

Tauziehen $167,256,259$

taximo 346,379

taxis $40 \mathrm{If}$.

Tekija templom 380

tekke 359 f., 374

telochraniteli $\mathrm{I} 43$

teloni $4 \mathrm{I} 6$

telonia 335, 4I 19, 42 I, 466, $50 \mathrm{I}$

templum 328, 338

Teratogenese 202

tetartaios 7 1, 94, 308 tetrahemeros 71, 94, 308

Teufel 62, 67, 80, 88, 92, 99, I I 2, I 48, I 55, I 58 , I6o, I74, I 76, 227 f., $272,274,3$ I 4, 340, 387 , 402, 405f., 434, 445

Teufelsfeuer 3 I 3

thanatikon 403

Thanatophobie 409

Thanatos 70,3 II

Theater I6-I 8, 28-30, 38-40, 52, 57, 59, 66, го9, I 24, I39f., I 44-I 46, I 49, I 57 , I 6 If., I 7 I- I 73 , I 79-I 8 I, I 92-20I, 206, 2 I I-2 I 7, 220-23 I, $238,24 \mathrm{I}, 25 \mathrm{O}, 252 \mathrm{f}$., $265,269,280,375,446$, $45 \mathrm{If}$.

Theateraufführung 67, 76, 2 10, 25 I, 453, 463

Théâtre Séraphin 229

Theodizee 406

Theologie 277, 302, 31 3, 361, 371, 386, 405, 447, $449,45^{2}, 455,465,484$

Theophanie 42f., 98 , I07, I $27, \mathrm{I} 32, \mathrm{I} 38, \mathrm{I} 47, \mathrm{I} 77$, $284,338,4$ orf.

theotokia $40 \mathrm{I}-403$

Therapie 22f., IOI, I 52 f., I 68, I 72, I 76, 202, 26 I, 270-272, 274f., 283 f., 32 I, 337, 343, 439, 442, $444 f ., 490$

Therapeutik 22,30, 269, 271, 273

thesmophoria I 24

Thomassonntag 138

threnos 73, I I 7 f., I 52 2, I $58-160$

Tierepidemien 272

Tiermaskierung 80, 87, 143

Tieropfer I 3 I, I 83, 295, 31 9, 343, 345f., 362, 367, $37 \mathrm{I}, 376,48 \mathrm{I}-383,429,466$

Tiryaki 232

Titić i Petrić 2 I9

toană $\mathrm{I} 36$

Tod 20, 4I , 44, 54, 56, 67,7 1, 74, 84f., г I 9f., г 26 , I 53, I 55, I6I, I 75-I 77, I 79, I96, 200, 237 , 245f., 276, 303, 306, 3 I 2, 324, 328, 337, 340, 368, 387, 394, 396, 402, 407, 4 I 8f., 423, 426f., 430, 440f., 499

Tod/Auferstehung-Motiv 86, I49, I60, I67, I 74, 308

Tod/Auferstehungs-Zyklus I 54, I 58, 225

Todaustragen 74 , I I 4

todorice 96 
todorusale 260

todoruse $26 \mathrm{I}$

toketos 3 I I

tollite portas 56, I 45

toponymica $\mathrm{I} 47$

topos 3 I If., 375, 449

torneo 263

tospagades IOI

Totenbeschwörung 264

Totenbrauchtum 47, I I 6

Totenlamentation 33

Totenseelen 43, 5 I, 67, I 29f., I 33, 3 I O, 4I 6, 4I 8, 427, 429, 43 If.

Totenwache 8 I, I I 5, I 35, I 53, 428

Tourismus 23, 33, 66, 97, I 45, I 86, 349, 353, 357, $359,366,404$

tournement 263

traballa 256

Tragödie 33, I45, I 80, I 94-I 97, 250, 308

Transhumanz 304

translatio 373

transplantatio morborum 2 If., I 5 2, 202, 274, 276, 342,435

Traum I 8f., 2 If., 252, 273, 3 I 9, 330, 332

Traumdeutung 21, 301, 323, 33 I

Traumdiagnosen 273

tretini 428

tri kralja I4 I

triakostia 428

trimina 429

trishagia I 29, 43 I

trita 428

Trivialliteratur I95, 223, 228

Troparium 393, 396, 401, 403

tsiattismata 255

tsikna 49

tsiknopefti 49

tsoliades 99

Tudorica I39, 430

túdos pasztor 326

tur 80

turcă $79 f$.

turcar $\mathrm{I} 37$

turcas, I 37

turce 44
Türgeld 206

turica 8of.

turkasok $8 \mathrm{I}$

Türken 80, 104, I 52, 2 I 3, 22 5, 236, $238 f$., 242, $258,264,368,378,392,397,475$

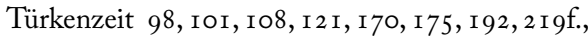
222, 229, 249, 28 I, 300, 36 I, 387, 390f., 394, 399, 4 I I , 449

Turkophone 422

Turniergedicht 262, 265

Turnierspiele 42, 90, 26 If., 268

Tuszuz Deli Bekir 232

Typologie 54f., 79, 92, 105, I72, 200, 260, 3 I 2, 345, 367f., 395, 409f.

"typologischen Übertragung« 277, 301, 308, 3 I I-3 I 3, 449-452, 455

tzamala 84f., I 24

tzatzala 342

tziomaka 60

tziumanika IO2

tzobanika 60

uğursuz 328

Umdrehverbot 202, 343

unchias 80

unchiașii 81, 89

Ungarn 39, 42, 6If., 73, 75, 78, 8of., 87f., 93, I 4 , I-7, I I3, I 32, I 34, I 4 I, I 48 f., I 5 I , I 54, I 56, I 76, I 87, I 89, 204, 208, 2 I I, 2 I 5 f., 2 I 8, 224, 226, 23 I , 25 5, 257, 260, 28 I , 29of., 3 I 4, 320, 355f., 368, 4I 3, 4I 7, 439, 46 I , 472, 484, 5 I $8-520,525$

„Ungesprochenes« Wasser I 26, I 3 I

»Unreines Blut« 387

uroklivjo oko 436

uroklivo oko 436

ursitori $4 \mathrm{I} 6$

Ursu 192

ustrel $4 \mathrm{I} 9$

vălăret $\mathrm{I} 38$

vălkolak 420

vampir I 84, 3 I 9, 409, 4I I, 4I 3, 4I6-420

vampiradžii $4 \mathrm{I} 9$

Vampire 319, 4I6f., 4I 9 
Vampirglaube 4I I

Vampirismus 409, 4I 7f., 420

vampirovići $4 \mathrm{I} 9$

văperari 4I 9

vapir $4 \mathrm{I} 8$

văpir $4 \mathrm{I} 8$

varkolak 420

vărkolak 4I 8, 420

»Vasilache și Marioara« I 9I, 2 I 5 f., 22 I, 225

vasiličari 60,102

»Vasilis»-Spiel I 83

vasilopitta 48, I 26, 330, 332

Vasyl 94

vătaf I 34-I 39, I 52

vătaf cel mic $\mathrm{I} 37$

vătaful cel mare $\mathrm{I} 37$

vedarec 4 I 9

vedomec 4 I 9

Vegetationsheros 95, 310, 375

vellame 390

vepir 4I 8

"Vergessene Braut« I 80

Verkleidung I 5, I 7, 2 I , 30, 39, 43. 5 I, 54, 59, 64-68, 83, 85, 87-89, 93, 96, 98-гоo, го4, го6f.,

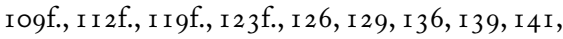

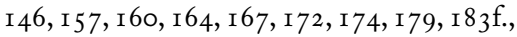
I 9I, 200, 22 5, 238, 290f., 405, 407, 427, 458f., $46 \mathrm{I}, 463,525$

anthropomorphe 63f., 90, 92, I40 arktomorphe 86

phytomorphe $70,77,79$

theriomorphe $58,79,8$ I, 88-9 I, 98, I36, I6o, I 67, I 92, 289, 410

zoomorphe $79,86,88,90,380,420$

Verkehrte Welt 36, 39, 4I, 43, 5 I, IO5

Verlobung 4I, I6o,204, 206, 332, 346

"Versklavung« 202f.

Versteigerung 42, 88, I69, 209, 366, 383

vertep I4 I, I48f., I 93, 2 I 7f., 224

vertepaši I $48,2 \mathrm{I} 7$

vertepi $\mathrm{I} 4 \mathrm{I}$

ververin $\mathrm{I} 43$

vešča $4 \mathrm{I} 9$

$v(j)$ estac $4 \mathrm{I} 9$

veštica 4I9, 426 $v(j)$ estica $4 \mathrm{I} 9$

vicleim I48f., I 9 I , I 93,2 I 5-2 I 7, 220, 224, 243

vicleiul I9I

Viehdiebstahl 397,399

viflejem I4I

vila 424

vila posestrima 387

Vilenheirat 425

vindecare 152

vîrcolac 420

virga thaumaturgica 309

virkulak 420

(v)jedogonja 4I 9

Vlachen 9I, I I 2, 395, 43 I

Vodica 422

»Vögel« 23 I

Vogelscheuchenfigur 90, I I 8

vojvoda I 43, I 57

Volksarchitektur 90

»Volksbücher« 362, 408

Volksetymologie I 6

Volksfrömmigkeit 23, 38, 5 I, 70, 302, 348-350, 38 I, 466

Volksglaube $325,35^{2}, 426,429,45^{8}$

Volkskunde I3, 20, I 22, I 25

Volkskultur I 2, I 5, I 9, 22 f., 3 I , 66, I 25, I 32, I43f., I 5 I , I 7 I , I 86, 2 I O, 245, 248, 25 7, 277, 300, 302, 3 I 3, 324, 339, 370, 4I I, 448, 450, 452, 45 , $457-459,466$

Volkslied 36, 366, 39I, 399, 405, 450

Volksliteratur 37,386

Volksmedizin 23, 270, 337, 423, 454

Volksmeteorologie 333

Volksreligiosität 307, 45 I, 454

Volksschauspiel 38, 80, I 39, I 44, I 54, I 83, I 86I 9o, I 99, 254, 263, 458, 46 I-464

Volkstheater 30, 38f., I 45, I 86, I 92, I 94, I 99, 2 I I, 2 20f., 248, 463

vombir $4 \mathrm{I} 8$

Voraufklärung I 2, 436

Vormoderne I I, I 9, 36, 302, 339, 466

vornici $\mathrm{I} 36$

Votiv-Ikonen $378 \mathrm{f}$.

Votivgaben 203, 280, 302, 343, 352f., 37 I, 375, $377,379-38$ I 
Votivopfer $2 \mathrm{I}$

vrachnas $4 \mathrm{I} 5$

vražalica 4 I 9

vrexudia $\mathrm{I} 27$

vrikolakes $4 \mathrm{I} 6$

vučari 8 , I4I

vukedlak 420

vukodlak 420

vuku večera 47

vurko(l)ak 420

vurkolak 420

vurvo(l)ak 420

vurkulak 420

Waffentanz I4O, I 50, 259

Wahlbruderschaft I 35, 300, 383-390, 392f., 395, 398-40I, 426, 467 f.

Wahlschwestern 387, 390, 397f., 425

Wallfahrt 2 I, 55, 57f., I 23 f., I 28 , I 3 I , I 45, 280 , 305, 349, 35 2-357, 359, 365f., 372f., 378f., 38 I, 404,44 I, 467,492

Wallfahrts-Tourismus I45

Wallfahrtswesen I 3 I, 305, 349f., 355f., 467, 494

Wandertruppe I90, 2 I If.

Wassermänner 4I 5

Wasserweihung 56

Wechselbalg 204

Wegkreuzung 47, 54, 58, I02, I 27, I 37, I 46, 202f., $273,283,318,443$

Wegsperre 56, 204

"Weiberfastnacht« 49, 96

Weihbrot 56, I 28, I4I, 276, 338, 343f., 346, 367 , 376

Weihbrotstempel 276

Weihnachten 4If., 47, 50, 82, 84, I 27, I 35, I $37 f$., I 4 I, I 74, I76, 332, 334, 354, 358, 383,429

"Weihnachtsklotz« 45

Weihnachtsspiele r 88-190

Weitsprung 258

Werberitual 95

wertepa $\mathrm{I} 48$

Werwolf 4I I, 4I 8-420

Werwolfsphantasien $4 \mathrm{II}$

Wetterprognose 21, 333f.

Wettervorhersage 48,404
Wettlauf 255,257

Winteraustragen II 4

Wochenbett 44, 20I, 284, 4I I

Wunderikonen 350, 352, 37 I

xematiasma 440, 444

»Yalova safâsi« 233

yaprak 49

Yürüken 92

zabavljač $\mathrm{I} 57$

zadušnici 208, 429

zafeiris 73

Zahlenmagie 318,320, 339

zana 335,424

zanë 424

zángózás $\mathrm{I} 33$

žarač 157

Zauber I2, I 9, 2 I , 23, 35, 44, 6I, I 80, 20If., 2 I3, 253, 269-272, 274f., 28 I , 284, 300f., 305, 309f., 3 1 3-323, 325f., 33 of., 335, 34 of., 343, 350, 400, $404,409,420,423,429,432-435,437-447,45^{2}$, $454,465,467$

Zauber-Medizin 270

Zauberei 279, 314, 323, 333, 400, 420, 467

Zauberformel 27I, 305,467

Zaubermärchen 180

Zauberpapyri 2I, 28I, 323, 33 I, 4I 2, 454

Zauberpflanzen $27 \mathrm{I}$

Zauberspruch 202, 274f., 3 I4, 32 of., 447

zazidan 420

zdrugamani 98

$z$ duhač $4 \mathrm{I} 9$

zduhaći 4I 9

Zelenj Juraj 70

Zené 232

zenne 197

Zentauren I39, 261, 410, 422

Zeremonien I36, I 44, I 54, I 88, 200, 206, 2 IO

zeybek $\mathrm{I} 44, \mathrm{I} 53$

Ziegenmaske 80, 82, I9I

Zielschießen $255 \mathrm{f}$.

Zielwurf 255

Zigeuner 24, 75, 86f., 98, roof., I I 10, I I 2 f., I 43 f., 
I 47, I6of., I64-I68, I 99, 205, 224, 226, 232, 238, 29I, 525

Zigeunerhochzeit I55, I58, I9I

zina 424

ziua babelor 49

zmaj 45, 4I9

Zmaj Ognenji Vuk 4 I 9

zmej 45, I 42, 4IO, 4I 7, 4I 9-42 I, 466

zvončari 89,140

zvongari 102, 108

Zwölften 4If., 44, 47f., 5 If., 56, 62, 84, I0If., I05, I 26 , I 28, I 33-I 35, I 37-I 39, I 43, I 49, I 72, I 74, I 8 I , I 92, 2 I 8, 25 8, 3 I 9, 34 I , 4 I If., 422, 427, 430

Zwölftendämonen 43, I 27, 4I 7f., 42of.

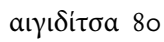

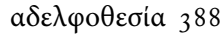

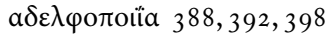

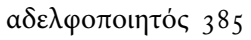

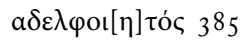

$\alpha \delta \varepsilon \lambda \varphi \circ \varphi \tau \dot{\varepsilon} \varsigma$ 39I

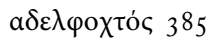

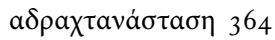

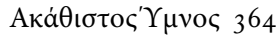

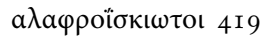

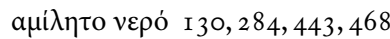

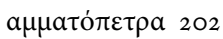

$\alpha \mu \pi o ́ \delta \varepsilon \mu \alpha \quad 322 \mathrm{f}$.

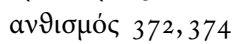

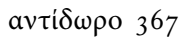

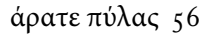

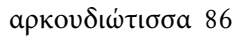

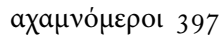

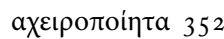

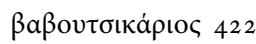

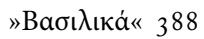

$\beta \lambda \alpha \dot{\alpha} \mu \delta \varepsilon \varsigma$ I 59

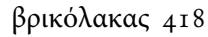

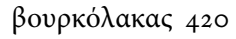

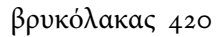

$\beta v \zeta \alpha \delta \varepsilon \dot{\lambda} \varphi$ เa 385

$\gamma \eta \tau \dot{\varepsilon} \mu \alpha \tau \alpha \quad 27 \mathrm{I}$ $\gamma \kappa \alpha \mu \eta \dot{\lambda} \alpha \quad 82$

$\gamma \lambda \omega \sigma \sigma o \varphi \alpha ́ \gamma \omega \mu \alpha \quad 440$

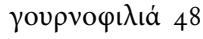

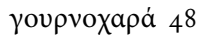

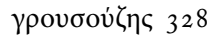

үúpa 57

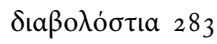

$\delta \iota \mu i \tau \zeta ı v ~ 259$

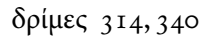

$\Delta \omega \delta \varepsilon \kappa \alpha \mu \varepsilon \rho i \tau\rceil \varsigma 423$

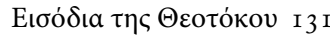

$\varepsilon \lambda \varepsilon \eta \mu о \sigma u ́ v \eta ~ 428$

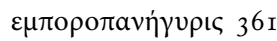

$\varepsilon \pi \omega \delta \dot{\varepsilon} \varsigma$ 27I, 274, 276, 32 I, 323, 465

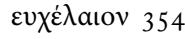

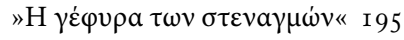

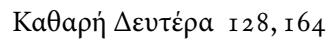

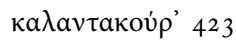

$\kappa \alpha \lambda ı \kappa a \nu \tau \zeta \dot{\alpha} \mu \varepsilon \rho \alpha 44$

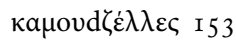

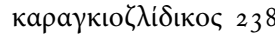

караүкıо ไіíкı 238

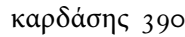

Koí

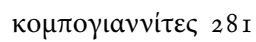

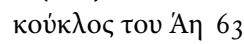

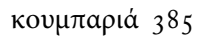

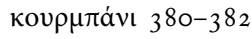

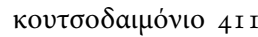

коvтбока́ $\lambda \omega \mathrm{I} 84$

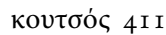

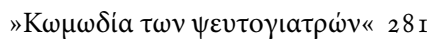

$\Lambda \alpha \mu \pi \rho \eta \dot{~ I 84 ~}$

$\lambda \varepsilon \dot{\eta} \sigma \eta 7$

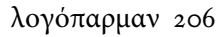

$\lambda$ úкоৎ 420

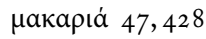

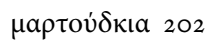

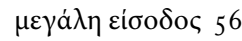


$\mu \varepsilon \lambda о \mu \alpha \kappa a ́ p o v a ~ 47$

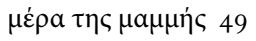

$\mu \varepsilon \sigma о \pi \varepsilon v \tau \eta$ кобтиं 337,364

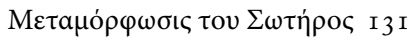

$\mu \mathrm{i} \lambda \eta \mu \alpha$ I 94

$\mu \nu \eta \mu \varepsilon$ íov 429

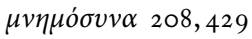

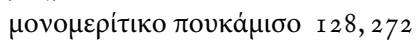

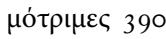

$\mu \pi \dot{\alpha} \mu \pi \omega \quad 49,63$

$\mu \pi$ ои入оúкıа 2 I I

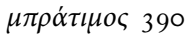

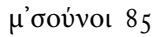

$\mu^{\prime} \tau \zeta$ oúv' 85

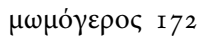

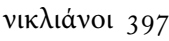

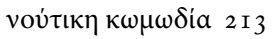

乡ó

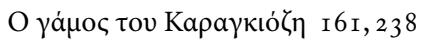

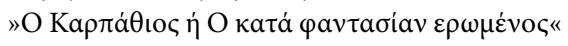
445

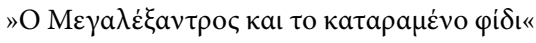
$246 f$.

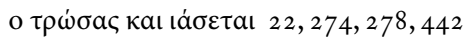

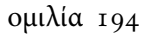

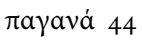

$\pi a \theta$ ó ı เатрóৎ 278

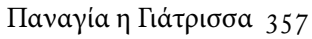

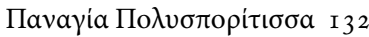

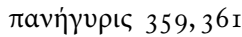

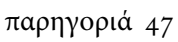

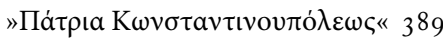

$\pi \varepsilon \rho i \delta \varepsilon \varepsilon \pi v a{ }_{42} 8$

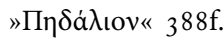

портарікıа 206

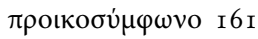

$\pi \rho ц$ пи́рเоৎ I 35

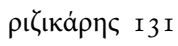

бípva 57

бкатолои́入ıа 3 I 6

$\sigma \kappa \lambda \dot{\beta} \beta \omega \mu \alpha 203$

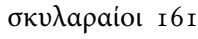

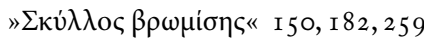

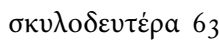

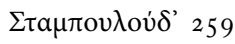

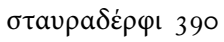

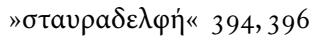

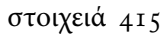

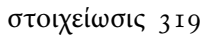

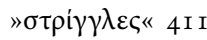

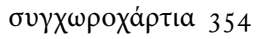

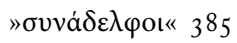

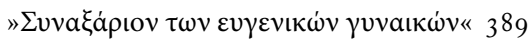

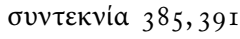

ovxípla 429

бuxípı $428 \mathrm{f}$.

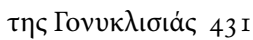

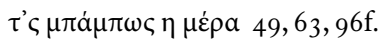

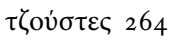

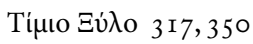

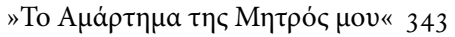

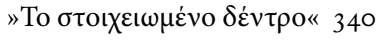

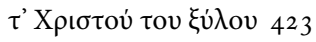

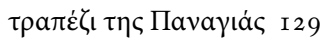

тритоле́рабна 277,319

$\tau \sigma \succ \gamma \kappa \lambda \dot{\omega}$ I 86

vं $\psi \omega \mu \alpha \quad 319,366,430$

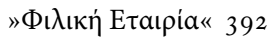

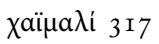

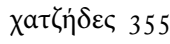

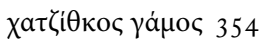

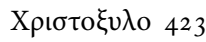

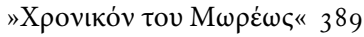




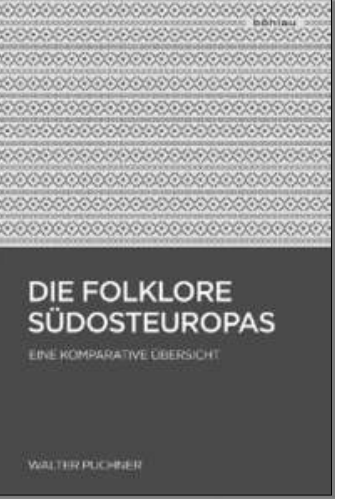

\section{WALTER PUCHNER}

\section{DIE FOLKLORE SÜDOSTEUROPAS}

EINE KOMPARATIVE ÜBERSICHT

Der vorliegende Band bildet eine bibliographisch reich dokumentierte Übersicht über die orale Literatur Südosteuropas und vergleicht zum ersten Mal mit übersetzten Beispielen gesungene Texte (Heldenlieder und historische Liedchroniken, Kleften- und Hajukenlieder, Balladen und Erzähllieder, religiöse Lieder und Ansingelieder, Lieder auf Tod und Trennung, Liebes-, Hochzeits- und Frühlingslieder, Karnevalslieder und Kinderlieder) und gesprochene Texte (Märchen, Sagen und Überlieferungen, Legenden und erbauliche Geschichten, Schwänke und Anekdoten, Sprichwörter und Rätsel) in einem sprach- und länderübergreifenden Zusammenhang in der traditionellen Volkskultur von Ungarn und Rumänien, den südslawischen Ländern und Albanien, Griechenland und der Türkei. 


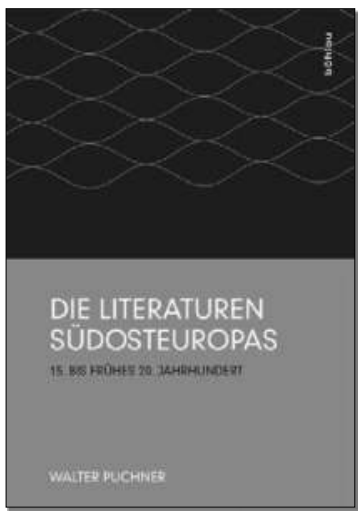

\section{WALTER PUCHNER}

DIE LITERATUREN SÜDOSTEUROPAS

15. BIS FRÜHES 20. JAHRHUNDERT EIN VERGLEICH

Das Buch bildet den erstmaligen Versuch einer Komparation der südosteuropäischen Literaturen von der frühen Neuzeit bis zur Moderne zu Beginn des 20. Jahrhunderts und bildet insofern einen Grundstock für eine künftige vergleichende Literaturwissenschaft Südosteuropas, die die ungarische, rumänische, südslawische, albanische, griechische und türkische Belletristik umfasst. Der Vergleich bezieht sich auf Gattungen und Epochenstile, ideologische Tendenzen, Thematik und Motivik bzw. Rezeptionsvorgänge und Vorbildwirkungen, Typologien und Langzeitstrukturen. Zu den Ergebnissen der Untersuchung der Fiktionalliteratur zählen gewisse Gemeinsamkeiten, wie die Durchlässigkeit der Gattungsgrenzen, die Modifikation von Stilbegriffen, der enorme Einfluss der mündlichen Literatur usw. Das Buch bildet den ersten Teil einer Trilogie zur Balkankomparatistik; der zweite Band ist der Folklore gewidmet und der dritte der Performanz und Imagination in den Oralkulturen Südosteuropas.

2015. 308 S. GB. $170 \times 240$ MM. I ISBN 978-3-205-79641-1

BÖHLAU VERLAG, WIESINGERSTRASSE I, A-IOIO WIEN, T:+43 I 33024 27-O INFO@BOEHLAU-VERLAG.COM, WWW.BOEHLAU-VERLAG.COM | WIEN KÖLN WEIMAR 

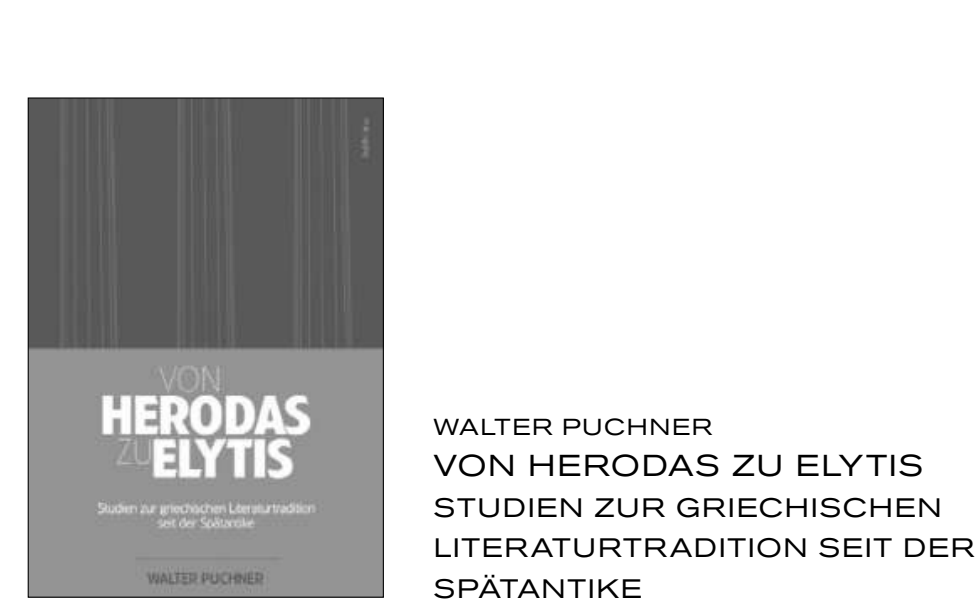

Die Monografie umfasst insgesamt zehn Studien, die sich chronologisch vom 3. Jahrhundert v. Chr. bis ins 20. Jahrhundert erstrecken und die Einmaligkeit der griechischen Schrifttradition über 2500 Jahre dokumentieren. Diese Führung beginnt mit den spätantiken Mimiamben des Herodas, führt über das mittelalterliche cento-Gedicht Christus Patiens und den zypriotischen Passionszyklus zum popularen Lesestoff des Bertoldo (1646) und von dort zur Literaturproduktion des 19. Jahrhunderts: Übersetzungen aus dem Deutschen, Frauendramatik zur Zeit der Revolution von 1821, die historisch-patriotischen Theaterstücke, Sprachsatiren und Dialektkomödien, die griechische Dorfnovelle (Der Tod des Pallikaren von Kostis Palamas 1891). Das 20. Jahrhundert ist mit einer Studie zum Werk des Nobelpreisträgers Odysseas Elytis und dem griechischen Surrealismus vertreten.

2012. 522 S. BR. $170 \times 240 \mathrm{MM}$.

ISBN 978-3-205-78710-5

BÖHLAU VERLAG, WIESINGERSTRASSE I, IOIO WIEN. T : + 43 (o) I 33024 27-O BOEHLAU@BOEHLAU.AT, WWW.BOEHLAU-VERLAG.COM | WIEN KÖLN WEIMAR 


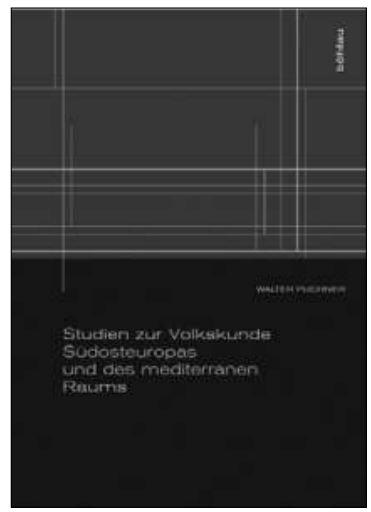

WALTER PUCHNER

STUDIEN ZUR VOLKSKUNDE SÜDOSTEUROPAS UND

DES MEDITERRANEN RAUMS

Mit den vorliegenden 24 Studien zu einer Vergleichenden Volkskunde Südosteuropas und des mediterranen Raums wird ein repräsentatives Kaleidoskop von Themen und Methoden regional-, sprach- und konfessionsübergreifender Kulturforschung in historischer-vertikaler und geographisch-horizontaler Komparation geboten.

DER AUTOR: Walter Puchner, geb. 1947 in Wien, seit 1991 Professor für Theatertheorie und Theatergeschichte am Institut für Theaterstudien der Universität Athen.

2009. 600 S. GB. M. SU. $15,5 \times 23,5$ CM.

ISBN 978-3-205-78291-9

BÖHLAU VERLAG, WIESINGERSTRASSE I, IOIO WIEN. T : +43(o) I 33024 27-0 BOEHLAU@BOEHLAU.AT, WWW.BOEHLAU.AT | WIEN KÖLN WEIMAR 


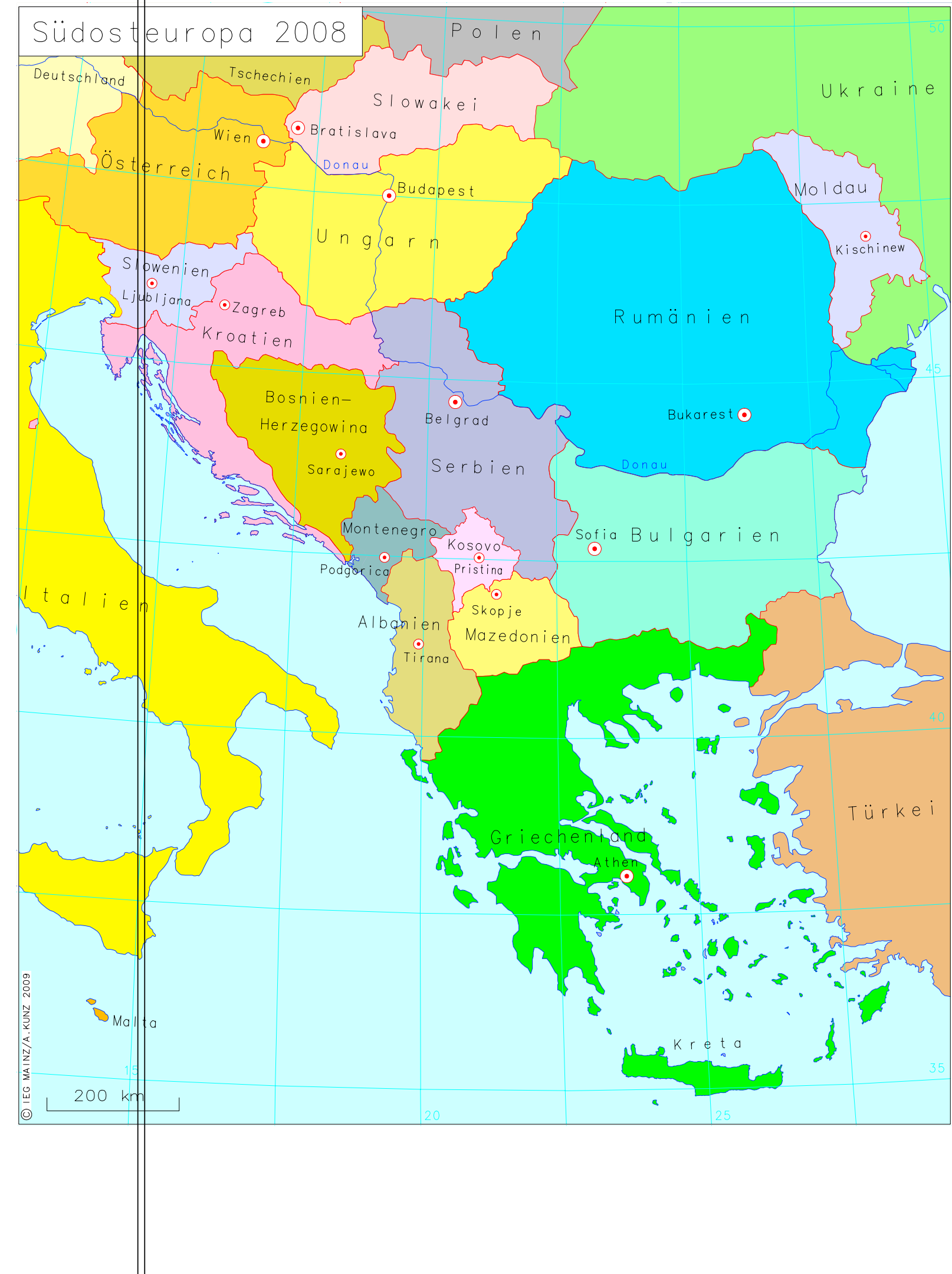


Der vorliegende Band bringt eine bibliographisch reich dokumentierte Übersicht über Formen der Performanz und Imagination in der Oralkultur Südosteuropas und vergleicht zum ersten Mal das Maskenwesen und Volksschauspiel, die Pastoralpraxis und Superstitionen in einem sprach-, nations- und religionsübergreifenden Zusammenhang, der Ungarn und Rumänien, die südslavischen Länder und Albanien sowie Griechenland und die Türkei umfasst.

Walter Puchner ist Professor für Theatertheorie und Theatergeschichte am Institut für Theaterstudien der Universität Athen. 